\title{
MERKUIEV ZBORNIK
}

INŠTITUT ZA SLOVENSKI JEZIK FRANA RAMOVŠA ZRC SAZU 


\title{
JEZIKOSLOVNI ZAPISKI \\ ISSN 0354-0448
}

\author{
Uredniški odbor \\ Kozma Ahačič, Metka Furlan, Janez Keber, Valerij M. Mokienko, \\ France Novak, Vera Smole, Alenka Šivic-Dular, Andreja Žele
}

Urednik

Janez Keber

Prevod izvlečkov in povzetkov $v$ angleščino

Donald Reindl, DEKS d. o. o.

\author{
Prelom \\ Brane Vidmar \\ Oblikovanje \\ Milojka Žalik Huzjan
}

\author{
Naslov uredništva \\ Inštitut za slovenski jezik Frana Ramovša ZRC SAZU \\ Novi $\operatorname{trg} 2,1000$ Ljubljana, Slovenija \\ Telefon: 014706160 \\ http://isjfr.zrc-sazu.si/ \\ E-pošta: isj@zrc-sazu.si \\ Letna naročnina $10 €$, za študente $8 €$ \\ Cena posamezne številke $7 €$, dvojna številka $14 €$ \\ Naročila sprejema \\ Založba ZRC, p. p. 306, 1001 Ljubljana \\ Telefon: 014706464 \\ E-pošta: zalozba@zrc-sazu.si
}

Jezikoslovni zapiski so glasilo Inštituta za slovenski jezik Frana Ramovša ZRC SAZU in slovenska znanstvena jezikoslovna revija. Izhaja dvakrat letno. V njih domači in tuji raziskovalci slovenskega in drugih slovanskih jezikov objavljajo svoje izsledke ter ocene in poročila o najnovejših slovenskih in tujih jezikoslovnih delih.

Jezikoslovni zapiski so uvrščeni v mednarodnih bazah podatkov MLA International Bibliography of Books and Articles on the Modern Languages and Literatures, New York; Bibliographie linguistique/Linguistic bibliography, The Hague, The Nederlands; IBZ, K. G. Saur Verlag, Osnabrück, Deutschland; New Contents Slavistics, Staatsbibliothek zu Berlin, Deutschland.

Jezikoslovni zapiski izhajajo s podporo Agencije za raziskovalno dejavnost Republike Slovenije.

Tisk: Eurograf d. o. o., Velenje 


\title{
JEZIKOSLOVNI ZAPISKI
}

Glasilo

Inštituta za slovenski jezik Frana Ramovša

\author{
$13 \cdot 1-2$ \\ 2007
}

\section{MERKUJEV ZBORNIK}

Ožji uredniški odbor

Silvo Torkar

Metka Furlan

Janez Keber

Alenka Šivic-Dular 



\section{VSEBINA}

Akademik Pavle Merkù - osemdesetletnik (S. Torkar) ............................................ 7

Tabula gratulatoria .......................................................................................... 11

Jezikoslovna bibliografija Pavleta Merkuja, Ob osemdesetletnici (M. Furlan).... 13

Kozma Ahačič, Primeri nekaj sklanjatev in spregatev v Megiserjevem

Dictionarium quatuor linguarum 1592 - druga slovnica

slovenskega jezika

Rosanna Benacchio, Slovansko-romanski jezikovni stik v moližanski

hrvaščini: vzporednost s slovenskimi narečji v Furlaniji

Hubert Bergmann, Gröfel, Gröbel 'Steinhaufen' - Dialektologisches und

Namenkundliches rund um einen Slawismus im Bairischen ....

Urszula Bijak, Barbara Czopek-Kopciuch, Imiona w nazwach jezior i stawów w Polsce

Inge Bily, Deappellativische Ortsnamen mit dem Bestimmungswort Graf-, Herr- und Pape-/Pfaffe- im Gebiet zwischen Saale und Neiße

Дмитро Бучко, Ойконіми Украӥни на -иия

Aleksandra Cieślikowa, Maria Malec, Nadawanie imion „literackich” w Polsce

Varja Cvetko Orešnik, Janez Orešnik, Povedkovo določilo v naravni skladnji slovenščine.

Dušan Čop, Imenoslovje in etimologija imen

Александр Д. Дуличенко, Академик Измаил Иванович Срезневский и резьяншина

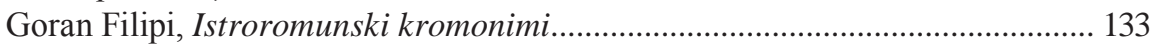

Anđela Frančić, Uvid u hrvatsku toponimiju na sjeverozapadnoj međi................147

Metka Furlan, K etimologiji toponima Mi'rišče »zaselek v Krajevni skupnosti Hotiza«....

Helena Grochoła-Szczepanek, Człowiek - to kto? Refleksja nad płcia czlowieka w jezyku ludowym

Елка Јачева-Улчар, Ојконимијата во Тиквешкиот регион.

Tjaša Jakop, Besedje za bratranca in sestrično v slovenskih narečjih (po gradivu za SLA)

Helena Jazbec, Metka Furlan, Od kod slovenski dendronim jâm »brest«?

Janez Keber, Pavle je Pavel, a ni bil Savel, tudi ni Peter in Pavel ne Peter ali Pavel ne pavliha 
Vlado Klemše, Vodna imena na doberdobskem Krasu

Фёдар Д. Клімчук, Дзве славянскія дыялектныя зоны

Marija Kozar-Mukič, Slovenska besedila v Arhivu Železne županije v Sombotelu pred 1919

Andreja Legan Ravnikar, Izpridevniški krščanski termini v knjižni normi do srede 19. stoletja.

Валянціна Лемцюгова, Айконімы з асновай -сад- на усходнеславянскім этнамоўным абшары

Witold Mańczak, Rzekoma archaiczność obszarów peryferycznych................. 279

Jožica Narat, Življenje besed v Bibliji: od nog do glave ........................................ 285

France Novak, Trubarjev Philopatridus Illyricus ............................................... 297

Heinz Dieter Pohl, Slowenische Namen und Wörter aus Kals in Osttirol............ 303

Maurizio Puntin, Alcuni casi di paronomasia fra sloveno e friulano nei toponimi del Friuli

Ludwig Selimski, Личното име Венцеслав и неговите производни в българската антропонимия....

Mitja Skubic, Slovenske leksikalne prvine v obsoški furlanščini: izpeljanke...... 345

Vera Smole, Urška Petek, Komentiranje leksično-besedotvornih kart v

1. zvezku Slovenskega lingvističnega atlasa »Človek«

(na primeru V617 teta in V618 ujna)

Liliana Spinozzi Monai, Sfogliando il Lessico del dialetto sloveno del Torre/Besedišče terskega narečja (Amarcord di Pavle Merkù)................... 361

Љубица Станковска, Македонско-словенечки топонимиски паралели........ 375

Krystyna Szcześniak, Kagor, tajemniczy desygnat zamów i recept lekarskich wschodniej Słowiańszczyzny.

Agata Šega, Nekaj ugotovitev o glasovnih značilnostih vulgarnolatinskih predlog za starejše latinizme in romanizme v slovenščini

Matej Šekli, Fonološki opis govora vasi Jevšček pri Livku nadiškega narečja slovenščine

Alenka Šivic-Dular, Psl. *stbgna v slovenskih govorih ......................................... 429

Jožica Škofic, Narečno besedilo kot vir za imenoslovno raziskavo ..................... 441

Rudolf Šrámek, Etymon, pojmenovací motiv a význam vlastních jmen .............. 459

Віктор П. Шульгач, *Bъlva, *Bъlvanъ та ін. (фрагмент праслов'янського антропонімного фонду)

Silvo Torkar, Toponim Preserje in slovansko-romansko prepletanje pripon -jane in -anum

Peter Weiss, Iz prvotnih ledinskih imen tvorjena hišna imena $v$ spodnji Zadrečki dolini

Voščilo Varji Cvetko Orešnik (Marko Snoj) .507 


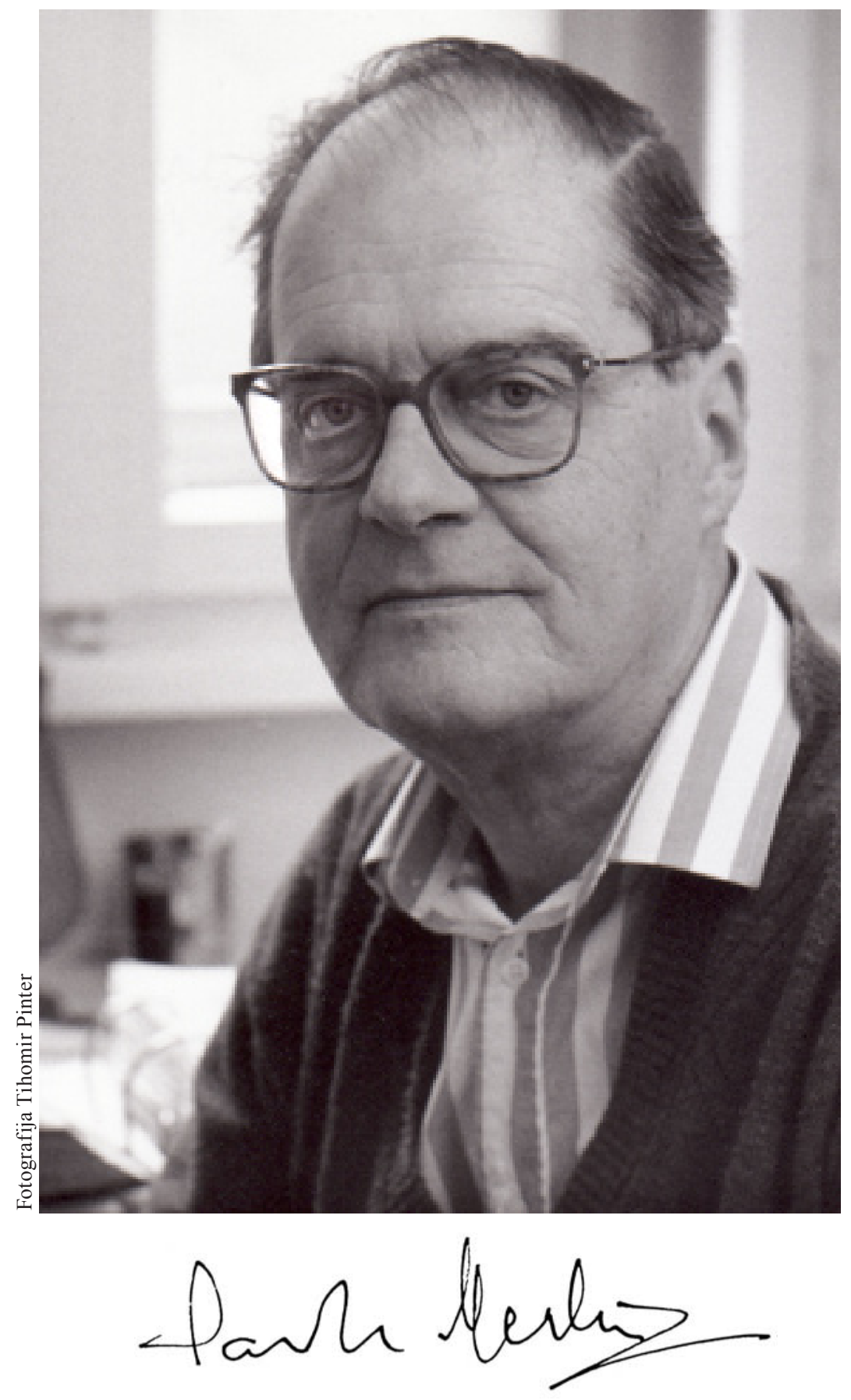





\section{Akademik Pavle Merkù - osemdesetletnik}

Pričujočo številko glasila Inštituta za slovenski jezik Frana Ramovša posvečamo njeni snovalci skupaj z vsemi, ki so se čestitkam jubilantu pridružili s člankom ali podpisom, enemu od najbolj radovednih in pozornih slušateljev profesorja Frana Ramovša, jezikoslovcu, etnomuzikologu in skladatelju Pavletu Merkuju, enciklopedistu ljudske kulture Slovencev v Italiji. Njegove knjige, članke, skladbe, oddaje je seveda mogoče prešteti, in vse, kar je napisal na jezikoslovne teme, je tudi zajeto v priloženi bibliografiji, skoraj nemogoče pa je preceniti izreden pomen in vrednost njegovega raziskovalnega opusa za Slovence na obeh straneh meje, za zamejce in unejce, a tudi za Italijane in Furlane.

Preletimo na kratko njegovih osem desetletij: naš slavljenec je bil rojen 12 . julija 1927 v Trstu, kjer je obiskoval klasično gimnazijo in licej, maturiral pa leta 1946 na slovenskem klasičnem liceju v Gorici. Diplomiral je 1950. na ljubljanski slavistiki in doktoriral iz literarne slovenistike na Univerzi v Rimu leta 1960. Do 1965. je poučeval književne predmete na slovenskem klasičnem liceju v Trstu, nato pa do upokojitve soustvarjal slovenske radijske oddaje na radiu TrstA, naposled kot programski režiser. Od začetka 70-ih let je sodelavec Univerze v Padovi in Inštituta za slovensko narodopisje SAZU. Od leta 1985 je dopisni član SAZU v razredu za umetnosti. Je prvi dobitnik Štrekljeve nagrade za dosežke pri zbiranju ljudskega blaga med Slovenci v Italiji (2001), prejemnik Srebrnega častnega znaka svobode Republike Slovenije (2001) in nagrajenec Prešernovega sklada (1972).

Brez njegovih terenskih zapisov in snemanj, predvsem iz časa, ko je deloval na tržaškem radiu, brez njegove sposobnosti vživljanja v jezikovni in duhovni svet beneških Slovencev, brez posluha za jezikovne pojave, značilne za jezike v stiku, brez njihove dobre jezikoslovne in etnomuzikološke obdelave bi bilo danes naše vedenje o Slovencih na skrajnem slovenskem zahodu občutno siromašnejše in, kar je nadvse pomembno, ga ponekod tudi pri najboljši volji ne bi bilo več mogoče pridobiti, ker je vlak medtem že odpeljal. Priznati moramo, da so Slovenci v Italiji prav po zaslugi Pavleta Merkuja uspeli rešiti pred pozabo pomemben del bogastva ljudske kulture, to pa je dosežek, s katerim se v matični domovini marsikje ne moremo ponašati.

Merkù je prehodil in prevozil neštete steze in poti v krajih pod Matajurjem, Mužci in Kaninom, po slovenskih vaseh v tržaškem kraškem in istrskem zaledju ter v samem Trstu, potem pa na terenu zbrano gradivo soočil z bogatim arhivskim gradivom, in ga, opremljen s potrebnim znanjem in potrpežljivostjo, pripravil za objavo v tisku, za radijske oddaje ali za predavanja. Izjemno pomembna za poznavanje ljudske kulture Slovencev v Italiji je njegova knjiga Ljudsko izročilo Slovencev 
v Italiji/Le tradizioni popolari degli Sloveni in Italia, ki je doživela dve izdaji (v Trstu 1976 in Vidnu 2004).

Merkù se je v letih odraščanja zavestno odločil, da je Slovenec, čeprav izhaja iz mešanega zakona in čeprav zaradi razmer v fašistični Italiji vse do svojega šestnajstega leta ni govoril slovensko niti v družini, kaj šele v šoli in na drugih javnih mestih. Obenem se je pri njem po njegovih lastnih besedah že od rosne mladosti naprej krepila zavest o pripadnosti jezikovnemu in etničnemu robu, iz česar sta zrasla njegova nepremagljiva želja po kulturnem posredništvu med dvema sosednjima narodoma in odpor do vsakršnega nacionalizma. Njegova razmišljanja o narodu, o jeziku, njegovi poskusi, da bi na podlagi skopih zgodovinskih podatkov preniknil v skrivnosti slovenske etnogeneze, so pronicljivi in nakazujejo pot, po kateri se bo šele potrebno prebiti do novih in globljih spoznanj. Vso pozornost zasluži tudi njegovo mnenje, da je za slovenstvo v globaliziranem svetu edina rešitev v navezanosti na korenine ljudskega in v zavesti, da je najtrdnejša korenina naša slovenščina, ki je edino razpoznavno znamenje, po katerem se bomo lahko priznali za Slovence.

Čeprav Merkù poklicno ni deloval na univerzi ali na raziskovalnem inštitutu, so ga v akademskih krogih - žal v slovenskih manj kot v italijanskih - vedno cenili in vabili, da je v predavanjih predstavil svoje raziskovalne rezultate, saj je njegovo delo tako po obsegu kot po strokovni neoporečnosti na ravni dosežkov najboljših raziskovalcev. S svojim zgledom je omogočil, da so se našli razmeroma številni navdušenci, ki so v svojih okoljih na dostojni ravni nadaljevali zlasti onomastične raziskave. Med temi je treba omeniti beneškoslovenskega duhovnika in kulturnega delavca Boža Zuanella, katerega objave o priimkih beneških Slovencev v časniku Dom so omogočile tudi sintezo o priimkih v Furlaniji izpod peresa E. Costantinija (2002), italijanskega raziskovalca Maurizia Puntina, ki se je usposobil za iskalca in razlagalca slovenske imenske dediščine v okolici Tržiča (Monfalcone), goriškega časnikarja in krajevnega zgodovinarja Vlada Klemšeta, ki raziskuje ledinska imena iz okolice Gorice, in še bi lahko naštevali.

Predmet jezikoslovnega zanimanja P. Merkuja je predvsem zgodovina slovenskega jezika, kot ji lahko sledimo skozi arhivske zapise v obliki priseg, oporok, pisem, pridig, starih slovarskih zbirk in številnih listin, živi ljudski jezik slovenskih narečij v Italiji, ki ga zaznamuje tisočletni stik z romanskimi sosedi, in zlasti osebno- in krajevnoimenska dediščina na zahodnem robu slovenskega poselitvenega območja, na meji z romanskim jezikovnim svetom. Svoje izsledke je objavljal tako v slovenščini kot v italijanščini, pretežno pri tržaških založbah in v slovenskih občinah od Barda do Zgonika, kar je eden od glavnih vzrokov za to, da ga osrednji slovenski prostor premalo pozna in kot jezikoslovca premalo upošteva. Terskim Slovencem, najbolj ogroženemu delu slovenskega etnosa v Italiji, je postavil dostojen spomenik z dialektološkimi spisi, z monografijo o ledinskih in krajevnih imenih (1997), a tudi S svojimi doživetimi dnevniškimi zapisi, eseji in celo $\mathrm{z}$ abecednikom Po našin v terskem narečju (1993). Zavedajoč se izjemne pomembnosti arhivskega gradiva pri študiju slovenske jezikovne in vsakršne zgodovine, se je potopil v bogate tržaške arhive in presenetil slovensko in tudi tržaško javnost z nekaterimi osupljivimi odkritji. Merkù je, podobno kot je to svoj čas storil že Ramovš, prav s pomočjo imenskega gradiva iz tržaških srednjeveških kodeksov (zlasti 14. stol.) uspel razkriti nekatere 
pomembne faze v slovenskem glasoslovnem razvoju. Njegove ugotovitve o prehodu ł v u v v tržaški slovenščini 14. stol. so delovanje moderne vokalne redukcije, ki jo je Ramovš umestil v 16. stol., vsaj za slovenski zahod pomaknile za 150 let nazaj.

Najbolj odmevna je bila objava slovenskih plemiških pisem s konca 17. stoletja (1980), saj je korenito spremenila poglede na status slovenščine v dobi pred nacionalnim preporodom. Njegove imenoslovne raziskave so pokazale, da je bil Trst že v srednjem veku s tretjino prebivalstva slovenski. V tržaških arhivih za 14. stoletje je Merkù našel na desetine čudovitih staroslovenskih osebnih imen, doslej znanih samo iz ljudskih pesmi, kot je to primer s Sončico. Romansko-slovanska jezikovna meja je ustvarila v jezikih v stiku zanimiva prepletanja, ki jih je Merkù preiskal predvsem na fondu krajevnih in ledinskih ter osebnih imen oz. priimkov. Na podlagi zgodovinskih zapisov in svojega filološkega znanja je obdelal problematiko priimkov na zahodni meji (1982), monografsko predstavil imena svetnikov v slovenskih osebnih in zemljepisnih imenih (1993) in v obširni študiji notarske knjige iz leta 1525 predstavil osebna in zemljepisna imena za slovenske vasi iz tržaške okolice (1994). Z italijansko pisanimi znanstvenimi in poljudnimi prispevki je širil vedenje o slovenski dediščini Tržaške, Goriške in Videnske pokrajine, pomagal razbijati številne stereotipe in očitne zmote $\mathrm{v}$ razlagah lastnih imen $\mathrm{v}$ enem ali drugem jeziku v stiku. Merkuja je narava obdarila s številnimi darovi, kar mu omogoča, da zna svoje znanstvene izsledke na čudovit in mikaven način predstaviti ne le strokovni, temveč tudi laični javnosti. Ljudi in kraje v slovenskem zamejstvu, ki jih je obiskal, nam je nemalokrat izjemno sugestivno in umetniško prepričljivo naslikal tudi v svojih popotnih dnevnikih in jih tako približal slovenskemu bralcu v osrednji Sloveniji, kot morda še nihče drug.

V rokopisu mu ostaja še zajetna knjiga o romanskih in slovanskih osebnih in zemljepisnih imenih v srednjeveškem Trstu: Nomi di persone e luoghi nei codici medioevali del Capitolo di San Giusto in Trieste (585 str.). Upamo in želimo, da bi bilo jubilantu dano dokončati to veliko sintezo, v katero je vložil že toliko truda in znanja.

Prijatelji, kolegi, bralci, občudovalci in znanci mu ob častitljivi obletnici želimo še veliko življenjskih moči in navdiha, obenem pa tudi zadovoljstva ob vsem postorjenem.

Silvo Torkar 



\title{
Tabula gratulatoria
}

\author{
Kozma AHAČIČ, Ljubljana \\ Zbigniew BABIK, Krakov \\ Rosanna BENACCHIO, Padova \\ Jelena BEREZOVIČ, Jekaterinburg \\ Angela BERGERMAYER, Dunaj \\ Hubert BERGMANN, Dunaj \\ Urszula BIJAK, Krakov \\ Inge BILY, Leipzig \\ Dunja BROZOVIĆ RONČEVIĆ, Zagreb \\ Dmytro BUČKO, Ternopil \\ Aleksandra CIEŚLIKOWA, Krakov \\ Varja CVETKO OREŠNIK, Ljubljana \\ Barbara CZOPEK-KOPCIUCH, Krakov \\ Dušan ČOP, Ljubljana \\ Liljana DIMITROVA-TODOROVA, Sofija \\ Roberto DAPIT, Viden \\ Janez DULAR, Ljubljana \\ Aleksandr D. DULIČENKO, Tartu \\ Goran FILIPI, Koper \\ Anđela FRANČIĆ, Zagreb \\ Metka FURLAN, Ljubljana \\ Alenka GLOŽANČEV, Ljubljana \\ Helena GROCHOŁA-SZCZEPANEK, Krakov \\ Milan HARVALÍK, Praga \\ Georg HOLZER, Dunaj \\ Elka JAČEVA-ULČAR, Skopje \\ Tjaša JAKOP, Ljubljana \\ Helena JAZBEC, Ljubljana \\ Marko JESENŠEK, Maribor \\ Janez KEBER, Ljubljana \\ Karmen KENDA-JEŽ, Ljubljana \\ Simona KLEMENČIČ, Ljubljana \\ Vlado KLEMŠE, Gorica \\ Fjodar D. KLIMČUK, Minsk \\ Mihaela KOLETNIK, Maribor
}


Marija KOZAR-MUKIČ, Sombotel

Zorjana KUPČYNS'KA, Lvov

Ljubov' V. KURKINA, Moskva

Andreja LEGAN RAVNIKAR, Ljubljana

Valjancina P. LEMCJUGOVA, Minsk

Viktor MAJDIČ, Ljubljana

Maria MALEC, Krakov

Witold MAŃCZAK, Krakov

Milko MATIČETOV, Ljubljana

Majda MERŠE, Ljubljana

Nikolai MIKHAILOV, Viden

Valerij M. MOKIENKO, Greifswald

Jakob MÜLLER, Ljubljana

Jožica NARAT, Ljubljana

Vladimir NARTNIK, Ljubljana

France NOVAK, Ljubljana

Irena OREL, Ljubljana

Janez OREŠNIK, Ljubljana

Urška PETEK, Ivančna Gorica

Heinz Dieter POHL, Celovec

Tijmen PRONK, Leiden

Maurizio PUNTIN, Fiumicello

Ludwig SELIMSKI, Katovice

Mitja SKUBIC, Ljubljana

Vera SMOLE, Ljubljana

Marko SNOJ, Ljubljana

Liliana SPINOZZI MONAI, Čedad

Ljubica STANKOVSKA, Skopje

Krystyna SZCZEŚNIAK, Gdansk

Agata ŠEGA, Ljubljana

Matej ŠEKLI, Ljubljana

Petar ŠIMUNOVIĆ, Zagreb

Alenka ŠIVIC-DULAR, Ljubljana

Jožica ŠKOFIC, Ljubljana

Rudolf ŠRÁMEK, Brno

Viktor P. ŠUL'GAČ, Kijev

Svetlana M. TOLSTAJA, Moskva

Silvo TORKAR, Ljubljana

Stefan WARCHOE, Lublin

Peter WEISS, Ljubljana

Zinka ZORKO, Maribor

Božo ZUANELLA, Tarčmun

Andreja ŽELE, Ljubljana 


\section{Jezikoslovna bibliografija Pavleta Merkuja \\ Ob osemdesetletnici*}

1967

1 Ljudsko izročilo v Terski dolini, Zaliv, Trst, 2, št. 8-9, str. 137-140.

\section{8}

2 Ljudje ob Teru, Sodobnost, Ljubljana, XVI, str. 890-897, 1156-1162, 1251-1258. [Ponatis odlomka s str. 1156-1162 in njegov prevod v italijanščino s povzetkom v furlanščini: Terska dolina/Alta Val Torre/Val de Tor, Terska dolina v besedi, sliki in pesmi Viljema Černa, uredila/a cura di M. Kožuh, Celjska Mohorjeva družba - Goriška Mohorjeva družba, Celje - Gorica 2006, str. 277-283, 284-290, 291.]

\section{9}

3 Pomenoslovni paberki iz zgornje Terske doline, Jezik in slovstvo, Ljubljana, 15, 1969/70, str. 60.

4 Ljudje ob Teru VI. Tersko narečje, Sodobnost, Ljubljana, XVII/4, str. 447-456. [Ponatis in prevod v italijanščino s povzetkom v furlanščini: Terska dolina/Alta Val Torre/Val de Tor, Terska dolina v besedi, sliki in pesmi Viljema Černa, uredila/a cura di M. Kožuh, Celjska Mohorjeva družba - Goriška Mohorjeva družba, Celje - Gorica 2006, str. 139-147, 148-158, 159.]

5 Ob imenih slovenskih krajev v Italiji, Jezik in slovstvo, Ljubljana, 14, 1969, str. 69-71.

1970

6 Sprehod skozi tersko besedišče, Jezik in slovstvo, Ljubljana, 16, 1970/71, str. 80-81, 259-260.

7 Pisava in raba slovenskih krajevnih imen v Italiji, Jezik in slovstvo, Ljubljana, 16, 1970/71, str. 74-75.

8 Staro in novo gradivo za terska krajevna imena, Jezik in slovstvo, Ljubljana, 16, 1970/71, str. 147-149, 186-189.

9 Terjani in njih narečje danes, rkp., predavanje pri Slavističnem društvu v Ljubljani, 17. 11. 1970, 12 str.

* Bibliografija je dopolnjen in mestoma popravljen jubilantov Kronološki katalog jezikoslovnih spisov Pavleta Merkuja, ki je leta 2006 izšel v njegovi monografiji Krajevno imenoslovje na slovenskem zahodu. 
1971

10 Sprehod skozi tersko besedišče, Jezik in slovstvo, Ljubljana, 17, 1971/72, str. 114.

\section{2}

11 Narečne pridige Petra Podreka, Letopis za leto 1971, Narodna in študijska knjižnica v Trstu, Trst, str. 8-14.

12 Tersko narečje, popravljeni ponatis iz Primorskega dnevnika, ZTT, Trst, 11 str.

13 Beseda o jeziku "Našega božicja“, Naš božic, beneška pastoralka, napisala skupina članov Kulturnega društva Rečan z Les, ZTT, Trst, str. 43-44; Slovarček, prav tam, str. 45-50.

\section{3}

14 Pojdimo v Beneško Slovenijo, Ognjišče 9, priloga 10, str. 31-37.

15 Il dialetto della Val Torre, rkp., predavanje na prireditvi Incontri culturali della Slavia Italiana 1973-74, Scrutto, 16. 11. 1973, 21 str.

16 Nekaj pripomb po objavi Starogorskega rokopisa v JiS, Jezik in slovstvo, Ljubljana, 19, 1973/74, str. 311-313.

\section{5}

17 Mundarten und Folklore der Slowenen in Friaul und im Resiatal, rkp., predavanje na Institut für Slawistik der Friedrich-Alexander-Universität Erlangen-Nürnberg, 18. 6. 1975, 18 str.

\section{7}

18 Trieste fra le culture italiana e slovena, rkp., predavanje na konferenci pri društvu Società Dante Alighieri, Trst, 17. 3. 1977, 15 str.

\section{8}

19 Tersko narečje, Govor, jezik in besedno ustvarjanje v Beneški Sloveniji, Zbirka Nediža 2, Špeter - Trst, str. 41-56; Il dialetto della Val Torre, Lingua, espressione e letteratura nella Slavia italiana, Quaderni Nediža 2, S. Pietro a/N-Trieste, str. 43-61.

\section{9}

20 Žive besede v naših narečjih, Mladika, Trst, 23, št. 1, str. 16; št. 2-3, str. 34, 44; št. 4, str. 58-59; št. 5, str. $84-85$; št. 6-7, str. 115 ; št. 8 , str. 126 ; št. 9, str. 158; št. 10 , str. $180,181$.

\section{0}

21 Rokopisni italijansko-slovenski slovarček iz arhiva Colloredo, Jadranski koledar 1980, ZTT, Trst, str. 205-215.

22 O slovenskem terskem narečju, Slavistična revija, Ljubljana, 28, št. 2, str. 167-178. [Prevod predavanja na videnski univerzi 26. 4. 1979.] 
23 Slovenska plemiška pisma družin Marenzi-Coraduzzi s konca 17. stoletja, ZTT, Trst, 198 str. [Dopolnilo pod 34.]

24 Analisi di un dialetto come punto di partenza per proposte didattiche, culturali e letterarie, ZTT/EST, Trieste, 15 str.

\section{1}

25 Nadiški rokopis o zdravilstvu, Jadranski koledar 1981, ZTT, Trst, str. 129155.

26 Narečje kot živo kulturno dogajanje: Analiza terskega narečja kot izhodišče za pobude na didaktični, kulturni in literarni ravni, Naši razgledi, Ljubljana, 30, str. 135-137. [Recenzija: B(ožo) Z(uanella), Pavle Merkù: Analisi di un dialetto come punto di partenza per proposte didattiche, culturali e letterarie, Novi Matajur, Čedad, 8, št. 2 (170), str. 4.]

27 Odgovori Pavleta Merkuja, Walter Della Monica, I dialetti e l'Italia, Inchiesta fra scrittori poeti sociologi specialisti, Pan editrice, Milano, str. 166, 168.

28 Onomastični problemi ob slovensko-romanski meji, Četrta jugoslovanska onomastična konferenca, Portorož, od 14. do 17. oktobra 1981, Zbornik referatov, SAZU, Ljubljana, str. 389-400.

29 Il dialetto del Torre e i versi di Uidji Skurjan (Pietro Negro), La Battana, XII Convegno italo-jugoslavo organizzato da "La Battana": Dialetto e Letteratura, Grado, 20-22. 11. 1981, str. 59-63.

30 Liber Primus Mortuorum Luseverae, 2000, Ljubljana, št. 17/18, str. 102-114.

\section{2}

31 Naši živalski priimki, Jadranski koledar 1982, ZTT, Trst, str. 117-122.

32 Precisazioni toponomastiche, Ambiente storico e vita di popolo nel territorio del Torre, Atti dell'incontro di Attimis 21 novembre 1981, A cura di E. Mirmina, Centro di Studi Nieviani, Udine, str. 57-62.

33 Slovenščina $v$ Trstu od srednjeveških listin do plemiških pisem, predavanje 12. 5. 1982 pri Slovenski matici v Ljubljani, Glasnik Slovenske matice 6, št. 1, str. 53-63.

34 Zasebna slovenščina v 17. stoletju, Slavistična revija, Ljubljana, 30, št. 2, str. 121-150.

35 Onomastica slovena in un quaderno cividalese del '400, Associazione per lo sviluppo degli studi storici ed artistici di Cividale, Quaderni cividalesi 10, II Seconda serie, Cividale, str. 21-25.

36 Slovenski priimki na zahodni meji, Mladika, Trst, 79 str.

37 De Felicejeva slovarja priimkov, Slavistična revija, Ljubljana, 30, št. 2, str. 215-221. [Recenzija.]

38 Analisi tipologica degli antroponimi nella Trieste del '300, rkp., konferenca "Trieste e il suo entroterra" v organizaciji Facoltà di lettere e filosofia, Istituto di storia medievale e moderna dell’Università di Trieste, Filozofske fakultete v Ljubljani in Institut für Zeitgeschichte der Universität Wien v Trstu, 11.-13. 11. 1982,7 str.

39 Precisazioni toponomastiche - 2, Il territorio di Attimis ed i suoi riferimenti 
Nieviani, Centro di Studi Nieviani, Atti dell'incontro di Attimis, 27. 11. 1982, Udine, str. 43-46.

\section{3}

40 Imena ob obali/I nomi della costa, Liburnia, Trieste, 6/3-4, str. 28-29.

41 Influenze del tergestino sull'onomastica slovena triestina, rkp., predavanje 26. 5. 1983 v Pescari na IV Congresso internazionale della cultura interadriatica, Chieti, Pescara, Spalato, Hvar, 26.-30. 5. 1983; 6 str.

42 Maver, Nemec in še kaj, Primorska srečanja, Nova Gorica, št. 44, str. 426.

43 Osebno ime v De Felicejevi knjigi I nomi degli italiani, Slavistična revija, Ljubljana, 31, št. 3, str. 256-257.

44 Fitotoponimi e dendrotoponimi sloveni nel Carso/Slovenski fitotoponimi in dendrotoponimi na Krasu, Carso triestino - natura e civiltà/Tržaški Kras - narava in človek. [Repen, 9 neoštevilčenih strani.]

45 Prehod - $t$ v - $u$ v tržaški slovenščini, Slavistična revija, Ljubljana, 31, št. 3, str. $260-262$.

\section{4}

46 Appunti toponomastici, L"'universo" del Torre ed Ippolito Nievo, Atti del Convegno Regionale e documenti della mostra collegata (Savorgnano del Torre, 17 dicembre 1983), Centro di studi Nieviani, Udine, str. 99-107.

47 Vzdevki in priimki, Jadranski koledar 1984, ZTT, Trst, str. 79-82.

48 Toponomastica del Comune di San Dorligo della Valle, rkp., Il quadrante nordorientale, 70 str.

49 Patronimici in -ič a Trieste nel basso Medioevo, Linguistica, Ljubljana, XXIV, str. 275-282.

50 Antropotoponimi sloveni sul Carso, Università degli Studi di Udine, Est Europa, Udine, separat, str. 3-15.

\section{5}

51 Il dialetto sloveno del Torre, Gente e territorio delle Valli del Torre, Comunità montana delle Valli del Torre, Tarcento-Udine, str. 179-181.

52 Radovednost slovenista pred besednjakom muglizanskega narečja, Slavistična revija, Ljubljana, 33, št. 4, str. 453-454.

53 I soprannomi nell'Ottocento, Reminiscenze storiche di Servola, a cura di Patrizia Pestrin Salmoni, Edizioni "Vita Nuova“, Trieste, str. 354-380.

\section{6}

54 Osebna imena v družini Bonomo, Znanstveno posvetovanje Družbena in kulturna podoba slovenske reformacije, SAZU in ZRC SAZU, 24. in 25. oktobra 1984 v Ljubljani, Družbena in kulturna podoba slovenske reformacije, SAZU, Ljubljana, str. 65-68.

\section{7}

55 Imena naših krajev, Mladika, Trst, 37 str. 
56 La realtà plurilinguistica a Trieste dal tardo Medioevo alla fine del '600: documenti storici in positivo e negativo, predavanje 6. marca 1987, Presenza e contributo della cultura slovena a Trieste, Associazione Culturale Regionale "Gruppo 85“ - Trieste, IRRSAE Friuli Venezia Giulia, str. 33-40.

57 Slovenska srednjeveška antroponimija ob romanski meji, Slavistična revija, Ljubljana, 35, št. 3, str. 321-327. [Predavanje v Lingvističnem krožku v Ljubljani 13. 12. 1982.]

58 Toponimi a confronto in due Carte Militari, Consuetudini e motivi storici del territorio di Taipana, Contributi di ricerca per il convegno regionale del 1987 (Taipana, 7 dicembre 1987), Centro Friulano di Studi "Ippolito Nievo“, Udine, str. 59-63.

\section{8}

59 Še enkrat o krajevnem imenu Mavhinje, Linu Legiši v spomin, Slavistična revija, Ljubljana, 36, št. 1, str. 120.

60 Tersko lánta, Lánta, Jezik in slovstvo, Ljubljana, 34, 1988/89, št. 4-5, str. 88.

61 La $i$ parassita nello sloveno triestino, Linguistica, Ljubljana, XXVIII, str. $53-54$.

\section{9}

62 I nomi delle acque in Val Rosandra, Alpi Giulie, Trieste, 83/1, str. 20-22.

63 Tehtanja in mnenja, Linguistica, Ljubljana, XXIX, str. 147.

64 Odprto pismo Janezu Kebru, Primorska srečanja, Nova Gorica, št. 95-96, str. 299-301.

1990

65 La toponomastica del comune di Duino Aurisina, Ricerca 1989, Comune di Duino Aurisina, 180 str.

\section{1}

66 Il dialetto e le radici di una cultura, Lusevera nell'Alta val Torre, Comune di Lusevera, str. 147-160.

67 Onomastica tergestina nel Trecento, Linguistica, Ljubljana, XXXI, str. 317324.

68 Odprto pismo uredniškemu odboru Slovenskega pravopisa SAZU, Primorska srečanja, Nova Gorica, št. 127, str. 975-976.

69 Percedo(1), Alpi Giulie, Trieste, 84/2, str. 109-112.

70 I nomi primari del monte S. Leonardo e del monte Lanaro: Lípnik e Vólnik, Alpi Giulie, Trieste, 85/1-2, str. 38-41.

71 Krajevno imenoslovje na Tržaškem, Zgodovinski časopis, Ljubljana, 45, št. 4, str. 565-580.

\section{2}

72 Šempolaj, Zgonik, Križ, Devin in Prosek s Kontovelom v dokumentu iz leta 1525, Jadranski koledar 1992, ZTT, Trst, str. 107-115. 
73 In memoriam: Angelo Cracina (16. 4. 1909-20. 9. 1992), Jezik in slovstvo, Ljubljana, 38, 1992/93, str. 175-176.

74 Prispevek k mikrotoponomastiki tržaške okolice, Slavistična revija, Ljubljana, 40, št. 1, str. 31-41.

75 Sui toponimi del Monte Coste - Kosten, Gradec e monte Voistri - Ostri vrh, Alpi Giulie, Trieste, 86/2, str. 127-128.

76 Kraški $j<$ l' pred polovico XVI. stoletja, Slavistična revija, Ljubljana, 40, št. 1 , str. $120-122$.

77 Imena slovenskih podjetij. Alenka Gložančev: Enobesedna imena slovenskih podjetij, SAZU 1991, 112 str., Primorska srečanja, Nova Gorica, št. 130, str. 159-160. [Recenzija.]

\section{3}

78 Una proposta pratica di scrittura resiana, Fondamenti per una grammatica pratica resiana, Atti della conferenza internazionale tenutasi a Prato di Resia (UD), 11-13 dicembre 1991, a cura di Han Steenwijk, Padova, CLEUP, str. $85-94$.

79 Imensko gnezdo: Grdina, Grdoš, Grdoša, Gerdol, Grdolići, Jadranski koledar 1993, ZTT, Trst, str. 143-144.

80 Svetniki v slovenskem imenoslovju, Mladika, Trst, 168 str.

81 Po našin, primo libro di lettura nel dialetto dell'Alta valle del Torre, illustrato da Jasna Merkù, Comune di Lusevera, 61 str.

\section{4}

82 Il "Libro di perticationi" del Notaro Giusto Ravizza (1525): il testo e l'analisi dei nomi personali, di istituzioni e di luoghi, Devin, Trst, 244 str.

83 Toponomastika občine Zgonik, Znanstvena raziskava 1993, iz italijanščine prevedli Mojca Švab Guštin in Franka Žerjal, Občina Zgonik, 100 str.

84 I cognomi di Roiano, Fabio Zubini, Roiano, Edizioni Italo Svevo, Trieste, str. 359-378.

85 Korespondenti J. Baudouina de Coutrenaya iz Furlanije pod Lečo, Primorska srečanja, Nova Gorica, št. 163, str. 790. [Recenzija knjige Liliane Spinozzi Monai, Dal Friuli alla Russia, mezzo secolo di storia e cultura, in margine all'epistolario (1875-1928) Jan Baudoiun de Courtenay, Udine, 1994, 242 str.]

86 Krajevna imena v števerjanski občini. Vlado Klemše: Krajevna, ledinska in vodna imena v Števerjanu, Gorica, Slovensko planinsko društvo 1993, Primorska srečanja, Nova Gorica, št. 160-161, str. 604.

\section{5}

87 La storia/Zgodovina, Dualità, Aspetti della cultura slovena a Trieste/Dvojnost, aspekti slovenske kulture v Trstu, Comune di Trieste, Settore attività culturali, str. $5-8$.

88 I cognomi della prima metà dell‘ 800 , Fabio Zubini, Gretta, Dalle prime ville 
patrizie De Bonomo e Marenzi, alla Chiesa della Madonna del Carmelo, al moderno sviluppo del rione, Edizioni Italo Svevo, Trieste, str. 171-184.

89 I cognomi di Barcola, Fabio Zubini, Barcola, Edizioni Italo Svevo, Trieste, str. 357-377.

90 Un idronimo ritrovato: Krmiščica, Scritti di linguistica e dialettologia in onore di Giuseppe Francescato, Università degli studi di Trieste, Trieste, str. 213-214.

91 Roberto Dapit, La Slavia friulana. Lingue e culture. Resia, Torre, Natisone. Bibliografia reagionata/Beneška Slovenija. Jezik in kultura. Rezija, Ter, Nadiža. Kritična bibliografija, Cividale - San Pietro al Natisone, Circolo Culturale "Ivan Trinko" - Cooperativa "Lipa", 1995, pp. 146, Ce fastu?, Udine, LXXI/2, str. 331-332. [Recenzija.]

92 Bohobare, Jadranski koledar 1995, ZTT, Trst, str. 151-152.

93 Italijanska izdaja Brižinskih spomenikov, Primorska srečanja, Nova Gorica, št. 166, str. 183.

\section{6}

94 Variacije na "brento", Dežela refoška, Vinogradništvo in vinarstvo slovenske Istre, Zbral in uredil Darko Darovec, Knjižnica Annales 10, Koper, str. 141-148.

95 Predkrščanska slovenska osebna imena v Trstu (1307-1406), Zbornik Brižinski spomeniki, SAZU, Ljubljana, str. 451-455.

96 Interazione linguistica nell'Alta Valle del Torre: isomorfia, eteromorfia e polimorfia, Tarcint e Valadis de Tôr, A cura di G. Ellero, Societât Filologjche Furlane, LXXIII Congres (22. 9. 1996), str. 253-266. [Prevod v slovenščino: Spremešanje jezikov $\mathrm{v}$ terskem besedotvorju: izomorfija, heteromorfija in polimorfija, Logarjev zbornik, referati s 1. mednarodnega dialektološkega simpozija v Mariboru, Zora, Maribor 1999, str. 186-201.]

97 I cognomi e soprannomi di Clastra e Grobbia, San Leonardo, cultura, storia, tradizioni popolari, Centro Friulano di Studi "Ippolito Nievo", Convegno regionale 30. 11. 1996, str. 45-49.

98 Slovenski toponimi med Oglejem in Sočo, Slavistična revija, Ljubljana, 44, št. 1, str. 83-85.

99 La toponomastica, Fabio Zubini, San Giovanni, Edizioni Italo Svevo, Trieste, str. 285-293.

\section{7}

100 Slovenščina, matica naše narodne identitete, Izzivi, Zbornik Drage 1996, str. 144-156.

101 La toponomastica del'Alta Val Torre, Comune di Lusevera, 244 str.

$102 \mathrm{Su}$ alcuni toponimi sloveni in Friuli, Ce fastu?, Udine, LXXIII/1, str. 169172.

103 La toponomastica, Fabio Zubini, Scorcola e Cologna, Edizioni Italo Svevo, Trieste, str. 265-274.

104 La toponomastica di Rozzol, Fabio Zubini, Chiadino e Rozzol, Edizioni Italo Svevo, Trieste, str. 369-375. 
105 L'antroponomastica nell'area di interferenza friulano-slovena, relazione al X Colloquio PATROM di Udine (7-9 ottobre 1996), Rivista Italiana di Onomastica, Roma, III/2, str. 363-370.

\section{8}

106 Onomastica e toponomastica del '300, rkp., predavanje 9. 3. 1998, ki ga je organizirala Italia Nostra v sodelovanju s Centro Permanente di Educazione Ambientale del Provveditorato agli Studi di Trieste "Aspetti di Trieste e del suo territorio nel periodo medievale e preemporiale", 13 str.

\section{9}

107 Slovenska krajevna imena v Italiji, Priročnik/Toponimi sloveni in Italia, Manuale, Mladika, Trst, 123 str. [Recenzija Mitja Skubica, Linguistica, Ljubljana, XLI, 2001, str. 178-180.]

108 Controproiezioni, La Trieste del terzo millennio/Protipogledi na Trst v tretjem tisočletju, Proiezioni - La Trieste del terzo millennio/Pogledi na Trst v tretjem tisočletju, Gruppo 85/Skupina 85, Hammerle Editori in Trieste, str. 64-67.

109 La toponomastica di Santa Maria Maddalena, Toponimi e microtoponimi, Fabio Zubini, S. Maria Maddalena Superiore e Inferiore e Zaule, Edizioni Italo Svevo, Trieste, str. 325-338.

110 Marino Bonifacio, Cognomi dell'Istria, Rivista Italiana di Onomastica, Roma, V/1, str. 184-186. [Recenzija.]

111 Vlado Klemše, S Poklona do Toplice - Krajevna, ledinska, vodna in druga imena $v$ Štmavru, Pevmi in Oslavju, Rivista Italiana di Onomastica, Roma, V/1, str. 211. [Recenzija.]

112 Roma nel lessico e nella fraseologia sloveni, Rivista Italiana di Onomastica, Roma, V/2, str. 478-479.

113 Unejci, Onejci ali Vnejci?, Traditiones, SAZU, Ljubljana, 28/1, str. 309-310.

2000

114 Cornelio Cesare Desinan, Le varianti dei nomi di luogo, Rivista Italiana di Onomastica, Roma, VI/1, str. 179-180. [Recenzija.]

115 Roberto Dapit, Aspetti di cultura resiana nei nomi di luogo I-II, Rivista Italiana di Onomastica, Roma, VI/1, str. 183-184. [Recenzija.]

116 Franco Finco, La toponomastica del comune di San Vito al Torre, Rivista Italiana di Onomastica, VI/1, 184-185. [Recenzija.]

117 Trieste: da Lùnedi a Kòsovel, Linguistica, Ljubljana, XL/1, str. 101-102.

2001

118 Appartengo alla minoranza di triestini che non rinuncia a nessuna parte di sé, Il Piccolo, Trieste, 17. 4. 2001, str. 17.

119 La datazione dei toponimi slavi in Friuli: problematiche e ipotesi, Paolo Diacono e il Friuli altomedievale (secc. VI-X), Atti del XIV Congresso internazionale di studi sull'Alto Medioevo, Cividale del Friuli - Bottenicco di Moimacco 24-29 
settembre 1999, Tomo secondo, Centro Italiano di Studi sull'Alto Medioevo, Spoleto, str. 697-712.

120 La presenza slovena nella città preemporiale, Storia economica e sociale di Trieste I, La città dei gruppi 1719-1918, Ed. R. Finzi \& G. Panjek, Lint, Trieste, str. 273-291.

121 Pokelca, slovensko ime, ki ga nihče ne pozna, Koledar 2002, Goriška Mohorjeva družba, Gorica, 2001, str. 100-101. [Ponatis v 142.]

2002

122 Sonja Grizila: Volkojebec in druge (ne)živali, Jana, Ljubljana, 31, 19. 3. 2002 , str. 36. [Intervju.]

123 Slovensko imenoslovje v Italiji, Słowiańska onomastyka, Encyklopedia, tom I, Warszawa-Kraków, str. 258-259. [Ponatis: Jezikoslovni zapiski, Ljubljana, 8/2, str. 133-136.]

1245 domande sul tema: Identità e sradicamenti, Almanacco del Ramo d'oro, anno 1 n. 1/2, Il Ramo d'Oro Editore, Trieste, str. 63-66.

125 I più antichi cognomi sloveni a Trieste: problematiche e realtà, Rivista Italiana di Onomastica, Roma, VIII/2, str. 381-392.

126 Devinski prisežni obrazec z začetka 17. stoletja, Jezikoslovni zapiski, Ljubljana, 8/1, str. $153-156$.

127 Un'oasi germanofona medievale sul carso triestino? Scritti offerti a Mario Doria in occasione del suo $80^{\circ}$ compleanno, Università degli Studi di Trieste, Quaderni di italianistica 4, Trieste, str. 121-123.

128 Novemu Slovenskemu pravopisu ob rob: Čao, lubi Slovenci, Kras, Ljubljana, junij 2002, str. 32.

129 Novemu Slovenskemu pravopisu ob rob: Proti zgodovini, Kras, Ljubljana, avgust 2002, str. 32-33. [Toporišičev odgovor: Proti zgodovini? Pavle Merkù o Slovenskem pravopisu 2002, Kras, Ljubljana, oktober 2002, str. 62-64.]

$130 \mathrm{La}$ toponomastica quale fonte di storia medioevale, rkp., Aspetti della ricerca toponimica, $\mathrm{II}^{\circ}$ Convegno di toponomastica friulana, Colloredo di Montalbano, Udine, 22.-23. november, 9 str. [V tisku.]

\section{3}

131 Bernard Nežmah: V svetu najzahodnejšega Slovenca, Mladina, Ljubljana, 21. 7. 2003, str. 40-44. [Intervju.]

132 La metodologia dell'opera/Metodologija dela, Maurizio Puntin, Toponomastica storica del Territorio di Monfalcone e del comune moderno di Sagrado, Centro Isontino di Ricerca e Documentazione Storica e Sociale "Leopoldo Gasparini", Gradisca d'Isonzo, str. 11-14. [Uvodna beseda.]

133 Roberto Dapit, Cognomi e nomi di famiglia dell'Alta val Torre, Rivista Italiana di Onomastica, Roma, IX/1, str. 303-304. [Recenzija.]

134 Enos Costantini, Dizionario dei cognomi del Friuli, Rivista Italiana di Onomastica, Roma, IX/2, str. 667-668. [Recenzija.] 
2004

1351300 primorskih priimkov, Mladika, Trst, 109 str.

136 Nomi di persone e luoghi nei codici medioevali del capitolo di San Giusto di Trieste, rkp., 585 str.

137 Il mio impegno nella ricerca toponomastica tra sloveno e friulano dall'alto Medioevo a oggi, rkp., prispevek za "Slavia Dilecta", Ricerche linguistiche ed antropologiche tra Friuli e Slovenia, Convegno, Udine, 7. maj 2004.

138 Krajevna imena v katastrski občini Polica v občini Cerkno, rkp.

139 Appunti di metodologia toponomastica nell'area di interazione slovena-friulana, rkp. [V avtorjevi odsotnosti z naslovom Le presenze slave nel Goriziano (Slovanska prisotnost na Goriškem) predstavljeno na simpoziju "Semenzis", Storia lingua e paesaggio nella toponomastica del Friuli orientale, 27. novembra 2004 v Romansu d'Isonzo, v tisku.]

140 Toponomastični ocvirki (Štanjel na Krasu, Igoụca, Križ, Sətú/Svetó), Jezikoslovni zapiski, Ljubljana, 10/2, str. 147-150.

141 Bernard Nežmah: Prof. Pavle Merkù, Izvori priimkov, Mladina, Ljubljana, 17. 5. 2004, str. 76. [Intervju.]

2005

142 Od babe do smrti, Bogastvo slovenskega besedja, Mladika, Trst, 36 str.

143 Študiji na pot, Vlado Klemše, Lucinis, Podgora, Štandrež, Krajevna, ledinska, vodna in druga imena v katastrskih listinah, Gorica, 2005. [Uvodna beseda.]

144 I nons dai paîs tes lenghis de regjon/Krajevna imena v jezikih naše dežele, I paîs de Patrie, Dizionariut toponomastic furlan / italiano / slovensko / deutsch, Par cure di S. Campigotto, S. dai Fantis, P. Merkù, L. Nazzi, R. Urban, Supliment a la "la Patrie dal Friûl" 3, Glemone, str. 3-4.

145 Darka Zvonar Predan: Od babe do smrti, vmes pa Pokelca, Večer, Maribor, 11. 6. 205, str. 42. [Intervju.]

2006

146 Il cognome Slataper, Rivista Italiana di Onomastica, Roma, XII/2, str. 490 493.

147 Krajevno imenoslovje na slovenskem zahodu, ur. M. Furlan in S. Torkar, Založba ZRC, Ljubljana, 215 str.

148 Bernard Nežmah: Od Oćenaša do Pizdine, Mladina, Ljubljana, 9. 12. 2006, str. 52-53. [Intervju.]

2007

149 Microtoponimi, Il bosco Igouza, Storia, natura e sentieri, Trieste, str. 143147.

150 Il dialetto di Maserolis. [Uvodna beseda. V tisku.]

Izdelala Metka Furlan 


\title{
Primeri nekaj sklanjatev in spregatev v Megiserjevem Dictionarium quatuor linguarum \\ 1592 - druga slovnica slovenskega jezika
}

\author{
Kozma Ahačič (Ljubljana)
}

IZVLEČEK: Megiserjevo malo slovnico (oziroma zbirko paradigem) iz leta 1592 lahko utemeljeno označujemo kot drugo slovnico slovenskega jezika in prvo večjezično slovnico, ki vsebuje tudi slovenski jezik. Prispevek prikazuje probleme, s katerimi se je spopadal Megiser, in opozarja na njegove izvirne rešitve.

ABSTRACT: Hieronim Megiser's concise grammar (or collection of paradigms) of 1592 can legitimately be characterized as the second grammar of the Slovenian language and the first multilingual grammar containing Slovenian. This article demonstrates the issues Megiser dealt with and draws attention to his original approach.

0 Megiser je svojemu štirijezičnemu slovarju iz leta 1592 (MD 1592) dodal Appendix, ki ga je poimenoval Primeri nekaj sklanjatev in spregatev (Exempla aliquot declinationum et coniugationium). Tak dodatek slovarju, ki za tedanje slovarje (ti so sicer radi bralcem prinašali razne »dodatke«) tudi nasploh ni običajen, je za nas še toliko zanimivejši, ker kljub svoji kratkosti predstavlja drugo slovnico, ki obravnava (tudi) slovenski jezik.

Mala slovnica štirih jezikov (nemškega, latinskega, slovenskega in italijanskega) prinaša paradigme sklanjatev in spregatev treh skupin pregibnih besed: imen (skupaj s členi), zaimkov in glagolov: takšne, od nepregibnih oblik ločene obravnave smo vajeni že vse od antike.

Za razliko od Bohoričeve slovnice so Megiserjeve paradigme strogo omejene na najnujnejše podatke o pregibanju besed in ne prinašajo teoretičnih opisov. Njihov namen je predvsem praktičen: podati osnovne podatke o vedênju besed, ki spreminjajo prvotno obliko, kakor je navedena v slovarju. Tako je povsem logično, da slovnica ne zajema nepregibnih oblik (ki jih najdemo v slovarju) in deležnikov (ki se sklanjajo enako kot pridevniki).

Megiserjeve paradigme so pomembne tudi zato, ker nam še jasneje prikažejo tedanji pogled na opisovanje sklanjatev in spregatev, kakor ga lahko opazujemo $\mathrm{v}$ slovnici Adama Bohoriča (BH 1584). ${ }^{1} \mathrm{~V}$ tej mali slovnici namreč še očitneje pride do

1 Prim. npr. Ahačič $(2006,139-145)$. 
izraza težnja po opisu skupnih značilnosti in po izogibanju razlikam v posameznih jezikih. Kot bomo videli v nadaljevanju, paradigme niso izbrane nepremišljeno in na nek način upoštevajo značilnosti vseh štirih obravnavanih jezikov ter se jim prilagajajo. Ta kratki dodatek zato predstavlja tudi enega prvih premišljenih poizkusov primerjalne slovnice več jezikov, v katerega je bila vključena slovenščina, pa tudi enega prvih nasploh..

Iz kakšnih vzgibov in pod čigavim vplivom je nastala omenjena slovnica? Megiserja je že v mladosti navdušila misel, da bi opisal dvainsedemdeset poglavitnih jezikov in narečij sveta. Povod za Megiserjevo navdušenje je skoraj gotovo predstavljalo delo Mithridates Conrada Gesnerja (Gesner 1555), ki je opisovalo »vse« tedanje svetovne jezike. V uvodu v MTh 1603, ki je končni rezultat te mladostniške želje, Megiser pravi:

»Pred mnogimi leti, ko sem bil skoraj še mladenič, sem začel za lastno uporabo sestavljati Priročnik ali nekakšen Uvod v dvainsedemdeset poglavitnih jezikov in narečij vsega sveta; pri tem sem mislil na to, da bi to delo kdaj zagledalo luč sveta."

Delo je nameraval razdeliti na dva dela:

»In sicer sem ga razdelil tako, da prvi del vsebuje navodila - pravopisna navodila o posebnih značilnostih posameznih jezikov in narečij, navodila o pravilnem načinu pisave in izgovorjave, kakor tudi etimološka in sintaktična navodila, o načinu pregibanja besed in izrazov in o njihovem medsebojnem povezovanju. Drugi del - to pa je ravno slovar, ki ga zdaj objavljam - pa vsebuje samo primere posameznih govorov, kolikor mi jih je bilo kdaj znanih. /.../ Zaradi gmotne stiske in težav (kajti izdelava tiskarskih znakov in nabava figur bi spričo tako različnih jezikov in pisav terjala previsoke stroške) sem moral izdajo prvega dela, ki sem ga omenil, za sedaj odložiti« (Stabej 1977, xvii, prevedel Kajetan Gantar).

Megiser si je torej ob svojem slovaropisnem delu vzporedno prizadeval tudi za slovnični opis jezikov, s katerimi je prišel v stik. Paradigme, kot jih beremo na koncu MD 1592, pa niso nič drugega kot v navedenem odlomku omenjena »etimološka navodila o načinu pregibanja besed in izrazov«.

Drobna Megiserjeva slovnica v MD 1592 ni bila v dosedanji literaturi deležna večje pozornosti. Kopitar $(1808,435)$ pravi o njej naslednje:

»Na zadnjih dveh polah [slovarja] so Exempla aliquot Declinationum et Conjugationum, brez orodnika in mestnika, celo brez dvojine, ki jo je podal že Bohorič. $\ll^{2}$

Tudi Ramovšu $(1971,223)$ se v rokopisni Zgodovini slovenske slovnice zdijo Megiserjevi »slovniški odlomki« nepomembni:

»Kakor Bohoričeva slovnica, tako so tudi drugi prvi gramatikalični poizkusi ostali osamljeni, pozabljeni in bili brez vpliva. Mislim tudi na slovniške odlomke Megiserjevega slovarja (1. 1592), ki stoje še mnogo za Bohoričem, ker

$2 »$ Das Dictionarium ist gerade ein Alphabet stark: auf den letzten 2 Bogen sind Exempla aliquot Declinationum et Conjugationum, ohne den Instrumental- und Local-Casus, sogar ohne den Dual, den doch Bohorizh schon gegeben hatte.» 
jih je pisal prvič nedomačin in drugič, ker se naslanjajo na narečje, ne književni jezik.«

Podobno kot Kopitar pišeta tudi Lägreid (1967, vi-vii) 3 in Lukman (1933, 86). ${ }^{4}$ Mnogi drugi, ki pišejo o MD 1592, slovnice ne omenjajo.

\section{Nomen - ime (MD 1592: Y 1a-Y 3b)}

MD 1592: Y 1a-Y 3b declinationes articulorum et nominum (sklanjatve členov in imen)

articulus + nomen [substantivum]

(člen + samostalnik)

[masculinum (moški spol)]

1. der Herr - dominus - ta gofpud-il Signore

2. der Vatter - pater - ta ozha - il padre

[femininum (ženski spol)]

1. die Fraw - domina - ta gospa-la signora

2. die Mutter-mater - ta mati - la madre articulus + nomen [adiectivum]

(člen + pridevnik)

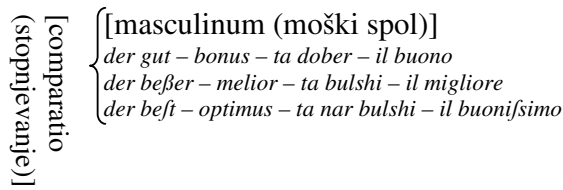

Na prvi pogled nam gornja izbira primerov in razporeditev »sklanjatev« deluje nenavadno, vendar moramo upoštevati možnosti in predvsem omejitve, ki jih je Megiserju nalagal sočasni opis paradigem štirih jezikov. Očitno je, da je Megiser izpuščal vse paradigme, ki ne bi bile izvedljive v vseh štirih jezikih:

1. dvojino slovenskih imen je izpustil, ker je nimajo preostali trije jeziki;

2. paradigmo samostalnikov srednjega spola je izpustil, ker je nima italijanščina;

3. ker je pri paradigmi samostalnikov izpustil samostalnike srednjega spola, pri paradigmi pridevnikov navaja zgolj primer za moški spol.

Izpustil je tudi člen ob latinskih imenih, kar je bilo vsekakor zavestno dejanje pod vplivom tedanjih modernejših latinskih slovnic. Enako zavestno je (verjetno pod vplivom Bohoričevih rešitev v slovnici) pustil člen ob slovenskih sklanjatvah. Da bi člen ob latinskih primerih izpuščal zaradi pomanjkanja prostora, ni verjetno, saj deli slovenske in italijanske primere na dve vrstici, latinskih pa ne, čeprav bi jih glede na razpoložljivi prostor lahko.

A zakaj navaja Megiser po dve paradigmi za moški in po dve za ženski spol? Gotovo ne zaradi italijanskih primerov, saj je paradigma besede il signore identična s paradigmo il padre, paradigma la signora pa s paradigmo la madre. Latinščina ločuje pet deklinacij, tako da v tem primeru tudi ni bila merodajna.

3 »Dem Wörterbuch fügt Megiser eine kleine, 30 Seiten umfassende, Grammatik bei: »Dictionarii quatuor linguarum Hieronymi Megiseri, Appendix. Exempla aliquot declinationum et conjugationum. « Dieser Anhang enthält einige Declinations- und Konjugationsbeispiele, die Megiser der Grammatik von Bohorič entnommen hat, wobei er allerdings den Instrumental und Lokativ ausläßt, sowie den Dual, den Bohorič anführt.《

4 »Megiser je iz Bohoričeve slovnice izpisal tudi primere za sklanjatev in spregatev.» 
$\hookrightarrow \quad$ Bohorič ločuje v BH 1584 paradigme glede na spole in Megiser prevzema tako Bohoričev primer za moški (ta ozha) kakor tudi ženski spol (ta mati). Za dodatna dva primera se je tako najverjetneje odločil zaradi nemške situacije. Primera der Vatter in die Mutter namreč ne pokrivata vseh deklinacij, kakor so jih opisovali tedanji nemški slovničarji. Megiser se pri tem ni mogel ozirati na Clajevo slovnico (Clajus 1578), ki ločuje sklanjatve podobno kot Bohorič glede na spol, ampak je imel najverjetneje pred očmi Albertovo (1573, F 8a-G 5b) ali Ölingerjevo (1574, 55-72). Po Albertu bi namreč der Vatter spadal v drugo sklanjatev, die Mutter v tretjo, dodana primera der Herr in die Fraw pa v prvo sklanjatev. Podobno sodita der Herr in die Fraw v prvo sklanjatev pri Ölingerju, ki celo navaja polni paradigmi teh dveh besed z latinskim prevodom (Ölinger 1574, 56-57). Kar se tiče tedanjega pogleda na nemški sistem sklanjatev, ni Megiser izpustil prav ničesar!

Res pa je, da je Megiserjeva paradigma imen ta gofpud in ta gospa do te mere različna od paradigme imen ta ozha in ta mati, da se nam lahko kot utemeljena kaže tudi izbira slovenskih primerov. $\mathrm{V}$ dodanih primerih bi lahko brali celo nekakšno skrito kritiko Bohoričevih paradigem. Vendar moramo Bohoriču v bran povedati vsaj to, da je sklanjatev gospud, gospudi itd. vse do DB 1584 in ponekod pri slovenskih protestantih tudi dlje tekla vzporedno ob sklanjatvi gospud, gospoda itd. (tako sklanja denimo DB 1578). Paradigma besede gospa pa je v celoti netipična in zato malo primerna kot zgled.

Paradigmi ta ozha in ta mati se v celoti naslanjata na Bohoričevo predlogo, kar vidimo predvsem iz dvojnic. Megiser jih je večinoma upošteval, izpustil je le rod. mn. ozhet in ozhov, loč. mn. ozhetov, ozhet in ozhov ter rod. mn. mater. Edina prava razlika med Bohoričem in Megiserjem je loč. mn. od tih materih pri Megiserju.

Paradigmi ta gospud in ta gospa, ki ju pri Bohoriču ni, nimata nobenih dvojnic, čeprav bi jih - kot sem že omenil - lahko imela. Tožilnik ta gospa je napaka.

Sklanjatev člena pri Megiserju sledi Bohoričevi z enim samim odstopanjem: zgolj pri sklanjatvi ta gospa rabi dajalnik ednine tej namesto ti, ki ga sicer rabi pri sklanjatvi ta mater.

Sklanjatev pridevnika je predstavljena samo z moškim spolom, najverjetneje spet zato, ker srednjega spola zaradi italijanščine ni moglo biti, moški in ženski spol pa se v nemščini, če izvzamemo določni člen, razlikujeta le v dveh oblikah. Za takšne prikaze netipična je združitev prikaza stopnjevanja pridevnika s prikazom sklanjanja. Kar ne moremo se znebiti občutka, da je Megiser s tremi stopnjami pridevnika skušal nadomestiti (pričakovane) tri spole pridevnika. 


\section{Pronomen - zaimek (MD 1592: Y 4a-Y 6b)}

MD 1592: Y 4a-Y 6b

declinationes pronominum

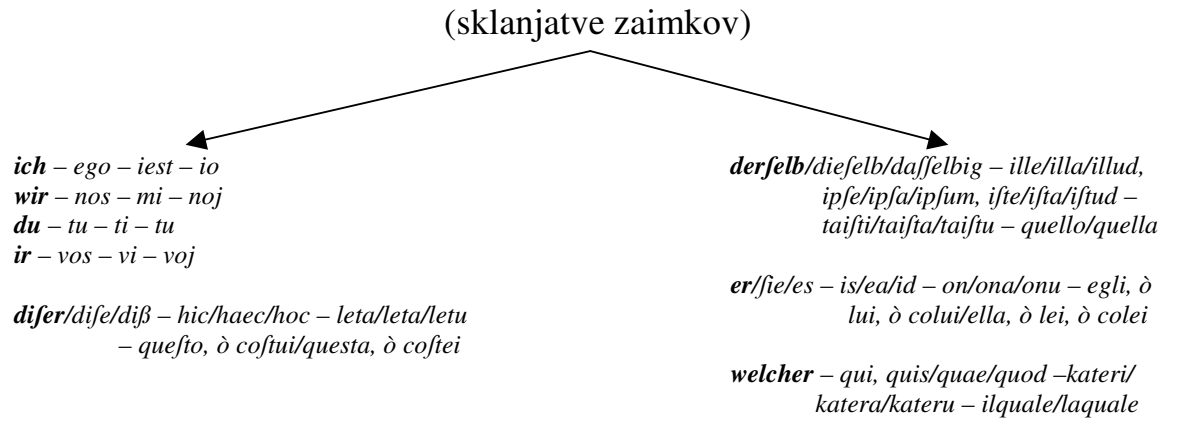

Zaporedje sklanjatev zaimkov pri Megiserju ne sledi v celoti ne Bohoriču ne zaporedju v kateri od nemških slovnic ali Donatu, vendar je razlika samo v drugačni poziciji zaimka hic in v v tem, da manjkajo osebni svojilni zaimki in sestavljeni zaimki - torej tisti, ki jih lahko sklanjamo tudi na podlagi prej navedenih paradigem.

Razlik med Bohoričevimi in Megiserjevimi paradigmami je tako malo, da lahko sklepamo, da je Megiser z razmislekom sledil Bohoriču. Pri Megiserju glede na Bohoriča:

- manjkata okrajšani tožilnik me in te v slovenščini,

- manjka povratni osebni zaimek febe,

- ni oblike od tih iftih za ločilnik srednjega spola množine, ampak ima za vse spole od tehiftih.

Poleg tega navaja Megiser zvalnik za razliko od Bohoriča samo takrat, ko oblika dejansko obstaja (v latinščini): torej zgolj pri osebnih zaimkih za drugo osebo: tu (ti) in vos (vi).

Pri Megiserju je še bolj kot pri Bohoriču očitna razlika med členom ta (der) in kazalnim zaimkom leta (difer), saj Megiser kazalni zaimek leta-difer sklanja v celoti, Bohorič pa le omeni njegov obstoj (BH 1584, 83): »Slovenci namreč rabijo zaimke ta, taifti, vni kot kazalne zaimke, kadar jim predpostavijo členico le. $\aleph^{5}$

Sklanjatev zaimka leta pri Megiserju sicer sledi Bohoričevi sklanjatvi člena ta, le da so oblike za tri spole kakor tudi sicer pri zaimkih navedene skupaj za vsak sklon (spet zaradi italijanščine, kjer bi manjkala oblika za srednji spol).

Odnos med slovenskimi zaimki in njihovimi latinskimi prevodi je pri Bohoriču in Megiserju enak, le da Bohorič navaja kot prevod zaimka on še latinski ille, Megiser pa ne, in da Bohorič zaimek kateri prevaja v nemščino kot wer, Megiser pa ima nemško izhodišče welcher.

5 »Vtuntur etiam Slavonici pronominibus, ta, taifti, vni, pro demonftratiuis, praepofita illis, particula, LE.« 
3 Verbum - glagol (MD 1592, Y 7a-Z 8a)

\begin{tabular}{|c|c|c|c|c|c|c|c|}
\hline MD 1592: Y 7a-Z 8a & $\begin{array}{c}\text { coniugatione } \\
\text { (spregatve }\end{array}$ & $\begin{array}{l}\text { ve } \\
\text { ag }\end{array}$ & & & & & \\
\hline indikativ prezenta & jest imam (ich hab, habeo, io ho) & & & & & & \\
\hline indikativ imperfekta & $\begin{array}{l}\text { sem imel (ich hatte, habebam, } \\
\text { havevo) }\end{array}$ & $\frac{2}{5}$ & $\stackrel{2}{\Xi}$ & 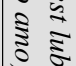 & 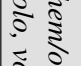 & 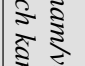 & $\frac{5}{5}$ \\
\hline indikativ perfekta & $\begin{array}{l}\text { sem imel (ich hab gehabt, habui, } \\
\text { io ha havuto/hebbi) }\end{array}$ & $\frac{\sqrt{2}}{2}$ & $\stackrel{-1}{\lessgtr}$ & 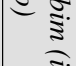 & 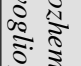 & 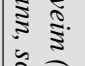 & $\sqrt{5} \frac{2}{5}$ \\
\hline $\begin{array}{l}\text { indikativ } \\
\text { pluskvamperfekta }\end{array}$ & $\begin{array}{l}\text { sem imel (ich hatte gehabt, } \\
\text { habueram, haveve havuto) }\end{array}$ & $\underset{5}{5}$ & $\frac{\mathfrak{2}}{\tilde{2}}$ & $\frac{\overline{2}}{\frac{\pi}{2}}$ & $\frac{\frac{9}{2}}{2}$ & ๖. & $\frac{2}{\frac{2}{2}}$ \\
\hline futur & $\begin{array}{l}\text { jest bom imel (ich wirdt haben, } \\
\text { habebo, haverò/harò) }\end{array}$ & 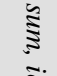 & $\frac{a}{a}$ & $\begin{array}{l}3 \\
8 \\
3\end{array}$ & & $\int \frac{\pi}{2}$ & $\frac{5}{\infty}$ \\
\hline imperativ & $\begin{array}{l}\text { ime ti (hab du, habe/habeto, habbi } \\
\text { tu) itd. }\end{array}$ & $\tilde{\Xi}$ & $\begin{array}{l}0 \\
8 \\
8\end{array}$ & & & & s \\
\hline $\begin{array}{l}\text { konjunktiv } \\
\text { (subjunktiv) prezenta }\end{array}$ & $\begin{array}{l}\text { kadar jest imam (ich habe, } \\
\text { habeas, habbia jo) }\end{array}$ & & 2 & & & & \\
\hline optativ & $\begin{array}{l}\text { debi jest imel (ich hette, haberem, } \\
\text { habe/haveria/have/si) }\end{array}$ & & & & & & \\
\hline $\begin{array}{l}\text { konjunktiv } \\
\text { (subjunktiv) perfekta }\end{array}$ & $\begin{array}{l}\text { aku sem jest bil imel (ich habe } \\
\text { gehabt, habuerim, habbia jo } \\
\text { havuto) }\end{array}$ & & & & & & \\
\hline $\begin{array}{l}\text { konjunktiv } \\
\text { (subjunktiv) } \\
\text { pluskvamperfekta }\end{array}$ & $\begin{array}{l}\text { aku fem jest bil imel (ich hette } \\
\text { gehabt, habui/sem, havrei ò } \\
\text { have/si havuto) }\end{array}$ & & & & & & \\
\hline $\begin{array}{l}\text { konjunktiv } \\
\text { (subjunktiv) futura }\end{array}$ & $\begin{array}{l}\text { kadar jest bom imel (ich würde } \\
\text { haben, habuero, haverò havuto) }\end{array}$ & & & & & & \\
\hline infinitiv & imejti (haben, habere, havere) & & & & & & \\
\hline
\end{tabular}

Pri paradigmah slovenskih glagolov se Megiser zelo verjetno naslanja na Bohoričeve paradigme, čeprav je tudi tu v vrstnem redu samostojen (»optativ« stoji med konjunktivom prezenta in perfekta, pri Bohoriču pa pred obema), saj je vrstni red dobil s kombiniranjem različnih paradigem $\mathrm{v}$ štirih jezikih.

Najlepše se Bohoričev vpliv kaže pri načinu izražanja konjunktiva (subjunktiva) in optativa, ki ju slovenščina sicer nima - tako kot ju nima tudi nemščina. Megiser namreč rabi po Bohoriču kot znamenje za konjunktiv veznika $a k u$ ali kadar (Bohorič ima v paradigmah sicer dosledno samo $a k u$, a dopušča tudi kadar), kot znamenje za optativ pa debi (Bohorič ima dosledno o debi). Toliko bolj zanimivo je, da nemški »konjunktivi« in »optativi« takih znamenj nimajo, čeprav so bila običajno tudi v slovnicah nemškega jezika (ach ali wolte Gott das za optativ ter wie/als/wann/so/da itd. za konjunktiv). Ölinger $(1574,119)$ celo poudarja, da razlike med optativom ter konjunktivom ni - razen v vezniku.

Kljub naslonitvi na Bohoriča pa Megiserju kot izhodiščni jezik za tvorbo časov najverjetneje služi latinščina. To po eni strani lahko razberemo iz dejstva, da v slovenskem delu paradigem zaradi narave ostalih treh jezikov kar trikrat ponovi isto skupino oblik (sem bil, si bil itd.), saj ustrezajo nemškemu, italijanskemu in latinskemu imperfektu, perfektu in pluskvamperfektu.

Po drugi strani pa so od posamezne latinske besede odvisni tudi pomeni v drugih jezikih: latinski glagol scio Megiser na primer prevaja s po dvema ustrezni- 
cama v nemščino in slovenščino (ich weiß/ich kann, snam/veim), latinski glagol eo pa v slovenščino, deloma tudi v italijanščino (grem/hodim, vo/vado). Skratka, lepo tečejo le latinske paradigme.

Dokaj nenavaden je izbor primerov. V tako zgoščeni zbirki paradigem primeri ponavadi niso izbrani brez premisleka - Megiserjevi primeri pa so nanizani navidez brez glave in repa. Pa vendar se moramo vprašati, po kakšnem kriteriju so bili primeri izbrani: je skušal Megiser podati pregled konjugacij? Slovenski primeri ne sledijo Bohoričevim v BH 1584, nemških pa ne najdemo kot osnovne primere $\mathrm{v}$ nobeni od tedanjih slovnic, ki vključujejo nemščino, in tudi v nobenem od pregledanih dvojezičnih donatov.

Italijanski slovničarji ločujejo običajno dve (Alberti, Fortunio, Dolce), tri (Trissino) do največ pet konjugacij (Giambullari) ${ }^{6}$ in prav zaradi različnih rešitev v slovnicah s pomočjo italijanskega stolpca težko oblikujemo kakršno koli razlago. Naše mnenje je, da italijanski stolpec na izbiro primerov ni imel posebnega vpliva.

Tudi nemški slovničarji konjugacij v današnjem pomenu niso poznali ${ }^{7}$ ali pa so jih ločevali več ter drugače, kot jih najdemo pri Megiserju. ${ }^{8}$

Ločen pregled nam torej ne da nobenih rezultatov. Če gledamo izbor primerov v vseh jezikih hkrati, pa dobimo zanimivo kombinacijo:

\begin{tabular}{|l|l|l|l|}
\hline slovenščina & nemščina & latinščina & primeri \\
\hline pomožni glagol & pomožni glagol & $\begin{array}{l}\text { nepravilni } \\
\text { glagol (verbum } \\
\text { substantivum) }\end{array}$ & jest sem (ich bin, sum, io sono) \\
\hline 1. konjugacija & pomožni glagol & 2. konjugacija & jest imam (ich hab, habeo, io ho) \\
\hline 3. konjugacija & 1. konjugacija & $\begin{array}{l}\text { jest lubim (ich liebe, amo, io } \\
\text { amo) }\end{array}$ \\
\hline 2. konjugacija & nepravilni glagol & $\begin{array}{l}\text { zhem/ozhem (ich will, volo, } \\
\text { voglio) }\end{array}$ \\
\hline $\begin{array}{l}\text { 1. konjugacija/ } \\
\text { 2. konjugacija }\end{array}$ & & 4. konjugacija & $\begin{array}{l}\text { snam/veim (ich weiß/ich } \mathrm{kann}, \\
\text { scio, so) }\end{array}$ \\
\hline $\begin{array}{l}\text { nepravilni } \\
\text { glagol z } \\
\text { bistveno } \\
\text { različnimi } \\
\text { osnovami/ } \\
\text { 3. konjugacija }\end{array}$ & $\begin{array}{l}\text { nepravilni glagol } \\
\text { (deloma po 3. } \\
\text { konjugaciji) }\end{array}$ & $\begin{array}{l}\text { grem/hodim (ich gehe, eo, vo/ } \\
\text { vado) }\end{array}$ \\
\hline
\end{tabular}

6 O tem natančneje tudi v opombi v Giambullari [= Bonomi] 1986, 42.

7 Albertus (1573, H 6b-H 7a) ločuje samo eno konjugacijo, Clajus $(1578,113-114)$ tri konjugacije: aktivno, pasivno inkonjugacijo, ki ni ne eno ne drugo (gre bolj za delitev glagolov po načinu).

8 Ölinger (1574, 96-97) ločuje kar štiri: s predzadnjim zlogom infinitiva 1. na -ei, 2. na -in, 3. na -ie-/-au-/-ä-/-e-, 4. na ostalo. Od tega najdemo pri Megiserju tri, a s popolnoma drugačnimi primeri, kot bi jih želel Ölinger. 
Nemški glagoli so predstavljeni s pomožnikoma sein in haben ter nekaj drugimi glagoli. Italijanski glagoli (ki jih v preglednici ne navajamo zaradi bistveno različnih obravnav v tedanji literaturi) so prav tako predstavljeni s pomožnima glagoloma essere in havere, ki jim sledijo amare, volere, sapere, andare. Prvega slovničarji običajno uvrščajo v prvo konjugacijo, ostali trije primeri pa so nepravilni glagoli, ki jih različni slovničarji obravnavajo različno. Zajete so vse Bohoričeve slovenske konjugacije, slovenski pomožni glagol (ki je posebej spregan tudi pri Bohoriču v BH 1584) ter en nepravilni glagol z bistveno različnimi osnovami. Prav tako so zajete vse latinske konjugacije, manjka samo čist primer za tretjo, ki pa ga »nadomešča deloma nepravilni glagol eo.

Zadnji primer je še posebej zanimiv z vidika slovenščine. Megiser namreč pri oblikah futura ob obliki bom shil pripiše še obliko puidem, za katero izrecno pove, da je bolj v rabi (»sed vfitatius est puidem«). Tako pravilno opažanje je znak zelo dobrega opazovanja jezika in je obenem precej drzno dejanje, saj se oblika puidem itd. obnaša v nasprotju s siceršnjim sistemom.

Kaže, da tudi pri izboru primerov za glagolske paradigme beremo pri Megiserju dobro premišljen kompromis med štirimi jeziki.

Po vsem povedanem lahko Megiserjevo malo slovnico (oziroma »zbirko paradigem«) iz leta 1592 utemeljeno označimo kot drugo slovnico slovenskega jezika in prvo večjezično slovnico, ki vsebuje tudi slovenski jezik.

\section{Viri in literatura}

Ahačič, Kozma, 2006, Nominalna paradigmatika Bohoričeve slovnice v luči evropskega slovničarstva, SR 54/2, 129-153.

Alberti, Leon Battista, 1437-41, Grammatica della lingua toscana, http://www. liberliber.it/biblioteca/a/alberti/grammatica della lingua toscana/html/ grammati.htm.

Albertus, Laurentius, 1573, Teutfch Grammatick oder Sprachkunft. Certissima ratio difcendae, augendae, ornandae, propagandae, conferuandaeque linguae Alemanorum fiue Germanorum, grammaticis regulis et exemplis comprehenfa et confcripta: per Laurentium Albertum Oftrofrancum, Augustae Vindelicorum, Michael Manger.

BH 1584 = Bohorič, Adam, 1584, Arcticae horulae fuccifivae, Wittenberg.

Bonomi, Ilaria, 1986, Pierfrancesco Giambullari: Regole della lingua fiorentina:

Edizione critica, (Grammatiche e lessici pubblicati dall'Accademia della Crusca), Firenze, Accademia.

Clajus, Johannes, 1578, Grammatica germanicae linguae ... ex bibliis Lutheri Germaniis et aliis eius libris collecta, Lipsiae.

Dolce, Lodovico, 1558, I quattro libri delle observationi di messer Lodovico Dolce, Venetia, P. Giolito de Ferr. 
Gesner, Konrad, 1555, Mithridates: De differentiis linguarum tum veterum tum quae hodie apud diverfas nationes in toto orbe terrarum in ufu funt, Conradi Gesneri Tigurini Obfervationes, Tiguri, Froschoverus.

Keil, Heinrich, 1961, Grammatici Latini II-IV, Hildesheim, Georg Olms Verlagsbuchhandlung.

Kopitar, Jernej, 1808, Grammatik der Slavifchen Sprache in Krain, Kärnten und Steyermark, Laibach, Wilhelm Heinrich Korn.

Lägreid, Annelies, 1967, Hieronymus Megiser: Slovenisch-deutsch-lateinisches Wörterbuch: Neugestaltung und Faksimile der ersten Ausgabe aus dem Jahre 1592, (Monumenta linguae Slavicae 7), Wiesbaden, Otto Harrassowitz.

Lukman, Franc Ksav., 1933, Megiser, Hieronim, SBL 2, 85ss.

MD 1592 = Megiser, Hieronymus, 1592, DICTIONARIVM QVATVOR LINGVARVM, Graz.

MTh 1603 = Megiser, Hieronymus, 1603, The faurus Polyglottus, Frankfurt.

Ölinger, Albert, 1574, Underricht der Hoch Teutschen Spraach: Grammatica seu Institutio verae Germanicae linguae ... In usum juventutis maxime Gallicae, ante annos aliquot conscripta ... Cum D. Joan. Sturmii sententia, de cognitione et exercitatione linguarum nostri saeculi, Argentorati, Nicolaus Vvyriot.

Ramovš, Fran, 1971, Zbrano delo: prva knjiga, (Dela SAZU, razred za filološke in literarne vede, Inštitut za slovenski jezik), Ljubljana, SAZU.

Stabej, Jože, 1977, Hieronymus Megiser: Thesaurus polyglottus: Iz njega je slovensko besedje z latinskimi in nemškimi pomeni za slovensko-latinsko-nemški slovar izpisal in uredil Jože Stabej, (Dela/opera 32), Ljubljana, SAZU.

Trissino, Giangiorgio, 1729, Tutte le opere di Giovan Giorgio Trissino gentiluomo Vicentino non piu' raccolte, Verona, Jacopo Vallarsi.

\section{The Concise Grammar of Four Languages in Megiser's 1592 Dictionary Summary}

The appendix with "examples of several declensions and conjugations" (Lat. Exempla aliquot declinationum et coniugationum) in Hieronim Megiser's 1592 quadrilingual dictionary (Dictionarium quatuor linguarum, 1592) can be characterized as a concise grammar of four languages. This concise grammar of German, Latin, Slovenian, and Italian offers declension and conjugation paradigms for three groups of inflected words: substantives (including articles), pronouns, and verbs. This type of presentation, separated from uninflected words, has been known since Antiquity. Although to a certain extent Megiser leans on the paradigms used in Adam Bohorič's grammar, many aspects of his approach are completely independent and subject to the principles of multilingual presentation of inflected word classes. A comparison with the presentations in other 
- European grammars and paradigm collections of that time demonstrates that much of what Megiser did was subject to the demands of multilingual presentation. This was the first multilingual grammar to include Slovenian, and one of the $\rightarrow \quad$ first grammars in general.

Kozma Ahačič

Inštitut za slovenski jezik Frana Ramovša ZRC SAZU

Novi trg 2, Ljubljana

kahacic@zrc-sazu.si 


\title{
Slovansko-romanski jezikovni stik v moližanski hrvaščini: vzporednost s slovenskimi narečji v Furlaniji
}

\author{
Rosanna Benacchio (Padova)
}

IZVLEČEK: V prispevku se avtorica posveti moližanski hrvaščini in obravnava jezikovne (oblikoskladenjske) posebnosti, ki so se razvile zaradi romanske interference, predvsem pa se osredotoča na tiste pojave, ki so prisotni tudi v slovenskih narečjih v Furlaniji. Tako je možno ugotoviti, da je večstoletna izpostavljenost stiku z bližnjim romanskim jezikovnim prostorom često privedla do podobnih sprememb na dveh sicer genetsko sorodnih, a geografsko oddaljenih območjih.

ABSTRACT: This paper examines the dialect of the Croatian linguistic island in Molise and addresses its morphosyntactic features that have developed as the result of Romance-language influence, concentrating in particular on those phenomena also present in Slovene dialects spoken in Friuli. It can thus be demonstrated that centuries of contact with a nearby Romance-language environment often led to similar changes in these two genetically related, but geographically distant, languages.

Znano je, da sta na italijanskem ozemlju prisotni dve slovanski jezikovni manjšini, ki sta stoletja živeli (in še živita) v položaju absolutnega stika ${ }^{1}$ z romanskim jezikovnim svetom: prva, številnejša, živi v vzhodnem delu Furlanije ob italijansko-slovenski meji in je torej neke vrste polotok, nadaljevanje slovenskega jezikovnega prostora, druga, številčno mnogo skromnejša, pa je hrvaška enklava v deželi Molise, ki ima značilnost jezikovnega otoka.

Prvi, ali bolje slovenskim narečjem v Furlaniji, sem doslej posvetila več raziskav, predvsem rezijanščini, a tudi terskim in nadiškim govorom; v njih sem obravnavala predvsem oblikoskladenjske posledice romanske interference (glej predvsem Benacchio 2002).

$\mathrm{V}$ tem prispevku se želim posvetiti moližanski hrvaščini in tudi tu osvetliti jezikovne (oblikoskladenjske) posebnosti, ki so se razvile zaradi romanske interfe-

1 Posrečeni izraz uporablja W. Breu (glej npr. Breu 2003, 28) in kaže na jezikovni stik v pravem pomenu besede, kot se pojavlja v položajih popolne dvojezičnosti, ko se isti ljudje izmenično poslužujejo dveh (ali več) jezikov. 
rence, predvsem pa se nameravam osredotočiti na tiste pojave, ki so prisotni tudi v omenjenih slovenskih narečjih v Furlaniji.

Tako bomo lahko opazili, da je večstoletna izpostavljenost stiku z bližnjim romanskim jezikovnim prostorom često privedla do podobnih sprememb na dveh sicer genetsko sorodnih, a geografsko oddaljenih območjih.

Hrvaške otoke v Molizeju sestavljajo danes naselja Acquaviva-Collecroce (Kruč), San Felice (Filič) in Montemitro (Mundimitar) .

Gre za tri občine z naselji na vrhu treh gričev, ki se nahajajo kakih trideset kilometrov daleč od morja med rekama Trigno in Biferno, v pokrajini Campobasso. Nedaleč od tu, nekoliko proti jugu in onstran reke Biferno, najdemo na drugih gričih občine, ki jih naseljujejo albanske skupnosti (Montecilfone, Portocannone, Campomarino in druge); v preteklosti pogosto niso ločili med prvimi in drugimi.

Za razliko od Slovencev v Furlaniji, ki naj bi se naselili na sedanje ozemlje zelo zgodaj, med koncem VI. in začetkom VII. stoletja, ${ }^{2}$ so srbohrvaške skupnosti v Molizeju prišle na današnje ozemlje v relativno bližnji preteklosti, po turških vdorih na Balkan v prvi polovici XVI. stoletja. To potrjuje tudi vrsta jezikovnih dejstev (glej npr. Rešetar 1997, 31-33).

Selitveni val se je spočetka usmeril na mnogo širše območje od Mark do Apulije, vendar je močneje zajel predel med rekama Pescara in Biferno. Naselbine v Abrucih so bile konec XVIII. stoletja že povsem italianizirane, v Molizeju pa so vztrajale dalj časa: v XVIII. stoletju je bila slovanska govorica prisotna ne le v treh omenjenih občinah, temveč še v drugih bližnjih naseljih: Castelmauro, Tavenna, Mafalda, San Biase, Montelongo, San Giacomo degli Schiavoni, Palata (Capaldo 1959, 59).

Selitveni tok naj bi izhajal iz verjetno obalnega ozemeljskega pasu, ki je ločeval čakavske govore severno od Cetine od štokavsko-jekavskih govorov južno od Neretve (na severu je bila čakavščina, na jugu štokavščina oziroma jekavščina) (Capaldo 1959, 60-61). Tudi v tem primeru podpirajo hipotezo jezikovna opažanja, predvsem pripadnost moližanske hrvaščine štokavsko-ikavski skupini.

Moližanska hrvaščina, ki se označuje tudi kot moližanska slovanščina ali z novejšo skovanko slavizanščina, "slavisano" (W. Breu, Piccoli 2000), je za govorce preprosto "naš jezik" ali "nanašu". 3

Danes je položaj moližanske hrvaščine zelo šibak in negotov, vsekakor mnogo bolj kritičen kot položaj Slovencev v Furlaniji.

Predvsem je v omenjenih krajih zelo malo ljudi: Acquaviva in San Felice štejeta vsak okrog 800 prebivalcev, Montemirto pa le polovico tega. V Montemirtu in

2 Sočasno s selitvami južnih Slovanov. Več o tem v delu Benacchio 2002, 19-20.

3 Podobne oznake so razširjene tudi v slovenskih narečjih v Furlaniji, tako v Reziji - "po näs" - kot v Terski dolini - "po našin". 
Acquavivi govori moližansko hrvaščino le 60/70 \% ljudi, še mnogo nižji je odstotek govorcev v kraju San Felice (ne več kot $10 \%$ ).

Skromne so tudi pobude, ki naj bi zaščitile to jezikovno dediščino, še posebej, če jih primerjamo s tistimi, ki se udejanjajo med Slovenci v Furlaniji.

Po dogovoru s hrvaško vlado je zagotovljen pouk hrvaškega knjižnega jezika v nižji srednji šoli, vendar ne moremo trditi, da je s tem ohranjanje domačega slovanskega govora lažje, saj ta pouk prispeva k izgubi značilnih potez tega govora. Prav zaradi tega niso vsi domačini nad njim navdušeni. Podobno se dogaja, to smo videli, tudi v Reziji (in v manjši meri tudi v Terski dolini), kjer sprejemanje krovnega jezika znotraj skupnosti ni samoumevno, ampak ga spremljajo konflikti.

V šolah, predvsem v osnovni šoli, poučujejo tudi moližansko hrvaščino, vendar so zaradi nizkega števila rojstev oddelki pogosto kombinirani; jasno je, da staršem taka organizacija šole ni pogodu in da torej raje vozijo otroke v šolo drugam, kjer pa je pouk zgolj italijanski.

Če odmislimo zbirke ljudskih besedil, je publikacij v moližanski hrvaščini le malo, čeprav smo v zadnjih desetletjih priča poskusom literarnega in še zlasti pesniškega izražanja, ki se objavljajo predvsem v mesečniku "Comoštra" ${ }^{4}$

Poleg te revije gre med novejšimi publikacijami omeniti le slikovni slovarček za otroke osnovnih šol in izdajo, ki prinaša fotografije in risbe orodja s komentarjem v moližanski hrvaščini (Sime do simena).

V skupnosti torej ne najdemo tiste bogate literarne, predvsem pesniške produkcije, ki je značilna na primer za rezijanščino. Prav tako manjka tudi izročilo cerkvene rabe, ki je danes tako razširjeno med Slovenci v Furlaniji.

Ne glede na vse to so ljudje na svoj jezik zelo navezani in gledajo na današnje stanje z zaskrbljenostjo in obžalovanjem. ${ }^{5}$

Negotov položaj moližanske hrvaščine se zdi povezan predvsem s skromnim številom govorcev. Če pomislimo, da živi danes v Reziji okrog 1300 govorcev domačega narečja, v Terski dolini okrog 2000 in v Nadiških dolinah okrog 7000 (Benacchio 2002, 65 sl.), lahko v grobem trdimo, da je hrvaška manjšina kar petkrat manjša kot slovenska manjšina v Furlaniji. ${ }^{6}$

Ne samo to, tudi prisotnost mnogo številnejše in strnjene slovenske skupnosti

4 Revija z albanskim imenom "Camastra" objavlja besedila v moližanski hrvaščini in v albanščini. V preteklih desetletjih je kratek čas, od leta 1967 do 1970, izhajal tudi mesečnik "Naš jezik/La nostra lingua"; revija je bila dvojezična (v moližanski hrvaščini in italijanščini) in si je prizadevala za etnični in jezikovni prerod moližanskih Hrvatov, ki se je začenjal v tistih letih.

5 Ta navezanost izhaja še iz starih časov in jo posebej pomenljivo izpričuje izročilo o znanem (in nesrečnem) predstavniku moližanske hrvaške skupnosti, Nicoli Neriju, ki je bil doma iz kraja Acquaviva-Collecroce in je poučeval na Univerzi v Neaplju, a so ga Burboni leta 1799 usmrtili kot italijanskega patriota. Vsakokrat, ko se je Nicola Neri vračal v svojo vas, je venomer ponavljal: "Nemojte zgubit naš jezik!” (Rešetar 1997, 82).

6 Zelo verjetno so moližanski Hrvati bili vedno mnogo manj številni kot tisti v Furlaniji. Selitveni val "čez morje" namreč nikakor ne more zajeti tako velikega števila ljudi kot preseljevanje, ki je predstavljalo 'naravno' naselitev oziroma postopno razširitev na 'obmejna' območja. 
na Tržaškem in Goriškem, ki je zaradi drugačnih zgodovinskih okoliščin ${ }^{7}$ ohranila neokrnjen občutek pripadnosti slovenskemu jeziku in kulturi in vseskozi vzdrževala tesne stike s Slovenci na drugi strani meje, je pozitivno vplivala na položaj in na različne načine spodbujala in podpirala varovanje jezika in kulture Slovencev v Furlaniji ter predstavljala trden, prepričljiv vezni člen med njimi in Slovenci onstran meje.

$* * *$

Prehajam torej k analizi nekaterih jezikovnih (točneje oblikoskladenjskih) dejstev, ki označujejo moližansko hrvaščino in so vezani na romansko interferenco, pri čemer se bom osredotočila predvsem na tiste pojave, ki jih zasledimo tudi v slovenskih narečjih v Furlaniji.

Pri sklanjatvi gre v prvi vrsti opozoriti na izgubo srednjega spola: v moližanski hrvaščini so izvorni samostalniki srednjega spola povsem izginili in prevzeli ženski oziroma moški spol po vzoru ustrezne italijanske besede, tako na primer: im. edn. mor, it. mare; mesa, it. carne (prim. hrvaško more, meso) (Muljačić 1973, 35).

Težnja po ošibitvi srednjega spola je prisotna tudi v rezijanščini. Razvidna je predvsem pri samostalnikih, kjer dobijo množinske oblike srednjih samostalnikov končnice ženske oziroma moške sklanjatve, vedno po vzoru ustrezne italijanske besede. Navajam oblike im. mn. jabulke (< jabulku, it. mela), jajce (< jajcë, it. uovo), jëzaravi (< jëzaru, it. lago).

Podobne pojave zasledimo tudi v terskih in nadiških govorih (Pellegrini 1975, 462-463, Skubic 1997, 62). Še posebno pomenljiv je pojav 'femininizacije' edninskih samostalnikov srednjega spola, ki ga je za nadiške govore opisal Cronia v primerih kot miesta (mesto) in brda (brdo, gora) (Cronia 1950, 324), ker povsem ustreza modelu moližanske hrvaščine.

Tudi izguba zvalnika v moližanski hrvaščini se zdi povezana z romanskim jezikovnim stikom, saj je v standardni hrvaščini ta sklon dobro ohranjen.

Podobno lahko imamo za posledico romanske interference tudi težnjo slovenskih narečij v Furlanji po opuščanju dvojine, ki je v standarni slovenščini dobro ohranjena.

Pri spregatvi so zagotovo vredne pozornosti oblike za pretekli čas. Znano je, da so slovanski jeziki izvorno imeli kompleksen sistem preteklih časov, ki so ga sestavljale tako nesestavljene (aorist, imperfekt) kot sestavljene oblike (perfekt, pluskvamperfekt) in da se je ta sistem s prevlado kategorije glagolskega vida postopoma skrčil vse do ohranitve ene same oblike preteklega časa (perfekta/preteklika). Iz rabe so izginili ne le aorist in imperfekt, temveč tudi pluskvamperfekt, ker je bil sestavljen s pomočjo imperfekta pomožnega glagola. Izvorni sistem preteklih časov je obstal le v bolgarščini (in v makedonščini), svoje sledi pa je pustil tudi v srbohrvaščini in v obeh lužiških srbščinah.

Opozoriti moramo tudi na to, da je v jezikih, ki so v svojem razvoju skrčili sistem preteklih časov, najprej izpadel iz rabe imperfekt in šele pozneje aorist. Tako je 
bilo na primer v ruščini, kjer je imperfekt zelo zgodaj izginil iz rabe, medtem ko se je aorist ohranil dlje. Isto lahko v splošnem trdimo tudi za druge slovanske jezike.

V moližanski hrvaščini pa je, nasprotno, aorist povsem izginil, medtem ko je imperfekt še dobro ohranjen. Naj navedem nekaj primerov: "Bihu na tat aš na mat" (Bila sta oče in mati), "Ova divojk ${ }^{\mathrm{a}}$ restaša lip ${ }^{\mathrm{a}}$, tun ${ }^{\mathrm{a}} \mathrm{ju}$ gledah ${ }^{\mathrm{u}} \mathrm{ka}$ biš naveče lip ${ }^{\mathrm{a}}$ do onga grada" (Ta deklica je lepo rasla, vsi so jo gledali, ker je bila najlepša v tistem kraju) (Breu, Piccoli 2000, 421).

Zelo podobno se nam ta pojav kaže tudi v slovenskih zahodnih narečjih oziroma točneje v rezijanščini (v terskih in nadiških govorih namreč ni sledu o nesestavljenih oblikah izražanja preteklosti).

Tudi v rezijanščini je namreč podobno kot v moližanski hrvaščini aorist izginil, medtem ko se je imperfekt ohranil, čeprav v veliko manjši meri. To se tudi sklada s stanjem v ustreznih standardih, saj je hrvaščina imperfekt nekako ohranila, medtem ko je v slovenščini povsem izginil.

V rezijanščini je torej raba imperfekta danes sporadična in v bistvu omejena na oblike bëše, diwašë, dujajaše, mëšë, morëše, tëšë, ki izhajajo iz glagolov byt (biti), diwat (devati), dujajat (dohajati), mët (imeti), morët (moči), parajat (prihajati), tët (hoteti) (Steenwijk 1992, 138). V 19. stoletju pa je po pričevanjih, ki jih je zbral Baudouin de Courtenay, aorist še obstajal, čeprav je bil občuten kot arhaizem, imperfekt pa je bil še v splošni rabi, podobno kot je danes v moližanski hrvaščini (Baudouin de Courtenay ${ }^{1895)}$.

Še najbolj zanimivo pa je, da se je v obeh primerih, tako v moližanski hrvaščini kot v rezijanščini, od obeh nesestavljenih oblik preteklega časa ohranil prav imperfekt, kar je v nasprotju z razvojno težnjo slovanskih jezikov. Pojav gre vsekakor uokviriti v romansko interferenco. ${ }^{8}$

Na moližansko hrvaščino so verjetno vplivali sosednji italijanski govori "jadranskega pasu", kjer se daljni preteklik (passato remoto) le malo uporablja in ga podobno kot v italijanskih narečjih severno od Pada nadomešča bližnji preteklik (passato prossimo), medtem ko je v ostalih narečjih Abrucov in Molizeja nasprotno.

Podobno je v rezijanščini prav stik s furlanščino in bližnjimi italijanskimi govori (kjer je glagolska oblika za daljni preteklik, ki semantično ustreza aoristu, že zdavnaj šla iz rabe) privedel do 'zgodnejše' izgube aorista, medtem ko se je imperfekt, ki ga omenjene jezikovne variante redno uporabljajo, ohranil več časa.

Romanska interferenca naj bi bila vidna tudi na oblikoslovni ravni: vplivala je namreč na razvoj imperfektovega spregatvenega vzorca, katerega oblike so poenostavljene v primerjavi z izvornimi.

Dejansko se pri imperfektu v moližanski hrvaščini kaže ista težnja, ki je značilna tudi za romanski imperfekt, to je težnja, da se zanj ustvari spregatveni vzorec, ki se od vzorca za sedanjik ne razlikuje po končnicah (ki so enake kot pri sedanjiku), ampak po osnovi, ki je drugačna kot sedanjiška in se ponavlja pri vseh osebah. Naj

8 To podobnost med moližansko hrvaščino in slovenskimi narečji v Furlaniji je opazil že Rešetar v svoji temeljni študiji o slovanskih kolonijah v južni Italiji (Rešetar 1997, 135).

O isti tematiki pišeta tudi Reichenkron 1934 in Breu 1993. 
$\hookrightarrow \quad$ kot primer navedem enotno obliko gredahu za I. os. edn. in III. os. mn. pri različnih vrstah spregatve (Breu, Piccoli 2000, 417-420).

Take poenostavitve so značilne tudi za spregatveni vzorec rezijanskega imperfekta. Oglejmo si na primer za I. os. edn. novo osnovo na -ho, po analogiji z osnovo za I. os. dv. in mn.; ta osnova dobi končnico $-n(<-m)$ po analogiji s sedanjikom (jedehon $<* j e d e h o-m)$. Za novejši čas naj navedemo še posplošitev osnove na -š- za I. os. edn.. (tœšon, poleg tœhon), pa tudi za III. os. mn. (tœšou), po analogiji z II. in III. os. edn. Prav te zadnje oblike predstavljajo že normo, medtem ko so oblike z morfemom -h- občutene kot arhaizmi (Steenwijk 1992, 139).

Tudi ta težnja se zdi v zvezi z jezikovnim stikom z romanskim svetom. V tem smislu so pomenljiva opažanja Ja. Sedlačka v zvezi s podobnimi poenostavljanji, ki se pojavljajo v nekaterih srbskih, zahodno bolgarskih in makedonskih narečjih v trikotniku Sofija-Niš-Skoplje, torej na območju, ki je bilo v preteklosti močno romanizirano in je po mnenju mnogih raziskovalcev eno od glavnih območij nastanka romunščine (Sedlaček 1962, 53). O teh tematikah piše tudi Reichenkron (1934, 331-332).

V zvezi s spregatvijo naj končno spomnimo še na dejstvo, da so tako moližanska hrvaščina kot slovenska narečja v Furlaniji poleg imperfekta ohranili tudi predpreteklik, kar jih spet veže z romanskim jezikovnim prostorom.

Gre za obliko, sestavljeno s pomočjo preteklika pomožnega glagola "biti", ki izraža dejanje iz daljne preteklosti ali preddobnost v preteklosti. Za moližansko hrvaščino naj navedemo vzorec "sa bi pisa, sa bi pisala” (sem bil pisal, sem bila pisala), "si si bi pisa, si bil pisala (si bil pisal, si bila pisala) in tako dalje. In še "Su bi sa vazal brižne brižn" (Poročila sta se bila revna revna) (Breu, Piccoli 2000, 421).

$\mathrm{Na}$ enak način je predpreteklik tvorjen tudi v slovenskih narečjih v Furlaniji. ${ }^{9}$ Na primer v rezijanščini: "na jë muknula; an bil pusikal din fregul" (Obmolknila je; on je bil pokosil le mrvico), "na bila gala süsit kake büle wökul špojerta" (dala je bila sušit perilo okrog štedilnika) (Steenwijk 1992, 182).

Podobno tudi v nadiškem narečju: "Če sœm bila poviedala, j jala, jih je bila zapustila njih mat" (Če sem bila povedala, je rekla, jih je bila mati zapustila) (Baudouin de Courtenay 1998, 88).

In tako tudi v terskem narečju: "si tiela ja sniesti, če nisi biu paršou” (Pojedla bi ga, če nisi bil prišel) (Merkù 1980, 171).

Pri obravnavi skladnje se bom ustavila predvsem pri nekaterih posebnostih v zvezi z rabo naslonk, predvsem naslonskih oblik osebnih zaimkov za odvisne sklone (dajalnik, rodilnik in tožilnik) in sedanjiških naslonskih oblik pomožnika "biti".

Vemo, da za začetna obdobja slovanskih jezikov velja, podobno kot pri drugih indoevropskih jezikih, pravilo, da naslonke ne morejo stati na začetku povedi, ampak stojijo takoj za prvo besedo in se nanjo opirajo. Zato naslonke niso bile sklopljene $\mathrm{z}$ glagolom, s katerim so se vezale, in so lahko stale tudi daleč od njega.

9 V rezijanščini je izpričana tudi druga, bolj arhaična oblika, ki jo sestavljata imperfekt pomožnika "biti" in deležnik na -l ustreznega glagola. Tako na primer.: "ći bëštë vïdïl ai miei tempi, si tratta del cinquanta, da muć jë bilu živïne" (Če bi videli [dobesedno: ste videli] v mojih časih, gre za petdeseta leta, koliko živine je bilo). Glej Benacchio 2002, 86. 
To pravilo, ki je dosledno izpričano v stari cerkveni slovanščini, se je bolj ali manj dosledno obdržalo v tistih slovanskih jezikih, ki so ohranili naslonke, z izjemo bolgarščine in makedonščine; slednji namreč izkazujeta podobne razvojne težnje kot romanski jeziki. Tako v bolgarščini kot v makedonščini namreč drugo mesto $\mathrm{v}$ povedi za naslonke ni več obvezno in se zato naslonke postavljajo zgolj v bližino glagola in to ne glede na to, katero mesto zavzema glagol v povedi. Ne samo to: $\mathrm{v}$ bolgarščini še vedno ostaja prepoved postavljanja naslonk na prvo mesto v povedi, v makedonščini pa tega ni več, tako da so naslonke lahko povsem normalno na samem začetku povedi, kakor se dogaja v sodobnih romanskih jezikih. Na primer: "Go gledam" (Gledam ga), “Ti gi davam” (Dam ti jih), "Sam došol” (Prišel sem) itd.

Zanimivo je, da se tudi v govorih, ki jih obravnavamo $v$ tem prispevku in ki so se razvijali v stiku z romanskimi govori, pojavljajo skladenjska zaporedja, ki niso v skladu s slovanskim vzorcem, ampak se približujejo vzorcem omenjenih balkanskih slovanskih jezikov ali, če hočemo, romanskim vzorcem.

Tudi v moližanski hrvaščini lahko naslonke zasedajo prvo mesto v povedi in so torej proklitične. Oglejmo si primere: "Kralj je vaza sòlda, mu hi da a je reka (Kralj je vzel denar, dal mu ga je in rekel), "Je vazal ${ }^{a}$ nu koštan , ju skorčal a a ju verla u jušta” (Vzel je kostanj, ga olupil in ga dal v usta) (Breu, Piccoli 2000, 423).

Isti besedni red je izpričan tudi za slovenska narečja v Furlaniji. Oglejmo si nekaj primerov iz rezijanščine: "sa diwa muko" (Daje se moko) (Steenwijk 1992, 196), “Ga ublikla?” (Ga je oblekla?) (Steenwijk 1992, 210).

Podobno tudi v terskem narečju: "mu je poviedala” (Povedala mu je) (Logar 1975, 56), "Se parbliža an zahleda" (Približa se in zagleda) (Logar 1975, 57).

In še primera iz nadiškega narečja: "Je bila na žena" (Bila je žena) (Baudouin de Courtenay 1998, 86), "Su ya vœrli dol” (Vrgli so ga dol) (Baudouin de Courtenay 1998,166$)$.

V zvezi z zaimenskimi naslonskimi oblikami lahko v moližanski hrvaščini opazimo še eno značilno zgradbo, ki sploh ni značilna za slovanske jezike, je pa v govornem jeziku močno razširjena $v$ italijanščini in to domala v vseh zvrsteh.

Gre za uporabo naslonske oblike zaimka pri "povzemanju" predmeta, direktnega ali indirektnega, izraženega s samostalnikom ali z naglašeno obliko osebnega zaimka, ki stoji levo, zunaj povedi. Na primer v moližanski hrvaščini: "Njevu zen $^{u}$ s(u) ju uhitil flat ${ }^{e}$ " (Njegovo ženo je zajela jeza), "Men mi bolil ${ }^{\mathrm{a}}$ mabača štomik ${ }^{\mathrm{a}}$ " (Bolel me je želodec) (Breu, Piccoli 2000, 424).

To zgradbo zasledimo tudi v slovenskih narečjih v Furlaniji, kjer je nanjo lahko vplivala tudi furlanščina poleg bližnjih beneških narečij. Na primer v rezijanščini "Mlë to mi plaža" (Meni je všeč), v nadiškem narečju "Mene me na nič intereša" (Mene sploh ne zanima).

Ta skladenjski pojav, ki je v splošnem tuj slovanskemu jezikovnemu sistemu, zasledimo tudi v hrvaških istrskih govorih - na primer "Mene me boli glava" (Boli me glava), "Tebe č'u te za uši”" (Za ušesa te bom) - in je izpričan tudi v bolgarščini - na primer "Na tebe ti kazach" (Rekel sem ti), "Tebe te izvikacha v direkciata" (Poklicali so te v direkcijo) - torej v jeziku, za katerega smo glede stave naslonk že ugotovili podobnosti z romanskimi jeziki. 
Tudi v tem primeru, podobno kot v prejšnjih, se na obeh obravnavanih manjšinskih območjih pojavljajo jasne sorodnosti (ki jih pogosto zasledimo tudi na drugih območjih slovansko-romanskega stika) in nam kažejo, kako je večstoletna izpostavljenost stiku z romanskim jezikovnim prostorom privedla do podobnih sprememb na dveh jezikovno sorodnih, a geografsko oddaljenih območjih.

Nakazanim skladenjskim posebnostim bi lahko dodali še mnoge druge, ki jih podobno pogojuje romanska soseščina in ki so izpričane predvsem v moližanski hrvaščini, a jih v taki ali drugačni obliki najdemo tudi v slovenskih narečjih v Furlaniji.

Pomislimo na primer pri pridevniku na primernik, ki se v moližanski hrvaščini tvori opisno s prislovom veče (a sa veče lip do tebe", jaz sem lepši od tebe), na zvezo predloga za z nedoločnikom za izražanje namernosti ("si bi mitan za jist”, povabljen si bil jesti), na imensko dopolnilo v rodilniku, ki se obvezno izraža s predlogom do ("Fest do štoga Mikel”, Praznik sv. Mihaela; "ključ do vrat", ključ od vrat, "ajar do veselja", vzdušje veselja), in tako naprej.

Dodatna analiza teh posebnosti, njihove pogostosti, obveznosti oziroma neobveznosti, pa tudi analiza drugih značilnosti moližanske hrvaščine, ki so prav tako vezane na romansko interferenco, a niso nujno prisotne tudi v slovenskih narečjih v Furlaniji, bi bila seveda zelo zaželena in umestna, da bi lahko ocenili stopnjo ohranjenosti tega manjšinskega govora v primerjavi s slovenskimi govori v Furlaniji.

Iz italijanščine prevedla Živa Gruden

\section{Viri in literatura}

Courtenay, J. Baudouin de, 1895, Materialen zur südslavischen Dialektologie und Ethnographie, I, Resianische Texte, gesammelt in den Jj. 1872, 1873 und 1877..., St. Petersburg.

Courtenay, J. Baudouin de, 1998, Materiali per la dialettologia e l'etnografia slavo-meridionale, IV, Testi popolari in prosa e versi raccolti in Val Natisone nel 1873 / Materiali za južnoslovansko dialektologijo in etnografijo, IV, Ljudska besedila v prozi in verzih, zbrana v Nadiških dolinah leta 1873, ur. L. Spinozzi Monai, Trst - Špeter.

Benacchio, R., 2002, I dialetti sloveni del Friuli tra periferia e contatto, Udine, Società Filologica Friulana.

Breu, W., 1993, Der Faktor Sprachkontakt in einer dynamischen Typologie des Slavischen, Slavistische Linguistik 1993, München, 41-64.

Breu, W., Piccoli, G., 2000, Dizionario molisano di Acquaviva Collecroce, Campobasso.

Breu, W., 2003, Der indefinite Artikel in slavischen Mikrosprachen: Grammatikalisierung im totalen Sprachkontakt, Slavistische Linguistik 2001, München, 27-68.

Capaldo, M., 1959, Slavi balcanici in Italia meridionale tra il VII e il XVI secolo, 
Sintesi storiografica e prospettive di ricerca, Contributi slavistici in riscordo di Carlo Verdiani, Pisa, 55-62.

Cronia, A., 1950, Contributi alla dialettologia slovena, Slavistična revija 3 (1950), 321-326.

Logar, T., 1975, Slovenska narečja (Besedila), Ljubljana, 56.

Merkù, P., 1980, O slovenskem terskem narečju, Slavistična revija 28/2 (1980), 167-178.

Muljačić, Ž., 1973, Su alcuni effetti del bilinguismo nella parlata dei croati molisani, Bilinguismo e diglossia in Italia, Pisa, 29-37.

Pellegrini, G. B., 1975, Sul dialetto e sulla toponomastica della Val Natisone: a proposito dei contatti linguistici slavo-friulani, Saggi di linguistica italiana, Torino, 462-477.

Reichenkron, G., 1934, Serbokroatisches aus Süditalien, Zeitschrift für slavische Philologie 11 (1934), 325-339.

Rešetar, M., 1997, Le colonie serbo-croate nell'Italia meridionale, a c. Di W. Breu e M. Gardenghi, Campobasso [Rešetar, M., Die serbokroatischen Kolonien Süditaliens, Kaiserliche Akademie der Wissenschaften. Schriften der Balkankommission: Linguistische Abteilung, I, Südslawische Dialektenstudien, V, Wien, 1911].

Sedlaček, Ja., 1962, Ob osobych dialektnych formach južnoslavjanskogo imperfekta, Balkansko ezikoznanie 5 (1962), 49-55.

Skubic, M., 1997, Romanske jezikovne prvine na zahodni slovenski jezikovni meji, Znanstveni inštitut Filozofske fakultete, Ljubljana.

H. Steenwijk, 1992, The Slovene dialect of Resia. San Giorgio (Studies in Slavic and General Linguistics, 18), Amsterdam - Atlanta, GA.

\section{Slavic-Romance Linguistic Contact in Italy: Slovene in Friuli and Croatian in Molise} Summary

This paper analyzes the dialect of a Croatian linguistic island in Molise (in the villages of Montemitro, Acquaviva Collecroce, and San Felice). Following a sociolinguistic introduction, various linguistic characteristics are singled out that are connected to the long contact that this peripheral Slavic area has had with the Romance area (i.e., with standard Italian and dialects spoken in Molise): gradual loss of the neuter and the dual, preservation of the imperfect and pluperfect, violation of Wackernagel's Law, clitic doubling, and so on. A comparison is made with another Slavic linguistic island in Italy: the Slovene spoken in Friuli.

\section{Rosanna Benacchio}

Sezione di Slavistica, Facoltà di Lettere, Università di Padova

Via Beldomandi 1, I-35100 PADOVA

rosanna.benacchio@unipd.it 



\title{
Gröfel, Gröbel 'Steinhaufen' - Dialektologisches und Namenkundliches rund um einen Slawismus im Bairischen
}

\author{
Hubert Bergmann (Dunaj)
}

IZVLEČEK: V pričujočem članku se bližje osvetljuje bavarski slavizem Gröfel oziroma Gröbel 'kup kamenja ipd.' (< slovensko groblja) in skuša iti po sledeh, ki jih je ta slovenski etimon pustil v imenoslovju vzhodne Tirolske in Koroške.

Bavarian Slavism Gröfel or Gröbel 'pile of stones, etc.' (<SIn. groblja) ABSTRACT: This article sheds additional light on the Bavarian Slavism Gröfel or Gröbel 'pile of stones, etc.' (< Sln. groblja) and seeks to identify the traces that this Slovenian etymon has left in the onomastics of East Tyrol and Carinthia.

Inhalt dieser kurzen Darstellung wird ein Slawismus in einigen bairischen Mundarten Osttirols, Kärntens, der Steiermark und des Salzburger Lungaus sein, der auch in der Namenlandschaft dieser Regionen Spuren hinterlassen hat. Es handelt sich dabei um Integrate, die dem modernen slowenischen grộblja entsprechen. Betrachten wir eingangs kurz die lexikografische Dokumentation dieses Lexems. Pleteršnik führt groblja mit der Bedeutung 'Steinhaufen' an ${ }^{1}$ und liefert einen Kontextbeleg aus der Bibelübersetzung von Dalmatin (1584). ${ }^{2}$ Für groblje gibt er zusätzlich eine Bedeutung 'Schutt, Ruinen' an, unter Verweis auf Cigales Deutsch-slowenisches Wörterbuch aus 1860, Janežičs Deutsch-Slovenisches Taschenwörterbuch in seiner zweiten Auflage aus 1867 und Miklošičs Material. Als weitere Zusatzbedeutung, ohne deutsches Äquivalent, nennt er pos[eben] kup kamenja $z$ njive pobranega, setzt hier einen Verweis auf Jarniks Etymologikon und liefert eine areale Verbreitungsangabe ljubljanska okolica. Schließlich führt er für

1 Pleteršnik I 255; an anderer Stelle (I 256) nennt er eine Nebenform grộmblja und verweist von dieser auf groblja.

2 Der betreffende Beleg: iz Jeruzalema so groblje kamenja storili. Offenbar stammt diese Stelle aus der Übersetzung des ersten Verses von Psalm 79: Gott, die Heiden sind eingedrungen in dein Erbe, / sie haben deinen heiligen Tempel entweiht / und Jerusalem in Trümmer gelegt (= Einheitsübersetzung lt. $<<$ www.bibelwerk.de $>>$ [22.3.2007]); vgl. die Übersetzung im Slovenski standardni prevod: $O$ Bog, narodi so prišli v tvojo dediščino, / oskrunili so tvoj sveti tempelj, / Jeruzalem so spremenili v kup razvalin (SPismo 855). 
$\hookrightarrow \quad$ das Syntagma ledniška groblja die fachsprachliche Sonderbedeutung 'Moräne' an, von hier geht ein Verweis auf Jesenko. ${ }^{3}$ Bereits vor Pleteršnik wird das Lexem bei Pohlin als Grobla 'Die Schutte'4 und bei Gutsman als grobla 'Schütt'5 verzeichnet. Betrachtet man die lexikografische Dokumentation von slowenisch groblja in der Zeit nach Pleteršnik, so verdient hier vor allem Badjura Erwähnung, der in seinem Werk Ljudska geografija schreibt:

„Navadna gróblja .. pomeni kup z njiv, senožeti, sečí .. pobranega napotnega kamenja, ki ga nakopičijo kje na rodem prostoru (kočniku, pleši), da ni plugu, kosi ali motiki v napoto." (Badjura 149).

Ganz ähnlich Karničars Anmerkung zu groblja bzw. grobljica: im Frühjahr wurden Steine zusammengerecht und am Nordrand des Ackers angesammelt. ${ }^{6}$ Bei Zdove findet sich das Wort als grũ bla. ${ }^{7}$ Dass SSKJ schließlich verzeichnet sowohl groblja als auch groblje (n.) sowie ein davon abgeleitetes Adjektiv grobljast:

„gróblja -e ž (ộ) 1. kup nametanega kamenja: pobiral je kamenje na njivi in ga nosil na grobljo; s plevelom porasle groblje // star. podrtija, razvalina: njegova domačija je pusta groblja; stolp je samo še črna groblja 2. geogr. nasutina ledenika: vzdolž ledenika se vlečejo groblje / čelna, stranska groblja“ (SSKJ I 766)

„gróblje -a s (ộ) 1. več grobelj: med grobljem so rasle koprive / od hiše je ostalo le še kamnito groblje 2. zastar. pokopališče: nihče v vasi ni več pomnil, kdaj so zadnjega pokopali na tisto groblje / staroslovensko groblje grobišče“ (SSKJ I 766)

„gróbljast -a -o prid. (ộ) nanašajoč se na grobljo: tam je svet razdrapan in grobljast / hodila sta po strmem, grobljastem plazu“ (SSKJ I 766)

In etymologischer Hinsicht ist slowenisch groblja letztlich zu urslawisch *grebti, *grebo 'graben' zu stellen. ${ }^{8}$ Skoks Vermutung, bei dem im kroatischen Dialekt der Gegend um Kastav (nordwestlich von Rijeka) belegten, in semantischer Hinsicht slowenisch groblja entsprechenden gröblja handle es sich um eine Kreuzung zwischen dem Substratwort grava und grob 'Grab', muss wohl als irrig angesehen werden. ${ }^{9}$

3 Das Syntagma ledniška groblja findet sich bei Pleteršnik noch unter zwei weiteren Lemmata, nämlich unter lednîški (I 505) und morēna (I 602). Ein weiteres Mal begegnet groblja schließlich unter dem Stichwort vališ (II 746).

4 Pochlin o.P.; Schutte wohl fälschlich für Schütte.

5 Gutsmann 271.

6 Karničar 78, s.a. ebd. 323.

7 Zdove 32.

8 ĖSSJ VII 132, SP VIII 222.

9 Skok I 610; zum Substratwort grava 'Stein' und dessen umstrittener sprachlicher Zuordnung s. Kramer, J.: Etymologisches Wörterbuch des Dolomitenladinischen (EWD). 8 
Slowenisch groblja wurde in einige süd- bzw. südmittelbairische Mundarten ${ }^{10}$ Osttirols, Kärntens, der Steiermark sowie des Salzburger Lungaus als Gröfel bzw. Gröbel entlehnt (zu den genauen Lautungen siehe weiter unten). Die Semantik dieser Integrate liegt dabei nahe an jener des modernen slowenischen Äquivalents. Als häufigste Bedeutung von bairisch Gröfel/Gröbelwird im untersuchten Material 'Steinhaufen, Schutthalde' angegeben. Aus den Bedeutungsangaben zu mehreren der unten aufgelisteten Belege geht darüber hinaus hervor, dass damit v.a. jene meist am Feldrand gelegenen Steinhaufen bezeichnet werden, die dadurch entstanden sind, dass man die bei der im Frühjahr erfolgten Flurreinigung auf den Feldern und Äckern aufgelesenen Steine an einem bestimmten Ort zusammenschichtete. Im Laufe der Jahrhunderte entstanden durch dieses Aufhäufen der Lesesteine Halden, die teils beeindruckende Dimensionen aufweisen. Sie dienen, ähnlich wie die Trockensteinmauern entlang der Feldwege, unterschiedlichsten Tieren und Pflanzen als Lebensraum und erfüllen so eine wichtige Rolle im Ökosystem der betreffenden Kulturlandschaft. ${ }^{11}$ Diese Bedeutung von Gröfel/Gröbel ist somit exakt die gleiche, wie sie etwa Pleteršnik und Karničar für slowenisch groblja anführen.

Wenden wir uns nun der wortgeografischen Verbreitung von Gröfel/Gröbel in den bairischen Mundarten zu. Diese reicht im Westen bis in jenen Teil Osttirols, der noch über ein slawisches Substrat verfügt (konkret sind dies das Einzugsgebiet der Isel, das Lienzer Becken sowie das Pustertal bis auf die Höhe der Ortschaft Assling). Die Osttiroler Belege seien im Folgenden in chronologisch aufsteigender Reihenfolge angeführt ${ }^{12}$ :

als Simplex:

- Dieses Mad ist voller Stain und Gröfl (Ainet; RF o.P.; 1775)

- Gröfl 'Steinhaufe, auf welchen auch noch andere Dinge geworfen werden' (,Pustertal“'13; Unterforcher [1887] 11)

- Gröfl Pl. 'wirr durcheinander liegendes Gerölle von großen Steinen’, (,in unseren Gegenden“ [= Defereggen?]; Hintner [1909] 43)

Bde. Hamburg 1988-1998, III 434. Kroatisch groblja wird im ĖSSJ sowie im SP nicht angeführt, ebensowenig wie Skoks etymologischer Deutungversuch.

${ }^{10}$ Zur Gliederung des bairischen Dialektraumes in Österreich vgl. die Übersichtskarte zum WBÖ-Beiheft Nr. 2 (Bergmann, H. / Geyer, I. / Glauninger, M. / Groschopf, E. / Wandl-Vogt, E.: Wörterbuch der bairischen Mundarten in Österreich. Beiheft Nr. 2. Erläuterungen zum Wörterbuch. Lautschrift, Abkürzungsverzeichnis, Literatur- und Quellenverzeichnis, Gebietsverzeichnis, Gemeindeverzeichnis [mit einer Übersichtskarte und 6 Detailkarten zum Gebietsverzeichnis]. Wien 2005).

${ }^{11} \mathrm{Vgl}$. dazu <<www.arge-naturschutz.at/projekte/kartierungen.html $>>$ [22.3.2007].

${ }^{12}$ Genus, soweit in der Quelle angegeben und nicht anders vermerkt, bei allen in diesem Beitrag angeführten bairischen Belegen stets feminin; Ortsnamen und Gemeindezugehörigkeit nach dem amtlichen Ortsverzeichnis 2001 der Statistik Austria.

${ }^{13}$ Mit Pustertal wurde bis ins 19. Jh. nicht nur, wie dies heute der Fall ist, das Tal der Rienz bzw. der Drau in Süd- und Osttirol bezeichnet, sondern man subsummierte darunter auch die gesamte Isel-Region. 


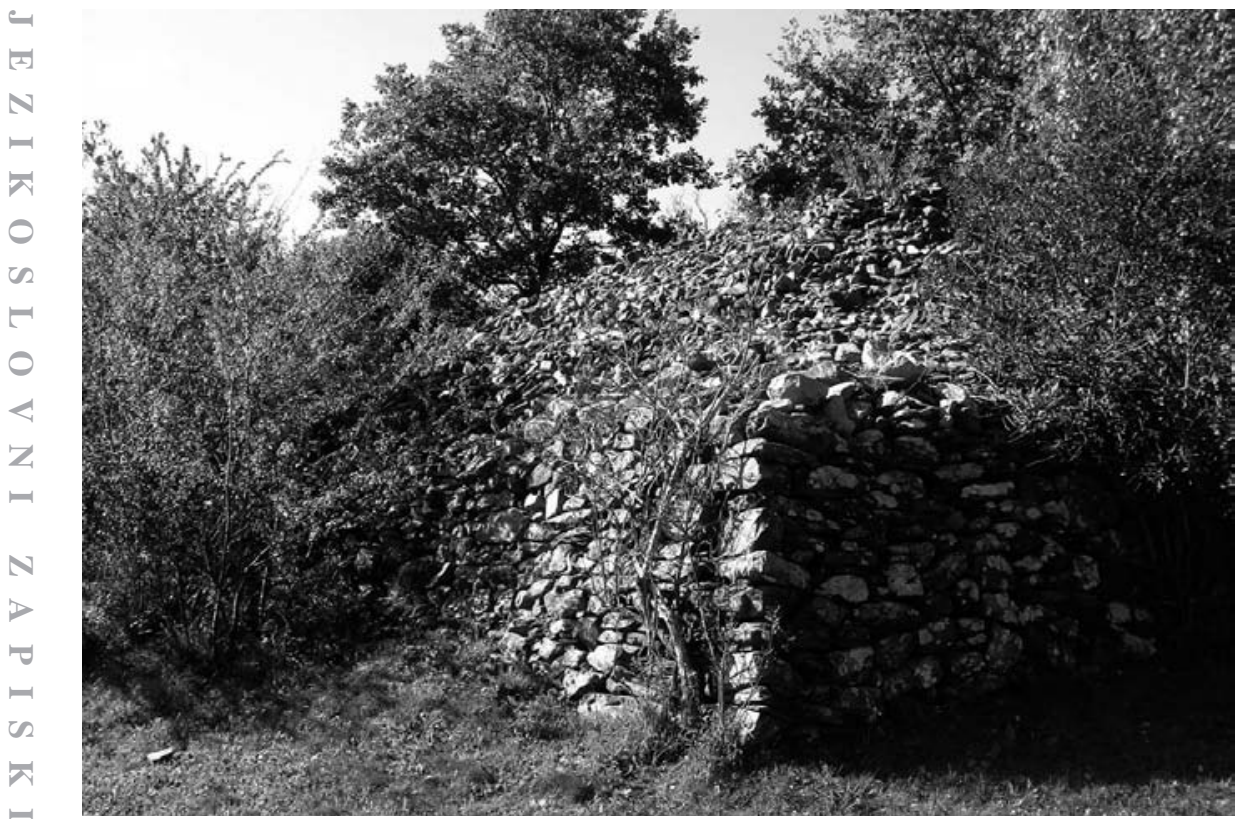

Eine Gröfel am Rande eines Feldes im Gemeindegebiet von Gaimberg (Osttirol). Deutlich zu erkennen ist, wie der Steinhaufen am Rande aufgemauert wurde (Foto: Bergmann 2006).

- $\quad$ gerẹifle 'Geröll-, Steinhalde’ (,Defereggen“; Schatz I 218)

- $\quad g_{R} \Phi_{1}$ ' 'Geröllhalde' (ME Schlaiten 159.5)

- $\quad g_{R} \bar{i} i v l$ 'Geröllhalde, Steinhaufen’ (ME Matrei i.O. 153.7)

- gẹēivlện n. 'Geröllhalde, voll größerer Steine’ (ME Hopfgarten i.D. 153.7)

- $\quad$ greivivl 'Geröllhalde, auf einen Haufen geklaubte Steine' (ME Virgen 159.5)

- $\quad$ greifl 'Steingeröll, Schutthalde' (Nikolsdorf; TSA III Karte 13)

- Greifl 'Steinhaufen am Rande der Felder' (Thurn; Mußhauser 14)

- $\quad$ grēifl 'Steinhaufen’ (Gaimberg; H.B.; 2007)

im Kompositum Stēiner-gröfel:

- $\quad$ štopnngrēifl (Gaimberg; H.B.; 2007)

Das Verbreitungsgebiet dieses Slawismus setzt sich nach Osten hin in den südbairischen Mundarten Kärntens fort, auch hier seien die betreffenden Belege in chronologischer Reihenfolge angeführt:

als Simplex:

- $\quad$ die Grofe ${ }^{14}$ (Spittal an der Drau; Regg.F.III H.13 Nr. 387; 1457)

${ }^{14}$ Es kann nicht sicher gesagt werden, ob sich dieser Beleg auf ein Toponym bezieht oder appellativisch zu verstehen ist. 
- $\quad$ grēifl (Döllach, Gem. Großkirchheim; KKK; 1910)

- Grêffl ‘Steinhaufen, entstanden durch Abladen der Feldsteine’ (Bad Bleiberg; HK/DBÖ, Sammler: Steinacher)

- Grēfl 'Haufen, auf die die Lesesteine geschichtet werden' (Obervellach; HK/ DBÖ, Sammler: Wenger)

- Gröifl, Gröfl ‘Steinmauerriegel, vom Felde zusammengetragene Steine, welche hügelweise aufgeschüttet werden und sozusagen eine Mauer bzw. einen Zaun bilden' (Winklern; HK/DBÖ, Sammler: Trojer)

- Gröfl 'Steinhaufen im Allgemeinen, auf dem Feldrain zusammengeworfene Steine“ („Gurktal“; HK/DBÖ, Sammler: Wintschnig)

- Gröfl 'Haufen, auf die die Lesesteine geschichtet werden; Steinhaufen, die schon längere Zeit liegen` (Kötschach, Gem. Kötschach-Mauthen; HK/DBÖ, Sammler: Weinländer)

- grēifl 'Schutthalde’ (Teuchl, Gem. Reißeck; HK/DBÖ, Sammler: Kranzmayer)

- Gröfl ‘Steingerölle, Schutthalde’ (Puch, Gem. Weißenstein; HK/DBÖ, Sammler: Poschinger)

- Gröfl 'Steinwand' (Ebene Reichenau, Gem. Reichenau; HK/DBÖ, Sammler: Schiwitz)

- grēfë 'Steinhaufen’ („Liesertal“; HK/DBÖ, Sammler: Kranzmayer)

- grəif ‘ 'Steinhaufen’ („Lurnfeld“; HK/DBÖ, Sammler: Kranzmayer)

- $\quad$ grēifl 'Steinhaufen'15 (Kalch, Gem. Greifenburg; KKK; 1916)

- $\quad$ greifl 'Geröllhalde’ (Mitten, Gem. Großkirchheim; KKK; 1917/1918)

- $\quad$ greifl ‘Steinhaufen’ (Teuchl, Gem. Reißeck; KKK; 192?)

- Gröwl ${ }^{16}$ 'Name eines ortsnahen zusammengeschütteten Steinhaufen [sic!]' (Kliening, Gem. Bad St. Leonhard im Lavanttal; AdV; 1930)

- Gröfl 'Steingeröll' (Unterlercher 234 ${ }^{17}$ )

- $\quad$ gręfl 'Steinhaufen’ (,Weißensee“; KKK; 1942)

- $\quad$ grcifl 'Steinhaufen' (Sonnberg, Gem. Stall; KKK; 1944)

- greiwd 'Steinhaufen’ (Judendorf, Gem. Friesach; KKK; 1946)

- grēifl 'Steingerölle’ (Göriach, Gem. Lurnfeld; KKK; 1946)

- grcivl (Pußtratten, Gem. Stall; KKK; 1946)

- Gröfl 'Steine, die im Laufe der Jahre beim Ackern zusammengeklaubt und im Felde oder an seinem Rande zusammengeworfen worden sind' (,Nockgebiet“; Moro [1952] 13)

- $\quad g_{R} \bar{e} f 1$ ‘Geröllhaufen’ (Villach; Herzmansky 130 bzw. 278)

- $\quad$ greifl ‘Steingeröll, Schutthalde’ (Oberdrauburg; TSA III Karte 13)

${ }^{15}$ Ich danke meiner Kollegin Dr. Barbara Piringer für die Transkription der hier und an anderer Stelle in Gabelsberger-Kurzschrift notierten Bedeutungsangaben.

${ }^{16}=$ Teil einer Antwort auf Frage 16 im 1. AdV-Fragebogen: Was erzählt man den Kindern über die Herkunft der kleinen Kinder? Der Antwortbeleg in vollem Wortlaut: das Kind sis af dea $a^{r}$ unte dea ${ }^{r}$ [das Kind - es ist auf der / unter der] „Gröwl“ gfunt'n g'woartn [gefunden worden] (wird der Name eines ortsnahen zusammengeschütteten Steinhaufen [sic!] genannt.

${ }^{17}$ Eintrag in der Liste der Worterklärungen am Ende des Bandes. 
- grēiflı n. 'Geröllhalde’ (Liesing, Gem. Lesachtal; Schabus 470)

in den Komposita Stēin-gröfel, Stēin-gröbel, Stēiner-gröfel und Stauden-gröfel:

- $\quad$ Schtåangröif ${ }^{18}$ (Winklern; HK/DBÖ, Sammler: Trojer)

- Stangröfl ‘Steinhaufen' (Ebene Reichenau, Gem. Reichenau; HK/DBÖ, Sammler: Schiwitz)

- Stoangröf $1^{19}$ (Thalsdorf, Gem. St. Georgen am Längsee; HK/DBÖ, Sammler: Ruderstorfer)

- af a Stoangröfl oder af an Raumachhaufn ${ }^{20}$ (St. Oswald, Gem. Reichenau; Moro [1928b] 1)

- Die Philister send über die Stoangröfl von der Lusn [Flurname] aufer und hâmp si ba der Bâstubm [Badstube] aufgstöllt .. Die Philister send über die Stoangröf1 âchn gekuglt (Unterlercher 28 ${ }^{21}$ )

- Darauf [d.i. nach diesem Wetterspruch] müssen die Hexen die Wolken weiterschieben an einen Ort, wo lauter Steingeröffel und Dürrholz ist ${ }^{22}$ (Graber 390)

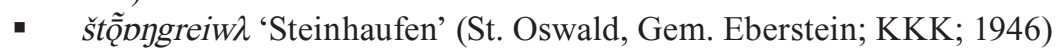

- Š Š̃̂̃ogrefe (Unterkreuschlach, Gem. Gmünd in Kärnten; KKK; 1947)

- Štẫygrēf ‘die am unteren Ackerende ausgeklaubten Steine [?]' (Laubendorf, Gem. Millstatt; KKK; 1947)

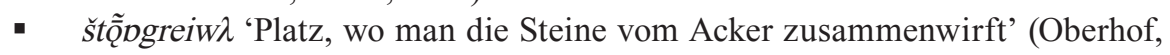
Gem. Metnitz; KKK; 1949)

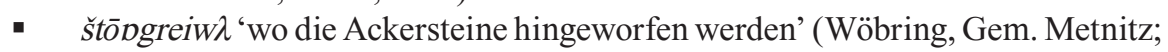
KKK; 1949)

- Stānagrēfl 'schotterige Streifen in einem Feld, Steinriegel' (Feistritz an der Drau, Gem. Paternion; HK/DBÖ, Sammler: Litscher)

- Stándărgreîfl 'Steinhaufen, entstanden durch Abladen der Feldsteine' (Bad Bleiberg; HK/DBÖ, Sammler: Steinacher)

- Štãnda(R)gReifl 'Steinhaufen; übertragen: steiniger Acker' (Molzbichl, Gem. Spittal an der Drau; Rudolf 313)

- S Štãnd

- $\quad$ štấn

$18=$ Antwort auf Frage B25i im 17. WBÖ-Fragebogen: Verwendung des Rains zur Ablagerung der ausgeklaubten Steine, als Rast- und Mahlstätte für die Feldarbeiter; Zusatzkommentar auf dem betreffenden Belegzettel: Hügel.

$19=$ Antwort auf Frage C8b im 17. WBÖ-Fragebogen: anstehender Fels im Ackerland.

${ }^{20}$ D.i. Raumach-haufen, Bestimmungswort ist eine Kollektivbildung zu bairisch raumen 'das Feld (meist im Frühjahr) von Laub, Kleinholz und größeren Steinen räumen', vgl. Schatz II 475.

${ }^{21}$ Der Autor beschreibt hier, wie er als Kind mit seinen Gefährten die biblische Geschichte von David und Goliath nachspielte.

${ }^{22}$ Der unmittelbar zuvorstehende Bannspruch stammt aus dem Mölltal, die Passage handelt von Wetterzauber in Mittel- und Oberkärnten. 
- Staudngröfl 'Gröfl, die schon so lange Zeit liegen, daß sie bereits mit Staudn usw. bewachsen sind' (Kötschach, Gem. Kötschach-Mauthen; HK/DBÖ, Sammler: Weinländer)

Ebenfalls belegt ist das Wort (allerdings nur sporadisch) für die Ober- und die Weststeiermark sowie vereinzelt auch für den Lungau, den südöstlichen, ebenfalls slawisch unterschichteten Teil des Bundeslandes Salzburg:

als Simplex:

- Gröbel n. 'durch Frost abgesprengtes Gestein auf Hochalpen, das in großen Felsstücken oft weite Strecken bedeckt' (Unger/Khull 308)

- greiwd 'Steinhaufen' (Rinneg; KKK; 1924)

- greiwl 'Steinhügel’ („Gerichtsbezirk Oberwölz“; Lawatsch 105)

- gräiwl n. 'Gröbel: Gerölle' (Graden; Hutterer/Kainz/Walcher 304²3)

im Kompositum Stēin-gröbel:

- Stoangröbl 'Haufen, wo die Lesesteine auf- bzw. zusammengeschichtet werden' (Neuberg an der Mürz; HK/DBÖ, Sammler: Sturm)

- Stoangrebl 'Steinhaufen' (Judenburg; HK/DBÖ, Sammler Steiner-Wischenbart)

- Stoa(n)grewl 'steiniger Bauerngrund'24 (Stiwoll; HK/DBÖ; Sammler: Wagner)

- Štopgrē'Wë 'Steinhaufen' (Seetal, Gem. Tamsweg; KKK; 1924)

- $\quad$ štōogrēi $w \ddot{\varepsilon}$ 'Schutthalde' (Seetal, Gem. Tamsweg; KKK; 1924)

- $\quad$ štǫogreiwl ‘Steinhügel’ ("Gerichtsbezirk Oberwölz"; Lawatsch 105)

- $\quad$ Steingröbel n. 'Steingerölle, -mure' (Unger/Khull 573)

$\mathrm{Zu}$ ergänzen sind noch die zu Gröfel gebildeten Kollektiv-Ableitungen Gröflach, Gröflach-haufen und Gröflerach:

- Gröflach 'Steinhaufe, auf welchen auch noch andere Dinge geworfen werden' („Pustertal“; Unterforcher [1887] 11)

- $\quad$ er [der Bauer] freut sich auch seines Besitzes und seiner zweiten Heimat; ,,koa Gröflach, koa Stoanach, koa Staudach“, so lobte er sie einmal (St. Oswald, Gem. Reichenau; Moro [1928a] 2)

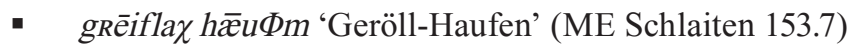

- $\quad g_{R} \operatorname{ẹn}_{i}{ }^{p} R D \chi$ 'Geröll' (ME Matrei i.O. 153.7)

Auch ein von Gröfel abgeleitetes Verb lässt sich nachweisen:

${ }^{23}$ Ebd. in etymologischer Hinsicht zu dt. grob gestellt.

${ }^{24}$ Anmerkung Orig.: die Bezeichnung hat den Beigeschmack eines humorvollen Sich-Abfindens. 
- Schtåanzsåmgröifln 'Steine zusammenschlichten, gewöhnlich an der Feldgrenze’ (Winklern; HK/DBÖ, Sammler: Trojer)

In lautlicher Hinsicht ist v.a. die Vertretung des $-b$ - im slawischen Ausgangswort im Bairischen interessant. In den meisten Formen aus Osttirol und Kärnten erscheint dieses als - $f$-, was darauf hindeutet, dass das Wort bereits vor 1200 in die betreffenden südbairischen Mundarten integriert wurde. Die steirischen Belege sowie jener aus dem Lungau weisen hingegen dafür stets einen Bilabial $-W$ - auf, was nahe legt, dass die Integration hier später erfolgte. ${ }^{25}$ Interessant ist, dass die wenigen Kärntner Belege mit $-W$ - allesamt aus dem Osten und Nordosten des Landes stammen, d.h. die Belegorte liegen in relativer räumlicher Nähe zur Steiermark. Wohl über eine Analogie zu den Kollektivbildungen auf $\mathrm{Ge}$ - lässt sich die Tatsache erklären, dass Gröfel/Gröbel vereinzelt neutrales Genus aufweist. Kranzmayer vermerkt in seinem Ortsnamenbuch von Kärnten, dass neben Gröfel in Oberkärnten auch Gröbel und in Osttirol die Form Gröbe in Gebrauch sei. ${ }^{26}$ In dem für diesen Beitrag durchgesehenen Material finden sich darauf jedoch keine Hinweise.

Obschon bereits Hintner zu Beginn des 20. Jh. auf einen möglichen slawischen Ursprung von Gröfel hingewiesen hat, ${ }^{27}$ interpretierte Schatz dieses (ohne Verweis auf slowenisch groblja) als Kollektivum auf Ge-, allerdings ohne näher auf das Grundworteinzugehen. Finsterwalder, derdieDrucklegung von Schatz'Wörterbuch besorgte, ergänzte den betreffenden Wörterbucheintrag mit einem Verweis auf Zillertalerisch gerẹfl 'Blockwerk aus feinerem Gestein als das 'Gemäuer', Dieses ist tatsächlich ein Kollektivum, gehört jedoch etymologisch offenbar zu einem areal ebenfalls auf das Zillertal beschränkten und gleichbedeutenden röflwerch. ${ }^{28}$ Möglicherweise sind dazu auch die Deferegger Belege zu stellen, die zum einen

${ }^{25}$ Vgl. Bergmann 299.

${ }^{26}$ Kranzmayer II 93.

${ }^{27}$ Hintner (1909) 43.

${ }^{28}$ Schatz I 218 u. II 489. Beide Wörter sind im HK/DBÖ sonst nicht belegt, möglicherweise besteht ein Zusammenhang mit dem ebenfalls singulär (für die Zillertaler Ortschaft Fügen) belegten Verb rōfeln 'rebeln, abstreifen' (HK/DBÖ, Sammler: Plenk), das wohl wiederum mit dem bei Schatz (II 477) genannten und weiter verbreiteten refflen 'sich an etwas reiben, streifen, kriechend klettern' in Verbindung stehen dürfte. Ingenhaeff/Reiter (73) verzeichnen ein gèrêfl n. 'Staudengebiet, von Stauden bewachsene Fläche'. Finsterwalder fragt sich zudem, ob ein Zusammenhang zwischen dem Zillertaler gerêfl und dem weit verbreiteten Wort Geräffel (graffl, $k$-) 'zusammengerafftes Zeug, Gerümpel' besteht, für welches er mehrere historische Belege mit der Bedeutung 'Blockwerk' anführt Schatz (I 217). Seine Aufzählung könnte unter Umständen um den Eintrag Großes Stein Geräffel ergänzt werden, welcher sich auf Anichs Karte aus 1774 als Benennung für eine große Felshalde südlich des Dorfer Sees im Gemeindegebiet von Kals am Großglockner findet. Es kann aber andererseits nicht gänzlich ausgeschlossen werden, dass Anichs Beleg zu unserem Gröfel gehört, man vgl. etwa die historische (1781) Schreibung Gräflhof für den im vorliegenden Beitrag behandelten Ortsnamen Gröfelhof. Vgl. in diesem Zusammenhang auch das bei Unger/Khull (572) angeführte Steingeraffel 'großer Steinhaufen, steiniger Absturz, Steinmure'. 
neutrales Genus sowie den ortsüblichen Reflex gə- für die Vorsilbe ge- vor $r$ aufweisen und zum anderen, wie der Autor dieser Zeilen durch Nachfrage bei Dialektsprechern in Erfahrung bringen konnte, die Geröllhalden im Hochgebirge, nicht jedoch Lesesteinhaufen benennen.

Slowenisch groblja hat auch in der Namenlandschaft Südösterreichs mehrfach Spuren hinterlassen. Ein dem oben angeführten Appellativ Gröfel entsprechender Siedlungsname bezeichnet einen Weiler bei Theißing (Gem. Bad St. Leonhard im Lavantal). ${ }^{29}$ Ein Ortsteil der Gemeinde Irschen im Oberkärntner Drautal trägt den zusammengesetzten Namen Gröfelhof, dessen erster Teil zu dem hier behandelten Wort zu stellen ist. ${ }^{30}$ Die Ortschaft geht auf einen im 16. Jh. errichteten herrschaftlichen Ansitz zurück ${ }^{31}$ (1674 Herr zu Rieterstorff und Grefflhof [Schnorr 97], 1781 der Besitzer des Adelichen Gut Gräflhof [ebd. 96]).

Gröflitze (greiflitsə f.) ist der Name einer Flur in Ainet im vorderen Osttiroler Iseltal. ${ }^{32}$ Hier ist an das Etymon die im Flurnamenbestand der Region häufig anzutreffende Endung ${ }^{*}$-ica getreten. ${ }^{33}$ Einige historische Belege $\mathrm{zu}$ diesem Onym:

1540-1562 inn Grofflize, ain ackher [LR f. 36']; 1553 in Gröfflize ain Ackher [LR f. 41']; Ain Ackher von der Kirchen hinauß in Gräfflize [LR f. 116]; 1775 ain Stückh Mad Gröfliz genant .. Dieses Mad ist voller Stain und Gröfl; an Mayrs sein Gröflütze [RF o.P.]; 1780 Ein schlechtes Maad, Gröflitz genannt [RA 15]; 1840 Ein schlechtes Mahd Groflitz genannt [TBA 25]; an die Nagelischen Grundstücke Gröflitz und Winkelacker [TBA 39]

Ein analoger Flurname Groflitze (grouflits f.) begegnet uns in der Ainet gegenüber liegenden Ortschaft Schlaiten, hier ist die Umlautung unterblieben. ${ }^{34}$ Ein Flurnamen Gröflitze lässt sich auch für Oberdrum nachweisen, einen Ortsteil

${ }^{29}$ Kranzmayer II 93.

${ }^{30}$ Kranzmayer II 93. Nicht geklärt werden konnte, ob ein in einem Dokument aus dem Jahre 1381 für die Gegend um Oberdrauburg bzw. Greifenburg genannter Gröfler [OR] in Zusammenhang mit diesem ON steht. Den Namen der Nachbarortschaft Griebitsch stellt Kranzmayer (II 92) ebenfalls zu slowenisch groblja, allerdings geht er von einer Ableitung *grobljišče aus. Ihm zufolge lautet der Ort im Dialekt griabišk, Schnorr (32) gibt die aktuelle (1975) ortsdialektale Aussprache mit Griewisch wieder. Im ANB (I 446) wird der Erstbeleg mit in monte Grwhis angegeben und der Name als *Grobišče (zu *grobъ 'Graben') etymologisiert. Kranzmayer (II 92) nennt einen späteren Beleg Grwoisch und datiert diesen mit 1267-1268. Offenbar derselbe Beleg findet sich bei Schnorr (32) als Grw $W^{\circ}$ isch. Weitere Belege für diesen Namen: 1509 die grüebitscher [Einwohnername] (Schnorr 104), 1576 die Pauern am Grüebitsch (ebd. 105).

${ }^{31}$ Näh. s. Wiessner, H. / Vyoral-Tschapka, M.: Burgen und Schlösser in Kärnten. Bd. 3: Hermagor, Spittal/Drau, Villach. 2. Aufl. Wien 1986: 100 f.; ebd. zur Etymologie des Namens: Der mundartliche Ausdruck "Gräfel" bedeutet so viel wie Mure oder Moräne und weist auf die Lage des Hofes hin.

32 Genauere Lokalisierung: südwestlich des Berger-Hofes gelegene, ehedem Steinhaufen und Gestrüpp enthaltende Weide, die später planiert wurde und heute als Mahdfeld dient, inzwischen teilweise jedoch verbaut ist.

${ }^{33}$ Vgl. Bergmann $301 \mathrm{f}$.

${ }^{34}$ Genauere Lokalisierung: unmittelbar an den vom Kraß Bach durchflossenen Graben 
$\hookrightarrow \quad$ der an Ainet und Schlaiten angrenzende Gemeinde Oberlienz. ${ }^{35}$ Die betreffenden [I] historischen Belege:

1680 Ain Grunt Flëckhl die Grofliz genant [StB f. 143']; 1780 Ein Maad, Gräflize genannt [ROd 9]; 1840 Gröflitz [TBOd 14]

In derselben Ortschaft liegt ein urkundlich schon relativ früh bezeugter weiterer Flurname gleichen Ursprungs ein, in dem das $-b$ - des slawischen Ausgangswortes nicht als - $f$-, sondern als - $b$ - erscheint, nämlich Gröblitze: ${ }^{36}$

1365 in der Grobliza [OR]; 1423 in der Groblize [OR]; 1471 in der Grobliza [OR]; 1501 in der Groblizen [LR f. 35], in der Groblitz [OR]; 1550 in der Groblizen [ULB f. 28]; 1553 ann der Groblizen [LR f. 85'], an der Gröblizen, das khlein Gröblize [LR f. 127']; 1680 ain Mader Gras die Grobliz genant [StB f. 131'], Ain Gruntstuckh in der Grobliz [StB f. 133]; 1746 die Groblizen [StB f. 558], von der Grobliz [StB f. 559]; 1775 Gröblizen [AF f. 147'], die Groblitzen [AF f. 222], Grobliz [AF f. 564]; 1780 Ein Acker, Gröbliz heisend [ROd 33], einen Acker, Grobliz genannt [RO 86], Ein Acker, das Gröblizle genannt [RO 29], Ein zu den Acker, Gröblizl gehöriger Wald [RO 30], ein .. Acker, die Gröblize heisend [RO 30], einen Acker, Groblitz genannt [RO 86], Ein Acker, die Groblizen heisend [RO 110]; 1840 Ein Acker Gröblitze genannt [TBO 34], Gröbliz [TBOd 48], Gröblitz [TBOd 98] ${ }^{37}$

Im benachbarten Oberlienz trifft man auf eine Laimgröfe ${ }^{8}$ (1780 Ein Stuck Acker, Laimgräfl genannt [RO 52]; 1840 Laimgrafl [TBO 60]) und eine Landgröfe ${ }^{\beta}$ (1359 an der Lantgröfel [OR]; 1746 Landtgröfl [?] [StB f. 582]), wobei unklar ist, ob sich die Oberlienzer Belege in der Lannggröfl bzw. in der Hinndern Langgröfl aus dem Jahre 1553 [LR f. 127] ebenfalls auf diese Flur beziehen. Ein Länergröfele, das 1746 für Oberlienz belegt ist [StB f. 599], weist eine Verkleinerungsform von Gröfel als Grundwort und vermutlich bairisch Läuner (im betreffenden Ortsdialekt lānn) 'Lawinenbahn, die Steilrinne, an der die Lawine oder der Bergrutsch abgeht' ${ }^{\prime 4}$ als Bestimmungswort auf. Schließlich lässt sich eine Flur Gröfel auch für Glanz (ebenfalls Gem. Oberlienz; 1840 Gröfel [TBGl 10]), für Nußdorf (Gem. Nußdorf-Debant, Osttirol; 1780 die Gröfl [Köfler (1973) 31]) sowie im Namenkompositum Gröfl-Acker ${ }^{41}$ auch für Lavant (Osttirol) belegen. Im Görzer Urbar von 1299 werden ein Besitz an der Gróvel [UVGG 36] sowie zwei Schweighöfe, ebenfalls an der Gróvel, für das Virgental (Osttirol)

angrenzendes Heimfeld des Kraßnig-Hofes. Zu diesem Namen konnten trotz gezielter Suche keine historischen Belege ausfindig gemacht werden.

35 Totschnig/Lobenwein 13.

${ }^{36}$ Totschnig/Lobenwein 13.

${ }^{37}$ Bei jenen historischen Belegen, die aus Dokumenten stammen, die den Ort Oberlienz betreffen, ist unklar, ob sie letztlich hierher zu stellen sind oder ob sie ein anderes Objekt benennen.

${ }^{38}$ Totschnig/Lobenwein 15; als Bestimmungswort dieses zusammengesetzten Namens fungiert Lèim 'Lehm'.

39 Totschnig/Lobenwein 15; Land, wohl das Bestimmungswort dieses Namenkompositums, trägt im Südbairischen auch die Bedeutung '(ebener) Talgrund', vgl. Schatz I 371.

${ }^{40}$ Schatz I 372.

${ }^{41}$ Moser 21. 
genannt [UVGG 44]. Es handelt sich dabei wohl um die früheste Nennung des heutigen Prägratner Gröfler-Hofes (1545 Cristan Gröfler [Köfler (1974) 16]), den auch Schatz als gröflhof verzeichnet. ${ }^{42} 1545$ wird ebenfalls für Virgen ein Ulrich Gröfler [StB f. 122] genannt. Der Familienname Gröfler ist noch heute im Virgental anzutreffen. ${ }^{43}$ Bidermann nennt für Obermauern (Gem. Virgen) einen Flurnamen Gröflizach. ${ }^{44}$ Darin kann wohl der oben genannte Aineter Flurname Gröflitze, erweitert um ein deutsches Kollektivsuffix -ach, erblickt werden. Für die Nachbarortschaft Niedermauern verzeichnet Bidermann ein Grobizach und stellt diesen Namen zum bereits erwähnten Gröflizach. ${ }^{45}$ Für die Ortschaft Saps in der Oberkärntner Gemeinde Malta ist Gröflach als Flurname belegt, ${ }^{46}$ eine Groflach benannte Flur liegt im Gitschtaler Weißbriach ein. ${ }^{47}$ Ebenfalls hierher gehört ein Hofname Gräfler ${ }^{48}$ (gręflp) in Zirkitzen (Gem. Bad Kleinkirchheim, Kärnten; 1827 Gröfler, 1872 Gräfler [Pichler 110]) sowie ein Hofname Gröflacher ${ }^{49}$ (gręflaxp) in Untertschern (Gem. Bad Kleinkirchheim; 1470 Gröflach, 1520 das Gröflach, 1668 in Gröflach, 1790 Gröflacher Hube, 1883 Gräflacherhube, Gröflacher Hube [Pichler 91]). Die Endung -ach in Gröblach, dem Namen eines in der Kärntner Gemeinde Maria Saal gelegenen, schon früh bezeugten Hofes (1200-1203 in Zagrublach), geht hingegen nicht auf ein deutsches Kollektivsuffix, sondern auf eine slowenische Kasusendung zurück. ${ }^{50}$ Zum Schluss seien noch zwei Onyme aus dem slowenischen Namenbestand der Südkärntner Gem. Eisenkappel-Vellach angeführt, die mit unserem Flurnamen Gröflitze etymologisch zusammenhängen, nämlich Groblje (Hofname, Trögern/Korte) und Grobljice (Flurname, Ebriach/

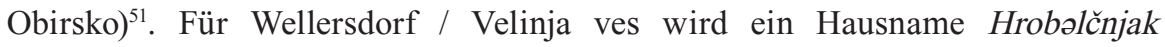
genannt. ${ }^{52}$

Auch im Familiennamenbestand finden sich Namen, die mit Integraten von slowenisch groblja in Zusammenhang stehen dürften. Feinig/Feinig stellen hierher die Familiennamen Grobelnig, Gröbel und Gröblacher. ${ }^{53}$

Außerhalb des geschlossenen bairischen Sprachraums schließlich findet sich in der (ehemaligen) südbairischen Sprachinsel Zarz/Sorica ein weiterer Hinweis auf eine unabhängige Übernahme von slowenisch groblja ins Deutsche, wobei

${ }^{42}$ Schatz I 218. Hintner (1909) 43 nennt auch für Gsies Gröfler als Personennamen. Zwischen Osttirol und dem in Südtirol gelegenen Gsies bestanden seit jeher enge Beziehungen.

${ }^{43}$ Vgl. das österreichische Online-Telefonbuch unter $<<$ www.herold.at $>>$ [22.3.2007].

${ }^{44}$ Bidermann (1877) 204, s.a. Mitterrutzner 19; bei Unterforcher (1889) 7 Gröflitzach.

${ }^{45}$ Bidermann (1877) 204, s.a. Mitterrutzner 19 und Unterforcher (1889) 7.

${ }^{46}$ HK/DBÖ (HK/DBÖ; Sammler: Podesser).

47 Hubmann 12.

${ }^{48}$ Pichler 110.

49 Pichler 91.

${ }^{50}$ ANB I 451.

${ }^{51}$ Karničar 78 bzw. 100.

${ }^{52}$ Feinig/Feinig 74.

${ }^{53}$ Feinig/Feinig 74. 
4 diese ein ähnliches Resultat gezeitigt hat wie im Binnenbairischen - greiwl (m.) ist dort der Name eines Berges. ${ }^{54}$

\section{Literatur- und Abkürzungsverzeichnis}

AdV - Belegmaterial zum Atlas der deutschen Volkskunde (AdV). Archiv des Instituts für Europäische Ethnologie / Volkskunde der Universität Innsbruck.

AF - Adelsfassionen des Landgerichtes Lienz (1775), Tiroler Landesarchiv, Kataster Nr. 120/5-6.

ANB - Altdeutsches Namenbuch. Die Überlieferung der Ortsnamen in Österreich und Südtirol von den Anfängen bis 1200, Wien 1989-1fd.

Anich, P., Hueber, B., 1974, Tyrolis sub felicis regimine Marice Theresice Rom. Imper. Aug. chorografice delineata a Petro Anich et Blasio Hueber colonis oberperfusianis curante Ignat. Weinhart prof. math. in univers. Enipontana. Innsbruck 1774 (Faksimile), Innsbruck, hrsg. H. Kinzl (= Tiroler Wirtschaftsstudien 30).

Badjura, R., 1953, Ljudska geografija. Terensko izrazoslovje, Ljubljana.

Bergmann, H., 2005, Slawisches im Namengut der Osttiroler Gemeinden Ainet und Schlaiten. Anmerkungen zur Slavia submersa im vorderen Iseltal, Wien (= Beihefte zur Österreichischen Namenforschung 5).

Bidermann, H. I., 1877, Die Romanen und ihre Verbreitung in Oesterreich. Ein Beitrag zur Nationalitäten-Statistik mit einleitenden Bemerkungen über deren Verhältniss zu den Rechts- und Staatswissenschaften, Graz.

ĖSSJ: Étimologičeskij slovar'slavjanskich jazykov. Praslavjanskij leksičeskijfond. Moskva 1974-1fd.

Feinig, A., Feinig, T., 2005, Familiennamen in Kärnten und den benachbarten Regionen, Klagenfurt (= Studia Carinthiaca 26).

Graber, G., 1941, Volksleben in Kärnten, 2. Aufl., Graz.

Gutsmann, O., 1789, Deutsch-windisches Wörterbuch mit einer Sammlung der verdeutschten windischen Stammwörter, und einiger vorzüglichern abstammenden Wörter, Klagenfurt.

H.B. - vom Autor vorliegender Arbeit aufgezeichnete mundartliche Belege aus dem Ortsdialekt von Gaimberg (Osttirol).

Herzmansky, S., 1969, Der alte Wortschatz der Bauern, Handwerker und Knappen in der Umgebung von Villach, Diss., Wien.

Hintner, A., 1878, Beiträge zur Tirolischen Dialektforschung. Der Deferegger Dialekt, Wien.

${ }^{54}$ Kranzmayer/Lessiak 76; zur Lokalisierung s. ebd. die zweite Karte im Anhang (dort eingetragener slowenischer Name: Grebl vrh). Bemerkenswert ist, dass sich in der Mundart der Sprachinsel Gottschee/Kočevje Gröfel/Gröbel nicht nachweisen lässt, obschon, wie oben angedeutet, davon ausgegangen werden kann, dass dieses in der Heimat der Gottscheer zur Zeit der Auswanderung nach lautlichem Befund bereits Teil der mundartlichen Lexik war. 
Hintner, V., 1909: Die Gsiesser Namen, Wien.

HK/DBÖ - Hauptkatalog zum Wörterbuch der bairischen Mundarten in Österreich (WBÖ), Österreichische Akademie der Wissenschaften / Zentrum Sprachwissenschaften, Bild- und Tondokumentation / Institut für Österreichische Dialekt- und Namenlexika (Wien) [Große Teile dieser Zettelkartei wurden bereits digitalisiert und bilden einen Teil des Datenbankverbundes Datenbank der bairischen Mundarten in Österreich (DBÖ), auf den für die Recherche zu diesem Beitrag auch zurückgegriffen wurde. Die mit der Quellenangabe HK/ DBÖ zitierten Belege wurden Großteils im Zeitraum 1913-1932 erhoben].

Hubmann, H., Die Toponyme und Hausnamen von Weißbriach (Gemeinde Gitschtal, Kärnten, Bezirk Hermagor), Österreichische Namenforschung 15-16 (1987-1988), 5-90.

Hutterer, C. J., Kainz, W., Walcher, E., 1987, Weststeirisches Wörterbuch. Grammatik und Wortschatz nach Sachgruppen, Wien - Köln - Graz (= Schriften zur deutschen Sprache in Österreich 13-14).

Ingenhaeff, W., Reiter, M., 1992, Kleines Zillertaler Wörterbuch, Schwaz.

Karničar, L., 1990, Der Obir-Dialekt in Kärnten. Die Mundart von Ebriach/Obirsko im Vergleich mit den Nachbarmundarten von Zell/Sele und Trögern/Korte (Phonologie, Morphologie, Mikrotoponymie, Vulgonamen, Lexik, Texte), Wien (= Österreichische Akademie der Wissenschaften. Philosophisch-historische Klasse. Sitzungsberichte 551).

KKK - Kranzmayer, E., Lessiak, P., Kundfahrtenkatalog, Österreichische Akademie der Wissenschaften / Zentrum Sprachwissenschaften, Bild- und Tondokumentation / Institut für Österreichische Dialekt- und Namenlexika (Wien) [Ca. 122000 Exzerpte aus den besonders in der 1. Hälfte des 20. Jh.s durchgeführten Mundarterhebungen in insgesamt 771 Orten (vorwiegend in Südösterreich und im angrenzenden Oberitalien und Slowenien)].

Köfler, W., 1973, Chronik von Nußdorf-Debant, Innsbruck (= Ortschroniken 5).

Köfler, W., 1974, Chronik von Prägraten, Innsbruck (= Ortschroniken 9).

Kranzmayer, E., Ortsnamenbuch von Kärnten, 2. Bde., Klagenfurt 1956-1958 (= Archiv für vaterländische Geschichte und Topographie 50-51).

Kranzmayer, E., Lessiak, P., 1983, Wörterbuch der deutschen Sprachinselmundart von Zarz/Sorica und Deutschrut/Rut in Jugoslawien, hg. v. M. Hornung u. A. Ogris, Klagenfurt (= Archiv für vaterländische Geschichte und Topographie 68).

Lawatsch, G., 1945, Die Mundart des Gerichtsbezirks Oberwölz, Diss., Graz.

LR - Lehenregister des Landgerichtes Lienz (1501), Tiroler Landesarchiv, Handschrift Nr. 1972. - Lehenregister des Landgerichtes Lienz (1540-62), Tiroler Landesarchiv, Handschrift Nr. 4111. - Lehenregister des Landgerichtes Lienz (1553), Tiroler Landesarchiv, Handschrift Nr. 1963.

ME - Mundarterhebungen. Unpaginierte Kopien von in den 1970-er Jahren in Hopfgarten i.D., Virgen, Matrei i.O. und Schlaiten durchgeführten Dialekterhebungen, Österreichische Akademie der Wissenschaften / Zentrum Sprachwissenschaften, Bild- und Tondokumentation / Institut für Österreichische 
Dialekt- und Namenlexika (Wien) [Anstelle der nicht vorhandenen Seitenzahl wird die jeweilige Fragebuchnummer angeführt].

ME Hopfgarten i.D. - Tatzreiter, H., Mundarterhebung Hopfgarten in Defereggen (1971). Näheres s. unter $\rightarrow$ ME.

ME Matrei i.O. - Gabriel, E., Mundarterhebung Matrei in Osttirol (1970/1971). Näheres s. unter $\rightarrow$ ME.

ME Schlaiten - Lipold, G., Mundarterhebung Schlaiten (1970). Näheres s. unter $\rightarrow$ ME.

ME Virgen - Tatzreiter, H., Mundarterhebung Virgen (1971). Näheres s. unter $\rightarrow$ ME.

Mitterrutzner, J. Chr., 1879, Slavisches aus dem östlichen Pusterthale (Drau- und Isel-Gebiet) in Tirol, Neunundzwanzigstes Programm des kaiserl.-königl. Gymnasiums zu Brixen, Brixen, 3-28.

Moro, O., 1928, Die Bichlbauerleut', Sonntagsblätter. Schriftleitungsbeilage der „Freien Stimmen“ (Klagenfurt) 7 (1928), 1-2.

Moro, O., 1928, Von Neujahr bis Aschermittwoch im St. Oswaldertal, Sonntagsblätter. Schriftleitungsbeilage der „Freien Stimmen“ (Klagenfurt) 52 (1928): $1-2$.

Moro, O., 1952, Volkskundliches aus dem Kärntner Nockgebiet. Volksmedizin / Volksglaube / Volksdichtung / Volkskunst / Hofwesen und Arbeitsleben, Klagenfurt.

Moser, H., 1976, Chronik von Lavant, Innsbruck (= Ortschroniken 26).

[Mußhauser, R.,] Von „A Boisl“ bis „Zwoschpan“. Dialektwörter aus Thurn, o.O., o.J. [ca. 2005].

OR - Oberforcher-Regesten / Osttiroler vor 1500 [handschriftliche Exzerpte in Karteiform], Archiv des Museums der Stadt Lienz auf Schloss Bruck.

Pichler, H., 1960, Die Haus- und Hofnamen des Gerichtsbezirkes Millstatt in Oberkärnten, Diss., Wien.

Pleteršnik, M., Slovensko-nemški slovar, 2 Bde., Ljubljana, 1894-1895. Digitale Version: Furlan, M./Dobrovoljc, H./Jazbec, H. (Hg.), Pleteršnik, M., Slovensko-nemški slovar. Transliterirana izdaja, Ljubljana 2006.

Pochlin, M., 1781, Tu malu besedishe treh jesikov. Das ist: das kleine Wörterbuch in dreyen Sprachen. Quod est: parvum dictionarium trilingue, Laibach.

RA - Rustikalsteuerkataster der Gemeinde Ainet (1780), Tiroler Landesarchiv, Kataster Nr. 120/16.

Regg.F.III H.13 = Herold, P. (Hg.), Regesten Kaiser Friedrichs III. (1440-1493) nach Archiven und Bibliotheken geordnet. Heft 13: Die Urkunden und Briefe des Österreichischen Staatsarchivs in Wien, Abt. Haus-, Hof- und Staatsarchiv: Allgemeine Urkundenreihe, Familienurkunden und Abschriftensammlungen (1447-1457), Wien 2001 (online unter <www.regesta-imperii.de> [22.3.2007]).

RF - Rustikalfassionen für die Gemeinden Ainet, Alkus, Amlach und Dölsach (1775), Tiroler Landesarchiv, Kataster Nr. 120/7.

RO - Rustikalsteuerkataster der Gemeinde Oberlienz (1780), Tiroler Landesarchiv, Kataster Nr. 120/32. 
ROd - Rustikalsteuerkataster der Gemeinde Oberdrum (1780), Tiroler Landesarchiv, Kataster Nr. 120/31.

Rudolf, I.: Die alte Bauernmundart von Molzbichl bei Spittal an der Drau. Diss. Wien 1965.

Schabus, W., 1971, Dialektgeographie des Lesachtals (Kärnten), Diss., Wien.

Schatz, J., 1955-1956, Wörterbuch der Tiroler Mundarten, 2 Bde., Innsbruck (= Schlern-Schriften 119-120).

Schnorr, G., 1975, Irschen. Eine Gemeindechronik, Irschen.

Skok, P., 1971-1974, Etimologijski rječnik hrvatskoga ili srpskoga jezika, 4 Bde., Zagreb.

$\mathrm{SP}=$ Słownik prasłowiański, Wrocław - Warszawa - Kraków 1974-lfd.

SPismo - Sveto pismo stare in nove zaveze. Slovenski standardni prevod iz izvirnih jezikov, Ljubljana, 1997.

SSKJ - Slovar slovenskega knjižnega jezika. Ljubljana 1970-1991 (online unter $<$ http://bos.zrc-sazu.si/sskj.html $>$ [22.3.2007]).

StB - Steuerbereitung des ganzen Pustertales (1545), Tiroler Landesarchiv, Kataster Nr. 0/8. - Steuerbereitung (Kataster) des Landgerichtes Lienz (1680), Tiroler Landesarchiv, Kataster Nr. 120/2a. - Steuerbereitung (Kataster) des Landgerichtes Lienz (1746), Tiroler Landesarchiv, Kataster Nr. 120/3.

TBA - Transportobuch (Güterbeschreibung und Namensregister) der Gemeinde Ainet (1840), Tiroler Landesarchiv, Kataster Nr. 120/41.

TBG1 - Transportobuch (Güterbeschreibung und Namensregister) der Gemeinde Glanz (1840), Tiroler Landesarchiv, Kataster Nr. 120/47.

TBO - Transportobuch (Güterbeschreibung und Namensregister) der Gemeinde Oberlienz (1840), Tiroler Landesarchiv, Kataster Nr. 120/58.

TBOd - Transportobuch (Güterbeschreibung und Namensregister) der Gemeinde Oberdrum (1840), Tiroler Landesarchiv, Kataster Nr. 120/57.

Totschnig, E., Lobenwein, P., 1978, Chronik von Oberlienz, Innsbruck (= Ortschroniken 37).

TSA - Tirolischer Sprachatlas, 1965-1971, 3 Bde., Innsbruck - Marburg (= Deutscher Sprachatlas. Regionale Sprachatlanten 3).

ULB - Urbarlehenbuch des Landgerichtes Lienz (1550), Tiroler Landesarchiv, Handschrift Nr. 2197.

Unger, Th., Khull, F., 1903, Steirischer Wortschatz, Graz (online unter <www. literature.at> [22.3.2007]).

Unterforcher, A., 1887, Beitrag zur Dialekt- und Namenforschung des Pusterthales, Jahres-Bericht des k. k. Staats-Ober-Gymnasiums zu Leitmeritz in Böhmen 1887, Leitmeritz, 3-22.

Unterforcher, A., 1889, Slavische Namenreste aus dem Osten des Pusterthales, Jahres-Bericht des $k$. k. Staats-Ober-Gymnasiums zu Leitmeritz in Böhmen für das Schuljahr 1889, Leitmeritz, 3-30.

Unterlercher, M., 1932, In der Einschicht. Das Leben eines Kärntner Bergbauernbuben. Erinnerungen eines Siebzigjährigen, St. Ruprecht / Villach.

UVGG - Klos-Bužek, Fr. (Hg.), 1956, Das Urbar der Vorderen Grafschaft Görz aus dem Jahre 1299, Wien (= Österreichische Urbare 1/3). 
$\hookrightarrow \quad$ WBÖ - Wörterbuch der bairischen Mundarten in Österreich, Wien 1970-1fd.

Zdovc, P., 1972, Die Mundart des südöstlichen Jauntales in Kärnten. Lautlehre und Akzent der Mundart der „Poljanci“, Wien (= Österreichische Akademie der Wissenschaften. Philosophisch-historische Klasse. Schriften der Balkankommission. Linguistische Abteilung 20).

\section{Gröfel, Gröbel 'kup kamenja, groblja' - dialektološka in imenoslovna razprava o bavarskem slavizmu \\ Povzetek}

Slovensko groblja »kup kamenja ipd.«najdemo danes kot slavizem v več različnih bavarskih narečjih na Vzhodnem Tirolskem, avstrijskem Koroškem, avstrijskem Zgornjem in Zahodnem Štajerskem, kakor tudi v Salzburškem Lungauu. Semantično so ti izposojeni elementi zelo blizu slovenski izposojni predlogi. Tako v slovenščini kot v večih od zgoraj navedenih bavarskih narečij gre za kupe kamenja, ki ležijo večinoma ob robu polja ali njive in predstavljajo rezultat večstoletnega čiščenja kmetijskih površin. Naš slavizem ima v bavarščini dve različni pojavni obliki, ki se $v$ glavnem razlikujeta po tem, kako se v bavarščini substituira glas - b-iz slovenske predloge za izposojo. Za ti dve bavarski pojavni obliki lahko uporabimo dve osnovni fonetični formi: Gröfel (slovensko -b- > bavarsko -f-) in Gröbel (-b- > -b-). Dejstvo, da imamo dve različni fonetični obliki, lahko pojasnimo z različnim časom prevzema iz slovenščine v bavarščino. Poleg tega se izkaže, da imata ti dve fonetični realizaciji tudi bolj ali manj jasno arealno porazdelitev: Gröfel prevladuje na Vzhodnem Tirolskem, avstrijskem Zgornjem in Srednjem Koroškem, medtem ko najdemo redkejše izpričbe različice Gröbel na avstrijskem Spodnjem Koroškem, avstrijskem Štajerskem kakor tudi v Lungauu. Beseda se ne pojavlja samo kot simpleks, ampak tudi kot osnovna beseda v različnih zloženkah in kolektivnih tvorjenkah, kakor tudi $v$ primeru neke glagolske tvorjenke. V pričujočem članku sem-seveda ne do popolnosti - skušal zbrati čimveč izpričb tega slavizma, pri čemer sem pregledoval predvsem gradivo za Wörterbuch der bairischen Mundarten in Österreich (WBÖ). Kot je bilo pričakovati, se slovensko groblja pojavlja nemalokrat tudi v imenskem gradivu raziskovanega zemljepisnega območja. Tudi za te izpričbe navajam ustrezne primere, deloma podkrepljene z zgodovinskimi zapisi.

Hubert Bergmann

Österreichische Akademie der Wissenschaften

Zentrum Sprachwissenschaften, Bild- und Tondokumentation

Institut für Österreichische Dialekt- und Namenlexika

Wohllebengasse 12-14, 1040 Wien 


\title{
Imiona w nazwach jezior i stawów w Polsce
}

\author{
Urszula Bijak, Barbara Czopek-Kopciuch (Krakov)
}

IZVLEČEK: V članku so obravnavana imena ribnikov in jezer na ozemlju Poljske, ki izhajajo iz imen. Analiziranih je 283 hidronimov iz 76 okrajev Poljske. Med hidronimi je 20 starejših, izpričanih od 14.-19., večina pa je prvič zapisana v 20. stoletju. Motivacijsko bazo tvorijo moška in ženska imena, ki so večinoma krščanska, ter maloštevilna staropoljska vosnovni, pogosto tudi manjšalni obliki. Večina hidronimov je nastala po imenih lastnikov, manjši del pa so spominska imena. Med slednjimi so opazna imena literarnega porekla, motivirana z zgodovinskimi in svetniškimi liki. Med izimenskimi hidronimi prevladujejo imena, nastala s transonimizacijo. Veliko skupino tvorijo besedne zveze z razlikovalnimi členi, maloštevilno pa imena, nastala s pluralizacijo.

\section{Personal Names in the Names of Polish Lakes and Ponds}

ABSTRACT: This article discusses the names of ponds and lakes in Poland that are derived from first names. It analyzes 283 hydronyms from 76 Polish districts. Among these, 20 are of an older date-that is, attested between the 14th and 19th century - whereas the majority were first recorded in the 20th century. Their motivational base is formed by male and female, mostly Christian, names, whereas a small number are created from old Polish names in their basic and often diminutive forms. The majority of hydronyms were created from the names of landowners, while a smaller proportion are commemorative. Among the latter, names with a literary origin motivated by historical characters and saints are evident. Among desubstantival hydronyms, names formed through transonymization predominate. A large group is formed by compounds with differential segments, whereas only a small number of names are formed through pluralization.

Hydronimom derywowanym od antroponimów nie poświęcano dotychczas zbyt wiele uwagi w literaturze onomastycznej. Uznawano je za nową warstwę nazw wodnych, niezbyt liczną, dotyczącą na ogół mniejszych obiektów, zwłaszcza 
stawów, sadzawek, źródeł, małych potoków i strugํㅗ. Materiał historyczny i objaśnienia takich nazw spotkać można w toponomastyczych opracowaniach regionalnych, opracowaniach hydronimicznych niektórych dorzeczy oraz w tomach serii Hydronymia Europaea. Zgromadzony tu materiał pochodzi z komputerowej bazy nazw wodnych, która powstaje w Pracowni Toponomastycznej Instytutu Języka Polskiego PAN w Krakowie (grant nr 1H01D01029). Podstawę źródłową tego onomastykonu stanowią wydane drukiem dokumenty historyczne, słowniki historyczne i geograficzne, mapy historyczne i współczesne, wykazy nazw wodnych i dotychczas opublikowane opracowania hydronimiczne. Baza ta będzie zawierać około 30 tysięcy obiektów wodnych.

Przedmiotem niniejszego artykułu są nazwy wód stojących (jezior i stawów) z terenu Polski, w jej współczesnych granicach, utworzone od imion w wyniku transonimizacji lub derywacji paradygmatycznej, a więc bez użycia sufiksów. Wyekscerpowano zarówno hydronimy jednoczłonowe, jak i zestawienia zawierające imiona, łącznie 283 nazw.

Pierwszy zapis takiego hydronimu pojawia się w źródłach już w XIV w.: Przedsław, nieistniejący staw w Myślenicach, koło Krakowa, por. lacus dictus Przedslaw (1364). Jego nazwa pochodzi od staropolskiego dwuczłonowego imienia Przedstaw ${ }^{2}$.

W XVI wieku odnotowane są 3 nazwy:

Jaga, nieistniejące dziś jezioro koło Góry Nawojowej, niedaleko Krakowa, por. Jaga (1553), którego nazwa motywowana jest zdrobniałym żeńskim im. Jaga (: Agata, Agnieszka, Jadwiga);

Seweryn, staw koło Czernichowa, pow. krakowski, por. Seweryn (1564); nazwa pochodzi od chrześcijańskiego im. Seweryn;

Dobrzynka-Wojtek — nazwa zestawiona, określająca staw na rzece Dobrzynka, w pow. łaskim, por. Staw Dobrinka Wojtek (1564-1565). Pierwszy człon zestawienia pochodzi od n. rzeki Dobrzynka (a ta od nazwiska Dobrzynka), drugi od zdrobniałego im. Wojtek (: Wojciech).

W XVIII wieku pojawia się w źródłach 12 nowych obiektów:

Adaś, nieistniejący staw w Pisarzowicach, pow. bielski, por. Adaś (1786-1788); n. od zdrobniałego im. Adaś (: Adam);

Barbara, nieistniejący staw, w Żywcu, por. staw Barbara (1715); od im. Barbara;

Daniło, nieistniejący staw koło Białegostoku, por. Daniło (1784); od białoruskiego im. Danito;

Frantosik, nieistniejący staw, we wsi Pławy, pow. oświęcimski, por. około stawu Frantosika (1786-88); od im. *Frantosik (: Franciszek);

1 K. Rymut, Nazwy wodne (w:) Słowiańska encyklopedia, t. II, Kraków 2003, s. 230; A. Cieślikowa, E. Wolnicz-Pawłowska, Krótka charakterystyka hydronimii polskiej (w:) Nazewnictwo geograficzne Polski, t. I: Hydronimy, Cz. I: Wody płynące, źródła, wodospady, Warszawa 2006, s. VIII.

2 Ponieważ nazwa została odnotowana w źródłach jedynie w formie mianownika, trudno rozstrzygnąć, czy ma ona postać bezsufiksalną, czy też tkwi w niej archaiczny przyrostek dzierżawczy ${ }^{*}-j b$. 
Frydeczek, staw (dziś obiekt bez nazwy), we wsi Pogórze, pow. cieszyński, por. Fridezek (1789); od zdrobniałego im. *Frydeczek (: Fryderyk);

Jadamaczek, nieistniejący staw we wsi Mazańcowice, pow. bielski, por. Jadamaczek a. Jedamaczek (1789); od zdrobniałego im. Jadamaczek (: Jadam < Adam);

Jagoszek, nieistniejący staw we wsi Mnich, pow. cieszyński, por. Jagoschek (1789); od zdrobniałego im. Jagoszek (: Agata, Agnieszka, Jadwiga);

Jan, nieistniejący staw w Żywcu, por. staw Jan (1715); od im. Jan;

Jędrzejek, nieistniejący staw, we wsi Polanka Wielka, pow. oświęcimski, por. Jędrzejek (1786-1788); od zdrobniałego im. Jędrzejek (: Jędrzej < Andrzej);

Kasia, nieistniejący staw we wsi Poręba Wielka, pow. oświęcimski, por. Kasia (1786-1788), od zdrobniałego im. Kasia (: Katarzyna $)^{3}$;

Krzysztof, nieistniejący staw w Żywcu, por. staw Krzysztof (1715), od im. Krzysztof;

Krzyś-Folwarcznik, nieistniejący staw we wsi Grojec, pow. oświęcimski, por. Krzyś Folwarcznik (1786-1788); n. zestawiona — od zdrobniałego im. Krzyś (: Krzysztof, Kryspin) i od ap. folwark, z suf. -nik (człon ten określa położenie stawu na terenie folwarku);

Mały Jakubik, nieistniejący staw we wsi Mnich, pow. cieszyński, por. Klein Jakubik (1789); n. zestawiona — od zdrobniałego im. Jakubik (: Jakub) z niem. przymiotnikiem klein 'mały' określającym wielkość obiektu.

W XIX wieku zanotowano po raz pierwszy 3 nazwy:

Judas, staw nieistniejący we wsi Strumień, pow. cieszyński, por. Judass (1820), od im. Judas, Judasz (znanego z Nowego Testamentu);

Maciej, nieistniejący staw we wsi Strumień, pow. cieszyński, por. Matiey (1820), od im. Maciej, czes. Matěj;

Maurycy, nieistniejący staw w Zatorze, pow. oświęcimski, por. Maurycy (1895), od im. Maurycego Potockiego. ${ }^{4}$

Wszystkie przedstawione powyżej hydronimy (20) odnoszą się do obiektów dziś nieistniejących, zapewne zasypanych, wyschniętych, czy osuszonych. Niewiele można powiedzieć o bezpośredniej motywacji tych nazw. To, że nazwy są formalnie równe imionom może wskazywać na ich charakter pamiątkowy. Mogły te niewielkie obiekty wodne otrzymywać imiona właścicieli gruntów, wówczas miałyby charakter przynależnościowy, typowo dzierżawczy. Pewnym przykładem nazwy pamiątkowej może być nazwa Maurycy nadana dla uczczenia Maurycego Potockiego. Podstawą ponad połowy nazw są imiona w formie zdrobniałej. Większość nazw jest formalnie równa różnym postaciom imion męskich, tylko 3 motywowane są przez imiona kobiece, jedno w formie pełnej, dwa w formie zdrobniałej.

Jeśli chodzi o strukturę hydronimów o starszej dokumentacji, to w większości są to nazwy proste, trzy spośród nich mają postać zestawień: Dobrzynka-Wojtek, Krzyś-Folwarcznik i Klein Jakubik.

3 Śladem po nazwie tego stawu jest współcześnie nazwa terenowa i część wsi Poręba Wielka.

4 Potoccy byli właścicielami stawów w Zatorze. 
Obiekty te rozmieszczone są głównie w Polsce południowej, we współczesnych powiatach: cieszyńskim (5), oświęcimskim (5), bielskim (2), krakowskim (3), we wsi Sporysz włączonej do Żywca (3) i po jednym koło Łodzi i Białegostoku.

„Eksplozję” hydronimów odimiennych obserwujemy w wieku XX. Odnotowano wtedy 263 nazwy dla obiektów rozmieszczonych na obszarze całej Polski w 76 powiatach..

W woj. podkarpackim, w pow. stalowowolskim, w gm. Zaklików znajdują się 24 obiekty: Adam (2 x), Antoni, Ewa, Ferdynand, Florian, Hala, Hanka, Jagienka, Jan, Janek, Jorgiś, Józef, Kajtek, Konstanty, Maryśka, Mateusz, Rafat, Stefan, Stefan, Teofil, Wanda, Władysław, Wojtek; w pow. jasielskim, gm. Skołyszyn (6): Jaś, Julian, Leszek, Małgosia, Oleś, Wacław.

W woj. dolnośląskim, w pow. milickim, gm. Krośnice, Milicz i Cieszków - 21: Andrzej (1983), Bolko, Duży Jaś (1983), Duży Karol (1983), Emilia (1983), Ernest, (1983), Halina, Henryk (Maty Henryk) (1983), Henryk, Henryk (1983), Henryk Nowy, Jan (1983), Karol (1983), Kazimierz Górny, Leszek, Mały Karol, Mieczysław (1983), Staś Dolny, Staś Górny, Władysław, Zofia (1983); w pow. oleśnickim, gm. Twardogóra - 3: Mała Amalia, (1983), Pelagia (1983) Wielka Amalia (1983 ); w pow. legnickim, gm. Chojnów - 2: Paulinki Drugie, Paulinki Pierwsze; w pow. ząbkowickim, gm. Ziębice - 2: Henryk, Karol; w pow. polkowickim, gm. Przemków - 1: Bolestaw.

W woj. małopolskim, w pow. oświęcimskim w gminach: Brzeszcze, Oświęcim, Osiek, Zator odnotowano 22 nazwy stawów: Adam Duży, Andrzej, Andrzej Duży, Danusia, Gabriela (1964), Gabriela (1964), Hanusia (1964), Helenka (1964), Józef, Karolcia, Marian Górny, Micia, Olusia, Stanisław, Stanisław, Sylwester, Teresa; w pow. wadowickim, gm. Spytkowice - 4: Adam//Staw Adam (1961), Adamek//Staw Adamek (1961); Artur, Róża; w pow. tarnowskim, gm. Wierzchosławice - 1: Maruszka.

W woj. podlaskim, w pow. białostockim, gm. Poświętne znajduje się 14 obiektów: Elżbieta Druga, Elżbieta Pierwsza, Gabriela, Gabrielka, Jerzy, Józef, Kazimierz, Maria, Marylka, Michat Drugi, Michał Pierwszy, Rafat, Witold, Zofia; w pow. zambrowskim, gm. Zambrów - 5: Aleksander, Grażyna, Kajtek, Krzysztof, Moryś; w pow. augustowski, gm. Augustów - 1: Święty Jan (1966), w pow. monieckim, gm. Knyszyn - 1: Jezioro Zygmunta Augusta.

W woj. lubelskim, w pow. tomaszowskim, w gm. Łaszczów i Tarnawatka odnotowano 14 hydronimów: Adam Drugi, Adam Pierwszy, Agatka, Aleksander Drugi, Aleksander Pierwszy, Ignaś, Jacek, Jan Dolny, Jan Górny//Jan (1965), Janek, Jaś, Kaźmierz, Małgosia, Marian; w pow. janowskim, gm. Potok Wielki i Modliborzyce - 12: Bogusław, Bohun, Lech, Michat, Nowy Witold, Nowy Władysław, Oleńka, Stanisław, Stary Witold, Stary Władysław, Wojciech, Zygmunt; w pow. zamojskim, w gm. Komarów-Osada, też Zamość - 11: Adaś (1954-60), Andrzej, Feliks, Grzegorz (2x), Józef, Kazimierz, Krzysztof, Marcin, Marian, Waldemar; w pow. parczewskim, w gm. Sosnowica i Siemień - 8: Andrzejki (1965), Helena, (1965), Jan (1965), Ksiażę Józef (1965), Marek (1965), Michałki (1965) Wojtek, Zofia (1971); w pow. włodawskim, gm. Stary Brus i Wola Uhruska - 6: Asia, Baśka (gw.), Januś, Jurek (gw.), Pawet, Jama Roma; w pow. lubartowskim, gm. Uścimów - 5: Adam, 
Jan// Święty Jan (1965), Michał (1965), Wanda Druga, Wanda Pierwsza; w pow. chełmskim - 3: Esterka (1954-60), Jezioro Jurka (1970), Jezioro Marcinka; w pow. ryckim, gm. Ryki - 1: Karol; w pow. hrubieszowskim, gm. Mircze - 1: Hala; w pow. puławskim, gm. Baranów - 1: Mateusz.

W woj. śląskim, pow. lublinieckim, gm. Ciasna, Kochanowice, Pawonków - 11: Staw Feliksa, Gustaw, Halina//Staw Halina (1962), Kacper//Staw Kacper (1962), Ludwik//Staw Ludwik (1962), Mańka, Marian//Staw Marian (1962), Ola (1924-38)//Staw Ola (1983), Stawy Sabiny, Walek, Wanda; w pow. i gm. Katowice - 6: Barbara, Janina, Małgorzata, Hubertus Drugi, Hubertus Pierwszy, Hubertus Trzeci i Hubertus Czwarty położony w gm. Mysłowice ; w pow. pszczyńskim, gm. Goczałkowice-Zdrój - 3: Maciek (1966), Maciek Borowy, Maciek Kanałowy; w pow. i gm. Świętochłowice - 2: Martyn, Matylda; w pow. bielskim, gm. Wilamowice - 1: Antoni; w pow. częstochowskim, gm. Janów - 1: Irydion; w pow. gliwickim, gm. Wielowieś - 1: Hubertus//Staw Hubertus (1983).

W woj. warmińsko-mazurskim, pow. olsztyńskim zanotowano 5 nazw: Klimunt, Pawlik (jez.), Bartosz (1964), Wojciech (1925), Wojtek//Wójtek (1925); w pow. piskim, gm. Ruciane-Nida - 2, Jany, Jany Małe; w pow. giżyckim, gm. Ryn - 2: Szymon, (jez.), Szymonek (jez.); w pow. mragowski, gm. Piecki - 2: Klimunt, Pawełek; w pow. szczycieńskim, gm. Jedwabno i Szczytno - 2; Klimek (jez.), Romanek (jez.); w pow. gołdapskim, gm. Gołdap - 1: Szymanek (jez.); w pow. iławskim, gm. Kisielice - 1: Bartek; w pow. oleckim, gm. Kowale Oleckie - 1: Marki (jez. 1963).

W woj. mazowieckim, w pow. siedleckim, gm. Kotuń i Przesmyki znajduje się 5 obiektów: Alina, Helena, Jadwiga (1962), Nana, Stefan; w pow. przysuskim, gm. Wieniawa - 4: Irena, Jerzy, Krystyna, Kuba; w pow. grodziskim, gm. Jaktorów - 2: Bolesław, Franciszek; w pow. węgrowskim, gm. Liw - 1: Franciszek; w pow. żyrardowskim, gm. Mszczonów - 1: Święta Anna; w pow. kozienickim, gm. Grabów nad Pilicą - 1: Staw Świętego Jana.

W woj. opolskim, w pow. namysłowski, gm. Pokój są 4 stawy: August, Staw Fryderyka, Staw Matyldy, Staw Zofii; w pow. opolskim, gm. Niemodlin - 2: Hubert, Zofia (1983 ); głubczycki, gm. Głubczyce - 1: Marysieńka (stawy).

W woj. lódzkim, w pow. poddębickim, gm. Dalików odnotowano 4 nazwy: Duży Staw Helena i Mały Staw Helena, Halina (1973), Kazimierz Duży; w pow. łódzkim, gm. Łódź - 1: Staw Jana; w pow. zgierskim, gm. Aleksandrów Łódzki - 1: Kazimierz.

W woj. pomorskim, w pow. gdańskim, gm. Trąbki Wielkie - 3: Jezioro Aleksandra, Jezioro Bronisława, Jezioro Stanisława (trzy jeziora); w pow. chojnickim, gm. Konarzyny i Chojnice - 2: Jacyś, Jezioro Olbrachta (jez.); w pow. słupskim, gm. Smłodzino - 1: Lolek.

W woj. wielkopolskim, w pow. ostrowskim, gm. Sośnie - 3: Antoni, Augustyn, Jan; w pow. gnieźnieńskim, gm. Gniezno - 1: Róża; w pow. międzychodzkim, gm. Międzychód - 1: Gertruda//Jezioro Gertruda, w pow. pleszewskim, gm. Gizałki - 1: Pawełek, (jez.); w pow. ostrzeszowskim, gm. Kobyla Góra-1: Mikołaj; w pow. poznańskim, gm. Pobiedziska - 1: Jezioro Uli (jez.).

W woj. świętokrzyskim, pow. pińczowskim, gm. Pińczów - 3: Aleksander, 
$4 \quad$ Izabela, Krzysztof; w pow. buskim, gm. Wiślica - 1: Marian; w pow. kazimierskim - 1: Janeczek.

W woj. kujawsko-pomorskim, w pow. mogileńskim, gm. Mogilno - 1: Bronisław (jez.); w pow. wąbrzeskim, gm. Wąbrzeźno - 1: Frydek (jez.); w pow. aleksandrowskim - 1: Jarosław (1928); w pow. brodnickim, gm. Bobrowo - 1: Marek (jez.).

W woj. zachodniopomorskim, w pow. choszczeńskim, gm. Pełczyce - 1: Jan; w pow. myśliborskim, gm. Myslibórz - 1: Paweł (jez.), w pow. wałeckim, gm. Mirosławiec - 1: Jezioro Hanki (jez.), w pow. łobeskim, gm. Łobez - 1: Helka.

Nazwy, które pojawiają się w XX wieku są, jak już powiedziano, wielekroć liczniejsze. W większości pochodzą one z wykazu nazw standaryzowanych, który ukazał się w 2006 roku - Nazewnictwo geograficzne Polski, T. I: Hydronimy, cz. 2. Wody stojące. Niestety, z powodu braku danych, niewiele można powiedzieć o ich motywacji. Można przypuszczać, że mają one związek z imionami właścicieli. Część z nich zapewne ma charakter pamiątkowy, część - dzierżawczy. Na charakter pamiątkowy wskazywać może chociażby „,seria” nazw w w pow. janowskim, gdzie spotkać można nazwy stawów: Bogusław, Bohun, Michat, Oleńka, Stary Witold, Nowy Witold. Zgromadzenie takich nazw w jednym regionie sugerować może ich motywację literacką, nawiązanie do imion bohaterów powieści Sienkiewicza. Proweniencję literacką ma zapewne nazwa Irydion (pow. częstochowski) i nawiązuje do tytułowego bohatera utworu Zygmunta Krasińskiego, także nazwy Jaś i Małgosia (stawy w pow. tomaszowskim i jasielskim), czy Jacek i Agatka (pow. tomaszowski) motywowane są przez imiona bohaterów bajek dla dzieci.

Inną "serię" spotkać można w pow. milickim, gdzie występują takie nazwy stawów jak: Bolko, Henryk, Jan, Kazimierz Górny, Leszek, Władysław, Henryk Nowy. Tu dopatrywać się można motywacji przez imiona książąt z dynastii Piastów Śląskich. Z pewnością charakter pamiątkowy mają nazwy typu: Jezioro Olbrachta (pow. chojnicki), Ksiażę Józef (staw w Sosnowicy, woj. lubelskie) czy Jezioro Zygmunta Augusta (podlaskie, gm. Knyszyn), nawiązujące do imion i królów i książąt polskich.

Uwagę zwracają też nieliczne nazwy z elementem święty, pochodzące zapewne od patronów kościołów lub kapliczek znajdujących się w pobliżu obiektów wodnych: Święta Anna, Staw Świętego Jana, Święty Jan.

Wśród prezentowanych nazw stawów i jezior dominują hydronimy utworzone od imion bez użycia wykładników formalnych i członów dyferencyjnych. Podstawami są imiona w formie pełnej, np. Bolesław czy Barbara lub w formie zdrobniałej, np. Bolko czy Baśka. Są to głównie imiona chrześcijańskie, występują też imiona staropolskie, np.: Przedsław, Bolesław, Kazimierz, Mieczysław, Stanisław, Wojciech lub ich zdrobnienia: Bolko, część z nich mieści się również w kanonie imion chrześcijańskich. Wyjątkowo pojawiają się imiona innego pochodzenia, por. nazwę stawu Moryś (podlaskie), zapewne od im. Moritz, Moryc, popularnego wśród Żydów. Bazą do utworzenia nazw stawów i jezior stało się 75 imion męskich. Ich liczba byłaby większa gdyby doliczyć postaci zdrobniałe. Najchętniej używane jest imię Jan (13) oraz Adam (10). Spośród imion kobiecych użyto 39; najchętniej tworzono nazwy małych obiektów wodnych od imienia Zofia (6) i Halina (5). Bardzo 
często tworzone są nazwy od imion zdrobniałych. Trudno tu zaobserwować jakąś prawidłowość, ale wygląda na to, że znacznie częściej mamy do czynienia z nazwami od zdrobniałych imion kobiecych niż od męskich, np. w woj. małopolskim, pow. oświęcimski, gm. Brzeszcze, na 8 nazw stawów 4 to nazwy od zdrobniałych imion kobiecych: Danusia, Karolcia, Olusia, Micia, zaś nazwy stawów od imion męskich w tej gminie pochodzą od pełnych imion - Stanisław, Andrzej, Sylwester.

Spotykamy kilka nazw utworzonych w wyniku pluralizacji: Paulinki Drugie, Paulinki Pierwsze, Michałki, Jany, Jany Małe.

Wśród struktur złożonych odnotować należy zestawienia zawierające terminy hydronimiczne takie jak: staw, jezioro, też jama oraz imię w mianowniku, np. Duży Staw Helena i Mały Staw Helena, Staw Marian, Jama Roma lub w dopełniaczu, np. Staw Feliksa, Stawy Sabiny, Staw Świętego Jana, Staw Fryderyka, Staw Matyldy, Staw Zofii; Jezioro Zygmunta Augusta, Jezioro Jurka, Jezioro Marcinka, Jezioro Aleksandra, Jezioro Bronisława, Jezioro Stanisława, Jezioro Olbrachta, Jezioro Hanki.

Dużo jest zestawień z członami dyferencyjnymi. Na uwagę zasługują człony odróżniające liczebnikowe, które pojawiają się w nazwach obiektów leżących w obrębie jednej gminy, np. Paulinki Drugie i Paulinki Pierwsze, Adam Drugi i Adam Pierwszy, Aleksander Drugi i Aleksander Pierwszy, Michat Drugi i Michat Pierwszy, Wanda Druga i Wanda Pierwsza, Hubertus Drugi, Hubertus Czwarty, Hubertus Pierwszy, Hubertus Trzeci. Do nazw od imion dodawane bywają człony odróżniające nawiązujące do wielkości (mały, duży), dawności (stary, nowy) lub położeniu obiektu (górny, dolny), np. Mały Karol, Mała Amalia i Wielka Amalia, Adam Duży, Andrzej i Andrzej Duży, Duży Staw Helena i Maty Staw Helena, Kazimierz Duż, Nowy Witold i Stary Witold, Nowy Władystaw i Stary Władysław, Kazimierz Górny, Staś Dolny i Staś Górny, Marian Górny, Jan Dolny i Jan Górny, także inne por. Maciek Borowy i Maciek Kanałowy. Nazwy z członami odróżniającymi stanowią około $25 \%$ ogółu badanych nazw.

Zapisy źródłowe dla hydronimów odimiennych są dość skąpe, ubogie, co wynika z niedoskonałości tworzonej dopiero bazy komputerowej. Nie można więc zaobserwować postaci wariantywnych. Udokumentowane są jedynie nieliczne poświadczenia zmian formy nazwy zestawionej w prostą, np. Adam//Staw Adam, Adamek//Staw Adamek, Jan Górny//Jan, Halina//Staw Halina, Marian//Staw Marian, Ola//Staw Ola, Hubertus//Staw Hubertus, Ludwik//Staw Ludwik, Marian//Staw Marian, Gertruda//Jezioro Gertruda, Staw Kasper//Kacper.

Przedstawiony materiał obejmuje 283 hydronimy (265 nazw stawów i 18 nazw jezior) dla obiektów rozmieszczonych w 13 województwach i 76 powiatach całej Polski. Najliczniej reprezentowane są one w powiecie stalowowolskim (24), oświęcimskim (22) i milickim (21) i co charakterystyczne obiekty te leżą w obrębie jednej gminy lub kilku znajdujących się w sąsiedztwie. Często badane nazwy występują seriami; w 39 powiatach odnotowano więcej niż jeden hydronim tego typu. Rzadko spotyka się je w „krainie tysiąca jezior”, jak poetycko określa się obszar Warmii i Mazur; gdzie dla dużych obiektów wodnych, typu jezioro, bardziej „odpowiednie” były inne nazwy. Często są one pochodzenia indoeuropejskiego, staropruskiego. Natomiast dla małych jeziorek oraz stawów nazwy formalnie równe imionom wy- 
4 dają się być charakterystyczne, podkreślają ich związki z właścicielami, widoczne jest tworzenie ich przez mieszkańców lokalnej społeczności i na jej użytek. Część nazw ma charakter sztuczny, nadany administracyjnie. Hydronimy odimienne należą w zdecydowanej większości do nowszej warstwy nazewniczej. W stosunku do całej bazy nazw wodnych, grupa tych nazw, choć stosunkowo nieliczna (poniżej $1 \%$ ), wyróżnia się poprzez częste użycie jako bazy motywacyjnej imion w formie zdrobniałej.

\section{Źródła i literatura}

Materiał z komputerowej bazy nazw wodnych w Pracowni Toponomastycznej Instytutu Języka Polskiego PAN w Krakowie (grant nr 1H01D01029).

Rymut, Kazimierz, Nazwy wodne (w:) Słowiańska encyklopedia, t. II, Kraków 2003, s. 230.

Cieślikowa, Aleksandra, Wolnicz-Pawłowska, Ewa, Krótka charakterystyka hydronimii polskiej (w:) Nazewnictwo geograficzne Polski, t. I: Hydronimy, Cz. I: Wody płynące, źródła, wodospady, Warszawa 2006, s. VIII.

\section{Rozmieszczenie stawów i jezior o nazwach od imion w Polsce}

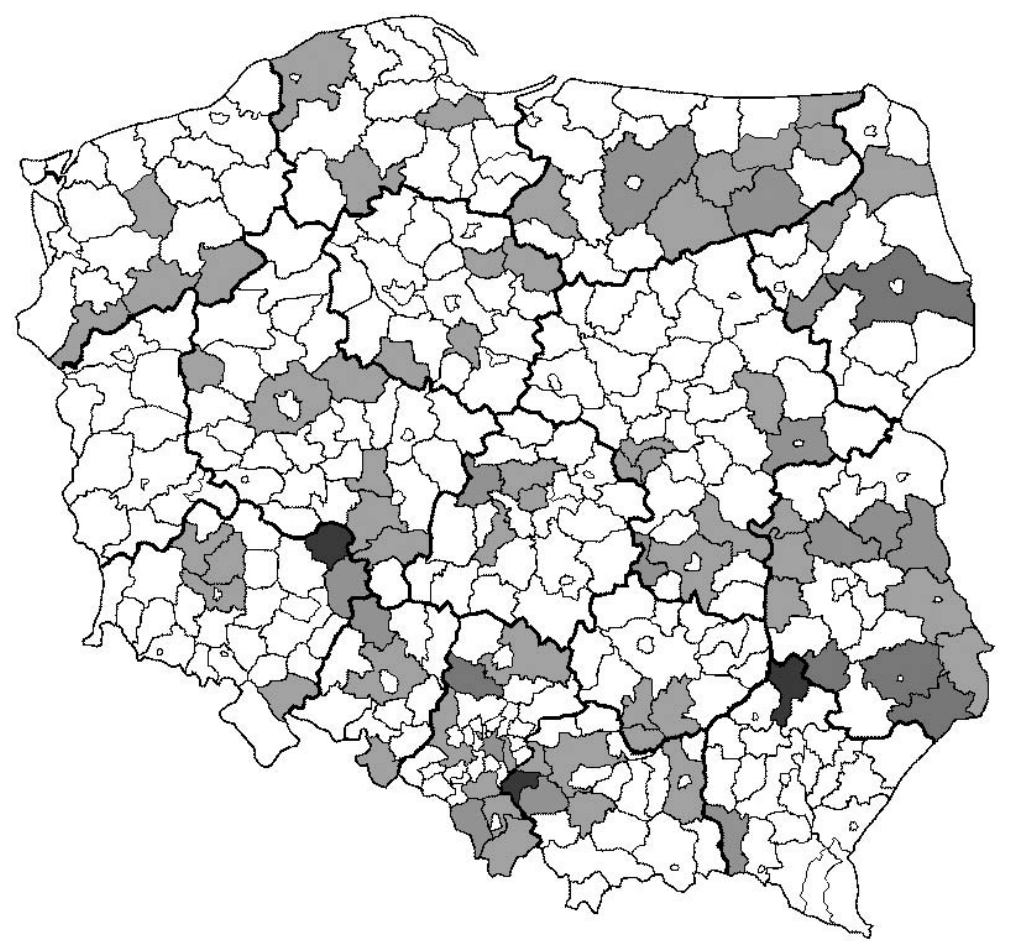


Razem 283 obiekty w 76 powiatach

\begin{tabular}{|c|c|c|}
\hline Lp. & Powiat & $\begin{array}{r}\text { Liczba } \\
\text { obiektów }\end{array}$ \\
\hline 1 & stalowowolski & 24 \\
\hline 2 & oświęcimski & 22 \\
\hline 3 & milicki & 21 \\
\hline 4 & białostocki & 15 \\
\hline 5 & tomaszowski & 14 \\
\hline 6 & janowski & 12 \\
\hline 7 & lubliniecki & 11 \\
\hline 8 & zamojski & 11 \\
\hline 9 & parczewski & 8 \\
\hline 10 & jasielski & 6 \\
\hline 11 & m. Katowice & 6 \\
\hline 12 & oleśnicki & 6 \\
\hline 13 & włodawski & 6 \\
\hline 14 & cieszyński & 5 \\
\hline 15 & lubartowski & 5 \\
\hline 16 & olsztyński & 5 \\
\hline 17 & siedlecki & 5 \\
\hline 18 & zambrowski & 5 \\
\hline 19 & namysłowski & 4 \\
\hline 20 & piski & 4 \\
\hline 21 & poddębicki & 4 \\
\hline 22 & przysuski & 4 \\
\hline 23 & wadowicki & 4 \\
\hline 24 & chełmski & 3 \\
\hline 25 & gdański & 3 \\
\hline 26 & m. Łódź & 3 \\
\hline 27 & ostrowski & 3 \\
\hline 28 & pińczowski & 3 \\
\hline 29 & pszczyński & 3 \\
\hline 30 & żywiecki & 3 \\
\hline 31 & bielski & 2 \\
\hline 32 & chojnicki & 2 \\
\hline 33 & giżycki & 2 \\
\hline 34 & grodziski & 2 \\
\hline 35 & legnicki & 2 \\
\hline 36 & mrągowski & 2 \\
\hline 37 & opolski & 2 \\
\hline 38 & szczycieński & 2 \\
\hline 39 & ząbkowicki & 2 \\
\hline
\end{tabular}

\begin{tabular}{|c|c|c|}
\hline Lp. & Powiat & $\begin{array}{c}\text { Liczba } \\
\text { obiektów }\end{array}$ \\
\hline 40 & aleksandrowski & 1 \\
\hline 41 & augustowski & 1 \\
\hline 42 & brodnicki & 1 \\
\hline 43 & buski & 1 \\
\hline 44 & choszczeński & 1 \\
\hline 45 & częstochowski & 1 \\
\hline 46 & gliwicki & 1 \\
\hline 47 & gnieźnieński & 1 \\
\hline 48 & gołdapski & 1 \\
\hline 49 & głubczycki & 1 \\
\hline 50 & hrubieszowski & 1 \\
\hline 51 & iławski & 1 \\
\hline 52 & kazimierski & 1 \\
\hline 53 & kozienicki & 1 \\
\hline 54 & m. Mysłowice & 1 \\
\hline 55 & m. Świętochłowice & 1 \\
\hline 56 & międzychodzki & 1 \\
\hline 57 & mogileński & 1 \\
\hline 58 & moniecki & 1 \\
\hline 59 & myślenicki & 1 \\
\hline 60 & myśliborski & 1 \\
\hline 61 & olecki & 1 \\
\hline 62 & opolski & 1 \\
\hline 63 & ostrzeszowski & 1 \\
\hline 64 & pleszewski & 1 \\
\hline 65 & polkowicki & 1 \\
\hline 66 & poznański & 1 \\
\hline 67 & puławski & 1 \\
\hline 68 & rycki & 1 \\
\hline 69 & słupski & 1 \\
\hline 70 & tarnowski & 1 \\
\hline 71 & wałecki & 1 \\
\hline 72 & wąbrzeski & 1 \\
\hline 73 & węgrowski & 1 \\
\hline 74 & zgierski & 1 \\
\hline 75 & łobeski & 1 \\
\hline \multirow[t]{2}{*}{76} & żyrardowski & 1 \\
\hline & RAZEM & 283 \\
\hline
\end{tabular}




\section{Rojstna imena v imenih jezer in ribnikov na Poljskem Povzetek}

V̌́lanku so obravnavana imena ribnikov in jezer na ozemlju Poljske, ki izhajajo iz rojstnih imen. Analiziranih je 283 hidronimov, od katerih je 20 starejših, s historičnimi zapisi od 14.-19. stoletja, večina pa je prvič izpričana v 20. stoletju. Motivacijsko podlago tvorijo moška in ženska rojstna imena, ki so večinoma krščanska, ter maloštevilna staropoljska v osnovni, pogosto tudi manjšalni obliki. Manjkajo podatki o neposredni poimenovalni motivaciji imen, večina imen je gotovo lastniškega značaja, del spominskega. Med slednjimi so opazna imena literarnega porekla, motivirana z zodovinskimi liki, in imena, povezana s češčenjem svetnikov. Med izimenskimi vodnimi imeni prevladujejo imena, nastala s transonimizacijo. Veliko skupino tvorijo besedne zveze z razlikovalnimi členi, maloštevilno pa imena, ki so nastala s pluralizacijo. Obravnavana vodna imena spadajo v novejšo imensko plast, tako poimenovani objekti se nahajajo $v 76$ okrajih (upravnih enotah) po vsej Poljski, največ jih je v stalowowolskem (24), oświęcimskem (22), milickem (< Milicz, 21).

Urszula Bijak

Instytut Języka Polskiego PAN, al. Mickiewicza 31, 31-120 Kraków urszulab@ijp-pan.krakow.pl

Barbara Czopek-Kopciuch Instytut Języka Polskiego PAN, al. Mickiewicza 31, 31-120 Kraków barbarac@ijp-pan.krakow.pl 


\title{
Deappellativische Ortsnamen mit dem Bestimmungswort Graf-, Herr- und Pape-/ Pfaffe- im Gebiet zwischen Saale und Neiße*
}

\author{
Inge Bily (Leipzig)
}

IZVLEČEK: Avtorica v prispevku obravnava deapelativna krajevna imena z determinantami Graf-, Herr- in Pape-/Pfaffe- na območju med Saalo in Niso. V tem nemško-slovanskem naselitvenem področju ne obstajajo vedno slovanske ustreznice $k$ nemškim krajevnoimenskim tvorbam.

Deappellative Toponyms with the Determiners Graf-, Herr-, and Pape-/Pfaffe- between the Saale and Neisse Rivers

ABSTRACT: This article discusses deappellative toponyms with the determiners Graf-, Herr-, and Pape-/Pfaffe-between the Saale and Neisse rivers. In this area of German and Slavic settlement, one cannot always find Slavic equivalents for German toponymic formations.

\section{Einleitung}

Die Auswertung von Ergebnissen namenkundlicher Untersuchungen durch Fachwissenschaftler benachbarter Arbeitsgebiete ist längst keine Besonderheit mehr (Donat, Reimann, Willich 1999; Brachmann 1995; Lübke 1998; Brachmann, Foster, Kratzke, Reimann 2003; Sperling 1999; Sperling 2005) wie umgekehrt für den Namenforscher die Arbeitsergebnisse der Nachbarwissenschaftler unverzichtbar sind.

Namenforscher, aber auch Archäologen, (historische) Geographen, Historiker und auch Rechtshistoriker gewinnen aus der Aufdeckung der Benennungsmotive von Toponymen vielfältige Aufschlüsse, denn Ortsnamen können bekanntlich in ihren appellativischen Ableitungsbasen u.a. Hinweise auf die natürlichen Gegebenheiten eines Siedlungsplatzes, auf Erhebungen und Vertiefungen im Gelände, auf Pflanzen, Tiere usw. enthalten. Diese Ortsnamen werden unter dem Terminus

* Gekürzte und geänderte Fassung des auf dem Ehrenkolloquium anläßlich des 75. Geburtstages von Prof. Dr. Dr. h.c. Ernst Eichler am 20. Mai 2005 in Leipzig gehaltenen Vortrages, vgl. Inge Bily, Hinweise auf Zugehörigkeit und Besitz in der historischen Überlieferung deutscher und slawischer Ortsnamen zwischen Saale und Neiße. In: Namenkundliche Informationen. Beiheft 23. Festschrift zu Ehren von Prof. Dr. Ernst Eichler. Leipzig 2005, 69-102. Dort ist auch das vollständige Material enthalten. 
$\hookrightarrow \quad$ Naturnamen zusammengefaßt. Kulturnamen dagegen geben Aufschluß über die Siedlungstätigkeit des Menschen, über Befestigungsanlagen und Grenzen, über Ackerbau, Viehzucht, Handwerk und soziale Stellung, und sie enthalten auch Hinweise auf Zugehörigkeit und Besitz. Thematische Zusammenfassungen von Kulturnamen, wie z.B. die Karten "Slawische Ortsnamen, die auf Viehzucht im frühen Mittelalter hinweisen" (Slawenhandbuch S. 90, Abb. 29) und "Hinweise auf Ackerbau im frühen Mittelalter" (Slawenhandbuch S. 67, Abb. 16) sowie die entsprechenden Erläuterungen zu diesen Karten (Slawenhandbuch 66ff.) sind für Namenforscher ebenso wie für die der Namenforschung benachbarten Wissensgebieten von nicht zu unterschätzendem Wert.

Eine Einbeziehung namenkundlichen Materials auch in rechtshistorische Untersuchungen fordert R. Schmidt-Wiegand, weist aber auch auf "Die Notwendigkeit einer systematischen Erfassung der Rechtsnamen und ihrer Aufbereitung von namenkundlicher Seite" hin (Schmidt-Wiegand FIN 614), vgl. auch R. Schmidt-Wiegands Bearbeitung des Stichwortes Ortsnamen (Toponyme) im Handwörterbuch zur deutschen Rechtsgeschichte (Schmidt-Wiegand HRG ${ }^{1} 3$, 1313-1323). K.H. Allmendinger (Allmendinger $\mathrm{HRG}^{1} 1,1143$ ) betont unter Hinweis auf E. v. Künßberg (Künßberg 1931; Künßberg 1936) und dessen Untersuchungen zu Flurnamen, daß "vor allem für den Fall der rechtsgeschichtl. Ausdeutung von F[lurnamen]... Behutsamkeit oberstes Gebot ist".

Zur von R. Schmidt-Wiegand zu Recht geforderten Erfassung und Aufbereitung der Rechtsnamen soll nachfolgend ein bescheidener Beitrag geleistet werden. Im Rahmen einer fächerübergreifenden Zusammenarbeit ist es die Aufgabe des Namenforschers, gesicherte Ergebnisse seiner Untersuchungen, die gewöhnlich auch die Einbeziehung von Ergebnissen (siedlungs)historischer Forschung voraussetzt, für eine Auswertung durch Nachbarwissenschaftler zur Verfügung zu stellen. Eine rechtsgeschichtliche Ausdeutung der Siedlungsnamen kommt dann allerdings dem Rechtshistoriker zu.

\section{Deappellativische Ortsnamen, die einen Hinweis auf Zugehörigkeit und Besitz enthalten}

Die Ortsnamen nach dem Besitz faßt T. Witkowski in seinem Verzeichnis der Termini unter einem eigenen Stichwort zusammen (Witkowski Grundbegriffe 70). Wir untergliedern sie in: Ortsnamen mit einem Hinweis auf weltlichen oder kirchlichen Besitz oder auch auf andere Besitzformen, wie z.B. gemeinsamen Besitz. Dabei sind Hinweise auf weltlichen oder kirchlichen Besitz nicht in jedem Falle voreinander zu trennen, wie u.a. die Ortsnamen mit dem Bestimmungwort mhd. hērre, herre 'Gebieter, Herr; Geistlicher' zeigen.

Ein Beispiel für gemeinsamen Besitz ist der ON Landesgemeinde sw. Klingenthal/Sa., zu mhd. gemeine 'gemeinschaftlicher Besitz': 1542 Eyn orthwaldes die Lanndesgemeynn ob dem dorff Goppelsgruhnn, der ist bereint mit kreuczen und zeichen, wass do leitt kegen dem fürstenthumb zu Sachssenn ist Sechssisch und das ander theil kegen dem landt zw Beheimb ist Schlickisch ... Und dieser orttwaldes 
wirdt umb deswillen Landtsgemein genannt, das in fürfallender notth den amptsvorwandten $\mathrm{zW}$ ihren gepeuden und schinttell $\mathrm{zW}$ machen darauss vorgonstigett wirdt. "Der Name bezog sich zunächst auf einen zu äußerst gelegenen Wald (1542 orthwald), der von Sassen des Amtes Voigtsberg, also des sächsischen Landes im Gegensatz zum angrenzenden Böhmen, in besonderen Fällen als eine Art Gemeineigen genutzt werden durfte. Der WaldN ging auf die sich seit 1661 entwickelnde Siedlung über.”, s. Sächs. ONB 1, 557; auch ON Vogtl. 51).

Entsprechenden slawischen Wortschatz für gemeinschaftlichen Besitz belegen die ON Nedlitz nö. Lindau: 1329 (Elysabeth) Nedelitzinne, 1330 (PN) Nedeliz, aso. Grf. *Nedělica (DS 38, 278; Eichler Slaw. ON 3, 12f.) und Nödlitz n. Stößen: um 1300 Nidelis, aso. Grf. *Nedělišče (DS 35, 234; Eichler Slaw. ON 3, 26), beide zu aso. *nedèt/*neděl' 'Gemeingut'; sowie der ON Oppitzsch nö. Oschatz 1207/10 Obtiz [Ociz?], 1236 Obsciz, mit der aso. Grf. *Ob'čic- (*Ob'čica bzw. *Ob'čici), zu aso. *ob'c 'Gemeinde, gemeinsames Land' (Sächs. ONB 2, 140).

Dabei sind in dem von uns untersuchten deutsch-slawischen Siedlungsgebiet zwischen Saale und Neiße nicht in jedem Falle slawische Entsprechungen zu deutschen Ortsnamenbildungen vorhanden, s.u.

Aus der Analyse von 130 Kulturnamen des Gebietes zwischen Saale und Neiße, die in ihrer appellativischen Ableitungsbasis auf Besitzverhältnisse hinweisen (Bily 2005), werden nachfolgend Ortsnamen vorgestellt, die im Bestimmungswort die Appellativa:

- mhd. grāve, grābe, mnd. grēve, md. grēbe 'königlicher Gerichtsvorsitzender, Graf; Dorfrichter',

- mhd. hêrre, herre 'Gebieter, Herr; Geistlicher' und

- mhd. pfaffe, mnd. pāpe 'Geistlicher, Priester' enthalten.

\section{$2.1 \dagger$ Gräfen, Gräfendorf, Gräfenhain, Nieder-, Obergräfenhain, Gräfen- hainichen}

Das Bestimmungswort mhd. grāve, grābe, mnd. grēve, md. grēbe 'königlicher Gerichtsvorsitzender, Graf; Dorfrichter' verbindet sich in den Ortsnamen des Gebietes zwischen Saale und Neiße mit den Grundwörtern -dorf und -hain, auch ein Simplizium ist belegt, vgl.:

- †Gräfen nw. Auerbach/Vogtl.: 1536 die wustenung Greffen genant, 'Siedlung eines Grafen bzw. eines Gräfe, Gref(f)e' (Sächs. ONB 1, 348);

- Gräfendorf sw. Torgau: 1251 Greuendorph (DS 38, 185; Sächs. ONB 1, 348); $\dagger$ Gräfendorf sö. Diesdorf: 1244 (Joh. vero de) Grevendorp (DS 38, 185), 'Dorf eines Grafen bzw. eines Gräfe o.ä.'; †Gräfendorf s. vor Merseburg, h. im Stadtbereich: 1274 in villa et pago Greuendorph ante civitatem Mersburg, (DS 35, 156), 'Das vom Grafen (von Merseburg) gegründete bzw. dem Grafen gehörende Dorf’; Gräbendorf sö. Calau, nso. Grabice: 1423 Gräfendorf(DS 36, 158), 'Dorf eines Grafen bzw. eines Gräfe o.ä.'. Die nso. Namenform entspricht wohl der deutschen, vgl. nso. †grabja 'Graf' (Mu. Wb. 1, 311);

- Gräfenhain sö. Königsbrück: 1309 Greuinhain, 'Rodungssiedlung eines königlichen Burggrafen (auf Königsbrück), kaum die eines Lokators Gräfe' (DS 28, 88; Sächs. ONB 1, 348f.); †Gräfenhain, in der Stadtflur Dahlen: 1284 Gräfenhain, 
$4 \quad$ 'Rodungssiedlung im (mark)gräflichen Walde oder einer Person namens Gräfe' (DS 20, 99; Sächs. ONB 1, 349); Gräfenhain, Nieder-, w. Geithain: 1274 Iohannes plebanus in Grevenhain und Gräfenhain, Ober-, nw. Penig: 1274 Grevenhain, 'Rodungssiedlung eines Grafen’ bzw. 'Siedlung im Walde eines Grafen' (Göschel 57; Sächs. ONB 1, 349).

Bei Gräfenhainichen sind die Bestimmungswörter Gräfen-, Albrechts- erst später zum Namen hinzugetreten. Sie wurden nach dem Grafen Albrecht II von Anhalt (†1362) gewählt, vgl. die historische Überlieferung: Gräfenhainichen sw. Wittenberg: 1285 (PN) de Indagine, 1325 mit deme Hayn,..., 1369 Albrechtishayn, 1377 den Hayn, 1381 Gravinalbrechtishayn, 1382 Albrechshayn, 1391 czum Hayn, 1400 den Hayn, den man nennte des Grefin Heynichen (DS 38, 185f.).

\subsection{Herrendorf, †Herrngrün, Herrenhaide, Herrnhut, Herrenwalde}

Das Bestimmungwort mhd. hērre, herre 'Gebieter, Herr; Geistlicher' ist in den Ortsnamen des Untersuchungsgebietes in Verbindung mit den Grundwörtern -dorf, -grün, -haide, -hut, -walde belegt, vgl.:

- †Herrendorf in der Stadtflur Zittau: 1275 villa dicta Herrendorf, 'Dorf der (geistlichen) Herren', d.h. der Herren des Johanniterordens, die den Ort besaßen (Sächs. ONB 1, 418); Herrndorf nö. Freiberg: 1532 Herrndorff, 'Dorf eines Grundherren' (Sächs. ONB 1, 418). "Da alle Dörfer einem Grundherren unterstanden und dies kein besonderes Merkmal war, ist wohl auch an das Dorf eines Freiberger Domherrn o.ä. zu denken.” (Sächs. ONB 1, 418);

- †Herrngrün sö. Reichenbach/Vogtl.: 1464 die Glashütte zu Herrngrün, 'Ansiedlung eines Herrn'. "Das BW könnte sich auf einen Hammerherrn, den Besitzer der Glashütte o.ä., beziehen.” (Sächs. ONB 1, 418f.);

- Herrenhaide s. Burgstädt: 1791 Herrenheide, 'Siedlung an/auf der Herrenheide'. "Der Name ... knüpft an einen FIN für das Jagdrevier des oder der Peniger Herren an." (Sächs. ONB 1, 418);

- Herrnhut sö. Löbau: 1759 Herrn Huth; religiös motivierter Name, bedeutet 'sich unter die Hut des Herrn, d.h. die Obhut, den Schutz Gottes, stellen' (DS 28, 102; Sächs. ONB 1, 419) und

- Herrenwalde w. Zittau: 1732 Herrnwalde, 'Siedlung im Stadtwald, Ratswald (von Zittau)', auch hier geben die Autoren des Sächs. ONB $(1,418)$ mit ihrem Hinweis "um 1580 von Zittauer Ratsherren in ihrem Walde angelegt." eine zusätzliche Stützung ihrer Namenerklärung.

Allerdings ist nicht automatisch jeder heutige ON mit dem BW Herr(e)n- ein Hinweis auf den Besitz eines Herren, zu vergleichen ist z.B. Herrnsdorf (1551 Hermßdorf, 1817 Hermsdorf auch Herrnsdorf): s. Wolkenburg/Mulde, bei dem es sich um ein Hermannsdorf handelt, denn die historische Überlieferung deutet auf einen PN Herman als Ableitungsbasis. "Die Umdeutung von Herms- zu Herrndorf ... wird im Zusammenhang mit dem in der Flur errichteten herrschaftlich-wolkenburgischen Gut erfolgt sein.”, dies zeigt sich auch in der historischen Überlieferung, vgl. besonders den Beleg von 1817 Hermsdorf auch Herrnsdorf (DS 3, 70; Sächs. ONB 1, 419). 
2.3 $†$ Papendorf, Pfaffendorf; Nieder-, Oberpfaffendorf, Pfaffengrün, Pfaffenhaus, Pfaffengut, Pfaffenmühle, Pfaffenhain, Pfaffroda

Mhd. pfaffe, mnd. pāpe 'Geistlicher, Priester' ist als Grundwort von -dorf, -grün, -hain, -roda-Namen nachgewiesen, vgl.:

- †Papendorf w. Calbe: 1345 de Papendorp (DS 38, 291); †Papendorf w. Zörbig: 1202 Papendorp (DS 14, 58); Pfaffendorf nö. Gröbzig: 1223 (Jacob) Papindorp (DS 38, 295); †Pfaffendorf ö. Kochstedt, sw. Dessau: 1547/49 Pfaffendorf, Papendorf (DS 38, 295f.); Pfaffendorf zu Gollma: 1404 Papendorff (DS 4, 87); †Pfaffendorf n. Grimma: 1540 Pfaffendorf, das wüste dorff (DS 13, 155; Sächs. ONB 2, 170); Pfaffendorf s. Königstein: (um 1437) Pfaffindorf(Sächs. ONB 2, 170); †Pfaffendorf s. Markranstädt: 1322 Papendorp (DS 8, 69; Sächs. ONB 2, 170); (†)Pfaffendorf n. Leipzig: 1213 Papendorp (DS 8, 69; Sächs. ONB 2, 170); †Pfaffendorfn. Schönburg, ö. Naumburg: (1278) 14. Jh. Pfaffendorf (DS 35, 243); Pfaffendorf nw. Beesko, nso. Popojce: 1418 Pfaffindorf(DS 36, 203). Die nso. Namenform ist eine Übersetzung des dt. ON; Pfaffendorf, Nieder-, Ober- sw. Görlitz: (um 1330) de Phafindorf (DS 28, 225; Sächs. ONB 2, 170f.), 'Dorf eines Geistlichen'.

- Pfaffengrün w. Auerbach/Vogtl.: $(1327,1377)$ in dem dorffe Pfaffengrün, 1459 Pfaffengrune, 'Rodungssiedlung der oder eines Pfaffen', mit evtl. Hinweis auf ehem. Kirchenbesitz (vgl. Pfaffenhaus bzw. Pfaffengut, Pfaffenmühle bei Plauen) (Sächs. ONB 2, 171);

- Pfaffenhain nö. Stollberg: (1442) Pfaffenhaynn, 'Rodungssiedlung der oder eines Pfaffen' (DS 39, 86; Sächs. ONB 2, 171);

- Pfaffroda nw. Glauchau: 1303 Sifridus de Phaffinrode, 'Rodungssiedlung der oder eines Pfaffen' (DS 39, 86; Sächs. ONB 2, 171); Pfaffroda sw. Sayda: 1445 Pfaffenrode. "Der ON bezieht sich wohl auf Rodungstätigkeit von Pfaffen des Klosters Osek.”, s. Sächs. ONB 2, 171.

Ebenfalls zahlreich sind die slawischen Entsprechungen dieser Ortsnamen, vgl. Papsdorf, †Poppewitz, Pobzig mehrfachem Papitz und zahlreichem Poppitz, alle als aso. *Popovici zu erklären, zu aso. *pop 'Pfarrer, Priester, Geistlicher', bei Papsdorf wurde der Name durch ein zusätzliches GW -dorf erweitert.

\section{Zusammenfassung}

Ergebnisse namenkundlicher Untersuchungen können Forschungsergebnisse benachbarter Arbeitsgebiete, z.B. der Archäologie, Geographie, Geschichte und auch der Rechtsgeschichte, stützen. Dabei ist zu beachten, daß es nicht genügt, nur die heutige Namensform zu betrachten, denn zum einen können Bestimmungs- oder auch Grundwörter erst später zu einem Ortsnamen treten, zum anderen kann durch Namenwechsel, Umdeutung oder sekundäre semantische Motivierung (Eichler 1976; Hengst SSM; Walther 1997) die heutige Form eines Ortsnamens im Vergleich zur ursprünglichen Benennung oder zu seinen Schreibungen in den historischen Quellen mitunter stark verändert sein, vgl. Herrnsdorf s. Wolkenburg/Mulde: 1551 Hermßdorf, 1817 Hermsdorf auch Herrnsdorf, das ein Hermannsdorf ist, denn die historische Überlieferung deutet auf einen PN Herman als Ableitungsbasis, s.o., nicht auf 
$\hookrightarrow \quad$ das Appellativum mhd. hērre, herre 'Gebieter, Herr; Geistlicher', zu dem u.a. die nachfolgenden ON zu stellen sind: $\uparrow$ Herrendorf (1275 villa dicta Herrendorf) in der Stadtflur Zittau, Herrndorf (1532 Herrndorff) nö. Freiberg, †Herrngrün (1464 die Glashütte zu Herrngrün) sö. Reichenbach/Vogtl., Herrenhaide (1791 Herrenheide) s. Burgstädt und Herrnhut (1759 Herrn Huth) sö. Löbau, s.o.

Neben der Stützung durch die appellativische Bedeutung der Ableitungsbasis eines Ortsnamens kann der Kontext der Namensnennung in der historischen Überlieferung eine wichtige Hilfe sein, vgl. den ON Herrenwalde w. Zittau: 1732 Herrnwalde, 'Siedlung im Stadtwald, Ratswald (von Zittau)' (DS 28, 102; Sächs. ONB 1, 418). Hier geben die Autoren des Sächs. ONB $(1,418)$ mit ihrem Hinweis "um 1580 von Zittauer Ratsherren im ihrem Walde angelegt.” eine zusätzliche Stützung ihrer Erklärung des Ortsnamens. Zu vergleichen ist in diesem Zusammenhang auch der ON Königshain w. Görlitz: 1298ff. Peczoldus ... de Kunigeshain, ..., 1346 Kunigyshayn, 1367 silva ... que der Kuniginnefurst vulgari nomine appellatur [Forst bei Königshain, später Königshainer Berge], 'Rodungssiedlung im Forst der Königin', “wie [der Beleg von] 1367 zu erkennen gibt (wohl altes Jagdgebiet der böhmischen Könige.”) (Sächs. ONB 1, 511).

Nicht immer ist bei der Ableitungsbasis eines Ortsnamens eine Trennung zwischen Appellativa und den aus ihnen abgeleiteten Personennamen möglich, vgl. z.B. die ON †Gräfen oder mehrere Gräfendorf, die erklärt werden müssen als 'Siedlung eines Grafen bzw. eines Gräfe, Gref(f)e’ (so auch im Sächs. ONB 1, 348). Gleiches gilt für die slawischen Bildungen, vgl. z.B. die ON Bonnewitz, Bannewitz, Pannewitz, Panitz, alle mit der aso. Grf. *Panici, 'Siedlung der Leute eines Herren, zu aso. *pan 'Herr', oder einer Person namens Pan o.ä.'. Zu den Deanthroponymica, die als Bestimmungswort einen Personennamen als Namen des Grundherren oder Ortsgründers enthalten, d.h. die zu erklären sind als 'Siedlung eines ...' oder 'Leute des ...' sind besonders DS 26; Walther 1978 und Walther 1993 zu vergleichen.

Bei der Unterscheidung zwischen einer deappellativischen und einer deanthroponymischen Bildung ist die Realprobe oftmals hilfreich. Ein treffendes Beispiel hierfür ist der ON Guben, nso. Gubin, poln. Gubin n. Cottbus (1211, 1222 Gubin), bei dem aufgrund der Lage an der Mündung der Lubst (poln. Lubsza) in die Neiße eine strukturell und auch auf der Grundlage der historischen Überlieferung mögliche Ableitung aus einem auch gut belegten PN Guba ausgeschlossen werden kann und die aso. Grf. *Gubin- als 'Ort an der Mündung' erklärt werden muß (Bily 1999).

Dennoch darf der Wert des in den Personennamen enthaltenen appellativischen Wortschatzes nicht übersehen werden (Wenzel 1981; Wenzel 1990; Wenzel 1997), denn nur ein in einer Sprachgemeinschaft verankertes Appellativum wird auch zur Namenbildung, hier zur Bildung eines Personennamens, verwendet, vgl. z.B. das Appellativum lenik 'Lehensmann, Lehngutsbesitzer, Vasall; Hüfner', das zwar nicht in den Ortsnamen des untersuchten Gebietes belegt ist, wohl aber im PN Lenik: 1374-82 Leynik, ..., 1498 Lenig, 1501 Leman, 1509 Lenigk, ..., 1589 Lönigk, 1652 Lehman, 1655 Stephan Lehmann oder Lehnigk (Wenzel Wb. I 244).

In eine Aufbereitung für die Nutzung durch Nachbarwissenschaftler sollten in Zukunft neben den Ortsnamen auch die Flurnamen stärker einbezogen werden, auch wenn sich aus ihrer gewöhnlich späteren historischen Überlieferung eine grö- 
ßere Unsicherheit ergibt (Schmidt-Wiegand FIN; Künßberg 1931; Künßberg 1936). Material sowie methodische Anregungen finden sich in den Flurnamenarbeiten der DS-Reihe, vgl. besonders DS 9, DS 18, DS 24 und DS $34^{1}$ wie auch in einem Teil der Ortsnamenbücher dieser Reihe, vgl. u.a. DS 3 und DS 13, außerdem Göschel; Reinhold 1996; Reinhold 2005; Bauer 2004 u.v.a.m. Als Beispiel für eine systematische Erfassung und Auswertung der Flurnamen, auch mit dem Ziel einer Bereitstellung für die Auswertung durch Nachbarwissenschaftler, seien die regelmäßig erscheinenden Flurnamenreports des durch G. Hänse $(\dagger)$ initiierten Projektes 'Flurnamen und Regionalgeschichte' genannt. Dieses Projekt, das durch den Heimatbund Thüringen getragen wird, hat eine gesamtthüringische Flurnamenerfassung im Blick. Es stützt sich auf engagierte Heimat- und Namenforscher aus der Region. Zu den slawischen Flurnamen in der Lausitz sind die Sammlungen bzw. Bearbeitungen P. Kühnels (Kühnel), E. Muckes (Mu. FIN; Mu. FIN Luckau) und Chr. Schwelas (Schwela) heranzuziehen, nicht zuletzt auch die Wörterbücher von Chr. Pfuhl (Pfuhl) und E. Mucke (Mu. Wb.). Auch darüber hinaus harrt reiches Material der Erfassung und nachfolgenden Auswertung.

\section{Literatur}

Allmendinger $\mathrm{HRG}^{1}$, K. H. Allmendinger, Art. 'Flurnamen', $H R G^{1} 1$ (1971), $1143-1144$.

Bauer 2004, Reinhard Bauer, Die Flurnamen der Gemeinde Andechs. Siedlungs-, Flur- und Hausnamen der Gemarkungen Erling, Frieding und Machtlfing, auf der Grundlage der vom Haus der Bayerischen Geschichte erarbeiteten Materialien, mit einem Beitrag von Anthony Rowley. In Verbindung mit Michael Henker hrsg. von Wolf-Armin Frhr. v. Reitzenstein. (Die Flurnamen Bayerns 10). München.

Bily 1980, Inge Bily, Die slawischen Flurnamen der Senftenberger Willkür (1523), Studia Onomastica I. (Namenkundliche Informationen, Beiheft 2). Leipzig, 4-15.

Bily 1999, Inge Bily, Die natürliche Umwelt als Benennungsmotiv in deappellativischen Ortsnamen des Mittelelbegebietes, Geographische Namen in ihrer Bedeutung für die landeskundliche Forschung und Darstellung, Referate des 8. Arbeitstreffens des Arbeitskreises "Landeskundliche Institute und Forschungsstellen in der Deutschen Akademie für Landeskunde", Trier 21.-23. Mai 1998, Hrsg. von Heinz Peter Brogiato (Dokumentationszentrum für Deutsche Landeskunde. Universität Trier. Berichte und Dokumentationen 2), Trier, 97-109.

Bily 2005, Inge Bily, Hinweise auf Zugehörigkeit und Besitz in der historischen Überlieferung deutscher und slawischer Ortsnamen zwischen Saale und Neiße, Namenkundliche Informationen, Beiheft 23, Festschrift zu Ehren von Prof. Dr. Ernst Eichler, Leipzig, 69-102.

1 Vgl. DS 9; DS 18, S. 323, 324; DS 24, S. 238, S. 241 (Rechtsleben, Flurverfassung und Herrschaftsverhältnisse, Abgaben); DS 34, S. 85 (Recht und Gericht, Militär). 
$4 \quad$ Bönisch 2001, 2004, F. Bönisch, Zur Praxis des Hofnamengebrauchs in der Niederlausitz, Erster Teil, Niederlausitzer Studien, Heft 30, 29-41; Zweiter Teil, ebd. Heft 31, 61-75.

Brachmann 1995, Hansjürgen Brachmann (Hrsg.), Burg - Burgstadt - Land, Zur Genese mittelalterlicher nichtagrarischer Zentren in Ostmitteleuropa (Forschungen zur Geschichte und Kultur des östlichen Mitteleuropa), Berlin.

Brachmann, Foster, Kratzke, Reimann 2003, Hansjürgen Brachmann, Elżbieta Foster, Christine Kratzke, Heike Reimann, Das Zisterzienserkloster Dargun im Stammesgebiet der Zirzipanen, Ein interdisziplinärer Beitrag zur Erforschung mittelalterlicher Siedlungsprozesse in der Germania Slavica (Geisteswissenschaftliches Zentrum Geschichte und Kultur Ostmitteleuropas e. V., Leipzig, Forschungen zur Geschichte und Kultur des östlichen Mitteleuropa 17), Stuttgart.

Debus 2000, Friedhelm Debus (Hrsg.), Stadtbücher als namenkundliche Quelle, Vorträge des Kolloquiums vom 18.-20. September 1998, Stuttgart (Akademie der Wissenschaften und der Literatur, Abhandlungen der Geistes- und sozialwissenschaftlichen Klasse, Einzelveröffentlichung, Nr. 7.

Donat, Reimann, Willich 1999, Peter Donat, Heike Reimann, Cornelia Willich, Slawische Siedlung und Landesausbau im nordwestlichen Mecklenburg (Forschungen zur Geschichte und Kultur des östlichen Mitteleuropa 8), Stuttgart.

DS, Deutsch-Slawische Forschungen zur Namenkunde und Siedlungsgeschichte, Hrsg. von Theodor Frings und Rudolf Fischer; ab Nr. 26 ... Begründet von Theodor Frings und Rudolf Fischer, Hrsg. von Rudolf Fischer und Rudolf Große; ab Nr. 27 ... Hrsg. von Ernst Eichler, Wolfgang Fleischer, Rudolf Große, Albrecht Neubert und Hans Walther; ab Nr. 36 ... Hrsg. von Ernst Eichler, Wolfgang Fleischer, Rudolf Große und Hans Walther; ab Nr. 39 ... Hrsg. von Ernst Eichler, Rudolf Große und Hans Walther. Halle 1956ff., Berlin 1961ff.

DS 3, Hans Walther, Die Orts- und Flurnamen des Kreises Rochlitz, Halle 1957.

DS 4, Ernst Eichler, Die Orts- und Flußnamen der Kreise Delitzsch und Eilenburg, Studien zur Namenkunde und Siedlungsgeschichte im Saale-Mulde-Gebiet, Halle 1958.

DS 9, Lothar Hoffmann, Die slawischen Flurnamen des Kreises Löbau, Halle 1959.

DS 13, Horst Naumann, Die Orts- und Flurnamen der Kreise Grimma und Wurzen, Berlin 1962.

DS 18, Wolfgang Sperber, Die slawischen Flurnamen des Kreises Kamenz (Ostteil), Berlin 1967.

DS 24, Günther Hänse, Die Flurnamen des Stadt- und Landkreises Weimar, Berlin 1970.

DS 26, Hans Walther, Namenkundliche Beiträge zur Siedlungsgeschichte des Saaleund Mittelelbegebietes bis zum Ende des 9. Jahrhunderts, Berlin 1971.

DS 28/29, Ernst Eichler, Hans Walther, Ortsnamenbuch der Oberlausitz, Studien zur Toponymie der Kreise Bautzen, Bischofswerda, Görlitz, Hoyerswerda, Kamenz, Löbau, Niesky, Senftenberg, Weißwasser und Zittau I, II, Berlin 1975, 1978. 
DS 34, Klaus Gansleweit, Untersuchungen zur Namenkunde und Siedlungsgeschichte der nordöstlichen Niederlausitz, Die Flur- und Ortsnamen im Bereich des früheren Stiftes Neuzelle, Berlin 1982.

DS 35, Ernst Eichler, Hans Walther, Untersuchungen zur Ortsnamenkunde und Sprach- und Siedlungsgeschichte des Gebietes zwischen mittlerer Saale und Weißer Elster, Berlin 1984.

DS 36, Siegfried Körner, Ortsnamenbuch der Niederlausitz, Studien zur Toponymie der Kreise Beeskow, Calau, Cottbus, Eisenhüttenstadt, Finsterwalde, Forst, Guben, Lübben, Luckau und Spremberg, Berlin 1993.

DS 38, Inge Bily, Ortsnamenbuch des Mittelelbegebietes, Berlin 1996.

DS 39, Karlheinz Hengst, Ortsnamen Südwestsachsens, Die Ortsnamen der Kreise Chemnitzer Land und Stollberg, Berlin 2003.

Eichler Slaw. ON: Ernst Eichler, Slawische Ortsnamen zwischen Saale und Neiße, Ein Kompendium, Bd. 1-3, Bautzen 1985, 1987, 1993.

Göschel, Joachim Göschel, Die Orts-, Flur- und Flußnamen der Kreise Borna und Geithain, Namenkundliche Untersuchungen zur Sprach- und Siedlungsgeschichte Nordwestsachsens (Mitteldeutsche Forschungen 31). Köln, Graz 1964.

Hengst SSM, K. Hengst, Sekundäre semantische Motivierung slawischer Lehnnamen im Deutschen, Namenkundliche Informationen 33 (1978), 25-33, Nachdruck in: Karlheinz Hengst, Beiträge zum slavisch-deutschen Sprachkontakt in Sachsen und Thüringen, Hrsg. von Wolfgang Dahmen, Ernst Eichler und Johannes Kramer, Veitshöchheim 1999, 61-69.

$\mathrm{HRG}^{1}$, Handwörterbuch zur Deutschen Rechtsgeschichte, Hrsg. von Adalbert Erler und Ekkehard Kaufmann, mitbegründet von Wolfgang Stammler, ab Bd. 2 unter philologischer Mitarbeit von Ruth Schmidt-Wiegand, Bd. 1-5, Berlin 1971-1996.

Kühnel, Paul Kühnel, Die slavischen Orts- und Flurnamen der Oberlausitz, Hrsg. und mit einer Einleitung und Bibliographie versehen von Ernst Eichler, Leipzig 1982.

Künßberg 1931, Eberhard Frhr. von Künßberg, Flurnamen und Rechtsgeschichte, Zeitschrift der Savigny-Stiftung für Rechtsgeschichte, Germanistische Abteilung 51, 93-110.

Künßberg 1936, Eberhard Frhr. von Künßberg, Flurnamen und Rechtsgeschichte, Weimar.

Lübke 1998, Christian Lübke (Hrsg.), Struktur und Wandel im Früh- und Hochmittelalter, Eine Bestandsaufnahme aktueller Forschungen zur Germania Slavica (Forschungen zur Geschichte und Kultur des östlichen Mitteleuropa 5), Stuttgart.

Mu. FIN, Ernst Mucke [Arnošt Muka], Serbske ležownostne mjena a jich woznam (Die sorbischen Flurnamen und ihre Bedeutung), Slavia Occidentalis VI (1927), S. 225-253; VIII (1929), S. 83-156). Nachdruck in: Ernst Mucke, Abhandlungen und Beiträge zur sorbischen Namenkunde, Hrsg. von Ernst Eichler, Leipzig 1984.

Mu. FIN Luckau, Ernst Mucke [Arnošt Muka], Deutung und Bedeutung der Flur- 
namen des Kreises Luckau, Bausteine zur Heimatkunde des Luckauer Kreises. Luckau 1918, S. 145-228, Nachdruck in: Ernst Mucke, Abhandlungen und Beiträge zur sorbischen Namenkunde, Hrsg. von Ernst Eichler. Leipzig 1984.

Mu. Wb., Ernst Mucke [Arnošt Muka], Stownik dolnoserbskeje rěcy a jeje narěcow, Wörterbuch der nieder-wendischen Sprache und ihrer Dialekte, Bd. 1-3, Petrograd, Prag 1911-1928, und Indeks a tergo do Dolnotużickiego słownika Arnošta Muki, Warszawa 1988.

ON Vogtl., Ernst Eichler, Volkmar Hellfritzsch, Johannes Richter, Die Ortsnamen des sächsischen Vogtlandes, 1-2. Plauen 1983, 1985.

Pfuhl, Chr. Tr. Pfuhl, Łužiski serbski słownik, Lausitzisch Wendisches Wörterbuch, Bautzen 1866, Nachdruck, hrsg. von Heinz Schuster-Šewc, Bautzen 1968, Obersorbisches Wörterbuch.

Reinhold 1996, Frank Reinhold, "Mord” in thüringischen Flurnamen, Eine namenkundliche Plauderei, Jahrbuch für den Saale-Holzlandkreis, Jena, 76-79.

Reinhold 2005, Frank Reinhold, Auf kirchliche Verhältnisse hinweisende Flurnamen im Raum Altenburg - Schmölln - Zeitz. In: Kirche und geistiges Leben im Prozeß des mittelalterlichen Landesausbaus in Ostthüringen / Westsachsen, Hrsg. von Peter Sachenbacher, Ralph Einicke \& Hans-Jürgen Beier (Beiträge zur Frühgeschichte und zum Mittelalter Ostthüringens 2), Langenweißbach, 117-121, bes. S. 119f.

Sächs. ONB, Historisches Ortsnamenbuch von Sachsen, Hrsg. von Ernst Eichler und Hans Walther, Bearb. von Ernst Eichler, Volkmar Hellfritzsch, Hans Walther und Erika Weber, Bd. I-III, Berlin 2001.

Scheuermann 1980, Ulrich Scheuermann, Die sprachliche Erschließung der Dorfflur mit Hilfe von Flurnamen. In: Heinrich Beck, Dietrich Dennecke, Herbert Jankuhn (Hrsg.), Untersuchungen zur eisenzeitlichen und mittelalterlichen Flur in Mitteleuropa und ihrer Nutzung. Berichte über die Kolloquien der Kommission für die Altertumskunde Mittel- und Nordeuropas in den Jahren 1975 und 1976. II. (Abhandlungen der Akademie der Wissenschaften in Göttingen. Phil.-hist. K1. Dritte Folge. Nr. 116), Göttingen, 323-353.

Schmidt-Wiegand FIN, Ruth Schmidt-Wiegand, Recht und Aberrecht in Flurnamen. In: Gießener Flurnamen-Kolloquium. 1. bis 4. Oktober 1984. Hrsg. von Rudolf Schützeichel (Beiträge zur Namenforschung, Beiheft 23). Heidelberg 1985, 600-620.

Schmidt-Wiegand $\mathrm{HRG}^{1}$, Ruth Schmidt-Wiegand, Art. 'Ortsnamen (Toponyme)', $H R G^{1} 3$ (1984), 1313-1323.

Schmidt-Wiegand 1969, Ruth Schmidt-Wiegand, Rechtssprachgeographie und Namenkunde, 10. Internationaler Kongreß für Namenforschung, Abhandlungen, Proceedings, Actes, Disputationes ad Montium Vocabula aliorumque nominum significationes pertinentes, Ed.: H. H. Hornung, Tom 1, Wien, 127-133.

Schmidt-Wiegand 1995, Ruth Schmidt-Wiegand, Rechtsbücher und Weistümer, Zum Sprachausgleich in der historischen Wortgeographie, Gotthard Lerchner u.a. (Hrsg.), Chronologische, areale und situative Varietäten des Deutschen in der Sprachhistoriographie, Festschrift für Rudolf Große (Leipziger Arbeiten zur Sprach- und Kommunikationsgeschichte 2), Frankfurt a.M., 153-158. 
Schmidt-Wiegand 1998a, Ruth Schmidt-Wiegand, Deutsche Sprachgeschichte und Rechtsgeschichte bis zum Ende des Mittelalters, In: Werner Besch, Anne Betten, Oskar Reichmann, Stefan Sonderegger (Hrsg.), Sprachgeschichte, Ein Handbuch zur Geschichte der deutschen Sprache und ihrer Erforschung, 2., vollständig neu bearbeitete und erweiterte Auflage, 1. Teilbd. (Handbücher zur Sprach- und Kommunikationswissenschaft 2.1., 2. Auflage). Berlin, New York, 72-87.

Schmidt-Wiegand 1998b, Ruth Schmidt-Wiegand, Deutsche Sprachgeschichte und Rechtsgeschichte seit dem Ausgang des Mittelalters. In: Werner Besch, Anne Betten, Oskar Reichmann, Stefan Sonderegger (Hrsg.), Sprachgeschichte, Ein Handbuch zur Geschichte der deutschen Sprache und ihrer Erforschung, 2., vollständig neu bearbeitete und erweiterte Auflage, 1. Teilbd. (Handbücher zur Sprach- und Kommunikationswissenschaft 2.1., 2. Auflage), Berlin, New York, 87-98.

Joseph Schnetz, Flurnamenkunde, München 1997³, 3. unveränd. Aufl.

Schuster-Šewc 1986, Heinz Schuster-Šewc, Die älteste Schicht der slawischen sozial-ökonomischen und politisch-institutionellen Termini und ihr Schicksal im Sorbischen, Lětopis A 33, 1-19.

Schuster-Šewc 1989: Heinz Schuster-Šewc, Der kirchliche Wortschatz des Sorbischen und sein Ursprung. Ein Beitrag zur europäischen Sprach- und Kulturgeschichte, Die Welt der Slaven, Neue Folge XIII, 297-322.

Schuster-Šewc HEW, Heinz Schuster-Šewc, Historisch-etymologisches Wörterbuch der ober- und niedersorbischen Sprache, Bd. 1-4 (Heft 1-24), Bd. 5 (Register). Bautzen 1978-1989 und 1996.

Schwela, Chr. G. Schwela, Die Flurnamen des Kreises Cottbus (Veröffentlichungen des Instituts für Slawistik der Deutschen Akademie der Wissenschaften zu Berlin 17), Berlin 1958.

Slawenhandbuch, Die Slawen in Deutschland, Geschichte und Kultur der slawischen Stämme westlich von Oder und Neiße vom 6. bis 12. Jahrhundert, Ein Handbuch. Neubearbeitung, Hrsg. von Joachim Herrmann, Berlin $1985^{2}$.

Slovnik pomistních jmen Čechách. I (A), Pod vedením Jany Matúšové zpracovali Libuše Olivová-Nezbedová, Jitka Malenínská, Milan Harvalík, Martina Mackovičová. Praha 2005.

Sperling 1999, Walter Sperling, Geographische Namen als interdisziplinäres Forschungsfeld. Disziplinhistorische und methodologische Aspekte, Geographische Namen in ihrer Bedeutung für die landeskundliche Forschung und Darstellung,. Referate des 8. Arbeitstreffens des Arbeitskreises "Landeskundliche Institute und Forschungsstellen in der Deutschen Akademie für Landeskunde", Trier 21.-23. Mai 1998, Hrsg. von Heinz Peter Brogiato (Dokumentationszentrum für Deutsche Landeskunde, Universität Trier, Berichte und Dokumentationen 2), Trier, 17-41.

Sperling 2005, Walter Sperling, Geographische Namen - ein Thema für Geographen. In: Namenkundliche Informationen 87/88, 57-87.

Walther 1997, Hans Walther, Benennungsparallelismus bei der Eindeutschung des Altsorbengebietes um Leipzig im hohen Mittelalter, Wort und Name im 
deutsch-slavischen Sprachkontakt, Ernst Eichler von seinen Schülern und Freunden, Hrsg. von Karlheinz Hengst, Dietlind Krüger und Hans Walther, unter Mitarbeit von Inge Bily (Bausteine zur Slavischen Philologie und Kulturgeschichte, Reihe A: Slavistische Forschungen, Neue Folge. Bd. 20), Köln, Weimar, Wien, 555-569.

Wenzel 1981, Walter Wenzel, Deappellativische sorbische Personennamen ohne Entsprechungen im niedersorbischen und obersorbischen Wortschatz, Onomastica Slavogermanica XIII, 131-143.

Wenzel 1990, Walter Wenzel, Sorbische anthroponymische Lexik in sprachgeographischer Sicht (Aus der Werkstatt des sorbischen Personennamenatlasses), Namenkundliche Informationen 58, 18-23.

Wenzel 1997, Walter Wenzel, Personennamen in ihrer Bedeutung für die historische Lexikologie und Sprachgeographie - Dargestellt an sorbischem Material, $\mathrm{Na}$ menkundliche Informationen 71/72, 128-132.

Wenzel Studien, Walter Wenzel, Studien zu sorbischen Personennamen, 1. Systematische Darstellung, 2. Historisch-etymologisches Wörterbuch. Bd. I-II, 3, Namenatlas und Beiträge zur Siedlungsgeschichte, Bautzen 1987, 1991, 1992, 1994.

Wenzel Wb., Walter Wenzel, Studien zu sorbischen Personennamen, 2. Historisch-etymologisches Wörterbuch. Bd. I-II. Bautzen 1991, 1992.

Witkowski Grundbegriffe, Teodolius Witkowski, Grundbegriffe der Namenkunde, Berlin 1964.

\begin{tabular}{ll}
\multicolumn{2}{l}{ Abkürzungen } \\
aso. & altsorbisch \\
BW & Bestimmungswort \\
bzw. & beziehungsweise \\
d.h. & das heißt \\
dt. & deutsch \\
FIN & Flurname \\
Grf. & Grundform \\
GW & Grundwort \\
h. & heute \\
mhd. & mittelhochdeutsch \\
mnd. & mittelniederdeutsch \\
n. & nördlich \\
nö. & nordöstlich \\
nso. & niedersorbisch \\
nw. & nordwestlich \\
ö. & östlich \\
ON & Ortsname \\
PN & Personenname \\
poln. & polnisch \\
S. & Seite
\end{tabular}




$\begin{array}{ll}\text { s. } & \text { südlich } \\ \text { sw. } & \text { südwestlich } \\ \text { u.a. } & \text { unter anderem } \\ \text { vgl. } & \text { vergleiche } \\ \text { w. } & \text { westlich } \\ \text { z.B. } & \text { zum Beispiel }\end{array}$

\section{Deapelativna krajevna imena z determinantami Graf-, Herr- in Pape-/Pfaffe- na območju med Saalo in Niso}

Povzetek

Vuvodu avtorica poudarja, da uporaba podatkov imenoslovnih raziskav s strani raziskovalcev bližnjih delovnih področij že dolgo ni nobena posebnost, kot tudi obratno, da so za imenoslovce raziskovalni rezultati bližnjih strok nepogrešljivi. To velja tudi za odkrivanje in raziskovanje poimenovalnih motivov krajevnih imen. Avtorica v prispevku obravnava deapelativna krajevna imena z determinantami Graf-, Herr- in Pape-/Pfaffe- na območju med Saalo in Niso. V tem nemško-slovanskem naselitvenem področju ne obstajajo vedno slovanske ustreznice k nemškim krajevnoimenskim tvorbam. V analizi je bilo obravnavano 130 kulturnih imen z območja med Saalo in Niso, ki v svoji apelativni podstavi z izpeljavo kažejo na posestna razmerja in kot krajevna imena $v$ determinantah vsebujejo naslednje apelative:

srednjevisokonemško grāve, grābe, srednjedolnjenemško grēve, srednjenemško grēbe 'kraljevi sodni prisednik, grof; vaški sodnik' (v imenih: †Gräfen, Gräfendorf, Gräfenhain, Gräfenhain, Nieder-, Gräfenhain, Ober-, Gräfenhainichen);

srednjevisokonemško hērre, herre 'zapovednik, gospod, gospodar; duhovnik' (v imenih: Herrendorf, †Herrngrün, Herrenhaide, Herrnhut, Herrenwalde);

srednjevisokonemško pfaffe, srednjedolnjenemško pāpe 'duhovnik' (vimenih: $\nmid$ Papendorf, Pfaffendorf; Nieder-, Oberpfaffendorf, Pfaffengrün, Pfaffenhaus, Pfaffengut, Pfaffenmühle, Pfaffenhain, Pfaffroda).

Inge Bily

Karl-Tauchnitz-Str. 1, D-04107 Leipzig

bily@saw-leipzig.de 



\title{
Ойконіми України на -иця
}

\author{
Дмитро Бучко (Ternopil)
}

IZVLEČEK: V članku avtor obravnava ukrajinske ojkonime na -ycja, zlasti z ozirom na tvorbo krajevnih imen po tem modelu, na njihov odnos do imen vodnih objektov kot tudi na izpeljavo in strukturo obravnavanih enot.

\section{Ukrainian Toponyms in -ycja}

ABSTRACT: The article addresses the origin of Ukrainian toponyms in -ycja, particularly the preconditions for the formation of location names according to this model, their reference to hydronyms, and the derivation and structure of these units.

В українській і східнослов'янській ономастиці ойконіми на -иця досі не були ще об'єктом спеціального монографічного дослідження. В українській ономастиці аналізу цієї моделі ойконімів спеціальну статтю присвятив I. Ковалик, вказавши на складність генезису цих назв і можливість творення їх не лише від прикметників/дієприкметників, але й безпосередньо від іменників та виділив у межах ойконімів на -иия різні лексико-семантичні групи [Ковалик 1960, 137-143]. Причиною неуваги до названої моделі ойконімів може бути насамперед затемнене словотвірне значення форманта -иц-я, відмінність його значення в ойконімах і гідронімах, а ще відмінність значень суфікса -ищ-я на онімному й апелятивному рівнях.

Суфікс -ищ-я $(<-\boldsymbol{i c}-\boldsymbol{a})$ виник у результаті приєднання структурного форманта $\boldsymbol{- k} \boldsymbol{k} \boldsymbol{a}$ до суфіксального елемента $-\overline{\boldsymbol{t}}$, на який закінчувалися іменники називного відмінка однини жіночого роду, напр.: *babi-ka > bab-ica "стара

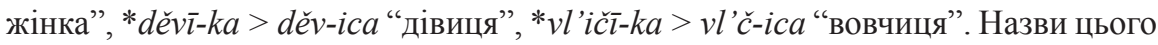
типу виникли на місці первинних форм $b a b \bar{l}$, děvì, $v l$ ' $c \bar{\imath}$ в результаті третьої палаталізації [Sławski I 1974, 99]. Похідність суфіка -ic-a від -bк-a/-bк-a виразно простежується при творенні “назв тварин жіночої статі від первинної демінутивної (через дедемінутивізацію)...при зіставленні найменувань без згаданих суфіксів і з ними : пор. прасл. kurb - kura - kurica (демінутив), lis - lisa; lisbcь (демінутив) і д.-р.-укр. куръ - кура, курииа, рос. кура, курица, біл. курыци а, але схв. курииа “молоденька курочка”; рос. лис-лиса-лисица, укр. лис 
- лисиия, срб. лисаи “лисиця-самець” - лисища “лисиця" [Білоусенко-Німчук 2002, 7-8].

Досліджувана модель ойконімів є дуже давньою, що підтверджується здатністю цього форманта ще в праслов'янський період виражати різні функції, найважливішими з яких є: 1) утворення назв істот жіночої статі, від відповідних іменників чоловічого роду, напр.: besédbnica < besědbn-ikъ "учасник розмови", lisica < lis, samica < sambcb і ін.; 2) субстантивація прикметників і творення назв з конкретним значенням: bystrica „швидка ріка" $<$ bystrъ „швидкий”, desbnica “права рука" < desьnъ “правий”, lèvica “ліва рука" < lěvъ "лівий”, starica < starъ; 3) творення демінутивів, напр.: babica < baba „стара жінка", brátanica < bratana “дочка брата", kozica < koza "коза", pъtica $<p b t a$, „тах”; 4) творення дериватів від іменників, які семантично пов'язані 3 твірними основами, напр. bukъvica, укр. буквиия "подорожник; первоцвіт" [ЕСУМ I, 286] < buky, bukъve [Sławski 1974 I, 98-99] та ін. Характерно, що практично ті самі функції на рівні апелятивів суфікс -иц-я (<-ic-a) виражає і в сучасній українській літературній мові [Синявський 1941, 122].

На думку Ф. Славського, П. Білоусенка і В. Німчука суфікс -ic-a міг виконувати у праслов'янській мові ще ряд інших функцій. Так, останні дослідники стверджують, що цей формант здатний був творити: а) назви осіб, рослин і тварин за їх зовнішніми чи внутрішніми характеристиками і при цьому наголошують, що твірними основами названих дериватів на -ica були насамперед прикметники чи дієприкметники, напр.: děvica < děva "яка годує

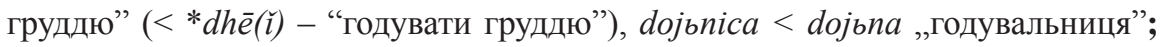
krasavica < *krasavъ/krasava, starica < starb; jalovica „яловиця" < jalovъ „безплідний “, galica „галка” < galъ „чорний”, borovica/borovbnica „лісова ягода" < borovъ < borъ „бір”; б) локальні назви та найменування приміщень за їх умістом, напр.: célica ${ }^{1}<$ célъ „цілина”, gnojbnica $<$ gnojьnъ “куча перегною, гноєвище", golica “щось голе, обідране, відкрите поле" gordica < gordъ/gorda "загороджене місце, огорожа", kalbnica < kalbnъ/kalbna "щось мутне, брудне, переважно вода”, kosbnica < kosbnъ/kosbna "сіножать”, lipovica „місцевість, де ростуть липи” < lipovъ “липовий”, bъčelьnica „бджільник” < bъčelbnъ; в) назви виробів за матеріалом, з якого вони зроблені, напр.: berzovica „березова палиця" < berzovb, gorxovica „горохова солома" < gorxovъ, kolesbnica „колісниця" < kolesbnъ; г) назви різних конкретних предметів, напр.: desbnica „права рука" < desьnъ, lěvica „ліва рука" < lěvъ, pivbnica “пивниця < pivbnъ < pivo “пиво, напій” та ін. [Білоусенко, Німчук 2002, 8-10].

Ще в праслов'янський період суфікс -ic-a здатний був творити й окремі назви географічних об'єктів-передусім гідрооб'єктів. Згодом ці назви, спершу, найімовірніше, внаслідок онімізації/трансонімізації ставали гідронімами, а щойно згодом ойконімами, напр.: brzica „дуже швидка ріка” < brzъ „швидкий”, bujica "рвучкий потік” < bujb „бурхливий”, bystrica „швидка ріка” < bystrъ „швидкий, рвучкий” [Sławski 1974, 98]. Саме назви цього типу, тобто 3

1 На обов'язковій наявності прикметникової стадії при творенні назв на -иця, зокрема топонімів, свого часу наголошував С.Добжицький [Dobrzycki 1922, 189]. 
локальним значенням на -иц-я, пізніше послужили підставою для виникнення однойменних гідронімів і ойконімів. Досить часто іменники на -ica творилися ще від прикметників або пасивних дієприкметників на -bnz, що дозволило виокремити складний формант на -bnica, напр.: kalenica „глиняний посуд” < kaliti “гартувати”, krbnica < krbnъ „викопаний”, tьтьnica „темниця” < tьтьпь “темний”. До праслов'янського періоду належить також і виабстрагування складного суфікса -ovic-a, який творив назви з просторовим значенням, напр.: kosovica „косовиця” < kosovъ, lipovica „липовий гай” < lipovъ [Білоусенко, Німчук 2002, 10, 13]

Словотвірне значення суфікса $-\boldsymbol{i c}-\boldsymbol{a}(>-\boldsymbol{u}-\boldsymbol{s})$ на апелятивному й онімному рівнях, без сумніву, має суттєві відмінності. Найважливіше для онімів субстантивуюче значення форманта -іс-a реалізувалося ним у відповідних назвах на -иця ще на апелятивному рівні. На онімному рівні воно найвиразніше виявилося насамперед у творенні відприкметникових назв водних об'єктів на зразок: Березовиия, Бистриия, Глинниця і под. У більшості сучасних гідронімів і ойконімів України на -иця це субстантивуюче значення зберігається й сьогодні. Разом з тим ряд дериватів на -иця є відантропонімного походження, і суфікс -иц-я в них виражає уже інші значення.

Як бачимо, уже в праслов'янський період суфікс -ic-a на апелятивному рівні міг утворювати субстантиви з різними значеннями, але лише окремі 3 них закріпилися і згодом збереглися в онімах, передусім у топонімах.

Ойконіми України на -иця належать до найдавніших утворень, витоки яких сягають ще праслов'янської доби, оскільки вони активно фіксуються уже в найдавніших давньоукраїнських літописах періоду Київської Русі і багато 3 них збереглося до наших днів, напр.: м. Гноиниия (1152 р.), м. Котєльниия (1143 р.), м. Муравиця (1149 р.), м. Мъльниця (1247 р.), м. Пересъпьниия (1149 р.), м. Сосъниця (1234 р.), м. Тисмяниця (1144 р.), м. Ушиця (1144 р.), м. Шеломьниия (1159 р.). У княжі часи, за даними "Повісті врем'яних літ" (XII ст.), існували дільниці Києва Хорєвиця і Щьковиця. В цьому ж джерелі зафіксовано й хоронім Въкраиниця (1282 р. - це територія, яка знаходилася на пограниччі Волинської області зі східними теренами Польщі [EC, 36]). У цих же писемних пам'ятках зафіксовано й ряд гідронімів на -иця, напр.: Бьзяниця (1151 р.), Л(ь)тиця (1149 р.), Ольшаниця (1150р.), Сальниця (1111 р.), Сьчниця (1245 р.), Хъртиця (1224 р.) [ЕС 43-175] і ін.

Навіть побіжний аналіз наведених топонімів переконує нас у тому, що етимони більшості з них відображають ознаки, характерні для гідрографічних об'єктів. Цей факт ставить перед дослідниками проблему встановлення відношення однойменних ойконімів і гідронімів на -иця. У свій час О.Трубачов стверджував, що формант -иц-я є “загальновизнаним давнім гідронімним формантом, що використовується на всіх слов'янських територіях” [Трубачев $1968,171]$. Сказане певним чином підтверджує правильність висловленого ще в 1939 р. твердження відомого українського ономаста Я.Рудницького, що при тотожності гідронімів і ойконімів перші (гідроніми) є базовими, первинними для других (ойконімів) [Rudnicki, 82-83].

Ойконіми України на -иця за часом їх виникнення можна поділити 
$\hookrightarrow$ щонайменше на три групи. Перші з них $є$ архаїчними, що беруть свій початок ще 3 праслов'янської доби, уперше фіксуються давньоукраїнськими (=давньоруськими) писемними пам'ятками XII-XIII ст. і виявляють чіткий зв'язок з гідронімами, оскільки в їх основах виразно фіксуються гідрографічні семи, пор.: Бистриия, Білорічиия, Болотниця, Вапниця, Глибочиия, Глиниця, Гнилиця, Гнійниця, Зарваниця, Кам'яниця, Квасниця, Кислиця, Коритниця, Луквичя, Льтиияя, Муравиця, Окниця, Піщуаницяя, Погиблиця, Понорницяя, Рибиия, Солониця, Студениця, Сушиия, Теплиця, Тисмениця, Черниия, Чернелиия, Ямниця і под., сюди ж належать і ойконіми, основи яких виражають зв'язок з назвами рослинного покриву, а також фауни на зразок: Березовиця, Бзовичя, Боровичя, Брусничя, Винниця, Вільшаниця, Дубовиця, Дубровиия, Івниия, Крушельниия, Липовиця, Мощзаниця, Оріховиця, Рокитниця, Сосниця, Тисовичя, Яблуновиця, Ягільниия, Ямельниия, Ясениця, Ясеновичя; Бобриия, Бобровичя, Видраниця, Вовковатиия, Жабориия, Зубриця, Линовиця, Рибниця та ін. Друхі, що є значно новішими за походженням, виникли шляхом онімізації однойменних апелятивів на -иця з різним значенням, у т. ч. на означення типів поселень, напр.: Волиия (понад 40 одиниць), Городниияя, Граниияя, Дільниияя, Залізниця, Каплиия, Митниця, Новоселиця (близько 40 назв), Одиниця, Торговиця та ін. Третю групу в межах українських ойконімів на -иця творять назви, в основах яких засвідчені антропоніми. Такі деривати ми схильні кваліфікувати як релятивно-посесивні утворення. У більшості 3 них наявний ускладнений суфікс -овищ-я/-евищ-я, що ілюструє імовірну здатність суфікса -иц-я виражати і словотвірне значення, напр.: Богачевиця, Болеславиця, Братениия, Васеклиия, Вороновиия, Гандеровиця, Годовиця, Дешковиия, Доманиия, Домничя, Дроздовиия, Ганьковиця, Гопчиця, Іваниця, Климовичя, Комарничя, Крукениця, Куштановиця, Миловиця, Мішкаровиця, Носовичя, Оляниия, Пащчениия, Радковиия, Розумниияя, Сокирниия, Соколовиця, Тарасиия, Тригубиия, Уляниця, Яструбиия та ін.

Е. Жетельська-Фелешко слушно твердить, що відантропонімні ойконіми на -иця належать до категорії вторинних назв, оскільки вони виникли після того, як суфікс -иц-я став структуральним (частково асемантичним) формантом і перестав виражати ті функції, які він виражав на апелятивному рівні [Rzetelska 1978, 130-131]. На жаль, дослідниця не висловлює своїх міркувань 3 приводу словотвору цих назв поселень. За нашим глибоким переконанням, деривація їх $€$ відмінною від деривації проаналізованих вище назв. Вони $є$ значно новішими від двох попередніх груп. На нашу думку, суфікс -ищ-я у цих “відантропонімних" топонімах, найімовірніше, первісно виконував посесивно-релятивну, а в окремих випадках i, можливо, посесивно-субстантивуючу словотвірну функцію. Отже, поселення Василиця, Ганьковиия, Дешковиия і под. були названі так не лише тому, що первісно їх власниками були відповідно Василь, Ганько, Дешко, а й тому, що названі особи могли бути першопоселенцями нововиниклих населених пунктів, і через те суфікс -иц-я в цих назвах виражав релятивність, тобто певний стосунок (якесь відношення) названої особи до цього чи іншого поселення.

Частина ойконімів на -иця, імовірно, виникла від однокореневих назв 
сусідніх чи дещо віддаленіших населених пунктів, але, напевно, через посередництво однойменних гідронімів. Наприклад, назву села Бру(ю)ховиця, напевно, утворено від назви річки/потоку * Брюховиия, а назву річки-відповідно від назви села Брюховичі (Лв), аналогічно виникли й ойконіми Лецовиця < p.*Лецовиия < с.Лецівка (ІФ), Свидниия < р.Свидниия < с.Свидник (Лв) і под.; інших пояснень виникнення назв Лецовиця, Свидниця та ін., здається, бути не може. Невеличку групу українських ойконімів на -иця творять також відонімні назви, що виникли з колишніх прийменникових сполучень, у склад яких входили назви різних географічних об'єктів. Спершу такі словосполучення лексикалізувалися, а потім зазнали субстантивації, замінивши форми непрямих відмінків географічних назв їх початковими формами, напр.: За Верешицею > Заверешицею > Заверешиия (Лв), За Мутвицею > Замутвицею > Замутвиця (Вл), Під Кримницею > Підкримницею > Підкримниця (ІФ), При Мощаниці > Примощзаниці > Примощзаниця (Вн) та ін.

Важливо додати, що архаїчні ойконіми на -иця, цілком імовірно, первісно були гідронімами, бо їх основи виразно відображають ознаки гідрооб'єктів, або ж мотивовані ознаками флори чи фавни, що теж $є$ характерними насамперед для гідронімів. Менш імовірно, що етимони окремих ойконімів на -иця $є$ назвами тих місцевостей, на яких згодом виникали однойменні поселення.

Найдавніші ойконіми на -иця локалізуються в основному на найдавніше заселених територіях України, які не зазнавали таких спустошливих руйнувань осілого життя, як території центральних та південно-східних регіонів нашої країни. До них належать терени Волинської, Рівненської, Львівської, Івано-Франківської і Тернопільської областей. Значно менше назв цього типу виявлено в ойконімії Закарпатської, Чернівецької, Хмельницької, Житомирської, Київської та Чернігівської областей України. В ойконімії інших областей України деривати досліджуваної моделі вживаються вкрай рідко, і до того ж це назви новішого й нерідко штучного походження на зразок: Дільниця, Криниця, Новоселиия, Торговиця та ін.

Ойконіми на -иця, будучи архаїчними за походженням дериватами, становлять порівняно невеликий процент назв по відношенню до всіх назв поселень на конкретних територіях. Найвищий процент ойконіми на -иця становлять у Рівненській (3,9 \%). Волинській (3,3 \%), Івано-Франківській $(3,45 \%)$, Львівській $(2,27 \%)$ і Тернопільській $(2,5 \%)$ областях. У той же час в ойконімії окремих південно-східних областей України, які належать до пізньозаселеного регіону України, топоніми цієї моделі можуть репрезентуватися максимально однією-трьома назвами, а в більшості областей і районів названої території вони зовсім не фіксуються.

На нашу думку, абсолютна більшість давніх ойконімів України на -иця України, однозначно, виникла від назв одноіменних гідрооб'єктів. Доказом цього може бути той факт, що відносно багато поданих нижче ойконімів на -иця є однойменними або ж структурно близькими з існуючими гідронімами. Крім цього, твірні основи багатьох ойконімів аналізованої моделі мотивовані ознаками, характерними виключно для гідрооб'єктів: вказують на колір, смак, температуру води; швидкість течії; характер грунту місцевості, де 
$4 \quad$ протікає річка (потік), характерну для водного середовища флору і фауну та ін.: Баговиия (пор. багно), Березовиия, Бистриия, Білиия, Білокриниия, Білорічищя, Бобриия, Бобровищя, Болотниия, Бродниия, Брусниия, Бусельниия, Вапниия, Варшиия (пор. біл. вархал “шум”), Вербиия, Видраниия, Витвиия (пор. витися), Вільховичя, Вільшаничя, Водиия, Глибочиия, Глин(н)чия, Гнилиия, Гнійниия, Головниия (пор. головиия “витік ріки”), Жабориця, Зарваниия, Іловиия, Квасниия, Квасовиия, Керниия, Клютковиия (пор. пол. klukać “булькотати”), Коблиия (пор. коблик “риба"), Конопниия (пор. коноплі), Коритниия, Корот(н)иия, Котельниия, Кривиия, Криниия (з різноманітними атрибутами), Круглиия, Крукениия (можливо, від кроткениия, пор. кроткий “тихий”), Лохвиия, Лукавичя, Лучиия (пор. лука “дуга”), Мошниия (пор. мох), Мутвиия (пор. мутний), Нересниия (пор. нерест), Новорічиия, Окониия (пор. окно), Ольшаниия (пор. ольха), Оржиия, Пересопниия, Піщзаниия, Погиблиия, Пониковиия, Понорниия, Рибниия, Річиия, Рокитниия, Роставиия, Рудниия, Сільниия, Солониия, Стариия, Студениия, Сушиия, Теплиия, Тисмениия, Тишивниия, Тишиця, Топільниця, Тростяниця, Ушиця, Хортиия, Чернелиия, Човниия, Човновиия, Шеметиия (пор. шемелити "шелестіти”), Ягільниия, Ямельниия, Ям(н)иия.

Таким чином, за нашим переконанням, понад 200 ойконімів України на -иця, частину з яких названо вище, утворилися шляхом перенесення назв гідрооб'єктів на ті поселення, що виникали поруч. Ми переконані також у тому, що подібним був генезис не тільки наведених вище назв досліджуваної моделі, а так з'явилася й більшість інших ойконімів на -иця з різними семантичними групами апелятивів в основах.

Семантико-словотвірний аналіз ойконімів на -иця дозволяє виділити в них наступні групи: 1. Назви, твірні основи яких мотивовані апелятивами. 2. Назви, в основах яких засвідчені оніми.

Кількісна репрезентація назв першої групи є домінуючою. Вони $\epsilon$ первинними і архаїчними, а відонімні ілюструються порівняно значно меншою кількістю прикладів. При детальнішому аналізі ойконімів першої групи (відапелятивних ойконімів), їх можна поділити ще на кілька підгруп: 1. Назви поселень на -иця, твірні основи яких мотивовані топографічними назвами. 2. Назви поселень на -иця, твірні основи яких мотивовані найменуваннями об’єктів, створених людиною, т. зв. „культурні назви”. Зупинимося на кожній 3 цих груп детальніше

I. Термін “топографічні” назви широко використовується у слов'янській і передусім польській ономастиці. Він об’єднує далеко неоднорідні ойконіми. В межах цих назв виділяємо ойконіми, в основах яких репрезентуються апелятиви з різними значенннями.

1) Ойконіми, основи яких мотивовані апелятивами на означення характеру грунту: Грузевиия (пор. грузевина „трясовина”), Кушниия (пор. кушниия „викорчуване місце”), Мірвиия (пор. мерва „грузьке болото”), Новиия (пор. новичя ,приготована для ріллі площа"), Теребенниия (пор. теребити) та ін.

2) Ойконіми, основи яких мотивовані апелятивами на означення 
загального виду місцевості (рельєфу): Бережниця, Голищя, Гориця, Кісниця (кісниия „сіножать”), Колодниия, Облазниця, Осовиця, разом 27 назв.

3) Ойконіми, основи яких мотивовані апелятивами на означення рослин, рослинного покриву місцевості: Березовиця, Бзовиия, Боровиия, Винниця, В'язовиия, Грабівниия, Грибовичя, Дубовичя, Слиця, Івниця, Крушельниия і под., разом 105 одиниць. Назви цього типу творять найчисельнішу групу не лише в українській, а й в західнослов'янській ойконімії. При цьому найбільше ойконімів мотивується назвами дерев: дуб, липа, вільха (ольха), а ще назвами різного типу трав.

4) Ойконіми, основи яких мотивовані апелятивами на означення тварин, комах, птахів: Вовковатиия, Воловиия, Вороновиця, Голубиия, Дроздовиия, Зубричя, Мідяниия, Нориия, Соколичя, Соколовичя, Язовичя (пор. яз “риба”), Яструбиця, усього понад 20 назв; окремі з цих назв можуть бути кваліфіковані також як відантропонімні.

5) Ойконіми, основи яких мотивовані апелятивами на означення місця розташування поселень стосовно інших об'єктів на місцевості: Вижниця, Заверешиця, Заголиця, Закаплиця, Залисиия, Замутвиця, Зарічиця, Передільниця, Підквасовиця, Примощчаниця та ін., більше 10 назв.

6) Ойконіми, основи яких мотивовані апелятивами 3 метафоричним значенням; мотиви номінації цих об'єктів сьогодні важко встановити, напр.: Близниия, Блиставиия, Крупиия, Ігровиия, Небелиия, Сальниия, Середниия, Скрипиия (скрипиия „дерев'яні кайдани”), Східниия, Тайниия, Хлоп'яниия, Чудниия, близько 20 назв.

2. Ойконіми, основи яких мотивовані апелятивами на означення об’єктів матеріальної та духовної культури. Включені до цієї групи ойконіми відзначаються насамперед своїм походженням і кількісною вираженістю.

1) Ойконіми, основи яких мотивовані апелятивами, що пов'язані 3 матеріальною культурою на означення господарської діяльності, об'єктами громадського вжитку, загород, будинків та ін.: Візниия, Війниця (пор. війя „дишель”), Возовиця (пор. возовицяя “період звезення скошеного хліба”), Вулиия, Городниця, Гостинниця, Граниия, Дарниия, Дільниия, Залізниця, Кам'яниия, Лозниия (лозниия “сушарка, виплетена з лози”), Мельниця, Митниця, Новоселиця (близько 40 назв), Одиниця, П'ятниця (за кількістю загонів), Ставниия (=стайня), Стадниия, Стебниия (стебник "приміщення для зимування бджолиних вуликів”), Стражниия, Тинниия, Торговиия та ін., понад 100 назв.

2) Ойконіми, основи яких мотивовані апелятивами на означення знарядь праці, предметів господарської діяльності, в т. ч. домашнього господарства (усі назви мають підтвердження в довідковій літературі): Бервениия, Битиия, Білогалиия, (галиия „сіть”), Бочаниия, Вежиия, Верениия, Горнатиия, Кадниия, Кияниия (пор. киянка „довбня”), Козубатиия (пор. козубецьь), Коновиия, Мазниия, Сирниия, Стужиия (пор. стуга “плетена коробка з лози”), Ступниця, Терлиия, Уздиия, понад 20 назв.

3) Ойконіми, основи яких мотивовані апелятивами зі сфери духовної і 
ч суспільної культури: Білобожниця, Ка(м)плиия; Вілищя, Вільниця, Волиця, Красноволиия, усього 25 назв.

Розглянуті вище ойконіми на -иця, думаємо, утворилися не морфологічним, а безафіксним, інакше семантичним способом; наявний у них суфікс -ищ-я виконував релятивно-субстантивуючу, а не топонімотвірну функцію. Не цілком переконливим є, на нашу думку, твердження 3.Франко, яка вивчаючи мікротопоніми, зафіксовані в староукраїнських пам'ятках ХІУ-ХУ ст., стверджувала, що формант -ица/-иця позбавлений лексичного значення, оскільки він чітко не закріплений за певними розрядами топонімів, “бо однаковою мірою властивий ойко-, гідронімам та іншим тереновим назвам” [Франко 1984: 45].

II. Відонімні ойконіми. У наших матеріалах ми виявили понад 30 ойконімів досліджуваної моделі, які кваліфікуємо як відантропонімні, напр.: Братениия, Богаревиия, Василичя, Ганьковиця, Годовиця, Дешковиця, Дисковиия, Дівиия, Доманиия, Домниця, Дуньковичя, Іваниия, Вашковиця, Климовиия, Кобаловичя, Лямковиия, Миловиця, Мішкаровиця, Полеславиия, Радковиця, Розумниия, Ромочевиця, Самовитиия, Тарасиия, Уляниця, Хемниця, Хоровиця, Хотовиця та ін. Засвідчені в основах цих ойконімів антропоніми є різного походження й різної структури - слов'янські та неслов'янські (християнські).

III. Назви з не цілком прозорою словотвірною семантикою. Порівняно невелику групу творять ойконіми на -иця, які можна кваліфікувати як “відапелятивні”, однак семантика їх твірних основ є практично затіненою. Гадаємо, що монографічне діахронічне вивчення ойконімів цієї моделі дозволить в майбутньому встановити їх реальне словотвірне значення i походження. До цієї групи належать назви: Білосовиия, Гандеровиия, Гнопелиия, Кістельниия, Кластниця, Куповатиця, Маморниия, Ольтениця, Орв'яниия, Перепростиия, Подульниия, Постовбиия, Поториия, Тепелиия, Устивиия, Черковатиия, майже 20 назв.

Що стосується структури ойконімів на -иця, то твірними основами домінуючого їх числа були прикметники чи дієприкметники, і лише незначна їх кількість деривована від іменників чи інших частин мови. Відсубстантивна деривація ойконімів на -иця може бути проілюстрована насамперед назвами, що виникли в результаті онімізації однойменних апелятивів на зразок: Водиця, Волиия, Криниия, Мельниця, Новоселиия, Річиця, Стариия та под.

Ми абсолютно переконані в тому, що існування апелятивів на означення nomina loci з суфіксом -иц-я/-ниц-я стало вихідним пунктом для перенесення цієї словотвірної формації з площини апелятивної в площину онімну. Уже перші власні назви з цим формантом означали конкретні просторові одиниці на місцевості. У процесі формування назв гідрооб'єктів, місцевостей і поселень досліджуваної моделі формант -иц-я 3 давніх своїх функцій реалізував, на думку Е. Жетельської-Фелешко, лише три функції: 1) субстантивацію прикметників, 2) творення відіменних дериватів, 3) творення демінутивів [Rzetelska 1978, 134]. На нашу думку, названі функції формант -иц-я виражав хіба що при творенні тих назв гідрооб'єктів і назв місцевостей, від яких згодом виникали однойменні ойконіми. На онімному рівні формант -иц-я здатний 
був творити топоніми як від основ якісних прикметників на зразок: бистра > Бистрищя, гола > Голиия, так і від архаїчних відносних прикметників на $-\mathbf{i} /-\boldsymbol{y}$, $\boldsymbol{- a}$, напр.: бобрь > прикм. бобр'я > Бобриия, липа > прикм. лип'я > Липиия, а крім цього міг творити назви безпосередньо від основ іменників, напр. нива > Нивичя, ріка > Річиия.

Варто зазначити, що за походженням назви Бобриия/Бобровиця, Липиия $\mathrm{i}$ Нивиия, Річиия належать до різних словотвірних типів. Різниця міжнимиполягає в тому, що певну ріку (пізніше поселення) названо Бобрицею/Бобровицею тому, що там водилися бобри, вона була боброва; відповідно місцевість, де росли липи, була липовою, тобто ці назви утворено від прикметників, а назви Нивиия, Річиия первісно виражали інше словотвірне значення. Однак при відсутності формального детермінанта в назвах першого типу ці назви важко чи просто неможливо розрізнити між собою. В результаті поєднання цих двох типів назв виникла порівняно чисельна група “відапелятивних" ойконімів. Досить чисельними є також ойконіми на -ниц-я 3 відад’єктивними основами, що є відносними прикметниками на *-ьнъ напр.: болото > прикм. болотн- > Болотниия, Бродниця, Бусельниця, Глинниия та ін. Цей формант міг нарощуватися ще афіксом -aн-, який, як відомо, характерний насамперед для відприкметникових дериватів, напр.: Бочаниця, Вільшаниця, Ольшаниця, Піщзаниця, Тростяниия чи віддієприкметникових основ: Видраниця, Зарваниця, Мощаниця (пор. мощений); назви з суфіксом -ель: Ямельниця. Суфікс -иц-я міг також приєднуватися до відносних прикметників з суфіксальним компонентом -ов/-ев в основах на зразок: бобр > прикм. боброва > Бобровиця, Березовиця, Грузевичя, Іловиця, Коновиця, Квасовичя, Линовичя, Пониковиця, Човновиця, Шестовиия. Кількома прикладами ілюструється формант -ищ-я, розбудований компонентом -ав: Лукавиця, Роставиця.

Прикладом відчислівникових ойконімів на -иця можуть бути назви Одиниия, П'ятниця, Троӥия, Шестовиця. У західнослов'янській ойконімії Е. Жетельська-Фелешко виявляє аналогічні ойконіми Piatnica, Setnica, Siodmica, Trojica [Rzetelska-Feleszko 1978, 138].

Назви з суфіксом -иц-я виникали також у результаті лексикалізації первісно прийменникових сполучень, які згодом зазнавали певних структурних змін на зразок: За Верешицею > Заверешиця, Заголиця, Закаплиця, Зарічиця, Підквасовиця, Примощаниця. До цієї групи, напевно, не можна зарахувати назву Замучениия, хоча, не виключено, що на цій території в минулому міг існувати певний географічний об’єкт з назвою Мучениця чи под.

Проаналізовані вище словотвірні типи ойконімів 3 формантом -иц-я і його похідними характеризуються різною продуктивністю. Домінуючими $€$ деривати з відприкметниковими основами на -иц-я (-н-иц-я, -ов-иц-я). Значно меншою кількістю назв репрезентуються відіменникові, віддієприкметникові і відчислівникові деривати.

Підсумовуючи, хочемо наголосити на тому, що українські топоніми на -иця в абсолютній своїй більшості виникли в результаті трансонімізації назв гідрооб'єктів або окремих місцевостей на ті населені пункти, які виникали поруч з ними, і лише порівняно незначна кількість ойконімів цієї моделі 
- утворилася також в результаті онімізації однойменних апелятивів на зразок: волиия, мельниия, новоселиия і под., а ще невеличка частина назв поселень на -иця , напевно, утворилася в результаті морфологічного способу деривації.

\section{Література}

Білоусенко, Німчук 2002 - Білоусенко П., Німчук В., Нариси з історії украӥнського словотворення (суфікс-иия), Київ-Запоріжжя, 205с.

Dobrzycki 1922 - Dobrzycki S., Próba objaśnienia kilku nazw geograficznych wielkopolskich//Slavia Occidentalis, t. II, Poznań, 172-218.

ЕС - Етимологічний словник літописних географічних назв Південної Русі, К.: Наукова думка, 1985, 253c.

ЕСУМ - Етимологічний словник украӥнської мови, т. І-ІУ, Київ 1982-2004.

Ковалик 1960 - Ковалик I., Словотворча будова української топоніміки (назви населених пунктів із суфіксом -иця (-ниця)//Питання українського мовознавства, книга 4, Львів: Вид-во Львівськ. універ-тету, 137-143.

Синявський 1941 - Синявський О., Норми украӥнської літературної мови, Львів, Українське видавництво, 363с.

Трубачев 1968 - Трубачев О., Названия рек Правобережной Украины, М., Наука, 289c.

Франко 1984 - Франко 3., Словотворчі типи мікротопонімів староукраїнської мови ХІУ-ХУ ст. //Мовознавство, 1984, № 4, 4-50.

Rudnicki 1939 - Rudnicki J., Nazwy geograficzne Bojkowszczyzny, Lwów, 239s.

Rzetelska 1978 - Rzetelska-Feleszko E., Rozwój i zmiany toponimicznego formantu -ica na obszarze zachodniosłowiańskim, Wrocław etc.: Wyd-wo PAN, 176s.

Sławski 1974 - Sławski F., Zarys słowotwórstwa prasłowiańskiego [W:] Słownik prasłowiański, t. I, Wrocław etc., 43-141.

\section{Прийняті скорочення адміністративних одиниц}

Вл - Волинська обл.

Вн - Вінницька обл.

І-Ф - Івано-Франківська обл.

Лв - Львівська обл.

\section{Ojkonimi na -ycja v Ukrajini}

Povzetek

Ojkonimi na -ycja spadajo med arhaične in razmeroma produktivne toponimske modele ne le na ozemlju Ukrajine, temveč v vsej Slaviji. Že v praslovanskem obdobju je pripona -yc-ja zmogla izražati celo vrsto različnih funkcij, in sicer: 1. substantivizirati pridevnike in tvoriti samostalnike s konkretnim in nekoliko 
posebnim pomenom, npr. bystrica 'bistra rečica', starica 'stara struga reke'; 2. tvoriti manjšalnice, npr. bratanica 'bratova hčerka' idr. Navedene funkcije pripone -yc-ja so se delno ohranile $v$ toponimih, med drugim $v$ imenih vodnih objektov in posameznih območij. Po našem globokem prepričanju obrazilo -ycja pri pretežni večini naselbinskih imen ni imelo ojkonimotvorne funkcije, temveč so ta imena nastala s transonimizacijo (prenosom) imen z istoimenskih vodnih objektov (rečic, potokov...), pa tudi imen določenih območij na naselbine, ki so nastale v bližini. $O$ povedanem priča, prvič, znatno število istoimenskih vodnih imen na -усја (Бистриця, Дубовиця, Топиільниця, Ямельниця idr.), iz katerih so nastala obravnavana naselbinska imena, in drugič, atributivna hidrografska semantika večine etimonov ustreznih ojkonimov na -ycja. In le v manjšem delu istoimenskih izantroponimnih in širše izlastnoimenskih ojkonimov je pripona -yc-ja/-ovyc-ja zagotovo imela ne le manjšalno, temveč tudi svojilno ojkonimotvorno funkcijo. Na to med drugim kaže pripona -ov-, s katero je razširjena pripona -ус-ja, npr. Ганьковиця, Івашковиця, Миловиця, Радковиця, Соколовиця $i d r$.

Dmytro Bučko

vul. Lučakivs'kogo 31, kv. 35, 46027 Ternopil', Ukraïna dmytrobucz@rambler.ru 



\title{
Nadawanie imion „literackich” w Polsce
}

\author{
Aleksandra Cieślikowa, Maria Malec (Krakov)
}

IZVLEČEK: V članku avtorici obravnavata dajanje ,,literarnih” imen na Poljskem. Pri tem razlikujeta književnost verskega značaja (Biblija, obredna besedila, življenjepisi svetnikov), ki je vir krščanskih imen, od književnosti posvetnega značaja in z njo povezano literarno motivacijo imen. Nadalje so bili ugotovljeni nekateri postopki, povezani z dajanjem literarnih imen na Poljskem. Na koncu je bil podan poskus oblikovanja definicije pojma „literarno ime”.

\section{Assigning Literary Names in Poland}

ABSTRACT: This article discusses the assignment of "literary" names in Poland. The authors distinguish between religious literature (the Bible, religious texts, and hagiography) as a source of Christian names, and secular literature with associated literary name motivation. In addition, some procedures are established connected with assigning literary names in Poland. The article concludes with an attempt to define the term "literary name".

Poniżej przedstawiamy nieco zróżnicowane spojrzenia autorek na specyfikę „imienia literackiego”.

W artykule będzie mowa nie o imionach znajdujących się w dziełach literackich lecz o wpływie imion z tekstów zarówno polskich jak i obcych na frekwencję imion nadawanych dzieciom, i o poszerzaniu przez imiona literackie zbioru imion, tzw. oficjalnych.

Imiona do tekstów literackich dostają się albo z różnych odmian języka (potocznego, oficjalnego) albo z innych tekstów literackich. Dzieje się to najczęściej wtedy, kiedy występuje zależność tematyczna, niekiedy między odległymi czasowo utworami, np. „Iliadą” Homera i „Odprawą posłów greckich”, Jana Kochanowskiego, największego polskiego poety okresu renesansu.

Z zupełnie innego okresu pochodzą imiona w poezji Haliny Poświatowskiej, żyjącej w XX wieku, a nawiązującej w wierszu do szekspirowskiej bohaterki: „Jestem Juliq mam lat 23 dotknętam kiedyś miłości. Tylko imię Julia i cytat ,Z balkonem" zaznaczają związek z opowieścią o tragicznej miłości” (por. Cieślikowa 1993: 37). Imię Julia pojawiło się w Polsce w wieku XVIII jako imię literackie 
- bohaterki „Nowej Heloizy” J. J. Rousseau. Współcześnie jest w Polsce modne. Nikt nie jest w stanie wyjaśnić, czy dzieje się to za sprawą dramatu szekspirowskiego wystawionego po raz pierwszy w roku 1796, wielekroć później ponawianego, czy którejś z licznych postaci literackich noszących to imię. Wystarczy wymienić dramat Strindberga „Panna Julia” czy Julkę, bohaterkę „Panien z Wilka” Jarosława Iwaszkiewicza, czy też z innej przyczyny.

Imiona wędrują w przestrzeni literackiej, która nie zna granic geograficznych ani chronologicznych. Nazywany to zjawisko intertekstualnością. Znakiem jej bywają imiona. Dzięki nim zaznaczana jest również zależność między tekstami. Z zaliczeniem imion do literackich bywa tak, jak z ich etymologia. Możemy zaobserwować pojawienie się imienia w jakimś kraju pod wpływem dzieła literackiego, ale w rzeczywistości pozaliterackiej istniało ono już dawno. Imiona Juliusz i Julia były spotykane w starożytnym Rzymie. Trzeba zaznaczyć, że z dzieł literackich do języków narodowych częściej są przejmowane imiona łatwiejsze do adaptacji. W roku 2000 imię Julia nadano 9927 Polkom i zajmowało szóstą pozycję wśród najpopularniejszych imion zarówno męskich jak żeńskich, natomiast imię Romeo - częściowo nieodmienne (kłopoty $z$ dativem $i$ ablativem), nabrało odcienia apelatywnego ' kochanek' jest bardzo rzadko nadawane (48 nosicieli) i w zasadzie nie poszerzyło zbioru męskich imion polskich.

Imionami zapożyczonymi z tradycji literackiej nazywa M. Malec (2001: 32, 33) imiona, które weszły do zbioru imion noszonych, a które kojarzymy ze znanymi utworami, np. , z bohaterkami oper Verdiego i Bizeta kojarzą się współcześnie noszone imiona Aida, Carmen, z sonetami Petrarki Laura”. Można zapytać, czy wpływ na frekwencję imienia nie miały bohaterki dramatów Juliusza Słowackiego „Kordian” i Zawisza Czarny”, a z późniejszych utworów - Laura Kościeniecka z „Przedwiośnia” Stefana Żeromskiego. Drugie pytanie dotyczy przede wszystkim wybierających imię, czy znają je z literatury, czy też inna motywacja zaważyła na wyborze?

W imionach zwanych literackimi mamy do czynienia z dwoma sytuacjami: imionami wędrującymi zarówno w przestrzeni realnej jak i literackiej, które dzięki znakomitości dzieła literackiego upowszechniało je w różnych krajach w rozmaitych gatunkach literackich, i w różnym czasie. Utwory wpływały na frekwencję, i przyczyniały się do tego, że imię znalazło się w zbiorze imion nadawanych i używanych w danym języku. Tylko znajomość dzieł literackich rodzimych i obcych, czas pojawienia się imienia, którego nie było przedtem uprawnia onomastę do zakwalifikowania imienia jako „motywacyjnie” literackiego. Czasem wiedza typu encyklopedycznego dostarcza wiadomości o imionach stworzonych przez autorów. Przykładów dostarczają nam utwory polskich romantyków. Jedne z nich osiągnęły popularność jak również stworzone w nich imiona, np. mickiewiczowska Grażyna utworzona od litewskiego przymiotnika gražùs 'piękny' (imię to nosiło w $2000 \mathrm{r}$. -261. 873 Polki). Znacznie rzadsze są imiona: z „Pana Tadeusza” - Telimena (101) i imiona stworzone przez Juliusza Słowackiego: Anhelli (5) i Balladyna//Baladyna (25), Kirkor (1), Lambro (1), a także imiona z utworów Zygmunta Krasińskiego, np. Irydion (1). Trudno powiedzieć, czy za zwiększoną frekwencję odpowiedzialne jest łączenie imienia z wyrazem pospolitym, jak w Grażynie i w Kordianie (cor, 
cordis 'serce') czy brzmienie imienia, czy wreszcie osoba bohatera literackiego jego pozytywne lub negatywne cechy (por. Balladyna i spopularyzowane przez dramat imię siostry głównej bohaterki - Alina (98402 nosicielki).

Ze Starego Testamentu nadano imiona Natanael spolszczone Nataniel, też Nehemiasz, ale nie ma w zbiorze imion polskich imienia Hiob - por. hiobowa wieść 'wieść zła, katastrofalna, tragiczna, przerażająca' Kopaliński 1996: 379).

Do ustalenia przyczyny wyboru imienia mogłyby prowadzić jedynie pytania zawarte w ankietach. Pisałam niegdyś, że na nadanie określonego imienia wpływ mają, w przypadku obcego imienia: motyw estetyczny (imię się podoba), motyw osobowy (podoba się osoba, bohater literacki noszący dane imię), poszukiwanie inności: oryginalności, małej powtarzalności, snobizm, zaś na przyczyny wyboru imienia tradycyjnego składają się: tradycyjny model nazywania w rodzinie i środowisku, względy ideowe i kulturowe (Cieślikowa 1994, 187).

Przejęcie imienia z obcej literatury powoduje wariantywność form graficznych: Ukochana Dantego Beatrice, której imię wystąpiło w wierszu Lechonia: „Nie ma nieba ni ziemi, otchłani ni piekła, Jest tylko Beatrycze. I właśnie jej nie ma”. Jej imię wystąpiło w danych urzędu statystycznego w 18 wariantach (w nawiasach podaję liczbę nosicielek): Beatrycza (19), Beatryca (22), Beatryce (2), Beatrycja (5) Beatrix (4), Beatris (3), Beatricze (12), Beatricza (5), Beatricz (1), Beatricia (1), Beatrice (31), Beatrica (16), Beatrlic (1), Beatrycze (116), Beatryczy (1), Beatryx (3), Beatryxa (4), Beatrysa (1) (Rymut 1994). Do innych form graficznych mogły się przyczynić zarówno komedia Szekspira z bohaterką Beatrix jak i liczne utwory oparte na autentycznej historii Beatrice Cenci (1577-!599) zwanej ,piękną ojcobójczynią", uwiecznionej w obrazach, rzeźbach, utworach literackich: The Cenci - tragedia Shelleya - Beatryks Cenci tragedia Słowackiego - Beatrix Cenci, opera Ludomira Różyckiego, według podanej wyżej tragedii Słowackiego (por. Kopaliński 1996, 84, 140).

$\mathrm{Na}$ frekwencję imion pochodzących z tekstów literackich miała wpływ ich forma. Według ustawy Prawo o aktach stanu cywilnego: „Kierownik urzędu stanu cywilnego odmawia przyjęcia oświadczenia o wyborze dla dziecka więcej niż dwóch imion, imienia ośmieszającego, nieprzyzwoitego, w formie zdrobniałej oraz imienia nie pozwalającego odróżnić płci dziecka”.

Dlatego obok Carmen (91) pojawiła się Karmena (28), obok Rut (254)-Ruta (2804), obok Beatrycze (116) - Beatrycza (19).

We wskazaniach Komisji Kultury Języka czytamy: „Imię powinno odróżniać płeć dziecka ze względów językowych (język polski wymaga odmiany imienia przez przypadki) ... Wskazane jest nadawanie dziewczynkom imion kończących się na $-a$... chłopcom imion kończących się na spółgłoskę $\ldots$ oraz na $-i,-y \ldots$ rzadko na -o." Wskazania Komisji Kultury pochodzą z roku 1996 i dopiero wtedy oficjalnie dopuszczono imiona inne niż zakończone na - $a$. Cytuję: „Są jednak utrwalone w tradycji kulturalnej lub literackiej imiona kobiece zakończone na głoskę inną niż - $a$, które - wbrew zasadzie - można nadawać dziewczynkom , np. Beatrycze, Noemi, Karmen, Rut (natomiast nie można nadawać ich chłopcom).

Ogólna uwaga w zaleceniach Komisji brzmi: „Imiona należą do kultury narodowej choć pochodzą z różnych stron świata . Znaczna ich część została przyswo- 
jona przez język polski w wiekach średnich i późniejszych, co spowodowało, że stały się wyznacznikiem narodowości ich nosicieli. Przez związek podstawowego zasobu imion z kulturą chrześcijańską należą one do zbioru imion używanych w wielu krajach Europy i świata. Szukając imienia dla dziecka, należy się starać o pogodzenie wolnego wyboru z tradycją i tendencjami uniwersalnymi”. Do szerzenia tendencji uniwersalnych przyczyniają się imiona zaczerpnięte $\mathrm{z}$ wielkich dzieł literackich, które niekiedy powodują zwiększoną frekwencję nadawania, imion ,literackich”.

Imionami literackimi, w skarbcu imion wybieranych i nadawanych dzieciom w poszczególnych językach narodowych Europy, można nazwać wszelkie imiona, które weszły do antroponimii europejskiej poprzez wielkie dzieła literatury światowej, takie jak Biblia, wielkie poematy epickie greckie i rzymskie epoki klasycznej, legendy i poematy celtyckie i prowansalskie, epos germański, jak opowieści, legendy i poematy a także żywoty świętych krążące zrazu w odpisach a wraz z wynalezieniem druku jeszcze szerzej rozpowszechniane, następnie wybitne dzieła w narodowych językach europejskich, jak np. Boska komedia (1555) Dantego, dramaty Szekspira, jak niezliczone powszechnie znane dzieła późniejszych okresów literackich. Bohaterowie tych dzieł żyją w kulturze literackiej narodów Europy a ich imiona są nadawane dzieciom. Jednak wśród dzieł literatury światowej należy wprowadzić konieczne rozróżnienie na teksty należące do sfery sakralnej, jak Biblia i różnego rodzaju utwory związane z liturgią i promocją świętych i pozostałe teksty zawierające treści świeckie. Imiona związane genetycznie z pierwszymi tekstami przyjęto nazywać imionami chrześcijańskimi. Są to imiona bohaterów biblijnych zaadaptowane przez chrześcijan wraz z przesłaniem Starego i Nowego Testamentu, np. Adam, Ewa, Abraham, Jakub, Józef, Maria oraz imiona świętych chrześcijańskich różnych epok. Ich niebywałe rozpowszechnienie w całej Europie jest związane z chrześcijańską doktryną o świętych obcowaniu, z kultem świętych i obrzędem chrztu podczas którego nadaje się imię. Mają one z genezy swojej, jako imiona świętych, symboliczną motywację sakralną. Wtórnie na ich wybór mogą również wpływać noszący dane imię świeccy bohaterowie późniejszych dzieł literackich. Natomiast niektóre imiona bohaterów dzieł literackich niezwiązanych bezpośrednio ze sferą sacrum mogą być nadawane jako imiona literackie, np. imię Beatrycze jest motywowane prymarnie przez imię bohaterki Boskiej komedii Dantego, imiona Ofelia i Hamlet pochodzą z Szekspirowskiego dramatu.

W ramach ogólnych tendencji panujących w antroponimii europejskiej, którą cechuje przewaga imion określanych jako chrześcijańskie, a także obecność imion mających swe źródło w literaturze nie związanej ściśle ze sferą sacrum, mieści się antroponimia poszczególnych języków narodowych. Imiona nadawane członkom danego kraju są - w czasach historycznych - wybierane z zasobu imion istniejących w zbiorowej świadomości danego narodu. Zasób ten nie jest zamknięty. Ma pewien korpus stały oraz części zmienne. Możliwe jest włączanie nowych imion i wycho- 
dzenie z użycia dawnych. Wpływ na przemiany w zasobie imion mają procesy i zmiany kulturowe, wpływ na kształt imion procesy językowe (Malec 2007).

W Polsce od początku jej dziejów historycznych obserwujemy wielkie przemiany w antroponimii. Największą z nich była dokonana w średniowieczu wymiana imiennictwa rodzimego na imiona chrześcijańskie obcego pochodzenia. Od najdawniejszych też czasów obserwujemy obecność imion motywowanych przez bohaterów literackich. „Słownik staropolskich nazw osobowych” notuje kilkanaście tego rodzaju imion w dokumentach XII - XV w. Z cyklem opowieści trojańskich można powiązać następujące imiona osób żyjących w tym czasie w Polsce: męskie Achilles, Ajaks, Hektor (także w postaci Jaktor, Jektor, Ektor), żeńskie Poliksena. Przez imiona bohaterów poematów z kręgu karolińskiego są motywowane obecne w staropolskich dokumentach imiona: Roland (także jako Rolant, Ruland, Rulant i Lorant, Lurand, Lurant, Rurant), Oliwier (jako Olwer, Olwir, Oliuirus), Ogier (jako Ojerz, Hojerz) i Raul (jako Raulus). Od bohaterów celtyckich legend o królu Artusie, Tristanie i rycerzach okrągłego stołu pochodzą imiona: Artusz (także Hartusz, Artusz), Parsifal (jako Parcyfat, Parcfat), Tristan (w postaci Tristram, Trestram) oraz żeńskie Izolda (w formie Isolde, Isoldis, Isalda). Kilka staropolskich imion ma przypuszczalnie związek motywacyjny z imionami głównych postaci epiki niemieckiej, w której obserwujemy pomieszanie wątków dawnych germańskich sag z wątkami o Burgundach i Teodoryku, królu Ostrogotów. Oto imiona i ich staropolskie adaptacje: Zygfryd (jako Zywrzyd, Zybrzyd, Zewrzyd, Zebrzyd, i inne), Gunter (jako Guncerz, Guncarz, Goncarz, Kuncerz), Teodoryk (jako Dytryk, Dzietrzyk, Dzietrzych, Wietrzych), Hildebrand (jako Hildebrandus, Hilbrandus, Helbrandus) (Malec 1990). Wymienione imiona mają też odpowiedniki w imionach nadanych w Polsce w XX wieku, według „Słownika imion współcześnie w Polsce używanych" ${ }^{1}$ :

1) Achiles 17 osób / Achilles 49, Ajaks 1, Hektor 17, Parys 35 / Paris 5, Poliksena 2 / Polikseni 11 / Poliksenia 2;

2) Roland 3643 / Rolland 3, ż. Rolanda 25 / Rolandia 2; Oliwer 231 / Oliwier 189, ż. Oliwera 2 / Oliwiera 4;

3) Artus 3 / Artur 164985, Izolda 510 / Isolda 2, Tristan 38 / Tristian 2 / Trystian 1.

Do „literackich” należą w szczególnym znaczeniu imiona utworzone przez autora dzieła literackiego. Z okresu średniowiecza imieniem takim jest mityczna Wanda, córka Kraka. Imię to pojawia się po raz pierwszy w Kronice Wincentego Kadłubka (z przełomu XII/XIII w.). Zostało ono utworzone, zdaniem M. Plezi, przez autora owej Kroniki w nawiązaniu do nazwy plemiennej Wandalów, które

1 Słownik imion współcześnie w Polsce używanych, wyd. K. Rymut, Kraków 1995. Słownik ten jest sporządzony na podstawie materiałów Rządowego Centrum Informatycznego PESEL według stanu banku danych z kwietnia 1994 r. Zawiera alfabetyczny wykaz imion polskich obywateli żyjących w $1994 \mathrm{r}$. oraz informacje o frekwencji danego imienia i chronologii jego nadawania w poszczególnych dziesięcioleciach XX wieku, począwszy od urodzonych przed r. 1920. 
to plemię germańskie niektórzy średniowieczni uczeni utożsamiali ze Słowianami, przodkami Polaków (Plezia 1995). Imię Wanda zostało włączone do imion w Polsce nadawanych w końcu XVIII w., przypomniane w utworach literackich na fali powrotu do źródeł i tradycji narodowej. Już w XIX w. stało się imieniem popularnym (Bystroń 1938), w XX w. nadano je 181157 razy. Są też współcześnie nadawane imiona stworzone przez polskich poetów romantycznych, jak imię tytułowej bohaterki poematu A. Mickiewicza Grażyna, nadane w XX w. 260973 razy, jak imiona z utworów J. Słowackiego Balladyna nadana 20 razy, Kordian 1061, imię tytułowego bohatera dramatu Z. Krasińskiego Irydion 6, i wiele innych.

Z literaturą są też związane imiona pochodzące od imion autorów dzieł literackich. W Polsce spotykane są np. imiona: Owidiusz 21 osób, żeńskie Owidia 3, od imienia sławnego poety rzymskiego, autora „Metamorfoz” (Publius Ovidius Naso); Wergiliusz 4 / Wergill 1 / Wirgiliusz 170, też formy żeńskie Wergilia 1 / Wirgila 1, Wirgilia 14 / Wirgiliana 1 / Wirgilla 1, od imienia wielkiego poety rzymskiego, autora "Eneidy” (Publius Vergilius Maro). „Ojciec Wirgiliusz” jest bohaterem tytułowym piosenki dziecięcej stanowiącej wstęp do dziecięcych zabaw:

Ojciec Wirgiliusz uczył dzieci swoje

A miał ich wszystkich sto dwadzieścia troje,

Hejże dzieci, hejże ha,

Róbcie to, co i ja (por. Kopaliński 1987, s. 782).

Termin „imię literackie” nie został dotąd zdefiniowany. Nie figuruje też w wydanej w r. 1983 słowiańskiej terminologii onomastycznej: „Osnowen sistem i terminologija na slovenskata onomastika", Skopje 1983.

Z punktu widzenia historii literatury i dzieła literackiego wszystkie imiona występujące w dziele literackim można nazwać imionami literackimi, ponieważ są użyte dla celów tego dzieła, nazywają osoby w mniejszym lub większym stopniu fikcyjne.

Nieco inaczej przedstawia się ten problem widziany od strony imion funkcjonujących w danym społeczeństwie jako imiona osób, nadawane w specjalnym obrzędzie, wybierane ze skarbca imion, zachowywanych w świadomości zbiorowej. Wybór imienia jest zawsze czymś motywowany. W polskiej tradycji można wyróżnić następujące motywacje:

1) przez imiona świętych,

2) przez imiona $z$ tradycji staropolskiej,

3) przez imiona z tradycji literackiej ('świeckich bohaterów dzieł literackich),

4) w czasach współczesnych trzeba jeszcze powiedzieć o imionach świeckich bo-

haterów innych (pozaliterackich) sztuk i imionach idoli kultury masowej.

W grę wchodzi również motywacja sytuacyjnie pierwszoplanowa ale genetycznie wtórna, uwzględniająca:

5) tradycję rodzinną (imiona po rodzicach, dziadkach, rodzicach chrzestnych), 6) względy estetyczne.

A zatem, jako ,imiona literackie" - w sferze antroponimii uzualnej - możnaby uznać imiona motywowane genetycznie przez imiona świeckich bohaterów dzieł literackich, w tym przede wszystkim imiona bohaterów utworzone przez au- 
torów tych dzieł i może niekiedy imiona twórców dzieł literackich, jak Owidiusz czy Wirgiliusz.

\section{Literatura}

Bystroń J. S., 1938, Księga imion w Polsce używanych, Warszawa.

Cieślikowa A., 1993, Nazwy własne w różnych gatunkach tekstów literackich, [w:] Onomastyka literacka, red. M. Biolik, Olsztyn 1993, s. 33-39.

Cieślikowa A., 1994, Imiona i nazwiska w polszczyźnie. Moda i użycie tekstowe, [w:] Polszczyzna a / i Polacy u schyłku XX wieku. Zbiór studiów, red. K. Handke, H. Dalewska-Greń, Warszawa, s. 185-198.

Grzenia J., 2002, Słownik imion, Warszawa.

Kopaliński W., 1996, Słownik mitów i tradycji kultury, Warszawa.

Malec M. , 1990, Onomastyczne sygnały obecności europejskiej kultury literackiej w średniowieczu polskim, [w:] Polszczyzna średniowieczna i renesansowa, Folia Linguistica 23, Łódź 1990, s. 95-102.

Malec M., 2001, Imię w polskiej antroponimii i kulturze, Kraków.

Malec M. , (2007), Stopnie otwartości systemu imion w Polsce, [w:] Nowe nazwy własne, nowe stanowiska metodologiczne (w druku).

Sł Słownik staropolskich nazw osobowych, red. W. Taszycki, t. I-VI 1965-1983, t. VII Suplement, oprac. pod kierunkiem M. Malec, 1984-1987, Wrocław-Warszawa-Kraków-Gdańsk.

\section{Dajanje ,literarnih" imen na Poljskem}

Povzetek

Literarno motivacijo pri dajanju imen je težko ugotoviti. Imena krožijo v literarnem prostranstvu, ki ne pozna ne zemljepisnih ne časovnih meja. Intertekstualnost otežuje razvozlavo, katero literarno delo spodbuja širjenje nekega imena kot uradnega. To se dogaja celo z imeni, ki so jih ustvarili pisatelji. Nekatera od njih dosegajo visoko pogostnost rabe, npr. Grażyna, druga ostajajo unikatna, npr. Lambro. Težko je ugotoviti, ali na pogostnost vplivajo občnoimenske konotacije imen ali značajske poteze literarnega junaka.

Tuja imena, ki izvirajo iz literarnih del, so prevzeta v poljščino v več pisnih različicah, npr. Beatricze.

Antroponimija različnih evropskih narodov ima - v zgodovinskem času-določene načelne skupne poteze. Te so: prevlada krstnih imen, povezana s pokristjanjenjem Evrope, ostanki ljudskega imenja in prisotnost imen, ki so motivacijsko povezana z imeni junakov splošno znanih evropskih literarnih del, začenši s klasično grško in rimsko literaturo prek vrhunskih del narodnih literatur iz različnih obdobij. V̌̌lanku je opozorjeno na razločevanje med literaturo verskega značaja 
- (Biblija, obredna besedila, življenjepisi svetnikov), ki je vir krščanskega imenja, in literaturo posvetnega značaja ter z njo povezano motivacijo literarnih imen. $V$

N nadaljevanju je izbranih nekaj motivov, povezanih z dajanjem 'literarnih' imen $\because \quad$ na Poljskem, na koncu pa je podan poskus formuliranja definicije 'literarnega' 저 imena.

Aleksandra Cieślikowa Instytut Języka Polskiego PAN, al. Mickiewicza 31, 31-120 Kraków aleksandrac@ijp-pan.krakow.pl

Maria Malec 


\title{
Povedkovo določilo v naravni skladnji slovenščine
}

\author{
Varja Cvetko Orešnik, Janez Orešnik (Ljubljana)
}

IZVLEČEK: Naravna skladnja je deduktivna teorija $v$ razvoju in veja teorije naravnosti. Sodbe o naravnosti so ubesedene v lestvicah naravnosti, ki sledijo iz osnovnih meril (ali "aksiomov"), naštetih v začetku sestavka. Napovedi teorije se izračunavajo $v$ t.i. izpeljavah, katerih glavni sestavini sta par lestvic naravnosti in pravila o ujemanju med soodnosnimi vrednostmi naravnosti.

V tem duhu se obravnava skladnja povedkovega določila, in sicer nekateri vidiki, ki zvečine niso samo slovenski. Povedkova določila se delijo na opisujoča in identificirajoča.

ABSTRACT: Natural Syntax is a developing deductive theory, a branch of Naturalness Theory. The naturalness judgements are couched in naturalness scales, which follow from the basic parameters (or "axioms") listed at the beginning of the paper. The predictions of the theory are calculated in the deductions, whose chief components are a pair of naturalness scales and the rules governing the alignment of corresponding naturalness values.

In this spirit the syntax of the subject complement is discussed, notably some of its features that are mostly not typically Slovenian. The subject complements are divided into descriptive and identifying ones.

Naravna skladnja je deduktivna jezikoslovna teorija (v razvoju), ki določa predpostavke, na podlagi katerih so neke (obliko)skladenjske razmere napovedljive - in tako na opisni ravnini razložene. Osnovna vrsta predpostavk so t.i. lestvice naravnosti in pravila povezovanja med soodnosnimi vrednostmi po dveh lestvic. (Obliko)skladenjske razmere so predstavljene v obliki med sabo primerljivih dvojnic. Naravna skladnja ne vsebuje nikakršne tvorbene sestavine.

Sledijo osnovna načela, s katerimi v okviru naravne skladnje določamo lestvice naravnosti. Na nekatera izmed njih se bova sklicevala v nadaljevanju:

(a) Načelo ugodnega za govorečega in ugodnega za ogovorjenega. Kar je ugodno za govorečega, je bolj naravno; govoreči je namreč središče sporazumevanja. Z lestvico: >nat (ugodno za govorečega, ugodno za ogovorjenega). Ta pogled na naravnost pozna jezikoslovje že dolgo (Havers 1931, 171), in sicer pod ime- 
noma težnja po gospodarnosti (to izkorišča predvsem govoreči) in težnja po natančnosti (ta godi predvsem ogovorjenemu).

(b) Načelo najmanjšega napora (Havers 1931, 171). Kar se bolj sklada s tem načelom, je govorečemu bolj naravno. Kar je za govorečega kognitivno preprosto, se zlahka tvori, zlahka prikliče iz spomina itd.

(c) Prototipičnost. Kar je bližje prototipu, je bolj naravno ogovorjenemu. Govorečemu je bližje neprototipično.

(č) Stopnja včlenjenosti v zgradbo. Kar je bolje včlenjeno v svojo zgradbo, je govorečemu bolj naravno.

(d) Pogostnost. Kar je v nekem jeziku bolj pogostno kot pojavnica, je govorečemu bolj naravno. Kar je za govorečega kognitivno preprostejše, se več rabi. (Toda obratno ne drži: kar je govorečemu naravno, ni nujno pogostno.)

(e) Majhen nasproti velikemu razredu. Raba (enote iz) majhnega razreda je govorečemu bolj naravna kot raba (enote iz) velikega razreda. Med tvorjenjem sporočila govoreči lažje izbira iz majhnih razredov kot iz velikih.

(f) Specializirana nasproti nespecializirani rabi. Če je na voljo specializiran način za izražanje neke kategorije, je specializirani način govorečemu zelo naraven za izražanje tiste kategorije. Denimo, da ima jezik povratne osebne zaimke. Slednji so specializirani za izražanje povratnosti (medtem ko drugi osebni zaimki niso specializirani za izražanje povratnosti, četudi jo morda pod določenimi pogoji izražajo) in njihova raba za izražanje povratnosti je govorečemu zelo naravna: >nat (+povratni, -povratni) / osebni zaimek za izražanje povratnosti.

(g) Govorečemu so naravni vsi poteki, le pri premikih velja: premik enote na levo je govorečemu bolj naraven od premika enote na desno.

(h) Sprejemljiva nasproti nesprejemljivi rabi. Kar je sprejemljivo, je govorečemu bolj naravno od nesprejemljivega. Bistveni razlog za sprejemljivost neke skladenjske zgradbe je ravno njena večja naravnost za govorečega v primerjavi s soodnosno nesprejemljivo zgradbo.

(i) Kar je bolj razširjeno po jezikih sveta, je govorečemu bolj naravno (tipološko načelo). Kar je za govorečega kognitivno bolj preprosto, se rabi v več jezikih.

Lestvica naravnosti se v najsplošnejši obliki glasi >nat (A, B), kjer sta A in B "vrednosti" lestvice. A se nanaša na ugodno za govorca, B pa na ugodno za ogovorjenega. Dovoljeni sta dve razširjeni lestvici, in sicer >nat $(A+B, B)$ in $>$ nat $(A, A$ $+\mathrm{B})$; razširjeni lestvici sta veljavni, kadar je veljavna soodnosna osnovna lestvica oblike $>$ nat $(\mathrm{A}+\mathrm{B})$.

Lestvice naravnosti se utemeljujejo z gornjimi načeli/merili naravnosti (v nadaljevanju: aksiomi). Navadno zadošča, da se neka lestvica utemelji z enim izmed aksiomov, pri čemer tisti aksiom podpira bodisi vrednost A bodisi vrednost B lestvice; nepodprta vrednost zavzame edino preostalo mesto v lestvici. Seveda se lestvica lahko podpre z več aksiomi. Morebitno nasprotje med aksiomi, s katerimi se podpre neka lestvica, se razreši z uporabo omejitev, ki veljajo za povezovanje aksiomov. Doslej je oblikovanih le malo takih omejitev, ni namreč veliko v tej zvezi merodajnega jezikovnega gradiva. 
Lestvice naravnosti so bistveni del t.i. izpeljav, v katerih izraža naravna skladnja svoje napovedi o razmerah v jezikovnem gradivu.

V vsaki izpeljavi igrajo pomembno vlogo pravila povezovanja. Ta pravila uravnavajo povezovanje soodnosnih vrednosti obeh lestvic, ki sta omenjeni v izpeljavi. Povezovanje more biti vzporedno ali križno. Recimo, da sta lestvici >nat $(\mathrm{A}, \mathrm{B})$ in $>$ nat $(\mathrm{C}, \breve{C})$. Vzporedno povezovanje poveže vrednost $\mathrm{A} z$ vrednostjo $\mathrm{C}$ in vrednost B z vrednostjo Č. Križno povezovanje pa poveže A s Č in B s C.

Pomembno vprašanje je, kdaj je povezovanje vzporedno in kdaj križno. Vzporedno povezovanje je privzeta vrednost (t.i. default). Izkušnja ob delu z mnogimi zgledi kaže, da križno povezovanje nastopi, kadar je jezikovno gradivo izpeljave omejeno na neko t.i. skrajno nenaravno okolje. Slednje je definirano kot vrednost B lestvice >nat (A, B), kadar se lestvica ne da podaljšati $v$ desno, tj. kadar ni nobene take vrednosti, ki bi bila še manj naravna od vrednosti B.

Sedanja vednost o naravni skladnji ne zmore razložiti, v čem je smisel dveh vrst povezovanja in zakaj sta razvrščeni, kot sta.

Sestavek je posvečen povedkovemu določilu. Ta stavčni člen slovenščine in najbrž kar vseh jezikov nahajamo v stavkih, v katerih je glavna glagolska oblika primerek t.i. vezi ali kopule. Najbolj navadna vez je BITI, npr. v stavku Janez je len. Preostala dela takega stavka sta osebek (v tem zgledu Janez) in povedkovo določilo (tukaj len). Osebek se v slovenščini kot znano lahko izpusti, npr. v stavku len je. Osebek in povedkovo določilo sta po zgradbi dostikrat oba samostalniška zveza, in $\mathrm{v}$ takih primerih je kdaj pa kdaj težko razpoznati, katera samostalniška zveza je osebek in katera povedkovo določilo. Npr. mesto, o katerem govorimo, so Brežice nasproti Brežice so mesto, o katerem govorimo. V najinih zgledih je prva samostalniška zveza vedno mišljena kot osebek, druga kot povedkovo določilo. Na tem mestu navajava samo zgled stavka, glede katerega ni nikakega dvoma, kaj je v njem osebek in kaj povedkovo določilo: kdo je bila ona. Vprašalni zaimek kdo je v stavku neizpodbitno osebek, torej je ona zanesljivo povedkovo določilo. Mimogrede ta zgled ponazarja ujemanje glagolske vezi s povedkovim določilom namesto z osebkom: je bila. Táko ujemanje se opaža izključno pri vezi BITI in nanj je že opozorila (tudi z zgledi) slovenska slovnica (SS00 609, 611, 613), le da pojav omejuje na needninska povedkova določila; taki omejitvi oporeka pravkar navedeni zgled. Ločeno omenja SS00 zglede z edninskim osebkom to, npr. to je bila soseda. A enako je glede ujemanja v najinem zgledu njegova zadnja žrtev je bil naš sosed.

Po pomenu se povedkova določila delijo na opisujoča in na identificirajoča. Opisujoče je povedkovo določilo, kadar nanosnika osebka opisuje, npr. v stavku Brežice so lepo mesto, kjer je nanosnik, tj. kraj Brežice, opisan kot lep. Identificirajoče je povedkovo določilo, kadar osebku, vzetemu kot spremenljivka, priredi vrednost, ki je izražena v povedkovem določilu. Npr. v stavku to lepo mesto so Brežice je spremenljivki to lepo mesto prirejena vrednost Brežice. Delitev na opisujoča in identificirajoča povedkova določila nam pomaga razmejiti ujemanje z osebkom in ujemanje s povedkovim določilom, kadar je glagolska vez v ednini. Ujemanje s povedkovim določilom nastopi, kadar je povedkovo določilo identificirajoče (in seveda samostalniška zveza). Tako je že v zgledu njegova zadnja žrtev je bil naš 
sosed. Nekateri zgledi so najbrž dvoumni: njegova zadnja žrtev je bil(a) moj brat. Če imam več bratov, povedkovo določilo žrtve ne identificira, temveč samo opiše, v kakšnem sorodstvu je žrtev z menoj; če pa imam enega edinega brata, povedkovo določilo mojega brata identificira. Torej v prvem primeru pričakujemo ujemanje $\mathrm{z}$ osebkom, v drugem s povedkovim določilom. Bolj jasen zgled bi bil njegova zadnja žrtev je bila eden izmed mojih bratov (povedkovo določilo opisujoče) nasproti njegova zadnja žrtev je bil moj edini brat (povedkovo določilo identificirajoče).

Zgledi, ki jih navajava, so iz slovenščine, vendar to besedilo ni slovenistično. V zgledih ni ničesar tipično slovenskega, marveč bo govor o slovničnih lastnostih, ki so razširjene po številnih jezikih, nekatere morda po vseh jezikih. (Soodnosni podatki angleščine: Huddleston \& Pullum 2002, 270-71 in op. 40.) Besedilo je torej splošnojezikoslovne narave. Izjema je pravkar na kratko že obravnavano ujemanje. Potenciala za ujemanje je po jezikih različno veliko, zato je najina rešitev ujemanja v slovenščini načeloma slovenistične narave.

Najini ključni zgledi ujemanja v ednini so naslednji (razlaga simbolov: $+=$ povedkovo določilo nanosnika osebka OPISUJE; $++=$ povedkovo določilo nanosnika osebka IDENTIFICIRA):

a) +gospodična $X$ je bila minister za čokolado; ++minister za čokolado je bila gospodična $\mathrm{X}$;

b) +ta genij babji je bil ministrica za čokolado; ++ministrica za čokolado je bil ta genij babji;

c) +Kosovo naj bi bilo pokrajina; ++ta pokrajina naj bi bilo Kosovo;

č) +Skopje je bilo nekoč vas; ++ta vas je bilo Skopje;

d) +naš kraj je bil gadje gnezdo; ++to gadje gnezdo je bil naš kraj;

e) +Ljubljana je bila majhno gnezdo; ++to majhno gnezdo je bila Ljubljana;

f) +Micka je bila drobno bitje; ++to bitje je bila Micka.

Podčrtano podaja najino izbiro. Poskusne osebe (slušatelji splošnega jezikoslovja) so namesto podčrtanega $v$ nekaterih primerih navajale še drugačne možnosti. Zadrega je predvsem zaradi parametra, ki ga pri informantih nisva mogla nadzorovati: namreč zgledi so brez sobesedila, zato se ne da vedeti, kaj je bilo komu, in v katerem zgledu, osebek in povedkovo določilo. S tem je povezano tudi vsakokratno tolmačenje pomena.

Najina rešitev ujemanja $\mathrm{v}$ ednini je torej samo začetni predlog o tej tvarini. Potrebne bi bile raziskave govorjenega jezika, ki bi ta predlog potrdile ali še raje ovrgle. Predvsem slovenistika mora odločiti, ali sva ujemanje s povedkovim določilom zajela pravilno ali ne. Za potrebe tega besedila mora najino ugibanje zadoščati. Mimogrede vidimo, da se slovenistika in splošno jezikoslovje lahko plodno dopolnjujeta.

Jedro naravne skladnje in tega besedila tvorijo t.i. izpeljave, zato kratko pojasnilo o njih. Izpeljave so preprost formalni aparat domače izdelave, $v$ katerem se določajo predpostavke, iz katerih se (še vedno v okviru iste izpeljave) izračunajo napovedi o razmerah $\mathrm{v}$ jezikovnem gradivu, ki je (skopo) predstavljeno na začetku 
take izpeljave. Povedano malo drugače: v izpeljavi so navedene predpostavke, katere moramo sprejeti, da postanejo razmere v nekem jezikovnem gradivu napovedljive. Predpostavke so utemeljene s t.i. aksiomi, naštetimi v točkah (a-i) na začetku besedila. Ko bo na vrsti prva izpeljava, ji bo sledil komentar o nekaterih podrobnostih, ki veljajo za vse izpeljave in ki pozneje zaradi gospodarjenja s prostorom ne bodo več ponovljene.

Zaradi lestvice naravnosti >nat (osebek, povedkovo določilo), ki se ne da podaljšati v desno in ki je utemeljena s tem, da je osebek kakor znano najbolj naravni stavčni člen, tvori povedkovo določilo t.i. skrajno nenaravno okolje. Vse izpeljave, ki so gradivsko omejene na povedkovo določilo, zahtevajo t.i. križno povezovanje soodnosnih vrednosti lestvic. V tem članku bo izkoriščeno še eno skrajno nenaravno okolje, namreč tisto, ki ga definira lestvica >nat $(+,-)$ / nanosnik osebka: okolja, $\mathrm{v}$ jezikovnem gradivu katerih osebek nima nanosnika, so skrajno nenaravna. Več o tem v izpeljavi (10). Če zajame kaka izpeljava v nadaljevanju kaj drugega razen povedkovega določila ali osebka brez nanosnika, je povezovanje soodnosnih vrednosti lestvic defaultno, torej vzporedno. Oboje, vzporedno in križno povezovanje, bo ponazorjeno sproti.

\section{Sledi prva izpeljava:}

(1) Slovenščina. Stavki z vezjo BITI, osebek in povedkovo določilo sta samostalniška zveza. Če sta oba stavčna člena v ednini, je ujemanje vezi po merilih pomena, namreč odvisno je od tega, ali povedkovo določilo opisuje ali identificira. Če je en stavčni člen v ednini, drugi v neednini, pa se ujemanje ne zgleduje po ednini, temveč poteka po merilih skladnje, namreč vez se brez izjeme ujema s samostalniško zvezo v neednini.

Dvojnici: ujemanje vezi po pomenu in po skladnji.

\section{Domneve naravne skladnje:}

1.1. >nat (po pomenu, po skladnji) / ujemanje vezi

Tj., ujemanje vezi po pomenu je bolj naravno kot ujemanje vezi po skladnji. - Ogovorjeni lažje dekodira ujemanje vezi po skladnji, zato mora biti táko ujemanje omenjeno na mestu B v lestvici. Po načelu ugodnega za govorečega in ugodnega za ogovorjenega, točka (a) v seznamu aksiomov.

1.2. >nat (ednina, neednina) / samostalniška zveza

Tj., samostalniška zveza v ednini je bolj naravna kot samostalniška zveza v neednini. - Ednina je po jezikih sveta bolj pogosto kodirana ničto kot neednina. Po načelu najmanjšega napora, točka (b) v seznamu aksiomov.

Posebni primer od 1.2:

1.2.1. >nat (samo ednina, ednina \& neednina) / samostalniška zveza

Tj., razmere, v katerih so samostalniške zveze samo v ednini, so bolj naravne kot razmere, $v$ katerih so samostalniške zveze $\mathrm{v}$ ednini in neednini. - Lestvica je dovoljene razširjene oblike >nat $(\mathrm{A}, \mathrm{A}+\mathrm{B})$ in je samodejno utemeljena, ker je že utemeljena soodnosna osnovna lestvica 1.2. 


\section{Pravila vzporednega povezovanja:}

2.1. vrednost A teži po povezovanju $\mathrm{z}$ vrednostjo $\mathrm{C}$,

2.2. vrednost B teži po povezovanju z vrednostjo Č.

\section{Posledice:}

Če jezik loči (v okviru stavkov z osebkom in povedkovim določilom, ki sta oba samostalniška zveza) med samostalniškimi zvezami, ki so samo v ednini, in samostalniškimi zvezami, ki so tudi v neednini, tako da zahteva ena vrsta samostalniških zvez ujemanje vezi po pomenu, druga vrsta samostalniških zvez pa ujemanje vezi po skladnji, tedaj težijo samostalniške zveze, ki so samo v ednini, da bi bilo ujemanje vezi po pomenu, in samostalniške zveze, ki so tudi v neednini, težijo, da bi bilo ujemanje vezi po skladnji. Q.E.D. (Ne pričakujemo obratnih razmer.)

\section{Sledi nekaj komentarja k tej izpeljavi:}

a) $\mathrm{Na}$ začetku so kratko predstavljene slovnične razmere, ki naj bi jih izpeljava naredila napovedljive.

b) V odstavku Dvojnici sta zaradi večje preglednosti izdvojena ključna pojma ali ključni enoti, okrog katerih se bodo sukale napovedi izpeljave.

c) $\mathrm{V}$ točkah 1 in 2 izpeljave so naštete predpostavke, v katere moramo verjeti, da bi lahko izrekli napovedi. Predpostavke v točki 1 imajo obliko lestvic naravnosti, predpostavke v točki 2 so preprost algoritem, s katerim povezujemo soodnosne vrednosti lestvic naravnosti.

č) Pod 1.1 je lestvica naravnosti najprej navedena v obliki obrazca (zaradi preglednosti), nato še z besedami. Za pomišljajem sledi utemeljitev lestvice. Bistveni del utemeljitve je sklicevanje na katerega izmed t.i. aksiomov.

d) Zgradba točke 1.2 je enaka kot v točki 1.1, le da se izjemoma iz osnovne lestvice 1.2 razvije posebni primer te lestvice 1.2.1 na način, ki je pod 1.2.1 tudi razložen. Pri izračunavanju napovedi se od točke 1.2 vzame v poštev samo posebni primer 1.2.1.

e) Pod točko 2 so navedena pravila t.i. vzporednega povezovanja vrednosti lestvic. Vrednost A je tu "ujemanje vezi po pomenu" iz lestvice 1.1, in ta vrednost se poveže z vrednostjo C, ki je "samo ednina" iz lestvice 1.2.1. Vrednost B je "ujemanje vezi po skladnji" iz lestvice 1.1 , in ta vrednost se poveže z vrednostjo $\breve{C}$, ki je "ednina in neednina" iz lestvice 1.2.1. - Pravila vzporednega povezovanja so defaultna. Pozneje bomo spoznali še pravila križnega povezovanja, ki se rabijo, kadar nastopijo posebne razmere.

f) Ko je povezovanje vrednosti lestvic izčrpano, se na podlagi dobljenih povezav izrečejo v točki 3 napovedi ali posledice.

g) V napovedih je najprej če-stavek, v katerem so v bistvu ponovljene predpostavke izpeljave. Sledijo prave napovedi, in sicer v glavnem stavku, ki se začne $\mathrm{z}$ besedo tedaj. Če napovedi res napovejo razmere v obravnavanem jezikovnem gradivu, štejemo izpeljavo za uspešno. Napovedi trdijo, da obravnavane jezikovne razmere sploh ne morejo biti drugačne, kot dejansko so. Končni smisel takih napovedi in naravne skladnje sploh je v oblikovanju sklepa, da jezikovne razmere ne morejo biti drugačne, kot so. 


\section{Nadaljujeva z naslednjo izpeljavo:}

(2) Slovenščina. Stavki z vezjo BITI, osebek in povedkovo določilo sta samostalniška zveza. Če sta oba stavčna člena v ednini, je ujemanje vezi odvisno od tega, ali povedkovo določilo opisuje ali identificira. V prvem primeru je ujemanje z osebkom; v drugem primeru je ujemanje s povedkovim določilom. Npr. Ljubljana je bila že takrat mesto; to mesto je bila Ljubljana. - Ta izpeljava se torej dotika najinega uvodnega predloga o ujemanju glagolske vezi v ednini.

Dvojnici: povedkovo določilo v ednini, ki opisuje ali identificira. - Izpeljava poteka v skrajno nenaravnem okolju "povedkovo določilo".

\section{Domneve naravne skladnje:}

\section{1. >nat (identifikacija, opis)}

Tj., identifikacija je bolj naravna od opisa. - Tisto povedkovo določilo, ki prispeva opis, je sistematično razširljivo, npr. to mesto je lepo se da raztegniti v to mesto je nekaj lepega ali v to mesto je lepo mesto. (Pomen se pri tem ne spremeni.) Torej mora biti opis omenjen na mestu B v lestvici po načelu najmanjšega napora, točka (b) v seznamu aksiomov.

1.2. >nat (ujemanje z osebkom, ujemanje s povedkovim določilom)

Tj., ujemanje z osebkom je bolj naravno kot ujemanje s povedkovim določilom. - Ujemanja z osebkom je v slovenščini bistveno več kot ujemanja s povedkovim določilom, saj je ujemanje s povedkovim določilom možno samo ob glagolu BITI, ujemanje z osebkom pa ob vseh glagolih (tudi deloma ob BITI). Po načelu pogostnosti, točka (d) v seznamu aksiomov.

\section{Pravila križnega povezovanja:}

2.1. vrednost A teži po povezovanju z vrednostjo Č,

2.2. vrednost B teži po povezovanju $\mathrm{z}$ vrednostjo $\mathrm{C}$.

3. Posledice:

Če jezik loči (v okviru povedkovih določil, ki so samostalniška zveza) med povedkovimi določili, ki opisujejo, in povedkovimi določili, ki identificirajo, tako da se vez v enem primeru ujema $z$ osebkom, v drugem pa s povedkovim določilom, tedaj teži povedkovo določilo, ki opisuje, da bi se vez ujemala z osebkom, in povedkovo določilo, ki identificira, teži, da bi se vez ujemala s povedkovim določilom. Q.E.D. (Ne pričakujemo obratnih razmer.)

(3) Slovenščina. Stavki z vezjo BITI, osebek in povedkovo določilo sta samostalniška zveza. Če je povedkovo določilo v neednini, se vez ujema z njim (SS00 609). Npr. Ljubljana niso samo hiše (Ljubljana nista samo ti dve hiši), te hiše še niso Ljubljana (ti hiši še nista Ljubljana).

Dvojnici: povedkovo določilo v ednini in neednini. - Izpeljava poteka v skrajno nenaravnem okolju "povedkovo določilo".

\section{Domneve naravne skladnje:}

1.1. >nat (ednina, neednina) / povedkovo določilo

Tj., v okviru povedkovega določila je ednina bolj naravna od neednine. - Ednina je po jezikih bolj pogosto kot neednina kodirana ničto. Po načelu najmanjšega napora, točka (b) v seznamu aksiomov. 
1.2. >nat $(+,-)$ / ujemanje vezi s povedkovim določilom

Tj., ujemanje vezi je bolj naravno kot neujemanje. - Ujemanje je potek, vsak potek je naraven po aksiomu o potekih, točka $(\mathrm{g}) \mathrm{v}$ seznamu aksiomov.

\section{Pravila križnega povezovanja:}

2.1. vrednost A teži po povezovanju z vrednostjo Č,

2.2. vrednost B teži po povezovanju z vrednostjo C.

3. Posledice:

Če jezik loči (v okviru povedkovih določil, ki so samostalniška zveza) med ednino in neednino, tako da poteka $\mathrm{v}$ enem primeru ujemanje vezi s povedkovim določilom, v drugem primeru pa táko ujemanje ne poteka, tedaj teži ednina povedkovega določila, da ujemanje vezi z njim ne bi potekalo, in neednina povedkovega določila teži, da bi ujemanje vezi z njim potekalo. Q.E.D. (Ne pričakujemo obratnih razmer.)

(4) Slovenščina. Stavki z vezjo, osebek je samostalniška zveza. Povedkova določila ob glagolskih vezeh razen ob BITI domala vedno opisujejo (NE identificirajo). Npr. ta oseba je postala smučarski skakalec. Nasprotno povedkova določila ob BITI bodisi opisujejo bodisi identificirajo (včasih odvisno, včasih neodvisno od vrste ujemanja vezi). Npr. ta oseba je bila eden izmed smučarskih skakalcev; ta kreatura je bil Janez.

Dvojnici: BITI in druge glagolske vezi. - Izpeljava NE poteka v skrajno nenaravnem okolju "povedkovo določilo", saj zajema tudi vezi.

\section{Domneve naravne skladnje:}

1.1. >nat (BITI, druge vezi)

Tj., vez BITI je bolj naravna kot druge vezi. - Vez BITI predstavlja majhen razred, druge vezi velik razred; torej je vez BITI naravna po načelu majhnega nasproti velikemu razredu, točka (e) v seznamu aksiomov. Glagol BITI je najpogostnejši glagol slovenščine, torej je naraven po načelu pogostnosti, točka (d) v seznamu aksiomov. Glagol BITI je po jezikih najbolj razširjeni glagol, torej je naraven po tipološkem načelu, točka (i) v seznamu aksiomov.

1.2. >nat (identifikacija, opis)

Tj., identifikacija je bolj naravna od opisa. - Tisto povedkovo določilo, ki prispeva opis, je sistematično razširljivo, npr. to mesto je lepo se da raztegniti v to mesto je nekaj lepega ali v to mesto je lepo mesto. (Pomen se pri tem ne spremeni.) Torej mora biti opis omenjen na mestu B v lestvici po načelu najmanjšega napora, točka (b) v seznamu aksiomov.

Posebni primer od 1.2:

1.2.1. >nat (identifikacija \& opis, samo opis)

Tj., razmere, v katerih sta možna identifikacija ali opis, so bolj naravne kot razmere, $v$ katerih je možen samo opis. - Lestvica je dovoljene razširjene oblike $>$ nat $(\mathrm{A}+\mathrm{B}, \mathrm{B})$ in je samodejno utemeljena, ker je že utemeljena soodnosna osnovna lestvica 1.2.

\section{Pravila vzporednega povezovanja:}

2.1. vrednost $A$ teži po povezovanju $\mathrm{z}$ vrednostjo $\mathrm{C}$, 


\section{Posledice:}

Če jezik loči med BITI in drugimi glagolskimi vezmi, tako da povedkovo določilo ob enih vezeh samo opisuje, ob drugih vezeh pa bodisi opisuje bodisi identificira, tedaj teži povedkovo določilo ob BITI, da bi bodisi opisovalo bodisi identificiralo, in povedkovo določilo ob drugih vezeh teži, da bi samo opisovalo. Q.E.D. (Ne pričakujemo obratnih razmer.)

(5) Slovenščina. Stavki z vezjo BITI, povedkovo določilo je samostalniška zveza. Povedkovo določilo, ki opisuje (ne identificira), sámo nima nanosnika, npr. Janez je nekak odvetnik, osebek ga pa ima.

Dvojnici: osebek in povedkovo določilo. - Izpeljava NE poteka v skrajno nenaravnem okolju "povedkovo določilo", saj zajema tudi osebek.

\section{Domneve naravne skladnje:}

1.1. >nat (osebek, povedkovo določilo)

Tj., osebek je bolj naraven od povedkovega določila. - Osebek je najbolj naravni stavčni člen. Osebek je tudi osnovni stavčni člen govorečega, zato naraven po načelu ugodnega za govorečega in ugodnega za ogovorjenega, točka (a) v seznamu aksiomov.

\section{2. >nat $(+,-)$ / nanosnik samostalniške zveze}

Tj., samostalniška zveza, ki ji je prirejen nanosnik, je bolj naravna kot samostalniška zveza, ki ji ni prirejen nanosnik. - Večina samostalniških zvez dopušča nanosnika in ga pogosto tudi res ima. Za večino samostalniških zvez je merodajna delitev na +/-živo. Da bi se v nekem primeru dalo izbrati med tema možnostima, moramo poznati nanosnika samostalniške zveze. Tako je pes bodisi +živo bodisi -živo (slednje npr. iz porcelana) in na tej podlagi znamo oceniti primernost ali neprimernost stavka pes si je zlomil nogo. Zato samostalniške zveze navadno imajo nanosnika in so samostalniške zveze $\mathrm{z}$ nanosnikom naravne po načelu pogostnosti, točka (d) v seznamu aksiomov.

\section{Pravila vzporednega povezovanja:}

2.1. vrednost A teži po povezovanju $z$ vrednostjo $C$,

2.2. vrednost B teži po povezovanju z vrednostjo $\breve{C}$.

3. Posledice:

Če jezik loči med osebki in povedkovimi določili (pri čemer slednji opisujejo), tako da en stavčni člen ima nanosnika, drugi pa ne, tedaj teži osebek, da bi imel nanosnika, in povedkovo določilo teži, da ne bi imelo nanosnika. Q.E.D. (Ne pričakujemo obratnih razmer.)

(6) Slovenščina. Stavki z vezjo BITI, povedkovo določilo je samostalniška zveza. Povedkovo določilo, ki opisuje (ne identificira), ne more biti osebni zaimek.

Dvojnici: povedkovo določilo, ki opisuje, kot osebni zaimek in kot drugačna samostalniška zveza. - Izpeljava poteka v skrajno nenaravnem okolju "povedkovo določilo".

\section{Domneve naravne skladnje:}

1.1. >nat (osebni zaimek, drugo) / samostalniška zveza

Tj., osebni zaimek je bolj naraven od drugih samostalniških zvez. - Oseb- 
$4 \quad$ ni zaimki so majhen razred, druge samostalniške zveze so velik razred. Zato so osebni zaimki naravni po načelu o majhnem nasproti velikemu razredu, točka (e) $\mathrm{v}$ seznamu aksiomov.

1.2. $>$ nat $(+,-)$ / sprejemljivo

Tj., sprejemljivo je bolj naravno od nesprejemljivega. - To je kar načelo sprejemljivosti, točka (h) v seznamu aksiomov.

\section{Pravila križnega povezovanja:}

2.1. vrednost A teži po povezovanju z vrednostjo $\check{C}$,

2.2. vrednost B teži po povezovanju $\mathrm{z}$ vrednostjo $\mathrm{C}$.

\section{Posledice:}

Če jezik loči, v okviru tistih povedkovih določil, ki opisujejo, med osebnim zaimkom in "drugo" samostalniško zvezo, tako da je ena vrsta samostalniške zveze sprejemljiva, druga pa nesprejemljiva, tedaj teži osebni zaimek, da ne bi bil sprejemljiv, in "druga" samostalniška zveza teži, da bi bila sprejemljiva. Q.E.D. (Ne pričakujemo obratnih razmer.)

(7) Slovenščina. Stavki z vezjo BITI. Kadar povedkovo določilo identificira, je skladenjsko lahko ubesedeno s stavkom, npr. vprašanje je, ali bo preživel. Kadar povedkovo določilo opisuje, skladenjsko ne more biti ubesedeno s stavkom, saj slednji ne more izražati lastnosti (nanosnika osebka). Druge skladenjske možnosti so pri obeh vrstah povedkovega določila zvečine enake.

Dvojnici: identifikacija in opis v povedkovem določilu. - Izpeljava poteka $\mathrm{v}$ skrajno nenaravnem okolju "povedkovo določilo".

\section{Domneve naravne skladnje:}

1.1. >nat (samostalniška zveza, stavek) / povedkovo določilo

Tj., samostalniška zveza je bolj naravna kot stavek. - Ker je samostalniška zveza zgradbeno preprostejša kot stavek, je bolj naravna po načelu najmanjšega napora, točka (b) v seznamu aksiomov.

Posebni primer od 1.1:

1.1.1. >nat (samo samostalniška zveza, samostalniška zveza \& stavek) / povedkovo določilo

Tj., razmere, v katerih se rabi samo samostalniška zveza, so bolj naravne kot razmere, v katerih se rabi tako samostalniška zveza kot stavek. - Lestvica je dovoljene razširjene oblike >nat $(\mathrm{A}, \mathrm{A}+\mathrm{B})$ in je samodejno utemeljena, ker je že utemeljena soodnosna osnovna lestvica 1.1 .

1.2. >nat (identifikacija, opis)

Tj., identifikacija je bolj naravna od opisa. - Tisto povedkovo določilo, ki prispeva opis, je sistematično razširljivo, npr. to mesto je lepo se da raztegniti v to mesto je nekaj lepega ali v to mesto je lepo mesto. (Pomen se pri tem ne spremeni.) Torej mora biti opis omenjen na mestu B lestvice po načelu najmanjšega napora, točka (b) v seznamu aksiomov.

\section{Pravila križnega povezovanja:}

2.1. vrednost A teži po povezovanju z vrednostjo Č,

2.2. vrednost $\mathrm{B}$ teži po povezovanju $\mathrm{z}$ vrednostjo $\mathrm{C}$. 


\section{Posledice:}

Če jezik loči v okviru povedkovih določil med tistimi, ki identificirajo, in tistimi, ki opisujejo, tako da so ena povedkova določila samostalniška zveza, druga pa samostalniška zveza ali stavek, tedaj težijo povedkova določila, ki identificirajo, da bi bila samostalniška zveza ali stavek, in povedkova določila, ki opisujejo, težijo, da bi bila samostalniška zveza. Q.E.D. (Ne pričakujemo obratnih razmer.)

(8) Slovenščina. Stavki z vezjo BITI. Če opravlja povedkovo določilo identifikacijo in če je osebek določni, namiguje povedkovo določilo na izčrpnost v njem navedenega, npr. tista, ki ju je videl, sta bila Janez in Micka 'tista, ki ju je videl, sta bila samo Janez in Micka in nihče drug'. Če pa je osebek nedoločni, takih namigov ni, npr. možen primer tega je bil njegov nenadni obisk NE pomeni 'možen primer tega je bil samo njegov nenadni obisk in nič drugega'.

Dvojnici: določni in nedoločni osebek ob povedkovem določilu, ki opravlja identifikacijo. - Izpeljava NE poteka v okviru skrajno nenaravnega okolja "povedkovo določilo", saj zajema tudi osebek.

\section{Domneve naravne skladnje:}

1.1. >nat $(+,-)$ / določni osebek

Tj., določni osebek je bolj naraven od nedoločnega. - V jezikih, ki izražajo (ne)določnost s členom, je pri osebku določnega člena precej več kot nedoločnega, npr. v angleščini štirikrat več (Biber in dr. 1999, 269). Torej je določni osebek bolj naraven, in sicer po načelu pogostnosti, točka (d) v seznamu aksiomov.

1.2. >nat $(+,-)$ / 'izčrpnost'

Tj., izražanje izčrpnosti je bolj naravno kot neizražanje izčrpnosti. - Ogovorjeni lažje dekodira pomen, ki ni dodatno obremenjen še z 'izčrpnostjo', zato mora odsotnost takega pomena biti omenjena na mestu B lestvice. Po načelu ugodnega za govorečega in ugodnega za ogovorjenega, točka (a) v seznamu aksiomov.

\section{Pravila vzporednega povezovanja:}

2.1. vrednost A teži po povezovanju $\mathrm{z}$ vrednostjo $\mathrm{C}$,

2.2. vrednost B teži po povezovanju z vrednostjo Č.

3. Posledice:

Če jezik loči (v okviru povedkovega določila, ki identificira) med določnim in nedoločnim osebkom, tako da ena vrsta osebka namiguje na izčrpnost v povedkovem določilu, druga vrsta osebka pa ne, tedaj teži določni osebek, da bi namigoval na izčrpnost v povedkovem določilu, nedoločni osebek pa teži, da ne bi namigoval na kaj takega. Q.E.D. (Ne pričakujemo obratnih razmer.)

(9) Slovenščina. Stavki z vezjo BITI. Če opravlja povedkovo določilo identifikacijo in če je osebek določni, namiguje povedkovo določilo na izčrpnost v njem navedenega, npr. tisti, ki jih je videl, so bili Micka, Janez in Tone 'tisti, ki jih je videl, so bili samo Micka, Janez in Tone in nihče drug'. Vendar sopomen izčrpnosti izgine, če se v stavek vloži prislovno določilo predvsem, v prvi vrsti, v glavnem ipd. Npr. tisti, ki jih je videl, so bili predvsem Micka, Janez in Tone. Ni več pomena 'tisti, ki jih je videl, so bili samo Micka, Janez in Tone in nihče drug'.

Dvojnici: navzočnost in odsotnost prislovnih določil kot predvsem ob poved- 
kovih določilih z določnim osebkom, ki opravljajo identifikacijo. - Izpeljava NE poteka v skrajno nenaravnem okolju "povedkovo določilo", saj zajema tudi prislovna določila kot predvsem.

\section{Domneve naravne skladnje:}

1.1. >nat $(-,+)$ / prislovno določilo predvsem ipd.

Tj., odsotnost prislovnega določila predvsem ipd. je bolj naravna kot njegova navzočnost. - Po načelu najmanjšega napora, točka (b) v seznamu aksiomov.

1.2. >nat $(+,-) /$ 'izčrpnost'

Tj., izražanje izčrpnosti je bolj naravno kot neizražanje izčrpnosti. - Ogovorjeni lažje dekodira pomen, ki ni obremenjen še z 'izčrpnostjo', zato mora odsotnost takega pomena biti omenjena na mestu B lestvice. Po načelu ugodnega za govorečega in ugodnega za ogovorjenega, točka (a) v seznamu aksiomov.

\section{Pravila vzporednega povezovanja:}

2.1. vrednost $A$ teži po povezovanju $\mathrm{z}$ vrednostjo $\mathrm{C}$,

2.2. vrednost B teži po povezovanju z vrednostjo C̆.

\section{Posledice:}

Če jezik loči v okviru povedkovega določila, ki identificira (pri čemer je osebek določni), med navzočnostjo in odsotnostjo prislovnih določil kot predvsem, tako da je v enem primeru podana 'izčrpnost', v drugem pa ne, tedaj teži navzočnost prislovnih določil kot predvsem, da jih ne bi spremljala 'izčrpnost', in odsotnost prislovnih določil kot predvsem teži, da bi jih spremljala 'izčrpnost'. Q.E.D. (Ne pričakujemo obratnih razmer.)

(10) Slovenščina. Stavki z vezjo BITI. Če opravlja povedkovo določilo identifikacijo, osebek nima nanosnika, npr. kar mi je všeč pri Micki, so njeni lasje; osebek kar mi je všeč pri Micki nima nanosnika.

Dvojnici: osebek z nanosnikom in brez njega ob povedkovem določilu, ki opravlja identifikacijo. - Izpeljava NE poteka v okviru skrajno nenaravnega okolja "povedkovo določilo", saj je zajet osebek, pač pa poteka v okviru skrajno nenaravnega okolja "osebek brez nanosnika" (to skrajno nenaravno okolje je definirano $\mathrm{v}$ lestvici 1.1 tu spodaj).

\section{Domneve naravne skladnje:}

\section{1. >nat $(+,-)$ / nanosnik osebka}

Tj., osebek z nanosnikom je bolj naraven kot osebek brez nanosnika. - Osebek je največkrat +človeško (Mayerthaler in dr. 1998, 344). A da bi mogli osebek določiti kot +človeško, moramo poznati njegovega nanosnika. (Šele iz vednosti o nanosniku se poučimo, ali je mislec v stavku mislec je $v$ sobi človek ali kip, in na tej podlagi ocenjujemo primernost ali neprimernost nadaljnjega stavka mislec je dvignil glavo.) Zato ima osebek pogosto nanosnika in nanosnik osebka je naraven po načelu pogostnosti, točka (d) v seznamu aksiomov. Podatek, da ima osebek navadno ali celo najpogosteje kakega nanosnika, je omenjan tudi v slovnicah, npr. za švedščino Teleman in dr. 4, 1999, 72.

1.2. >nat $(+,-)$ / sprejemljivo

Tj., sprejemljivo je bolj naravno od nesprejemljivega. - To je kar načelo sprejemljivosti, točka (h) v seznamu aksiomov. 


\section{Pravila križnega povezovanja:}

2.1. vrednost A teži po povezovanju z vrednostjo Č,

2.2. vrednost B teži po povezovanju z vrednostjo C.

3. Posledice:

Če jezik loči ob povedkovem določilu, ki opravlja identifikacijo, med osebkom z nanosnikom in brez njega, tako da je eden sprejemljiv, drugi pa ne, tedaj teži osebek z nanosnikom, da ne bi bil sprejemljiv, in osebek brez nanosnika teži, da bi bil sprejemljiv. Q.E.D. (Ne pričakujemo obratnih razmer.)

4. Opomba. V naših dosedanjih delih o naravni skladnji je obveljalo stališče, da se lestvica, s katero se določi morebitno skrajno nenaravno okolje izpeljave (taki lestvici smo rekli "tretja lestvica", prim. Dobrovoljc 2005, 23 in drugod), ne sme rabiti v izpeljavi sami. Zdaj iz izpeljave (10) vidimo, da to v nekih posebnih razmerah vendarle gre. "Tretja lestvica" >nat $(+,-)$ / nanosnik osebka se namreč pojavlja v točki 1.1 izpeljave. Pogoje, pod katerimi je to dovoljeno, bo treba še doreči.

\section{Literatura}

Biber, Douglas, Stig Johansson, Geoffrey Leech, Susan Conrad in Edward Finegan, 1999, Longman grammar of spoken and written English, London.

Dobrovoljc, Helena, 2005, Slovenska teorija jezikovne naravnosti, Ljubljana. Havers, Wilhelm, 1931, Handbuch der erklärenden Syntax, Heidelberg. Huddleston, Rodney, in Geoffrey K. Pullum, 2002, The Cambridge grammar of the English language, Cambridge.

Mayerthaler, Willi, Günther Fliedl in Christian Winkler, 1998, Lexikon der natürlichkeitstheoretischen Syntax und Morphosyntax, Tübingen.

SS00 = Toporišič 2000

Teleman, Ulf, Staffan Hellberg in Erik Andersson, 1999, Svenska Akademiens grammatik, 4 knjige, Stockholm.

Toporišič, Jože, 2000, Slovenska slovnica, četrta izdaja, Maribor.

\section{The subject complement in the Natural Syntax of Slovenian Summary}

(The consecutive numbering repeats the numbering of the "deductions" in the main text.)

The following aspects of the syntax of the subject complement are treated in the framework of Natural Syntax:

(1-3) If the subject and the subject complement are NPs and both are in the singular, it depends on the function of the subject complement whether the agreement of the copula will be with the subject or with the subject complement. If one of the two clause elements is in the non-singular, the agreement is invariably with that clause element. 
(4) If the copula is other than 'be' and the subject is an NP, the subject complement is prevalently descriptive.

(5-6) The descriptive subject complement that is an NP lacks any referent and cannot be a personal pronoun.

(7) If the subject complement is identifying, it can be a clause. If the subject complement is descriptive, it cannot be a clause.

(8-9) If the subject is definite and the subject complement is identifying, the latter implies the exhaustiveness of its contents. This feature is absent if the clause contains adverbials such as 'first of all'.

(10) If the subject complement is identifying, the subject lacks any referent.

Varja Cvetko Orešnik

Filozofska fakulteta Univerze v Ljubljani

Aškerčeva c. 2, Ljubljana

cvetko@zrc-sazu.si

Janez Orešnik

Filozofska fakulteta Univerze v Ljubljani

Aškerčeva c. 2, Ljubljana

janez.oresnik@sazu.si 


\title{
Imenoslovje in etimologija imen
}

\author{
Dušan Čop (Ljubljana)
}

IZVLEČEK: V prispevku avtor skuša razložiti, na kaj je treba pri etimologiji imen predvsem paziti: treba je do zadnjih podrobnosti poznati narečje in pokrajino, kjer so imena, ki jih raziskujemo, ter zbrati čim več primerov (tudi iz drugih dežel). Prav tako je treba poznati zgodovino kraja, zgodovinske dokumente. Pogosto so lahko odločilne drobne narečne posebnosti. Ob slovanskih imenskih značilnosti pa je pri številnih imenih treba upoštevati tudi križanje z romanskimi in germanskimi.

ABSTRACT: This article seeks to explain what must be taken into account in the etymology of names: one must know the dialect and region of the names studied in great detail, and collect as many examples as possible (including from other countries). In addition, one must know the history of the place and historical documents. Minute special features in a dialect can often be a decisive factor. In addition to Slavic onomastic features, hybrids with Romance and Germanic characteristics must be taken into account for numerous names.

Po letu 1950 se vse bolj razvija veda, ki jo imenujemo imenoslovje (onomasti$\mathrm{ka}$ ). S to vedo se (oziroma naj bi se) ukvarjali predvsem jezikoslovci, kajti po vsem tem, kar smo spoznali doslej, je imenoslovje prav gotovo ena od najtežjih vej jezikoslovne znanosti. Izkušnje, ki nam jih posreduje ukvarjanje s to znanostjo na terenu, nam to v polni meri tudi dokazujejo. Zelo pogosto se namreč zgodi, da naletimo na domačine, to je potomce rodu (rodov), ki v kraju žive že stoletja in ledinska imena poznajo zelo dobro. Ker je njihova narečna izreka neoporečna (čeprav lahko, celo $\mathrm{v}$ isti družini, v določeni meri tudi različna), so mnogi povsem prepričani, da samo oni poznajo pravi izvor imena. Seveda to ni res, kajti da lahko nekdo govori o izvoru tega ali onega imena z vso odgovornostjo, da lahko poda edino veljavno resnico o imenu, da ime pravilno razloži, mora biti jezikovno dovolj izobražen, mora poznati kraj dodobra, in to tudi v smislu zgodovine kraja, o katerem govori (tudi če gre za ledine, vodne tokove, gozdove...), predvsem pa mora biti trezen realist. Imena imajo namreč (že zaradi časovne starosti) dostikrat neprijetne lastnosti, lahko bi v njih našli vrsto izvorov, pravi izvor pa je skoraj vedno samo eden. V takih presoja- 

vrst, pisatelji in celo jezikoslovci), če niso izobraženi v pravi jezikovni smeri in če nimajo pravega vpogleda $\mathrm{v}$ to znanost oziroma intuicije.

V okolici Žalca je ob rečici Pirešici velik travnik, obdan z visokim grmovjem. Imenuje se Loka. Človek, ki je pisal o teh krajih, pravi takole: »Tu so stari Slovani lomili izredno močne veje in iz njih delali loke« (!). Loke, Loka ... so znana in pogosta imena, ki izvirajo iz »lQka«, kar v stcsl. pomeni: »močvirnat travnik ob vodi«. Eden najlepših dokazov za to so veliki in dolgi travniki na desnem bregu Save (od cerkve sv. Klemena proti reki) v južnem, skrajnem koncu vasi Mojstrana v Gornjesavski dolini s skupnim imenom V LONKAH.

Še en tak primer: ob vzhodni obali Bohinjskega jezera je majhen borov gozd, ki mu domačini pravijo mrešše (izgovarjajo tudi mrenše in mrelše) in to izvajajo iz »(žabji) mrest«, ker se prav v tem delu jezera ob obali zbira »mrest«. To seveda ne drži, ker so podobna imena tudi visoko v gorah (npr. Mrešce, kakor se reče gozdu nad planino Lipanca na Pokljuki), tudi blizu Begunj oz. Radovljice je večji mešan gozd z imenom Mrešče. Isto ime najdemo tudi blizu Cerkniškega jezera za večje gozdnato področje. Ime izhaja vsekakor iz »mreža«, vsi kraji s tem imenom vzbujajo vtis, da drevesa stoje v nekakšni pravilni oddaljenosti drugo od drugega, kakor da bi tvorila mreži podobno skupino.

Ime Žirovnica, ki ga mnogi izvajajo iz (bukov) žir, ima čisto drugačen izvor: ime najdemo tudi na Koroškem, v Avstriji, na Češkem, celo v Srbiji (SV od Kragujevca), predvsem pa tudi v prvotni obliki Žrnovnica v Dalmaciji (npr. ob obali blizu Senja in vzhodno od Splita) in to ime lepo kaže pravi izvor iz psl. žъrny, žъrnovъ $=$ mlinski kamen.

Tako ime je tudi Uskovnica (nar. (W)uskounca), planina nad Srednjo vasjo v Bohinju. Domačini trdijo, da je planina razmeroma ozka, da ime izhaja iz »ozek«. Žal je to docela zgrešeno: $v$ radovljiškem urbarju iz leta 1498 je čisto jasno zapisano: LUSKOWINTZA. Prav na tem območju od Bohinja do Jesenic in še naprej proti Kranju najdemo priimek LUSKOVEC; poznamo tudi rastlino, ki se imenuje lusnec - vsa ta imena imajo isti izvor: luska (lusnec je pokrit z luskami).

Omenimo še ime Pišnica (kranjskogorsko »pî̌ñnca《). Mnogi, ki so se ukvarjali s tem imenom, so mnenja, da je ime oblikovano iz »kopišče«, češ da so bila ob reki na več mestih oglarska kopišča (tako trdi tudi J. Voljč v svoji knjigi o Podkorenu iz 1. 1938). Toda kopišča so nastajala $\mathrm{v}$ poznejših stoletjih, ne ob času, ko so se tukaj naseljevali (stari) Slovani. Povejmo kar naravnost: v znamenitem delu »Slovenija na vojaškem zemljevidu $1763-1787$ « je zelo lepo zapisano za vse tri Pišnice (Mala -, Velika -, Suha -): »Peschtschenitza«. To potrjuje tudi dejstvo, da je cesar Franc Jožef dal dvakrat zgraditi jez v zgornjem toku te reke (Velike Pišnice), ker teče po izrazito peščenih tleh. (Tako se tudi še danes dogaja: v hudem deževju konec julija 2000 je reka prenesla svoj tok na peščeni breg ob cesti proti Krnici in odnesla pesek, da je bila cesta na več mestih popolnoma uničena.) Ime ima torej po besedi pesek (stcsl. pěsъkъ), - ̌́- je prešel v domačem govoru v -i-. Mimogrede: Pesnica (potok in kraj severno od Maribora) ima ime po pesku (F. Bezlaj) in ne po povrtnini, ki jo imenujemo pesa.

Pa še Danje naj omenim pri tem osnovnem poglavju mojega prispevka. Vse 
mogoče smo brali o izvoru tega imena: (das ist) meine, (jenes) ist deine (ker so bili prvotni naseljenci iz leta 1283 in pozneje priseljeni iz Južne Tirolske, iz okolice Innichena), drugi menijo, da je ime nastalo iz »dno«, kakor imena več krajev v Sloveniji: Dane ipd., toda kraja Spodnje in Zgornje Danje ne ležita na dnu neke doline ali gorskega kotla, ampak Spodnje Danje na grebenu med dvema dolinama (med Roselpoharsko in Danjarsko grapo), Zgornje Danje pa so vsaj za dobro uro hoda više pod vrhovi Ratitovca! Poleg tega vemo (iz zgodovine tega predela naše Slovenije - prav zato je izredno pomembno, da raziskovalec, imenoslovec zelo dobro pozna tudi zgodovino krajev in naselij, katerih imena raziskuje), da naseljenci teh krajev od 13. do 17. stol. zaradi trdega kmečkega dela na ne preveč rodovitnem območju niso plačevali davka, ki ga pisatelji kot Ivan Tavčar poznajo kot danj. In to je izvor imena Danje (Unter - in Oberhuben). To ime pozna tudi Pleteršnik, vendar besedo zapiše dan.

Kako trezno in realno mora raziskovalec imen presojati vse zgodovinske vire in dostikrat zelo skope podatke, ki so mu dani, da mora biti izredno natančen, da mora biti nadvse razgledan po vsej deželi, zelo dobro, do največjih podrobnosti seznanjen z narečjem in da mora imeti pred seboj čim več primerov, naj pokažejo še imena Farjevec, Zapoden (nar. izg. »za pódnem«), Podvin.

Za Farjevec (pobočje nad Spodnjimi Rutami v Martuljku na karavanški strani) mnogi, tudi sicer resni ljudje, pravijo, da se je tam ubil neki »far«, za Farjevec na desnem bregu Save Bohinjke, nasproti starega zaselka Obrne (pri Bohinjski Beli) sem izvedel pri domačinih, da je bil lepi travnik, ki ga tako imenujejo, v preteklosti kupljen od blejske fare, da pa so tam vedno pasli (mlade) vole; to velja tudi za Farjevec nad Mojstrano oz. pri Vrtaški planini: tudi tam pasejo (mlade) vole - toda voli se pasejo tudi na pobočju Farjevca nad Rutami v Martuljku. Iz stvis. nemščine pa vemo, da so mlademu volu Nemci rekli »Far(r)o«, danes je to nemško »Farre «. Mirno lahko rečemo, da je ime prišlo iz nemščine: Farjevec je torej toliko kot naš »volovljek« ali »volovje«.

Več kakor samo zanimiv pa je primer Za podnem, danes Zapoden. Domačini in obiskovalci Trente (Zapoden je blizu izvira Soče) so prišli do »spoznanja«, da je izvor imena »za poldne(vo)m«. Takole so govorili nekateri: »Z besedo 'poden = dno doline' nima to ime nič opraviti, ker je obrnjena proti jugu, proti poldnevu!« In ravno to je napačno (V knjigi Bovška hiša (M. Kajzelj) je omenjen tudi ta kraj z imenom Zapoudan). Ljudje so se v te kraje naselili (zaradi revščine so morali kopati železno rudo tudi $2000 \mathrm{~m}$ visoko pod Pelci in Mojstrovko) v 16. stol., da so bili bliže »rudnikom«. Ime Za podnem kaže na zelo zanimivo posebnost (zgornjesoškega) narečja - končnica -em (mask.) za šesti sklon, sicer vedno -om. Tudi v češčini in poljščini najdemo isto končnico (npr. za potokem, před Bohem in poljsko: pod kotlem, przed domem). In ta končnica (končni - $m$ se navadno sliši - $n$ !) je v narečju že zelo stara, gotovo pa je iz časov dokončnega izoblikovanja slovenskih narečij: v letu 1409 imamo v historičnih virih tale zapis imena vasi pod Krnom: »Namabisgonden«, 30 let pozneje druga roka zapiše: »Na mali gosden« - vas se v 18. in 19. stol. imenuje oz. zapisuje Mali gozd, zdaj Magozd. K sreči se je oblast odločila za obliko Zapoden - $\mathrm{k}$ temu je treba na kratko še dodati, da poden $\mathrm{v}$ gorskih predelih vedno pomeni »dno doline« do tam, kjer se začnejo gorska pobočja. Zato so tudi v Kara- 

skih govorih poznamo namreč tudi dolge soglasnike oz. podvajanje soglasnikov, npr.: »to je pa Johanna ruta!«, »prane (= perilo) se pa že sší / šší.«. Treba je res zelo dobro prisluhniti, da sogovorca prav slišimo. Geodeti (po domače »žolnirji«), ki so imena popisovali, pa so jih velikokrat zapisali napačno (bili so tujci, med njimi tudi Čehi) prav zato, ker niso poznali narečnih posebnosti. Imamo torej opravka z izredno staro slovansko obliko: sem gotovo spada tudi ime Devin (grad pri Trstu). Blizu Želeč (ime Želeče, del Bleda, je izvedeno iz imena Želimir) je bilo majhno naselje Dindol. Na tej strani hriba Straža je visoka, navpična pečina (taka skala je omenjena tudi pri Podvinu). Ime Dindol je zelo verjetno »devin dol«<»děva«. Ljudje sicer omenjajo vse možnosti (tudi vinograd). Povezovati Podvin z Vintgarjem je huda zmota že zato, ker je bil Vintgar vse do začetka 20. stol. le ime soteske, po zgraditvi poti skozi njo konec 19. stol. (po 1. 1893) je J. Žumer zgradil blizu izhoda zgraditvi poti skozi njo konec 19. stol. (po 1. 1893) je J. Zumer zgradil blizu izhoda
oz. vhoda v sotesko restavracijo Vintgar. Vas v neposredni bližini pa se je vedno, do srede 20. stol., imenovala Leskè, $v$ Leskàh (z naglasom na 2. zlogu - torej ni mogoče, da bi bila soteska dobila ime po vasi, ampak prav obratno). Da je zgodovina oz. da so zgodovinska dejstva res pomemben element pri od-

vankah imena kot Poden, Podnar. - Poldne ni označba za dolino, ampak predvsem za gorske vrhove: blizu tromeje Češka - Avstrija - Nemčija je gorski vrh Polednik (v češčini poledne $=$ poldne, jug), Polinik večkrat v Alpah v Avstriji: gora, ki nad njo sonce stoji točno opoldne $-\mathrm{z}$ mostu med krajema Kötschach (= Hoče, ne Koče, kakor nekateri napačno prevajajo to ime) in Mauthen (= Muta, staro ime) se lepo vidi: točno na jugu je Polinik (= poldnik), malo na levo proti vzhodu Elferkofel in še bolj na levo Zehnerkofel. (Ni pa tega izvora Poludnik v Karnijskih Alpah - ime v Karavankah Trupejevo poldne in Maloško poldne, v Julijcih so Rutarško poldne (zdaj Velika Ponca). Ponce (Mala, Visoka, Srednja, Zadnja) so iz »poldnica«. So pa

Poldnevnice: na meji goriške in tolminske občine, v Beneški Sloveniji.
Na Pokljuki je kraj Meja dolina, ki se v Jožefinskem katastru imenuje Meduedia Dol(l)ina, in to zelo dosledno - v 19. stol. pa je to že Meja dolina. Ni mogoče trditi, da se tu križajo meje posestnikov, izhajamo lahko samo iz Medja dolina (-dje izpadel kakor v ograja < ogradja, zbu(d)jen..). Še po 2. svetovni vojni so se sem zatekali medvedi na svoji poti čez Pokljuko. V bližini je tudi Meji vrh (prav tako iz »medved«). V imenu Medje voše (= medvedje jelše) in imenu sedla Medji dol pa je

Že iz dosedanjih ugotovitev ob imenih, ki sem jih omenil, je razvidno, kako pomembno je, da imenoslovec temeljito pozna zgodovino in posebnosti krajev, s katerih imeni se ukvarja. Tak kraj, ki ima navidezno lahko razložljivo ime, je Podvin, ime starega gradu blizu Radovljice. Omenja se že zelo zgodaj, že leta 1311. Krajev $\mathrm{z}$ istim ali podobnim imenom je veliko: Podvin pri Žalcu, Podvine pri Zagorju ob Savi, Podvinje pri Slavonskem Brodu, Podvin je tudi v Bolgariji in na Slovaškem, .. Nemško ime za kraj je bilo Podwein; zato nekateri mislijo, da je to »v zvezi z vinom«, drugi iščejo zvezo z imenom Vintgar, a to je popolna zmota. Če dobro poslušamo domačine iz kateregakoli kraja na Zgornjem Gorenjskem, kako to ime (1) zgovarjajo, slišimo: »pod dvinam je biu.«, »zei grem pa pod dvin.« ipd. V gorenj(a)

(1)


krivanju pravega izvora nekega imena, kažeta npr. hišno ime Ps(t)nak (v Zg. Radovni pod Triglavom) in krajevno ime Mojstrana.

Ime Pstnak oz. Psnak ne izvira iz pes, ampak je iz posoškega pustina. Na Gorenjskem je to pustota, proti vzhodu pusta, pušča ... torej pomeni pustina pusto zemljišče, kjer ni ne hiše in tudi ne polja, lastnik pa je Pustinak; gorenjsko in koroško je to Pustotnik, Pestotnik, Pistotnik (nar. Pstotnek) - pstuh je človek, ki je pust, živčen. Zapis Pisnak v nekaterih geografskih kartah je torej čisto zgrešen.

Mojstrana pa ni imenovana po mojstrih, ki naj bi bili v tem kraju nekoč nadzirali »bžince« (= fužinice), ki so bile tukaj (kakor tudi v Ratečah in na belopeškem področju...) - vsekakor je do sem in še dlje segal furlanski vpliv. Ime izvira iz *magjustra (F. Bezlaj), kar v st. furl. besedišču pomeni »črnica« oz. borovnica. Da so to besedo tukaj zares poznali že od konca srednjega veka, priča ime travnikov severno od Mojstrane, v smeri proti Savi = »črnîče râvən«, (tudi Črničje ravne): Zgodovina je vsekakor pomemben element pri odkrivanju imen.

Drugo dejstvo, ki je neizogibno povezano z imenoslovjem v Sloveniji (zlasti v zahodnih in severnih predelih), pa je, da so prav geodeti zagrešili hude napake pri zapisovanju imen v nekdanjih avstrijskih katastrih. Potok Plaznica (blizu Krope) je zapisan kot Poznica, potok Hladnik (v Martuljku) pa Hodnik. Če človek ne prisluhne dobro, sliši pač -o- namesto -wa-! Še hujše je, da je ime Žale (na Bledu) zapisano Scherschlach (seveda v gotici) - da omenim le nekaj primerov. A tudi zapis Belo polje (v Bohinju) /namesto Velo -/ je docela zgrešen: v Sloveniji je precej krajev, ki imajo v svojih imenih staro, krajšo obliko za »velik» (Velesovo < Velo selo in ne po imenu nekega božanstva Veles- $a$, u vélmo lêso $=$ v velikem gozdu). - Nekatera imena so zaradi take površnosti in neznanja še danes čisto popačena. Eno od njih je tudi ime potoka Rečica (pod Jelovico), zapisano pa (v že omenjenih katastrskih mapah, a tudi še v novejših, povojnih mapah) Vrčica (F. Bezlaj poskuša to razložiti iz »vrč« ali »vir«, a ne gre!). Primer je res nekaj čisto posebnega: ko so Italijani 1. 1942 objavljali svoje vojaške karte (po napadu na Jugoslavijo in po zasedbi dela Slovenije), so na mejni karti (v škofjeloškem delu Gorenjske) čisto zgoraj, skrajno levo, zapisali ime istega potoka Orciza (= po izgovoru Orčica). Ta imena je težko pravilno razbrati že zato, ker domačini tako rekoč v vsaki vasi drugače izgovarjajo začetni u-, v-, o-, tudi če gre za predlog »v« pred besedo. Tako slišim npr. »u mlîno« (= V mlinu), »u završənc« (=V Završnici), »u rádoun« (=V Radovni), a tudi »o ledinah« (=V Ledinah / Poljče), »O bwâscəx (V blatcih, iz česar je nastalo Obvasca / Doslovče). Obranca je npr. planja na vzhodnem pobočju Mežakle (ime je staro več kot 400 let, ko so se tja ob vpadu Turkov zatekale domače družine in se tu skrivale, branile pred njimi); drugje, npr. na Hrušici, so mi lovci za isto ime govorili V Branci (= u bránc). Ime Vrčica namesto Rečica se pojavlja večkrat, in to ne samo na Gorenjskem. Naj tu samo omenim, da je za »Rečico« v rabi tudi ime Ročica (npr. v Bovcu in na Dolenjskem, a tudi na Gorenjskem) - z »razlago«, da si je tam nekoč neki otrok zlomil ročico ali da je kmet nerodno zavozil z vozom v potok in pri tem zlomil ročico pri vozu.

Da bomo današnje napačne oblike imen prav razumeli, naj tu omenim še dve imeni. Prvo je gorsko ime Vrtača (drugi najvišji vrh v Karavankah, med Stolom in Begunjščico). Ljudje na gorenjski strani (lastniki zemljišč na Zelenici in na po- 
$-\quad$ bočjih teh gora, so bili vedno Slovenci, a tudi na severni strani so vedno živeli le Slovenci. V vaseh na južni strani Karavank ljudje goro imenujejo Nemški vrh (v PV je dolgo vrsto let trajalo razpravljanje o tem imenu - celo pisatelj F. S. Finžgar je v PV trdil, da so njegovi starejši sorodniki goro vedno omenjali le s tem imenom). Na koroški strani goro imenujejo Vrtača, zato so se naši geografi odločili za to ime. Ni pa to pravo ime: Vrtača je kraška dolinica med Stolom in goro s spornim imenom. Temu prastaremu prehodu s Kranjskega na koroško stran, ki pa je v celoti na kranjski strani, vse do mejnega prehoda Belščica, rečejo domačini Čez Vrtačo, kakor je zabeleženo tudi na karti 1:25000 Geodetskega zavoda RS, št. 141 - in očitno so to ime na koroški strani vzeli za gorski vrh. Nihče tega imena ni znal razložiti pravilno. Res je, da je ime Nemški vrh zgrešeno, to pa spet zaradi posebnosti v zgornjesavskem narečju. Prav pri tem imenu se vidi, kako izredno pomembno je, da tisti, ki se ukvarja z imenoslovjem, zares dobro pozna tudi narečje in da je (iz dokumentov) dodobra seznanjen z zgodovino krajev in krajevnih (tudi gorskih) imen. Zelo so v takih primerih uporabni tudi opisi meja starih graščinskih posestev. Prav po imenovanem delu Karavank je tekla meja blejske graščinske posesti. »Stou ... Menischke Werch« (V opisih graščinskih meja so imena zelo dosledno zapisovali v narečnih oblikah!). To ime »Menischke Werch« je zanimiva priča posebnosti v današnjem severozahodnem slovenskem naselitvenem prostoru - metateze so tu kar pogoste. Ime Meniški vrh je prešlo v Nemški vrh (tudi naglas je v tem delu Slovenije dostikrat prešel na prvi zlog), Čomoradnek (rovt pod Stolom) $<$ Močeradnik, ker je tudi močerad > čomorad, Zapret < Zatrep. Gobatec < Bogatec (tolminsko ime za bohinjski Bogatin, Kupljenik (nad Bohinjsko Belo) se 1. 1511 beleži kot Pukl(j)enik, a tudi sicer: gomazin < magazin, potariše < toporišče i. dr. Ime Meniški vrh je v Sloveniji tudi na Štajerskem, SV od Sevnice.

Da brez temeljitega znanja drobnih narečnih posebnosti ni mogoče zanesljivo ugotoviti izvora (ledinskih) imen, dokazuje popačena oblika imena Na Sušeh (= planina nad Srednjo vasjo v Bohinju). Ljudje dosledno govorijo »na sšéx« - nenaglašeni -u- (zlasti v prednaglasnem zlogu) v zgornjegorenjskem narečju dosledno izpada: Suši so v govoru Sši (ali celo Šši) in to ime ni osamljeno (niže na Gorenjskem je to Səší). Tudi hišna imena so »pri sšîunko« (vzporedno pa tudi »pr səšîunko«/ /sušînko«). Na današnjih geografskih in planinskih kartah pa poleg imena Na Sušeh najdemo tudi nesprejemljivo obliko $\mathrm{Na}$ Šehu (kar je brez pravega pomena), Na Sušeh pomeni »kjer so sušili posekana drevesna debla« (ali kaj drugega).

Naj tu ob koncu razprave o posebnostih izvora imen dodam na hitro še nekaj primerov - že zato, ker se tu v Sloveniji križajo tudi vplivi romanskih in nemškega jezika in se prepletajo z zelo starimi slovanskimi imeni. Zato bi morali imenoslovci dobro poznati tudi sosednje romanske jezike, nemščino in njihove narečne posebnosti. Na Koroškem (v vseh narečjih od Vzhodne Tirolske pa do Ruš pri Mariboru) zelo pogosto naletimo na imena Ladine, priimek Ladinek (Ladinig), Wadne... v vseh drugih slovenskih narečjih je to Ledine, Ledinek. Vedeti je treba, da v koroških govorih -e- v ponaglasnem (tudi prednaglasnem) zlogu pogosto preide $\mathrm{v}$-a- (npr. Sadwò = sedlo, jasánovc = jésen; »tam pa drgáče račó«...). To nekateri tuji jezikoslovci popolnoma napačno razlagajo iz »Latinus, Latinicus«. Zato je bil večletni prepir v PV v devetdesetih letih 19. stol.: na Jezerskem danes rečejo: $N a$ 
Vodinah oz. na Vadinah (govor domačinov je koroški - stari zapisi pa dosledno kažejo Ledine, na Ledinah).

Gorskega imena Škrlatica ni mogoče razlagati iz »škrlat(en)《. Nemško ime (die) Scharlachröte in tudi angleško »Scarlet Crag« je zgrešeno! Za pojem »rdeč« domačini nikjer ne uporabljajo »škrlaten«, imamo pa za »rdeč« vrsto izrazov, ki so ostali v imenih do danes! Blizu meje Zgornje Avstrije in nemško govoreče Štajerske je kraj z imenom Rottenmann, ki se v 13. stol. imenuje še Zirminach, na pobočju pod gorskimi vrhovi Dovški križ, Škrnatarica v Škrlatičini skupini sta jarka dveh hudournikov: Mali in Veliki Čr(v)lovec. Če si ogledamo pesek okrog »izvirov« teh hudournikov, ki ima izredno nežno svetlo rdečo barvo, nam je takoj jasno, odkod njuno ime: Že Megiser pozna zherlen = rdeč, Ramovš opozarja na čъrvlenъ in *čъrmъnъ. - Tudi imena Krvavec, Krvavka (vzhodni vrh Golice v Karavankah), Krvava peč idr., ne samo Rdeča skala, nam povedo, da je tu mišljena rdeča barva.

Dr. H. Tuma je v Imenoslovju Julijskih Alp in v drugih spisih večkrat zagrešil hude napake: Tako je $\mathrm{v}$ Karavankah oz. na njihovih pobočjih našel tudi taka imena kot Male deva; to je zanj napaka - pisati je treba, pravi, Mala deva. Prav to dokazuje, da Tuma narečja sploh ni poznal: Male déwa v zgornjegorenjskem narečju pomeni »Mali deli« oz. male parcele (gozdne - , poljske - ). Značilnost zgornjegorenjskega narečja (tako je tudi drugje, vendar v manjši meri) je, da moški in ženski spol samostalnika preideta v množini v srednji spol (zato v govoru: Spodnje Gorjuša, Zgornje ..., Zdénšca = Studenčice; »tam so pa tri xîša za trî držina«). Če stoji spredaj pridevnik, je ta navidezno $\mathrm{v}$ ženski obliki. Male deva torej tudi ne pomeni »mala dela«, kakor nekateri mislijo, ampak na Spodnjem Gorenjskem (npr. v okolici Kranja) beremo v geodetskih kartah: Mali deli, Veliki deli, tako tudi za Šmarno goro, čeprav so vmes tudi tukaj napake; da gre res za del = parcelo, nam lepo pove beseda »part« (gozdna parcela, romansko), v okolici Bleda, ta(j)1 v Bohinju (germansko / nemško) in tudi v Gornjesavski dolini.

Ime slapa Boka pri Bovcu ne izvira iz dejstva, da je slap na pobočju kaninskih gora, ampak iz ital. la bocca (usta, ustja), zaliv pred mestom Cannes v Južni Franciji se imenuje La Bocca in tudi prvi del imena Boke Kotorske je tega izvora. (V Hercegovini je večkrat »vrelo Boka«.)

Ime kraja Srpenica (ob Soči) ne izvira iz »srp«, ampak iz »stirpe« (to v ladinskem jeziku pomeni »jalovo govedo«; 1.1496 se v odločbi Goriškega mejnega grofa ta kraj imenuje Sterpeniza (istega izvora je ime kraja Stirpnik - v hribih nad Škofjo Loko; malo znano je, da se vršnji deli nekaterih srednjevisokih hribov imenujejo Frtica (npr. Višelnica nad Gorjami pri Bledu; pri Drenovem Griču, pri Litiji, hrib nad Grosupljim!) < fortitia.

Priimek Kverh (v vaseh med Bovcem in Trento) ne izvira iz »Gewerk« (ker so v Trenti od 16. stol. do 18. stol. imeli železarske fužine zaradi rudnikov pod Pelci in Mojstrovko), ampak iz Quarg, kar je slovensko Žmitek (prav ta priimek, lepo slovenski, ni < Schmid, kakor nekateri zmotno mislijo, je najti na kamnogoriškem področju, a tudi v Bohinju). Končni -g v nemških besedah je -x- $\mathrm{v}$ izreki, kratkonaglašeni -a- pa je v zgornjesoškem narečju -è- (npr. brèt, brátra).

Ker se ne spoštuje narečja in njegovih zakonov, se pri nas mnogo imen piše napačno. Tudi ni res, da bi tisti, ki so veliko pisali o naših krajih in gorah (npr. dr. 
$4 \quad$ H. Tuma) pisali vselej pravilno. Po mojem mnenju bi morali napake popraviti in tako ohraniti prvotno, staro, resnično pravo obliko imen. Zlasti še zato, ker domačini dosledno uporabljajo svoja, stoletja stara imena, zaradi česar pride do nerodnih primerov, da turisti zaradi napak v zemljevidih krenejo po napačni poti. Naša imena je treba pisati v knjižnem jeziku in njihovem pravem pomenu - to nam lepo prikazuje duha in mišljenje naših davnih prednikov in njihov odmev - njihove usode vse do današnjih dni. To je eden najdragocenejših dokazov o slovenski prisotnosti v Vzhodnih Alpah. Da ne bomo nekega dne prisiljeni reči tako, kakor pravijo keltski Valižani v svojem pregovoru: Cenedl heb iaith cenedl heb galon ${ }^{1}$.

\title{
Viri in literatura
}

Badjura, Rudolf, Ljudska geografija (Terensko izrazoslovje) I, II, Ljubljana 1953, 1957.

Bezlaj, France, Etimološki slovar slovenskega jezika I, II, III, IV, Ljubljana 1976, 1982, 1995, 2005.

Bezlaj, France, Slovenska vodna imena I, II, Ljubljana 1956, 1961.

Čop, Dušan, 1983, Imenoslovje zgornjesavskih dolin, Disertacija, Ljubljana, Tipkopis.

Čop, Dušan, 1995, Jezikovne in imenske značilnosti okrog Krope in v dolini Lipnice, Kroparski zbornik, Ob 100-letnici Plamena, Kropa, Radovljica, Muzeji radovljiške občine, 190-197.

Čop, Dušan, 2002, Gorska, terenska (ledinska) in vodna imena v Sloveniji, Jezikoslovni zapiski 8/2, Ljubljana, ZRC SAZU, 93-108.

Klemše, Vlado, Krajevna, ledinska in vodna imena v Števerjanu, Gorica 1993.

Mrdavšič, Janez, Krajevna in domača imena v Mežiški dolini, Ravne na Koroškem 2001.

Tuma, Henrik, Imenoslovje Julijskih Alp, Ljubljana 1929.

\section{Onomastics and the Etymology of Names}

\author{
Summary
}

Onomastics is one of the most demanding linguistic disciplines. In their assessment of the origin of names, both locals, who think they know the names, and highly educated people are almost always mistaken. The author seeks to explain where attention must especially be directed in the etymology of names. First, one must know the dialect and region of the names studied in great detail, and collect as many examples as possible (including from other countries). In addition, one must know the history of the place and historical documents. In this regard, one 
must bear in mind that surveyors (from abroad) often made gross errors in past centuries because they did not know the local language and its dialects. Minute special features of a dialect often played a decisive role (especially in the cases of Vrčica, Vrtača, and Vintgar). In Slovenia and ethnically Slovenian areas, Slavic onomastic features formed hybrids with many Romance and Germanic features. The consequences of all these issues are numerous mistakes, as demonstrated by the examples presented. 



\title{
Академик Измаил Иванович Срезневский и резьянщина
}

\author{
(с извлечениями из его путевых заметок \\ по Резье в 1841 году)
}

Александр Дмитриевич Дуличенко (Tartu)

IZVLEČEK: V članku avtor obravnava odnos I. I. Sreznjevskega do rezijanščine ter rezijanske kulture in folklore, kar ponazarja z izvlečki iz njegovih popotnih zapiskov o Reziji leta 1841. Sreznjevski je Rezijo obiskal kot prvi slavist. Potovanje po Reziji je bilo samo del njegovih popotovanj po mnogih slovanskih deželah v letih 1839-1842.

\section{Academy Member Izmail Ivanovich Sreznevskii and Resian (With Excerpts from His Resian Travel Notes of 1841)}

ABSTRACT: This article discusses Izmail Ivanovich Sreznevskii's attitude towards the Resian dialect and Resian culture and folklore, illustrated with excerpts from his 1841 travel notes. Sreznevskii was the first Slavist to visit Resia. His travels through Resia were merely part of his travels through many Slavic lands between 1839 and 1842.

Имя русского слависта академика Измаила Ивановича Срезневского (1812-1880) хорошо известно специалистам по южнославянским языкам и особенно по словенистике. Можно сказать, что от середины и до 80-х гг. XIX в. - это эпоха Срезневского в русской славистике. Он занимался практически всеми ветвями славянства - их историей, древностями, языками и литературами. А все началось с путешествия в славянские земли, которое он совершил в 1839-1842 гг. Путешествие было длительным и охватывало многие славянские регионы. Для нас важно то, что одной из главнейших задач Срезневского было посещение Словении и знакомство с историей, традиционной культурой, языком и говорами словенцев.

Нельзя сказать, что об этой странице русской словенистики мало известно - вспомним, например, монографию И. В. Чуркиной (1986, с. 38 и далее). Тем не менее есть моменты, на которые хотелось бы обратить специальное внимание. Прежде всего это касается Резьи, которую Срезневский посетил первым как славист в 1841 г., обратив при этом внимание как на культуру и фольклор, так и на речь резьян. О важности для славистики его научных наблюдений в Резье сказано в ряде статей последнего времени (см., например: Цыхун 1993, 63-67; Дуличенко 1996, 567-590).

О своем путешествии в славянские земли, в Словению и прилегающие 
4 регионы, в том числе и в Резью, Срезневский писал в «путевых письмах» и [1. в письмах к своей матери Елене Ивановне, изданных уже в конце XIX в., а N также в ряде статей и в написанной накануне смерти обширной работе «Фри-1 ульские славяне» (Срезневскій 1892; 1893, 20-63; 1878-1881; 1895; этот текст неоднократно переиздавался в дополненном или сокращенном виде, в академических сериях или самостоятельно).

Поскольку эта статья пишется в Тарту (старое название также Дерпт/ Дорпат и Юрьев), важно указать на то, что, выехав в путешествие из Санкт-Петербурга, Срезневский проехал через Эстонию и, в частности, через город Дерпт, и далее по Прибалтике через Польшу в Берлин. Вот как он сам пишет о начале своего путешествия:

«Города по дорогъ - Ямбургъ, Нарва, Дерптъ, Валкъ, Волмаръ - промелькнули мимо, такъ что я объ нихъ сохраниль самое темное понятіе: Ямбургъ еще Русскій городъ, Нарва — въ половину Нъмецкій, всъ другія почти чисто Нъмецкія; болье всъхъ Нъмецкій - Дерптъ, Нъмецъ старый - улицы красивы, узки, кирка чисто Нъмецкая съ башнею, дома высоки и покрыты черепицей <...>».

Однако давайте посмотрим, каков был маршрут Срезневского по Словении и словенским землям. Вот как он сам обозначает его в апреле-мае 1841 г.:

Апрель

14. [это день месяца] Любляны (словен. Ljubljana, нЊм. Laibach)

Торжецъ (словен. Teržič, нъм. Neumarkt)

17. Целовецъ (словен. Celovec, нъм. Klagenfurt)

18. Мошбургъ

20. Целовець (словен. Celovec, нъм. Klagenfurt)

22. Верба (Velden)

Роженъ (Rosenthal)

24. Быстрица (Feistritz)

25. Деревня св. Георга

Блейбергъ

26. Быстрица (село въ Зильской долинъ)

27. Тарфисъ

Резіута

Венцоне

Джемона

Тарченто

Май

1. Ложѐваро

Чивидаль 
2. Горица (словен. Gorica, нъм. Görz)

4. Липава (словен. Vipava, нъм. Wippach)

Постоина (словен. Postojna, нъм. Adelsberg)

Любляны (словен. Ljubljana, ньм. Laibach)

7. Триесть (серб. Трст)

11. Венеция (серб. Млетци)

13-27. Триесть

28. Копръ (серб. Копаръ, ит. Саро d'Istria) < ..> (Срезневскій 1895, 359).

Каковы же были впечатления Срезневского о словенском языке? Из записи от 5-го апреля:

«Воть я и тутъ < .. >. И досада: когда я читаю Краинскую книгу, понимаю почти всъ, разве какое-нибудь слово заставить задуматься, а слушаю, когда говорятъ, какъ ни слушаю, какъ ни вслушиваюсь, то разве десятое слово разберу. Удареніе дивное, большая половина гласныхъ проглочена, другія измънены. Досада, да и только. А языкъ <..> очень приятенъ для слуха» (Срезневскій 1893, 40).

Как известно, Срезневский планировал направиться в Резью вместе со Станко Вразом. Однако последний заболел, и Срезневскому пришлось отправиться в путь одному (позже Враз совершил поездку в Резью самостоятельно). Оставим в стороне промежуточные продвижения и остановки Срезневского. Обратим внимание на то, как он описывает в письме к своей матери подход к Резье и само ее посещение:

«Въ Тарфись - Нъмцы. Но мнъ нужно было пройти черезъ него, чтобы пробраться къ Резіянамъ. Эти Резіяне - жители Резіянской долины (Vale della Resia) въ Венеціанской Италіи на границахъ Краинскихъ. Два слова о нихъ были сообщены Добровскому когда-то, и съ тъхъ поръ никто не говорилъ ни слова, такъ что даже и тутъ хорошо не зна[ютъ], гдъ собственно лежитъ эта долина. Отыскавши на карть селеніе Резіуту, я не могъ предположить, что эта долина недалеко отъ Резіуты, и отправился въ Тарфисъ, съ тъмъ чтобы оттуда пробраться к Резіуть и далъе, какъ Богъ дастъ. Я хотьль 27-го же идти или ьхать въ Резіуту, но въ этоть день должна была приьхать въ Тарфисъ императрица $<\ldots>$ По нъволи остался ночевать, видъль императрицу, видъль равнодушіе народа къ ней и на другой день пођхалъ въ Резіуту. <...> Въ Дуньъ я остановился объдать, все еще не зная, куда ьду и какъ найду Резью. Къ счастью хозяинъ зналъ два слова по Нъмецки. Я спрашиваю его о Резіи, а онъ въ отвьтъ указываетъ на молодого человъка въ черныхъ чулкахъ и башмакахъ, говоря, что онъ капелланъ изъ Резіи. О счастье! < ..> Къ нему — и по Ньмецки. «No саріsсо» (не понимаю), отвъчаеть онъ мнъ по Фурлански. Вотъ тъ и счастіе! Что туть дълать! Надобно было рђшиться въ первой разъ въ жизни начать говорить по Итальянски. Можете представить, какъ шло: однако шло. Къ тому же, капелланъ, хоть родомъ и Фурланъ, говоритъ однако по Резіянски; такимъ образомъ, чего я не могъ ему объяснить по Итальянски, то добавляль по Краински, и на оборотъ, — и сошелся. Капелланъ сказалъ мнъ между про- 
чимъ, что долженъ ђхать сей же часъ по дъламъ, но что въ Резіутъ увидится со мною, и оттуда пойдемъ вмъсте въ долину. Такимъ образомъ 28-го [мая] еще былъ я въ Резіи» (Срезневскій 1893, 47-48).

Что же увидел в Резьянской долине Срезневский, с кем встречался и чем занимался? Из того же письма выясняется, что встретили его в Резье очень гостеприимно, ср.:

«Долина какъ котель, со всъхъ сторонъ обнесенная дикими стремнинами, и только съ одной стороны дающая въ себя узкій проходъ. Отъ Резіуты $1 \frac{1}{2}$ часа. Священникъ, старикъ 73 льтъ, но живой, веселой, и гордящійся тъмъ, что Резія и Россія одно и тоже, обласкалъ меня какъ могъ и въ тотъ же вечеръ еще сообщиль мнъ много любопытныхъ извъстій о жителяхъ. Русскіе были однако тутъ: нъсколько соддатъ проходомъ изъ Италіи, да графъ Потоцкій (не бывшій у насъ попечителемъ, а братъ его), случайно услышавши въ Резіуть ньсколько Славянскихъ словъ. 29-го я провель весь день въ долинь, обходя деревни, расспрашивая объ обычаяхъ, языкъ и такъ далье. Капелланъ всюду со мною. Тутъ узналъ я и о другихъ Славянахъ Итальянскихъ, живущихъ въ горахъ на югъ отъ Резіи, взялъ одного Резіяна проводникомъ, и съ нимъ ходиль 3 дни, дошедши до сюда [въ Горицу]. 30-го прошли черезъ Резіуту, Венцоне, Джемону въ Тарченто» (Срезневскій 1893, 48-49).

«Священникъ, старикъ 73 льть, но живой, веселой» - это был Одорико Буттоло, который переводил на резьянский молитвы, а также пытался составлять резьянско-итальянский словарь.

В публикации 1881 г. о встрече с Резьей сказано так:

«Резія. Вотъ я и туть <..> Съ нами шла женщина изъ деревни Нивы $<\ldots>$ Въ БЪль мы зашли въ одинъ изъ дворовъ отдохнуть и освъжиться виномъ < ..> Черезъ 4 часа мы были на боргъ Равенць у приходской церкви <..> Патеръ Одорико Буттоло, добрый старикъ (ему уже 73 года), всьмъ сердцемъ обрадовался моему приходу. 'Резія и Русія одно и то же': это его любимая поговорка, какъ онъ началь ее».

Чуть ниже еще одно интересное замечание:

«Плебанъ сообщилъ мнъ между прочимъ, что Резія должна быть извъстна въ Россіи. Графъ Потоцкій, прођздомъ изъ Италіи, остановился однажды въ Резіуть. Резьянки случились тамъ съ виноградомъ, и обратились къ нему съ вопросомъ: купите вина? Славянскій вопросъ изумиль графа; онъ сталъ расспрашивать ихъ, откуда они, велель себя привъсти въ долину, провелъ въ ней ночь и записаль 'Отче нашъ' Солдаты русскіе заходили въ Резію и говорили съ жителями по русски» (Срезневскій 1881, 4, 5).

Срезневский, несмотря на краткое пребывание в Резье, сумел записать по-резьянски «Отче наш», лексику, отражающую быт, ландшафт, культуру резьян; сделал он и замечания по особенностям резьянской речи - анализ этого материала дан нами в докладе «У истоков резьянологии» на международном симпозиуме «Ерней Копитар и его эпоха. Симпозиум по случаю 150-летия со дня его смерти», прошедшем в Любляне 29 июня - 1 июля 1994 г. (см. Дуличенко 1996, 567-590). Здесь лишь отметим, что и публикацию работы Срезневского «Фриульские славяне» 1881 г. осуществил И. А. Бодуэн де 
Куртенэ, который ревниво делал неоднократные «исправления» в примерах Срезневского. Так, Срезневский пишет, что о деревне Белой говорят: tä na Bili — Бодуэн в примечании тут же поправляет: «(Первую деревню при выходь называютъ теперь tù и Bili или tò u Bili, смотря по говорамъ)». И т. д.

Как мы уже сказали, Срезневский записал в Резье также несколько фольклорных тестов. В публикации 1878 г. это, например:

Göra Kílina mojà!

ná ma trísti počuwál,

da, kòj so pride nûtu dnö,

Ná ma trísti anu dnö.

Под текстом помечено: «(Изъ Резьянской Бълы - S. Giorgio).

Далее следуют небольшие поэтические тексты из Раванцы и Осоян, а в Ниве Срезневский записал прозаический текст (всего в 7 строк), озаглавленный «Káko ni právjo, káko ni so paršlè tò u Rézjo» (Срезневскій 1878, 57-58). В бодуэновской публикации 1881 г. в письме Срезневского к чешскому слависту Вячеславу Ганке приводятся еще два поэтических текста и молитва «Отче наш» (Срезневскій 1881, 29).

Из приведенного анализа и извлечений видно, как И. И. Срезневский добирался до Резьи, что его там прежде всего интересовало и что он представил славистике в качестве наблюдений и конкретных образцов живой резьянской речи и устного народного творчества.

\section{Литература}

Дуличенко 1996 - А. Д. Дуличенко, У истоков резьянологии, Kopitarjev zbornik, Mednarodni simpozij v Ljubljani, 29. junij do 1. julij 1994 «Jernej Kopitar in njegova doba, Simpozij ob stopetdesetletnici njegove smrti», (Obdobja, 15), Ljubljana 1996, s. 567-590.

Срезневскій 1878-1881 - И. И. Срезневскій, Фріульскія славяне, Статьи И. И. Срезневскаго и Приложенія, С.-Петербургъ, 1878, (4) + 91 с.; переиздание: Сборникъ ОРЯС Императорской Академіи наукъ, С.-Петербургъ, томъ XXI, 1881, 32 с. и др.

Срезневскій 1892 - Путевыя письма И. И. Срезневскаго къ матери его Елень Ивановнъ Срезневской (1839-1842), Живая старина, годъ II, C.-Петербургъ, выпускъ I-IV, год 3, 1893, выпускъ I, с. 20-63.

Срезневскій 1895 - Путевыя письма И. И. Срезневскаго изъ славянскихъ земель 1839-1842, Съ приложеніемъ карты, С.-Петербургъ 1895.

Цыхун 1995 - Г. А. Цыхун, Славістычныя інтарэсы I. І. Срезнеўскага, Рэзія і ўсходнія славяне. - Славянские языки, письменности и культура, Киев 1993, с. 63-67. 
Ч Чуркина 1986 - И. В. Чуркина, Русские и словенщуы. Научные связи конца XVIII в. - 1914 г., Москва 1986.

\author{
Akademik Izmail Ivanovič Sreznjevski in rezijanščina \\ (z izvlečki iz njegovih popotnih zapiskov o Reziji v letu 1841) \\ Povzetek
}

Akad. I. I. Sreznjevski je bil prvi slavist, ki je z znanstvenimi nameni obiskal Slovenijo, med drugim tudi Rezijo, v času svojega dolgotrajnega popotovanja (1839-1849) po slovanskih deželah. Pomembno je to, da je dokaj podrobno opisoval smer svojega gibanja in postaj v krajih, kjer so živeli Slovenci. V njegovih popotnih zapiskih in pismih materi Jeleni Ivanovni lahko preberemo, od kod in na kakšen način se je trudil priti v Rezijo in kako jo je videl. Ni se le seznanil z rezijanskimi vasmi, temveč se je tudi veliko pogovarjal z ljudmi in med drugim z duhovnikom Odoricom Buttolom, ter pri tem zapisal nekaj narodopisnih besedil, prevod molitve Oče naš in zbral jezikoslovno gradivo, po katerem so slavisti bolj temeljito $v$ primerjavi s prikazom, ki ga je podal v začetku stoletja J. Dobrovský (na podlagi gradiva Pišelyja), lahko sodili o stanju rezijanske govorice. To potovanje je predstavljalo spodbudo in izhodišče za poznejša večkratna potovanja J. Baudouina de Courtenayja v Rezijo.

Aleksandr D. Duličenko 50002 Tartu, box 31, Estonija aleksd@list.ru 


\title{
Istroromunski kromonimi
}

\author{
Goran Filipi (Koper)
}

IZVLEČEK: V prispevku so obravnavana poimenovanja barv v istroromunskih govorih $v$ Istri. Obdelanih je 14 kromonimov (poleg njih še nekateri pojmi, ki so na kakršen koli način povezani z določeno barvo). Besedje je bilo zbrano v zadnjih dvajsetih letih (večji del je, kot gradivo, objavljen v IrLA). Poleg istroromunskih terminov, ki jih je avtor sam zabeležil, se dosledno navajajo tudi oblike iz istroromunskih slovarjev in glosarjev.

ABSTRACT: This article discusses the names of colours in the Istro-Romanian dialects of Istria. In addition to 14 chromonyms, selected terms connected with specific colours are analyzed. The vocabulary was collected over the last twenty years (the majority appears as material in the Istro-Romanian Linguistic Atlas, or IrLA). In addition to Istro-Romanian terms that the author recorded himself, forms from Istro-Romanian dictionaries and glossaries are consistently cited.

\section{0 .}

Za istroromunske besede, ki smo jih sami zbrali, uporabljamo grafijo, ki smo jo sestavili za IrLa - gre za prilagojeno hrvaško latinico z dodanimi grafemi, ki označujejo istroromunske glasoslovne posebnosti:

å - zamolkli $a$

$\varepsilon$-zelo širok $e$

ə - polglasnik - ustreza romunskemu ă

ś - mehki ̌̌

Ź - mehki ̌̌

3-začetni glas v it. zelo

$\breve{\mathrm{g}}$ - ustreza $\operatorname{sln} . d \check{z}$

$\gamma$ - mehkonebni zveneči pripornik, kot v šp. lago

í - približno ustreza hrvaškemu $l j$

ń - približno ustreza hrvaškemu $n j$

Naglas v večzložnih besedah beležimo tako, da podčrtamo naglašeni samo-

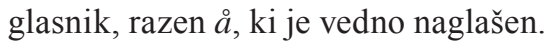


Ir. samostalnike navajamo v ednini brez člena, sledijo obrazila za določni člen (-u ali -a), oblika ali obrazilo za mn. (-ø, -e, - ̌̌, -ure ...), obrazilo za množinski določni člen (-i, -ele, -urle ...) in na koncu oznaka spola (m., ž., bg., sr.); glagole navajamo v nedoločniku, za katerim sledi 1. os. ednine sedanjika; za pridevnike pa navajamo najprej edninske (m., ž. in, če obstaja, sr.) oblike, ki jih ločujemo z vejico, za njimi, ločene s podpičjem, sledijo še množinske oblike.

Čakavsko besedje, ki smo ga sami zbrali, pišemo z enako grafijo kot ir., naglas pa beležimo tako, kot je to običajno $\mathrm{v}$ dialektološki slavistični literaturi. Izrazje iz virov prenašamo po izvirniku.

V prispevku smo uporabili naslednje kratice:

ar. - aromunsko

arab. - arabsko

b - beležka

ben. - beneško

bg. - srednji spol romunskega tipa (dvospol)

čak. - čakavsko

gl. - glagol

dr. - dakorumunsko

fran. - frankovsko

germ. - germansko

ir. - istroromunsko

it. - italijansko

juž. v. - južne vasi (Šušnjevica, Nova vas, Jesenovik, Letaj, Brdo, Škabići, Trkovci, Zankovci, Miheli, Kostrčan)

knjiž. - knjižno

lat. - latinsko

m. - moški spol

mn. - množina

mr. - meglenoromunsko

nem. - nemško

perz. - perzijsko

prid. - pridevnik

prim. - primerjaj

prisl. - prislov

pslovan. - praslovansko

rom. - romunsko

sln. - slovensko

sr. - srednji spol slovanskega tipa

srvnem. - srednjevisokonemško

stvnem. - starovisokonemško

šp. - špansko

tur. - turško

ž. - Ženski spol 


\section{Barva}

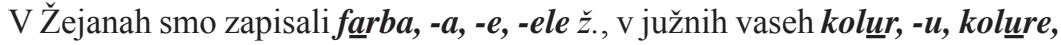
-ele bg., v Jesenoviku tudi kolur, -u, -ø, -i m.

Maiorescu je zapisal colur, pl. colure (VIr 118) in farbă (VIr 123), Popovici colur, $-u$, pl. -i (DRI 99). ${ }^{1}$

Izposojeno iz čakavskih govorov: npr. v Brgudu färba (IrLA 305), v Senju in Novem Vinodolskem fãrba (SR 29; RČGNV 60); v Čepiću kolûr (IrLA 305), v Labinu kolôr (RLC 127), kolòr (PI 50). Izrazi tipa farba so germanskega [< srvnem. Farbe (SES 122)], tipa kolur pa beneškega izvora [ben. color (BOE 181) < lat. cŏlor, -ōre, REW 2056].

\section{Bel, bela, belo}

V Žejanah åb, åba; åb/åbi, åbe prid., v Šušnjevici in Novi vasi åb, åb $\boldsymbol{a} ; \boldsymbol{a} \mathbf{l} \boldsymbol{b}$, åbe prid., v drugih južnih vaseh åb, åba; åĺb, åbe prid., v Zankovcih tudi åb, åbe; ålb, åbe prid. ${ }^{2}$ Potrdili smo tudi obliko za sr. slovanskega (čakavskega) tipa: åbo; åb(i) v Žejanah, åbo; åĺb v juž. vaseh: åbo de ócl’u „,beločnica”, dobesedno ,,belo od očesa" (IrHR 20).

V virih: $a b, a b a ̆ a, a b i, a b e$ (VIr 105), $Q b$, $q l b \breve{\imath}$ (IrG 296), åb, -ę (DRI 89), ŭab, -e (TIr 157), åb, - $a$ (DIr 186), åb, åbe, ål’b, åbe za juž. v. in åb, åba, åb(i), åbe za Žejane (IrHR 20).

Domača beseda < lat. albus, REW 331.1 > dr., mr. alb, - $\breve{a}$ (DEX 23, DMr 10), ar. álbu, -bă (DDAr 81), albu, -bâ (DAr 33, s. v. alb).

\section{3. ̌̌rn, črna, črno}

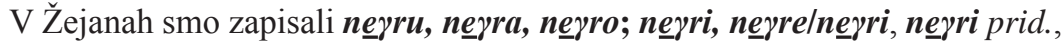
v Šušnjevici in Novi vasi negru, negre, negro; negri, negre, negri prid., v ostalih vaseh negru, negra, negro; negri, negre, negri prid.

V virih: négru, -rę, -ri, -re (IrG 286); negru, nęgre (SIr 316); negru, neagră, mn. negri, negre (VIr 136); négru, -e (TIr 172); negru, nęgre, -o (DIr 236); négru,

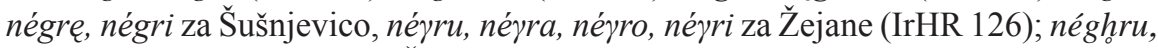
néaghra; néghri, néghore za Žejane, négru, néágra; négri, néágre za Letaj; négru, nęagră ; négri za Šušnjevico; négru, néágra; négru, néágre za Novo vas; négru, né/a/gra; négri, négre za Jesenovik; négru, néágra; négri, négre za Brdo, Kostrčan (MALGI 239).

Domača beseda < lat. nĭger, REW $5917>$ dr., ar., mr. négru, neágră (DEX 682, DDAr 748, DMr 205).

1 Byhan ima samo glagol koloręi, -ręit, -résk „,barvati” (IrG 244) - mi smo v Žejanah zapi-

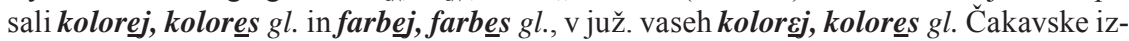
posojenke: npr. v Labinu koloràt (RLC 127), v Orbanićih kolorät, kolorievät (ČDO 468), koloràt, kolorìvat (PI 50); v Senju fãrbat (SR 29), v Novem Vinodolskem fārbät (RČGNV $60)$.

2 V vseh krajih se pridevnik uporablja tudi za lase, s pomenom „siv”: åíb peri „sivi lasje”. 


\section{Rdeč, rdeča, rdeče}

V Šušnjevici smo zapisali rojsu, rojse, rojso; rojsi, rojse, rojsi prid., v Novi vasi rojšu, rojšs, rojšo; rojši, rojše, rojši prid., v Trkovcih in Mihelih rojšu, rojše, rojšo; rojši, rojše, rojši prid., v ostalih vaseh rojšu, rojša, rojšo; rojši, rojše, rojši prid., v Škabićih mn. za m. in ž. tudi rojš.

Byhan navaja róisis (IrG 329), Puşcariu rois, -ę (TIr 323), Maiorescu roişu, roişie, roşu (VIr 145), Popovici roiss, -ę (DRI 145), Cantemir róişu, -e (TIr 178), Sârbu in Frățilă roişu, - $a$ (DIr 268), Kovačec za juž. v. róíisu, róişse, róişso (IrHR 167).

Domača beseda: dr. róşu, -ie (DEX 934), ar. aróşu, aróşe (DDAr 150), mr. roş, $-\breve{a}(\mathrm{DMr} 251)<$ lat. rŏseus, REW 7379.

\section{Rumen, rumena, rumeno}

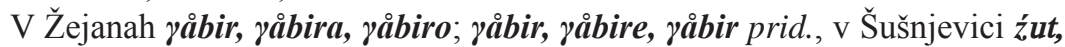

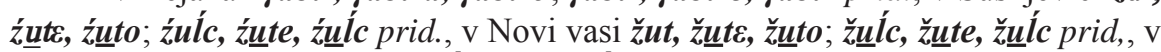

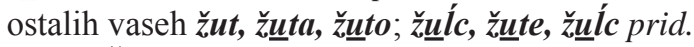

Žejanski izraz je domač [v ir. glosarjih, ki so nam na razpolago, beremo: gabir, gabiră, pl. gabiri, gabire (VIr 125), gåbir, gåbu (DRI 111), gábir, -e (TIr 166), gåbir, -a (DIr 214)], prisoten tudi v drugih romunskih narečjih: dr. gálben, -ă,

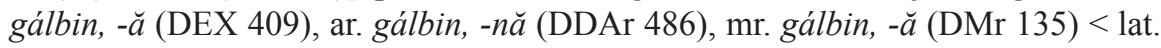
galbĭnus, REW 3646.

Termini tipa žut [Byhan je zapisal žut (IrG 396), Popovici jut, -ă (DRI 118), Cantemir jut, -o, -e (TIr 169), Sârbu in Frațilă jut, -a, -o (DIr 221), Kovačec žut, -e, žult (IrHR 230 - za Šušnjevico)] so izposojeni iz čakavskih govorov: npr. v Brgudu žüt, - $a$, -o, v Čepiću žût, - $a$, -o (IrLA 309), v Senju žût, žutä, žûto (SR 181) itd. itd. < pslovan. *žblţ (SES 765, s. v. žộlt).

\section{Moder, modra, modro}

V Žejanah smo zapisali modor, modra, modro; modri, modre, modri prid., v Šušnjevici in Novi vasi blåv, blåve, blåvo; blåvi, blåve, blåvi prid., v ostalih vaseh blåv, blåva, blåvo; blåvi, blåve, blåvi prid.

Žejanski kromonim modər [Sârbu in Frățilă sta zapisala modru, - $a$, -o (DIr 230), Kovačec za Žejane módar, módra, -dri (IrHR 119)] je izposojen iz čakavskih govorov: npr. v Brgudu in Senju mödar, $-a,-o($ IrLA 310; SR 77) < pslovan. *modr (SES 350, s. v. mọ́der).

Tudi termini tipa blav [Popovici je zapisal blåv, -e (DRI 93), Cantemir blav, -e (TIr 159), Sârbu in Frățilă blav, - $a$ (DIr 192)] so čakavizmi: npr. v Čepiću blôv, -a, -o (IrLA 310), v Pićnu blòvo (PI 14), v Orbanićih blãvi (ČDO 419). M. Snoj za sln. pläv, pláva „moder” piše „Prevzeto iz bav. nem. plau, kar ustreza knjiž. nem. blau 'moder' (...) To se je razvilo iz stvnem. blāo, kar je sorodno z lat. flāvus 'zlatorumen, blond' (...) germ. beseda je torej prvotno morala pomeniti *'svetlomoder'." (SES 451), Skok pa poleg creškega pridevnika blaviten ,modrikast” pravi: „,unakrštanjem frank. blao s domaćim plavetın ๖, izvedenica od plav (...), srlat. blavus $>$ tal. biavo. Možda je plâv (16-17.) dobio značenje «modar» mjesto «žut, nažut, žućkast» unakrštanjem slavenske i romanske riječi franačkog postanja." (SKOK I/169). Menimo, da je čakavske oblike tipa blav možno razlagati ali kot ostanke 
iz predbenečanskih romanskih jezikovnih plasti, ki ustrezajo ben. biavo „azzurro” (BOE 79), biavo (VG 90 - za Grado in Piran) < lat. blavum (VEI 131, s. v. biavo) $<$ fran. blao, REW 1153, ali pa kot germanizme.

\section{Zelen, zelena, zeleno}

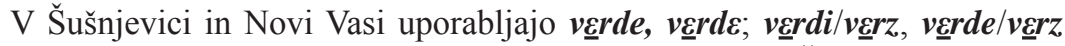
prid., v ostalih vaseh verde, verde; verdi, verde/verdi prid., v Šušnjevici in Novi vasi tudi zelen, zelene, zeleno; zelen, zelene, zelen prid., $\mathrm{v}$ ostalih vaseh pa tudi zelen, zelẹna, zeleno; zelen, zelene, zelen prid.

$\mathrm{V}$ vseh vaseh uporabljajo torej domač in tuj izraz; tujka je pogostejša, domača beseda pa prevladuje v besednih zvezah (npr. v Šušnjevici in Novi vasi verde gušćerice „,zelenec (Lacerta viridis)”).

Kromonimi tipa verde so domači [vęrde (IrG 380), verde, mn. verzi (VIr 156), verde (TIr 185), vęrde za Žejane (IrHR 212)] < lat. *vĭrdis, REW 9368a.2 > dr. vérde (DEX 1156), ar. veárde (DDAr 1106), mr. veárdi (DMr 324), viărd (DMr 325).

Tip zelen [zelen, - $a$, -o (DIr 304), zelén, -ę za Šušnjevico in Brdo in zelén, - $a$ za Žejane (IrHR 224)] je izposojen iz čakavskega narečja: npr. v Brgudu in Čepiću zelën, - a, -o (IrLA 311) itd. itd. < pslovan. *zelenz (SES 746).

\section{Rjav, rjava, rjavo}

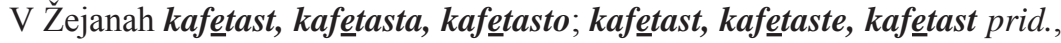

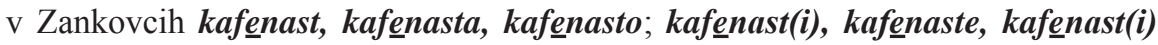

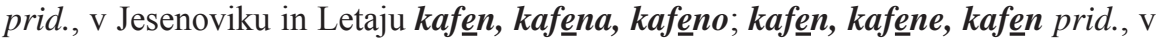

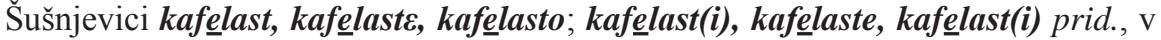
ostalih vaseh in Šušnjevici pa smo zapisali pomensko zvezo kolür kafe.

Kromonimi tipa kafen, kafetast, kafelast [samo Sârbu in Frăţilă imata izraz za barvo: cafeno (DIr 195) - oblika za sr.] so prevzeti iz čakavskih govorov: kafën, $-a,-o$ (povsod po Dalmaciji in Istri), kafëtast, kafëlast (v mnogih istrskih krajih), izpeljanke od čak. kafë, kafël, kafët ${ }^{3}$ (povsod po Istri) ${ }^{4}<$ ben. cafè $($ BOE 114$)<$ turš. kahve < arab. qahvah (SES, s. v. káva).

Tudi pomenska zveza kolur kafe je prevzeta iz čakavskih govorov: kolûr/ kolôr kafë (v mnogih istrskih krajih). Za kolur glej 1.

\section{Pomarančast, pomarančasta, pomarančasto}

$\mathrm{V}$ Žejanah smo slišali narančcast, narančasta, narančasto; narančast, narančaste, narančast prid., v Šušnjevici naråncast, naråncaste, naråncasto;

3 Slednji dve besedi z ben. pomanjševalno pripono.

4 Istroromuni so si od čakavskih sosedov izposodili tudi besedo za kavo: v Žejanah smo

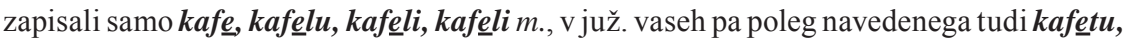
kafẹtu, kafeti, kafẹti m. - v virih: cafée (IrG 236), café (SIr 565), café (TIr 160), cafè (DRI 95), cafe, cafet (DIr 195). Dr. cafeá (DEX 124), ar. café (DDAr 237), mr. cafè (DMr 54) so direktne izposojenke iz turščine, Istroromuni pa so se od romunskega etničnega korpusa ločili pred pojavom turcizmov (kakor tudi grecizmov), zato moramo predpostaviti, da so kavo spoznali šele na tej strani Donave. 
- naråncast, naråncaste, naråncast prid., v Novi Vasi narånčast, narånčaste, narånčasto; narånčast, narånčaste, narånčast, v ostalih juž. vaseh narånčast, narånčasta, narånčasto; narånčast, narånčaste, narånčast prid.

Navedene besede so prevzete iz čakavščine: narančast, $-a$, - o (povsod po Istri in Dalmaciji), izpeljanka od narânča, ,pomaranča” (povsod po Istri in Dalmaciji) ${ }^{5}<$ ben. naranza (BOE 436) < perz. nāräng, REW $1653 .^{6}$

\section{Siv, siva, sivo}

V Žejanah, Jesenoviku, Letaju, Brdu, Škabićih in Trkovcih rečejo sivvast, sivvasta, sivvasto; sivvast, sivvaste, sịvast prid., v Šušnjevici in Novi vasi sịvast, sịvaste, sịvasto; sịvast, sịvaste, sịvast prid., v Mihelih in Kostrčanu sịvast, sịvaste, sịvasto;

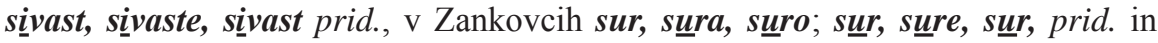
surast, surasta, surasto; surast(i), suraste, surast(i) prid.

Samo Popovici in Kovačec imata izraz za barvo, ki nas zanima: sur, surast, -e (DRI 153); sívast, -ę za Šušnjevico in Brdo, sívast, - a za Žejane „siv (o laseh)” (IrHR 177).

Kromonimi tipa sivast so prevzeti iz čakavskih govorov: sîv, sïvast (povsod po Istri in Dalmaciji) < pslovan. *sivъ (SES 570).

Izraze tipa sur (ki so enaki čakavskim oblikam tipa sûr) pa so Istroromuni najbrž že imeli v svojem besednem zakladu še pred prestopom Donave: dr. sur, - $\breve{a}$ (DEX 1046), sur, -ə (IrLA 314 - v Rudni Glavi ${ }^{7}$ ), izposojeno ali iz srbščine ali iz bolgarščine (v ar. in mr. ni podobnih oblik za ,siv”). Izrazi na -ast (surast) so prevzeti iz čakavskih govorov. Globlja etimologija pridevnika ni najbolj jasna. ${ }^{8}$

\section{Vijoličast, vijoličasta, vijoličasto}

V Šušnjevici, Novi vasi in Jesenoviku vijola prid., neskl., v ostalih vaseh vijolast, vijololasta, vijolasto; vijolast, vijôlaste, vijolast prid.

$\mathrm{V}$ ir. glosarjih, ki so nam na voljo, ne najdemo ustreznih kromonimov. Zabeleženi izrazi so prevzeti iz čakavskih govorov: npr. v Čepiću vijôla, v Brgudu vijöličasta (IrLA 315), v Orbanićih vijuôlas (ČDO 583), v Pićnu vijòlas (PI 126), v Novem Vinodolskem vijõlast (RČGNV 342), izpeljanke iz rastlinskega imena ${ }^{9}$ tipa vijola ,vijolica (Viola odorata)"10 [npr. v Vrgadi vijôla (RGV 231), v Dračevici na otoku Braču vijộla (ČL 1323)] < viòla (BOE 795) < lat. viǒla, REW 9357.

5 Istroromuni so od čak. sosedov prevzeli tudi fitonim (za drevo in plod): v Žejanah smo slišali narånže, -a, narånže, -ele ž., v Šušnjevici narånce, -a, narånc, -ele ž., v Novi vasi narånč $\mathrm{v}$ ostalih juž. v. narånče, -a, -e, -ele ž. - Byhan je zapisal narôntŝse (IrG 286), Cantemir naránce $($ TIr 172) < čak. narânča, narânža.

${ }^{6}$ Možno je, da sta kromonim narančast in fitonim naranča $\mathrm{v}$ čak. govore prevzeta iz knjiž. hrvaščine, ali pa sta se oblikovala naslonjena nanje, kar je bolj verjetno.

7 Rudna Glava je mestece v Srbiji (pri Majdanpeku) s pretežno romunskim prebivalstvom.

8 Glej SKOK III/363 in ESSJ III/342.

9 Prim. v Valturi kolôr lübitsa (ILA 315).

${ }^{10}$ Kot fitonim uporabljajo Istroromuni pomanjševalnico od vijola: v Žejanah, Jesenoviku, 
12. Sinji, sinja, sinje

V Žejanah in Šušnjevici smo zapisali celeste prid., neskl., v Mihelih blåvast, blåvasta, blåvasto; blåvast, blåvaste, blåvast prid., v ostalih vaseh čeleste prid., neskl.

Nesklonjiv pridevnik $c(\check{c})$ eleste je izposojen iz čakavskih govorov: npr. v Valturi in Orbanićih čelěšte (ILA 316; ČDO 428). V čak. govorih je beseda prevzeta ali iz knjiž. italijanščine [(it. celeste ,nebesen, barva neba” (DLI-cd) < lat. caelěstis, REW 1465] ali prek istrobeneških govorov (npr. v Pulju če'lešte ILA 316), kjer je tudi iz knjiž. it.

Tudi kromonimi tipa blåvast so prevzeti iz čak. govorov: npr. v Čepiću blävičasta (IrLA 316), v Orbaničih blavï̌̌as (ČDO 419), izpeljanke na -ast od blav (glej 6.).

\section{Roza}

V Novi vasi, Zankovcih, Mihelih in Kostrčanu smo slišali roza prid., neskl., v Žejanah, Brdu, Škabićih in Trkovcih rozast, rozasta, rozasto; rozast, rozaste, rozast prid., v Šušnjevici sintagmo kolür roza.

$\mathrm{V}$ ir. glosarjih, ki so nam na voljo, ne najdemo ustreznih kromonimov.

Navedeni ir. termini so izposojeni iz čakavskih govorov: npr. v Brgudu, Čepiću, Svetvinčentu in Valturi rôza (IrLA 317), v Svetvinčentu in Ližnjanu rôža (ILA 317). Čakavski izrazi so izposojeni iz beneških govorov: ben. colòr de ròsa (BOE 583, s. v. rosa), dobesedno ,barva od vrtnice” (de < lat. de, REW 2488; ròsa $<$ lat. rŏsa, REW 7375; za color glej 1.) - tudi v mnogih čakavskih govorih v Istri uporabljajo sintagmo kolôr de rôza; od tod šušnjevski kromonim.

\section{Pisan, pisana, pisano}

V Jesenoviku, Letaju, Brdu, Trkovcih in Mihelih smo zapisali šårast, šårasta, šårasto; šårast(i), šåraste, šaråst(i) prid., v Šušnjevici sarast, saraste,

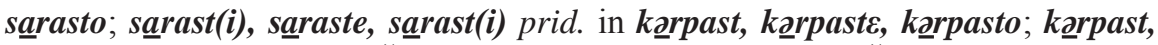
korpaste, korpast prid., v Žejanah čuda farbe, v Novi vasi, Škabićih, Zankovcih

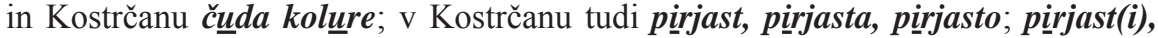
pirjaste, pirjast(i) prid.

$\mathrm{V}$ ir. slovarjih in glosarjih, ki jih uporabljamo ne najdemo ustreznih kromonimov.

Nazivi tipa šarast so izposojeni iz čakavskih govorov: šâr(ast) (povsod po Istri in Dalmaciji) < slovan. *šarъ, ,barva” - ,verjetno zgodnja izposojenka iz turš. jezikov" (SES 627, s. v. šâr).

Letaju, Brdu, Škabićih, Trkovcih, Mihelih in Kostrčanu smo zapisali vijolica, -a, -e, -ele $\check{z}$., v Šušnjevici in Novi vasi vijolice, -a, -e, -ele ž. [fitonim navaja samo Popovici: violițe (DRI 164)], izposojeno iz čakavskih govorov: npr. v Brgudu in Čepiću vijölica (IrLA 1881), v Orbanićih vijuôlica (ČDO 583), v Pićnu vijòlice mn. (PI 126), v Labinu vijôlica (RLC 200), v Dračevici vijộlica (ČL 1323). V Mihelih smo zabeležili samo drugo izposojenko iz čakavščine, ĺubica, -a, -e, -ele ž., v Žejanah pa poleg vijolica tudi lúbičica, -a, -e, -ele ž:: npr. v Svetvinčentu in Čabrunićih ĺübitsa, v Valturi lubĩtsa, v Ližnjanu ĺubičĩtsa (ILA 1881) < pslovan. *l'ивъ (SES 306). 
Tudi kromonimi tipa karpast so prevzeti iz čakavščine: čak. körpast, izpeljano na -ast iz körpa (povsod po Istri in Dalmaciji) ${ }^{11}<$ pslovan. *kъrpa (SES 279). Kromonim je metaforičen.

Prid. pirjast so Istroromuni prevzeli šele v Istri: pirihast „pisan” „govori se samo u Istri." (ARJ IX/864), pïrihast (ID 199, s. v. pïrih), p̈̈rihastega ${ }^{12}$ adj 'spotted, many-coloured' (said of a pig); Pïriha (ime ovce) (ČDO 519) ${ }^{13}$. Marko Snoj za sln. pirh ${ }^{14}$ povzema Bezlaja (ESSJ III/39, s. v. píruh): „Prvotni pomen je *rdeče obarvan, obarvan z barvo ognja' (...) Pslovan. *pyriti je pomenilo 'kuriti' (...)” (SES 445).

Sintagmi čuda farbe in čuda kolure sta lahko nastali znotraj istroromunščine. Prvi element čudda „mnogo” prisl. [v Novi vasi smo zapisali ču $\underline{u} d \boldsymbol{\varepsilon}$ prisl., v Šušnjevici

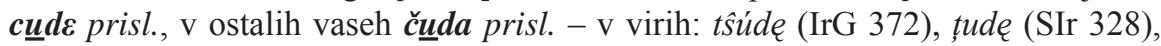
ciudă (VIr 117), čúda (TIr 162), čude,-a, -o (DRI 106), čúda (TIrG 161), čúda, čúdę, túdę (IrHR 63)] je izposojen iz čakavskih govorov: čudo, čuda (Istra, Dalmacija), prislov nastal iz samostalnika čudo < pslovan. *čudo (SES 77). V Istri uporabljajo v glavnem obliko čuda, v Dalmaciji pa predvsem drugo: npr. v Labinu cūda (RLC 65), v Pićnu čùda (PI 21), v Orbanićih čüda (ČDO 430); v Vrgadi, Kukljici, Rivnju, Salih čüdo (RGV 38; RGK 44; RRG 72; RGS 58). Za farbe in kolure glej 1.

\section{Zaključek}

Od štirinajstih obdelanih kromonimov je šest (42,8 \%) domačih: åb, yåbir, negru, rojšu, sur (poleg hibridnega termina surast) in $v \underline{\varepsilon} r d \varepsilon$. Ostali so prevzeti iz čakavskih govorov; med njimi je sedem beneških izposojenk v čakavščini in en kromonim (blåv), ki bi ga lahko imeli za ostanek iz predbeneških jezikovnih plasti.

\section{Kazala}

\section{Kazalo romunskih izrazov}

\section{A. Istroromunski:}

a. ki smo jih sami zabeležili: åb -2 .

\author{
åĺb peri - b3 \\ blåv -6 . \\ blåvast -12 . \\ celeste -12 . \\ cund $\varepsilon-14$. \\ čeleste -12 .
}

\author{
čuda -14 . \\ čuda farbe -14 . \\ čúda kolure -14 . \\ čude -14 . \\ farba -1 . \\ farbej - b2
}

${ }^{11}$ Istroromuni so si izposodili tudi apelativ: mi smo v Šušnjevici in Novi vasi zapisali

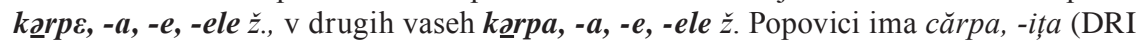
98), Cantemir cărpe, - $a$ (TIr 161), Kovačec cấrpa, -e za Žejane (IrHR 48).

${ }^{12}$ Tožilnik je naveden kot geslo; imenovalnik pïrihast je verjetno pomotoma opuščen.

${ }^{13}$ Mi smo samostalniške izpeljanke iz tega pridevnika zabeležili samo kot lastna imena za

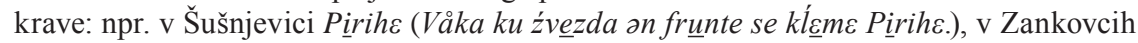
Piriha < čak. P̈̈riha „krava z rdečimi lisami” (ID 199), Pirih „,pisan vol”, Piriha ,pisana krava" (ARJ IX/864).

${ }^{14}$ Enako je čak. pirih „crvena pisanica” (ID 199); pirih „pisanica (uskršnje jaje)” (ARJ IX/864). 
yåbir -5

kafelast -8 .

kafe - b5

kafen -8 .

kafenast -8 .

kafetast -8 .

kafetu - b5

kərpa - b12

kərpast - 14 .

kərp $\varepsilon-b 12$

kolorgj-b2

kolores - b2

kolür -1 .

kolur kafe -8 .

kolur roza -13 .

lúbica - b11

lúbičica - b11

modər -6 .

naråncast -9 .

narånc $\varepsilon-\mathrm{b} 6$

narančast -9 .

narånčast -9 .

narånče $-\mathrm{b} 6$

narånč $\varepsilon-b 6$

narånže $-\mathrm{b} 6$

negru -3 .

ne $\gamma r u-3$.

pirjast -14 .

rojsu -4 .

rojšu -4 .

roza -13 .

rozast -13 .

sarast -14 .

sivast -10 .

sur -10 .

surast -10 .

šårast -14 .

verde -7 .

verde - 7 .

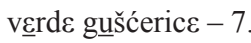

vijola - 11 .

vijolast - 11 .

vijolica - b11

vijolice - b11

zelen -7 .

žut -5 .

źut -5 .

b. iz virov:

$\mathrm{ab}-2$. åb -2 .

åbo de ócl'u -2 .

blav -6 .

blåv -6 .

cafe - b5

café - b5

cafè - b5

cafę - b5

cafeno -8 .

cafet - b5

cărpa - b12

cărpe - b12

cấrpa - b12

cúúda - 14 .

ciudă -14 .

colur -1 .

čúda - 14 .

čûdę - 14 .

čude -14 .

farbă -1 .

gabir -5 .

gábir -5 .

gåbir -5 .

jut -5 .

koloręi - b2

naránce - b6

naróntŝę - b6

módar -6 .

modru -6 .

néghru -3 .

negru -3 .

négru -3 .

néүru -3 .

$\mathrm{Qb}-2$.

rois -4 .

róísu -4 .

roiş -4 .

róî́ -4 .

roiş̧u -4 .

róişu - 4 .

sívast -10 .

sur -10 .

surast -10 .

tŝúdę - 14 .

țûdę - 14 .

țud $\varepsilon-14$.

ŭab -2 .

verde -7 .

verde -7 .

vęrde -7 . violițe - b11

zelen -7 .

zelén -7 .

žut -5 .

\section{B. Iz drugih romunskih} narečij:

a. dakoromunščina:

alb -2 .

cafeá - b5

gálben -5 .

gálbin -5 .

négru -3 .

róşu -4 .

sur -10 .

vérde -7 .

b. aromunščina:

albu -2 .

álbu -2 .

aróşu -4 .

café - b5

gálbin -5 .

négru - 3 .

veárde -7 .

c. meglenoromunščina:

$\mathrm{alb}-2$.

cafè $-\mathrm{b} 5$

gálbin -5 .

négru -3 .

roş -4 .

veárdi -7 .

viărd -7 .

\section{Kazalo izrazov v dru- gih idiomih}

\section{A. Čakavski:}

a. ki smo jih sami zabeležili:

čuda -14 .

čudo -14

kafề -8 .

kafël -8 .

kafëlast -8 .

kafền -8 .

kafèt -8 .

kafëtast -8 .

kə̈rpa -14 . 
kə̈rpast - 14 .

kolôr de rôza - 13 .

kolôr kafē - 8 .

kolûr kafề -8 .

naranča $-\mathrm{b} 7$

narânča $-9 .$, b6

narančast $-9 ., \mathrm{b} 7$

narânža - b6

sîv -10 .

sïvast -10 .

šâr - 14 .

šârast - 14 .

b. iz virov:

blãvi -6 .

blavǐčas -12 .

blävičasta -12 .

blavìten -6 .

blôv -6 .

blòvo $-6 .-14$.

cūda -14 .

čelëšte -12 .

čùda -14 .

čüda -14 .

čüdo -14 .

färba -1 .

fãrba -1 .

fãrbat - b2

fārbät - b2

kolôr -1 .

kolòr -1 .

kolôr lûbitsa - b10

koloràt - b2

kolorät - b2

kolorievät - b2

kolorìvat - b2

kolûr - 1 .

ĺubičĩtsa-b11.

Íübitsa - b11

lubĩtsa - b11

mödar -6 .

pirih - b14

pìrih - b14

Pirih - b14

Piriha-b14
Pïriha - 14., b14

pirihast -14 .

pìrihast -14

pìrihast - b13

rôza - 13 .

rôža -13 .

vijôla -11 .

vijộla - 11 .

vijòlas -11 .

vijõlast -11 .

vijôlica - b11

vijộlica - b11

vijölica - b11

vijòlice - b11

vijöličasta -11 .

vijuôlas -11 .

vijuôlica - b11

zelën -6 .

žüt -5 .

žût -5 .

\section{B. Slovenski:}

pläv -6 .

pírh -14 .

C. Italijanski:

a. beneški:

biavo -6 .

cafè -8 .

color - 1., 13.

colòr de ròsa -13 .

de -13 .

naranza -9 .

ròsa -13 .

viòla -11 .

b. istrobeneški:

če'lešte -12 .

c. iz knjiž. it.:

celeste -12 .

D. Nemški:

blau -6 .

plau -6 .
III. Kazalo končnih etimonov

A. Latinski:

albus -2 .

blavun -6 .

blavus -6 .

caelěstis -12 .

cŏlor -1 .

de -13 .

galbĭnus -5 .

nĭger -3 .

rŏsa -13 .

rŏseus -4 .

*vĭrdis -7 .

viŏla - 11

B. Slovanski:

*čudo - 14

*kъrpa -14.

*modrъ -6 .

*pyriti - 14.

*sivъ -10 .

*šarı -14 .

*zelenъ -7 .

*žbltъ -5 .

C. Iz drugih jezikov:

a. srednja visoka nemščina:

Farbe -1 .

b. frankovščina:

blao -6 .

c. turščina:

kahve -8 .

d. arabščina:

qahvah -8 .

e. perzijščina:

nāräng -9 . 


\section{Viri in literatura}

ARJ - Rječnik hrvatskoga ili srpskoga jezika, I-XXIII, JAZU (danes HAZU) Zagreb, 1880-1976.

BOE - Giuseppe Boerio, Dizionario del dialetto veneziano, Martello Editore, Milano, 1971. (ponatis beneške izdaje iz 1. 1856).

ČDO - Janneke Kalsbeek, The Čakavian Dialect of Orbanići near Žminj in Istria, Editions Rodopi B. V., Amsterdam - Atlanta, 1998.

ČL - Mate Hraste \& Petar Šimunović, Čakavisch-deutches Lexicon, knj. I, Böhlau Verlag, Köln - Wien, 1979.

DAr - Matilda Caragiu Marioțeanu, Dicționar aromân, I (A-D), Editura Enciclopedică, Bukurešta, 1997.

DDAr - Tache Papahagi, Dicționarul dialectului aromîn, Editura Academiei Republicii Populare Romîne, Bukurešta, 1963.

DIr - Richard Sârbu \& Vasile Frațilă, Dialectul istroromân, Editura Amarcord, Temišvar, 1998.

DLI-cd - Giacomo Devoto \& Gian Carlo Oli, Il Dizionario della Lingua Italiana, Firenze, 2003. (izdaja na CD-ju)

DMr - Theodor Capidan, Meglenoromâni III, Dicționar meglenoromân, Bukurešta, brez letnice izdaje.

DRI - Josif Popovici-Dialectele romîne, IX: Dialectele romîne din Istria, partea a $2^{\text {A }}$ (texte şi glosar), Halle A. D. S., Editura autorului, 1909.

ESSJ - France Bezlaj, Etimološki slovar slovenskega jezika (I-IV), Ljubljana, 1977, 1982, 1995, 2005.

ID - Josip Ribarić, O istarskim dijalektima, Pazin, 2002.

IE - Istarska enciklopedija, Zagreb, 2005.

ILA - Goran Filipi \& Barbara Buršić Giudici, Istriotski lingvistički atlas, Znanstvena udruga Mediteran, Pulj, 1998.

IrG - Arthur Byhan, Istrorumänisches Glossar, u Iahresbericht des Instituts für rumänische Sprache, IV, Leipzig, 1899, str. 174-396.

IrHR - August Kovačec, Istrorumunjsko-hrvatski rječniks gramatikom i tekstovima, Znanstvena udruga Mediteran, Pulj, 1998.

IrLA - Goran Filipi, Istrorumunjski lingvistički atlas / Atlasul Lingvistic Istroromân / Atlante Linguistico Istrorumeno, Pulj, 2002.

PI - Šime Ružić Sudčev, Pićan i pićònski idiomi, C. A. S. H., Pulj, 1999.

RČGNV - Josip M. Sokolić - Kozarić, Gojko M. Sokolić - Kozarić, Rječnik čakavskog govora Novog Vinodolskog, Rijeka - Novi Vinodolski, 2003.

REW - W. Meyer-Lübke, Romanisches etymologisches Wörterbuch, Heidelberg, 1972.

RGK - Tomislav Maričić Kukljičanin, Rječnik govora mjesta Kukljice, Matica hrvatska, Zadar, 2000.

RGS - Ankica Piasevoli, Rječnik govora mjesta Sali, Zadar, 1993.

RGV - Blaž Jurišić, Rječnik govora otoka Vrgade, II, JAZU (danes HAZU) Zagreb, 1973.

RLC - Marijan Milevoj, Gonan po nase (rječnik labinske cakavice), Labin, 2006. 
$4 \quad$ RRG - Ladislav Radulić, Rječnik rivanjskog govora, Zadar, 2002.

SES - Marko Snoj, Slovenski etimološki slovar, Ljubljana, 1997.

SIr - Sextil Puşcariu, Studii istroromâne, III, Cvltvra Naţională, Bukurešta, 1929.

SKOK - Petar Skok, Etimologijski rječnik hrvatskoga ili srpskoga jezika, I-IV,

JAZU (danes Hazu) Zagreb, 1971-1974.

SR - Milan Moguš, Senjski rječnik, Zagreb - Senj, 2002.

TIr - Traian Cantemir, Texte istroromîne, Editura Academiei Republicii Populare Romîne, Bukurešta, 1959.

TIrG - Richard Sârbu, Texte istroromâne şi glosar, Tipografia Universității din Timişoara, Temišvar, 1992.

VG - Enrico Rosamani, Vocabolario giuliano, LINT, Trst, 1999.

VIr - Ioan Maiorescu, Itinerario in Istria e vocabolario istriano-romeno, Edizioni Parnaso, Trst, 1996.

\section{Denumirea culorilor în istroromână}

Rezumat

Prezenta lucrare tratează denumirea culorilor în istroromână. Istroromâna este unul din cele patru dialecte istorice româneşti, cu cel mai mic număr de vorbitori (nu peste 200). Dialectul rezistă încă în 11 localități din Monte Maggiore (Učka): Jeiăn, Susnievița, Nosela, Sucodru, Letai, Bărda, Şcabici, Tărcovți, Zancovți, Miheli şi Costărcean. Au fost redactate 14 numiri de culori (şi câteva forme care au, într-un oarecare fel, legătură cu cuvintele în chestiune). Materialul a fost cules de autor în ultimii 20 de ani (şi a fost în bună parte publicat în IrLA - ca atare). In afară de termeni istroromâni culeşi de autor, au fost tratate şi formele din dicționarele şi glosarele istroromâne pe care el le posedă. Alături de fiecare termen tratat este dată şi propunerea soluției etimologice la care se ajunge comparând formele istroromâne cu cele asemănătoare din dialectele ceacaviene, slovene şi venete, sau, dacă forma istroromână este moştenită din latină sau vechea slavă cu cele corespunzătoare dacoromâne, aromâne şi meglenoromâne. Printre cele 14 denumiri de culori tratate $6(42,8 \%$ ) aparțin lexicului moştenit din latină sau veche slavă: åb, åbir, negru, rojšu, sur (alături de forma hibridă surast) şi verrde. Celelate sunt împrumutate din graiurile ceacaviene, în care, 7 dintre ele provin din venetă, iar cea de a opta (blåv) poate fi considerată ca o relicvă a straturilor lingvistice prevenete. La sfârşitul lucrării găsim trei indici: I. Indicele formelor româneşti; II. Indicele formelor din alte idiomuri; III. Indicele etimoanelor.

\section{Istro-Romanian chromonyms}

Summary

This article discusses the names of colours in the Istro-Romanian dialects of Istria. In addition to 14 chromonyms, selected terms connected with specific colours 
are analyzed. The vocabulary was collected over the last twenty years (the majority appears as material in the Istro-Romanian Linguistic Atlas, or IrLA). In addition to Istro-Romanian terms that the author recorded himself, forms from Istro-Romanian dictionaries and glossaries are consistently cited. Etymological information is provided for each term; these data were obtained by comparing the term with similar forms in the neighbouring Čakavian, Slovenian, and Venetian dialects. For native Istro-Romanian words, this information was established through comparison with similar words from the other three Romanian dialects (Daco-Romanian, Aromanian, and Megleno-Romanian).

Goran Filipi

Univerza na Primorskem, Znanstvenoraziskovalno središče Koper

Garibaldijeva ul. 1, 6000 Koper

goran.filipi@zrs-kp.si 



\title{
Uvid u hrvatsku toponimiju na sjeverozapadnoj međi
}

\author{
Anđela Frančić (Zagreb)
}

IZVLEČEK: Toponimija najbolj severozahodne hrvaške pokrajine Medžimurje do danes še ni bila popisana in ustrezno obdelana. Po kratkem orisu dosedanjih obravnav medžimurske ojkonimije in prikazu nekaj primerov sprememb ojkonimov skozi zgodovino avtorica v glavnih potezah prikaže morfološke, besedotvorne in pomenske značilnosti sodobne uradne medžimurske ojkonimije.

\begin{abstract}
An Insight into Croatian Toponymy on the Northern Border ABSTRACT: The toponymy of Medimurje, the northernmost Croatian county, still has not been catalogued or systematically dealt with. Following a brief review of studies of Medimurje toponymy to date and some examples of historical changes of toponyms, the author sketches out the morphological, word-formative, and (domain) semantic features of current official Međimurje toponyms.
\end{abstract}

\section{Uvod}

Od 17. st., u koje sežu počeci hrvatskih onomastičkih istraživanja, do danas popisano je i obrađeno podosta toponimijske građe. Zahvaljujući dosad objavljenim radovima hrvatskih i inozemnih onomastičara, sve je manje bjelina na hrvatskome toponomastičkom zemljovidu. Među nedovoljno istražena područja, kad je o toponimiji riječ, ulazi i Međimurje, najsjeverozapadnija hrvatska pokrajina omeđena hrvatsko-mađarskom državnom granicom, hrvatsko-slovenskom državnom granicom te rijekom Dravom. Međimurje ima $724 \mathrm{~km}^{2}$ površine a u njegovih 129 današnjih naselja, od kojih tri imaju status grada, živi oko 120000 stanovnika.

Polazeći od najstarijih u povijesnim dokumentima zasvjedočenih potvrda te oprimjerujući samo neke od mnogobrojnih promjena međimurskoga ojkonimikona od 13. stoljeća do danas, u ovome ćemo radu prikazati suvremenu međimursku ojkonimiju s morfološkog, tvorbenog i semantičkog aspekta. U prikazu i opisu građe služit ćemo se ovim ojkonomastičkim terminima: ojkonim (ime naselja), astionim (ime grada), komonim (ime sela), ojkonimija (ukupnost ojkonima nekoga 
područja), ojkonimski (koji se odnosi na ojkonim), ojkonimijski (koji se odnosi na ojkonimiju).

\section{Međimurska ojkonimija}

\subsection{Dosadašnja proučavanja}

Međimurska ojkonimija te toponimija uopće, izuzme li se horonim Međimurje, rijetko su bile predmetom znanstvenog istraživanja. Toponomastička bibliografija međimurskoga područja svodi se na samo nekoliko naslova, a bilješke i zapažanja o pojedinim ojkonimima nalazimo u većem broju radova čiji se autori tek usput, pišući o kojoj drugoj temi, dotiču pitanja postanka, etimologije ili preimenovanja nekog naselja. Među malobrojnim dosad objavljenim radovima o međimurskoj ojkonimiji posebno mjesto zauzima Muraköz helynevei (Budapest, 1934) Lászla Hadrovicsa. To je prvi i do danas najopsežniji, najpregledniji i najsustavniji rad o imenima međimurskih naselja. U sedamdesetak godina, koliko nas dijeli od nastanka Hadrovisceva rada, došlo je do mnogih promjena u međimurskoj ojkonimiji, neka Hadrovicseva tumačenja etimologije ojkonimijskog lika zahtijevaju korekcije, a popis ojkonima nadopunu.

\subsection{Terra beati Michaelis - najstariji potvrđen međimurski ojkonim}

Od najstarijih arheološkim nalazima zasvjedočenih tragova naseljenosti Međimurja u prapovijesnome neolitiku (Vidović 1989) do prvoga indirektnog spomena nekoga međimurskog lokaliteta u povelji kralja Stjepana Svetog iz 1024. (Kalšan 2006, 22-23) prošlo je više tisuća godina. Najstariji dosad nam poznati spomen imena nekoga međimurskog naselja sadrži listina u kojoj se prvi put izrijekom spominje i Međimurje. Riječ je o ispravi iz 1203. godine. U njoj se, kao i u mnogim poslije nastalim zapisima, Međimurje spominje opisno - «inter Muram et Dravam», a u sintagmi «terra beati Michaelis» prepoznajemo današnje međimursko naselje Mihovljan (Frančić 2000).

Ojkonimijske potvrde nalazimo u mnogobrojnim, dijelom još nedovoljno proučenim ispravama iz starijih razdoblja međimurske povijesti. Dragocjene podatke o međimurskim ojkonimima prošlog vremena pružaju nam, uz ostalo, najstariji popisi župa Zagrebačke biskupije (1334. i 1501.), kanonske vizitacije, shematizmi, urbari, popisi stanovništva, zemljovidi i drugi povijesni dokumenti.

\subsection{Međimurska ojkonimija kroz povijest}

Usporedbom povijesne i suvremene međimurske ojkonimije zapažamo mnogobrojne razlike. Neka su naselja nestala, a njihova imena čuvaju samo povijesni izvori (npr. Črnec, Nova Ves, Kota, Đurđanec, Svetošinec), neki su se ojkonimi tijekom vremena sasvim promijenili (npr. nekadašnji Bistric danas je Donji Vidovec, Pomorje je danas Sveti Martin na Muri, Altarec i Držimurec spojeni su u jedno naselje imena Sveta Marija), neka su manja naselja pripojena većim te im je ime izbrisano iz popisa međimurskih naselja koja imaju status samostalnog naselja (npr. Buzovec je danas u sastavu Čakovca, Benkovec je u sastavu Male Subotice, 
Gornji Vidovec je u sastavu Ivanovca), dio naselja uz slovensku granicu pripojen je Sloveniji (npr. Veščica, Globoko, Gibina, Razkrižje) te njihova imena ne ulaze u suvremeni međimurski ojkonimijski sustav, prijašnji i sadašnji ojkonim nerijetko se djelomično razlikuju (npr. nekadašnji ojkonim Zasad danas je Zasadbreg, Sobotica je Mala Subotica, Brest je Podbrest, Dobrava je Donja Dubrava).

U povijesti je bilo i nasilnog aloglotiziranja, tj. mađariziranja međimurskih ojkonima (tako je npr. Mala Subotica u mađarskoj inačici postala Kis Szabatka, Orehovica je dobila ime Drávadiós, Stanetinec je preimenovan u Hataros, Trnovec u Drávamagyarad, Vugrišinec u Vargahegy, Pribislavec u Zalaujvár, Peklenica u Bányvár, Knezovec je nazvan Gyümolcsfalva, Jalšovec je postao Erzsebetlak). U vrijeme nasilnoga štokaviziranja svega neštokavskog međimurski ojkonimi s prepoznatljivim kajkavskim biljegom dobivaju «pravilniji» lik lišen «dijalektne devijacije» (npr. Peklenica se dekajkavizira u Paklenicu, Nedelišće se preimenuje u Nedjeljište, ime Čakovec mijenja se u Čakovac, Čukovec u Ćukovac, Ferketinec u Frketinac). Imena naselja nositelji su mnogih važnih jezičnih i izvanjezičnih obavijesti, te bi trebalo poštovati iskonski imenski lik, a ne nepotrebnim i neopravdanim promjenama svjedočiti o nebrizi preimenovatelja za imensku baštinu. Osim toga, svako preimenovanje rezultira višeimenošću, a svaka višeimenost krnji onomastičku obavijest i narušava komunikaciju.

Sudeći po zapisima imena međimurskih naselja u starijim dokumentima, nekad pluralni oblici nekih ojkonima s vremenom su singularizirani (npr. u listini iz 1598. spominju se «Vid Kerznarich z welikeh Mihelenecz ... Iuan Sgudlin z ternowecz ... Andr Mezar z maleh Mihalewecz ... Mihal ferlofetich z Lopatinec»») ${ }^{1}$ te je jedna od specifičnosti suvremene službene međimurske ojkonimije gotovo isključiva dominacija singularnih oblika (izuzetak su Pušćine, Celine i Slemenice), a pluralni se likovi mogu i danas čuti u neslužbenoj komunikaciji (npr. Idem v Mihaljefce, Bil sem v Vidofci).

\section{Uvid u suvremenu međimursku ojkonimiju}

Popis službenih međimurskih ojkonima² sadrži 127 ojkonima. Od toga 3 ojkonima pripadaju kategoriji astionima (Čakovec, Prelog, Mursko Središće), a ostala 124 ojkonima jesu komonimi.

\subsection{Međimurska ojkonimija s obzirom na broj riječi ojkonimskog znaka}

S obzirom na broj riječi, u međimurskoj ojkominiji dominiraju jednorječna imena. Ima ih 96 i čine 75\% ukupne ojkonimije. To su sljedeći ojkonimi:

Badličan, Banfi, Belica, Bogdanovec, Brezje, Brezovec, Bukovec, Celine, Cirkovljan, Čakovec, Čehovec, Čestijanec, Črečan, Čukovec, Dekanovec, Domašinec, Dragoslavec, Draškovec, Držimurec, Dunjkovec, Ferketinec,

1 Listine hrvatske, str. 307.

2 Pod službenim ojkonimom razumijevamo ime naselja koje ima status samostalnog naselja. 
Frkanovec, Gardinovec, Goričan, Grabrovnik, Gradišćak, Grkaveščak, Hemuševec, Hlapičina, Hodošan, Ivanovec, Jalšovec, Jurovčak, Jurovec, Kapelščak, Knezovec, Kotoriba, Krištanovec, Križovec, Kuršanec, Lapšina, Lopatinec, Macinec, Mačkovec, Marof, Martinuševec, Merhatovec, Mihovljan, Miklavec, Nedelišće, Novakovec, Oporovec, Orehovica, Otok, Palinovec, Palovec, Peklenica, Plešivica, Pleškovec, Podbrest, Podturen, Praporčan, Prekopa, Prelog, Preseka, Pretetinec, Prhovec, Pribislavec, Pušćine, Robadje, Selnica, Sivica, Slakovec, Slemenice, Stanetinec, Strahoninec, Strelec, Šandorovec, Šenkovec, Štefanec, Štrigova, Štrukovec, Totovec, Trnovec, Tupkovec, Turčišće, Vratišinec, Vrhovljan, Vučetinec, Vugrišinec, Vukanovec, Vularija, Zasadbreg, Zaveščak, Žabnik, Žiškovec.

Dvorječnih je ojkonima znatno manje od jednorječnih. Njih 27 čini 22\% ukupne međimurske ojkonimije. Riječ je o ovim ojkonimima:

Donja Dubrava, Donji Hrašćan, Donji Koncovčak, Donji Kraljevec, Donji Mihaljevec, Donji Pustakovec, Donji Vidovec, Donji Zebanec, Dragoslavec Breg, Dragoslavec Selo, Gornja Dubrava, Gornji Hrašćan, Gornji Koncovčak, Gornji Kraljevec, Gornji Kuršanec, Gornji Mihaljevec, Gornji Zebanec, Mala Subotica, Mali Mihaljevec, Mursko Središće, Okrugli Vrh, Savska Ves, Sveta Marija, Sveti Križ, Sveti Urban, Zebanec Selo, Železna Gora.

U suvremenoj međimurskoj ojkonimiji samo je jedan trorječni ojkonim (Novo Selo Rok) te tri četverorječna ojkonima (Novo Selo na Dravi, Sveti Juraj u Trnju, Sveti Martin na Muri).

Budući da je kraće ime funkcionalnije s gledišta jezične ekonomije, pretkaziva je pretežitost takvih ojkonima u ojkonimijskome sustavu.

\subsection{Rod, broj i sklonidba međimurskih ojkonima u službenoj komunikaciji}

Među međimurskim ojkonimima najviše je (76 \%) imena muškog roda, ojkonimi ženskoga roda čine $16 \%$ ojkonimije, a najslabije su zastupljena ( 8 \%) srednjorodna imena. Osim triju pluralnih ojkonima (Celine, Pušćine, Slemenice), svi ostali imaju singularni službeni lik. Jednorječni ojkonimi muškog roda završavaju uglavnom na suglasnik (izuzetak je Banfi). Svi se sklanjaju po singularnoj paradigmi $a$-sklonidbe, pri čemu se u imenima na -ec e gubi u kosim padežima (nepostojano e; npr. N Knezovec, G Knezovca), a ojkonim Banfi proširuje osnovu glasom -j- (G Banfija). Ojkonimi ženskog roda (završavaju na - $a$ ) sklanjaju se po singularnoj paradigmi e-sklonidbe (npr. N Lapšina, G Lapšine). Ojkonimi srednjeg roda, koji završavaju na -e, sklanjaju se po singularnoj paradigmi $a$-sklonidbe (npr. N Brezje, G Brezja). Pluralni ojkonimi ženskoga su roda te imaju pluralnu paradigmu $a$-sklonidbe (npr. N Celine, G Celina, D Celinama). Dvorječni ojkonimi pridjevno-imeničke strukture jesu muškog (npr. Donji Mihaljevec), ženskog (npr. Sveta Marija) ili srednjeg roda (npr. Mursko Središće). Pridjevna se sastavnica sklanja po pridjevnoj, a imenička po imeničkoj sklonidbi (npr. N Mursko Središće G Murskog(a) Središća). U imeničko-imeničkim strukturama prva se sastavnica ne sklanja (npr. N Dragosla- 
vec Breg, G Dragoslavec Brega). Trorječnomu te četverorječnima ojkonimima rod određuje druga sastavnica, a u sklonidbi se mijenjaju samo prve dvije sastavnice (npr. N Novo Selo Rok, G Novog(a) Sela Rok; N Sveti Martin na Muri, G Svetog(a) Martina na Muri).

Budući da se službeni ojkonimi kadšto razlikuju od neslužbenih, ta će različitost biti uzrokom različitih sklonidbenih paradigmi u kojima će se očitovati dijalektne morfološke odlike.

\subsection{Tvorbena analiza jednorječnih međimurskih ojkonima}

\subsubsection{Jednorječni neizvedeni ${ }^{3}$ ojkonimi}

Banfi, Brezje, Celine, Marof, Otok, Prekopa, Prelog, Preseka, Pušćine, Strelec

Većina ojkonima ove nevelike skupine nastala je onimizacijom, a samo dva ojkonima rezultat su transonimizacije prezimena (Banfi) i osobnog imena (Otok).

3.3.2. Jednorječni ojkonimi sufiksalne tvorbe (tvorbeni obrazac: $\mathrm{O}+-\mathrm{s}^{\mathbf{4}}$ ) $\mathrm{O}+$-ec (-ovec/-evec, -inec)

Bogdanovec, Brezovec, Bukovec, Čakovec, Čehovec, Čestijanec, Čukovec, Dekanovec, Domašinec, Dragoslavec, Draškovec, Držimurec, Dunjkovec, Ferketinec, Frkanovec, Gardinovec, Hemuševec, Ivanovec, Jalšovec, Jurovec, Knezovec, Krištanovec, Križovec, Kuršanec, Leskovec, Lopatinec, Macinec, Mačkovec, Martinuševec, Merhatovec, Miklavec, Novakovec, Oporovec, Palinovec, Palovec, Pleškovec, Pretetinec, Prhovec, Pribislavec, Slakovec, Stanetinec, Strahoninec, Šandorovec, Šenkovec, Štefanec, Štrukovec, Totovec, Trnovec, Tupkovec, Vratišinec, Vučetinec, Vugrišinec, Vukanovec, Žiškovec

Sufiks -ec (-ovec/-evec, -inec) najplodniji je sufiks međimurske ojkonimije. Najčešće se pridodaje antroponimskim osnovama (tip Bogdanovec) tvoreći sufiksalne izvedenice s posvojnim značenjem. Dodavanjem apelativnim, ponajčešće fitonimnim, osnovama (tip Brezovec) nastaju sufiksalne izvedenice s mjesnim značenjem. U tu skupinu ubrojit ćemo i ojkonim Štrigova pretpostavljajući da je riječ o eliptičnom ojkonimu nastalom izostavljanjem manje obavijesne sastavnice (toponimijskog apelativa).

Složenim sufiksom -evec izvode se ojkonimi čija osnova završava na palatal (Hemuševec, Martinuševec), ali i oni u kojima je završni glas osnove nepalatal (Jalšovec, Križovec), dok sufiks -inec sudjeluje u tvorbi od imena koja završavju na - a (tip Preteta $>$ Pretetinec, Staneta $>$ Stanetinec).

3 Za neke od navedenih ojkonima pretpostavili smo da su nastali onimizacijom apelativnih tvorenica, tj. da je do tvorbe došlo na apelativnoj razini (npr. Brezje; usp. Rječnik hrvatskoga ili srpskoga jezika, s.v. brezje) ili transonimizacijom antroponimske tvorenice (npr. Banfi). U potonjemu primjeru riječ je o današnjim korisnicima toga ojkonima neprepoznatljivome mađarskom patronimskom sufiksu, pa ojkonim nije opravdano tvorbeni raščlanjivati.

${ }^{4} \mathrm{O}=$ osnova, $\mathrm{s}=$ sufiks. 
Ostali sufiksi sudjeluju u tvorbi kudikamo manjeg broja imena međimurskih naselja:

-ica (-ice, -ovica): Belica, Orehovica, Peklenica, Plešivica, Selnica, Sivica, Slemenice;

-an (-čan, -ljan): Badličan, Cirkovljan, Črečan, Goričan, Hodošan, Mihovljan, Praporčan, Vrhovljan;

-čak (-ščak, -ovčak): Gradiščak, Grkaveščak, Jurovčak, Kapeľ̌čak;

-ina: Hlapičina, Lapšina;

-išće: Nedelišće, Turčišće;

-nik (-ovnik): Grabrovnik, Žabnik;

-ija: Vularija.

\subsubsection{Jednorječni ojkonimi prefiksalne tvorbe (tvorbeni obrazac: $\mathbf{p}-+\mathrm{O}^{5}$ ) \\ pod- + $\mathrm{O}$}

Podbrest, Podturen

Samo dva ojkonima nastala su prefiksalnom tvorbom. Oba su prvotno zabilježena u neprefigiranome liku - Brezth, Thurren (Buturac 1984).

\subsubsection{Jednorječni ojkonimi nastali ostalim tvorbenim načinima}

a) srastanjem: Zasadbreg - prvotno (1505.) potvrđen u liku Zazad (Hadrovics 1934), tek 1866. javlja se u današnjem liku. Vjerojatni razlog dodavanja toponimske imenice breg jest postizanje razlikovnosti. Naime, iste je godine zabilježen i ojkonim Zasadselo (Sabljar 1866);

b) prefiksalno-sufiksalnom tvorbom: Zaveščak.

\subsection{Dvorječni međimurski ojkonimi}

Među dvorječnim ojkonimima najviše je ojkonimskih parnjaka koji se razlikuju u samo jednoj (antonimnoj) sastavnici, koje su poredane tako da diferencijacijska prethodi identifikacijskoj (npr. Donja Dubrava, Gornja Dubrava). Neki ojkonimi koji u današnjoj službenoj ojkonimiji nemaju antonimski parnjak nekad su ga imali. Tako npr. Gornji Pustakovec, Gornji Vidovec, Veliki Mihaljevec danas pripadaju povijesnoj međimurskoj ojkonimiji. Povijesni dokumenti svjedoče o velikom broju ojkonima toga tipa koji danas ne pripadaju službenoj ojkonimiji (npr. Mali Banfi, Veliki Banfi, Mali Kozlovčak, Veliki Kozlovčak, Mali Slatnjak, Veliki Slatnjak). Među dvorječnim ojkonimima pretežu pridjevno-imeničke sintagme (tip Mala Subotica; 24 imena). Samo tri ojkonima imaju imeničko-imeničku strukturu (Dragoslavec Breg; Dragoslavec Selo, Zebanec Selo). Tvorbena analiza sastavnica dvorječnih ojkonima pokazuje da su imeničke sastavnice najčešće nastale sufiksalnom tvorbom (preteže sufiks -ec (-ovec/-evec, inec), npr. Donji Kraljevec).

Većina danas (službeno) dvorječnih ojkonima nije oduvijek bila dvorječne strukture, nego je nastala dodavanjem diferencijacijske sastavnice da bi se postigla razlikovnost među istoimenim naseljima. Tako su se npr. pridjevne sastavnice donji

${ }_{5} \mathrm{p}=$ prefiks, $\mathrm{O}=$ osnova. 
i gornji najvjerojatnije u 16. st. počele dodavati homonimnim imenima međimurskih naselja da bi se postigla jednoznačnost ojkonimskog znaka (Frančić 1995). Kad je riječ o dvorječnim ojkonimima sa sastavnicama gornji/donji/mala/mali/mursko u neslužbenoj se komunikaciji rabi isključivo jezično ekonomičniji, za pridjevni dio kraći lik (npr. umjesto Mala Subotica > Sobotica, umjesto Donji Miljaljevec $>$ Mihaljevec, umjesto Gornji Mihaljevec > Mihalovec).

Među dvorječnim ojkonimima tri su s pridjevnom sastavnicom sveta/sveti: Sveta Marija, Sveti Križ, Sveti Urban, a istu sastavnicu sadrže i dva četverorječna ojkonima: Sveti Juraj u Trnju i Sveti Martin na Muri. Sredinom 20. st. sastavnica sveta/sveti briše se iz hrvatske ojkonimije. Preimenovanja iz ideoloških razloga nisu pošteđeni ni međimurski ojkonimi toga tipa - Sveta Marija na Muri (kako se tada zvalo naselje), Sveti Martin na Muri, Sveti Juraj u Trnju, Sveti Križ Dravski (kako se tada zvalo naselje) i Sveti Urban skraćuju se za sastavnicu sveta/sveti. Devedesetih godina prošloga stoljeća tim su naseljima vraćena prvotna imena (pritom je imenu Marija na Muri izostavljen prijedložni izraz koji nema oslonca u topografiji, a imenu Križ Dravski potonja sastavnica).

\subsection{Osvrt na doimensko značenje ojkonimskih sastavnica}

Svakomu imenu, pa tako i imenu naselja, u času nastanka zna se povod nadijevanja. Vezanjem imena uz dotično naselje i njegovim ustaljivanjem te informacije s vremenom blijede jer one i nisu bitne za obavljanje identifikacijske i diferencijacijske funkcije (ojk)onima. Kako nas od postanka međimurskih naselja i njihova imenovanja dijeli višestoljetno razdoblje, danas iz ojkonimskog lika iščitavamo vjerojatna doimenska značenja riječi u ojkonimskoj postavi. Za pojavnost nekih osnova uporište nalazimo u povijesnim dokumentima. Tako se npr. pouzdano zna da Čakovec svoje ime duguje grofu Dmitru Čaku (Csak), vrhovnome dvorskom sucu i palatinu kralja Bele IV., da je naselje Otok prvotno (13. st.) bilo posjed u vlasništvu plemića Otoka, da je grof Banffy, gospodar Lendave, u 14. st. podigao utvrdu na mjestu današnjega naselja Banfi, Hodošan je nazvan po feudalnome posjednik grofu Hodošu (13. st.), Hemuševec po vlastelinu Hemušu... Neka su naselja ime dobila po imenima svetaca kojima je posvećena crkva ili kapela u njima podignuta (npr. Sveta Marija, Sveti Martin na Muri, Sveti Juraj u Trnju, Sveti Urban, Mihovljan, Donji Vidovec...). Antroponimsku osnovu nalazimo i u ovim ojkonimima: Domašinec, Dragoslavec, Draškovec, Držimurec, Ferketinec, Frkanovec, Martinuševec, Novakovec, Palinovec, Palovec, Pribislavec, Stanetinec, Šandorovec, Štefanec, Vukanovec, Žiškovec...). Neki ojkonimi temelje se na nazivima biljnog svijeta (npr. Brezje, Brezovec, Bukovec, Donja/Gornja Dubrava, Donji/Gornji Hrašćan, Grabrovnik, Jalšovec, Orehovica, Praporčan, Trnovec...), neki ojkonimi sadrže podatak o reljefnim odlikama (npr. Goričan, Okrugli Vrh, Vrhovljan, Železna Gora...), o izgledu zemljišta i odlikama tla (npr. Celine, Crečan, Prelog, Plešivica, Prhovec, Pušćine...), informaciju o objektima nastalim ljudskom djelatnošću (npr. Cirkovljan, Marof), o zanimanju i službi nekadašnjih stanovnika (Vularija, Strelci) itd. Etimologija i etiologija nekih ojkonima još su zagonetne. Budući da je ime sociolingvistička činjenica, vrlo je važno voditi računa i o izvanjezičnim okolnostima koje su dovele do njegova nastanka. Katkad se iz naoko jasnog značenja riječi u imenu ne iščitava 
$-\quad$ obavijest o stvarnom poticaju nastanka imena (npr. Savska Ves nije dobila ime po rijeci Savi) ${ }^{6}$ ili se pak zapada u pučku etimologiju, pa se npr. Kotoriba tumači kao «kut (s mnogo) riba» (Kolarić 1992, 16).

\subsection{Dijalektne osobitosti međimurskih ojkonima}

Ojkonimi nastaju u zavičajnome idiomu te u neslužbenoj komunikaciji nose jezična obilježja toga idioma. Ulaskom u sferu službene komunikacije ojkonim postaje standardnojezičnom činjenicom, do određene se mjere prilagođuje standardnojezičnoj normi, ali i zadržava neke dijalektne odlike.

Službeni međimurski ojkonimi čuvaju ove odlike međimurske kajkavštine: glas e na mjestu jata i poluglasa (Belica, Podbrest, Preseka, Strelec, Zasadbreg, Dragoslavec Breg, Nedelišće; Peklenica, Savska Ves, Zavešćak, Podturen, Čakovec i svi ojkonimi na -ec); suglasničku skupinu čr (Črečan); suglasničku skupinu ščšsć (Donji /Gornji Hrašćan, Gradiščak, Grkaveščak, Kapelščak, Mursko Središće, Nedelišće, Pušćine, Turčišće, Zaveščak); depalatalizirano lj (Železna Gora); iz palatala ne dolazi (uvijek) do prijeglasa (Križovec, Jalšovec; ali Kraljevec, Mihaljevec, Hemuševec); slijed ir na mjestu slogotvornog $r$ (Cirkovljan).

Dok su službena imena naselja zadržala tek pokoju odliku zavičajnog idioma, u njihovim neslužbenim varijantama do izražaja dolaze odlike pojedinih mjesnih govora međimurskog dijalekta (zatvoreni i otvoreni vokali, dvoglasi, obezvučeni završni šumnici, izostavljanje početnoga nenaglašenog vokala, glas o kao kontinuanta stražnjega nazalnog vokala...). U neslužbenoj komunikaciji većina dvosložnih ojkonima gubi manje obilježenu (diferencijacijsku) sastavnicu svodeći se na mnogo funkcionalnije jednorječne izraze, singularni se oblici zamjenjuju pluralnima... Tim i drugim promjenama ojkonimi katkad poprime lik vrlo različit od onoga službenog (npr. Čehovec > Čofce, Hodošan > Fodošene).

\section{Međimurski ojkonimi u Hrvatskome enciklopedijskom rječniku}

Prije nekoliko godina tiskan je jednojezično-jednosvezačni Hrvatski enciklopedijski rječnik. U njemu je onomastika «znatno zastupljena jer se je nastojalo pokazati da je hrvatski imenski korpus neodvojiv dio cjelokupnoga hrvatskoga leksičkog blaga kroz koji se ujedno bjelodano ogledaju različite faze jezičnoga razvoja hrvatskoga jezika.»» Uz ostalo, u Rječnik su uvršteni i neki međimurski ojkonimi. Ukupno su 53 rječnička članka «naslovljena» imenom međimurskog naselja. Uz ojkonimsku natuknicu stoji kratica gramatičkog roda, informacija o smještaju naselja, podaci o broju stanovnika dotičnog naselja, većinom je tu i etnik za mušku i žensku osobu te ktetik. Ponekad se dodaje i množinski nominativni lik etnika te završetak ojkonima u genitivu jednine. Osim nejasnoga kriterija izbora međimurskih ojkonima koji su uvršteni

6 «Pravo ime sela moralo bi glasiti Saska Ves - ne po rijeci Savi s kojom nema nikakve veze, nego po Sasima koji su u 16. i 17. stoljeću naseljeni ovdje kao kovači oružja i oruđa za potrebe čakovečke utvrde i feudalnog posjeda» (Kapun 1982, 193).

7 Hrvatski enciklopedijski rječnik XIX. 
u Rječnik (uz ostale izostalo je i ime Murskog Središća, jednog od triju međimurskih gradova), uočava se poprilična nesustavnost. Različite su informacije koje čitatelj doznaje iz rječničkoga članka - u nekim člancima izostaju etnici (za mušku i žensku osobu), u nekima ktetici, a ima i takvih koji ne sadrže nijednu od tih potvrda. Preko svega nabrojenog mogli bismo prijeći (iako takva neusustavljenost ne priliči rječniku enciklopedijskoga formata), ali neoprostiva je pogreška kad je samo ime naselja krivo napisano. Npr. umjesto Cirkovljan (jd.) čitamo Cirkovljani (mn.), Gornji Hrašćan preimenovan je u Gornji Hraštan (u članku iza etnika stoji «stanovnik Gornjih Hraštana»), Gornji Kuršanec postao je Gornji Krušanec. Katkad se pogriješilo u naglasku ojkonima (npr. Krušánec, Lopatínec, Štefánec krivo su naglašeni). Stanovnik Hodošana, prema autorima Rječnika, jest «Hodošanec» (sufiks -ec u tvorbi etnika dijalektna je odlika koja, prema vrijedećoj normi ne ulazi u standardni jezik), uz ojkonim Križovec donosi se ktetik krížovečkī definiran «koji se odnosi na Križovce»... Stanovnici pojedinih međimurskih naselja ne bi se prepoznali u ponuđenim kabinetskim etničkim konstruktima (Pribislavéčanin < Pribislavec, Malosùbotičanin < Mala Subotica, Svetomàrijanin < Sveta Marija...). U Hrvatski enciklopedijski rječnik trebalo je uvrstiti sve ojkonime pazeći da budu točno zapisani (i naglašeni), uza svaki donijeti etnik i ktetik pokazujući više sluha za likove koje rabe sami stanovnici tih naselja.

\section{Umjesto zaključka}

Svekolika međimurska ojkonimija (povijesna i suvremena) do danas nije popisana ni iscrpno obrađena. Mnogobrojni su mikrotoponimi zauvijek zaboravljeni. Slična sudbina čeka još tisuće imena danas zapuštenih livada, sjenokoša, gajeva, šumaraka te umjetnim jezerima potopljenih oranica i šuma. Nemarno se odnosimo prema imenskoj baštini svojih predaka te bez imalo osjećaja krivnje odbacujemo stara imena dijelova naselja i ulica dajući im «lijepa, suvremena» imena. Imena su svjedoci naše prošlosti i sadašnjosti. Ona svjedoče o vremenu u kojem su nastala, o svojim nadjevateljima, o jeziku kojim su oblikovana. Međimursku toponimiju treba što prije popisati, analizirati i leksikografski obraditi. Prikaz suvremene međimurske ojkonimije samo je mali prilog poznavanju hrvatske toponimije na sjeverozapadnoj međi. Glavni, kudikamo opsežniji i zahtjevniji, dio posla stoji pred budućim istraživačima.

\section{Literatura}

Frančić, Anđela, Hadrovicsev prinos proučavanju međimurske ojkonimije, Hrvati u Budimu i Pešti, zbornik radova 1997.-2000., Hrvatska samouprava Budimpešte, Budimpešta 2001, str. 209-217.

Frančić, Anđela, Prilog proučavanju međimurske ojkonimije: dvoleksemni ojkonimi s pridjevima donji/gornji, Rasprave Zavoda za hrvatski jezik 21, Zagreb, 1995, str. $25-50$.

Frančić, Anđela, Prvi spomen Međimurja, Kaj XXXIII, 1-2, Zagreb 2000, str. 61-70. 
$4 \quad$ Frančić, Anđela, Međimurska ojkonimija i književni jezik, Rasprave Zavoda za jezik 14, Zagreb 1988, str. 51-58.

Hadrovics, László, 1934, Muraköz helynevei, Nyelvtudományi Közlemények 48, Budapest, str. 3-34.

Buturac, Josip, Popis župa zagrebačke biskupije 1334. i 1501. godine, Starine 59, 43-108, Zagreb 1984.

Kalšan, Vladimir (2006), Međimurska povijest, Čakovec.

Kapun, Vladimir (1982), Međimurje 1918., Zrinski, Čakovec.

Kolarić, Juraj (1992), Povijest Kotoribe, Zagreb.

Listine hrvatske (1863), izdaje Ivan Kukuljević Sakcinski, Zagreb.

Sabljar, Vinko (1866), Miestopisni riečnik kraljevinah Dalmacije, Hervatske $i$ Slavonije, Zagreb.

Skupina autora (2002), Hrvatski enciklopedijski rječnik, Novi Liber, Zagreb.

Vidović, Josip (1989), Vodič stalnim postavom Arheološkog odjela Muzeja Međimurja Čakovec, Čakovec.

\section{Vpogled v hrvaško ojkonimijo na severozahodni meji}

Povzetek

Severozahodna hrvaška pokrajina Medžimurje meri $724 \mathrm{~km}^{2}$ in ima $127 \mathrm{na}$ selij, pretežno vasi. Primerjava med historičnim in sodobnim medžimurskim ojkonimskim sistemom kaže veliko razlik. Nekatera naselja so izginila in z njimi tudi imena, nekateri ojkonimi so bili delno (npr. Brest > Podbrest) ali popolnoma spremenjeni (npr. Bistric > Donji Vidovec). Nekateri so bili nasilno pomadžarjeni (npr. Pribislavec > Zalaujvár), nekateri pa so izgubili svojo kajkavsko podobo (npr. Nedelišće > Nedjeljište). Najbolj pogosti so enobesedni ojkonimi in večina jih je moškega spola. Pretežno so tvorjeni s sufiksacijo, med sufiksi pa prevladuje -ec (-ovec/-evec, -inec). Medtem ko v neuradni, krajevni rabi ojkonimi ohranjajo svojo medžimursko kajkavsko podobo, v uradni rabi nekatere od fonoloških, oblikotvornih in besedotvornih značilnosti niso ohranjene (npr. Dragoslavec Breg, Zaveščak, Črečan; Železna Gora; Križovec). Ojkonimi antroponimskega izvora so ob nastanku izražali svojilnost (npr. Bogdanovec), tisti, ki so nastali iz apelativov, pa so označevali značilnost tal, površine (npr. Donja Dubrava). Kratek pregled gesel, ki v delu Hrvatski enciklopedijski rječnik (2002) obravnavajo medžimursko ojkonimijo, je pokazal, da se imena kljub neprestanemu opozarjanju, kako pomembno je njihovo čim bolj natančno dokumentiranje, še danes obravnavajo površno in prikazujejo $v$ izkrivljenih oblikah (npr. Gôrnjī Hráštan namesto Gôrnjī Hrâšćan).

Anđela Frančić

Filozofski fakultet, Ivana Lučića 3, Zagreb afrancic@ffzg.hr 


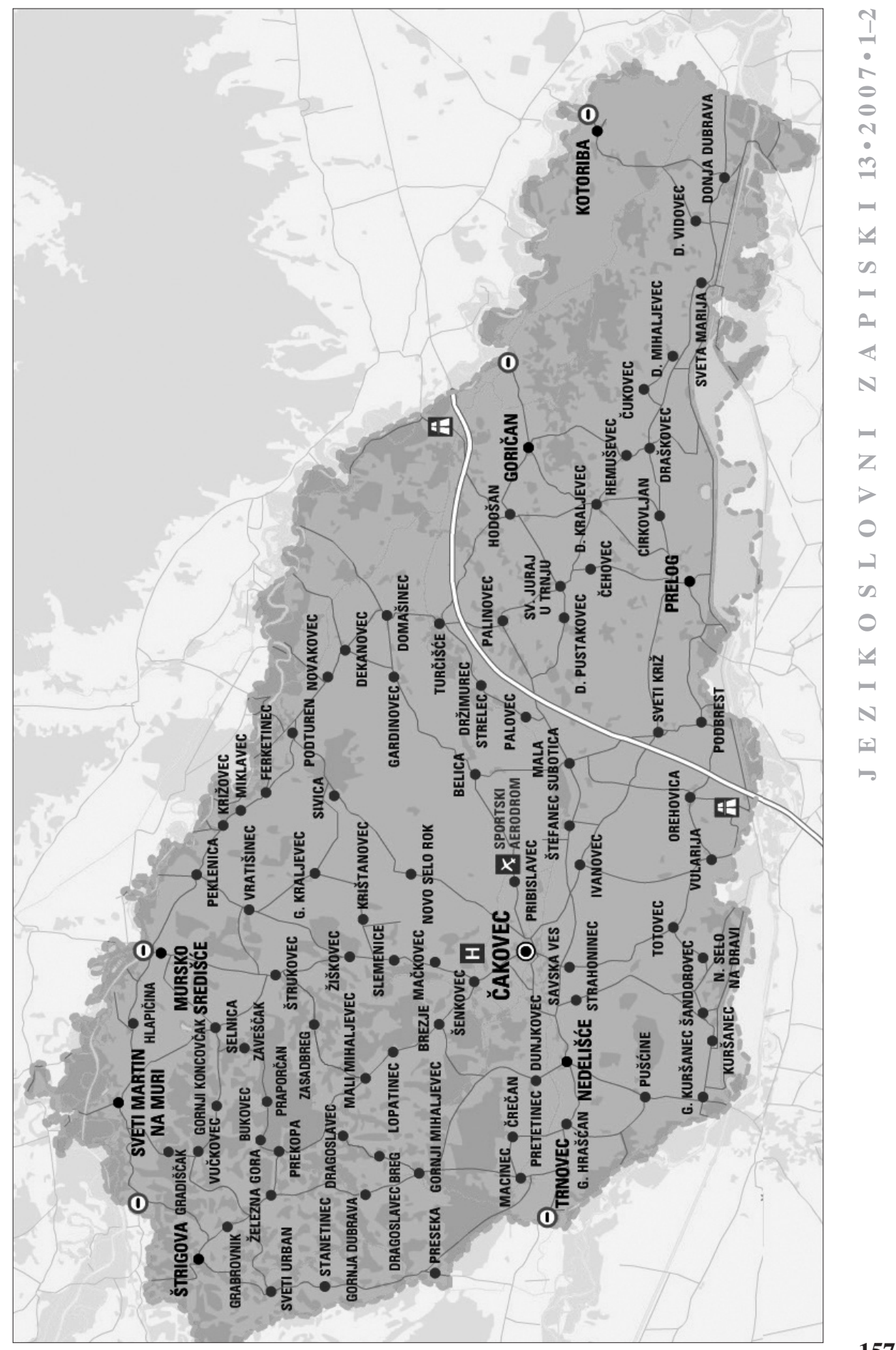





\title{
K etimologiji toponima Mi'rišče "zaselek v Krajevni skupnosti Hotiza“
}

\author{
Metka Furlan (Ljubljana)
}

IZVLEČEK: Hotiški toponim Mi'rišče ni tvorjenka iz hidronima Mûra, hotiško 'Mü:ira, kot pravi ljudska etimologija, ampak nomen loci na -išče iz samostalnika 'mü:-ire (f. pl.) »opuščeni rokavi reke Mure».

ABSTRACT: The Hotiza toponym Mi'rišce is not derived from the hydronym Mûra, or 'Mü:ira in the Hotiza dialect, as claimed by folk etymology, but is a place name ending in-išce derived from the noun 'mü:-ire (f. pl.) denoting "former branches of the Mura River".

O S toponimom Mirišč $e^{1}$ poimenovan zaselek v Krajevni skupnosti Hotiza v občini Lendava je v Krajevnem leksikonu Slovenije označen za vas, ki leži »jugozahodno od Hotize med rokavi Mure na sušni polici severno od njenega glavnega toka. V vseh pogledih teži k Hotizi, s katere je dostopna po krajevni poti. Večji del vasi je na desnem bregu Mure v SRH« (KLS, IV, 101). Zaselek danes šteje le nekaj hiš in je nastal na tamkajšnjem območju opuščenih rokavov reke Mure, ki ga po informaciji ge. Tilke Žalik, rojene v Hotizi, domačini od nekdaj imenujejo Mi'rišče, opuščene Murine rokave pa mi'rice (K. Kenda-Jež, ustno). ${ }^{2}$ Po pripovedovanju iste informatorke je zaselek nastal na zgornjem delu območja z imenom Mi'rišče, ${ }^{3} \mathrm{ka}-$

1 Preučevanje etimologije toponima Mirišče je vzpodbudil župan Občine Lendava, ki je na Komisijo za standardizacijo zemljepisnih imen Vlade Republike Slovenije, katere članica sem, lani jeseni naslovil vprašanje, ali obstaja kakršen koli strokovni zadržek, da bi z variantami Murišče, Dolnji Brezovec in Mirišče poimenovani zaselek v Krajevni skupnosti Hotiza uradno poimenovali Mirišče, češ da je to ime že od nekdaj uveljavljeno v vsakdanjem življenju občanov.

2 Narečno gradivo s terena, ki je potrdilo krajevno izgovorjavo imena zaselka Mi'rišče, mi je posredovala dialektologinja dr. Karmen Kenda-Jež z Inštituta za slovenski jezik Frana Ramovša ZRC SAZU, ta pa je nekatero gradivo pridobila prek prof. dr. Mihaele Koletnik z mariborske Filozofske fakultete. Obema se za njuno pomoč pri pridobivanju narečnega gradiva, ki so ga prispevali trije informatorji različne starosti, iskreno zahvaljujem.

Novo pridobljeno narečno gradivo je v prispevku predstavljeno po t. i. novi nacionalni transkripciji, gradivo iz SLA pa v Ramovševi transkripciji. O tem Kenda-Jež 1996, IX.

3 Pri navajanju imena območja sedanjega zaselka je informatorka včasih uporabila tudi zvezo s pridevnikom gornji. 
$\hookrightarrow \quad$ mor so ljudje sprva prihajali le zaradi obdelovanja konoplje in lanu (namakanje, sušenje in trenje), sčasoma je tu nastal prvi mlin, ljudje so si začeli postavljati iz blata ali lesa narejene barake itd. V Ižakovcih ime zaselka izgovarjajo Me'rišče z jezikoslovno zanimivim razširjenim izgovorom nenaglašenega $e<i$ pred $r$ (M. Koletnik, ustno). ${ }^{4}$

Zaselek je mlad in skladno s tem sta njegov opis in ime zabeležena redko in le v novejših tiskih. Na jožefinskem vojaškem zemljevidu iz let 1763-1787 območje današnjega zaselka ni označeno z imenom. Zaselek tudi ni omenjen v Leksikonu dravske banovine iz leta 1937. V KLS, IV, 101, iz leta 1980 je poimenovan Brezovec (del), ker je zaselek spadal in, kot je znano, še vedno spada pod hrvaško k. o. Brezovec. Enako ime zaselka je na str. 169 zapisano v Krajevnem leksikonu Ljudske republike Slovenije iz leta 1954 in tudi še v Priročnem krajevnem leksikonu Slovenije iz leta 1996. V prvi izdaji Atlasa Slovenije iz leta 1985 nosi ime Murišče (47/B2), v tretji iz leta 1996 Brezovec (47/B2), v četrti pa ponovno Murišče (42/C2). Na karti Pomurje in vzhodno Podravje z merilom 1 : 75.000, ki jo je leta 1998 izdal Geodetski zavod Republike Slovenije, se prav tako pojavlja ime Brezovec. Na Državni topografski karti Republike Slovenije z merilom 1 : 25.000 iz leta 1996 najdemo Murišče..$^{5}$

Ime zaselka, ki se v krajevni izgovorjavi glasi Mi'rišče, v različnih tiskih pa je zapisano tudi kot Murišče, je torej nastalo iz homonimnega ledinskega imena, ki je označevalo območje starih opuščenih Murinih rokavov.

1 Iz fonetično-morfološke ocene variant Mirišče in Murišče in na podlagi lege zaselka v bližini toka reke Mûre (SP 2001) je razvidno, da lokalna varianta in njena različica iz različnih tiskov odražata izimenski besedotvorni vzorec z znano pripono -išče. Ta v slovenščini in v širšem slovanskem prostoru tvori samostalnike $\mathrm{s}$ pomensko podstavo »tam, kjer je X«, npr. strn-išče »tam, kjer je strn«, gumn-íšče »tam, kjer je gumno«, grad-íšce »tam, kjer je bil grad/utrdba«. V tem oziru bi imeni pomenili »območje, kjer je reka Mura« oz. »območje, kjer je nekdaj tekla reka Mura«, ker gre za območje starih Murinih rokavov.

2 Preverjanje ustreznosti te etimologije pa je pokazalo, da ni zanesljiva zaradi aplikacije funkcije besedotvornega vzorca s pripono -išče in da je na ravni ljudsko-

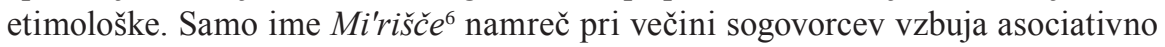
vez s knjiž. hdn Mûra, v hotiški izgovorjavi 'Mü:íra (M. Koletnik, ustno).

4 Pojava Ramovš 1935 pri predstavitvi prekmurskega narečja ni evidentiral. Drugod na slovenskem območju mu zaradi ižakovskega $e<i<u$ pred $r$ ustreza le površinsko enak in tipološko primerljiv pojav npr. v gorenjskih govorih zgornjesavskih dolin, prim. atn Cerîla "Cirila", mtn Veríše < sln. *virišče (Čop 1983, 49) <*virǐšče.

5 Za pomoč pri zbiranju zapisov imena tega zaselka po geografski literaturi (karte, zemljevidi ...) se zahvaljujem dr. Maji Topole in Primožu Gašperiču, oba z Geografskega inštituta Antona Melika ZRC SAZU.

${ }^{6}$ To ime seveda ni v etimološki povezavi z imenom Mirišče $\leftarrow$ miríšče (n.) "zidovje, razvaline, podrtija" (Pleteršnik) $\leftarrow$ mîr (m.) "zid” (Pleteršnik) < psln. *myrъ $\leftarrow$ lat. mūrus 
Razlaga imena Mi'rišče, po kateri naj bi hdn Mûra in pripona -išče tvorila ledinsko ime *Muríšče, ki se je po fonetičnem razvoju sln. nenaglašenega $u \mathrm{v} i$ razvilo v hotiško Mi'rišče enako, kot se je tamkajšnje si'šit ı iz sušiti, di'šiṭ iz dušiti ${ }^{7}$ je namreč pokazala, da vzorca

\section{hidronim + -išče $\neq$ ledinsko ime}

slovenska imena na -išče ne potrjujejo. Pri nas in tudi v širšem slovanskem prostoru namreč ni ledinskih imen na -išče, ki bi bila neposredno izpeljana iz hidronimov.

2. 1 Na podlagi razpoložljivega slovenskega gradiva je mogoče ugotoviti, da je pripona -išče neposredno pritaknjena na hidronim le v enem zanesljivem primeru. Tu pa rezultat ni ledinsko ime, ampak hidronim:

\section{hidronim + -išče $=$ hidronim}

To sta potok Dravišče »panoga od Drave v občini Trgovišče (Ptuj) « ${ }^{8}$ (PMS) in zahodno od njega Dravišse »potok, ki se odcepi od Drave v občini Formin (Ptuj)« (PMS), ki z asimilacijo -š- $<-\check{S} \check{c}$ - kaže na vpliv govorne podstave Slovenskih goric. $^{9}$

V obeh hidronimih se ohranja hdn Dráva, pripona -išče pa tu ne označuje »območje, kjer je $\mathrm{X}=$ Drava $«{ }^{10}$ ampak »tok, ki pripada toku $\mathrm{X}=$ Dravi« in ima torej pripadnostno funkcijo, ki v slovenščini pri tej priponi do sedaj ni bila prepoznana, čeprav je zastopana tako v apelativnem kot imenskem fondu.

Dravišče namreč ni »tok, kjer je/teče reka Drava«, ampak je »tok, ki pripada reki Dravi«, ker ime označuje Dravin pritok oz. tok, ki se v Dravo izliva. Tudi *Kraljiščce = 1818 Kraliszhe, pozabljeni mikrotoponim pri Mavhinjem v občini Devin Nabrežina (Italija), ne označuje območja = posesti, kjer je posestnik z imenom

“isto” (Bezlaj ESSJ, II, 185), ker na območju, ki ga označuje, ni nobenih ostankov zidov starih gradišč.

7 Glagolsko gradivo je posredovala M. Koletnik, ustno. O tem fonetičnem pojavu Ramovš 1935: 184.

8 Pomeni imen so predstavljeni kot v PMS, zato pripadnost konkretni občini lahko tudi ni odraz aktualnega stanja.

9 O arealni razporeditvi sln. -š- $(<-\check{s} \check{c}-):$ šč Ramovš 1924, 279.

${ }^{10} \mathrm{~V}$ zvezi s predstavljanjem te pogoste funkcije pripone -išče želim opozoriti na jezikoslovno neprepričljive razlage, da pripona v primerih, kot je npr. gradišče, označuje kraj, kjer je kaj bilo (npr. v Miklošič 1875, 274; Bajec 1950, 114; Šimunović 1972, 252, itd.). Kategorija časa, ki naj bi jo po teh razlagah pripona izražala, ni slovnična kategorija, ki bi bila imanentna samostalniku (pač pa seveda glagolu) in zato je v jezikoslovnem oziru ne izražajo niti tvorbe na -išče. Časovna funkcija pripone -išče, ki se prepoznava na podlagi tipa gradišče, izvira in pripada v takšnih primerih etimološki razlagi vsakokratnega primera, ki temelji tudi na upoštevanju zgodovinskega stanja konkretnega območja, ki ga ime označuje. Metodološko neupravičeno pa je, da se iz etimološkega pomena besede, ki temelji tudi na zunajlingvističnih podatkih, kategorijo časa, pridobljeno na podlagi zunajlingvističnih podatkov etimološke razlage, vnaša v slovnično funkcijo/pomen imenske pripone. 
$\hookrightarrow \quad \operatorname{Kralj}($ Merkù 2006, 110), ampak območje = posest, ki pripada posestniku Kralju. V slednjo pomensko skupino spadajo vsa nekdanja in sedanja imena območij na -išče, ki so izvedena iz priimkov ali vzdevkov, npr. *Baronišče = 1822 Baronsche, zaselek in potok v Sv. Mariji Magdaleni zgornji v občini Trst (Italija), $\leftarrow$ cgn Baron (Merkù 2006, 41), Furlánišče, ledina med Briščami in Gabrovcem v občini Zgonik (Italija), $\leftarrow$ cgn Furlán (Merkù 2006, 76 s.), Komaríšče, ledina pri Praprotu v o. Devin Nabrežina (Italija), $\leftarrow$ cgn Komár (Merkù 2006, 104), Obrámǐ̌če, ledina pri Vizontu v o. Neme (Italija), $\leftarrow$ cgn Abram (Merkù 2006, 142) itd.

V kraškem rẹ́pišče »repno perje« (Legiša 1951, 572) $\leftarrow$ rẹpa »Brassica rapa« funkcija pripone -išče ni enaka tisti v répišče/repišče »njiva, na kateri raste repa« (SSKJ), ampak se je leksikalni pomen besede razvil na podlagi pripadnostne funkcije pripone -išče in ga je zato potrebno izvajati iz *»tisto, kar pripada repi«, tj. »repno perje«. Enako je kosíšče »držaj pri kosi« (SSKJ) iz kósa izpeljano s pripono -išče v pripadnostni funkciji. Pomen »držaj pri kosi« zato predstavlja leksikalizacijo strukturalnega *»tisto, kar pripada kosi«. Dolenjsko krompirišče »zelnati del krompirjeve rastline« (Pleteršnik) iz krompír je leksikalizirano iz »tisto, kar pripada krompirju«.

Pripadnostno funkcijo slov. imenske pripone *-išče je mogoče prepoznati npr. v hrv. mikrotoponimu na Braču Pôvlišće, izvedenem iz osebnega imena Pavao, ki ga Šimunović 1972, 252, razlaga kot »Pavlova posest«, pomen pripone v tem imenu pa pojasnjuje, da označuje »območje v posesti lastnika«. Tudi 6 ukrajinskih hidronimov Dneprišče iz hdn Dnepr (Trubačev 1968, 33) vsebuje isto pripadnostno fukcijo pripone ${ }^{*}$-ǐ̌če.

Besedotvorni vzorec $\mathrm{z}$ imensko pripono -išče $\mathrm{v}$ pripadnostni funkciji je torej mogoče ponazoriti:

\section{$\mathbf{X}(=$ samostalnik $)+$-išče $=\mathbf{X}$-išče $» t o$, kar pripada $X "$}

Pripona -išče ima pri omenjenih hidronimih in drugih imenih enako pripadnostno funkcijo kot -ica ${ }^{11}$ npr. v hrv. hdn Savica »rokav reke Save v okolici Zagreba « (Arj, XIV, 728) ali v sln. hdn Murica »rokav Mure, mejni objekt med ozemljem Tišine in Petanjcev«, 1348 in eodem fluvio Muricha currit ad fluvium Mura (Zelko 1982, 66) oz. v mtn Kraljica »posest, ki pripada Kralju« (Merkù 2006, 110). Oba besedotvorna vzorca iz istih samostalniških predlog ustvarjata pomensko enake rezultate, kot je razvidno iz naslednjih primerov:

sln. cgn Kralj:

+ -išče > sln. Kraljišče »posest, ki pripada Kralju« (Merkù 2006)

+ -ica $>$ sln. Kraljica »posest, ki pripada Kralju« (Merkù 2006)

hrv. hdn Sava:

+ -išče > hrv. Savišće »rokav reke Save« (Arj, XIV, 732; Skok, III, 208)

+ -ica $>$ hrv. Savica »rokav reke Save v okolici Zagreba« (Arj, XIV,

728)

${ }^{11}$ O tej funkciji pripone prim. npr. Šimunović 1972, 249; Lubaś 1966, 108 s. 
2. 2 Glede na prepoznano pravilo, da je prvi rezultat besedotvornega vzorca hdn + pripona -išče hidronim s pomensko podstavo »tisto, kar pripada podstavnemu hidronimu«, bi ime zaselka Mirišče vsebovalo hdn Mûra le, če bi bilo mogoče dokazati, da se je to naselbinsko ime prek nenaselbinskega ledinskega razvilo iz hidronima *Murišče, ki pa je, če upoštevamo pomen drugih tovrstnih hidronimov, označeval samo en Murin rokav.

Poleg imena zaselka Mi'rišče se na območju toka reke Mure tudi dejansko pojavlja nekaj ledinskih imen Mirišče. Na Državni topografski karti Republike Slovenije z merilom 1 : 25.000 iz leta 1996 najdemo ledinsko ime Dolnje Mirišče južno od Hotize. Na Osnovni državni karti z merilom 1 : 5.000 iz leta 1971 pa se ledinsko ime Mirišče (Ljutomer - 16) pojavlja južno od območja zaselka Mi'rišče, ki na karti ni označen. Enakozvočno ledinsko ime je zabeleženo dvakrat, in sicer vzhodno in zahodno od Hotize (Ljutomer - 17). Na tem območju se torej ledinsko ime Mirišče pojavlja večkrat, ni pa znakov za obstoj enakozvočnega hdn *Muríšče $(\leftarrow \operatorname{hdn}$ Mura $)>$ hotiško *Mi'rišče.

Ime Mi'rišče ne označuje območja enega Murinega rokava in niti območja nekdanjega enega Murinega rokava, ampak močvirnato območje več opuščenih Murinih rokavov. Ime je vedno uporabljano v edninski obliki. Ker zaradi navedenih argumentov povezanosti imena Mi'rišče s hdn Mûra = hotiško 'Mü:i ra ni mogoče zanesljivo dokazati, se vsiljuje domneva, da se v njem verjetno ohranja apelativ, ki je bil enakozvočen s hdn Mûra = hotiško 'Mü: ${ }^{i} r a$.

Da prenos hdn na -išče $\rightarrow$ mtn na -išče lahko pričakujemo, ponazarja stanje takih imen na območju toka reke Drave. Tu je prenos iz hidronima na ledinsko ime potrjen pri obeh omenjenih hdn Dravišče »panoga od Drave v občini Trgovišče (Ptuj)« (PMS) in Dravíše »potok, ki se odcepi od Drave v občini Formin (Ptuj)« (PMS). Slednji hdn se še danes ohranja v imenu parcele Pri Dravišu, variantno Pri Draviši v k. o. Formin v naselju Formin občine Gorišnica (LiAKZ), prvi pa v Dravišče, imenu dela naselja Cvetkovci v občini Trgovišče (REZI5).

2. 3 Pot do bolj ustrezne etimologije imena Mi'rišče je po mojem mnenju nakazala informatorka ga. Tilka Žalik, ko je povedala, da ime Mi'rišče sicer označuje območje ob reki Muri in tudi, da je to vedno le območje, kjer so opuščeni rokavi reke Mure, ki so, ko jih je Mura napolnila, tudi vsako leto poplavljali. Medtem ko ti opuščeni rečni rokavi Mure nimajo svojih imen in so označeni z apelativom mi'rice (f. pl.), je območje miric poimenovano z Mi'rišče, je dodala. Med pripovedovanjem pa je namesto apelativa mi'rice enkrat uporabila tudi obliko 'mü: $r e$ (f. pl.), ko je želela povedati, da so na Mirišču le-te vsako leto, ko jih je Mura napolnila, poplavljale.

Iz tega je mogoče sklepati, da sta narečna apelativa mi'rice in 'mü:i $r e$ sinonima in da oba označujeta opuščene rokave reke Mure, za katere ni značilna stalna tekoča voda in so poplavljali, ko jih je napolnil Murin tok. Ime Mi'rišče je torej lahko nomen loci na -išče s pomensko podstavo »tam, kjer je X« iz apelativa 'mü:i $r e$. Vokalna razlika $i$ : $\ddot{~}$ v prvem zlogu teh treh besed odraža različne razvoje prvotnega slovenskega vokala $u$, ki se v hotiškem govoru pod naglasom realizira kot ü (zato 'mü:-ire enako kot hotiško ki'püvati »kupovati«, hdn 'Mü:íra »Mura«), v nenaglašenem položaju pa kot $i$ (zato mi'rica, Mi'rišče enako kot hotiško si'šiț »sušiti«, di'šit! 
$\hookrightarrow \quad$ »dušiti«). Razmerje 'mü: ${ }^{i} r e$ : ki'püvati jasno kaže, da je element ${ }^{i} \mathrm{v}$ 'mü:i $r e$, 'Mü:i $r a$

Mi'rišče (n. ) »območje, kjer so 'mü::'re« $\leftarrow^{\text {'mü: }}$ 're (f. pl.) »opuščeni rokavi reke Mure, ki občasno poplavljajo«

Apelativ mi'rica »močvirnat potok brez tekoče vode« je bil dokumentiran že v PMS. V zapisu müríca »močvirnat potok s stoječo vodo« apelativ za okolico Ljutomera v SVI, II, 44, omenja Bezlaj, ki dvomi, da bi bil apelativ kot tudi ime potoka Murica, ki se izliva v reko Ščavnico, etimološko povezan s hdn Mûra = nar. 'Mü: ${ }^{i} r a$. Po gradivu za SLA je beseda mirïca $(=\text { mi'rica })^{12} \mathrm{v}$ pomenu »rokav reke« znana v Hotizi, Veržeju in Spodnjem Kamenščaku, ki ležijo na območju toka reke Mure.

3. 1 Deonimizacija hidronimov je v slovanskem prostoru znan pojav. Tako se npr. hrv. hdn Sáva kot apelativ sãva (f.) »reka« pojavlja v hrvaškem delu Istre (Hraste-Šimunović, III, 545). Apelativ *dünajb (m.) »reka, potok, potoček« iz psl. hdn *Dünajb je znan v poljščini, ruščini in ukrajinščini (ÈSSJ, 5, 156).

Možno bi torej bilo predpostaviti, da sicer samo v pluralu evidentirani apelativ 'mü: ${ }^{i} r e$ odraža deonimizirani hdn Mûra, mi'rice pa deonimizirani hdn Murica, ki poimenuje en rokav reke Mure na območju med Tišino in Petanjci (Glej zgoraj.)

Ob taki domnevi je dejanski pomen apelativa mi'rica enak pričakovanemu:

\section{Murica »rokav reke Mure« $\rightarrow$ *muríca »kateri koli rokav reke Mure«: mi'rice "rokavi reke Mure ${ }^{13}$}

Nasprotno pa bi pri domnevi o deonimizaciji iz hdn Mûra pričakovali, da bo apelativ po vzoru znanih deonimiziranih hidronimov označeval reko ali potok, manj pa je pričakovan pomen »rokav reke Mure«:

\section{Mura »reka Mura« $\rightarrow$ *mura *»katera koli reka«: 'mü: ${ }^{i} r e$ »rokavi reke Mure«}

Muri domačini pravijo tudi 'Velka 'Mü: $r a$ (informacija ge. Milojke Žalik Huzjan). Uporaba pridevnika vélik je v tej zvezi relevantna in razumljiva, ker je bil pri označevanju glavne struge reke Mure uporabljen za izražanje razlikovalnosti v odnosu do njenih stranskih strug = rokavov, ker so bili označeni z 'mü:ị re (f. pl.).

3. 2 Ker ob predpostavki, da sta apelativa mi'rica in 'mü: ${ }^{i} r a$ deonimizirana iz hdn, ostaja nepojasnjeno vprašanje nastanka pomena »rečni rokav« namesto pričakovanega »reka«, se kot alternativna ponuja tudi naslednja razlaga.

${ }^{12} \mathrm{~V}$ oklepaju je podana Ramovševi ustrezna nova nacionalna transkripcija narečne besede.

${ }^{13} \mathrm{~V}$ naselju Breg ob Savi na Gorenjskem rokav reke označujejo z gráben (m.), -bna pa tudi s skladenjsko zvezo ta máunwa Sáúca (SLA) = ta mala Savica, kar kaže na podoben poimenovalni vzorec, kot je znan tudi v hrv. Savica »rokav reke Save v okolici Zagreba« (Arj, XIV, 728). 
Pomen »(mrtvi) rečni rokav« se namreč lahko razvije tudi iz splošnega »močvirnat svet«:

»močvirnat svet « $\rightarrow$ (mrtvi) rečni rokav«

Tako pomensko motivacijo potrjuje méčava (f.) »rečni rokav« (Blače/Vorderberg; SLA) «mečâva »močvirje« (Pleteršnik) <*męčava »mehko (tj. močvirnato) območje«; béreg $(\mathrm{m}$.$) ) »rečni rokav« (Dolnja Bistrica v Prekmurju; SLA) \leftarrow$ bèreg »močvirje« (Pleteršnik) iz madž. bereg »močvirje, obrežje« (Bezlaj ESSJ, I, 16), láva (f.) »močvirnato območje ob reki; usahla rečna struga« (štaj.), »luža« (kor.) iz kor. n. laue »majhna mlaka, ki se naredi ob potoku ali reki«, srvn. lâ »mlaka, močvirje« (Bezlaj ESSJ, II, 127).

V tričlenski besedni družini Mi'rišče (n. sg.), mi'rice (f. pl.) in 'mü:ịre (f. pl.) bi se zato lahko ohranjal psl. geografski termin *murä (f.) »močvirno, blatno območje«, ki se potrjuje v hrv. múra »blato pomešano z vodo« (Bačka), čak. murãva »tratina kojom se cijedi voda«, npr. Pöviše Nerežîšć su murãve (Šimunović 2006, 303), ukr. murýna »manjša močvara, ki nastane po povodnji«, s sorodstvom v lit. máuras, pl. mauraĩ »umazanija, blato« (ÈSSJ, 20, 191 s.; ÈSUM, III, 538; Fraenkel, LEW, 419; Nevskaja 1977, 52). ${ }^{14}$ Vendar tudi te razlage s samim slovenskim gradivom ni mogoče zanesljivo argumentirati, čeprav se zaradi večje pomenske prekrivnosti zdi bolj verjetna in mak. Murište »nekoč okoli 300 ha veliko močvirje v naselju Dolno Palčišta, ki je bil po 1. 1950 izsušeno in spremenjeno v obdelovalno površino, ki se danes imenuje Vakaf $\ll^{15}$ potrjuje imenotvornost psl. apelativa *murä:

psl. *murả (f.) »močvirno, blatno območje«:

sln. hotiško 'mü:: re (f. pl.) »rokav reke Mure« $\rightarrow M i$ 'rišče *»območje, kjer so 'mü:re«;

mak. *mura *»močvirje« $\rightarrow$ Murište *»območje, kjer je *mura»

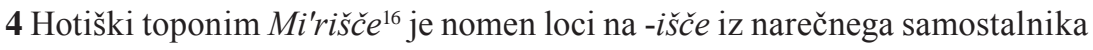

${ }^{14} \mathrm{~S}$ tem geografskim apelativom je sorodna slov. pomenska skupina, $\mathrm{v}$ katero spada tudi sln. murâva "mehka nizka trava" (Schütz 1957, 51 s.; Bezlaj ESSJ, II, 206).

${ }^{15}$ Za podatek o legi in sodobni/pretekli konfiguraciji tal območja, poimenovanega z Murište, se zahvaljujem kolegici dr. Elki Jačevi-Ulčar (Makedonija).

${ }^{16}$ Naj odgovorim še na vprašanje, zastavljeno v prvi opombi. Jezikovna standardizacija slovenskih zemljepisnih imen (tako kot poknjiževanje slovenskega narečnega občnoimenskega fonda) se izvaja na podlagi dveh osnovnih načel. Pri aplikaciji diahronega etimološko-zgodovinskega načela se pri poknjiženju (popolnem ali delnem) upoštevata zgodovinski razvoj imena in njegova genetična povezanost v širšem slovenskem prostoru ter njegova etimologija (npr. knjiž. Kóper, gen. Kópra je popolno poknjižena uradna oblika imena za izhodno sln. *Kọpor < *Kòprb in nar. 'Kuọ:pər; knjiž. Kobaríd je delno poknjižena uradna oblika imena za izhodno sln. *Koborïd in nar. Kobẹ́rd). Pri aplikaciji sinhronega načela ničtega poknjiženja pa se narečna beseda le pretvori v fonetično najbližje foneme knjižnega jezika (npr. knjiž. orn Prísank za nar. Prísank, starejše Prísaunnk za izhodno sln. *Prisolnik (Čop 1983, 6; Čop 1995, 495 s.). Razumljivo je, da je aplikacija prvega načela upravičena le, če sta zgodovinski in etimološki nastanek imena zanesljivo dognana.

Aplikacija prvega diahronega ali drugega sinhronega načela bi morala biti pri sodobni je- 
'mü::ira »opuščeni rokav reke Mure« s pomensko podstavo »območje, kjer so 'mü: ${ }^{i} r e=$ opuščeni rokavi reke Mure«. Izvor hotiškega apelativa 'mü:i re (f. pl.) ostaja manj jasen. Samostalnik je morda nastal z deonimizacijo iz hdn Mûra = hotiško 'Mü:: ra, čeprav je zaradi njegovega pomena bolj verjetno, da se tako kot v njegovem sinonimu mi'rica $<*$ murïca ohranja psl. geografski apelativ *murä(f.) »močvirno, blatno območje $\ll$.

\section{Viri in literatura}

ARj: Rječnik hrvatskoga ili srpskoga jezika, Zagreb 1880-1976.

Bajec 1950: A., Besedotvorje slovenskega jezika I, Izpeljava samostalnikov, Ljubljana.

Bezlaj 1956-61: F., Slovenska vodna imena I-II. Ljubljana.

Čop 1983: D., Imenoslovje Zgornjesavskih dolin, Disertacija, Ljubljana.

Čop 1995: D., Prisank ali Prisojnik? - Planinski vestnik 11, november, 495-496.

ÈSSJ: Ėtimologičeskij slovarb slavjanskich jazykov, Praslavjanskij leksičeskij fond 1-. Moskva 1974-.

ÈSUM: Ètymologičnyj slovnyk ukrajins'koji movy I-. Kyjiv 1982-.

Fraenkel: E., Litauisches etymologisches Wörterbuch I-II. Heidelberg 1962-1965. Hraste-Šimunović: M. Hraste, P. Šimunović, Čakavisch-Deutsches Lexikon I-III, Köln - Wien 1979-1983.

Kenda-Jež 1996: K., Uvodna pojasnila, V: Logar, T., Dialektološke in jezikovnozgodovinske razprave, Ljubljana, str. VII-XVIII.

KLS: Krajevni leksikon Slovenije IV. Podravje in Pomurje, S sodelovanjem Franceta Planine pripravil in uredil Roman Savnik. Ljubljana 1980.

Legiša 1951: L., Kos kraškega narečja 8 - Razgledi 6 (Trst), 567-579.

LiAKZ: Datoteka ledinskih imen Agencije RS za kmetijske trge in razvoj podeželja (Ljubljana).

Lubaś 1966: W., Posesivna funkcija sufiksa -ica u južnoslovenskoj toponimiji - Naš jezik XV/1-2, 108-113.

Merkù 2006: P., Krajevno imenoslovje na slovenskem zahodu, Uredila M. Furlan in S. Torkar, Ljubljana.

zikovni standardizaciji $=$ poknjiženju zemljepisnih imen uporabljena smiselno, odvisno od vsakega primera posebej.

Pri etimološko nespornih primerih imen, ki vsebujejo sestavine knjižnega jezika, kot je npr. gor. puanína $=$ knjiž. planína, aplikacija načela ničtega poknjiženja ni smiselna in niti priporočljiva, saj bi taka imena v širšem slovenskem kontekstu popolnoma zastrla njihovo etimološko povezanost s splošnoslovenskim apelativnim fondom. Pri imenu zaselka Mi'rišče pa aplikacije diahronega načela kljub prepoznani etimologiji imena ne bi priporočila, ker bi z uradno obliko *Murišče v sistemu slovenskega knjižnega sprožili možnost, da bi ime ob knjiž. hdn Mûra vzbujalo jezikoslovno neustrezno asociacijo o njegovi neposredni izpeljanosti iz njega. Taka asociativna vez pa bi celo lahko po nepotrebnem sprožila zgodovinsko neutemeljen, umeten neologistični besedotvorni vzorec. 
Miklošič 1875: F., Vergleichende Stammbildungslehre der slavischen Sprachen, Wien.

Nevskaja 1977: L. G., Baltijskaja geografičeskaja terminologija, Moskva.

Pleteršnik: M., Slovensko-nemški slovar I-II, Ljubljana 1894-1895 = Slovensko-nemški slovar, Transliterirana izdaja, Ur. M. Furlan, Ljubljana 2005.

PMS: Pleteršnikova zbirka zemljepisnih imen Matice slovenske, Hrani Etimološko-onomastična sekcija Inštituta za slovenski jezik Frana Ramovša ZRC SAZU v Ljubljani.

Ramovš 1924: F., Historična gramatika slovenskega jezika II. Konzonantizem, Ljubljana.

Ramovš 1935: F., Historična gramatika slovenskega jezika VII. Dialekti, Ljubljana.

REZI5: Register prostorskih enot 1 : 5000 (Geodetska uprava Republike Slovenije).

Schütz 1957: J., Die geographische Terminologie des Serbokroatischen, Berlin.

Skok: P., Etimologijski rječnik hrvatskoga ili srpskoga jezika I-IV, Zagreb 197174.

SLA: Gradivo za Slovenski lingvistični atlas, Hrani Dialektološka sekcija Inštituta za slovenski jezik Frana Ramovša ZRC SAZU v Ljubljani.

SP 2001: Slovenski pravopis, ur. J. Toporišič et al., Ljubljana.

SSKJ: Slovar slovenskega knjižnega jezika I-V. Ljubljana 1970-1991.

Šimunović 1972: P., Toponimija otoka Brača, Supetar.

Šimunović 2006: P., Rječnik bračkih čakavskih govora, Supetar.

Trubačev 1968: O., Nazvanija rek Pravoberežnoj Ukrainy, Moskva.

Vasmer: M., Ètimologičeskij slovarb russkogo jazyka I-IV, Perevod s nemeckogo i dopolnenija člena-korrespondenta AN SSSR O. N. Trubačeva, Izdanie vtoroe, stereotipnoe, Moskva 1986-1987.

Zelko 1982: I., Historična topografija Slovenije I. Prekmurje do leta 1500, Murska Sobota.

\section{On the Etymology of the Toponym Mi'rišče, a Settlement in the Hotiza District}

Summary

The Hotiza toponym Mi'rišče is a place name ending in -išče derived from the dialect noun 'mü:-re (f. pl.), denoting "former branches of the Mura River", with the semantic basis "an area where 'mü:-re are located". The origin of the Hotiza appellative is less clear. It is possible that the noun was created through deonymization from the hydronym Mûra ('Mü:-'ra in the Hotiza dialect) although, given its meaning, it is more likely that it, like the synonym mi'rice (f. pl.), preserves the Proto-Slavic geographical appellative *murä (f.), denoting "a swampy, muddy area". The word formation productivity of this Proto-Slavic geographical appellative is confirmed by the identical Macedonian toponym Murište, denoting " a once circa 
$\rightarrow$ 300-hectare swamp in the settlement of Dolno Palčište that was drained after 1950 [.] and converted into a cultivable area today known as Vakaf".

Metka Furlan

Inštitut za slovenski jezik Frana Ramovša ZRC SAZU Novi trg 2, 1000 Ljubljana metka.furlan@zrc-sazu.si 


\title{
Czlowiek - to kto?
}

\section{Refleksja nad płcią człowieka w języku ludowym}

\author{
Helena Grochola-Szczepanek (Krakov)
}

IZVLEČEK: Članek vsebuje razmišljanje na temo izražanja spola v ljudskem jeziku. Predmet razmišljanja je izraz človek (człowiek), njegovi pomeni in kolokacije. To je poskus razmisleka o tem, kaj pomeni pojem człowiek, v kakšnem odnosu je do obeh spolov, ali se v enaki stopnji nanaša na žensko in moškega. Tu podana opažanja in narečni material se v glavnem nanašajo na obmejno poljsko-slovaško regijo Spisz.

\begin{abstract}
Man - Who's That? Reflection on the Semantic Gender of cztowiek 'man' in Polish Dialect

ABSTRACT: This article reflects on the Polish word czlowiek 'man', and its meanings and collocations in dialect. The author poses the question whether the word czlowiek refers to a woman or man equally. Data from dialect texts show that człowiek is used asymmetrically for both genders. Człowiek is usually identified with a male person, and in its connotations the masculine gender is dominant. Examples of czlowiek with the general meaning 'human being' are very rare. The word czlowiek does not fully refer to humans in general in dialect or official language because it does not reference women and men to the same extent. The plural form ludzie 'people' refers to humans in general.
\end{abstract}

Artykuł zawiera spostrzeżenia na temat sposobu wyrażania płci w języku ludowym. Przedmiotem rozważań jest wyraz człowiek, jego znaczenia i kolokacje. Jest to próba zastanowienia się nad tym: jakie znaczenia ma pojęcie człowiek, jakie ma odniesienia do obu płci, czy w takim samym stopniu odnosi się do kobiety i do mężczyzny.

Zawarte tu obserwacje oraz materiał gwarowy dotyczą głównie regionu Spi- 
$4 \quad$ sza $^{1}$. Materiałem badawczym są spiskie teksty gwarowe, zebrane po stronie polskiej i po stronie słowackiej².

Język polski posiada ogólne określenie istoty ludzkiej (człowiek) oraz osobne określenia na osobę rodzaju żeńskiego (kobieta, pani, baba, ...itp.) i osobę rodzaju męskiego (mężczyzna, pan, chłop, ...itp). W niektórych językach jedno określenie obsługuje zarówno nazwę całego gatunku, jak i nazwę męską, np. w języku angielskim słowo man ma dwa znaczenia 'człowiek' i 'mężczyzna', podobnie w języku niemieckim (Mann/Mensch), hiszpańskim (hombre) ${ }^{3}$. Wydawać by się mogło, że skoro język polski dysponuje wieloma określeniami dotyczącymi osoby płci męskiej i żeńskiej, to wyraz człowiek powinien być stosowany tylko w ogólnym, gatunkowym znaczeniu istoty ludzkiej.

Przeglądając słowniki języka polskiego można odnieść wrażenie, że wyraz czlowiek jest nazwą całego gatunku ludzkiego i można go odnosić zarówno do kobiet, jak i do mężczyzn. Płeć nie stanowi tu jakoby przeszkody. W Słowniku języka polskiego, pod red. M. Szymczaka $(1978,340)$ pod hasłem czlowiek znajdujemy następujące znaczenia i (wybrane) przykłady:

1. 'homo sapiens, istota żywa z rodziny człowiekowatych, z rzędu naczelnych wyróżniająca się wśród innych najwyższym rozwojem psychiki i życia społecznego, jedyna posiadająca kulturę i zdolna do jej tworzenia', np.:

Człowiek rozumny.

Człowiek pierwotny, cywilizowany.

Człowiek młody, dojrzały, stary.

Człowiek neandertalski.

Człowiek bez czci i wiary.

Człowiek starej daty.

Człowiek z głowa.

Człowieku... 'zwrot poufały odpowiadający znaczeniowo zwrotom: mój drogi, bracie, przyjacielu’.

1 Teren Spisza położony jest w Karpatach Zachodnich, w dorzeczu górnego Popradu, górnego Hornadu oraz w części dorzecza Dunajca. Od północy i zachodu Spisz sąsiaduje z Podhalem, od wschodu z Szaryszem, na południu z Abowem i Gemerem, na południowym zachodzie z Liptowem. Większa część Spisza należy obecnie do Słowacji. Do Polski należy 14 miejscowości.

2 Najstarsze teksty gwarowe z tego regionu pochodzą z początku 20 wieku. Są to „Powieści spiskie” L. Malinowskiego, wydane przez R. Zawilińskiego w 1903, teksty w pracach S. Czambela (1906), J. Grzegorzewskiego (1919) oraz M. Małeckiego (1935). W 1960 roku opublikowano teksty K. Nitscha i M. Karasia. Najobszerniejszym zbiorem tekstów spiskich jest praca J. Bubaka pt. „Spiskie teksty gwarowe z obszaru Polski” (1972). Autor nagrał i zapisał około 140 tekstów. F. Sowa opisując system fonologiczny polskich gwar spiskich, załączył do pracy teksty gwarowe (1990). Z innych opublikowanych tekstów można wymienić prace takich autorów jak, np.: Z. Cygal-Krupy $(1969,1971)$, F. Sowy (1974), H. Grocholi (1994). Na koniec przeglądu spiskich tekstów trzeba jeszcze wspomnieć o twórczości literackiej spiskich autochtonów m.in. A. Jazowskiego (1967), M. Balary (1986), J. Plucińskiego (1997).

3 Ciekawym faktem jest, że po szwedzku männinska 'człowiek' to hon 'ona', zob. M. Kostera $(2003,160)$, por. także B. Nilsson (2003, 11-12). 
2. 'człowiek jako reprezentant najlepszych cech ludzkich, jednostka wartościowa społecznie, etyczna, szlachetna', np.:

Być (prawdziwym) człowiekiem.

Bądź jak człowiek, mów, zachowuj się, postępuj jak człowiek.

Okazać się, pokazać się człowiekiem.

Zrobić z kogoś człowieka.

3. 'osoba dorosła, dojrzała', np.:

Wyrosnąć z dziecka na człowieka.

4. pot. 'robotnik, pracownik', np.:

Nająć człowieka do noszenia węgla.

5. 'W funkcji zaimka osobowego: ja lub w funkcji zaimków nieokreślonych: ktoś, ktokolwiek, każdy', np.:

Bądź tu, człowieku, mądry.

Trudno człowiekowi to zrozumieć.

Jak widać w żadnym ze znaczeń nie ma informacji jakoby odnosiło się tylko do mężczyzny. Jednak nie można przyjąć, że we wszystkich wypadkach są to nazwy ogólne istoty ludzkiej, które możemy odnieść zarówno do kobiety, jak i do mężczyzny. Zwrot człowieku w znaczeniu 1) jest synonimem potocznych wyrażeń: chłopie, stary itp. W tym samym kontekście odpowiednimi zwrotami do płci żeńskiej byłyby wyrażenia: kobieto, babo ${ }^{4}$. Znaczenie 4) 'pracownik, robotnik' z przykładem: najać człowieka do noszenia węgla, dotyczy mężczyzny, a nie kobiety. W pracach poświęconych zagadnieniu gender zwraca się uwagę, że wyraz człowiek to nie tylko pojęcie ogólne, ale także węższe, odnoszące się do rodzaju męskiego, do mężczyzny5. Nowsze słowniki języka polskiego (Dunaj 1998, 146; Bańko 2000, 224) notują pod hasłem człowiek znaczenie 'mężczyzna'.

Wyraz człowiek w spiskich tekstach gwarowych pojawia się zazwyczaj w postaci mazurzącej cłowiek, z miejscownikiem liczby pojedynczej człowiekowi, np. Tak my tele dole uciekali, co juz po kiel dyf w cłowiekowi byt (Bubak 1972, 22) ${ }^{6} \mathrm{i}$ narzędnikiem liczby mnogiej ludziami, np. Ci hajducy barz się znęcali nad ludziami na pańskim (Jazowski 1967, 178). W przypadku wołacza, podobnie jak w języku literackim, występują dwie formy: człowieku, np. Cłowieku! Coz to robis? (Bubak 1972, 26) i człowiecze, np. Bóg ci za to szczodrze wynagrodzi, poczciwy człowiecze (Jazowski 1967, 174). Pojawiają się też określenia: człek, np. Hucało mu strasznie w głowie. „To człek, stojac na warcie we dnie $i$ w nocy, fse ino Justynkę miat przed oczami, a ona taak?" (Jazowski 1967, 80) oraz człeczyna, np. Tam w dolinie jakiś człeczyna wala tę górę (Jazowski 1967, 108). W tekstach częściej pojawiają się konotacje w liczbie mnogiej (ludzie) niż w liczbie pojedynczej (człowiek). Wyrazowi

${ }^{4}$ Zob. na ten temat M. Karwatowska, J. Szpyra-Kozłowska (2005, 61).

5 Szerzej na ten temat, zob. w pracach R. Rothsteina (1976), A. Jaworskiego (1986), B. Miemietz (1993), A. Pajdzińskiej (2001), M. Karwatowskiej, J. Szpyry-Kozłowskiej (2005).

6 Ponieważ cechy fonetyczne gwary nie są tutaj istotne, rezygnujemy z wiernego zapisu fonetycznego cytatów, wprowadzając uproszczoną, literacką pisownię zachowującą tylko główne cechy wymowy. 
$4 \quad$ czlowiek towarzyszą określenia: chudobny 'biedny', bogaty, dobry, energiczny, fajny, każdy, poczciwy, prawdziwy, stary, szumny, umęczony, uónaczóny 'tu: urobiony', wyuczony, zgodliwy 'zgodny', zly i wiele innych.

Biorąc pod uwagę znaczenie wyrazu czlowiek, zauważa się, że konotacji w znaczeniu ogólnym, gatunkowym jest niewiele:

[1] Każdy ta człek nosi jakąsi trapę, każdy ta, każdy ma jakąsi mamunę życia, co mu zaprzątuje głowę (Jazowski 1967, 69),

[2] Jes u clowieka taki talynt, wiycie do cegoś (Bubak 1972, 49),

[3] Ne to godali, ze clowiek mo dwa duchy, ale przy biyrzmuwaniu tyn zły ucieknie z clowieka (Sowa 1990: 105),

[4] Wilk sie clowieka tyz boi (Bubak 1972, 116),

[5] Trza byłoby się, Michał, przejść pomiędzy chałupy - gada jednego razu baba do chłopa - i wybadać, co ftora z tyf dziewek warta. - Dobrze gadasz, babo - zauważył chłop. - Ale jakoz to zrobić? Człowiek człowieka nie przeźre; najlepiej ponoć to jeszcze, powiadają ludzie, można poznać człowieka w biedzie. (Jazowski 1967, 257).

Forma ludzie jest bez wątpienia nazwą gatunkową, odnoszącą się zarówno do kobiet jak i do mężczyzn. Oto wybrane przykłady:

[6] Zgodliwe ludzie som (Nitsch 1960, 98),

[7] No to tu na Śpisie ludzie godajóm, przewaźnie, no bo to tak powiedzieć, wiyncyj z polscyzny jes (Bubak 1972, 124),

[8] A ludzie, jak ludzie. Zaczeni holofić, krzyczeć na tego pana, co jaż na ostatku doszło i do bitki (Jazowski 1967, 64),

[9] To zacón okrutnie hruby śnieg kurzyć i kurzyć bez końca. Dosło do tego, ze ludzi fciało zaprać na „Amen”. Bronili sie ludzie, furt odgarniali śnieg ze swoik dróg, ale duzo ludzi wymarło skrony złej zimy (Pluciński 1997, 41),

[10] Jak przysło kosynie na tyk polanak, to cało wiyś prawieze wysła, prawie zostali we wsi ino tacy ludzie starzy, co juz nie byli do roboty, [...], ludzie z dzieciami, z takymi kolómbkami, grostuchami śli na te polany, [...]. Ni mieli ta ludzie takyk wózeckóf, jak teroz prze dzieci (Sowa 1990, 95),

[11] Ludzie sie skar-zyli, śli do Morcina a potym godali, ze sie poprawiyło (Grochola 1994, 214).

W takim samym znaczeniu jak forma ludzie wystąpił w tekstach rzeczownik świat:

[12] -Jasiek, Jasiek! - podeszła Kaśka do chłopa. -E dy byk była do krzty zabaczyła. Kielo mam pytać za tę krowiczkę?

- Co się ta bes dużo trzymała - kiwnął chłop ręką.

- Daj za telo, kielo ci be świat dawał. Krówka stara, to mały pieniądz be (Jazowski 1967, 252).

W spiskich tekstach gwarowych większość przykładów z wyrazem człowiek odnosi się do rodzaju męskiego. Człowiek jest synonimem mężczyzny. Oto wybrane przykłady:

[13] Wte on skoczył temu panowi na pomoc, bo się widziało, że to szumny i poczciwy czlek (Jazowski 1967, 64),

[14] Dopiero koło połednia zjawił się na drodze jeden człowiek [...]. - Zjem 
cię, człowieku [...]. Chłop stanął, bo to chłop był i do tego doś taki dobry bunkoś, krzepki, i patrzy się na wilka (Jazowski 1967, 88),

[15] Rzónca [...] był taki bardzo dobry cłowiek (Bubak 1972, 36),

[16] Nie było, [...] takiego pijana jako nieboscyk Jonek spod Palenice. Nie był cłowiek zły, to niy, ni móc o niymu powiedzieć. Ani muchy nie zabiół, nikomu nie ublizół, ani ludziom, ani nijakyj zywinie a w doma zaś baby nie bijoł, lym ze jak ona na niego kufe ozdarła, tak jyj dłuzny nie był (Sowa 1990, 104),

[17] Wspomóż biednego dziada w biedzie, dobry człowieku [...]. - Masz, stary człowieku, wdziej se to - Michał podał mu serdak. - Barz dziękuję - kłaniał się mu potem ten dziad pięknie jaż do ziemie. - Bóg ci za to szczodrze wynagrodzi, poczciwy człowiecze (Jazowski 1967, 174),

[18] Toś to chłop jest człowiekiem jak każdy inny i należy się mu sprawiedliwość i szacunek, podobnie jak każdemu człowiekowi (Jazowski 1967, 180),

[19] Nie śmie się starymu dziadkowi zminiać fajke, bo w tyj fajce to jes dusa tego starego cłowieka (Sowa 1990, 93),

[20] W niedziele to sie juz jadło, to jedzynie było nojgłówniejse, kazdy mioł w dóma swojóm dómaśnóm kiełboske, a fto ni mioł, tak se jóm musioł jako zegnać, tak ze i nochudobniyjsy cłowiek we wsi, taki poććiorz tyz tóm kiełboske se musioł zaobstarać (Sowa 1990, 94).

Dobitnym przykładem na to, że człowiekiem jest mężczyzna, a nie kobieta może być fragment opowiadania, w którym młody niedźwiedź wysłany przez ojca - niedźwiedzia, poszukuje człowieka:

[21] Pódziesz chycić człowieka i skosztujesz mięsa ludzkiego. Ale łap prawdziwego człowieka, bo ze słabym pasować się to nie honor na niedźwiedzia. [...] - Jak dasz radę człowiekowi, to cię bem uważówał za mocnego i przyryftówanego do życia. [...] Pod lasem chłopiec i dziewczyna paśli bydło. [...] Niedźwiedź zaszeł if od zadku i z niespodzionka przyskoczył ku nim. - Tyś człowiek?! Zjem cię! - wychrapał niedźwiedź i zamierzył się z łapami na chłopca. - Nieee! - wrzasnął chłopiec ze strachu. - Ja dopiero będę człowiekiem (Jazowski 1967, 94).

Określenie człowiek często pojawia się w wypowiedziach informatorów, kiedy mówią, opowiadają o sobie lub ogólnie o kimś, czyli w funkcji zaimka osobowego: ja lub w funkcji zaimków nieokreślonych: ktoś, ktokolwiek, każdy. Oto wybrane przykłady:

[22] Zarno schodzi piyknie, ładnie, siumnie, nó tak juz potym zaś kapke sobie cłowiek odychnie, [...]. Tak sie zaś cłowiek biere, jak juz na łónkaf jes trowa wielko [...] do kosynio (Bubak 1972, 16),

[23] Jo móm bardzo zamiłowanie do owiec, [...]. Jedyn rokef naganioł, no to mie i poprzewracały w kosorze, ubrudzónyf taki był wiecór, domocóny, lygóm pod pryc albo pod ławe, nojcyńści jak dys loł to do popiołu, casym sie ta cłowiek i spolył, jak juz piekło bardzo no to wtedy wycióngnół sie, ale kosula spolona, nogawice spodnie spolone. Takif chodziył jak Cygón (Bubak 1972, 74),

[24] Ja jesce nie był tam zebyf był w śpytolu, abo dzie, zadnego wypadku, tak powiedzieć ni mo cłowiek, zeby tak cuł, zachoruwał i cuł tam dolegliwości, bolało go co. [...] chodzi cłowiek, zeby zarobić (Bubak 1972, 77),

[25] E panosku, co jo przezył na świecie. No jak cłowiek był chłopcym, wiy- 
$\hookrightarrow \quad$ cie, no to nie dali spokoja chłopcu w dóma, niy ojcowie no bo trza było iś gynsi paś (Bubak 1972, 137),

[26] To ni ma sie co dziwić, bo mnie słowiyńskie pismo idzie, a polskie nic nie idzie tak, bo cłowiek naucóny słowiynskie pisać (Bubak 1972, 104),

[27] A my to se tu sami robiyli te putnie, sómsieki, no toto syćko, co potrzebne na gazdówce z drewa, a tak samo wóz, koła, tak ze w kazdyj opcy był taki, co wiedzioł robić koła, no taki kolorz, a robiół i wozy, pługi, no bo jak cłowiek to nie wiedzioł zrobić, tak syćko musioł kupić, a z tymi pinióndzami było chodźjako (Sowa 1990, 99-100).

Podane powyżej wypowiedzi pochodzą od mężczyzn. Znalazły się cztery przykłady, w których kobieta użyła wyrazu człowiek mówiąc o sobie (lub ogólnie o każdej istocie ludzkiej):

[28] Sąsiade mamy niedobre, ale sie clowiek niefce prawocić (Nitsch 1960, 98),

[29] A ta clowiek tak piniyndzy ni mioł (Bubak 1972, 9),

[30] Myjyme sie pinióndzami, zeby to cłowiek mioł pinióndze (Bubak 1972, 10),

[31] Ta Maryna to tako popaniato, ani sie do clowieka nie obezwie tak jak nolezy (Grochola-Szczepanek 1996, 41).

Z polem semantycznym człowiek wiążą się określenia przymiotnikowe typu człeczy, człowieczy, człowiekowy, ludzki, występujące najczęściej w połączeniach z rzeczownikami takimi jak: ciało, gwara, mowa, życie, mięso. Nie znaleziono w tekstach określeń tego typu, odnoszących się bezpośrednio do człowieka (typu ludzki człowiek), za wyjątkiem jednego określenia ludzki, użytego w stosunku do kobiety: Ona, wiecie, była starq dziewka, ne i nie fciała się niczym innym zajmówać, ba jacy księdzami. Ludzka była, a barz pobozna (Jazowski 1967, 241).

Analizując spiskie teksty gwarowe pod kątem znaczenia i konotacji pojęcia człowiek, należy podkreślić, że pomimo ogólnego bogactwa tekstów, materiał dotyczący człowieka jest dość ograniczony i ubogi. Przy określeniu istot ludzkich wyraz człowiek ustępuje miejsca konkretnym określeniom żeńskim lub męskim typu: baba, dziewka, gospodyni, kobieta, ona, chłop, gazda, on, parobek, ...itp., np.:

[32] Chłop stanął, bo to chłop był i do tego doś taki dobry bunkoś, krzepki, i patrzy się na wilka (Jazowski 1967, 88),

[33] Ón tak długo był przi ni, [...] jaze óna, od niego i hruba została (Malinowski 1903, 136),

[34] Jednymu chłopu umarła baba i ostała się po niej córka, Marysia. (Jazowski 1967, 134),

[35] Nó chłop to pokosi, piyknie kobiyty ostrzepujóm ładnie hej! Cyscóm, ryftujóm, hej, zeby skło (Bubak 1972, 16),

[36] Óna sie spodobała jymu a ón jyj. Juz tam kukoł do niyj, juz zachodziół (Bubak 1972, 17),

[37] Był tu jeden chłop taki trochę dziadowaty, robotę zrobić zrobił, ale sićko mu trza było pokazać, nagadać, ażeby tak sam co zrobił, to nic. [...], baba rada rządziła sama (Jazowski 1967, 237), 
[38] Ej dy byciez dobro ino gazdyni dy weźciez ino tego chłopca (Bubak 1972, $60)$.

Ma to najprawdopodobniej związek z tym, że język ludowy operuje głównie nazwami konkretnymi, a w małym stopniu nazwani uogólnionymi, czy abstrakcyjnymi.

Jeszcze jedna uwaga, o której trzeba powiedzieć na temat tekstów gwarowych, to fakt, że informatorami są w większości mężczyźni. Tak wynika z danych informatorów oraz z kontekstu wypowiedzi (tam, gdzie nie podano danych rozmówców). Może ma to związek z tym, że osobami pytającymi byli także głównie mężczyźni? Jednak nie wydaje się, aby płeć informatora mogła mieć tu wpływ na znaczenie i konotacje wyrazu człowiek, ale powszechny uzus językowy. Męski narrator ma jednak wpływ na wybór bohatera oraz na użycie pewnych konstrukcji językowych. Narrator zwykle opowiada o sobie lub o osobach mu znanych (głównie o mężczyznach, rzadziej o kobietach), więc i bohater jest rodzaju męskiego. Taki stan powoduje, że w tekstach odnajdujemy więcej konotacji dotyczących postaci męskich i rodzaju męskiego. Wśród męskich postaci odnajdujemy całą galerię gazdów, mężów, ojców, kawalerów, baców, zbójników, panów i wielu innych. Postaci kobiece zwykle ograniczają się do żon, panien, gospodyń i matek. Płeć postrzegana jest przede wszystkim przez pryzmat ról społecznych, jakie pełnią kobiety i mężczyźni. Zachowania językowe oddają tradycyjny podział funkcji i ról społecznych kobiet i mężczyzn. Kobieta zwykle zajmuje się domem, wychowaniem dzieci, pracą na gospodarstwie, natomiast mężczyzna - pracą poza domem, na gospodarstwie, zarobkowaniem i reprezentowaniem rodziny na zewnątrz. Konsekwencjami językowymi takiego podziału jest m.in. występowanie męskich lub żeńskich nazw związanych z danym obszarem działalności, np. baca, furman, hajcy 'gajowy', juhas, babica 'akuszerka', troczka/trojaczka 'kobieta trąca len', przqdka, szwaczka.

W wypowiedziach informatorów, zarówno kobiecych jak i męskich, w kwantyfikacji zdaniowej dominującym rodzajem jest rodzaj męski lub męskoosobowy, np.:

[39] Tu sie dwa fcieli zyjść, jedna para (mowa o pannie i kawalerze) (Bubak 1972, 17),

[40] U jednego jedyn dziyń, u drugiego drugi (mowa o weselu, które odbywa się najpierw u panny młodej a później u pana młodego) (Bubak 1972, 18),

[41] A co toci ojcowie tym młodym dadzóm. (Sowa 1990, 98)

[42] Przyśli panowie dwa, no pan i pani i ta dziywka. [...] pani i ta dzywka zemgleli (Bubak 1972, 68),

[43] No jak sie poznajóm, to jedyn do drugiego chodzi (mowa o kawalerze i pannie). [...] Młodzi panowie (panna młoda i pan młody) (Bubak 1972, 101).

Powyższe spostrzeżenie, że w tekstach spiskich człowiekiem jest zasadniczo mężczyzna (rzadko kobieta), znajduje potwierdzenie w poświadczeniach z innych terenów Polski. W Słowniku gwar polskich (1994, 136-137) pod hasłem człowiek w znaczeniu ogólnym 'homo sapiens' nie ma ani jednego przykładu, który dotyczyłby naprawdę kobiety. Znajdujemy tam natomiast dodatkową informację, że w tym ogólnym znaczeniu często w kontekstach jest to mężczyzna, np.

[44] Był tu cłowiek, co ón chodził, co mówił, co jes owcoz [!], 
[45] Taki elegancki człowiek przysiod sie do jich,

[46] Jakiś obci czowiek [!] jidzie do nas.

Słownik gwar polskich (1994, 136-137) notuje znaczenia węższe, odnoszące się tylko do rodzaju męskiego: 'mężczyzna' oraz 'mąż'. Oto kilka przykładów:

[47] W tych sukmanach to chodzili człowieki, baby chodzili w postołach, tak samo jak i człowieki,

[48] Sumowina to zły cłowiek albo baba,

[49] Mogo iść na przypatrunek wszyskie, ale żeby wszysko człowieki, żeby ani jedny kobiety,

[50] Tam takie prawo, że jak umrze żona, to człowieka w trumne żywego kłado,

[51] Człowiek żonke lubi jak zdrowa.

W słowniku kaszubskim B. Sychty udało się znaleźć jeden przykład, w którym mowa jest o kobiecie jako człowieku: Jego kobieta toj je ewetreksa 'wesoła kobieta' i dobry człowiek (Sychta 1967, t. I, s. 275).

Materiał wydobyty z tekstów gwarowych wykazuje, że pojęcie człowiek stosowane jest asymetrycznie w stosunku do obu płci. Człowiek utożsamiany jest głównie z mężczyzną, a w konotacjach dominuje płeć męska. Przykładów z człowiekiem w znaczeniu ogólnym ‘homo sapiens' jest znikoma ilość. W języku ludowym, podobnie jak w języku literackim ${ }^{7}$, wyraz człowiek nie jest zatem w pełni nazwą gatunkową, gdyż nie odnosi się w takim samym stopniu do rodzaju żeńskiego i męskiego. Nazwą gatunkową, ogólną jest liczba mnoga ludzie ${ }^{8}$. Można zatem powtórzyć myśl z „Teorii polityki płciowej” Kate Millet (1982, 58-97), że zarówno język, jak i tradycja utożsamiają człowieczeństwo z mężczyzną.

\section{Źródła}

Balara, Michał, 1986, Na Spiszu, Warszawa.

Bubak, Józef, 1972, Spiskie teksty gwarowe z obszaru Polski, „Zeszyty Naukowe Uniwersytetu Jagiellońskiego. Prace Językoznawcze”, 36, Kraków.

Cygal-Krupa, Zofia, 1969, Teksty gwarowe ze Spisza, „Prace Językoznawcze Uniwersytetu Śląskiego", 1, s. 136-139.

Cygal-Krupa, Zofia, 1971, Teksty gwarowe ze Spisza, „Zeszyty Naukowe Uniwersytetu Jagiellońskiego, Prace Językoznawcze", 35, s. 257-260.

Czambel, Stanisław, 1906, Slovenska reč a jej mesto v rodine slovanskych jazykov.

7 Zob. m.in. prace A. Jaworskiego (1989, 83-92), B. Miemietz (1993, 169-180) i M. Karwatowskiej, J. Szpyry-Kozłowskiej (2005). Jak wynika z badań w języku literackim pojęciem, które w jednakowym stopniu określa kobietę i mężczyznę, jest rzeczownik osoba (Jaworski 1989, 83-92).

8 Aczkolwiek forma ta podlega także pewnym ograniczeniom. Nie odnosi się do grupy składającej się tylko z kobiet. Przykład: Ludzie z naszego bloku niechętnie rodzą dzieci w tym szpitalu, jest niepoprawny, gdyż wyraz ludzie ma odmianę męskoosobową, zob. D. Weiss $(1988,413-443)$. 
I. Osnovy a iny materiál rečovy. 1. Vychodnoslovenské nárečie, Turč. Sv. Martin, s. 449-451.

Grochola, Helena, 1994, Teksty gwarowe [Rzepiska], „Język Polski”, 74, s. 211214.

Grochola-Szczepanek, Helena, 1996, O niektórych formach grzecznościowych mieszkańców wsi Rzepiska na Spiszu, „Język Polski”, 76, s. 40-44.

Grzegorzewski, Jan, 1919, Na Spiszu. Studia i teksty folklorystyczne. Lwów.

Jazowski Andrzej, 1967, Opowieści ludu spiskiego, Warszawa.

Malinowski, Lucjan, 1903, Powieści spiskie, „Materiały Antropologiczno-archeologiczne i Etnograficzne", VI, 1903, s 126-152.

Małecki, Mieczysław, 1935, Polskie teksty gwarowe ze Spisza, „Sbornik Matice Slowenskej", XIII, č. 1, s. 136-140.

Nitsch, Kazimierz, 1960, Wybór polskich tekstów gwarowych, Warszawa, s. 95-98 (wyd. 2).

Pluciński, Jan, 1997, Teksty napisane badź opracowane przez Jana Plucińskiego,

[w:] Jan Kowalczyk, Jan Pluciński niestrudzony budziciel, s. 37-47.

Sowa, Franciszek, 1974, Teksty gwarowe [Dursztyn], „Język Polski”, 54, s. 45-47.

Sowa, Franciszek, 1990, System fonologiczny polskich gwar spiskich, Wrocław-Warszawa-Kraków.

Sychta, Bernard, 1967-1976, Słownik gwar kaszubskich na tle kultury ludowej, t. I-VII, Wrocław-Warszawa-Kraków.

Słownik gwar polskich, 1994, oprac. przez Pracownię Dialektologii Polskiej Instytutu Języka Polskiego PAN w Krakowie pod kier. Jerzego Reichana, t. V, z. 1 (13), red. Jerzy Reichan, Stanisław Urbańczyk, Kraków.

\section{Literatura}

Bańko, Mirosław (red.), 2000, Inny słownik języka polskiego, Warszawa.

Dunaj, Bogusław (red.), 1996, Słownik współczesnego języka polskiego, Warszawa.

Jaworski, Adam, 1989, On gender and sex in polish, „International Journal of the Sociology of Language", 78, s. 83-92.

Karwatowska, Małgorzata, Szpyra-Kozłowska, Jolanta, 2005, Lingwistyka płci. Ona i on w języku polskim, Lublin.

Kostera, Monika, 2003, Męskie struktury - kobiece sieci: od stereotypu do archetypu w organizowaniu, [w:] Obszary kultur kobiecych w badaniach ptci/rodzaju, red. Elżbieta Pakszysz, Monika Baer, Poznań, s. 160-174.

Miemietz, Baerbel, 1993, Kto to jest „człowiek”, „Teksty drugie”, 4-5-6, s. 169-180.

Millet, Kate, 1982, Teoria polityki płciowej, [w:] Nikt nie rodzi się kobieta, red. Teresa Hołówka, Warszawa, s. 58-97.

Nilsson Barbro, 2003, Człowiek - mężczyzna, O klasach, indywiduach i instancjach, [w:] Wizerunki mężczyzny w języku i literaturze polskiej/Images of Man 
in Polish Language and Literature, red. Ewa Teodorowicz-Hellman, Dorota Tubielewicz-Mattsson, Stockholm, s. 9-17.

Pajdzińska, Anna, 2001, Kobieta najlepszym przyjacielem człowieka (przyczynek do językowego obrazu świata), [w:] Studia z historii języka polskiego i stylistyki historycznej, red. Czesław Kosyl, Lublin, s. 151-159.

Rothstein, Robert, 1976, Uwagi o rodzaju gramatycznym i cechach semantycznych wyrazów, „Język Polski”, 56, s. 241-253.

Szymczak, Mieczysław (red.), 1974, Słownik języka polskiego, Warszawa.

Weiss, Daniel, 1988, Kurica ne ptica, (a) baba ne čelovek, [w:] Slavistische Linguistik 1987, red. Jochen Raecke, München, s. 413-443.

\section{Človek - kdo je to? \\ Razmišljanje o spolu besede človek v ljudskem jeziku \\ Povzetek}

Predmet razmišljanja je spol besede człowiek v ljudskem jeziku. Avtorica se sprašuje, ali se beseda człowiek v enaki meri nanaša na žensko in na moškega.

Podatki, ki so bili pridobljeni iz narečnih besedil, kažejo, da se beseda człowiek za oba naravna spola ne uporablja simetrično. Navadno označuje moškega in njen slovnični spol je dominantno moški. Primeri, kjer označuje človeško vrsto, so zelo redki. Beseda człowiek ni popolna oznaka za človeško vrsto niti v narečjih niti v knjižnem jeziku, ker se ne nanaša v enaki meri na moškega in na žensko. To označuje množinska oblika ludzie.

Helena Grochola-Szczepanek

Instytut Języka Połskiego PAN, al. Mickiewicza 31, Kraków helenags@interia.pl 


\section{Ојконимијата во Тиквешкиот регион \\ Елка Јачева-Улчар (Skopje)}

IZVLEČEK: Ojkonimski sistem Tikveške regije, ki leži v centralnem in južnem delu Makedonije, je v prispevku obravnavan s semantičnega in besedotvornega vidika. Na kratko je prikazan tudi izvor ojkonimov.

\section{The Toponyms of the Tikveš Region}

ABSTRACT: This article discusses the toponym system of the Tikveš region of central and southern Macedonia in terms of semantics and word formation. In addition, the origin of toponyms is briefly presented.

Тиквешкиой рег̄ион, познат уште и како Тиквешија, претставува пространа иниска котлина, сместена во средното Повардарје со површина

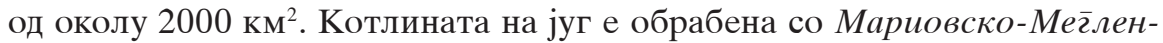
скийе Планини и пл. Кожуф, на запад ја заградуваат планините Борила и Клейа, на исток планините Балија и Карадаг̄, а на север, наспроти Велес, Овче Поле и Шйий нејзиниот раб е најнизок и има висина од само 400 до 550 м.

Во Тиквешкиот регион на самиот терен, како и во историските извори се регистрирани 140 населени места. Тоа се следниве: Бања, Барово,

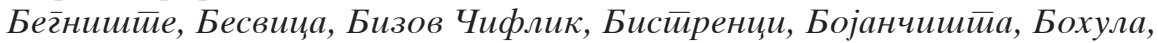
Брусник, Брушани, Будур Чифлик, Бунарче, Вайаша, Величани, Вешје, Влашево, Возариц, Војшанци, Волчи Дол, Врбниц̧, Галишиее, Гавран, Глишик, Грниково, Големо Полошко, Горна Бошава, Горни Дисан, Горни

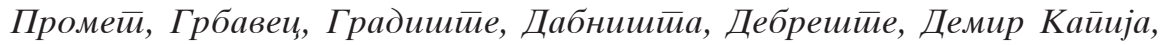

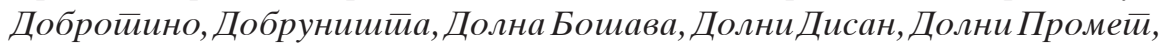
Дошница, Драг̄ожел, Драдња, Драчевица, Дрен, Дреново, Дублани, Дуброво, Дукена, Дуњица, Елешница, Енборија (Емборија), Желишйа, Злешево, Злешйа, Иберли, Јанков Чифлик, Јаношево, Кавадарци, Камен Дол, Камениц̧а, Калањево, Кесендре, Клейовник, Клиново, Клисура, Клуч, Книно, Конойишӣе, Койришниц, , Корешница, Кошани, Кошарка, Кошариц, Криволак, Крњево, Крушевица, Кукуричани, Куманичево, Курија, Лег̄ово, Лийа, Мајден, Мало Полошко, Манасииир,

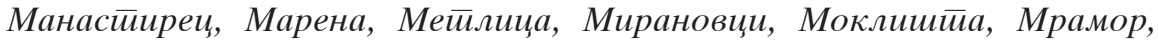


$-\quad$ Мрежичко, Мрзен Ораовец, Мушиичани, Неволани, Нег̄оӣино, Оризари,

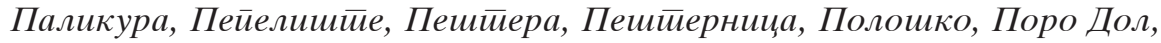
Порович, Праведник, Прждево, Просек, Радња, Раец, Рајница, Ракийа, Раковеи, Ресава, 'Ржаново, Рибарци, Рожден, Росоман, Свейа Пейка,

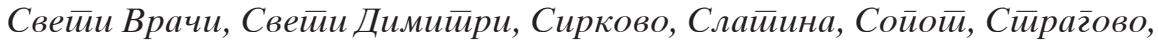
Сйрмашево, Тиквеш, Тимјаник, Тремник, Трсиеник, Тушанец, Фариш, Хохово, Храниславци, Храшйани, Црвени Брег̄ови, Челевец, Чемерско, Чифлик, Џидимирци, Шеоба, Шешково и Шивец.

Според статистичките податоци од претпоследниот попис во $\mathrm{P}$ Ма-кедонија од 1994 год. ${ }^{1}$ од горенаведениве населени места само $71 \mathrm{ce,}$ сѐ уште, активни, додека остатокот, кој изразен во проценти изнесува $49 \%$, се раселени и опустени населени места.

При обработката на ојконимискиот, како и на целиот топонимиски материјал од Тиквешкиот регион, се раководевме од класификацијата на В. Пјанка, којашто во македонската научна јавност беше презентирана

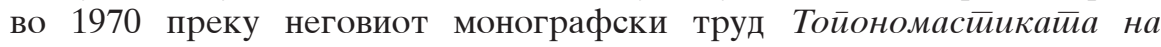
Охридско-йресйанскиой базен. ${ }^{2}$ Во овој труд, севкупниот топонимиски материјал, е класифициран на две основи: лексичко-семанииичка и

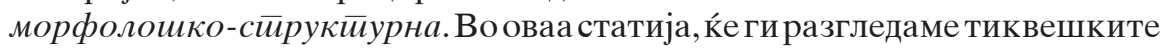
ојконими од овие два аспекта, а на крајот ќе кажеме збор-два за нивното потекло, кое, пред сѐ, е словенско.

Лексичко-семантичка класификација на ојконимите од Тиквешкиот регион

Од лексичко-семантички аспект ојконимискиот материјал од Тиквешијата можеме да го класифицираме во две основни групи и тоа: 1. Ојконими образувани од айелайиви и 2. Ојконими образувани од оними.

\section{1. Ојконими образувани од айелайиви}

Ојконимите од оваа група, од своја страна се делат во неколку подгрупи во зависност од тоа на која зборовна група ѝ припаѓаат апелативите коишто се вложени во основата на топонимот, односно во зависност од тоа дали во основата е вложена именка, придавка, глагол или некоја друга зборовна група. Во овој контекст, кај ојконимискиот материјал од Тиквешкиот регион се издвоија следниве подгрупи: 1. I Ојконими образувани од именски основи; 1. ІІ Ојконими образувани од придавски основи; 1. III Ојконими образувани од глаголски основи; 1. IV Ојконими образувани од предлози

\section{I Ојконими образувани од именски основи}

Ојконимите образувани од именски основи, се поделени во две

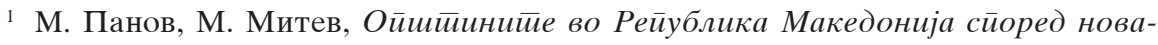

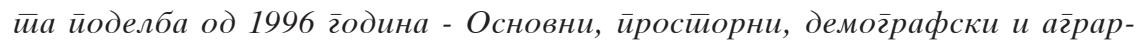
но-сиирукииурни обележја, Скопје 1997, 67-68. 
подгрупи и тоа: а) ојконими образувани од неперсонални именки и б) ојконими образувани од персонални именки.

\section{I а. Ојконими образувани од неперсонални именки}

Во оваа група се издвојуваат две групи ојконими и тоа:

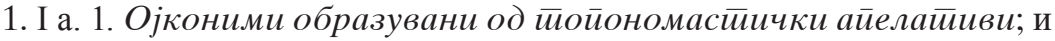

1. I а. 2. Ојконими образувани од нейойономасииччки айелайиви.

1. I а. 1. Ојконими образувани од йойономасииички айелайиви ги поделивме во следниве подгрупи:

\section{I a.1.1. Ојконими изведени од физиографски термини}

1. I a.1.1.1. Ојконими изведени од орогррафски ииермини

Во оваа подгрупа влегуваат ојконимите: Галишие (: галиште 'голо место, камењар'), Каменица, Клисура, Пешиеера, Пешиеерница, Просек, Тремник (: трем 'скрито, сенчесто место'), Челевец (: чело 'преден дел од рид, планина, рамно и голо место на планина, рамнинка меѓу два рида'); ${ }^{3}$ Волчи Дол, Камен Дол, Горни Промей (: *промет 'место од каде што се поминува, се префрла; превалец'), Долни Промей, Поро Дол.

1. I a.1.1.2. Ојконими изведени од хидрогррафски йермини

1. I a.1.1.2.1. Ојконими образувани од хидрографски термини со кои се означуваат истечни води се следниве: Клуч, Кесендре (: тур. гл. kesmek 'сече, пресечува' + им. dere 'река, дол'), Марена (: супстр. мара 'вода, река'), ${ }^{4}$ Слайина, Сойой.

1. I a.1.1.2.2. Ојконими кои се образувани од хидрографски термини со кои се означуваат неистечни води се: Глишиќ (:*іллиосек 'глибаво, мочурливо место што го пресечува река или пат' (: прсл. *г̃лива 'габа, печурка', супстантивизирана придавка образувана со суфиксот - ио од ие. корен *glei- 'лепи, мачка' + -сек : прсл. гл. *sěk-ti 'сече'), ${ }^{5}$ Криволак $(:$ криволака < крив $(a)<$ прсл. *krivъ и именката лака < прсл. *lqka со начење 'залив, мочуриште'), ${ }^{6}$ Моклишӣ $а$, Раец, Рајниц̧а (: прсл. *rajb 'блатно место'), ${ }^{7}$ Ресава (: реса 'блатесто место, блато') ${ }^{8}$ и Тимјаник (: прсл. *timěnъ 'глибаво, мочурливо место'). ${ }^{9}$

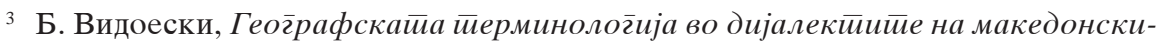
ой јазик, Скопје 1999, 171.

4 Љ. Станковска, Несловенски айелайиви во македонскайа йойонимија, Зб. реферати од XXIX Научна конференција одржана во Охрид , 19-20 август 2002, Скопје 2003, 436.

5 Љ. Станковска, Македонска ојконимија, кн. 1, Скопје 1995, 66-68.

6 В. Десподова, Е. Јачева-Улчар, С. Новотни, М. Чичева-Алексиќ, Сӣарословенско-македонски речник, Прилеп - Скопје 1999, 214.

7 D. Brozović, Nazivi za blatišta i njihovi toponimijski odrazi u hrvatskome jeziku, Folia onomastica Croatica, knj. 8, Zagreb 1999, 32; Е. Јачева-Улчар, За некои ојконими од Тиквешкиот̄ рег̄ион, сп. Balcanoslavica 30-31, Prilep 2002, 206-208.

8 Сп. рус. дијал. ряса 'влажно место, блато' кај М. Фасмер, Эйимолог̄ический словарь русског̄o языка, III, Москва 1987, 539,

9 D. Brozović, Nazivi za blatišta i njihovi toponimijski odrazi u hrvatskome jeziku, Folia 
1. I а.1.1.3. Ојконими изведени од йермини со кои се означуваай видови йочва и минерали

Во ова група влегуваат ојконимите: Брусник, Мрамор, Пейелишӣе; Демир Кайија (: тур. demir 'железо)'.

1. I a. 1. 2. Растителен и животински свет

1. I а. 1.2.1. Ојконими во чија основа се вложени фийоними, називи на делови од расиенија и йлодови

На оваа група ѝ припаѓаат следниве ојконими: Врбница, Дабнишӣа, Драчевица, Дрен, Дреново, Дуњица, Грниково (: граника 'бел даб, летен даб, Quercus pedunculata'), ${ }^{10}$ Елешниц̧а, Конойишйе, Койришниц̧а (: прсл. *kopriva/*kropiva), Корешниц̧а (: прсл. *kore)), Лийа, Мейлица, Ракийа, 'Ржаново, Сирково (: сирка 'дрво со жолтокафени ситни тврди плодови, со големина на бадем, Zizifus vulgaris'), Тиквеш, Трсииеник, Храшйани; Мрзен Ораовец.

1. I а.1. 2.2. Ојконими во чија основа се вложени шумски иеермини

Такви се ојконимите: Книно (: прсл. *kъnъ/*kъnь 'пенушка, шума, пресечено дрво')11 и Курија (: тур. им. koru 'мала гора, шумичка').

1. I а.1. 2.3. Ојконими во чија основа се вложени зооними

Тука спаѓаат ојконимите: Гавран, Раковец; Волчи Дол.

1. I a.1. 3. Ојконими во чија основа се вложени апелативи со кои се именуваат објекти изградени од човекот со специјална намена

Во оваа група ги поместивме следниве ојконими: Бања, Бег̄нишӣе, Бунарче, Мајден, Кошарка и Клейовник.

1. I a.1. 4. Ојконими образувани од апелативи со кои се именува имот што ѝ припаѓa на општествената заедница

Во оваа подгрупа се наоѓаат следниве ојконими: Чифлик; Бизов Чифлик, Будур Чифлик и Јанков Чифлик.

1. I a.1. 5. Ојконими во чија основа се вложени апелативи со кои се именуваат сакрални објекти

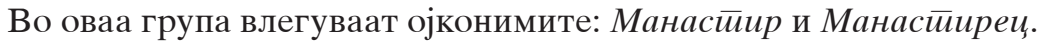

1. I a.1. 6. Ојконими во чија основа се вложени апелативи со кои се именуваат административни целини

Оваа група е претставена со ојконимите: Градишйе, Енборија (грч.

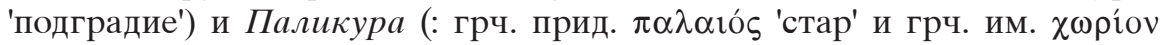
'село', т.е. 'старо село'). ${ }^{12}$

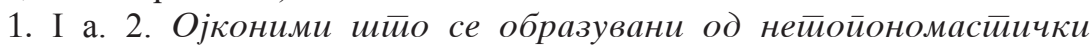
айелайиви:

Onomastica Croatica, knj. 8, Zagreb 1999, 34.

10 Сп. буг. т. Граниковец, Тројанско кај Н. П. Ковачев, Тойонимияйа на Троянско, София 1969, 120.

${ }^{11}$ P. Skok, Etimologijski rječnik hrvatskoga ili srpskoga jezika, II, Zagreb 1972, 108; M.

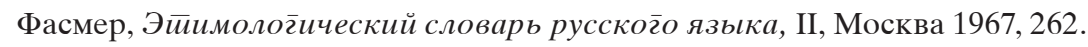

${ }^{12}$ Сп. ојконим Палеохори, село во Гребенската каза, кај В. Кънчов, Избрани ироизведения, т. II, София 1970, 575. 
1. I а. 2. 1. што именуваат метеоролошки појави: Дошницая;

1. I а. 2. 2. апелативи со кои се именуваат алати: Клиново и Шивец; и

1. I a. 2. 3. апелативи со кои се именуваат делови од куќа: Демир Kaйuja.

\section{I б Ојконими образувани од персонални апелативи}

Во оваа група се издвоија само оние ојконими во чија основа се влезени апелативи со коишто се именуваат занимања: Муйичани (пл. од им. мойичанин 'оној што врши мерење на лозја'), Оризари и Фариш (: арап. им. faris 'јавач, коњаник, витез'); ${ }^{13}$ Свейи Врачи (: врач 'лекар').

\section{II Ојконими образувани од придавски основи.}

Во оваа група се поместени оние ојконими во кои се вградени придавки што означуваат:

1. II 1. големина: Величани; Големо Полошко, Мало Полошко;

1. II 2. положба: Горна Бошава, Горни Дисан, Горни Промей, Долна Бошава, Долни Дисан, Долни Промей;

1. II 3. старост: Паликура (Старо Село)

1. II 4. облик на објектот: Криволак;

1. II 5. боја: Црвени Брег̄ови;

1. II 6. својства на човекот: Бесвица (: бесен), Бошавица (бос), Грбавец (: грбав), Праведник (: праведен); Свейа Пейка, Свейи Врачи, Свейи Димитири (: свет)

1. III Ојконими образувани од глаголски основи: Кесендре; Мрзен Ораовец (: гл. мрзне).

1. IV Ојконими образувани од предлози: Енборија (: слож. грч.

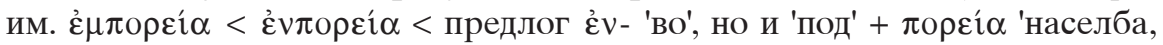
живеалиште', односно 'подградие').

\section{2. Ојконими шито се образувани од оними}

Во втората поголема група ојконими, насловена како Ојконими ийо се образувани од оними се издвоија следниве подгрупи:

\section{I Ојконими образувани од антропонимиски основи}

Во оваа група се сместени ојконимите што се образувани од:

2. I 1. машки лични имиња: Барово (: Баро), Бохула (: Бохул), Вайаша (: Ватах), Вешје (: Увет), Влашево (: Влах), Дебрешйе (: Дебрет), Дисан (: Дисан), Добройино (: Доброта), Драг̄ожел (: Драгожел), Драдња (: Драг), Злешево (: Злеш), Злешйа (: Злета), Јаношево (: Јанош), Калањево (: Калањ), Крњево (: Крње), Крушевица (: Круше), Куманичево (: Коумамнць $\left.{ }^{14}\right)$, Радња (: Рад), Рожден (: Рожд), Росоман (: Росоман), Лег̄ово (: Лего), Нег̄ойино (: Негота), Порович (: Поровит),

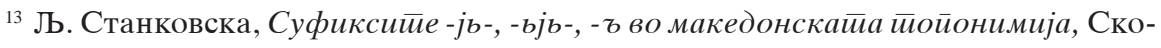
пје 2002, 405.

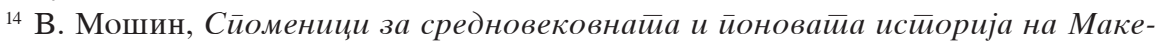
донија, т. I, III, IV, Скопје 1975-1981, 307. Ова име сп. со старите словенски л. 


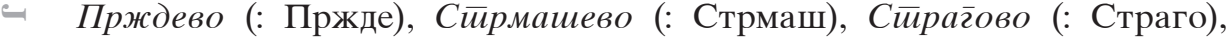
Тушанец (: Тушан ), Хохово (: Хохо), Шеоба (<*Шејова : Шејо), Шешково (: Шешко); Бизов Чифлик (: Бизо), Будур Чифлик (: Будур), Јанков Чифлик (: Јанко), Поро Дол (: Поро).

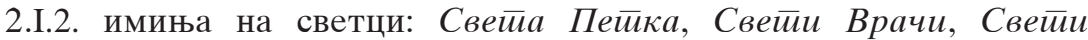
Димийри;

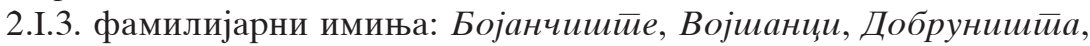
Желишӣа, Кошарци, Мирановци, Рибарци, Храниславци, Џидимирци.

2. II Ојконими образувани од други топоними: Бисйренци (: *Бистрени < топ. *Бистра), Брушани (: *Брус), Возарци (: *Возари < антр. *Возар < ап. возар 'лице кое превезува стока со кола, кочиџија, кираџија, превозник' или 'лице кое прави возови, коли $\left.{ }^{15}\right)$, Дублани (: топ. *Дубла < ап. дубла 'дупка, спила, длабока долина, пештера'), Иберли (: *Берт < ап. бер $\bar{u}^{16}$ 'непристапно, тешко проодно место'), Кавадарци (: *Кавадари < антр. Кавадар < ап. кавадар 'лице кое се занимава со правење наметки од скапоцен материјал') ${ }_{17}^{17}$ Кукуричани (: *Кукурица $<$ антр. Кукур $\left.{ }^{18}\right)$, Неволани (: *Невол < антр. Невол), Мрежичко (: *Мрежица < дем. ап. *мрежица), Полошко (: *Полог < ап. йолог) $)$ Чемерско (: *Чемер < антр. *Чемер ).

\section{Морфолошко-структурна класификација на ојконимите од Тиквешкиот регион}

Ојконимите од Тиквешијата, од структурно морфолошки аспект, можат да се поделат во две основи групи: I Еднокомпонентни и II Двокомпонентни. Еднокомпонентните се делат на 1. Недеривирани топоними (примарни) и 2. Деривирани топоними (секундарни), додека двокомпнентните најчесто се изразени со именска група составена од придавка во функција на атрибут и именка, како центар на именската група.

\section{1. Еднокомпонентни недеривирани ојконими}

Недеривираните топоними настануваат со топонимизација на апелативи и оними, а овој модел на создавање топоними претставува најелементарен начин за создавање топоними ${ }^{19}$ кој е практично и

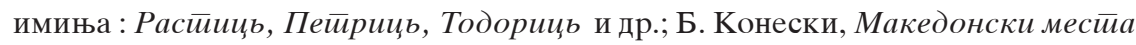
и имиња, Скопје 1981, 84.

15 Љ. Станковска, Македонска ојконимија, кн. 2, Скопје 1997, 49.

${ }^{16}$ О. Т. Молчанова, Исйорическая связь йюркской йойонимии Горног̄о Алйая и Тувы, Историческая ономастика, Москва 1977, 274.

17 Љ. Станковска, Македонска ојконимија, кн. 1, Скопје 1995, 124-125.

${ }^{18}$ Ова име кај нас се засведочено во еден запис од 1302 година во следнов контекст: Арагославь, Коукоуровь Zеть. B: L. R. P. Petit, B. Korablev, Actes de Chilandar, Санктпетербург 1911, 398.

${ }^{19}$ P. Šimunović, Toponimija otoka Brača, Supetar 1972, 241. 
еден од најстарите модели на топонимизација што им е познат и на другите индоевропски јазици. ${ }^{20}$ Топонимијата на Тиквешкиот регион, како микросегмент од глобалниот индоевропски ономастички систем, не покажува никакви отклонувања во овој контекст. Врз основа на тоа какви апелативи, односно оними, се наоѓаат во основата на недеривираните топоними се издвоија и по неколку подгрупи коишто ќе ги проследиме во продолжение.

\section{1. 1. Еднокомпонентни недеривирани ојконими рамни на именски апелативи}

Во рамките на оваа група се издвојуваат две подгрупи и тоа: 1 . Тойоними рамни на основни именки и 2. Тойоними рамни на изведени именки.

I 1. 1. 1. Групата ојконими рамни на основни именки се дели на ојконими рамни на неперсонални и на персонални именки.

I 1. 1. 1.1. Групата ојконими кои се рамни на основни неперсонални именки се следниве: Бања, Дрен, Клисура, Клуч, Курија, Мајден,

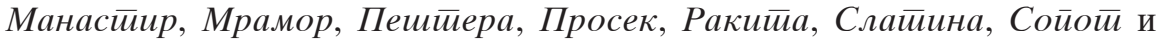
др.

I1.1.1.2. Групата ојконими основни персонални именки се следниве: Оризари и Муйичани.

I 1. 1. 2. Тойоними рамни на изведени именки:

I 1.1. 2.1.1. од именски основи со суф. - ишйе: Галишйе, Градишйе,

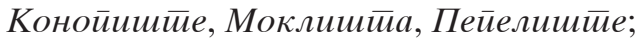

I 1. 1. 2.1.2. со деминутивните суфикси: -че (Бунарче), -ка

(Кошарка) и -ец, (Раец).

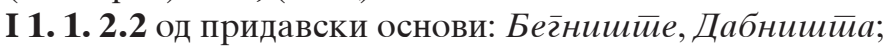

I 1. 1. 3. Ојконими рамни на сложени именки: Глищиќ, Енборија и Криволак.

\section{1. 2. Ојконими рамни на оними}

I 1. 2.1. Ојконими рамни на деривирани етници со:

а) суф. -јани/-ани: Брушани, Дублани, Кошани, Неволани, Кукуричани и Храшйани;

б) суф. -ции: Бистиренции, Возарции и Кавадарции;

в) тур. суф. -ли: Иберли;

I 1. 2. 2. Ојконими рамни на патроними: Војшанци, Кошарци, Рибарци, Храниславции и Џидимирции.

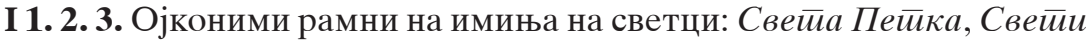

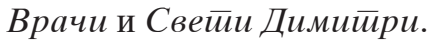

\section{2 Еднокомпонентни деривирани ојконими}

Овие ојконими се настанати како резултат од суфиксната супстантивизација која може да биде извршена по пат на интегрална и на дезинтегрална деривација. Супстантивизацијата на ојконимите од Тиквешијата се врши со следниве суфикси:

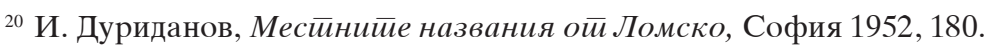


-ец: Грбавец, Манасӣирец, Раковеи, Тушанеи, Челевец и Шивец;

-еш: Тиквеш;

-ик/-ник: Брусник, Клейовник, Праведник, Тремник, Трсииеник, Тимјаник;

-ища: Врбница, Бесвица, Дошница, Драчевица, Дуњица, Елешница, Каменица, Койришница, Корешница, Крушевица, Мейлица, Пешиеерница, Рајница.

\section{3 Елиптични топоними}

Овие ојконими се добиени со бессуфиксна супстантивизација на придавската компонента од некоја хипотетична именска група, чиј центар, како редундантен отпаднал, а атрибутот продолжил да живее како елиптично име. Придавката кај елиптичните ојконими од Тиквешкиот регион, најчесто, е образувана со следниве суфикси:

-ин: Добройино, Нег̄ойино;

-jb и - bjb: а) Ојконими образувани со овој суфикс од лично име: Вайаша, Вешје, Дебрешиее, Драг̄ожел, Злешйа, Порович, Росоман; б) Ојконими образувани со овој суфикс од персонални именки: Фариш; в) Ојконими образувани со овој суфикс од неперсонални апелативи: Гавран;

-ъ: а) од лични имиња: Бохула; Дисан; б) од патронимиски

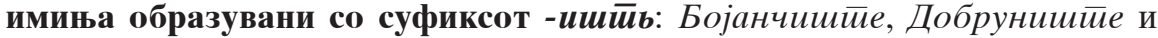
Желишй $a$; в) од неперсонални апелативи: Лий

-ов/-ев-: Барово, Влашево, Грниково, Дуброво, Калањево, Клиново, Крњево, Куманичево, Лег̄ово, 'Ржаново, Сирково, Сйраг̄ово, Сйрмашево, Хохово, Шеоба (< *Шејова), Шешково;

-ск-: Овој суфикс, кај наведениве ојконими има секундарно-топонимиска функција: Мрежичко, Полошко и Чемерско;

-н-: Драдња, Марена, Радња и Рожден;

-ав: Бошава и Ресава.

\section{II Двокомпонентни топоними}

Овие ојконими се делат на 1. Топонимиски сложенки и на 2. Сложени

\section{1. Топонимиски сложенки}

Во оваа група ги поместуваме ојконимите: Кесендре и Паликура.

\section{2. Сложени ојконими}

Како сложени ојконими најчесто изразени со придавка и именка во ојконимијата на Тиквешијата се издвојуваат следниве: Бизов Чифлик, Будур Чифлик, Волчи Дол, Големо Полошко, Горна Бошава, Горни Дисан, Горни Промет̄, Демир Кайија, Долна Бошава, Долни Дисан,

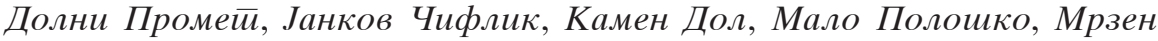
Ораовец, Поро Дол и Црвени Брег̄ови.

\section{За потеклото на ојконимите во Тиквешијата}

Од горенаведените ојконими се забележува дека најголем процент од нив имаат словенско потекло. Еден ојконим има супстратно потекло 
(Марена), помал дел имаат грчко (Паликура, Енборија, Манасӣир), латинско (Бања, Клисура), како и турско (Иберли, Кесендре, Мајден, Чифлик; Демир Кайија). Како хибридни ојконими ги сметаме Бунарче и Манасйирец (образувани се со македонскиот деминутивен суфикс -че, односно со сесловенскиот -ец), како и сложените ојконими Бизов Чифлик, Будур Чифлик и Јанков Чифлик, кај кои првата компонента е претставена со лично име од словенско потекло, а втората им е заедничка и води потекло од турската лексема çiftlik 'феудален земјоделски имот'.

\section{Извори}

Petit, L. R. P. , Korablev, B. , Actes de Chilandar, Санктпетербург 1911.

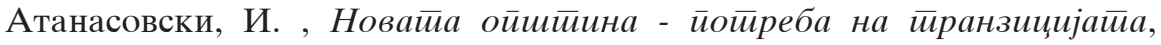
Кавадарци 1996.

Кънчов, В., Избрани ӣроизведения, том II, София 1970.

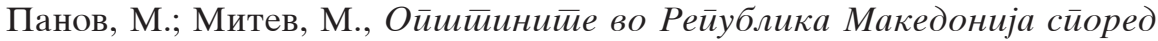

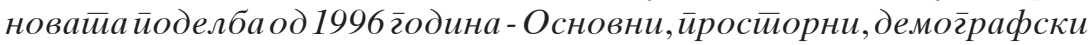

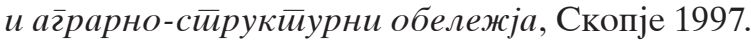

Радовановић, С. В. , Тиквеш и Рајец, Насеља и порекло становништва, књ. XVII, Београд 1924.

Стојановски, А. (редактор), Турски документи за историјата на

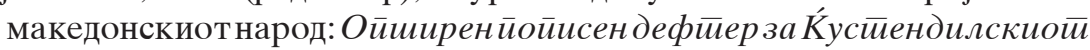
саниак од 1570 г̄од., т. V, кн. III, Скопје 1982.

Яранов, Д., Carte de la Macédoine dan ses limites géographiques, echelle 1 : 300.000, Sofia, 1933.

\section{Користена литература}

Brozović, D., Nazivi za blatišta i njihovi toponimijski odrazi u hrvatskome jeziku, Folia onomastica Croatica, knj. 8, Zagreb 1999, 1-44.

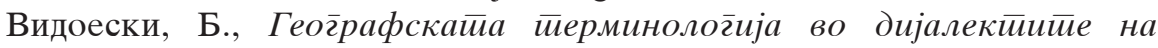
македонскиой јазик, Скопје 1999.

Десподова, В.; Јачева-Улчар, Е.; Новотни, С.; Чичева-Алексиќ М., Сйарословенско-македонски речник, Прилеп - Скопје 1999.

Дуриданов, И., Месйнийе названия ой Ломско, София 1952.

Јачева-Улчар, Е., Тойонимијайа на Тиквешкиой рег̄ион, Скопје 2005 (докторска дисертација - машинопис).

Јачева-Улчар, Е., За некои ојконими од Тиквешкиой рег̄ион, сп. Balcanoslavica 30-31, Prilep 2002, 206-208.

Ковачев, Н. П., Тойонимияйа на Троянско, София 1969, 120.

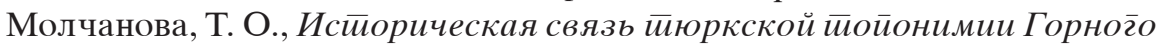
Алйая и Тувы, Историческая ономастика, Москва 1977.

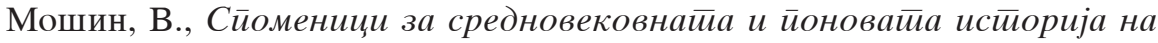
Македонија, т. I, III, IV, Скопје 1975-1981.

Конески, Б., Македонски месӣа и имиња, Скопје 1981.

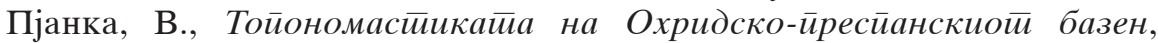
Скопје 1970. 
$-\quad$ Skok, P., Etimologijski rječnik hrvatskoga ili srpskoga jezika, II, Zagreb 1972.

Станковска, Љ., Македонска ојконимија, кн. 1, Скопје 1995.

Станковска, Љ., Македонска ојконимија, кн. 2, Скопје 1997.

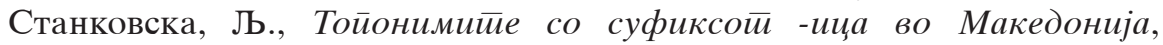
Скопје-Прилеп 2001.

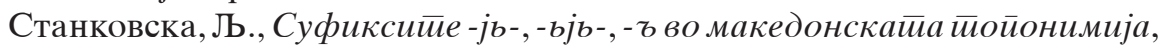
Скопје 2002.

Станковска, Љ., Несловенски айелайиви во македонскайайойонимија, 3б. реферати од XXIX Научна конференција одржана во Охрид, 19-20 август 2002, Скопје 2003.

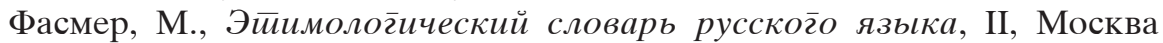
1967.

Фасмер, М., Эйимолог̄ический словарь русског̄о языка, III, Москва 1987, 539.

Šimunović, P., Toponimija otoka Brača, Supetar 1972.

\section{Naselbinska imena v Tikveški regiji}

Povzetek

$V$ prispevku je semantičnega in besedotvornega vidika analiziranih in klasificiranih 140 naselbinskih imen Tikveške regije, večjega območja v srednjem Povardarju. Klasifikacija ojkonimov je narejena po tisti, ki jo je v svoji doktorski disertaciji z naslovom Топономастиката на Охридско-преспанскиот базен (Toponomastika Ohridsko-prespanskega bazena) predstavil Poljak Włodzimierz Pianka. Analiza je pokazala, da se v ojkonimih Tikveške regije ohranjajo geografski apelativi, fitonimi, zoonimi in osebna imena. Poseben tip ojkonimov predstavljajo tisti, ki so enaki stanovniškim imenom in patronimikom. Z besedotvornega vidika so ojkonimi s tega območja pretežno nastali s toponimizacijo apelativov ali pa $s$ sufiksalno substantivizacijo. Precejšen del ojkonimov je eliptičnih, manjše število je zloženk in večbesednih imen. Glede izvora je najvišji odstotek ojkonimov slovanskega izvora, manjši pa turškega, grškega ali romanskega.

Elka Jačeva-Ulčar

Institut za makedonski jazik Krste Misirkov, Skopje 


\title{
Besedje za bratranca in sestrično v slovenskih narečjih (po gradivu za SLA)
}

\author{
Tjaša Jakop (Ljubljana)
}

IZVLEČEK: V članku je z metodo lingvistične geografije predstavljeno besedje, ki v slovenskih narečjih poimenuje sorodstvena razmerja, in sicer tetine ali stričeve otroke. V vprašalnici za Slovenski lingvistični atlas (SLA) sta v XIII. poglavju Družina tudi vprašanji št. 626 (bratranec) in št. 627 (sestrična), katerih raznoliki odgovori so prikazani na leksično-besedotvornih kartah.

ABSTRACT: This article uses linguistic geography to present vocabulary denoting blood relationships in Slovenian dialects; specifically, the children of aunts and uncles. Section thirteen of the SLA questionnaire titled "Family" also includes questions 626 (bratranec 'male cousin') and 627 (sestrična 'female cousin'). The various answers to these questions are presented on lexical and word-formative maps.

\section{Uvod}

Poimenovanja za ožje sorodstvene vezi so po slovenskih narečjih leksikološko dokaj enotna, z morebitnimi vplivi sosednjih jezikov (zlasti na zahodu). Najenotnejša so poimenovanja za pomen oče (V604) in mati (V605), sin (V606) in hči (V607) ter brat (V620) in sestra (V621), medtem ko se poimenovanja bratranec (V626) in sestrična (V627) že bolj pokrajinsko razlikujejo.

\section{Gradivo}

Pogostnost in prostorska razširjenost poimenovanj bratranec in sestrična je razvidna z jezikovnih kart s pripadajočima legendama. Karti sta napisno-izoglosno-znakovni, z legendo $\mathrm{v}$ desnem kotu spodaj. Znake obeh kart sem slušala čim bolj uskladiti, da bi bila njuna primerjava preglednejša. Notranje modifikacije znakov kažejo na različne pone, zunanja modifikacija pa pove, da gre za večbesedno poimenovanje (npr. mali brat). Nezapolnjenost znaka kaže, da je leksem prevzet. Pri točkah, ki še vedno niso zapisane, je namesto znaka številka kraja podčrtana 
(npr. 14), manjkajoči odgovori sicer zapisanih točk pa so označeni s poševnico (/). Diferenciranost leksemov in tujejezikovni vplivi so obdelani v komentarjih. ${ }^{1}$

Pri kartografiranju leksike je potrebno gradivo poknjižiti, tj. poiskati pravo stopnjo oz. mero abstrakcije, pri čemer se upošteva glasovne zakone posameznega govora (kot npr. popolna redukcija nenaglašenih samoglasnikov). ${ }^{2}$ Pri tem so nam $\mathrm{v}$ pomoč fonološki opisi posameznih govorov, katerih število se iz leta v leto veča (trenutno je od 404 točk oz. govorov SLA narejenih že 41 fonoloških opisov). Besede je potrebno tudi etimološko in besedotvorno razčleniti.

\section{Izvor in pomen leksemov}

Leksem bratránec (bratránka 'sestrična') je soroden ali enak cslovan. bratanı 'bratov sin, nečak, bratov vnuk', star. hrv. bràtan 'bratov sin', češ. bratranec 'bratranec'. V praslovanščini sta za koren brat- obstajali še obe obliki: bratrb in (po disimilacijski izgubi -r) bratb. Pslovan. *braträns je izpeljanka iz *bra̋trı 'brat', kar je prvotno pomenilo *'bratov sin, nečak'. Pridana pripona -an označuje specifikacijo v krvnem sorodstvu (bratan, bratana). Ta pomen se dobi tudi z razširitvijo s pomanjševalno pripono -ec (brat(r)anec) ali -ka (bratranka) ali pa pripono -ič (bratič, sestrič). Leksema bratran(ec) in bratan(ec) torej izhajata iz dveh različnih osnov, katerima je pridana pripona -an.

Današnji pomen 'stričev (ali tetin) sin' je nastal tako, da so to sorodstveno oznako otroci prevzeli od svojih staršev. Prvotni pomen se (poleg v zgoraj naštetih slovanskih primerih) ohranja še v redko rabljenem sloven. bratän 'bratov sin, nečak', bratána ali bratrána 'bratova hči, nečakinja'. Enako je iz séstra tvorjeno danes redko rabljeno sestrânec 'bratranec (prvotno po očetovi ali mamini sestri)', sestrána 'sestrična'. V etimoloških slovarjih najdemo še različice brâtič, brátranec, bratânec, bratrânček; sestrîčnik, sestrînec, sestrînek, séstrnik, sestrânič.

Leksem sestrîčna s pomenom 'sestrina hči' je v ženskem spolu posamostaljeni pridevnik od sestríca, manjšalnice od séstra. Iz manjšalnice moškega spola je sloven. sestrïč 'sestrin sin, nečak' (16. stol.) < *sestrît'b. Sestrîčna je bila torej prvotno *'sestrina hči, nečakinja'. Današnji pomen 'stričeva (ali tetina) hči' je nastal tako, da so to sorodstveno oznako otroci prevzeli od svojih staršev in pri tem niso upoštevali spremembe sorodstvenega razmerja (kot v primeru bratránec). Enako je iz brät tvorjeno danes redko rabljeno bratǐc 'bratranec (prvotno po očetovem ali maminem bratu)', bratîčna ali bratrîčna 'bratova hči, nečakinja'. Različice so še: séstrna, séstrnica, sestrîčka.

Leksem str̂nič je nastal iz *strъjb-nî́čb s pomenom 'stričev sin', posamostaljeno

1 Pri fonetičnem zapisu je uporabljena pisava ZRCola, ki jo je na Znanstvenoraziskovalnem centru SAZU v Ljubljani (http://www.zrc-sazu.si) razvil Peter Weiss, na kartah pa znaki SIMBola. Gradivo je vneseno s programom SlovarRed, karte pa narejene s programom CorelDraw.

2 Čeprav imata Pleteršnik in Bezlaj v slovarjih zapisani obe naglasni različici (brátranəc in bratânəc), prav tako tudi SSKJ (brátranec tudi bratránec), na karti št. 1 (V626) mesto naglasa ni posebej označeno. 
iz pridevnika *strъjb-nb 'stričev' (stryjb-na(ja) 'stričeva' $\rightarrow$ strina). ${ }^{3}$ Strnič, strénič in strnična so izrazi, ki se uporabljajo v slovenski Istri, le na jugu se mešajo z zermanom in zermano. ${ }^{4} \mathrm{~V}$ (etimoloških) slovarjih ne najdemo naslednjih leksemov, ki se nahajajo v gradivu SLA: bratran (le bratan), sestričen, sestranica, sestrinka, bratrančka in bratrančinja (le bratranka), kar kaže na izredno bogastvo slovenskega narečnega besedotvorja.

Od neslovanskih izrazov najdemo v gradivu SLA naslednje prevzete besede: $\mathrm{Na}$ zahodu najdemo romanske sposojenke kužin, kužina (< it. cugino) 'bratranec, sestrična', kusen, kusena ( $<$ furl. in ben. cusìn) 'bratranec, sestrična'5 in zurman, zurmana $^{6}$ ( $<$ furl. in ben. zermàn '1. bratranec, 2. sorodnik iste generacije, 3. star družinski prijatelj (Istra))' [v furl. je bila verjetno prevzeta iz fr. le cousin germain 'prvi bratranec', la cousine germaine 'prva sestrična']. Na vzhodu najdemo madžarsko sposojenko unokateštver $(<\operatorname{madž}$. unokatestvér = skupno ime za bratrance, sestrične, nečake, nečakinje, vnuke in vnukinje, otroke bratov in sester (ponekod v Porabju) ${ }^{7}$ ([madž. barát ima drug pomen, in sicer 'prijatelj'].

\section{Razširjenost leksemov v slovenskih narečjih (komentar h kartam)}

Najbolj razširjen leksem v pomenu 'stričev ali tetin sin' je bratranec, v pomenu 'stričeva ali tetina hči' pa sestrična. Leksema najdemo v vseh narečnih skupinah: $\mathrm{v}$ celotni koroški narečni skupini, v vzhodnem delu primorske narečne skupine (brez rezijanskega, terskega, nadiškega, briškega, istrskega in dela kraškega in notranjskega narečja), v celotni rovtarski, dolenjski in gorenjski narečni skupini, v štajerski narečni skupini (razen v južnem delu kozjansko-bizeljskega in južnopohorskega narečja). $V$ panonski narečni skupini prevladuje poimenovanje bratranec, namesto leksema sestrična pa se pogosteje rabi leksem sestrana oz. sestranica, le v eni točki haloškega narečja pa sestrinka.

Različico brez - $r$ - bratanec poznajo le na vzhodu: $\mathrm{v}$ panonskem prleškem in zahodnem delu prekmurskega narečja. Oblike brez pripone -ec so še redkejše; bratran poznajo le kot različico $\mathrm{v}$ točki rovtarskega baškega govora in točki vzhodnogorenjskega govora gorenjske narečne skupine, v točki zgornjesavinjskega in dveh točkah srednjesavinjskega narečja štajerske narečne skupine. Leksem bratan se kot dvojnica pojavi le v točki na skrajnem vzhodu istrskega narečja. Različico bratič poznajo tri točke na skrajnem JV štajerske narečne skupine: srednještajerskega in kozjanskega narečja na meji s Hrvaško (338-340).

Drugo najpogostejše poimenovanje je strnič. Značilen je za primorsko narečno skupino (jugovzhodni del kraškega narečja, istrsko in notranjsko narečje),

3 Povzeto po Bezlaj (1977, 38, 1995, 230, 330-331), Pleteršnik (2006), Skok (1971, 199200) in Snoj (2003, 54-55, 651).

4 Ravnik (1996, 267).

5 Slovenski etnološki leksikon $(2004,274)$ in Pirona $\left(2001^{2}, 181\right)$.

6 Kot obliko zermán (ž. zermána) leksem najdemo v Slovenskem etnološkem leksikonu $(2004,707)$ in v Bezlaj $(2005,406)$.

7 Slovenski etnološki leksikon $(2004,654)$. 
točka rovtarskega črnovrškega narečja ter laški govor posavskega narečja in kozjansko-bizeljsko narečje štajerske narečne skupine. Leksem strnična imamo na jugozahodu primorske (kraško in notranjsko narečje) ter ločeno še na jugovzhodu štajerske narečne skupine (posavsko in kozjansko-bizeljsko narečje). Različico s pripono -ka (strnička) najdemo le na zahodu: kot dvojnico v točki kraškega narečja in v notranjskem narečju primorske narečne skupine ter v točki črnovrškega narečja rovtarske narečne skupine.

Leksem sestrič poznajo v Celju in okolici (v srednjesavinjskem, srednještajerskem in južni polovici južnopohorskega narečja štajerske narečne skupine), kot dvojnico pa še v točki na skrajnem severovzhodu severnopohorsko-remšniškega narečja koroške narečne skupine. Manj razširjen je leksem sestričen; najdemo ga v točki ziljskega narečja koroške narečne skupine, kot dvojnico pa še v točki zagorsko-trboveljskega govora in dveh točkah srednjesavinjskega narečja. Leksem sestranec se pojavi le enkrat, še takrat kot dvojnica: v točki na zahodu prekmurskega narečja. Poimenovanje sestrička imajo le v dveh točkah na skrajnem severu podjunskega narečja $(32,33)$.

Razlikovanje bratran(ec) s pomenom 'stričev sin' in sestrič(en) s pomenom 'tetin sin', torej po sestri in bratu (očeta ali mame), je zabeleženo v zagorsko-trboveljskem govoru, srednjesavinjskem, srednještajerskem in južnopohorskem narečju štajerske narečne skupine ter $\mathrm{v}$ točki na skrajnem severovzhodu koroške narečne skupine. To razlikovanje se je začelo mešati z bratran(ec) s pomenom 'bratranec po očetu' in sestrič(en) s pomenom 'bratranec po mami', torej po mami in očetu, ne pa po sestri in bratu. Tako so po očetovi strani bratranci in bratranke, po mamini pa sestriči in sestrične (v Velenju in okolici). Razlikovanje sestrična in bratran(č) ka poznajo štajerska zgornjesavinjsko, srednjesavinjsko in srednještajersko narečje ter točka na skrajnem vzhodu podjunskega narečja, točka na vzhodu mežiškega narečja ter točki na zahodu severnopohorsko-remšniškega narečja koroške narečne skupine.

Leksem bratranka je značilen za severovzhod: vzhodni del koroške narečne skupine in severozahodni del štajerske narečne skupine (zgornje- in srednjesavinjsko narečje). Pomanjševalnica bratrančka obstaja kot dvojnica le v dveh točkah koroškega severnopohorsko-remšniškega narečja. Malce bolj razširjen je v koroški narečni skupini izraz bratrančinja, in sicer v rožanskem, obirskem in podjunskem narečju. Leksem bratana se kot dvojnica pojavi le v točki na skrajnem vzhodu istrskega narečja.

Opisna poimenovanja ta mali brat ali mali brat najdemo le v dolenjski narečni skupini: v točki 237 (tåo mâl brạ̈t), kot drugi leksem (poleg bratranec) pa še v točkah 256 (ta mâl brät), 258 (ta mâl brät) in 279 (mâlę brät). Tudi opisno poimenovanje (ta) mala sestra najdemo le v dolenjski narečni skupini: v točki 237 (ta mâta sięstra), kot drugi leksem (poleg sestrična) pa se pojavi še v točkah 234 (tị mâla siệstra), 238 (to mầta siéstra), 256 (ta mâta seấstra) in 279 (mâlla siệstra).

Na obrobju slovenskega etničnega prostora se uporabljajo prevzete besede. Romanski različici kužin in kužina se pojavita samo na zahodnem robu slovenskega jezikovnega prostora: v rezijanskem, terskem, nadiškem in briškem narečju, banjškem govoru ter severnem delu kraškega narečja, kjer poleg romanske najdemo tudi 
slovensko dvojnico - bratranec. Različico kusen, kusena pozna le točka na jugu ziljskega narečja. Romanizem zurman, zurmana se pojavi v eni sami točki na skrajnem zahodu istrskega narečja (ob obali). Na vzhodu se samo v eni točki pojavi iz madžarščine prevzeta beseda unokateštver: kot dvojnico (poleg leksema bratranec) jo najdemo na severu prekmurskega narečja, v madžarskem Porabju.

\section{Viri in literatura}

Arhiv Dialektološke sekcije Inštituta za slovenski jezik Frana Ramovša, ZRC SAZU, Ljubljana, Listkovno in zvezkovno gradivo za Slovenski lingvistični atlas (SLA) za vprašanji št. 626 in 627.

Benedik, Francka, 1999, Vodnik po zbirki narečnega gradiva za Slovenski lingvistični atlas (SLA), Ljubljana, Založba ZRC (ZRC SAZU).

Bezlaj, France, 1977, 1995, 2005, Etimološki slovar slovenskega jezika I, III, IV Ljubljana, Mladinska knjiga.

Hradil, Jože, 1996, Slovensko-madžarski slovar = Szlovén-magyar szótár, Ljubljana, DZS.

Logar, Tine \& in Rigler, Jakob, 1993, Karta slovenskih narečij, Ljubljana, MK (zemljevid).

Logar, Tine, 1996, Dialektološke in jezikovnozgodovinske razprave (ur. Karmen Kenda-Jež). Ljubljana: ZRC SAZU, Inštitut za slovenski jezik Frana Ramovša.

Pirona, Giulio, 2001², Il nuovo Pirona: vocabolario friulano, Udine, Societa filologica friulana.

Pleteršnik, Maks, 2006, Slovensko-nemški slovar I-II, CR-ROM, Transliterirana izdaja, Uredila M. Furlan (Original izšel 1894-5), Ljubljana, Založba ZRC, ZRC SAZU.

Ravnik, Mojca, 1996, Bratje, sestre, sestriči, zermani: družina in sorodstvo v slovenski Istri, Ljubljana: Založba ZRC (ZRC SAZU).

SSKJ (Slovar slovenskega knjižnega jezika), Založba ZRC, ZRC SAZU, Inštitut za slovenski jezik Frana Ramovša, Ljubljana, 1995.

Slovenski etnološki leksikon (ur. Angelos Baš), 2004, Ljubljana, Mladinska knjiga.

Snoj, Marko, 2003, Slovenski etimološki slovar, Ljubljana, Modrijan.

Skok, Petar, 1971-1973, Etimologijski rječnik hrvatskoga ili srpskoga jezika I-III, Zagreb, Jugoslavenska akademija znanosti i umjetnosti.

\section{Vocabulary Denoting "cousin" in Slovenian Dialects (Using Material for the SLA)}

Summary

An analysis of names denoting the children of uncles or aunts shows considerable dialect diversity, which is the result of various phonological and word-for- 
$4 \quad$ mative development processes in Slovenian dialects. On the periphery in particu[I lar, this is also the result of language contact. The forms bratranec 'male cousin' $\mathrm{N}$ and sestrična 'female cousin' are found throughout most Slovenian territory. The $\rightarrow \quad$ second most frequent terms are strnič and strnična/strnička. The majority of other 그 dialect lexemes for 'male cousin' and 'female cousin' are also of Slovenian origin; they only differ in the word-formative suffixes used with the bases brat(r)- or sestr(i.e., -an, -ec, -ič, -en; -a, -(a)na, -ica, -in-ka, -an-ka, -an-čka, an-činja, -ič-na, and -ič-ka). Names referring to the children of uncles or aunts are thus interesting not only because of these various lexemes, but primarily because of the great variety of word-formative affixes in Slovenian dialects. This is also demonstrated by certain forms that cannot be found in dictionaries (for example, sestranica and sestrinka, or bratrančka and bratrančinja).

In terms of loanwords, the lexemes kužin-a, kusen-a, and zurman-a appear in the west, borrowed from Italian or Friulian (the word-formative morphemes of these loan words are, however, Slovenian). The vocabulary is presented through linguistic geography; lexical and word-formative maps demonstrate the spatial distribution of names denoting 'male cousin' and 'female cousin' in Slovenian dialects. The texts accompanying the maps present their frequency and differentiation-for example, the differentiation in Styrian dialects between bratran(ec) 'uncle's son' and sestrič(en) 'aunt's son', which has begun mixing with the differentiation between bratran(ec) 'paternal male cousin' and sestrič(en) 'maternal male cousin'.

\section{Priloga:}

Leksično-besedotvorni karti:

Karta št. 1 - SLA V626 (bratranec)

Karta št. 2 - SLA V627 (sestrična)

Tjaša Jakop

Inštitut za slovenski jezik Frana Ramovša ZRC SAZU

Novi trg 2, 1000 Ljubljana

jakop@zrc-sazu.si 


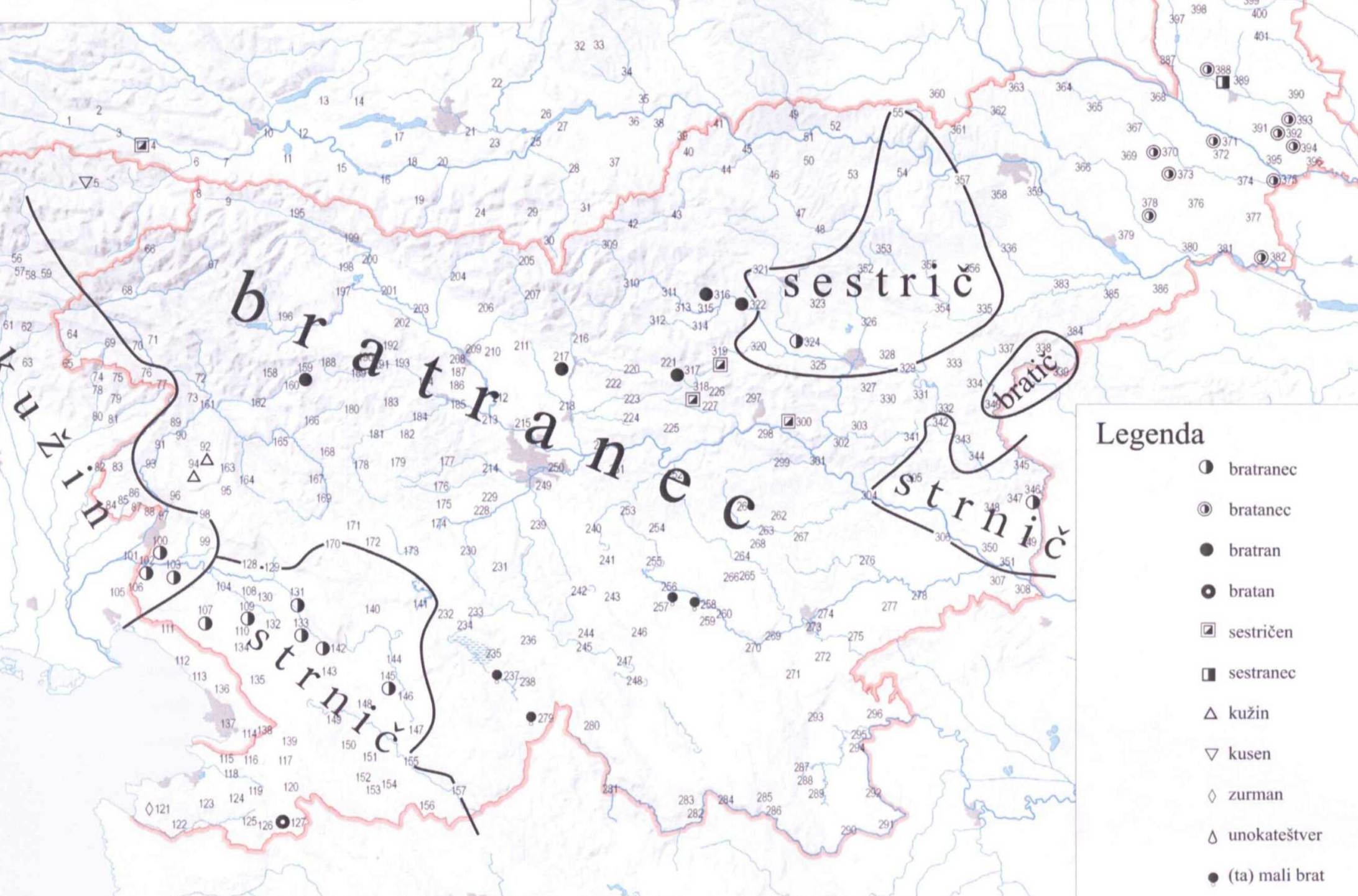



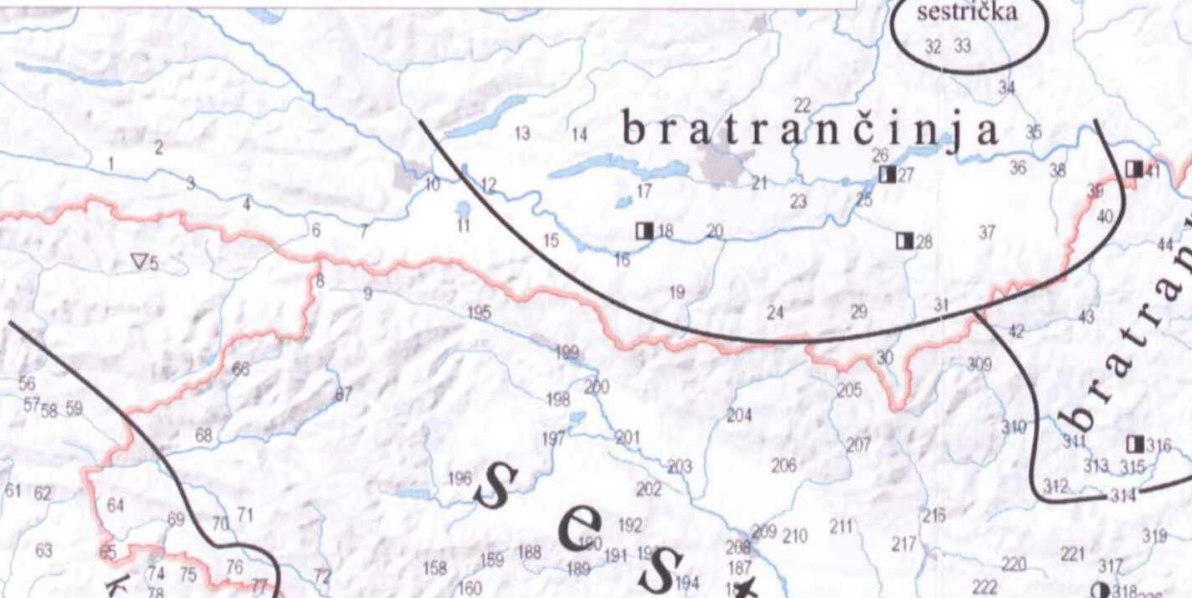

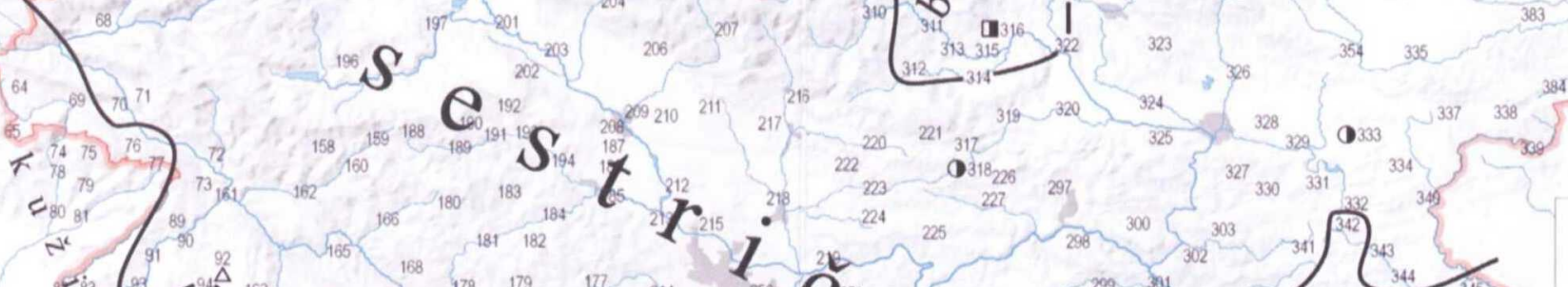
S. $\quad 1$ (3.
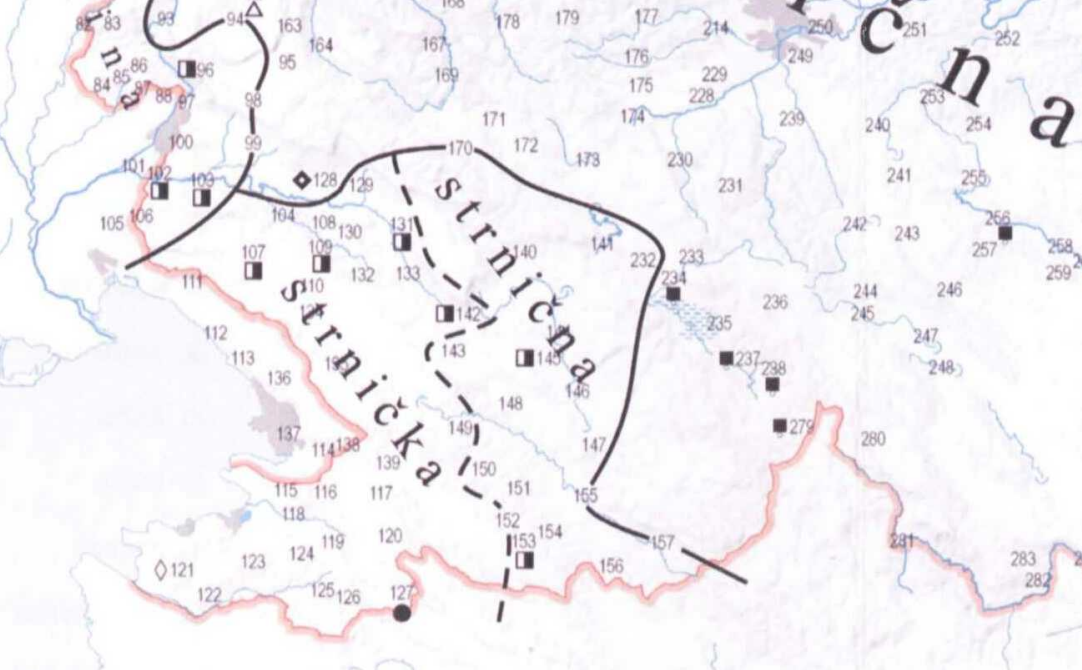

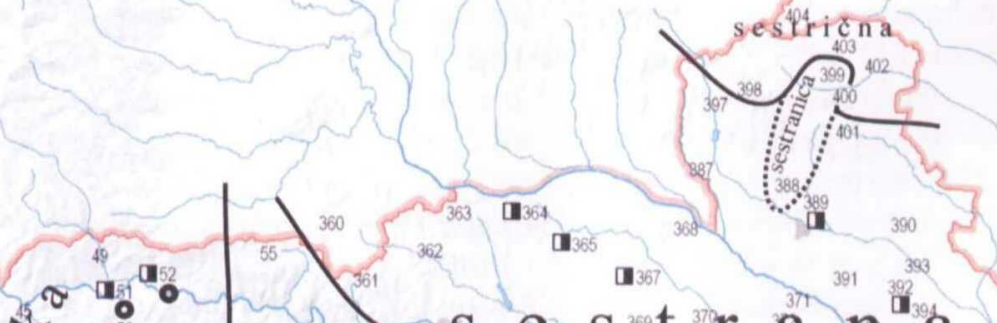
$\left.\sigma^{2}\right|_{4} ^{-10}$

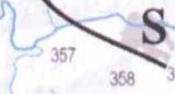

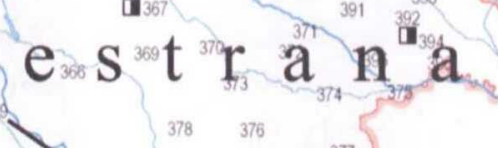

\section{Legenda}

[ sestrična

- sestrinka

- bratranka

- bratrančka

- bratana

- strnicka

$\Delta$ kužina

$\nabla$ kusena

¿ zurmana

- (ta) mala sestra 


\title{
Od kod slovenski dendronim jâm »brest«?
}

\author{
Helena Jazbec, Metka Furlan (Ljubljana)
}

IZVLEČEK: Slovenske dendronime jâm »brest«, jân »isto« in läm se izvaja iz srednjevisokonemške predloge, ki se ohranja v bav. nvn. Alme »brest«.

ABSTRACT: The Slovenian dendronyms jâm, jân, and läm (all 'elm') derive from a Middle High German base preserved in Bavarian NHG Alme (elm).

1. $\mathrm{Za}^{1}$ drevesno vrsto Ulmus imamo v slovenščini ob splošno znanem brẹ́st še vrsto podobnozvočnih izrazov, pri katerih upravičeno lahko domnevamo, da so etimološko povezani, a so v slovenščini deloma izposojeni, deloma pa podedovani iz praslovanščine. Maks Pleteršnik v svojem Slovensko-nemškem slovarju navaja jâm »brest«, jámovəc, gen. -vca »isto«, jân, lìm, gen. líma, lom, ilmovəc, gen. -vca in ilom, gen. ilma. V Etimološkem slovarju slovenskega jezika pa France Bezlaj dodaja še läm, lemovec in lemkovec (ESSJ, II, 142), ki so verjetno posredno povzeti iz Šulekovega slovarja fitonimov (Šulek 1879, 189, 193). Slovenske dendronime lam, lemovec in lemkovec namreč Šulek brez naglasnih oznak navaja po gradivu, ki mu ga je Henrik Freyer predal leta 1850 in vsebuje predvsem fitonime s Kranjske (Šulek 1879, XIV-XV). Različica imovec, ki je tudi navedena v ESSJ, 1. c., je verjetno povzeta iz Brinarjevega Gozdarskega slovarja, ki navaja ímovec »gorski brest, Ulmus scabra« (Brinar 1970, 76). Ta dendronim je izpeljanka tipa jâm $\rightarrow$ jámovəc iz različice 'i:m, ki je še živa v štajerskih govorih Zadrečke doline (Weiss 1998, 108). ${ }^{2}$

1 Besedilo je bilo pripravljeno z vnašalnim sistemom ZRCola, ki ga je na Znanstvenoraziskovalnem centru SAZU v Ljubljani (http://www.zrc-sazu.si) razvil Peter Weiss.

2 Fonem tega dendronima je posredoval P. Weiss, ustno. 
2. Vse te dendronime lahko glede na fonetično podobo in njihov možen izvor razdelimo na štiri skupine.

2.1. Različice iləm, ilmovəc, po zgodnji asimilaciji - $l m->-m^{3}{ }^{3}$ 'i:m (Zadrečka dolina), ímovec in po internoslovenskem premetu lim, gen. líma s skupno slovensko osnovo *ilm- so lahko dediščina iz psl. *jblımь ${ }^{4}$ (Bezlaj ESSJ, II, 142; ĖSSJ, 8, 222-3), čeprav bi enako fonemsko zaporedje *ilm- imela tudi izposojenka iz srvn. ilm (f.) »brest «. ${ }^{5}$ Ker varianta iləm do sedaj v narečjih ni bila potrjena in je bila zabeležena pozno, v drugi polovici 19. stoletja, v Cigaletovem in Janežičevem slovarju, je možno, da je bila umetno uvedena na podlagi r. ílem, gen. ílbma »Ulmus« (Pleteršnik 2006, 291; Berneker 1908-1913, I, 424).

2.2. Če samo iz Freyerjevega rokopisnega gradiva potrjeni varianti lemovec in lemkovec nista morda le zapisa za reducirani obliki *lomovəc in *lomkovəc (iz sln. *lim(k)óvəc), kot nakazuje obirsko koroško lomó:wc, gen. -a »brest« (Karničar, 157) in iz Planine nad Jesenicami posredovano Imóvěc (Pintar, 21), se v njiju lahko ohranja psl. dendronimu $* j b l(b) m ъ$ variantni in sorodni *elmъ, ${ }^{6} \mathrm{ki}$ ga Schuster-Šewc, 859, predpostavlja iz dl. lom »Ulmus«, ukr. lьom »isto《 in br. lëm »Ulmus foliacea«, prim. še r. nar. lëmok»mladi brest« (ÈSSJ, 8, 222-223).

2.3. Varianta lom, ki jo Pleteršnik navaja po Mateju Cigaletu in Oroslavu Cafu, kot slovenska, povzeta po Freyerjevem gradivu, pa je bila zabeležena tudi v Šulekovem slovarju (Šulek 1897, 203), je zaradi preohlapnih podatkov o arealu še težje razložljiva. Bezlajeva razlaga, da naj bi bila ta, tako kot druge pri njem omenjene dendronimske različice v slovenščini, bolj verjetno praslovanska dediščina, kot pa izposojena iz srvn. ilm »Ulmus« (Bezlaj ESSJ, II, 142), je nezadostna.

2.4. V četrto skupino pa smemo uvrstiti različice jâm, jámovəc, jân in tudi läm, kot se bo izkazalo v nadaljevanju.

3. Pričujoči članek skuša v prvi vrsti razložiti nastanek in izvor variant iz zadnje

3 Relativna kronologija asimilacije v zgodnjo plast tipa sonce $\leftarrow$ solnce (Ramovš 1924, 39) je postavljena zaradi tpn Ímovica »naselje v občini Lukovica pri Domžalah«, v katerem se ta dendronim po vsej verjetnosti ohranja in je bil že leta 1384 zabeležen kot Ymowitz (Kos 1975, 215).

4 Ob domnevi, da je drugi polglasnik v psl. *jblbmъ »Ulmus«, na katerega nedvomno kaže npr. p. ilm, sekundaren, bi bilo v psl. *jblms možno prepoznati popolno paralelo z lat. ulmus »brest«, oboje pa izvajati iz praide. ${ }^{*} H_{l} l m-o ́-s$. Glej tudi op. 6.

5 Domnevo o nemškem izvoru slovanskih dendronimov, ki se jih danes pretežno razlaga kot praide. dediščino iz psl. *jblımb (ÈSSJ, 8, 222-3), je postavil Miklošič 1886, 95, sprejel pa Berneker 1908-1913, I, 424. Dalje glej op. 11.

$6 \mathrm{~V}$ psl. dendronimu *elmъ »Ulmus« bi bilo možno prepoznati paralelo s stvn. elmo »U1mus«, elm »isto« iz praide. ${ }^{*} H_{1}$ élm-o-s. Razmerje ${ }^{*} H_{1}$ élm-o-s : ${ }^{*} H_{l o} l m-o ́-s$ lahko odraža prvotni konzonantni samostalnik s paradigmo ${ }^{*} H_{l}$ élōm, gen. ${ }^{*} H_{l o} l m$-és, lok. ${ }^{*} H_{l} l e ́ m$, pa-

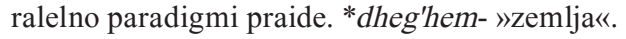


omenjene skupine, predvsem jâm »brest« s tvorjenko s sestavljeno pripono -ov-ec jámovac ${ }^{7} » b r e s t \ll$ in jân. Te v etimoloških slovarjih še niso bile obravnavane.

3.1. V geslu jâm »brest« Pleteršnik 2006, 355, opozarja, da naj bi to bila izposojenka iz tirol. nem. ilm (f.) »Ulmus « (Schöpf 1982, 286), kar zaradi razlike v fonetični podobi nemške predloge ne prepričuje.

Pleteršnik po Cafovem slovarskem gradivu navaja, da je dendronim jâm znan v mariborski okolici, po Erjavčevem gradivu iz Pótne torbe iz leta 1879 pa tudi v Sevnici na Štajerskem (Erjavec 1879, 121). Različico jân je Caf poznal iz Frama na Štajerskem, jámovoc pa iz Slovenj Gradca na Koroškem. Širši areal tega dendronima potrjuje terski jám »brest«, ki ga tako onaglašenega omenja Pavle Merkù, ko iz njega izvaja terski mikrotoponim Potjám pri Zavarhu v občini Bardo/ Lusevera (Merkù 2006, 159).

Zaradi fonetičnega neujemanja sln. jâm ne moremo izvajati iz tirol. nem. predloge ilm »Ulmus«, ampak je bolj verjetno, da se v njem odraža slovenski substitut iz srvn. predloge, ki še živi v bavarskem nvn. Alme »Ulmus« (Marzell 1943-1958, IV, 903). Tako relativno kronologijo izposoje iz srvn. *alme »Ulmus« = bav. nvn. Alme je potrebno predpostaviti zaradi areala slovenskih dendronimov in znakov, ki kažejo, da je do izposoje prišlo v času pred narečnim podaljšanjem skrajšanega psl. starega akuta v enozložnicah tipa brät $\rightarrow$ 'bra:t.

Čeprav se vključno do 16 . stoletja $^{8}$ nemški izglasni in predkonzonantni $l \mathrm{v}$ slovenščino še prevzema kot trdi $1,{ }^{9}$ je bila predloga za narečno jâm v slovenščino prevzeta prej, iz srednjevisokonemškega ustreznika *alme »Ulmus« za bav. nem. Alme. V slovenščini je bila ta srvn. predloga s kratkim vzglasnim zlogom po vzorcu krämp »orodje za kopanje« $\longleftarrow$ srvn. krampe (Grafenauer 1923, 372) prevzeta kot sln. *äłm in se je vključila v deklinacijski tip brät, gen. b'rá:ta, ki se ga glede podaljšave skrajšanega psl. starega akuta v nezadnjem besednem zlogu postavlja v konec 14. stoletja (Ramovš 1950, 21). V nadaljnjem slovenskem razvoju se je konzonantna skupina - $ł m$ - poenostavila $v-m$ - po vsej verjetnosti še pred prehodom ı> un: sln. *äłm > *äm. Primeri iz Ramovševega Konzonantizma (1924, § 25, § 34) sicer kažejo, da do takih asimilativnih izpadov predkonzonantnega $\nmid$ lahko pride samo za $o$-jem ali $u$-jem: ọhrovt $<$ sln. *ołhrout $\leftarrow$ bav. srvn. *kôlkrout, bav. nvn. Kohlkraut »zelje, ohrovt«; špọgati (si) »uporabljati; privoščiti si« < sln. * špołgati $\leftarrow$ srvn. spulgen »biti navajen, uporabljati« (Ramovš 1924, § 25; Striedter-Temps, 185, 225). Vendar nam na možnost enakega pojava pred a-jem kaže npr. obirsko koroški pridevnik há:mužən, f. -žna »V srce segajoč, nesposoben, slaboumen« (Karničar, 117), v katerem se ohranja starovisokonemška izposojenka v slovenščini álmožna »miloščina« (Striedter-Temps, 80).

Vzglasni j-v jâm je torej protetičen kot npr. v nemških izposojenkah jamati »izmeriti vsebino soda $\mathrm{z}$ odčitalno palico, tj. $\mathrm{z}$ amo« $\longleftarrow$ âmati »isto« ali bkr. jásla

7 Besedotvorni postopek je pravzaprav sledeč: jam »brest «+ -ov = jamov »brestov«; jamov $+-e c=$ jamovec $» b r e s t \ll$. Pridevnik jámov »brestov« navaja Pleteršnik.

8 Začetek nove visoke nemščine se datira $\mathrm{z}$ letom 1500.

9 Po 16. stoletju smo nemški izglasni in predkonzonantni 1 prevzemali s $\operatorname{sln}$. srednjim 1 (Striedter-Temps, § 112-120). 
$\exists \quad$ »ognojek, tvor, čir« $\leftarrow$ ásla »ognojek, uljé, tvor, čir, prisad v rani« (Striedter-Temps, 81, 84; Bezlaj ESSJ, I, 4, 6).

3.2. Različica jân »Ulmus«, ki je znana samo iz Frama na Štajerskem, ni mogla po slovenskem fonetičnem razvoju nastati iz jâm, ker tam razvoj $-m>-n$ ni znan. Izglasni - $n$ v jân je v odnosu do jâm možno razložiti z nemško fonetiko. V bavarščini je razvoj izglasnega $-m>-n$ pogost, prim. bav. nvn. Qtn za širše nvn. Atem, srvn. âtem»sapa, dih« (Striedter-Temps, § 132; Kranzmayer 1956, § 48b). Sln. substitucijo - $n$ za bavarski $-n<-m$ izkazuje npr. sln. pûšpan »Buxus sempervirens « $\leftarrow$ bav. srvn. *puhśpān < bav. srvn. puhśpām »isto« (Striedter-Temps, 205). Na podlagi tega bavarskega fonetičnega pojava in pogoste apokope v nemščini, ki jo pri tej nem. besedni družini potrjuje npr. švicarsko nem. Olm »Ulmus« (Marzell 1943-1958, IV, 903), je možno predpostaviti, da je v bav. srvn. obstajal dendronim *aln »Ulmus « $(<*$ alm $<* A l m e)$, ki je bil v slovenščino prevzet verjetno sočasno kot srvn. sinonim *alme in oba substituta *äłm in *äłn sta se v nadaljnjem slovenskem razvoju obnašala enako:

\section{sln. *âłm $>*$ âm $>*$ j-äm $\operatorname{sln} . *$ äłn $>* a ̈ n ~>* j$-än}

3.3. V luči razlage nastanka in izvora sln. jâm in jân je smiselno dopolniti Bezlaja ESSJ, II, 142, ki za sln. läm»Ulmus«, tako kot za vse druge enakopomenske različice, ki jih obravnava, domneva, da so praslovanska dediščina v slovenščini. Za sln. läm, ki z redukcijo v imenovalniku kot 'lęm z gen. lá:ma, lá:mę »brest« še živi v bovškem govoru (Ivančič 2000, 40), je namreč bolj verjetno, da tako kot jâm odraža izposojenko iz iste srvn. predloge, le da je bil slovenski substitut *äłm podvržen premetu, kar je dalo läm. Pojav je pri obravnavanih dendronimih razviden iz razmerij ilmovəc: lìm, potrjuje pa ga tudi drugo domače gradivo, kot je razvidno iz sln. sołza $>$ sloza; $\ln$. dołgo $>*$ dłogo $>$ zilj. dwogo; sln. kolnica »pokrit

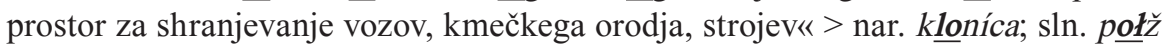

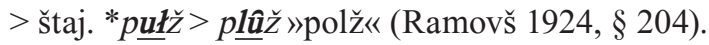

3.4. Iz razlage, da se v narečnih dendronimih jâm (štaj.), jân (Fram) in läm = bovško 'lęm, gen. lá:ma/lá:me ohranja srednjevisokonemška izposojenka *äłm z varianto *äłn, je razvidno, da imata štajerski enozložnici dolg vokal, internoslovensko podaljšan po tipu brät $\rightarrow$ b'ra:t, prvotna kračina pa je še ohranjena v läm = bovško 'lęm. Iz sistema pričakovanih kvantitetnih razmerij izstopa le terski dolg vokal v jám. Tu bi zaradi izglasnega $-n<\operatorname{sln}$. $-m$ na širšem zahodnem območju pričakovali refleks *'jan s kračino kot npr. v p'rax = knjiž. präg (Šekli 2006, 169). Izglasni $-m$ bi bilo $\mathrm{v}$ terskem jám sicer možno razložiti kot sandhi varianto iz prvotnega terskega $*^{\prime} j a n^{10}$, sporočena dolžina v enozložnici namesto pričakovane kračine pa bi še vedno ostala nepojasnjena.

\subsection{Osamljena varianta lom lahko izvira iz slovenskega narečnega sistema z}

${ }^{10}$ O tem pojavu na skrajnem zahodnem območju Furlan 1991, 26. 
ohranjeno kračino v tipu brät in lahko predstavlja vokaliziran refleks reducirane oblike, ki je nastala ali po redukciji kratkega a v əiz läm ali pa po redukciji kratkega i v ə iz lim: ${ }^{11}$

$$
\text { lom }<\text { *ləm }<\text { läm/lìm }
$$

4. Za konec si oglejmo bav. nvn. Alme »Ulmus«, nemško predlogo za sln. izposojenke jâm, jámovəc, jân, läm in morda tudi lom. Nemški etimološki slovarji razlagajo izvor nvn. različic Elm(e) (f.), IIm(e), Ulme in Olme (<Ulme), različice nvn. Alme ( $>$ Olme) pa ne omenjajo. Tako kot lahko ugotavljamo v slovenščini, so tudi v nemščini različice delno izposojene, delno pa dediščina iz pragermanščine. Nvn. Elm(e), Ilm(e), srvn. elm(e), elmboum, ilmboum, stvn. elmo, elm, elmboum, ilma Pfeifer izvaja iz praide. samostalnika *elem- s korenom *el-, *ol- »rdeč, rjav«, s katerim naj bi bil brest poimenovan po barvi sveže posekanega rdečerjavega lesa (Pfeifer, 1482). Nvn. Ulme in iz tega Olme pa je bilo v nemščino izposojeno iz lat. ulmus »brest« (ibid.)

Bavarska nvn. različica Alme je iz Elme lahko nastala pod vplivom vzglasja bav. nvn. Alber, ker ta dendronim ob »topol, Pappel« lahko pomeni tudi »brest« (WBMÖ, 3, 132). Formalna kontaminacija Elme v Alme na podlagi Alber pa je po drugi strani sprožila, da so narečni refleksi Alme ponekod začeli označevati topola, npr. bavarsko narečje na Moravskem pozna labializirano različico $\bar{Q} l m$ »beli topol, Weißpappel« (<*alm), nemško narečje na Gradiščanskem pa Q̄lme »topol, Pappel« (WBMÖ, 3, 132). Areal te nemške izposojenke v slovenščini in naglasna razmerja $\mathrm{v}$ njej pa vodijo k domnevi, da je do kontaminacije in nastanka različice Alme prišlo vsaj že v srednji visoki nemščini. Takemu sklepu nemško gradivo ne nasprotuje, saj je dendronim Alber kot albari obstajal že v stari visoki nemščini (Kluge-Seebold, 24).

\section{Okrajšave jezikov/narečij}

bav. $=$ bavarsko, bkr. $=$ belokranjsko, br. $=$ belorusko, dl. $=$ dolnjelužiško, gen. = genitiv, lat. = latinsko, nar. = narečno, nem. = nemško, nvn. = novovisokonemško, p. $=$ poljsko, praide. $=$ praindoevropsko, psl. $=$ praslovansko, r. $=$ rusko, sln. $=$ slovensko, srvn. = srednjevisokonemško, stvn. = starovisokonemško, štaj. = štajersko slovensko, tirol.= tirolsko, ukr. = ukrajinsko, zilj. = ziljsko

${ }^{11}$ Sln. dendronime, ki jih je mogoče izvajati iz prvotnega sln. *iłm (npr. ímovec (Brinar), 'i:m (Zadrečka dolina), lim, gen. líma (Plužna, Trenta; Pleteršnik 2006, 515)), bi bilo zaradi naglasnih razmer kljub Bezlaju ESSJ, II, 142, bolje razlagati kot nemške izposojenke iz srvn. ilm »brest« $\rightarrow$ sln. *ïłm. V Kanalski dolini izpričana oblika lìma »Ulmus glabra« (Oman 1992, 51) kaže, da je pri vzorcu prevzema srvn. ilm (f.) nad fonetično podobo predloge prevladal spol besede, ki je povzročil substitucijo s sln. *iłma (f.). Podoben dvojni vzorec prevzema odražata npr. srednjevisokonemški izposojenki márter (m.), gen. -tra »trud, napor« (nižje pogovorno) in mârtra (f.) »trpljenje, bolečina« (starinsko; oboje SSKJ) iz srvn. marter(e) (f.) »trud, napor, bolečina« (Striedter-Temps, 177). 


\section{$4 \quad$ Literatura in viri}

Bergmann, H., Pohl, H. D., 2002, Die Namen der Karnischen Alpen. Teil I: Kärntner Anteil (von Steinkarspitz bis Plöckenpass). Gemeinden Lesachtal und Kötschach-Mauthen, Kärnten. Hrsg. P. Anreiter (= Beihefte zur Österreichischen Namenforschung 2), Wien, Ed. Praesens.

Berneker, E., 1908-1913, Slavisches etymologisches Wörterbuch I-II. Heidelberg, C. Winter's Universitätsbuchhandlung.

Bezlaj ESSJ = Bezlaj, F., 1976-2005, Etimološki slovar slovenskega jezika I-IV, Avtorji gesel F. Bezlaj, M. Furlan in M. Snoj, Ljubljana, Mladinska knjiga, ZRC SAZU.

Brinar, M., 1970, Gozdarski slovar, Ljubljana, Zveza inženirjev in tehnikov gozdarstva in industrije za predelavo lesa Slovenije.

Cigale, M., 1860, Deutsch-slovenisches Wörterbuch I-II, Laibach.

Erjavec, F., 1879, Iz pótne torbe, V: Letopis Matice slovenske za leto 1879, Ur. J. Bleiweis, Ljubljana, Matica Slovenska.

ÈSSJ = Trubačev, O. N. (red.) 1974-, Ėtimologičeskij slovar' slavjanskich jazykov. Praslavjanskij leksičeskij fond I-. Moskva, Izdatel'stvo »Nauka« Akademija Nauk SSSR.

Furlan, M., 1991, Slovensko slima »faliua, plouagne« (Alasia) in srbohrvaško slîm (Žumberek) - novo gradivo za slovansko-germansko izogloso *slímъ : *slīma- Jezikoslovni zapiski 1, 25-30.

Grafenauer, I., 1923, Naglas v nemških izposojenkah (Donesek k zgodovini slovenskega naglasa) - Razprave $Z D H V$ I, Ljubljana, Znanstveno društvo za humanistične vede v Ljubljani.

Ivančič, B., 2000, Diferencialni slovar bovškega govora, Seminarska naloga na magistrskem študiju, Mentorica Vera Smole, Rokopis, Ljubljana.

Janežič, A., 1867, Deutsch-slovenisches Taschen-Wörterbuch für Schule und Haus. 2., umgearb. und vermehr. Auflage. Klagenfurt, E. Liegel's Buchhandlung.

Karničar, L., 1990, Der Obir-Dialekt in Kärnten. Die Mundart von Ebriach/Obirsko. Wien, Verlag der Österreichischen Akademie der Wissenschaften.

Kluge-Seebold, E., 1995, Kluge - Etymologisches Wörterbuch der deutschen Sprache. Bearbeitet von E. Seebold, 23., erweiterte Auflage, Berlin, New York, Walter de Gruyter.

Kos, M., 1975, Gradivo za Historično topografijo Slovenije (za Kranjsko do leta 1500) I-II, Ljubljana.

Kranzmayer, E., 1956, Historische Lautgeographie des gesamtbairischen Dialektraumes, Wien.

Marzel1, H., 1943-1958, Wörterbuch der deutschen Pflanzennamen I-V, Unter Mitwirkung von W. Wissmann. Leipzig, S. Hirzel.

Merkù, P., 2006, Krajevno imenoslovje na slovenskem zahodu, Uredila Metka Furlan in Silvo Torkar, Zbirka: Lingustica et philologica 15, Ljubljana, Založba ZRC, ZRC SAZU.

Miklošič, F., 1886, Etymologisches Wörterbuch der slavischen Sprachen. Wien, W. Braumüller. 
Oman, A., 1992, Etnobotanica della Val Canale. Con particolare riguardo ai fitonimi sloveni di Ugovizza, Valbrunna e S. Leopoldo. Čedad v Furlaniji, Società Cooperativa Editrice Dom.

Pfeifer, W., 2000, Etymologisches Wörterbuch des Deutschen, München, DTV.

Pintar, L., 1895, Slovarski in besedoslovni paberki, Letopis Slovenske matice za leto 1895, str. 1-52. Ljubljana, Slovenska matica.

Pleteršnik, M., 2006, Slovensko-nemški slovar I-II. CR-ROM. Transliterirana izdaja. Uredila M. Furlan. (Original izšel 1894-5). Ljubljana, Založba ZRC, ZRC SAZU.

Ramovš, F., 1924, Historična gramatika slovenskega jezika II. Konzonantizem. V Ljubljani, Učiteljska tiskarna.

Ramovš, F., 1950, Relativna kronologija slovenskih akcentskih pojavov-Slavistična revija III, 16-23.

Schöpf, J. B., 1982, Tirolisches Idiotikon. Nach dessen Tode vollendet von A. J. Hofer. Neudruck der Ausgabe 1866, Schaan/Liechtenstein, Sändig Reprint Verlag.

Schuster-Šewc, H., 1978-89, Historisch-etymologisches Wörterbuch der ober- und niedersorbischen Sprache, Bautzen, VEB Domowina.

SSKJ, 1970-1991, Slovar slovenskega knjižnega jezika I-V, Ljubljana, Državna založba Slovenije.

Striedter-Temps, H., 1963, Deutsche Lehnwörter im Slovenischen. Berlin: Osteuropa-Institut.

Šekli, M., 2006, Tersko narečje v kraju Subid, Terska dolina/Alta Val Torre/Val de Tor, Terska dolina $v$ besedi, sliki in pesmi Viljema Černa, Uredila/A cura di Milena Kožuh, Celje - Gorica, Celjska Mohorjeva družba in Goriška Mohorjeva družba, str. 161-170.

Šulek, B., 1879, Jugoslavenski imenik bilja, Zagreb, JAZU.

WBMÖ = Bayerisch-österreichisches Wörterbuch I-, Österreich, Wörterbuch der bairischen Mundarten in Österreich. Wien, Österreichische Akademie der Wissenschaften, 1963-.

Weiss, P., 1998, Slovar govorov Zadrečke doline med gornjim Gradom in Nazarjami, Poskusni zvezek A-H, Ljubljana, ZRC SAZU, Založba ZRC.

\section{The Origin of the Slovenian Dendronym jâm 'elm'}

Summary

This article seeks to explain the creation and origin of the Slovenian terms for Ulmus jâm and jân. The dendronym jâm is known in the Maribor area and in Sevnica (Styria), the variant jân is known in Fram (Styria), and jámovəc is used in Slovenj Gradec (Carinthia). The broader area of this dendronym is confirmed by Torre Valley dial. jám. Most likely, dial. jâm reflects a Slovenian substitute from a Middle High German base that still exists in Bavarian NHG Alme 'Ulmus'. Such relative chronology of borrowing from $M H G$ *alme 'Ulmus' must be assumed 
$-\quad$ given the area of Slovenian dendronyms and signs indicating that the borrowing took place before the dialectal lengthening of the shortened Proto-Slavic old acute in monosyllabic words of the type brät $\rightarrow$ b'ra:t. In the later development of Slovenian, the cluster - $1 \mathrm{~m}$ - was simplified to -m-, most likely even before the change $1>$ un; thus SIn. *äłm > *äm. Similar phonetic development is indicated by the Ebriach (Carinthian) adjective há:mužən (f. -žna) 'touching, incapable, weak-minded'; cf. the preservation of the Old High German loanword in Sln. álmožna 'alms'. The initial j- in jâm is thus prothetic as in the German loanword jamati 'to measure the contents of a barrel using a measuring stick or ama' $\leftarrow$ âmati 'idem'. According to Slovenian phonetic development, the variant jân for 'Ulmus', known only in Fram (Styria), could not have derived from jâm because the development - $\mathrm{m}>$ -n is unknown in this area. The final -n in jân compared to jâm can be explained with German phonetics; i.e., the Bavarian development -m > -n. On the basis of this Bavarian phonetic phenomenon and frequent apocope in German, it can be presumed that the dendronym *aln 'Ulmus' $(<M H G$ *alm) was present in Bavarian Middle High German.

Based on the explanation of SIn. jâm and jân, it is possible that Sln. läm, which is still preserved in the Bovec dialect in the reduced nominative form 'lęm (gen. lá:ma, lá:mę) 'elm', reflects a loanword from the same Middle High German base as jâm, except that the Slovenian substitute *äłm underwent metathesis, resulting in läm.

Helena Jazbec

Inštitut za slovenski jezik Frana Ramovša ZRC SAZU

Novi trg 2, 1000 Ljubljana

jazbec@zrc-sazu.si

Metka Furlan

Inštitut za slovenski jezik Frana Ramovša ZRC SAZU

Novi trg 2, 1000 Ljubljana 


\title{
Pavle je Pavel, a ni bil Savel, tudi ni Peter in Pavel ne Peter ali Pavel ne pavliha
}

\author{
Janez Keber (Ljubljana)
}

IZVLEČEK: V̌̌lanku, posvečenem Pavletu Merkuju, avtor obravnava besedje in frazeologijo, povezano z imenom Pavel. V naslovu članka pa bolj retorično odgovorja na vprašanje, ali rek Nomen est omen glede na to ime ter besedje in frazeologijo velja za jubilanta.

ABSTRACT: This article dedicated to Pavle Merkù discusses the vocabulary and phraseology connected with the name Pavel 'Paul'. The article's title provides a more rhetorical answer to the question of whether the saying Nomen est omen also applies to Pavle Merkù with regard to this name, vocabulary, and phraseology.

\section{Uvod}

Z jubilantom Pavletom Merkujem sva se osebno spoznala spomladi 1989, v letu po izidu mojega Leksikona imen. Oglasil se je na Inštitutu za slovenski jezik ZRC SAZU in prinesel s seboj tipkopis prispevka z naslovom Odprto pismo Janezu Kebru. Prispevek, ki je recenzija Leksikona imen, je pod tem naslovom kmalu potem izšel v reviji Primorska srečanja. ${ }^{1}$ To je bila prva ocena Leksikona imen, ki jo je napisal slovenski kolega po stroki ${ }^{2}$, tj. slavist (Pavle Merkù je namreč leta 1960 na Univerzi v Rimu doktoriral iz literarne slovenistike), zato je bila še toliko bolj dragocena. Sledila ji je nadaljnja strokovna diskusija v reviji Mladika. V njej je namreč Merkù od januarja 1988 objavljal svoje prispevke o imenih z naslovom Svetniki v slovenskem imenoslovju. ${ }^{3}$ Začenši z imenom Elisabeth pri črki E je za-

1 Glej Primorska srečanja 1989, št. 95-96, str. 299-301.

2 Po izidu Leksikona imen je sicer izšlo precej različnih domačih in tujih ter večinoma zelo ugodnih ocen in poročil, od slovenskih kolegov slavistov pa razen Merkujeve samo še ocena Janka Modra v Rodni grudi.

3 Kot piše v uvodni besedi v začetku pisanja imenskih člankov v Mladiki in kasneje ponovljeni v knjigi Svetniki v slovenskem imenoslovju je svoje prispevke o imenih začel objavljati zaradi neobstajanja celovitega dela o svetniških imenih v slovenskem imenoslovju: "Ne razpolagamo pa še s temeljito in metodično razpravo o svetniških imenih v slovenskem imenoslovju, s kakršno se že ponašajo drugi evropski narodi. Zato se lotevamo takega poskusa, čeprav se zavedamo, da bo tudi ta študija nujno nepopolna. Sloven- 
ci namreč ne razpolagamo s temeljno zgodovinsko študijo o diahronično in teritorialni razvrstitvi češčenja svetnikov po slovenskem prostoru, ki bi naši študiji morala služiti za osnovo in podporo..."

Glede na povedano je izid mojega Leksikona imen leta 1988 vsekakor zapolnil nekatere vrzeli v slovenskem imenoslovju in razveselil Merkuja, kar je razvidno tudi iz njegovega odprtega pisma. Da je potreba po knjigi o rojstnih imenih v Sloveniji v drugi polovici 80-ih let resnično dozorela, dokazuje razen Merkujevega pisanja Svetnikov tudi dejstvo, da sta knjigi o imenih pripravljala tudi etnolog Damjan Ovsec in Silvester Čuk. Prvi je odstopil od namere, ko je zvedel, da je pri celjski Mohorjevi družbi za tisk pripravljen moj Leksikon imen, ponudbo drugega po objavi pa je ta družba zavrnila in dala prednost moji. Oba sta pred tem imela imenski rubriki v Pionirju in Ognjišču (moje oddaje o imenih so bile v letih 1984-1985 na Radiu Ljubljana). Kasneje je Ovsec izdal samostojni knjižici o Jožefu in Mariji, Čuk pa knjigo Svetniki za vsak dan v dveh delih leta 1999 (I. del januar-junij 1999, II. del julij-december 1999, druga popravljena izdaja leta 2004).

4 Ti prispevki so imeli naslednje naslove: Franc Jakopin, Nekaj pripomb in dopolnil k Merkujevim Svetnikom v slovenskem imenoslovju (str. 151-154; Janez Keber, Ob slovenskem imenoslovju (str. 155-157); Dušan Čop, Pripombe k študiji: Svetniki v slovenskem imenoslovju (str. 158-161). Po izidu knjige smo bili leta 1993 vsi trije povabljeni na tiskovno konferenco v Trst, ki sva se je udeležila Jakopin in jaz.

5 Na kakšen način je Merkù v člankih in knjigi obravnaval imena, je zapisano v že omenjeni uvodni besedi: "Izhajali bomo iz svetniških imen, iz katerih so nastala slovenska krajevna in osebna imena, v latinski obliki, kakršno uporablja rimska Cerkev, in jih bomo nanizali v alfabetskem redu. Sledila bo, kjer je mogoče, razlaga samega imena s seznamom svetnikov istega imena, ki jih Cerkev časti.

Iskali bomo zgodovinske vire iz poznega srednjega veka, v katerih so prvič izpričane slovenske imenske oblike, kakor so se razvile iz latinščine naravnost ali po posredovanju sosednjih narodov: utemeljiti bomo skušali zgodnjo prisotnost teh imen pretežno na slovenskem Zahodu tudi iz virov, ki niso še objavljeni in javnosti dostopni.

Skušali bomo slediti razvoju imenskih oblik v slovenskem prostoru skozi stoletja do današnje rabe in navajali, kolikor so nam dostopne, oblike osebnih imen, iz njih nastalih priimkov, vzdevkov, hišnih imen, imen naselij in zaselkov, ledin, voda in gora..." 
spoštovanega ruskega kolega Valerija M. Mokienka ${ }^{6} \mathrm{v}$ čast jubilanta odločil za zapis o imenu Pavel ter besedju in frazeologiji, ki sta povezana s tem imenom.?

V nadaljevanju prehajam na obravnavo imena Pavel ter besedja in frazeologije, ki izhajata iz njega.

\section{Pavel - Pavle, Pavliha}

Ime Pavel je med najpogostejšimi moškimi imeni na 81. mestu. Tako je bilo leta 2006 v Sloveniji po podatkih Statističnega urada RS z imenom Pavel poimenovanih 2926 (1971: 4730; 1994: 3671) oseb. Pogostejša je bila ženska oblika Pavla (4234, 64. mesto) manj pogosta Pavlina (786, 209. mesto). Pavle (251, 353. mesto) je manjšalna in (ali) ljubkovalna različica imena Pavel. Zaradi pogoste rabe (prim. Anže, Brane, Jože, Tine, Tone) se manjšalni in ljubkovalni pomen imen na - $e$ večinoma že izgublja. Tako tudi pri imenu Pavle. ${ }^{8} \mathrm{~V}$ taki funkciji bi zdaj uporabili obliko Pavelček.

Ime Pavel izhaja iz latinskega imena Paulus. Razlagajo ga iz latinskega pridevnika paulus ‘majhen'. Pavlu je protipomensko ime Maksim, latinsko Maximus z nekdanjim pomenom 'največji'. Zgodovinske osebe so ob svojem imenu pogosto imele vzdevek Veliki, npr. Aleksander, Karel, Peter Veliki, zelo poredko Mali, npr. Pipin Mali.

V nasprotju z obliko Pavle je večalna (lahko tudi slabšalna) oblika imena Pavel ime Pavliha. ${ }^{9}$ To danes ni več v rabi, da pa je obstajalo, dokazuje današnji priimek Pavliha ${ }^{10}$ (2006: 92 oseb) in nekdanja raba, npr.: Nekdaj v poznej noči je lezel

6 Valerij M. Mokienko je namreč v čast 70-letnice znanega beloruskega jezikoslovca Adama Supruna napisal članek o imenu Adam v slovanskih jezikih. Moj pristop ne bo toliko primerjalno slovanski, vsekakor pa bom upošteval vsaj srednjeevropski jezikovni bazen, in to ne samo z imenoslovnega, ampak tudi z leksikološkega in frazeološkega vidika.

7 Svoj priimek je poskusil razložiti že sam jubilant. Razlaga priimka Merku je npr. v njegovi knjigi z naslovom 1300 primorskih priimkov (str. 65-67). Ta izhaja iz kraja Velike Žablje v ajdovski občini na Vipavskem iz hiše, ki se ji pravi po domače pri Polákcih, kjer se je sredi 19. stoletja rodil njegov ded Josip Merku. Priimka Merkù v Sloveniji ni več, obstaja pa njegova izvorna različica Merkelj (po podatkih Statističnega urada RS leta 2006: 25 oseb).

8 Da je oblika Pavle trdno zasidrana tudi v ljudskem jeziku, dokazuje njena prisotnost v slovenski ljudski pesmi, npr.v razdelku Posmehulje osebam po imenih:

7673. (Kranjska) Dandanašnji mladi Paglavci zabavljivo omenjajo žab, ko si nagajajo: Pavle Paližgal /Žabam je žvižgal, /Žabe lovil, / pa nobene dobil! (SNP IV 375).

9 O večalnih oblikah - Vergrößerungsformen - z priponskima obraziloma -iha, -uha govori že F. S. Metelko v svoji slovenski slovnici Lehrgebäude der Slowenischen Sprache, 1825, str. 63, in navaja besedi pavliha, pavluha ein Harlekin. Prav tam omenja še priponsko obrazilo - uša z zgledom Maruša groß und verächtlich (Marie).

${ }^{10}$ Priponsko obrazilo -iha je v priimkih zelo redko. Tako je npr. še v priimkih Jeriha, Lavriha, Lovriha, Urbiha, Ladiha, Rumiha ter Stariha, Dobriha. Tvorbeno in pomensko so priimkom na -iha blizu priimki na -iša, npr. Jakiša, Braniša, Staniša, Deniša, Mikiša, Jeriša, Periša, Jutriša, Lavriša, Mikiša itd., dalje -uha, npr. Raduha, in -uša, 
$-\quad$ Šarevčev Pavliha domu (I. Tavčar, Miha Kovarjev, Slov. knj. 1880, 56). Neko nedeljo napil se je v gostilni, pretepel Polončevega Matijčka, opraskal lica Kovačevemu Pavlihi ... (I. Tavčar, Med gorami, LZ 1882, 168). Slabšalni pomen imenske oblike Pavliha se je v procesu leksikalizacije uveljavil v poimenovanju komične figure in poimenovanju za 'šaljiv, hudomušen človek': pavliha (v pomenu 'šaljiva, burkasta figura’ pisano tudi Pavliha), o čemer pa glej v nadaljevanju.

Iz imena Pavel in njegovih različic so nastali številni priimki. Po priiimkovnem procesu pa sta priimka postala tudi Pavel (2006: 77 oseb) in Pavle (7).

Pavel je tudi zelo znano svetopisemsko ime. Pavel iz Tarza, pred spreobrnjenjem Savel, je zgodovinska oseba iz 1. stoletja. Najprej je bil preganjalec kristjanov, leta 34 pa se je spreobrnil v Jezusovega učenca. Bil je na misijonskih potovanjih na Cipru, v Mali Aziji, Makedoniji, Grčiji in ustanavljal cerkvene občine. V Rimu so ga obglavili leta 67. V Pavlovih pismih, ki so del nove zaveze, so opisani Kristusovo poslanstvo, njegova smrt in poveličanje. Pavel naj bi mlado krščanstvo prilagodil izraznim oblikam orientalsko-helenističnega kulturnega sveta in mu utrl pot do statusa svetovne religije. Praznih apostolov Petra in Pavla je 29. junija, spreobrnitev apostola Pavla pa je v koledarju 25. januarja.

Kot vsa znana imena se tudi Pavel kot tudi Peter pojavljata kot sestavini frazemov, v procesu leksikalizacije pa so iz njih nastali najrazličnejši izrazi. Dlje časa je neko ime v nekem prostoru, dlje živi med ljudmi, več možnosti je, da jih najdemo v znanih frazemih in t. i. izimenskih izrazih. V zvezi z imenom Pavel bom v nadaljevanju svojega prispevka pojasnil izvor frazemov iz Savla postati Pavel, Peter in Pavel, Peter ali Pavel, nadalje izraz pavliha (Pavliha) in z njim povezane frazeme in izraze.

\section{3 iz Savla postati Pavel}

S svetopisemskim Pavlom je povezan knjižni frazem iz Savla postati Pavel v pomenu 'iz človeka s slabim, negativnim značajem postati človek z dobrim, pozitivnim značajem; zelo se spremeniti; preporoditi se', npr.: Če nisem bil do sedaj Slovan, ne bodem nikedar. Da bi postal Pavelj iz Savla, tega čuda se mi ni več nadejati z nebes; ne prikliče ga ne molitev, ne pokora! (J. Stritar, Pogovori, Zvon 1879, 46). Iz Saula je postal Pavel, srečanje z otroškim vrtcem na ljubljanski cesti je njegova pot v Damask, otroci so mu prišli v srce kot Kristus s hostijo pri prvem obhajilu (T. Kermauner, Na poti k niču, 1968, 23). To izpričujejo napr. nravstveno “izpreobrnitev", ko recimo kdo iz Savla postane Pavel (K. Ozvald, Osnove psihologije, 208).

Meni se ni zbudilo rodoljubje o tej in tej priložnosti, kakor se je temu ali onemu pri nas, ki ga je neka čudovita prikazen hipoma izpremenila iz Savla v Pavla (J. Stritar, Lit. pog., Z. 1876, 29). Spreobrnila me je iz Savla v Pavla švedska pisateljica Selma Lagerlöf (Burnett-Pribil, Mali lord I).

npr. Pauluša, Pavluša, Ivanuša, Maruša, Petruša ter Bratuša, Vratuša. Da je ob priimkih Pavliha, Pauluša in Pavluša obstajal tudi priimek ali ime Pavliša, kaže priimek 
Napis Made in Germany so leta 1887 uzakonili Britanci, da bi domače proizvode dovolj jasno ločili od tistih s celinske tekmice in tako otežili prodajo nemških proizvodov... Najkasneje po drugi svetovni vojni se je slabševalna označba spremenila v znamenje kakovosti in izdelki Made in Germany so zasloveli po vsem svetu. "Znamka je iz Savla postala Pavel," komentira Doris Möller, ki je prepričana, da pobuda med članicami EU ne bo dobila podpore (Delo, 31. jan. 2004, Nova beseda $=$ NB).

Možnost, da bi Haider nekoč postal pravi avstrijski zvezni kancler, ne le kancler v senci, kar je zdaj, je bila po vsej verjetnosti dovolj zastrašujoča, da so se države EU odločile za ukrepe zgodnjega omejevanja škode. V zakup so vzele očitek, da avstrijski vladi niso hotele dati priložnosti in da Haiderjeve spremembe iz Savla v Pavla niso nagradile s potrpežljivim in vzgojnim zaupanjem (Delo, 12. feb. 2000, NB). Dosti je bilo takšnih preobrazb iz Savlov v Pavle, ne le v takratnih razmerah, ampak vselej na velikih prelomnicah; zato ta epizoda v ničemer ne jemlje časti predavatelju, ki je kmalu zatem sprevidel svojo napako, se vključil kot prediren znanstvenik v slovensko kulturno snovanje, prešel v času odločitve k Slovenskemu društvu... (M. Mušič, Novomeška pomlad, 1974, 71).

Svetopisemski Pavel iz Tarza je bil pred spreobrnitvijo Savel in vnet preganjalec kristjanov. V Jezusovega učenca se je spreobrnil na poti v Damask leta 34, ko je sprejel tudi novo ime. Frazem se izvorno nanaša prav na to spreobrnitev, se pa, kot kažejo navedeni zgledi, lahko nanaša tudi na stvari. Slovenskemu iz Savla postati Pavel, ki ima tudi različice spremeniti (se) iz Savla v Pavla, sprememba iz Savla v Pavla ipd. (gl. navedeno gradivo) ustrezajo nemško aus einem Saulus wurde ein Paulus in sopomenski seinen Tag von Damaskus erleben ter hrvaško ali srbsko od Savla postao je Pavle. Nemški frazem seinen Tag von Damaskus erleben prav tako temelji na Savlovi spreobrnitvi na poti v Damask. V zgoraj navedenem gradivu ga najdemo tudi pri Kermaunerju: srečanje z otroškim vrtcem na ljubljanski cesti je njegova pot $v$ Damask. Sicer pa so frazem iz Savla postati Pavel z različicami poznali že naši klasiki (gl. pri J. pri Stritarju), o spreobrnitvi pa govori tudi že ljudska pesem:

\section{Pavelj apostelj}

O sveti Pavel, si poprejšnji Savel, / sam Bog pozneje te prestavil... (SNP III, 842, XIV, 2).

\section{Peter in Pavel}

Po apostolih Petru in Pavlu je nastal frazem Peter in Pavel v pomenu 'vsakdo, kdorkoli', a je raba v tem pomenu bolj redka kot raba sopomenskega Peter ali Pavel, npr. Moj bog, zdi se mi, da ni nič in nikogar na svetu, za kar in kogar bi naša Barica ne spraševala. Peter in Pavel, njej je vseeno, ona sprašuje, sprašuje in ti moraš odgovarjati (Zofka Kvedrova, Veliki in mali ljudje, NB).

Frazem Peter in Pavel se lahko uporablja tudi zanikano, npr. Ne bom potreboval ne Petra ne Pavla, tj. 'nikogar'. Ustrezajo mu hrvaško ali srbsko Petar i Pavao, Petar i Pavle v pomenu 'vsakdo', v francoščini Paul et Pierre, Paul et Jacques 
$\hookrightarrow \quad$ v enakem pomenu. V zvezi s tem omenjam še francosko découvrir saint Pierre pour couvrir saint Paul, angleško to rob Peter to pay Paul v pomenu 'vzeti enemu, da bi dali drugemu'. Omenjenim parom bi lahko dodali še poljski rimani par Pawel-Gawel. To sta junaka pesmi Aleksandra Fredre iz komedije Pan Jowialski.

Peter in Pavel pomeni tudi 'šaljivo tekmovanje' (gl. R. Gööck-S. Krušnik, Štiristo najlepših, 1967, 202). V literaturi je imenski par Peter in Pavel posrečeno uporabil Janez Trdina: Kakor je nekdaj Peter, rekel je tudi Pavel, naj ga svobodno obleče (Peter in Pavel, LZ 1884, 660).

Kot dvojčka pa nastopata Peter in Pavel v naslednjem navedku: Ljubljana - Štiriintridesetletna brata Peter in Pavel K., doma sta iz iz Bele Krajine, se bosta morala zagovarjati pred sodniki zaradi kaznivega dejanja goljufije, ker naj bi se bila pri uvozu sladkorja v celoti izognila plačilu vseh dajatev in tako državo oškodovala za enajst milijonov 134.932 tolarjev (Delo, 6. avg. 1999, NB).

Nastanek dvojčičnega izraza Peter in Pavel, kot tudi Peter ali Pavel temelji na skupnem delovanju Petra in Pavla kot prvih krščanskih apostolov. O tem skupnem delovanju govorijo še naslednji navedki:

Vodilni strokovnjak za Novo zavezo Ben Witherington III. pa razkriva presenetljiva dejstva o zgodbi, za katero smo vsi mislili, da jo poznamo: o Jezusovi vzgoji v veliki, versko konservativni judovski družini, o nezaupanju njegovih bratov in sestra do njegovih naukov vse do Jezusove smrti, o tem, kako je Jezusov brat Jakob postal voditelj judovskega krščanskega gibanja v Jeruzalemu, pri katerem sta nasvet in privoljenje iskala tudi Peter in Pavel, o Jakobovi vlogi v velikem cerkvenem sporu v prvem stoletju in o tem, kako je napisal eno od svetopisemskih knjig, o njegovi mučeniški smrti in kako ga je iz zgodovine izbrisala Rimskokatoliška cerkev (Delo, 3. dec. 2003, NB). Jakob je dolgo deloval v senci teh velikanov. Vendar sta Peter in Pavel, kot je razvidno iz Gal 1-2 in Apd 15, odgovarjala Jakobu in se podrejala njegovim zapovedim. Potrditev za to najdemo v opisu znamenitega zbora v Apd 15. Tam sta govorila Peter in Pavel, končno odločitev pa je sprejel Jakob (Delo, 3. jan. 2004, NB). Katoliška cerkev je godova obeh apostolov združila na isti dan. Peter in Pavel sicer nista umrla istega dne, niti v istem letu, toda njuni življenjski zgodbi se tesno prepletata. Po drugem izročilu pa je njun god 29. junija zato, ker naj bi bili 29. junija 258 izkopali kosti Petra in Pavla iz grobov zaradi nevarnosti, da bi jih oskrunili (Delo, 29. jun. 1999, NB).

\section{Peter ali Pavel}

Po apostolih Petru in Pavlu je nastal tudi frazem Peter ali Pavel v pomenu 'kdorkoli', npr.: Za tatu je predobro oblečen. Pa naj bo Peter ali Pavel, denar ima, kakor vse kaže, in treba mu bo pač dati, kar bo zahteval. Saj ne ločimo med poštenim in nepoštenim denarjem (Ciril Kosmač, Prazna ptičnica, NB). "Kaj nam hoče, ako ga ne dobomo!" reče drugi. "Glave si ne bom lučal po kamenju za njim, naj mi zapoveduje Peter ali Pavel." "Ti lahko govoriš," reče župan, "a krop bo mene najbolj poparil (J. Jurčič, Domen, NB). Zapomnite si to! Peter ali Pavel: godlja je godlja! $\mathrm{Na}$ vaši posetnici, pribiti tam zunaj, sem bral, da ste ta in ta; modroslovec (Rado 
Murnik, Nirvana, NB). Kako neki! Ime je postranska reč; naj bi bil napisal to brošuro Peter ali Pavel, stavim, da bi se ne bil domislil ne Petkovška, ne Groharja, ne Jakopiča... (Ivan Cankar, Pozabljene rokavice, Kritike, NB). Tragikomično pa je to, da se država v človekovo poslednjo voljo vmešava čisto po nepotrebnem, saj od tovrstnega vmešavanja nima nobenih materialnih koristi niti takega vmešavanja ne narekujejo višji državni interesi. Državi je popolnoma vseeno, ali neko premoženje podeduje Peter ali Pavel (Delo, 9. jun. 2001, NB).

Leksikalizacija najbolj znanih imen ali njihovih različic v izimenske izraze, ki označujejo splošne, pogosto tudi komične ali negativne človeške like, je splošno znan pojav (npr. pri imenih Janez, Jaka, Jurij, Pavliha; podrobneje o tem glej v navedeni literaturi). Redkejši so pri imenih v paru, kot Peter in Pavel ter Peter ali Pavel. V slovenskem jeziku bi bil ustrezni par še Ciril in Metod, kot moško-ženski par pa Janez in Micka, ki sta že v ljudski pesmi. V evropskem imenoslovju je takih parov še več, uporabljajo pa se zlasti pri poimenovanju dvojčkov. ${ }^{11}$

\section{6 pavliha (Pavliha)}

\section{1 pavliha (Pavliha) 'šaljiva, burkasta figura v gledališču'}

Igral je harmoniko, gosli, klarinet, citre in trobento, sploh vse, kar mu je prišlo v roke, pel pa je tako lepo, da je ženske spreletavala mrščavica. Bil je potepuh in nekakšen Pavliha. Uganjal je prijetne, včasih pa tudi malce neprijetne norčije (C. Kosmač, Tantadruj, NB). "Kajpak, kajpak! - Povedaj mi ti rajši, ko se že tako lepo poznava od nekdaj, s kom si se doma razprl ali stepel, da se zdaj že tri dni tako tiho in na pol skrivaje poteplješ tod okoli ter si kakor Pavliha, ko je mislil, da ga je medved snel?" (J. Jurčič, Sosedov sin, NB). Ta je zapeljal že dosti žensk. Laže kot Pavliha. Iz bataljona te ne dam; čeprav pride tisti iz divizije, ki rad kriči." (Matevž Hace, Naši obrazi, NB). Vsa ta modrovanja imajo telesne in duševne oči zamegljene! Poznam nekaj Hamletov, ki so klavrni Pavlihe. Poznam Pavliho, ki je žlahten Hamlet (Delo, 29. jan. 2000, NB).

Književnik in poslanec Tone Partljič je kabaret napisal na pobudo gledališča, s katerim je v preteklosti sodeloval tudi že kot njegov umetniški vodja. Kljub slabim izkušnjam s tem posebnim odrskim žanrom se je odločil, da bo vpletel v anekdotično kabaretno obliko nekatere svoje humoreske o politiki in jih povezal med seboj v celoto s tradicionalnim likom Pavlihe kot ljudsko pojavnostjo pomembne, a najpogosteje skrbno skrite psihološke razsežnosti slovenskega človeka (Delo, 22. apr. 1998, NB). Za režiserja Andreja Stojana je najdragocenejša avtorjeva misel o neumrljivosti Pavlihe (in pavlihovstva). Sicer je v samem zaključku kabareta videti, da ga je nazadnje pokopala prav prva demokratična slovenska država, toda prav $\mathrm{z}$ avtorjem, vztrajnim komediografom, živi Pavlihovo osvobajajoče izročilo še naprej (Delo, 22. apr. 1990, NB).

Ker pa po smerti slavnih mož Kljukca in Pavlihata nihče še v križem svet ni

${ }^{11}$ V zvezi s tem je vredno omeniti monografijo Milice Lađević z naslovom Tvorbeni modeli imena blizanaca u Vojvodini (Novi Sad 1988). 
$\hookrightarrow \quad$ poti najdel, nam ostanejo ti imenitni in visoko učeni spisi zgubljeni (J. Trdina, Pripovedka od zlate hruške, LČ 1850, 284). Kmetje imajo še celó veselje nad lažnjivim Klukcem (Münchhausen) in nemškim Pavlihom v slovenski obleki (Eulenspiegel) (F. Levstik, Popotovanje, SG 1858, 82).

Njihov Pavliha je Švanda dudák, po katerem se je imenoval tudi nekdanji humoristični list. Iz davne češke preteklosti je ohranjen spomin na dvornega norca kralja Jiřija Poděbradskega Palečka; tudi po tem se je imenoval neki češki humoristični list (Slavko Krušnik, Smeh stoletij, NB).

Pavliha, pavliha je glavni junak pri klasičnih igrah za ročne lutke, slovenska inačica za nemškega Gašperčka (Kasper). V naše lutkarstvo ga je leta 1939 uvedel dr. Niko Kuret. ${ }^{12}$ Po leksikalizaciji sta se iz tega poimenovanja razvila pomena 1. šaljiva, hudomušna figura v lutkovnem gledališču 2. ekspr. šaljiv, hudomušen človek. ${ }^{13} \mathrm{~V}$ Pleteršnikovem slovarju najdemo tudi sopomenke pavlišec, pavlišek, pavluha. Zadnja je tudi v reklu Pavluha nima sluha, dokler mu hrbta ne nabuha v pomenu 'kdor noče slišati, bo pa čutil'. Kot je razvidno iz zadnjega zgleda, v češčini našemu Pavlihi ustreza Švanda dudák. Blizu temu je tudi hrvaško kajkavsko dudek. V italijanščini izraz paolino nuovo pomeni 'tepec', izraz paolotto pa 'menih pavlanec' in 'klerikalec, pobožnjakar', v angleščini Paul Pry 'radovednež'. Sicer pa našemu pavlihi v angleščini ustreza Merry-Andrew 'pavliha, šaljivec'; nekdaj 'pomočnik sejmarskega mazača', v poljščini pa polyszynel 'pavliha, burkež; javna skrivnost'. Slednji izhaja prek francoskega policinelle iz italijanske ženske komične figure Pulcinella. Ta je tudi v izrazu il segreto di Pulcinella v pomenu 'kar vsi vedo'.

Slovenski Pavliha je tudi v pregovoru Pavliha ljudi gliha. Ruska različica tega pregovora se glasi U vsjakogo Pavla svoja pravda.

\section{2 pavliha 'šaljiv, hudomušen človek'}

Naj vam povem, da je Washington kalvarija za snoba, za vsakogar, ki je kaj vreden, ker se mora tukaj spoprijemati z vsemi temi pavlihi in padarji, ki so preslepili ljudi, da so volili zanje... »Vsi niso pavlihe.« (G. Vidal-J. Fistrovič, Washington, D. C., 1976, 77). Najprej mora priti kdo - kdo, ki vas bo spet spravil v smeh, dober, vesel pavliha, plesalec in vetrnjak in divjak, kakšen star norec: - kaj se vam zdi? (F. Nietzsche-J. Moder, Tako je dejal Zaratustra, 1974, 284). Eden je bil visok, suhljat, s petelinjim obrazom, drug pa bolj majhen, debelušen, z obrazom pavlihe (B. Zupančič, Plat zvona, 1970, 144). Videl se je kot nebogljenega tujca, zabavnega malega pavliho, ki ga ta velikanska in daljna bitja ljubkujejo in negujejo (Thomas Wolfe-M. Mihelič, Ozri se proti domu, angel, 1957, 47). Ubogi pavlihe, vi, politiki,

${ }^{12}$ V zvezi z njegovo dejavnostjo je tudi t. i. Pavlihova druščina - lutkovna skupina, ki je pod vodstvom dr. N. Kureta 1. 1939 in 1940 redno mesečno nastopala v Ljubljanskem radiu.

${ }^{13} \mathrm{Na}$ teh pomenih temelji tudi poimenovanje Pavliha za satirični list, katerega tri številke je na Dunaju uredil Fran Levstik. Kot humoristični list je Pavliha izhajal še v letih 1892-1894, leta 1909 Nemški Pavliha v slovenski obleki (v Ljubljani, J. Giontini), po letu 1944-1999 pa s presledki njegov naslednik tednik Pavliha, zabavno-satirični list za resno zafrkancijo. 
muči vas častihlepje, ko mislite, da ste voz zgodovine, a vas dogodki dneva podijo pred seboj kot pleve. Noben strankarski človek ne razume niti zvestobe samemu sebi (Delo, 2. dec. 2004, NB).

\subsection{1 imeti koga za pavliho 'norčevati se iz koga'}

Zame bi bilo važno, sicer se bom imel vedno le za pavliho (V. Ocvirk, Hajka, 1957, 133).

6.2.2 biti komu za pavliho 'pustiti, da se kdo norčuje iz koga'

Glej, da spodobno prišantaš do jame/ in z vso častitljivostjo ležeš v grob,/ če ne, boš še po smrti nam pavliha (O. Župančič, Veronika Deseniška, 1924, 14, in Dela 3, 1936, 39).

Lahko sem pač podložnik, celo suženj, toda za pavliho nočem biti niti Gospodu Bogu (M. Klopčič, Demon, 259).

6.2.3 biti pavliha, postati pavliha 'biti, postati smešen, hudomušen človek'

Zapisi, da je prepovedal balet, porušil gledališča in pozaprl bolnišnice zunaj glavnega mesta, so iztrgani iz konteksta in nimajo zveze s tukajšnjo resničnostjo," je poudaril sogovornik in opozoril, da Turkmenbaši le ni bil tak pavliha, kot so ga skušale orisati tuje tiskovne agencije, ki so včasih kar tekmovale, katera bo zapisala najbizarnejšo vest o njem. Mož pa je imel izredno moč in so bile njegove odločitve vse prej kot smešne za tamkajšnje prebivalce (Delo, 27. dec 2006, NB). Mislil sem že res, da si Pavliha, / A ostal si, sósed, mož-beseda! / Čarodéj si; rad ti čast priznávam (A. Aškerc, Balade in romance, NB). Razlika je le ta, da os tedaj to sublimacijo tudi izvedli, Husserl pa samo govori o njej. Danes je pač težko spustiti se v tako početje, ne da bi postal smešen Pavliha (C. Logar, Femenologija, 1971, 583).

6.2.4 igrati pavliha 'igrati šaljivo, burkasto figuro'

Preden je /Chaplin/ podpisal pogodbo s podjetjem Keystone, kjer naj bi igral pavlihe, je bajal o vlogah ljubimcev, sanjaril, da bo igral Romea (G. Sadoul-F. Brenk, Zgodovina filma, 1960, 152). Funkcionarji se od svojih odlično plačanih služb prostovoljno zagotovo ne bodo poslovili, prav tako se bo, žal, vedno našlo dovolj študentov, ki bodo za majhne privilegije, kakor so sejnine in brezplačna pijača v študentskem klubu Štuk, pripravljeni igrati pavlihe v tako imenovanem parlamentu (Delo, 17. nov. 2001, NB).

Izraz pavlíha (1. šaljiva, hudomušna figura v lutkovnem gledališču 2. ekspr. šaljiv, hudomušen človek) se je izkazal tudi kot izredno produktivna podstava za izraze - tvorjenke, ki se pomensko navezujejo nanjo. To so: pavliharija, pavliharski, pavliharstvo, pavlihast, pavlihiada, pavlihovanje, pavlihovati, pavlihovski, pavlihovski sam., pavlihovsko prisl., pavlihovstvo (glej ponazoritve v nadaljevanju).

pavliharija 'šaljivo, burkasto obnašanje, dejanje'

Pridušeno so oporekali starejši gorečneži in poznavatelji. Opičarije! Pavliharije, ki bi jih v prejšnjih časih ne bili trpeli!... Na glas pa si niso upali ziniti nobene, ker jih je sililo k molku ljudsko kričanje in navdušeno vzklikanje (V. B. Ibanez-S. Leben, Krvave arene, 1932, 50).

pavliharski ‘tak kot pri pavlihi; šaljiv, hudomušen'

Edino, kar je, je dejstvo, da tisti, ki v nekem okolju nastopi z brezzvezno pesniško govorico, požanje efekt nekakšne osuplosti - pa še ta »inovator« postane hi- 
$4 \quad$ tro celo za naklonjene opazovalce neprostovoljno smešna prikazen, medtem ko je množici sploh samo dobrodošel povod za pavliharsko oponašanje, ki v tem primeru vsebuje precej resnice (M. Kramberger, Pazljivejša branja, 1975, 341). šnosti'

pavliharstvo 'vse, kar nosi znake Pavlihe = norca, torej višek norosti in sme-

Mislim, da uvidite, koliko mi dolguje ta čudna družba, ko skuša s svojim pavliharstvom izvajati med ljudmi neko tiranijo... (Erazem Rotterdamski-Sovre, Hvalnica norosti, 83).

pavlíhast 'tak kot pri pavlihi; šaljiv, hudomušen, burkast'

pavlihasti Kotzebue (A. Funtek, LZ 20, 34) burkast, šaljiv. »Bolje zame, če bi bil tak kakor ta ubogi Peggotty ali njegov pavlihasti nečak«, je rekel... »kot pa jaz, ki sem desetkrat bogatejši in desetkrat umnejši, pa se moram mučiti sam s seboj (Ch. Dickens-O. Župančič, David Copperfield II, 1937, 36). - Ali bi tole rad videl, kljukec pavlihasti? - je zaklicala, se čudovito gibčno vzravnala in se spet obrnila proti Fominu (Šolohov, Tihi Don IV, 412). Nedavno mi je sin prinesel iz šole oceno za vedenje »prav dobro...« Pa sem šla v šolo in povprašala učiteljico, kaj je bilo. Povedala mi je dobesedno takole; »Veste, tako je pavlihast, da mi spravi v smeh ves razred (Pavliha, 1965, št. 9, 2).

pavlihiada 'naziv za smešno lutkovno igro, v kateri leži vsa teža igre na $\mathrm{Pa}-$ vlihi'

Po njegovem mnenju /mnenju St. Lebna/ je bil namreč »Cervantes v svoji preprosti, tako pristni, prostodušni in že ljubeznivi naivnosti ... trdno prepričan, da se mu je z Don Kihotom posrečila imenitna knjiga za zabavo in kratkočasenje, imenitna pavlihiada« in prav zaradi tega vse do svojega zadnjega diha ni niti od daleč samo slutil, kaj je napisal«,... (D. Pirjevec, Evropski roman, 1979, 443).

pavlihovanje 'posnemanje, igranje pavlihe'

... ker je igral Foma Fomič še za svojega pavlihovanja na damski polovici generalove hiše povsem drugačno vlogo (Dostojevski-V. Levstik, Selo Stepančikovo, 9).

pavlihovati 'biti, obnašati se kot pavliha' 16).

On je pavlihoval - zdaj je čutil potrebo, da bi imel sam svoje pavlihe (idem,

pavlihovski 'nanašajoč se na pavlihe'

Po Inemannovem odhodu, ko je vse bolj prevladoval Govekarjev vpliv, so Verovška radi uporabljali za pavlihovske vloge (D. Moravec, Slovensko gledališče Cankarjeve dobe (1892-1918), 1974, 96). Ne glede na to, da so tako aktivisti Jurijevega ali mežnarji Nepomukovega ter celo komolčarji Boltežarjevega kova že oveneli tipi včerajšnjega dne, ne presegajo niti humor in posmeh, niti drastična pretiranost, niti pavlihovske domislice ravni enodnevne anekdotike in tudi do resnične, pristne komedijske sproščenosti ne zavro (V. Predan, Sinočnje premiere, 1974, 158). Prvi predlaga ta sestanek stari Karamazov, in sicer v šali. Ta predlog je ena izmed njegovih pavlihovskih gest in zvijačnosti, kakor pravi Dostojevski (Josip Vidmar, Meditacije, 1934, 175).

Ti glumači so po sejmih in na proščenjih zabavali preprosto ljudstvo s svojimi 
pavlihovskimi tipi (Arlecchino, Pulcinella, Pantalone, Brighella; Dottore, Capitano, Colombina itd.) (F. Bohanec, Estetska vzgoja, 1967, 61/62).

pavlihovski sam.

Nekaj pavlihovskega se je prebujalo v njem. Imelo ga je, da bi se na glas zasmejal, ali pa mahnil s stisnjenimi pestmi po vratih (I. Koprivec, Hiša pod vrhom, 1957, 441). Držal se je resno in strogo, dasi je razdiral take pavlihaste (R. Murnik, Na Bledu, 144).

pavlihovsko prisl. 'kot pavliha, burkasto, smešno, hudomušno'

Pieta je zamikalo, da bi se pavlihovsko obnašal - nadvse rad bi se napravil nevidnega, skrit za tradicionalno masko klovna (J. Updike-M. Mihelič, Zakonski pari, 1971, 412). Toda na ta predlog je nesrečnež izbočil obrvi, večkrat odkimal s svojo kot gobs golo glavo, da bi pokazal svoj odpor, češ: »Ne, ne, ne Lyskamm - Zermatt, Zermatt!«. Stisnil je pest in jo potisnil med svoje pavlihovsko nabrane obrvi (J. Kugy-M. Lipovšek, Božanski nasmeh Monte Rose, 1976, 68). Med svojimi vrstniki ni bil priljubljen. Da bi se jim nekako prikupil, je počenjal vse mogoče neumnosti in nerednosti: obnašal se je pavlihovsko (Vojan Arhar, Otrok in družina, 1962, 48)

pavlihovstvo ekspr. 'lastnost šaljivega, hudomušnega človeka' in ‘šaljivo, hudomušno dejanje'

Skoraj nemogoče je ilustrirati miselno in kritično bogastvo s posameznimi primeri, saj se v florentinskih nočeh preliva domislica v filozofsko oceno, kritična sodba v literarno impresijo. Neredko so nasprotniki skušali potopiti Heineja zaradi njegove polemične ostrine v pavlihovstvo (B. Štih, Tema in antitema, 1982, 130). Verjamem v razumnega, čustveno bogatega, videnjskega in osebnostno polnokrvnega ustvarjavca, vse drugo je za moj okus spretnjaštvo, rokodelstvo, pavlihovstvo, ki nima nikakršne zveze s poslanstvom in cilji umetniškega gledališča (M. Mahnič, Upanje, 1971, 19). »Pravica pesti« je tipičen Kirstov roman skrajnje napetosti. Priljubljeni avtor pripoveduje zgodbo, polno presenečenj, na neposredni in odkritosrčni način, prepleten s suhimi, udarnimi pavlihovstvi, kakor tega nihče drug ne zna (Delo, 13. 11. 1970, 12).

Z izrazi, izpeljanimi iz izvirno slovenskega poimenovanja komičnega lika pavliha, končujem prispevek o imenu Pavel ter besedju in frazeologiji, povezanim z njim. Iz zapisanega je glede na v naslovu retorično podane trditve, ki temeljijo na reku Nomen est omen (Ime je pomenljivo), možno ugotavljati, ali in v kolikšni meri se le-te lahko nanašajo na ime jubilanta Pavleta Merkuja. Vsekakor je ta Pavle poseben Pavel, ki že z obliko in pomenom svojega imena prerašča izvorno »majhnost« Pavla v njegovo nasprotje. Pri tem pa prevzema veliko svetopisemske simbolike in apostolstva Pavla, saj je naš jubilant izreden ambasador slovenstva v zamejstvu in tujini sploh ter je lahko svetel zgled tudi vsem v matični domovini. Z zanikanimi oblikami frazemov in izimenskih izrazov, izhajajočih iz imena Pavel (ni Peter in Pavel ne Peter ali Pavel $=$ ne kdorkoli, ne pavliha) se pomembnost jubilantovega dela in njegove izredne osebnosti še poudarja. Vsaj zame pa o odprtosti njegovega 
značaja in raziskovalne nesebičnosti še vedno najlepše govori njegovo Odprto pismo Janezu Kebru, ob katerem sva se osebno spoznala.

\section{Viri in literatura}

Byryh, A.K., Mokienko, V.M., Stepanova, L.I., Slovar' russkoj frazeologii, Istoriko-etimologičeskij spravočnik, Sankt-Peterburg 1988.

Gak, V. G. \& al., Francuzsko-russkij frazeologičeskij slovar, 804.

Keber, Janez, Nekateri semantični vidiki in motivi prehoda osebnih imen v občna imena v slovenščini, Traditiones 23 (1994), Ljubljana, 27-32.

Keber, Janez, Osebna imena v ljudskih pesmih, Traditiones 28 (1999), 1, Ljubljana, 269-280.

Keber, Janez, O strukturi rojstnih imen v Sloveniji, Jezikoslovni zapiski 7 (2001), št. 1-2, 21-111.

Keber, Janez, Rojstna imena, hišna imena, vzdevki, psevdonimi v Sloveniji, Jezikoslovni zapiski 8 (2002), št. 2, 47-69.

Keber, Janez, Imena v rimah, Družinska pratika, 1995, 48-51.

Keber, Janez, Urha klicati, Zakaj tako, $7 D$ (Maribor), 1. oktober 2003, letn. 52, št. $39,50$.

Keber, Janez, Iti kot Elija, Zakaj tako, 7D (Maribor), 17. nov. 2004, letn. 53, št. 46, 50.

Keber, Janez, Leksika in frazeologija iz osebnih imen, Ivić, Pavle (ur.), Zbornik šeste jugoslovenske onomastičke konferencije (Donji Milanovac, 9-12. oktobar 1985), (Naučni skupovi, Odeljenje jezika i književnosti, knj. 37, knj. 7), Beograd, Srpska kademija nauka i umetnosti, 1987, [437]-443.

Keber, Janez, Izimenska leksika in frazeologija v Slovarju slovenskega knjižnega jezika, Rječnik i društvo : zbornik radova sa znanstvenog skupa o leksikografiji i leksikologiji održanog 11-13. X. 1989. u Zagrebu, (Znanstveni skupovi razreda za filološke znanosti, knjiga 2), Zagreb, Hrvatska akademija znanosti i umjetnosti, 1993, 183-188.

Keber, Janez, Ženska imena v Sloveniji, Derganc, Aleksandra (ur.), Zbornik predavanj, Ljubljana, Filozofska fakulteta, Oddelek za slovanske jezike in knjiŽevnosti, 1997, 33-43.

Keber, Janez, Einige semantische Aspekte und Motive des Übergangs von Personennamen zum Appellativum im Slowenischen, Zusammenfassungen, Trier, Universität Trier, 1993, 72-73.

Keber, Janez, Ob slovenskem imenoslovju, v: Merkù, Pavle, Svetniki v slovenskem imenoslovju, Trst, Mladika, 1993, 155-157.

Keber, Janez, Leksikon imen, Izvor imen na Slovenskem, tretja, dopolnjena izdaja, Celje 2001.

Keber, Janez, Frazeološki slovar slovenskega jezika, Poskusni zvezek, Ljubljana 2003.

Kopaliński, Władysław, Słownik mitów i tradycji kultury, Warszawa 1987.

Lađević, Milica, Tvorbeni modeli imena blizanaca u Vojvodini, Novi Sad 1988. 
Matešić, Josip, Frazeološki rječnik hrvatskoga ili srpskoga jezika, Zagreb 1982.

Merkù, Pavle, Odprto pismo Janezu Kebru, Primorska srečanja 1989, št. 95-96, str. 299-301.

Merkù, Pavle, Svetniki v slovenskem imenoslovju, Mladika, Trst 1993.

Mrazović, Pavica, Primorac, Ružica, Nemačko-srpskohrvatski frazeološki rečnik, Beograd 1981.

Žukov, V. P., Slovar' russkih poslovic i pogovorok, Moskva 1966, 459.

\section{Pavle Is Pavel, but He Was Not Savel, And Also Not Peter in Pavel nor Peter ali Pavel nor pavliha \\ Summary}

This article dedicated to Pavle Merkù discusses the vocabulary and phraseology connected with the name Pavel 'Paul'. Following an introduction, it focuses on the names Pavle and Pavliha, and the name of the comic character Pavliha, as well as the terms pavliha, pavlišec, pavlišek, and pavluha (all 'clown'), in addition to the phrasemes iz Savla postati Pavel 'for Saul to become Paul', Peter in Pavel 'Peter and Paul', Peter ali Pavel 'Peter or Paul', biti pavliha 'to be a clown', imeti koga za pavliha 'to make fun of someone', and igrati pavliho 'to play the clown'. In the article's title, the author provides a more rhetorical answer to the question of whether the saying Nomen est omen 'true to its name' also applies to Pavle Merkù with regard to this name, vocabulary, and phraseology.

\section{Janez Keber}

Inštitut za slovenski jezik Frana Ramovša ZRC SAZU

Novi trg 2, 1000 Ljubljana

keber@zrc-sazu.si 



\title{
Vodna imena na doberdobskem Krasu
}

\author{
Vlado Klemše (Gorica)
}

IZVLEČEK: V članku obravnava avtor vodna imena Doberdobskega, Prelosnega in Sabeljskega jezera ter Močil, navaja dosedanje ugotovitve in razlage imen ter opozarja na značilne hidronime, kot so Črepola/Črepolo, P'č, Počka, Rebok, Rošta, Roja in Pivka.

ABSTRACT: This articles discusses the hydronyms associated with Lake Doberdo, Lake Pietrarossa, the Sablici Marsh, and the Mucille Lakes, presents findings and explanations of the names to date, and draws attention to typical hydronyms such as Črepola/Črepolo, $P$ '̌́, Počka, Rebok, Rošta, Roja, and Pivka.

Kamen je razpoznavni znak Krasa, voda pa element, ki omogoča življenje in preživetje v pokrajini, ki je v prejšnjih stoletjih kazala drugačno, zagotovo manj prijazno podobo. Voda v najbolj naravni obliki, kot dež, voda, ki se zbira v škavencah, v umetno narejenih zbiralnikih, štirnah, voda v obliki občasnih tokav, potokov, žlebov in strug, kalov in luž. Pa tudi voda v kraških jamah, kamor odteka skozi požerljuhe, živa voda presihajočih jezer, ki so značilnost doberdobskega Krasa, območja med Timavo in Vipavo ter med Dolom in Furlansko ravnino oziroma Laškim.

Poleg Doberdobskega jezera, ki je po površini največje in najbolj znano, so na tem območju še Prelosno in Sabeljsko jezero, Močila in vrsta drugih manj izrazitih kraških pojavov, vezanih na vodo. K temu velja dodati še močvirnat svet med Štivanom in Tržičem, imenovan Ližerc (it. Lisert). Za to območje se občasno uporablja tudi ime Laško jezero, vendar gre za netočnost oziroma za zamenjavo, zelo verjetno sad nepoznavanja zgodovinskih okoliščin in velikih sprememb, posledic posegov v prostor z gradnjo prometnih infrastruktur (železnica, ceste, daljnovodi, melioracije), ki so ta prostor povsem preoblikovale, začenši od druge polovice 18 . stoletja. Podobno razmišljanje, glede lokacije namreč, velja za hidronim, reko oziroma kanal Lokóvec/Lokávac (it. Locovaz).

$\mathrm{V}$ prostoru med Vipavo in Timavo ter med Dolom in Laškim je več vasi in zaselkov: Jamlje, Dol s svojimi zaselki, Doberdob s Poljanami, Medja vas, Vrh in Martinščina. Na obrobju pa so Štivan, Gabrje, Rupa, Peč in Miren. Na severozahodu so še Rubije, Petovlje, Zdravščine in Zagraj.

Geografski oris je podatek, ki ga ni mogoče zaobiti ob preučevanju krajevne- 
ga imenoslovja, posebej v prostoru, ki je stoletja stičišče slovanskega/slovenskega in romanskega sveta.

Prav tako ni mogoče mimo zgodovinskega dejstva, da je prav skozi ta prostor, od Zagraja, po zadnjih obronkih Krasa do prvih vzpetin nad Tržičem (it. Monfalcone), dolgo potekala državna meja med Beneško republiko in avstrijskimi deželami in se ohranila do leta 1797. Značilnost tega prostora je tudi stoletja dolgo sobivanje po izvoru romanske, šmartinske (Martinščina) skupnosti s slovensko okolico, kar se seveda odraža tudi v toponomastiki. Pogosti so primeri dvojnega poimenovanja (polimorfna imena), kakor tudi prisotnost slovenskih toponimov na območju Martinščine, Zagraja, Petovelj in tudi drugih krajev in seveda tudi obratno. Značilen primer polimorfnega imena je toponim Razkriž/Crosera (cestno križišče na meji med katastrskimi občinami Doberdob, Zagraj in Martinščina). Najvišja točka doberdobskega Krasa je Debela griža $(275 \mathrm{~m})$. Ime uporabljajo prebivalci slovenskih vasi, medtem ko je za Šmartince gora od nekdaj samo Cimòn, kar po slovensko pomeni Veliki vrh. Hidronim Fontane/Fontana, kar po pomenu ustreza štirnam, štirni oziroma štirnci, je zabeležen na območju Martinščine, vendar se je ime ukoreninilo tudi v nekaj kilometrov oddaljenem Opatjem selu (bolj pravilna in utemeljena bi bila množinska raba imena - Opatja sela; ljudsko Pačjasela) in tudi v nekaterih drugih krajih matičnega Krasa. Podobna ugotovitev velja za splošno razširjeni hidronim Potok. Ime je pogosto na teritoriju Petovelj, Zdravščin, Zagraja in deloma Foljana. Rošta, roja in rebok so izposojenke iz furlanščine, ki pa so se razširile daleč v notranjost slovenskega etničnega prostora na Primorskem.

Značilen hidronim je Črepola/Črepolo v spodnjem toku Vipave. Verjetno novejšega izvora sta hidronima $P^{\prime c}$ s pomenom »vodnjak s talno, izvirno vodo«, in Počka, s pomenom »manjši vodni vir, studenec«. V seznam značilnih vodnih imen tega območja bi lahko uvrstili hidronim Pivka/Piuka (navedba v Franciscejskem katastru).

Nekaj nemških ali domnevno iz nemščine izvedenih imen je zaslediti predvsem v arhivskem gradivu, npr. mikrotoponim Regališče na območju med Dolom in Opatjim selom, dalje mikrotoponim Kuglišče/Kulišče na območju Vrha, hidronima Bajer pri Rupi ter Mautte, potok, ki razmejuje občini Sovodnje ob Soči/Savogna d'Isonzo in Zagraj/Sagrado. Tudi oronim Varda nad Boneti in Jamljami bi po vsej verjetnosti sodil $\mathrm{v}$ to skupino imen.

Še zmeraj močno opazne so sledi, ki jih je tudi na področju toponomastike zapustila prva svetovna vojna. Doberdobski Kras je bil med najbolj krvavimi prizorišči nesmiselnega in tragičnega početja. Številni žegni, jarki, špitali, kaverne in komande nosijo v sebi sporočilnost o dogajanju in dogodkih, ki so še zmeraj globoko zasidrani v kolektivnem spominu prebivalstva, čeprav so se dogodili pred devetdesetimi leti.

Morda se bodo, poleg zbirateljev materialnih ostankov prve svetovne vojne, našli tudi zbiralci in zapisovalci dediščine, ki je sicer manj otipljiva kakor staro orožje, topovske granate, vojaška oprema, vendar s prav tako močno sporočilnostjo. Vendar to je drugo, novo poglavje. Danes bi spregovorili o vodnih imenih na doberdobskem Krasu, vsaj o nekaterih. 
ČRÉPOLA/ČRÉPULA, f. s., mtn in hdn na Vipavi, na območju Rupe, Peči, Gabrij in Rubij. Označuje kraj v rečni strugi, do koder je bila speljana pot oziroma je imela živina lahek dostop. Na črepoli se je napajala živina, ob suši pa so krajani in tudi prebivalci kraških vasi zajemali vodo za kuhanje in druge potrebe. Še po drugi svetovni vojni so v sušnem obdobju $\mathrm{Na}$ črepoli zajemali in vozili vodo v lesenih lodricah, posebnih, na vozovih nameščenih sodih. V krajevnem govoru je črepola ženskega spola, kar potrjuje tudi mestniška oblika Na črepoli. Znana je tudi starejša oblika, Serepalo (mapa Franciscejskega katastra, 1818, za Rubije). V Terezijanskem katastru za Miren sta zabeleženi imeni Na chirepolo in Chirepola. Črepola pri Rupi se prekriva z mikrotoponimom Brod, $\mathrm{Na}$ Brodu.

SABELJSKO JEZERO, n. s., hdn na meji med občinama Doberdob/Doberdò del Lago in Tržič/Monfalcone. Močvirnato območje, ki je bilo po številnih posegih, zlasti ob gradnji avtocestnega vozlišča, povsem spremenjeno. Prve navedbe so iz 13. stoletja: Gesira je nedvomno slov. jezero (TEA). To potrjuje tudi domnevo, da je današnje sestavljeno ime, Sabeljsko jezero, nastalo kasneje. Številne so navedbe iz 17., 18. in 19. stoletja, zlasti iz Franciscejskega katastra (Sablicz, Sablitz). Jožefinski vojaški zemljevid (1763-1787) navaja potok Sabliz, nekoliko niže, v smeri proti morju, pa Palustine.

Navedba (PSCC, 174) iz 18. stoletja govori, da je hišo na mestu z imenom Sabliza zgradil devinski grof.

Nad (nekdanjim) jezerom je zaselek Sabliči, m. pl. Danes šteje šest hiš, ki so na območju katastrske občine Jamlje, upravno pa sodijo v občino Doberdob.

Raba krajevnega imena Sabliči (v predložni rabi pri Sabličih, od Sabličev, etnik ni znan) opozarja, da je ime zaselka verjetno izvedeno iz osebnega imena ali priimka, podobno kot so iz imen oziroma priimkov izvedena imena zaselkov v Dolu (Boneti, Ferletiči, Vižintini, Devetaki, Mikoli, Palki, v novejšem času se za slednje vse bolj dosledno uporablja ime Palkišče). Milko Kos navaja (Srednjeveški urbarji za Slovenijo III, str. 167, 168) nekega Saubkizha, Saukhicza, Saukicza v Števerjanu, okrog leta 1523.

Glede pomena imena bi veljalo upoštevati še drugo možnost, da je ime nastalo po značilnosti kraja oziroma območja. Mokrišča so idealno naravno okolje za žabe. Žabč, Žabnic, Žabelj in podobnih imen pa je veliko v slovenskem prostoru.

Manj verjetna se zdi razlaga, po kateri naj bi se v imenu Sabeljsko (jezero) skrivala romanska beseda sabulum s pomenom »pesek«, kar omenja France Bezlaj v knjigi Slovenska vodna imena II. Dvomi se porajajo zlasti ob upoštevanju geomorfoloških značilnosti kraja. Vode v presihajočih kraških jezerih običajno ne odlagajo peska. Isti avtor uporablja ime Sabliško jezero, krajani pa pravijo Sabeljsko jezero, kar se mi zdi bolj pravilno.

Na ožjem območju Sabeljskega jezera so še trije hidronimi: Studenci, Vrba in Puščjetka. Na obrobju najdemo še Žleb, Krč in Pološko.

MOČILA/MUCILLE, n. pl., hdn v občini Ronke/Ronchi dei Legionari označuje kraški izvir, manjše presihajoče jezero. Območje je izgubilo prvobitno podobo zaradi gradbenih in drugih posegov (avtocesta, stanovanjske hiše, konjerejska farma itd)

Ime Muzilas se prvič omenja leta 1382 (Domini 1998) in kasneje Mocille (1741). 
$4 \quad$ V Franciscejskem katastru katastrske občine Romjan/Vermegliano, Mocille. V istem viru je omenjen tudi potok roja Mocille, ki je povezoval različne kraške izvire. Ime se je ohranilo tudi v uradni toponomastiki današnje občine Ronke/Ronchi dei Legionari (ulica Mucille). Dva izvira presihajočega jezera sta v bizjaškem narečju evidentirana kot Gorgo in Gorghet (gorghet je pomanjševalnica za gorgo; Puntin).

PRELOSNO/PRELAZNO JEZERO, n. s., bizjaško Lago di Pierarossa, it. Lago di Pietrarossa, v nem. besedilu Prerassel (Urbar za Devin 1494, M. Kos, Srednjeveški urbarji za Slovenijo III, str. 207), hdn v občini Tržič/Monfalcone, na meji z občino Doberdob. Danes je Prelosno jezero v območju naravnega rezervata Doberdobskega in Prelosnega jezera.V osrednjem in najglobljem delu voda nikoli ne presahne. Celotno območje je kljub zaščiti znatno spremenjeno, ker je skozi kotlino speljana avtocesta. Moteč je tudi vpliv naftovoda in plinovoda. Še do nedavna pa je bilo na vzpetini nad jezerom veliko vojaško strelišče.

Poleg hidronima Prelosno se občasno uporablja tudi ime Laško jezero. Delno razlago najdemo v Jožefinskem vojaškem zemljevidu, kjer je omenjeno jezero navedeno kot Jesero Veneto, kar bi ustrezalo hidronimu Laško jezero. Navedba vojaških topografov iz druge polovice 18. stoletja je smiselna in razumljiva. Jezero je bilo takrat v celoti na ozemlju Beneške republike in je bilo zato pač Jesero Veneto. Težko pa je odgovoriti na vprašanje, ali so vojaški topografi vpisali ime, ki je bilo že v rabi med krajani, ali pa so, na osnovi neke tudi takrat močno prisotne birokratske miselnosti, jezero poimenovali kar po svoje.

O izvoru in rabi imena Laško se je mogoče poučiti v zborniku Slovenci v Laškem (2005).

Bolj zapletena pa je razlaga nastanka in pomena imena Prelosno (narečno Prielostno) jezero. Maurizio Puntin (Toponomastica storica del Territorio di Monfalcone) navaja (ASCM, 43) citata iz leta 1569 Piera rossa in 1583 Pierarossa, kjer se omenja tudi mlin. Ime Pietrarossa je zabeleženo tudi v Franciscejskem katastru in na mapah katastrske občine Jamlje in katastrske občine Tržič/Monfalcone.

Puntin pojasnjuje nastanek italijanske oblike imena (Pietra rossa) s prisotnostjo državne meje med Beneško republiko in avstrijskimi deželami. Mejo so označevali kamni, ki so bili škrlatnordeče barve in avtor navaja podobno situacijo, prav tako na mejnem območju, v kraju Isola Morosini (občina Škocjan ob Soči/San Canzian d'Isonzo) ter na nekdanji meji med Beneško republiko in deželo Tirolsko.

$\mathrm{V}$ podkrepitev take razlage govori še en podatek, in sicer oronim Cimo di Pietra rossa, ki je zelo verjetno tudi nastal po letu 1420 (ime je navedeno tudi v Franciscejskem katastru).

Ob tem se seveda postavlja vprašanje, odkod slovensko Prelosno, oziroma Prelostno in Prielostno jezero. Gre za domači govorici prilagojeno obliko italijanskega imena Pietra/Pierarossa? ${ }^{1}$

V krstnih knjigah za vikariat Jamlje (do leta 1873 so se vodile v Devinu, potem samostojno), kamor je sodil tudi mlin v Prelosnem, sta zabeleženi obliki, Prelazno (ex Prelazno) in Prelostno.

1 O razlagi imena Prelosno po disimilaciji iz *Preroslo France Bezlaj, Etimološki slovar slovenskega jezika III, 109, sub voce Prẹ́doslje. (Op. ur.) 
Ob upoštevanju dejstva, da gre za področje, kjer so pogosti medsebojni jezikovni vplivi (interference), bi kazalo vzeti v poštev še eno možno razlago. Nad jezerom se namreč dviga (kota 144) kopast vrh, ki je na zemljevidih in mapah označen Arupacupa in ki je bil, po moji oceni, zelo nerodno poslovenjen v Gerupo kopo.

Ni dvoma, da gre za sestavljeno ime in da je drugi del (kopa) pravšnji, saj povsem odraža morfologijo reliefa. Dvom se pojavlja glede prvega dela Arupa/Gerupa. Jameljci uporabljajo za goro ime Vrtače. Wertatschek je zabeleženo na Jožefinskem vojaškem zemljevidu.

Gerup oziroma gherjup v krajevni govorici pomeni zoprn, nesladek, bridek, v prenesenem pomenu, tudi s težavo pridobljen. Kaj pa če je hibridna in težko razumljiva oblika (Arupacupa) samo rezultat netočnega ali površnega zapisa ali prepisa in imamo v osnovi opravka z navadno Ruso kopo? Rús na Primorskem in posebej na Goriškem pomeni rdeč (Pleteršnik). Če poznamo in sprejemamo imeni Rdeči rob in Bele stene, zakaj ne bi sprejeli Ruse kope? Toliko bolj, ker imamo čisto blizu vsaj dva primera sestavljenih oziroma dvodelnih imen. Z Gerupe kope/Ruse kope se nad Doberdobskim jezerom lepo vidi Rúsi škólj, obsežnim, nekdaj srenjskim pašnikom, ki se spuščajo od Doberdoba proti jezeru pa krajani od nekdaj pravijo Črna griža.

DOBERDOBSKO JEZERO, n. s., it. Lago di Doberdò, nem. Doberdoer See (Franciscejski kataster in kasnejši dokumenti). V vseh primerih gre, po vsej verjetnosti, za umetno in iz upravnih potreb oblikovano ime. Krajani, tako v Doberdobu kakor v Jamljah (površina jezera je namreč razdeljena med omenjeni vaški skupnosti, pri čemer je večji del, nekaj nad 20 hektarov, v katastrski občini Doberdob), uporabljajo samo ime Jezero, kar je povsem razumljivo, saj je to edino jezero na njihovem območju, od nekdaj glavni vir pitne vode. Jezero je bilo v preteklosti intenzivno koriščeno, od lova in ribolova do košnje peluda (rogoza). Obsežna površina, ki je danes del naravnega rezervata Doberdobskega in Prelosnega jezera in hidrološke značilnosti - izviri podtalnice so na jugozahodni strani, podzemni odtoki, požiralniki pa na vzhodni (jameljski) strani, povezuje pa jih vijugasta rečica - so prispevale k nastanku niza zanimivih vodnih imen. Glavnemu izviru v jezeru domačini pravijo Grulja, manjšim pa Luknja. Rečica, po kateri voda odteka proti Jamljam, je Močivnica. Manjši kanal (hidrografija se namreč pogosto spreminja) pa je Roja.

V jezerskem dnu so se do danes, kljub različnim poskusom, vrtanjem in sondiranjem (pred desetletji so na območju jezera nameravali graditi raziskovalni center s svetlobnim pospeševalnikom in so v ta namen opravili niz geoloških raziskav in poskusov stabilnosti jezerskega dna) ohranile tri kotanje, bézni, ki so stalno zaliti z vodo (Prvi bézen, Drugi bézen, Treči (Tretji) bézen). Največji in od daleč najbolj opazen je Treči bézen na jameljski strani. Na skrajnem vzhodnem delu jezera je Plutnik. Območje jezera, kjer so še pred nekaj desetletji kosili rogoz, bodisi za nastilj bodisi za pletenje piconov, je Pelud.

Pelúd (ponekod tudi Palud) je fitonim za rogoz. Pomeni pa lahko tudi močvirje, mlakužo, kjer uspeva trsje. Picòni so posebne iz trsja (peluda) pletene mreže za sušenje sadja. Uporabljali so jih tudi pri gojenju sviloprejke. Nekdaj so iz trsja pletli tudi mreže, ki so jih uporabljali v gradbeništvu, za ometavanje lesenih stropov. Ime tako pletene mreže je gržòla. 
Pelúd, picòn in gržòla so izposojenke iz furlanščine: palût, pezzòn (tudi gradiz) ter grisòl (grisòle, grisiòle).

Nejasen je pomen imen Grulja in Plutnik. Možno, vendar ne dovolj prepričljivo razlago za Plutnik najdemo v Pleteršnikovem slovarju, kjer za plutnik navaja, da je to vrsta perunike. Jezero je dejansko zelo zanimivo tudi s florističnega vidika (posebej velja opozoriti na bujno cvetenje poletnega velikega zvončka - Leucojum - ob bregovih) in v okolici rastejo tudi perunike. Ne vidim pa logične povezave, zakaj bi kraški požiralnik poimenovali po rastlini, ki dobro uspeva v skalnatih prisojnih legah.

$\boldsymbol{M O S} \breve{\boldsymbol{C}} \boldsymbol{E} \boldsymbol{N I C A} \boldsymbol{M} \boldsymbol{M O} \check{\boldsymbol{S}} \breve{C} \boldsymbol{E N I C E}$, f. s, f. pl., hdn in tpn na meji med katastrskima občinama Jamlje in Tržič/Monfalcone (danes tudi meji med občinama Doberdob/ Doberdò del Lago in Tržič/Monfalcone). Pavle Merkù (Krajevno imenoslovje na slovenskem zahodu, str.135) navaja imeni Moščénca in Muščénice za mlin in hišno ime. Terenska raziskava opozarja na množinsko obliko toponima (pri Moščenicah). Maurizio Puntin navaja, sklicujoč se na listine iz obdobja beneške uprave, vsekakor po letu 1558, ime Moscheniza, in razlaga, da je ime veljalo za območje bližnjega hriba in tudi potoka. V opisu občinske meje med katastrskima občinama Jamlje in Medja vas (Franciscejski kataster, 1818) zasledimo Mosiniza (isti vir navaja tudi lastnika zemljiške parcele, Pavletiča iz Gabrij), kar se zdi bliže Močivnici (ime roje v bližnjem Doberdobskem jezeru, po kateri se pretaka voda od izvirov na zahodni strani (Grulja) proti požiralnikom na vzhodni strani).

V krstnih knjigah župnije Jamlje je beležka (ex Moščenice, 6), kar navaja k razmišljanju, da se za različnimi oblikami pravzaprav skrivata dve imeni: hidronim Močivnica, potok, ki priteka iz Sabeljskega jezera, in mikrotoponim oziroma toponim Moščenice.

MAUTTA, hdn potoka na meji katastrske občine Rubije in Petovlje. Danes poteka po strugi, ki je običajno suha, ob deževju pa bogata $\mathrm{z}$ vodo, in predstavlja mejo med občinama Sovodnje ob Soči/Savogna d'Isonzo in Zagraj/Sagrado. Ime Mautta je navedeno v Franciscejskem katastru, v opisu meje katastrske občine Rubije (1818) in na opisu priloženi risbi, medtem ko se v kolektivnem spominu ni ohranilo. Potok, ki izvira na majhni planoti pri zaselku Boškini, je za domačine samo Potok.

Skromen podatek, da je nastanek imena mogoče pojasniti z obstojem mitnice, najdemo v razpravi Milka Kosa (Srednjeveški urbarji za Slovenijo III, str. 209). Navedba je sicer precej splošna in omenja samo mitnico v Gabrjah, kar pa ni daleč od Rubij oziroma od potoka Mautte.

Odkod torej ime? Z ozirom na to, da je tod potekala meja med Goriškim in Tržaškim okrožjem in da je ob Vipavi in Soči bila speljana pot med Rubijami, Petovljami in Zagrajem, kjer je bila v bližini tudi državna meja, je bila najbrž tu mitninska postaja. Globoka struga potoka je že sama predstavljala naravno zapreko, ki jo je bilo težko zaobiti. Die Maute v nemščini pomeni mitnino oziroma mitnico. V slovarju Nuovo Pirona (NP) je naveden toponim Mauta v kraju Pravisdomini, v zahodni Furlaniji.

P'Č/POČKA

Apelativ p’̌́, m. s., je iz furlanskega pòc , pòz s pomenom »vodnjak s talno, 
izvirno vodo«. V drugem primeru imamo opravka $\mathrm{z}$ istim apelativom, le da je tu uporabljena manjšalna pripona $-k a$.

$P^{\prime} c ̌$ je splošno znano in razširjeno vodno ime v spodnjem nižinskem delu goriške kotline (Miren, Sovodnje, Rupa, Peč, Gabrje).

$P O C \check{C} A$, f. s., je ime manjšega vodnega vira nad zaselkom Mikoli v Dolu. Za isto, vendar širše območje, je znano tudi ime Dolina pri Kalu. Glede pomena imena $P^{\prime c}$ velja opozoriti na furlanski priimek Pozzâr (kopač vodnjakov) in hišno (domače) ime $P^{\prime c ̌ a r ~ v ~ S o v o d n j a h . ~}$

PÍVKA/PÍUKA, f. s., pri Píu(v)ki, na Píu(v)ki, ime označuje večje območje na dveh prodnatih terasah, na meji med Štandrežem, Sovodnjami in Pečjo. Ime bi lahko uvrstili tudi v kategorijo mikrotoponimov. Na Pivko sem naletel le v arhivskih virih (Franciscejski kataster). Domnevati je mogoče, da je bil na tem mestu požiralnik oziroma močno prepusten prodnat teren, kamor je izginjala voda iz Velikih roj. Podoben geološki pojav je bil v preteklosti med Rupo in Mirnom. V Terezijanskem katastru najdemo toponim Nad beznom. Novejšega nastanka pa je mikrotoponim Velika jama.

\section{ROJA, ROŠTA, REBOK}

To so hidronimi na območju Rubij, Sovodenj, Petovelj, Zdravščin.

$R O J A$, f. s., pomeni umetni kanal, speljan za dovajanje vode na mlinska kolesa (npr. Roja pri Rubijah). V Furlaniji pomeni Roja tudi naravni vodotok. Izvedeno iz furlanskega ròje, ròe.(NP)

$R O S ̌ T A$, f. s., pomeni jez, umetno pregrado v rečni strugi, redkeje se ime uporablja za naravno pregrado. Izvedeno iz furlanskega ròste. (NP).

$R E B O K, \mathrm{~m}$. s., mrtev rokav v rečni strugi, običajno bogat z ribami.

Ime je v rabi v Sovodnjah, Petovljah in Zdravščinah. Izvedeno je iz furlanskega revòc, rivòc $(\mathrm{NP})$.

$\boldsymbol{P O Z ̌ E R L J U ́ H , ~ m . ~ s . , ~ j a m a , ~ p o z ̌ i r a l n i k , ~ o b i c ̌ a j n o ~ v ~ n a j n i z ̌ j e m ~ d e l u ~ k r a s ̌ k e g a ~}$ polja, kamor ob deževju odteka voda. Požerljuh med Vižintini in Palkiščem.

\section{Viri in literatura}

ASCM - Archivio Storico Comune di Monfalcone.

Bezlaj, France, 1956, 1961, Slovenska vodna imena I-II, Ljubljana.

Bezlaj, France, 1976-2005, Etimološki slovar slovenskega jezika I-IV, Ljubljana.

Brecelj, Marijan, 2005, Furlansko-slovenski slovar, Nova Gorica.

Waltritsch, Marko (ur.), 1988, Doberdob včeraj in danes, Doberdob, 1988.

Domini, Silvio, 1998, Staranzano: storia, società e cultura tra Otto a Novecento, Staranzano.

Fajt, Vilko, 2002, Družinska imena v Sovodnjah. Utrinki naše preteklosti, Sovodnje ob Soči.

Franciscejski kataster. Opisi katastrskih občin, lastnikov zemljiških in stavbnih parcel, cenitve in mape. Gradivo v Državnem arhivu v Gorici (Archivio di Stato).

Goriško ozemlje. Zemljevid s krajevnimi in ledinskimi imeni, Trst - Gorica, 1999. 
- Jožefinski kataster. Registri lastnikov in popis parcel. Gradivo v Državnem arhivu $v$ Gorici (Archivio di Stato).

Klemše, Vlado, 1997, S Poklona do Toplice. Krajevna, ledinska, vodna in druga imena v Štmavru, Pevmi in na Oslavju, Štmaver.

Kos, Milko, 1954, Srednjeveški urbarji za Slovenijo III. Urbarji Slovenskega Primorja. Drugi del, Ljubljana.

Krstne knjige. Prepisi krstnih knjig posameznih župnij, v Nadškofijskem arhivu v Gorici.

Martinčič, Andrej, Sušnik, Franc, 1969, Mala flora Slovenije, Ljubljana.

Merkù, Pavle, 2006, Krajevno imenoslovje na slovenskem zahodu, Ljubljana.

Pirona, Giulio Andrea, 1979, Il Nuovo Pirona. Vocabolario friulano, Udine.

Pleteršnik, Maks, 2006, Slovensko-nemški slovar. Transliterirana izdaja, Ljubljana.

PSCC - Provveditori Sopraintendenti alla Camera dei Confini, v Archivio di Stato di Venezia.

Puntin, Maurizio, 2003, Toponomastica storica del Territorio di Monfalcone e del comune moderno di Sagrado, Gradisca d'Isonzo.

Klemše, Vlado (ur.), 2005, Slovenci v Laškem, Tržič.

Slovenija na vojaškem zemljevidu 1763-1787 (1804), 3. zvezek, Ljubljana, 1997.

Snoj, Marko, 1997, Slovenski etimološki slovar, Ljubljana.

Waltritsch, Marko (ur.), 1983, Sovodenjski zbornik, Sovodnje.

Tabor "Doberdob 82". Gradivo mladinskega raziskovalnega tabora, Ljubljana, 1983.

TEA - Thesaurus Ecclesiae Aquileiensis.

Terenska raziskava avtorja.

Terezijanski kataster. Registri lastnikov, kolonov in bremen. Gradivo v Državnem arhivu v Gorici (Archivio di Stato).

Tržaško ozemlje. Zemljevid in seznam ledinskih imen, Ljubljana - Trst, 1978.

\section{Hydronyms in the Doberdo Karst Area}

Summary

Doberdob (the Doberdo) karst area stretches between Štivan (San Giovanni) and the Vipava (Vipacco) River, and between Dol (Vallone) and the Friulian Plain, and is of great toponymic interest. This has been an area of intersection between the Slavic and Romance worlds for centuries. The border between Venice and Austria ran along the karst rim between Soča (the Isonzo) River and Tržič (Monfalcone) for several centuries. As a result, the intertwining of linguistic influence is more present and obvious in this area.

In addition to the special historical features mentioned above, this region is also interesting in another way. The Doberdo karst area is rich and interesting in terms of geomorphology. In a relatively small area, there are four intermittent 
lakes, as well as numerous ponds, sinkholes, distinctly flashy streams, and caves with groundwater.

Water has always been a precious element and an element of survival for people living in the Karst region. This is also reflected in its wealth of hydronyms, the majority of which have been preserved either through oral traditional or archival material.

The author concentrates on the hydronyms associated with Doberdobsko jezero (Lake Doberdo), Prelosno jezero (Lake Pietrarossa), Sabeljsko jezero (the Sablici Marsh), and the Močile (Mucille Lakes). Findings and explanations of the names to date are presented, and attention is drawn to typical hydronyms such as Črepola/Črepolo, P'č, Počka, Rebok, Rošta, Roja, and Pivka.

Vlado Klemše

Case sparse 54, I-34070 Sovodnje/Savogna d'Isonzo (GO) vlado.klemse@virgilio.it 



\title{
Дзве славянскія дыялектныя зоны
}

\author{
Фёдар Д. Клімчук (Minsk)
}

IZVLEČEK: Po nekaterih lastnostih se slovanski narečni kontinuum deli na dve coni - severno in južno. Kot osnova za tako delitev je vzeta različna realizacija soglasnikov *d, *t, *z, $*_{s}, *_{n}$ pred $*_{e}, *_{i}$, in samoglasnikov $* i$, *y. Obstajajo govori z različno stopnjo prehodnosti. V nekaterih govorih se je ohranil arhaični model, ki je blizu praslovanskemu.

\section{Two Slavic Dialect Zones}

ABSTRACT: In certain features, the Slavic dialect continuum is divided into two zones: north and south. Various realizations of the consonants $*_{d}, *_{t}, *_{z}, *_{s}$, $*_{n}$ before $*_{e}$, $*_{i}$ and the vowels $*_{i}$, *y have been taken as the basis for this division. There are dialects with different degrees of sound change. Some dialects have preserved an archaic model close to Proto-Slavic.

Па некаторых асаблівасцях славянскі дыялектны кантыніум падзяляецца на дзве зоны - п а ў н о ч н у ю і п а ў д н ё в у ю. Да такіх асаблівасцей, у прыватнасці, адносяцца наступныя. 1. Рэалізацыя зычных *d(d), *t(m), *z(з), $*_{s}(c), * n(u)$ перад этымалагічнымі *e(e), *i(u). 2. Захаванне галосных *i(u), *y(bl) або іх зліццё ў адным гуку. У паўночнай зоне зычныя *d(d), *t(m), *z(з), * $s(c)$, *n(u) у адзначанай пазіцыі мяккія, у паўднёвай зоне - цвёрдыя. Галосныя *i(u), *y(bl) ў паўночнай зоне захавалі сваю якасць, у паўднёвай зоне яны зліліся ў адным гуку.

Як вядома, усе славянскія мовы ўзыходзяць да мовы (прамовы) праславянскай. У мовах праславянскай, стараславянскай і кніжнай старажытнарускай ранняга перыяду галосныя *i(u), *y(bl) адрозніваліся паміж сабою, уяўляючы два гукі [БЕРНШТЕЙН, 238-241; БОШКОВИЧ, 91-92; СЕЛИЩЕВ, 110-112; ФИЛИН, 303-312; ИВАНОВ 1968; ИВАНОВ 1990, 125; СТСЛ, 59]. Зычныя *d(d), *t(m), *z(3), *s(c), *n(н) перад этымалагічнымі *e(e), i(u) ў адзначаных мовах мовах вымаўляліся «паўмякка». Інакш кажучы, яны былі цвердымі, але невелярызаванымі, у адрозненне ад тых жа цвёрдых гукаў велярызаваных у іншых пазіцыях, у тым ліку перад *y(bl). Цвердыя невелярызаваныя гукі 
५ вымаўляюцца трохі «мягчэй» чым цвердыя велярызаваныя, таму іх нярэдка называюць «паўмяккімі».

Праславянская мадэль рэалізацыі зычных *d(d), *t(m), *z(з), **s(c), *n(н) перад *e(e), i(u) захавалася ў некаторых рэгіёнах і мікрарэгіёнах Славіі, якія пераважна знаходзяцца на сумежжы паўночнай і паўднёвай зон, у прыватнасці, у многіх украінскіх гаворках Карпат і вярхоўяў р. Сан [ЗАЛЕСЬКИЙ, 34-51; ПШЕП’ЮРСЬКА, 151-122; АУМ 1988, карты 16, 17], часам на Палессі [КЛИМЧУК 1998, 118-135; КЛИМЧУК 1999, 214-227; КЛИМЧУК 2004, 454-465; КЛІМЧУК 2003, 245-256, карты 1, 2; КЛІМЧУК 2005, 119-123; KURASZKIEWICZ, 27-28, 151-153, 263-264] і уу іншых рэгіёнах [ПАУФОШИМА, 74-77].

У гаворках жа большай часткі Славіі старая праславянская мадэль разбурылася [БОШКОВИЧ, 38-39, 42-43, 50-53, 126-128; КЛИМЧУК 1998, 120]. Як паказваюць дадзеныя сучасных гаворак, знікненне «паўмяккіх» (цвёрдых невелярызваных) зычных пайшло двума шляхамі, п а ў н о ч н ы м і п а ў д н ё в ы м: у адных выпадках яны сталі мяккімі, у другіх - набылі велярызацыю і сталі «звычайнымі» цвёрдымі. Адначасова адбываліся змены ў суадносінах гукаў *y(bl) i *i(u). У адных гаворках гэтыя гукі захаваліся, у другіх зліліся ў адзін гук. Пераход «паўмяккіх» *d(d), *t(m), *z(3), *s $s$, , *n( *e(e), $i(u)$ ў мяккія пры захаванні адрозненняў паміж *y(bl) i *i(u) мы ўмоўна называем п а ў н о ч н а й тэндэнцыяй, паколькі яна рэалізавалася ў гаворках паўночнай зоны Славіі. Набыццё адзначанымі зычнымі дадатковай велярызацыі і пераход іх у звычайныя цвёрдыя зычныя пры зліцці галосных *y(bl) i *i(u) ў адзін гук называем п а ў д н ё в а й тэндэнцыяй - яна рэалізавалася ў гаворках паўднёвай зоны Славіi.

Ніжэй мы пераважна абмяжуемся разглядам рэалізацыі зычных *d(d), *t(m) у пазіцыях перад *e(e), $i(u)$, *y(bl) [КЛІМЧУК 1993, 81-83]. Прывядзём прыклады. Матэрыялы ўзяты з апублікаваных прац [ДАБМ; ДАРЯ; АУМ, 1984; AУM, 1988; DEJNA; ČNT; ČJA; ASJ; SSA; STIEBER; SŁAWSKI], у тым ліку з выпускаў Агульнаславянскага лінгвістычнага атласа, з уласных запісаў, а таксама запісаў калег з іх дазволу. Выкарыстоўваем транскрыпцыю, прынятую для Агульнаславянскага лінгвістычнага атласа.

Заўважым, што ў значнай частцы гаворак славянскіх моў паўночнай зоны мяккія зычныя *d(d), *t(m) перайшлі ў $\left[d z^{\prime}\left(\partial 3^{\prime}\right)\right],\left[c^{\prime}\left(u^{\prime}\right)\right]$. Гэтая з'ява атрымала назву ц е к а н н е - д з е к а н н е. Прамежкавы этап у гэтым пераходзе - гукі $\left[d^{z^{\prime}}\left(\partial^{3^{\prime}}\right)\right],\left[t^{c^{\prime}}\left(m^{\text {ц'}}\right)\right]$. Такія гукі зафіксаваны ў сучасных гаворках [НАЗАРОВА: карта 29]. Працэс адзначанага пераходу адбываўся наступным чынам: *d·( $\partial \cdot)$, ${ }^{*} t^{\cdot}(m \cdot)>* d^{\prime}\left(\partial^{\prime}\right),{ }^{*} t^{\prime}\left(m^{\prime}\right)>* d^{z^{\prime}}\left(\partial^{3}\right),{ }^{*} t^{\prime}\left(m^{\amalg \prime}\right)>* d z^{\prime}\left(\partial 3^{\prime}\right),{ }^{*} c^{\prime}\left(u^{\prime}\right)$.

Беларуская мова: dz'es'ac', c'ec'aruk, dz'ik'i, c'ix'i, dym.

Польская мова : dz'es'ęc', c'etšev, dz'ik'i, c'ixy, dym.

Верхнялужыцкая мова: dz'esac', c'ec'or, dz'iŭy, c'ixy, dym.

Ніжнялужыцкая мова: z'ases', z'eŭs', z'iŭy, s'ixy, dym.

Руская мова: d'es'at', t'et'er'ev, d'ik'ij, t'ix'ij, dym.

Славацкая мова: d'esat', t'etrov, d'ivi, t'ixi, dim. 
Чэшская мова: deset, tetřev, d'ivoki, t'ixi, dim.

Украінская мова: des'at', teterev, teteruk, dykyj, tyxyj, dym.

Сербскахарвацкі дыялектны арэал: deset, tetreb, divl'i, tix, dim.

Славенская мова: deset, tepsti, diuji, tih, dim.

Балгарская мова: deset, tetrev, div, tix, dim.

Македонская мова: deset, tetrev, div, tix, dim.

Ляшскія гаворкі (Чэхія): idz’e, idže, dz’ivoky, džyvoky, c’ixy, čyhy, dym [ČNT, 283-323].

Усходнеславацкія гаворкі (Славакія): idzece, dziki, cixo, sin [ASJ; ДУЛИЧЕНКО, 198-224].

Заходнеславацкія гаворкі (Славакія): idete, idzece, dzivoki, dzivoki, tixo, cixo, $\operatorname{dim}[\mathrm{ASJ}]$.

Надсноўскія гаворкі (Украіна): d'es'at', dz'es'ac', t'et'eruk, c'ec'eruk, d'ik'i, dz'ik'i, t’ix'i, c’ix’i, dym [АУМ 1984: карти 62, 102; БЕЛАЯ].

Славечанскія гаворкі (Украіна, Беларусь): d'es'et, t'et'eruk, d'ik'i, t'ix'i, dym [АУМ 1988, карта 87; НИКОНЧУК; ДАБМ: карты 52, 53, 55-57; OSSOWSKI, 98-100].

Беражноўскі дыялектны тып (Беларусь, Украіна, Падляшша): d'es’et, t'et'eruk, d'ik'i, t'ix'i, dym [КЛИМЧУК 1998, 121-123].

Дубенецкі дыялектны тып адрозніваецца ад беражноўскага «паўмяккімі» (цвёрдымі невелярызаванымі) губнымі зычнымі перад *e, *i: do t'eb·e, rob·it'i, dym [КЛІМЧУК 2007, 83-87].

Верхняясельдскія гаворкі, смаляніцкая падгрупа (Берасцейска-Пінскае Палессе): desec', teteruk, d'ik'i, c'ix’i, dym [А. БОСАК, В. БОСАК, карты 21-24].

Верхняясельдскія гаворкі, рудніцкая і ліноўская падгрупы (Берасцейска-Пінскае Палессе): desec', teteruk, dz'ik'i, c'ix'i, dym [А. БОСАК, В. БОСАК: карты 21-24].

Стрыгінскія, паўднёвацеляханскія, сярэднепагарынскія, заходнепадляшскія гаворкі (Беларусь, Падляшша, Украіна): deset', teteruk, d'ik'i, t'ix'i, dym [ЛЕВАНЦЭВІЧ; САМУЙЛІК; ГРАЧЫХА, 294-297; КЛІМЧУК, 1983, 10-14; КЛИМЧУК 1998, 120-121; ЛЕСІВ, 239-412; АУМ 1988, карта 87; НИКОНЧУК; KURASZKIEWICZ, 8-48, 120-172, 211-227, 279-271, mapy; AGWB, mapa 1; CZYŻEWSKI, 40-43, 81-89, 109-120, 192, 199, 207, 208].

Гараднянскія гаворкі (Берасцейска-Пінскае Палессе): d·es·et', t·et·eruk, d·yk·y, t·yx·y, dym [КЛИМЧУК 2004, 454-465].

Брэсцка-пінскія гаворкі (Берасцейска-Пінскае Палессе): deset', tytyruk, teteruk, dykyj, tyxyj, dym [КЛІМЧУК 1983].

Як бачым, мяжа паміж адзначанымі паўночнай і паўднёвай славянскімі зонамі не зусім выразная (гл. карту).

Да тыповых гаворак паўднёвай зоны адносіцца большасць гаворак украінскіх і паўднёваславянскіх. Сюды ж адносяцца брэсцка-пінскія гаворкі на тэрыторыі Беларусі. У гаворках паўднёвай зоны зычныя *d(d), *t(m) вымаўляюцца цвёрда як перад *e(e), так і перад *i(u). 

ларускіх, польскіх, лужыцкіх, а таксама ляшскіх (Чэхія). У ix *d(d), *t(m) у разглядаемай пазіцыі перайшлі ў мяккія [dz'], [c']. Большасць гаворак рускай i славацкай моў, гаворкі беражноўскага тыпу на Палессі і ў Падляшшы, у тым ліку славечанскія гаворкі і частка надсноўскіх, адносяцца да паўночнай зоны, але маюць ужо прыкметы пераходнасці да зоны паўднёвай: *d(d), *t(m) у іх вымаўляюцца перад *e(e),*i(u) мякка, але яны не перайшлі ў [dz'], [c'].

У гаворках паўночна-ўсходняй Польшчы (кашубска-мазавецкі падтып) галосныя *y(bl), *i(u) зліліся ў адным гуку [i] [DEJNA, 149-162, mapa 25; КЛИМЧУК, 1999, 222].

Ва ўсходнеславацкіх і частцы заходнеславацкіх гаворак адбыўся пераход *d(d), *t(m) y̆ $[d z],[c]$, аднак, апошнія ў адзначанай пазіцыі вымаўляюцца цвёрда. У рудніцкай і ліноўскай падгрупах верхняясельдскіх гаворак (Берасцейска-Пінскае Палессе) перад *е зычныя $[d(\partial)],[t(m)]$ цвёрдыя, а перад *i яны перайшлі ў [dz'], [c'], якія вымаўляюцца мякка.

У смаляніцкай падгрупе верхняясельдскіх гаворак перад *е зычныя [d(d)], $[t(m)]$ цвёрдыя, перад * $i[d(\partial)]$ захаваў сваю якасць (праўда, набыў адценне гука $\left[d z^{\prime}\right]$ і вымаўляецца як $\left[d^{v^{\prime}}\left(\partial^{3}\right)\right] ;$ * $t(m)$-- перайшоў у $\left[c^{\prime}\right]$.

У большасці чэшскіх гаворак, а таксама ў гаворках стрыгінскіх паўднёвацеляханскіх, сярэднепагарынскіх, заходнепадляшскіх перад *е зычныя [d(d)], $[t(m)]$ цвёрдыя, перад $*_{i}$ - мяккія, пераходу іх у [dz'], [c'] не адбылося. Гэтыя гаворкі сярод моўна-дыялектных адзінак, якім характэрна большая або меншая ступень пераходнасці [КЛІМЧУК, 2003a, 88-91] паміж гаворкамі паўночнай і паўднёвай зон, бліжэй за іншыя стаяць да гаворак паўднёвай зоны. У адзначаных гаворках спалучыліся паўночная і паўднёвая тэндэнцыі развіцця * $d(\partial)$, $*_{t}(m), *^{2}(3), *_{s}(c), *_{n}(u)$, а таксама *i(u), *y(bl). Відавочна, у «продкаў» гэтых гаворак доўга захоўвалася старая праславянская мадэль «паўмяккіх» $* d(\partial),{ }^{*} t(m)$, $*_{z}(3),{ }_{s}(c), * n(u)$ перад *e(e), i(u) і адрознення галосных *i(u), *y(bl).

У арэале гаворак рускай мовы захаваліся ці да нядаўняга часу захоўваліся астравы і масівы гаворак, у якіх зычныя *d(d), *t(m), *z(3), *s(c), *n(H) перад *e(e), *i(u) цвёрдыя або «паўмяккія», у некаторых з іх галосныя *i(u), *y(bl) зліліся ў адным гуку [ДАРЯ, карта 65; ДУРНОВО, СОКОЛОВ, УШАКОВ, 31-32, 57, 58, 83; ДУРНОВО 1903, 9, 20-22, карта; ХРЕСТОМАТИЯ, 154-157, 174-175; ПАУФОШИМА, 74-77].

Значнай спецыфікай характэрызуецца палабская мова [LEHR-SPŁAWIŃSKI 1966, 5-18, 39-97; LEHR-SPŁAWIŃSKI, POLAŃSKI; PAPIERKOWSKI, 11-76; СУПРУН; КЛИМЧУК, 1999, 223-224]. У ёй галосныя *i(u), *y(bl) далі розныя рэфлексы, г. зн. у прапалабскай мове яны не зліліся ў адзін гук. Зычныя *d(d), *t(m), *z(3), *s(c), *n(н) перад рэфлексамі *e(e),*i(u) цвердыя. Такім чынам, па адзначаных асаблівасцях палабская мова захавала праславянскую аснову, старадаўні праславянскі стан, і далей развівалася па свайму ўласнаму шляху. Праўда, у гісторыі гэтай мовы назіраюцца паралелі з гаворкамі іншых славянскіх рэгіёнаў. Палабская мова не пайшла ні па паўночнаму, ні па паўднёваму шляху развіцця зычных $* d(\partial), *^{*}(m), *_{z}(3), *_{s}(c), *_{n}(u)$ перад $*_{e}(e),{ }^{*} i(u)$ i галосных *i(u), *y(bl). 
Мяжа паміж абедзвюма славянскімі дыялектнымі зонамі не ўяўляе сабою прамой лініі (гл. карту). Ёй характэрны рознага характару “выступы” і “кліны”. 3 чым звязана іх узнікненне? Відаць не малую ролю ў гэтым зрабілі розныя міграцыйныя рухі старажытных часоў.

Узнікненне выяўленых зон, відавочна, з'ява старажытная, праславянская, бо мяжа паміж імі перацінае арэалы славянскіх груп і асобных моў.

3 якімі фактамі далёкага мінулага звязана ўзнікненне выяўленых зон? Хутчэй за ўсё яно адлюстроўвае нейкае дзяленне праславян у мінулым на паўночную і паўднёвую групы. Цікавым уяўляецца назіранне В.В. Сядова аб дзяленні пшэворскай культуры II ст. да н.э. - V ст. н.э. на паўночную і паўднёвую зоны [СЕДОВ, 92-93]. Выдзяленне паўднёвай зоны вучоны бачыць ва ўплыве кельтаў. Сапраўды, уплыў кельтаў на праславян вялікі [ЦВЕТКОВ]. Але магчыма ў дадзеным выпадку адлюстраваўся не толькі кельцкі ўплыў. Магчыма выдзяленне паўднёвай зоны у нейкай ступені звязана з кантактамі праславян з індаеўрапейскімі народамі Паўднёвай і Цэнтральнай Еўропы, у мовах якіх адсутнічаў гук *y(bl). Як вядома, гука $[y(b l)]$ не існавала ў праіндаеўрапейскай мове, ён з'яўляецца праславянскай інавацыяй [САВЧЕНКО, 85-87]. Атрымліваецца, што ў гаворках паўднёвай славянскай зоны часткова аднавілася старая праіндаеўрапейская мадэль, бо ў іх знік гук * $y(b l)$, зліўшыся $з$ гукам *i(u).

Для гаворак паўночнай славянскай зоны, як і для найбольш архаічнай балцкай мовы - літоўскай, характэрна шырокая дыстрыбуцыя мяккіх зычных. Напрошваецца выснова, што ў фарміраванні паўночнай славянскай дыялектнай зоны адыгралі істотную ролю кантакты праславян з балтамі.

Звернем яшчэ ўвагу на этнонім «ляхі». У позняе сярэднявечча і ў наш час так «неафіцыйна» называлі і называюць палякаў. Але «Аповесць мінулых гадоў» («Повесть временных лет») падае гэты этнонім трохі інакш. Паводле «Аповесці...», да ляхаў адносяцца польскія паляне, мазаўшане, памаране, люцічы, радзімічы, вяцічы. Цікава, што яны размешчаны ў розных кутках паўночнай славянскай зоны. Хутчэй за ўсё гэта не выпадкова [КЛІМЧУК, 1994, 119-121]. Ляхаў у Верхнім Падняпроўі і на сумежжы змяшчае не толькі «Аповесць мінулых гадоў». Пра іх гаворыць і Канстанцін Багранародны (Парфірагеніт) у сваёй працы «Аб кіраванні імперыяй», напісанай у 948-952 гг. [КОНСТАНТИН БАГРЯНОРОДНЫЙ, 272]. Праўда, ён іх называе лендзані-

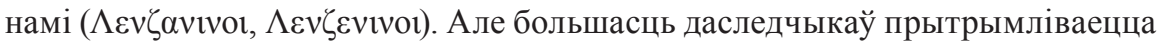
думкі, што лендзаніны Канстанціна Багранароднага і ляхі - назвы тоесныя.

\section{Літаратура}

АУМ, 1984, Атлас української мови. Т. 1. Середня Наддніпрянщина, Полісся і суміжні землі. Київ.

АУМ, 1988, Атлас української мови. Т. 2. Волинь, Наддністрянщина, Закарпаття і суміжні землі. Київ.

Константин Багрянородный, 1982, Об управлении империей // Развитие этни- 
ческого самосознания славянских народов в эпоху раннего средневековья, Москва.

Александра С. Белая, 1972, Надсновские говоры на Черниговщине (фонетика), Автореф. канд. дис, Киев.

Самуил Б. Бернштейн, 1961, Очерк сравнительной грамматики славянских языков, Москва.

Алёна А. Босак, Віктар М. Босак, 2005, Атлас гаворак Пружанскага раёна Брэсикай вобласиі і сумежжа (Верхняга Над’ясельдзя). Фанетыка $i$ марфалогія, Мінск.

Радослав Бошкович, 1984, Основы сравнительной грамматики славянских языков, Фонетика и словообразование. Москва.

Таццяна А. Грачыха, 2005, 3 гаворкі роднай вёскі // Скарбы народнай мовы, Дыялекталагічны зборнік, Мінск.

ДАБМ, 1963, Дьялекталагічны атлас беларускай мовы, Мінск.

ДАРЯ, 1986, Диалектологический атлас русского языка, Фонетика. Москва.

Александр Д. Дуличенко, 2004, Славянские литературные микроязыки, Образиь текстов, Т. II. Тарту.

Николай Н. Дурново, 1903, Диалектологическая карта Калужской губернии. Санкт-Петербург.

Николай Н. Дурново, Николай Н. Соколов, Дмитрий Н. Ушаков, 1915, Onblm диалектологической карты русского языка в Европе с приложением очерка русской диалектологии // Труды Московской диалектологической комиссии, вып, 5. Москва.

Антін М. Залеський, 1970, Про конвергенцію давніх *bl, *i в південно-західних говорах української мови // Праці ХІІІ Республіканської діалектологічної наради. Київ.

Валерий В. Иванов, 1968, Историческая фонология русского языка. Москва.

Валерий В. Иванов, 1990, Историческая грамматика русского языка. Москва.

Фёдар Д. Клімчук, 1983, Гаворкі Заходняга Палесся. Фанетычны нарыс. Мінск.

Фёдар Д. Клімчук, 1993, Рэфлексы *d, *tперад этылмалагічнылі *e, *i у славянскіх гаворках // Беларуска-руска-польскае супастаўляльнае мовазнаўства, Матэрыялы Другой міжнароднай навуковай канферэнцыі 5-6 лютага 1993 г. Пад рэд. Г.М. Мезэнкі. Віцебск.

Фёдар Д. Клімчук, 1994, Старажытныя ляхі // Беларуска-руска-польскае супастаўляльнае мовазнаўства і літаратуразнаўства. Матэрыялы Трэцяй міжнароднай навуковай канферэнцы 5-7 снежня 1994 г. Ч. І. Віцебск.

Фёдар Д. Клімчук, 2003, Гаворкі Берасиейска-Пінскага Палесся і Падляшша як вынік гістарычнага развіция // Pogranicze. Tom 4. Lublin.

Фёдар Д. Клімчук, 2003a, Пераходныл гаворкі і пункт адліку // Pogranicza języków. Pogranicza kultur. Studia ofiarowane Elżbiecie Smułkowej. Warszawa.

Фёдар Д. Клімчук, 2005, Рэцээнія: “Говірка села Машеве Чорнобильського 

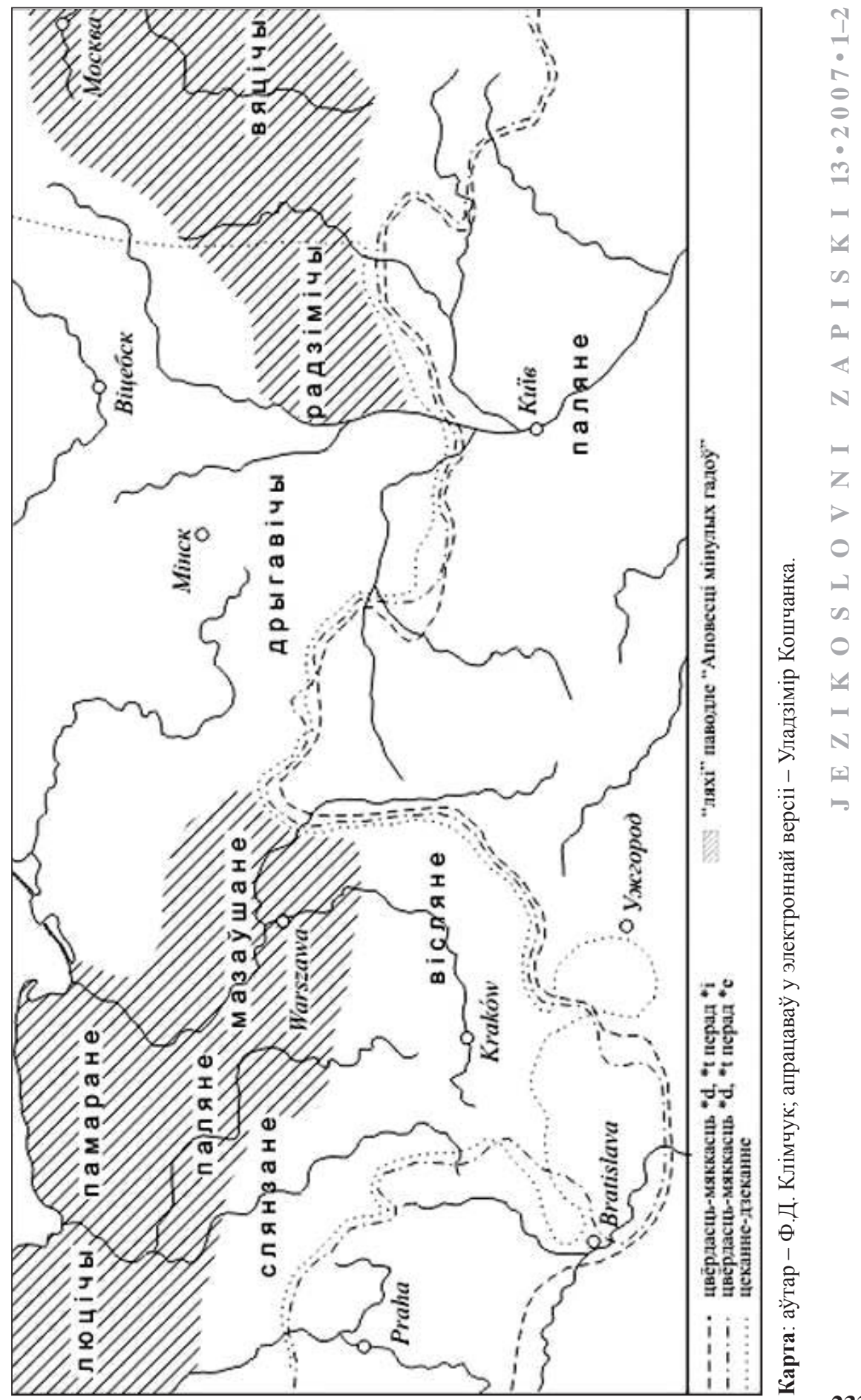
району”. Ч. 1: Тексти / Укладачі: Ю.І.Бідношия, Л.В.Дика. - 456 с., іл. Ч. 2. Тексти / Укладачі: Г.В.Воронович, Л.А.Москаленко, Л.Г.Пономар. - 608 с., іл. Ч. 3. Матеріали до лексичного атласу української мови / Укладачі: Ю.І.Бідношия, Г.В.Воронич, Л.В.Дика, Л.А.Москаленко, Л.Г.Пономар. - 225 с., іл. (Київ, 2003) // Беларуская лінгвістыка. Выпуск 55. Мінск.

Фёдар Д. Клімчук, 2007, Гаворка вёскі Дубенеи Столінскага раёна // Фальклор і этнакультура Палесся уу індаеўрапейскім кантэксце. Матерыялы III Міжнароднай навуковай канферэнцыі (7-8 снежня 2006 г., г. Мінск). Мінск, 2007.

Фёдар Д. Клімчук, 1998, Диалектные типь Полесья // Слово и культура. Памяти Никиты Ильича Толстого. Москва.

Фёдар Д. Клімчук,1999, Диалектные типь Полесья на общеславянском фоне

// Славянские этюды. Сборник к юбилею С.М. Толстой. Москва.

Фёдар Д. Клімчук, 2004, Отголоски праславянщчины в Столинском районе Брестской области // Язык культуры: Семантика и грамматика. К 80-летию со дня рождения академика Никиты Ильича Толстого (1923-1996). Москва.

Лена В. Леванцэвіч, 1993, Атлас гаворак Бярозаўскага раёна Брэсикай вобласиі. Фанетыка, Ч. I, II. Брэст.

Михайло Лесів, 1977, Українські говірки у Польщі, Варшава.

Тетяна В. Назарова, 1985, Лінгвістичний атлас Нижньої Прип'яті, Київ.

Микола В. Никончук, 1994, Лексичний атлас Правобережного Полісся, Київ - Житомир.

Розалия Ф.Пауфошима, 1961, Согласные неполного смягчения перед гласными переднего образования в говорах Харовского района Вологодской области // Материалы и исследования по русской диалектологии, вып. 2. Москва.

Марія Пшеп’юрська, 1938, Надсянський говір // Праці Українського наукового інституту, Варшава.

Алексей Н. Савченко, 1974, Сравнительная грамматика индоевропейских языков, Москва.

Яраслаў Р. Самуйлік, 1986, Дьялектны мікраатлас Выганаўскага Палесся. Дыпломная работа (Беларускі дзяржаўны універсітэт), Мінск.

Валентин В. Седов, 2002, Славяне, Историко-археологическое исследование, Москва.

Афанасий М. Селищев, 1951, Старославянский язык, Ч. І. Москва.

СТСЛ, 1994, Старославянский словарь (по рукописям Х-ХІ веков), Москва.

Адам Е. Супрун, 1987, Полабский язык, Минск.

Федот П. Филин, 1972, Происхождение русского, украинского и белорусского языков, Москва.

Хрестоматия, 1910, Хрестоматия по великорусской диалектологии, Москва. Сергей В. Цветков, 2005, Кельты и славяне, Санкт-Петербург.

AGWB, 1980, Atlas gwar wschodniosłowiańskich Białostocczyzny, T.1. Wrocław - Warszawa - Kraków - Gdańsk.

ASJ, 1968, Atlas slovenského jazyka, T. 1. Bratislava. 
Feliks Czyżewski, 1994, Fonetyka i fonologia gwar polskich i ukraińskich potudniowo-wschodniego Podlasia, Lublin.

ČJA, 1992, Česky jazykový atlas, T. I. Praha.

ČNT, 1976, České nářeční texty. Praha.

Karol Dejna, 1973, Dialekty polskie. Wrocław - Warszawa - Kraków - Gdańsk.

Władysław Kuraszkiewicz, 1985, Ruthenica, Warszawa.

Tadeusz Lehr-Spławiński, 1966, Studia i szkice wybrane z językoznawstwa słowiańskiego. Seria 2. Warszawa.

Tadeusz Lehr-Spławiński, Kazimierz Polański, 1962, Słownik etymologiczny języka Drzewian połabskich, Wrocław - Warszawa - Kraków.

Leszek Ossowski, 1992, Studia slawistyczne, Wrocław - Warszawa - Kraków.

Stanisław K. Papierkowski, 1972, Z badań nad językiem i literaturq. Lublin.

SSA, 1961, 1968, Sorbische Sprachatlas. T. I, II, Bautzen.

Franciszek Sławski, 1962, Zarys dialektologii języków południowosłowiańskich z wyborem tekstów gwarowych. Warszawa.

Zdzisław Stieber, 1956, Zarys dialektologii języków zachodnio-słowiańskich z wyborem tekstów gwarowych. Warszawa.

\section{Dve slovanski narečni coni}

Povzetek

Glede na nekatere značilnosti se slovanski narečni kontinuum deli na dve coni - severno in južno. Podlaga za takšno delitev je $v$ različni realizaciji soglasnikov

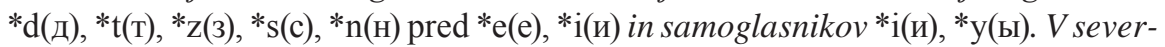
ni coni se ti soglasniki izgovarjajo mehko, v južni coni pa trdo. Samoglasnika *і(и), *у(ы) sta v severni coni ohranila svojo kvaliteto, v južni coni sta se zlila v en glas.

K severni coni spada večina beloruskih, poljskih, lužiških, ruskih in slovaških govorov, kjužni coni pa večina ukrajinskih in južnoslovanskih. Vvečini čeških govorov, v nekaterih govorih Polesja in Podlasia, v posameznih narečnih enotah ruskega jezika so se združile severne in južne tendence. Redkokje se je ohranil stari praslovanski model, v katerem so soglasniki $*_{\mathrm{d}}\left(\right.$ д), ${ }^{*} \mathrm{t}(\mathrm{T}),{ }^{*} \mathrm{z}(3), *_{\mathrm{s}}(\mathrm{c}), *_{\mathrm{n}}(\mathrm{H})$ pred *е(е), *i(и) polmehki, samoglasnika *i(и), *у(ы) pa predstavljata dva glasova.

Fjodar D. Klimčuk

vul. Njakrasava 35, korpus 2, kv. 253, 220040 Minsk, Belarus'

fdk@tut.by 



\title{
Slovenska besedila v Arhivu Železne županije v Sombotelu pred 1919
}

\author{
Marija Kozar-Mukič (Sombotel)
}

IZVLEČEK: Vobravnavanih besedilih je ohranjena stara knjižna prekmurščina, ki so jo uporabljali tudi prekmurski pisci od začetka 18. stoletja. Besedni zaklad teh piscev je zbran v Slovarju stare knjižne prekmurščine Vilka Novaka. S tem je avtorica primerjala zgodovinsko-narečna besedila, ohranjena v Županijskem arhivu v Sombotelu, $v$ katerih je izrazje strokovno, uradovalno.

ABSTRACT: The texts discussed here preserve the old literary Prekmurje dialect, which was also used by Prekmurje writers from the beginning of the 18th century onwards. These writers' vocabulary is gathered in Vilko Novak's Slovar stare knjižne prekmurščine (Dictionary of the Old Literary Prekmurje Dialect). The author compares this vocabulary with the historical and dialect texts preserved by the Szombathely County Archives, which contain technical and administrative terminology.

Arhiv Železne županije v Sombotelu hrani tudi dokumente, ki se nanašajo na nekdanjo Slovensko okroglino (Tótság) oziroma Slovensko krajino (Vendvidék) in so zapisani v slovenskem narečju te pokrajine. Območje nekdanje murskosoboške občine je do 1.1919 upravno spadalo k Železni županiji. Madžarski in slovenski jezik se v dokumentih pojavljata od 18. stoletja naprej. Pred tem so bili zapisani v latinščini in nemščini.

Obravnavana besedila so se ohranila v obliki zapisov v zvezi z urbarji (Ivanovci 1767), v gorskih bukvah (Stanjevci 1795: kazenske sankcije in Moščanci 1808: prisega), učbeniku (Puconci 1833), pismu vaškega župana (Pečarovci 1867), pozivu za trgatev (Murska Sobota 1867) in osnutku za ustanovno listino hranilnice (Murska Sobota 1911). Razen učbenika so vsi teksti uradni, zaradi tega smo uradni tekst izbrali tudi iz učbenika.

Poskušali smo ugotoviti, če so prekmurski tiski vplivali na zapisovalce glede besedišča in črkovnih znamenj. Primerjali smo jih z Novakovim slovarjem iz leta 2006. ${ }^{1}$

1 Novak, Vilko, Slovar stare knjižne prekmurščine, Ljubljana, 2006. 
Pri vseh sedmih tekstih so črkovna znamenja zapisana po sodobnem madžarskem pravopisu. Prekmurski knjižni jezik je normiral s svojim prevodom Novega zakona protestantski pisec Števan Küzmič $(1771)^{2}$. Na normo in predpise, ki so se izoblikovali v tej knjigi, se je navezovala glasoslovno-oblikoslovna podoba prekmurskih abecednikov in čitank tako pri protestantih kot pri katoličanih. Od druge polovice 19. stoletja so katoličani iz svojih tiskov začeli umikati madžarski črkopis in uvajati gajico ("novoslovenščino"), protestanti pa so ostali pri "staroslovenskem" jeziku in črkopisu. ${ }^{3}$

Prva uradna besedila v prekmurščini (z močnim vplivom kajkavskega hrvaškega narečja) so bila zapisana v zvezi z davčno rektifikacijo Marije Terezije. Slovencem v Prekmurju je bila v 18. stoletju bližja panonska kajkavščina kot osrednjeslovenski knjižni jezik. Kajkavščina je bila sicer le nadomestni knjižni jezik v cerkvi, nikoli pa se ni zamenjevala s prekmurščino v drugih govornih položajih. ${ }^{4}$

Enotni urbar s tiskanim besedilom so dobila vsa naselja v 43 županijah takratne Ogrske in ga dopolnila z lokalnimi podatki. Pred sestavljanjem urbarjev so popisovalci (conscriptores) v vsakem naselju izpraševali podložnike in zapisovali odgovore na devet vprašanj (novem punta). Vprašanja so bila prvotno zapisana $v$ latinščini, ki so jih posamezni izpraševalci v Železni županiji prevedli v madžarski, nemški, hrvaški in slovenski jezik. V Arhivu Železne županije sem našla odgovore iz 105 vasi petih gospostev Slovenske okrogline (Tótság). ${ }^{5}$ Večina popisov je bila izvedena v letu 1767, nekaj pa leta 1768 in 1787. Slovenska vprašanja in odgovore so zabeležili v šestnajstih naseljih. ${ }^{6}$ Samo slovenski odgovor je zapisan v trgu Gornja Lendava in v vaseh Satahovci in Vidonci (murskosoboško gospostvo). ${ }^{7}$

\section{Odgovori na devet vprašanj v zvezi z urbarji (Ivanovci 1767)}

Marija Terezija je v svojih devetih vprašanjih iskala odgovore na naslednja vprašanja:

2 Küzmič, Števan: Nouvi zákon, Halle, 1771.

3 Prim. Jesenšek, Marko, Jezik prekmurskih abecednikov in učbenikov v 19. stoletju, Slovensko-madžarski jezikovni in književni stiki od Košiča do danes, Budimpešta, 1998, $128,121,123$.

4 Jesenšek, Marko, Zgodovinska dinamika prekmurskega jezika, Prekmurska narečna slovstvena ustvarjalnost (ur. Vugrinec Jože), Murska Sobota, 2005, 70.

5 Vas Megyei Levéltár, Novem Puncta IV/1/h, fascikel 1-3. (V nadaljevanju VaML NP)

6 VaML NP, Alsó Szlávecsa - Dolnji Slaveči 1/5, Csekefa - Čikečka vas 1/38, Bokrács - Bokrači 1/45, Dolinc - Veliki Dolenci 1/46, Felső Szlávecsa - Gornji Slaveči 1/60, Falkóc - Fokovci 1/62, Ivanóc - Ivanovci 2/9, Korosec - Korovci 2/53, Lukasóc - Lukačovci 2/66, Muraszombat - Murska Sobota 2/80, Motovilc - Motovilci 2/87, Nemsóc - Nemčavci 3/9, Pecsaróc - Pečarovci 3/37, Poznanóc - Poznanovci 3/38, Sidahegy - Vučja gomila 3/107, Vescsica - Veščica 3/145.

7 VaML NP 1/59, 3/96, 3/146.

Prim.: Marija Kozar-Mukič, Jezik urbarjev Slovenske okrogline (Tótság) v 18. stoletju, Szlavisztikai Napok II. (Slavistični dnevi), Szombathely, 1986, 115-120. 
1. Ali ima kraj urbar in od kdaj?

2. Ali imajo pogodbo ali pa služijo zemljiškemu gospodu iz navade?

3. Če ni urbarja ne pogodbe, koliko davkov plačujejo in od kdaj?

4. Katere okoliščine so spodbujale ali ovirale življenje kmetov?

5. Koliko orne zemlje in travnikov je spadalo k posesti?

6. Koliko tlake, s koliko živinami so dolžni opraviti in če se prihod in odhod vračuna v tlako?

7. Ali plačujejo devetino in od kdaj ter kakšne dajatve plačujejo še z denarjem ali v naturalijah zemljiškemu gospodu?

8. Ali so bile neobdelane njive in kdo jih je uporabljal?

9. Ali so bili podložniki dedni ali svobodni?

Iz odgovorov na devet vprašanj se lahko ugotovi, kakšen je bil položaj podložnikov v določenem naselju pred davčno rektifikacijo.

V Ivanovcih (gl. Prilogo) so bili kmetje podložniki treh zemljiških gospodov, ne urbarja ne pogodbe niso imeli. Ne glede na velikost posesti so morali kmetje na tlako vsak teden od ponedeljka do sobote. Po stari navadi (brez pogodbe) je moral plačevati davek tisti, ki je gospodaril na četrtini kmetije. In sicer: 8 grošev v gotovini in poldrugi voz gnoja. Niso imeli pašnikov in drv za kurjavo. Ko so prišli zemljiški gospodje v vas, so jih morali nahraniti. V vasi cele kmetije ni bilo, ampak samo četrtine, v katerih je dobre orne zemlje bilo le za en plug (oral). Na travnikih so imeli za en voz sená, otave niso kosili. Na tlako so morali hoditi od ponedeljka do sobote, s štirimi živinami. Pot tja in nazaj ni bila všteta v tlako. Kdor ni šel na tlako, je moral plačati denarno kazen zemljiškemu gospodu. Devetine niso plačevali, desetino so plačevali škofu v Győru. V vasi sta bili zapuščeni dve četrtinski kmetiji, ker sta lastnika umrla. Obdelovali so ju drugi kmetje, v najemu. Vsi kmetje so bili dedni tlačani. (Tlačani niso plačevali devetine nikjer v Železni županiji, ne samo v slovenskih vaseh.) Tudi podatki slovenskih odgovorov tlačanov ostalih devetih vasi govorijo o težkih življenjskih okoliščinah slovenskega kmeta med Muro in Rabo v 18. stoletju. ${ }^{8}$

Zapisovalec devetih vprašanj in odgovorov je uporabljal naslednja črkovna znamenja:

s = ss, sz (kossiti, doszta); $\breve{s}=$ s (nasy); $\check{c}=$ cs, ch (Dacse, Selische); $\check{z}=$ zs, $\mathrm{s}$ (veszdazsnyem, Sivinczi); c = cz (czeloga); l = tudi ll (Szello, illiti); v = tudi ff (od Pavroff); $\mathrm{i}=$ tudi y (nasy); nj = ny (idenye); e = ei (vreimena). Prisotna sta za prekmurščino značilna samoglasnika ö in ü (dönok, plüg, zvün).

Besede, ki so jih uporabljali tudi pisci že pred $1767^{9}$ :

dacsa - davek (1754 KS $)$

dugovanje - stvar, reč (1715 TF, $1747 \mathrm{SM})$

gda - ko, kadar (1715 TF, 1747 SM, 1754 KŠ)

goszpoczki prid. - gosposki (1754 KS )

8 Prim. Marija Kozar-Mukič, Podatki o načinu življenja prekmurskih Slovencev v 18. stoletju, Zbornik soboškega muzeja 4, Murska Sobota, 1995, 77-89.

9 Gl. seznam kratic 


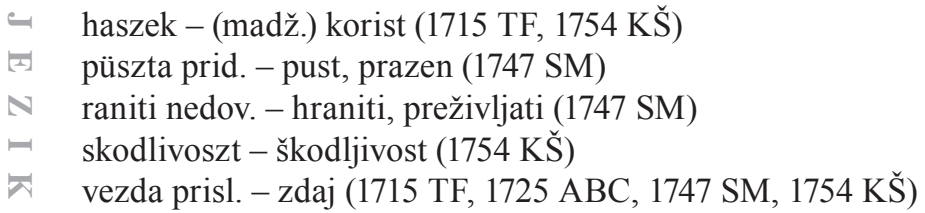

\section{Kazenske sankcije v gorskih bukvah (Stanjevci 1795)}

Gorske bukve so vsebovale vrsto določil, ki so zagotavljala redno obdelavo vinogradov, določale so kazenske sankcije v okviru nižjega sodstva in urejale delo gorskih pravd. Odlomka predstavljata, kako so kaznovali prekrške v vinogradih:

"4. Csi bi sto kaj vkradno [v] vészi, ino bi tiszto blágo pri Goriczaj meo v klejti, ino sze more pravicsno poszvedocsiti táksi Goricze zgibi, stere Goricze sze morejo odati pouleg vreidnoszti, i one czejne tri tále sze dosztája Zemelszkoga Goszpouda, strti tao Esküttom osztáne, tiszto vkrádnyeno blágo sze more nazaj dati onomi steroga je bilau, csi bi káksi Decsko vcsino tou, i gazda more zadoszta poszvedocsiti ka je zvün nyegovoga znánya, táksi sze more z sibov ali sz korbátsom kastigati.

6. [...] csi bi sto z drüga zsenov v klejti pio vnotsi ali vujdné, dveri bi doli zápro, ino bi tam praznüvao snyov, csi o'zenyeni plácsa $12 f$, csi je Junák $6 f$. stere plácse sze tri tále dosztája zemelszkoga Goszpouda, strti tao pa Hegységa. "10

Zapisovalec je uporabljal naslednja črkovna znamenja:

$\mathrm{s}=\mathrm{sz}$ (tiszto); $\breve{\mathrm{s}}=\mathrm{s}$ (stere); $\check{\mathrm{c}}=\mathrm{cs}$, ts (vcsino, korobáts); $\check{\mathrm{z}}=\mathrm{zs}$, ’z (zsenov, o'zenyeni); c = cz (Goricze); nj = ny (vkrádnyeno); e = ej (v klejti). Prisoten je za prekmurščino značilen samoglasnik ü (zvün).

Besede, ki so jih uporabljali tudi pisci že pred 1795:

dosztajati sze nedov. - pripadati (1771 KŠ)

eskütt - (madž.) priča

gorice $\check{z}$ - vinograd, gorice (1754 K $\breve{S}, 1771$ KŠ)

hegység - (madž.) vinograd

korbáts - korobač (1833 KOJ)

pravično prisl. - pravično (1715 TF)

praznüvati nedov. - prešuštvovati (1754 KŠ)

vcsiniti dov. - narediti, storiti (1715 TF)

vujdné prisl. - podnevi (1715 TF)

\section{Prisega v gorskih bukvah (Moščanci 1808)}

V gorskih bukvah iz Moščancev je zapisana prisega župana goric, porotnikov in notarja zakupnikov vinogradov v prekmurskem slovenskem narečju:

"Jasz N.N. Preszégam na 'sivoga Bouga, ki je Boug Ocsa, Boug Szin, i Düh Szvéti, Blásen[em] u sz. Troisztvu, ka kaikoder bi proiti tén Articuluson vidu, csüu, ali szpoznao, Hegységi notri uvádim, i ne prestimam niti szouszidsztvu, kumsztvu, niti Priátelsztvu, niti moi 
haszek, niti lützki kvár: na sztrán nihám szrditoszt, bujaznoszt, nenávidnoszt, prusnyou ali mitu, z епио ritsjouv, vszo cslovecsjo prestimánye, nego vszo Duguványe htsém pravitsnu $i$ isztinszku Hegységi notr uvaditi, inu dokuncsávati. Taku meni Boug pomori."

Zapisovalec je uporabljal naslednja črkovna znamenja:

$\mathrm{s}=\mathrm{sz}(\mathrm{Szin}) ; \mathrm{s}=\mathrm{s}$ (prestimanye); $\breve{\mathrm{c}}=\mathrm{cs}$, ts (Ocsa, htsém); $\check{\mathrm{z}}=\mathrm{zs}$, 's (zsenov, 'sivoga); c = tz (lützki); nj = ny (duguvanye); dj = gy (Hegység); e = ej (v klejti), $1=\mathrm{u}, \mathrm{o}(\mathrm{csüu}$, szpoznao), $-\mathrm{el}=\mathrm{u}(\mathrm{vidu}), \mathrm{j}=\mathrm{i}$ (moi). Prisoten je za prekmurščino značilen samoglasnik ü (Düh, csüu).

Besede, ki so jih uporabljali tudi pisci že pred 1808 :

dokuncsávati nedov. - dokončevati (1754 K KŠ, 1771 KŠ)

haszek - (madž.) korist (1715 TF, 1754 KŠ, 1771 KŠ, 1783 KM, 1790 KM, 1789

BKM)

hegység (madž.) - vinograd

lützki prid. - tuj (1754 K ك̌, 1747 SM, 1771 KS̆, 1783 KM)

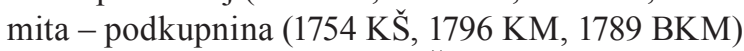

nenavidnoszt - zavist (1771 K $\breve{S})$

prestimávanye - spoštovanje (1771 KŠ, 1790 KM, 1796 SŠ)

\section{Lülikov učbenik (Puconci 1833)}

Županijski arhiv v Sombotelu hrani dvojezični rokopisni učbenik Števana Lülika, ki je nastal ok. leta $1833 .{ }^{11}$ Napisan je za odrasle, v obliki pogovorov. Obsega 276 strani. Vse besedilo je napisano vzporedno v prekmurskem slovenskem narečju in v madžarščini. Rokopis je razdeljen na osem poglavij (govor in pisava, pogovori o dobrih delih, naravoslovje in zgodovina, zemljepis Ogrske in županij Vas, Zala, Somogy - v teh so živeli Slovenci - zgodovina »Szlovenov« in Madžarov, obrti, 33 poučnih zgodb, temelji računstva). Na koncu knjige je na šestih straneh dodan slovensko-madžarski slovar - z 894 enotami -, ki je najbrž prvi poskus te vrste. (Prvi poskus madžarsko-slovenskega slovarja je priloga v knjigi Jožefa Košiča Kratki Navuk Vogrskoga jezika ...V-Gradczi, 1833).

Glede na ostala obravnavana besedila smo iz Lülikovega rokopisa izbrali „Czembe-liszt” (zapustnico) zaradi strokovno-uradovalnega izrazja (s. 42-43.). Lülik navaja zapustnico kot primer uradnega dokumenta. Po tem primeru naj bi imel kmet podložnik domačijo, ki jo sestavljata 6-celično stanovanjsko poslopje (sesztéri rami) in skedenj s svinjaki. Za tem je našteta živina (konji, krave, telice, prašiči), poljedelsko orodje, posoda za shranjevanje živil, živila in žitarice (pšenica, rž, ajda, oves, proso).

${ }^{11}$ Ta velke ABC ali Solszka-Vcsenyá v-zgovárjanyi vu Plemenitom Vas Vármegyövi sztojécsim Szlovenom na vörazsirjávanye vogrszkoga jezika zgotovlena po Lülik Stevani. = A nagy $\mathrm{ABC}$ vagy Oskolai-oktatások beszélgetésben. A Tekintetes Nemes Vas vármegyében létező Vendusok számára magyar nyelv kiterjesztése végett készítette Lülik István. VaML; Kozar-Mukič, Marija: Etnološko gradivo Štefana Lülika (prispevek k zgodovini slovenske etnologije), Zgodovinske vzporednice slovenske in hrvaške etnologije -1, Ljubljana, 1982. 75-76. 
Lülik je uporabljal naslednja črkovna znamenja:

$\mathrm{s}=\mathrm{sz}$ (liszt); $\breve{\mathrm{s}}=\mathrm{s}$ (stero); $\breve{\mathrm{c}}=\mathrm{cs}$ (sztojecsega); $\check{\mathrm{z}}=$ 'z (du'zni); c = cz (3 telicze); nj = ny (4 konyi); e = ei (vrejdnoszt). Prisoten je za prekmurščino značilni ü (2 plüga, 50 füntov szoli).

Besede, ki so jih uporabljali tudi pisci že pred 1833:

hajdina (madž.) - ajda (1780 KMS)

kebel - mernik (1790 KM)

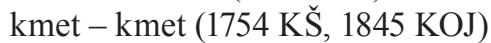

kola, koula mn. - voz (1771 KŠ, 1833 KOJ, 1796 KM, 1789 BKM)

lagev - sod (1780 KMS, 1790 KM, 1807 SIZ)

plüg - plug, orodje (1771 KS̆, $1780 \mathrm{KMS}, 1796 \mathrm{KM})$

ram - hram, stavba (1833 KOJ)

raszoje $\mathrm{mn}$. - senene vile (1780 KM)

skegyen - skedenj (1771 K ك̌, 1790 KM, 1833 KOJ)

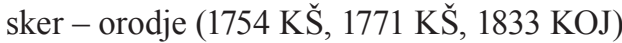

'zaklov, žakeu - vreča (1771 KŠ, 1796 KM)

\section{Pismo vaškega župana (Pečarovci 1867)}

Vaški župan prosi za pomoč glavnega župana v zvezi z dediščino. Hči kmeta Ivana Severa se je skregala z očetom zaradi dediščine. Člani vaškega odbora so hoteli posredovati in hčerki svetovati, naj se zadovolji zaenkrat z vinogradom in mlinom. Gozda in zemljišča ne more dobiti, dokler ji oče živi.

Trnó lipou damo Pozdraviti!

Plemenitoga Goszpon fö biróva, nyuvo Dobroto. Ete lidi szmo dali med vész pozvati poulek tisztoga dela, kak szo med szebov meli paulek bitja Sontavec (?), ka bi za toga volo, ka kak szo sze vö parlivali (?) pri veskoj szodbi. Pred veskimi lidmi sze je szama kriva zalaga (?), ka je vérta tak dalecs za nikoj prestimala, pa zosinfala, ka sze tiszte ricsi nikaksemi cslövöki nedosztajajo, nej pa enomi verti. Zato szmo [...] da bi zravnali na tiszti [...] Plemenitomi Goszpon föbirovi kaj sté 'z nyima vcsinijo.

[...] nyefko med szebof majo, ka ona szama szvoj taou scsé fkraj meti od tiszte Hi'ze, kak je Szever Iván pravi vért. Za toga volo ona tou lüdi nikak nescse prvoliti, ka bi vész nyej fkraj szpoznala, kak bi po pravici njej sló, Ivanova tou. Gocsi, ka sze poulek falinge (?) sze ne zgilja, ka de ona goszpodi sla. Mi szmo szpoznavali gorénséino (?) pa je nej stela zéti. Pa drügocs mlin pa je tou ni edno nej stela privoliti. Szelszkoga Grünta pa leisz tak nemre dobiti dokecs ocsa 'zivé.

Pecseróczi agós 25 dneva 1567 leta

'Zoksz Józf eskét

szvedok Horvat Józf Fujsz Iván

Szever Mihály veski Ritar

potpiszani $^{12}$

${ }^{12}$ VaML IV. 286/b, dokumenti iz 1. 1867. 
Zapisovalec je uporabljal naslednja črkovna znamenja:

$\mathrm{s}=\mathrm{sz}$ (Goszpon); $\breve{\mathrm{s}}=\mathrm{s}$ (pri veskoj); $\breve{c}=\mathrm{cs}$, ts (dalecs, htsém); ž = 'z (Hi'ze, 'zivé); c = c (po pravici); nj = ny (nyefko); dj= gy (Hegység); e = ei (leisz), o = ou (tou, pouleg); v = f(fkraj, med szebof); $-\mathrm{l}=$ ou (taou). Prisotna sta za prekmurščino značilna samoglasnika ö in ü (cslovöki, lüdi, drügocs).

Besede, ki so jih uporabljali tudi pisci že pred 1867:

falinga - napaka, slabost (1783 KM, 1790 KM, 1833 KOJ, 1848 KAJ, 1848 TA, $1848 \mathrm{KOJ})$

szpoznati - priznati (1771 KŠ, $1848 \mathrm{KOJ})$

fő biróv (madž.) - glavni župan

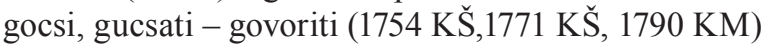

goszpon - gospod, spotoštljiv naslov za odraslega moškega (1833 KOJ,1845 KOJ)

leisz - tu: gozd (les pri $1771 \mathrm{KS}$ )

nyefka - njevkanje, prepir (1823 BRM)

prvoliti - privoliti, pristati (1771 KŠ, 1780 KMK, 1783 KM, 1790 KM,1796 KM,

1823 BRM, $1870 \mathrm{KAJ})$

grünt - zemljišče, posest (1796 KM, $1848 \mathrm{KOJ})$

vcsiniti - narediti, storiti (1715 TF,1725 ABC, 1754 KŠ, 1771 KŠ, 1783 KM, 1807

SIZ, 1823 BRM)

vért - gospodar (1754 K ک̌, 1783 KM, $1790 \mathrm{KM}, 1833 \mathrm{KOJ})$

(za nikoj) prestimati - (sploh ne) spoštovati, ceniti (1715 TF, 1754 K ̌̌, 1771 KŠ, 1789

BKM, 1790 KM, 1796 SŠ, 1823 BRM, 1848 KAJ, 1848 TA)

zgilajti sze - poravnati se (1771 KŠ, $1790 \mathrm{KM})$

\section{Začetek trgatve (Murska Sobota 1867)}

Glavni župan Slovenske krajine - Šandor Agustič - je izdal okrožnico, v kateri poziva lastnike vinogradov, naj se 18. septembra 1867 ob 10. uri zberejo v Murski Soboti, da bi določili termin za začetek trgatve. Kdor bo prej začel s trgatvijo, bo moral plačati od 12 do 24 forintov kazni.

Nej szamo Za Orszátskoga goszpodarsztva i haszka, liki tüdi za obcsinszkoga Goricze imajoucsi vértov haszka volo, nasega Vármegyöva Obcsina je dokoncsala, ka bránye goricz, touje brátva, i vetoi Szlovenszkoi okroglini naj sze dotisztoga vrejmena nazajzadr'si, dokecs, té plemeniti szád sze szploj dozori, i snega Grünta ládavczi takse vino szpraviti morejo, ka nej szamo vdomácsi ostarijai, liki vzünszka Dr'sála za dobro czejno odati, i tak za szébe véksi haszek dobiti mogoucsni bodejo. Ar zdaj 'se je nasega Orszaga vino tudi v zvünszki Országai za visesko szpoznano, i potom sze vékso czejno dobiti more, sterom nej szamo Vinogradov okroglina liki czejli nas Ország vu trstvi na prej priti. I csibi po vrejmeni Goricze zbousi stális posztaviláne bilé escse sze obogatiti bi mogeo; na tou pa prvi sztopaj pri brátvi sze zatsna, ar nezreli szád lagoje, vö dozreljeni pa vitesko vino da; záto dokoncsánye Vármegyöszko je ka naj birovija z grünta vinogradov ládavczi vküper szi dogocsi, gda bi brátva tak sze zatsnoti mogla, ka nebi czeloj obcsini na skodo bilou. Tak zatou je odlocseni dén 18-ga etoga mejszecza vsterom v Szobiti pri Váraski hisai za goidna okoli 10 vöre vküp pridemo, na stero szpráviscse véksi Goricz vértovje csi scéjo szami ali navküp, po zebrani i poszláni namesznikov sze pozivajo; gde sze odloucsi dén v sterom sze brátva zatsnoti má. 
Do tisztoga vrejmena pa sze z Vármegyöszkov oblásztjov prepovej, kaj naj niscse brátvo zatsnoti naj sze ne zasztoupi, ar birovije dusnoszt bode tisztoga, brezi vsze miloscse, ka 'se obznanyeno máte od 12 do 24 ránykov kastigati, naj szi zatogavolo niscse tou kastigo szám na szébe ne 'selej dobiti. ${ }^{13}$

Zapisovalec je uporabljal naslednja črkovna znamenja:

$\mathrm{s}=\mathrm{sz}$ (haszka); $\breve{\mathrm{s}}=\mathrm{s}$ (nasega); $\breve{\mathrm{c}}=\mathrm{cs}$, ts (dokoncsala, zatsnoti); $\check{\mathrm{z}}=$ 's (dr'sala); $\mathrm{c}=\mathrm{cz}($ Goricze $) ; \mathrm{nj}=$ ny $($ obznanjeno $) ; \mathrm{dj}=$ gy $($ Vármegyöva $) ; \mathrm{e}=\mathrm{ej}($ czejno $), \mathrm{o}$ $=$ ou (tou, mogoucsi); $\mathrm{h}=\mathrm{j}$ (sploj); $-1=-\mathrm{o}$ (mogeo). Prisotna sta za prekmurščino značilna samoglasnika ö in ü (vö, vöra, grünta); v $+\mathrm{u}=$ vöra (ura).

Besede, ki so jih uporabljali tudi pisci že pred 1867:

bránye goricz, brátva - trgatev (1771 K $\breve{S}, 1833$ KOJ, 1848 KAJ)

dokoncsati dov. - skleniti, odločiti (1747 SM)

grünta vinogradov ládavczi - lastniki zemljišča vinogradov (kalk iz madž.)

grünta ládavczi (ládavec) - lastnik (1833 KOJ)

obcsinszke Goricze - občinski, mestni (1747 SM, 1771 KŠ)

orszátsko - (madž.) državno (1747 SM, 1771 KŠ)

ostarija - gostilna (1754 KS̆,1771 KS̆, 1790 KM,1796 KM, 1807 SIZ)

Szlovenszka okroglina (1796 KM)

szpráviscse - zbor, zborovanje (1771 K $\breve{S})$

trstvo - trgovanje, trgovina (1771 K ̌̌, $1796 \mathrm{KM}, 1848 \mathrm{KAJ})$

Vinogradov okroglina - madž. pokrajina v Železni županiji (Hegyhát)

vzünszka Dr'sala - tuja dežela (1771 K ̌̌s, 1848 KOJ)

\section{Osnutek ustanovne listine hranilnice (Murska Sobota 1911)}

Osnutek je napisan v madžarščini in v prekmurskem slovenskem narečju. Slovensko besedilo je prevod madžarskega. Strokovni izrazi so kalki madžarskih besednih zvez. Večina jih je novotvorb, le nekaj so jih uporabljali že pisci pred letom 1911.

Vu szlovenszkoj krajini, stera lezsi na graniczi Vas i Zalavármegyőva, pa zvékse sztráni pod szobocsko i lendaszko birovijo szlisi, sze vu szlejdnyem vrejmeni pri obcsinszkoga vértivanya zsitki veliko naprej-idejnye dá na pamet vzéti. Körmedinszka-szobocska zseleznicza, stera po Vasvármegyőva czejlom jügzáhodnom táli prej ide, je edno veliko i rodno krajino notri zakapcsila vu obrácsanye obcsinszkoga vértivanya, paje k-ednomi doszégamao szplój vkrajzaprejtomi pláczi k-czój hodécso pout odprla, z-kój tou zhája, ka sze vu zsítki obcsinszkoga vérsztva vszakse delo i vszaksa moucs vrsenécs povéksáva i dale naprej i vise pridti nakanüje.

Kan aj eto nakanejnye vu naprej-idejnye na stero vszaksi cslovek jus i zrok má, bole i zaisztino naprej pomoremo, mí odszpodi podpiszani v-Muraszombati, kak na szredini szlovenszke krajine, edno tákso sparkaszo posztávlamo, stera vu zsitki obcsinszkoga vérsztva vsze potrejbcsine vö scsé za davoliti, pa k-tomi nakanejnyi, stero vnogo de lüdém na haszek, z-postenyom proszimo podpéranye i vüpazen.

Namenijmo polszkoga vérsztva, mestriei trzstva porgo pobouksati, vértov porgoi

${ }^{13}$ VaML dokumenti javne uprave iz 1. 1867. 
grüntov czjeno podignoti i ober vszega falejso pousszodo dati. Tou je nasega nakanejnya visesnyi czil.

Te sparkasze, stera sze na vönedokoncsano vrejmen posztávla gori, imé bode: „Muravidéki Takarékpénztár Részvénytársaság” (po szlovenszkom jeziki: Mőrszke krajine Sparkasza.)

Nyénoga sztáliscsa meszto de: Muraszombat.

Nyéni kapitális za fundament je 400.000 koron, za steri cil sze 2000 falátov, poednom 200 koron iménavrejdni akcil vödá.

Tá sparkasza de pa naszledüvajoucsa dela szpunyávala:

1. na interes de pejneze notrijemála i obravnávala,

2. kaporo bade dávala,

3. pouszodo bode dávala na tokoucso skonto z-vrejdnosatjov zagvüsano,

4. na poroke i na grünt,

5. na vekszline,

6. küpüvala i odávala bode papére-vrejonoszti,

7. naprej pomore tej pogobde pre küpleniczáj odavanyáj, parczellaványe i arendo dávanye bode financzejrano,

8. naprej bode pomágala vszefelé aszekuráczio, za steroga volo naszébe vzeme ednoga naprej-valen aszekurenszkoga drüsztva zavüpanoszt. ${ }^{14}$

Zapisovalec je uporabljal naslednja črkovna znamenja:

$\mathrm{s}=\mathrm{sz}$ (sztráni); $\breve{\mathrm{s}}=\mathrm{s}$ (stera); $\check{\mathrm{c}}=\mathrm{cs}$, ts (szobocsko); $\check{\mathrm{z}}=\mathrm{zs}$ (lezsi, zseleznica); $\mathrm{c}=\mathrm{cz}$ (na graniczi, czjeno); nj = ny (vértivanya); dj = gy (Zalavármegyöva); e = ej (szlejdnyem vrejmeni), o = ou (tou, pouszodo). Prisotna sta za prekmurščino značilna samoglasnika ö in ü (vö, naszledüvajoucsa, grünt).

Besede, ki so jih uporabljali tudi pisci že pred 1911:

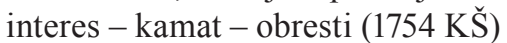

kapora - előleg - ara (1875 AI, 1876 AIP)

Körmedinszka-szobocska zseleznica - Körmend-Muraszombati vasút - železnica

iz SKJ

na vönedokoncsano vrejmen - határozatlan időre - za nedoločen čas (kalk iz madž.)

nakanejnye - törekvés - namen, namera (1780 KMK, 1783 KM, 1789 BKM, 1796

$\mathrm{KM})$

naprej - idejnye - fellendülés - napredek (kalk iz madž.)

notri zakapcsniti - bekapcsolni - vključiti (kalk iz madž.)

obrácsanye obcsinszkoga vértivanya - közgazdasági forgalom - ekonomski promet (kalk)

od szpodi podpiszani - alulírottak - podpisani (kalk iz madž.)

po jühzáhodnom táli - délnyugati részén - v jugozahodnem delu - novotvorba

podpéranye - támogatás - podpiranje (1754 KS

polszko vérsztvo - mezőgazdaság - poljedelstvo (kalk iz madž.)

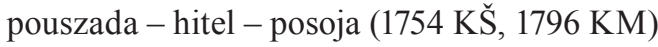

pri obcsinszkoga vertivanja zsitki - közgazdasági életében - v ekonomskem življenju

${ }^{14}$ VaML SZT Társ. c. 486. sz. Muravidéki Takarékpénztár Részvénytársaság. 
sparkasza - pénzintézet - hranilnica (kalk iz madž.)

szobocska i ledanszka birovija - Muraszombati és Alsólendvai járás (kalk iz madž.)

trzstvo - kereskedelem - trgovanje, trgovina (1771 KŠ, 1796 KM, 1848 KAJ, 1848 KOJ)

vkrajzaprejti plácz - elzárt piac - izoliran trg (kalk iz madž.)

vu szlednyem vrejmeni - a legutóbbi időben - v zadnjem času (kalk iz madž.)

V obravnavanih besedilih je ohranjena prekmurščina kot nadnarečni pokrajinski knjižni jezik. Stara knjižna prekmurščina, ki so jo uporabljali tudi prekmurski pisci od začetka 18. stoletja. Besedni zaklad teh piscev je zbran v Slovarju stare knjižne prekmurščine Vilka Novaka. S tem sem primerjala zgodovinsko-narečna besedila, ohranjena v Županijskem arhivu v Sombotelu, v katerih je izrazje strokovno, uradovalno. Uporabljalo se je na upravno-pravnem področju. Domnevam, da so pisci poznali prekmurske tiske, ob tem pa so bili prisiljeni, da tudi sami tvorijo nove besede. To priča o ustvarjalnosti piscev in odkriva novo zvrst prekmurskega narečja.

\section{Slovstvo}

Jesenšek, Marko, Jezik prekmurskih abecednikov in učbenikov v 19. stoletju, Slovensko-madžarski jezikovni in književni stiki od Košiča do danes, Budimpešta, 1998. 121-138.

Jesenšek, Marko, Zgodovinska dinamika prekmurskega jezika, Prekmurska narečna slovstvena ustvarjalnost (ur. Vugrinec Jože), Murska Sobota, 2005. 69-80.

Kozar-Mukič, Marija: Etnološko gradivo Štefana Lülika (prispevek k zgodovini slovenske etnologije). Zgodovinske vzporednice slovenske in hrvaške etnologije -1, Ljubljana, 1982. 75-76.

Kozar-Mukič, Marija, Jezik urbarjev Slovenske okrogline (Tótság) v 18. stoletju, Szlavisztikai Napok II. (Slavistični dnevi), Szombathely, 1986. 115-120.

Kozar-Mukič, Marija, Podatki o načinu življenja prekmurskih Slovencev v 18. stoletju, Zbornik soboškega muzeja 4, Murska Sobota, 1995. 77-89.

Novak, Vilko, Slovar stare knjižne prekmurščine, Ljubljana, 2006.

\section{Seznam kratic}

1715 TF Temlin, Ferenc: Mali katechismus. Halle 1715

1725 ABC Abecedarium szlowenszko. 1725

1747 SM Sever, Mihal: Réd zvelicsánsztva. Halle 1747

1754 KS̆ Küzmič, Števan: Vöre krsztsánszke krátki návuk. Halle 1754

1771 KS̆ Küzmič, Števan: Nouvi zákon. Halle 1771

1780 KMK Küzmič, Mikloš: Krátka summa velikoga katekizmussa. Sopron 1780 
1780 KMS Küzmič, Mikloš: Szlovenszki silabikár. Sopron 1780

1783 KM Küzmič, Mikloš: Kniga molitvena. Sopron 1783

1789 BKM Bakoš, Mihal: Nouvi Gráduvál. Sopron 1789

1790 KM Küzmič, Mikloš: ABC kni'sicza. Budim 1790

1796 KM Küzmič, Mikloš: Sztároga i nouvoga testamentoma szvéte histórie kratka summa. Szombathely 1796

1796 SŠ Sijarto, Števan: Mrtvecsne peszmi. Szombathely 1796

1807 SIZ Sztarisinsztvo i zvacsinsztvo. Sopron 1807

1823 BRM Barla, Mihal: Krscsanszke nove peszmene knige. Sopron 1823

1833 KOJ Košič, Jožef:Krátki návuk vogrszkoga jezika za nacsetnike. Gradec 1833

1845 KOJ Košič, Jožef: Zobriszani Szloven i Szlovenka med Mürov in Rábov. Körmend 1845

1848 KAJ Kardoš, Janoš: Krsztsanszke czerkevne peszmi. Köszeg 1848

1848 TA Terplan, Aleksander: Knige 'zoltárszke. Köszeg 1848

1848 KOJ Košič, Jožef: Zgodbe vogerszkoga králesztva. Szombathely 1848

1870 KAJ Kardoš, Janoš: Nove knige cstenyá za vesznicski sol drügi zlocs. Budim 1870

1875 AI Agustič, Imre: Prijátel 1. Budimpešta 1875

1876 AIP Agustič, Imre: Prijátel 2. Budimpešta 1876

\section{Priloga}

Vprašanja in odgovori v slovenskem jeziku iz vasi Ivanovci leta 1767:

Ob Pervim Ako i kakova Urbaria vezda jeszu i od kakovoga vreimena ona szu vopelana?

1. Vu ovom Szellu Ivanocz jeszmu troje gospode kmetje, i neznamo od nikakvoga Urbaria, kaibiga do veszdasnyega vreimena proti nam imeli goszpoda zemelska.

Ob Drugim Gde pak nikakvoga Urbaria do veszda neszu bila, Dache kmeczke od Pavroff jeli sze terjau polek dokoncsanoga med szobom pogoenya illiti Contractussa, ali pak polek nuter vzete navade, od kakovoga vreimena ali takova nuter vzeta navada, ali pak pogoenye jeszusze pricsela, i nuter vzeta? Ako neszu pred veszdazsnyem pogoenyem ali Urbariem drugoga bila, kakova i gdasze jeszte vezdasnye navade dusnost pricseta?

2. Kak je gore recseno da Urbarioma neiszo imela niti Contractusa vendar dönok ali je imel doszta ali mala vsze jednako vszaki tiden od Pondelka do szobote jeszu nasy gospoda na roboti dersali, i na robotu gonili.

Ob Tretyim Gde sze nikakova Urbaria i pogoénye ne nahajaju po Zemellszkom Goszponu od kmeta polek navade priemtenye? Dacse vu kom sztoju, gda i sz kakovim talom tak veszu noter vpelane?

3. Koie imel jeden fertal, jeszte davat gotovi novsse 8 grosof poudrugi vouz gnoja, i ovo szo nasz poleg navade terjali, nei poleg pogoenya. 

jednom?

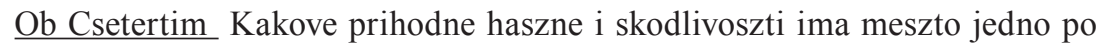

4. Haszke nikakve neimamo, skodlivoszti doszta, ar pasnika naima derva za sganye neimamo, to nasz nai bole tesi, ar gdagodi pridejo goszpoczki ludje moremo je raniti, ovo nasy sme?

Ob petim Kuliko i kakove oratje Zemle i Travnike kmet czeloga Szelische ima, i na kuliko Posonszki keblof i ako sze mara na oni Travniki otava kosziti?

5. Vu nassem Szellu Szelischa neiga, nego Stritine, i vu ovi jeszte dobre Zemle na jeden plüg. Travnika na jeden voz, otava sze nemre kossiti.

Ob Sesztim Kakovo kmet jeden po jednom i kuliko dan Goszpocsine i z kolikimi Sivinczi do vezda jeszte szlusil? Nadale, idenye i odhajanye jeli sze jeszte kmetom vu goszpocsinu zracsunalo ali nei?

6. Vszaki jeszte csetrimi Sivincsetimi od pondelka do Szobote do ovoga vreimena hodit na robottu, pridenye i odhajanje do szeimau neisze je vu robottu racsunalo.

Ob Szedmim Ako devetina do vezda i od kakvoga vreimena i od kakvoga dugovanja jeszte dana? I ako ove Devetine Dajenye vu drugi ovoga Varmegyöve Goszponi vu navadu jeszte vzeta? Vzün toga kakovu dacsu jeszu Pavri Zemellszkomu Goszponu du ovoga vreimena czerez Lettu davali, i poimenom ona Dacsa i daruvanje po Zemellszkom Goszponu od kmeta, ali vu gotovi novceti? Ali vu Naturalski dugovanyszki zterga na puimenu vuhom sztoju?

7. Od devetine neiszmo csuli ni neiszmo davali, nego Deszetino szno Davali Szvetlomi Győrszkomi Püspeki, drugo nikai, pretemtoga koi je zamudil robottu jeszu ga Goszpoda Zemelszka vu gotovi novci kastigali.

Ob Oszmim Kuliko jeszte vu mesztu jednom po jednom pusztih Szelissh? Od kakovoga vreimena, za kakovoga zroka i ova gdo usiva?

8. Vu ovom Szellu dva fertallya jeszta püszta, vumirajuczi Ludje odnut, i ona kmetje zarende dersiju.

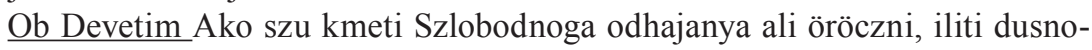
sztyom zvezani.

9. Vszi jeszmu öröczni kmetje, iliti dusnosztyom zvezani.

Ezen kilencz Punctumokra való feleletünket nevünk végén tett köröszt vonzássunkal meg erösitettünk.

(Odgovore na devet vprašanj smo potrdili s križem, ki smo ga narisali za svojim imenom.)

$\begin{array}{ll}\text { Hari Istvany } & \text { X Inkei Ur Jobbagya (kmet gospoda Inkei) } \\ \text { Koudila Mihály } & \text { X Inkei Ur Jobbagya } \\ \text { Csorba Janos } & \text { X Kellenen Ur Jobbagya } \\ \text { Nencsics Sebjan } & \text { X Inkei Ur Jobbagya } \\ \text { Adanics Mihaly } & \text { X Saller Ur Jobbagya } \\ \text { Pergorec Mihaly } & \text { X Saller Ur Jobbagya } \\ \text { Porza Mihaly } & \text { X Inei Ur Jobbagya }\end{array}$




\section{Slovenian Texts in the Szombathely County Archives before 1919}

Summary

The texts discussed in the article have been preserved in the form of land register records (Ivanovci 1767), in the Viticultural Estates Code (Stanjevci 1795: Criminal Penalties, and Moščanci 1808: Oath), a textbook (Puconci 1833), a letter by a village mayor (Pečarovci 1867), a call to harvest (Murska Sobota 1867), and a draft charter for a savings bank (Murska Sobota 1911). Apart from the textbook, all the texts are administrative and this is why an administrative text was also selected from the textbook.

The graphemes in all seven texts follow modern Hungarian orthography. The Prekmurje literary language was standardized with the translation of Nouvi zákon (The New Testament) by the Protestant writer Števan Küzmič (1771). The norm and rules formed in this book were the basis for the phonological and morphological character of Prekmurje spelling books and readers among both Protestants and Catholics. In the second half of the 19th century, the Catholics started eliminating Hungarian orthography from their publications and introducing Ljudevit Gaj's "new Slovenian" orthography instead, while the Protestants continued to use the "old Slovenian" language and orthography.

The texts discussed here preserve the old literary Prekmurje dialect, which was also used by the Prekmurje writers from the beginning of the 18th century onwards. These writers' vocabulary is gathered in Vilko Novak's Slovar stare knjižne prekmurščine (Dictionary of the Old Literary Prekmurje Dialect). The author compares this vocabulary with the historical and dialect texts preserved by the Szombathely County Archives, which contain technical and administrative terminology used for local government and legal purposes. The author presumes that the writers were familiar with the publications in the Prekmurje dialect but were also compelled to create new words of their own. This testifies to their creativity and reveals a new form of the Prekmurje dialect.

Marija Kozar-Mukič

Vaci 39, H-9700 Szombathely/Sombotel

mukic@t-online.hu 



\title{
Izpridevniški krščanski termini v knjižni normi do srede 19. stoletja
}

\author{
Andreja Legan Ravnikar (Ljubljana)
}

IZVLE ČEK: V prispevku analiziramo tvorbene postopke samostalniških krščanskih terminov z besedotvorno podstavo iz pridevnika. Terminološke tvorjenke, izpričane v nabožnem slovstvu od srede 16. do druge polovice 19. stoletja, smo znotraj besedotvornopomenskih kategorij razvrščali po enakofunkcijskih obrazilnih morfemih. Pri evidentiranju smo upoštevali produktivnost tvorbe in pogostnost rabe tvorjenk $v$ besedilih.

ABSTRACT: This article analyzes the word-formative processes of nominal Christian terms formed from adjectival bases. Terminological derivatives in religious literature from the mid-16th to the second half of the 19th century were classified within word-formative semantic categories by affixal morphemes with the same function. The classification takes into account the productivity of formation and the usage frequency of coined words in texts.

0 Izpridevniški samostalniki se po produktivnosti tvorbenih postopkov in številu obrazilnih morfemov uvrščajo za izglagolskimi in izsamostalniškimi terminološkimi tvorjenkami. ${ }^{1} \mathrm{~V}$ mislih imamo po večini liturgične termine, t.j tiste krščanske termine, ki so kot najstarejše zapisano slovensko tematsko besedje izpričani že v srednjeveških rokopisih. ${ }^{2} \mathrm{~V}$ pisni rabi so se razmahnili najprej v osnovnih

1 V pripravi za tisk sta dve razpravi avtorice prispevka, in sicer Izglagolske krščanske terminološke tvorjenke v slovenskih nabožnih priročnikih do srede 19. stoletja (Obdobja 24) in Izsamostalniške krščanske terminološke tvorjenke v razvoju slovenskega knjižnega jezika (Slavistična revija 55/1), ki potrjujeta to ugotovitev.

2 O liturgičnih besedilih v predknjižni dobi prim. razprave M. Orožen, ki so zbrane v monografiji Poglavja iz zgodovine slovenskega knjižnega jezika (1996): Brižinski spomeniki in njihovo razmerje do stare cerkvene slovanščine, Brižinski spomeniki v razvoju slovenskega (knjižnega) jezika (učinkovanje na knjižno normo in znanstveno slovenistiko), Fran Miklošič - raziskovalec slovanske obredne terminologije, Liturgična terminologija $v$ zgodovinskem razvoju osrednjega in vzhodnoslovenskega knjižnega jezika (do konca 18. stoletja), Molitveni obrazci starejših obdobij v osrednjeslovenskem in vzhodnoslovenskem knjižnem jeziku. 
$\hookrightarrow \quad$ protestantskih verskih priročnikih v drugi polovici 16. stoletja, od katoliške obnove dalje (z izjemo severovzhodnega etničnega ozemlja pod ogrsko krono, kjer so tolerirali obe veroizpovedi) pa v katoliškem nabožnem slovstvu.

0.1 Jezikovno gradivo za analizo smo zbrali iz preko 40 nabožnih del, predvsem iz protestantskih in katoliških katekizmov ter katekizemskih delov lekcionarjev, deloma iz molitvenikov in obrednih besedil od srede 16 . stoletja do druge polovice 19. stoletja. ${ }^{3}$ Izbrana vzorčna besedila segajo s prvo slovensko knjigo (Trubarjevim katekizmom iz leta 1550) v dobo normiranja slovenskega knjižnega jezika, zaključujejo pa se s Slomškovim katekizmom za prvošolce (prva izdaja leta 1951, druga leta 1969) v enotnem novoslovenskem knjižnem jeziku (gl. vire). ${ }^{4}$ Samostalniške terminološke tvorjenke iz pridevniških podstav smo po metodi izbirnega izpisa (izjemoma paberkovalno) luščili in izpisovali v sobesedilni rabi. Izkazalo se je, da je bilo sobesedilo nujno "orodje" že v prvi fazi obdelave gradiva, predvsem za prepoznavanje občutnega deleža liturgičnih terminov, ki so nastali s terminologizacijo splošnopoimenovalnih izrazov. ${ }^{5}$ Nepogrešljivo je bilo tudi v nadaljnjem postopku razvrščanja tvorjenk po pomenskih kategorijah, ker besedotvornega pomena ni bilo vedno mogoče prepoznati oz. razložiti s pretvorbo v sinhrono določeno skladenjsko podstavo.

0.2 Pri besedotvorni analizi smo zato kombinirali sinhroni in diahroni metodološki pristop. Čeprav smo terminološke tvorjenke sinhrono (v istočasju) razvrščali po tvorbenih postopkih, po besedotvornih pomenih in enakofunkcijskih

3 Zglede za arhaične liturgične termine, ki so se v vezani besedi ohranjali v pesmih srednjeveškega izvora, medtem ko so jih pri liturgiji in v katehezi že opuščali, najdemo v cerkvenih pesmaricah vsaj do konca 19 . stoletja, ki smo jih v tej raziskavi pustili ob strani. Zgleden primer za raziskavo je objava kopije rokopisnih besedil Tinjske pesmarice. Leta 2000 je pesmarico iz Rakol pri Tinjah na Koroškem, opremljeno z Glosarjem in jezikoslovno študijo, v samoizdaji pripravil Pavel Zdovc. Pet let kasneje je pod uredništvom M. Orožen izšla Tinjska rokopisna pesmarica (2005), ki poleg ponovno objavljenih pesmi, prečrkovanih v sodobno pisavo, prinaša izčrpno jezikoslovno analizo cerkvenih pesmi na izrazni in pomenski ravnini.

4 Jezikovno gradivo je bilo zbrano za potrebe doktorskega dela Obredna terminologija v razvoju slovenskega knjižnega jezika (Legan Ravnikar 2001/02), mentorica prof. dr. Martina Orožen, somentor prof. dr. Marijan Smolik. Če izvzamemo evidentiranje samostalniških terminoloških tvorjenk, $\mathrm{z}$ besedotvornega vidika še ni bilo raziskano.

5 Problem v vsej razsežnosti je posebej izpostavil F. Novak v monografiji o samostalniški večpomenskosti v jeziku slovenskih protestantskih piscev (2004). Pri pomenih na podlagi liturgičnih besedil je opozoril na pojav, ki smo ga tudi sami opazili pri luščenju terminološke leksike. Novak $(2004,239)$ je na podlagi evangelijskih odlomkov o Kristusovem življenju in beril, molitev in psalmov ugotovil ter z zgledi prikazal, da so tako rekoč vse polnopomenske besede $\mathrm{v}$ liturgičnih besedilih liturgični izrazi. Njihovo pomensko območje je široko, izrazi nastajajo kot nekakšni simboli, naslonjeni na metaforo ali metonimijo. Značilnost liturgičnih pomenov je, da se lahko uporabljajo v ožjem ali širšem pomenu, kar je odvisno od zmožnosti uporabnika. To so pogosto izrazi iz prilik, zgodb in imajo poleg liturgičnega tudi stvarni pomen iz vsakdanjega življenja, npr. Kdo fo ti nai manfhi Criftufovi Vfi vbosi, nedolshni, bolni, Slepi, Krulôvi, Mutci, Gobavci, préprofti, pregnani (Krelj, Postilla slovenska, 1567, XXIa). 
obrazilnih morfemih, nismo zanemarili razvojnega vidika. Posamezne tvorjene termine smo opazovali v raznočasju: kdaj so se začeli pojavljati v izbranih besedilnih virih, kakšna je bila besedotvorna podoba izpridevniških samostalnikov v nabožnih delih iz različnih obdobij (protestantizem, ${ }^{6}$ protireformacija in barok, razsvetljenstvo, predromantika), primerjali smo tvorjenke v pokrajinskih knjižnih različicah ter beležili izmenjave $\mathrm{v}$ besedotvornem sistemu krščanskih terminov $\mathrm{v}$ tristoletnem obdobju.

1 Samostalniške krščanske termine, ki so se iz pridevnika oblikovali po besedotvornih tvorbenih postopkih, lahko delimo na nemodifikacijske in modifikacijske tvorjenke. Toda besedotvorna analiza je pokazala, da je razmerje med njimi skoraj povsem v prid prvim, kajti izpridevniške modifikacijske izpeljanke in sestavljenke se v terminološki rabi pojavljajo le izjemoma. Tako jih bomo obravnavali skupaj, le da bomo na modifikacijsko tvorbo sproti opozarjali. Prevladujoča besedotvorna vrsta v vsaki pomenski kategoriji je izpeljava. Tvorjenke iz predložne zveze in zloženke, ki so nastale z zlaganjem iz podstav, kjer je pridevnik določujoča sestavina jedrnega samostalnika, so redke. Večina izpridevniških terminoloških tvorjenk se razvršča v dve besedotvornopomenski kategoriji: lastnost in nosilec lastnosti (živo). Tovrstne značilnosti, izpričane seveda na manjšem številu zgledov, kažejo že istovrstne tvorjenke v Brižinskih spomenikih. ${ }^{7}$ Znotraj posameznih besedotvornih pomenov sta praviloma produktivna dva tvorbena vzorca, ki si konkurirata $\mathrm{v}$ istočasju in raznočasju. Tudi zgledi le-teh v besedilih izkazujejo najvišjo frekvenco. Tvorjenke z besedotvornim pomenom nosilec lastnosti (neživo), kraj in čas se le izjemoma pojavljajo z več kot enim (večpomenskim) obrazilnim morfemom. Potrjene so z enim ali dvema zgledoma za dani besedotvorni vzorec, toda prav ti krščanski termini so v vseh jezikovnozgodovinskih obdobjih na celotnem slovenskem etničnem prostoru zelo stabilni.

6 M. Merše $(1990,171)$ je za obdobje slovenskega protestantizma med drugim raziskovala izmenjavo podstavno enakih, obrazilno pa različnih tvorjenk v Trubarjevih novozaveznih prevodih, npr. zakriven-zakrit, tihost-tihota, vrabčec-vrabčič, svetovanje-svet. Raznolikost je bila posledica pomenske neustaljenosti obrazil in tudi njihovega razvrščanja na podstavo. Ugotovila je, da je kasnejši načrtni izbor lahko rezultat predhodnega preizkušanja izrazov in različne produktivnosti obrazil.

7 A.Vidovič - Muha (1989) je analizirala besedotvorno tvorbo vseh polnopomenskih besed v Brižinskih spomenikih. Pri samostalniških tvorjenkah z besedotvorno podstavo iz pridevnika je izluščila tri besedotvorne pomene. Pri pregledu zgledov tvorjenk iz vzorčnih besedil, ki smo jih razdelili po besedotvornih pomenih in obrazilnih morfemih, smo ugotovili, da se krščanske terminološke tvorjenke razvrščajo le v dve najpogostejši besedotvornopomenski kategoriji: lastnost (besedotvorni vzorec izpeljave s priponskimi obrazili -ot'a, -tvo, -stvo, -ost in -ot) in nosilec lastnosti (izpeljava s priponskimi obrazilnimi morfemi $-e c,-i k$ in $-i n)$. 


\subsection{Izpridevniške terminološke tvorjenke $z$ besedotvornim pomenom lastnost ali stanje}

\subsubsection{Izpridevniške izpeljanke s priponskim obrazilom -ost}

Prva in v krščanski tradiciji do današnjega dne pogosto rabljena izpridevniška krščanska tvorjenka z nenaglašenim obrazilnim morfemom -ost: milost (poimenuje liturgični in teološki pojem) je zapisana že v Brižinskih spomenikih ${ }^{8}$ iz 10. stoletja. Izpeljava s priponskim obrazilnim morfemom -ost je v terminološko rabo verjetno prišla po analogiji iz splošne leksike. Ker je abstraktni, pojmovni svet v strokovnem jeziku bolj razvit in raznolik kot v konkretnem svetu vsakodnevnih realij, se je potrdilo naše pričakovanje, da je $v$ terminološki plasti besedja ta besedotvorni model postal še bolj produktiven, kot se izkazuje v splošni rabi. ${ }^{9}$ Produktivnost tvorbe in pogosta raba, kar ni nujno v premem sorazmerju, sta se vzdrževali skozi vsa obdobja jezikovne zgodovine. Manjša odstopanja se kažejo v pokrajinskoknjižnih različicah 18. stoletja.

$\mathrm{V}$ protestantizmu in dobi katoliške prenove se je tvorbeni model s priponskim obrazilom -ost potrjeval v zgledih, ki poimenujejo Bogu ljube lastnosti in kreposti protestantskega ali katoliškega vernika in (po antitezi) v poimenovanjih za grešne lastnosti, ki bodo nespovedane grešnike, predvsem pa verske nasprotnike privedle v večno pogubljenje. Naj naštejemo več primerov izpeljank (medponsko-priponske zloženke so izjema, npr. bogarodnost, vsegamogočost): čednost, čistost, dolžnost, krotkost, lakomnost (prim. zgled lakomstvo iz Brižinskih spomenikov, kjer se na skoraj identično podstavo lakom- pripenja konkurenčni obrazilni morfem abstraktnih samostalnikov -stvo), milost, modrost, nedolžnost, nemarnost, nevoščljivost, pohlevnost, potrpežljivost, pravičnost, prevzetnost, skopost, skrivnost, slobodnost, sramežljivost, svetost, večnost, zlobost in zlobnost, žalost. Sem prištevamo tudi drugostopenjske tvorjenke s prevzeto pridevniško podstavo, kot brumnost, ferbežnost, ferdamnost, zastopnost, žihrost. V razsvetljenstvu se je terminološki fond ohranjal in še širil, npr. božjost, brezbožnost, edinost, pobožnost, ponižnost, senagoltnost, trojnost, vsegamogočnost, ${ }^{10}$ zmaznost (prim. izglagolska tvorjenka vzmastvo v Bri-

8 V besedotvornem pogledu izvornega besedišča sta že v Brižinskih spomenikih zaznavni dve tendenci: prvi in drugi spomenik vsebujeta predvsem tvorbe, potrjene kasneje v osrednjem tipu slovenskega knjižnega jezika, npr. vernik, močenik, krilatec, drugi in delno tretji pa izpeljanke, potrjene kasneje v vzhodnoslovenskem knjižnem jeziku in v sodobnih panonskih govorih, npr. spasitel, spasenje, obet, obečanje (Orožen 1996, 75).

9 Bajec $(1950,70)$ opozarja, da se je tvorbeni vzorec izpeljave s priponskim obrazilom -ost široko razmahnil in ostal zelo produktiven tudi v sodobni rabi. Izpeljanke se tvorijo od večine pridevnikov, ki se končujejo na - $\partial n$, od pridevnikov na -iv, -av, -ov, -at, -en, od večine deležnikov in od števniških osnov. Tvorbeni vzorec je izpodrinil izpeljavo s sopomenskimi obrazilnimi morfemi -oča, -oba in -ota.

${ }^{10} \mathrm{~V}$ protestantizmu je v nekaterih primerih obstajala dvojnost krajših in daljših oblik pridevnikov, npr. stanovit - stanoviten, svojevolj - svojevoljen, zlat - zlaten, zlob - zloben. Iz pridevnika vsegamogoč se je tvorila izpeljanka vsegamogočost; iz daljše (mlajše) oblike pa imamo v razsvetljenstvu izkazano izpeljanko vsegamogočnost (tudi v Vorenc-Kastelčevem slovarju na prelomu iz 17. v 18. stoletje je izpričana le krajša oblika pridevnika 
žinskih spomenikih). $\mathrm{V}$ dobi predromantike $\mathrm{v}$ prvi polovici 19. stoletja najdemo $\mathrm{v}$ katekizmih zglede tvorjenk različnih besedotvornih vrst: bogaboječnost, grešnost, posvetnost, previdnost.

V prekmurskem knjižnem jeziku 18. stoletja, v katerem se je vzdrževala evangeličanska (F. Temlin, Š. Küzmič) in katoliška knjižna tradicija (M. Küzmič), je v dani besedotvornopomenski kategoriji prevladovala izpeljava z nenaglašenim priponskim morfemom -ost, le zgledi se, deloma zaradi drugačne narečne podstave pokrajinskega knjižnega jezika (panonska slovenščina nasproti alpski slovenščini) in delne kontinuitete s starocerkvenoslovansko terminologijo (Orožen 1996, 54), velikokrat razlikujejo. Naj navedemo le terminološke tvorjenke z različnimi besedotvornimi podstavami, npr. batrivnost 'tolažba' in batrivost 'prevzetnost', darovitost in darovnost (oboje 'darežljivost'), dužnost, gizdost, grešnost in grešlivost, hotlivost, jakost, krepkost, milostivnost, nenavidnost, pogibelnost, pokornost, radost, skvarjenost, smilenost, spametnost, srditost, trplivost, vtraglost, vernost, zahvalnost. Razdvojenost, razklanost, boj med dobrim in zlim, ki je značilen za krščanski svetovni nazor, se kaže tudi v strukturi tvorjenk. Med izpeljanke s priponskim obrazilom -ost lahko uvrščamo drugostopenjske tvorjenke, kot nanasitlivost $(<$ to, da je nenasitliv), ${ }_{11}^{11}$ nepobožnost, nepokornost, neposlušnost, nepravdenost, neskvarjenost, nevernost, nezahvalnost. Med medponsko-priponskimi zloženkami po pogostosti rabe izstopajo termini bogabojaznost, bogolübnost, milosrčnost, vekivečnost. V prekmurski knjižni normi se je ustalil tudi naglašeni obrazilni morfem -óst in njegova dvoglasniška različica -óust, kar je v slovarju stare knjižne prekmurščine (2006) predstavljeno kot enakovredna ali bolj oz. manj pogosta dvojnica, npr. čèdnost tudi čednóust, modróust tudi móudrost tudi módrost, nevoščenóst in nevoščenóust tudi nevouščenóst, skóupost tudi skopóust. V vzhodnoštajerski knjižni različici se besedotvorna podstava izpeljank in (za podpičjem) zloženk deloma razlikuje, npr. krepost, modrost, nabožnost, služebnost, smilečnost; krivovernost, vseganazočnost, vsegavedočnost.

\subsubsection{Izpridevniške izpeljanke s priponskim obrazilom -stvo}

Vzorec izpeljave s priponskim obrazilom -stvo ki je bil prvotno naglašen na končnici (Škrabec 1994, II, 180), je najbolj produktiven pri terminoloških samostalniških tvorjenkah iz samostalniške podstave (Legan Ravnikar 2007b). Pri tvorjenkah iz pridevniške podstave se uvršča na drugo mesto, vendar po številu zgledov bistveno zaostaja za izpeljankami z obrazilnim morfemom -ost. Termini iz te skupine so v osrednjem prostoru od protestantizma dalje v vzorčnih besedilih izkazovali stabilno rabo, npr. boga(t)stvo 'kraljestvo' (Trubar), (v)boštvo, edinstvo, (i)zveličanstvo, krivoverstvo, prekletstvo, veličastvo.

vsegamogoč). S. Škrabec (1994, II, 204-205) je zagovarjal stališče, da med tvorjenkama la'kom in (mlajšo) la'komàn ni pomenskega razločka, zato sta pravilni izpeljanki la'komìca in la'komnìca.

${ }_{11}$ Termine s predponskim obrazilom ne- lahko štejemo tudi med modifikacijske sestavljenke, kajti večstopenjsko tvorjenko nenasitlivost se da na predhodni stopnji razvezati tudi v skladenjsko podstavo > ne biti nasitlivost (Legan Ravnikar 2007b). 
V prekmurskem knjižnem jeziku 18. stoletja je bila tvorba krščanskih terminov s priponskim obrazilom -stvo bolj razširjena kot v osrednjeslovenskem, npr. bláženstvo, cérkvenstvo 'cerkvenost', jedínstvo, jeretínstvo, králestvo in králevstvo, pápinstvo, prekléstvo ${ }^{12}$ tudi preklénstvo, svèstvo tudi svétstvo 'zakrament', vadlüvánstvo, zveličánstvo, židòvstvo.

\subsubsection{Izpridevniške izpeljanke $z$ manj rodnimi priponskimi obrazilni morfemi}

Manj rodnih ali praktično nerodnih priponskih obrazil za besedotvorni pomen lastnost je precej. Raba niha glede na različne časovne in prostorske koordinate. Poglejmo si nekaj primerov. Protestantski pisci 16. stoletja so zapisovali in tudi sami tvorili izraze s priponskim obrazilom -ina, npr. krivina 'krivica', pohlevščina (konkurenčna terminološka tvorjenka pohlevnost je v 16. stoletju redko rabljena, v protireformaciji pa povsem prevlada), pokorščina (in redko pokornost), zveščina (namesto mlajšega termina zvestoba). Manjšo rodnost izkazujejo še nekatera priponska obrazila z ustaljeno rabo tvorjenk na vsem slovenskem etničnem prostoru. Številčno prednost ima vzorec izpeljave z obrazilom -je: (i)zveličanje, ferdamanje, poštenje, (nebeško) veselje. Ostali tvorbeni vzorci so potrjeni s po dvema tvorjenkama, ki imajo znotraj terminološkega sistema krščanske terminologije pomembno mesto: -oba: hudoba, lenoba; -da: krivda, pravda; -ica: pravica, resnica; -ota ${ }^{13}$ : dobrota, slepota. V splošnem izrazju je izbor priponskih obrazil v tej pomenski kategoriji neprimerno večji. V prekmurskem knjižnem jeziku so v razmerju do »osrednjih« terminoloških tvorjenk izpričani razlikovalni obrazilni morfemi, ki se pripenjajo na enako podstavo, npr. -ouča in -oča: čistouča ${ }^{14}$ (čistost $\mathrm{v}$ osrednjem knjižnem jeziku), krotkouča (v terminološkem pomenu tudi besedotvorna varianta krotkost), - ošča: milošča (milost v osrednjeslovenskem knjižnem jeziku). V vzorčnih besedilih evangeličanskih in katoliških prekmurskih piscev 18. stoletja je v liturgičnem pomenu rabljen le izraz čistoča, na kar kažejo tudi zbrani slovarski pomeni, medtem ko sta za splošni pomen 'stanje brez umazanije' potrjeni besedotvorni varianti čistost in čistóuča (Novak 2006). Med zgledi v tej pomenski kategoriji izstopa tudi arhaični termin, izpeljan z neproduktivnim priponskim obrazilom -ot: (večni) život 'življenje'.

12 Onaglašeni zgledi so citirani iz Slovarja stare knjižne prekmurščine Vilka Novaka, v katerem so navedena gesla, ki so se oblikovala na podlagi gradiva od Temlinovega katekizma iz leta 1715 do Košičevih zgodb iz leta 1914.

${ }^{13}$ Boškovič ugotavlja, da je obrazilni morfem -ot'a poleg -ota (oboje za abstraktna poimenovanja) značilen za zahodnojužnoslovanska jezika slovenščino in srbohrvaščino in med njima z redkimi izjemami ni pomenskih odtenkov. Posebej opozarja na pomensko razlikovanje pri tvorjenkah čistoća $\mathrm{v}$ materialnem smislu 'odsotnost umazanije' in čistota $\mathrm{v}$ abstraktnem pomenu $(1984,267)$.

${ }^{14}$ Naglašeni priponski morfem -óuča je bil produktiven v prekmurski splošni leksiki (Novak 2006), npr. krotkouča, mokrouča, slatkouča, svetlouča, teškouča, toplouča, velikouča. Enako velja za različico -óča, npr. besnoča, britkoča, dragoča, dugoča, ednakoča, grdoča, krhkoča, lehkoča, mokroča, nagoča, sladkoča, suhoča, teškoča, toploča . 


\subsection{Izpridevniške terminološke tvorjenke $\mathrm{z}$ besedotvornim pomenom nosilec lastnosti ali stanja (s slovnično kategorijo živosti)}

\subsubsection{Konverzni samostalniki}

Jezikovna analiza je pokazala, da je konverzija produktiven postopek tvorbe ${ }^{15}$ liturgičnih terminov. ${ }^{16}$ Konverzni samostalniki se po večini oblikujejo s prevedbo lastnostnih pridevnikov (v eni stopnji) ali pridevniških deležnikov (v dveh stopnjah), ki jim v imenovalniku in tožilniku ednine moškega spola dodamo oblikotvorni morfem -i, oziroma gre za besednovrstno spremembo pridevniške besede v določni obliki v samostalnik. ${ }^{17} \mathrm{~V}$ izbranih nabožnih priročnikih so poleg produktivnosti tvorbe krščanski termini izkazovali tudi najpogostejšo rabo. Konverziji so bili podvrženi lastnostni pridevniki v izhodiščnem ali prenesenem pomenu, ki označujejo vernike ali nevernike po telesnih značilnostih ter po duševnih in duhovnih lastnostih ali trajajočem stanju (pridevniški deležniki). Izjemoma so se »sprevrgli« vrstni pridevniki na -ski: duhovski, malikovski, z ženskospolskim obrazilom -ska: (duhovska) gosposka ter na -nji: bližnji. Posamostaljenje so doživele po metaforičnem pomenskem prenosu oblikovane modifikacijske izpeljanke na -ji: višji in -ši: mlajši (tudi ženskega spola mlajša 'joginja'), stariši ${ }^{18}$ Tudi konverzija pridevnika v srednjem spolu na -o: dobro, hudo ostaja posebnost. Za te primere je praviloma značilno, da so edninski, medtem ko je večina zgledov konverzije iz lastnostnih pridevnikov izpričana v množini (splošnost nasproti individualnosti!). Iz sobesedilne rabe je tudi razvidno, da so konverzni termini stilno nevtralni izrazi, medtem ko splošni izrazi lahko po posamostaljenju preidejo med stilno zaznamovano besedje.

1.2.1.1 Tvorba krščanskih terminov po konverziji je znana iz Brižinskih spomenikov, npr. sveti 'svetnik'. Od prve slovenske knjige prevladujejo zgledi z domačo besedotvorno podstavo, ki so navadno množinski (nosilci lastnosti niso individualizirani), ni pa nujno. Označujejo človekov zunanji izgled, npr. čisti, gnusni, grdi,

${ }^{15}$ Nekateri slovničarji izražajo dvom, ali je to pravi tvorbeni postopek, saj gre pri konverziji (v našem primeru substantivizaciji) za nastanek nove besede s spremembo besednovrstne kategorije brez dodajanja obrazilnih morfemov. Podstava se ne menja niti glasovno niti naglasno, samo prevzema sintaktične in (ne nujno) morfološke lastnosti nove besedne vrste (Babić 1986, 35-36).

${ }^{16}$ Pri raziskovanju postopkov za poimenovanje novih pojmov v 16. stoletju (Novak 2000, 115) je bila že ugotovljena živost besedotvornega sistema, ki se kaže skozi produktivne besedotvorne tipe, kateri so bili v 16. stoletju zelo produktivni - tudi na primeru posamostaljenja pridevnikov. Prim. pripombo o številčnosti samostalnikov, tvorjenih iz pridevnikov po konverziji (Vidovič - Muha 1986, 357).

${ }^{17} \mathrm{~V}$ 16. stoletju se je konverzija izvršila tudi pri nekaterih izpeljanih ali zloženih pridevnikih v nedoločni obliki, kar je eksplicitno razvidno le v imenovalniku ednine moškega spola. Nedoločno in določno obliko pridevnika v samostalniški rabi izkazujejo vsaj naslednji pari lastnostnih pridevnikov, npr. bogaboječ - bogaboječi, duhoven - duhovni, maloveren - maloverni, moder - modri, pravičen - pravični, živ - živi. Enako velja za pridevniške deležnike s prevzeto podstavo, npr. zastopen - zastopni, žalban - žalbani (Legan Ravnikar 2007a, 113).

${ }^{18}$ Prim. pomenske razlage primernika stariši na podlagi gradiva slovenskih protestantskih piscev 16. stoletja (Premk 2000, 86). 
$-\quad$ lepi, mali, majceni, majheni, mokri, veliki, visoki, ali duhovne in duševne lastnosti, npr. dobri, dobrotljivi, grozoviti, hudi, hudobni, krivi, krijžejni (konverzija zloženke z enomorfemskim medponskim obrazilom!), krivični, krotki, lakotni, lažnivi, leni, ljubeznivi, mrtvi, nagli, nori, pobožni (konverzija tvorjenke iz predložne zveze!), pošteni, potrebni, preprosti, prevzetni, prijatljivi, prijaznivi, prilizavi, revni, sladki, šibki, tihi, togotni, verni, vbogi, zanikrni, zli, zvesti, žalostni. Delež deležniških pridevnikov na $-n$, izjemoma na $-t$ ali $-\check{c}$, ki so bili podvrženi konverziji, ni zaostajal za pridevniki, npr. (i)zgubljeni, (i)zveličani, križani, očiščeni, odpahnjeni, odstavljeni, pogubljeni, pohlevni, poklicani, posvečeni, potlačeni, povzdigovani, vsegamogoči, zakleti, zaobljubljeni, zapuščeni, zatajeni. Do razsvetljenstva so se v besedilnih virih ohranjali tudi primeri konverzije pridevnikov in pridevniških deležnikov s prevzeto podstavo iz nemščine, med katerimi so najfrekventnejši naslednji zgledi: brumni, cagavi, ferdamani in ferdamnani, firmani, ofertni, vtragljivi, zašpotovani, žegnani.

1.2.1.2 Pri protestantskih piscih 16. stoletja je malo zgledov konverznih samostalnikov, ki se izmenjujejo z izpeljanimi besedotvornimi različicami. ${ }^{19}$ Izmenjava je pretežno potekala z izpeljankami na -ec ali -ik. Tipični so naslednji zgledi: gluhi - glušec, gobavi - gobavec, hromi - hromec, mutasti - mutec, ofertni - ofertnik, ohranjeni - ohranjenik. Številčno razmerje med konverznimi samostalniki in sopomenskimi izpridevniškimi priponskimi tvorjenkami se je v kasnejših stoletjih prevesilo v prid drugih.

1.2.1.3 V prekmurskem knjižnem jeziku je izpričanih manj zgledov konverznih terminoloških tvorjenk, čeprav je bil ta postopek oblikovanja liturgičnih terminov produktiven. Prevladujejo »spreobrnjeni« pridevniški deležniki, kot blagoslovljeni, krstšeni, namazani (v vzhodnoštajerski knjižni različici pomazani 'maziljeni'), potrdjeni, skvarjeni, trouštajouči, vadlüvajouči, vörujouči in vörvajouči, vsamogouči in vsemogouči, vzhšt. moleči in pismovučeni.

\subsubsection{Izpridevniške izpeljanke $\mathrm{z}$ nenaglašenim in naglašenim priponskim obrazilom -ik za moški spol in parnim obrazilom -ica ženskega spola}

Največ izpridevniških terminoloških tvorjenk se tvori s priponskim obrazilnim morfemom -ik, ki se po primerjavi z izpeljankami v splošni rabi izkazuje kot temeljni priponski morfem izpridevniške tvorbe v slovenščini. ${ }^{20}$ Že iz zgodnje dobe

${ }^{19}$ Primerjava delov besedila z Luthrovo prevodno predlogo (Die gantze Heilige Schrift, 1545 ) in sodobnim slovenskim standardnim prevodom (Sveto pismo stare in nove zaveze, 1996) je pokazala, da je razlogov za tolikšno razširjenost konverzije več (Legan Ravnikar 2007, 116-120). Biblični in katekizemski teksti so bili primeren tematski okvir in tudi vplivu nemške predloge lahko pripišemo določen delež. Bolj upravičeno pa govorimo o vzporednem razvoju in razmahnitvi postopka konverzije v slovenščini in nemščini. Konverzija je bila enostaven, ekonomičen, zato v starejši dobi oblikovanja knjižnega jezika in tudi besedotvornega sistema pripraven tvorbeni postopek.

${ }^{20}$ Priponsko obrazilo -ik se pri samostalniških izpeljankah iz pridevniških podstav v Slovarju slovenskega knjižnega jezika (1970-1991) s skoraj četrtino vseh tvorjenk uvršča na prvo mesto. Med najproduktivnejšimi obrazili moškega spola je tudi -ec, ki se razvršča na tretje mesto (Stramljič Breznik 1999, 15). 
pokristjanjevanja naših prednikov so znani zgledi, kot grešnik, izvoljenik, močenik, vernik (božji) 'duhovnik', (božji) zakonik 'svečenik', zoprnik 'hudič' (Brižinski spomeniki). To kaže na tisočletno tradicijo tovrstnih tvorjenk in hkrati veliko stabilnost danega besedotvornega modela za tvorbo krščanskih terminov. Pri protestantskih piscih so najpogosteje izpričane naslednje terminološke tvorjenke $\mathrm{z}$ nenaglašenim obrazilnim morfemom -ik: grešnik, hudobnik, lakomnik, mašnik, martrnik, nevernik (< neveren), ofertnik, podružnik, pokornik, prešustnik, sovražnik, zoprnik, žalbanik; manj je zgledov za izpeljanke z naglašenim priponskim obrazilom -ik, ${ }^{21} \mathrm{npr}$. dolžnik, krščenik, lažnik, oblastnik, ohranjenik, učenik. Po omejenih gradivskih virih se tvorjenkam v protireformaciji pridruži še puščavnik. V dobi razsvetljenstva, ki ga zaznamujejo pokrajinske knjižne različice, v osrednjem knjižnem jeziku izstopajo različice martrnik, matrnik in mantrnik (v koroški knjižni različici). Na vzhodnoslovenskem jezikovnem prostoru so potrjeni razlikovalni zgledi z nenaglašeno in naglašeno različico (za podpičjem) priponskega obrazila -ik, npr. dühovnik, darovnik, dužnik, manternik, pokornik, pravdenik 'pismouk', sredbenik, vernik; betežnik, krstšenik, močenik, püščenik, redovnik. V vzhodnoštajerski knjižni različici najdemo enake ali tvorjenke, ki se razlikujejo od prekmurskih po besedotvorni podstavi ali po glasoslovnih posebnostih v njej, npr. bolenik (poleg betežnik), pridružnik, samotnik, zovražnik, župnik (Muršec).

Nenaglašenemu priponskemu obrazilu -ik pripada naglašeni parni obrazilni morfem ženskega spola -ica. Tudi ta besedotvorni vzorec izpridevniške izpeljave se v terminološki rabi potrjuje najprej v predknjižni tradiciji, npr. svetica ${ }^{22}$ v Stiškem rokopisu, in v vzhodnoslovenski obredni tradiciji evangeličanov in katolikov, kot jo izkazujejo nabožna besedila prekmurskih piscev 18. stoletja in vzhodnoštajerskih piscev do štiridesetih let 19. stoletja. Produktivnost tvorbe in frekvenca terminoloških tvorjenk ženskega spola je v besedilih precej manjša kot pri izpeljankah moškega spola. V osrednjem slovenskem prostoru so v tristo letih, kolikor zajemajo naši besedilni viri, najpogosteje potrjeni zgledi z nenaglašenim in (za podpičjem) naglašenim priponskim obrazilom: grešnica, marternica; krščenica, (božja) porodnica. V vzhodnoslovenskih knjižnih različicah izstopa sopomenski termin starocerkvenoslovanskega izvora, ki se je tvoril z medponsko-priponskim zlaganjem: bogorodica. Tudi arhaični krščanski termin iz števniške podstave se je izpeljeval z ženskospolskim

${ }^{21}$ Nenaglašeno in naglašeno različico priponskega obrazila -ik smo ločili na podlagi onaglašenih iztočnic iz Novakovega slovarja (2006).

${ }^{22}$ Svetik je potrjen v vseh treh poznosrednjeveških jezikovnih spomenikih: v apostolski veri Celovškega rokopisa občina svetkov, v Starogorskem rokopisu na identičnem mestu gmajna vseh svetikov, v Stiškem rokopisu je dvakrat potrjen svetik (vse božje svetike inu svetice da mi račite prositi, volnu vdal ti oblasti tiga hudiča inu nega svetikom - iz sobesedila izluščimo antitetični pomen, ki kaže na stilno zaznamovano tvorjenko v neterminološki rabi) in enkrat konkurenčna izpeljanka svetnik. V protestantizmu je svetik arhaizem, ki ga je iz katoliške obredne tradicije sprejel le še Trubar. Nova tvorbena vzorca z obrazilnima morfemoma -nik in -nica, tipična za izglagolsko in izsamostalniško izpeljavo, sta se verjetno uveljavila zaradi navidezne analogije $\mathrm{z}$ besedotvornim vzorcem z obrazilom -ik, npr. grešnik, martrnik. Tvorba po analogiji se vedno znova dokazuje kot odločilni znotrajjezikovni razlog oblikovanja terminoloških tvorjenk. 
$\hookrightarrow \quad$ priponskim obrazilom -íca: (sveta) trojica. Ekvivalent v vzhodnoslovenski obredni tradiciji je besedotvorna različica $\mathrm{z}$ obrazilnim morfemom srednjega spola -stvo: trojstvo, ${ }^{23} \mathrm{ki}$ je v dani besedotvornopomenski kategoriji nepričakovan.

\subsubsection{Izpridevniške izpeljanke s priponskim obrazilom -ec moškega spola in -ka ženskega spola}

Po naših virih sodeč je tvorbeno najbolj produktivnemu obrazilu -ik vztrajno konkurirala izpeljava s priponskim obrazilom -ec. Pri protestantskih piscih so se po analogiji poleg domačih, npr. krivec, mrtvec, mrlec, pijanec, vbožec, tako tvorile tudi izpeljanke s prevzeto besedotvorno podstavo, npr. šentavec, špotljivec. V razsvetljenstvu je dani besedotvorni vzorec dobil nov zagon, ki se kaže v dejstvu, da je izpodrival starejše ustaljene tvorjenke, npr. v rabo je prodiral krščenec namesto krščenik, mučenec namesto mučenik in močenik, posvečenec namesto izglagolske tvorjenke posvetitel, birmanec namesto konverznega termina firmani. V vzhodnoštajerski knjižni različici je bil tvorbeni vzorec produktiven med splošnim besedjem, npr. bogatec, boječlivec, skopec 'skopuh', gizdavec, slabec 'slabič', lybec 'ljubček' (Rajh 2002, 114), in terminološkim besedjem, npr. obredenec, potrdenec (potrda namesto firma, birma), svetec, (v)učenec. Med terminološkimi ustreznicami ženskega spola so v gradivu izpričani zgledi, ki se pripenjajo na enako podstavo kot moškospolske izpeljanke, npr. obredenka, odrešenka, potrdenka.

\subsubsection{Izpeljanke z nerodnimi priponskimi obrazili}

Primerjalna analiza je pokazala, da so za vsako dobo v vseh besedotvornopomenskih kategorijah izpridevniških tvorjenk značilni neproduktivni obrazilni morfemi. V prvi dobi knjižnega jezika se je za pomen nosilec lastnosti ali stanja ustalil obrazilni morfem -nik, vendar je izpeljava z njim v nasprotju z izglagolsko izpeljavo ostala povsem na obrobju tvorbenih možnosti: svetnik, jetnik. Enako velja za parni obrazilni morfem ženskega spola -nica: svetnica, ki je nastal pod vplivom obrazila za moški spol, sicer je to priponski morfem za besedotvorni pomen kraj (Škrabec II, 204). Od Stiškega rokopisa iz 15. stoletja dalje lahko v osrednjem slovenskem prostoru zasledujemo prav tako pogosto rabljen termin z redkim morfemom izpridevniške tvorbe -ič: hudič (namesto vrag na severovzhodu), ki je bil sredi 19. stoletja tudi sprejet v enotni novoslovenski knjižni jezik.

\subsection{Izpridevniške terminološke tvorjenke $\mathrm{z}$ besedotvornim pomenom nosilec lastnosti ali stanja (s slovnično kategorijo neživosti)}

Ta pomenska kategorija je med krščanskimi termini redko uresničena. Trubar je namesto termina sakrament večkrat zapisoval izpeljanko s priponskim morfemom -inja (skrivna) svetinja; termin je v današnjem pomenu 'relikvija' izpričan od

${ }^{23}$ Krščanski termin trojica se pojavlja le izjemoma, verjetno pod vplivom osrednjeslovenske protestantske knjižne produkcije, in sicer v protestantskih katekizmih F. Temlina (1715) in Š. Küzmiča (1754) (Novak 2006). 
katoliške obnove iz 17. stoletja dalje. V slovarju stare knjižne prekmurščine je potrjen termin svetina 'svetišče', medtem ko ima poimenovanje za relikvije drugačno tvorbeno motivacijo: (sveti) ostanki. V vzhodnoštajerski knjižni različici (Dajnko) se od začetka 19. stoletja pojavljata izpeljanki s priponskim obrazilom -ec: presmec 'kruh' in -je: razpetje 'razpelo'.

\subsection{Izpridevniške terminološke tvorjenke $\mathrm{z}$ besedotvornim pomenom mesto}

Skozi vsa obdobja slovenske jezikovne zgodovine se na vsem etničnem ozemlju pojavlja vzorec izpridevniške izpeljave z drugotnim priponskim obrazilom -stvo: kralje(v)stvo.

\subsection{Izpridevniške terminološke tvorjenke $\mathrm{z}$ besedotvornim pomenom čas}

Tudi za besedotvorni pomen čas so v nabožnih besedilih izpričani le neproduktivni obrazilni morfemi. Za obredno tradicijo osrednjeslovenskega prostora je značilno priponsko obrazilo -ik: praznik, za severovzhodni del pa -ek: svetek. Za praznični dan v cerkvenem letu je v vseh pokrajinskih knjižnih različicah razširjen termin svečnica, pri katerem se na besedotvorno podstavo pripenja večpomenski priponski morfem -ica.

\section{Sklep}

Skromnejša zastopanost tvorbenih vzorcev izpridevniške tvorbe, malo realiziranih besedotvornih načinov (povsem prevladuje navadna izpeljava!) in neenakomerna številčna zastopanost obrazilnih morfemov znotraj posameznih besedotvornopomenskih kategorij je pravzaprav pričakovana. Podobno sliko je namreč pokazala že jezikoslovna analiza samostalniških tvorjenk iz glagolske (Legan Ravnikar 2005) in iz samostalniške podstave (Legan Ravnikar 2007b). Liturgične terminološke tvorjenke iz pridevnika in pridevniškega deležnika so se po večini oblikovale po najproduktivnejših besedotvornih načinih in s priponskimi obrazili, ki so bili ustaljeni v splošnem besedju. Specializirani obrazilni morfemi, ki se pojavljajo v sodobnih terminoloških sistemih, med temeljnimi krščanskimi termini v osnovnih verskih priročnikih niso izkazani.

\section{Viri}

Jožef Burgar, 1833, LISTI IN EVANGELJI (MOLITVE PER SLUSHBI BOSHJI S

GLAVINO KERSHANSKIGA UKA), Ljubljana.

Janez Čandik, 1615, CATECHISMUS, Augsburg. 
$\rightarrow \quad$ Peter Dajnko, 1826, EVANGELIA INU LISTUVI, Radgona.

[T. - 1826, VELIKI KATEHIZEM, Radgona.

N Jurij Dalmatin, 1580, CATEHISMVS, Ljubljana.

$\rightarrow \quad--1585$, AGENDA, Wittenberg.

Ožbald Gutsman, 1780, EVANGELIE INO BRANIE ALI PISME (nemško-slovenski), Celovec.

- - 1790, TA VELKI KATEKISMUS S PRASHANJAMI INU ODGOVARMI, Celovec.

(Janez Adam Gaiger) Hipolit, 1715, EVANGELIA INU LYSTUVI (CATECHISMUS), Ljubljana.

Jurij Japelj, 1779, 1787, TA VELIKI KATEKISMUS S PRASHANJAMI INU ODGOVORMI, Ljubljana.

- - 1787, LYSTI INU EVANGELIA, Ljubljana.

Luka Jeran, 1852, KERŠANSKI JUNAK ALI MOLITVENE BUKVICE ZA SLOVENSKE VOJAKE IN SPLOH KATOLIŠKE MLADENČE, Ljubljana.

Matija Kastelec, 1688, NAVUK CHRISTIANSKI, Ljubljana.

Sebastijan Krelj, 1566, OTROZHIA BIBLIA, Regensburg.

Anton Krempl, 1843, SVETI NEDELNI IN SVETEŠNI EVANGELJI, Gradec.

Mikloš Küzmič, 1780, KRATKA SUMMA VELIKOGA KATEKIZMUSA, Sopron.

- - 1783, KNIGA MOLITVENA, Sopron.

Števan Küzmič, 1754, VÖRE KRSZTSANSZKE KRATKI NAVUK, Halle.

Jožef Muršec, 1850, BOGOČASTJE SV. KATOLŠKE CERKVE, Gradec.

Franc Mihael Paglovec, 1741, EVANGELIA INU BRANIE (CATECHISMUS), Ljubljana.

- - 1742, 1767, SVESTI TOVARSH ENGA SLEDNIGA CHRISTIANA (CATECHISMUS), Ljubljana.

(Ignacij Parhamer), 1760, CATECHISMUS, Ljubljana.

- 1777 , KNISHIZA SPITAVANYA TEH PET GLAVNIH SHTÜKOV KERSHAN-

SKEGA NAVÜKA, Gradec.

Marko Pohlin, 1768, TA MALE CATECHISMUS, Dunaj.

Janez Ludvik Schönleben, 1672, EVANGELIA INU LYSTUVI (CATECHISMUS),

Gradec.

Anton Martin Slomšek, 1845, SVETI EVANGELJI (KATEKISEM SVETE KA-

TOLSHKE VERE), Celje.

- - 1851, 1869, MALI KATEKIZEM ZA PERVOŠOLCE, Dunaj.

Franc Ksaver Taufferer, 1770, 1804, KRATKI SAPOPADIK KERSHANSKIGA

NAVUKA SA OTROKE INU KMETISHKE LUDY, Ljubljana.

Ferenc Temlin, 1715, MALI CATECHISMUS, Halle.

Primož Trubar, 1550, CATECHISVMS, Tübingen.

--1555 , CATECHISMVS, Tübingen.

- 1564 , CERKOVNA ORDNINGA, Tübingen.

- - 1575, CATEHISMVS SDVEIMA ISLAGAMA, Tübingen.

Valentin Vodnik, 1811, KERSHANSKI NAVUK SA ILLIRSKE DESHELE, Ljubljana. 
Listkovno gradivo, zbrano s popolnimi izpisi del slovenskih protestantskih piscev 16. stoletja, Hrani Sekcija za zgodovino slovenskega jezika Inštituta za slovenski jezik Frana Ramovša ZRC SAZU.

\section{Literatura}

Bajec, Anton, 1950, Besedotvorje slovenskega jezika, I Izpeljava samostalnikov, Ljubljana.

Babić, Stjepan, 1986, Tvorba riječi u hrvatskom književnom jeziku, Nacrt za gramatiku, Jugoslavenska akademija znanosti i umjetnosti, Razred za filologiju, Knjiga 62, Zagreb.

Boškovič, Radoslav, 1984, Osnovy sravnitel'noj grammatiki slavjanskih jazykov, Fonetika i slovoobrazovanije, Sostavila i perevela N. M. Elkina, Moskva.

Legan Ravnikar, Andreja, 2001/2002, Obredna terminologija v razvoju slovenskega knjižnega jezika (Od Brižinskih spomenikov do ustalitve enotne knjižne norme sredi 19. stoletja), Doktorska disertacija, Ljubljana, Filozofska fakulteta.

Legan Ravnikar, Andreja, 2005, Izglagolske krščanske terminološke tvorjenke v slovenskih nabožnih priročnikih do srede 19. stoletja, Razvoj slovenskega strokovnega jezika, Obdobja 24 - Metode in zvrsti (v tisku).

Legan Ravnikar, Andreja, 2007a, O konverziji kot postopku knjižne (terminološke) tvorbe pri slovenskih protestantskih piscih 16. stoletja, Riječ, Časopis za slavensku filologiju, 13/2, Rijeka, 108-127.

Legan Ravnikar, Andreja, 2007b, Izsamostalniške krščanske terminološke tvorjenke v razvoju slovenskega knjižnega jezika, Slavistična revija 55/1-2, 191-209.

Merše, Majda, 1989, Izpridevniški glagoli v Dalmatinovi Bibliji, Slavistična revija 37/1-3, 189-200.

Merše, Majda, 1990, Jezikovne spremembe v Trubarjevih prevodih Nove zaveze, Razprave - Dissertationes, SAZU, Razred za filološke in literarne vede, 163-179.

Mikhailov, Nikolai, 1998, Frühslowenische Sprachdenkmäler, Die handschriftliche Periode der slowenischen Sprache (XIV. Jh. bis 1550), Amsterdam - Atlanta.

Novak, France, 2001, Kako so protestantski pisci 16. stoletja poimenovali nove pojme, 450-letnica slovenske knjige in slovenski protestantizem, Ljubljana, Slovensko protestantsko društvo in Znanstveni inštitut Filozofske fakultete, 103-120.

Novak, France, 2004, Samostalniška večpomenskost v jeziku slovenskih protestantskih piscev 16. stoletja, Zbirka Linguistica et philologica, Ljubljana, Založba ZRC, ZRC SAZU.

Novak, Vilko, 1988, Odzadnji slovar stare knjižne prekmurščine, Seznam besed hrani Sekcija za zgodovino slovenskega jezika ISJFR ZRC SAZU v Ljubljani (tipkopis).

Novak, Vilko, 2006, Slovar stare knjižne prekmurščine, Ljubljana, Založba ZRC, ZRC SAZU.

Orožen, Martina, 1996, Poglavja iz zgodovine slovenskega knjižnega jezika, (Od Brižinskih spomenikov do Kopitarja), Ljubljana, Filozofska fakulteta. 
$\hookrightarrow \quad$ Orožen, Martina (ur.), 2005, Tinjska rokopisna pesmarica, Zora 40, Maribor, Slavistično društvo.

Pleteršnik, Maks, 1894-1895, Slovensko-nemški slovar I-II, Ljubljana.

Premk, Francka, 2000, Posebni načini izražanja primerniške in presežniške mere pri slovenskih protestantih, Riječ 6/2, Časopis za filologiju, Rijeka, 77-91.

Rajh, Bernard, 2002, Od narečja do vzhodnoštajerskega knjižnega jezika, Zora 19, Maribor, Slavistično društvo.

Stabej, Jože, 1997, Slovensko-latinski slovar po: Matija Kastelec - Gregor Vorenc, Dictionarium latino-carniolicum (1680-1710), Ljubljana, Založba ZRC.

Stramljič Breznik, Irena, 1999, Prvostopenjske samostalniške izpeljanke iz pridevniških podstav v SSKJ, Prispevki iz slovenskega besedoslovja, Zora 7, Maribor, Slavistično društvo, 13-120 .

Toporišič, Jože (ur.), 1994, 1994, 1995, 1998, Stanislav Škrabec, Jezikoslovna dela $I-I V$, Nova Gorica, Frančiškanski samostan Kostanjevica.

Toporišič, Jože, 2000, Slovenska slovnica, Četrta, prenovljena in razširjena izdaja, Maribor, Obzorja.

Vidovič - Muha, Ada, 1986, Neglagolske tvorjenke v Trubarjevi Cerkovni ordningi, 16. stoletje v slovenskem jeziku, književnosti in kulturi, Obdobja 6, 349-374.

Vidovič - Muha, Ada, 1988, Slovensko skladenjsko besedotvorje ob primerih zloženk, Ljubljana, Partizanska knjiga, Znanstveni tisk.

Vidovič - Muha, Ada, 1989, Zgradba tvorjenk v Brižinskih spomenikih, Srednji vek v slovenskem jeziku, književnosti in kulturi, Obdobja 10, Ur. J. Toporišič, Ljubljana, Filozofska fakulteta, 51-62.

\section{Deadjectival Christian Terms in Literary Slovenian to the Mid-19th Century Summary}

This article discusses coined words for Christian terminology in literary Slovenian formed from adjectival bases from the mid-16th to the second half of the 19th century. Among extant medieval manuscripts (basic prayer forms), pre-literary Christian tradition was taken into account. Liturgical terms, which represent the oldest segment of Christian terminology, were separated from the basic religious manuals from this 300-year period. Comparative linguistic analysis demonstrates that coined terminology was formed following the most productive word-formative patterns and using affixal morphemes created in general vocabulary. In the word-formative semantic category of quality or condition, the most productive word-formative pattern is derivation using the suffix -ost (for example, milost 'grace', pobožnost 'piety', svetost 'holiness', and večnost 'eternity'); the second most productive affixal morpheme is -stvo (for example, blaženstvo 'beatitude', svetstvo 'holiness', and zveličanstvo 'redemption'). Other terminological coined words were formed using relatively unproductive affixal morphemes that could differ in the 18th-century regional literary versions; for example, -ina (krivina 'guilt') and -je (zveličanje 'redemption') in the central Slovenian literary language, 
or -ošča (milošča 'grace'), -ot (život 'life') in the Prekmurje literary language. Conversion is typical of deadjectival coined words in the word-formative semantic category of quality or condition (animate). Using this process, adjectives and adjectival participles were converted into nouns; for example, krivični 'the guilty', krotki 'the meek', mrtvi 'the dead', živi 'the living'; križani 'the crucified', očiščeni 'the purified', poklicani 'the called', and posvečeni 'the consecrated'. In terms of word formation, the most productive affix is the morpheme-ik, and derived terms in -ik also exhibit the most frequent use in the sample texts (for example, dolžnik 'debtor', grešnik 'sinner', martrnik 'martyr', and krščenik 'Christian'). The only competing affix is -ec, which was gradually replaced by the morpheme -ik in later periods; for example, mučenec instead of mučenik and močenik (all 'martyr'). In the same semantic category, derivatives with unproductive suffixes - for example, -nik (svetnik 'saint') and -ič (hudič 'devil') - show frequent use. In the remaining three word-formative semantic categories, coined Christian terms occur only exceptionally; for example, a place with the suffix -stvo (nebeško kraljevstvo/kraljestvo 'kingdom of heaven').

Andreja Legan Ravnikar Inštitut za slovenski jezik Frana Ramovša ZRC SAZU Novi trg 2, 1000 Ljubljana alegan@zrc-sazu.si 



\title{
Айконімы з асновай -сад- на ўсходнеславянскім этнамоўным абшары
}

\author{
Валянціна Лемцюгова (Minsk)
}

IZVLEČEK: V članku je prikazan proces formiranja vzhodnoslovanskih ojkonimov s podstavo -sad- (Сад, Садок, Сады, Садки, Новосады, Новосадки, Садовка, Самосадка, Садовая, Садовое). Ugotavlja se konkretna semantična motivacija ob upoštevanju posebnosti socialno-ekonomskega razvoja posameznih zgodovinsko izoblikovanih območij, določa se relativna kronologija njihovega nastan$k a$, prikazano in komentirano je območje njihove razprostranjenosti. Članek je opremljen s shematskim zemljevidom.

Toponyms with the Base -sad- in the East Slavic Ethnolinguistic Area

ABSTRACT: This article presents the process of forming East Slavic toponyms with the base-sad- (e.g., Сad, Садок, Caдbl, Садки, Новосады, Новосадки, Садовка, Самосадка, Садовая, Садовое). Concrete semantic motivation is established by taking into account special features of the socioeconomic development of individual historically formed areas. The relative chronology of toponym formation is defined, and the area of their distribution is presented and discussed. The article includes a schematic map.

На ўсходнеславянскай тэрыторыі з даўніх пор функцыянуе група ўласных геаграфічных назваў (айконімаў i мікратапонімаў) 3 карнявой марфемай $=c a d=$. Чым бліжэй да нашага часу, іх колькасць паступова змяншаецца. Як правіла, гэта назвы сельскіх паселішчаў (вёсак, хутароў, засценкаў), частка якіх ужо не існуе. Тым не менш толькі на тэрыторыі Беларусі зараз налічваецца каля сямідзесяці адзінак гэтага тыпу айконімаў у структурным афармленні Садок, Садкі, Садзішча, Садоўка, Садоуиччьна, Садкоўшчьна, Садавічы, Садовая. Амаль палову ўсіх назваў (33 адзінкі) складаюць назвы-кампозіты: Haвасада, Навасадbl, Нaвасядbl. У купе з мікратапонімамі іх колькасць можа памножыцца. Але паколькі немагчыма раўнамерна сабраць мікратапонімы на ўсёй усходнеславянскай тэрыторыі, абмяжуемся ў артыкуле толькі айконімамі. I не сучаснымі, а засведчанымі “Списками населенных мест Российской империи” і другімі спіскамі аналагічнага характару, якія не ўвайшлі ў гэтую 
$\hookrightarrow \quad$ серыю (гл. Крыніцы). Храналагічны зрэз іх фіксацыі - другая палова XIX - першая палова XX ст. У “Списках” усходнеславянскія айконімы з асновай $=c a d=$ не толькі колькасна больш шматлікія, але і больш разнастайныя паводле структурнага афармлення.

Сярод іх выдзяляецца група назваў у форме Cad, Caдbl, Садок, Садки (аднаслоўныя ці з азначальным кампанентам). Нярэдка яны суправаджаюцца лексічнымі і марфалагічнымі варыянтамі: Красный Сад, к. Вн., Ореховатский Сад Большой, д. Кв., Ореховатский Сад Мальй, д. Кв.; Кривобузанское (Пушкин-Сад, Крымно), с. при р. Кривом Бузане и Крылиной Астр.; Caдbl, д. Віл., д. Вн., д., им. Гр., х. Мг., д. Мк.; Садок, х. при рч. Садках Ек., д. Пр., Садок (Вошеваки-Кудтенок, Кутченок), д. См., Подскудская (Садок, Харина), д. Пр.; Верхний Садок, д. Кр., Нижний Садок, д. Кр.; Садки, д. Віц., с. Вн., д. Вн., д. Ек., сц. Кж., д. Кв., к. Кв., д., ф. (2), им., х. (2) Мн., с., пдм. Пд., д. Пл., д. (3) Пск., д. Смр., д. Сб., д. (2) См., д. Тб., сц. Тл., д. Хрк.; Садки (Лопасня), с. при р. Лопасне Мк., Гредякина (Садки), сл. Вр., Знаменское (Садки), с. Мк., Ивановское (Садки), с. Мк., Крутеи (Садки), д. Нж., Пановка (Садки), сц. Кз., Чесманская (Садки), дача Мк.; Садки Новые, д. Нж., Большие Садки, к. Вн., малье Садки, с. Вн., к. Вн., Новые Садки, д. Цв., Шпиков (с предместьем Садками Шииковскими), м. Пд.

Пры адносна невысокай канцэнтрацыі прыведзеныя назвы накладваюцца на велізарную прастору, якая суцэльнай паласой працягнулася з захаду на ўсход, з крайняга поўдня да лініі Ноўгарад - Пскоў - Кастрама - Вятка - Перм на поўначы. Гэта сведчыць пра тое, што назвы 3 асновай $=c a d=$ глыбока пусцілі карані ва ўсходнеславянскі моўны грунт. Асаблівай словаўтваральнай актыўнасцю яны вызначаліся ў старабеларускай мове, дзе засведчана найбольшая колькасць вытворных лексем ад асновы = cad= у форме назоўнікаў і дзеясловаў. Тым не менш тапанімісты не праяўляюць да іх асаблівай цікавасці. Звычайна за аб'ект даследавання імі абіраюцца мікратапонімы, якія часам нават без спасылкі на факты зводзяцца да апелятыва сад (садок) 'фруктовыя насаджэнні’ (МБ: 216; ММП: 172). Гэтае значэнне слова сад з тымі ці іншымі нюансамі вядомае ўсім славянскім мовам (гл. бел., укр., руск., серб., блг. сад, польск., славен. sad). Безумоўна, для нейкай часткі назваў усходнеславянскіх паселішчаў яно магло паслужыць у якасці матывавальнага. Прычым, спачатку назва павінна была б замацавацца за полем ці урочышчам 3 фруктовымі насаджэннямі і толькі пасля іх засялення перайсці на паселішча. У іншым выпадку спярша трэба было б заводзіць сад, а потым засноўваць паселішча, што супярэчыць прынятай практыцы. Таму цяжка ўявіць сабе такі працяглы арэал айконімаў 3 семантычнай матывацыяй 'фруктовыя насаджэнні'. У нейкай ступені можна дапусціць магчымасць матывацыі асобных тапонімаў Caдbl прозвішчам Сад, вядомым у беларусаў і уукраінцаў [Шульгач: 121], а тапонімаў Садок, Садкі - апелятывам садок у значэнні 'штучны вадаём для развядзення рыбы', ‘пастка на звяроў і птушак', засведчаным ва ўсіх усходнеславянскіх мовах. Кожнае 3 прыведзеных значэнняў патэнцыяльна магло быць задзейнічана ў працэсе ўтварэння айконімаў, але ж не ў такім масавым парадку. 
Звяртае на сябе ўвагу выяўленая ў старабеларускіх пісьмовых крыніцах лексема $c a \partial z$, якая служыла назвай царкоўнай зямлі, на якой сялілі (“садили”) парабкаў [Шадурскі]. 3 невялікага кантэксту раздзельнага акта XVI в. вынікае, што $c a \partial ь$ - гэта дзялянка аселай зямлі, сядзіба: $A$ ку тому з делу ровного, вечистого досталосе брату моему, пану Фёдору, на Суходорове село Совостьяновское и другое село Борисовщина з людми осельми и со всякими пожитками, яко се в собе маеть... селищами, з будованьемь, кгрунть пашныли, сеножатми и обаполь реки Суходорови ... досталосе брату моему, пану Фёдору, два сады - Борисовщина и Дворище со всякими пожитъками, што ку тымь землямь належить, с чоловекомь осельмъ, до того река Черница... (ИЮМ, ХХ: 379; 1594). У паўднёва-ўсходняй дыялектнай зоне Беларусі слова сад засведчана не толькі ў сэнсе 'фруктовыя насаджэнні', а і ў сэнсе 'месца, дзе раней жылі людзі'. Гэтыя значэнні развіліся на аснове семантыкі дзеясловаў садити 'сяліць, пасяляць', посадити 'пасяліць', якія даволі шырока фіксуюцца старабеларускімі, стараўкраінскімі і старарускімі пісьмовымі крыніцамі. Прывядзем некалькі кантэкстаў: и мы пожаловали его и дали есмо ему тыи дворища самому пахати и люди садити (АЛМ: 12; 1454); землю они распахали и чоловека своего нанове посадили (КПД: 158; 1496); он тьхх людей своихъ Олекъсичъ с того села ихъ звель и посадиль ихъ на пущи (АЛРГ: 73; 1390); на пустоши техъ земель посадять людей (АЮБ I: 109 - 110; 1499); на врочисиу Ходлинь моркговъ петнадцать, на которомъ кгрунть их подданый съдит, на име Иван (АВАК II: 55-56, 1628 - 1629).

Нярэдка садить, посадить азначала 'засноўваць на новым месцы (пра паселішча): допустили садити село Княжую Луку на сыромъ корени (АЗР I: 22; 1383); на лесу на чорномъ на дичи ... посадиль деревню Малцово (АГДР I: 97; XV в.); садити село (СлСУМ I; 1377); починокъ посаженъ на льсу Кочевинские пустоши (Арх. Стр. I: 88; 1490). Паселеныя на зямлі ўласніка сяляне ў старажытнасці называліся “садокамі” [Дьяконов: 15], сяляне, якія знаходзіліся на аброку - “осадниками” [Новицкий: 110]; заснавальнікі сялянскіх паселішчаў - “садчиками” [Рубцова: 246].

Прыведзеныя кантэксты і наяўнасць некалькіх суадносных 3 дзеясловам садити субстантываў нагадваюць пра існаванне ў мінулым лексемы садъ, якая абазначала паняцце 'новаасаджанае паселішча'. А яшчэ больш важкім доказам гэтага з'яўляюцца выяўленыя пры даследаванні данскіх помнікаў XVIII ст. апелятывы садок, садки 'пасёлак на новым месцы' [Рубцова: 245]. Па сведчанні даследчыцы, паселішчы з такімі назвамі ўзнікалі па ініцыятыве “садчиков” і імянітых данскіх старшын. Слабада Садки Краснощзоковых у речки Кондрючей, напрыклад, была заснавана сямействам Краснашчокавых, якое “пасадило” тут падуладных яму ўкраінскіх сялян. Значыць, апелятыў садки як тып паселішча функцыянаваў у мовах усходнеславянскіх народаў яшчэ ў час засялення данскіх прастораў (XVII - XVIII стст.). На Дон яго занеслі перасяленцы з заходніх, паўднёва-заходніх ці больш паўночных рускіх абласцей. На перыферыі ва ўмовах першапасялення ён аказаўся прыдатным у практыцы земляробаў.

У той час, калі на Доне апелятывы садок, садки толькі ўваходзілі ва 
- ўжытак, на асвоеных усходнеславянскіх землях яны па сутнасці страцілі сваю функцыю і трапілі ў разрад нежыццядзейных. У XV - XVII стст. лексема сaдъ i вытворныя садокъ, садки нярэдка фіксуюцца ва ўсходнеславянскіх пісьмовых помніках ужо ў якасці ўласных назваў паселішчаў і іншых геаграфічных аб’ектаў. Напрыклад, сяло Садки на Валыні (1478 г. - СлСУМ); деревня Нижний Садъ, деревня другая Верхний Садъ (АИ II: 307; 1556); nустошь, что была деревня Садъ (ПКМГ I: 211; XVI ст.); половина деревни Садковъ (A3P IV: 352; XVI ст.); деревня Сад Монастырской (ОПКМ: 183; XVII ст.); пустошь Caдbl (A3P IV: 361; 1610); пустошь Садки (ОПКМ: 144; XVII ст.). Асабліва частыя назвы 3 асновай $=c a \partial=$ у пісцовых кнігах XVI ст., якія адносяцца да беларускай этнамоўнай тэрыторыі. Сярод іх шмат назваў урочышчаў: $y p$. Садъ (ПКПКК: 160, 190, 274); ур. Долгій Садъ села Кущчичъ (там жа: 285); ур. Старый Садъ в Клечкомъ повете (там жа: 561); ур. Садокъ дворищъ Сечковичъ, Панкратовичъ, Воробъевщизнь (там жа: 183, 203, 207); ур. Садокъ дворищъ и трехъ сель (ПКПС ІІ: 220, 314, 316, 318, 328, 430); ур. Садки села Купятичь (ПКПКК: 323, 327); ур. Садовищи (ПКПС II: 372). Падобна, што уурочышчы 3 такімі назвамі ўзніклі на месцах запусцелых дробных пасёлкаў (садоу і садкоў), пасяленцы якіх “садились на нови”, на падсецы (“сыромъ корне”). Звычайна такія паселішчы ў старажытны перыяд былі нядоўгавечнымі. Праз 2-3 гады зямля знясільвалася і трэба было перабірацца на новае месца.

На заходняй акраіне ўсходнеславянскага арэала айконімаў Сад, Садок, $C a d b l, C a \partial \kappa i$ склаўся астравок з 90 назваў-кампозітаў, у якіх =cad= з'яўляецца толькі адным з кампанентаў: Новосада, д. Віл.; Новосады, д. (7), ф. (4), им., 3. (13), выс. (2) Віл.; з. Віт.; д. (9), им. Гр.; д. (10), ф. (2), з. (4), ус., х. (2) Квн.; д. (3), ф. (3), им. (2), з. (2), х. (2) Мн.; Новосады І, д. Квн., д. Мн.; Новосады II, д. Квн., д. Мн.; Новосяды, д. (3), ус. (6) Віл.; пос. Квн.; Новосяды І, д. Віл., Новосяды II, д. Віл.; Новосадки, д. Гр. Сюды прымыкае арэал польскіх назваў Nowosady. Найперш гэта Беластоцкае ваяводства (былая тэрыторыя Беларусі), powiaty Augustów, Białowieża, Białystok, Bielsk, Sejny і іншыя.

Тапанімічныя кампозіты Hoвосады, Новосадки не маюць прамых апелятыўных адпаведнікаў. Яны сфарміраваліся на базе словазлучэнняў новы сад, новы садок (ці новыя садкі) 'паселішча новапасаджаных сялян; новы сад $($ (садок)', па той жа мадэлі, што і Новосёлки. У старабеларускіх пісьмовых помніках нярэдка можна сустрэць роднасны гэтым тапанімічным утварэнням дзеяслоўны кампозіт новоосадити 'пасяліць (пасадзіць) на новым месцы' і двухслоўны тэрмін новоосаженное село, якія склаліся на той жа матывацыйнай аснове, што і айконімы-кампозіты. Напэўна, няма патрэбы даказваць, што гэтыя айконімы не маюць нічога агульнага $з$ апелятывамі сaд, садок у сэнсе ‘фруктовае насаджэнне'. Не праглядваецца і сувязь з беларускімі і ўкраінскімі прозвішчамі Навасад, Навасяд у значэнні 'навасёл', паколькі большасць беларускіх тапонімаў зарэгістравана ў пісьмовых помніках XVI - XVII стст., г. зн. яшчэ да часу з'яўлення прозвішчаў. Ёсць тыпы назваў паселішчаў, для якіх не існуюць ні апелятыўныя, ні антрапанімныя прататыпы. Да іх ліку належаць і айконімы-кампозіты Новосада, Новосады, Новосадки, Новодворы, Нововоля, Новосёлка, Новосёлки. 
У пісьмовых крыніцах назвы-кампозіты адзначаюцца 3 другой паловы XVI ст. у розных раёнах беларускай этнамоўнай тэрыторыі: Hoвосады, село и остров-урочище под г. Клецком (ПКПКК: 401 - 402; 1552 - 1555); Коповище въ Новосадахъ - селе пана Троикого (АВАК XVIII: 89; 1590); въ сель Новосадкахъ (A3P IV: 352; XVI - XVII стст., Смоленский уезд); село Новосады (ABAK VI: $543 ; 1749)$. Пазней (XIX - пачатак XX ст.) беларускія населеныя пункты 3 такімі назвамі лакалізуюцца выключна ў пяці былых губернях - Віленскай, Віцебскай, Гродненскай, Ковенскай і Мінскай на беларуска-польскім памежжы. Пытанне ў тым, ці з'яўляюцца гэтыя назвы па прыродзе сваёй беларускімі, аўтахтоннымі, ці запазычанымі ў суседніх палякаў. Безумоўна, на станаўленне беларускіх айконімаў ў пэўнай ступені паўплывалі польскія асаднікі, бо памежныя раёны Беларусі, як і Украіны, уяўлялі найбольшую цікавасць для каланістаў. Але тлумачыць польскім уплывам усе без выключэння беларускія назвы-кампозіты беспадстаўна. Як ужо ўказвалася вышэй, у старажытны перыяд кампозіты Hовосады, Новосадки мелі значна больш шырокую геаграфію, куды польскія каланісты не пранікалі. Таму зусім пэўна можна гаварыць пра наяўнасць уласнабеларускай кампозітнай мадэлі.

Беларускія кампозітныя тапонімы маюць аналагі не толькі ў тапаніміі Польшчы, але і ў тапаніміі іншых славянскіх краін. Напрыклад, Новосад у Славакіі, Нови-Сад - сталіца Ваяводзіны ў былой Югаславіі. С.Іосіфавіч устанавіў, што сучасная назва Нови-Сад у старажытны перыяд мела форму Новосад. На яго думку, апошняя ўзнікла на базе дыялектнага апелятыва новосад 'новае насаджэнне', які ў айканіміі ўжыты ў пераносным сэнсе ‘новазаснаваны горад’ [Јосифовић Стеван: 183 - 184].

На паўднёвай ускраіне арэала невялікі астравок склалі айконімы ў форме субстантаваных прыметнікаў: Садовая, с. Астр., д. (2) Вр., д. Ек., з. (2) Квн., сл. Мк., Садовая (Мандрыковка), д. Хр.; Садовае, с. (2) Вр., с. Хрс. Несумненна, назвы гэтага тыпу ўтвораны ад той жа асновы $=c a \partial=$, але тут яны падпалі пад уздзеянне мясцовай традыцыі, паводле якой любая новая назва паселішча павінна была ўпісвацца ў прынятую мясцовую сістэму. Таму пачатковая форма назвы рэдка прыжывалася адразу. Да прыкладу, упамянёны вышэй айконім Садки Краснащзокава (ЗВД) у “Списках” значыцца як Садковская Краснощуова, а хутор Садки Садковский Хутор) - як хутар Садковский.

На крайнім паўднёвым усходзе сфарміраваўся астравок назваў у форме Садовка. Частка іх суправаджаецца варыянтамі: Садовка, д. (5) Срт., д. Сб., Смр., Садовка (Садовая, Маховка), д. См., Садковская Слобода (Садовка), д. См., Терновка (Садовка), д. Тб., Мардовская Садовка, д. Пз., Русская Садовка, сц. Пз. Структура гэтых назваў магла таксама сфарміравацца пад уздзеяннем рэгіянальнай тапанімічнай сістэмы, у прыватнасці, пад уплывам надзвычай папулярных на поўдні і паўднёвым усходзе назваў на $=$ овка, =евка тыпу Кукуевка, Михайловка, Тимофеевка. Але не выключана, што іх прынеслі сюды перасяленцы з захаду. Як відаць з прыведзенага спісу, назва Садовка двойчы значыцца на Смаленшчыне.

Зрэдку трапляюцца назвы ў афармленні пасэсіўных фармантаў -ов, -ово: Садков, х. при рч. Сале (ЗВД), Садова, с. Пд. Матывацыю гэтых назваў 
$\hookrightarrow$ нельга звесці толькі да вынікаў асіміляцыі мясцовай тапанімічнай сістэмай. У хрысціянскім іменаслове ёсць уласнае асабовае імя Садок (са стараяўр. шадок 'быць праведным, справядлівым'), а ў беларусаў і ўкраінцаў засведчаны прозвішчы Сад, Садовіч, Садоўскі, Садзік, у рускіх - Садов (магчыма ад імя Cad, якое ў дадзеным выпадку з'яўляецца скарочанай формай імя Садок). Менавіта ад антрапоніма Сад выводзіцца этымалогія ўкраінскага айконіма Caдiв, вядомага $з$ першай паловы XVI ст. як Sadowo - 1514, “имение Caдово” - 1554, Sadow - 1552, “въ Садове” - 1649, Sadow - 1778 [Шульгач: 121].

Праведзены аналіз паказвае, што арэал айконімаў, які наклаўся больш як на палову ўсходнеславянскай тэрыторыі, у цэлым сфарміраваўся на адзінай матывацыйнай аснове (сад 'паселішча новапасаджаных сялян'). Маштабы арэала, наяўнасць лакальных асаблівасцей у структуры айконімаў сведчаць пра тое, што працэс станаўлення айконімаў быў працяглым у часе, што пры агульнай матывацыі ён рэгуляваўся своеасаблівасцю і ўзроўнем сацыяльна-эканамічнага развіцця асобных рэгіёнаў.

У арэале выразна дамінуюць аднаслоўныя назвы Сад, Садок, Садки або 3 азначальнымі кампанентамі тыпу Сад Большой, Нижний Садок, Новые Садки. Большасць іх лакалізавана ў беларускай і ўкраінскай этнамоўных зонах. Менавіта ў губернях Віленскай, Віцебскай, Гродзенскай, Магілёўскай, Мінскай, Смаленскай і ў Екацярынаслаўскай, Кіеўскай, Падольскай. За ix межамі арэал працягваецца ў Беластоцкім ваяводстве, а затым і на ўласнапольскіх землях. Польскія назвы таксама старажытныя, як і беларускія і ўкраінскія. Некаторыя з іх засведчыліся ў пісьмовых крыніцах нават раней за ўсходнеславянскія. У другой палове XIII ст. у Позненскім і Тухольскім паветах упамінаюцца весь і фальварак Sady, у Вырыскім - асада Sadki, у Адаланоўскім - весь Sadowie, у XV ст. у Концкім - весь Sadek (SG, t. 10). Таму на першы погляд складваецца ўражанне, што ўсходнеславянскія $\mathrm{Cadbl}$ і Садки паводле свайго паходжання з'яўляюцца польскімі. Аднак, як ужо падкрэслівалася вышэй, у старабеларускай і стараўкраінскай мовах была адпаведная база для ўтварэння такіх назваў. Тым не менш пэўную ролю ў працэсе ўзнікнення айконімаў гэтага тыпу палякі ўсё ж адыгралі. У складзе Вялікага княства Літоўскага беларускія і ўкраінскія землі паступова ўцягваліся ў сферу ўласцівых для Літвы і Польшчы формаў землеўладання. У выніку на фоне буйнога княжацкага і панскага землеўладання хутка развілося прыватнае панска-шляхецкае землеўладанне, дзякуючы якому на беларускіх і украінскіх землях (асабліва ў заходніх абласцях) шырокае развіццё атрымала дваравая шляхецкая гаспадарка. Побач $з$ вялікакняжацкімі дварамі вырасталі двары панскія, баярскія, а таксама двары польскай і мясцовай шляхты. Паявіліся фальваркі, найбольшая колькасць якіх прыпала на заходнюю Валынь, Берасцейшчыну, Галіччыну і Заходнюю Беларусь. Кожны земляўласнік імкнуўся прывабіць у свой маёнтак як мага больш насельнікаў. 3 гэтай мэтай слабодчыкі і польскія асаднікі вялі актыўную дзейнасць па “прысадзе” новых людзей. Шырока практыкавалася раздача пусташаў. У выніку ўзнікала маса сялянскіх пасёлкаў-асабнякоў, сярод якіх, як высветлілася, былі і caдbl (caдкі). Так што можна гаварыць пра агульны, беларуска-ўкраінска-польскі характар 
усходнеславянскіх садоў і садкоў, асноўным імпульсам для якіх паслужыла дваравая гаспадарка, што, на думку Ф.Леантовіча, фарміравалася пад польскім уплывам. У параўнанні з вялікакняжацкімі і буйнымі вотчыннымі дварамі Паўночна-Усходняй і Паўночна-Заходняй Русі ва ўмовах Вялікага княства Літоўскага і Рэчы Паспалітай панска-шляхецкі двор сапраўды меў некалькі адметных рысаў. Ён, як і фальварак, будаваўся адасоблена ад астатніх паселішчаў і з'яўляўся не толькі сядзібай, але і месцам пражывання, населенай часткай землеўладання, пасёлкам. Разам з тым складаў галоўную, цэнтральную частку зямельнай і любой іншай уласнасці. Але чаму тады сады і садкі так сціпла абазначыліся ў старабеларускіх і стараўкраінскіх пісьмовых крыніцах? Найперш таму, што гэта ў сваёй большасці былі дробныя пасёлкі людзей падданых: прыгонных, парабкоў, бабылёў, кутнікаў, якія траплялі ў афіцыйныя рэестры надзвычай рэдка.

Усходнеславянскі арэал айконімаў з асновай $=c a d=$ нельга разглядаць як адзіны, непадзельны з пункту гледжання прынцыпаў фарміравання тапаніміі. У яго ёсць ядро і перыферыя.

Ядро арэала, несумненна, сфарміравалася на беларускай і ўкраінскай этнамоўных тэрыторыях. Пра гэта сведчыць не столькі іх колькасная перавага, колькі той факт, што тут айконімы 3 асновай $=c a d=$ у найбольшай ступені захавалі зыходнае структурнае аблічча матывавальных апелятываў (Cad, Cadbl, Садок, Сaдкі). Менавіта на гэтыя тэрыторыі прыпадае самая вялікая колькасць айконімаў, матываваных іншымі назвамі сялянскіх паселішчаў 3 асновай $=c a d=$ : осада, посада, посады, подсады, присады, присадки, пересады. Усе яны знайшлі адлюстраванне ў айканіміі: Ocaда Вил., Ocaды Мг., Подсадье Вит., Мг., Подсады Вил., Мн., Присады Мн., Пересады Мн. і інш. Старабеларускія і стараўкраінскія пісьмовыя помнікі месцяць шмат роднасных ім дзеясловаў тыпу осадити, посадити 'пасяліць', подсадити, присадити 'падсяліць'. Да ўсяго трэба дадаць, што беларускія і ўкраінскія айконімы структурна простыя, выразна акрэсленыя і безварыянтныя. А гэта ёсць адзнака іх працяглай у часе апрацоўкі, тапанімічнай “сталасці” і дасканаласці.

Айканімія астатняй часткі арэала носіць адзнакі, характэрныя для перыферыі.

Паўднёвая сцяпная ўскраіна - край адносна позняга засялення. Пачатак яго каланізацыі звязаны з паяўленнем у сярэдзіне XVII ст. рускіх вартавых пастоў і паселішчаў вольных казакоў. Пасля ўзвядзення "Белгородской черты” і прыняцця захадаў па бяспецы месцаў пражывання прыток сюды славянскага насельніцтва прыкметна ажывіўся. На “вольныя” землі больш актыўна пацягнуліся і рускія перасяленцы, галоўным чынам 3 суседніх уездаў Расіі - Варонежскага, Тамбоўскага, Разанскага. А ў 20-х гадах XVII ст. перасяленне на Дон украінцаў набывае масавы характар. Сярод іх было шмат беларусаў. Адны $з$ іх прыбылі сюды непасрэдна з Беларусі, а другія - праз Украіну, куды яны ў XVI - XVII ст. эмігравалі ў пошуках лепшай долі. За кошт перасяленцаў хутка папаўняліся рады казакоў. 3 ліку беларусаў былі не толькі радавыя службоўцы, але і казацкія атаманы. Неўзабаве тут з'явіліся буйныя землеўладальнікі. Яны захоплівалі вялікія зямельныя прасторы і “осаживали” 
- на іх сваіх прыгонных сялян. Шырока практыкаваліся пасяленні людзей на ільготных умовах. Як вынік гэтага ў межах панскіх займішчаў з’явілася мноства дробных пасёлкаў - слабод, пачынкаў, калоній, садкоў. Традыцыйным казацкім паселішчам заставаўся гарадок, а з пачатку XVIII ст., калі гарадкі страцілі значэнне вайсковых умацаванняў, - станіца. Такім чынам, тапанімія паўднёвай сцяпной ускраіны фарміравалася ў асноўным на базе “прышлага" элемента.

Перыферыю нагадвае і ўсходняя (руская) частка арэала. Чым далей на ўсход, тым радзей трапляюцца назвы з асновай $=c a d=$. У параўнанні з назвамі зоны ядра яны вылучаюцца больш ускладненай структурай, значна часцей вар'іруюцца, што характарызуе іх як перыферыйныя. Асноўная большасць назваў сканцэнтравана на акраінных землях, у цэнтральных губернях яны зусім рэдкія. I, відаць, невыпадкова. На ўскраінах заўсёды было больш незанятай зямлі, не ўся яна была ў руках феадалаў. Таму тут пасяленцы мелі магчымасць асесці самастойна, пра што выразна сведчаць назвы Самосадка Сб., Самосадки Пр. Найбольш верагодна, што іх, як і назву Садовка, прынеслі сюды перасяленцы з захаду, бо “Списки” фіксуюць два айконімы (Самосадки) у Віцебскай губерні і адзін (Самосядки) - у Магілёўскай. Дакладны час 3'яўлення на ўсходзе назваў $з$ асновай $=c a \partial=$ вызначыць складана, паколькі каланізацыйны рух 3 заходніх зямель з большай ці меншай інтэнсіўнасцю адбываўся здаўна, пачынаючы 3 XIII ст. Арэал, які сфарміраваўся на базе гэтых назваў, з'яўляецца адбіткам вольнай сялянскай каланізацыі неасвоеных ўсходнеславянскіх зямельных прастораў.

\section{Літаратура}

Дьяконов М, Очерки из истории сельского населения в Московском государстве (XVI-XVII вв.), СПб, 1899.

Јосифовић Стеван, О постанку назива Neoplanta, Зборник за филологију и лингвистику, Нови Сад, 1957, Т. 1.

Леонтович Ф., Крестьянский двор в Литовско-Русском государстве, ЖМНП, СПб, 1896, № 2 .

Новицкий И., Очерк истории крестьянского сословия Юго-Западной России в XV-XVIII веке, Киев, 1876.

Рубцова 3.В., Из истории донской топонимии, “Историческая ономастика”, М., "Наука", 1977.

Шадурскі І.В., Сельскагаспадарчая лексіка ў старабеларускай пісьмоваймове: Дыс. канд. філал. навук, Мн., 1967.

Шульгач В.П., Ойконімія Волині, Етимологічний словник-довідник, Київ, "Кий”, 2001. 


\section{Крыніцы}

Списки населенных мест Российской империи, СПб, 1859- 885.

Виленская губерния. Полный список населенных мест, Сост. И. И. Гошкевич, Вильно, 1905.

Список населенных мест Витебской губернии, Под ред. А. П. Сопунова, Витебск, 1906.

Список населенных мест Вольнской губернии, Житомир, 1911.

Список населенных мест Киевской губернии, Киев, 1900.

Список населенных мест Минской губернии, Сост. В.С.Ярмолович, Минск, 1909.

Список населенных мест Могилевской губернии, Под ред. Г. П. Пожарова, Могилев, 1910.

Список населенных мест Новгородской губернии, Новгород, Вып.1, 1907; вып. 10, 1912; вып. 11, 1912.

Указатель населенным местам Гродненской губернии. Гродно, 1905.

Крылов А., Населенные места Подольской губернии, Каменец - Подольск, 1905.

\section{Прынятыя скарачэнні}

АВАК - Акты, издаваемые Виленскою археографическою комиссиею, Вильна, 1865-1915, T. 1- 9.

АГДР - Акты, относящиеся до гражданской расправы древней Росии. - Киев, 1860-1865, T. 1-2.

АЗР - Акты, относящиеся к истории Западной Росии. - СПб, 1846-1853. Т. $1-5$.

Арх. Стр. - Архив П.М.Строева, Пг., 1915-1917, Т. 1-2.

АИ - Акты исторические, собранные и изданные Археологическою комиссиею (1334-1548), СПб, 1841-1842, Т. 1-5.

АЛМ - Акты Литовской метрики (1413-1498), Варшава, 1896, Т. 1, вып. 1.

АЛРГ - Акты Литовско-Русского государства (1390-1529), М., 1899, вып. 1.

АЮБ - Акты, относящиеся до юридического быта древней России, СПб, 1857-1884, T. 1-3.

ИЮМ - Историко-юридические материалы, извлеченные из актовых книг губерний Витебской и Могилевской, Витебск, 1871-1906, Т. 1-32.

КПД - Литовская метрика. Книга публичных дел. //РИБ. Юрьев, 1914, Т. 30. КСДР - Картотека словаря Древнерусского языка XI-XIV вв. (Москва, Ин-т рус. яз. РАН).

МБ - Мікратапанімія Беларусі, Мінск, “Навука і тэхніка”, 1974.

ММП - Иванова А.А., Микротопонимия Мозырского Полесья, Мозырь, 2003.

ОПКМ - Обозрение писцовых книг по Московской губернии с присовокуплением краткой истории древнего межевания, М., 1840. 
๑ ПКМГ - Писцовые книги Московского госудаства. Ч. 1, отд. 1, СПб, 1872, Ч. 2, отд. 2, СПб, 1877.

ПКПКК - Писцовая книга Пинского и Клецкого княжеств (1552-1555), Вильна, 1884.

ПКПС - Писцовая книга бывшего Пинского староства, Вильна, 1874, Ч. 1-2.

СлСУМ - Словник староукраінськоі мови XIV-XV стст., Київ, 1977-1978, Т. $1-2$.

SG - Słownik geograficzny Królewstwa Polskiego i innych krajów słowiańskich, Warszawa, 1880-1904, T. 1-15.

\author{
Астр. - Астраханская \\ Віл. - Віленская \\ Віц. - Віцебская \\ Вн. - Валынская \\ Вр. - Варонежская \\ Гр. - Гродзенская \\ Ек. - Екацярынаслаўская \\ ЗВД - Зямля войска Данскога \\ Кв. - Кіеўская \\ Квн. - Ковенская \\ Кр. - Курская \\ Мг. - Магілёўская \\ Мк. - Маскоўская \\ Мн. - Мінская \\ Нж. - Ніжагародская
}

\section{Губерні}

Пд. - Падольская

Пз. - Пензенская

Пл. - Палтаўская

Пр. - Пермская

Пск. - Пскоўская

Сб. - Сімбірская

См. - Смаленская

Смр. - Самарская

Срт. - Саратаўская

Тб. - Тамбоўская

Тл. - Тульская

Хр. - Харкаўская

Хрс. - Херсонская

Цв. - Цвярская

\section{Тыпы паселішчаў}

выс. - выселак

д. - дзярэўня

3. - засценак

им. - іменіе

к. - калонія

м. - мясцечка пдм. - прадмесце

с. - сяло

сл. - слабада

сц. - сяльцо

ус. - усадзьба

х. - хутар 


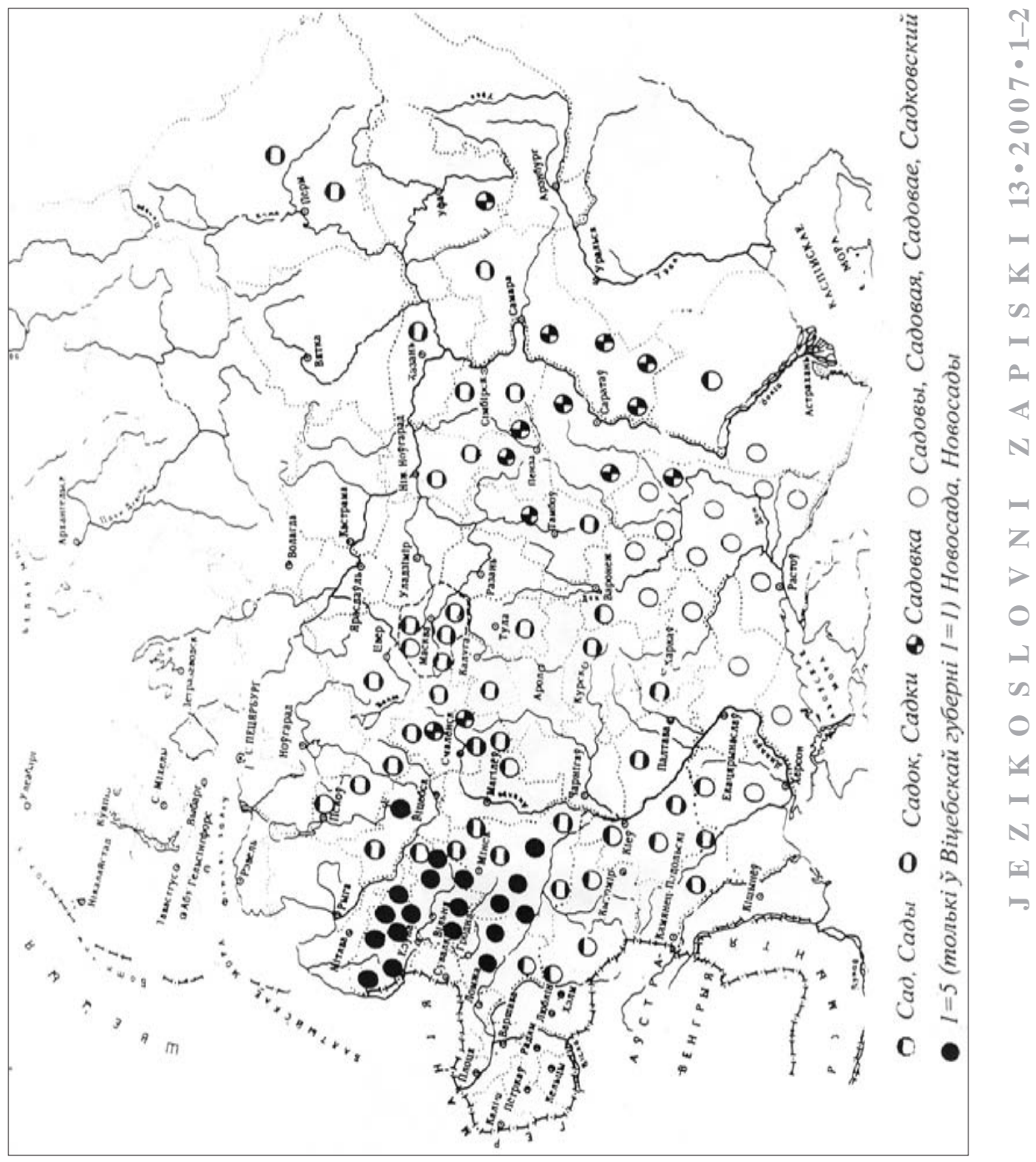

\section{Ojkonimi s podstavo -sad- v vzhodnoslovanskem etnojezikovnem prostoru}

Povzetek

Včlanku je prikazan proces formiranja vzhodnoslovanskih ojkonimov s podstavo -sad- (Сад, Садок, Сады, Садки, Новосады, Новосадки, Садовка, Самосадка, Садовая, Садовое). Ugotavlja se konkretna semantična motivacija ob upoštevanju posebnosti socialno-ekonomskega razvoja posameznih zgodovinsko izoblikovanih območij, določa se relativna kronologija njihovega nastanka, prikazano in komentirano je območje njihove razprostranjenosti. Na podlagi pisanih virov, pričevanja 
$-\quad$ sodobnih narečij in toponimskih podatkov se dokazuje, da so se vzhodnoslovanski [.] ojkonimi s podstavo-sad-izoblikovali na podlagi občnih imen sad, sadok v pomenu N 'naselje novonasajenih podložnikov'. Pretežna večina teh imen je osredotočena v $-\quad$ okviru beloruskega in ukrajinskega etnojezikovnega prostora, ki tudi predstavlja 거 jedro vzhodnoslovanskega areala, ki ima svoje nadaljevanje na ozemlju Poljske. - Proces nastajanja jedra in periferije areala spremlja vrsta posebnosti. Članek je us opremljen s shematskim zemljevidom.

Valjancina P. Lemcjugova g. Minsk 220100, vul. Kul'man, 15-175, Belarus' ira175@tut.by 


\title{
Rzekoma archaiczność obszarów peryferycznych
}

\author{
Witold Mańczak (Krakov)
}

IZVLEČEK: Leta 1974 je poljski jezikoslovec Z. Stieber objavil članek, $v$ katerem je prišel do ugotovitve, da je število arhaizmov na obrobjih bolj ali manj enako številu inovacij, toda do svoje smrti leta 1980 si ni drznil povedati, da je Bartolijevo načelo napačno. Namen tega članka je predstaviti dokaze, da je Bartolijevo ,pravilo” napačno.

\section{The Pseudo-archaic character of lateral areas} ABSTRACT: In 1974, the Polish linguist Zdzisław Stieber published an article in which he arrived at the conclusion that in peripheral areas the number of archaisms is more or less equal to innovations. However, until his death in 1980, he dared not contradict Matteo Bartoli's principle. This article presents arguments to show that Bartoli's "norm” is false.

W r. 1974 Z. Stieber opublikował artykuł pt. O archaizmach i innowacjach peryferycznych, w którym napisał między innymi, co następuje:

Od dawna już panuje pogląd, że archaizmy utrzymują się głównie na peryferiach różnych obszarów językowych, zaś innowacje szerzą się z obszarów centralnych. Jak wiadomo, pogląd ten propaguje szczególnie silnie włoska szkoła „neolingwistyczna".

Oczywiście nie można negować istnienia archaizmów peryferycznych. Przykładów z różnych obszarów językowych podano już wystarczająco dużo. Dodajmy tu jeszcze jednak parę przykładów słowiańskich. Jak wiadomo, centrum słowiańskiego obszaru językowego objęła zmiana zwartego $g$ na szczelinowe $h$, która zaszła najprawdopodobniej w XIII w. Objęła ona cały obszar czesko-słowacki, obszary górnołużycki, ukraiński i białoruski, wreszcie dialekty południoworosyjskie i północno-zachodnie dialekty słoweńskie a także część czakawskich. Zmiana ta nie zaszła jednak na trzech wielkich peryferiach: 1) lechicko-dolnołużyckiej, 2) północnorosyjskiej, 3) południowosłowiańskiej (poza wymienionymi wyżej dialektami) ...

Ale czy nie istnieją także innowacje peryferyczne? Istnieją, a jest ich tak wiele, że przykładami można sypać jak z rękawa. Typowymi innowacjami peryferycznymi są przecież „bałkanizmy”, jak zanik infinitivu i fleksji imiennej, powstanie 
artykułu postpozytywnego, zmiana typu stopniowania przymiotników itp. Zajmują one wschodnią część południowej Słowiańszczyzny, a więc obszar w stosunku do całości terytorium słowiańskiego niewątpliwie peryferyczny...

Widzimy więc, że innowacje peryferyczne nie są chyba rzadsze od archaizmów peryferycznych. Przyczyny występowania na peryferiach zarówno archaizmów, jak i innowacji są na ogół jasne. Jednak sformułowanie ich wymagałoby od autora tych słów dość znacznego wysiłku myślowego, do którego w tym czasie nie czuje się zdolny.

Artykuł Stiebera wymaga następującego komentarza:

1) Pogląd, że obszary peryferyczne są bardziej archaiczne od obszarów centralnych, sformułował w r. 1925 włoski romanista Bartoli, twórca „neolingwistyki”, a jego pogląd został zaaprobowany przez wiele tzw. autorytetów.

2) Stieber zmarł w r. 1980. W r. 1974 uświadomił sobie, że ,innowacje peryferyczne nie są chyba rzadsze od archaizmów peryferycznych", z czego powinien był wyciągnąć wniosek, że zasada Bartolego jest błędna. Jednak w mentalności Stiebera wiara w nieomylność autorytetów była tak głęboko zakorzeniona, że do śmierci nie zdobył się na odwagę, żeby twierdzenie Bartolego określić jako nieprawdziwe.

Na poparcie sformułowanej przez siebie zasady Bartoli przytaczał garść przykładów tego typu co następujący. Stół się nazywał po łacinie mensa, a romańskie kontynuanty tego wyrazu przetrwały w Hiszpanii i Dacji, a więc na peryferii romańskiego obszaru językowego, podczas gdy w Galii i Italii, które Bartoli uważał za centrum tegoż obszaru, pojawiły się w znaczeniu 'stół' kontynuanty łac. tabula 'deska':

$\begin{array}{llll}\text { Hiszpania } & \text { Galia } & \text { Italia } & \text { Dacja } \\ \text { hiszp. mesa } & \text { fr. table } & \text { wł. tavola } & \text { rum. masă }\end{array}$

Mnie osobiście pogląd, jakoby innowacje miały powstawać z reguły w centrum obszaru językowego, a archaizmy miały się zachowywać przeważnie na obszarach peryferycznych, wydawał się równie irracjonalny jak pogląd (przez nikogo nie wyrażony), jakoby obszary północne lub zachodnie miały mieć charakter bardziej archaiczny od obszarów południowych lub wschodnich czy na odwrót. Ponadto kilka przykładów typu hiszp. mesa, fr. table itd., jakie Bartoli przytaczał na poparcie swej tezy, wydawało mi się ilością zbyt małą, abym mógł zaakceptować pogląd włoskiego romanisty. Z tych powodów w r. 1965 opublikowałem artykuł, w którym przedstawiłem wyniki skonfrontowania ,normy” Bartolego z obfitym materiałem leksykalnym zawartym w słowniku Bucka A Dictionary of Selected Synonyms in the Principal Indo-European Languages, który to słownik podaje synonimy m.in. w języku łacińskim, hiszpańskim, francuskim, włoskim i rumuńskim. Wyekscerpowawszy słownik Bucka w całości, ustaliłem, że figurujące w nim słowa łacińskie zachowały się w językach romańskich w następujących ilościach:

\section{Hiszpański 324 Francuski $260 \quad$ Włoski $380 \quad$ Rumuński 182}


feryczne miały być bardziej archaiczne od języków centralnych, jest błędny. Wprawdzie w peryferycznym języku hiszpańskim jest więcej archaizmów niż w centralnej francuszczyźnie, ale centralna francuszczyzna wykazuje więcej archaizmów od peryferycznego języka rumuńskiego, a centralny język włoski przewyższa ilościa archaizmów oba języki peryferyczne, zarówno hiszpański jak i rumuński. Zgromadzone przeze mnie dane statystyczne udowodniły, że poparta zaledwie kilkoma przykładami teza Bartolego nie jest niczym innym, jak fałszywym uogólnieniem. Jednak przytoczone dane statystyczne nie wywołały wśród językoznawców żadnego zainteresowania i dlatego do sprawy tej kilkakrotnie powracałem (por. Mańczak 1976 czy 1988). Ponieważ zaś liczenie wyrazów w słownikach nie zawsze prowadzi do tych samych wniosków co liczenie słów w tekstach, warto zweryfikować zasadę Bartolego na tekstach. W tym celu porównałem fragment Wulgaty (Mat. 13 i Łuk. 15) z przekładem włoskim, hiszpańskim i rumuńskim. Oto początkowy fragment sporządzonego wykazu. W wykazie tym kursywą wydrukowane są wyrazy łacińskie oraz słowa romańskie, które zawierają ten sam szkielet spółgłoskowy pierwiastka co wyraz łaciński (liczba po wyrazie wskazuje, że w wyekscerpowanych tekstach był on zaświadczony więcej niż raz):

łac. $a b$, wł. da, hiszp. desde, rum. dela; abscondere, nascondere, ocultar, ascunde; abscondere, nascondere, poner, pune; absconditus, occulto, oculto, ascuns; abundare, abbondanza, abundar, prisos; accendere, accendere, encender, aprinde; accipere, ricevere, recibir, primi; accurrere, correre, correr, alerga; ad, a, a, la 2; ad, a, hasta, pînă; adducere, menare, traer, aduce; alligare, legare, atar, lega; amica, amica, amiga, prietenă; amicus, amico, amigo, prieten 2; apparere, apparire, aparecer, iveală; approprinquare, accostarsi, acercarse, se apropia; appropinquare, vicino, acercarse, se apropia; arbor, albero, árbol, copac; audire, ascoltare, oír, auzi; audire, udire, oír, asculta; auris, orecchio, oído, ureche 5; beatus, beato, dichoso, ferice; cadere, gettarsi, arrojarse, cădea 3; calceamenta, calzari, sandalias, incălțăminte; centesimus, cento, ciento, sută 2; centum, cento, ciento, sută; chorus, danza, coro, joc; civis, abitante, ciudadano, locuitor; claudere, chiudere, cerrar, inchide; colligere, cogliere, arrancar, smulge 2; colligere, cogliere, tomar, smulge; colligere, raccogliere, recoger, smulge 2; collum, collo, cuello, grumaz; comedere, mangiare, comer, mînca; consummatio, fine, consumación, sfî̀ş̧it 3; convertere, convertere, convertir, întoarce; convocare, chiamare, convocar, chema 2; cor, cuore, corazón, inimă 3; crescere, nascere, crecer, răsări; dare, portare, dar, da; de, di, de, cu; desertum, deserto, desierto, islaz; devorare, divorare, consumir, mînca; dicere, dire, decir, răspunde; dicere, dire, decir, spune 4; dicere, dire, decir, vesti; dignus, degno, digno, vrednic 2; discipulus, discepolo, discípulo, ucenic 2; dissipare, dissipare, disipar, risipi; dividere, spartire, dividir, impărți; dominus, signore, señor, domn.

W wyekscerpowanych fragmentach ewangelii najwięcej zbieżności leksykalnych z łaciną (a więc archaizmów) wykazał tekst włoski, a mianowicie 320, mniej hiszpański, a mianowicie 256, a najmniej rumuński, mianowicie 98. Jest to jeszcze jeden dowód na to, że obszary peryferyczne - wbrew twierdzeniu Bartolego - bynajmniej nie są bardziej konserwatywne od centralnych.

W mojej książce (Mańczak 1991) została przedstawiona nowa klasyfikacja 
$\hookrightarrow \quad$ języków romańskich, oparta na podobieństwach leksykalnych zachodzących między tymi językami w tekstach. Okazało się przy tym, że słów mających odpowiedniki etymologiczne w pozostałych językach romańskich znalazło się we włoskim 7498, w hiszpańskim 7114, a w rumuńskim 3564. A więc i to badanie, jakkolwiek przeprowadzone inną metodą, wykazało, że język włoski, używany w centrum obszaru romańskiego, jest bardziej archaiczny od języków peryferycznych, jakimi są hiszpański i rumuński.

Sprawdzenie zasady Bartolego jest najłatwiejsze na materiale romańskim, gdyż 1) Bartoli sam określił, które języki należy uważać za centralne, a które za peryferyczne, i 2) znany jest język praromański, tzn. łacina, dzięki czemu rozstrzyganie, który wyraz jest archaizmem, a który innowacją, nie nastręcza żadnych trudności (skoro np. stół się nazywał po łacinie mensa, jest oczywiste, że hiszp. mesa jest archaizmem, a wł. tavola innowacją). Sprawdzenie zasady Bartolego na materiale germańskim jest trudniejsze, gdyż 1) Bartoli, o ile mi wiadomo, nigdy nie określił, które języki germańskie należy uważać za peryferyczne, a które za centralne, a ponadto 2) język pragermański nie jest zaświadczony. Pomimo to wydaje mi się, że dialekt dolnoniemiecki można by uznać za centralny, zważywszy, że na północ od obszaru dolnoniemieckiego występują języki skandynawskie, na zachód - holenderski, fryzyjski i angielski, a na południe - gwary środkowo- i górnoniemieckie, używane na obszarze Niemiec, Austrii i Szwajcarii. Poza tym nie ulega wątpliwości, że zapisany w IV w. język gocki był bez porównania bliższy języka pragermańskiego aniżeli dzisiejsze języki germańskie. Biorąc to wszystko pod uwagę, postanowiłem sprawdzić zasadę Bartolego porównując fragment biblii gockiej (Mat. VII, 13-29, i VIII) z przekładem dolnoniemieckim i szwedzkim. Okazało się, że zgodności leksykalnych między gockim a dolnoniemieckim było 99, a między gockim a szwedzkim 49, co jest jednym dowodem więcej świadczącym przeciw twierdzeniu, jakoby języki peryferyczne były bardziej konserwatywne od centralnych (Mańczak 1996, 181-182).

Wśród tysięcy językoznawców przekonanych o tym, że obszary peryferyczne są bardziej konserwatywne od obszarów centralnych, jest i H. Popowska-Taborska (1980), która uważa dialekt kaszubski z racji jego położenia za bardziej archaiczny od polskiego języka literackiego, czemu niejednokrotnie dawała wyraz w swych publikacjach. W tym stanie rzeczy kwestię domniemanej archaiczności dialektu kaszubskiego postanowiłem zbadać metodą zastosowaną już w odniesieniu do języków romańskich i germańskich, a mianowicie porównując fragment Kodeksu mariańskiego (Mat. XIII-XVIII), który reprezentuje język bliski języka prasłowiańskiego, z polską Bibliq Tysiqclecia i przekładem kaszubskim. Okazało się, że w sumie zgodności leksykalnych między staro-cerkiewno-słowiańskim a polskim było 88 , a między staro-cerkiewno-słowiańskim a kaszubskim 72, co jest jeszcze jednym dowodem obalającym twierdzenie, jakoby obszary peryferyczne były bardziej konserwatywne od centralnych (Mańczak 2002, 37-39).

Ponieważ zebrane przykłady pokazują, że „norma” Bartolego jest błędna, ktoś mógłby zadać pytanie, czy obszary centralne nie są bardziej archaiczne od obszarów peryferycznych. Odpowiedź na to pytanie jest negatywna: ani położenie peryferyczne, ani położenie centralne nie ma wpływu na archaiczność języka czy 
dialektu. W rzeczywistości o archaiczności decyduje chronologia: obszary zasiedlone lub językowo zasymilowane wcześniej są bardziej konserwatywne od obszarów zasiedlonych lub językowo zasymilowanych później. Hiszpański, francuski i rumuński wykazują więcej innowacji niż włoski, gdyż Hiszpania, Galia i Dacja zostały podbite przez Rzymian później niż Italia (Mańczak 1991, 95). Dolnoniemiecki jest bardziej archaiczny od szwedzkiego, gdyż indoeuropeizacja obszaru germańskiego dokonywała się w kierunku z południa na północ (Mańczak 1992, 57 nast.). Polski język literacki jest bardziej archaiczny od dialektu kaszubskiego, gdyż polski język literacki powstał w praojczyźnie Słowian, podczas gdy slawizacja Pomorza dokonała się później (Mańczak 2002, 7-20).

\section{Bibliografia}

Mańczak, W., 1965, La nature des aires latérales, Lingua 13, 177-184.

Mańczak, W., 1976, Le cinquantième anniversaire des “normes” de Bartoli, General Linguistics 16, 1-8.

Mańczak, W., 1988, Bartoli's second “norm”, Historical Dialectology. Regional and Social, Berlin, 349-355.

Mańczak, W., 1991, La classification des langues romanes, Kraków.

Mańczak, W., 1992, De la préhistoire des peuples indo-européens, Kraków.

Mańczak, W., 1996, Problemy językoznawstwa ogólnego, Wrocław.

Mańczak, W., 2002, O pochodzeniu i dialekcie Kaszubów, Gdańsk.

Popowska-Taborska, H., 1980, Kaszubszczyzna. Zarys dziejów, Warszawa.

Stieber, Z., 1974, O archaizmach i innowacjach peryferycznych, Studia indoeuropejskie, Wrocław, 239-241.

\section{Lažna arhaičnost obrobnih območij}

Povzetek

Leta 1965 je avtor tega članka objavil statistične podatke o latinskih, španskih, francoskih, italijanskih in romunskih besedah, ki dokazujejo neveljavnost Bartolijevega načela. Pozneje je avtor z uporabo različnih metod skušal pokazati, da je več arhaizmov $v$ italijanščini kot pa $v$ španščini in romunščini, ki se govorita na obrobju. Pri germanskih jezikih je pokazal, da je v dolnji nemščini, ki zavzema osrednji položaj, več etimoloških ustreznic z gotščino kot v švedščini, ki zavzema obrobni položaj. In naposled je avtor tudi pri slovanskih jezikih pokazal, da ima poljščina, ki zavzema osrednji položaj, več etimoloških ustreznic s starocerkvenoslovanščino kot kašubščina, ki se govori na obrobju.

Witold Mańczak

Zakątek 13/59, 30-076 Kraków, Poljska 



\title{
Življenje besed v Bibliji: od nog do glave
}

\author{
Jožica Narat (Ljubljana)
}

IZVLEČEK: Članek je besedoslovna obravnava besed noga in glava $v$ Dalmatinovi Bibliji, kontrolno pa tudi v Japljevem in najnovejšem slovenskem svetopisemskem prevodu. S tem je nakazana razvojna črta, primerjava posameznih mest z Luthrom, Rosalinom in Vulgato pa pokaže odnos naših prevodov do svojih predlog.

ABSTRACT: This article is a lexicological study of the words noga (foot) and glava (head) in Jurij Dalmatin's Bible. It also examines the two words in Jurij Japelj's translation and the latest Slovenian translation of the Bible. This reveals a developmental line, and comparison of individual sections with Martin Luther's and Franz Rosalino's translations, as well as the Vulgate, demonstrates the relation of Slovenian translations to these models.

0 Članek je besedoslovna obravnava besed noga in glava, ki se - zaradi njune središčnosti $\mathrm{v}$ besednem sestavu je to predvidljivo - pojavljata tako v Dalmatinovem biblijskem prevodu iz leta $1584^{1}$ kot tudi v Japljevem, ki je začel izhajati leta 1784, tj. točno 200 let za Dalmatinovim (prva knjiga vsebuje evangelije), konec njegovega izdajanja pa sega v leto 1802 , ko je izšla zadnja, deseta knjiga. ${ }^{2}$ Stalnost

1 Dalmatin je začel prevajati Staro zavezo v prvi polovici sedemdesetih let. Njegov Jezus Sirah (JESVS SIRAH) je izšel leta 1575 kot prvi ljubljanski tisk, tri leta kasneje (1578) je bilo natisnjeno Peteroknjižje (BIBLIE, TV IE, VSIGA SVETIGA PISMA PERVI DEIL, VKATERIM SO TE PET MOSESSOVE BVQVE, sdai peruizh is drugih iesikou vta Slouenski sueiftu ftolmazhene), čez dve leti (1580) pa Pregovori (SALOMONOVE PRIPVVISTI). Celotna Biblija je izšla leta 1584 v Wittenbergu.

2 Tako imenovani Japljev biblijski prevod je delo več prevajalcev, ime pa je dobil po organizatorju del in prevajalcu v prvem prevajalskem obdobju - duhovniku Juriju Japlju, doma iz Kamnika, ki je v času prevajanja služboval na Ježici pri Ljubljani. Pri delu je sodelovalo večje število prevajalcev in pregledovalcev, ki so popisani v uvodih k posameznim knjigam. Peteroknjižje je izšlo leta 1791, prevedla pa sta ga Jurij Japelj in Blaž Kumerdej. V tem času je prišlo v prevajalski ekipi že do korenitih sprememb: Japelj je prevajal po črki, njegovi sodelavci pa so začeli prevajati po smislu. Glavni zagovornik in izvajalec prevajanja po smislu je bil Jožef Škrinjar, ki je med drugim prevedel tudi Vi- 
$4 \quad$ in spremenljivost obeh samostalnikov sta ugotavljani oz. analizirani na izbranem besedilnem korpusu - Prva in Druga Mojzesova knjiga ter Visoka pesem - in to na osnovi popolnih samostalniških izpisov v dvovrstičnem sobesedilu. ${ }^{3}$

$1 \mathrm{~V}$ Dalmatinovi Bibliji se beseda noga pojavlja 435-krat, od tega $\mathrm{v}$ konkordančno izpisanih in zaradi tega posebej obravnavanih delih $(1 \mathrm{Mz}, 2 \mathrm{Mz}$ in Vp) 77-krat, primerjava teh 77 mest z Japljem pa pokaže, da je bilo na teh mestih čez 200 let 10 zapisov nog manj, torej 67, in da se v 56 pojavitvah noge Dalmatin in Japelj prekrivata, $\mathrm{tj}$. v 73 \% Dalmatin in v 84 \% Japelj. Vzrokov za izpust noge v Japljevem prevodu je več: nadomestna uporaba zaimka, zgoščevanje besedila in zato opuščena ponovitev besede ali uporaba druge besede.

1.1 (1-2) Noga v Bibliji opomenja zlasti del telesa (človeka, živali, tudi nadnaravnega bitja), ki ga lahko razložimo (1a) 'okončina bitja ali nadnaravnega bitja, namenjena za oporo trupa, premikanje' (She je tukaj en Ionatanou Syn, hrom na nogah - 2 Sam 9,3; fo vidili Israelfkiga Boga. Pod njegovimi nogami je bilu, kakòr enu dellu is lepiga Saphiroviga kamina - $2 \mathrm{Mz} 24,10$ ); (1b) 'okončina živali kot jed' (pèr Ognju pezhenu, njegovo glavo, shnjegovimi nogami inu shnjegovim drobom - $2 \mathrm{Mz} 12,9$ ); (2) 'del te okončine od gležnjev do konca prstov' (palce na nyh defni nogi-2 Mz 29,20; Issuj tvoje zhreule is tvoih nug - Joz 5,15; Naj fe vam

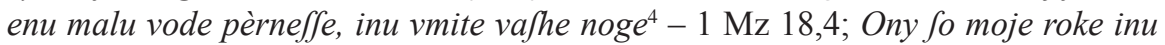
noge Jkus prebyli - Ps 22,17). Japelj ne prinaša na teh mestih nobenih sprememb, enkrat samkrat (1 Mz 49,10) pa je zamenjal Dalmatinovo nogo s pomensko ožjimi ledji: Krajleva paliza néma od Iuda vseta biti, ni mojster od njegovih nug ${ }^{5} \rightarrow \ldots$ tudi ne ta vajvoda od njegóvih lédi. ${ }^{6}$

Če vzamemo za izhodišče konkordance treh Japljevih bibličnih besedil, pa vidimo, da je z nogo Japelj nadomestil kar 3 Dalmatinove dele noge: bedra, ${ }^{7}$

soko pesem - izšla je leta 1798. O različnih predlogah za Japljev svetopisemski prevod - Japelj naj bi jih uporabljal kombinirano - piše natančno Breznik 1928.

3 Konkordančni program je pripravil mag. France Baraga.

4 Umivanje nog velja v deželi, kjer so poti prašne in popotniki hodijo bosi ali v sandalih, za osnovno dolžnost gostoljubnosti. Umivanje nog je bila zadeva sužnjev. (Grabner-Haider - Krašovec 1984: 739-740.) Je pa med Judi to veljalo za skrajno ponižujoče opravilo; celo če je Jud postal suženj, mu njegov judovski gospodar ni smel naložiti tega opravila (SP 1997, 1627). Zagonetnejši je primer je noge ${ }^{d} v^{\prime} m a f l i$ vmival, vendar ga razlaga ob robu ${ }^{d}$ Vmafli) tu je, ker fim vfiga obilnu inu sadofti imèl) dovolj jasno razloži: gre za frazem, ki pomeni uživanje izobilja. Noge so objekt tudi v zvezah z glagoli omakati, osnažiti, žalbati, močiti s solzami, kušati/kušovati, treti/otreti z lasmi, kopati v'tiga Nevernika krij.

5 Dalmatinov prevod se prekriva z Luthrom: Es wird das ${ }^{a}$ Scepter von Juda nicht entwendet werden / noch ein Meister von seinen füssen.

6 Z Japljem se prekriva Rosalinov prevod: noch der Fürst von seinen Lenden.

7 D: inu on je hramal na fvoji bedri $\rightarrow \mathrm{J}$ : on pak je na eni nogi fhantovu hodil (1 Mz 32,31). Luther ima na tem mestu ujemalno z Dalmatinom: Vnd er hincket an seiner Hüfft, Rosalino pa se prekriva z Japljem: er aber hinkte an einem Fuße. 
goleno, ${ }^{8}$ peta $^{9}$ - izbor je bil tako pri Dalmatinu kot pri Japlju delno pogojen s prevodno predlogo. Prav tako je pri opisu oblačila Japelj uporabil prosto opisno zvezo spodej pri nogah ( $2 \mathrm{Mz} 28,33$ in 2 Mz 39,22), ki se pod vplivom Rosalina ${ }^{10}$ orientira glede na telo v oblačilu, medtem ko je uporabil Dalmatin prav tako nazorna opisa (ozdolaj na nje krajih in na nje okrilji), pod vplivom Luthra oba orientirana glede na oblačilo. ${ }^{11}$

(3) Noga je v Bibliji pogosto poosebljena: pomeni (3) osebo ali žival, kateri pripada: Kadar pak ta Golob nej nafhèl, kej bi fe njegova noga pozhilla (1 Mz $8,9) ;{ }^{12}$ Japelj je to mesto prevedel enostavneje, brez noge: Ali kęr letá ny nefhàl, kam bi fędèl..$^{13}$

(4-6) 66-krat v celotni Dalmatinovi Bibliji (od tega kar 39-krat v 2 Mz, ki opisuje zunanjščino in notranjščino svetega šotora ter njegovo gradnjo in opremljanje) se nanaša noga na nežive predmetne denotate, ki jih lahko pomensko opredelimo kot (4) 'spodnji, ožji del predmeta, naprave, ki drži, ohranja telo v pokončnem položaju', in sicer pri mizi ${ }^{14}$ in deski; ${ }^{15}(5)$ 'spodnji, širši del predmeta, naprave, ki drži, ohranja telo v pokončnem položaju', in sicer pri svečniku; ${ }^{16}$ (6) 'telo, predmet, na katerem kaj stoji; podnožje, podstavek', in sicer pri stebru, ${ }^{17}$ oltarju, ${ }^{18}$ oltarnem ognjišču, ${ }^{19}$

8 D: Tiga Ouna pak ima hh na koffe reffékati, inu njegou Drob, inu Golena oprati $\rightarrow$ J: Tiga

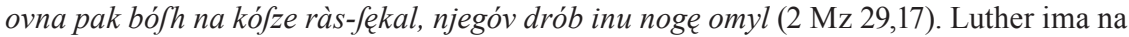
tem mestu sein eingeweide wasschen vnd schenckel, Rosalino den Füssen waschen - Dalmatin in Japelj se torej tudi tokrat $\mathrm{v}$ izboru prekrivata s svojima prevodnima predlogama.

9 D: inu en Madras na ftèsi, inu bo Kojna v' peto vgrisnil $\rightarrow \mathrm{J}$ : ena rogata kazha na ftèsi, katęra konja v' nógo vpizhi (1 Mz 49,17). Luther ima na tem mestu Dan wird ... das Pferd in die ferssen beisen, Rosalino pa welche in die Fußsohlen des Pferdes beisset. Edino v tem primeru je pomenski razkorak tako med Dalmatinom in Luthrom kot tudi med Japljem in Rosalinom.

${ }^{10}$ Rosalino: Herabwärts aber gegen die Füsse (2 Mz 28,33); Unten an den Füssen (2 Mz $39,22)$.

${ }^{11}$ Ustrezno mesto iz $2 \mathrm{Mz} 28,33$ je pri Luthru izpričano takole: unten an seinem Saum, mesto iz 2 Mz 39,22 pa se glasi: er macht den seidenrock zum Leibrock.

${ }^{12}$ Luther ima na tem mestu: Da aber die Taube nicht fand, da jr fuss rugen kund, kar prav tako ustreza Dalmatinovemu prevodu, saj je kund stara oblika pomožnega glagola können v pretekliku in rugen stara oblika glagola ruhen, ki pomeni tudi 'počivati' (Luther III 1974, 346, 362).

${ }^{13}$ Japelj ni sledil Rosalinu, ki piše tako kot zgoraj Luther in Dalmatin: Als aber dieselbe nichts fand, wo ihr Fuß ruhen konnte. Enak tip formulacije, torej različen od Japlja, je tudi v Vulgati: Quae, cum non invenisset ubi requiesceret pes eius.

${ }^{14} \mathrm{D}$ : inu je nje djal na te Shtiri kraje, na nje Shtirih Nogah, raunu pod to Lajfhto, de fo fe Jkusi njo Shtange vtikale, de fe je ta Mysa mogla no/siti (2 Mz 37,13-14).

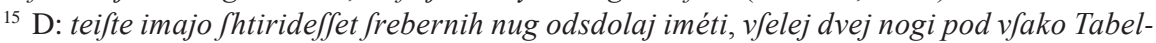
nizo (2 Mz 26,19).

${ }^{16}$ D: Ti imafh tudi en Svejzhnek fturiti is zhiftiga kovaniga slatá, na tém bo enu *Stalu $<*$ noga $>(2 \mathrm{Mz} 25,31)$.

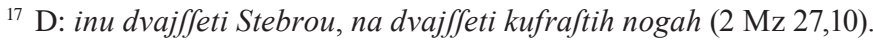

${ }^{18}$ D: LEtu je pak tiga Altarja mera ... Njegova Noga je en komulz viffoka (Ezk 43,13).

${ }^{19}$ D: Ariel pak je bil dvanajft komulzeu dolg, inu dvanajft komulzeu fhirok ... inu njegova Noga je bila en komulz viffoka, inu njegove Shtable fo bilé pruti Iutru (Ezk 43,16-17). 
$\hookrightarrow \quad$ umivalniku $^{20}$ in zagrinjalu ${ }^{21}$. Primerjava z Luthrom, ki ima za navedene pomene fus, füssen, pri svečniku pa schafft, ki ga Dalmatin v besedilu prevaja s stalom, na robu pa ga razlaga z nogo - pokaže popolno prekrivnost z Dalmatinom. V Japljevem prevodu je pri mizi in deski zapisana noga, medtem ko je pri umivalniku in stebru podstava, pri svečniku (enako kot pri Dalmatinu) ter pri oltarju in oltarnem ognjišču pa stalo, kar kaže na večjo specializacijo izrazov. Dalmatinov primer iz $2 \mathrm{Mz} 38,31$ : Inu noge tiga Dvora okuli inu okuli, inu noge téh Vrat na Dvoru je danes pomensko težko razumljiv, pri Japlju pa se glasi: Inu podftave tiga dvorifha takú dobru okuli, kakòr na njega vratih. Primerjava s prevodnimi predlogami je pokazala njihov vpliv na slovenski besedili. ${ }^{22}$

$\mathrm{V}$ dveh primerih je Japljeva noga neustrezno rabljena namesto Dalmatinove besede rog. ${ }^{23}$ Ker se Luther, Vulgata in Rosalino $\mathrm{z}$ rabo besed hörner in cornua ujemajo z Dalmatinom, gre pri Japlju očitno za napako.

Frazemov je v ožji, konkordančni skupini malo. Prvi je iz 2 Mz 21,23-25: dati nogo za nogo 'enako vrniti z enakim' in se v Dalmatinovem prevodu glasi: taku ima dana biti Dufha sa Dufho, Oku sa Oku, Sob sa Sob, Roka sa Roko, Noga sa Nogo, Opezhenje sa Opezhenje, Rana sa Rano, Zhernauka sa Zhernauko. V jeziku sta živa samo dva elementa: oko za oko in zob za zob, rabljena skupaj ali posamezno. ${ }^{24}$

Drugi frazem je iz $1 \mathrm{Mz}$ 41,44: pres tvoje vole néma nihzhe fvojo roko ali nogo ganiti po vfej Egyptoufki desheli in pomeni 'ne sme ničesar storiti oz. nikamor iti'.

Kalkirana zveza možje $k$ nogam ${ }^{25}$ (Luther: sechs hundert tausent Man zu fuss) je $\mathrm{v}$ besedilu označena $\mathrm{z} *$ in na robu pojasnjena s sopomenko pešci ( $\mathrm{v}$ celotni Bibliji se pojavlja ta zveza še na dveh mestih), kar kaže tako na Luthrov vpliv kot na Dalmatinovo zavest o neustreznosti zveze; samostalnik pešci je na tem mestu uporabil tudi Japelj (V: sescenta fere milia peditum virorum), enako tudi SP 1997. Samo enkrat v celotni Dalmatinovi Bibliji ni omenjena Luthrova zveza prevedena kalkirano: Jhtiri krat ftutaushent Mosh pejfhzou (Sod 20,2). V SSKJ je

${ }^{20} \mathrm{D}$ : Vmivalnik is kuffra, inu njegovo Nogo is kuffra (2 Mz 38,8).

${ }^{21}$ D: Is téh ftu centou Srebra fo ony slyli Noge te Svetinje, inu Noge tiga Pèrta, ftu Nug is ftu Centou (2 Mz 38,27).

${ }^{22}$ Luther: Dazu die füsse des Vorhofs rings rumb / vnd die füsse des thors am Vorhofe; Vulgata: et bases atrii, tam in circuitum quam in ingressus eius; Rosalino: Dazu die Fußgestelle des Vorhofes, sowohl in seinem Umfange, als Eingange.

${ }^{23} \mathrm{D}:$ njegove krij imafh vseti, inu jo $s^{\prime}$ tvoim pèrftom na tiga Altarja Rogé djati $\rightarrow \mathrm{J}:$ kar vsamefh od kryví tiga telęta pomashi noge tiga Altarja s' tvojim pèrftam $(2 \mathrm{Mz} 29,12)$. Dalmatin ima k 2 Mz 27,2 dodano opombo z razlago, kaj je rog: tu fo bily majhini Stebèrci na Shtirih vogleh tiga Altarja, s' Knoffy inu s' isresanimi roshizami. Sveto pismo 1997 ima na obeh mestih rogovi.

${ }^{24}$ Po analogiji z navedenimi frazemskimi zvezami obstaja $\mathrm{v}$ živem jeziku tudi frazem glava za glavo. V SSKJ je razložen kot 'če je kdo zakrivil človekovo smrt, naj se kaznuje s smrtjo', kar je v primerjavi z zgoraj navedeno določnejša razlaga. V Svetem pismu ni ta zveza nikjer izpričana (Beseda 98).

${ }^{25}$ Navedek je iz Dalmatinove 2 Mz 12,37: okuli fheftkrat ftutaushent Mosh $\boldsymbol{k}^{\prime}$ nogam <*ali pejfhzou>. 
zabeležena prislovna zveza iti k nogam, označena kot nižje pogovorna, medtem ko pridevniškega pomena zveze, izpričanega v Dalmatinu, v SSKJ ni. ${ }^{26}$

Vzdigniti svoje noge 'podati se na pot' je slikovita Dalmatinova zveza iz 1 Mz 29,1: Iacob je pak fvoje noge vsdignil, ${ }^{27} \mathrm{ki}$ jo je Japelj nadomestil z izrazno enostavnejšo: Jakob fe je tèdaj dalej podál. ${ }^{28} \mathrm{~V}$ navedenih zgledih se je pomen noge razvil iz njene funkcije, vezane na premikanje, hojo, ki se lahko frazemsko poveže tudi z rezultatom premikanja (1 Mz 30,30): GOSPVD je tebe shegnal fkusi mojo ${ }^{k}$ nogo, ki je razložena v opombi: ${ }^{k}$ tu je, ker fim jeft moral fem tèr tam tekati, de fi ti taku bogat poftal. Moja noga je tu morala opraviti, ${ }^{29}$ je pri Japlju npr. zamenjana s pomensko jasnejšo: po mojim prihódi je Gofpód tebe poshęgnal, ${ }^{30}$ ki ne potrebuje dodatne razlage. Prav tako ne uresničitev v SP 1997: Gospod te je blagoslovil za vsak moj korak.

1.2 Upoštevanje celotne Dalmatinove Biblije (435 pojavitev) ${ }^{31}$ vnaša malo sprememb v osnovno pomensko zgradbo besede noga. Predstavljenim pomenom se pridružuje le še noga (7) kot okončina kipa: Tigaiftiga Pilda glava je bila is zhiftiga Slata ... njegove Noge fo bilé en dejl shelesne en dejl yllovate (Dan 2,33).

Pač pa celotna Dalmatinova Biblija precej razširi frazeologijo besede noga. ${ }^{32}$ Zlasti prevladujejo glagolski frazemi s sestavino noga: pasti pod noge koga 'podrediti se komu' in dati koga pod noge komu/podvreči kaj nogam koga 'podrediti koga/kaj komu': Ony bodo morali pod moje noge pafti (L: Sie müssen vnter meine füsse fallen - Ps 18,39), ${ }^{33}$ GOSPVD je nje pod vafhe noge dal (L: der HERR hat sie vnter ewre füsse gegeben - Jdt 14,5), ${ }^{34}$ Ti fi vfe rizhy njegovim nogam podvèrgal ${ }^{35}$ (L: Alles hastu vnter seine Füsse gethan - Ps 8,7). ${ }^{36}$

Biti lahkih nog 'hitro, z lahkoto hoditi, teči': Asael pak je bil lahkih nug, kakòr

${ }^{26}$ Prav tako ni tega pomena v Kastelec-Vorenčevem slovarju pa tudi 200 let kasneje v Pleteršnikovem ne.

${ }^{27}$ Luther ima na tem mestu: DA hub Jacob füsse auff, kar pomeni njegov neposredni vpliv na Dalmatina.

${ }^{28}$ Rosalinov prevod tega mesta ni dobesedno prekriven z Japljevim: Also zog Jacob hin.

${ }^{29}$ Luther ima na tem mestu formulacijo, ki jo je očitno - skupno z opombo - posnel Dalmatin: der HERR hat dich gesegenet durch ${ }^{f}$ meinen fus.

${ }^{30}$ Prevedek se ujema z Rosalinom po smislu, ne pa dobesedno: der Herr hat dich, nachdem ich zu dir eingegangen bin, gesegnet.

${ }^{31}$ V Sekciji za zgodovino slovenskega jezika pri Inštitutu za slovenski jezik Frana Ramovša so popolni izpisi vseh slovenskih besedil slovenskih protestantskih piscev iz 16. stoletja. Za ta prispevek sem uporabila izpise noge in glave iz Dalmatinove Biblije.

${ }^{32}$ Kržišnik - Kolšek $(1990,144)$ navaja posredno ugotovitve Romunke Slave, da so poimenovanja delov telesa med najpogostejšimi sestavinami frazemov: glava, kri in roka so na prvih treh mestih.

33 J: ony fo meni pod nóge pádli; SP 1997: padejo pod moje noge.

${ }^{34} \mathrm{~J}$ : sakaj Gofpód bo nję ftàrel pod vafhimi nogami; V: quoniam Dominus conteret eos sub pedibus vestris.

35 Variante v Dalmatinu so (pod)vreči njegovim nogam/pod njegove noge.

${ }^{36} \mathrm{~J}$ : Vee fi ti njegóvim nogám podvèrgèl. 
$4 \quad$ ena Sèrna na púli (L: Asahel aber war von leichten füssen wie ein Rehe auff dem felde - 2 Sam 2,18). ${ }^{37}$

Primerjava z Luthrom kaže v vseh primerih medsebojno prekrivnost, z Japljem pa $\mathrm{v}$ prvem in tretjem; $\mathrm{v}$ drugih dveh primerih ima Japelj prosti zvezi: streti jih pod vašimi nogami; biti silno hiter $v$ teku. Frazem dati pod noge je analogen $\mathrm{z}$ dati $v$ roke, saj oba pomenita možnost razpolaganja z nekom, je pa dati $v$ roke bolj živ (Kržišnik - Kolšek 1990, 147-148; gl. noga in roka v SSKJ). Pomen podreditve v zgornjih dveh frazemih je predvidljiv, saj je noga $\mathrm{v}$ Bibliji simbol in nosilka oblasti (Grabner-Haider - Krašovec 1984, 486).

Zveza (po)teptati/treti koga z nogami ne pomeni fizičnega teptanja, pač pa sovraštvo do nekoga oz. željo po njegovem uničenju: ${ }^{38}$ Kateri je moj Kruh jedil, taifti mene s'nogami teptá (Ps 41,10) in Kateri moj kruh jej, ta mene s'nogami tare $(\mathrm{Jn} 13,18) .{ }^{39} \mathrm{~V}$ obeh primerih ima Luther glagol treten.

Pogost frazem v Dalmatinu je od mladih nog 'od mladosti', ki ni motiviran z Luthrom (von Jugent, von kind), prav tako se ne pojavlja v Japlju (od (moje) mladofti) in SP 1997 (od otroštva, od mladih let), čeprav je živ še danes.

Prav tako se je, sicer variiran, ohranil v Dalmatinu rabljeni frazem od glave do nog 'v celoti', ${ }^{40}$ ki pa je izrazno in pomensko prekriven z Luthrom (von dem heubt an bis auff die füsse); enako velja za njegovo izrazno-pomensko še natančnejšo varianto od podplatou téh nug do vèrha glave (Luther: von der fussolen an bis auff seine scheitel).

Zveza pokrivati svoje noge se v Dalmatinu (1 Sam 24,4) pojavlja kot evfemizem za 'opravljati potrebo'; izpričana je v Luthru, na njen omiljevalni način izražanja pa je opozorjeno v opombi tako v Luthru kot Dalmatinu, medtem ko je v opombi v SP 1997 naveden dobesedni prevod iz originala: si pokril noge, v rednem besedilu pa je opravil potrebo.

V posebno skupino spadajo zveze, ki pomenijo simbolna dejanja in so zaradi svojega opisovanja realnega $\mathrm{v}$ Bibliji (morda) šele na poti v frazem, npr. otresti prah od nog: Inu kateri kuli vas nebodo gori vseli, ni poflufhali, ondi pojdite prozh vunkaj, inu otrefite prah od vafhih nug, k'eni prizhi zhes nje - Mr 6,11. V SP 1997 (str. 1492 v opombi) je otresti prah od nog razloženo kot kretnja, ki izraža željo po prekinitvi določene medčloveške vezi in je bila pri Judih znak prezira, ko so se vračali iz poganskih krajev.

Enak pomen ima tudi zveza otresti prah s svojih oblačil (SP 1997, 1668). Pri Dalmatinu se to mesto (Apd 18,6) glasi: je on gvant iftrefsil. Po Bibličnem leksikonu $(1984,521)$ je to znamenje radikalne prekinitve vsakršne skupnosti z nekim krajem in njegovimi prebivalci. V SSKJ zveza ni navedena ne med frazemi ne med prostimi zvezami, v elektronski zbirki Nova beseda pa jo najdemo samo kot citat iz Biblije.

Podobno simbolno dejanje, ki pa ni vezano samo na biblijska besedila, je (doli)

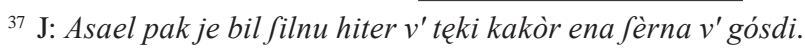

${ }^{38}$ Gl. Sveto pismo 1997, 1627.

${ }^{39}$ Po Bibličnem leksikonu (Grabner-Haider - Krašovec 1984, 486) je to znak zaničevanja.

${ }^{40} \mathrm{D}$ : inu pokryo vfo Kosho, od glave do nug - $3 \mathrm{Mz} 13$,12; SP 1997: od glave do peta; SSKJ: od nog do glave. 
pasti (nekomu/pred nekoga/na svoje obličje) $k$ nogam, npr. v Raz 19,10: Inu jeft fim padèl pred njega k'njegovim nogam, de bi ga molil. To dejanje je znamenje ponižnosti in podrejenosti, vendar je lahko tudi nehoteno in nima simbolnega pomena, npr. v Sod 5,27: On fe je krivil, je doli padil k'nje nogam, kakòr fe je svial, taku je leshal konzhan.

V skupino simbolnih dejanj oz. položajev spada sesti k nogam koga, npr. v 5 Mz 33,3: Ony bodo h'tvoim nogam fejdli, inu fe bodo vuzhili od tvoih befséd. V drugem poglavju 2. knjige kraljev sta v opombi razloženi kot opozicijski biti pri glavi in biti pri nogah: Pèr glavi biti, fe rezhe druge vuzhiti: Pèr nogah biti, fe rezhe od drugih fe vuzhiti, kakòr ta Shular. Sakaj kadar Shulmefhter vuzhy, taku on vifhe fedy kakòr njega Shularji.

2.1 Glava se v treh konkordančno izpisanih besedilih pojavlja pri Dalmatinu 41-krat, pri Japlju pa 30-krat, od tega je 26 pojavitvenih mest prevodoma skupnih. Kljub razmeroma nizkemu številu pojavitev je pri Dalmatinu izpričanih kar pet osnovnih pomenskih enot:

(1) '(zgornji) del človeškega telesa z možgani': je vsel ta Kamen, kateri je bil pod fvojo glavo polushil (1 Mz 28,18);

(2) '(sprednji) del živalskega telesa z možgani': njegovi Synuvi imajo fvoje roke poloshiti timu Iunzu na Glavo (2 Mz 29,10);

(3) 'človek':41 inu vsami sa flejdno glavo en Gomer, po zhifli téh Dufh v' fvoji Vtti (2 Mz 16,16);

(4) 'vodilni človek v skupini': je nje poftavil h' glavam zhes ta folk (2 Mz 18,25); Letu fo te Glave mej Ozheti Levitovih shlaht (2 Mz 6,25); ${ }^{42}$

(5) 'okroglast vrhnji del stebra': fo bily fturjeni téh Stebrou Knoffi, inu nyh Glave okovane, inu nyh Obrozhi (2 Mz 38,28).

Tudi Japljeva glava je večpomenka, vendar zadnjih dveh Dalmatinovih pomenov Japljeva tri besedila ne izkazujejo več. V pomenu 'vodilni človek v skupini' je zamenjana glava z besedama oblastnik in poglavar, ${ }^{43} \mathrm{ki} v$ Dalmatinovi Bibliji sploh še nista zabeleženi, ${ }^{44}$ vrhnji del stebra pa je pri Japlju glavica. ${ }^{45}$ Dalmatinov opis vrh glave je zamenjal Japelj s preciznim leksemom teme, ponekod pa je glavo enostavno izpustil (jesti iz te korbe na moji glavi $\rightarrow$ jesti iz nje; tega vikšiga teh ključarjov/

${ }^{41}$ Po SSKJ je glava v pomenu 'človek' zlasti glede na njegove značilnosti, umske sposobnosti. V obravnavanih svetopisemskih besedilih ni pri tem pomenu izpostavljena nobena človekova sposobnost niti značilnost.

${ }^{42}$ Luther ima na obeh mestih Heubter.

${ }^{43} \mathrm{~V} 2 \mathrm{Mz}$ 18,25 pravi Japelj: inu ene je sa oblaftnike zhes ludftvu ... poftavil. $2 \mathrm{Mz} 6,25$ pa se pri Japlju glasi: Lety fo poglavarji Levitovfkih shlaht.

${ }^{44}$ Dalmatin ima samo oblast in poglavnik.

${ }^{45} \mathrm{~V}$ Japljevem prevodu se to mesto glasi: je on fturil glavize tih ftèbrov, letę ftèbré je on tudi $s^{\prime}$ frębram povlęjkel $(2 \mathrm{Mz} 38,28)$. Prevedek je za Japlja značilen, medtem ko je glava v tem pomenu pri Dalmatinu netipična. V pomenu 'okroglast vrhnji del stebra' ima Dalmatin najpogosteje besedo glavič (Narat 1999, 112-113). 
$\rightarrow \quad$ fištrov glava $\rightarrow$ ta vikši teh ključarjov/pekov) in s tem jezik poenostavi. ${ }^{46}$ Oboje ni rezultat Japljevega zavestnega krčenja oz. izboljševanja jezika, pač pa je pogojeno s predlogo. ${ }^{47}$ Podobno gre pri Dalmatinu za prevodno odvisnost od Luthra. ${ }^{48}$

Frazemov s sestavino glava je v izpostavljenih treh besedilih malo: kaj priti čez glavo koga 'kdo postati deležen česa': D: shegni tvojga Ozheta ... imajo priti zhes Iosephovo glavo ${ }^{49} \rightarrow \mathrm{J}:$ Shęgni tvojga ozhęta ... naj fe dopólnio nad Jósephovo glavó $^{50} \rightarrow$ SP: Blagoslovi tvojega očeta ... Naj pridejo na Jožefovo glavo $(1 \mathrm{Mz}$ 49,26).

Dalmatinovo zvezo v $1 \mathrm{Mz}$ 27,12: bom fam zhes fe pèrpravil prekletje, inu nikar Shegen je Japelj zamenjal s frazemom: de fi jeft na męti shęgna klętu na glavo ne nakóplem.

Že navedeni Dalmatinov frazem povišati glavo koga 'dati komu višji položaj' in 'obesiti koga' je besedna igra z dvojnim smislom (gl. $1 \mathrm{Mz} 40,12-13,18-20):{ }^{.1}$ Try mladice, fo try dnévi. Zhes try dny bo Pharao tvojo glavo povifhal, inu te bo fpet v' tvoj pèrvi ftan poftavil ... Try Korbe fo try dnevi, inu zhes try dny bo Pharao tvojo glavo povifhal, inu tebe na Galgo obéfsil ... inu je povifhal tiga vifhiga téh Kluzharjou glavo, inu tiga vifhiga téh Fifhtrou glavo. Japelj je besedno igro nadomestil z nedvoumno in jasno formulacijo: Try mladike pomęnio fhe try dny. Po katęrih bó Pharao na tvojo Jtręshbo Jpómnil, inu bó tebe v' tvojo pèrvo flushbo nasaj poftavil ... Try pletenize pomęnio Jhe try dny. Po katęrih bó Pharao tebi glavó vsęl, inu te bó potle na en krish obęsil ... fi je med jèdjó Jpómnil na tiga Vikfhiga

${ }^{46} \mathrm{Za}$ ta prikaz so potrebna daljša ponazorila. Prvi primer $(1 \mathrm{Mz} 40,17)$ se pri Dalmatinu glasi: inu v' tej sgurajni Korbi voo shlaht pezheno Shpendio Pharaonu, inu Ptice fo jédle is te Korbe na moji glavi; medtem ko ima Japelj na tem mestu: Inu de fim v' eni pletenizi, katęra je na vèrhi bilá, vfe fórte jedy od teftenine nefsèl, inu de fo ptize is nję jędle.

Drugi primer (1 Mz 40,20-22) se pri Dalmatinu glasi: je povifhal tiga vikfhiga téh Kluzharjou glavo, inu tiga vikfhiga téh Fifhtrou glavo, mej fvojemi Hlapci, inu je tiga vifhiga téh Kluzharjeu Jpet poftavil v' njegovu Kluzharftvu, de je Pharaonu Pehar v' roke dajal: Ali tiga vifhiga téh Fifhtrou je on puftil obéfiti. Japelj ima na tem mestu: katęri je fvojim flushabnikam enu veliku goftovanje narędil, inu fi je med jèdjo Jpómnil na tiga Vikfhiga tih kluzharjov, inu na tiga Vikfhiga tih pękov. Inu eniga je v' njegóvo flushbo nasaj poftavil, de bi njemu tó pytno po/sódo podajal. Tiga drugiga pak je na galge puftil obęsit.

${ }^{47} \mathrm{~V}$ Rosalinovem prevodu je prvi primer $(1 \mathrm{Mz} 40,17) \mathrm{v}$ naslednji, z Japljevim prevodom prekrivajoči se obliki: Und trüge in dem obersten Korbe allerhand nach der Beckerkunst gebackene Speisen, daraus die Vögel frassen; drugi primer (1 Mz 40,20-22) se prav tako prekriva z Japljem: und er richtete seinen Dienern eine grosse Mahlzeit an; bey dem Essen aber gedachte er des Oberschenkens, und Oberbeckers. Und er setzte den einen wieder in sein Amt, damit er ihm ... Becherreichte. Den andern ließ er an den Galgen aufhängen.

${ }^{48} \mathrm{~V}$ Luthrovem prevodu sta oba primera prekrivna z Dalmatinom, tako $1 \mathrm{Mz}$ 40,17: vnd im öbersten korbe allerley gebacken Speise dem Pharao / Vnd die Vogel assen aus dem korbe auff meinem Heubt; kot tudi $1 \mathrm{Mz}$ 40,20: das Heubt des öbersten Schenken / vnd das Heubt des öbersten Beckers.

${ }^{49}$ Luther ima na tem mestu: vnd sollen kommen auff das heubt Joseph.

${ }^{50}$ Vulgata: fiant in capite Ioseph.

${ }^{51}$ Tako so poimenovane te formulacije v Svetem pismu 1997 (str. 93, opomba). 
tih kluzharjov, inu na tiga Vikfhiga tih pękov. Sodobni standardni prevod ohranja Dalmatinov izrazni način, ker ustreza originalu, in v opombah opozarja na popolno različnost pomenov iste zveze. ${ }^{52}$

2.2 V celotni Dalmatinovi Bibliji se glava pojavlja 532-krat, vendar ta množica pojavitev - enako kot pri besedi noga - dopolnjuje osnovno pomensko strukturo le s pomenskim odtenkom k 1) oz. 2): 'zgornji/sprednji del kipa človeškega/živalskega telesa', medtem ko je zveza prisegati pri svoji glavi že frazem 'podkrepiti trdnost svoje prisege z zastavitvijo lastnega življenja': Ti némafh tudi pèr tvoji Glavi prifsegati (Mt 5,36).

Večkrat izpričan je npr. frazem vaša kri bodi čez vašo glavo ${ }^{53} \mathrm{z}$ variantami tega kri bodi na njega glavi, kri Abnerja padi nad Joabovo glavo in njiju kri bo plačana na Joabovo glavo, s pomenom 'nositi odgovornost za smrt koga, za svoje ravnanje'. Prvi primer (Apd 18,6) nam s sobesedilom razkrije, da gre za pravi frazem: Kadar fo ony pak supèr govurili inu Shentovali, je on gvant iftrefsil, inu je djal k'nym:

\section{Vafha kry bodi zhes vafho glavo.}

Variante Dalmatinovega frazema položiti/vreči/dati dejanje/zasluženje koga na glavo ${ }^{54}$ pomenijo 'terjati od koga račun za njegova dejanja'. Razlaga je vzeta iz opombe v SP 1997 k Ezk 9,10; sodobni prevod se ujema z Dalmatinom: Njihovo ravnanje bom spravil na njihovo glavo. Japelj je frazem nadomestil z variirano prosto zvezo povrniti njim po njih delih/zasluženju, ${ }^{55} \mathrm{ki}$ ni utemeljena v Vulgati in je očitno rezultat prevajalčevega (Škrinjar s svojo skupino) tvornega odnosa do predloge.

Dalmatinov frazem ne imeti, kamor bi svojo glavo položil (Mt 8,20): Ptice pod Nebom imajo gnesda: Ampak Syn tiga zhloveka néma, kam bi jvojo glavo polushil v pomenu 'ne imeti stanovanja, prenočišča'. Glagol položiti uporablja v tej zvezi še Japljev svetopisemski prevod, medtem ko ima Wolfov prevod iz leta 1856 in vsi nadaljnji glagol nasloniti.

Po svoji glavi ravnati 'ne ozirati se na mnenje drugih' je iz Dalmatinovega predgovora k Prvemu pismu Korinčanom: kakòr de bi velika framota bila, kadar bi fleidni kaj fußebniga naprej nevsel, inu po fvoji laftni glavi nerounal. V SSKJ zveza ni uvrščena med frazeme, ampak neustrezno med zglede, ki dokazujejo pomen glave kot 'ta del pri človeku kot središče njegovega razumskega in zavestnega življenja'.

Pasti kaj (komu) na njegovo glavo 'doleteti koga kaj slabega, zgoditi se komu kaj slabega', npr. Ps 140,10: Padi ta nefrezha na nyh glavo. ${ }^{56} \mathrm{~V}$ Japljevem prevodu je Traven izpustil besedo glava: Vfe njih salásùvanje ... bó na nję pádlu. ${ }^{57}$

${ }^{52}$ V Svetem pismu 1997 se iztržek iz 1 Mz 40,12-13, 18-20 glasi: tri mladike so trije dnevi. Še tri dni in faraon bo povzdignil tvojo glavo in te postavil nazaj v tvojo službo /.../ tri košare so trije dnevi. Še tri dni in faraon bo povzdignil tvojo glavo s tebe in te obesil na drevo /... / Tedaj je sredi svojih služabnikov povzdignil glavo vélikega točaja in glavo vélikega peka.

${ }^{53}$ Luther: Ewer Blut sey vber ewer heubt. SP 1997: Vaša kri nad vašo glavo.

${ }^{54}$ Luther: Sondern ich wil jr Thun auff jren Kopff werffen (Ezk 9,10).

${ }_{55}$ Vulgata: viam eorum super caput eorum reddam.

${ }^{56}$ Luther: Das vnglück ... Müsse auff jren Kopf fallen.

${ }^{57}$ Vulgata: Caput circuitus eorum, labor labiorum ipsorum operiet eos. 
Živo oglje spravljati na glavo koga se v Dalmatinu (Rim 12,20) glasi: Aku je tedaj tvoj Sovrashnik lazhen, taku ga nafiti ... Sakaj kadar ti letu fturifh, taku ti shivu ogele fpravla/h na njegovo glavo. V robni opombi je zveza razložena: fe fovrashnik fkusi tvojo dobruto fam zhes fe referdi, de je on tebi taku hudu fturil. Japljev $^{58}$ in standardni prevod ${ }^{59}$ se z Dalmatinom ujemata; v standardnem prevodu sta navedeni v opombi dve možni razlagi tega mesta: 1) poostrena Božja kazen, ki bo doletela nasilneža, če se bo v dobroti žrtve še jasneje zrcalila njegova hudobija; 2) bolečina kesanja, kazen pekoče vesti. V Novi besedi je zgled iz F. Milčinskega: Primanjkljaj petinšestdeset kron in šestintrideset vinarjev je bil pokril iz lastnega žepa, da zbere žarečega oglja na glave svojih nasprotnikov, zakaj bil je uverjen, da se mu godi krivica. Gre za nekoliko spremenjen biblijski citat s pomenom 'vzbuditi komu slabo vest'.

Glava se pojavlja tudi v številnih zvezah, ki upovedujejo simbolna dejanja. Zelo znan in na Biblijo vezan primer je trositi/potresati/raztresati/posipati/metati na svojo glavo prah/pepel/prst/pepel in prah. To dejanje je v Bibliji in v kulturah Bližnjega vzhoda sploh pomenilo znamenje žalovanja, tudi pokore (prim. še valjanje po pepelu, sedanje v pepel, trganje svojih oblačil). Zveza posuti se s pepelom je danes živa predvsem v publicistiki: ${ }^{60}$ Tisti, ki je kriv, naj se hitro posuje s pepelom in $v$ prihodnje za obči blagor drži jezik za zobmi, in ima s pomenom '(javno) obžalovati kaj, pokesati se' vse značilnosti frazema. ${ }^{61}$ Glava ni ostala del tega frazema. V Novi besedi najdemo Cankarjevo prenovo tega frazema: Nato ne gre $k$ spovedniku, ne $k$ sodniku, ne posuje si temena s pepelom, ne obleče meniške halje, ki ga lahko razumemo kot niz spokornih dejanj.

Stresati/potresati (z) glavo (čez nekoga/za nekom) pomeni izražati s temi gibi nestrpnost oz. odpor do nekoga, pri tem pa gre zgolj za ubesedeno govorico telesa, ne za pomenski premik.

Žalbati glavo z oljem / izliti žalbovo olje na glavo - s tem dejanjem se podeljuje komu duhovniška ali kraljevska čast, v Novi zavezi pa je to dejanje znamenje spoštovanja in ljubezni (Biblische Realkonkordanz, 643), npr. Lk 7,46: Ti néfi moje Glave s'ojlem shalbal: Ona je pak moje noge s'shalbo shalbala.

\section{Zaključek}

Besedi noga in glava imata $\mathrm{v}$ Japljevem prevodu v treh konkordančno izpisanih besedilih manj pomenov kot v Dalmatinovem. Nogo (4) 'spodnji, ožji del predmeta, naprave, ki drži, ohranja telo v pokončnem položaju' ohranja Japelj samo pri mizi in deski, medtem ko je pri vseh drugih predmetih zamenjana s podstavo ali stalom. Za

\footnotetext{
$58 \mathrm{~J}$ : taku bófh sherjavzo nad njegóvo glavó vkùp fpravlal.

${ }^{59}$ SP 1997: boš sipal žarečega oglja na njegovo glavo.

${ }^{60} \mathrm{~V}$ zbirki Nova beseda zlasti v besedilih iz Državnega zbora in iz časnika Delo.

${ }^{61}$ Simbolno dejanje, ki je prešlo v frazem, je npr. tudi umiti si roke, le da v zgledu iz Kreljeve Postile slovenske (str. CLXIb), ki ga navaja Novak 2004 (str. 186), ta prehod še ni izveden, ker gre za sočasnost fizičnega in govornega dejanja: Pilatuf ... vsame vode, inu roke vmije vprizho vfiga Folka rekoch: Ias néfàm dolshan na tei krij letiga pravizhniga.
} 
dva Dalmatinova pomena glave ('vodilni človek v skupini' in 'okroglast vrhnji del stebra') ima Japelj izraze oblastnik in poglavar ter glavica.

Celotna Dalmatinova Biblija prinaša poleg šestih pomenov noge in petih pomenov glave iz konkordančnih izpisov še po enega pri vsaki besedi, kar je glede na veliko večji besedilni obseg zelo malo. Je pa v celotni Dalmatinovi Bibliji izpričanih veliko več frazemov - v konkordančnih izpisih je frazeologija pri obeh avtorjih skromna, kar je zaradi omejenega obsega razumljivo, najzanimivejša pa je zveza povišati glavo nekoga, ki je rabljena kot besedna igra z dvojnim smislom - ter več opisov simbolnih dejanj, ki kasneje postanejo frazemi (posuti se s pepelom) ali pa tudi ne (otresti prah od nog). V frazeologiji se primerjana prevoda večkrat razlikujeta, medtem ko so si opisi simbolnih dejanj v vseh bibličnih prevodih - kar je razumljivo - zelo podobni, če že ne enaki.

\section{Viri in literatura}

Beseda 98, Slovenski standardni prevod Svetega pisma na CD-ROM-u, 1998, Ljubljana, Svetopisemska družba Slovenije.

Bibel-Lexikon, 1968, Zürich-Köln, Benzinger Verlag Einsiedeln.

Biblische Realkonkordanz, 1913, Regensburg.

Breznik, Anton, 1928, Japljev prevod sv. pisma, Časopis za slovenskijezik, književnost in zgodovino $7,77-107$.

Dalmatin, Jurij, 1584, BIBLIA, TV IE, VSE SVETV PISMV, Wittemberg, Faksimile, Ljubljana 1968.

Grabner-Haider, Anton, in Krašovec, Jože, s sodelavci, 1984, Biblični leksikon. Celje, Mohorjeva družba.

Japelj, Jurij, in sodelavci, 1784-1802, SVETU PISMU STARIGA INU NOVIGA TESTAMENTA, I-X, Ljubljana.

Kastelec - Vorenc, gl. Stabej.

Kržišnik - Kolšek, Erika, 1990, Sestavina roka v frazeologemih slovenskega knjižnega jezika, Seminar slovenskega jezika, literature in kulture 26, 141-154.

Kržišnik, Erika, 2000, Biblične stalne zveze v Slovarju slovenskega knjižnega jezika in v slovenskem jeziku, Razprave / Dissertationes XVII, 67-80.

Luther, D. Martin, 1545, Biblia, Das ist die gantze Heilige Schrifft Deudsch auffs new zugericht, I-III, Wittenberg. München, Deutscher Taschenbuch Verlag, 1974.

Narat, Jožica, 1999, Semantika samostalnika v jeziku Jurija Dalmatina in Jurija Japlja, Doktorska disertacija, Ljubljana, Filozofska fakulteta, 214 str. [Tipkopis.]

Nova beseda - Besedilni korpus na Inštitutu za slovenski jezik Frana Ramovša.

Novak, France, 2004, Samostalniška večpomenskost v jeziku slovenskih protestantskih piscev, Ljubljana, Založba ZRC.

Pleteršnik, Maks, 1894-95, Slovensko-nemški slovar, Ljubljana, Knezoškofijstvo.

Rosalino, Franz, 1793-94, Biblia sacra, oder die heilige Schrift des alten und neuen Testaments, Wien.

Slovar slovenskega knjižnega jezika, I-V, 1970-1991, Ljubljana. 
$-\quad$ Stabej, Jože, 1997, Slovensko-latinski slovar. Po: Matija Kastelec - Gregor Vorenc, Dictionarium latino-carniolicum (1680-1710), Ljubljana, Založba ZRC.

Sveto pismo Stare in Nove zaveze, 1997, Ljubljana, Svetopisemska družba Slovenije.

Vulgata: Bibliorum Sacrorum iuxta Vulgatam Clementinam, Vatikan, 1946. [Nova izdaja.]

\title{
The Life of Words in the Bible: noga (foot) and glava (head)
}

\author{
Summary
}

The author discusses the words noga (foot) and glava (head) in terms of lexicology. These are two nominal constants that appear in both Jurij Dalmatin's and Jurij Japelj's translation of the Bible. Nominal constancy and variability were first established in the selected text corpus - Genesis, Exodus, and the Song of Solomon - based on fully transcribed nouns within a two-line context. For greater clarity, the article extends the analysis of the words noga and glava to all of Dalmatin's Bible, whereas Japelj's translation and the 1997 standard translation of the Bible were only included where necessary.

Nearly the entire basic semantic structure of the words noga (77 occurrences in Dalmatin and 67 in Japelj) and glava (41 occurrences in Dalmatin and 30 in Japelj) is established on the basis of the three selected texts alone. Dalmatin's noga has six different attested meanings, while glava has five; Japelj uses three different meanings for both of them, but replaces the others with other terms. The entire text of the Bible offers only one additional meaning for both words; in general, new features occur in phraseology and citations expressing symbolic acts that may or may not have become phrasemes.

Translations of the Bible from different periods are extremely well-suited for determining linguistic - or in this case, lexical - development because the sacredness of Biblical text does not permit any major conceptual or stylistic alterations. However, major or minor differences occur even between individual translation models (i.e., between Martin Luther's German translation and the Latin Vulgate, or Franz Rosalino's German translation), which result in differences between the Slovenian translations as well.

Jožica Narat

Inštitut za slovenski jezik Frana Ramovša ZRC SAZU

Novi trg 2, 1000 Ljubljana

jozica.narat@guest.arnes.si 


\title{
Trubarjev Philopatridus Illyricus
}

\author{
France Novak (Ljubljana)
}

IZVLEČEK: V sestavku avtor kritično obravnava slovenski prevod Trubarjevega psevdonima Philopatridus Illyricus z izrazoma rodoljub ilirski in se odpoveduje svoji nekdanji domnevi, da se nanaša na Matijo Vlačića Ilirika.

ABSTRACT: The author critically examines the Slovenian translation of Primož Trubar's pseudonym Philopatridus Illyricus - that is, rodoljub ilirski 'the Illyrian patriot' - and rejects his earlier hypothesis that this was actually the pseudonym of Matija Vlačić Ilirik.

1 Trubarjev Philopatridus Illyricus ne bi smel biti problem, saj je splošno znano, da je Trubarjev psevdonim v prvi slovenski knjigi. Meni je kljub temu postal problematičen zaradi slovenske ustreznice rodoljub ilirski (Rupel 1966, 16). V tej obliki lahko namreč vzbuja napačne predstave, saj je beseda ilirski dobila v slovenščini po Trubarjevem času več novih pomenskih odtenkov, sam Trubar pa tudi drugi slovenski pisci tega časa je v slovenščini niso uporabljali. ${ }^{1}$ To je bilo vzrok za prvi pomislek. Drugi pomislek sem imel zaradi tega, ker je bil Philopatridus Illyricus uporabljen v bližini pridige o veri, ki jo je napisal Matija Vlačić Ilirik - Matthias Flacius Illyricus. Zato sem sklepal, da je morda s tem vzdevkom mišljen avtor pridige o veri - Matthias Flacius Illyricus. Pridevnik illyricus sem spravil v zvezo z njim. To misel sem tudi dvakrat zapisal, in sicer v Novak 2001, 116-117 in Novak 2004, 36, v opombi. Po natančnejšem pregledu gradiva spreminjam trditev: Philopatridus Illyricus je psevdonim za Primoža Trubarja. Pojdimo po vrsti.

1.1 P. Trubar uporablja to ime na naslovnici TC 1550. Navajam kontekst:

\section{Catechifmus}

In der Windifchenn Sprach/

fambt einer kürtzen Außlegung

in gefang weiß. Item die Lita $=$

1 Trditev je postavljena na podlagi podatkov kartoteke popolnega izpisa slovenskega besedja slovenskih protestantskih piscev 16. stoletja v Sekciji za zgodovino slovenskega jezika Inštituta za slovenski jezik F. Ramovša ZRC SAZU. 


\author{
nai vnd ein predig vom rech \\ ten Glauben/ geftelt/ durch \\ Philopatridum \\ Illiricum.
}
Anu kratku Poduuzhene lkate= rim vfaki Zhlouik more $\mathrm{v}=$ nebu pryti.

Problem je bil v tem, na kaj se nanaša geftelt/ durch Philopatridum Illiricum (sestavil Philopatridus Illiricus). Če bi veljal za celoten naslov, bi šlo za Trubarjev psevdonim, če bi veljal samo za zadnji podatek ein predig vom rechten Glauben/ geftelt/ durch Philopatridum Illiricum, bi se nanašal na Matija Vlačića Ilirika. Ker gre za drugo poved v naslovu, se mi je zdel pomislek kar verjeten.

2 Glavni podatek o stvari pove že sam Trubar v publikaciji Regifter vnd fummarifcher Innhalt ... Tübingen, 1561. Na strani B III a o TC 1550 pravi: Diß Büchlin ift deß Trubers erfte Prob/ ob man auch die Windifchen Sprach/ fchreiben vnd lefen möchte/ wölches er heimlich vnnd vnder einem erdichten Namen/ (von wegen/daß jme die Superattendenten der Truckereyen/an zweyen orten/zur zeitt deß Interims/gemelt Büchlin/zutrucken nicht wolten geftatten) hat müffen trucken lasfen/ daffelbig helt inn fich dife nachuolgende Stuck. ${ }^{2}$

Drugo mesto v tej publikaciji, ki pojasnjuje to vprašanje, je 19. točka: Am letften/ift ein gantze Predig/von dem Wort/Glaube/vnd von Glaubens eigenfchafft vnd würckungen/ colligiert auß Illirici Büchlin/de voce \& re fidei (TR 1561, B IIII a). ${ }^{3}$

Trubar sam pove, da je publikacijo izdal pod izmišljenim imenom. Psevdonima ne povezuje s piscem pridige Ilirikom.

2.1 Matija Vlačić Ilirik je bil znan pod imenom Illyricus, kot smo videli že iz Trubarjevega navedka (TR 1561, B IIII a), enako je v Kreljevem naštevanju reformacijskih teologov Illyrikuf(KB 1566, E 6) ali pa s celotnim imenom, npr. Illyricus, Mathias Flacius s. [glej] Flacius Illyricus, Mathias (VD 16, Band 9, str. 626).

Da bi za Vlačića veljal Philopatridus Illyricus, nisem dobil nikjer izpričano.

2 V prevodu se glasi: Ta knjižica je Trubarjev prvi poskus, ali bi se tudi slovenski jezik dal pisati in brati; moral jo je dati tiskati na skrivaj in pod izmišljenim imenom (ker mu nadzorniki tiskarn v dveh krajih za časa interima natisa omenjene knjižice niso hoteli dovoliti). Le-ta vsebuje tele razdelke. Rajhman 1986: 43.

$3 \mathrm{~V}$ prevodu: Na koncu je celotna pridiga o besedi vera in o lastnostih in učinkih vere, povzeta iz Ilirikove knjižice de voce \& re fidei (Rajhman 1986: 49). 
Nima ga Mijo Mirković v monografiji Matija Vlačić Ilirik, Zagreb 1960. Tudi VD 16 pozna to ime samo za Trubarjev psevdonim (VD 16, Band 16, str. 58).

3 Poglejmo še vzorec naslovov knjig slovenskih protestantskih piscev, da bomo videli, kakšno vlogo imajo imena na takih mestih. V vzorec naslova štejemo, kar je na prvem mestu na naslovnici in kar je pred naslovom $v$ drugem jeziku, če je naslov v dveh jezikih, ali pred kakim citatom. Glavni vzorec ima praviloma dolg naslov in ime prireditelja, omenjenega na koncu ali proti koncu naslovnega teksta. Torej velja za vso knjigo. Tudi, če obsega več kot eno poved, kar je uporabljeno v TC 1550. Model dela povedi, ki kaže na sestavljalca ali prevajalca knjige, je praviloma tak kot v nemških naslovih: trpni deležnik + prislovno določilo vršilca dejanja; v nemščini geftelt/ durch Philopatridum Illiricum, v slovenščini pa te fo prepifane od aniga Peryatila vfeh Slouenzou. Trpni deležniki, ki se uporabljajo, so še: zveistu preobernen, zveistu tolmačen, zastopnu izložen, iztolmačen, zložen, vkupe zbran, stolmačen ipd. (Berčič 1968, 168-250).

3.1 Prireditelj je imenovan na naslovnicah naslednjih izdaj: TC 1550 (durch Philopatridum Illiricum), TA 1550 (od aniga Peryatila vfeh Slouenzou), ${ }^{4}$ TT 15571558 (Skufi Primosha Truberia), TT 1560 (skufi Primosha Truberia Crainza), TL 1561 (SKVSI PRIMOSHA Truberia Crainza), TAr 1562 (skufi Primosha Truberia Crainza), TPs 1566, TC 1567 nekoliko prilagojen vzorec), TL 1567, TP 1567, TPs 1567 (od P. Truberia, s. Krelia, inu od drugih sloshene), TC 1574, TP 1575 (nekoliko prilagojen vzorec), TC 1575 (skufi Primosha Truberia), DPa 1576 (šele v drugi, nemški varianti naslova je Durch. M. Georgium Dalmatinum), TT 1577 (od Primosha Truberia), DB 1578 (skusi Iuria Dalmatina), TM 1579 (Skusi Iansha Tulszhaka), TC 1579, DPr 1580, TT 1581-82 (skufi Primolha Truberia Crainza Raftzhizheria), DB 1584 (Ckusi IVRIA DALMATINA), DC 1584, DM 1584, BH 1584 (ADAMI BOHORIZH), TPo 1595, DM 1595, TfC 1595, ZK 1595 (SKVSI Iansha Snoillhika). Ta vzorec je močno prevladujoč. Uporabljala sta ga zlasti Trubar in Dalmatin. (Prim. Berčič 1968, 168-250).

Tudi vzorec naslova kaže, da je Philopatridus Illyricus v TC 1550 Trubarjev psevdonim.

3.2 Podatki o avtorjih prevedenih ali prirejenih del se navajajo sprva redkeje, proti koncu obdobja pa čedalje pogosteje, vendar so njihove omembe pred imenom prireditelja, bodi da so sestavni del prvega glavnega dela naslova, npr. HISHNA POSTILLA D. MARTINA LVTHERIA (TPo 1595) ali pa KATECHISMVS DOCTORIA MARtina Luthra (ZK 1595). Tudi ta podatek bi kazal na to, da mesto Philopatrida Illyrica ne kaže na avtorja enega izmed besedil, vključenih v TC 1550.

4 Prvi dve knjigi imata najprej naslov v nemščini, šele na drugem mestu je slovenski. Pri drugih knjigah v slovenščini je na začetku slovenski naslov. 
4 Oglejmo si naslovnico druge Trubarjeve knjižice, ki je izšla hkrati s Catechismom, to je TA 1550. Tudi ta ima najprej naslov v nemščini:

\section{Abecedarium \\ vnd der klein Catechifmus \\ In der Windifchen \\ Sprach.}

Ane Buquice/ is tih fe ty

Mladi inu preprofti Slouenci

mogo lahku vkratkim zhafu

brati nauuzhiti/ Vtih fo tudi

ty vegfhy ftuki te kerfzhanfke

Vere inu ane Molytue/

te fo prepifane od ani=

ga Peryatila vfeh

Slouenzou.

Zanimivo je, da imamo v drugi Trubarjevi knjigi (TA 1550) slovensko varianto nemško-latinskega psevdonima iz TC 1550 - od aniga Peryatila vfeh Slouenzou. Namesto pridevnika illyrikus imamo tu ime Slovenci. Spet moramo opozoriti na to, da v takratni slovenščini ni pridevnika ilirski. Do neke mere bi ga lahko nadomeščal pridevnik slovenski, katerega glavni pomen bi bil »slovanski s tistega dela ozemlja, kjer je bila rimska provinca Ilirik«.

4.1 Ker je Philopatridus Illyricus psevdonim iz naslova v nemščini, je namenjen nemškemu jezikovnemu okolju in ker je v latinščini, je značilen tudi za latinščino tistega časa. Ni najboljša rešitev, če ga v slovenščino prevajamo dobesedno rodoljub ilirski. Avtorjev ustreznik je Peryatil veh Slouenzou. Sklepam, da je perjatil vseh Slovencov po vsebini pravi ustreznik za nemško-latinski Philopatridus Illyricus.

4.2 O pravilnosti takega sklepanja imamo še en dokaz. Krajevno ime Ilirik se uporablja v Bibliji, in sicer v Pavlovem pismu Rimljanom (Rim 15, 19). To mesto se v Vulgati glasi: ita ut ab Ierusalem per circuitum usque ad Illyricum repleverim evangelium Christi (Vulgata 1946, 1068), pri Lutru pa: Also/ das ich von Jerusalem an vnd vmbher bis an Jllyricum/ alles mit dem Euangelio Christi erfüllet habe (Luther 1545, 2293). Ime pozna tudi slovenski prevod Svetega pisma: Vse od Jeruzalema tja do Ilirika sem v velikem krogu dopolnil Kristusov evangelij (SP 1996, 1702). Če upoštevamo te podatke in primerjamo med seboj psevdonima iz TC 1550 in iz TA 1550, lahko sklepamo, da gre tudi pri pridevniku illyricus za nemško-latinsko varianto psevdonima, pri imenu Slovenci pa za slovensko, saj tako Trubar kot tudi Dalmatin prevajata ta del Pavlovega pisma Rimljanom z izrazom Slovenske dežele: Taku, de fem od Ierufaleme inu undukai okuli noter do te Slouenske deshele napolnil fteim Euangeliom Criftufeuim (TT 1560, 24 b-25 a); ... Taku, de fim jeft 
od Ierusalema, inu okuli notèr do Slovenfke deshele, vfe s'Criftufovim Evangeliom napolnil (DB 1584, III, 88 a).

Ilirik je rimska provinca na severozahodnem delu Balkanskega polotoka (Kastelic 1990: 106). Trubar in Dalmatin sta ga prevajala Slovenske dežele, kar pomeni $\mathrm{v}$ tistem času to, kar poimenujemo danes slovanske in slovanski vključuje tudi pridevnik slovenski. V Trubarjevem času ni ta provinca več obstajala. Namesto ilirski bi Trubar uporabljal slovenski. Treba je povedati tudi to, da je bilo v Trubarjevem času na tem ozemlju drugačno stanje kot za časa Rimljanov. Kasneje je izraz ilirski prišel v rabo tudi v slovenščino, in sicer v drugačnih pomenih. Če bi prevajali Philopatridus Illyricus kot rodoljub ilirski, bi se nekako približali Trubarjevemu pojmovanju, vendar ne natančno. Ta pot niti ni potrebna, ker je avtor sam dal slovenski ustreznik latinskemu psevdonimu - Peryatil veh Slouenzou. Pa tudi ta psevdonim je treba pojasniti: Slovenec je takrat pomenil tudi druge Slovane, Slovence avtomatično neposredno. Pomemben je pri tem zaimek vseh. Pri psevdonimu ni mislil samo na Slovence v današnjem smislu, če želi poudariti samo ta pomen, potem jih imenuje tudi z bolj natančnim izrazom oz. izrazi, saj velikokrat uporablja pokrajinska imena. To razlaganje bi bilo najenostavnejše.

4.3 Rodoljub ilirski torej kot prevod ni dober, ker je preveč prekrit z novejšimi pomeni, ki so prišli v slovenščino kasneje in ne odražajo natančno tiste misli, ki jo je Trubar izrazil v nemškem jeziku s pomočjo latinskih izrazov, v očitnem slovenskem ustrezniku pa kot prijatelj vseh Slovencev.

\section{Viri in literatura}

Berčič 1968 = Branko Berčič, Das slowenische Wort in den Drucken des 16. Jahrhunderts, Bibliographie, Abhandlungen über die slowenische Reformation, München 1968, 163-250.

Kastelic 1990 = Jože Kastelic, Ilirik, Enciklopedija Slovenije 4, Ljubljana 1990, $106-107$.

KB 1566 = Sebastijan Krelj, OTROZHIA BIBLIA, Regensburg 1566.

Luther 1545 (1974) = Martin Luther, Biblia, Das ist die ganze Heilige Schriff, Deudsch auffs new zugericht, Wittenberg 1545, I-III, München 1974.

Mirković 1960 = Mijo Mirković, Matija Vlačić Ilirik, Zagreb 1960.

Novak 2001 = France Novak, Kako so protestantski pisci 16. stoletja poimenovali nove pojme, Zbornik posvetovanja 450-letnica slovenske knjige in slovenski protestantizem, Ljubljana 2001, 103-120.

Novak 2004 = France Novak, Samostalniška večpomenskost v jeziku slovenskih protestantskih piscev 16. stoletja, (Zbirka Linguistica et philologica), Ljubljana, 302 str.

Rajhman 1986 = Jože Rajhman, Pisma Primoža Trubarja, Ljubljana 1986.

Rupel 1966 = Mirko Rupel, Slovenski protestantski pisci, Druga dopolnjena izdaja, Ljubljana 1966. 
$4 \quad$ Sveto pismo $1966=$ Sveto pismo stare in nove zaveze, Slovenski standardni prevod iz izvirnih jezikov, Ljubljana 1996.

TA $1550=$ Primož Trubar, Abecedarium vnd der klein Catechifmus, Tübingen 1550.

TC 1550 = Primož Trubar, Catechifmus, Tübingen 1550.

TR 1561 = Primož Trubar, Regifter vnd fummarifcher Inhalt, Tübingen 1561 .

VD 16 = Verzeichnis der im deutschen Sprachbereich erschienenen Drucke des XVI. Jahrhunderts, I. Abteilung, Verfasser-Körperschaften-Anonyma, 1-22, Stuttgart 1983-1995.

Vulgata 1946 = Bibliorum Sacrorum iuxta Vulgatam Clementinam, Nova editio, Curavit Aloisius Gramatica, 1946.

\section{Primož Trubar's Philopatridus Illyricus}

Summary

This article critically examines the Slovenian translation of Primož Trubar's pseudonym Philopatridus Illyricus used in his first book, Catechismus (Catechism, TC 1550). The pseudonym was translated as rodoljub ilirski 'the Illyrian patriot' despite the fact that the word ilirski is unknown in the Slovenian language that Trubar used. However, in his Abecedarium (Abecedary), which was published simultaneously with Cathecismus, he used the Slovenian equivalent of the Latin Philopatridus Illyricus - that is, Peryatil vfeh Slouenzou 'a friend to all Slovenians'. The author rejects his earlier hypothesis that Philopatridus Illyricus actually referred to Matija Vlačić Ilirik (a.k.a. Matthias Flacius Illyricus).

France Novak

Inštitut za slovenski jezik Frana Ramovša ZRC SAZU

Novi trg 2, 1000 Ljubljana

FNovak@zrc-sazu.si 


\title{
Slowenische Namen und Wörter aus Kals in Osttirol
}

\author{
Heinz-Dieter Pohl (Celovec)
}

IZVLEČEK: V članku so obravnavani slovenska imena in nekatere besede iz Kalsa na Vzhodnem Tirolskem. Dialektološko se prištevajo $k$ stari slovenščini, tj. jeziku, ki so ga v zgodnjem srednjem veku govorili v kneževini Karantaniji in je osnova za imenoslovje na jugu in jugovzhodu Avstrije. Pri tem je prišlo tam tudi do stikov z romanskimi (ladinsko govorečimi) prvotnimi prebivalci.

\section{Slovenian Names and Selected Words from the Kals Valley in East Tyrol \\ ABSTRACT: This article discusses names and words of Slavic origin in the Kals Valley in East Tyrol. In terms of dialectology, they are classified as Old Slovenian in origin - that is, the language spoken in the principality of Karantania in the early Middle Ages and that served as a basis for creating names in South and South-East Au- stria. In addition, contacts were formed with indigenous Romance (Ladin-speaking) people.}

\section{Allgemeines}

Unter ,slowenisch“ ist in diesem Zusammenhang nicht die heute noch lebendige Sprache der Kärntner Slowenen gemeint, sondern die mittelalterliche Vorstufe, die Sprache der Karantanen, eine altslowenische Mundart, früher meist ,,alpenslawisch" genannt. ${ }^{1}$

Die Gemeinde Kals am Großglockner in Osttirol gehört zu den namenkundlich bemerkenswertesten Regionen Österreichs: hier haben im Mittelalter Romanen, Slawen und Deutsche friedlich nebeneinander gerodet, gewirtschaftet und gelebt (wie dies treffend Maria Hornung festgestellt hat ${ }^{2}$ ), was sich im Namenschatz des Kalser Tales noch heute deutlich zeigt, denn wir finden Namen romanischer (ladinischer), slawischer („karantanischer") ${ }^{3}$ und deutscher (südbairischer) Herkunft.

1 Dazu vgl. Pohl 2005ab, zu Osttirol erstmals Pohl 1997.

2 Hornung 1976, ähnlich 1964, 79.

3 Die seit dem 7. Jhdt. in den Alpen nachweisbaren Slawen sind bekanntlich die Vorfahren der heutigen Slowenen; deren nur aus Namen bekannte und erschließbare Sprachform 
Diese Vielfalt betrifft nicht nur die (amtlichen) Siedlungs- und Hofnamen, sondern auch die Flur-, Berg- und Gewässernamen. Deshalb befassten sich seit über hundert Jahren immer wieder verschiedene Sprachwissenschaftler mit der Erforschung dieses bis vor 100 Jahren noch so schwer zugänglichen Hochtales. Die durchgehend asphaltierte Landstraße mit mehr oder weniger breiter Zweispurigkeit wurde erst 1998 fertig gestellt. Eine bescheidene Straßenverbindung (1912 begonnen) gibt es seit 1927.

Nach den in den achtziger Jahren erfolgten systematischen Erhebungen im Kalser Tal durch meinen Kollegen Karl Odwarka und mich ${ }^{4}$ können wir heute mit hoher Wahrscheinlichkeit folgendes zu den Kalser Flurnamen sagen: knapp $2 /{ }_{3}$ sind deutsch (bairisch) zu deuten, 6-7\% slawisch bzw. slowenisch und ca. 29\% romanisch bzw. ladinisch (einschließlich vorrömische Schicht), wobei einerseits der Anteil romanischer Namen im oberen Bereich des Tales am höchsten ist, andererseits slawische Namen eher im unteren Bereich häufig sind. Es wurden zunächst fast 1300 Namen von Bergen, Bächen, Feldern, Weiden, etc. von Kalser Informanten gesammelt und von uns analysiert. Weitere (über 180) Vulgo- und Schreibnamen können bis auf etwa 20 romanische und vier slawische Namen, also über $85 \%$, deutsch (bairisch) erklärt werden.

Die dreizehn Oikonyme (also Dorf- und Weilernamen) des Kalser Tales zeigen wiederum eine andere Verteilung: sechs slawische (inkl. Kals), also fast die Hälfte, je drei deutsche und romanische Namen, also je fast ein Viertel, sowie einen Ortsnamen, der sowohl Deutsch als auch Romanisch gedeutet werden kann. ${ }^{5}$ Bei manchen Personen- und Flurnamen kann man nicht mit Sicherheit feststellen, ob es direkte Benennungen durch Romanen oder Slawen sind oder eventuell bereits ins Bairische übernommene Entlehnungen: ist Maier deutsch zu deuten (als Lehnwort < romanisch maior '(etwa) Verwalter'), Groder aber romanisch (von croda 'Felsen', also etwa 'Felsner'), wie wir es tun? Ähnlich verhält es sich mit einigen Flurnamen, die Alm, Alp, Alwe deuten wir als bereits voll integriert und somit bairisch. Müssen wir aber Balfen < vorrömisch *palva 'Fels (-höhle, -vorsprung)' als romanische Namengebung bezeichnen? Wohl eher nein, da der Balfen noch bei älteren Kalsern etwa dem Kofel im unteren Iseltal entspricht, d.h. 'Felsen' bedeutet und als bairisches (Tiroler) Wort angesehen wird. Zusätzlich zur Frage, ob ein Name bairisch zu deuten ist, können wir auch nicht immer sicher sein, ob ein anderer Name romanischer oder slawischer Herkunft ist (so kommt beispielsweise für Golz sowohl romanisch collis 'Berg, Hügel' als auch slowenisch golica 'kahle Stelle' in Frage). ${ }^{6}$

bezeichnet man „Alpenslawisch“ oder „Karantanisch“, sie entspricht weitestgehend der, wie sie uns in den „Freisinger Denkmälern“ begegnet (s. dazu v.a. Pohl 2005a).

4 Unter Berücksichtigung und Würdigung früherer Forschungen (v.a.) durch August Unterforcher, Karl Finsterwalder, Wilhelm Brandenstein und Maria Hornung; zuletzt kamen noch zahlreiche bemerkenswerte Beobachtungen und Deutungsversuche von Peter Anreiter (dem ich auch für einige weitere Hinweise dankbar bin) und Hubert Bergmann dazu (zu allen s. Literaturverzeichnis).

5 S. Anm. 20.

${ }^{6}$ In diesem Fall ist die romanische Deutung die wahrscheinliche (vgl. Anreiter 2004b, 91). 
Deshalb darf man die statistisch ausgewerteten Prozente je Sprachschicht nicht absolut sehen. Einige Flurnamen können nach heutigem Wissensstand nicht oder nur ungenügend erklärt werden.

Das Kalser Tal kann in drei Abschnitte aufgeteilt werden, die sich statistisch ${ }^{7}$ recht stark voneinander unterscheiden. Im Abschnitt I, dem höher gelegenen Norden, also im Dorfer Tal und Teischnitz Tal (mit Almwirtschaft über 1600 Meter) sind $38 \%$ der Flurnamen romanisch (davon sind einige vorrömisch), 7\% sind slawisch und 55\% bairisch. Dort hat sich das romanische Element am längsten gehalten.

Im mittleren Teil des Tales (Abschnitt II) mit fruchtbarem Ackerboden, umsäumt von Wiesen und Weiden, beträgt der Anteil des Romanischen (mit wenig Vorrömischem) über $35 \%$, der des Bairischen über $60 \%$ und nur $2 \%$ sind slawisch, meist in höheren Lagen.

Der Abschnitt III im Süden zeigt wieder ein anderes Bild: Bairisch dominiert mit $65 \%$, gefolgt vom Slawischen mit 20\% und mit nur 15\% romanischem Anteil (darunter kaum Vorrömisches). Dort hat sich wohl auch das slawische Element am längsten gehalten (s. 5).

Bisher wurden die drei, eventuell vier, Sprachschichten romanisch, slawisch, germanisch, sowie vorrömisch genannt, wobei uns die vorrömische Sprachschicht durch den Mund der Romanen vermittelt wurde. Eigentlich müsste man aber von fünf Sprachschichten sprechen, da ja ab ca. 1800 die Verhochdeutschungen und Verballhornungen einsetzten, vor allem durch Kartographen.

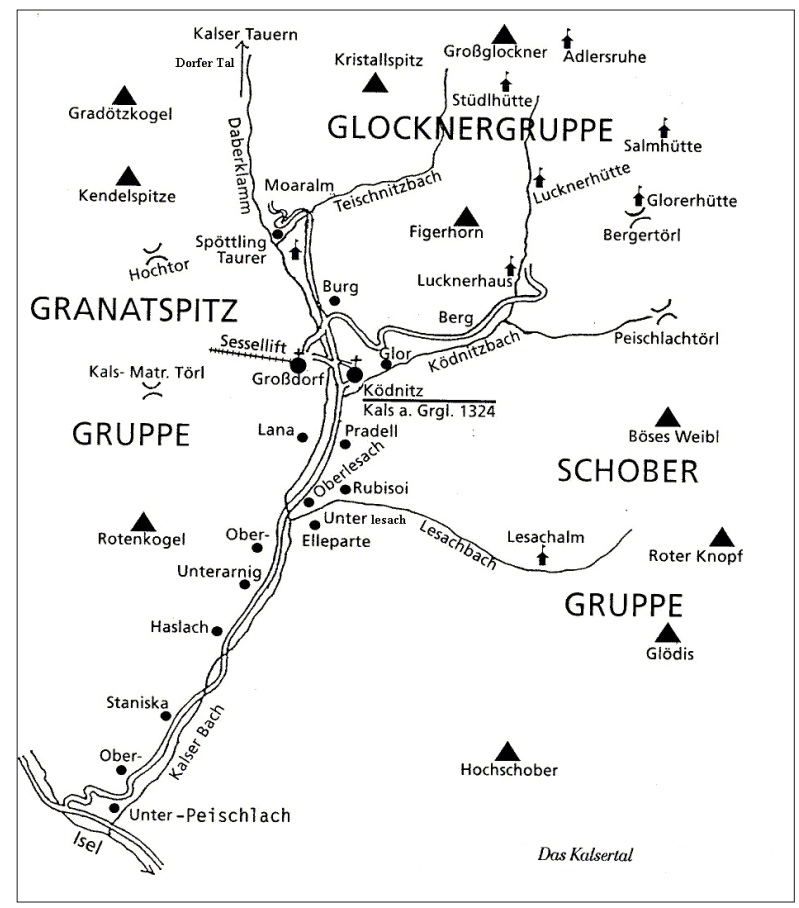

(Quelle: Leimser 1998, 71 u. Pohl 2004a, 53)

7 Zur Statistik: Bei den 1300 Flurnamen zählen wir jeweils nur das Grundwort, z.B. Muntanitz (BN im Dorfer Tal) und nicht die weiteren sieben abgeleiteten Namen, wie Muntanitz Bach, Muntanitz Balfen, Muntanitz Kees, etc. So erhalten wir z.B. in Abschnitt I 222 Grundwörter von 335 erfassten Flurnamen. Wir nehmen aber gleiche Namen in die Statistik dann auf, wenn sie an verschiedenen Orten vorkommen. So gibt es im Dorfer Tal z.B. je einen Luckenkogel im Osten und im Westen, was dann zwei bairische Namen ergibt. 
Man kann annehmen, dass vor 2000 Jahren das von Kelten bzw. ihren Vorgängern besiedelte Kalser Tal nach und nach romanisiert wurde. Frühestens im 7. und 8. Jahrhundert begann dann das Eindringen der Slawen bzw. deren Ansiedlung neben und mit den bereits ansässigen Romanen. Die große Namenkontinuität lässt vermuten, dass es zu keiner Verdrängung oder Überlagerung des romanischen Elements gekommen ist, sondern im Gegenteil, das (romanische) Ladinische muss wohl noch bis ins 15/16. Jahrhundert gesprochen worden sein, ${ }^{8}$ d.h., dass das Slowenische früher ausgestorben sein muss bzw. dass es im Romanentum aufgegangen ist. Das kann auf Grund von bestimmtem Lautentwicklungen in den Namen slawischer Herkunft festgestellt werden: sie sind durch einen ,romanischen Filter" gegangen, wie dies Peter Anreiter anschaulich gezeigt hat. ${ }^{9}$ Auch die nebeneinander bestehenden Übersetzungsnamen Ködnitz (3) neben Glor, *Fig neben Zöttl (11) und (Groß-) Dorf sprechen dafür sowie die Tatsache, dass slowenische Benennungen vorwiegend in den semantischen Bereichen „Bodenbeschaffenheit" und „Pflanzen“ vorkommen, hingegen (u.a.) „Topographie“, „Verkehr und Wege“ und „Klima und Witterung“" meist romanische Etyma aufweisen, also die typischen Benennungsfelder von bereits Ansässigen. ${ }^{10}$

Die während der letzten fünfzehn Jahre gesammelten Flur-, Orts-, Vulgo- und Schreibnamen - inzwischen sind es fast 1500 geworden - ermöglichen es, eine Besiedlungsgeschichte des Tales auf Grund der drei Sprachgruppen zu skizzieren:

o bis ca. 700 Romanisierung

o nach 700 Einwanderung der Slawen

o nach 1000 Romanisierung der Slawen (im oberen Bereich, Abschnitt I u. II)

o 1197 erster urkundlicher Beleg: Rainardus plebanus de Calce, somit spätestens

o ab 1200 schrittweise Ausbreitung der deutschen (bairischen) Verkehrssprache

o um 1500 Aussterben des Ladinischen (und auch des Slowenischen im südlichen Abschnitt III).

\section{Siedlungsnamen}

1. DerName Kals (urkundlich 1197 de Calce, 1329 Chalt(e)s, 1545 Kallss) dürfte ursprünglich ein Gegendname gewesen sein (für das heutige Kalser Tal) und wurde dann Name der Gemeinde. Er ist wahrscheinlich auf slowenisch kalec $(<$ kalbcb, zu slawisch kalb 'Kot, Schlamm; Lache, Pfütze; Viehtränke', im Slowenischen kal 'Kot in Pfützen; flache Vertiefung, in der sich Regenwasser ansammelt, Lache; Viehtränke') bzw. kaluža '(Kot-) Lache, Pfütze' zurückzuführen. Man vergleiche damit heutige slowenische Siedlungsnamen wie Kalce, Kalše, Kališe und Kaluže.

Der Kalser Bach fließt in seinem Mittelabschnitt in einem relativ ebenen Gebiet

8 Dr. Lois Craffonara, ehemals Direktor des Institut Ladin in St. Martin de Tor, Südtirol, meint, dass in Kals wahrscheinlich noch bis ins 16. Jahrhundert Ladinisch gesprochen wurde (Juni 1999 in Kals); vgl. auch Videsott 2004: 63f.

9 Anreiter 2004a, 59f. ${ }^{11}$ und 2004b, 88ff. (mehrere Beispiele), s.u. Zusammenfassung.

${ }^{10}$ Genaueres bei Anreiter 2004b, 111. 
sehr ruhig dahin und sein Bett ist von Lachen und Pfützen begleitet, insbesondere im Frühjahr nach der Schneeschmelze und im Hochsommer nach ausgiebigen Regenfällen oder heftigen Gewittern ${ }^{11}$. Von diesem (mittleren) Abschnitt II könnte also die (slawische) Namengebung ausgegangen sein, wo sich auch andere Namen slawischer Herkunft finden, z.B. Lesach, Arnig und Staniska. Schon Karl Finsterwalder hat darauf hingewiesen, dass in diesem Bereich des Kalser Tales der historische Kern der slawischen Besiedlung zu suchen ist ${ }^{12}$, liegen doch vier von den sechs Siedlungsnamen slawischer Herkunft in jenem Bereich (außerhalb liegt nur Ködnitz, Übersetzungsname zu romanisch Glor; der Name Kals selbst gilt heute für das ganze Tal und die Gemeinde).

Eine zweite Deutungsmöglichkeit ergibt sich aus der Tatsache, dass die slawischen Wörter kals und kaluža die gleiche Bedeutung haben können wie der in Tirol nicht seltene (ursprüngliche Flur-) Name Lizum (z.B. Axamer Lizum, Aussprache [litsúm], zu romanisch lozza 'Kot'), etwa 'Kotalm, Kotanger'13, mundartlich das Kot [khoat] bedeutet in Tirol überhaupt 'Lagerplatz des Viehs, wo viel Kot liegt' ${ }^{14}$; der Boden der Viehleger ist bekanntlich überdüngt. In diesem Fall würde der Name Kals mit der Viehzucht zusammenhängen; gestützt wird diese Erklärung durch den Flurnamen Kaluse (44), eine ehemalige Viehweide im Bereich zwischen dem Burger und Ködnitztal.

Eine romanische Herkunft des Namens Kals ist aus lautgeschichtlichen Gründen unwahrscheinlich, da romanisch $c a-$ [ka-] im Ladinischen gewöhnlich zu tscha- [ča-] wurde ${ }^{15}$, z.B. Flurnamen wie Tschadin < romanisch catinus '(Gebirgs-) Kessel, Kar' oder Tschamp < romanisch campus 'Feld'. Die Ausprache des Namens, mundartlich [khåls], setzt ein mittelhochdeutsches *khalz voraus, also affriziertes $k$, primäres $a$ (kein Umlaut) und stimmloses Fortis-s. Alle Laute können in entlehnten Wörtern und Namen vorkommen. ${ }^{16}$

Im Slawischen bedeuten die beiden in Frage kommenden Wortstämme kals und kaluža: ${ }^{17}$

(1) Schmutz, Unrat, Dreck;

(2) Kot, Schlamm;

(3) Kehrichtplatz

(4) Viehtränke;

(5) Lache, Pfütze;

(6) Sumpf, Morast.

Davon abgeleitet sind kališće 'Lache, Pfütze' und kalina 'Schneeball (Pflanze):

${ }^{11}$ Diese Ansicht wird durch die geomorphologischen und hydrologischen Gegebenheiten bei der Entstehung des Kalser Tales bestätigt (wie dies aus einem Vortrag von W. Wirkner, Limnologe aus Innsbruck, auf dem XII. Kalser Namenkundlichen Symposium hervorging). - Vgl. auch Odwarka 1999.

${ }^{12}$ Finsterwalder 1990-1995, I 54.

${ }^{13}$ Vgl. v.a. Finsterwalder 1990-1995, II 640.

${ }^{14}$ Schatz 351.

${ }^{15}$ Finsterwalder 1929, 240 f.

${ }^{16}$ Die einzelnen Vorschläge zu einer romanischen Deutung s. bei Pohl 2004b, 8f.

17 Šmilauer 1970, 87. 
$\hookrightarrow \quad$ Viburnum, L.)'. Davon kommen für das Slowenische (und damit wohl auch für das Alpenslawische) nur die Bedeutungen 2, 3 und 5 in Frage sowie kališće. Ein Blick ins slowenische Wörterbuch weist folgende Wörter und Bedeutungen aus ${ }^{18}$ :

(1) kât 'Kot in Pfützen; flache Vertiefung, in welcher sich Regenwasser sammelt, Lache; Viehtränke';

(2) kalǐč 'kleine Lache';

(3) kališs, kalíšče 'Pfütze, Mistlache';

(4) kalúža 'Kotlache, Pfütze'.

Ein kalec ist nicht greifbar, aber fürs ältere Slowenische nicht ausgeschlossen, zumal die Wortform kalec vom Homonym kal 'Keim' sehr wohl belegt ist.

In Osttiroler Flurnamen kommt der Wortstamm kal- weiters in Gelíschge [kəlíškə] (Alkus, Gemeinde Ainet) vor (1553 Goliskh Ackher) ${ }^{19}$ Ortsnamen mit diesen Elementen in Kärnten sind: Gall (Gemeinde St. Urban), Galling (Gemeinde St. Veit an der Glan, 1539 Gelicz, daher wohl zu kalič oder kališče), Kalischka (heute Ortsteil von Camporosso/Saifnitz, Kanaltal, Italien), in der Steiermark Kollisch (Gemeinde Stocking, Wildon) und in Salzburg der Hofname Galli (zweimal, Zederhaus und Sauerfeld). Beispiele aus Slowenien s.o.

Man wird wohl keinen ernsthaften Einwand gegen eine slawische Deutung von Kals vorbringen können.

Die Siedlungsnamen slawischer Herkunft im einzelnen: ${ }^{20}$

2. Arnig ([ấnik(h), alt árnik(h)], urkundlich 1288 Abernig, 1307 Awernichk, 1501 Ernigkh u. Ernickhen): altslowenisch *avornik (< slawisch *avorbnikъ), ursprünglich wohl Hofname, etwa 'Ahorner' zu slawisch (j)avorz, slowenisch javor 'Ahorn'. Dieser Name ist der einzige, bei dem die Ausgangsform *avor so stark

18 Nach Pleteršnik s.v.

19 Bergmann 2003, 144.

${ }^{20}$ Siedlungsnamen romanischer Herkunft: Glor (s. 3, amtlich auch Glor-Berg); Pradell (früher Pradel geschrieben, so auch urkundlich um 1600, Aussprache [pradél], aus romanisch pratellu 'kleine Wiese'); Elleparte (1553 Elepart, mundartlich [elepắrt(e)], älter [lepórtən], aus romanisch (ad) illam partem 'jenseitiger Teil'). - Der Name Lana kann entweder direkt auf romanisch labina 'Erdsturz, Lawine' bzw. *labinarium 'Lawinenzug' zurückgehen oder repräsentiert das aus letzterem entlehnte deutsch-mundartliche Lahner. - Siedlungsnamen deutscher Herkunft: Großdorf (der heutige Hofname Figer, urkundlich 1307 Zefig < romanisch sub vico 'unter dem Dorf', 1428 Fyger, weist darauf hin, dass Großdorf einst *Fig < romanisch vicus 'Dorf' geheißen haben dürfte; ein Hof heißt Zöttl, was slawisch *sedlo repräsentiert [s. 11]. Die Bezeichnung Großdorf ist auch urkundlich villa maior 'größeres Dorf' bezeugt, sie ist aber relativ jung, einst wird es wohl einfach Dorf geheißen haben, denn der ehemalige Gemeinbesitz von Kals-Großdorf wird mundartlich [dórfər álwe], das ist Dorfer Alm, amtlich Dorfer Tal, genannt); Burg und Unterburg (urkundlich um 1300 underbi̊rg, mundartlich [untər (dər) wurkh], Hinweis auf ehemalige Burg oder Fluchtburg. Es ist wegen der Aussprache [wurkh] statt des zu erwartenden [p-] auch slawisch vrbxz > slowenisch vrh 'Gipfel, Anhöhe' vermutet worden) sowie (ober Glor) Berg; Haslach (das ist die 'Haselstaudengegend', deutsch Hasel + bairisches Kollektivsuffix - ach). - Dazu kommen noch einige Rotten (Rotte '(abgelegener) Teil einer Dorfgemeinde bzw. zwei oder mehr Häuser in getrennter Lage') wie z.B. die Praderrotte und Taurerrotte (Hofnamen enthaltend) in Großdorf. 
reduziert erscheint, über arn- > ān-, sonst haben wir im Deutschen Formen wie Auernig (Oberkärnten) oder Jauernigg (Steiermark). Daher ist bei diesem Namen ein romanischer Filter denkbar, ${ }^{21}$ der Umlaut (auf Grund der urkundlichen Belege von 1501 und der heutigen Aussprache [a-]) spricht für frühe Eindeutschung.

3. Ködnitz ([khéidnits], urkundlich 1664 Ködniz) < slawisch *kqtbnica 'Gegend im Winkel bzw. Winkelbach' zu slawisch *kotz 'Winkel', slowenisch kot; vgl. den bedeutungsgleichen Nachbarort Glor (urkundlich 1329 Anglar, 1428 Angular, 1653 Glar < romanisch angulare 'im Winkel gelegen', beide Namen übersetzen einander). Die Lautentwicklung $-t->-d$ - ist auf einen romanischen Filter zurückzuführen. ${ }^{22}$

4. (Ober-, Unter-) Lesach ([léßa], urkundlich 1244 Lescha, 1369 Lesach): altslowenisch *lešah (< slawisch *lěšaxъ), Lokativ zu *leš(an)e 'Waldbewohner', Einwohnername zu slawisch lěs b, slowenisch les 'Wald'.

5. (Ober-, Unter-) Peischlach ([páišla], urkundlich 1329 Peuschler, 1338 Underpa ${ }^{e}$ uschlern, 1428 Päuschlarn u. Peuschlärn, 1501 Pauschlarn u. Peüschlarn): altslowenisch *pišljah (< slawisch *pyšl'axъ), Lokativ zu *pyšl'(an)e, einem von slawisch *pyxati 'blasen, wehen' abgeleiteten Einwohnernamen, etwa 'Ort, wo der Wind weht', slowenisch pišlje; der urkundliche Beleg Peuschler zeigt den alten deutschen Einwohnernamen, die Form auf -arn/-ärn den Dativ, der syntaktisch dem slawischen Lokativ entspricht, also eine deutsch-slowenische Mischform. Dass sich letztlich der Auslaut -ach < Lokativendung slowenisch -ah gehalten hat und nicht die deutsche Wortbildung, ist ein Indiz, dass dort noch ziemlich lange das Slowenische lebendig gewesen sein muss. - Der Ortsname erinnert semantisch an deutsche Ortsnamen wie Windschnurn (Gemeinde Lendorf, Spittal an der Drau), was auch mit der Realprobe übereinstimmt.

6. Staniska (mundartlich [níška, alt nîške], urkundlich 1545 zu Tanitsch, Tanitschga, 1553 Tanischgg[en], 1653 u. später Stanischga): altslowenisch *stanišće (< slawisch stanz 'Standort, Lagerplatz' + Suffix -isko / -išće), eine alte Bezeichnung für Almhütten (slowenisch stanišče).

\section{Hofnamen}

7. Niederarnig(er) ([nídər-arnik(ər)], Arnig). Urkundliche Belege: 1299 Awernick 1637 Arnig

\section{Niederarniger Gut}

Oberarnig gab es früher auch; ein alter Hofname dürfte der Nukleus der heutigen Ortschaft Arnig sein (Deutung s.o. 2).

8. Oblasser ([óplaßər], Peischlach). Direkte urkundliche Belege fehlen, jedoch im Flurnamen 1553 Oblaser Waldt bezeugt.

${ }^{21}$ Im Sinne Anreiters (s. Zusammenfassung), wie u.a. auch bei Rane (64), zumal auch sonst im Kalser romanischen Namenmaterial ähnliche Kontraktionen begegnen, z.B. Raspú-< *raspatura 'raue Gegend', Volschgú < valle obscura 'Finstertal', Wolfe-loare < *luparia 'Wolfsgrube' (Tautologie) usw.

${ }^{22}$ Vgl. Anreiter 2004a, $60^{11}$ u. 2004b, 93 Nr. 39. 
Zu slowenisch $o b+$ plaz 'längs der Lawine, Lahner'²3 + -er.

9. Perloger ([pəlók kər], Staniska). Urkundlicher Beleg: 1778 Perloger

Wohl zu slowenisch prelog 'Brachland', ${ }^{24}$ kommt auch in Ainet vor: 1410 Prelug ${ }^{25}$ mit deutscher Wortbildung (-er).

10. Rantschnigg ([rántšnik], Glor, heute unbekannt). Urkundlicher Beleg: 1608 Rantschnigg

Wie der Hofname Rantschner zu deuten, gleichsam die slawische Version dazu mit slawischer Wortbildung -nik, das wie deutsch-er Lagenamen bildet (zu romanisch *runca 'Rodung, Gereut', die romanische Version dieses Hofnamens ist in Glor-Berg Ranggetín(er) < romanisch *runca + -ittu + -inu/-a mit Suffixagglomeration); eine der seltenen romanisch-slawischen Mischformen (s. 14).

11. Zöttl ([tsetl], Großdorf). Urkundliche Belege fehlen.

Aus slawisch se(d)lo 'Dorf, Siedlung'; einerseits bleibt in Osttirol die Lautgruppe -dl- erhalten, ${ }^{26}$ andererseits fügt sich slawisch se(d)lo, das semantisch gut zu romanisch vicus 'Dorf' > *Fig (im Hofnamen Figer bezeugt, ebenfalls in Großdorf) und zu deutsch Dorf, heute Großdorf, passt - ein Name, der semantisch durch alle drei Sprachschichten gelaufen ist. ${ }^{27}$

\section{Gewässernamen}

12. Fruschnitzbach ([frúšnits-], demnach auch der Flurname Fruschnitzeben im Dorfer Tal) aus slawisch *brusbnica 'Steinbach' zu slawisch brusb 'Wetzstein' (vgl. slowenische Gewässernamen wie Brusnica); slowenisch brusnica bedeutet auch 'Preiselbeere', kommt aber für unseren Namen kaum in Betracht.

16. Kalser Bach (s.o. 1).

13. Laperwitzbach ([lắpərwits-], Dorfer Tal): aus slawisch *laporjevica 'Mergelbach' (zu slowenisch lapor 'Mergel').

14. Muntanitzbach ([múntanits-], um 1900 endbetont bezeugt [muntaníts-], Dorfer Tal, auch als Bergname (Muntanitz), meines Erachtens eher aus slawisch mQtbnica 'Trübenbach' in alter Lautung (*montǐnica), vgl. die jüngere Entwicklung in Metnitz < Mötnitz, Kärnten; denkbar ist auch entweder ein romanisch-slawischer Mischname, romanisch montanus 'Berg-' + slawisch -(bn)ica ${ }^{28}$ oder (eher unwahrscheinlich, da direkte Parallelen fehlen) ${ }^{29}$ rein romanische Herkunft, etwa

${ }^{23}$ Odwarka-Pohl VIII 987.

${ }^{24}$ Odwarka-Pohl VII 901.

${ }^{25}$ Finsterwalder 1990, 196

${ }^{26}$ Vgl. Pohl 2005a, 132f.

${ }^{27}$ In Odwarka-Pohl IX 159 habe ich diesen Namen noch anders gedeutet: Übername für den 'Struppigen', zu althochdeutsch zata, zota 'Zotte, wirre Haarlocke' (vgl. Finsterwalder 1990, 546f., betrifft aber einen Kufsteiner Namen) bzw. mundartlich zout 'Haarsträhne, ungeordnetes Haar', zot(t)l 'Zottel, Haarsträhne' (Schatz 733).

${ }^{28}$ So Finsterwalder 1990-1995, I 36. - Dass hier ein altslawisches Jer als Vollvokal erscheint, ist in Osttirol nicht ungewöhnlich, vgl. Zettalunitz- $<$ *sed blovbnica oder Zedlach $<*^{*}$ sedbl'achb, Erstbeleg 1022-39 Cetulic.

${ }^{29}$ Es wäre in unserem Gebiet der einzige Fall von romanisch munt- < mons 'Berg' (in zwei 
${ }^{*}$ montanities bzw. -itia. ${ }^{30}$ Da meist die Gewässernamen älter sind und nach ihnen die benachbarten Objekte benannt sind, ist davon auszugehen, dass der Name Muntanitzbach zunächst dem Flurnamen Im Muntanitz (woher der Bach zu Tal fließt) zu Grunde liegt und von diesem ausgehend ist dann auch der Berggipfel so benannt worden.

15. Teischnitz(bach) ([táišnits-], Dorfer Tal): die wahrscheinlichste Deutung dieses Namens (der auf der Anich-Karte als Eischnitz erscheint) dürfte slawisch *dъždbnica etwa 'Regenbach' zu *dbždb 'Regen' (slowenisch dež) sein (wie auch die Tüschnitz in Bayern).

\section{Flur- und Bergnamen}

17. Blas ([plāß], Dorfer Tal): eine Hanglichtung, zu slawisch plazъ 'Lawine, Lahn' (slowenisch plaz); s.a. Blos.

18. Blas ([plāß], Burger Tal): zwei nach Hofnamen unterschiedene Weideflächen: Kuenzer Blas und Jochblas, wie 17.

19. Blos ([plāß], Arnig): Kuhweide, wie 17.

20. Blossen (pl., [plôßßon, -ắ-], Großdorf): Felder, Plural zu 17.

21. Boroditze ([porodítse], Lana): Name eines Weges, wohl wie Paraditze (57) zu deuten.

22. Bossenig ([póßənik], Peischlach): eine Bergwiese, entweder zu slowenisch požnjak 'Wiese, die nur einmal abgemäht wird, meist spät' (von pozen 'spät') oder auf Grund von slowenisch po ševi 'an der schrägen Stelle' (pošev 'schräg') entstanden. ${ }^{31}$

23. Daba-, Daberklamm ([dấwa-, dấwər-], Dorfer Tal): urkundlich 1501 auf der Täber, 1533 an Kalser Däber, eine romantische Klamm, vom Kalser Tal aus gesehen der Eingang ins Dorfer Tal, zu mundartlich Daber (s.u. 74) aus slowenisch deber/daber 'Klamm, Schlucht'.

24. Debantgrat ([dé́wənt-], Staniska): Berggrat östlich vom Schoberkees zum Debanttal hin, nach der Ortschaft Debant so benannt; der Name dieser in der Umgebung des alten Aguntum gelegenen Ortschaft beruht auf slawisch *děvina 'Jungfrauenort', urkundlich 1274 Dewin, 14. Jhdt. Dewein, mit -t erstmals 1479 Debant, später auch (so 1583) Tebant (auf ins Christentum übernommene alte Frauenkulte hindeutend).

25. Drage (Droge) ([drắge], Arnig): ein Abbruch bzw. eine Geschiebefläche, auf dem mundartlichen Wort Droge (s.u. 75) beruhend, von slowenisch draga 'Schlucht, Wasserfurche; Mulde'.

weiteren Kalser Flurnamen [Matitz-, Matoitz-] erscheint mat- wie auch in Nordtirol und Vorarlberg, dazu vgl. Anreiter in Druck).

${ }^{30}$ Romanische Herkunft auch von Anreiter 2005, 23 erwogen; seiner Meinung nach hätte hier der slawische Nasalvokal fallen müssen (Anreiter im Druck), was bei einer frühen Entlehnung ins Romanische aber nicht zwingend erscheint. Immerhin liegt der Bach im Abschnitt I, wo es früh zu romanisch-slawischen Kontakten gekommen ist. - Denkbar ist auch, dass die Romanen den slawischen Namen nicht verstanden haben und ihn mit munt- 'Berg' assoziiert haben.

${ }^{31}$ So Bergmann 2003, 79. 
26. (Hoch-) Droge ([drắge], Peischlach): ein Abbruch im Gelände, wie 25.

27. Foledíschnitz ([fo ulədíšnits], Dorfer Tal): Bergname, wohl ein aufgewanderter Flurname $<$ slowenisch *voletiščnica 'Ochsenpferch' (der Name ist durch einen romanischen Filter gegangen, was den ungewöhnlichen Anlaut [f-] und die Abschwächung des -t- erklärt). ${ }^{32}$

28. Fruschnitzeben (s.o. 12).

29. Ganimitz (-Kopf) ([ganî́mits], auch Gaminitz [gamínits], Dorfer Tal): Bergname, zum häufigen slowenischen Flurnamen kamenica 'mit Steinen durchsetzte Flur, Steinberg'.

30. Gebroinig ([gebróinik(h)], Staniska): ein Graben mit Buchenbestand zwischen Arnig (2) und Haslach (Anm. 20) < slowenisch gabrovnik zu gaber 'Weißbuche'.

31. Glödis ([gléidəs, glö́idəs], Lesachtal): Bergname; dieser ca. $3200 \mathrm{~m}$ hohe Bergkegel ist mit Platten und größeren Steinbrocken übersät, er macht einen ,zernagten“ Eindruck, daher aus frühslowenisch *glodišće 'Ort, der vom Wasser zernagt ist' (zu slowenisch glodati 'nagen'), doch lautlich schwierig, ${ }^{33}$ wahrscheinlicher und auch wortbildungmäßig möglich ist der Ansatz *glodež mit ähnlicher Bedeutung (allerdings bezeichnet das Wort glodež auch mythologische Wesen).

32. Gogewischwald ([kốkewiš-], älter [kokewí̌̌s-], Staniska): ein waldiger Vorsprung (Viehtrift und Heuriese), das Vorderglied wohl aus slawisch *kokavišće zu slowenisch kokava / kukava 'steinige, unfruchtbare Gegend; Schlucht, Gestrüpp'.

33. Gol ([gōl], Peischlach): eine kahle Fläche bzw. ebene Bergwiese, zu slawisch golb 'kahl'.

34. Gössnitzfeldscharte ([géßnits-, gốßnits-], Ködnitztal): Bergname (Übergang), nach den Gössnitzfeldern auf der Kärntner Seite, so nach dem Gössnitztal (zum Hydronym Gößnitz < slawisch *kozbnica 'Ziegenbach') benannt.

35. Gost ([köš], Arnig): eine felsige Mahd mit Steinen und Stauden, zu slowenisch gošča(va) 'Dickicht, dichtes Gestrüpp'.

36. Gowen ([gốwən], Peischlach): ein Acker, wohl < slowenisch govne 'Schafweide'.

37. Gramul ([gramúll], Dorfer Tal): Bergname, slawischer Herkunft, vgl. slowenisch krmol, krmulja 'Felsvorsprung, Anhöhe' oder grmulja 'Haufen, Klumpen' (unklarer Herkunft) ${ }^{34}$, vgl. auch 40.

38. Graunitz ([gráunits], Peischlach): eine felsige Weide, vielleicht aus slowenisch *grbavinica 'höckerige, buckelige Flur', zu grb(av)ina 'Höcker, Buckel' (die Lautentwicklung lässt einen romanischen Filter vermuten).

39. Greiwiesen ([grai-], Ködnitztal): ein Wiesen- und Weidegebiet am Ende des Ködnitztales gelegen, zu slawisch krajb 'Rand, Gegend, Ende' (vgl. auch Groje 41).

${ }^{32}$ So Anreiter 2004b, 96.

${ }^{33}$ Weil slawisch -išće in Kals und Osttirol in der Regel zu -ischk wird (vgl. Pohl 2004a, 131f.).

${ }^{34}$ Deutungsversuche bei Bezlaj 1982, 96. 
40. Gremul, Gramulkopf ([gremúl, gramúl-], Ködnitztal): Bergname, die vor Ort übliche Aussprache ist Gremul; s. Gramúl (37).

41. Groje ([króie], Lesachtal): Rasenstreifen zwischen zwei Bergmähdern, zu slawisch krajb 'Rand, Gegend, Ende'; diese Flur wird statt Groje heute meist March 'Grenzgebiet, -zeichen' genannt (semantisch ähnlich, vgl. Greiwiesen 39).

42. Iwilschg ([íwilšk, í-], Peischlach): eine steile Wiese, aus frühslowenisch *ilovišće 'Ort mit Ton, Lehm'.

43. Jessen ([jéisən], Peischlach): ein Feld, zu slawisch*(j)ěsa, slowenisch jasa 'Lichtung'.

44. Kalúse ([kalúse], Burger Tal): ein ehemaliges Weidegebiet, $<$ slawisch kaluža 'Lache, Pfütze, Sumpf' (s. 1).

45. Ladine ([ladîne], Staniska): ein Weidegebiet, zu slowenisch ledina, mundartlich ladina 'Brache, Brachland'. ${ }^{35}$

46. Lassen ([lấsən], Großdorf): Felder, wohl zu slowenisch laz 'Rodung, Gereute'.

47. Lasteretz (Losteretz) ([loštəréts], Arnig): ein Hügel und eine Kluft über einem Bach, wohl wie Losteres, 48.

48. Losteres ([lóštərets], Lesachtal): spitz zulaufendes Waldstück, erinnert (wegen [-ets]) an slawische Namen wie *ostrbcb 'Spitzberg', was semantisch bei allen vier in Fragen kommenden Namen (47-50) passen würde, doch der Anlaut $l$ bleibt unklar (vielleicht eine slawisch-romanische Mischform: romanischer Artikel + slawisches Appellativ). ${ }^{36}$

49. Lostrasbödlan ([lóštras-], Großdorf): unter dem Ganotzeck (einer spitzen Erhebung) liegender Wald und Weide; wie 48.

50. Lostretzkluft ([loštréits-], Lana): schmaler Einschnitt zwischen Lana und Arnig; wie 48.

51. Lotischgen ([lotíškən], Peischlach): eine Bergwiese, aus frühslowenisch *lqtišče zu lqtъ 'Lindenbast, Gerte' bzw. lqtbje 'Lindenwald'. ${ }^{37}$

52. Mörbetzspitz(e) ([mérbets-], Lesachtal): von einem alten Flurnamen abgeleiteter Bergname, zu slowenisch murava / murova 'Au, Rasen; für Milchkühe geeignetes Gras' (vgl. slowenischen Flurnamen Murovica).

53. Mullitzboden ([múlits-], Arnig): höchste Bergwiese der Niederarniger Bergwiesen, zu slowenisch muljica 'Geröll usw.', eine der zahlreichen Ableitungen von slowenisch mulj 'feiner Sand, Flusssand'.

54. Mullitz-, Mollitzgraben ([mốlits-], Arnig): ein Graben, eigentlich ein Gewässername, wie 53.

${ }^{35}$ Ursprünglich mit Nasalvokal (*lędina), wobei das nasale Element vor Dental meist schwindet (so Anreiter in Druck). - In Nordtirol gibt es einen ähnlichen Namen, Ladins (vorrömischer Herkunft, beide gehen unabhängig voneinander auf indogermanisch *lendhinā- zurück). Bemerkenswert erscheint mir die Tatsache, dass auch im Romanischen der Nasal oft schwindet (worauf auch Anreiter in Druck hinweist).

${ }^{36}$ Eine andere Deutung könnte sich aus romanisch *lustera 'Heidel-, Schwarzbeere' (Substratwort, vgl. Grzega 1997, 72) ergeben.

${ }^{37}$ Mit häufigem Nasalschwund vor Dental (Anreiter in Druck), vgl. 45. 
55. Obring ([ốbrin] Peischlach); eine Wiese, zu slawisch $o b+$ brinb 'Wacholder', slowenisch brin oder brinje. ${ }^{38}$

56. Ostadan ([öštərdắn], Staniska): steile Bergwiese, vielleicht Zusammensetzung aus slowenisch oster 'spitz, scharf' + dno 'Boden, Grund' (Nebenform dane, vgl. den Ortsnamen Dane in Slowenien), ${ }^{39}$ also etwa 'spitz zulaufendes Grundstück').

57. Paraditze ([paradítse], Großdorf): ein Gebiet, wo Erdrutsche und Hangrutschungen häufig sind, dürfte romanisch pratum 'Wiese' enthalten, das in Komposita oft als par- erscheint; ein solches Kompositum dürfte in unserem Fall dann slawisiert worden sein, so wohl auch Boroditze (21). ${ }^{40}$

58. Plasischgegraben ([plaßíschke-], Arnig): ein Graben, der eigentlich ein Lawinengang ist, aus altslowenisch *plazišće 'Lawinengang', das Grundwort plaz ist in 17-20, 59 und 60 enthalten.

59. Plos ([plōß], Ködnitztal bzw. [plāß], Arnig): Weidegebiete, wie Blas 17.

60. Ploss ([plōß], Lesachtal): eine Wiese, wie Blas 17.

61. Poletztrog ([poletstrốg], Peischlach): eine große, trogförmige Geländemulde mitten im Wald, Zusammensetzung wohl aus slowenisch polica 'Gelände-, Berg-, Gebirgsstufe, Terrasse' + deutsch Trog.

62. Popbichelen (pl., [pópichelen], Lana): ein Hügel mit Kirche inmitten eines Wald- und Weidegebietes, wohl ein umgeformtes slowenisches podpolje 'Unterfeld' (vgl. Siedlungnamen Poppichl in Kärnten).

63. Prad (Brod) ([proud], Arnig): eine höher gelegene Weide, wohl zu slowenisch prod 'Geröll, Grieß' (wegen der Aussprache [-o $\left.{ }^{\mathrm{u}}-\right]$ wahrscheinlicher als aus romanisch pratum 'Wiese').

64. Rane ([rấne], Staniska und Peischlach): ein Feld bzw. ein Waldstück, wohl aus slowenisch ravnje 'eben Fläche, Ebene; Terrasse' (zum Lautlichen vgl. Arnig 1 sowie den Osttiroler Ortsnamen Raneburg [rấnewa], der auf slowenisch ravnoba beruht). ${ }^{41}$

65. Ströbnitzfeld ([štréiwnitse, štröiwnitse], Burg): ein höher gelegenes Feld, zu slawisch strops 'Dachstuhl; zwischen Bächen liegender Teil eines Berges', *strqpbnica 'steile, abschüssige Flur' (der Name ist durch einen romanischen Filter gegangen, was die Abschwächung des - $p$ - erklärt). ${ }^{42}$

66. Sunzkopf ([sunts-], Dorfer Tal): Bergname, zu slawisch zqbbcb 'kleiner Zahn' (slowenisch zob 'Zahn' in der Oronymie für 'stark zugespitzte Steinform; allein stehender hoher Felsen'), slawisch zQbbcb $>$ romanisch *sombitsa $>$ bairisch *somb(i)ts bzw. sunts. ${ }^{43}$

${ }^{38}$ So Anreiter 2004a, 58.

${ }^{39}$ Vgl. auch den Osttiroler Flurnamen Dane in Ainet (Bergmann 2003, 102f.).

${ }^{40}$ Kaum zu slowenisch prod 'Geröll, Schotter', denn der merkwürdige Vokaleinschub im Anlaut (auch bei 21) bleibt unerklärbar; das -itze kann kategorienbildend sein (im Sinne von Hornung 1981).

${ }^{41}$ Badjura 1953, $38 f$.

${ }^{42}$ So Anreiter 2004a, $60^{11}$ u. 2004b, $95^{45}$.

43 So Anreiter 2004b. 93. 
67. Teschgitz ([tōškits], Peischlach): ein Feld östlich der Oberpeischlacher Kapelle, wohl aus frühslowenisch *tešćica 'schwierig zu erreichendes Grundstück' (was man sich auf Grund der Topographie in früheren Zeiten vorstellen kann).

68. Tscha(r)nitzen (alm usw., urkundlich 1553 im Tscharnitschen) ([tšanítsn-], Lana): Waldparzellen, zu slowenisch črnica 'Heidel-, Schwarzbeere'.

69. Tschumpawitz (urkundlich die Schümppeniz, [ť̌úmpawits], Staniska): abgekommener Name eines Waldes und Felsens, wohl aus frühslowenisch *sqpovica 'Geierhorst' (zu sqpъ 'Geier').

70. Tschumpetschegg ([tšumpenék], Staniska): Bergname, ähnlich wie 69, zusammengesetzt aus einer Weiterbildung zu slawisch *sqp ‘ 'Geier' + deutsch Egg 'Berg-, Geländevorsprung' (man beachte die Divergenz zwischen Schreibung und Aussprache).

71. Waldniger ([wáldnikər], Ködnitztal): ein Acker, zu einem abgekommenen Familien- oder Hofnamen (deutsch Wald + slowenisch -nik + deutsch -er).

72. Zales ([tsấles], Lesachtal): eine Wiese, wohl aus slawisch za lěs- 'hinter dem Wald'.

73. Zelense (Große, Kleine) ([tselénse], Ködnitztal): eine Gemeinschaftsweide, aus slawisch zelenica 'grün bewachsener Platz in einer felsigen Gegend' ${ }^{44}$

\section{Wörter slowenischer Herkunft in der Kalser Mundart}

74. Daber (die) 'Klamm' [dấwa] < slowenisch deber / daber 'Klamm, Schlucht' (dieses Reliktwort, das in Kärnten aus dem appellativischen Wortschatz verschwunden ist, kommt auch in anderen Osttiroler Gegenden vor); ${ }^{45}$ s.o. 23.

75. Drage (Droge) 'Furche eines Erdrutsches' [drắge] < slowenisch draga 'Schlucht, Wasserfurche' (auch im Defreggen vorkommend) ${ }^{46}$ s.o. 25.

76. Gaislitz 'ein gesäuerter, fettloser Brei aus Hafer, der in erstarrtem Zustand gegessen wurde', überhaupt 'dicker Brei, Polenta' [gái(s)lits, auch gáiletse], schon in der mittelalterlichen Küche bekannt (gīselitze) < slawisch kyselica 'Säuerliches' von kyselb 'sauer'. Ursprünglich ein weit verbreitetes Wort, heute in Vergessenheit geraten. ${ }^{47}$

77. Glitsch (der) 'schuppenartiger Abstellraum' (heute nicht mehr in Gebrauch), ${ }^{48}$ sonst meist 'verschlagartige Abteilung im Stall (vor allem für Kleinvieh wie Schweine, Schafe) oder im Keller bzw. Vorratsraum (etwa für Erdäpfel, Rüben)', weit verbreitet in den meisten Osttiroler Talschaften. ${ }^{49}$ Das Wort muss sehr früh ins Deutsche gelangt sein, denn es findet sich auch in solchen Gegenden, wo kein slawisches Substrat anzunehmen ist, u.a. im Pustertal und auch in den norditalienischen deutschen Sprachinseln Pladen und Zarz. Zur Etymologie von Glitsch (auch Gglitsch) ist zu sagen, dass es wohl zu einer Ableitung von

\footnotetext{
${ }^{44}$ In Frage kommt auch *zenense zu romanisch cena 'Abendweide'.

${ }^{45}$ Schatz 125.

${ }^{46}$ Schatz 132.

47 Vgl. Pohl 2004, 35f. mit Lit.

${ }^{48}$ Hornung 1964, 82.

${ }^{49}$ Bergmann 2003, 162-165 mit Lit.
} 
$\hookrightarrow \quad$ slowenisch klet 'Keller, oberirdischer Keller' ${ }^{50}$ zu stellen ist, etwa kletič, also etwa 'kleiner Keller, Kellerabteil (o.dgl.)'. ${ }^{51}$

78. Gopritz 'ein gutes Futterkraut (Ligusticum mutellina L.)' (in anderen Gegenden Madaun genannt) [kóprits oder kốprits], entspricht dem slowenischen koprc 'Fenchel' (verwandt mit koper 'Dille'). ${ }^{52}$ Das Wort kommt auch im Raum Lienz sowie im Oberen Mölltal in Kärnten vor. ${ }^{53}$

79. Jach 'Tauwind' [jāch], es tut jachen 'es geht der warme Wind', außer in Kals auch im Defreggen, auf dem auch in Kärnten weit verbreiteten Wort Jauk 'Föhn, warmer Wind' (< slowenisch jug 'Süden') beruhend. ${ }^{54}$

80. Jause 'Zwischenmahlzeit', v.a.das Verbumjausnen 'eineZwischenmahlzeit einnehmen' [jáusnən], v.a. in Lesach neben Marende und marenden (romanischer Herkunft) für die Vormittags- (sonst meist Neuner '9-Uhr-Jause', neunern) und Nachmittagsmahlzeit. Das Wort beruht auf slowenisch južina 'Mittagessen' und hat sich zu einem Parade-Austriazismus entwickelt. - In anderen Osttiroler Gegenden hat Jause noch die ältere Bedeutung 'Mittagessen' (Defreggen, Tilliach, so auch im Kärntner Lesachtal). ${ }^{55}$

81. Lampitze 'Lamm (weibliches Jungtier)', im östlichen Teil von Osttirol verbreitet, $^{56}$ in Kals meist Lämpitzlein [lémpotsle oder lémpitsle], ${ }^{57}$ also eine Mischform aus deutsch Lamm (mittelhochdeutsch lamp) + slawisch -ica + deutsch -lein in Osttirol ist -itze $(n)<$ slawisch -ica sonst ein weit verbreitetes Flurnamen bildendes Suffix. ${ }^{58}$

82. Lunitsch 'Mäusebussard (Buteo buteo)' [lúnitš], zu slawisch *luńb 'Bezeichnung für verschiedene Greifvögel' + -ičb, das bei mehreren Raubvogelarten begegnet. ${ }^{59}$ Das Wort ist auch aus anderen Gegenden Osttirols bezeugt.

83. Meisch(k)itze 'Stachelbeere' [máišitsn oder máiškətsn], ${ }^{60}$ jedenfalls eine deutsch-slawische Mischform, kommt in Osttirol in mehreren Varianten vor, ${ }^{61}$ in Oberkärnten Meitschkelein; jedenfalls besteht ein Zusammenhang mit den Kärntner Mauchelein, slowenisch mundartlich mathelj, das selbst wiederum ein deutsches Lehnwort sein dürfte. ${ }^{62}$

84. Naunitze 'Hagebutte' [náunitsn], im nördlichem und östlichen Osttirol verbreitet (neben Aunitze) ${ }^{63}$ und beruht auf einem slawischen *(j)agodbnica 'kleine

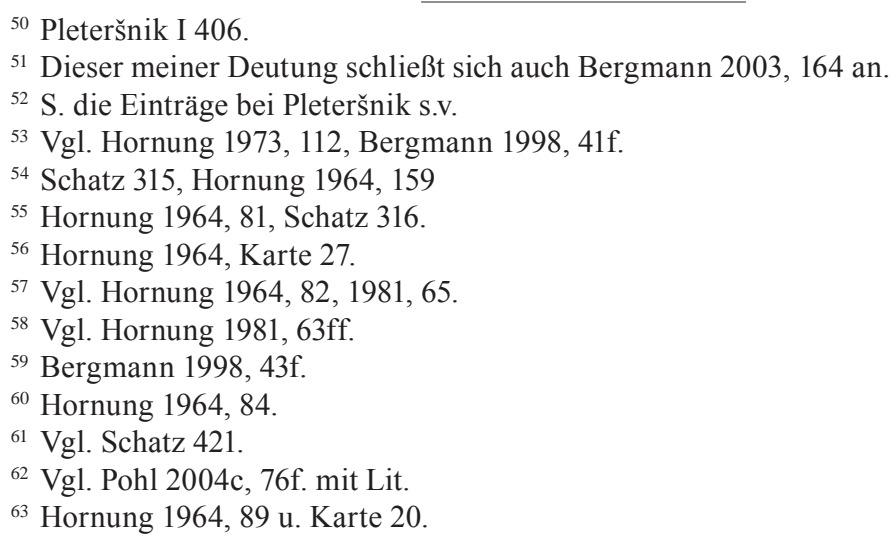


Beere'; ${ }^{64}$ auch im Slowenischen bedeutet jagoda eigentlich 'Beere', meist 'Erdbeere', u.a. auch 'Hagebutte'. ${ }^{65}$ Die Lautentwicklung lässt einen ,romanischen Filter“ im Sinne Anreiters (wie bei 3 und 65) vermuten (Abschwächung des intervokalischen -g- ähnlich wie *ille Aguntum > Lauent, geschrieben Lavant).

85. Struggel 'Strudel' [štrúkl], hier der Vollständigkeit halber erwähnt, in Kals ist Struggel die Nebenform von deutsch Strudel und sicher nicht entlehnt, ${ }^{66}$ in Kärnten ist jedoch das aus dem Slowenischen rückentlehnte Wort Struckel (< slowenisch štrukelj) ein anderes Gericht. ${ }^{67}$

86. Topanitz 'eine trockene Bähschnitte' [téupenits], dieses Reliktwort bezeichnet ein in Vergessenheit geratenes einfaches Gericht, wohl aus altslowenisch *topenica zu topel 'warm', topiti 'zum Schmelzen bringen' (also 'erhitzen'). ${ }^{68}$

\section{Zusammenfassung}

Für das Sprachgut slowenischer Herkunft im Kalser Tal sind folgende Eigenschaften typisch:

(1) vor $a$ - fehlt das prothetische j- (s. 2, 7);

(2) die altslowenische Lautgruppe *stj bzw. $s k^{e / i}$ wurde etwa [šk'] oder [šć] ausgesprochen, was im Deutschen schk [šk] ergeben hat (s. 6, 42, 51, 58, 67);

(3) die Nasalvokale sind vor Dentalen meist $(3,45,51,65)$, aber nicht immer (14), geschwunden, erhalten vor Labial $(\mathbf{6 6}, \mathbf{6 9}, \mathbf{7 0})$;

(4) eine nicht geringe Anzahl von Namen ist durch einen ,romanischen Filter“ gegangen $^{69}$ (s. 2, 3, 27, 38, 64, 65, 84);

(5) mitunter kam es auch zu romanisch-slawischen Mischformen (s. 10, 14?, 21, 47-50? 57);

(6) deutsch-slowenische Mischformen (s. 5, 7, 8, 9, 10, 62, 70, 71, 81, 83);

(7) bemerkenswerte Übersetzungen $(3,11)$. tisch. $^{70}$

Die Punkte (1), (2) und (5) sind für den ganzen Osttiroler Raum charakteris-

\section{Literatur}

Anreiter 2004a, Peter Anreiter, Deutungsversuche von rätselhaften Kalser Namen. In: Pohl (Hg.) 2004, 55-61.

Anreiter 2004b, Peter Anreiter, Onomasiologische Klassifikation der romanischen und slawischen Namen des Kalser Tales, In: Pohl (Hg.) 2004, 81-116.

Anreiter 2005, Peter Anreiter, Nichtslawische Onyme auf -i(t)z in Österreich, Österreichische Namenforschung, Jg. 33/3, 13-27.

\footnotetext{
${ }^{64}$ Hornung 1964, $26^{85}$ mit Lit.

${ }^{65}$ lt. Pleteršnik s.v.

66 Ähnlich Hornung 1964, 79.

${ }^{67}$ Vgl. zuletzt Pohl 2004c, 85 u. 42.

${ }_{68}$ Vgl. Hornung 1964, 79 und Pohl 2004c, 36.

${ }^{69}$ Im Sinne von Anreiter 2004ab

${ }^{70}$ Vgl. Pohl 1997 und 2005a, 130ff.
} 
Anreiter in Druck, Peter Anreiter, Das Schicksal der slawischen Nasalvokale im Osttiroler Namengut, Onomastica Slavogermanica (Leipzig).

Badjura 1953, Rudolf Badjura, Ljudska geografija, Ljubljana.

Bergmann 1998, Hubert Bergmann, köprits „Alpen-Mutterwurz“ und luunitš „Mäusebussard“ - zu zwei slawischen Relikten in Osttiroler Mundarten, Österreichische Namenforschung, Jg. 26/1-2, 39-47.

Bergmann 2003, Hubert Bergmann, Slawisches im Namengut der osttiroler Gemeinden Ainet und Schlaiten, Anmerkungen zur Slavia submersa im vorderen Iselta, Klagenfurt, Dissertation, $396 \mathrm{~S}$.

Bezlaj 1976, 1982, 1995, 2005, France Bezlaj, Etimološki slovar slovenskega jezika I-IV, Ljubljana.

Brandenstein 1978, Wilhelm Brandenstein, Kleine namenkundliche Arbeiten, Graz.

Finsterwalder, Karl Finsterwalder, Ueber Tauernnamen, Zeitschrift für Ortsnamenforschung 5 (1929) 228-242.

Finsterwalder 1990, Karl Finsterwalder, Tiroler Familiennamenkunde, Innsbruck, 2. Auflage.

Finsterwalder 1990-1995. Karl Finsterwalder, Tiroler Ortsnamenkunde I-III, Innsbruck.

Grzega 1997, Joachim Grzega, In memoriam Hugo Schuchardt (II): Kelto-Zentralromanisches, Grazer Linguistische Studien 47, 67-75.

Hornung 1964, Maria Hornung, Mundartkunde Osttitols, Wien.

Hornung 1973, Maria Hornung, Dialektgeographische Raumgestaltung im oberen und mittleren Mölltal, Zeitschrift für Dialektologie und Linguistik, Beiheft 9 = Festschrift Kurath 107-117.

Hornung 1976, Maria Hornung, Zur Problematik der Ortsnamenforschung in Osttirol, Osttiroler Heimatblätter 44/5.

Hornung 1981, Maria Hornung, Beobachtungen über die kategorienbildende Funktion slawischer Suffixe bei deutschem Namenmaterial in Sprachberührungszonen, Onomastica Slavogermanica 13, 61-66.

Leimser 1998, Hilda A. Leimser, Geschichte von Kals am Großglockner durch die Jahrhunderte, Kals am Großglockner.

Odwarka 1999, Karl Odwarka, Zum Namen Kals, Österreichische Namenforschung 27/1-2, 83-88.

Odwarka-Pohl, Karl Odwarka - Heinz Dieter Pohl, Materialien zu einem Namenbuch von Kals (Osttirol), Österreichische Namenforschung: I ÖNf 14/1-2 (1986) 83-111; II-III ÖNf 18 (1990) 5-54; IV-V ÖNf 21 (1993) 71-92; VI-VIII ÖNf 22-23 (1994-95) 59-71, IX (Hofnamen) ÖNf 26/1-2 (1998) 123-145.

Odwarka 2004, Karl Odwarka - Heinz Dieter Pohl, Alle Kalser Namen auf einen Blick: Register zu allen bearbeitetenund erhobenen Namen des Kalser Tales mit kurzer Erläuterung (Herkunft), In: Pohl (Hg.) 2004, 11-52.

Pleteršnik: Maks Pleteršnik, Slovensko-nemški slovar, Ljubljana 1894-1895, 2 Bde. (Neudruck Ljubljana 2006). 
Pohl 1997, Heinz Dieter Pohl, Po slovenskih sledeh na Vzhodnem Tirolskem, In: Historični seminar II, Ljubljana.

Pohl 2004a, Heinz Dieter Pohl (Hg.), Kalser Namenbuch, In: Österreichische Namenforschung (Sonderband), Wien, Edition Praesens.

Pohl 2004b, Heinz Dieter Pohl, Einleitung. Der Name der Gemeinde Kals am Großglockner, In: Pohl (Hg.) 2004, 7-10.

Pohl 2004c, Heinz Dieter Pohl, Die Sprache der Kärntner Küche / Jezik koroške kuhinje, Ein Lexikon mit Ausblicken auf die österreichische und internationale Küche, Klagenfurt, Hermagoras.

Pohl 2005a, Heinz Dieter Pohl, Die Slavia submersa in Österreich: ein Überblick und Versuch einer Neubewertung, Linguistica XLV-Ioanni Orešnik septuagenario in honorem oblata I, Ljubljana, 129-150.

Pohl 2005b, Heinz Dieter Pohl, Slowenisches Erbe in Kärnten und Österreich: ein Überblick, Kärntner Jahrbuch für Politik 2005, 127-160.

Schatz 1955 (21993), Josef Schatz, Wörterbuch der Tiroler Mundarten, Innsbruck, Wagner.

Šmilauer 1970: Vladimír Šmilauer, Přiručka slovanské toponomastiky / Handbuch der slawischen Toponomastik, Praha, Academia.

Unterforcher 1899, August Unterforcher, Die Namen des Kalserthales, Zeitschrift des Ferdinandeums für Tirol und Vorarlberg 43 (1899) 21-68.

Videsott 2004, Paul Videsott, Die Stellung der Kalser Namenlandschaft im ostalpinen Raum, In: Pohl (Hg.) 2004, 63-80.

\section{Slovenska imena in nekatere besede iz Kalsa na Vzhodnem Tirolskem Povzetek}

Vzhodna Tirolska ponuja obilico slovanskega besednega in imenskega gradiva, ki zaradi svoje obrobne lege izkazuje veliko arhaizmov (med drugim manjkajoč $i$ protetični j-, izgovor -šk- za današnji slovenski -šč-). To gradivo je treba uvrstiti $h$ „,karantanskemu“, staroslovenskemu narečju, ki se je govorilo v karantanski kneževini in je izpričano v Brižinskih spomenikih. Medtem ko imamo v drugih vzhodnotirolskih dolinah (Defreggen, Virgental, Iseltal, Lienzer Becken) - če odmislimo substrat - samo prednemško slovansko plast, je prišlo v dolini Kals do tesnih stikov z romanskimi praprebivalci. Posledica teh stikov so nekatera imena, ki so šla skozi romanski filter (npr. Arnig, št. 2, Ködnitz, št. 3 in Foledischnitz, št. 27), kakor tudi nekaj mešanih tvorb (npr. hišno ime Rantschnigg, št. 10 in ledinsko ime Paraditze, št. 57). Poleg tega najdemo nekaj zanimivih prevodov, kot sta npr. sosednji naselbinski imeni Ködnitz in Glor (št. 3) 'nahajajoč se v kotu' ter hišni imeni Zöttl in Figer (št. 11) 'vas'. Obstaja velika verjetnost, da se je slovansko prebivalstvo najprej asimiliralo z romanskim elementom (približno po letu 1000) in se je nemščina dokončno uveljavila šele okoli 1500. Strinjati se moramo, da je sámo ime doline in 
$-\quad$ okoli polovica naselbinskih imen slovanskega izvora, čeprav delež imen slovanskega [I] izvora drugače znaša povprečno 6-7\% (v južnem predelu pa $20 \%$ ).

N Poleg imenskega gradiva članek posveča primerno pozornost tudi narečne$-\quad$ mu besedišču. Tipične vzhodnotirolske besede oz. za dolino Kals tipične besede so 고 med drugim Daber 'soteska' (št. 74) ali Glitsch 'shramba' (št. 77), dalje Lunitsch 'navadna kanja' (št. 82) ali Topanitz 'vrsta peciva' (št. 86). Deloma so to relikti, $k i$ jih bolj vzhodno (na Koroškem) sploh ne zasledimo.

Heinz Dieter Pohl

Institut für Sprachwissenschaft und Computerlinguistic, Universität Klagenfurt Universitätsstr. 65-67, 9020 Klagenfurt 


\title{
Alcuni casi di paronomasia fra sloveno e friulano nei toponimi del Friuli
}

\author{
Maurizio Puntin (Fiumicello)
}

IZVLEČEK: Avtor obravnava 11 primerov paronomazije s historičnega območja Furlanije, zlasti z njenega najbolj zanimivega vzhodnega dela. Tu je več kot tisočletni stik med slovenskimi in romanskimi (furlanskimi) narečji sprožil prevzeme, kalkiranja, paretimologijo (in druge procese), ki jih je potrebno proučevati od primera do primera, od območja do območja, saj ima vsako območje svojo zgodovino, ki omogoča razložiti posamezne jezikovne pojave.

\begin{abstract}
Selected Examples of Paronomasia between Slovene and Friulian in Friulian Toponyms

ABSTRACT: The author discusses 11 examples of paronomasia from the historical region of Friuli, primarily its most interesting eastern part. More than a millennium of contact between the Slovene and Romance (i.e., Friulian) dialects in this region has resulted in processes that include borrowing, loan translations, and para-etymology. These must be studied on a case-to-case basis and from one area to another because each area has its own history that can provide an explanation of individual linguistic phenomena.
\end{abstract}

Il Friuli, specialmente nella parte orientale, è un'area interessantissima dal punto di vista della storia linguistica poiché, se si fa eccezione per la Romania ${ }^{1}$, risulta essere oggi l'unica zona dove una antica lingua neolatina come il friulano ha convissuto per quattordici secoli accanto ad una lingua slava come lo sloveno, rappresentato qui da una serie di dialetti, alcuni dei quali molto arcaici. Questa lunga

1 Ed escludendo pure l'antica lingua dalmatica (scomparsa con l'ultimo parlante nel giugno 1898 a Veglia). La Romania (con i gruppi Aromuni e Istrorumeni sparsi per i Balcani) ha una posizione geografica e una storia del tutto particolari se paragonata alle altre culture neolatine. 
convivenza ha avuto diversi riflessi, forse nella fonetica ${ }^{2}$ ma soprattutto nel lessico ${ }^{3} \mathrm{e}$ nella toponomastica dei paesi dove sono parlati i locali dialetti friulani e sloveni.

Qui si presenteranno in maniera succinta solo alcuni casi significativi, presi da alcune aree dove vi fu in passato o esiste ancora una consistente presenza stabile slovena: il Canal del Ferro, il Codroipese, Prepotto e l'Isontino goriziano e monfalconese ${ }^{4}$.

Non ci si dilungherà certo sul fenomeno della paronomasia o 'paretimologia', basterà dire che è antico quasi quanto il linguaggio ed è ben attestato già in epoca classica $^{5}$.

Ed ancora che ci appare qui spesso "sbilanciato" fra le due realtà linguistiche, nel senso che si tratta di una impossibilità soprattutto della parte romanza di comprendere il significato di un toponimo per esempio come Podercia (o Predigoi ${ }^{6}$ ) e della tendenza a "risistemarlo" all'interno del proprio orizzonte semantico; e questo naturalmente dopo il passaggio, più o meno completo, di una zona da una fase linguistica ad un'altra. Per esempio nel Territorio di Monfalcone da un'antica situazione bilingue (friulano-sloveno) ad una monolingue veneto bisiaca.

BELEPEIT PRADOVAN, (friul.) Belepèit Padoàn, (monte, q. 1170, Chiusaforte, Ud).

XIX sec. "Bele Peit Pradovan" (CN); XX sec. "Piccolo Belepeit" (IGM). Nelle attuali mappe la montagna è indicata come Piccolo Belepeit per distinguerlo dal vicino e più alto Belepeit (q. 1284), caratterizzato da una "roccia assai chiara" (esattamente il senso dello slov. bela péč). Pradovàn ha un etimo incerto: si può ipotizzare un toponimo ibrido composto da friul. Prâ(t) 'prato' - $d(i)$ - *Ovan, es-

2 Si sa per esempio che un noto studioso, l'Alinei, ha sostenuto che la palatalizzazione delle velari seguite da - $a$ - nei dialetti ladini sarebbe dovuta all'antichissimo influsso di metallurghi slavi protostorici provenienti dai Balcani e penetrati nelle Alpi alla ricerca di zone minerarie (Alinei 2000, 739-762). Questa posizione non è condivisa da diversi studiosi.

3 Si veda in generale Rocchi 1990 ("Latinismi e romanismi ...). Si può vedere anche una mia anticipazione sulla rivista Isonzo Soča (n. 61, 2005, 22-23) sui prestiti sloveni nel friulano: il contenuto di questo e di un altro articolo sui prestiti friulani nello sloveno goriziano confluiranno in un breve lavoro di prossima pubblicazione.

4 Nel Territorio di Monfalcone i dati onomastici e toponomastici indicano una presenza addirittura maggioritaria di contadini sloveni, almeno fino alla prima metà del sec. XVI.

5 Solo due esempi fra i tanti. Che il nome dell'aquila, il "primo" degli uccelli (e simbolo presente sulle insegne romane) fosse all'origine di Aquileia era cosa già scontata al tempo dell'imperatore Giuliano (355-363); il Candido nel sec. XVI menzionava questa antica paretimologia aggiungendovi altre due allora correnti, "ab aquis" ('dalle tante acque') oppure dal nome di un troiano, Aquilius, profugo come Enea ed Antenore. Il nome della

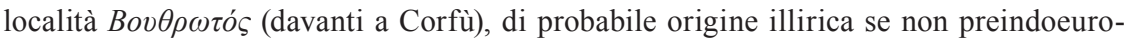
pea, era dai Greci interpretato come '(luogo dove) saltano i buoi' (-Bovৎ $\theta \rho \omega ́ \sigma \kappa \omega-\mathrm{cfr}$. in Mayer 1957, 103).

6 Naturalmente anche i popolani sloveni non avrebbero compreso il top. Predigoi, ma per lo meno sarebbe stato più facile che intuissero di avere a che fare con un nome della serie Bodigoi, Sfiligoi, Cernigoi, diffusissimi nel Goriziano. 
sendo il secondo elemento vicino ad una forma antroponimica di Johannes spesso menzionata negi archivi friulani (Juvan, Jovan, Juuan, Ivvan ${ }^{7}$ ). Si danno forse altre possibilità di ricerca partendo dalle voci prôdalen, pródovje, pridol (ecc.), ma tutte le vie interpretative finora esplorate comportano difficoltà. Ad un certo punto, in una situazione di opacità semantica, il toponimo è stato reinterpretato con un noto etnico italiano, abbastanza vicino alla pronuncia locale moderna.

BERTIOLO, (friul.) Bertiûl, Britiûl (Ud).

1275, 1300 “Bratigul ... Bratiulo" (TEA 167, 212); 1277 “Berthiolo sive Bertegul” (di Prampero 20); XIV sec. "Bratiulo" (SAC); 1311 “de Bratigullo" (STC); XV sec. "Paulus di Bratiol” (8); 1418 “de Bratiulo"; 1435, 1437, 1439 “de Bratiul, Brathiulo" (SAC); 1448 “in Bertiolo" ( $\left.{ }^{9}\right) ; 1459$ "Brathiulo"; 1552 "del Vuat de Bracthiulo" (SAC); 1552 “In Bratiolo ... Jn Bratiol” $\left({ }^{10}\right)$. Secondo il Frau e altri studiosi il toponimo deriva dal noto personale germ. Berto (Frau 1978, 34). Ma tenendo conto della maggior parte delle forme antiche e di una delle due dizioni moderne (Britiûl) sembra molto più plausibile un'etimologia slovena, dal pers. Brat- (formante incerta) ${ }^{11}$. In Bertiolo si dovrebbe ipotizzare una forma antroponimica altomedievale *Bratigui, in cui era già iniziato il processo di romanizzazione di un originario Bratigoi (forse come denominazione di un clan stabilitosi in zona). *Bratigui è stato successivamente sentito come un plurale di un *Bratigul; ed è infatti da quest'ultima forma, vista come nome del singolo villaggio, che parte la massa delle attestazioni conosciute. La scomparsa della velare intervocalica e una possibile metatesi (Bra-> Bar-/Ber-) sono fenomeni "normali" in friulano. La metatesi sarà certo stata favorita dal fatto che il passaggio dei contadini della zona ad un dialetto friulano ha reso del tutto opaco il nome originario Bratigul o Bratiul, mentre una forma Bertiûl evocava un personale germanico, Bert(o), “di moda” per lunghi secoli del medioevo, come tanti altri di questo strato linguistico dominante che sono all'origine di molti personali italiani. La presenza della variante Britiûl (usata in paesi vicini) ci indica però che questa tendenza paretimologica si è fermata a mezza strada: probabilmente a livello popolare aveva un successo molto parziale ma venne successivamente imposta dalla tradizione scritta e colta, nella forma attuale (generale dopo il XVI secolo). A livello toponomastico Bertiolo conta pochissimi confronti, per esempio con i top. Bràtis di Porpetto (<*Bratec ?), Val Bertàt (Paularo), Cjà Bertòs (Faedis), Bertogne (XVIII sec. Perteole), casale Bertòs da crôs a Scodovacca (Cervignano) ecc.; ma

7 Forme parallele al più diffuso slov. Ivan; esiste in Carnia anche un cognome Ovan. Il toponimo Belepeit Padovan è stato registrato nella raccolta di AA.VV., Legami tra una terra e la sua gente, I vol., 2004, 116-117.

8 Pellicciai, 32, 139.

9 Arch. Colloredo, b. 4, ASUd.

${ }^{10}$ Statistica dei beni delle chiese, anno 1529, ms. del fondo princ., BCU.

${ }^{11}$ Cfr. i nomi slavo-alpini Bratrěj e Bratrica individuati dal Kronsteiner in attestazioni carinziane e stiriane dei secc. XI-XIII (Kronsteiner 1981, 26); la schiera dei Bratecz, Bratigoy, Bratina, Bratonya, Bratosch, Bratosniczicz, Bratrong, Brattitsch, Brattusch, Bratus ecc. in Kos (Kos Urbarji 1954, 315). Anche la forma semplice Brat / Brati sembra documentata nel Friuli dei secc. XIV e XV (SAC). 
gli ultimi si dimostrano derivazioni di cognomi friulani per i quali è certo possibile anche un'ipotesi slavistica ${ }^{12}$. Fuori del Friuli troviamo Bertilo, Bertoio, Bertuolo (Vr, Pd) ecc., ovviamente dall'antico antroponimo germanico.

CAMINizzE, (bis.) Comunize (Pieris, fraz. di S. Canzian d'Is., Go).

1818 “Caminizze",'Cominiza”(CN); XX sec. "Comunizze” (MC). Probabilmente da confrontare con slov. kámeničje "terreno pietroso"13; trattandosi di una "strada campestre" a nord di Pieris, il riferimento va al fondo sassoso della via. Nella pronuncia popolare moderna (si nota già la tendenza nella seconda attestazione del sec. XIX) si è sviluppata la paretimologia sulla nota base "comune, fondo comunale".

LUCINICO, (friul.) Luzinîs, (slov.) Ločnik (fraz. di Gorizia).

1193 "Lucinigo" (STC); 1214 "villam de Lucinico"; 1247 “Lucenicum”; 1254 “Castrum Lucinici”; 1286 “de Lucinicho" (di Prampero 95). La dizione friulana ci assicura che il toponimo va inserito nel gruppo dei prediali di origine latina, quasi sicuramente da Lucinius $\left({ }^{14}\right)$, col normale esito in - $\hat{l} s$, -ì o -ìns. La forma slovena pare influenzata dalla paretimologia, attratta dall'appellativo lốnik 'divisione, confine': forse la tendenza pareva confermata dal fatto che da diversi secoli il "confine" linguistico fra friulano e sloveno si è assestato proprio fra Lucinico e Piedimonte. Nel medioevo invece, come sappiamo oggi, lo sloveno penetrava a fondo nella pianura goriziana e monfalconese.

PODERCIA, (bis.) Strada de le Portanzie (Monfalcone, Go).

1569 “...loco dicto oltra la Podercia in suburbijs Montisfalconi ” (ASCM 43); 1679 "Strada detta della Podercia va alle Paludi"; sec. XVIII "Strada publica Prodacia" (MPVE, Bianco 1988, 110-111, 130); XIX sec. "Stradella delle Portanzie" (Pocar). Lo storico toponimo sloveno di Monfalcone indicava anticamente una "rovina" (< slov. podrtîja con palatalizzazione) a sud della cittadina. La forma originaria era ancora ben riconoscibile nel XVII secolo ma già un secolo dopo risulta modificata ${ }^{15}$. Fra '700 e ' 800 si ha la modifica definitiva attraverso passaggi ricostruibili (Podrcìa > Podercìa > Prodacìa $>$ Pordaçìa > Portazìa > Porta(n)zìa), arrivando ad una situazione non chiara ma comunque evocante l'idea del "portare" e delle "portantine", che si legava alla realtà di una cittadina che aveva un suo piccolo volume di traffici portuali e che si avviava a diventare industriale.

${ }^{12} \mathrm{Cfr}$. come si ponga lo stesso problema in due cognomi friulani sparsi per il Friuli orientale, Bertòs e Bertogna (Bisiacaria), che possono esser fatti derivare da Berto (+ suff.) ma anche, come variante (con suffissi slov. -óž e -ónja), da nomi attestati nelle aree goriziana, monfalconese, aquileiese ed istriana fra i secc. XIII e XV, Bratogna, Bratuç, Bratus, Bratusinum, Bratusius, Bretoiga, Pratuz ecc. (SAC).

${ }^{13}$ Cfr. kámeničje in Pleteršnik I, 383. La forma ottocentesca trova tanti precedenti nella tradizione scritta e colta di antichi toponimi sloveni come la villa di Caminiza (1422, Tolmino, STC).

${ }^{14}$ Cfr. Pellegrini 1958, 109.

${ }^{15} \mathrm{Nel}$ XVIII secolo si completa la venetizzazione del territorio attorno a Monfalcone. 
PREDIGOY, (friul.) Pradigòi (Romans d'Is., Go) ${ }^{16}$.

1170 "das Dorf Predegoy"; 1276 "Predigoy" (STC); 1300 "in villa que dicitur Prydichoy" (TEA 167); XIV sec. "Predigoy" (Kos 122-126); XX sec. "Pradigoi" (MC). Le attestazioni antiche ci mostrano un tipico antroponimo medievale slavo alpino *Predigojb, accostabile per il primo elemento ai nomi Predimir, Predislav, attestati in Austria fra i secc. X e XII ${ }^{17}$. E proprio al di là delle Alpi, nella Stiria dei secc. XI e XII (ancora parzialmente slovena), si rintraccia il top. Predegoy, Predigoy (oggi Preg presso Knittelfeld ${ }^{18}$ ). La seconda parte del nome contiene un elemento antroponimico slavo che ritroviamo conservato in numerosi cognomi sloveni, Bodigoj, Černigoj, Maligoj, Mišigoj, Šaligoj, Suligoj ecc.. Un'attestazione poco nota, Bratigey (scrittura imprecisa o evidente errore di lettura per Bratigoy; NA I, $16{ }^{19}$ ) farebbe pensare pure alla possibilità di un diverso nome slavo, Bratigoj, ben attestato nel medioevo (Kos 55, 72). Purtroppo il passaggio di $B$ - iniziale a $P$-, giustificabile nei dialetti bavaresi dell'Austria, si spiegherebbe in Friuli solo attraverso una precocissima paronomasia romanza, in un paese che risulterebbe dunque già passato interamente al friulano nel sec. XII. E noi sappiamo come ciò sia difficile per la pieve di S. Andrea della Versa Sclavica. ${ }^{20}$ Per questi motivi sembra molto più convincente la prima proposta antroponimica. In ogni caso sia il personale ricostruito *Predigojb sia il ben documentato Bratigoj sono scomparsi dall'uso (anche cognominale) del Goriziano. Per cui in tempi a noi vicini si è imposta la scontata paretimologia Pra(t) di Gòi 'Prato di (un certo) Goi', confermata, se si vuole, dal fatto che effettivamente esiste nell'Alto Friuli il cognome $G o i{ }^{21}$.

SABORNIZZA - Sabbionizza (Pieris, fraz. di S. Canzian d'Is., Go) 1586 “... in pertinentiis ... Pieris loco nuncupato la Sabornizza" (ASCM 43); 1818 "Sabbionizza" (CN). Nel nome di luogo sloveno si intravede forse un composto

${ }^{16}$ Il toponimo Pradigoi verrà analizzato, assieme a tutti gli altri del Comune di Romans d'Isonzo, in un volume di prossima pubblicazione, della studiosa Francesca Parutto.

${ }^{17}$ Cfr. Kronsteiner 1981, 55.

${ }^{18}$ Cfr. Mader 1986, 395.

191347 “.. item mansum unum positum in villa de Bratigey emptum per dictum capitulum ..” (NA, p. 107).

${ }^{20}$ Che ha toponimi "interni" come Tapogliano (< Topoljane), Prestau, Racoiàn (*Orehovljane), In Blacca, Bobiz, Juaniz, Clagniz, Napalis, Pissacca, Pront, Scjìpis, Supanis ecc.

${ }^{21}$ Fino a non molto tempo fa questa etimologia era ritenuta corretta anche dallo scrivente. A dire il vero già in età medievale sono attestati in Friuli cognomi con questa forma "semplice": cfr. 1318 Goglio de Albana; 1322 Goys de Alnico (SAC). In Carinzia già nel sec. XI Gojica (1030 Gohza, Kronsteiner 1981, 40). Dal XVI secolo Goii fra Gemona e Cavazzo Carnico (Costantini 2002, 310). Sono attestati attualmente i cognomi slov. Goich, Gojč, Gojčič, Gojča (Merkù 1982, 25). Forse bisognerebbe ipotizzare un'antica presenza del personale in forma semplice con la valenza semantica ('pace') che ritroviamo in altre lingue europee. Il discorso comunque non vale assolutamente per il top. Pradigoi che può contare su una coerente ed ininterrotta tradizione (scritta ed orale) di toponimo unitario. 
$\hookrightarrow \quad$ toponimico con za- 'dietro' + brna / brnja 'terra d'argine, terra nera' ${ }^{22}+$ la diffusa formante -iza /-ica. A proposito di "terra d'argine" notiamo che queste terre confinavano ad occasum cum repario ('argine'). E "sotto il reparo" si trovavano nel CN 1811 i terreni chiamati Sabbionizza, un lampante caso di paretimologia bisiaca su un toponimo che già nel XVII secolo probabilmente non era più compreso.

SAGRADO - (bis.) Segrà, (friul.) Sagrât, (slov.) Zagráj (Go).

Etnici: (bis.) Segradini, (friul.) Segradìns, (slov.) Zagrájec, Zagrájka.

1130 “Otto de Sagrat” (Di Prampero); 1386 “Issegrado...Issigradum"; 1398 "Sagrud" (Kos, Urbarji); 1422 "villa de Isagrat... plebs S.ti Petri de ultra Isoncium"; 1422 "Isograd"; 1426 "de Zagrat" (STC); 1447-48 "Paganus de Xagrad... de Sigraz", (CC 13, 101); 1495-1501 "villa de Sagrat" (VAA); 1500 "Sagrà " (doc. veneziano, STC); 1562 "in villa Sacratj” (ASCM 43); 1563 "Sagrà" (Mappa veneziana -Lago 1989, 92); 1630 "Segrat”, 1653 /1667 "Segrad”, 1670 "Sagrad", 1672 "Segrat" (APSP); 1718 "Sagrat imperiale sotto li conti Della Torre" (STC).

Un prefisso con funzione locativa iz 'da' (o izzà 'da dietro') pare riconoscibile davanti alla voce zagrada 'recinto, campo recintato' o al termine grad 'castello' (o 'vallo' di antichi castellieri). Il toponimo Za-grad ha una vasta diffusione nelle aree slavofone e, per la nostra regione, menzioniamo solo Sagrado / Zagradec di Sgonico (TS), Zagradum (XVIII sec. Oslavia), Zagrádec / Zagráda nel Tarvisiano e a Resia ed infine il toponimo Sagredigh di Prepotto dell'anno 1736. In Carinzia troviamo il paese di Sagrad / Zagrad (slov. dial. *Zagraje). A favore di un significato storico della serie "grad / castello" sta il fatto, notevole, dell'esistenza in zona di diversi toponimi, Castelvecchio, Castelnuovo e Toràssa (vecchia torretta isolata). Ma, nonostante annose ricerche, non si trovano attestazioni antiche di castelli in questa zona carsica ${ }^{23}$. Bisogna dunque seriamente ipotizzare che dietro al nostro Sagrado / Zagraj si celi non un castelletto bensì un 'vallo', un 'recinto', forse un castelliere le cui tracce sono scomparse, essendo state sconvolte dalle guerre e dai vari riusi del materiale inerte.

Un dialetto sloveno fu sicuramente parlato a Sagrado nel medioevo da quei contadini che dettero il nome alla zona ${ }^{24}$ : ma non sappiamo quando si estinse del tutto. Dall'inizio del '500 sono attestati contadini veneti trasferitisi nel paese: cfr. "J. Rua et Baptista Bartholaemei et Hercules Titiani de Soligo" (Domini 1994, 30). Ma ancora fra i secoli XVII e XVIII Sagrado dimostra nei toponimi e di più nei cognomi di essere un paese misto con famiglie di origine slovena, friulana e veneta: '600 Vittor, Petrusig, Perco, Jusig; '700 Batistig, Blason, Furlan, Boschin, Marega, Zanella, Pelican, Pian, Pettean. Comunque è in questi ultimi secoli che deve essersi diffusa la paronomasia popolare bisiaca che parlava di un "segrà",25,

22 Cfr. Pleteršnik I, 64.

${ }^{23}$ Non si riesce infatti a far risalire questi toponimi "castellani”" oltre il sec. XVI, cioè il periodo delle guerre della Lega di Cambrai. Probabilmente si tratta di denominazioni improprie di palazzi o ville chiuse da muraglie, come quella ben documentata dei Della Torre.

${ }^{24}$ Si conservano anche microtoponimi come Cossèbia (< kočevje), Patòc, Grìse ecc..

${ }^{25}$ Dal latino sacratum 'terra consacrata' (it. 'sagrato', veneto segrà), ad indicare il terreno 
un cimitero attorno ad una chiesetta, in cui si seppellivano gli annegati nel fiume Isonzo. La paronomasia era quasi scontata, essendo il toponimo sloveno ormai opaco; era normale dunque che nascesse una diceria riguardo una chiesetta del luogo. Ma 'sagrato' o ‘cimitero' sono nomi di luogo solo in senso improprio generico e sono pochissimo produttivi di veri toponimi in tutta Italia. Pure l'Olivieri constatava l'assenza di sicure continuazioni di lat. sacru nella toponomastica veneta. Se a Sagrado ci fosse stato un cimitero attorno ad una certa chiesetta di S. Anna, è proprio questo titolo religioso che, secondo una tradizione millenaria, avrebbe dato il nome alla località, non certo un appellativo generico come 'cimitero'. Si consideri che ancora nel sec. XVII i morti di Sagrado venivano sepolti nella vicina ed antica chiesa di Fogliano ${ }^{26}$. A cominciare dagli studiosi ottocenteschi tutti quelli successivi (con l'eccezione del Domini ${ }^{27}$ ) non hanno fatto altro che confermare quello che molti volevano vedere nella scripta tradizionale (Sagrat, Sagrado) e nell'attuale forma venetizzata del toponimo, Segrà ${ }^{28}$; oppure che veniva sostenuto in loco sulla base della suddetta leggenda.

SDRAUSSINA - (friul.) Sdràussina, (slov.), Zdrávščina, Zdrávščine (fraz. di Sagrado, Go), (nome amministrativo e ufficiale italiano) Poggio Terza Armata.

1031 "Drausan" (STC); 1176-1184 “Bransan" (di Prampero, recte *Drausan); 1499 "villa et pertinentijs Sdrause", "Drausa" (ACTMG); 1500 "Drausa" (STC); 1523 "Drämbschina" (Kos, Urbarji); 1533 "Drampsina”, "Rausena" (Mattiussi, 60, 66); 1546 “Drausina” (Arch. C. Gradisca, Fondo Mosetti); 1562 "Sdrausinae” (ASCM 43); 1652 "Sdrausina” (APSP); 1692 "Sdrains” (Mappa Coronelli); 1713 "Sdrausena" (MPVE, Bianco 1988, 94-95); 1818 "Sdrausina" (CN). Antico e rarissimo toponimo (un unicum nel Friuli) che, nonostante le annose ricerche, rimane alquanto incerto nell'etimo e nell'evoluzione morfologica. Riguardo alla seconda, sono documentate tre forme del toponimo: la più antica *Drausan (XII sec) da cui deriva verosimilmente quella attuale (S)dràussina, una forma non suffissata Drausa (XV sec.) e una simile e contemporanea in cui compare per la prima volta la -s- iniziale, Sdrause (forse da slov. iz 'da' come nel vicino Issegrado - oggi Sagrado / Zagraj).

Riguardo alla difficile etimologizzazione del toponimo, le proposte avanzate si suddividono subito in a) *drausa, ipotesi preromana "alpina" (forse celtica secondo

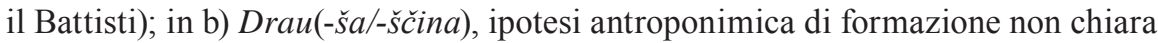
e in un'ultima ipotesi, slovena, c) drâvsa 'erbe'.

a) L'ipotesi indicata dapprima dal Mosettig e in seguito sostenuta dubitativa-

circostante le chiese con le sepolture (fino in epoca napoleonica in gran parte dei casi).

${ }^{26}$ Annotiamo quanto si dice in documenti seicenteschi veneziani: “.. Commun di Sagrà in temporale sotto Gradisca, nel spirituale il medesimo Commune di Sagrà è sotto la nostra chiesa della pieve di S. Pietro nella Giurisdizione di Monfalcon .. Commun di Fogliano, nella qual chiesa si sepeliscono i Morti di Segrà .. pagano il quartese al Pievano e alla Chiesa di S. Pietro" (PSCC 174).

${ }^{27}$ Il Domini sostenne più volte, in scritti e conferenze, l'etimologia slovena del top. Sagrado.

${ }^{28}$ Così per esempio C. L. Bozzi e G. Frau (Castelli 303). 
4 mente da C.C. Desinan vuole che alla base del toponimo Sdraussina ci sia un antichissimo fitonimo preromano *drausa 'ontano di monte' ${ }^{29}$.

Anche sorvolando sulla questione dell'areale solo montano di questa pianta, bisogna far notare come la diffusione della voce preromana riguardi i dialetti delle Alpi occidentali e centrali arrivando ad est fino alla Val di Fassa (TN): come toponimo troviamo per es. la Val Drosina nel Ticino ${ }^{30}$. In Friuli non emerge purtroppo nulla, non nel lessico e non nella toponomastica, che possa far pensare ad una antica estensione di questa voce in regione.

b) la seconda ipotesi antroponimica prende in considerazione un soprannome, Drau, attestato nel 1344 a Cervignano: un contadino di nome Henricus Drau è presente fra i livellari del Monastero benedettino di S. Maria di Aquileia ${ }^{31}$. Drau può ben essere un soprannome "etnico" indicante un'origine carinziana dalla valle della Drava: cfr. il top. carinziano Drâvčava presso Wernberg indicante una località abitata dai Dravci 'abitanti presso la Drava'32 .

Drau in tedesco e Drava in sloveno vanno considerati prestiti toponimici da un dialetto residuale neolatino dei Walchen transalpini: pure nel friulano medievale si può ricostruire una forma idronimica *Dràu (cfr. Timàu, Donàu).

Considerando che nel XII sec. il Gradiscano è un contesto etnico misto con una certa prevalenza slovena, al nome Drau si saranno aggiunte formanti slovene -ša/-ščina, delle quali solo l'ultima è giunta fino a noi con fonetica influenzata dal friulano. La suffissazione *Drávščina avrebbe un senso locativo (talvolta di proprietà) rintracciabile pure nel nome sloveno del limitrofo paese di S. Martino, Martinščina. La -S- iniziale (dal XV sec.) potrebbe essere in questo caso un'innovazione romanza passata in seguito agli Sloveni. In una situazione di "opacità semantica" del toponimo si sarebbe prodotto in un periodo imprecisabile un nuovo assestamento fonetico sloveno, Zdrávščina, con tendenza alla paretimologia, per assonanza, col noto personale Zdravko.

c) Più semplice ma meno probabile una seconda ipotesi slovena basata sulla voce slovena drâvs o drâvsa, nome generico di "erbe pungenti" 33: in questo caso si trattarebbe di un sinonimo di "incolto", nome dato da Sloveni alla zona quando nel VII secolo la trovarono abbandonata.

L'unico toponimo in regione che sembra avere una certa somiglianza con Sdraussina è un Dravosans / Drovosano / Dravasan degli anni 1330-41 a Moggio (STC). Ancor di più che sull'Isonzo nel Canal del Ferro vi furono certamente immigrazioni di Slavi provenienti dalla valle carinziana della Drava: Dravosàns in teoria poteva rappresentare il relativo etnico friulano.

${ }^{29}$ Cfr. REW 2767; DESF 15, 43-46.

${ }^{30}$ Cfr. Pellegrini - Zamboni, 1974, 25-26.

${ }^{31}$ I nomi dei livellari compaiono in un Elenco delle rendite del Monastero di S. Maria di Aquileia, dell'anno 1344 (presso BMNC).

${ }^{32}$ Cfr. Kranzmayer 1956-58, 226.

${ }^{33}$ Cfr. Pleteršnik I, 168. 
TERCIMONTE - (slov.) Tarčmún, (friul.) Terçimònt (Savogna, Ud). (etnico slov.) *Tarčmúnjan, *-nka; (ant., da cogn.) Tercimoniach (SAC) 1807-16 "Tercimonte" (CN).

L'origine di questo difficile toponimo è da ritenersi sub iudice. La forma slovena pare poggiare su un toponimo ricostruibile come *Tarcemon-. Secondo qualche studioso sarebbe possibile una derivazione da un lat. tertium montem. Ma un nome latino avrebbe dovuto dare verosimilmente un esito slov. *Trčmat- / *Tračmat- ${ }^{34}$. Si osservi la tipica resa slovena, Trmun, Tramuna ${ }^{(35}$ ), di un diffuso toponimo triestino e istriano, Termón / Tremón ${ }^{(36}$ ).

È vero che una pronuncia slavo-alpina di un top. *Tarcemon- avrebbe potuto assestarsi su un *Tarčmin / Tračmin come in Krmin da Cormones, ma nella toponomastica del Friuli e delle aree viciniori non andrebbe mai tralasciata la possibilità di interferenze di eventuali dialetti residuali neolatini del sostrato ${ }^{37}$ e della lingua friulana (dopo il X sec.).

Venendo alla forma friulana pensiamo che potrebbe trattarsi di una delle tante paretimologie prodottesi nel basso medioevo sotto l'influsso del prestito veneto rustico mònt, per cui tante antiche denominazioni terminanti in -mòn, -mùn sono state assimilate alla voce mònt che all'inizio indicò in Friuli solo le "malghe"38.

Un ipotetico *Tarcemon- (da cui slov. Tarčmun) andrebbe inserito in una serie prelatina che ha forse come primo elemento la base *tark(w)-: cfr. Tarcento, Tarcetta (XIVsec. Tercint iuxta landrum, 1444 Tarcìt), rio Tarcenò (Tramonti), Tàrces, Tàrcines $(\mathrm{Bz})^{39}$.

${ }^{34} \mathrm{Cfr}$. Matajur da un antico *M o n t e $\mathrm{m}$ a i o r e.

${ }^{35}$ Cfr. la simile resa, Paramun, di un toponimo derivato da lingue dell'antichità (greco $\pi \alpha \rho \alpha \mu$ ๆ nale non molto lontana dallo sloveno (Franck 1932, 221).

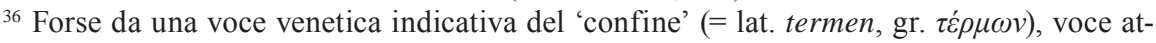
testata in iscrizioni venetiche ("termon, termonios deivos") e noriche (termunes), conosciuta da qualche autore latino (termon, -em, Festo) e penetrata in epoca classica nel latino "aquileiese"; le rare continuazioni, oltre che in termini e microtoponimi istriani (Decarli 1994), andrebbero individuate anche nei top. Tramonti / Tramònç, Tramoni, Tramùgna (Prealpi pordenonesi; cfr. Puntin 2003, Tramoncio) e Tramun nelle Alpi carinziane (Valle del Gail). Quest'ultimo nome di malghe e pascoli al "confine" fra la Gailtal e la Carnia) non è stato spiegato dal Kranzmayer.

${ }^{37}$ Questo deve esser stato determinante per esempio per il Tramun carinziano, così pronunciato un tempo dagli Slavi Carantani avendolo appreso dai Walchen (di cui perdura qualche ricordo nei top. Cornat, Frondell, Kosta, Stoffanell, forse Nostra). Fra il Friuli, la Carinzia e la Slovenia occidentale troviamo il monte Canin, pronunciato "alla friulana" Ćanèn, höra Ćanýnawa dai Resiani, i toponimi di sostrato Nadiža, Trenta, Federaun (< *Vederun), Drava ecc. Non sempre l'antica fonetica slava-alpina ha potuto esplicarsi coerentemente e totalmente.

38 Il toponimo ha pure un riflesso cognominale attestato in epoca tarda: cfr. 1616, 1639 "Pietro Tercimonte...Terzmont" (SAC; Zuanella 1996, Dom 9): fra l'altro si noti come anche il genere (m. invece che f., non *terçamont, cfr. friul. la mont) denunci il fatto che si tratta di un adattamento friulano non antico.

${ }^{39}$ La base suddetta è documentata nell'onomastica etrusca: Tarchas, Tarchis, Tarchume- 
Per completare questa ipotesi prelatina confronteremmo il nostroTarčmun con antichi toponimi sicuramente preromani aventi come secondo elemento o formante un -mon: nella montagna friulana Pisimòn, Esemòn (1295 Desamon, STC; -s- sonora), nell'Istria del XV sec. Corzemon ed infine il toponimo alto-veneto Cismòn ecc..

Un'ultima possibilità sarebbe teoricamente quella di inserire il nome fra i composti germanici medievali, aventi come secondo elemento germ. -mund (come per es. Trasemundus). In questo caso però il primo elemento resterebbe difficile da giustificare nella forma friulana e la forma slovena (col relativo etnico) diverrebbe quasi inspiegabile.

Esiste ancora una piccola località chiamata Tercimonte in comune di Prepotto ma qui la forma attuale del toponimo, non antica, deriva da un cognome friulanizzato (attestato in zona dal XVII secolo) che ricordava il luogo d'origine di una famiglia, Tercimonte di Savogna ${ }^{40}$.

\section{VALROMANA (Tarvisio)}

Per finire vogliamo chiudere con un caso emblematico come la cosiddetta Valromana di Tarvisio, dove si è aggiunto fra XIX e XX secolo, per complicare le cose, anche l'ottuso pregiudizio nazionalistico. In un campo dove già interferivano da sempre le paretimologie di origine colta o popolare si volle, dopo la sconfitta dell'Austria nel 1918, mutare in sede ufficiale un toponimo che per una vaga assonanza era accostabile all'etnico romanus. La Valromana vorrebbe "tradurre" infatti un tedesco dialettale Remmertal 'valle dei corvi', appoggiandosi al fatto che in tedesco l'etnico letterario Römer ${ }^{41}$ risulta foneticamente vicino alla voce alto ted. dial. remmer (pl. di ramm 'corvo'; ted. lett. rabe) ${ }^{42}$. La forma tedesca invece traduceva abbastanza correttamente lo sloveno dialettale Vranjica; questo perché le due culture coesistevano nella Val Canale da secoli, con molti fenomeni di interferenza linguistica e con la diffusa presenza del bilinguismo, specialmente da parte slovena .

naia, Tarchunies, Tarcnei ecc. (TLE). Nelle Alpi orientali un top."etruscoide" potrebbe riflettere uno strato di tipo retico, risalente cioè ad una lingua preindoeuropea parlata ancora in epoca romana nell'area alpina centro-orientale (Trentino, Tirolo, Veronese, Feltre ecc.). Nell'attuale Friuli toponimi risalenti a questo strato (Fanna, Feltrone, Pièltinis, forse Udine ecc.) sono evidentemente molto antichi poichè nella nostra regione già all'inizio del primo millennio la lingua più diffusa pare essere quella indoeuropea venetica, di cui abbiamo iscrizioni scoperte in varie zone.

${ }^{40}$ Questo borgo infatti ha attestazioni che hanno in comune col nome attuale solo una certa somiglianza nella prima parte, *Tarci-(-nt) / Terci- (mont): cfr. 1512 "Tarcent supra Ciallam" (SB); 1813 “de Tarcento sub Communi S. Petri de Cassacco" (APP). La somiglianza ha probabilmente facilitato l'assunzione del cognome quale ultima forma del toponimo.

${ }^{41}$ Ma l'etnico letterario non ha autentici riflessi toponimici popolari, essendo sostituito ancora da un'età protostorica da altri aggettivi etnici indicanti l'elemento romano e latino (originariamente i Galli - Celti), walh / walisch / welsch ecc..

${ }^{42}$ Cfr. Kranzmayer 1958, 240-241; Domenig 1997, 266-268. 


\section{Fonti e loro abbreviazioni}

ACTMG - Archivio del Capitolo Teresiano Metropolitano di Gorizia (A 24).

APP - Archivio della Pieve di Prepotto.

APSP - Archivio Parrocchiale di S.Pier d'Isonzo.

ASCM - Archivio Storico Comune di Monfalcone.

ASG - Archivio di Stato di Gorizia.

ASUd - Archivio di Stato di Udine.

ASVE - Archivio di Stato di Venezia.

BCU - Biblioteca Civica di Udine.

BMNC - Biblioteca del Museo Nazionale di Cividale del Friuli.

BSU - Biblioteca del Seminario, Udine.

CN - Catasto Napoleonico, anno 1818, presso ASG.

MC - Catasti (austriaci e italiani) secc. XIX-XX, presso ASG.

MPVE - Mappe veneziane, sec. XV-XVIII.

NA - Necrologium Aquileiense.

NP - Nuovo Pirona (Vocabolario Friulano).

PSCC - Provveditori Sopraintendenti alla Camera dei Confini, b. 174 (presso ASVE).

SAC - Schedario Antroponimico Corgnali (presso BCU).

SB - Schedario Biasutti, archivio ms. presso BSU.

STC - Schedario Toponomastico Corgnali (presso BCU).

TEA - Thesaurus Ecclesiae Aquileiensis.

VAA - Visite dell'Arcidiaconato inferiore nella Diocesi di Aquileia (1495-1501).

\section{Altre abbreviazioni}

bis. - dialetto veneto "bisiaco" (dal XVII secolo) $)^{43}$

friul. - friulano

it. - italiano

slov. - sloveno (nel Territorio di Monfalcone parlato almeno fino alla metà del XVI secolo)

\section{Bibliografia}

AA.VV. 2005 - AA.VV., Legami tra una terra e la sua gente - Toponomastica di Chiusaforte, I vol. (destra orografica del Fella), Comune di Chiusaforte, 2005.

Alinei 1996, 2000 - Alinei, M., Origini delle lingue d'Europa, I. La Teoria della Continuità, 1996, II. Continuità dal Mesolitico all'età del Ferro nelle principali aree etnolinguistiche, 2000, Bologna.

${ }^{43}$ La denominazione "bisiàc / bisiaco" è di origine slava ma di etimo non chiaro. Il dialetto attuale è un dialetto di tipo veneto con arcaismi lessicali friulaneggianti e con un limitato residuo lessicale sloveno. 
$4 \quad$ Bianco 1988 - Bianco, F., Monfalcone e il Territorio, Mariano d. F., 1988.

[.] Bozzi 1969 - Bozzi, C. L., Sagrado e la sua storia, Sagrado, 1969.

Castellarin 1998 - Castellarin, B., Toponomastica del territorio del comune di Bertiolo, Bertiûl, 1998, 459-494.

Costantini 2002 - Costantini, E., Dizionario dei cognomi del Friuli, Udine, 2002.

Decarli 1994 - Decarli, L., Una locuzione dialettale istriana: bàter tremón, "Atti e memorie" della Società istriana di archeologia e storia patria, v. XLII n.s., Trieste, 1994, 375-384.

Di Prampero 1882 - Di Prampero, A., Glossario Geografico Friulano, dal VI al XIII secolo, Venezia, 1882.

Domenig 1997 - Domenig, R., Sotto il triplice confine Weissenfels Bela Peč-Fusine in Valromana, Maniago, 1997.

Domini 1994 - Domini, S., Teodoro del Borgo - Capitano di balestrieri e la chiesetta di Fogliano, Mariano d. F., 1994.

Franck 1932 - Franck, O., Studien zur serbokroatischen Ortsnamenkunde, Leipzig, 1932 .

Frau 1969 - Frau, G., I nomi dei castelli friulani, “Studi linguistici friulani” I, (introduz. di G.B. Pellegrini), 1969, 257-315.

Kos 1954 - Kos, M., Srednjeveški urbarji za Slovenijo (voll. 3), Urbarji Slovenskega Primorja, II, Ljubljana, 1954.

Kranzmayer 1956-58 - Kranzmayer, E., Ortsnamenbuch von Kärnten, Klagenfurt, 1956-1958.

Kronsteiner 1981 - Kronsteiner, O., Die Alpenslawischen Personennamen, ÖNF Sonderreihe 2, Wien, 1981 .

Lago 1989 - Lago, L., Theatrum Adriae, Dalle Alpi all'Adriatico nella cartografia del passato, Trieste, 1989.

Legami 2004 - AA.VV., Legami tra una terra e la sua gente, I vol., 2004.

Mattiussi 1998 - Mattiussi, D., Il bosco nell'acqua - La comunità di Sdraussina e Peteano: storia società e ambiente fra il Carso e l'Isonzo, Sagrado, 1998.

Mayer 1957, 1959 - Mayer, A., Die Sprache der alten Illyrier, Band I, II, Wien, 1957, 1959.

Merkù 1982 - Merkù, P., Slovenski priimki na zahodni meji, Trst.

Pellegrini 1958 - Pellegrini, G.B., Osservazioni sulla toponomastica prediale friulana, SG, XIII, 93-113.

Pellegrini, Zamboni 1974 - Pellegrini, G.B., Zamboni, A., Commenti a nomi friulani di piante raccolti nell' ASLEF, Studi linguistici friulani, IV, SFF, 1974.

Pellicciai - Vicario, F. (a cura di), Il registro della confraternita dei Pellicciai di Udine, Pasian di Prato, 2003.

Perco, Puntin 1998 - Perco, F., Puntin, M., "Feras bisontes" alle soglie del Friuli, Ce fastu? LXXIV, 2, 1998, 281-296.

Puntin 2003 - Puntin, M., Toponomastica storica del territorio di Monfalcone e del comune moderno di Sagrado, Gorizia, 2003.

Rocchi 1990 - Rocchi, L., Latinismi e romanismi antichi nelle lingue slave meridionali, Udine, 1990. 


\section{Nekaj primerov paronomazije med slovenščino in furlanščino v furlanskih toponimih}

Povzetek

Kot vemo, je paretimologija (ali paronomazija) etimologija, ki se na prvi pogled zdi ustrezna, po natančni preučitvi pa se izkaže znanstveno neutemeljena. Pojem paretimologija ne vključuje tistih ljudskih paretimologij, ki jih je na podlagi slušne podobe pogosto skovalo ljudstvo, kot je to npr. v primeru nekaterih furlanskih imen: Redipuglia (Gorica) jasno asociira na re di Puglia "kralj Puglia”; v Lusevera se kaže luse vera "prava luč”; Driolassa, Palazzolo, Pocenia so bili vključeni v cikel kratkih pripovedi o Atili. Poglavar Hunov naj bi, ko je na konju prečkal nižino, rekel, da se v nekaterih pustih krajih ni bilo vredno ustaviti, ker je bilo v kraju Pocenia pôc e nîe (furl.) "malo in nič", v Palazzolo, ker je bil palàç sôl "samo en dvorec", $\checkmark$ Driolassa pa naj bi rekel drìo làssa (ben. it.) "pusti zadaj”, ker je bil kraj povsem nepomemben. Pojem paretimologija ne vključuje niti številnih "učenih" paretimologij, ki toponime navadno razlagajo z latinskimi ali pa celo z grškimi besedami, da bi kraju dali antični prizvok, npr. Tarcento naj bi izviral iz ter cinctum 'tri krat ograjen (z obzidjem)', Turriaco iz turris aquae, Scodovacca iz scolum aquae, Perteole iz prae tegulis, Cormons iz cor montium itd.

V prispevku so obravnavane tiste paretimologije, ki se tudi v očeh srednje izobraženega človeka zdijo ustrezne in se kot neutemeljene in nesprejemljive izkažejo šele po natančni preučitvi in uporabi posebne metode. Iz bogatega repertoarja toponimov, ki so bili podvrženi paronomaziji, je bilo izbranih 11 z vzhodne Furlanije, kjer se furlanščina in slovenščina stikata že več kot tisoč let. Med njimi sta dva, Sdraussina in Tercimonte, skoraj gotovo predlatinska toponima, njuna nejasna semantika je že zelo stara, zato sta bila verjetno podvržena večkratnim paronomastičnim interpretacijam

V primerih, kot so Bertiolo, Portanzìe, Sabbionizza in Sagrado, se je paronomazija izvršila, ko je na teh območjih prišlo do zamenjave jezikov in je toponim postal pomensko nejasen. Če je v novem jeziku obstajala beseda, ki je bila podobna staremu toponimu, je podobnost med njima lahko tako kot v primeru Sagrado, ki se je povezal z ben. it. segrà "pokopališče”, sprožila pomensko razlago, ki je bila sprejemljiva tudi za srednje izobraženega človeka. V drugih primerih kot npr. v Portanzìe in Sabbionizza tuji sufiksi kažejo, da delovanje paretimologije ni bilo popolno. V Sabbionizza lahko npr. ugotavljamo, da je toponim razumljiv in povezljiv z izpeljankami iz nar. sabiòn 'mivka', toda sufiks je očitno slovenski in neusklajen z osnovo, pri kateri bi pričakovali *sabionìz.

Pojav paronomazije je potrebno vključiti v samosvojo zgodovino vzhodne Furlanije, ki je delno že znana in ki za nekatera naselja z območja Tržiča in sodobnih občin Corno di Rosazzo, Manzano, Visco, Aiello, S. Vito al Torre, Romans, Capriva in Gradisca ugotavlja, da so bila v srednjem veku na jezikovno slovanskem območju.

Sprememba jezikovnega registra se je v poznem srednjem veku v različnih skupnostih izvrševala različno, zato je potrebno, da se primere proučuje vsakega 
zase: ustrezna sinteza bo možna šele čez nekaj desetletij, ko bo pretežno že zaključeno topnomastično in onomastično zbiranje, ki sedaj še poteka.

Na koncu je potrebno omeniti še nacionalistični dejavnik, ki je s prevaro segel tudi na področje onomastike. Ugoden rezultat Valromana je dal pri trbiškem Remmertal, ki je bil nemški narečni prevod (remmer je množina k ramm 'vrana'; torej 'dolina vran') starega slovenskega toponima in ki se je naslonil na dejstvo, da je knjižno nemško Römer 'Romani' fonetično blizu apelativu remmer. Ta goljufiva, a premišljena paronomazija je skoraj znosna v primerjavi s skoraj sistematičnim izbrisanjem starih lokalnih toponimov, ki so kazali na slovanski svet: Pasiano Schiavonesco (> Basiliano), S. Pietro degli Slavi (> S. Pietro al Natisone) in S. Leonardo degli Slavi (> S. Leonardo) v Videnski pokrajini.

Maurizio Puntin 


\title{
Личното име Венцеслав и неговите производни в българската антропонимия
}

\author{
Ludwig Selimski (Katovice)
}

IZVLEČEK: V članku je predstavljena analiza imena Венчеслав kot substitucije italijanskega Venceslao in Венцеслав, ki izhaja iz latinskega Venceslaus. To je latinizirana oblika zahodnoslovanskega (moravskočeškega) Veceslavъ. Prva sestavina tega imena izhaja iz praslovanskega *vętje- 'več'. Z njim so torej želeli poimenovanemu 'več slave'. V članku so obravnavane tudi druge bolgarske različice iтепа Венчеслав: Вячеслав (cerkvenoslovanska in ruska oblika), Вечеслав (izposojeno iz srbščine), Ващлав (iz с̌еščine), Венцел (iz nemščine ali madžarščine).

The Name Venceslav and its Variants in Bulgarian Anthroponomy

ABSTRACT: This paper analyzes the name Венчеслав as deriving from Ital. Venceslao, and Венцеслав from Lat. Venceslaus, which represents a Latinized form of the West Slavic (Moravian Czech) Veceslavb. Its first component is a continuation of Common Slavic *vętje- 'more'. Thus, this name expresses a wish for "greater glory" to its bearer. It was first borrowed as a name by Bulgarian Catholics. The name Венцеслав is also used by Czech emigrants to Bulgaria, parallel with Вацлав. The paper also examines some other variants of this name: Вячеслав (а Church Slavic or Russian form), Вечеслав (from Serbian), Вацлав (from Czech), and Венцел (from German or Hungarian).

1 Няколко пьти съм засягал произхода на името Венцесла̀в, но все накратко. Тук го анализирам подробно и в светлината на вторично осъществявания в продължение на няколко века контакт между европейския запад и славянския изток, благодарение на който върху българския - типично източен - ареал, се появяват и елементи, които са по същност западнославянски и/или западноевропейски. Бих желал да обоснова по-обстойно схващането, че името Венцесла̀в (и Венчесла̀в) по своя произход не е домашно, народно българско, с предполагаема първа съставка венѐц (венчѐ), а е проникнало в този ареал от Западна Европа като християнско и представлява субституция на лат. 
$\hookrightarrow$ Venceslaus, което е латинизиран облик на западнославянското (моравско-чешко) Veceslavb.

2 В българската антропонимия Венцеслав е сравнително ново име. По данни от най-пълния засега речник на личните имена у българите (Ковачев $1995,108)^{1}$, то се появява едва в началото на XX век, а по-точно в 1908 г., като в I десетилетие на XX век е отбелязано само 3 пьти, във II - 4, а в следващите няколко десетилетия увеличава честотата си: в III е отбелязано 10 пъти, в IV 34 , в V - 70, в VI - 114, в VII - 137, а в 80-те години бележи известен спад - на 135 пьти. Със своите общо 507 отбелязвания в основния облик Венцееслав то се представя и като рядко. За незначително - с около четвърт век - по-стара дата на поява в българския ареал („Крива Паланка, р[оден] 1881, Кюстендил, 1893”) и за разпространение „нарядко из цялата страна” пише 30 години по-рано Ст. Илчев $(1969,106)$, според когото Венцеслав представлява „свободен превод на гръц. Стефан”. Докато Н. Ковачев (1995: 108) не държи сметка за смислова

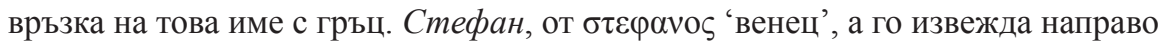
„от Вѐнце + сла̀в, венещ,”, при което началната съставка на Венцесла̀в счита за готово име * Вѐнце, каквото в неговия речник липсва. Съвсем определено името Венцеелав свързват с венѐ и други автори. Н. Иванова и П. Радева $(1985,114)$ го споменават сред имена с подобен звуков състав, които смятат ,пожелателни [...], образувани от венеи 'сплетени в кръг цветя или клонки"”, а по-нататък пишат, че и „сложното име Венеслав означава 'увенчан със слава' или 'венец на славата', както и Венцеслав”. И - като че ли с недоверие - продължават: „Според Ст. Илчев Венцееслав е възникнало в Югозападна Македония като превод на гръцкото Стефан” (ib.).

Схващането на Ст. Илчев за зависимост на българското име от гръцкото Ковачев $(1995,108)$ взема под внимание при анализа на Венцисла̀в, което на свой ред тълкува също по два начина: като образувано „от Вѐнц̧и + сла̀в” и като „превод на грьцкото Стефан”. Докато самото мъжко име Вѐнци, залегнало според него в първата съставка на Венцислав, счита „ськратено от Венѐци, венѐ ”, с което е трудно да се съгласим - гласните подлежат на елизия / синкопа само в неакцентирана позиция. Както ще видим по-нататък, Вѐнции се обосновава от Венциислав (Венциислав $\rightarrow$ Венции), а не е обосноваващо спрямо него. Неправилно у Н. Ковачев имената Венцесла̀в и Венциисла̀в са обяснени като отделни формации, образувани независимо една от друга. Още Ст. Илчев $(1969,106)$ отбелязва, че Венциислав е „вм[есто] Венцеслав”. В по-ранна публикация, посветена специално на името Венцееслав, той обяснява варианта Венцислав, с поява на $\boldsymbol{u}$ във втората сричка вместо $\boldsymbol{e}$, като възникнал „не само поради редукция на неударено $\boldsymbol{e}$, но и под влияние на имена като Борислав, Владислав" и др., с първи компонент от глагол, в които това и е закономерно (Илчев 1959). Също така и Н. Намерански $(2005,41)$, без да добавя нещо по-съществено, като счита името „пожел[ателно] - 'да носи венеца на славата"”, за разлика от Н. Ковачев, забелязва все пак, че Венцесла̀в

1 Тези и привежданите по-нататък статистически данни относно личните имена са според Ковачев 1995. 
и Венцисла̀в се различават едно от друго само формално-звуково и правилно счита Венцисла̀в „фон[етичен] вар[иант] на Венцесла̀в”. Поради също така погрешен анализ на името Венцеслав като съдържащо в състава си думата венѐu, българският православен календар сочи като имен ден за носителите на това име Стефановден (27 декември) - православната църква, както българската, така и руската, не взема под внимание деня на св. Венцеслав.

В случая - както не рядко става в развоя на езика, - една диалектно променена форма, с редуцирано $е$ (> u), каквато е Венциисла̀в, е стеснила значително първичната спрямо нея форма (Венцесла̀в). Защото в българската антропонимия истинска кариера прави тъкмо формата Венциисла̀в. За тази посока на развитие може да е допринесло функционирането му и в съкратения облик Вѐнци, оформен с новия суфикс-окончание $-u$, който се оказва модерен и експанзивен. Най-вероятно, тъкмо с това ,английско/европейско” изгласно $\boldsymbol{- \boldsymbol { u }}$ от съкратения облик на името се асоциира звукът $\boldsymbol{u}$ от състава на варианта Венцицла̀в в съзнанието на много от носителите на името Венцесла̀в (или техните родители), без да се отчита неговият диалектен характер - с редукция на $\boldsymbol{e}(>\boldsymbol{u})$. Нищо чудно и ако други пък в началната му съставка венции съзират форма за мн. ч. на думата венѐu, считана - погрешно, както ще видим - за съставка в смисловия строеж на името. По данни у Ковачев $(1995,108)$ обликът Веничисла̀в се появява 2 години по-рано, още в 1908 г., само с 4 отбелязвания в десетилетието, като достига през 70-те г. на XX век 4756 появи и се доближава до 40-те най-често срещани мъжки имена. Честотата му продължава да расте и през 80-те г., когато вече влиза в тази ранг-листа, като заема 33 място в нея (Ангелова-Атанасова 2001, 32).

3 Когато въпросът е за името Венцеслав (3.1), анализът няма да е изчерпателен, ако не се вземат под внимание и облиците Венчесла̀в (3.2), Вячесла̀в (3.3), Вечеслав (3.4), Ва̀щлав (3.5) и Вѐнц̧ел (3.6), които се разглеждат по-нататьк.

3.1 Венцесла̀в. Откога, откъде и по какъв начин прониква в България това име?

Макар и при облика Венцислав, Ст. Илчев определя името като „типично за Свищов". Сред католиците - и в Свищовско и в Пловдивско - е известно в облиците Венцеслав, Венцислав и Венчеслав, Венчислав (Селимски 1999, 134; Селимски 2006, 32, 33, 141, 141, 144). За тях то е календарно, християнско. Като име на светец, честван на 28 септември, са го познавали добре, или най-малко са чували в църквата в облика * Венчеслао поне от XVIII в. насам (вж. по-долу: 3.2). И така, няма да е рисковано предположението, че 1) името Венцееслав е християнско, но от римо-католическия календар, и 2) че в България то е проникнало с покатоличването в началото на XVII век на павликяните, както и много други имена от този конфесионален тип (Селимски 1999, 19-33; Селимски 2006, 132-154). Затова най-правилно е то да бъде анализирано като субституция на латинския му облик Venceslaus, каквато се среща и в други славянски езици.

В споменатата бележка, посветена на името Венцеслав, Илчев (1959) пише, че „някои заселили се у нас чехи след време побългарили чешкото си 
$\hookrightarrow \quad$ име Ващлав на Венцееслав". За подмяна на чеш. Ва̀щлав с облика Венцеслав се съди от приведените в бележката данни за чешки емигранти (и техни потомци) с това име: „Венцеслав Венцеславов Сребров (син на Вацслав Стрибърни), Венцеслав Павел (бивш преподавател по музика във Варна) и др." (Илчев 1959). Според мене, при тази подмяна става дума не за „побългаряване” на чешкото Ващлав, а за представяне на това име в неговия „европейски”, а по-точно латински облик Венцеслав, като - може би - по-престижен, а още по-вероятно е да се отнася за субституция на чеш. Věnceslav (за него вж. 3.5). Още с внедряването на името в българска среда началната му съставка Венце- (или Венци-) се оказва в отношение на частична омонимия с думата венец, поради което и съкратените му облици варират все около тази дума, а в научните анализи, между другото, се търси смислова връзка с гръцкото Стефан. Такова тълкуване то получава и в синодалния Именник $(1942,13)$, поради което там то е с буквата „двойно $e^{”(~(ち) ~ в ~ п ъ р в а т а ~ с р и ч к а: ~ „ В ь н ц е с л а в ъ ~}$ (»прославенъ съ в'нецъ«), Вьнецко, Вьнко; ж. Вьна, Вьнка”. В синодалния Именник - в съответствие с това тълкуване - не е отбелязан и ден в годината за честване на светец. Като считам появата на бълг. Венцеслав за независима от грьц. Стѐфан, това не означава, че отричам наличието в българския език на собствени и нарицателни, оформени по гръцки словообразувателни образци. То обаче се отнася предимно за някои сложни имена, а Стѐфан е проста формация.

3.2 Венчесла̀в е несравнимо по честота дори само с Венцеслав. Според данните у Ковачев то е засвидетелствано само 21 пъти. За отбелязване е едно важно обстоятелство, на което Ковачев не е обърнал внимание: в облика Венчеслав интересуващото ни име е с малко по-стара дата на начално регистриране - 1903 г. (докато Венцеслав е от 1908, а Венцислав - от 1906 г.). С анализа му у Ковачев $(1995,108)$ като образувано на домашна почва „от Венчѐ + сла̀в" е трудно да се съгласим.

В България това име е разпространено сред католиците. Ще припомня, че още у Илчев името Венцислав е определено като „типично за Свищов”. В облика Венчеслав то е намерило отражение и в малкото календарче (Чок 1902), което издава тъкмо в Свищов католическият свещеник от полски произход Вилибалд Чок, прекарал няколко години в Белене (Свищовско) като мисионер. Впрочем, в италианския облик Венчеслао (от итал. Venceslao < лат. Venceslaus) е било известно на българските католици още през XVIII в. (Селимски 1999, 29-30; Селимски 2006, 148). За използвани при тях преписи на сборник от 111 жития на светци, между които и „Живот од свети Венчеслао (Venceslao), мученик, крал од Боемія. На 28. Септ.”, пише Л. Милетич $(1903,250)$. В италианска звукова форма, покрай лат. Venceslav, то се среща и в хърватски - в три правописно-звукови облика: Venceslao, Venčeslav, Venćeslav (Šimundić 1988, 356-357). Италиански прототип, според мене, стои и зад словен. Vénčeslav (вж. 7).

3.3 Вячесла̀в, което според Ковачев, се появява в 1943 г. (а още в 1942 г. във варианта с редукция Вячислав), авторът правилно счита заето от рус. Вячеслав. В синодалния Именник $(1942,13)$ Вячеслав е поместено отделно от 
Венцеслав (по стария правопис ВЊнцеславъ) и - за разлика от последното - с отбелязване на ден за честване на светеца: 4/17 март. На 4 март и руската православна църква отбелязва Вячеслав, като прибавя при това име и 28 септември, с пояснението “князья” (Тихонов, Бояринова, Рыжкова 1995, 112), което трябва да се отнася за княз/свети Вацлав. В българския синодален Именник тази звукова форма трябва да се счита църковнославянско-руска. В руско-църковнославянски облик го намираме и в списъка „кръстителни” имена във „Френско-български речник” срещу фр. Wenceslas (Богоров 1873, 505), без посочване там на месец и ден от годината за честване на светец. Но като се вземе под внимание обстоятелството, че от общата честота на двата варианта $75(62+13)$ близо половината - 35 отбелязвания - се отнасят към 40-те години и то, вероятно, към тяхната втора половина (т.е., след преврата на 1944 г.), името Вячеслав трябва да бъде отнесено по-скоро към съветската (болшевишката) част на руския компонент в българската антропонимия - като предпочитано от най-върлите привърженици на комунистическия режим поради популярността през онова десетилетие на съветския партиен и държавен ръководител Вячеслав Молотов (Селимски 2006, 25, 32, 41).

3.4 Вечеслав, според Ковачев $(1995,114)$ от 1905 г., с 37 отбелязвания (и еднократно жен. Вечеслава, 1953 г.), както и Вечислав, от 1933 г. (и жен. Вечислава, от 1974 г., с 2 появи), може би също - поне отчасти - правилно се свързва с рус. Вячеслав (вж. 3.3), от което е получено поради погрешно третиране на $я$ от първата сричка според правилото за „двойното $e^{\prime}(я>e)$ или като частично звуково побългаряване (с $\boldsymbol{e}$ срещу църковнославянско-руско $\boldsymbol{я}$ за прасл. $\left.{ }^{*} \boldsymbol{e}\right)$ и редукция на $e$ от втората сричка $(* e>u)$. При друга част от случаите - особено при тези от С3 и ЮЗ ареал и по-специално при отбелязаното в 1905 г. - зад него трябва да стои сръбското Bећеслав (= хърв. Većeslav).

3.4.1 Самото сръб. Већеслав и хърв. Većeslav (днес Većesav) по всяка вероятност не е непосредствен застъпник на праслав. Vetjeslavb, а фонологично сърбизиран, съответно хърватизиран, вариант на Венцеслав / Venceslav, представляващ субституция на лат. Venceslaus, или на паралелното Venčeslao / Venceslao (от итал. Venceslao < лат. Venceslaus). Констатацията на Вл. Шаур, че „u jižních Slovanů jméno nežije” (Šaur 1987, 218), трябва да се разбира в смисъл, че в южнославянските езици то не е наследено по непрекъсната устна традиция от праславянски.

3.4.2 Макед. Венцеслав / Вечеслав (и лат. Venceslaus) неправилно е извеждано непосредствено „од стсл. ВАшТеславъ - сложено име составено од комП. вАште - повеќе, поголемо и им. слав- $а$ ” (Станковска 1992, 60-61). Твърдението на Вл. Шаур, че „сред българите не можем да очакваме това име” (т. е. не може да се очаква застъпник за прасл. Vetjeslavъ), „понеже там няма застъпник за прасл. vętje" (Šaur 1987, 218; срв. Šaur 1984), може да се отнесе и към македонския ареал. Мак. Вечеслав, трябва да е от сръб. Већеслав.

3.5 Ва̀щлав. Свързването на тази фонетична форма на името у Илчев $(1969,104)$ с пребиваването на „стари чешки емигранти в България” е правилно. Но все пак трябва да се взема под внимание участието и на словашки етничен елемент в България и за словаш. Václav (заето от чешки). По данни 
$\dashv$ у Ковачев $(1995,101)$ Ващлав е от 1918 г., с общо 10 засвидетелствувания, а жен. Ващлава - от 1925 г., с 4 отбелязвания. Чеш. Václav е континуант на ст.-чеш. Váceslav, в което á застыпва прасл. e, а $\boldsymbol{c}$ е от прасл. *tj. Носил го е чешкият княз Вацлав (ок. 906/907-929/935), чиято гибел от ръката на брат му е била спонтанно счетена за мъченичество, поради което и скоро в Чехия започнали да го почитат като светец и го провъзгласяват за покровител на страната. Прачешкото Veceslavъ (< прасл. *Vetjeslavъ) се разпространява като християнско главно в латинизирания облик Venceslaus, към който възхождат съвременните му облици в много европейски и славянски езици, в това число и в самия чешки: формата Vénceslav, употребявана покрай домашната Václav, представлява чешка субституция на латинизираната Venceslaus, но на местна почва свързвана с думата věnec 'венец' (Knappová 1996, 175), както в български. В чешки фонетичен облик името е широко разпространено в Полша: Wactaw (вж. 5). Възпоменаването на светеца е на 28 септември, т. е. в деня на насилствената смърт на княз Вацлав, която някои източници отнасят към 27 септ., в деня на св. св. Козма и Дамян.

3.6 Вѐнцел. Неправилно е счетено за образувано на българска почва, уж „от Вѐни $(u)+$ ѐл, като Рад-ѐл” (Ковачев 1995, 108) - то е заемка от нем. Wenzel, съкратено от Wenzeslaus (< лат. Venceslaus), заето и в хърватски (Vencl) и словенски, унгарски и естонски (Vencel).

3.7 Във формата Вяцеслав, с ден за честване на светеца 28 септември, името е отбелязано в староруския календар, възстановен от Н. Н. Срезневски (Древній русскій календарь по мьсячнымъ минеямъ XI-XIII века, Хрест. Древн. и Археол. Прохорова, кн. VII, Петербург 1863) (по Chronologia polska $1957,262)$. Това е частично приспособен - с източнослав. $\boldsymbol{x}$ за прасл. ${ }^{*} \boldsymbol{e}-$ западнославянски (моравско-чешки) облик на името Veceslavъ (със зап.-слав. с за праслав. *tj), от прасл. Vetjeslavъ.

4 Рус., белорус. и укр. Вячеслав се счита не за домашно, наследено от праславянски, а за стара заемка (от чеш. Václav), но русифицирана фонетично - с източносл. я и ч за прасл. *e и *tj (Фасмер 1, 378; Kopečný 1974, 128-129; ЕСУМ 1, 443). Според чешкия славист Владимир Шаур източните/руските славяни още от XI век четат формата вАчеслдвъ (У автора - на латиница Večeslavъ) като Вячеслав, което доказва, че името им е било познато още преди приемането на християнството и че при тях то закономерно застъпва праслав. *Vetjeslavъ (Šaur 1987, 217-218, 220). Първата част от името е наречие в сравнителна степен, означаващо 'повече'.

Известно и в Полша, Wiaczesław, носено понастоящем от 527 души, се счита „заето от украински и руски” (Grzenia 2006, 322). В този облик то се среща и у българи (вж. 3.3).

5 В историята на полския език името е отбелязано в няколко варианта (Więcsław, Więsław и Więsław), резултат от домашна еволюция на праславянския облик, но в полската антропонимия то се употребява предимно в облика Wactaw, представляващ субституция на чеш. Václav. Обликът Wacław започва да се разпространява в полски при управлението на Wacław II (1271-1305), крал на Чехия, който се короновал като полски крал. Не е без значение за 
това и голямата популярност в Полша на култа към св. Вацлав, който е патрон на катедралата на Вавел в Краков (Siatkowski 1970; Bubak 1993, 307). А домашната полска форма се среща много рядко, като понякога се явява и в облиците Wienczysław и Wiesław - в резултат на погрешно разчитане на ст.-пол. име Więceslaw или свързване с глагола wieńczyć ‘венчая’ (Fros, Sowa 1995, 517; Grzenia 2006, 323). Към производните от нея спада може би и Wiestaw и жен. Wiestawa (Bubak 1993, 307-308).

6 В хърватски се срещат няколко основни облика на името: освен очакваното Većeslav (и жен. Vé́eslava), с хърв. ć за праслав. *tj, т.е. с първи компонент veće 'повече', това са: Venceslav (и Venceslava), от латиниз. Venceslaus; Vencislav и Vencislava, същото, но с і вм. е под влияние на имена като Branislav, Tomislav (Šimundić 1988, 356); Venčeslav (и Venčeslava), субституиращо итал. Venceslao, което и в хърватски се среща в този облик; Venćeslav (и Venćeslava),

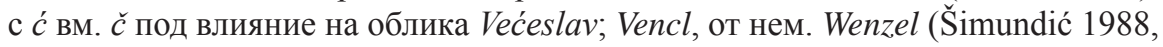
353-357).

7 Звуковият облик Vénčeslav, с който името е популярно в словенски език, трябва да е субституция на итал. Venceslao, на което не е обърнато внимание у Я. Кебер (Keber 1996, 480), както употребяваният покрай него облик Venceslav / Vencislav - на латинизираното Venceslaus.

8 И така, най-ранното проникване на името Венцеслав (> Венцислав) в български ареал е свързано с покатоличването през XVII век на бившите павликяни, както се съди по отбелязването му в итал. облик Венчеслао в ръкописен миней от XVIII век (Милетич 1903, 25). Покрай италианския облик Венчеслао (< итал. Venceslao), при католиците се среща, и даже по-често, обликът Венцеслав, субституиращ среднолат. Venceslaus, което пък е латинизиран облик на моравско-чеш. Vęc(es)lavъ (от праслав. *Vętjeslavъ, сложно, с първа съставка *vętje 'повече'). В облик Venceslaus е разпространено и в други славянски / европейски езици. Обликът Венцеслав се среща и у чешки, а може би и у словашки емигранти в България, които с него заместват Bauллав (от чеш. Václav). В облик Венц̧еслав то е очаквано и при немскоезични емигранти (от нем. Wenzeslaus). Макар и славянско по произход, в българския език то е европейска заемка. На българска езикова / говорна почва първата му съставка Венце се свързва с нарицателното венец, особено във формата му за мн. ч. венцй. И италианският му облик Венчеслав (от Венчеслао < итал. Venceslao) буди на българска почва асоциация с венчѐ, умалително от венѐц. Но не само асоциациите с венѐц / венчѐ и слава и благозвучността на името Венцеслав обуславят бързото нарастване на честотата му. То се дължи, между другото, и на общо взето зачестилата употреба на сложни, двуосновни имена, към каквито българите проявяват значително предпочитание през последните десетилетия на XX век (Ангелова-Атанасова 1996). Освен в латински и италиански облик (Венцеслав / Венчеслав) това име се среща у българите и в облиците Вячеслав (руски), Вечеслав (сръбски), Ващлав (чешки), Венцел (немски, унгарски). 


\section{$\hookrightarrow$ Библиография}

Ангелова-Атанасова, Мария, 1997: Сложните лични имена в българската личноименна система през периода 1981-1990 г. Onomastica 42, Kraków, 149-169.

Ангелова-Атанасова, Мария, 2001: Личните имена у българите (1981-1990). Състояние и проблеми на съвременните български лични имена. Унив. изд. „Св. св. Кирил и Методий”, Велико Търново, 272 с.

Богоров, Иван, А., 1983: Френско-български и българско-френски речник, Дял първи. Френско-български дял, Виена, 512 с.

ЕСУМ 1: Етимологічний словник української мови, т. 1, А-Г, Київ, 1982, 632 c.

Иванова, Недялка, Радева, Пенка, 1985: Om 'A' до 'Я'. Имената на българите, „Народна младеж. Изд. на ЦК на ДКМС”, София, 250 с.

Илчев, Стефан, 1959: За името Венцеслав. Език и литература XIV, София, № 3, 228.

Илчев, Стефан, 1969: Речник на личните и фамилни имена у българите, София, $628 \mathrm{c.}$

Именник, сир. списък на имената, които се дават при св. кръщение, Издава Св. Синод на Българската църква (Издание второ), София 1942, 60 с.

Ковачев, Николай, 1995: Честотно-етимологичен речник на личните имена, Изд. ПИК, Велико Търново, 620 с.

Намерански, Никола, 2005: Личните и фамилни имена в Северозападна България. Етимологичен честотно-сравнителен речник. „Фабер”, Велико Търново, 212 с.

Селимски, Людвиг, 1999: Християнските имена у българските католици. Проблеми на усвояването. Prace Naukowe Uniwersytetu Ślqskiego w Katowicach nr 1781, Wydawnictwo Uniwersytetu Śląskiego, Katowice, 203 c.

Селимски, Людвиг, 2006: Етюди по българска антропонимия, Лични имена (Studia z antroponimii bułgarskiej, Imiona chrzestne), Унив. изд. „Св. св. Кирил и Методий”, Велико Търново, 224 с.

Станковска Љубица, 1992: Речник на личните имиња кај Македонците, Скопје, 478 с.

Тихонов, Александр, Н., Бояринова, Лариса, 3., Рыжкова, Альбина, Г., 1995: Словарь русских личных имен, Школа-Пресс, Москва.

Чок, Вилибалд, 1902: Ново римокатолическо и православно календарче „Мир”за 1902 година, Наредил О. В. Чок, катол. свещеник, Свищов.

Bubak, Józef, 1993: Księga naszych imion, Wrocław etc., 360 c.

Fros, Henryk, Sowa, Franciszek, 1995: Twoje imię, Przewodnik onomastyczno-hagiograficzny, Wyd. czwarte, uzupełnione, Wyd. WAM, Księża Jezuici, Kraków, $557 \mathrm{c}$.

Chronologia polska, Praca zespołowa pod red. Bronisława Włodarskiego, Warszawa, 1957.

Grzenia, Józef, 2006: Słownik imion, Wyd. naukowe PWN, Warszawa, 362 c. 
Keber, Janez, 1996: Leksikon imen, Izvor imen na Slovenskem, Druga, dopolnjena izdaja, Celje.

Knappová, Miloslava, 1996: Jak se bude Vaše dítě jmenovat? Akademia/Praha, $360 \mathrm{c}$.

Kopečný, František, 1974: Průvodce našimi jmény, Praha.

Siatkowski, Janusz, 1970: Kiedy Wacław zastąpił Więcesława? W stużbie nauce i szkole, Księga pamiątkowa poświęcona Prof. Drowi Z. Klemensiewiczowi, Warszawa, 277-279.

ŠAUR, Vladimír, 1984: Je bulharské veče/veke z vętje? Slavia, r. 53, Praha, č. 1, $12-15$.

ŠAUR, Vladimír, 1987: Prvotní grafická podoba jména Vác(es)lav, Slavia, r. 56, Praha, č. 3, 217-222.

Šimundić, Mate, 1988: Rječnik osobnih imena, Zagreb, 571 c.

\section{Osebno ime Venceslav in njegove različice v bolgarski antroponimiji}

Povzetek

Rojstno ime Venceslav/Venčeslav so pogosto razlagali kot zloženo ime s pomenom ovenčan s slavo. Prvo sestavino so napačno povezovali z besedo venec ali z njeno manjšalnico venče. V članku je predstavljena analiza imena Venčeslav kot substitucije italijanskega Venceslao in Venceslav, ki izhaja iz latinskega Venceslaus. To je latinizirana oblika zahodnoslovanskega (moravsko češkega) Vęceslavъ. Prva sestavina tega imena izhaja iz praslovanskega *vętje- 'več'. Z njim so torej želeli poimenovanemu 'več slave'. Najprej so ga uporabljali bolgarski katoliki. Ime Venceslav so uporabljali tudi češki emigranti v Bolgariji, in to vzporedno ob imenu Vaclav. V članku so obravnavane tudi druge bolgarske različice imena Venčeslav: Vjačeslav (cerkvenoslovanska in ruska oblika), Večeslav (izposojeno iz srbščine), Vaclav (iz češčine), Vencel (iz nemščine ali madžarščine).

Ludwig Selimski

Instytut Filologii Słowiańskiej

ul. Żytnia 12, 41-205 Sosnowiec, Poljska

selimski@wp.pl 



\title{
Slovenske leksikalne prvine v obsoški furlanščini: izpeljanke
}

\author{
Mitja Skubic (Ljubljana)
}

IZVLEČEK: Avtor želi opozoriti na nekaj prevzetih leksikalnih prvin v furlanščini, tj. predstaviti nekaj izrazov iz obsoške furlanščine, v katerih najdemo leksikalne prvine iz slovenščine, predvsem iz stičnih obsoških, goriških govorov, pri katerih so v izpeljavi uporabljeni furlanski oblikoslovni ali tvorbeni elementi. Njegov namen je pretehtati vraslost nekaterih slovenskih besed v obsoško furlanščino, tj. ugotoviti, do katere mere je slovenska beseda postala last stične furlanske govorice.

ABSTRACT: The author draws attention to several borrowed lexical elements in Friulian - specifically, several terms from Friulian as spoken along the Isonzo (Sln. Soča) River in which Slovenian lexical elements can be found, primarily from the Gorizia (Sln. Gorica) contact dialects along the Isonzo, in which Friulian morphological or word-formative elements are used in derivation. The goal is to evaluate the incorporation of selected Slovenian words in the Friulian spoken along the Isonzo - that is, to determine to what extent Slovenian words became part of the Friulian contact dialect.

Kot poklon ob visokem jubileju prijatelju in kolegu Pavletu Merkuju bi težko izbral kako drugačno temo kot tako, ki načenja zmeraj privlačno vprašanje, kako jezikovno vplivata druga na drugo etniji v stiku, ali bolje, etniji, ki že stoletja delita isto ozemlje, kot sta to slovenščina in furlanščina, natančneje, govori ene in druge ob Soči. Stik med njima je starodaven; traja že tisoč in več let. Slavljenec je prispeval marsikaj dragocenega k poznavanju medsebojnega jezikovnega prevzemanja, še posebej v interpretaciji posameznih slovenskih besed, zlasti v toponimih. Gre mu tudi zasluga, da se je v slovenskem jezikovnem okolju uveljavilo pravilno gledanje, da smo namreč Slovani/Slovenci od prvih stoletij po naselitvi dalje mejili na »Ladine«, na bodoče Furlane, ne kar enostavno na Italijane.

1. Opozoriti želim na nekaj prevzetih leksikalnih prvin v furlanščini, natančneje, predstaviti nekaj izrazov iz obsoške furlanščine, v katerih najdemo leksikalne prvine iz slovenščine, predvsem iz stičnih obsoških, goriških govorov, pri čemer 
$\hookrightarrow \quad$ pa so v izpeljavi uporabljeni furlanski oblikoslovni ali tvorbeni elementi. Namen teh vrstic je pretehtati vraslost nekaterih slovenskih besed v obsoško furlanščino, se pravi, ugotoviti, do katere mere je slovenska beseda postala last stične furlanske govorice.

Za to jezikovno dogajanje je mogoče upoštevati več izhodišč. Eno je vsekakor pogostnost rabe $v$ furlanskih knjižnih in neknjižnih besedilih današnje in preteklih dob, za naš čas pa tudi slika, ki jo nudi furlanski jezikovni atlas, ASLEF, Atlante storico-linguistico-etnografico friulano. Pri tem mislim seveda na tiste eksplorirane kraje, ki niso slovensko govoreči (teh ima ASLEF raziskanih in upoštevanih osem), so pa slovenskemu ozemlju blizu in torej izpostavljeni jezikovnemu vplivu zahodnoslovenskih govorov. Raba slovenskih leksemov je sama po sebi umevna za izraze iz slovenskega ljudskega izročila, za svojska oblačila, jedi, igre, razvedrila. Potrdilo, da je slovenski izraz pognal korenine, da je docela vrasel v furlansko besedje, je tudi raba v prenesenem pomenu. In morda še bolj to, da je ustvaril družino izpeljank, manjšalnic predvsem, pomensko največkrat ljubkovalnic, in se torej obnaša kot izvirna, iz latinščine podedovana furlanska beseda. Slavljenec sam je zbral kopo izpeljank in jih nanizal v svoji študiji iz zadnjih let, izdani v knjigi z naslovom Od babe do smrti. Za nekdaj, a danes ne več furlansko govoreči Trst navaja baba, babaria, babata, babezo, babuza, babùnzola: osnovni izraz in izpeljanke imajo slabšalni pomen. Za babo v goriški furlanščini pa ugotavlja Merkù, da ima beseda tudi pošteno starinsko pomensko rabo in da je to "znamenje, da so si jo Furlani izposodili od nas, ko smo jo mi še rabili z lepim pomenom.«

2. V svoji slovnici furlanskega jezika, Lineamenti di grammatica friulana, str. 41, pravi Giuseppe Marchetti, da je iz slovenščine (»dallo slavo«) prevzetih kakih sto besed, katerim je treba dodati še približno enako število izpeljank. Tudi če je tako visoko število po mnenju italijanskih jezikoslovcev nekoliko pretirano, je vendar gotovo, da jih je iz slovenščine prevzetih precej in pa, kar nas tu še posebej privlači, da je v današnji furlanščini iz slovenskih leksemov veliko izpeljank.

3. V prispevku puščam vnemar slovenske besede $\mathrm{v}$ prenesenem pomenu. Ravnotako tudi lastna in krajevna imena, saj bi ta zahtevala posebno obravnavo. Toponimov je Merkù kar nekaj zbral v svojem priročniku Slovenska krajevna imena $v$ Italiji iz leta 1999 in v nedavno izdani monografiji Krajevno imenoslovje na slovenskem zahodu in ti deli nista zgolj seznama, ampak interpretacija toponimov, večkrat tudi tehten, utemeljen ugovor siceršnjim zmotnim mnenjem: dovolj je pomisliti na njegove razlage za Opčine, Redipulja, Repen, Trebče, Križ, itd., objavljene ponajveč v tržaški Mladiki. Moj prispevek se omejuje na furlanske slovnične elemente, ki jih najdemo v iz zahodnoslovenskih govorov prevzetih besedah, torej ne s prevzetimi besedami kot leksikalnimi prvinami; se pravi, ugotavlja, da so bile sprejete $\mathrm{v}$ furlansko besedje in da o tem pričajo furlanske slovnične prvine, ki te slovenske lekseme vklapljajo v furlanski besedni zaklad.

4. Prispevek ne posveča prav velike pozornosti tvorbi oblik za spol samostalnika. Navaja samo tiste primere, kjer je izraz v enem od obeh slovničnih spolov $(m, f)$ 
stilno drugače obarvan. V svoj seznam uvrščam tiste slovnične elemente, morfeme, ki spreminjajo izvirni pomen, torej nimajo samo stilistične vloge, kot jo sicer največkrat imajo, npr. v babute, colazut, babân: Benedete la nestre babute (Koseworte 1915: I, 170); Mi fermavi a fevelà cun qualche baba o cun qualche babàn (Spangher 1990: 18), 'ustavljal sem se, da bi govoril s kako babo ali kakim dedcem'; Ti àn puartat el mâi cu lis norançis e i colaçuç (Koseworte 1915: II, 633) 'prinesli so ti butarico s pomarančami in kolački'. Raba obeh izrazov v drugem navedku ni močno stilistična, vsekakor pa ni slabšalen nobeden od njiju. Da samostalnik v ženskem spolu nima slabšalnega zvena, je ugotovil Merkù tudi za dolino ob Teru.

V svoje tehtanje ne uvrščam izrazov, ki z drugimi jezikovnimi prvinami, nespremenjeni, tvorijo kak frazeologem, stalno besedno zvezo, denimo, tirâ i cracs 'stegniti se, umreti', NP, in pustot 'obupan, v stiski', kar najdemo že pri znamenitem furlanskem pesniku Ermesu iz Colloreda: par passion ses in pustot 'zaradi svoje strasti ste obupani'. Privlači pa nas raba tistih izrazov, kjer se ob nedvomno dobro vidnem leksemu iz zahodnoslovenskih govorov pojavi neka ravnotako dobro zaznavna furlanska slovnična, morfološka prvina, a pri tem ne gre za manjšalnico ali sicer za kak drug izraz s stilistično vrednostjo. Uporabljeni morfem zagotavlja, da je slovenski izraz vrasel v furlanski govor. Pri tem je prepričljivo dejstvo, da je taka izpeljava znana furlanščini in da ni verjetno, da bi bila beseda v celoti prevzeta iz slovenščine. To je morda sprejemljivo za glagol razâ 'racati', kar je sicer svojsko za premikanje te ptice in bi torej prav lahko zraslo na furlanskem jezikovnem področju ali pa bilo skupaj s samostalnikom prevzeto iz slovenščine, ne pa, na primer, za glagol babâ. Takega glagola v slovenščini ni, torej smemo sklepati, da je bil v pomenu 'klepetati' izpeljan, torej skovan v furlanščini.

5. Privlačijo nas takile pojavi:

a) Tvorba glagola iz samostalnika

Babâ: k primerom, ki jih daje Merkù, naj dodam furlansko inačico reka v latinščini Dum Romae consulitur, Saguntum expugnatum est, ki govori o Hanibalovem zavzetju Sagunta in vdoru Kartažanov preko Ebra, s čimer se je začela 2. punska vojska. Furlanski navedek je iz sodobnega časopisnega jezika, Patrie dal Friûl, julija 2006. Časnikar toži, da si je Trst prigrabil oblast nad vso deželo, medtem ko se v Furlaniji samo govoriči: Intant che in Friûl al babuie, Triest al a gafât la region.

Izsamostalniški glagol je tudi triestinski pesternar. Slovenska pestrna je danes rabljena tako v Trstu kot v Gorici, torej v mestnem okolju, kot pesterna. V zahodni furlanščini in v beneščini, zunaj pokrajin Trst in Gorica samostojne dežele Furlanije-Julijske krajine, nista znana ne samostalnik ne glagol, pač pa oba potrjuje Doria (1987) za Istro in kvarnerske otoke (Lošinj, Cres), kamor naj bi se bil izraz po njegovem razširil iz Trsta, iz triestinščine. Na tem mestu sem najbrž dolžan, da nekako upravičim termin triestinščina. Triestinščina, it. il triestino, današnji romanski govor Trsta, je beneško narečje, ne furlansko. Iz kulturnih, najbrž pa še bolj političnih, nacionalističnih vzrokov je to narečje v Trstu nekaj stoletij dušilo furlanščino in jo v 19. stoletju dokončno zadušilo, je pa prevzelo in ohranilo iz izginjajoče južne furlanščine, torej iz svoje romanske predhodnice, tergestinščine, veliko izrazov; ni si mogoče misliti, da bi prišlo ob opuščanju nekega jezika, nekega govora, in še celó 
tako sorodnega, kot sta bili beneščina, italijansko narečje, in južna furlanščina, do popolne pozabe dotedanjega govora.

Nekaj izsamostalniških glagolov je tvorjenih s pomočjo predpon. Tako najdemo iz dokaj pogosto rabljenega samostalnika colàz izpeljani glagol incolazzâ 'zviti v spiralo, kar je sicer ravno', 'oviti se okrog nečesa, okrog palice, meča': Incolazze la cuarde che no s'ingredei, NP, 'zvij vrv, da se ne zaplete'; I madràcs quant che son in amôr 'e s'incolazzin, NP, 'kadar se kače gonijo, se zvijejo v klopčič'. Glagol najdemo celo v sodobnih prevodih, za katere se misli, da so bolj kot izvirna knjižna besedila zvesti normi, ki vlada v jeziku. V furlanskem prevodu Svetega pisma iz leta 1997 beremo: La sô man a impire il madrac incolačât, Job 26,13 'njegova roka prebada kačo, zvito v klobčič'.

Podobno tvorbo pozna samostalnik blec: leksem je iz nemščine, a izraz je obsoški furlanščini posredovalo slovensko jezikovno okolje: Lis feminis si metevin a imblecâ barghesis (Cossàr 1930: 76) 'ženske so začele krpati hlače'; I nostris vistîs erin di regadìn imblecâz mil voltis (Macôr 1980: 30) 'naša oblačila iz platna so bila tisočkrat pokrpana'. Najdemo ga uporabljenega tudi v prenesenem pomenu: Cumò chest fondament al clope, ma al tocje a saldâlu, stagnâlu, imblecâlu, Patrie dal Friûl, julij 2006, 'dandanes to mnenje šepa, a treba ga je učvrstiti, podpreti, dopolniti'.

Štrekelj (1890) navaja izsamostalniški glagol ob slovenskem izrazu blato: imblatâsi. Navaja ga po starem furlanskem slovarju Jacopa Pirone iz leta 1871: Lant a passòn ai praz umiz lis pioris s'imblatin 'ko gredo na pašo na mokre travnike, se ovce z blatom umažejo'.

\section{b) Tvorba samostalnika iz samostalnika}

Bilo je že povedano, da puščam za samostalnik precej vnemar tvorbo ženskega spola iz oblik za moški, naj pa vendar navedem pec, peca, pechariza, ali, dokaj redko, postopek v obratni smeri: raza, razât; canya, cagnàs.

Pomembnejši so izsamostalniški izrazi za poklice in dejavnosti: iz nedvomno slovenske osmice navaja Doria 1987 kot prevzeto besedo osmiza 'skromen, priložnosten vinotoč, kjer je vinogradnik osem dni lahko točil vino svojega vinograda, ne da bi za to plačal davek', in pa izpeljanko osmizaro 'oštir, lastnik ali najemnik takega vinotoča'. Enako tvorbo pozna za zaposlenega v peki slaščic iz slovenskega kolača prevzeti colàz in ob njem furlansko colazâr. Isti morfem najdemo za poklic lonzàr, ki ga pozna ASLEF (II, 1377), pri čemer pa nikakor ni mogoče izključiti prevzemanja slovenske besede z zgolj pofurlanjenjem palatalnega zlitnika: to je verjetneje kot pa izpeljava izraza lonzàr iz slovenskega samostalnika lonec s pripono, ki je sicer furlanščini ravno za tvorbo imen za poklice dobro znana.

Podoben postopek ugotavljamo tudi za slovenski samostalnik koš. V furlanščini je znan že dolga stoletja v oblikah kot cos, cosse, cospa. Iz izraza za predmet je izpeljan izraz za človeka, ki plete koše, in tudi za poklic, zaposlitev, ki je s takim predmetom v tesni zvezi: cossàr, cossàn 'dninar; težak, ki nosi koš'. Izraz je v furlanščini častitljivo star: že v 14. stoletju se najde zapisan vzdevek Toni cossàn.

Koš se pojavlja tudi kot vir za rodbinsko ime. Mario Ranieri Cossàr, zagreti raziskovalec goriške zgodovine in kulture, zbiralec ljudskega izročila, je zapisal, gl. Cossàr (1930), da je ime Cos za staro goriško grofovsko familijo iz furlanščine in tako tudi izpeljanke Cossàr, Cossut, Chossio. Moramo pač upoštevati, da piše 
v letih najmočnejšega fašističnega pritiska. Ne gre pa dvomiti, da je ime res staro: Cossàr ga je našel zapisanega v Huminu za leto 1319: presbitero Blasio nepote qm Cossarii 'duhovnik Blaž, nečak nekega Košarja'.

Iz zahodnoslovenskih govorov prevzeti leksemi so s pomočjo furlanskih pripon kdaj pa kdaj postali izrazi, ki so v tesni zvezi s pomenom leksema: za prodajo kruha beremo v Spangherjevih mladostnih goriških spominih pecheria.

c) Za tvorbo pridevnika iz samostalnika prav prepričljivih primerov nimamo. Morda je tak primer po Štreklju (1890) oz. po Ascolijevem mladostnem delu iz leta 1846 pridevnik clopadìz 'gnil, pokvarjen (za jajce); medel, slaboten'. Ascoli (1846) namreč ugotavlja nekaj leksikalnih sličnosti med romunščino in furlanščino; v potrdilo navaja rom. babă, tată, rață, boare 'burja', bătrîn 'star', iz lat. VETERANUS, kar se frl. glasi vedran, amiază 'poldan', kar je frl. miez-dì, misdì: za clopadìz 'počen glinast lonec, ki ima slab zvok', podoben zvok pa da ima pokvarjeno jajce, klopotec, meni Ascoli, da ga je mogoče imeti kot pridevniško izpeljavo s furlansko pripono iz romunskega clopot 'zvon'. Pridevnik je v furlanščini rabljen v različnih pomenskih odtenkih: un ûf clopadìz, NP, 'klopotec', v prenesenem pomenu pa 'slab, medel, ne popoln (za luno'): La lune je clopadize 'luna je pri koncu, zadnji krajec'; Di une setemane in câ 'o soi, mi sint clopadìz, NP, 'že cel teden se počutim nekam slabotnega'; Ce voleso fâ di chê int clopadizze, NP, 'kaj si boste pomagali s takimi klavrnimi ljudmi'; La italianitât triestine accusi debule e clopadice, Patrie dal Friûl 2006, 'tisto šibko italijanstvo v Trstu'. Prepričanost v slovenski/slovanski vir pridevnika v furlanščini nekoliko omaje njegova razširjenost v romanskem svetu: francoski prislov clopin-clopant je v etimološkem slovarju Bloch-Wartburg pojasnjen kot onomatopeičen izraz, ki ima svoj (pra)vir v poznolatinskem CLOPPUS, kar nekako ponazarja šum, glasovno podobo pri šepanju. Ascolijeva razlaga potemtakem le ni čisto prepričljiva.

d) Prav verjetno pa je iz glagola, natančneje iz velelnika slovenskega glagola molčati furlanski pridevnik muzzìn/mucìn 'molčeč, molčljiv'. NP navaja Dolfa Zorzuta iz Krmina (1894-1960): Rivin a ciase, la viodi senze voe e muzzine 'pride domov in jo najde brez vsake volje in čisto tiho'. Isti zbiralec rekov v furlanščini je zapisal: Po no sta stâ-mi a li muçine, come se tu fòssis une muarte (Koseworte 1915: II, 398) 'ne bodi tako tiho, kot da bi bila mrtva'. ASLEF zaznava ta pridevnik predvsem ob spodnjem teku Soče, od Krmina navzdol. NP in ASLEF pojasnjujeta, da je izraz največkrat rabljen kot medmet: muci, muz. Kot medmet je znan tudi bližnjim beneškim govorom. Enkrat samkrat se pojavi celo pri Goldoniju, Sior Todero Brontolon, 4, 57, kot muchi.

6. Furlanskih primerov, kjer bi našli iz zahodnoslovenskih govorov prevzete lekseme in s furlanskimi oblikoslovnimi prvinami tvorjene izpeljanke, ni veliko, so pa močan dokaz za trdoživost neke slovenske besede v stičnem jeziku, tako kot so v zahodnoslovenskih govorih na Goriškem prepričljiv argument o medsebojnem jezikovnem vplivanju izpeljanke z romanskim leksemom, npr. ričast, furbast: uporabljeni morfem iz ciljnega jezika, iz slovenščine oz. iz furlanščine, dokazuje vraščenost leksikalne prvine v stično jezikovno okolje. 


\section{$4 \quad$ Viri in literatura}

Ascoli, G. I., 1846, Sull'idioma friulano e sulla sua affinità colla lingua valaca. Schizzo storico filologico, Udine.

ASLEF: Pellegrini, G. B., Atlante storico-linguistico-etnografico friulano, Udine, 1972-1984.

La Bibie. Traduzion Antoni Bellina, Udine/Udin 1997.

Cossàr, R. M., 1930, Storiutis gurizzanis, Udin.

Doria, M., 1987, Grande dizionario del dialetto triestino, Trieste.

Koseworte 1915 - Zärtlichkeitsaudrücke und Koseworte in der friulanischen Sprache, Prag, 1915.

Macôr, C., 1980, I fucs di Belen, Udine.

Marchetti G., 1952, Lineamenti di grammatica friulana, Udine.

Merkù, P., 1999, Slovenska krajevna imena v Italiji/ Toponimi sloveni in Italia, Trst.

Merkù, P., 2005, Od babe do smrti. Bogastvo slovenskega besedja, Trst.

Merkù, P., 2006, Krajevno imenoslovje na slovenskem zahodu, Ljubljana.

NP - Pirona, G., Carletti, E., Corgnali, G. B., Il nuovo Pirona, Udine, 1935.

La Patrie dal Friûl, Udin 2006 (julij).

Spangher, L., 1990, Di cà e di là da la Grapa. Di cà e di là dal Pomeri. Blecs gurizans, Guriza.

Štrekelj, K., 1890, Zur Kenntniss der slavischen Elemente im friaulischen Wortschatze, Archiv für slawische Philologie, Berlin, 474-486.

\section{Slovenian Lexical Elements in Friulian along the Isonzo River: Derivatives Summary}

Western Slovenian dialects and easternmost Friulian have been in contact or shared their territory along the Isonzo (Sln. Soča) River for over a millennium. It is therefore understandable that the languages influence each other and, as a result, a considerable number of loanwords can be found in both.

This article concentrates on the aspect of belonging, by determining how Slovenian lexemes are incorporated into Friulian and how they have taken root in the contact language. This includes more than frequent use and semantic shifts. The author seeks to shed light on word formation: the formation of feminine gender from masculine (e.g., pec, peca 'stove') and vice versa (e.g., razza, razzât 'duck'), and the formation of verbs from nouns (e.g., baba 'woman' and babâ 'to chat, chatter'), especially when the use of prefixes and suffixes (or left and right morphemes) is evident in the formation. Absolute incorporation is also seen in lexemes formed with both procedures: Slovenian kolač 'cake' is colàz in Friulian, and derivatives such as colazàr 'cake-maker' and incolazâ 'to entwine' can be found; a similar example is blato 'mud' and imblatâ 'to cover with mud'.

Mitja Skubic

Filozofska fakulteta Univerze v Ljubljani, Aškerčeva c. 2, 1000 Ljubljana 


\title{
Komentiranje leksično-besedotvornih kart $v$ 1. zvezku Slovenskega lingvističnega atlasa „Človek« (na primeru V617 teta in V618 ujna)
}

\author{
Vera Smole, Urška Petek (Ljubljana, Ivančna Gorica)
}

IZVLEČEK: Komentarji so ena od bistvenih, a tudi najbolj variabilnih sestavin vsakega lingvističnega atlasa. V prispevku bo na primeru komentarjev h kartama za vprašanji V617 teta in V618 ujna predlagana zgradba komentarja, kakršnega bi lahko imel 1. leksično-besedotvorni zvezek Slovenskega lingvističnega atlasa s pomenskim poljem »človek«.

ABSTRACT: Texts accompanying maps are one of the essential, but also most variable, components of any linguistic atlas. Using examples of texts accompanying the maps for questions 617 teta and 618 ujna, this article proposes a structure for these texts for use in the first lexical and word-formative volume of the Slovenian Linguistic Atlas dedicated to the semantic field 'man'.

$0 \mathrm{Uvod}^{1}$

Minilo je več kot leto dni od javne napovedi izida 1. leksično-besedotvornega zvezka SLA s pomenskim poljem »Človek« (Smole 2006). Po poldrugem letu intenzivnih priprav tega zvezka v Dialektološki sekciji Inštituta za slovenski jezik Frana Ramovša ZRC SAZU, ${ }^{2}$ ko se bližajo koncu zahtevne tehnične predpriprave digitaliziranja in samodejnega računalniškega kartografiranja gradiva na eni stra-

1 Gradivo, ki vsebuje posebna naglasna in druga znamenja, je bilo vneseno z vnašalnim sistemom ZRCola, ki ga je pri ZRC SAZU razvil Peter Weiss. Pri kartografiranju so grafični znaki vzeti iz nabora SIMBola. Za tehnično pomoč pri kartografiranju se zahvaljujeva Domnu Uršiču.

2 V pripravo SLA I so bile v okviru svojih diplomskih del vključene tudi tri študentke slovenistike, in sicer Mojca Horvat, Petra Kostelec in Urška Petek, ki so z vnosom znatnega dela gradiva $v$ računalniško obliko in nato nadaljnjo analizo in kartografiranjem prispevale precejšen delež k nastajanju zvezka, zato je prav, da se jim tudi na tem mestu zahvalimo. Pričujoči prispevek je narejen na podlagi dveh kart s komentarjema iz diplomskega dela Urške Petek z naslovom Geolingvistični prikaz nekaterih leksemov s pomenskega polja »Človek« (po gradivu za SLA), UL, FF, Oddelek za slovenistiko, april 2007, 89 str. (mentorica V. Smole). [op. Vera Smole] 
ni, hkrati pa potekata tudi analiza in poskusno kartografiranje, je potrebno določiti smernice, po katerih se bodo pisali komentarji k posameznim kartam. Pri tem bomo izhajali iz načeloma sprejetih sekcijskih dogovorov, objavljenih v zgoraj omenjeni napovedi zvezka: 1) gradiva oz. t. i. indeksov (tj. odgovorov na zastavljeno vprašanje po zaporedju oštevilčenja krajev) kartam ne bomo pridajali, 2) tehnika kartografiranja bo pretežno kombinirana, tj. napisno-izoglosno-znakovno-ploskovna, 3) vsaka karta bo imela legendo, v kateri bodo uporabljena grafična sredstva natančno pojasnjena. Zgledov za izdelavo komentarjev je veliko - toliko kot obstoječih atlasov (ki vsebujejo komentarje); prav tako pa je velika tudi specifika vsakega atlasa oz. gradiva in prav tej je komentarje treba prilagoditi. Veliko je tudi že objavljenih leksično-besedotvornih kart za SLA, ki so z različnih tematskih področij, komentarji v obliki člankov pa dostikrat bolj ali manj obširni, pisani »avtorsko« svobodno, neshematizirano, $\mathrm{z}$ različnimi poudarki in povezovanji vsebin.

1 Predlog komentarja h kartam 1. leksično-besedotvornega zvezka SLA s pomenskim poljem »Človek«

Če hočemo zadostiti osnovnim zahtevam komentarja $\mathrm{v}$ atlasu, tj. da bralcu omogoči hitro orientacijo na karti, ga opozori na obravnavane probleme in poda strokovno razlago zanje, morajo imeti komentarji poleg enotne vsebinske zasnove tudi ustaljeno zgradbo, v kateri se podatki določenega tipa (npr. podatki o etimologiji besed, o razširjenosti določenega leksema, njegovi pogostnosti ipd.) nahajajo vedno na istem mestu. Za komentiranje leksično-besedotvornih kart SLA predlagamo naslednjo zgradbo:

Naslov komentarja \{SLA I V-yx (številka vprašanja iz izbranih vprašanj za »Človek «) $)^{3}$ [Vxy (št. vprašanja v vprašalnici SLA)] vprašanje (tj. kartografirani leksem) - Karta št. $\mathbf{x y}\}$

I Pomen, ki se kartografira, ${ }^{4}$ knjižna ustreznica (ali ustreznice), fonetično

3 V SLA I Človek bodo kartografirana in komentirana vprašanja iz različnih razdelkov Vprašalnice za SLA, in sicer I Telo, X Bolezni, XII Družina in nekaj posamičnih vprašanj iz drugih razdelkov, zato imajo zelo različne zaporedne številke. Menim, da bi bilo tako izbrana vprašanja smiselno oštevilčiti zaporedno - enako potem pri vseh nadaljnjih zvezkih SLA - in se tega zaporedja držati pri komentarjih; karte imajo vedno svoja posebna številčenja, saj gradivo enega vprašanja lahko karte ne da (ker je preveč enotno), ali pa jih da več (npr. vprašanje za barvo las, kjer je naštetih vsaj pet barv ali pa vprašanje šepav, iz katerega je mogoče narediti posebej leksično (kartografiranje samo korenov pridevnika) in posebej besedotvorno (kartografiranje samo pripon) ali pa (še) kombinirano leksično-besedotvorno karto.

4 Glede na tip vprašalnice za SLA, ki največkrat podaja samo knjižni leksem, ta pa ima lahko več, tudi precej različnih pomenov, za katere so zapisovalci včasih navedli ustrezne narečne lekseme, jih pomensko opredelili ali še večkrat ne, morda ne bo odveč opozorilo, da je za kartografiranje potrebno izbrati le en pomen, kar hkrati pomeni, da iz gradiva izločimo druge pomene, ali te, z določeno upravičenostjo, kako drugače kartografsko prikažemo in ustrezno komentiramo (prim. karto in komentar k V617 teta in pomene leksema strina). Primer: v točki 374 se ob odgovoru na V617 teta, in sicer tetíca, pojavi odgovor strina s pomenskim pojasnilom »stričeva žena«, to pa ni predmet kar- 
poknjiženi narečni leksemi zanj, ${ }^{5}$ njihova pogostost in medsebojna razmerja (morebitna dvojničnost leksemov) in razmerje do knjižnega jezika.

II Izvor leksemov, povzet po obstoječih etimoloških (ESSJ, SES, ERSHJ... $)^{6}$ ali dvojezičnih slovarjih ter slovarjih izposojenk; zabeleženost in pomen leksemov v knjižnem jeziku (po SSKJ), ${ }^{7}$ zabeleženost in pomen leksemov, ki v SSKJ niso bili sprejeti in jih ni niti v sln. etimoloških slovarjih, v narečnih in zgodovinskih slovarjih. ${ }^{8}$

III Opis prostorske razporeditve leksemov in pon (besednih zvez, pred- in pri-pon) - tistih, s svojimi sklenjenimi ali nesklenjenimi areali, in tistih, ki se pojavljajo razpršeno. ${ }^{9}$

tografiranja na tej karti, zato odgovor izločimo in ga lahko upoštevamo pri naslednjem vprašanju. Na drugačen primer naletimo v Istri, ko je ob odgovoru teta na isto vprašanje dodan še leksem strina v pomenu »starejša ženska, soseda«, kar je drugi pomen knj. leksema teta, posebnega vprašanja pa za ta pomen ni, zato vsaj z opozorilom na komentar (*) obstoj leksema prikažemo in ga v komentarju navedemo. Tega ne storimo v primeru, ko je za isti pomen naveden enak leksem oz. dodano pojasnilo, da npr. teta pomeni tudi vsako starejšo žensko, sosedo ipd. Tudi v nadaljevanju komentarja se moramo omejiti predvsem na kartografirani pomen; v nasprotnem primeru se komentar lahko preveč razvleče in zgreši svoj osnovni namen.

5 Pomen tega termina glej v Smole 2006, 232. S stališča zgodovinskega in primerjalnega jezikoslovja bi bila nujna tudi t. i. morfonološka analiza leksemov, izvedena na poznopraslovansko ali izhodiščnoslovensko osnovo in predstavljena v razdelku II; ali bo ta izvedena, še ni odločeno. - Pri fonetično poknjiženih narečnih leksemih se pojavi še en problem: zaradi velike glasoslovne raznolikosti slovenskih narečij njegova glasovna podoba v nekaterih primerih tako odstopa od narečne, da ju mnogi bralci ne bodo prepoznali/priznali kot isti leksem. Iz teh razlogov bo v tem razdelku potrebno navesti tudi nekaj glasovnih približkov narečnim glasovnim podobam, kar bo za avtorja komentarja precej zapletena naloga. Vzemimo za primer leksem ujna, kateremu se pogosto dodaja protetični $v$, ta pa povzroči skupaj z $j$ mnoge položajne razvoje samoglasnika $u$, kar bi lahko poenostavljeno zapisali takole: vujna, vojna, vejna, vəjna, vüna, vüjna, vüuna, vina itd., pri čemer je treba upoštevati še različen izgovor $v(\operatorname{kot} v, w$ ali $\underline{u})$.

6 Da v primeru ustrezne obravnave leksema v več etimoloških slovarjih damo prednost slovenskima etimološkima slovarjema, je razumljivo; kateremu med njima, pa je odločitev sestavljalca komentarja - seveda na podlagi jasnosti, prepričljivosti, izčrpnosti pa tudi gospodarnosti razlage ter za vsak leksem posebej.

7 Slovar slovenskega knjižnega jezika (SSKJ) je za slovenski knjižni jezik še vedno edino referenčno delo in za leksiko, kakršna je obravnavana v pripravljajočem se Slovenskem lingvističnem atlasu (SLA), tudi povsem zadovoljivo.

8 Zaradi gospodarnosti predlagam, da se v komentarju okrajšano navajajo samo slovarji, ki obravnavani leksem vsebujejo; kateri so bili pregledani in leksema nimajo, bo razvidno iz seznama vseh slovarjev v uvodnem delu zvezka.

9 Pogosto smo v dilemi, ali prostorsko razširjenost leksemov opisovati glede na prisotnost v narečju/-ih ali navajati zemljepisna področja. Ker bo atlasu pridana narečna karta, je prvi način možen. V primeru, ko je leksem omejen na zemljepisno območje ne glede na narečne meje, pa se nagibamo k zemljepisni predstavitvi. Tako prvi kot drugi način opisovanja sta zaradi velike narečne razčlenjenosti in (pre)majhne uzaveščenosti manjših pokrajin in krajev problematična; zato bodo zemljevid, narečna karta in mreža krajev tudi za bralce nepogrešljiv pripomoček. 
IV Razlaga specifičnosti tehnike kartografiranja (če je to potrebno).$^{10}$ Opozorilo na morebitne probleme $\mathrm{v}$ zvezi z nerazumevanjem vprašanja (s strani zapisovalca ali informatorja), semantičnimi nejasnostmi ipd. ter predstavitev konkretne kartografske rešitve.

V Uporabljena dodatna literatura (slovarska je okrajšano navedena v razdelku II), npr. že objavljene karte, etnološka literatura ipd.

VI Sklic na karte (oziroma samo na vprašanja, če karte še niso bile objavljene) $\mathrm{z}$ istim vprašanjem $\mathrm{v}$ večjezičnih atlasih $\mathrm{z}$ vključenim slovenskim jezikom, in sicer v Slovanskem (OLA) in Evropskem (ALE), ter v področnih atlasih. Opozorilo na pomensko in/ali problemsko sorodne karte in/ali komentarje v samem 1. zvezku SLA.

2 Uresničitev predlaganega komentarja na primeru komentarjev h kartama za vprašanji V617 teta in V618 ujna (Če je izraz znan, določiti pomen.) ${ }^{11}$

2. 1 V617 teta

SLA I V-121 [V617] teta - Karta št. $1^{12}$

I Na karti so predstavljeni leksemi za pomen 'sestra očeta ali matere', knjižno teta. Leksem teta (nar. tjeta, tjata, teata, tieta, tetà, tatà) je najpogostejši tudi v narečjih. Večje sklenjeno območje imata naglasni različici tetíca (nar. tudi tíca) in tética (nar. téca), manjše pa besedotvorni različici tétka in tétika (nar. teatəka). Leksem tétka je vedno dvojnica leksemu téta, ta pa pogosto leksemu tetíca. V SSKJ so leksemi tética, tétka in tétika označeni s kvalifikatorjem ljubkovalno, naglasne različice tetíca v slovarju ni. - Na sklenjenem območju se v kartografiranem pomenu rabi tudi leksem strina, ki je v SSKJ v istem pomenu označen s kvalifikatorjem narečno. Kadar se ta leksem pojavi kot dvojnica, ima običajno drug pomen. - Le dvakrat je zabeležen leksem njanja - enkrat kot dvojnica leksemu téta - in enkrat, prav tako dvojnica, moma; obeh v SSKJ ni.

II Leksem teta, pslovan. * teta̋ v pomenu 'teta', je prvotno otroška beseda, nastala s podvojitvijo zloga (ESSJ), in jo v enakem pomenu poznajo tudi $\mathrm{v}$ drugih jezikih, npr. hrv., srb. téta, tëtka, rus. tëtja, tëtka, češ. teta, lit. tetà, sorodno šved. titta (SES). S pomanjševalno oziroma ljubkovalno pripono $-k a$, tetka, v pomenu

${ }^{10}$ Osnovna načela tehnike kartografiranja bodo navedena v uvodnem delu zvezka. - Poleg možnosti, predstavljenih v Smole 2006, 232, obstaja še možnost izbire barv - ali bo v SLA I izkoriščena, še ni gotovo.

${ }^{11}$ Vprašanji se zdita v ta namen primerni, ker je s stališča kartografiranja in komentiranja: 1) V617 razmeroma enostavno, V618 pa bolj zapleteno, 2) ker se navezujeta na pomensko in problemsko sorodni vprašanji V615 stric in V616 ujec (materin brat). Oštevilčenje in formulacija je iz Vprašalnice za SLA (Ramovš; objavljena v Benedik 1999), 1. zvezek pa bo imel tudi svoje posebno (zaporedno) številčenje tako vprašanj kot kart.

12 Oštevilčenje vprašanj za SLA I »Človek« še ni dokončno rešeno, in sicer tako glede zaporedne številke kot oblikovno (vmesni stični vezaj); V-121 teta in V-122 ujna je ena od možnih rešitev. Še manj je mogoče reči, katero številko bo karta imela, saj bodo nekatera vprašanja samo komentirana, druga pa lahko predstavljena z več kartami; to oštevilčenje je prirejeno tukajšnji objavi. 
'teta', je bila beseda znana v stcslovan. tetъka (SES) in je še vedno v mak. tetka. Kot pomanjševalno-ljubkovalni lahko razlagamo tudi priponi -ika in -ica/-íca v leksemih tétika ter tética in tetíca.

Leksem strina, pslovan. *strъjbna̋ je v ženskem spolu posamostaljeni pridevnik *str̋̈jьnъ 'stričev', ki je izpeljan iz *strb̈jb 'stric, očetov brat', nar. zilj. pomeni 'teta', starejše (16. stol.) in nar. pkm. le 'stričeva žena', zahodnosln. 'starejša (znana) ženska'. Enako je hrv., srb. strîna, mak. strina 'strina', nar. hrv. strïna, stčeš. stryna, sorodno še nar. rus. strýnja, strýja, slovaš. stryńa (po SES). ${ }^{13}$

Leksem njanja je prevzet iz furl. agne ‘teta, splošno' oziroma gnagne ‘teta, v otroški govorici' (Pir).

Leksem moma je prevzet iz nem. die Muhme 'teta, splošno'.

III Leksem teta v pomenu 'očetova ali materina sestra' poznajo skoraj vsa slovenska narečja; izjema je koroško ziljsko narečje. V prleški točki 378 (Juršinci) je pomen leksema teta zamejen na 'očetova sestra', v belokranjskih točkah 291 in 292 pa na 'materina sestra'. Ta leksem je redek v panonskih prekmurskem in haloškem narečju, pogostejši v slovenskogoriškem in prleškem, kjer sobiva ob sicer prevladujoči besedotvorni različici tetíca. Leksem tetíca, okrajšano celo tíca (404 Gornji Senik), je torej najpogostejša panonska ustreznica za knjižni leksem teta, ki pa ima vzhodno od črte Ljutomer-Ormož do meje s Hrvaško naglasno različico *tética, okrajšano v téca. V najsevernejših koroških podjunskih točkah 32 in 33 najdemo sorodno izpeljanko tétika ( $i$ je reduciran v ə). Ali je narečna izpeljanka tetka, ki se kot dvojnica pojavlja v treh točkah štajerskega kozjansko-bizeljskega narečja (345347), tvorjena s pripono -ika ali -ka, je z gotovostjo težko trditi, bolj se nagibamo k drugi možnosti. - V koroškem ziljskem narečju se je posplošil leksem strina in leksema teta ne poznajo (navedeno za točki 2 in 6); samo leksem strina je naveden v kostelski točki (284 Spodnja Bilpa). V eni od točk mežiškega narečja (46 Pameče) je prav tako kot v Ziljski dolini splošni izraz strina, teta pa je lahko samo neporočena. Leksem strina se brez pomenske določitve kot dvojnica pojavi še v točki primorskega kraškega narečja (98 Trnovo), v istrskem narečju (točke 116-117) pa dvakrat od treh pojavitev z razlago 'naziv za katero koli (znano starejšo) žensko'; na pomen 'stričeva žena' (ki se ne kartografira), zabeležen v prleški točki 374, lahko sklepamo morda še za točko istega narečja 382 in prekmursko točko 388 (prim.: Novak 1996: 142). - Iz stičnega jezika prevzeti leksem njanja se pojavi v primorskem nadiškem narečju. - Prav tako prevzeti leksem moma je zapisan v gorenjskem selškem narečju, na področju z zgodovinsko izpričano nemško naselitvijo.

IV Karta je napisno-izoglosno-znakovna. Močnejša črta (izoleksa) zamejuje leksem strina od leksema teta; med leksemoma teta in tetíca je tanjša črta (enak korenski morfem), v teca okrajšan leksem tética pa je oddeljen s pretrgano črto. Leksemi z majhnim ali razpršenim arealom so kartografirani znakovno. Leksemi, ki ne vsebujejo pomena 'očetova ali materina sestra', niso kartografirani; nanje v primeru, da so pomensko zanimivi, opozarja * (zvezdica) desno od številke kraja, zapisovalčeve opombe (redko) tipa 'tudi vsaka starejša ženska' niso označevane,

${ }^{13}$ Formulacija »po SES« je rabljena v primeru, ko so podatkom iz slovarja dodani še drugi; $\mathrm{v}$ tem primeru narečni in za makedonščino. 
saj se tudi ta pomen predvideva $v$ bistveno večjem številu točk. Zvezdica označuje tudi zožitve pomenov, sam leksem pa je kartografiran. Na pomenske nejasnosti je opozorjeno v prejšnji točki komentarja.

$\mathrm{V}-$

VI OLA: F (Sm) 1875, ALE: - (prim. 472 stričeva žena); SLA I: 122 [618] ujna, 119 [615] stric, 120 [616] ujec (materin brat).

\section{2 V618 ujna}

SLA I V-122 [V618] ujna (Če je izraz znan, določiti pomen.) ${ }^{14}$ - Karta št. 2

I S karte so razvidna 1) področja (zamejena so z izogloso), na katerih je leksem ujna (nar. ujna, vujna, vojna, vejna, vəjna, vüna, vüuna, vüjna, vina) (še) v rabi oziroma poznan, 2) dodatno (z znaki) še pomeni leksema ujna, kadar so zapisovalci pomen navedli. V knjižnem jeziku ima leksem s kvalifikatorjem starinsko dva pomena: 1. 'materina sestra, teta (po materini strani)', 2. 'navadno kot nagovor starejša znana ženska, teta'. V narečjih drugi pomen ni bil iskan, za prvi pomen pa je najpogosteje (24 krat) potrjen pomen 'ujčeva žena, žena materinega brata', manjkrat (2 krat) pomen 'materina sestra', v eni od teh točk (378) je zabeležena sprememba pomena od starejšega 'ujčeva žena, žena materinega brata' k mlajšemu 'materina sestra'. ${ }^{15}$ Po enkrat, zato morda nezanesljivo, so navedeni pomeni 'stričeva žena' (76), 'očetova sestra' (79), ${ }^{16}$ ‘žena moževega brata' (90), 'materina ali očetova sestra' (145), ${ }^{17}$ ‘žena, ki živi na domačiji svojega moža' (148), 'daljna sorodnica' (235) in 'bratova žena, svakinja' (291). Nepovezan z našim pomenom je pomen 'vzklik nad svinjo’ v točki 300. Enkrat se pojavi besedotvorna različica ujnika (nar. vuneka).

II Slovan. *üjbna je v ženskem spolu posamostaljeni pridevnik *üjьnь 'ujčev', ki je izpeljan iz *üjb 'ujec, materin brat', kakor je iz pslovan. *stry̌jьnъ 'stričev' posamostaljeno *stry̌jbna 'strina' (SES). Ujna, v istem pomenu kot v večini slovenskih narečij z ohranjenim leksemom, poznajo še v hrv., srb., mak. (vujna) in ukr. (vujna) jeziku (po ESSJ).

III Leksem ujna, s prevladujočim pomenom 'ujčeva žena' oziroma ‘žena materinega brata', poznajo narečja na obrobju slovenskega jezikovnega prostora, in sicer na zahodu je to nekaj govorov obsoškega, nadiškega, tolminskega in kraškega narečja, na jugu so to predvsem govori notranjskega narečja, ki se jim pridružuje še nekaj sosednjih govorov istrskega, kraškega in jugozahodnega dela dolenjskega narečja, ter večina govorov kostelskega in obeh belokranjskih narečij, na severovzhodu pa leksem poznajo vsa panonska narečja z izjemo slovenskogoriškega. Manjše

${ }^{14}$ Dopolnjena formulacija vprašanja (v oklepaju) je nastala leta 1961, pred tem letom so zapisovalci vprašanje razumeli po svoje. O tem problemu prim. Benedik 1999, 15-16.

15 Podobna sprememba pomena se je očitno zgodila tudi v knjižnem jeziku, saj Pleteršnikov slovar navaja oba pomena enakovredno, SSKJ od njiju izpostavlja pomen 'materina sestra' (krvno sorodstvo! - op. avt.), pomen 'teta (po materini strani)' pa nekoliko zamegljeno vključuje/nadomešča pomen 'ujčeva žena, žena materinega brata'.

${ }^{16} \mathrm{~V}$ obeh točkah (76 in 79) ostaja nejasno pomensko razmerje leksema teta nasproti ujna.

${ }^{17} \mathrm{~V}$ tem primeru bi na V617 teta pričakovali odgovor ujna, vendar je teta - kakšno je pomensko razmerje med leksemoma, tako iz obeh odgovorov še vedno ni jasno. 
strnjeno območje s tem leksemom sega še od Raven na Koroškem do srede Pohorja, tj. v dveh mežiških in dveh severnopohorskih govorih, medtem ko se v Posavju leksem pojavlja v posameznih točkah. Oznake starinsko, ki se pojavljajo zlasti na stiku z govori, ki leksema ne poznajo več, kažejo na prepričljivo ožanje območja s tem leksemom in zamenjavo s pomensko splošnejšim leksemom teta. V primerjavi z območjem, kjer je v rabi/znan leksem $u j(e c)$, se to z njim prekriva, vendar je precej manjše.

V nasprotju s knjižnim, ne natančno definiranim pomenom 'materina sestra, teta (po materini strani) ${ }^{\prime 18} \mathrm{v}$ narečjih prevladuje pomen 'ujčeva žena, žena materinega brata'.

IV Karta je izoglosno-znakovna. Izoglosa zaobjema najširše področje z rabljenim in/ali znanim leksemom ujna, pomeni so v točkah, kjer so v gradivu navedeni, prikazani znakovno, prazno mesto ob številki pomeni prisotnost/poznavanje leksema ujna brez razlage pomena. Znotraj izoglose so točke, kjer raba in/ali poznavanje tega leksema nista potrjeni (ali pa je naveden drug leksem) $-\mathrm{v}$ tem primeru stoji pred številko poševnica. Izven izoglose so označene samo nezapisane točke. Zvezdica desno od številke opozarja na opombo zapisovalca, da je leksem (in pomen) arhaičen, $\mathrm{v}$ točki 281 pa pomeni, da se namesto leksema ujna tam rabi izpeljanka $\mathrm{z}$ ljubkovalno-pomanjševalno pripono -ika, ujnika.

$\mathrm{V}-$

VI OLA: LSl 1874, ALE: -; SLA I: 121 [617] teta, 119 [615] stric, 120 [616] ujec (materin brat).

\section{Zaključek}

Že samo dve karti s komentarjema dokazujeta, da gradivo SLA za posamezno vprašanje zahteva najprej temeljito analizo, nato pa tehten premislek tako glede tehnike kartografiranja kot komentiranja karte in gradiva. Možna in nujna so enotna načela kartografiranja in enotna zgradba komentarja, medtem ko bodo končne rešitve načina kartografiranja in zapolnitve komentarja izrazito avtorske.

\section{Viri in literatura}

Gradivo za Slovenski lingvistični atlas (SLA), ki ga hrani Dialektološka sekcija Inštituta za slovenski jezik Frana Ramovša ZRC SAZU.

ESSJ: Bezlaj, France, 2005, Etimološki slovar slovenskega jezika - četrta knjiga $\breve{S}-\check{Z}$, ur. Marko Snoj in Metka Furlan, Ljubljana, izdala SAZU, ZRC SAZU - Inštitut za slovenski jezik Frana Ramovša (Etimološko-onomastična sekcija), založila Založba ZRC.

${ }^{18}$ Ni namreč povsem jasno, kaj razumeti pod razlago »teta (po materini strani)«, saj ni nujno, da je to materina sestra; teta po materini strani je navsezadnje lahko tudi 'žena materinega brata'. 
$\rightarrow \quad$ Petek, Urška, 2007, Geolingvistični prikaz nekaterih leksemov s pomenskega polja »Človek« (po gradivu za SLA), UL, FF, Oddelek za slovenistiko, april 2007, 89 str. (mentorica V. Smole).

Pir, Pirona, Giulio Andrea, 2001, Il Nuovo Pirona (Vocabolario Friulano), Udine, Società Filologica Friulana.

SES, Snoj, Marko, 2003, Slovenski etimološki slovar, Ljubljana, Modrijan.

SSKJ, Ahlin, Martin, Bokal, Ljudmila et al., 2000, Slovar slovenskega knjižnega jezika (elektronski vir), Ljubljana, DZS.

Smole, Vera, 2006, Prvi zvezek Slovenskega lingvističnega atlasa - realnost ali utopija? Diahronija in sinhronija v dialektoloških raziskavah. Maribor, Slavistično društvo, 226-234.

\section{Texts Accompanying Lexical and Word-Formative Maps in Volume 1 of the Slovenian Linguistic Atlas for the Semantic Field 'man' (based on questions 617 teta and 618 ujna)}

Summary

1 The purpose of texts accompanying maps in a linguistic atlas is to enable readers to orient themselves quickly on the map, draw their attention to the issues discussed, and explain these issues. In addition to a uniform conceptual design, these texts must also have an established structure in which certain types of data are always located in the same place. We propose the following conceptual structure for texts to accompany the lexical and word-formative maps of volume one of the Slovenian Linguistic Atlas (SLA) dedicated to the semantic field 'man':

I The meaning presented on the map, its standard language equivalent(s), phonetically standardized dialect lexemes for this meaning, their frequency and mutual relationship, and their relationship to standard Slovenian;

II The origin of the lexemes, and the presence and meaning of the lexemes in standard Slovenian, or other literature if they do not exist in standard Slovenian;

III Description of the spatial distribution of lexemes and word-formative morphemes;

IV Explanation of details of the cartographic technique (if necessary). Drawing attention to possible problems related to misunderstanding the issue, lack of semantic clarity, and so on, and a concrete cartographic presentation;

V Additional literature used;

VI Reference to maps (or issues only, if maps have not been published yet) dealing with the same issue in multilingual atlases that include Slovenian; for example, the General Slavic Linguistic Atlas (OLA) and the Linguistic Atlas of Europe (ALE), and regional atlases. Drawing attention to similar maps in terms of semantics and/or issues discussed, and texts used in volume one of the SLA;

2 Map no. 1 demonstrates the range of use of lexemes denoting 'father's or mother's sister', or teta 'aunt' in standard Slovenian. The lexeme teta (dial. tjeta, tjata, teata, tieta, tetà, and tatà) is also the most frequent in dialects. East of Maribor, 
the stressed version tetíca is used, whereas in the area along the Croatian border between Ljutomer and Ormož the version tética (dial. téca) is used; in the northernmost Carinthian villages of the Jaun Valley (Sln. Podjuna) the word-formative variant tétika is used, and in the area along the Sotla River the variant tétka. The lexeme tétka is always used as a variant of the lexeme téta, and the latter of the lexeme tetíca. In the Gail Valley (Sln. Ziljska dolina) and on the Banjšice Plateau, the lexeme strina is used in the meaning presented on the map; the same meaning of the lexeme is marked with the qualifier dial. 'dialect' in the Dictionary of Standard Slovenian (SSKJ). In western Slovenia, the lexeme njanja occurs twice $(<$ Friul. agne 'aunt [generic]') and moma once (< Germ. Muhme 'aunt [generic]').

Map no. 2 shows 1) the areas (bounded by an isogloss) in which the lexeme ujna (dial. ujna, vujna, vojna, vejna, vojna, vüna, vüuna, vüjna, and vina) is (still) used or known, and 2) additional meanings of the lexeme ujna (marked with symbols) where the transcribers recorded this meaning. The lexeme ujna has been preserved in peripheral regions, whereas in other regions the lexeme teta or (rarely) strina has become generally established. In dialects, the most frequent meaning of the lexeme ujna is 'uncle's wife, wife of mother's brother' and only in two attestations means 'mother's sister'. In standard Slovenian, the primary meaning of ujna is 'mother's sister, maternal aunt', marked with the qualifier star. 'archaic'.

\title{
Priloga:
}

Leksično-besedotvorni karti

Karta št. 1 - SLA V617 (teta)

Karta št. 2 - SLA V618 (ujna)

\author{
Vera Smole \\ Filozofska fakulteta Univerze v Ljubljani \\ Aškerčeva c. 2, 1000 Ljubljana \\ vera.smole@guest.arnes.si \\ Urška Petek \\ Ulica Dolenjskega odreda 50, 1295 Ivančna Gorica \\ Petek.Urska@gmail.com
}





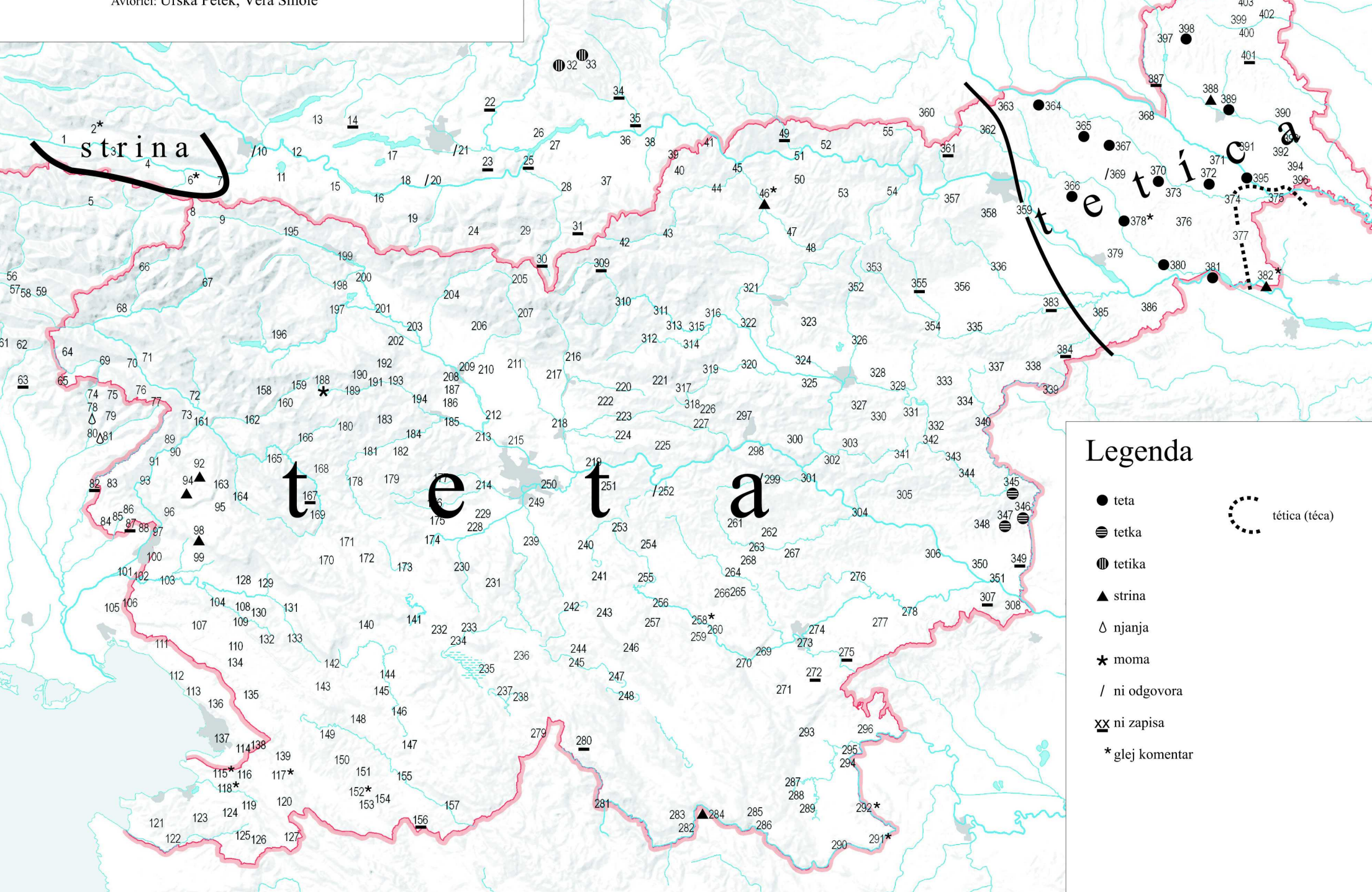



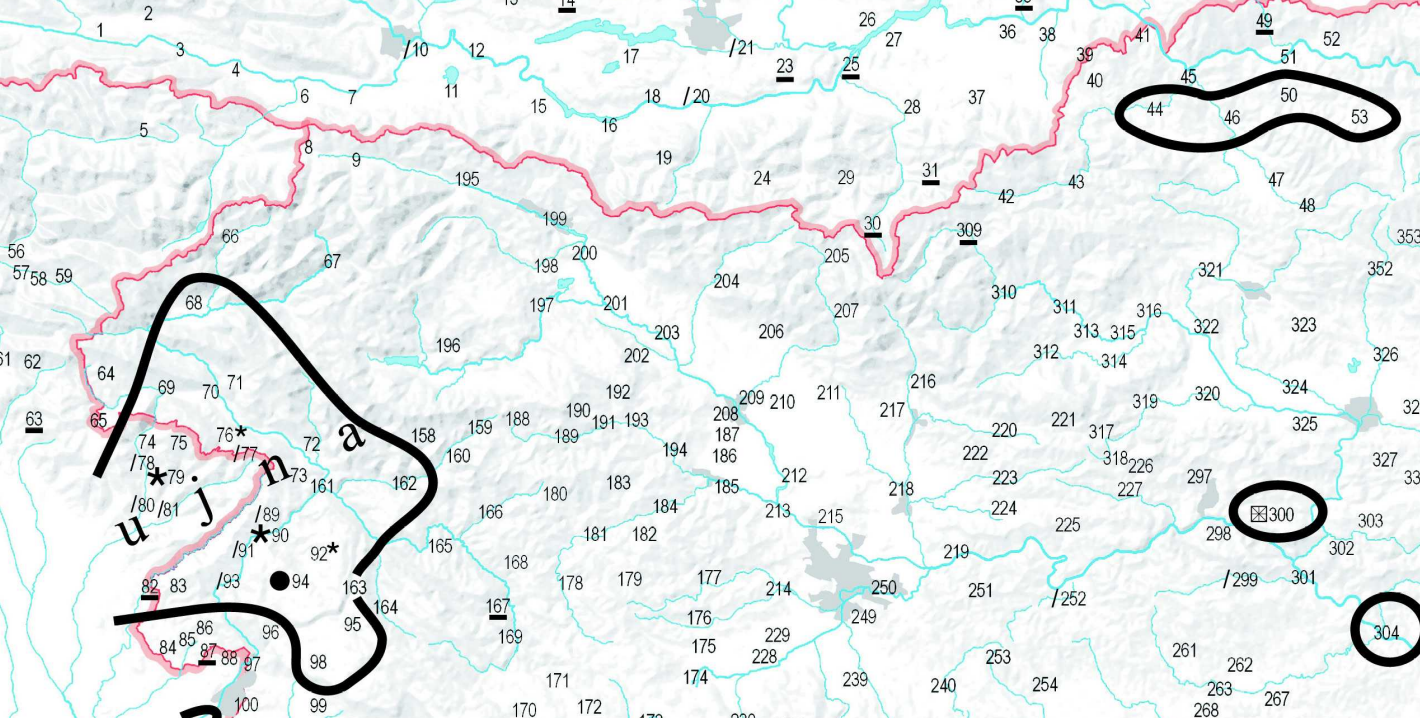

3

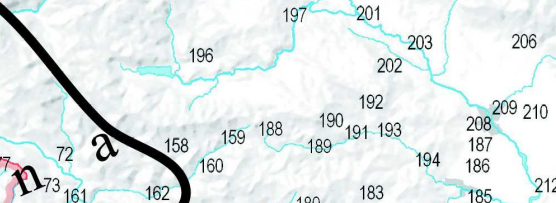

$311 \quad 311^{313} 315$
312
314

(
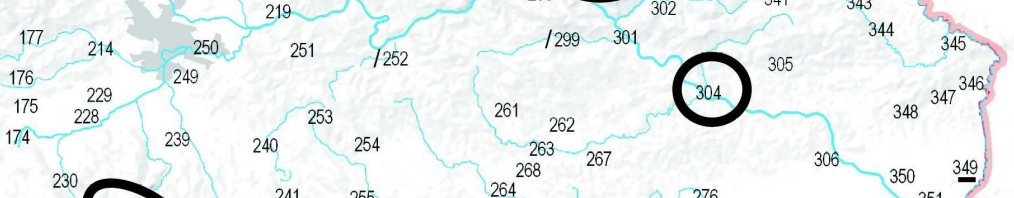

(1) 


\title{
Sfogliando il Lessico del dialetto sloveno del Torre/Besedišče terskega narečja \\ (Amarcord di Pavle Merkù)
}

\author{
Liliana Spinozzi Monai (Viden)
}

IZVLEČEK: Leksikološko delo Pavleta Merkuja na področju terskega narečja je v prispevku soočeno z več kot stoletje starejšim delom jezikoslovca Jana Baudouina de Courtenayja. Gradivo enega in drugega avtorja je redka priložnost, da se Glossario del dialetto del Torre Baudouina de Courtenayja, ki vsebuje približno 8.000 kartotečnih listkov, primerja s še neobjavljenim gradivom, ki ga je Merkù po tridesetletnem zbiranju zlil v svoj Lessico del dialetto sloveno del Torre/Besedišče terskega narečja.

\begin{abstract}
Browsing through Lessico del dialetto sloveno del Torre/Besedišče terskega narečja (A Reminiscence of Pavle Merkù)

ABSTRACT: This article compares Pavle Merkù's lexicological work in the Torre Valley dialect with a work over a century older by the linguist Jan Niecistaw Baudouin de Courtenay. The material collected by both authors provides a rare opportunity to compare Baudouin's Glossario del dialetto del Torre (Glossary of the Torre Valley Dialect), which contains approximately 8,000 index cards, with still unpublished material that Merkù used for his Lessico del dialetto sloveno del Torre/Besedišče terskega narečja (Vocabulary of the Torre Valley Dialect) after thirty years of collection.
\end{abstract}

I festeggiamenti per il genetliaco di Pavle Merkù si collocano in un momento della mia attività scientifica in cui il festeggiato figura come protagonista accanto a colui che, oltre un secolo fa, inaugurò lo studio sistematico delle varietà slovene del Friuli: Jan Baudouin de Courtenay.

Che Baudouin abbia pubblicato dei lavori di carattere etnolinguistico sul resiano e sul dialetto del Torre (tersko) è cosa risaputa ${ }^{1}$. Meno risaputo, forse, che, a fronte delle pubblicazioni, esiste un enorme lascito documentario sui dialetti sloveni della Benečija, finora edito in misura minimale ${ }^{2}$, tra cui spicca quello di carattere lessicografico, attualmente in corso di elaborazione e/o di stampa. Alludo al Dizionario resiano, curato da N.I. Tolstoj, M. Matičetov e A. Duličenko nel quadro di una collaborazione tra le Accademie Slovena e Russa; ed al Glossario del dialetto del Torre, un complesso di quasi 8000 schede, pensate per un "dizionario 
$\hookrightarrow \quad$ scientifico"3. Ed è a proposito del Glossario che l'attività di Merkù si innesta in quella del suo illustre predecessore.

Quando, nel 1984, nella rosa di pubblicazioni propedeutiche assegnatemi per la tesi di laurea sul dialetto del Natisone, trovai l'articolo di Merkù $O$ slovenskem terskem narečju (Slavistična revija 28, št. 2, 167-178), non potevo prevedere quali orizzonti mi avrebbe dischiuso tale lettura. L'autore, infatti, parla delle sue esplorazioni nella Valle del Torre, dei materiali ivi raccolti ai fini di un repertorio storico-linguistico-etnografico (zgodovinsko-jezikoslovno-etnografski besednjak), e, nel ricordare l'apporto di Baudouin allo studio di questo dialetto, auspica che Rado Lenček, della Columbia University di New York, pubblichi quanto prima il Glossario del dialetto del Torre, conservato negli archivi di Leningrado, messogli a disposizione dalle autorità sovietiche.

Mentre sorvolo sulla serie di circostanze che hanno dirottato detti materiali all'Ateneo udinese, nel cui ambito viene attualmente svolto il lavoro di redazione, vorrei qui ricordare la circostanza, alquanto curiosa, che ha favorito quella che potremmo chiamare una collaborazione scientifica ideale tra i due slavisti-Baudouin e Merkù -, mediata dalla mia persona.

Udine, 7 maggio 2004. Pavle Merkù ed io sediamo allo stesso tavolo di un ristorante del centro, per la pausa pranzo del convegno "Slavia dilecta", organizzato per salutare l'ingresso della Slovenia nell'UE. Siamo in compagnia, tra l'altro, di Vida e Milko Matičetov e di Rosanna Benacchio. Quella mattina Merkù aveva parlato della toponomastica sloveno-friulana, mentre io avevo annunciato la decisione di redigere il Glossario del dialetto del Torre di Jan Baudouin de Courtenay. Colui che meglio di altri poteva capire la natura e l'entità dell'impegno era proprio Merkù, che aveva in cantiere la sua poderosa raccolta. Nel mentre se ne parla in toni conviviali, dichiara - tra il serio e il faceto - che sta affidando i suoi materiali alla cura di altri studiosi, in vista di un trasloco. Quale trasloco? ... Quello definitivo! Allora, tra il serio e il faceto, propongo che, se mai decidesse di 'liberarsi' anche del dizionario, potrebbe nominarmi sua erede ante litteram, permettendomi così di affiancare questo moderno complesso a quello datato di Baudouin.

Dieci mesi dopo...

15 marzo del 2005. Sono le ore dieci e trenta. Sono appena arrivata nella casa di Pavle Merkù. Siamo seduti ad un tavolo ricoperto da un drappo verde per le operazioni di consegna, da parte del padrone di casa, del Lessico del dialetto sloveno del Torre/Besedišče terskega narečja, non più steso in forma manoscritta, ma 'passato' al computer, sia pure in maniera provvisoria.

Sapevo che questo, per me, sarebbe stato un evento memorabile, perciò mi ero munita di un piccolo registratore per fissare quantomeno le parole di quell'incontro.

"Prego, Professore. Possiamo cominciare con la registrazione." 
Io ho potuto iniziare un lavoro di lessicografia insieme a quello di etnomusicologia appena dopo il '65. Fino al settembre del '65 avevo insegnato, e non avrei potuto pensare ad altro. Ma col primo ottobre sono entrato in RAI come dipendente (prima ero stato consulente e critico musicale per otto anni) e per prima cosa abbiamo cercato di capire come si può coinvolgere la Benečija all'ascolto: non certo con trasmissioni in lingua standard, non certo con trasmissioni dialettali, perché allora era proibito, tranne che Il Campanone e cose del genere. E abbiamo deciso che avrei iniziato con la raccolta di materiale - che io chiamo etnofonico, perché serviva alla RAI soltanto per l'ascolto - sia di carattere musicale che di carattere orale (racconti). Così negli ultimi mesi del '65 ho intrapreso la raccolta che riguarda tutta la zona dove vive la minoranza slovena: le tre Province di Trieste, Gorizia e Udine. Conoscendo abbastanza la materia, ho prestato maggiore attenzione alle zone e ai temi fino allora più negletti, perciò ho cominciato con la Benečija. Ho iniziato dalla Valle del Natisone, dove ho raccolto molte centinaia di reperti. Ovviamente non lo facevo per un'istituzione culturale o scientifica. Ogni mio viaggio aveva un suo costo che andava ripagato con un numero congruo di trasmissioni, per cui non potevo ritornare più volte in uno stesso posto per ritentare di trovare una cosa rara che stavo cercando, ma dovevo compensare i ritorni a mani vuote con altri rientri con ricca messe per poter sopperire ai primi e portare avanti le trasmissioni.

Così, nel '65 ho iniziato in Val Natisone, nel '67 in Val Torre, nel '69 in Val Resia, senza per questo trascurare la Provincia di Trieste, la Provincia di Gorizia e la Val Canale. Ho lavorato otto anni. Alla fine ho ritenuto conclusa la raccolta, perché ormai non c'era più la speranza di trovare elementi tali da giustificare le spese. Ed ho pensato ad una pubblicazione che ho offerto in primo luogo alla ERI - Edizione Radio Italiana -, che poteva benissimo mettersi questo fiore all'occhiello. Ma il funzionario, il vice direttore, che si era occupato della cosa, disse che da Torino non gli avevano neppure risposto. Allora mi sono rivolto ad un editore esterno, precisamente alla Editoriale Stampa Triestina/Založništvo tržaškega tiska, che ha provveduto alla stampa de Ljudsko izročilo Slovencev v Italji/Le tradizioni popolari degli Sloveni in Italia [1976], un libro che in due anni è andato esaurito, che molti cercano, e che ora l'editore Pizzicato ha deciso di ristampare, dotandolo anche di un CD con alcune trasmissioni (60 minuti di esempi più o meno validi).

Io non ero preparato da etnomusicologo o da etnografo: la mia preparazione era musicale da una parte e slavistica dall'altra (dialettologo si). Quindi ho dovuto per prima cosa studiare di nuovo il mestiere, farmi aiutare da etnografi sia sloveni che italiani, finché non sono stato capace di portare avanti il lavoro da solo.

Fin dal primo giorno, però, non ho trascurato la lessicografia, e ho cominciato da subito - alla fine del '65 - a prendere molti appunti. Ma dal '67, quando ho iniziato a lavorare nella Valle del Torre, ho deciso di preparare un dizionario dialettale, e l'ho fatto. Speravo - una volta andato in pensione - di poter ritornare più spesso in loco per portarlo a termine. La cosa non è andata in porto, perché mia moglie si è ammalata: prima che andassi in pensione io, è dovuta andare in pensione lei, anzitempo. Sono seguiti dodici anni di disastri crescenti, 
$-\quad$ prima per un male, poi per un male peggiore, che complessivamente sono durati dodici anni. Gli ultimi tre anni non potevo quasi nemmeno uscire di casa e il tempo, chiamiamolo libero, lo passavo al computer, che allora mi ero procurato. E, fra l'altro, ho continuato a preparare questo Lessico del dialetto sloveno del Torre/ Besedišče terskega narečja.

Non sono mai più riuscito a ritornare lì, per varie ragioni, quindi [il Lessico] è rimasto incompiuto. Eppoi mi ero reso conto di non aver prestato fin dal primo giorno sufficiente attenzione all'accento musicale. Né riesco a ricostruirlo con sicurezza dai testi raccolti nel 1873 e 1901 da Baudouin de Courtenay. Ho problemi grossissimi. Ho cercato di risolverli, ma vedo che, di solito, da quello che si può capire dalla sua complessa scrittura, l'accento musicale, che sembra essere presente nella Valle del Torre, è contraddetto da quello della Val Cornappo, che è l'opposto. Se il tonema è crescente da una parte, dall'altra è calante e viceversa. Mi ripromettevo appunto di ritornare sul posto, ma mi sono accorto che nel frattempo era morta anche la generazione dei miei più anziani informatori e che la generazione seguente, cioè la mia, ha già perso molto l'orecchio per l'accento musicale. Parlare con i più giovani non ha senso, perché i dati risulterebbero confusi quindi inaffidabili. Perciò ho perso in po' la voglia e il coraggio di continuare con questa ricerca, anzi ho dovuto fare altre cose che mi stavano altrettanto, se non più a cuore, riguardanti il campo musicale.

[Inizia a sfogliare la pila di pagine 'volanti' del complesso lessicografico.]

Qui ho cominciato a scrivere un'introduzione: l'identificazione del dialetto, la storia..., la dialettologia della zona, che è molto complessa; la fonetica ... Certo, molte cose sono ancora da completare: l'accento, la morfologia. Qui ci sono le abbreviazioni e simboli. Questo [l'ultima pagina dell'introduzione] l'avevo fatto per me: la quantità dei lemmi e dei rimandi. Ma insomma, seimila lemmi sono ben poca cosa per un dizionario dialettale. La quantità di lemmi di un dizionario dialettologico che i dialettologi prendono sul serio è di ventimila lemmi.

"Ma, considerata l'area e il fatto che l'uso del dialetto si è contratto, mi pare che sia un numero di tutto rispetto..."

[Passa al "vocabolario" vero e proprio.] Qui sono riuscito a stampare tutto, dalla A alla Ź. Spero sia sufficientemente chiaro. Quando ho sottolineato una segno come qui in abračáti, vuol dire che non sono sicuro dell'accento: abračáti o abračâti? La distinzione tra kráva crescente e dân calante è enorme in questo dialetto: non dappertutto allo stesso modo, ma soprattutto nella Valle del Torre. Nell'Alta Val Torre e anche in Val Cornappo questa distinzione è molto precisa. Era precisa - ora è sparita - nelle frazioni slovene di Cergneu, ma più a oriente ho anche lavorato di meno per una minore quantità di popolazione presente.

Ho fatto una registrazione in una località vicina a Canebola, Podrata ovviamente a metà agosto, perché tutti i giorni di ferragosto li passavo al lavoro (bisogna cercare queste cose quando sono presenti gli emigrati, che venivano a casa per le ferie estive) - e lì ho registrato un gruppo vocale maschile. E mentre li registravo, due tra i più anziani piangevano. Alla fine ho chiesto loro: "Ma perché piangevate?" Mi hanno risposto: "Sono venticinque anni che non cantiamo più ..." 
... venticinque anni sono una generazione...

$C^{\prime} e ̀$ anche una bella fotografia a ricordare questa registrazione, che comparirà sulla copertina della ristampa [de Le tradizioni popolari degli Sloveni in Italia] a cura di Pizzicato. La ristampa è prevista entro la fine di aprile. Seguiranno a fine aprile e primi di maggio presentazioni a Udine, a Gorizia e a Trieste: a quelle di Udine e di Gorizia provvederà Bruno Rossi, a quella di Trieste e a una in seguito a Lubiana provvederò io. L'iniziativa intende mettere questa pubblicazione a disposizione di quanti la cercano da anni, e l'editore intende venderla a prezzo di costo. "Allora questa è una operazione prettamente culturale..." Si, Bruno Rossi vuole avere anche questo merito.

[Torna alla pag. 1 del Lessico.] ... e qui, se vuole vedere un momento ... I lemmi sono fatti come vanno fatti: con estrema concisione. C'è un duplice lemma $\boldsymbol{a} \grave{\boldsymbol{a}}$ - atono oppure con accento breve - [continua a leggere e a decodificare le abbreviazioni] koinè - quindi l'ho udito dappertutto. Devo averlo udito più o meno in tutte le vallate che compongono questo territorio: trenta chilometri per quindici, dove l'estremo occidente e l'estremo oriente non si comprendono, pur parlando lo stesso dialetto. Quelli di Masarolis e di Canebola non comprendono quelli della Valle del Torre. L'ho esperito di persona tante volte. [Torna al testo.] E la versione italiana dello sloveno non si può fare, perciò ho scritto: introduce un'interrogazione. FR (fraseologia): a ste kapíu, divinmaéštri?

[Legge il secondo esempio - che qui non viene trascritto con assoluta fedeltà.] à si tî tè tentatôr? Queste î e ô ... quando è segnato l'accento decrescente, vuol dire che sono sicuro al cento per cento dell'accento [melodico].

[Passa al secondo lemma, costituito ancora una volta da a.] Questa a è una congiunzione copulativa: "in" "e". SIN sta per sinonimo. Il numero 2. indica una variante, e precisamente la congiunzione avversativa "a, à" "ma". M̌̆ indica Masarolis. Mai stato a Mažerole. Però, fuori Mažerole incontro uno, mi metto a parlare con lui, trascrivo qualcosa e gli chiedo :" Di dove sei?" "Ja si Možérac" ("Sono uno di Masarolis."). Del resto sembra che Baudouin non sia mai stato a Cergneu ${ }^{5}$. Io invece ritornavo molto spesso a Cergneu, perché la parlata di Cergneu è molto differente dalla parlata del Torre, ma è altrettanto arcaica e interessante. Sono i due punti più interessanti: il fondovalle del Torre e Cergneu. Li avevo informatori splendidi: tornavo spesso da loro. Avevo informatori privilegiati, sapevo di poter passare con loro tutta la giornata: anziani che per una ragione o l'altra non si potevano muovere. Allora andavo col Nagra, con quaderni, e passavo giornate intere.... [Osserva un altro lemma.] Le evidenziature a colori devono essere per me. Ci sono anche i nomi di luogo [Illustra il lemma Áhten "Ahten" "Attimis" e le varianti raccolte. Passa quindi al lemma ajódica].

Poi abbiamo ajódica con questa metatesi di jágodica ... Io sentivo sempre ajódica in Valle del Torre, ma poi ho cominciato a sentire ajódeca, ojódeca, ojôdeca: a Subit con tutti e due gli accenti, l'accento crescente e l'accento calante. Questo può essere già un segno di sfaldamento del sistema: non può essere altro. C'è poi la variante jaódica. Ajódica conserva la forma primaria con la soppressione - come dappertutto - della g. ...Bot. = botanico Fragaria vesca: lo metto sempre, dove è possibile ... Ho la fortuna di avere un'ex allieva botanica che mi dà una mano. E' 
$-\quad$ venuta anche con me. Una volta le ho detto: "Io rimarrò su una settimana: se hai un giorno libero, vieni, andremo in giro a chiedere i nomi mostrando le piante." Perché, io conosco il nome dialettale: ma come posso indovinare il nome latino? E non mi posso fidare di nomi italiani e friulani. Un giorno, abbiamo svolto questa ricerca per i vari paesi, dalla mattina alla sera. Alle 9 siamo andati a dormire, ma dopo un po' ci hanno svegliato: erano arrivati Peterle con la sua fidanzata e con la sorella accompagnata dal fidanzato, in bicicletta. Peterle aveva saputo che ero li, mi ha fatto svegliare e... siamo diventati amici.

... E' l'unico politico che ho visto da quelle parti.

[Torna al lemma ajódica.] In alcuni casi metto anche il nome sloveno e italiano. La voce dialettale è formata dalla forma diminutiva jágodica con scomparsa della g e metatesi. FR: jaódice te ciépjene "Vrtne jagode" "Fragole coltivate" ... E poi ... ho aggiunto il lemma amen. ... L'avevo inteso molte volte, amen, come interiezione. Ma, quando l'ho aggiunto? L'unica volta che ho udito un vecchio a Canebola dire amen in risposta al mio saluto (Io li salutavo in dialetto, parlavo solo in dialetto, perché altrimenti non avrei ottenuto niente - ci ho messo un anno per imparare il dialetto). Lo saluto, gli chiedo se conosceva il nome di una pianta (eravamo in ottobre, c'era una nuova fioritura di genziane), ma lui non lo sapeva. Poi abbiamo parlato e, ad un certo punto, si è messo a ridere: "Ah ah, si slovejski!" Abbiamo continuato a chiacchierare, quindi l'ho salutato come si saluta a Canebola: "Buóh ti díj zdróujje, Buóh ti dij srénćo, Buóh ti dij dan láhan vjáč. "["Dio ti dia salute, Dio ti dia fortuna, Dio ti dia un viaggio facile"] E lui mi risponde: "Amen." Si volta e va via.

"Così sia."

L'unica volta in vita mia che l'ho udito: sono stato sicuramente l'ultimo a sentire un saluto del genere. Così si rispondeva ancora all'inizio del diciannovesimo secolo a saluti del tipo: "Búóh ti dij zdróuje, srénćo, dan láhan vjáč." [è la nota apposta in rosso sul margine destro della pagina].

E tutto questo lavoro mi ha talmente arricchito... Però ha anche dei risvolti negativi, che ho esperito di persona: i primi cinque anni avevo sempre $i$ carabinieri alle calcagna ... "Come Logar..." ... come Matičetov. Come tutti, insomma. Solo che io ero cittadino italiano e avevo un documento della RAI che pregava le forze dell'ordine di facilitare il dottor Pavle Merkù nell'espletamento dei suoi doveri professionali. Una sola volta mi hanno fermato e poi mai più. Però, dopo il mio passaggio, entravano nelle case dove ero stato: "Chi era, cosa voleva, cosa vi ha chiesto, cosa avete risposto" .... Terrorismo, vero e proprio. Per cui, in seguito, alcuni si sono rifiutati di ricevermi, mentre altri no. "E' molto triste..." Io l'ho scritto già più volte, ma non serve. Certo che è triste. La cortina di ferro ... Dopo che avevo conosciuto Matičetov - ci siamo incontrati più volte a Resia-mi ha detto che, da quando io lavoravo in zona, il lavoro era diventato molto più facile anche per loro. - Mi ha fatto piacere.

[Si passa al lemma argilót, affiancato dalla sigla $N$ e corredato da una nota a margine vergata in rosso, con asterisco che rimanda a un foglietto incollato a pie' pagina.] Questa deve essere la scrittura di Marinka Pertot, la mia allieva, e ora amica, botanica. Collabora con l'Università di Trieste. La noticina in rosso: 
"Ne odgovarja" = "Non corrisponde". [Merkù allude al fatto che Capsella bursa pastoris non può corrispondere a "motovilec" "valerianella".] Io non so come l'ho capito...Qui c'è $\mathbf{N}$ - Njivica - Infatti me l'avevano dato a Vedronza. Ma non può essere "valerianella" "motovilec" ... "Argilót sarebbe il friulano argielùt, la cosiddetta valeriana."

Ho aggiunto anche qualche testo popolare che non avevo incluso nella mia raccolta: questa 'conta', ad esempio, li manca. Qui ho messo proprio tutto.

[La 'conta' infantile figura sotto il lemma biežáti:]

\author{
Ána bána \\ tùntumbána, \\ kéri šúgi, \\ kéri bána, \\ plíka plíka \\ te li lọ́n, \\ ti si bába, \\ biéži ùòn!
}

[Commento di Merkù nell'articolo di dizionario:] Il testo di questa conta è incomprensibile ad eccezione degli ultimi due versi/Besedilo te izštevalnice je nerazumljivo z izjemo zadnjih dveh stihov.

Qui bisogna controllare: [legge] Vedi Tab 1. [La Tabella 1. figura a parte e riporta tutte le forme del verbo biti "essere"]....Questa o [corretta in rosso su un lemma] è una o aperta e non chiusa. "Mio Dio, Professore, quanto lavoro ha avuto nel predisporre tutto questo ..." Sì, ma io mi sono sempre divertito a lavorare. Fino al 6 giugno dell'anno scorso [2004]. Dal 7 giugno ....[Segue la narrazione delle difficoltà derivanti da un repentino problema di salute, che gli ha riservato un paio di incontri alquanto insoliti ...]

Mi mandano a Cattinara. Il primario direttore del reparto mi fa una visita preventiva, lunghissima e inizia: "La opererò io" (Ma perché me lo dici subito? Perché non dici: ti farò operare da un medico qualsiasi della mia équipe...) e poi mi fa una serie di domande che nessun medico mi aveva mai fatto. "Mi vuole ripetere il suo nome?" Glielo ripeto. "Ma Lei ha scritto un'opera." "Si, è anche stata rappresentata al [Teatro] Verdi nel '76, ma Lei era un bambino e allora non lo può ricordare." "Mi ricorda il titolo?" "La libellula." "Il regista era Pressburger." Poi mi spiega che allora era studente e che per tre anni aveva fatto da comparsa nelle opere, compresa la mia. Mi dice che per lui è stata un'esperienza ricchissima, che non riesce a dimenticare.

Il giorno dopo mi trovo di fronte ad un altro specialista. Mi guarda e dice: "Lei ha studiato violino." "Si..." "Con chi?" "Con Cesare Barison, e prima con mio padre, che era stato allievo di Arturo Brahms." "Mia zia Maria parlava sempre di un violinista Merkù." "Mio padre mi ricordava sempre sua zia Maria." (il dottor Brahms era nipote o pronipote di Brahms). 
$[\ldots]$

Ecco brínica-Bot. Pinus mugo. Ha un sinonimo, buór, e un altro borovíca. L'ho capito dopo e l'ho aggiunto a mano [infatti l'aggiunta in rosso risalta in bella grafia sul vicino margine]. Ho sempre cercato di scrivere con molta chiarezza.

$[\ldots]$

Cognome Brešán: tutta l'Italia del Nord è piena di questo cognome, in tutte le salse. E li ho messi tutti [cioè 26]: c'è sempre il tempo di toglierne qualcuno, se si vuole. [Passa alla pagina successiva.] Briéśćić nome di casato; Briéščica 1. [sostantivo femminile] "abitante di Briéh/Pers", ma anche [Briéščica 2.] Briežánka "abitante di Briézja/Montemaggiore di Taipana". Ecco il cognome Cééncić. Non riesco a evincere la qualità della $\boldsymbol{e}$ : aperta o chiusa? ... [Osserva alcuni fogli di carta scritti a mano, inseriti tra le pagine 54 e 55 della stampata.] Qui ci sono forme delle quali avevo preso nota altrove e vanno messe per es. sotto dva. Sono riportate tutte quelle che possedevo con le rispettive sigle dei paesi. Questo è drugi = te drú $\gamma \mathbf{i}$ - koiné: sono forme che trovo qua e là. Tutto può servire.

"Questo materiale è prezioso, complementare a quello di Baudouin: lo integra. Anche se potrebbe essere il contrario: forse è il complesso di Baudouin che integra questo, così, a occhio." "Questo sì: sa perché? Io non sono solo un dialettologo, linguista: mi rendevo conto di essere salito sull'ultimo tram per fare qualcosa, quindi ho preso nota di tutto quanto potevo. Non mi limitavo a registrare le singole voci. Qui, ad esempio, ci sono tutte le forme del verbo "andare", perché non ho avuto il tempo di inserirle nell'articolo di dizionario ...

Tutto questo, però, non ce l'ho più nel computer ... Questo è jedan, dan "eden, en" "uno, un" con tutte le forme ... "E quindi lo ha eliminato?" No, perché in genere conservo molte cose sul dischetto. Devo vedere se ne trovo qualcuno. Vedrò.

[Nel maneggiare le carte sparse sul tavolo, gli si strappa un manoscritto, con mio rincrescimento.] ... Non fa niente! Se io dovessi conservare tutta la mia corrispondenza con linguisti, con compositori, con solisti, sarei morto soffocato dalle carte.

$[\ldots]$

... Qui siamo già abbastanza avanti: il tutto sembra facilmente consultabile. Ah, il cognome Sigura che diventa Sura ... Questo è un testo che mi ha dato Anton Birtig, una poesia scritta da don Luciano Slobbe ${ }^{6}$ [mi consegna un cartoncino recante da un lato lo spartito, dall'altro il testo del canto per coro "Ne se buoj", eseguito il 15 maggio 2001 a Mezzana/Mečana, un paesino di poche anime a mezza costa sopra Ponteacco, Com. di San Pietro al Natisone/Špeter]. Io, don Slobbe, non lo conosco. Lui potrebbe forse chiarirle qualche termine.... E questo, chi me l'ha dato? [osserva e sfoglia un plico contenente dattiloscritti, sul quale annoto trattarsi di materiale di provenienza ignota.]

$[\ldots]$

Anche questa è una cosa da aggiungere [foglietti sparsi con annotazioni di varia natura]. Questi sono alcuni numeri di "Mlada lipa", quel giornale pubblicato a Subit, mi pare, agli inizi degli anni 2000. Pensavo di scrivere qualcosa anch'io, di andare a Subit per conoscere questa signora ${ }^{7}$ 


\section{$[\ldots]$}

Per diverso tempo ho collaborato con tre o quattro ricercatori dell'Università di Padova che si occupano di statistica: Miro Tasso, Luchetti e Scaravello L'estate scorsa sono venuti a Trieste, ci siamo incontrati qui per parlare di antroponimia e poi mi hanno mandato alcune copie del loro studio sui cognomi sloveni, che serve a studiare la migrazione all'interno dei Comuni italiani ${ }^{8}$. Gliene do una copia. E poi... A suo tempo avevo conosciuto l'unico testo che Bezlaj' aveva scritto nel '39 o '40, quando era stato nella Val Torre, da etnografo, non da dialettologo. E aveva trascritto alcune poesie dialettali di Pietro Negro. A distanza di anni ho incontrato Pietro Negro e ho registrato quattro sue poesie dalla sua viva voce, e dal nastro originale ricavato un $C D$ con i quattro testi. Inoltre possiedo quello che mi aveva dato lo stesso Pietro Negro - pseudonimo UUiğo Škúrjan ${ }^{10}$ - .... Ecco: questo è l'articolo di Bezlaj che mi ha portato sulle tracce ... Questo block notes? ... Ah, si! Mi avevano detto che Pietro Negro aveva scritto per il "Matajur"11: ho fatto una ricerca e mi son trascritto tutti i suoi testi: questa, dunque, è la sua opera omnia. Ma, quando ascolterà il nastro, sentirà più la sua dentiera che la sua voce: quando parlava non era che un cloc cloc cloc. - Simpatico - Le do tutto il materiale: può servire a Lei o ad altri.

$[\ldots]$

Però lì, a Taipana, ho avuto anche un po' da fare con il sindaco. Taipana è un capoluogo di Comune, gli interessi si incrociano... Anche se ho dei bei ricordi dei miei inizi.... Poi Taipana è troppo cambiata ...

Febbraio 2007. Ho appena trascritto l'amarcord di Pavle Merkù. Le riflessioni e i commenti li lascio al lettore. Salvo a sottolineare il potenziale racchiuso in documenti faticosamente raccolti da due studiosi distanziati nel tempo, ma che uno strano destino pone oggi l'uno accanto all'altro.

Il mio apporto personale a questo duplice inestimabile patrimonio, lo ripeto, non può che essere quello di una mediazione, di cui avverto tutta la responsabilità, ma di cui parlerò in altra occasione.

Per il momento mi limiterò a dire che la redazione del Glossario procede di pari passo con il confronto delle sue singole voci con quelle del Merkù, il che moltiplica, più che sommarle, le possibilità di utilizzo i due repertori ai fini della ricerca.

Per dare una pallida idea degli spunti offerti dal confronto diacronico (ricordiamo che i testi di Baudouin risalgono al 1873 e al 1901), passerò in rapida rassegna alcuni frammenti del Glossario, facendo presente che rispecchiano un quadro parziale, passibile di modifiche, dato che la redazione si trova attualmente a metà cammino. La scelta dei termini è caduta su un ristretto campo semantico apparentemente anomalo, dato che vede l'accostamento di verbi denotanti da un lato il "nuotare" e sim., dall'altro lo "scavare", cosa di cui daremo ragione nelle brevi note che seguono la esemplificazione, avvertendo che i singoli esempi sono 
$\hookrightarrow \quad$ accompagnati dal nome della località in cui sono stati rilevati e dalla sigla [PM], qualora abbiano riscontro nel Lessico di Merkù ${ }^{12}$.

1. kopátb "scavare / vangare" (slov. kopáti) [Platischis / Plestišča, Flaipano / Fejplan, Montemaggiore / Brezje, Monteaperta / Viškorsa, Masarolis / Mažerola] [PM]

2. wkopắtb "scavare / vangare" (slov. skopáti) [Platischis / Plestišča]

3. vanḍ̂ătı "vangare" (slov. kopáti) [cf. frl. vangiâ][PM vanǵati] [Cergneu / Černjeja] [PM]

4. vagátb se "farsi il bagno" (slov. kópati se) [Lusevera / Bardo]

5. plấvatı "nuotare" (slov. plavati) [Platischis / Plestišča]

6. nadàtı "nuotare" (slov. plavati) [cf. frl. nadâ] [Flaipano / Fejplan]

7. najátı se (slov. utapljati se) "annegare" [cf. frl. nejâsi] [Flaipano / Fejplan]

8. unejấtı se "annegare" (slov. utopiti se) [cf. frl. nejâsi] [Lusevera / Bardo]

\section{Osservazioni:}

- degli otto termini, solamente due (nn. 1. e 3.) trovano riscontro nel Merkù

- quattro termini su otto (nn. 3., 6., 7. e 8.) si collegano al friulano: i nn. 3., 6. e 7. come prestiti diretti; il n. 8. come forma secondaria rispetto al n. 7., in quanto le si oppone per l'aspetto perfettivo creato autonomamente dal tersko

- il n. 4. si ricollega a it. vangare o al ven. vangà per la veste esteriore (data la presenza della occlusiva velare sonora $\mathbf{g}$ in corpo di parola), risultando in realtà un calco semantico interno al tersko, dovuto ad errata equivalenza, motivata dall'omofonia dei due verbi che lo sloveno standard trascrive come kópati (se) "fasi il bagno" e kopáti "scavare", ma che nel punto di rilevamento compiuto da Baudouin devono avere neutralizzato il tratto distintivo soprasegmentale, attivando un processo così schematizzabile:

[vanḍ’ắtı "vangare" = kopátı "vangare/scavare"] $\rightarrow$ [kopáti se* "farsi il bagno" = se vagátb "farsi il bagno" - cf. it. vangare "vangare/scavare" $] \rightarrow[\varnothing=\mathbf{s e}$ vagátb "farsi il bagno"]

- l'ipotesi del fraintendimento appena visto sembra confortata dal fatto che a Lusevera - dove la voce se vagátb "farsi il bagno" è stata registrata -, e in tutta la fascia alta del territorio, rappresentata dalle località al punto 1., la nozione "scavare" conosca unicamente l'autoctono kopátb, e non il prestito friulano vanḍ’ătb, presente solo a Cergneu, dove ha sostituito kopátb

- che il verbo kópati se "farsi il bagno" fosse sconosciuto al tersko è provato dalla nota apposta in russo da Baudouin accanto al verbo plấvatb, registrato a Platischis - la cui parlata, risente dell'influsso del vicino sloveno - dove è detto espressamente "kopati se non si usa"

- il maggior grado di conservazione della varietà di Platischis viene ribadita dall'opposizione tra plávatı e l'equivalente nadàtı, raccolto a Flaipano. Viceversa, Flaipano e Lusevera mostrano la tendenza al prestito, dato che registrano najátb se e unejắtb se, oltre alle forme ricordate se vagátb e nadàtb. All'inverso, tutte queste località mostrano una comune tendenza conservativa riguardo all'aspetto verbale: l'opposizione perfettivo/imperfettivo, ricreata autonomamente dai parlanti, si 
registra infatti tanto a Platischis (kopátb - wkopấtı) quanto a Flaipano e a Lusevera (najátı se - unejắtı se).

Sarebbe ovviamente interessante rivisitare sul terreno che gli è proprio il mosaico qui abbozzato, e verificare la tenuta delle tessere per numero, collocazione e tipologia. E se una tale esigenza è sentita per questi pochi frammenti, è facile immaginare quali prospettive per la ricerca si dischiudano grazie all'apporto congiunto di Baudouin e di Merkù.

\section{NOTE}

1 Cf. Opyt fonetiki rez'janskich govorov, Varšava-Peterburg, 1875; Rez'ja i Rez'jane, "Slavjanskij sbornik", t. III, Sankt-Peterburg 1876, otd. I: 223-371 (ora nella versione italiana - Resia e i Resiani - eseguita a fine Ottocento da Giuseppe Loschi e uscita nel 2000 presso il Comune di Resia, a cura di A. Madotto e L. Paletti); Materialien zur südslavischen Dialektologie und Ethnographie. I. Resianische Texte, gesammelt in den Jj. 1872, 1873 und 1877, geordnet und übersetzt von J. B. de C./Materialy dlja južnoslovjanskoj dialektologii i etnografii. I. Rez'janskie teksty sobral v 1872, 1873 i 1877 gg., uporjadočil i perevel I.A. B.-de-K., St. Petersburg/Sanktpeterburg, 1895; Materialien zur südslavischen Dialektologie und Ethnographie. II. Sprachproben in den Mundarten der Slaven von Torre in Nordost-Italien, gesammelt und herausgegeben von J. B. de C./Materialy dlja južnoslavjanskoj dialektologii i etnografii. II. Obrazcy jazyka na govorach Terskich Slavjan v severovostočnoj Italii sobral i izdal I.A. B.-de-K, S.-Petersburg/S.-Peterburg, 1904.

2 L'esistenza di manoscritti di Baudouin presso gli archivi dell'Accademia delle scienze di San Pietroburgo, cui egli li aveva affidati nel 1902, venne data al mondo scientifico da Nikita I. Tolstoj con il suo articolo O rabotach I.A. Boduèna de Kurtenè po slovenskomu jazyku, in A.A. V.V., I.A. Boduèn de Kurtenè (k 30-letiju so dnja smerti). Moskva 1960: 67-81. I testi raccolti nella Valle del Natisone sono stati pubblicati nel 1988 con il titolo: Materiali per la dialettologia e l'etnografia slava meridionale/za južnoslovansko dialektologijo in etnografijo. IV. Testi popolari in prosa e in versi raccolti in Val Natisone nel 1873/Ljudska besedila $v$ prozi in verzih, zbrana $v$ Nadiških dolinah leta 1873. Inediti pubblicati a cura di/Pripravila za prvo objavo Liliana Spinozzi Monai con commento folklorico di/folklorni komentar prispeval Milko Matičetov, Trieste/Trst-San Pietro al Natisone/Špeter.

3 Per una disanima delle questioni legate a Glossario cf. L. Spinozzi Monai, Rilevanza e potenziale scientifico dei materiali inediti del Glossario del dialetto del Torre di Jan Baudouin de Courtenay, "Ce fastu?" 72.2, 1996: 203-222.

4 In realtà Baudouin ha visitato Cergneu in entrambi i viaggi compiuti in questi luoghi, come documentato dalle pagg. 122-139 della pubblicazione del 1904 da noi cit. in nota 1, e dalle schede manoscritte del suo Glossario del dialetto del Torre (Archivio dell'Accademia delle scienze russa - sez. di S. Pietroburgo, Fondo 102, 1, 11, pagg. 497-531; Fondo 102, 1, 12, pagg. 50-61).

5 In una mia successiva ricerca sul Pirona leggo: argielùt = Valerianella olitoria "agnellino", "dolcetta" (cf. Pirona, G.A.-E. Carletti-G.B. Corgnali,. Il Nuovo Pirona. Vocabolario friulano, Udine, 1992 : 18). Quanto a Capsella ecc., può assumere diverse denominazioni volgari: capsella, borsa di pastore, borsacchino...

6 Don Luciano Slobbe, nato a Taipana nel 1939, è ora parroco nel Comune di Moimacco (Prov. di Udine). Antonio Birtig/Anton Birtič - conosciuto come Mečanac per essere 
nato a Mezzana, dove vive attualmente -, in qualità di ex partigiano era riparato a Lubiana, fondandovi il complesso "Beneški fantje".

7 Si tratta della maestra Bruna Balloch, di Subit, molto attiva nel recuperare e valorizzare il patrimonio linguistico e culturale della Val Torre. A lei si deve l'iniziativa dell'opuscolo annuale "Mlada lipa", nato nel 1998.

8 Cf. Miro Tasso-Enzo Lucchetti-Paola Pizzetti-GianUmberto Caravello, Distribution of surnames and linguistic-cultural identities of the Slovenian and German minorities of northeastern Italy, Anthrop. Anz., Jg. 62/2, Stuttgart, Juni 2004: 185-202.

9 France Bezlaj (1910-1993) lega il suo nome soprattutto all'Etimološki slovar slovenskega jezika, Ljubljana I-IV, 1976-2005. L'articolo di cui parla Merkù è Ljudski pevec iz Tera, Slovenski etnograf, I, Ljubljana 1948: 65-71.

10 Riporto fedelmente la nota di Merkù dalla sua Introduzione al Lessico...: Úiğo è la forma dialettale friulanizzante per il personale Luigi; Škúrjan è forma dialettale per il soprannome corrispondente all'ornitonimo sl škrjánec, Alauda L., usignolo, diffuso simbolo per l'attività poetica e, nella Slovenia centrale, diffuso cognome. L'assenza, nella forma qui attestata, della formante diminutiva -ec testimonia una fase arcaica del nome: infatti i diminutivi decrescono dal centro linguistico sloveno verso la periferia; il dialetto del Torre è probabilmente il dialetto sloveno più povero di diminutivi, fatto che esalta la sua arcaicità.

11 Il "Matajur" nasce nel 1950 come foglio quindicinale degli Sloveni della Provincia di Udine. Nel 1974 prende il nome di "Novi Matajur", quindi diventa settimanale. I componimenti di Luigi Negro escono sul "Matajur" dal 1950 al 1959. Nel piccolo block notes su cui Merkù li ha ricopiati, è riportata anche la notizia della sua morte: "umrl 15. 1. 1972 - 86 let" (morto il 15. 1. 1972 - 86 anni).

12 I lemmi del Glossario sono trascritti fedelmente grazie al sistema dei caratteri ZRCola (http://ZRCola.zrc-sazu.si), elaborato dal dott. Peter Weiss al Centro di ricerca scientifica dell'Accademia slovena delle Scienze e delle arti di Lubiana (http://www. zrc-sazu.si).

\section{Listanje po Lessico del dialetto sloveno del Torre/Besedišču terskega narečja (Spominjanje Pavleta Merkuja)}

Povzetek

Leksikološko delo Pavleta Merkuja na področju terskega narečja je v prispevku soočeno z več kot stoletje starejšim delom jezikoslovca Jana Baudouina de Courtenaya. Gradivo enega in drugega avtorja je redka priložnost, da se delo Glossario del dialetto del Torre Baudouina de Courtenaya, ki vsebuje približno 8.000 kartotečnih listkov, primerja s še neobjavljenim gradivom, ki ga je Merkù po tridesetletnem zbiranju zlil v svoj Lessico del dialetto sloveno del Torre/Besedišče terskega narečja.

Osrednji del prispevka prinaša hitri pregled neobjavljenega gradiva, ki ga avtor Pavle Merkù podaja avtorici prispevka v pogovoru, v katerem ne prihaja $v$ ospredje le bogastvo in raznolikost gradiva, ampak tudi poteze, ki označujejo strokovnjakovo osebnost.

Znanstveni pomen prispevka, ki ga kot celoto predstavlja delo Baudouina de 
Coutrenaya in Merkuja, je ponazorjen s posameznimi primeri iz Glosarija, ki so soočeni s tistimi iz Lessico/Besedišča in podvrženi hitri kontrastivni in diahroni analizi.

Liliana Spinozzi Monai

Università degli Studi di Udine, Centro Internazionale sul Plurilinguismo, Udine liliana.spinozzi@alice.it 



\title{
МАКЕДОНСКО-СЛОВЕНЕЧКИ ТОПОНИМИСКИ ПАРАЛЕЛИ
}

\author{
Љубица Станковска (Skopje)
}

IZVLEČEK: Med makedonskim in slovenskim toponimskim sistemom obstajajo identične relacije v najrazličnejših pomenskih skupinah zemljepisnih imen. Včlanku se dotikamo samo nekaj zemljepisnih imen s slovenskega in makedonskega jezikovnega območja, ki so motivirana z osebnimi imeni. Obravnavani toponimi kažejo skupne lastnosti tako glede na besedotvorno zgradbo kot na izvor.

\section{Macedonian-Slovene Toponymic Parallels}

ABSTRACT: The article focuses on the etymological position of the Macedonian toponyms Boletin, Zgošta, Ivankovci, Ivanje, Martinica, Martinj krst and Raduša as well as on the Slovenian toponyms Boletina, Zgoša, Ivanjkovci, Ivanje selo, Ivanja vas, Martinca, Raduha, Raduše and Radušnica. Particular emphasis is laid on their semantic and structural connection.

Во рамките на македонската и словенечката топонимија се јавуваат релации во најразлични семантички групи топоними, кои особено се изразени кај топонимите образувани од географски термини, фитонимиски и зоонимиски основи. Идентични паралели се забележуваат и меѓу антропонимиските системи на македонскиот и словенечкиот јазик во кои се среќаваат редица исти или слични лични имиња. По овој повод внимание им посветуваме на селектирано одреден подбор на заеднички топонимиски единици, мотивирани од лични имиња, кои можеме да ги посведочиме преку еквивалентните примери во македонското и словенечкото лингвистичко подрачје.

Селото Болейин се наоѓа во областа Мала Река или Долна Река. Селската населба е лоцирана во подножјето на планината Дешат, во непосредната близина на десниот брег на реката Радика. Според најновата административна поделба на населените места на територијата на Република Македонија, селото Болейин е вклучено во Општина Маврово и Ростуша. ${ }^{1}$ Неговото име првпат се споменува во

1 Закон за територијалната организација на локалната самоуправа, Службен весник на Рейублика Македонија, бр. 55, Скопје, 16 август 2004, 5. 
турските пишани извори од XV и XVI век. Имено, во турскиот опширен пописен дефтер за Вилаетот Река од 1467 година е регистрирано Село

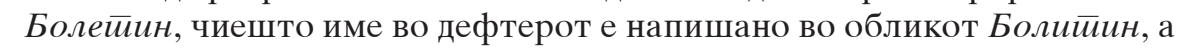
во пописниот дефтер од 1583 година е напишано Болйин. ${ }^{2}$

Ојконимот Болейин претставува метонимиско име, коешто е преземено од некое постаро оронимиско или хидронимиско име

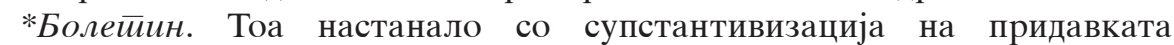
од првобитната синтагматска формација *Болейин (Дол, Рид).

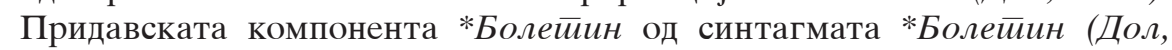
Рид) е образувана од личното име Болей $а$ со придавскиот суфикс -ин

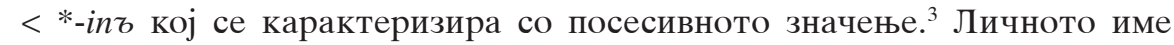
Болей $а$ е образувано со суфиксот $-\bar{u} a$, односно со сложениот суфикс -ей $a$, од личното име Боле, коешто е засведочено во историските писмени споменици од XIV век. Личното име Боле е добиено по пат на скратување од сложените имиња Болемир, Болеслав. Кај нас ова име може да биде изведено и со деминутивниот суфикс -е од личните имиња Борислав, Бог̄дан. ${ }^{4}$ Значењето на ојконимот Болейин може да се дефинира како 'дол или рид кој му припаѓа на Болета, односно каде што живее Болета'.

Придавскиот суфикс-ин, кој е продуктивна деривациска морфема, во македонскиот јазик образува топоними со посесивно значење од имиња на живи суштества, по правило од машки и од женски род, чија основа завршува на вокалот - $a$. Во нашата топонимија се среќаваат и други ојконимиски единици кои се образувани со придавскиот суфикс -ин, сп. Боройино - село во Прилепско, Брајчино - село во Ресенско, Велушина - село во Битолско, Гнеойино - село во Битолско, Жељувино - село во Кумановско, Жубрино - село во Кичевско, Куйрейино - село во Демирхисарско, Милейино - село во Тетовско и други.

Слично топонимиско образување се среќава и во словенечката топонимија. Тоа е името на селото Boletina, ${ }^{5}$ кој се наоѓа во близината на селото Пониква. ${ }^{6}$ Ојконимот Boletina, исто така, е елиптично име, добиено со супстантивизација на постарата адјективна синтагма *Boletina (vas), чијашто придавка е образувана со формата за женски род -іпа од посесивниот придавски суфик -in. Во неговата основа се наоѓа личното име Boleta, коешто е, исто така, образувано со антропонимискиот суфикс -ta од името Bole, добиено со скратување од сложените антропоними

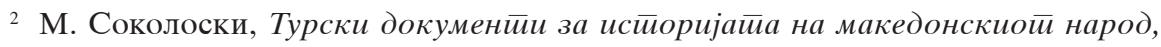
ойиирни йойисни дефйери од XV век, том III, Скопје 1976, 397.

3 Љ. Станковска, Присвојните образувања кај ојконимите во Гостиварско, Биг̄орски научно-куличурни собири, Скопје 1983, 71.

4 Љ. Станковска, Речник на личнитее имиња кај Македонцииее, Скопје 1992, 45.

5 Slovenska krajevna imena, avtorji: F. Jakopin, T. Korošec, T. Logar, J. Rigler, R. Savnik, S. Suhadolnik, Ljubljana 1985, 23.

6 Atlas Slovenije, 1 : 50 000, Ljubljana 2005, 87/C3 (понатаму: Atlas). 
Bolemir, Boleslav. Семантичката вредност на ојконимот Boletina може да се искаже со дефиницијата 'село кое му припаѓа на Boleta, или каде што живее Boleta'.

Во словенечката топонимија, како и во македонската, се среќаваат топонимиски единици образувани со посесивниот придавски суфикс -in, сп. Dobrina - село, град и облас, Dobrotin - име на објект во реонот на градот Војник, Črnetina - село, Petrina - село, Pačetina - река7 и други.

Компонентата Боле-/Bole- од сложените имиња од типот на Болемир/Bolemir, Болеслав/Boleslav потекнува од адјективот *bolijb, стсл. Болнн 'поголем, подобар', среден род *bolje. Во антропонимијата на полскиот јазик со компонентата Bole- се засведочени, на пример, личните имиња: Bolebor, Bolelut, Bolemir, Bolemyst, Bolesław. ${ }^{9}$ Во бугарскиот јазик се потврдени сложените имиња Болеслав, Болислав, како и женското име Болеслава, ${ }^{10}$ а во антропонимијата на српскиот јазик се регистрирани личните имиња Бољедраг, Бољемир, Бољерад, Бољеслав. ${ }^{11}$

Името на дебарското село Зг̄ошй е документирано во словенските писмени споменици од XIV век. Имено, со формата Қьгоца неговото име е запишано во еден запис во Верковичевиот апостол, кој е датиран од втората половина на XIV век, а таму стои: донде граматнкь $\omega($ А) Қьгоџа. Потоа, селото Зг̄ошйа се споменува во турските пишани извори од XV век. Во обликот Изг̄ошй името на селото е напишано во турскиот опширен пописен дефтер за вилаетот Черменица од 1467 година, а од преведувачот се предава како Село Зг̄ошйе. ${ }^{12} \mathrm{~A}$. Селишчев во својата монографија за словенското население во Албанија името на селото го предава со формата Зг̄ожд. ${ }^{13}$ Во поновите географски карти ова село се бележи како Зг̄ожде. Денес селото Зг̄ошйа се наоѓа во областа Чемерница, која припаѓа во Република Албанија.

Тргнувајќи од најстарата документирана форма на името на селото, може да се констатира дека неговото примарно име е обликот Зг̄oшйа. Ојконимот претставува елиптично име, коешто настанало со супстантивизација на придавката од првобитната синтагматска

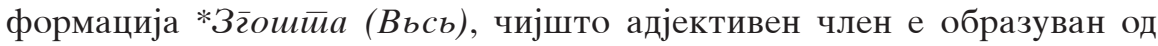

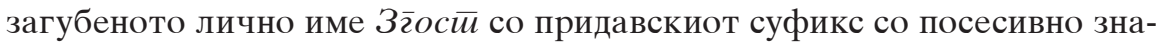

7 Ibid., 90/B2, B3, 109/C3; 86/B3; 13/C3; 112/C3.

8 В. Десподова, С. Новотни, Е. Јачева-Улчар, М. Чичева-Алексиќ, Сйарословенско-македонски речник (со грччки йаралели), Прилеп-Скопје 1999, 40 (понатаму: В. Десподова).

9 M. Malec, Budowa morfologiczna staropolskich złożonych imion osobowych, WrocławWarszawa-Kraków-Gdańsk 1971, 68.

${ }^{10}$ Й. Заимов, Бълг̃арски именник, София 1988, 28.

${ }_{11}$ М. Грковић, Речник личних имена код Срба, Београд 1977, 41.

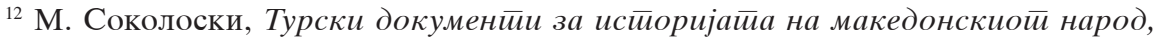
ойширни йойисни дефйери од XV век, том III, Скопје 1976, 425.

13 А. М. Селищев, Славянское население в Албании (Карйа), София 1931, 341, Карта 3c. 
$4 \quad$ чење -jb во неговата форма за женски род -ja. ${ }^{14}$ Значењето на ојконимот

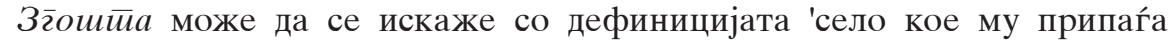
на Згост, или каде што живее Згост'. Третирајќи ја формата Згेожда како основно име на селото, Ј. Заимов и С. Роспонд неговата основа ја изведуваат од личното име Зг̄od < *ъъгодъ, што сметаме дека не е аргументирано решение. ${ }^{15}$

Во словенечката топонимија е познат хидронимот Zgóša - река, лева притока на реката Сава. ${ }^{16}$ Во горниот тек на реката Zgoša, во нејзината непосредна близина е лоцирано селото Zgóša. ${ }^{17}$ Во историските извори ојконимот Zgoša е регистриран повеќепати. Така, во писмени документи од 1075-1090 година името е запишано со формата Guscha, во документи од 1085-1090 година стои: in villa Goscha. Подоцна се споменува во документи од 1331: ze Gi̊scha, 1406: Zguosh и од 1415 година: Skusch. ${ }^{18}$

Поаѓајќи од историските извори, во кои ојконимот Zgoša, главно, е запишан со формите Guscha и Göscha, а притоа, имајќи го предвид и фактот дека топонимот Zduša кај Камник во 1344 година е запишан како Gíschez, Ф. Безлај вели дека за двете имиња, веројатно, би било можно да се реконструира почетниот облик *zdigostb-ja. Според него, од антропонимот *Zdigostb би требало да се изведе хипокористикот Zdih, а за споредба ги посочува словенечките топонимот Zdihovo, Zdiše, како и хрватските топоними Zdihovo и Zgošća. ${ }^{19}$ Изнесеното гледиште на $\Phi$. Безлај, според нас, остава простор за дообјаснување на етимологијата на хидронимот, односно на ојконимот Zgoša.

Иако не располагаме со историски податоци за името на реката Zgoša, сметаме дека неговата првобитна форма била *Zgošča. Упростувањето на консонантската група -̌̌́̆- во словенечкиот јазик не е непозната фонетска појава, сп. Belšica, Bukovšica, Radešica ${ }^{20}$ од првобитните *Belščica, *Bukovščica, *Radeščica. Хидронимиското име Zgoša < * Zgošča претставува елиптично име со посесивно значење.

14 Љ. Станковска, Исчезнати лични имиња во македонската топонимија, Македоснки јазик, год. XL-XLI, Скопје 1995, 559.

15 Й. Заимов, Бълг̃арски геог̄рафски имена с -јь, София 1973, 109; S. Rospond, Toponimy na -јь, Македонски јазик, год. ХХХ, Скопје 1979, 138.

${ }^{16}$ Atlas 77/B1;

${ }^{17}$ Slovenska krajevna imena, Avtorji: F. Jakopin, T. Korošec, T. Logar, J. Rigler, R. Savnik, S. Suhadolnik, Ljubljana 1985, 348.

${ }^{18}$ Историските податоци се користени од книгата: F. Bezlaj, Slovenska vodna imena, II del, Ljubljana 1961, 336.

${ }^{19} \mathrm{~F}$. Bezlaj, Zanimivosti iz toponomastike (V: Pogovori o jeziku in slovestvu. Predavanja na zborovanju slovenskih slavistov v Mariboru od 26. junija do 1. julija 1954. Maribor 1955. Str. 66-81), Zbrani jezikoslovni spisi, I, uredila: M. Furlan, Ljubljana 2003, 62; F. Bezlaj, Etimološki slovar slovenskega jezika, Prva knjiga, Ljubljana 1976, 336.

${ }^{20}$ M. Furlan, Odzadnji slovar zemljepisnih imen po Atlasu Slovenije, Ljubljana 1993, $27-$ 28. 
Во структурен поглед постарото име на реката *Zgošča настанало со супстантивизација на адјективот од првобитната синтагматска формација *Zgošča (reka), чијашто придавска компонента е образувана со формата за женски род -јa од посесивниот придавски суфикс -jb, а по елизијата на апелативот reka, адјективот *Zgošča се супстантивизирал и продолжил да суштествува како елиптично име. Во основата на хидронимот Zgoša < * Zgošča ce наоѓа личното име Zgost. Семантичката

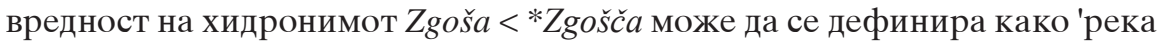
која му припаѓа на Zgost, односно покрај која живее Zgost'. Ојконимот Zgoša, веројатно е метонимиско име, преземено од името на постарото име на реката Zgoša.

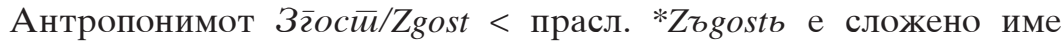
составено од морфемите 3-/z- од предлогот *zъ/sъ и -г̃ociu/gost од прасл. именка *gostb 'гост(ин)', чиешто првобитно значење било 'туѓинец, дојденец во одредена заедница', сп. стсл. гость, или од глагол *gostiti, стсл. гостнтн 'се гости, угостува', ${ }^{21}$ а се доведува во врска со ие. *ghosti-s. ${ }^{22}$ Во антропонимискиот систем на словенските јазици морфемата з-/ z- од сложеното име Зг̄ocū/Zgost е потврден деривациски елемент за образување на композитните антропоними, сп. пол. Zbor, Zbqd, чеш.

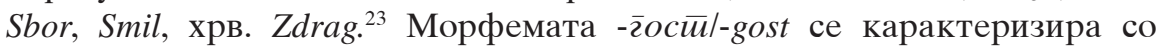
поголема продуктивност во образувањето на старите општословенски сложени имиња и може да биде употребена во улога на прв член, сп. чеш. Hostibor, Hostimil, Hostirad, срп. Госииидраг, Госииимир, хрв. Gostislav, пол. Gościmir, Gościrad, Gościwid, и во улога на втор член, сп. чеш. Bolehost, Budihost, Malohost, *Zahost, пол. Dobrogost, Lubogost, Niegost,

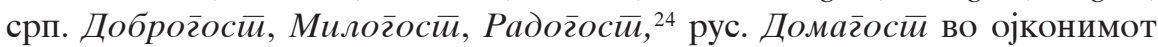

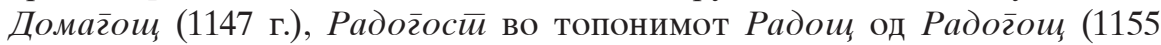
г.). ${ }^{25}$ Во македонската топонимија се зачувани стари сложени имиња

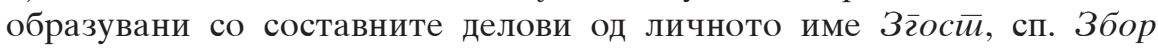

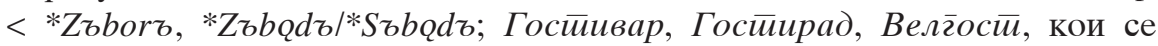
заложени во основите на ојконимите Зборско - село во Воденско

${ }^{21}$ В. Десподова, op.cit., 88.

${ }^{22}$ P. Skok, Etimologijski rječnik hrvatskoga ili srpskoga jezika, knjiga prva, Zagreb 1971; 595; Бълг̄арски ейимолог̄ичен речник, т. І, ред. Вл. И. Георгиев, София 1971, 268; F. Bezlaj, Etimološki slovar slovenskega jezika, Prva knjiga, Ljubljana 1976, 164.

${ }^{23}$ M. Malec, Budowa morfologiczna staropolskich złożonych imion osobowych, Wrocław-Warszawa-Kraków-Gdańsk 1971, 129; J. Svoboda, Staročeská osobní jména a naše přijmení, Praha 1964, 103; M. Šimundić, Nepoznata hrvatska osobna imena do polovice 11 stoljeća, Onomastica jugoslavica, knj. 10, Zagreb 1982, 235.

${ }^{24}$ J. Svoboda, op. cit., 76; М. Грковић, op. cit. 67, 78, 134, 166; M. Šimundić, Rječnik osobnih imena, Zagreb 1988, 131; M. Malec, Budowa morfologiczna staropolskich złożonych imion osobowych, Wrocław-Warszawa-Kraków-Gdańsk 1971, 87.

25 А. М. Селищев, Из старой и новой топонимии, Избраные йруды, Москва 1968, 49; С. Роспонд, Структура и стратиграфия древнерусских топонимов,

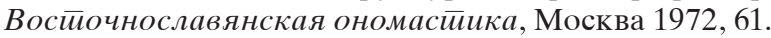




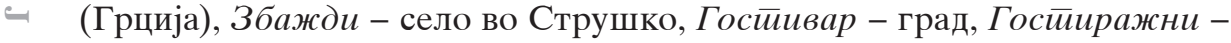
село во Прилепско, Велг̄ошӣu - село во Охридско и други.

На територијата на Словенија се среќаваат редица топонимиски единици кои се мотивирани од личното име Ivan и од неговите деривати како што се, на пример, случаите: Ivanac, Ivanci, Ivanček, Ivandol, Ivanjše, Ivanjševci, Ivankovec, Ivanovci, Ivanšica, Ivanuša. Нивната зачестеност е забележлива и во македонската топонимија, сп. Иванова Нива, Иванов Врв, Иванова Красӣа, Ивановци, Иванчев Осој, Ивени, Ивица, Ивкова Млака, Ивова Глава. Од гледна точка на нашиве споредбени проучувања, ги разгледуваме само оние имиња кои се присутни во топонимијата на словенечкото и македонското јазично подрачје.

Паралелни топоними на словенечкиот ојконим Ivanjkovci - село ${ }^{26}$ на нашата територија се ојконимите Иванковци - село во Велешко и Иванковце - раселено село во Кумановско. Името на селото Ivanjkovci е регистрирано во 1433 година каде што е запишано како Ilankancz и во 1445 година каде што е напишано со формата Ybankowitc. ${ }^{27}$ Писмените потврди за кумановското село Иванковце датираат од XVI век. Во обликот Иванковци неговото име е запишано во турскиот пописен дефтер за Нагоричката нахија од 1570 година. ${ }^{28}$

Во основата на ојконимот Иванковци е заложен хипокористикот Иванко. Ова име е образувано со суфиксот -ко од личното име Иван. Антропонимот Иван е библиско име и потекнува од хебр. Jehochann 'бог

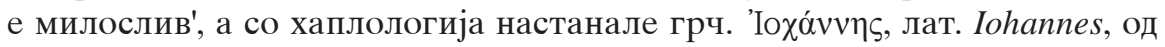
кои потоа се развиле антропонимите Јован и Иван. ${ }^{29}$

Од структурна гледна точка, ојконимот Иванковци е примарно име кое настанало со топонимизација на патронимот *Иванковци. ${ }^{30}$ Патронимиското име *Иванковци потекнува од постарата синтагма *Иванкови (деца, йойомци), чијшто придавски член *Иванкови, кој е образуван со множинската форма -ови од посесивниот придавски суфикс -ов, се супстантивизирал со патронимискиот суфикс -ц̧и < - ьци по елизијата на именскиот член од составот. Од семантички аспект ојконимот Иванковци означува 'место каде што живеат децата, потомците кои потекнуваат од Иванко, т.е. место каде што живее семејството *Иванковци'.

Основата и на словенечкиот ојконим Ivanjkovci < *Ivankovci е изведена од личното име *Ivanko, коешто, исто така, е изведено од името Ivan. Во словенечкиот антропонимиски фонд е потврдено

${ }^{26}$ Atlas 77/A1.

${ }^{27}$ P. Blaznik, Historična topografija slovenske Štajerske in jugoslovanskega dela Koroške do leta 1500, I, A-M, Maribor 1986, 297.

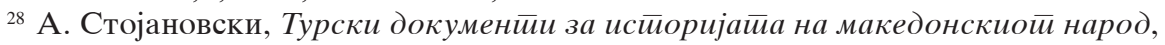
т. V, кн. V, Скопје 1995, 308.

${ }^{29}$ F. Bezlaj, Etimološki slovar slovenskega jezika, Prva knjiga, Ljubljana 1976, 214.

30 љ. Станковска, Имињайа на населениие месйа во Кумановско, Скопје 2003, 123. 
хипокористичното име Janko, а се наоѓа, на пример, и во основата на топонимот Jankovec, ${ }^{31}$ којшто е еднакво име со нашиот ојконим Јанковец, - село во Ресенско.

Во структурен поглед, ојконимот Ivanjkovci < *Ivankovciпретставува примарно име, добиено по пат на топонимизација на патронимот *Ivankovci. Патронимиското име *Ivankovci, според нашето мислење, води потекло од првобитната синтагма *Ivankovi (otroci, potomci), чијашто придавска компонента е образувана со плуралната форма -ovi од придавскиот суфикс -ov, кој се карактеризира со посесивното значење, а по елиминацијата на именскиот член од составот, придавката *Ivankovi се супстантивизирала со патронимискиот суфикс -ci <*-bci. Според тоа, името на градот Ivanjkovci, исто така, означува 'место каде што живеат децата, потомците кои потекнуваат од *Ivanko, т.е. место каде што живее семејството *Ivankovci'. Во словенечката топонимија се среќаваат низа ојконимиски единици настанати според истиот деривациски модел, сп. Berkovci, Cvetkovci, Dankovci, Markovci, Mihalovci, Mihovci, Pavlovci, Radovci, Ratkovci ${ }^{32}$ и други.

Во семантички и структурен поглед, како еквивалентни топонимиски единици можеме да ги третираме, исто така, словенечкиот ојконим Ivanje selo - село, што се наоѓа во околината на селото Сподња Поханца, ${ }^{33}$ со нашиот ојконим Ивање - раселено село во Скопско, регистрирано во грамотата на Андрејаш од 1389 година за манастирот Свети Андреја на Треска каде што е запишано како Gємо иваме и Иваме. ${ }^{34}$ Денеска неговото име се чува во името на една месност со пасишта и трла, што се наоѓа во атарот на селото Чајлане, Скопско, која од албанското население се вика Ivoń.

Ојконимот Ivanje selo претставува атрибутско име, составено од придавката Ivanje, којашто е образувана од личното име Ivan со суфиксот -jb во формата за среден род -je, и од именката selo. На словенечкиот терен со исто име се именува и селото Ivanje selo. ${ }^{35}$

Нашиот ојконим Ивање претставува елиптично име, коешто настанало со супстантивизација на придавскиот дел од некогашното атрибутско име *Ивање (Село), чијшто именски член, изразен со апелативот село, поради неговата помала комуникативна информираност, а во духот на јазичната економичност, се елиминирал. Придавскиот член *Ивање од составот *Ивање (Село), исто така, е обра-

${ }^{31}$ F. Bezlaj, Etimološki slovar slovenskega jezika, Prva knjiga, Ljubljana 1976, 214.

${ }^{32}$ M. Furlan, op.cit., 180.

${ }^{33}$ Atlas 150/B2.

${ }^{34}$ В. Мошин, Сйоменици за средновековнайа и йоновайа исӣорија на Македонија, т. I, Скопје 1975, 392.

${ }^{35}$ Atlas 159/B2. 
зуван од личното име Иван со формата за среден род -је од посесивниот придавски суфикс $-j b .^{36}$

Од направената етимолошка анализа на словенечкиот ојконим Ivanje selo и на македонскиот Ивање се констатира дека нивната семантичка вредност може да се искаже со дефиницијата 'село кое му припаѓа на Иван, односно село каде што живее Иван'.

Според истиот топонимиски модел се образувани, на пример, словенечките ојконими Ivanja vas - село кај Ново место, Ivanji Grad село во околината на Комен, како и нашите топоними Иван Врв - врв во атарот на селото Евла, Ресенско, Иван Гроб - ниви (Лисичани, Кичевско), Иван Дол - раселено село во Кичевско, Иван Тор - планинска месност со бачила (Галиште, Кавадаречко).

Во својата монографија Krajevno imenoslovje na slovenskem zahodu Павле Мерку го нотира микротопонимот Martinca, кој се наоѓа во општината Девин. Во врска со етимологијата на овој микротопоним, тој се изјаснува дека името е образувано со суфиксот -іса од личното име на сопственикот. ${ }^{37}$ Од изнесеното мислење може да се заклучи дека, според П. Мерку, првобитниот облик на микротопонимот Martinca e *Martinica и дека тој се карактеризира со посесивното значење. Соодветни примери во кои вокалот $i$ од суфиксот -іса испаѓа се познати во словенечката топонимија, сп. Ваbca, запишано во 1892 година како Babitza, Briestenca, Bukovca, Cerkvenca, Dedenca, Dolinca, Gostinca, Mihelca, Radelca, Studenca и други. ${ }^{38}$

Во топонимијата на македонската јазична територија ce засведочени неколку идентични топонимиски единици. Во Кривопаланечко е познато селото Марйиница, во атарот на селото Отишани, Дебарско една месност под ниви се именува Марӣuниц̧а, со името Марйиница се именува и една месност во атарот на селото Горна Лешница, Тетовско, а во атарот на селото Бегниште, Кавадаречко се наоѓ микротопонимот Марӣин'ц̧а - месноста под ниви и лозја. Во топонимијата на Битолскиот регион се среќаваат два микротопонима: Марӣиница - нивје, што се наоѓа во атарот на селото Голем Радобил и

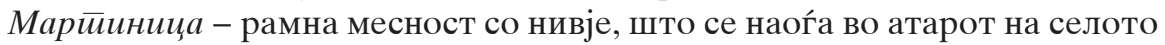
Трновци. Основата на наведените топонимиски единици е изведена од личното име Марйuн, кое потекнува од лат. Martinus 'оној кој е посветен на богот Марс', а при нивното образување учествува суфиксот -ица, којшто врши структурно-топонимиска функција. ${ }^{39}$

Од структурна гледна точка, топонимите од типот на Марӣuниц̧а

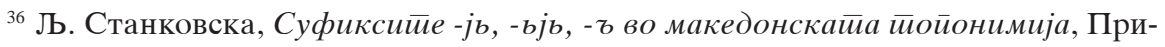
леп 2002, 177.

${ }^{37}$ P. Merkù, Krajevno imenoslovje na slovenskem zahodu, Ljubljana 2006, 128.

${ }^{38}$ P. Merkù, Ibid., 38, 52, 62, 67; M. Furlan, op. cit., 29-31.

39 Љ. Станковска, Тойонимийе со суфиксой-ица во Македонија, Скопје - Прилеп 2001, 265. 
може да се создадени на два начина. Прво, топонимот Марӣиница може да е создаден со дезинтегралната деривација, која се состои во елиминирањето на морфемите пред суфиксот кој се присоединува кон изведувачката основа. ${ }^{40}$ Според тоа, топонимот Марйиница може да потекнува од некогашната синтагматска формација *Марйинова $(B b c b, H u в a)$, чијшто придавски дел е образуван со формата за женски род -ова од посесивниот придавски суфикс -ов, кој отпаѓа при процесот на супстантивизацијата со суфиксот -ица, така што се добива впечаток дека суфиксот -ица директно се присоединува на личното име Марйин:

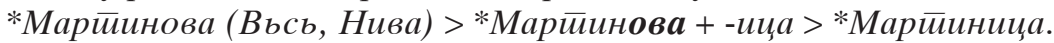

Второ, топонимот Марӣиница може да настанал со интегралната деривација, која се состои во тоа што при извршувањето на супстантивизацијата на придавките од првобитните топонимиски состави придавските суфикси формално се присутни во топонимискиот дериват, или се изразени во замаглен, скриен облик. Според тоа, топонимот Марӣиница може да потекнува од некогашната придавска

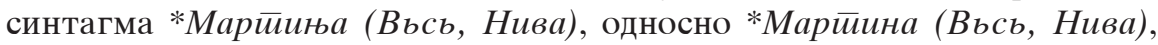
чијашто придавска компонента се супстантивизирала со суфиксот -ица по елизијата на именскиот член, изразен со географските термини вьсь

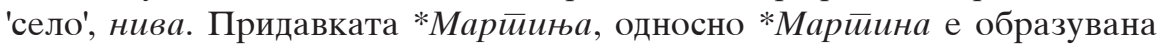
со формата за женски род -ја од стариот придавски суфикс -jb, односно со формата за женски род - $a$ од придавскиот суфикс - $。$. Во семантички поглед, топонимот Мариииница означува 'вьсь, т.е. село, или нива која му припаѓа на Мартин, односно каде што живее Мартин'.

Во нашата топонимија се среќаваат сложени топоними, чијашто придавска основа е изведена од личното име Марйин, во кои е присутен

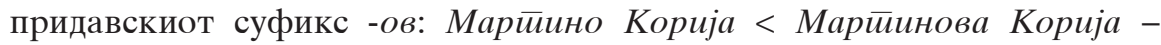
шума, ниви и пасиште (Блаце, Скопско), но е засведочен и топонимот

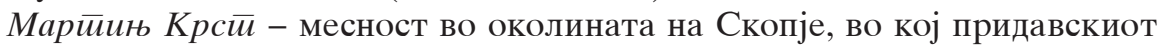
член е обрзуван со суфиксот -jb. Овој микротопоним е регистриран во Милутиновата грамота од 1299-1300 година, со која се подаруваат имото на манастирот Св. Георги-Горг-Скопски каде што е запишано: та ма Мартннь крьсть. ${ }^{41}$

Во словенечката топонимија, исто така, се среќаваат топонимиски единици кои можат да послужат како потврда за објаснувањето на топонимот Martinca < *Martinica. Така, на пример, името на селото Martinja vas $^{42}$ претставува сложено име во кое првиот дел е претставен co придавскиот член Martinja, којшто е образуван од личното име Martin со придавскиот суфикс -jb, односно со формата за женски род -ja, а вториот дел Vas е еднаков на апелативот vas < прасл. 'vbsb 'село'.

${ }^{40}$ P. Zwoliński, Substantywizacja sufiksalna przymiotników w językach słowiańskich, Z polskich studiów slawistycznych, Seria 2, Językoznawstwo, Warszawa 1963, 92-93.

${ }^{41}$ В. Мошин, циий. дело, 222.

${ }^{42}$ Atlas 145/B2. 
$\rightarrow$ Според истиот деривациски модел се образувани и топонимите: Martinje - село, Martinji hrib - гребен во околината на селото Хрушица, Martinj Vrh - врв. ${ }^{43}$ Инаку, личното име Martin е заложено и во други словенечки топоними, сп. Martince, Martinovec. ${ }^{44}$

Од сето досега изнесено, можеме да констатираме дека при образувањето на словенечкиот топоним Martinca < *Martinica, секако, е искористена една од наведените деривациски постапки што ги претставивме погоре, при етимолошката анализа на нашиот топоним Марйиница. Во оваа пригода сакаме да укажеме и на фактот дека во словенечката топонимија суфиксот -иц̧а како структурно-топонимиска деривациска морфема се одликува со голема продуктивност во образувањето на топонимите: Bistrica, Blaževica, Brezovica, Dragovica, Gabrovica, Globočica, Golobica, Jasenovica, Javorovica, Jerebica, Košutica, Kozjica, Kovačevica, Ledenica, Leskovica, Mikulovica, Oblica, Radovljica, Toplica, Topolovica, Vidovica. ${ }^{45}$

Името на селото Радуша (Скопско) е документирано во историските писмени споменици од крајот на XIII век. Во грамотата на Михаил IX Палеолог од 1299 година, со која му се подаруваат имоти на манастирот Св. Никита кај Скопје, името на селото е напишано

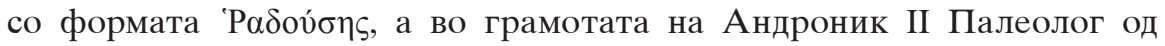
1299-1300 година, со која се потврдуваат даровните имоти на манастирот Св. Никита, којашто е дополнета со Милутиновата грамота од 1308 година е запишано: е регистрирано во турските пишани извори од XV век. Во турскиот опширен пописен дефтер за Тетовската нахија од 1467-1468 година името на селото е запишано со формата Радуша, а во истиот облик е наведено во пописниот дефтер за Скопскиот вилает од 1467-1468 година. ${ }^{47}$ Во статистичкиот преглед, направен во монографијата на В. К'нчов, името на селото е наведено како Радуше. ${ }^{48}$ Со извршената административна поделба на населените места на територијата на Република Македонија селото Радуша е вклучено во Општина Сарај. ${ }^{49}$ Дијалектното име на селото е Радуша.

Во структурен поглед, името на селото Радуша е елиптично име со посесивно значење. Тоа настанало со супстантивизација на придавката од некогашното сложено име *Рaдуша (Bbcb), чијшто атрибутски член

${ }^{43}$ Ibid., 3/A1; 192/A2; 138/C2.

${ }^{44}$ P. Merkù, Krajevno imenoslovje na slovenskem zahodu, Ljubljana 2006, 128.

${ }^{45}$ M. Furlan, op. cit., 16-30.

${ }^{46}$ В. Мошин, циий. дело, 290, 320.

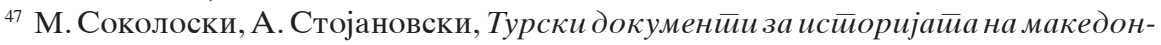

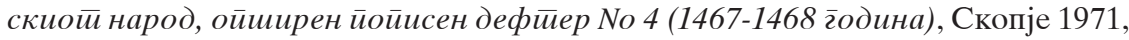
$349,427$.

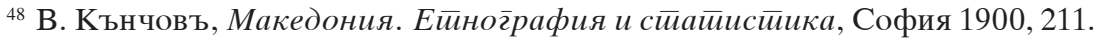

49 Закон за територијалната организација на локалната самоуправа, Службен весник на Рейублика Македонија, бр. 55, Скопје, 16 август 2004, 6. 
е образуван од личното име Радух со формата за женски род -ја од посесивниот придавски суфикс-jb, или од личното име Радуши со формата за женски род - $a$ од суфиксот - $b$, палаталната варијанта од посесивниот придавски суфикс - ъ. ${ }^{50}$ Во врска со етимологијата на ојконимот Радуша во досегашната научна литература е изнесено и поинакво мислење. Имено, Ј. Заимов смета дека името на селото Радуша е образувано од личното име Радуш со придавскиот суфикс -jb. ${ }^{51}$ Поаѓајќи од фактот дека со суфиксот -jь не можат да се образуваат придавки од лични имиња, чијашто основа завршува на палатален консонант, ние предност му даваме на првото решение, односно дека во основата на ојконимот Радуша се крие загубеното име Радух. Токму заради тоа во семантичката и структурната класификација, што е направена во нашиот научен труд за топонимите образувани со суфиксите $-j b,-b j b,-ъ$ во македонската топонимија, ојконимот Радуша го подредивме во групата топоними образувани со суфиксот $-j b .{ }^{52}$ Според тоа, значењето на името на селото Радуша може да се дефинира како 'вьсь, т.е. село, која му припаѓа на Радух, односно каде што живее Радух'.

Личното име Радух е образувано со антропонимискиот суфикс - $y x$ од личното име Радо. Ова име е засведочено во антропонимијата на словенските јазици, сп. буг. Рaдyx, пол. Raduch. ${ }^{53}$ Во нашиот антропономастикон се нотирани неговите деривати Радухан, Радухна, Радухче, документирани во турските пишани извори од XV век, ${ }^{54}$ кои потврдуваат дека во постариот период од развојот на македонскиот антропонимиски ситем постоело личното име Радух.

Хипокористичното име Радо може да е создадено по пат на скратување од композитните антропоними од типот на Радог̄ocū, Радомир, Радослав, а може да е изведено со антропонимискиот суфикс -о од сложените имиња од типот на Белорад, Госииирад, Малорад. Морфемата рад-/-рад, којашто е вклучена во составот на наведените сложени имиња, потекнува од стсл. придавка радъ 'волен, расположен' < прасл. *radz.

Во словенечката онимија личното име Радух е засведочено во основата на неколку топонимиски единици. Во Словенија е позната планината Raduha, која е дел од Камнишки Планини, односно од Савински Алпи, со врвовите Velika Raduha, висок 2062 м, и Mala Raduha,

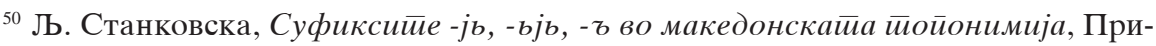
леп 2002, 341.

${ }^{51}$ Й. Заимов, Бълг̄арски гееографски имена с -јь, София 1973, 150.

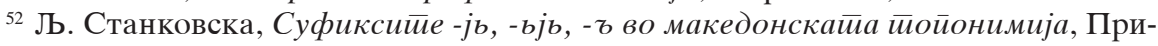
леп 2002, 442, 449.

${ }^{53}$ Й. Заимов, Бълг̄арски именник, София 1988, 188; M. Malec, Staropolskie skrócone nazwy osobowe od imion dwuczłonowych, Wrocław-Warszawa-Kraków-Gdańsk-Łódź 1982, 73.

54 Љ. Станковска, Речник на личнииее имиња кај Македонцииее, Скопје 1992, 233-234. 
4 висок 2029 м. ${ }^{55}$ Во географската карта на Словенија со името Raduha се бележат уште два географски објекта, од кои едниот се наоѓа во околината на градот Свечане, а другиот се наоѓ во околината на градот Чрешневци ${ }^{56}$. Во околината на реката Савиња, пак, постои населено место кое, исто така, се вика Raduha, ${ }^{57}$ чиешто име во обликот Radoch е регистрирано во документи од 1426 година. ${ }^{58}$ Неговото име во речникот на имињата на населените места во Словенија, исто така, е запишано со формата Raduha. ${ }^{59}$

Во структурен поглед топонимот Raduha, според нашето мислење, претставува посесивно топонимиско образување. Ова име потекнува од постарото атрибутско име *Raduha (gora, vas), чијашто придавка е образувана од личното име Raduh со исчезнатиот придавски суфикс -ъ во формата за женски род - $a$. По елиминирањето на именскиот дел од составот *Raduha (gora, vas), изразен со географските термини gora 'планина', или vas 'село', придавката *Raduha се супстантивизирала и продолжила да суштествува во форма на елипса. Семантичката вредност на топонимот Raduha може да се дефинира како 'гора, или село, што му припаѓa на Raduh, односно каде што живее Raduh'.

Во топонимијата на Словенија сличен топоним на нашиот ојконим Радуша е словенечкиот ојконим Raduše - село, које се наоѓа во непосредната близина на реката Радушница. ${ }^{60}$ Во историските извори од XIV и XV век ова населено место е регистрирано како село, а неговото име со формата Radus е запишано во 1375 година, во пишани извори од 1452 година е напишано во обликот Radusch, а во документи од 1461 година стои Raduss. ${ }^{61}$ При објаснувањето на потеклото на името на реката Radušnica, Ф. Безлај претполага дека во основата на овој хидроним би требало да се бара личното име Raduchъ, или Radušb, поткрепувајќи го своето гледиште со примери од словенската онимија: српхрв. Raduš, Raduša, регистрирано во 1222 година, хидронимот Radušnički Potok, луж. Raduš, Radušc, чеш. Radouš, пол. Radusz, герм. Radusse. ${ }^{62}$

Земајќи ги предвид историските потврди за името на населеното место Raduše, може да се претпостави дека неговото постаро име било Raduš, а локативната форма "v Rádušah", наведена во речникот на

${ }^{55}$ Atlas 55/C3.

${ }^{56}$ Ibid., 13/A/2; 15/A3.

${ }^{57}$ Ibid., 82/A1.

${ }^{58}$ P. Blaznik, Historična topografija slovenske Štajerske in jugoslovanskega dela Koroške do leta 1500, II, N-Ž, Maribor 1988, 196.

${ }^{59}$ Slovenska krajevna imena, Avtorji: F. Jakopin, T. Korošec, T. Logar, J. Rigler, R. Savnik, S. Suhadolnik, Ljubljana 1985, 230.

${ }^{60}$ Atlas 58/B1.

${ }^{61}$ P. Blaznik, Historična topografija slovenske Štajerske in jugoslovanskega dela Koroške do leta 1500, II, N-Ž, Maribor 1988, 196.

${ }^{62}$ F. Bezlaj, Slovenska vodna imena, II del, Ljubljana 1961, 139. 
имињата на населените места во Словенија, ${ }^{63}$ укажува дека сегашното име Raduše претставува скратена форма од постарото етничко име *Radušane.

Постарото име Raduš, според нашето мислење, треба да се третира како метонимиско име, односно дека тоа е преземено од името на некој друг географски објект. Бидејќи населеното место се наоѓа во непосредната близина на реката Radušnica, не е исклучено оваа река најпрвин да се именувала *Raduš. Ова хидронимиско име потекнува од некогашното синтагматско име *Raduš (potok), чијашто придавска компонента е образувана од личното име Raduh со посесивниот придавски суфикс -jь и означува 'поток кој му припаѓа на Raduh, односно поток покрај кој живее Raduh'. По елизијата на именската компонента од составот *Raduš (potok), изразена со географскиот термин potok, придавката *Raduš продолжила да суштествува во форма на елиптично име. Кога во соседството на реката се развило населеното место, името од потокот *Raduš се пренесло на селото Raduš, а потоа реката започнала да се именува според името на селото Raduš како *Raduška reka, чијшто адјектив е образуван со формата за женски род -ska < *-sska од придавскиот суфикс *-bskъ. Потоа, од синтагмата *Raduška reka отпаднал географскиот апелатив reka, а придавскиот дел *Raduška се супстантивизирал со помош на суфиксот -іса и се добила формата *Raduščica. Потоа, под влијание на топонимите од типот на Blatnica, Rakitnica, Slivnica, во кои суфиксната морфема -nica <*-ьnica е регуларна појава: *Blat(o)-bnica, *Rakit(a)-bnica, *Sliv(a)-bnica, ${ }^{64}$ пред суфиксот -іса, а зад групата -šč- се вметнува консонантот $n$, така што се добила формата *Raduščnica, а потоа добиената консонантска група -̌̌čn-, се упростила во -šn- со губење на консонантот $\check{c}$ и се добила сегашната форма на хидронимот Radušnica. Деривациската постапка при создавањето на хидронимот Radušnica се одвивала по следниот пат: Raduš + -bska > *Raduška reka $>$ *Raduška + -ica $>$ *Raduščica $>*$ Raduščnica $>$ Radušnica.

Како епилог, во врска со името на селото Raduše, односно со неговата постара форма *Radušane, би заклучиле дека ова етничкото име, според нас, настанало со топонимизација на етникот во множина *Radušane, кој е образуван од хидронимот *Raduš со морфемата -ane, непалаталната варијанта на етничкиот суфикс -јапе и означува 'луѓе кои живеат покрај потокот *Raduš'.

${ }^{63}$ Slovenska krajevna imena, Avtorji: F. Jakopin, T. Korošec, T. Logar, J. Rigler, R. Savnik, S. Suhadolnik, Ljubljana 1985, 230.

${ }^{64}$ И. Дуриданов, Южнославянски успоредици в развоя на един топонимичен

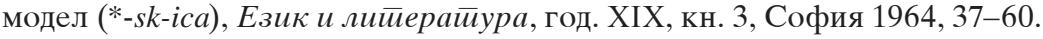




\section{Makedonsko-slovenske toponimične paralele \\ Povzetek}

Med makedonskim in slovenskim toponimskim sistemom obstajajo identične relacije $v$ najrazličnejših pomenskih skupinah zemljepisnih imen. Včlanku se dotikamo samo nekaj zemljepisnih imen s slovenskega in makedonskega jezikovnega območja, ki so motivirana z osebnimi imeni. Obravnavani toponimi kažejo skupne lastnosti tako glede na besedotvorno zgradbo kot na izvor.

Ljubica Stankovska 


\title{
Kagor, tajemniczy desygnat zamów i recept lekarskich wschodniej Słowiańszczyzny
}

\author{
Krystyna Szcześniak (Gdansk)
}

IZVLEČEK: V članku obravnava avtorica eno od skrivnostnih poimenovanj, ki so jih vrači in čarovniki oziroma čarovnice uporabljali $v$ tradicionalnih vzhodnoslovanskih ljudskih besedilih, $t$. $v$ zagovorih. V vračarskih zagovorih zoper alkoholizem se posebno pogosto pojavljata leksema vino, vino ,kagor” kot način zdravljenja ,,istega z istim”.

Kagor - The Mysterious Designatum of East Slavic Healing Spells and Folk Remedies

ABSTRACT: The author discusses one of the mysterious terms that healers and wizards or witches used in traditional East Slavic folk texts or incantations. In healers' incantations against alcoholism, the lexemes vino and vino "kagor" as a method of treating "like with like” are especially frequent.

W zamówieniach wschodniosłowiańskich, ${ }^{1}$ które są specyficznymi zaklęciami słownymi, do dziś funkcjonującymi nie tylko w Rosji, na Białorusi i Ukrainie, ale także w szerokim pasie przygranicznym polsko - białoruskim (okolice Białowieży, Narewki i Hajnówki) występują różne desygnaty, mające wzmacniać ich moc. Niekiedy wspominane są one również w samych tekstach owych modlitewek, jak

1 Istota terminu i zbiory zamów zobacz: Słownik folkloru polskiego pod red. J. Krzyżanowskiego, Warszawa 1965, s. 459; И.М. Соколов, Русский фольклор, Москва 1941, c. 187-199; J. Sembrzycki w Przyczynkach do charakterystyki Mazurów [w:] Mazurzy. Tradycja i codzienność. Wybór i posłowie Andreas Kossert. Teksty z języka niemieckiego przełożyli Elżbieta Kaźmierczak i Wiktor Leder, Olsztyn 2002, s. 17-53; Беларуская міфалогія. Энщыклапедычны слоўнік, Мінск 2004, с. 180; А. В. Юдин, Восточнославянский заговор: структура, семантика и прагматика текста [w]: Tekst. Analizy i interpretacje. Pod red. Jerzego Bartmińskiego i Barbary Bonieckiej. Lublin 1998, s. 169-182. Zob. też tego autora: Магические перформативы в заговорах и календарных песнях восточных славян, „Etnolingwistyka. Problemy języka i kultury”, nr 13, Lublin 2001, s. 139-148; В. Шуклин, Русский мифологический словарь, Екатеринбург 2001; И. Э. Платонова, Любовные заговоры, Санкт - Петербург 1997; Замовы. Уклад, сістэм тэкстаў, уступ. арт. і камент. Т. Барташэвіч, Мінск 2000. 
$\hookrightarrow \quad$ je nazywa lud nadniemeński, ale są i takie teksty, w których te same desygnaty występują zarówno w tekście, jak i są dodatkowo używane przy odrzekaniu choroby, jako swoisty pomocnik znachora czy wieduna. Mogą to być rośliny ${ }^{2}$ (macierzanka M 20) lub drzewa (odrzekanie uroku zarzuconego na wiatr powinno się odbywać w czasie obchodzenia dookoła samotnej brzozy, szczególnie podatnej, $\mathrm{z}$ racji swego rośnięcia, na podmuchy wiatru; M 115), ich pojedyncze elementy, jak witka, sęczek lub skupiska (sad, las, murawa, darń), mogą to być inne desygnaty, jak np. czerwona szmatka (M 115), wełniane nici (należy oderwać od kłębka wetnianych nici kawałek i nawiqzać na nim tyle węzetków, ile ma нamonbumu osoba, która ma być leczona, a potem zakopać ja pod męskim drzewem, M 92) lub czaga (grzyb rosnący na brzozie, M 115), mocz osoby, nad którą wypowiadany jest tekst (M 47).

Pewne zamowy wypowiadano tylko w wypadkach szczególnych, jak na przykład tylko wtedy, jeśli swacha idac do domu wybranej przez chtopca dziewczyny, nie spodziewa się zgody rodziców wybranki na ślub młodych (P 89). Inne należało wypowiadać przy codziennych czynnościach gospodarskich, jak pieczenie chleba ( $\mathrm{P}$ 139), wchodzenie do lasu ( $\mathrm{P} 137$ ), czy rozpoczynanie polowania (P 150) lub połowu (P 151), czy też wtedy, gdy szukano pracy (P 142) lub szybko chciano dorobić się fortuny (P 143). Niekiedy, dla prawidłowego zafunkcjonowania tekstu magicznego były wymagane dodatkowe okoliczności, lub spełnienie pewnych wcześniejszych zastrzeżeń, jak np.: witka powinna pochodzić z palmy wielkanocnej (M 116), a suchą gałązkę używaną do odrzekania należało wyłamać z kwitnącego drzewa (M 76). Jabłko, będące innym desygnatem zamowy powinno być poświęcone na tzw. яблочный спас ${ }^{3}$ (M 52), zaś na ziele, używane do zamówienia nadawało się tylko takie, które rosło przy drodze i było zerwane 12 lipca lub w dzień św. Jana lewą ręką (M 20), a potem ususzone (M 80, 82).

Desygnatem wspomnianych zabiegów magicznych mogły też być płazy, jak np. żaba: словите жабу, лягуху, посадите в носовой платок больного,

2 Zob. mój artykuł złożony do druku roku 2006 w „Acta Baltico-Slavica”, zatytułowany: Świat roślinny zapisany we wschodniosłowiańskich zagaworach leczniczych.

3 W genezie tego święta, obchodzonego w cerkwi prawosławnej od IV wieku na 6 avgusta (stara data) lub 19 tego samego miesiąca (wg nowego kalendarza) widnieje pobyt Jezusa na górze Tabor. W tradycji ludowej Преображение Господне nazywane jest Вторым Спасом, Спасом на горе, Яблочным Спасом. W dniu tym, powołując się na zalecenia Mojżesz, w cerkwi prawosławnej święcono winorośl i kłosy pszenicy, a z czasem wszelkie płody z sadu i pola (jabłka, miód, pszenicę elej, wosk), które dopiero po poświęceniu pozwalano używać do jedzenia. Bogatsi ludzie przekazywali w ów dzień płody rolne biedniejszym, chorym. Ci, którzy nie dopełnili tej powinności, nie byli godni, według wierzeń, Królestwa Niebieskiego. Poświęcone kłosy i ziarna nowego zbioru, chroniono do siewu, a potem je dosypywano do siewnego ziarna. Od tego też dnia zezwalano na jedzenie owoców, dojrzałych w promieniach słońca, a nie zielonych, kwaśnych i cierpkich (symbolika wiązała ten czas z duchową przemianą człowieka). W tymże dniu jedzono jabłka pieczone, bliny z jabłkami, grzybami i jagodami (wszystkim, czym obdarza ludzi sad, ogród i las oraz pole). Poszczącym zalecano pieczenie ciast bez mleka, jajek i śmietany, ale z tłuszczami roślinnymi, szczególnie z gorczycy). Zob. Православие день за днем, Москва 2004, с. 188-189; Православные праздники, Минск 2001, с. 86-88. 
начинайте на нее заговор, повесьте в узелке на осине, в четверг [...]: иди на жабу, на трасунью - осину, на ее корни, на ее листья [...] (M 41) lub kawałki jeleniego rogu, zalecane szczególnie w sytuacji, gdy zamówienie dotyczyło zmiany charakteru męża, szczególnie skorego do gniewu, kłótni, a nawet rękoczynów (P 112).

Czasem zalecenia wstępne były jeszcze bardziej skomplikowane, jak te, występujące w zamowie, dotyczącej odwrócenia uroku na kogoś rzuconego: zebrać wode z siedmiu domów do jednej bańki półlitrowej, podzielić ja na trzy części, a następnie je namówić i poić nimi chorego; woda, pozostała w bańce umyć odbyt (M 107) lub inne, zapisane przy modlitewce, pozwalającej na pozbycie się brzydkiego zwyczaju obgryzania paznokci: osoba, ogryzajaca paznokcie powinna wyciagnać ręce przed siebie, paznokciami do wierzchu, które, każdy z osobna, zaczynajqc od prawej ręki należy zahaczyć nożem (M 94). Zalecenia mogły też dotyczyć dni, odpowiednich dla przeprowadzania samego zabiegu uleczenia. I tak pewne odrzekania należało czytać $w$ środę, gładzac od siebie ręka chore miejsce (M 104). Dopiero po spełnieniu tych wszystkich przedwstępnych zaleceń i czynności, można było przystąpić do wypowiadania magicznej formuły (M 94).

Niekiedy owe dodatkowe zalecenia dotyczą nie tyle samego rozpoczęcia zamowy, ile zakończenia owego zabiegu. I tak w wypadku innego tekstu, który, jak to zapisano, miał leczyć z uroku po zakończeniu rytuału powinno się wrzucić do wody szczyptę soli i trzy zapalone zapałki, a krzyż, który jest $w$ domu, zanurzyć $w$ tejże wodzie; przy czym woda winna być świeżo przyniesiona. Gdy się idzie ро niq - należy wypowiedzieć dodatkowa modlitewkę: Здравствуй, вода Татьяна, земли Ульяна, а ключ Иван, дайте мне воды от всякой беды. Wode można pić dopiero po wykonaniu powyższych czynności, a ponadto należy nia pokropić ciało, pościel, pokoje i podwórzec, a reszta-umyć się (M 109/110). W kolejnym nagaworze od przestrachu zalecano wypowiedzenie tekstu dziewięć razy na wodę (nazywano tę czynność wylewaniem, lub odlewaniem), którą potem powinno się wylać pod drzewo albo w sadzie (M 68). Czasem owe przedwstępne zalecenia dotyczyły wszystkich części zabiegu: początku, samego zabiegu i jego zakończenia, jak na przykład to, wypowiadane nad opuchlizną, które nakazywano wypowiadać w środę na malejacy księżyc poprzez 12 wieczornych zórz, jedna ręka wodzqc czerwonq wetnianq szmatkq wokót opuchlizny, w drugiej - trzymajac czagę, zamawiać opuchliznę (po zamowie owinać czagę $w$ tę czerwona szmatkę $i$ zanieść na świeża mogiłe (M 99).

Ciekawym i dość często występującym desygnatem, towarzyszącym badanym tekstom magicznym było wino, występujące na przykład w odrzekaniu alkoholizmu, czego dowodzą poniższe przykłady:

- $\quad$ trzykrotne wypowiedzenie: хмель и вино, отступись от раба Божия (имя) в темные леса, где люди не ходят, и кони не бродят, и птица не летает; хмель $и$ вино выходи на быструю воду, по которой воде люди не ездят, от раба Божия (имя); хмель и вино, пойди на буйные ветры - которой ветер по дальности ходит (M 18; też: P 158; P 160; Pr 64); хмель и вино, отступись от раба Божьего [...] (M 19);

- $\quad$ żywego szczupaka należy włożyć w tues, albo w buraka z winem i nastawić 
na 12 dni; szczupak wydzieli wiele śluzu i nalewka stęchnie. Poić tym pijaka, mówiąc: jak szczupak nie cierpi wina, tak i ty nie powinieneś jego również, rabie boży (tu imię) (M 18).

- $\quad$ żywą żabę należy włożyć do wina, wypowiedzieć nad tą zawartością jeden z zagoworov, a potem wstawić na jedną dobę do ciepłego miejsca i dawać do picia tak, aby osoba nim pojona nie wiedziała co pije ( $\operatorname{Pr} 67)$ :

- хмель и вино, отступись от раба Божия (имя) в темные леса, где люди не ходят, и кони не бродят, и птица не летает (М 18);

- $\quad$ (modlitwa do świętego Bonifacego Miłościwego): [...] Услышь прибегающих к тебе одержимых пагубным пристрастием к винопитию $(\operatorname{Pr} 62)$.

O ile w badanych tekstach zamów, będących odrzekaniami, wino wymieniano zwykle jako nienazwany bliżej apelatyw (nie wspominano w nich jego nazwy ani koloru i występuje ono tylko w przywołaniach, a nie jako desygnat, konieczny do odprawienia czarów słownych), to inaczej jest przy podawaniu ludowych sposobów leczenia ziołami, nalewkami i niestandardowymi receptami (M 177). Tutaj zwykle wymieniano, bądź to jego kolor: wino czerwone (M 191), bądź zalecano użycie konkretnej jego marki, czyli wina kagor (M 177, 178, 181, 182). Ponadto, o ile w odrzekaniach wino jest zwykle wymieniane przy tekstach dotyczących alkoholizmu i leczenia konkretnej osoby z jego skutków, to w zamowach leczniczych i receptach ów desygnat zalecany jest do leczenia różnych chorób: ангина (M 177, 178), воспаление легких (M 181, 182), истощение (M 191).

Wino, zwane kagor (кагор) jest do dzisiaj dość popularnym winem deserowym, ${ }^{4}$ które zawdzięcza swą nazwę niewielkiemu francuskiemu miastu Cahors [kaor], leżącemu na prawym brzegu rzeki Lot, prawie w równej odległości 200 kilometrów od Pirenejów, Morza Śródziemnego i Oceanu Atlantyckiego. Już w XIII wieku słynęło ono z rosnących tam specyficznych szczepów winnej latorośli (Saperavi, Cabernet-Savignion, Matras, Kachet, Morastel, Bastardo), charakteryzujących się szczególnie intensywnym wybarwieniem i dużą zawartością cukru (nie mniejszą, niż 20\%). Wyrabiano z nich niezwykłe w barwie i smaku wino, przygotowywane z miazgi winogronowej wspomnianych szczepów, przygrzewanej do temperatury 70-80 stopni C przez 18-24 godziny. W efekcie takiego zabiegu otrzymywano gęste wino o intensywnie czerwonej barwie, przypominające smakiem i zapachem konfitury malinowe, czarną śliwę, a ze szczepów później uprawianych w Hiszpanii - czekoladę. Jego szczególna popularność przypadała na lata 70. wieku XIX, kiedy to uprawiano tam 60 tysięcy hektarów tychże winorośli.

Ten niezwykły napój stawiano początkowo tylko na stołach królewskich i papieży, choć pojawiało się też ono sporadycznie wśród magnaterii i wyższego duchowieństwa. Z czasem wśród wiernych prawosławia owo wino stało się symbolem przemiany w krew, dokonywanym w czasie Mszy świętej. W Rosji kagor pojawił się w czasach Piotra I, a jedna z legend głosi, że car poznał smak

4 Pierwotnie było ono lekko cierpkie, półsłodkie, teraz są to raczej wina cięższe o smaku (w zależności od regionu, w którym je się wytwarza: migdałowo-malinowo-czarnośliwowe lub czekoladowe. Zawsze ważny był kolor: od ciemnoczerwonego do rubinowego, o głębokiej barwie i gęstośći. 
tego trunku w czasie podróży do Francji i tak w nim zasmakował, że postanowił w okolicach Sankt Petersburga uprawiać ten właśnie szczep winny, z którego go wytwarzano. Inna opowieść wspomina, iż tenże car miał wyjątkowo słaby żoładek, a wino mu przepisywane, miało regulować jego pracę w czasie wielogodzinnych uczt. Jeszcze inna wersja głosi, iż obecność tego wina na stołach rosyjskich zawdzięczamy patriarchom rosyjskiej cerkwi prawosławnej, którzy (chcąc wybrać wino, odpowiednie dla Przeistoczenia) wybrali się w specjalną podróż po winnoprodukcyjnych regionach Francji i szczególnie zasmakowali w tym właśnie gatunku. Wino to wówczas przywożono do Rosji carskiej bezpośrednio z Francji lub Hiszpanii. W końcu XIX wieku winiarze francuscy podpisali specjalną umowę z przedstawicielami Rosyjskiej Cerkwi Prawosławnej, na mocy której dostarczali do Rosji specjalnie wyprodukowane wino tylko do potrzeb religijnych. Legenda o magicznym oddziaływaniu tego wina na organizm ludzki była tak wielka, że podawano je dzieciom przy piersi podczas chrztu. $Z$ czasem, ze względu na stałe używanie go do Mszy świętej w prawosławiu i koszty, związane z jego przywozem, winiarze rosyjscy odtworzyli system jego wytwarzania i zaczęli go stosować na gruncie rodzimym, wykorzystując doń krymskie odmiany winnej latorośli. Technologia wykluczała dodawanie do otrzymanego w ten sposób ekstraktu jakichkolwiek ziół, cukru, wody, czy spirytusu pochodzenia ziemniaczanego. Obecnie wytwarzane jest ono w Azerbejdżanie (od roku 1927), Kazachstanie (od roku 1957), Tadżykistanie i Uzbekistanie (od roku 1936), a także w Mołdawii (od lat 50. XX wieku). Szczególnym odbiorcą rodzimych win owej marki, zwanymi „Церковное”, Пасхальное” i „Соборное”, była i nadal jest rosyjska cerkiew prawosławna, która na przykład do roku 1918 zamawiała dla 48 tysięcy cerkwi - 300 tysięcy dekalitrów tego wina. Obecnie również to pierwsze wino („Церковное”) jest zamawiane przez Watykan dla tych samych celów mszalnych. Wśród pośledniejszych gatunków najczęściej jest wymieniany kagor, wytwarzany na Ukrainie. Na etykietach wszystkich butelek często, niezależnie od nazwy wina, wyobrażona jest sylwetka zakapturzonego mnicha lub duchownego, trzymającego kielich w czasie Podniesienia. Do wspomnianego typu należą dziś takie wina, jak: „Кагор”, „Кагор 32”, „Церковное”, Пасхальное” і „Соборное” (Rosja i dawne republiki radzieckie), „Rogom”, Visant”, „Kagor-Gran-Konstan”, Kagor-diuroc”, Kagor-Marker” (Francja) i na terenie Hiszpanii „Beni Karlo”.

Mimo, że w latach porewolucyjnych owe wina (jak rzadko które), były fałszowane, to cerkiew rosyjska nigdy nie zrezygnowała $\mathrm{z}$ ich używania. $\mathrm{O}$ jego markę zaczęto ponownie dbać wśród winiarzy dopiero jednak w latach 60.-70. minionego wieku, a w roku 1971 kagor zyskał najwyższy znak jakości: Apppellation d'Origine Controllee (AOS) - Cahors. Nazwa ta została zastrzeżona tylko dla trunku wytwarzanego ze szczepu Malbek (z minimalnym dodatkiem szczepu Merlot i Tanna), nadającemu winu smak migdałowo - czarnośliwowy. Zapisano też w owej umowie, że napój jest zdatny do użytku dopiero po 2-3 latach przechowywania go w dębowych kadziach.

I żeby zamknąć koło naszych rozważań, również we Francji i Hiszpanii wspomniane gatunki win zalecane są przez lekarzy, jako wyjątkowe trunki nie tylko nienaruszające pracy wątroby, ale nawet wzmacniające ów organ. Wina kagor zale- 
$4 \quad$ cane są również przy przeziębieniach i zapaleniach płuc (należy je pijać lekko pogrzane małymi łykami), a także stosowane są jako środek regulujący pracę żołądka i na inne niedomagania. Nadal również są one używane podczas Przeistoczenia w Rosyjskiej Cerkwi Prawosławnej. A występowanie w zamowach tylko samego leksemu wino, bez określania bliżej jego nazwy związane jest prawdopodobnie ze swoistym tabu. W tradycji ludowej nie wolno nazywać bowiem bezpośrednio czegoś, co związane jest ze świętością (pod groźbą utracenia tej cechy), a tym czymś jest na pewno Msza święta. W dodatku owo wino jest używane w jednym z jej najważniejszych elementów, czyli Przeistoczeniu. Wiara w szczególną moc tego wina jest wspierana przez czucie $i$ wiarę ludu, iż to, co używane jest w czasie Mszy świętej, ma szczególnie wielką moc leczniczą i uzdrawiającą. W dodatku wspominanie go przy magicznym leczeniu z alkoholizmu jest kolejnym przywołaniem zasady leczenia tego samego przez to samo. Prawdopodobnie działa tu ponadto przekonanie, że wino, jakim leczono z opilstwa (ze względu na wspominane wyżej przeznaczenie), ma większą moc, niż to, którym do tej pory ów alkoholik się upijał.

\section{Bibliografia}

Stownik folkloru polskiego pod red. J. Krzyżanowskiego, Warszawa 1965.

Беларуская міфалогія, Энцылклапедычны слоўнік, Мінск 2004.

[Z] Замовы, Уклад., сістэм тэкстаў, уступ. арт. і камент. Т. Барташэвіч, Мінск 2000.

Лекарственные растения. Энџыклопедия, Минск 2003.

[M] Молитвенный народный лечебник, Минск 2000.

[Р] И. Э. Платонова, Любовные заговоры, Санкт-Петербург 1997.

Православие день за днем, Москва 2004.

Православные праздники, Минск 2001.

И.М. Соколов, Русский фольклор, Москва 1941.

А. В. Юдин, Восточнословянский заговор: структура, семантика и прагматика текста [w]: Tekst. Analizy i interpretacje, Pod red. Jerzego Bartmińskiego i Barbary Bonieckiej. Lublin 1998, s. 169-182.

А. В. Юдин], Магические перформативы в заговорах и календарных песнях восточных славян, „Etnolingwistyka. Problemy języka i kultury”, nr 13, Lublin 2001, s. 139-148.

В. Шуклин, Русский мифологический словарь, Екатеринбург 2001.

\section{Kagor, eno od skrivnostnih poimenovanj v zagovorih vračev v vzhodnoslovanskih jezikih}

Povzetek

Članek se nanaša na eno izmed skrivnostnih poimenovanj, ki so jih vrači 
uporabljali v tradicionalnih ljudskih besedilih, tj. zagovorih (rus. заговор, наговор, присушка, отсушка).

Vino, vino kagor - ta dva leksema se pojavljata posebno pogosto v vračarskih zagovorih (заговор) zoper alkoholizem, kot način zdravljenja ,istega z istim”. Vino z imenom kagor (rus. кагор) se pojavlja zlasti v ljudskih zdravilnih receptih (rus. лекарование).

Po preučevanju niza takšnih zagovorov oz. večje količine receptov, in tudi ob spremljanju zgodovine te vrste vina, je bilo ugotovljeno, da beseda kagor označuje mašno vino, ki je prišlo v Rusijo v obdobju Petra I. in se do danes uporablja v pravoslavni liturgiji (med transsubstanciacijo). Ponovno se je pokazalo, da se ob stiku religije in poganstva pojavlja adaptacija določenih religijskih elementov v običaje, v prepričanju, da jim dajejo dodatno moč.

Krystyna Szcześniak Katedra Slawistyki Uniwersytetu Gdańskiego ul. Wita Stwosza 55, 80-952 Gdańsk, Poljska kr.szczesniak@wp.pl 



\title{
Nekaj ugotovitev o glasovnih značilnostih vulgarnolatinskih predlog za starejše latinizme in romanizme $\mathrm{v}$ slovenščini
}

\author{
Agata Šega (Ljubljana)
}

IZVLEČEK: V prispevku avtorica na podlagi preučevanja substitutov za latinske glasove $v$ besedah, ki pripadajo najstarejši plasti slovenskih latinizmov in romanizmov, poizkuša ugotoviti morebitne glasovne posebnosti govorjene latinščine na območju vzhodnih Alp in severnega Jadrana.

ABSTRACT: This article analyzes substitutes for Latin sounds in words belonging to the oldest layer of Latinisms and Romanisms in Slovene in order to identify possible special phonetic features of Latin as spoken in the Eastern Alps and Northern Adriatic.

\section{Predmet in cilj raziskave}

Do ugotovitev, ki jih podajamo v tem prispevku, smo prišli na podlagi preučevanja glasovnih značilnosti besednega fonda, zbranega $\mathrm{v}$ zadnjih letih $\mathrm{v}$ okviru dela za doktorsko disertacijo o starejših latinizmih in romanizmih v slovenščini. Med tovrstne izposojenke v slovenskem jeziku prištevamo besede, za katere se da utemeljeno sklepati, da so bile prevzete pred koncem alpskoslovanskega obdobja, se pravi nekako do 11. stoletja. Pri tem smo se omejili le na besede, ki imajo za predlogo vulgarno latinske oziroma romanske apelative, zato so krajevna in osebna imena izključena. ${ }^{1}$ Število takih izposojenk je v slovenščini zelo omejeno: gre pravzaprav samo za kakih 130 besed. Na osnovi tega besednega fonda lahko ugotavljamo, s katerimi glasovi je alpska slovanščina substituirala tuje glasove, kakšne rezultate so dali v kasnejšem slovenskem glasovnem razvoju in v kolikšni meri se substitucijska pravila, ki se jih da razbrati iz glasovne podobe obdelanega besednega gradiva, ujemajo s tistimi, ki so bila postavljena na podlagi preučevanja toponimov in antroponimov, starejših izposojenk iz drugih jezikov in starejših latinizmov oziroma romanizmov v drugih slovanskih jezikih. V pričujočem prispevku bomo skušali razmišljati o glasovnih značilnostih vulgarnolatinskih oziroma romanskih predlog, iz katerih so bile naše izposojenke prevzete. Zlasti pa nas bodo zanimala

1 S tem mislimo predvsem na substratna krajevna imena, kot so Soča, Ptuj, Celje in mnoga druga, pa tudi na imensko gradivo, kot so npr. imena svetnikov (Jurij in podobna). 
$-\quad$ morebitna odstopanja od običajnega romanskega glasovnega razvoja, saj bi ravno ta morda lahko pričala o za vulgarno latinščino oziroma protoromanščino na območju vzhodnih Alp in severnega Jadrana značilnem razvoju. ${ }^{2}$ Vendar moramo pri tem že na začetku opozoriti na nekatere omejitve, zaradi katerih na podlagi analize zbranega fonda ne smemo delati prenagljenih sklepov.

\section{Problemi}

\subsection{Omejen pomen izposojenk}

Na prvem mestu je treba upoštevati dejstvo, da je ciljni jezik v procesu izposoje podal glas iz izhodiščnega jezika s tistim glasom, ki mu je bil v njegovem fonološkem sistemu najbližji. Substitut se včasih sicer sklada z ustreznim glasom v izhodiščnem jeziku, včasih pa se glasovno vendar ne ujema popolnoma, preprosto zato, ker jezik, ki si besedo izposoja, takega glasu ne pozna. Zgrešeno bi bilo torej sklepati o glasovni podobi določenega glasu v katerem koli jeziku izključno na podlagi preučevanja substitutov tega glasu v drugih jezikih. Oziroma, kot opozarja Radosav Bošković v prvem delu svoje primerjalne slovnice slovanskih jezikov, ki je posvečen fonetiki "... pozajmice, same za sebe uzete, nisu pouzdan materijal za određivanje prirode glasova na osnovu onoga što one pokazuju ..." (Bošković, 1977, 42).

\subsection{Substitucijske nepravilnosti}

Druga težava, s katero se srečujemo, je možnost nepravilnega fonetičnega razvoja. Nanjo je v zvezi s predslovanskim substratom v slovenskem jezikovnem fondu France Bezlaj opozarjal že v svojem delu Eseji o slovenskem jeziku iz leta 1967. Tam pravi, da bi po starejših merilih "smeli upoštevati samo takšne besede, pri katerih bi mogli nedvomno dokazati glasoslovno normalen prehod v alpsko slovanščino na prelomu med 7. in 8. st. Tuje kratko - $u$ - mora dati $-b-$, dolgo $-u-$ pa $-y$ - itd. Toda takšnih vzornih primerov ni veliko." (Bezlaj, 1967, 96). Do tega je prišlo lahko po njegovem mnenju tudi zato, ker se je beseda "... na določenem področju že zelo zgodaj čutila izolirano." (ibid., 142). Domnevamo lahko, da je bila možnost za to pri izposojenkah še toliko večja.

Podobno mnenje o odstopanjih od normalnega glasovnega razvoja kot Bezlaj je zapisal tudi hrvaški jezikoslovec Pavao Tekavčić v svoji oceni Vinjevega dela Jadranska fauna. Etimologija i struktura naziva (1987, 168), kjer poudarja, da mora etimolog dati prednost vsebini pred izrazno ravnijo, se pravi, da so fonetična pravila pogosto drugotnega pomena. $Z$ njihovo pomočjo se, kot trdi, ne da pojasniti

2 Take teorije so se v preteklosti že oblikovale. Tako je Eberhard Kranzmayer (prim. Kranzmayer 1939, zlasti str. 112) na podlagi substitucije začetnega vlat. $k$ - s $h$ - sklepal o obstoju posebnega govora, celo jezika, ki ga je poimenoval "severovzhodna romanščina" (das Nordostromanische) in kjer naj bi bil imel začetni $k$ - drugačno glasovno vrednost kot drugod. Težava je v tem, da je Kranzmayerju primanjkovalo zanesljivih primerov za tako substitucijo v neposredni izposoji, če izvzamemo starejši romanizem hlače $\leftarrow$ CALCEA "Strumpf" (REW 1495), pa še tam ni izključena možnost vpliva druge, domače osnove z enakim pomenom, kot je menil že Skok (prim. ERHSJ 1, 670). 
primerov, ko je prišlo do nepravilnega razvoja iz semantičnih razlogov. Vendar pa hrvaški romanist kljub temu upravičeno opozarja, da je bil ne glede na stopnjo afektivnosti, ki je botrovala nepravilnemu fonetičnemu razvoju, in ne glede na to, kako močno rezultat odstopa od normalnega, na začetku vendarle potreben neki sprožitveni dejavnik. Po njegovem do nobene spremembe, pa naj bo še tako nenavadna in osamljena, ne more priti na popolnoma arbitraren način. Vsaka sprememba mora imeti vzrok, obstajati mora torej nekakšen začetni impulz, da do nje sploh pride. Težava, s katero se srečujemo pri analizi zbranega besedja, je seveda v tem, da je dejavnike, ki so botrovali odstopanju od substitucijskih pravil, za tako oddaljeno obdobje izredno težko določiti.

V nekaterih primerih pa je to vsaj v določeni meri vendarle mogoče. Tak primer bi bila slovenska izposojenka jegulja, pri kateri se iz glasovne podobe da sklepati, da ni mogla biti prevzeta iz nekega vulgarnolatinskega oziroma romanskega refleksa za klasično latinsko ANGUILLA "Aal" (REW 461), ampak iz izhodiščne oblike z metatezo *ANGULLIA, ki pa je ne pozna noben romanski jezik. Slovenska in ostale južnoslovanske izposojenke bi tako predstavljale edini dokaz o njenem obstoju. $\mathrm{Ob}$ tem se seveda zastavlja vprašanje, kako je do metateze pri tej besedi sploh prišlo. Nanj pa ni tako težko odgovoriti, če nam je znano, da je zlogovna metateza neredko lahko tudi posledica jezikovnega tabuja. Zakaj naj bi v tem primeru prišlo do pojavov, povezanih z jezikovnim tabujem, ni težko ugotoviti: pri imenih kač in tudi kači podobnih rib so tabuistične nepravilnosti zelo pogoste ${ }^{3}$. Vendar se pri besedi jegulja pojavlja še en substitucijski problem: glas $e$, ki ga najdemo na mestu vulgarnolatinske skupine $a+$ nosni konzonant, je lahko nastal le iz praslovanskega nosnega $e$, ne pa iz nosnega $Q$, ki je običajni substitut za tako skupino in ki je dal običajno $\mathrm{v}$ slovenščini o kakor v skodla $\leftarrow$ SCANDULA (REW 7652). Tudi protetični j- pred diftongom $a+N$ po mnenju strokovnjakov ni mogoč (Shevelov 1964, 241). Lahko bi torej suponirali izposojo iz neke vulgarnolatinske variante *ENGULLIA, iz katere tudi res izhaja Marc Greenberg $(2000,70)$. To pa se vendarle zdi razmeroma drzno, saj bi v tem primeru pričakovali reflekse iz *ENGULLIA ali pa vsaj iz *ENGUILLA še na kakem drugem območju Romanije, vendar jih slovarji ne navajajo. Zelo zanimivo je ob tem dejstvo, da lahko med našimi starimi romanizmi najdemo še en primer substitucije te skupine z nosnim e, to je medrija "ograda za koze ali ovce" $\leftarrow$ MANDRA "Herde" (REW 5290), kar bi se moralo po pravilu torej glasiti *modrija $>{ }^{*}$ modrija. Ali bi potemtakem lahko predpostavljali kot izhodišče za izposojo tudi v tem primeru neko domnevno obliko *MENDRA, ki v romanskih refleksih ravno tako ni potrjena? Ali bi lahko celo govorili o prehodu an v en kot posebni značilnosti vulgarne latinščine tega območja? Na žalost imamo na voljo samo dva primera, medtem ko se druge izposojenke vedejo "normalno", tako da

3 V zvezi s tem lahko omenimo še nekaj, pri čemer pa ne gre za fonetiko in tudi ne za izhodiščni, ampak za ciljni jezik: ni izključeno, da je bil jezikovni tabu sploh motiv za izposojo te besede v slovanske jezike, saj so evfemizmi pogosto tujke kot posledica naivnega verovanja, da demoni ne razumejo tujih jezikov. To pa ni tako brez povezave z našo temo, kot bi se zdelo na prvi pogled. Metateza v romanski obliki in raba tujke v slovanski sta sicer dva popolnoma različna mehanizma, ki pa imata oba enak cilj: narediti besedo neprepoznavno za temne sile. 
$\hookrightarrow \quad$ končnih sklepov seveda ni mogoče potegniti. Res je zapiranje vokalov za nosnimi konzonanti splošna značilnost romanskih jezikov, še zlasti romunščine. ${ }^{4}$ Seveda pa ne moremo zatrdno vedeti, ali je do spremembe res prišlo že v izhodiščnih oblikah in ali ne gre preprosto za to, da je bil ob izposoji teh besed tuji skupini an v alpskoslovanskem vokalnem sistemu ejevski nosnik glasovno bliže od ojevskega. Še zlasti te možnosti ni mogoče docela izključiti, ker Shevelov (1964, 329-330) izrecno poudarja odprtost nosnega $e$ in s tem v zvezi navaja nekaj primerov substitucije tuje skupine "a + nosni konzonant" z nosnim ę v stari cerkveni slovanščini. ${ }^{5}$ Še posebej ob tem opozarja na zapisa vuafa za vaše in raba za rabę v tožilniku množine moškega spola iz Brižinskih spomenikov (II 110 in 111), ki po njegovem nedvomno pričata o odprtosti nosnega $e^{6}$ Seveda obstajajo vsaj za ta dva zapisa tudi druge razlage $^{7}$, vendar se zdi zaradi navedenega kljub temu prenagljeno sklepati na obstoj protoromanskih različic *ENGULLIA ali *MENDRA.

Seveda pa stvari niso vedno tako zavite $\mathrm{v}$ temo kakor v navedenih dveh primerih in marsikateri nepravilni razvoj se da laže pojasniti. Vzemimo na primer slovensko kum: to je po Bezlaju (ESSJ II, 109) izposojeno iz COMMATER (REW 2082), po Snoju (SES 283) pa iz neke skupne osnove, nastale na podlagi kombinacije osnov COMMATER in COMPATER (REW 2096). Kakorkoli že, do neregularnega krajšanja, katerega rezultat je nedvomno ta splošnoslovanska izposojenka, je gotovo prišlo šele v slovanskih jezikih. V romanskih refleksih namreč pojav v taki obliki ni potrjen, čeprav je v nekaterih od njih prišlo do nepravilnega razvoja, tudi do izpada nekaterih glasov. Še pomembneje je, da je v slovanskih jezikih očitno obstajala in ponekod še obstaja neokrajšana oblika, potrjena v csla. kbmoter, st. polj. komotra, češ. kmótr, dol. luž. kmotś. Drugod, namreč v vseh južnoslovanskih jezikih, ruščini in ukrajinščini je potrjeno le kum, kar pa ne pomeni, da neokrajšana oblika ni nikoli obstajala, še zlasti ker je očitno predstavljala osnovo tudi za romunski slavizem cumătru, cumătră. ${ }^{8}$ Jezikoslovci na splošno ugotavljajo, da nazivi krstnih botrov v najrazličnejših jezikih izkazujejo neredno redukcijo. ${ }^{9}$ Nekateri to pripisujejo pogostosti ${ }^{10}$, kar gotovo drži, vendar po našem mnenju ta ni toliko posledica rabe v pomenu "boter" kot član sorodstva, ampak predvsem proklitične rabe v pomenu "kmet, sosed" za klicanje in nagovarjanje znanih oseb, sovaščanov, itd., do česar prihaja zlasti v povezavi z osebnim imenom. To trditev potrjuje zanimivo dejstvo, da do vzporednega pojava prihaja še v enem starejšem romanizmu z enakim pomenom, a z neprimerno bolj omejenim arealom: hrvaška narečna beseda sutla,

4 Tam se zaprejo do najmanjše stopnje zaprtosti (Lausberg 1956, §230).

5 Tako Aleksędrovu kot dajalnik ednine v Codex Marianus in Kъsnętinj gradz za Konstantinopel v Codex Suprasliensis (Shevelov, ibid.).

6 Sicer najdemo v Brižinskih spomenikih za $e$ dvainvajsetkrat zapis $e$ in enkrat $e n$.

7 Prim. mnenje Rudolfa Kolariča v Pogačnik 1968, 23, ki potrjuje mnenje starejših avtorjev, da gre za napako zaradi prepisovanja iz neke starejše predloge; o obstoju predloge razmišlja tudi Igor Grdina v najnovejši izdaji Brižinskih spomenikov (prim. Dolinar - Faganel 2004, 26-27).

8 Prim. REW 2082.

9 Podrobneje o tem v Mańczak, 1975.

${ }^{10}$ Tega mnenja je tudi Mańczak, ibid. 
izposojena iz sanctula, pomanjševalnice ženskega spola od sanctus (REW 7569), se namreč v kombinaciji z osebnim imenom uporablja tudi v skrajšani obliki, torej sla Mare namesto sutla Mare. ${ }^{11}$ Obstoj neokrajšanih slovanskih oblik iz naše predloge in neredno krajšanje še ene stare izposojenke $\mathrm{z}$ istim pomenom pa poleg tega govori tudi proti izvajanju sla. kum in sorodnega iz turško-tatarske osnove kuma "priležnica, služabnica".12

\subsection{Nezanesljive etimologije}

Tretje, kar moramo poudariti, ko govorimo o starejših latinizmih oziroma romanizmih v slovenščini, je nemajhno število besed, ki jih med tovrstne izposojenke lahko prištevamo le z zadržki, tj. da je bilo zanje podanih več etimoloških predlogov in da na podlagi podatkov, ki so na voljo, ni mogoče dokončno sklepati o njihovem izvoru. Nekaj je tudi takih besed, pri katerih se moramo upravičeno spraševati o trenutno veljavnih etimologijah. Tako nismo mogli upoštevati narečnega zahodnega žrdana "karželj, Amanita caesarea" z variantami, kar je Bezlaj uvrščal med starejše romanizme in predlagal vlat. izhodišče *CAESARETANUS, izpeljanko iz lat. CAESAR. ${ }^{13} \mathrm{Ne}$ le, da je to po substitucijskih pravilih nemogoče - imena gob so navsezadnje pogosto tabuizirana in zato podvržena glasovnim spremembam evfemistične narave -, proti govori tudi popolna odsotnost romanskih refleksov iz *CAESARETANUS, kakršnih koli drugih izpeljank in celo same izhodiščne oblike CAESAR $v$ romanskih refleksih, če seveda izvzamemo mnogo kasnejše latinizme. ${ }^{14}$

\subsection{Pomanjkanje primerov}

$\mathrm{Na}$ koncu naj opozorimo še na eno nevšečnost, s katero se srečujemo: zlasti pri nekaterih glasovih je število zanesljivih primerov izposoje $\mathrm{v}$ obravnavanem obdobju tako majhno, da bi bilo kakršno koli sklepanje na tej podlagi nedopustno. V takih primerih smo se morali zateči k podatkom, pridobljenim izven obravnavanega besednega fonda, saj $\mathrm{k}$ sreči ponujajo krajevna imena nekoliko več materiala za substitucijo nekaterih glasov. Za vulgarnolatinski zaprti naglašeni $o$, ki je v zgodaj prevzetih toponimih zastopan $\mathrm{z}$ alpskoslovanskim $y>\sin . i$, v našem materialu najdemo le verjetno nekoliko mlajši substitut $u{ }^{15}$ Določeni substituti se sploh pojavijo samo po enkrat. Tako je pri kmet $\leftarrow$ COMES, -ITE "Begleiter, Graf" (REW 2058) izvajanje $b$ iz vulg. lat. naglašenega odprtega $\rho^{16}$ glasoslovno sicer še sprejemljivo, čeprav je pri tem glasu na splošno na voljo zelo malo substitucijskih primerov; ni pa seveda najti nobene druge starejše izposojenke, ki bi kazala na substitucijo nenaglašenega kratkega vlat. $i$ s sla. naglašenim $e$. Pri

${ }^{11}$ Beseda je zabeležena na Rabu in Krku, raba, o kateri govorimo, pa je znana na Krku (ERHSJ III, 366).

12 Prvi jo zgolj omenja Miklošič (EWSS 154-55), to mnenje pa je nazadnje zagovarjal Rocchi, 1990, 141-43.

${ }^{13}$ Bezlaj 1967, 95; ESSJ I, 232 (geslo jordana).

${ }^{14}$ Snoj v zadnjem zvezku ESSJ (IV, 479) Bezlajevo izhodišče potrjuje, vendar je beseda po njegovem prevzeta prek furlanščine.

${ }^{15}$ Primeri so navedeni spodaj, v odstavku 3.2.5.

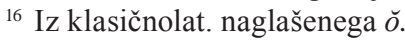


$\hookrightarrow \quad$ takih besedah poskušajo etimologi včasih s kakim alternativnim predlogom. Tako Skok domneva, da je kmet izpeljano iz kъmetija ${ }^{17}$, kar naj bi bilo po njegovem izposojeno iz srednjelat. oblike COMETIA z dodatnim pomenskim vplivom lat. glagola COMMITTERE. Seveda pa je takim predlogom vedno možno tudi ugovarjati. ${ }^{18}$

\section{Ugotovitve}

Zaradi večkrat težko razložljivih odstopanj od substitucijskih pravil, premajhnega števila primerov in dvomov o izvoru nekaterih besed dokončnih sklepov torej ne moremo podati. Kaj se da potemtakem na podlagi obravnavanega besednega fonda sploh ugotoviti o glasovni vrednosti posameznih vulgarnolatinskih glasov v času prvih stikov s slovanskimi priseljenci? Pokazalo se je, da so glasovne značilnosti latinskih predlog za naše izposojenke znane tudi vsem romanskim jezikom ali vsaj večini, samo za eno od njih lahko rečemo, da je intenzivneje izražena le na ožjem območju prevzema.

\subsection{Konzonantizem}

\subsubsection{Palatalizacija}

Do palatalizacije, se pravi do artikulacijskih sprememb, ki prizadenejo velare in dentale pred $j$ in velare pred prednjimi vokali, pride v večini romanskih jezikov, njeni rezultati pa se kažejo tudi v obravnavani plasti izposojenk. Opozoriti moramo, da so vzporedni pojavi delovali tako v praslovanščini kakor tudi v vulgarni latinščini, zato se jezikoslovci pravzaprav še vedno niso zanesljivo opredelili, ali so bili velari palatalizirani že v romanski predlogi do take stopnje, da so se ob prevzemu le substituirali z domačimi glasovi, ki so nastali s prvo in drugo slovansko palatalizacijo in z jotacijo, ali pa so slovanski substituti rezultat slovanskega jezikovnega razvoja. V zvezi s tem je bilo že v dvajsetih letih prejšnjega stoletja prelitega precej črnila, zlasti iz peres Petra Skoka, Frana Ramovša, Frana Šturma in drugih ${ }^{19}$. Nekateri jezikoslovci menijo, da so velari pred prednjimi vokali v romanskih predlogah doživeli 2. slovansko palatalizacijo, do katere je sicer prišlo le pred ě. ${ }^{20}$ Ta razlaga

${ }^{17}$ Ta oblika je znana, kot ugotavlja, le v slovenščini in kajkavščini, torej na področju, kjer je razširjen tudi pomen "agricola, homo rusticus".

${ }^{18}$ Težava pri Skokovi razlagi je v tem, da se v doslej znanih srednjeveških dokumentih cometia med poimenovanji za kmetijo v naših krajih sploh ne pojavlja (prim. Kos 1985, zlasti strani 221-222), pa tudi njena popolna odsotnost - ne glede na pomen - v slovarju srednjeveške latinščine na območju nekdanje Jugoslavije (LLMAI) je verjetno vredna pozornosti.

${ }^{19}$ Od daljših prispevkov prim. zlasti Skok 1926 in 1929, Ramovš 1927 in Šturm 1927 (za staro fazo izposoje predvsem strani 45-48).

20 "It (namreč 2. palatalizacija; op. A.Š.) is also found in a few loan words with velars followed by front vowels other than $\check{e}$. The assumption is that these words entered Sl while 
pa je lahko pravilna le, če dopustimo možnost, da so se glasovi v besedah tujega izvora razvijali drugače kot v domačih, kar je vendarle problematično. Če gledamo na stvari z romanističnega vidika, se dajo namreč različni substituti pojasniti z dejstvom, da je romanska palatalizacija velarnih zapornikov pred palatalnimi vokali dala različne rezultate na različnih področjih, in z domnevo, da so jih Slovani pač substituirali s tistimi glasovi, ki so jim bili v njihovem jeziku najbližji. Ni izključeno, da je bil v oblikah, ki so bile prevzete iz različnih vulgarnolatinskih govorov v različnih obdobjih, velarni zapornik palataliziran na različne načine in do različnih stopenj in naši predniki so ga glede na to substituirali bodisi z rezultati prve, bodisi $\mathrm{z}$ rezultati druge palatalizacije, $v$ nekaterih primerih pa celo z velari. Seveda bi bilo za dokončno rešitev problema potrebno skrajno poglobljeno pretehtati vse starejše in mlajše substitute za romanske velare pred palatalnimi vokali v luči novejših - tudi romanističnih - spoznanj, kar bi zahtevalo samostojno razpravo. Pri dokončnem razreševanju tega vprašanja pa si z apelativi ne moremo kaj dosti pomagati: utemeljeno lahko sklepamo, da so se nekatere besede razširile zelo daleč od področja prevzema, pri čemer je treba žal ugotoviti, da si areala marsikatere od njih morda nikoli ne bomo mogli pojasniti. Več snovi za natančnejše preučevanje tega pojava nam sicer ponujajo krajevna imena ${ }^{21}$, nekaj primerov pa najdemo vendarle tudi med našimi apelativi. Tako češnja iz CERASEA "Kirsche" (REW 1823) in cer iz CERRUS "Zerreiche" (REW 1838) potrjujeta, da lahko pričakujemo različne rezultate tudi v zelo starih izposojenkah, saj sta bili ti dve besedi prevzeti tako zgodaj, da sta splošno slovanski. Z različnimi substituti se srečamo včasih celo, kadar obstaja več starih izposojenk iz iste latinske predloge. Tukaj velja omeniti poleg za romaniste že kar slovitih toponimov Čedad in Cavtat (oboje iz CIVITAS, -ATE "Stadt", REW 1959), vsaj še predlogo ACIALE "Stahl" (REW 103), ki je ravno tako dala v slovenščini dvojne rezultate: vzh. štaj. ocel "jeklo" in gor. cêl "orodje" na eni strani in ptujsko čêl "jeklen" na drugi. ${ }^{22}$ Dogaja se tudi, da substituti kažejo na odsotnost palatalizacije tam, kjer bi jo sicer pričakovali, zato je treba za take primere poiskati drugačno razlago: slovensko bisága očitno ni bilo prevzeto iz BISACCIA "Quersack" (REW 1121), ampak iz neke suponirane romanske različice *bisaca. ${ }^{23}$

\subsubsection{Sonorizacija}

Pri konzonantizmu lahko omenimo še sonorizacijo medvokalnih konzonantov, ki se pojavlja v vseh zahodnoromanskih jezikih. O tem pojavu, ki ga slovanščina ne pozna, pričajo le nekatere od obravnavanih izposojenk, npr. FOCACEA "eine Art Kuchen" (REW 3396) $\rightarrow$ pogáča, RUBETUM "Brombeergebüsch" $\rightarrow$ robida (REW 7407), GALLETA "Eimer" (REW 3656) $\rightarrow$ golída, SCUTELLA "Schüssel" (REW 7756) $\rightarrow$ skléda, medtem ko druge kažejo na izposojo iz oblik z

the second palatalization of velars was in operation, and became involved in the trend." (Shevelov 1964, 294; podobno Lamprecht 1987, 46).

${ }^{21}$ Prim. Bidwell 1961, 122-124.

${ }^{22}$ Prim. Plet. I, 81, 82, 97, 756; ESSJ I, 77, in II, 239.

${ }^{23}$ Tu opažamo zelo zgodnjo poenostavitev geminate, očitno še pred romansko sonorizacijo medvokalnih zapornikov, ki jo postavljamo v drugo polovico 4. stoletja. 
$\hookrightarrow \quad$ ohranjenim nezvenečim konzonantom, npr. PIPER "Pfeffer" (REW 6521) $\rightarrow$ pôper, RUTA "Raute" (REW 7470) $\rightarrow$ rúta $^{24}$, LACTUCA "Lattich" (REW 4833) $\rightarrow$ ločíka, PARRICATU(M) $)^{25} \rightarrow$ prekát.

\subsubsection{Druge konzonantne spremembe}

Poenostavljanje geminat je seveda mlajše od sonorizacije medvokalnih konzonantov, kot potrjujeta CUPPA "Becher" (REW 2409) $\rightarrow$ kupa in SACCUS "Sack" $($ REW 7489) $\rightarrow$ sák. Obravnavane izposojenke pričajo tudi o nekaterih drugih konzonantnih spremembah, npr. o prehodih $v>b$ kot v CAVEA "Höhlung; Vogelkäfig; Korb" (REW 1789) $\rightarrow$ gájba, $b$ - > v- kot v VINCA (iz ž. spola prid. VINCUS "biegsam", REW 9242) > béka in $k->g$ - kot v CAVEA > rom. gabia $\rightarrow$ gájba ali rom. ${ }^{*}$ cardass $^{26} \rightarrow$ gradáš/e/). O treh primerih substitucije začetnega $p$ - z $b$ - težko povemo kaj določnejšega: prvi je rom. ${ }^{*}$ plania $^{27} \rightarrow$ blanja, kjer gre verjetno za istroromanski in furlanski prehod $p$ - $\mathrm{v} b$-, tj. da je sprememba nastala že v predlogi. V primeru besede breskev $\leftarrow$ PERSICA "Pfirsich" (REW 6427) gre verjetno za vpliv druge izposojenke, namreč broskev, ki je stara splošnoslovanska izposojenka iz lat. BRASSICA "Kohl" (REW 1278), torej je do spremembe prišlo šele po izposoji. Tretji primer take substitucije je bek "ognjišče; trd kamen v kuhanem apnu", ki ga Bezlaj razlaga takole: iz latinskega FOCUS "Feuer" (REW 3400) naj bi bila beseda najprej izposojena $\mathrm{v}$ ilirščino, ki glasu $f$ ne pozna in ga substituira $\mathrm{z} b$, od tod pa naj bi bila prevzeta $\mathrm{v}$ lokalno vulgarno latinščino $\mathrm{z}$ drugačnim pomenom kakor običajni refleks iste latinske osnove. To pa pomeni, da bi šlo pravzaprav za posredno izposojenko. Do prehoda $p>b$, kot vse kaže, torej ni prišlo v vseh primerih niti iz istega vzroka niti $\mathrm{v}$ istem od obeh jezikov izposoje, zato teh primerov kljub enakim rezultatom ne kaže povezovati med seboj. Latinska konzonantna kupina -ns- se je seveda že pred prevzemom asimilirala, zato imamo različna rezultata za MENSA "Tisch" (REW 5497) $\rightarrow$ miza in MENTA "Minze" (REW 5504) $\rightarrow$ méta. Substitucija s $\check{c}$ v besedi LACTUCA "Lattich" (REW 4833) $\rightarrow$ ločíka bi kazala na prevzem skupine -kt- v vsaj do določene stopnje palatalizirani obliki.

\subsection{Vokalizem}

\subsubsection{Sinkopa}

Eden od pojavov, ki so najbolj spremenili podobo latinskih besed, je gotovo sinkopa. Ta je bila v določenih primerih v predlogi že izvršena, tako SYR(I)CUS "syrisch; purpurrot" (REW 8503) $\rightarrow$ sirk, SOL(I)DUS "eine Goldmünze" (8069) $\rightarrow$ sold, *PULL(I)CELLA "Mädchen" (REW 6819) $\rightarrow$ púnca, PARR(I)CATU(M) ${ }^{28} \rightarrow$ prekát, *PERS(I)CA "Pfirsich" (REW 6427) $\rightarrow$ bréskev, oblika bróskev za BRAS-

${ }^{24} \mathrm{Za}$ razliko od mlajše furlanske ali beneške izposojenke ruda (ESSJ III, 204).

${ }^{25}$ Izpeljano iz PARRICUS "Pferch" (REW 6253).

${ }^{26}$ Iz CARDUUS "Distel" (REW 1687).

${ }^{27}$ Iz PLANA "Hobel" (REW 6567).

${ }^{28}$ Glej opombo 25. 
SICA "Kohl" (REW 1278) pa bi lahko pričala o tem, da je bila beseda v času prevzema še trizložnica, ker je $a$ podan z 0 .

\subsubsection{Slabljenje nenaglašenih vokalov}

Starejši latinizmi in romanizmi v slovenščini pričajo tudi o slabljenju nenaglašenih vokalov: sln. čéš(nja) se je razvilo iz CERESEA (nam. CERASEA, REW 1823), v sln. poper $\leftarrow$ PIPER, -ERE "Pfeffer" (REW 6521) se je polglasnik mogoče razvil iz asla. $b$, čeprav bi bil običajnejši substitut $e$.

\subsubsection{Delno ohranjanje diftonga au}

Le en primer iz zbranega gradiva priča o tem, da je bil vulgarnolatinski difong $a u \mathrm{v}$ času najstarejših stikov še ohranjen: lavdica, eno od narečnih imen za škrjanč$\mathrm{ka}^{29}$, izhaja iz latinske besede galskega izvora ALAUDA "Lerche" (REW 313).

\subsubsection{Krajši izgovor vokalov $v$ naglašenih predpredzadnjih in/ali odpr- tih zlogih}

V romanistiki je znano dejstvo, da sta klat. kratki $i$ in dolgi $e$ sovpadla in dala $\mathrm{V}$ vulgarni latinščini enak rezultat, namreč vlat. zaprti e, vzporedno s tem pa je prišlo tudi do sovpada klat. kratkega $u$ z dolgim $o$ v vlat. zaprti $o$. Tako stanje potrjujejo tudi refleksi teh glasov $v$ romanskih jezikih in raziskave epigrafskega materiala. Vendar pa je vulgarnolatinski glas iz nekdanjega klas. lat. kratkega $\breve{l}$ v najstarejših latinizmih v nekaterih primerih celo v naglašeni poziciji podan $\mathrm{z} b$, se pravi, da pri substituciji ne daje vedno enakih rezultatov kot vlat. zaprti e. Tako imamo golida $\leftarrow$ GALLETA, kot smo videli zgoraj, za razliko od maša $\longleftarrow$ MISSA "Messe" (REW 5610), kjer je prvi a kasnejši refleks za ultrakratki ijevski vokal. Glede tega težko rečemo karkoli drugega, kot da v času najstarejših stikov alpski Slovani teh glasov niso slišali enako, zato so potrebovali zanje različne substitute. Bidwellova razlaga je, da se primeri substitucije naglašenih vokalov s slovanskimi ultrakratkimi vokali pojavljajo praviloma v zaprtih ali predpredzadnjih zlogih (oz. v takih, ki so oboje, se pravi zaprti in predpredzadnji). Do takih substitutov naj bi po njegovem prišlo, ker so se vokali v takih zlogih na večini romanskega ozemlja izgovarjali krajše kot v odprtih in predzadnjih (Bidwell 1961, 114-115 in 117). Taka razlika v izgovoru je v romanskem jezikoslovju znana, ${ }^{30}$ dokaz zanjo je gotovo dejstvo, da v večjem delu romanskih jezikov naglašeni vokal diftongira le v odprtih zlogih. V zbranih izposojenkah najdemo tudi različne substitute za vulgarnolatinski naglašeni $a$ v penultimi ali antepenultimi, tako SACCUS "Sack" (REW 7489) $\rightarrow$ sák, toda BRASSICA "Kohl" (REW 1278) $\rightarrow$ bróskev. ${ }^{31}$ Ta razlika potrjuje, da je prišlo v naglašenih predzadnjih zlogih do podaljšanja vokala, se pravi, da se je vulgarnolatinski naglašeni vokal v predzadnjem zlogu izgovarjal daljše kot v predpredzadnjem.

\footnotetext{
${ }^{29}$ Prim. Plet. I, 503. Po Filipiju (1994, 25-27) živo še danes v slovenski Istri.

${ }^{30}$ Prim. Lausberg 1956, § 163.

${ }^{31}$ Prim. Bidwell 1961, 115.
} 


\section{Viri in literatura}

Bezlaj, France, 1965, Od kod ime Jereka?, JiS, 10, str. 224.

Bezlaj, France, 1967, Eseji o slovenskem jeziku, Mladinska knjiga, Ljubljana.

Bidwell, Charles E., 1961, The Chronology of Certain Sound Changes in Common Slavic as Evidenced by Loans from Vulgar Latin, Word (Journal of the linguistic cercle of New York), 17, str. 105-127.

Bošković, Radosav, 1977, Osnovi uporedne gramatike slovenskih jezika. I. Fonetika, Naučna knjiga, Beograd.

Dolinar, Darko - Faganel, Jože (eds.), 2004, Brižinski spomeniki, ZRC SAZU, Ljubljana.

Doria, Mario, 1981, Il vocalismo istriano preveneto alla luce della toponomastica medievale e moderna, Incontri linguistici, 7, str. 55-68.

ERHSJ - Skok, Petar, 1971-74, Etimologijski rječnik hrvatskoga ili srpskoga jezika, I-IV, JAZU, Zagreb.

ESSJ - Bezlaj, France, 1976-2005, Etimološki slovar slovenskega jezika, I-IV, Mladinska knjiga - ZRC SAZU, Ljubljana.

32 Zlasti med krajevnimi imeni na -ona, kot je Humin iz GLEMONA, Krmin iz CORMONES in podobno, le nekaj primerov vendarle $\mathrm{v}$ drugačnih pozicijah, npr. Trogir < *trogyr $\leftarrow$ TRAGURIUM in za nas zanimivejši UTINU(M) $>$ st. furl. udino $\rightarrow$ alpsko sla. ${ }^{*} v-y d b n ъ>V i d e n$, po hiperkorekciji knjižno Videm (Ramovš, 1936, 34-35; Bidwell, 1961, 116). O tem Lamprecht 1987, 45: "Rovněž románske 'temné' o před nosovými konsonanty je do slovanštiny přejimáno jako $y$ (b)...". Prim. zgoraj, op. 4.

33 "V onem vulgarnem romanskem dialektu, iz katerega so si Slovenci marsikako besedo izposodili (stara furlanščina), je bil e že tako ozek, da je bil za Slovana slišen kot njegov i." (Ramovš 1936, 40). 
EWSS - Miklošič, Fran, 1886, Etymologisches Wörterbuch der slavischen Sprachen, Wilhelm Braumüller, Wien.

Filipi, Goran, 1994, Istarska ornitonimija. Etimologijski rječnik pučkog nazivlja, Izdavački centar Rijeka, Rijeka.

Greenberg, Marc, 2000, A Historical Phonology of the Slovene Language, Universitätsverlag C. Winter, Heidelberg.

Kos, Milko, 1985, Mansus sclavonicus, Srednjeveška kulturna, družbena in politična zgodovina Slovencev. Izbrane razprave, Slovenska Matica, Ljubljana, str. 217-224.

Kranzmayer, Eberhard, 1939, Frühromanische Mundarten zwischen Donau und Adria in deutschen und slavischen Ortsnamen, Zeitschrift für Namenforschung, 15/3, str. 193-224.

Lamprecht, Arnošt, 1987, Praslovanština, Univerzita J.E.Purkyně, v Brně.

Lausberg, Heinrich, 1956, Romanische Sprachwissenschaft I, Vokalismus, Walter de Gruyter, Berlin.

LLMAI - Kostrenčić, Marko (et alii), 1969-1978, Lexicon latinitatis medii aevi Iugoslaviae, I-VII, Editio Academiae scientiarum et artium Slavorum meridionalium, Zagrabiae.

Mańczak, Witold, 1975, Etimologija besede kumb, Slavistična revija, 23/1, str. 59-66.

Plet. - Pleteršnik, Maks, 1894-95, Slovensko-nemški slovar, I-II, Ljubljana.

Pogačnik, Jože (ed.), 1968, Freisinger Denkmäler, Rudolf Trofenik, München.

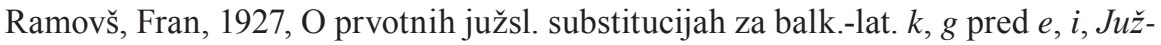
noslovenski filolog, 6, str. 153-165.

Ramovš, Fran, 1936, Kratka zgodovina slovenskega jezika, Ljubljana, Akademska založba (ponatis izvirne izdaje: ZRC SAZU, Ljubljana, 1995).

REW - Meyer-Lübke, Wilhelm, 1935³, Romanisches etymologisches Wörterbuch, Carl Winters Universitätsbuchhandlung, Heidelberg.

Rocchi, Luciano, 1990, Latinismi e romanismi antichi nelle lingue slave meridionali, Udine, Campanotto Editore.

SES - Snoj, Marko, 1997, Slovenski etimološki slovar, Mladinska knjiga, Ljubljana.

Shevelov, George Y., 1964, A prehistory of Slavic, The historical phonology of common Slavic, C. Winter Verlag, Heidelberg.

Skok, Petar, 1926, Zur Chronologie der Palatalisierung von $c, g$, qu, gu vor e, i, y, $i$ im Balkanlatein, Zeitschrift für Romanische Philologie, 46, str. 385-410.

Skok, Petar, 1929, O slovenskoj palatalizaciji s romanističkog gledišta, Južnoslovenski filolog, 8, str. 38-64.

Striedter-Temps, Hildegard, 1963, Deutsche Lehnwörter im Slovenischen, Osteuropa-Institut Berlin, Berlin - Dahlem.

Šturm, Fran, 1927, Refleksi romanskih palataliziranih konzonantov v slovenskih izposojenkah, Časopis za slovenski jezik, književnost in zgodovino, 6, str. 45-85.

Tekavčić, Pavao, 1987, Vojmir Vinja, Jadranska fauna, Etimologija i struktura 
naziva, I-II, Split, Logos, 1986, I. vol. 5-504, II. vol. pp. 1-588., Linguistica, 27, str. 167-174.

\section{Some Findings on the Phonetic Characteristics of Vulgar Latin Etyma for Older Latinisms and Romanisms in Slovene}

Summary

On the basis of some 130 older Latinisms and Romanisms in Slovene, this paper seeks to determine what these borrowings, received some time before the end of the 11th century, reveal about the phonetic value of individual phonemes at the time of initial contacts with Slavic immigrants. The paper begins by drawing attention to a number of restrictions that must be taken into account. Through comparison with previous research, which was limited to toponomastic material, it then establishes several phonetic features of Latin bases for older Latinisms and Romanisms in Slovene. In consonantism, the duality of substitutional results for proto-Romance velar stops before a front vowel or vowel hiatus and for intervocalic stops, which may or may not be evidence of sonorization, reveal a great deal. With regard to vocalism, cases that confirm the lengthening of proto-Romance vowels in stressed penultimate syllables and the weakening of unstressed vowels and syncope are also fruitful. However, these are phenomena that can be noted across the entire Romance area. As a phonetic feature particular to the area of adoption (i.e., the Eastern Alps and the Adriatic region), only the levelling of proto-Romance o and $\mathrm{u}$ in Alpine-Slavic substitutes is noteworthy.

Agata Šega

Filozofska fakulteta Univerze v Ljubljani, Aškerčeva c. 2, 1000 Ljubljana 


\title{
Fonološki opis govora vasi Jev̌̌̌čk pri Livku nadiškega narečja slovenščine ${ }^{1}$
}

\author{
Matej Šekli (Ljubljana)
}

IZVLEČEK: V članku je prikazan fonološki opis govora vasi Jevšček pri Livku (Občina Kobarid, Slovenija) nadiškega narečja slovenščine, in sicer tako s sinhronega kot z diahronega gledišča. Opisnojezikoslovni vidik podaja nabor prvin samoglasniškega, soglasniškega in naglasnega sestava ter njihovo razvrstitev. Zgodovinskojezikoslovni pogled določa izvor posamezne prvine ter opisani fonološki sestav postavlja $v$ širši slovenski in slovanski kontekst.

ABSTRACT: This article presents a phonological description of the local dialect of Jevšček (located near Livek in the Municipality of Kobarid, Slovenia) of the Nadiško (Nadiža/Natisone) dialect of Slovenian, from the diachronic and the synchronic points of view. The descriptive-linguistic perspective presents the inventory of vowel, consonant and accent systems as well as the distribution of the elements in the system. The historical-linguistic point of view determines the origin of a single element and ascribes to the described phonological system its position in the context of Slovenian and other Slavic languages.

1 Nabor

1.1 Samoglasniški sestav

1.1.1 Dolgi naglašeni samoglasniki

ir

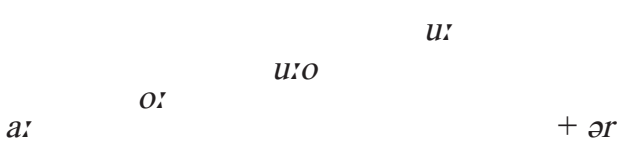

1 Besedilo je bilo pripravljeno $\mathrm{z}$ vnašalnim sistemom ZRCola, ki ga je na Znanstvenoraziskovalnem centru SAZU v Ljubljani (www.zrc.sazu.si) razvil Peter Weiss. 


\subsubsection{Kratki naglašeni samoglasniki}

i

$$
\begin{array}{llll}
\partial & o & u
\end{array}
$$

1.1.3 Nenaglašeni samoglasniki

$\begin{array}{llllll}i & & & & & u \\ & & \text { o } & & o & \\ & & & & \end{array}$

\subsection{Soglasniški sestav}

\subsubsection{Zvočniki}

$\begin{array}{llll}\underset{\sim}{U} & & & m \\ j & & r & \stackrel{m}{n}\end{array}$

Fonološko nasprotje med /v/ in /un/ ni trdno, saj je [u] najpogosteje fonemska različica /v/, zato je /u/ lahko definiran kot t. i. obrobni fonem. ${ }^{2}$

/j/ je v položaju pred samoglasniki artikulacijsko in akustično bližji priporniškemu [j], v položaju ne pred samoglasnikom pa bližji dvoglasniškemu [i].

\subsubsection{Nezvočniki}

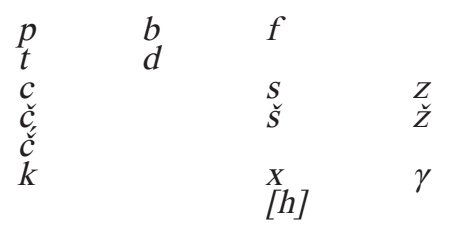

$/ \check{c} /$ in $/ \check{c} /$ sta v procesu sovpadanja. ${ }^{3}$

2 Natančna razvrstitev obeh fonemov je podana v razdelku 2.2.1.

3 Informator, roj. leta 1939, v spontanem govoru fonemov/č/ in /č́/ ne ločuje. Zaveda pa se, da je (bila) razlika med fonemoma $v$ govoru prisotna in da je sam v preteklosti fonema

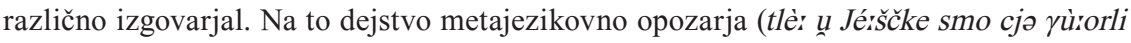

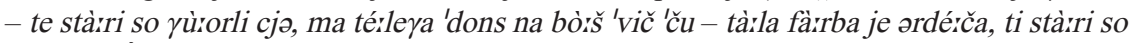
jà:l ordérča, ordércja ... čá:k, še 'jest na znà:m 'vič rérjč - je jàiun, son že ứse 'jest plárcju, 'dons reče'mo plá:ču, ko pripoveduje o vaščanu, roj. leta 1919, ki se je po drugi svetovni vojni izselil v Francijo in v jezikovni izolaciji ohranil starejšo glasovno podobo krajevnega govora, ki jo informator pozna iz svojega otroštva), na podlagi česar je mogoče določiti prvotno razvrstitev obeh fonemov. 
/č́/ se fonetično realizira kot [c] v izglasju ${ }^{4}$ in kot [cj] v medsamoglasniškem položaju. $^{5}$

\subsection{Naglasni sestav}

\subsubsection{Naglasno mesto}

Naglasno mesto je prosto in fonološko relevantno (pomenskorazločevalna vloga), npr. ormérna kot rod. ed. od or'men 'jermen' orme'na 'rumena'.

\subsubsection{Samoglasniška kolikost}

Kolikostna nasprotja obstajajo na naglašenih samoglasnikih in so fonološko relevantna, npr. 'bank 'lesena skrinja za drva' bànk kot rod. mn. od bànka 'banka', 'duh prid. 'dolg' dù̀h sam. 'dolg', 'las 'laz' làrs 'las', 'pas 'pes' pàrs 'pas', 'sit prid. 'sit' sìt kot rod. mn. od síto 'sit', 'vas 'ves' ali tož. mn. od mì 'mi' vàis sam. 'vas'.

\subsubsection{Tonemskost}

Tonemska nasprotja obstajajo na dolgih naglašenih samoglasnikih in so fonološko relevantna, npr. komárr 'komar' komàir kot rod. mn. od komàra 'pomočnica pri porodu'.

\section{Razvrstitev}

\subsection{Samoglasniški sestav}

2.1.1 Dolgi naglašeni samoglasniki se pojavljajo v vseh besednih zlogih in v vseh soglasniških okoljih.

2.1.2 Kratki naglašeni samoglasniki se $\mathrm{z}$ izjemo /o/ pojavljajo samo v edinih ali zadnjih besedenih zlogih in v vseh soglasniških okoljih. Samoglasnik /ə/ se pojavlja kot neobstojni samoglasnik samo $\mathrm{v}$ edinih/zadnjih besednih zlogih $\mathrm{v}$ položaju pred /r/ (če'bər čeb'ra) ter v pložaju med /r/ in /n/ (čə'ron čər'na, Kə'rən Kər'na).

2.1.3 Nenaglašeni samoglasniki z izjemo /a/ se pojavljajo v vseh besednih zlogih in v vseh soglasniških okoljih. Samoglasnik /a/ se pojavlja samo v položaju $\mathrm{ob} / \mathrm{r} /$, in sicer kot obstojni samoglasnik ne v izglasju (ər'men, $ә r^{\prime} j a$, rod. ed. vər'xa) in v pomožniku za 1 . os. ed. sən/səm ter kot neobstojni samoglasnik v izglasju (dósbor dob'ra).

${ }_{4} \mathrm{Na}$ to, da se /č́/ v izglasju fonetično realizira kot [c], bi kazala rima v otroški pesmici: $T i$ povírem no prárfco: / Tòifel ma no bírelo kráifco, / 'yu Polírc ma dvìre kopírc, / kər tíste sníre, nírema 'vič, v kateri se kopírc rima z 'vič́.

5 Tovrsten izgovor/č́/ je značilen za vzhodne nadiške govore (Dreka in okolica v smeri na Livek in Sovodnje), drugod pa je razlika med /č/ in /č́/ komaj slišna (Logar 1966, [150]). 


\subsection{Soglasniški sestav}

\subsubsection{Zvočniki}

Razvrstitev fonemov/v/ in/u/je v glasovnem nizu v večini pojavitev določljiva z njunim glasovnim okoljem: [v] se pojavlja $\mathrm{v}$ položaju pred nezaokroženimi samogasniki $i$, ire, e, o, a (vírdet, víredet, véxje, vesèrun, vòrx vər'xa, vàis vasì); [u] se pojavlja v položaju pred samoglasnikom o (úózzen, uno'da). [u] se zelo redko pojavlja tudi pred nezaokroženimi samoglasniki (uí́ba'vrba', uiis'ka'vojska', 'uemp, trá:uenk, Uà:nac, 'Uank, férboruar). Ker pojavljanje glasu [u] v glasovnem nizu ni vedno določljivo z glasovnim okoljem, gre pri tem nedvomno za samostojni fonem, in sicer za t. i. obrobni fonem znotraj fonemskega sestava.

/v/ se v položaju pred pavzo premenjuje v /ü/ ali /f/ (krárva $\sim \operatorname{rod}$. mn. krà:ú $\sim$ daj./mest. ed. krá:f), v položaju pred nezvenečim nezvočnikom v /f/ (živíret, 1. os. mn. sed. Živmór 3. os. mn. sed. Živjór $\sim 2$. os. mn. sed. Žiftái).

/v/ in /u/ se ne pojavljata v položaju pred /ur/ in /uro/.

/j/ se ne pojavlja v položaju pred /ire/.

$/ \mathrm{m} /$ se v položaju ne pred neustničnikom in pred $m$ premenjuje $\mathrm{v} / \mathrm{n} /$ (končnica -m/-n za 1. os. ed. sed. direlan\#, rečen\#, sən dírelu, son '̌u səm víredu, səm prárvu - končnica -en za or. ed. m pridevnikov in zaimkov $z$ nen dob'ren človírekan, $z$ nen dob'ren mò:žan $\sim$ z nen dob'rem pùroban). ${ }^{6}$

\subsubsection{Nezvočniki}

Zveneči nezvočniki se $\mathrm{v}$ položaju pred pavzo premenjujejo $\mathrm{v}$ nezveneče nezvočnike.

$/ \gamma /$ se v položaju pred pavzo premenjuje v/h/ (snìreh sne $\gamma \dot{a}$ ').

\subsection{Naglasni sestav}

2.3.1 Dolgi naglašeni samoglasniki, ki se pojavljajo $\mathrm{v}$ vseh besednih zlogih, tj. edinih/zadnjih in nezadnjih, imajo tonemski naglas, so akutirani ali cirkumflektirani.

2.3.2 Kratki naglašeni samoglasniki, ki se pojavljajo samo v edinih/zadnjih besednih zlogih, imajo jakostni naglas.

6 Premenjevanje fonemov $/ \mathrm{m} / \mathrm{in} / \mathrm{n} / \mathrm{v}$ nadiškem narečju in širše na slovenskem zahodu je značilno za sandhijevski položaj, kjer je zgodovinsko izpričan tudi prehod /n/ v /m/, npr. v Alasijevem slovarju iz leta 1607 (adam 'vno', vum 'fuora', dam 'giorno', sim 'figliuolo') in v jezikovnem gradivu Baudouina de Courtenaya iz druge polovice 19. st. (Škrátec am máslar) (Furlan 1991, 26). 


\section{Izvor}

\subsection{Samoglasniški sestav}

\subsubsection{Dolgi naglašeni samoglasniki}

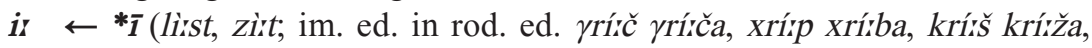

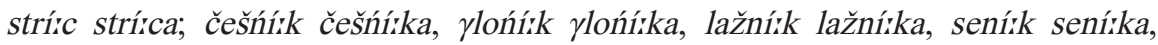
svetník svetní:ka; mìšenk miršenka; rod. ed. mazìnca - ylísta, zírma; motìka, sìunka-lírce, vínno - mìsu - im. ed. ned. nírzek níska níssko-im. ed. m in ž ned.

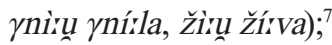

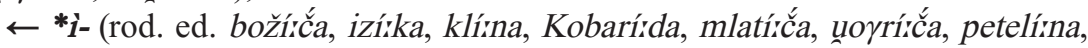

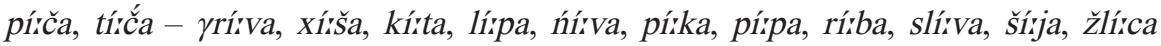

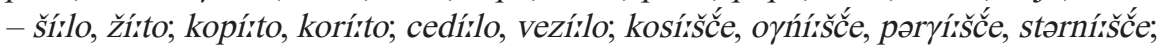
vírme - im. ed. ž in s ned. čírsta čísto, sírva sírvo, tírxa tírxo; bírstra bírstro, xírtra xístro);

$\leftarrow$ sln. âj v primeru mìxxen mìxxna mìxxno;

$\leftarrow$ v prevzetem besedju (brìtof, butì $\gamma a$, oštarìja);

ux $\leftarrow{ }^{*} \bar{u}$ (brùss, dùrx, pùsst, strùsp, trùsp; jú:nc; im. ed. in rod. ed. klúuč klúuča, klú:n klú:na, klabú:k klabú:ka, žú:í žú:la; rod. ed. kùspca 'kup trave' - dú:ša, kú:na, lú:na; xrùıška; súrša - ússta - lúrč, žùič - im. ed. ž ned. čùrdna-im. ed. m in ž ned.

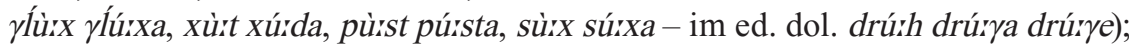

$\leftarrow$ *ù- (im. ed. in rod. ed. kúršč́er kú:šč́erja; rod. ed. júrya, kažúxxa, krúrxa, kúspa, trebú:xa- bú:la, klúuka, lú:ža, múxxa, nústa čreda' - jústro-im. ed. ž in s ned. rúrsa rússo 'rjav' - im. ed. m ned. čúrden);

$\leftarrow$ *Ī̄ (dùsh, ù̀k'volk'; im. ed. in rod. ed. Xú:m Xúuma, pú:š pú:ža - túršča, žúrna - im. ed. $\mathrm{m}$ in ž ned. tùrst túrsta); púnno);

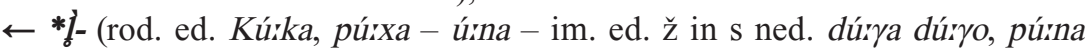

$\leftarrow *_{i ̄ u} \mathrm{v}$ primeru dúuj dú:ja dú:je;

$\leftarrow$ v prevzetem besedju (púnńa);

ixe $\leftarrow *$ ě (brìeh, brìest, cirep, cvìet, ìes, lìes, mìex, slìet, snireh, svìret, Žlìrep; Níremc; im. ed. in rod. ed. dríren drírena, yrírex yrírexa, xlíreu xlíreva, smírex smírexa; lírešenk lírešenka; mìesc mìesca; rod. ed. xlìrepca-lírexa, líreska, stírena, strírela, zvírezda; klírešče; besìreda, obìela, sirenca - Brìezje, smrìrečje; dlíreto,

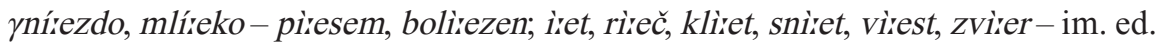
ned. bíreu bírela bírelo, ríredek ríretka ríretko - im. ed. dol. lírevi líreva líreve - im. ed. $\mathrm{m}$ in ž ned. blìret blíreda, cireu círela, lìen lírena, lìep lírepa, slìep slírepa, srìep srírepa);

$\leftarrow$ *ĕ̀- (rod. ed. človíreka, orírexa, sanosíreka, sosíreda, svíredra - bríreka, bríreza, círesta, mírera, mríreža, plíreša, rírepa, smríreka, strírexa - dírelo, líreto, míresto; kolíreno, políreno, želírezo; bríreme, síreme, slíreme, tíreme - im. ed. ž in s ned. zdrírela zdrírelo);

${ }^{7}$ Kjer to ni posebej navedeno, znak * uvaja prvine izhodiščnega splošnoslovenskega fonemskega sestava. 
$\leftarrow$ *ē po skrčitvi < *-biè (im. ed. Bazoíre, Kleníre, koraníre, žyaníre - im. mn.

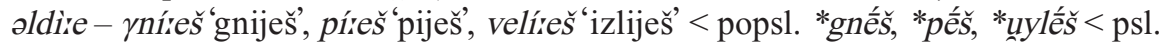
*gnьièšs, *pьiéšs, *u్nlbiéšs $)$;

Odraz issln. ${ }^{*} \bar{e}$, nastalega po razvitem tipu skrčitve, ${ }^{8} \mathrm{v}$ nadiškem narečju kaže na to, da je ta ${ }^{*} \bar{e}$ fonološko sovpadel s issln. *ě in ne issln. ${ }^{*} \bar{e}$, saj izkazuje enake

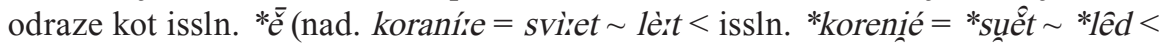
psl. *korenbiè, *suét

$\leftarrow *_{\bar{i}} \mathrm{v}$ položaju pred $r$ (žirer; im. ed. in rod. ed. mexírer mexírerja, pastírer pastírerja);

$\leftarrow *_{i-\mathrm{v}}$ položaju pred $r$ (rod. ed. sírera 'sir' - skírera - síreršč́e);

$\leftarrow *_{i}$ v položaju pred $r \mathrm{v}$ prevzetem besedju (funcjonírerat, študírerat);

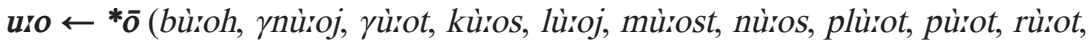
rùroh, sùrok; im. ed. in rod. ed. duxùror duxùrorja, yaspùsot yaspùroda, zlùrodi zlùrodja - blaүùro, kolùro, mesùro, nebùro, prosùro, senùro, testùro, uxùro, zlatùro - kakùroš, kùrost, mùroć, nùroć - im. ed. m ned. bùros - rod. mn. otrúrok);

ex $\leftarrow *_{\bar{e}}$ (lè̀t, mèst; korèrn, plamèrn; im. ed. in rod. ed. večèrr večèrra-jezèrro, sərcèr - jesèrn; pèzjč́, smèrt - im. ed. $\mathrm{m}$ in s ned. vesèru vesèrlo);

$\leftarrow{ }^{*} \dot{e}$ - (rod. ed. studérnca - debérlca, pastérlá, térpka, žérmba, žérnska močérńe; im. mn. čérla, rérbra, sérdla - del. na -lm mérdu, nérsu, pérku, rérku, térku - im. ed. ž in s ned. debérla debérlo - im. ed. dol. dérsni dérsna dérsne);

$\leftarrow{ }^{*} \bar{\varepsilon}$ (plèrs, rèrt; pértk; im. ed. in rod. ed. rérp rérpa - pérta - imèr, prasèr pèrst, vèrs - im. ed. ž ned. čèrdna-im. ed. $\mathrm{m}$ in s ned. ledèrn ledèrno, lesèrn lesèrno, posnèrt posnèrto, strupèrn strupèrno - im. ed. dol. svért svérta);

$\leftarrow$ *è-(rod. ed. poylérda, zérta-dérteĺa, srérč́a-jértra - im. ed. m ned. čérden - ned. Žért);

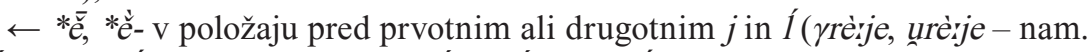
sèıjč - pandèilk; brérja - ned. oblérjč́, sérjč - nedérla, vérja - vérje);

$\leftarrow * a \bar{i} i \mathrm{v}$ primeru zèrjc zè̀j $j c a$

$\leftarrow$ v prevzetem besedju (kapèrla);

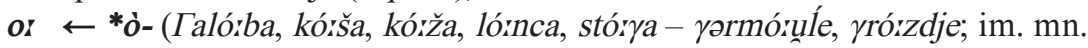
ó:kna - im. ed. m ned. dórbər, mó:kər, órstər, tó:pu);

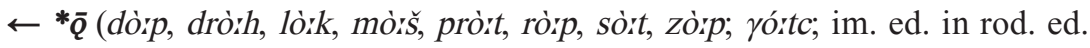

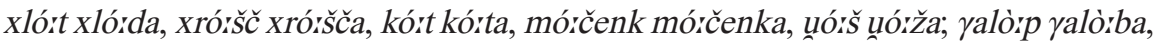

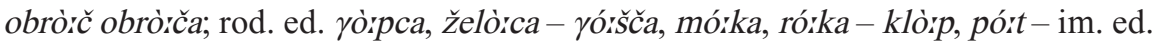
ned. mórdor mórdra mórdro, unózzek unórska unórsko, unórtu unórtla unórtlo - im. ed. m in

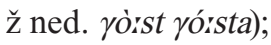

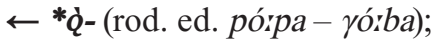

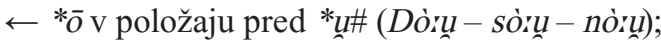

$\leftarrow$ v prevzetem besedju (batòin, facòıu, kantò:n, madònn);

8 Šivic-Dular 1998, 14-18, 31-32.

9 Razviti tip skrčitve je S pomočjo nadiškega gradiva mogoče datirati tudi relativnokronološko. Oblike tipa nad. əldìe < psl. *lûdbie bi namreč kazale na to, da je bila kontrakcija v času spl. sln. naglasnega pomika s psl. starocirkufmlektiranega zloga na naslednji zlog, ki se datira v 10./11. st., še v teku. 


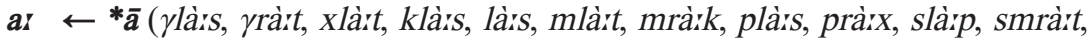

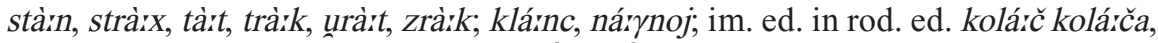
komárr komárrja, kovárč kovárča, krá:í krá:Ía, lopárr lopárrja, mlá:i mlárja, plá:šč plá:šča, roká:u rokárva, sorńá:k sorńá:ka, žárr žárra; prá:zenk prá:zenka, trárunenk

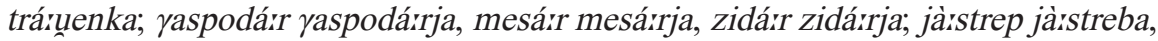

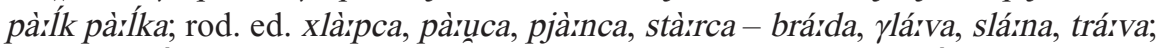

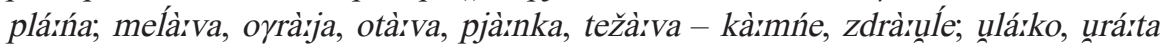

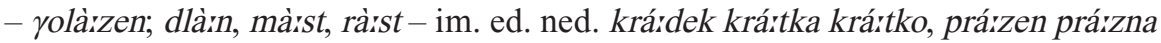

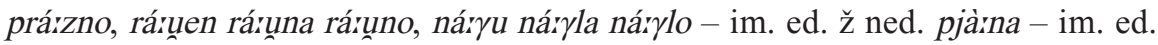

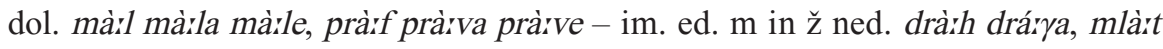
mlárda, nà:h nárya, plà:n plá:na, sà:m sá:ma, slà:n slá:na, zlà:t zlá:ta);

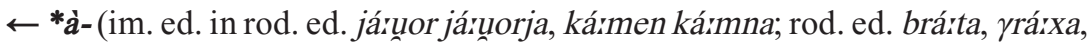
xrá:ma, Lá:xa, lá:za, má:ka, mačerárda, modrársa, mrá:za, obrá:za, potplá:ta, prárya,

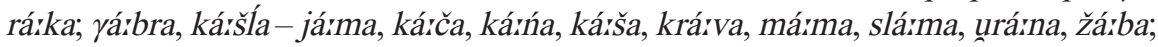
lopárta - blárto, márslo, sárdlo (!); klárdvo, tná:lo - lárkot, pá:met, stárrost - im. ed.

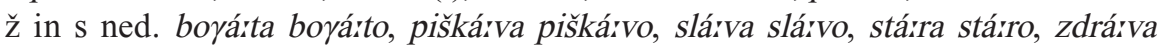
zdrárvo - im. ed. m ned. ylá:dek, lárčen - im. ed. ned. s pjá:no);

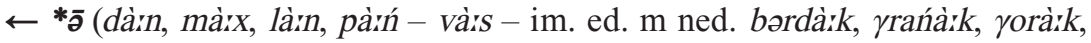
sladà:k, težà:k - bolà:n, dužà:n, dromàin, laxà:n, mastà:n, mexà:n, močà:n, potà:n, prašà:n, sočà:n, stormà:n);

$\leftarrow$ *j̀- (márša - im. ed. m ned. márdu, pársji);

$\leftarrow$ v prevzetem besedju (im. ed. ž in s ned. plárva plárvo);

or $\leftarrow{ }^{*} \bar{r}$ (tórńe - òrž, smòrt-mórtu-im. ed. dol. pòrf pòrva pòrve);

$\leftarrow{ }^{*} \dot{\zeta}-($ yórlo, zórno - im. ed. ž in s ned. mórzla mórzlo);

$\leftarrow *_{-} \grave{r}($ vòr $x)$.

\subsubsection{Kratki naglašeni samoglasniki}

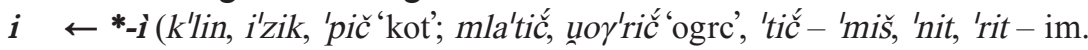
ed. m ned. 'čist, 'siü, 'sit, 'tix);

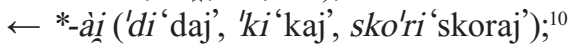

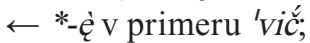

$\leftarrow *_{-j}$ v primeru $o^{\prime} \gamma$ iń;

$\boldsymbol{u} \leftarrow \boldsymbol{*}_{\text {-ù }}\left({ }^{j} \mathrm{juh}, \mathrm{ka} \mathbf{a}^{\prime} \mathrm{z} u x, k^{\prime}\right.$ rux, 'kup - im. ed. m 'rus);

$\leftarrow *_{-}-{ }_{0}(' K u k$, 'pux - im. ed. m 'duh, 'pun);

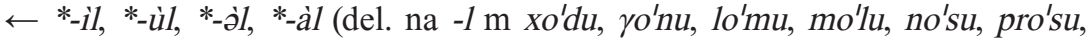
to'ču, uno'zu; del. na $-1 \mathrm{~m}$ 'ču; ko'tu, o'ru, pa'ku - del. na $-1 \mathrm{~m}$ 'šu; del. na $-1 \mathrm{~m}$ če'su, dor'žu, i $\left.\gamma^{\prime} r u, k l e^{\prime} s u, k o ' p u, p e^{\prime l} u, p o z^{\prime} n u, m e^{\prime} t u, z^{\prime} n u\right)$;

$\boldsymbol{e} \quad \leftarrow$ *-è̀(člo'vek, x'lep, x'ren, med'vet, op'len, o'rex, sano'sek-zd'reu-del. na

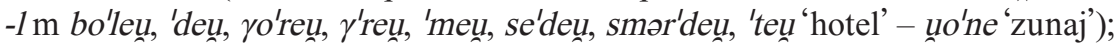

$\leftarrow *_{\text {-è }}\left({ }^{\prime c} \mathrm{e} e p\right.$ - im. ed. m ned. de'beu, or'men, ze'len);

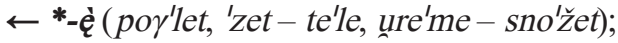

$\leftarrow$ prednaglasni *e v zlogu pred * $*_{-i}$, *̇̀ (stu'denc, Ko'bart);

$\leftarrow{ }^{*}$-j̀ v položaju pred ${ }^{*} n$ in *ń (a'den 'eden', po'zen, ske'deń);

${ }^{10}$ Prim. ledinsko ime (Perati) or. ed. Pot krárjam, tož. ed. Pot k'ri. 
$\leftarrow *_{-i}$ v položaju pred $n$ v primeru pete'len;

$\leftarrow$ prednaglasni *ov primeru 'seda 'zdaj';

$\boldsymbol{o} \leftarrow{ }^{*}$-o ('bop, $\gamma^{\prime} r o p, \gamma^{\prime} r o s t, k^{\prime} l o p$, 'koun, 'koń, 'mol, 'pot, sa'kou 'sokol', s'nop,

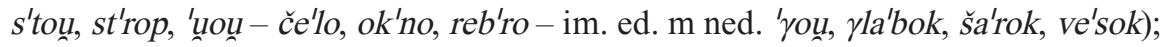

$\leftarrow *_{\text {- }}$ ('pop 'popek' - tož. ed. sest'ro, te'to, že'no);

$\leftarrow$ prednaglasni *o v zlogu pred *i, *jo ('bošč - ka'zounc, k'lounc, 'konc, 'korc, 'lonc, z'unonc);

$\partial \leftarrow{ }^{*}$-j̀ v položaju pred izglasnim $*_{r}\left(\check{c} e^{\prime} b ə r\right)$

$\leftarrow{ }^{*} \varnothing \mathrm{V} *$-rn $($ Kə'ron, to'ron - čə'ron);

$\leftarrow *_{-i}$ v položaju pred $r$ ('sər'sir');

a $\leftarrow$ *à (b'rat, $\gamma^{\prime}$ rax, x'ram, 'Lax, 'las, 'mak, mače'rat, mod'ras, m'ras, ob'ras, potp'lat, p'rah, 'rak - t'la - im. ed. m ned. bo'yat, p'jan, piš'kaun, s'lab, s'tar, zd'raun);

$\leftarrow$ *-̀े ('bat, 'daš, 'pas, sta'bar - 'vas 'ves');

$\leftarrow$ prednaglasni *av zlogu pred *-i (Ko'bart);

$\leftarrow$ v prevzetem besedju ( $p^{\prime} l a u$ ).

\subsubsection{Nenaglašeni samoglasniki}

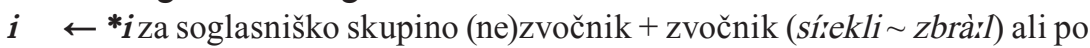
naliki na naglašeni položaj (im. ed. s ned. ynilùro $\sim$ Žvùro, tož. ed. zmòr ob mlajšem Živùio, zimòi);

$\leftarrow *_{i e ̨-}\left(i_{c}^{\prime} m e n, i^{\prime} z i k\right) ; *_{-e ̌ i}, *_{i a-}$ *-oi-v primerih zlùrodi, i'sen, i'ce, unis'ka;

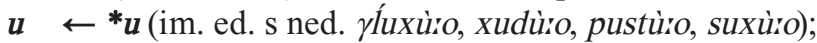

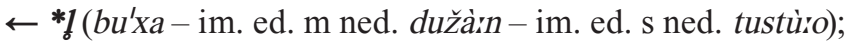

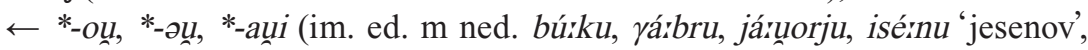
sosíredu, ${ }^{11}$ bú:ku, brítu, círerku; 'ta na Múrruc);

$\leftarrow{ }^{*}$-il, drugotni *av soglasniškem sklopu soglasnik + 1 , *-al, *-ěl(del. na -lm

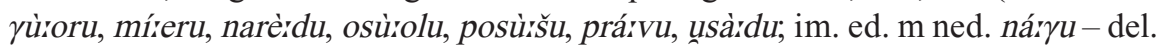

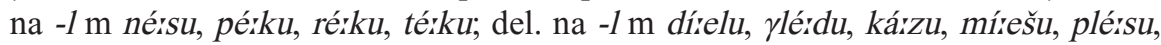
zvérzu; kírsu - del. na -l vírdu, víredu);

$\leftarrow{ }^{*} \oslash \mathrm{v}$ primerih bušè̀la, duxùror;

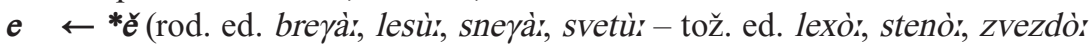
- im. ed. s ned. bledùro, celùro, lenùro, lepùro, slepùro, srepùro);

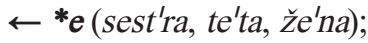

$\leftarrow{ }^{*} \varepsilon$ (rod. ed. pestì, vezir);

$\leftarrow$ prednaglasni *ov primerih če'bor, Če'dat, ske'deń;

$\leftarrow$ drugotni *o v soglasniškem sklopu soglasnik $+m / n$ ( olàzzen, piresem); ponaglasni *ə pri pridevnikih na $*_{-}$一n in $*_{-} \curvearrowright k$, ki je prvotno najverjetneje onemel (kot npr. pri samostalniških na *-əc in *-ək, npr. xlà:pc, júnc-pértk, pandèrĺk), kasneje pa se je za olajšanje soglasniškega sklopa ponovno vrinil neobstojni $e$ (im. ed. m ned. čérden, čúrden, lárčen, mlárčen, prá:zen, rá:unen, trúrden - ylárdek, krárdek, nírzek, ríredek, úórzek);

$\leftarrow *$ os sklopu *črě (čerìrešńa, čerìreulí, čerìres);

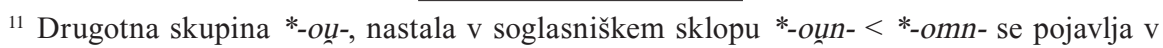
nad. pítun pítuna pítuno 'velik o sadu, plodu; necepljen, o sadnjem drevju' $<$ issln. *pitomn-< psl. *pïtombn-. 
$\leftarrow$ prednaglasni $*_{i}$ v položaju za $v$ (veníkka, ve'sok veso'ka veso'ko - v psl. predponi *uy-kot npr. v vebrárt, vekírdat, velít, vepíkat);

$\boldsymbol{o} \quad \leftarrow{ }^{*} \boldsymbol{o}\left(k^{\prime}\right.$ sa, ko'za, os'la, uno'da - líreto, míresto, ulárko 'del sani');

$\leftarrow{ }^{*} \boldsymbol{Q}$ (rod. ed. sosíreda; možài, robùs, zobài - rod. ed. klopì - im. ed. ned. s rostùro);

$\leftarrow$ *ə v primerih lox'no 'lahko', uno'ne 'zunaj';

$\leftarrow *_{a u}$, *u v v primerih rlonírk, Bazoíre;

ə $\leftarrow{ }^{*} r$ skupaj z $r$ (im. ed. ž in s ned. mort'va mort'vo - im. ed. ž in s ned. $\left.\gamma \partial r^{\prime} d a, t^{\prime} d a\right)$;

$\leftarrow$ drugotni *ə v soglasniškem sklopu soglasnik + r (vì̀ətər-dó:bər, mórdər, mó:kər, óstər);

$\leftarrow *_{r i}$ po izpadu nenaglašenega $*_{i}$ ob $*_{r}$ skupaj z $r$ (bərdà:k bərt'ka bərtkùro,

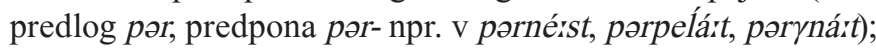

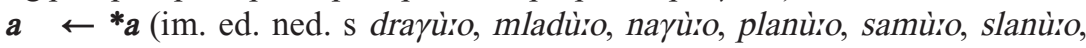
zlatùio);

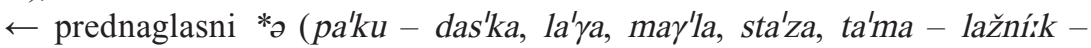
staklérnca, žańírca - im. ed. ž in s ned. mad'la mad'lo);

$\leftarrow$ prednaglasni $*_{O}$ najverjetneje položajno (sporadično disimilatorično $o$-jevsko akanje, pogosteje za mehkonebniki in ustničniki) (damóru - yalòxp,

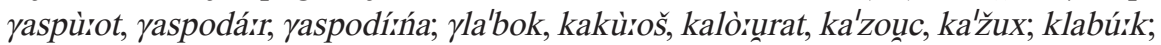
mače'rat, pa'loh, pandèrík, pastérla, pa'tok, sa'koun, sabórta, taporíršče);, ${ }^{12}$

$\leftarrow$ ponaglasni $*_{o}$ redko (síreratka);

$\leftarrow$ prednaglasni *e, *ě sporadično (e-jevsko akanje) (a'den ad'na ad'no, rrańà:k, mazìnc, sano'sek, tras'ka, vas'na);

$\leftarrow$ prednaglasni $*_{i}$ v primeru ša'rok.

\subsubsection{Izguba samoglasnikov}

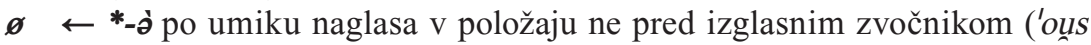
- ka'zounc, k'lounc, 'konc, 'korc, 'lonc, z'unonc - stu'denc);

$\leftarrow$ ponaglasni *əv položaju ne pred izglasnim zvočnikom, npr. v priponskih

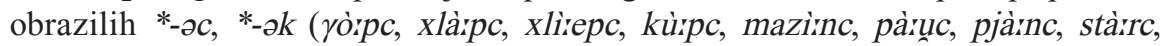

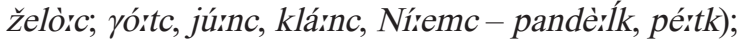

$\leftarrow$ *-i po umiku naglasa v položaju ne za soglasniškim sklopom (ne)zvočnik + zvočnik ('bošč, Ko'bart, 'velk-im. mn. ot'roc-daj./mest. ed. '̌̌en, 'kop-mest. ed. po'noć, ú 'peč, ú 'vas, ko'koš-2. os. ed. velelnika 'nes, 'unos); ${ }^{13}$

$\leftarrow$ izglasni ponaglasni $*_{i}$ v odprtem zlogu v položaju ne za soglasniškim sklopom (ne)zvočnik + zvočnik (lá:n - dosledno v daj./mest. ed. samostalnikov a-jevske sklanjatve $\mathrm{z}$ nepremičnim naglasom na osnovi in mešanim naglasmom

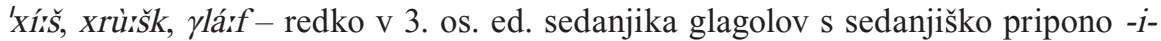
tipa mórt, kjer je bil onemeli *-i nalikovno nadomenščen z -e-iz oblik, v katerih se

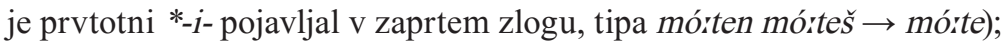

12 Pogoji, v katerih prihaja do položajnega o-jevskega akanja, so opredeljeni takole: »disimilacijsko akanje « (Logar 1966, [149]), »v položaju za labiali in velari ter sporadično za dentali« (Logar 1981b, [257]), »za k, h, m, p« (Logar 1996a, [315]).

${ }^{13}$ Prim. 3.3.1. 
$\leftarrow$ neizglasni ponaglasni $*_{i}$ v priponskih obrazilih -ica, -ina (jú:žna, krá:fca, ló:nca, níífca, pá:lca, prá:fca, rú:sca, tá:šca, žá:pca);

$\leftarrow$ prednaglasni $* i$ v položaju ob zvočnikih (dosledno v položaju za $r$ : bərdà:k bərt'ka bərtkùro 'priden', predlog pər, predpona pər- npr. v pərnérst, pərpelát, pərүnást - dosledno $\mathrm{v} \mathrm{mn}$. in $\mathrm{dv}$. sed. glagolov s sed. pripono $*_{-i}$, kjer je bil $*_{i}$ sicer nalikovno nenaglašen, npr. živmór žiftár živjór živmár žiftá: žiftár, tako boljór, visjór, tiščjór, živjór - nedosledno v drugih pregibalnih vzorcih: starejše zíma zmò: za običajno zíma zimò', starejše žìiu žírva žvùro za običajno žìu žííva živùio - Žvàiu Žvalì, Žvína;

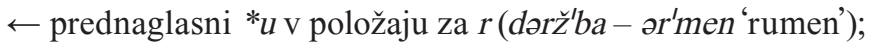

$\leftarrow{ }^{*}$ e, ${ }^{*}$ e $\mathrm{v}$ položaju ob $r$ (or'men 'jermen', por'češ 'porečeš, nardmó: 'naredimo');

$\leftarrow$ *ě v večzložnicah v položaju za $s$ redko ( príreska, skírera - sno'žet);

$\leftarrow$ ponaglasni *ę $\mathrm{v}$ primerih mìresc mìesca, pàiĺk pàilka, zèrjc zè̀jca ob naslonitvi na samostalnike s priponskima obraziloma $*_{-} \curvearrowright c, *_{-} \curvearrowright k$;

$\leftarrow{ }^{*} O$ v položaju ob $\underline{n}\left(u^{\prime} c a-\gamma\right.$ unorit $\left.t\right)$.

\subsection{Soglasniški sestav}

\subsubsection{Zvočniki}

Nastali iz enakih izhodiščnih splošnoslovenskih zvočnikov, poleg tega pa še:

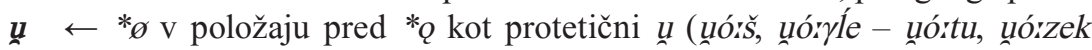
- unó:xat);

$\leftarrow{ }^{*} b$ v primeru $k^{\prime} l o u c k$ kloụ'ca 'klobčič;;

$\boldsymbol{V} \leftarrow *_{u} \mathrm{v}$ položaju pred nezaokroženimi (naglašenimi ali nenaglašenimi) samoglasniki, ki niso onemeli (vídet, víredet, vàrs, vər'ca 'vrv za vezanje sena,

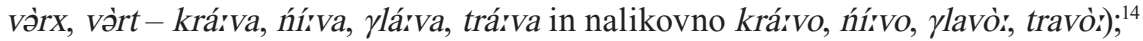

$\boldsymbol{m} \leftarrow{ }^{*} b$ v skupini ${ }^{*} b n$ (im. ed. ž in s ned. drom'na dromnùro);

$\boldsymbol{n} \leftarrow{ }^{*} m$ v položaju, ko ta ni pred ustničnikom, izjema je ustničnik ${ }^{*} m$ (končnica -m/-n za 1. os. ed. sed. direlan\#, ${ }^{15}$ re'čen\#, sən dírelu, sən 'šu səm víredu, səm prá:vu - končnica -en za or. ed. m pridevnikov in zaimkov $z$ nen dob'ren človírekan, $z$ nen dob'ren mò̀žan $\sim$ Z nen dob'rem pùroban); ${ }^{16}$

$\leftarrow * I$ po različenju $\mathrm{v}$ soglasniškem sklopu $* I l$, nastalem po onemitvi neneglašenega *i (so mírsenli 'mislili so', sta mírsenla 'mislila sta');

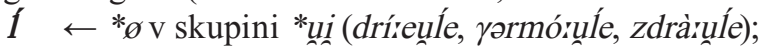

${ }^{14}$ Na sledi glasovne spremembe issln. *u $>$ Jevšček $b$ v položaju pred sprednjimi samoglasniki bi kazal primer Jevšček bazobínna 'bezeg' < psl. *bъzouilna. Mogoče je tudi, da je leksem prevzet iz sosednjih govorov (Piki, Avsa, Perati, Plohi, Livek), kjer je ta prehod znan. Na mešanje odrazov za issln. *u in issln. *bbi kazala tudi primera s'lap slárva slárvo < psl. *släbъ *släba *släbo s issln. *ụ v medsamoglasniškem položaju in bazò:un bazùrola 'vozel' s protetičnim *u‥

${ }^{15}$ Znak \# označuje pavzo.

${ }^{16}$ Prehod issln. *-m> - $n$ je značilen za večino nadiških govorov z izjemo govorov Dreke in okolice (Logar 1966, [150]) ter govorov na Livškem z izjemo Jevščka. 
$\leftarrow *$ Iv primeru $\gamma$ ĺùix

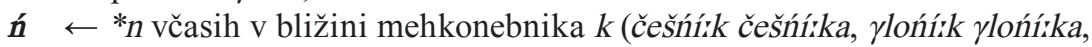

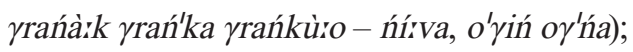

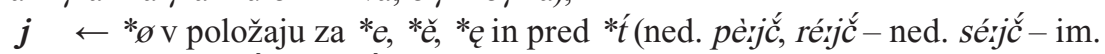
ed. $\mathrm{m}$ in s ned. ordérjč́a ordérjč́e).

\subsubsection{Nezvočniki}

Nastali iz enakih izhodiščnih splošnoslovenskih nezvočnikov, poleg tega pa še:

$\boldsymbol{d} \leftarrow{ }^{*} \varnothing \mathrm{v}$ skupinah ${ }^{*} z r$, *žr (zd'reu zdrírela zdrírelo; ždríret, ždre'be);

$\leftarrow{ }^{*} t$ v primeru krárdek krástka krástko po naliki na tip ríredek ríretka ríretko,

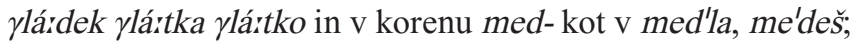

$\check{\boldsymbol{s}} \leftarrow *_{S}$ v položaju pred *ń ali drugotnim ń(češńík češńíḱ ‘česen');

$\leftarrow *^{*} \check{c}^{\mathrm{v}}$ primeru bušèrla 'čebela';

$\check{z} \quad \leftarrow{ }^{*} Z \mathrm{v}$ položaju pred *ń ali drugotnim ń (or. ed. Ž 'ńí́n' ‘z njim', ž ńó:' 'z njo', Ž ńìm 'z njimi');

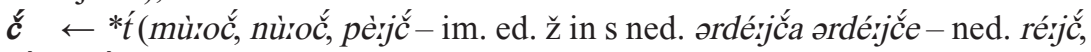
oblé:jč́, sé:jić);

$\gamma \leftarrow *_{g}$ ne v položaju pred pavzo ( $\gamma o ́: b a$, sne $\gamma a ̀$ ) $)$

$\leftarrow *^{*} \varnothing \mathrm{v}$ položaju pred *o redko kot protetični glas ( $\gamma o^{\prime} s a^{\prime}$ osa');

$\leftarrow$ v prevzetem besedju (butìr $\gamma a$, fír $\gamma a)$;

$\boldsymbol{h} \leftarrow *_{g}$ v položaju pred pavzo (snireh);

$\boldsymbol{x} \leftarrow *_{x}($ xlíreu $)$

$\leftarrow$ tujejezični $f$ v starejšem besedju ('luxt);

$\boldsymbol{f} \leftarrow *_{u} \mathrm{v}$ položaju pred nenaglašenim $i$, ki je onemel, in nezvenečim nezvočnikom (ńífca, prá:fca, 'ta na rlá:f, 'tu un niif-im. ed. dol. m prà:f, pòrf);

$\leftarrow$ tujejezični $f$ v mlajšem besedju (brìtof, fír $\gamma a)$.

\subsubsection{Izguba soglasnikov}

$\varnothing \quad \leftarrow *_{i}$ v položaju pred *ě $>$ nad. ire (íren ‘jem', ìes, ìret - končnica im. mn. samostalnikov moške $o$-jevske sklanjatve z mešanim naglasom -ì̌e, npr. oldìe);

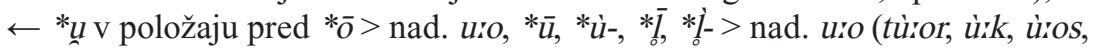

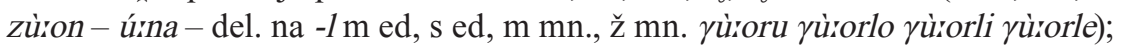

$\leftarrow *_{-u}$ skupaj s predhodnim kratkim naglašenim ali nenaglašenim *o, ki preideta v kratki naglašeni ali nenaglašeni $u$ (glej $3.1 .3 u$ );

$\leftarrow *_{-} 1$ skupaj s predhodnimi kratkimi naglašenimi ali nenaglašenimi $*_{i}$, *u, *a, *a, ki preideta v kratki naglašeni ali nenaglašeni $u$ (glej $3.1 .3 u$ );

$\leftarrow *_{-}-i$ skupaj s predhodnim kratkim naglašenim ali nenaglašenima $*_{a}$, ki preideta v kratki naglašeni ali nenaglašeni $i$ (glej $3.1 .3 i){ }^{17}$

$\leftarrow *_{g}$ v obliki mórú 'mogel'; doli';

$\leftarrow{ }^{*}$, *l skupaj z $*_{i}$ v kratki obliki krajevnih prislovih ' $\gamma o$ 'gor, gori', 'do 'dol, $\leftarrow * d v$ položaju pred $* c(\gamma o ́ r c$, želòrc $)$

${ }^{17}$ Prim. vire za kratka naglašena $i$ in $u$ (razdelek 3.1.2) ter nenaglašena $i$ in $u$ (razdelek 3.1.3). 


\subsection{Naglasni sestav}

\subsubsection{Naglasno mesto}

Nesplošnoslovenske naglasnomestne spremembe so: 1. narečni praslovanski umik naglasa s praslovanskega dolgega srednjega samoglasnika z naglasom tipa novega akuta na prednaglasno kračino ( polóržeš, počérsan) (umik na prednaglasno dolžino je splošnoslovenski: xvá:leš, napírsan); 2. nesplošnoslovenski umik naglasa s cirkumflektiranega dolgega srednjega skrčka na prednaglasno kračino (pózznaš pózznate) (umik na prednaglasno dolžino je splošnoslovenski: mírešaš mírešate); 3. nesplošnoslovenski umik naglasa $\mathrm{s}$ *-j v položaju ne pred izglasnim zvočnikom (ka'zouc, k'louc, 'konc, 'korc, 'lonc, 'ouss, stu'denc, z'unonc če'bor, po'zen) in s *i v položaju ne za soglasniškim sklopom (ne)zvočnik + zvočnik, in sicer dosledno v zaprtem zlogu ('bošč 'božič', Ko'bart 'Kobarid', 'velk 'velik') in nedosledno v odprtem zlogu (im. mn. ot'roc ko'ńi, po'noć).

\subsubsection{Samoglasniška kolikost}

Nesplošnoslovenski kolikostni spremembi sta: 1. zahodno- in južnoslovensko zgodnje podaljšanje kratkih akutiranih samoglasnikov v nezadnjih besednih zlogih, in sicer tako v predzadnjih kot v predpredzadnjih (já:ma, járyoda); 2. skrajšanje prednaglasnega zlogotvornega $*_{\sigma}<{ }^{*} C_{b r C}{ }^{*} C b r C$ (čər'na, $\gamma ə r^{\prime} d a$, tər'da).

\subsubsection{Tonemskost}

Nesplošnoslovenska tonemska sprememba je pojavljanje odraza popraslovanskega novega cirkumfleksa v nekaterih slovničnih kategorijah (deležnik na -l tipa yorìrela; rod. mn. tipa kùspu, bràstu; or. ed. tipa kùspmi, bràstmi; nedoločniki tipa kupist, nosìt, sušist).

\section{Besedilni zgledi}

\subsection{Godec opolnoči gode na pokopališču}

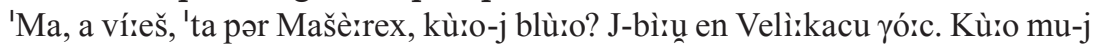

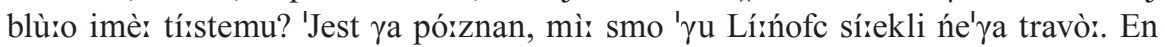

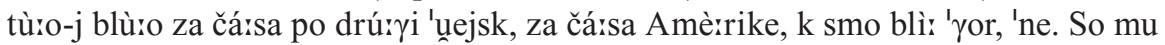
jà:l, mìsslen, de mu dajó: ..., de so mu zbràıl za círeleya telé:t sòzundu kupì̀t, 'ne, če

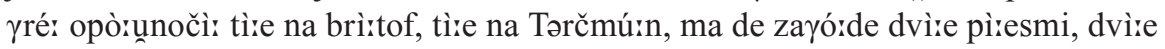

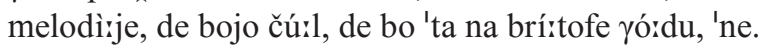

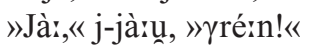

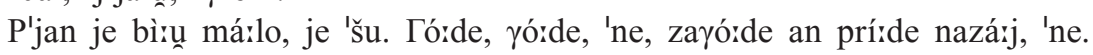

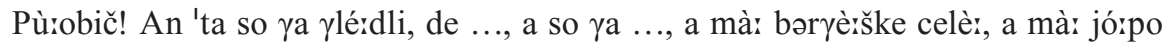
celò:, a so ya rastóryal te mórtvi, 'ne. Kor ní:e blùro 'nič:

»Ma kùıo? A-t ní:eso 'nič narèrdli?»

»'Nič!«

»Ma kù:o-j tùro, de-t níreso 'nič narèrdli! Ja pa bi ti mùrorli 'ki narérst!« 'ne.

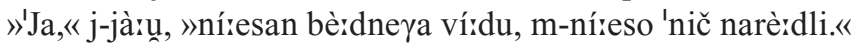

So mírsenli, de prírde 'vas rastòryan nazárj, de ya stòryajo te mórtvi, 'ne. 
An te'le, za círeleya telért kupì̀t dná:rja-j zaslú:žu. An pot'le in je pa prá:vu, kakùıo-j narè:du. Je ré:ku:

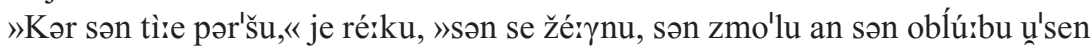
tí:sten mòrtven, k-so 'tan potkó:pani, de pò:u dnárrja, kar ya zaslú:žem, de plà:čan máiše.«

An je pò:ư dná:rja za má:še dà:ư, za tírste mòrtve, jà:.

\subsection{Tatova ponoči preštevata ukradena jabolka na pokopališču}

'Du Čeplešìrščex sta dvà: krá:dla, tatà:, já:pke, 'ne, po'noč. En 'ta sevírede, po'noč celò: nùyoč okò:u xodílla an 'ta:

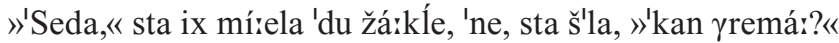

»Jà:, tlè: nas bojo vírdli, nas ưšà:fajo.«

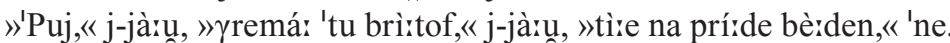

'Ta, kər sta brì̀tof ..., kər sta otpé:rjala unrá:ta, 'ne, se in je tísst žá:keĺ usù:, 'ne, en 'ta so dvì̀e já:pke 'úon pá:dle.

»À:!« j-jà:u, »'naj so tlè̀, sa prírdma pot'le,« 'ne, »sa prírdma pot'le po ńè:,« 'ne.

'Ta sta šlla 'yor za en spomení:k en 'ta sta takolè::

»Ad'no me'ne, ad'no te'be, ad'no me'ne, ad'no te'be,« 'ne, »sta tá:lala já:pke,« 'ne.

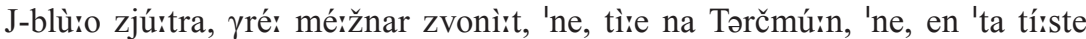
čùrje.

»Ad'no me'ne, ad'no te'be.»

An 'ta letí: xí:tro 'do $\gamma$ yaspùrodu:

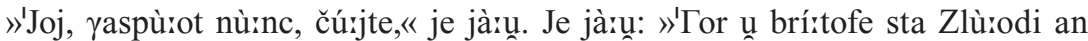
Bùioh, dušírce parttá:, dušírce tà:lata,« j-jà:un.

»A ríres,« j-jàiun, »'puj, 'puj,« j-jà:un.

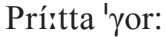

»Ad'no me'ne, ad'no te'be.«

Onà:dvà: sta 'ta za ưrá:tex pa $\gamma$ lé:dla, 'ne, poslušála.

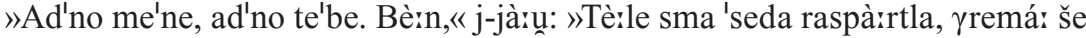
po te drú:ye dvìe 'do zza unráit.«

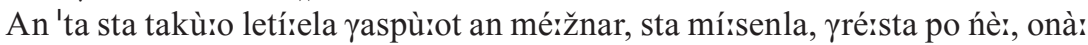

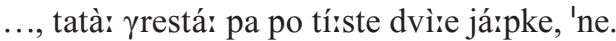

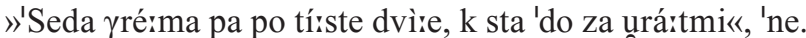

Ta'da sta takù:o letí:ela, de so se im petè: 'tu 'rit tú:kle.

\section{$4.3 \mathrm{O}$ zlodeju in zakladu}

Je b'la na družírna 'do pər Pikó:ne, sa-j vàis, 'ne? En za pòrvi 'maj so blè: šmá:rence, 'ne, cìreu 'maj so xodírl rožá:r 'molt en Marì̀jo častì̀t, má:ja mìresca, 'ne. En 'ta je tista družínna, tist méržnar, k-je bìuu ' yor, so š'li, so cí:erku lepùro opúccal, k-je blùıo 'do spùrot, 'ne. So círerku opúccal en so bríssal prà:x an 'do pər sveten Mixí:ele, 'ne, en 'ta so 'še zlùrodja opúrcal, tí:st ya-j lepùıo opú:cu, zlùrodja,

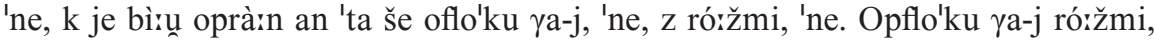
'ne. 
»Nùr, 'seda bo lepùı, smo cí:erku unští:mal, bojo lax'no šmá:rence, «'ne.

En 'ta, je b'la pa navà:da ..., je b'la pa navà:da ux tíssti 'vas za pòrvi 'maj mlá:j míret, 'ne, unsé:jč. De 'kam pó:jde pù̀oń drú:h dà:n, je takolè: študì̀eru. En 'ta po'noč sá:ńa, po'noč je sa'ńu.

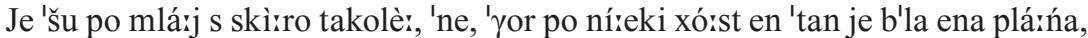
raunírna, an círesta an 'ta príde na čor'nem ko'ńe en mòrš 'sa x ńe'mu, 'ne. Prí́de 'san, tírst końenírk se unstà:ve, 'ne. Je 'meu 'ta pot klabú:kan royè:. Je bì̀u zlù:odi.

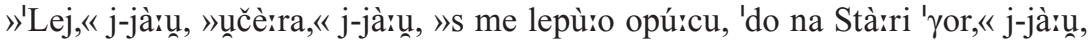

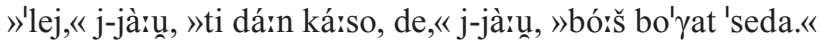

Mu-j dàzu ká:so zlatài, 'ne, en 'ta-j jàzư:

»Zakopàrj jo,« j-jà:u, »te bojo əldì̀e ví:dli, te unkrà:dejo,« j-jàru, »sa mà:š

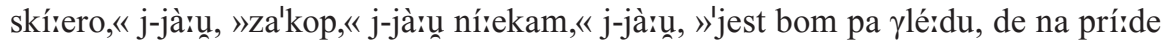
ká:k,«'ne.

En se-j obr'nu, j-šu tì̀e 'pot ..., j-'šu xístro 'ưon s pó:t tì̀e po ... blízu ene' $\gamma a$

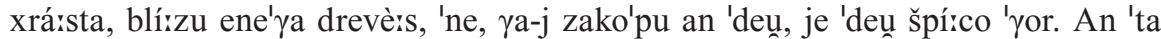
j-pər'šu zlùrodi 'yor.

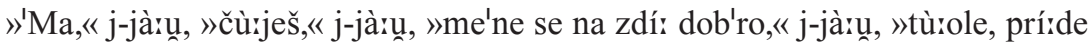
ká:k,«j-jà̀u, »unzá:me špícco an 'ta na boš víredu [kíre-j].»

»Jài, bè̀n,« j-jàzun, »recì̀ mi pa tì̀, 'ki naj nardímm. Ká:ko zná:mje naj dé:nen?«

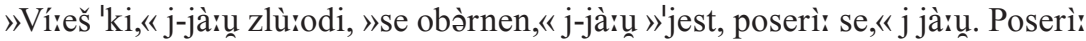
se!« 'ne. »Ti na nobè:den d'rek ưzá:me.«

'On se-j pos'ru, u resnírc se-j pa 'du pasté:í pos'ru. Je 'du pasté:ílo s'ru, de-j začè̀lo smərdí:et en 'ta j-jà:la že'na:

»'Ki dìselaš,«j-jà:la, »tlèr, tlè̀ un onì̀, tlè: un pasté:Ío sé:rješ, «'ne.

En 'ta sta xi ..., je b'la ứsa pasté:ía unmàzzana, ự'sa ká:mra smərdíela, an 'ta: »Ká:-j s tàrbo! Ká:-j s tàıbo!«

En 'ta i prá:vu, 'ne, kùıo-j sa'ńu ob zlùrodja.

»P'rou ti stojír, 'ka si zlùrodja oflo'ku unčèrra. Ká: si zlùıodja,« j-jà:la, »uূčè̀ra oflo'ku«.

\subsection{Sveti Tilih zbeži med mašo $\mathrm{z}$ oltarja}

So mírel tlè: un Benečíiji - ma čá:k, un kérrem krá:ju, je p'rou povíredlo, un ké:rem krá:ju - círerku, je b'la posveče'na svetníkku svértemu Tì̀lixu. On en'kərt na lí́eto

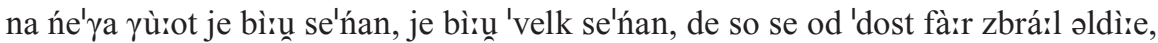

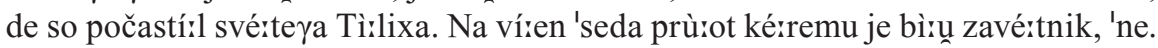
Dob'ro. Zn so tú:t pé:tjarji xodí:l, 'ne, tlè: po Benečíij so petlá:l mó:ko, in je tú:t pre'cej pè:tĺarju xodíilo, $\mathrm{k}$ so petlá:l tlè: po Benečíij, 'ne [...]. In tísst mé:žnar je 'šu 'yor, je očé:du círerku an kar je bì̀u 'vas ot pàijčune an ot praxù: tist svet Tì̀lix, 'ne,

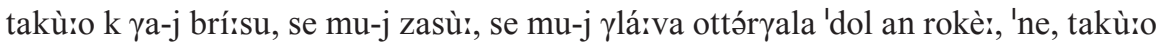
je bì̀u s'tar.

»À:, mú:oj Bù:oh, mú:oj Bù:oh,« je ré:ku, »'ki nardí:n? Jú:tre, jú:tre je prá:znik,« 'ne, »jú:tre je prá:znik, svet Tì̀lix se-m je pa zasù.. Jldì:e me unbí:jejo, me unkú:nejo, 'ne. 'Ki naj nardín?«

U'se, úse se mu j zasú:lo, stáro j blùıo. 
»Ki naj nardí:m?«

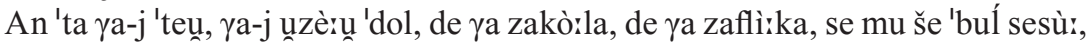
'ne. Je jàrự:

»Drú:zeya mi na preostà:ne ku ...«

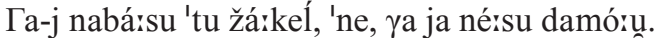

»Гa múroren skrírt,« j-jà:un.

ən ta 'do na pó:t srèrča pa pértlarja, k-je bìru tá:kšen ku své:t Tì:lix. j-jà:u.

»'Jej,« je ré:ku, je ré:ku, »vì̀,« je jàrun, »čúrjte, čúrjte, pùrjte 'do x me'ne,«

»Ja za'ki,« j-jàzún.

An 'ta pé:tlar lá:čen, 'ne, pértĺar lá:čen, mu-j poví:edu, 'ne.

Je jàrư⿱: »'Lej,« j jàru, »'lej, se najiiseš tlè: pər 'men.«

Mu-j dàru za írest, pértlar že dúrgo nie ìredu mesàr.

»Jú:tre,« j-jàrú, »tù:ole,« j-jàrư, »vas naštì:man, k-bo má:ša, 'ne, de vas

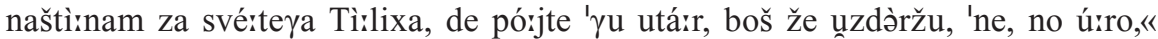
j-jàzu, »ti dá:n, boš ìredu tlè̀ pər me'ne,« j-jàzun, »še trì̀ dnì̀ an en te velì̀k žáikeĺ mó:ke ti dá:n.«

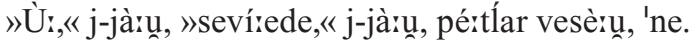

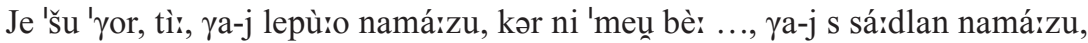

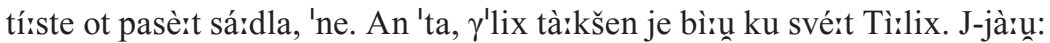

»Bórt zamá:kńen,«j-jàru , »əldìre bodo,«j-jà:un, »bórjo zamárkńeni,«j-jàrun, »če takolè: 'ki nardí:šs, « j-jà:un, »sa na bórjo víredli, 'ne, se 'jem bo zdírelo, 'ne.«

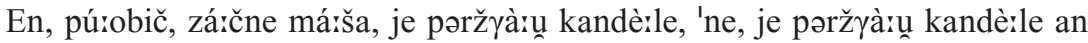
'ta, kandè:le so ya pek'le, 'ne. Je bìuu 'va ..., je bì̀ s sá:dlan namà:zan, so mú:xe 'yo po 'ńen xodírle. An 'ta lepùro 'yor, oldì̀e so ylé:dli:

»Ma ká:-j 'dons své:temu Tìllixu,« 'ne, »de mà: 'vas, de-j 'vas od mùrx, « 'ne,

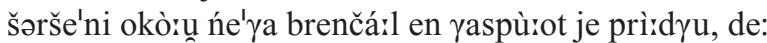

»S'ta poxùrjš ...«, de, »s'ta pokvàrrjeni, poxujšùrjeta drúr $\gamma e$ e. Če na ... se na pobùrojšata, de na bó:ta bùıojš, nas bo své:t Tì̀lix zapùrstu.

»Na bon,«j-jau, » »čá:ku pobùrojšańa,« an 'ta j sko'ču 'ư⿱on z utá:rja an damórú, 'unon s círerkve utérku. An 'ta əldìre ərjú:l, tulí:1, šlli, yaspùrot le'teư, 'ne, de-j b'la ob momé:ntu círerku prá:zna. U'se tírste žbrìnčĺe, k-so predàijal, ư⿱'se-j letí:elo, ư⿱'se-j pùistlo, ứse ứse-j letírelo. En 'ta mé:žnar je víredu, mé:žnar je ví:du, je bì:u tí:xo. 'Ta ní:e bèxdnemu prá:vu, 'ne. An pértlar ní:e màrj 'vič pər'šu, de mu ní:e blùro trí:eba ne trì: dnì: írest mu dá:t an mó:ko, žá:kĺa, 'ne.

\section{Zaključek}

Govor vasi Jevšček pri Livku spada v okvir nadiškega narečja slovenščine, to pa $\mathrm{v}$ beneško-kraško skupino zahodnih slovenskih narečij. Najznačilnejše glasovne spremembe, preko katerih je iz izhodiščnega splošnoslovenskega fonemskega sestava (Logar 1981a) nastal fonemski sestav jevškega govora, je z zgodovinskoglasoslovnega stališča na osnovi relativne kronologije njihovega nastanka in posledično njihove zemljepisne razširjenosti na slovenskem jezikovnem 
$4 \quad$ ozemlju (Rigler 1963) mogoče razdeliti na zahodnoslovenske, beneško-kraške, splošnonadiške in nesplošnonadiške.

Zahodnoslovenske značilnosti so: 1 . issln. ${ }^{*} \bar{e} /{ }^{*} \bar{o}>$ ire/uro(Jevšček lìres, sìenca, mlíreko; bùroh, mesùro, rod. mn. otrúrok), skupno s severnimi slovenskimi narečji; 2. zgodnje podaljšanje issln. kratkih akutiranih samoglasnikov v nezadnjem besednem zlogu in posledično npr. sovpad odrazov issln. *ě in issln. *è̀- (Jevšček círesta, líreto, rod. ed. orírexa), skupno z južni slovenskimi narečji; 3 . issln. ${ }^{*} /{ }^{*}$ j̀-> ar (Jevšček dànn, bolà:n, pássji), skupno z južnimi slovenskimi narečji.

Beneško-kraška značilnost je pozno raznosnjenje psl. nosnih samoglasnikov $*_{e} / *_{Q} Q$ in posledično njuna (prvotna) široka odraza z odsotnostjo udvoglašenja:

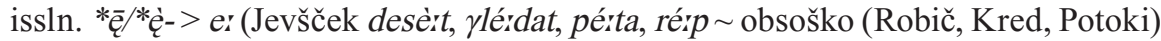

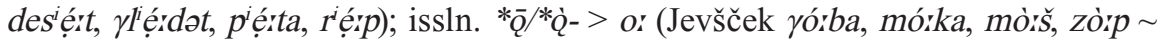

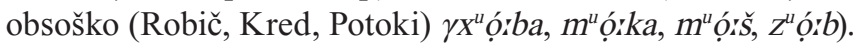

Splošnonadiške značilnosti so: 1 . prisotnost (podedovanih) tonemskih nasprotij in odsotnost naglasnega umika tipa issln. *sestrà, *kozà, *moglà > *sèstra, *kòza, *mògla (Jevšček sest'ra, ko'za, may'la briško (Šmartno) sè̀stra,

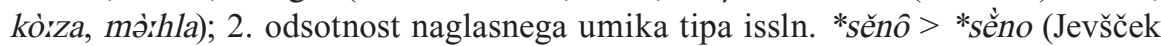
senùro, tož. ed. unodòr tersko (Subid) sé:no, tož. ed. unórdọ) ter naglasnih pomikov tipa issln. *zímà > *zīmä (Jevšček mó́ka, zírma tersko (Subid) mo'́ka, zi:'ma) in issln. *iùžina > *iužina (Jevšček dírelat, jú:žna tersko (Subid) die'lato, ju'žəna).

Nesplošnonadiške značilnosti so: 1 . issln. ${ }^{*}-m>-n$ (Jevšček direlan, pod

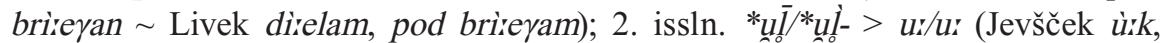
ú:na Livške Ravne vù̀k, vú:na); 3. issln. *í > Í (Jevšček klúrč, pù̀ole $\sim$ Ošnje kjú:č, pùoje); 4. issln. *u $>V$ v položaju pred nezadnjim samoglasnikom (Jevšček vídet, 'velk, vàrs, pod vasjó: Livek bírdet, 'belk, ùàss, pod unasjó:); issln. *u $>$ f po onemitvi sledečega sprednjega samoglasnika (Jevšček pòrf, prá:fca Livek pòrp, prá:pca); 5. issln. ${ }_{-j}$ j/*-i> $>$ (Jevšček 'konc, 'velk Ošnje ko'nac, ve'lik); issln. *-ə> $\varnothing$ (Jevšček xlàspc, píresk Ošnje xlàrpac, piẹ́sak). Govor izkazuje relativno majhno stopnjo t. i. sodobnega samoglasniškega upada (popolnoma lahko onemita samo $*_{\partial} / *_{-} \dot{\partial}$ in $\left.*_{i} / *_{-}-i\right)$, ki pa je večja kot $\mathrm{v}$ nadiških govorih, ki ne mejijo na obsoško narečje (Ošnje).

V govoru Jevščka je v besedi sá:dlo < psl. *sädlo ter morda v krajevnih imenih Sed'lo $<*$ sedló in Stà:re sed'lo < *stäroịe sedló ohranjen psl. soglasniški sklop *dl, ki je $\mathrm{v}$ slovenščini splošno znan $\mathrm{v}$ ziljskem narečju, $\mathrm{v}$ ostankih pa tudi $\mathrm{v}$ ostalih koroških slovenskih narečjih (Ramovš 1924, 195-197). V posameznih besedah (in $\mathrm{v}$ omenjenih krajevnih imenih) se ta soglasniški sklop ohranja tudi v obsoškem narečju, in sicer tako v bovškem (Bovec jérdu/jérdla 'jelka', sárdlo, šírdlo; Ivančič Kutin 2007) kot v kobariškem podnarečju (Libušnje sádlọ; Pleteršnik 1894/95).

\section{Literatura}

Bezlaj, France, 1976, Etimološki slovar slovenskega jezika. Prva knjiga. A-J, Ljubljana. 
Bezlaj, France, 1982, Etimološki slovar slovenskega jezika. Druga knjiga, K-O, Ljubljana.

Bezlaj, France, 1995, Etimološki slovar slovenskega jezika, Tretja knjiga. P-S, dopolnila in uredila Marko Snoj in Metka Furlan, Ljubljana.

Bezlaj, France, 2005, Etimološki slovar slovenskega jezika. Četrta knjiga, Š- ̌̆, avtorji gesel France Bezlaj, Marko Snoj in Metka Furlan, uredila Marko Snoj in Metka Furlan, Ljubljana.

Дыбо, В. А., 1981, Славянская акиентология, Москва.

Дыбо, В. А., 2000, Морфологизованные парадигматические акцентные системь, Москва.

Furlan, Metka, 1991, Slovensko slima 'aliua, plouagne' (Alasia) in srbohrvaško slîm (Žumberek) - novo gradivo za slovansko-germansko izogloso *slímb : *slìma-, Jezikoslovni zapiski 1, Ljubljana, 25-30.

Ivančič Kutin, Barbara, 2007, Slovar bovškega govora, Ljubljana.

Logar, Tine, 1951, Obsoško-nadiška dialektična meja, Slavistična revija 4, Ljubljana, 223-237, ponatis v Logar 1996, 137-147.

Logar, Tine, 1981a, Izhodiščni splošnoslovenski fonološki sistem, Fonološki opisi srpskohrvatskih/ hrvatskosrpskih, slovenačkih i makedonskih govora obuhvaćenih opšteslovenskim lingvističkim atlasom, ur. Pavle Ivić idr., Sarajevo, 29-33, ponatis v Logar 1996, 243-247.

Logar, Tine, 1981b, Ošnje pri Sv. Lenartu (Osgnetto; OLA 2), Fonološki opisi srpskohrvatskih/hrvatskosrpskih, slovenačkih i makedonskih govora obuhvaćenih opšteslovenskim lingvističkim atlasom, ur. Pavle Ivić idr., Sarajevo, 41-46, ponatis v Logar 1996, 254-258.

Logar, Tine, 1981c, Šmartno v Brdih (OLA 4), Fonološki opisi srpskohrvatskih/ hrvatskosrpskih, slovenačkih i makedonskih govora obuhvaćenih opšteslovenskim lingvističkim atlasom, ur. Pavle Ivić idr., Sarajevo, 53-58, ponatis v Logar 1996, 264-269.

Logar, Tine, 1996, Dialektološke in jezikovnozgodovinske razprave, uredila Karmen Kenda-Jež, Ljubljana.

Pleteršnik, Maks, 2006 (1894/95), Slovensko-nemški slovar, Transliterirana izdaja, Ljubljana. [elektronska različica]

Ramovš, Fran, 1924, Historična gramatika slovenskega jezika II, Konzonantizem, Ljubljana.

Ramovš, Fran, 1935, Historična gramatika slovenskega jezika VII, Dialekti, Ljubljana.

Ramovš, Fran, 1936, Kratka zgodovina slovenskega jezika, Ljubljana.

Ramovš, Fran, 1950, Relativna kronologija slovenskih akcentskih pojavov, Slavistična revija 3, Ljubljana, 16-23.

Ramovš, Fran, 1952, Morfologija slovenskega jezika, Ljubljana.

Ramovš, Fran, 1971, Zbrano delo I, uredila Tine Logar in Jakob Rigler, Ljubljana. Ramovš, Fran, 1997, Zbrano delo II, uredil Jože Toporišič, Ljubljana.

Rigler, Jakob, 1963, Pregled osnovnih razvojnih etap v slovenskem vokalizmu, Slavistična revija 14. 25-78. 
$\hookrightarrow \quad$ Rigler, Jakob, 1970, Akcentske variante I, Slavistična revija 18, Ljubljana, 5-15, ponatis v Rigler 2001, 320-328.

Rigler, Jakob, 1971, Akcentske variante II, Slavistična revija 19, Ljubljana, 1-12, ponatis v Rigler 2001, 329-338.

Rigler, Jakob, 1978, Akcentske variante III, Slavistična revija 26, Ljubljana, 365-374, ponatis v Rigler 2001, 338-346.

Rigler, Jakob, 2001, Zbrani spisi 1: Jezikovnozgodovinske in dialektološke razprave, uredila Vera Smole, Ljubljana.

Snoj, Marko, ${ }^{2} 2003$, Slovenski etimološki slovar, Ljubljana.

Slovar slovenskega knjižnega jezika I-V, 1970-1991, Ljubljana. [elektronska različica]

Slovenski pravopis, 2001, Ljubljana. [elektronska različica]

Stang, Christian S., 1957, Slavonic Accentuation, Oslo.

Šekli, Matej, 2006, Tersko narečje v kraju Subid / Il dialetto sloveno del Torre nel paese di Subit, Terska dolina / Alta Val Torre / Val de Tor, Terska dolina v besedi, sliki in pesmi Viljema Černa, ur. Milena Kožuh, Celje, Gorica, 161-187.

Šivic-Dular, Alenka, 1998, Kontrakcija v slovanskih jezikih (V kontekstu poznopraslovanskega akcentskega pravila), Slavistična revija 46/1-2, Ljubljana, 5-43. Toporišič, Jože, 1992, Enciklopedija slovenskega jezika, Ljubljana.

Toporišič, Jože, ${ }^{4} 2000$ ('1976), Slovenska slovnica, Maribor.

\title{
Krajšave:
}

daj. = dajalnik; dv. = dvojina; ed. = ednina; im. = imenovalnik; issln. = izhodiščni splošnoslovenski; mest. = mestnik; $\mathrm{m}=$ moški spol; $\mathrm{mn} .=$ množina; nad. $=$ nadiški, nadiščina; or. = orodnik; os. = oseba; popsl. = popraslovanski; psl. = praslovanski, praslovanščina; rod. = rodilnik; s = srednji spol; spl. sln. = splošnoslovenski; tož. = tožilnik; $\check{z}=$ ženski spol.

\section{A Phonological Description of the Local Dialect of Jevšček near Livek of the Nadiško Dialect of Slovenian}

\author{
Summary
}

The local dialect of Jevšček, located near Livek, is part of the Nadiško (Nadiža/Natisone) dialect of Slovenian, which enters to the Beneško-Kraško (Benečija-Kras) group of the Western Slovenian dialects. The most characteristic sound changes, by means of which the phonemic system of Jevšček dialect evolved from the Original Common-Slovenian (OCSIn.) phonemic system (Logar 1981a), can be devided, from historical-phonological point of view on the basis of relative chronology nad consequently their geographical expansion on the Slovenian language territory (Rigler 1963), into three groups, i. e. Western Slovenian, BeneškoKraško, Common-Nadiško and Non-Common-Nadiško sound changes.

The Western Slovenian characteristics are as follows: 1. OCSIn. *ě/*ō > ire/uro (Jevšček lìres, sì̀enca, mlíxeko; bùzoh, mesùio, gen. pl. otrú:ok), common also to the Northern Slovenian dialects; 2. early lengthening of OCSIn. short acuted 
vowels in a non-final syllable and consequently merger of OCSIn. *ě and OCSIn. *è̀-, for instance (Jevšček cír esta, lí: eto, gen. sg. orí:exa), common also to the Southern Slovenian dialects; 3. OCSIn. *ð̄/*ذ̀- > a: (Jevšček dà:n, bolà:n, pá:sji), common also to the Southern Slovenian dialects.

A Beneško-Kraško group characteristic is the late denasalization of the Proto-Slavic nasal vowels $* \mathrm{e}^{\mathrm{e}}{ }^{*} \mathrm{Q}$ and consequently their (original) wide reflexes with absence of monophtongization: OCSIn. *ę/*è̀- > e: (Jevšček desèrt, $\gamma$ lé: dat, pé:ta,

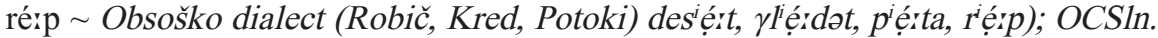

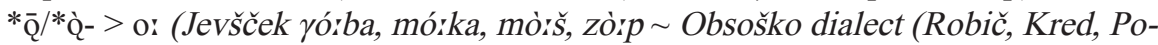

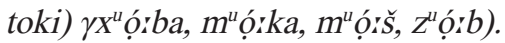

The Common-Nadiško characteristics are as follows: 1. the presence of (inherited) tonal opositions and the absence of accent retraction of the type OCSIn. *sesträ, *kozä, *məglä > *sèstra, *kòza, *mògla (Jevšček sest'ra, ko'za, may'la Briško dialect (Šmartno) sèrstra, kò:za, mòrhla); 2. the absence of the accent retraction of the type OCSIn. *sěnô > *sě̀no (Jevšček senùro, acc. sg. uodò: Tersko dialect (Subid/Subit) sé:no, acc. sg. uóxdọ) and of the accent advancement of the types OCSIn. *zímà > *zīmä (Jevšček mó:ka, zí:ma Tersko dialect (Subid) mo:'ka, zi:'ma) and OCSIn. *iùžina > *iužìna (Jevšček díselat, jú:žna Tersko dialect (Subid) die'lato, ju'žəna).

The Non-Common-Nadiško characteristics are as follows: 1. OCSIn. *-m >

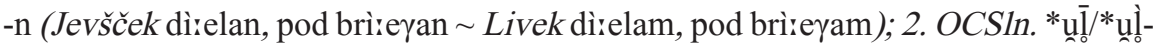
$>$ ui/u: (Jevšček ù:k, ú:na Livške Ravne vùzk, vú:na); 3. OCSln. *í > 1́ (Jevšček klú:č, pù:oĺle $\sim$ Ošnje/Osgnetto kjú:č, pùoje); 4. OCSIn. *u $>$ v in the position before non-back vowels (Jevšček ví:det, 'velk, vàrs, pod vasjó: Livek bírdet, 'belk, ùàs, pod unasjó:); OCSIn. *u $>$ f after loss of the following front vowel (Jevšček pòrf, prá:fca $\sim$ Livek pə̀rp, prá:pca); 5. OCSIn. *-̀े/*-̀̀ > ø (JevŠček 'konc, 'velk Ošnje ko'nac, ve'lik); OCSIn. *-ə> $>$ (JevŠček xlà:pc, pír esk $\sim$ Ošnje xlà:pac, piẹ́sak). The local dialect reflects a relatively small degree of the so called modern vowel reduction (only *ə/*-ว̀ and $*_{\mathrm{i}} / *_{-1}$ can be fully dropped), which is nevetheless higher than in the Nadiško local dialects not bordering to the Obsoško dialect (Ošnje).

In the local dialect of Jevšček, the Proto-Slavic consonant cluster *dl is preserved in the word sá:dlo < PSI. *sädlo and, maybe, in the toponyms Sed'lo < *sedló and Stàire sed'lo < *stäroie sedló. This cluster is generally preserved in the Ziljsko dialect of Slovenian and occurs in other Carinthian Slovenian dialects as well (Ramovš 1924, 195-197). In single words (and in the above cited toponyms), this cluster is also retained in the Obsoško dialect, both in Bovec (Bovec jérdu/ jérdla, sárdlo, šírdlo; Ivančič Kutin 2007) and Kobarid subdialects (Libušnje sádlọ; Pleteršnik 1894/95).

Matej Šekli

Filozofska fakulteta Univerze v Ljubljani, Aškerčeva c. 2, 1000 Ljubljana matej.sekli@guest.arnes.si 



\title{
Psl. *stbgna v slovenskih govorih
}

\author{
Alenka Šivic-Dular (Ljubljana)
}

IZVLEČEK: V članku je na podlagi dostopnega gradiva predstavljena naglasoslovna, oblikoslovna in arealna problematika odrazov psl. leksema *stbgna v slovenščini in na ozadju drugih slovanskih jezikov.

ABSTRACT: Based on the material available, this article presents accentological, morphological, and areal issues in reflexes of the Proto Slavic lexeme *stbgna in Slovenian, comparing this with reflexes in other Slavic languages.

Namen članka je predstaviti prostorsko razmeščenost imenskih in občnoimenskih glasovno-naglasnih različic psl. leksema *stbgna slovenskih govorih in jezikoslovno problematiko te besedne skupine.

\section{Etimologija}

Prve etimološke navezave dolgujemo F. Miklošiču, ki je v geslu stĭgna povezal stcsl. stbgna, sln. stegna 'triebweg', hrv. stagna 'platea', kaš. stegna 'pfad' (Miklošič LP, 899; Miklošič SEW, 328), v geslu stbdza pa med drugim dodal še polj. ściegno, stegno 'spur' in vse skupaj navezal na let. stiga, stvn. stīgan, stīc, steiga in got. staiga (Miklošič, 328). Ugotovljena je bila zveza z gr. $\sigma \tau \varepsilon i ́ \chi \omega$ 'gehe' (Pedersen KZ 38,322 ), poizkus povezave z rus. stegátb, stegnútb s psl. *stbg- (Kořínek, Studie onomat. 268) ${ }^{1}$, gradivo iz ide. jezikov je navedeno pri kor. *steigh- 'schreiten, steigen' (Pokorny 1017). Od slovanskih etimoloških slovarjev je polj. stegno 'wygon, ścieżka' povezano s psl. *stbdza (Brückner 515), rus. stógna 'ploščad, ulica', mn. stógny ${ }^{2}$ se izvaja iz psl. *stbgna, povezuje pa s stcsl. stъga 'tropa' in glag. -stigátb (Vasmer 3, 17), hrv. stagna 'platea' se povezuje s staza, stignuti, stići (Skok 3, 324, 333-334), bolg. stźgda, stbolg. stıgda in stıgna (stъgna) < psl. *stıg- s stbza, stigamъ (Mladenov 615), sln. stegnë ž mn. in stágne ž mn. < *stighnā pa s stezä in stígniti, vse iz ide. kor. *stě̄igh- (Bezlaj 3, 314-315/M.S.).

1 J. Pokorny ga uvršča h kor. *stegh-/*stengh- 'stechen; Stange, Halm, Spitzes, Steifes' (Pokorny 1014-1015).

2 Vasmer opozarja na bolg. stъgdá 'rynočnaja ploščads', sl. stəgnè stəgə̀n R mn., nareč. stognà, stpolj. ściegna 'pereputьe', polj. nareč. ściegna, slovin. stẽigna. 


\section{Besedotvorje}

Navezava na gornji ide. koren je splošno sprejeta, več neujemanja pa obstaja glede funkcije in števila priponskega obrazila: Tudi stcsl. stı̆gna 'platea' F. Miklošič prvi razlaga kot tvorjenko s pripono -na iz kor. *stĭg- (Miklošič II, 117-118) ${ }^{3}$, stcsl. stbgnb 'platea' pa s pripono -nb $(<$ ide. *-ni-) za tvorbo abstraktnih samostalnikov Ž. sp., a brez oblik s priponama -na oz. -no (Vondrák 1906, 480, 414) ${ }^{4}$, A. Vaillant stcsl. stı̆gna 'place (publique)'5 navaja med leksemi s pripono -na, ki so »très anciens « ali/in etimološko »tout à fait claires $«{ }^{6} \mathrm{z}$ opozorilom na pogostost pripone *-nā v baltskih jezikih, ne omenja pa leksema s pripono *-no- (Vaillant IV, 585586, 583-585), F. Sławski v *stbgna kot nemotivirani tvorjenki k *stbza ugotavlja strukturalno funkcijo pripone *-na <ide. *-nā, kot razširjevalca arhaičnega leksema, podobno kot $\mathrm{v} *_{\text {stogda }}$ (SPsł I, 116), o substantivizaciji »starega ptc. f. *stighnā k prez. *stě igh-ne/o- > psl. *stïgně̌b « govori M. Snoj (Bezlaj 3, 314-315/M.S.). Dodatni korak stori K. Zierhoffer, ki izhajoč iz poljskih različic (prim. stpolj./polj. nareč. stegna/ściegna in stegno/ściegno) govori o priponah -na ž sp. in -no s sp. (prim. stcsl. cěna, luna, sěno) v leksemu *stbgna/*stbgno in o priponi -da (prim. stcsl. uzda, qda, brazda) v sinonimnem stcsl. stbgda, bolg. stъgdá (Zierhoffer 15).

\section{Gradivo iz slovanskih jezikov}

Besedje iz slovanskih jezikov pritegujem v obsegu, ki se zdi smiseln za oris problematike, izkoriščam pa priložnost, da podrobneje predstavim odlično študijo Karola Zierhofferja, v kateri je na slovanskem ozadju prikazal izraze za pojem 'steza' in etimološki družini iz kor. *stigh- v zgodovini poljskega jezika, narečjih in onomastiki.

\section{Južnoslovanski makroareal}

Leksem *stbgna v občno- in/ali lastnoimenski funkciji je izpričan iz slovenskih in hrvaških govorov, prve zapise pa prinašajo stcsl. spomeniki (Ev Supr Apost (Grš) Bes), ki izvirajo iz Makedonije oz. Bolgarije. Izpričan je leksem stbgna -y ž ed. v pomenih 'ulice; ulica, stogna; Straße, Gasse; vicus platea' (npr. skvozě vsi i stbgny ištju jegože ljubitb d(ou)̌̌a moja 'per vicos et plateas quaeram' Ct 3,2; Bes 25, 158a $\beta$ 2sq; po oulicamъ i po stbgnam jego ištet(b) 'per vicos et plateas' Bes 25, uvar 86a $\alpha$ 33); kot stbgny ž mn. pa v pomenu 'námestí; Markt; forum' (prim. pride /.../ na stogny Supr 137, 13) in v pomenu 'dvorana, vestibul; zal; Vorhalle, Vestibül' (npr. stbgnъi dvoju lokъtou izměrejutb sę 'vestibulum' Bes 38,295b $\beta$ 22sq (Ez 40,9); vъ

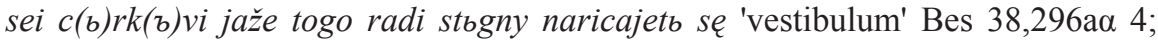
SJS 194) ${ }^{7}$, pri Miklošiču tudi stъgda 'platea' sup. (Miklošič LP, 899). V stbolg. se

3 Pod pripono -no uvršča homonimni stcsl. stbgno ob psl. *stegno 'femur' (Miklošič 2, 116).

4 Ta stsrb. besedna različica naj bi bila analogna po tipu *kostb (Zierhoffer 17).

5 A. Vaillant na tem mestu navaja rus. stógna (slavonizem), stsrb. stagna 'place, rue', sln. stegnà 'piste pour le bétail', stpolj./dial. ściegna 'sentier' in 'pâturage' ob stcsl. stǐza.

6 Sem uvršča stcsl. cěna luna, pěna, vlŭna 1-2; vesna, glina, měna, slana, strana itd.

7 Pri obravnavi stcsl. polglasnikov V. Jagić pravi, da je beseda stbgna zapisana tudi z b, tj. 
pojavlja leksem tudi v pisnih oblikah stbgna/stogna 'platea' (Miklošič LP, 899) in stъgdá 'ploščadı' oz. v slovarju N. Gerova kot stb̈gda v pomenu 'široko ravno město meždo kQšty-ty vъ gradъ, vъ selo; płoštь, razkolъ, mejdanъ, mejdanłokъ; płoštadь, placь' (Zierhoffer 7). V občnoimenski funkciji sta $\mathrm{v}$ starosrbskem pismenstvu registrirani različici stbgna ' $\pi \lambda \alpha \tau \varepsilon 1 \alpha$, platea' in stbgnb ž ed. 'platea' (Miklošič LP, 899). Po podatkih starejših in novejših pisnih virov se je leksem *stbgna v tej funkciji ohranil do današnjih dni v čakavskih govorih srednjedalmatinskih otokov. Kot stagna v pomenu 'platea', 'semita, trames' je zabeležen v slovarjih F. Vrančića in J. Stullija ${ }^{8}$, v živi rabi pa še pri dalmatinskih piscih M. Maruliću, J. Barakoviću, M. Albertiju), novejša dela ga beležijo kot občno ime in topoleksem samo na dveh dalmatinskih otokih: sam. stãgna ž ed. pomeni 'Dorfstraße' in 'steiler Bergweg' z manjš. stagnïca (Brač; ČDL I, 1149), stãgna ž ed. 'širok seoski put', 'prošireni put u naselju' (Šimunović 2006, 543) z manjš. stagnïca ž ed. 'mala stagna' (Donji Humac; Šimunović 2006, 543). Toponime navaja z Brača: Stãgna (Bol), Stãgne (Donji Humac), Stagnïca (Donji Humac, Nerežišća) s pojasnilom, da »označuju proširenu ravnu stazu i okolišno područje« (Šimunović 1972, 190). V deloma spremenjeni obliki, tj. Stagnä (Bol), Stãgne (Donji Humac), Stagnïca (Gornji Humac, Nerežišća) jih navaja P. Šimunović še v slovarju otoka Brača (Šimunović 2006, 543). Poleg tega P. Skok prinaša še obliko top. Stagnâ 'strmi del Bola' z Brača (Skok 3, 324) in top. Stágna ž ed. (Smokvica) kot ime 'vrlo strm/e/ ulic/e/' s Korčule (Skok 3, 324, geslo stagna).

\section{Slovensko občnoimensko gradivo}

Najbolj izčrpne informacije o obliki, pomenu, lokaciji tega psl. leksema $\mathrm{v}$ sln. prinašata slovarja $M$. Pleteršnika in sodobnega knjižnega jezika (SSKJ). M. Pleteršnik zabeleži štiri različice iz slovarjev in besednih zbirk iz O. Gutsmanna (1789), A. Murka (1832-33), M. Cigaleta, A. Janežiča (1867), M. Valjavca (Rad), L. Svetca (rokopisni slovar), J. Zalokarja (rokopisni slovar) in književnih del (J. Jurčič, F. Levstik):

- Sam. stágna -gən s mn. 'der Viehtriebweg (meist eingefriedet)' (P1 2, 560); vira: J. Zalokar, F. Levstik (prim. na stagnih ).

stъgny luc. XIV, 21. 187 , stъgnaхъ matth. VI.2.8 (Zografski ev.) in dodaja »Es scheint auch diese Schreibart nicht zu verwerfen zu sein; mann erinnere sich der später häufig vorkommenden Form stogna und nehme hinzu, dass auch Zogr. stbza schreibt. Möglich ist es also, dass man in der Aussprache stъgna und stbza unterschieden hat. Ostrom., Sav. kn., Grig. nanz. haben allerdings b, doch Cod. Supr. schreibt mit ъ: 101, 104.« (Jagić 27).

8 Vrančićev Dictionarium quinque nobilissimarum Europae linguarum Latinae, Italicae, Germanica, Dalmaticae et Ungaricae (Benetke 1595) vsebuje okrog 5800 hrvaških besed, največ izvorno čakavskih, predvsem iz Vrančićevega rojstnega kraja. - Stulli je sestavil tri slovarje: Lexicon latino-italico-illyricum (Budim 1801), Rječosložje ilirsko-italijansko-latinsko (Dubrovnik 1806), Vocabolario italiano-illirico-latino (Dubrovnik 1810); slovar iz leta 1806 vsebuje besedišče iz objavljenih del dubrovniških, dalmatinskih, hercegovskih, bosanskih, slavonskih in istrskih piscev. 
- Sam. stognà -gว̀̀n s mn. 'stegne' (Pl 2, 566); vir je J. Jurčič (prim. po stegnih; po ozkih stegneh)

- Sam. stágne -gən ž mn. (gor.; Pl 2, 560).

- Sam. stəgnè -gว̀n ž mn. 'der Triebweg für das Vieh, gewöhnlich zwischen zwei Zäunen' (Pl 2, 566); viri: O. Gutsmann, A. Murko, M. Cigale ${ }^{9}$, A. Janežič, M. Valjavec, L. Svetec. Tu sta dodani različici stegna ž ed. (Murko, Miklošič), stəgnà (Valjavec).

Gradivo 20. stoletja v SSKJ (1994) $)^{10}$ je označeno kot narečno s pomenom 'pot, steza, po kateri hodi živina na pašo', opažamo pa drugačno razmerje med vrsto osnove in slovničnim spolom, tj. osnova stagn- je vezana na ž sp., osnova stəgn-/ stägn- pa na s sp.:

- Sam. stāgne/stâgne -gen ž mn. (prim. je gnal živino po stagnah; SSKJ 1300); listkovna kartoteka obsega zpise iz gorniških (B. Režek), zemljepisnih (F. Ilešič), književnih del (J. Jalen, F. S. Finžgar) in prevodov.

- Sam. stegnä -gön/stägna -gen s mn. (prim. po stegnih; SSKJ 1308); listkovna kartoteka obsega izpise iz književnih del (I. Zorec: za mejo po stegnéh 1935; živinogon ali stegná/stegnà, ponekod bolj podobna kozjim stezam 1935; po stegneh in rebreh 1929; po ozkih stegneh, ki so še dandanes pod vasjo, da se hudournica odceja in da ima živina kod s paše domov 1934; po stegnih za vasjo 1929).

Med drugimi deli naj bo omenjena še dragocena knjiga R. Badjure Ljudska geografija, kiv razdelku Vozne poti (Badjura 285-286) prinaša naglasno-oblikoslovni različici z osnovo stégn-, tj. stégna in stégne (poleg stágna -gən) in razširjenim pomenom »navadna pota, kolovozi, ulice, ki se stegujejo iz vasi čez polje proti večji cesti, in sicer z obeh strani skoraj pravokotno « (Komenda), a dostavlja, da je prvotni pomen stegen »poljska ulica, zagrajena pot, ki drží iz vasi na kak pašnik« (Badjura 286).

Iz gornjih virov pridobljeni podatki kažejo naslednjo sliko:

1. Naglašeno osnovo stágn- (Pleteršnik), stägn-/stâgn- (SSKJ) vsebujejo samostalniki ž mn. (tj. stágne stágən), ki se pojavljajo po Gorenjskem, medtem ko so sam. s mn. z enako osnovo (tj. stágna stágən) arealno teže določljivi; zapisala

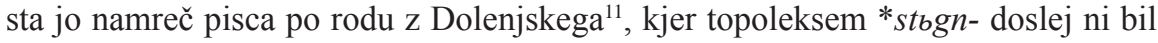
opažen.

2. Nenaglašeno osnovo stəgn- vsebujejo samostalniki ž mn. (tj. stəgnè

9 Leksem stegne ž mn. najdemo v geslih der Triebweg (tudi gonje mn., zgon 'Zusammentrieb; Cigale 2, 1643), der Viehtrieb (tudi gonje mn., živinski tir, ulice mn., klanec; Cigale 2, 1800, medtem ko v geslih der Pfad (Cigale 2, 1153), der Steig (Cigale 2, 1544) navaja samo steza z manjš. stezica, (peš)pot, tir oz. steza z manjš. stezica, pešpot, gaz.

${ }^{10}$ Podatke povzemam tudi po listkovni kartoteki Inštituta za slovenski jezik Frana Ramovša (ZRC SAZU).

${ }^{11}$ J. Zalokar (1792-1872), rojen v Vinici pri Šmarjeti, po prihodu v Ljubljano (1853) se posveti slovaropisju (ES 15, 51); F. Levstik (1831-1887), rojen v Donjem Retju, živel v Ljubljani, Olomoucu, na Dunaju, gradu Turn pri Moravčah pri Gabrovki, gradu Kalec pri Knežaku, v Trstu. 
stəgə̀n), ki so širše znani (koroški, deloma gorenjski, morda dolenjski?), medtem ko sam. s mn. z enako osnovo (tj. stəgnà stegə̀n) navaja spet samo Dolenjec J. Jurčič.

3. Naglašeno osnovo stägn- vsebujejo samostalniki s mn. (tj. stägna -gen), ki jih poznamo po SSKJ in so morda nedavnega nastanka, čeprav bi v Jurčičevih dveh glasovno-naglasnih oblikah M mn. (tj. končniški naglas: po ozkih stegneh (1870), naosnovni naglas: po stegnih (1864)) lahko videli neustaljenost iktusa kot posledico mešanja več akcentskih paradigem pri leksemu, ki izginja.

4. Naglašeno osnovo stégn- vsebujejo samostalniki ž mn. (tj. stégne) in s mn. (tj. stégna), ki so izrecno locirani samo s sintagmo »/n/a deželi po ravnem«.

\section{Slovensko lastnoimensko gradivo}

* Stbgna kot topoleksem označuje geografske objekte, najpogosteje ledinska imena, zato je gradivni korpus do določene stopnje odvisen od velikosti merila toponimičnih zbirk, identifikacija na terenu od natančnosti ubikacije, njegova vrsta pa od opisov narave (vrste) objekta. Viri za toponimično gradivo so: Register zemljepisnih imen Geodetske uprave RS (REZI5), Digitalna datoteka ledinskih imen Agencije RS za kmetijske trge in razvoj podeželja (Datoteka LI 2003) ${ }^{12}$, T. Jarca popis ledinskih imen, Krajevni leksikon Slovenije I-IV (KLS) in drugo.

1. Topoleksem Stégne ( $\mathrm{tj} . \mathrm{z}$ osnovo stégn-) navaja in locira nekam nad Bohinjsko Bistrico H. Tuma: »Matajurski vrh 193; iz Poljan na zahod čez Stégne v Šoštarjevo konto, pod njo Rjavec 1505 m do 1206 m (gozd)« (Tuma 56).

2. Stanovniško ime Stâgnarjə I mn. 'vzdevek za Kupljenčane' (Bohinjska Bela) $<$ topoleksema *stbgna (Čop 1983, 23).

3. M ed. un Stegníce 'ime poti' (Zgornje Laze; Čop 1983, 21) <*stegnïca.

4. Veliko podatkov za različne geografske objekte z opisi podaja T. Jarc: Top. Stagne 'pot obrobljena s starimi lipami' (Jarc, št. 480, k.o. Zabreznica); Za stagnam 'njive in travniki vzhodno od stagen' (Jarc, št. 483, k.o. Zabreznica); Za Stagnam 'travniki in njive na ježi vzhodno od cerkve sv. Marka' (Jarc, št. 606, k.o. Zabreznica); Za stagnam 'deloma listnat gozd, deloma travniki' (Jarc, št. 764, k.o. Hraše); Za stagnam 'njive in travniki' (Jarc, št. 866, k.o. Hraše); Na Stagnah 'stagne na meji Vrba-Studenčice ob Blejski cesti Smokuč-Blejski most; listnat gozd in košenice' (Jarc, št. 754, k.o. Zabreznica); Med Stagnami 'travniki med vrbenskimi in Studenškimi stagnami. /. ../ Nekdaj srenjsko zemljišče' (Jarc, št. 759, k.o. Zabreznica); Pri stagnah (Jarc, št. 599, k.o. Zabreznica); Stagne 'Stagne so tukaj širok klin, kjer so prej potekale Vrbenske in Studenške stagne, ki so se združile pod vahtnico pri železniški progi. Med stagnami pa je bil pod ježo dokaj širok travnik, danes je tod nogometno igrišče. Skozi Stagne so potekale Blejska pot iz Smokuča in nekoč tudi stara pot v Doslovče (mimo kužnega znamenja), sekala pa jih je starodavna pot Vrba - Radovljica. Danes jih sekajo še železnica, regionalna cesta in avtocesta. Lipov drevored.' (Jarc, št. 744, k.o. Zabreznica); Hraške stagne (Jarc, št. 865, k.o Hraše); Vrbenske stagne 'stagne vasi Vrba, imenovane tudi Ulce. Lipov drevored. Potekajo po ježi. Skozi stagne poteka pot v Studenške stagne in nekdanja pot Vrba-Studenčice' (Jarc,

${ }^{12}$ Hrani Etimološko-onomastična sekcija ISJ ZRC SAZU (Ljubljana). 
št. 622, k.o. Zabreznica); Studenške stagne 'Stagne vodijo po ježi do Blejske ceste in ob njej navzdol do Golfa' (Jarc, št. 759, k.o. Zabreznica).

5. Top. Stágne 'zaselek v neposredni bližini ceste Tržič-Podbrezje' (KLS I, 440, Kovor), danes vključen v naselje Kovor (ustno dr. Marjan Klemenčič).

6. Top. Stagne (Datoteka LI 2003, k.o. Lahovče, naselje Lahovče).

7. Top. Stagne (Datoteka LI 2003, k.o. Suha, naselje Suha pri Predosljah).

8. Top. Stagne (Datoteka LI 2003, k.o. Voglje, naselje Voglje).

9. Top. Stagne (Datoteka LI 2003, k.o. Velesovo, naselje Praprotna Polica).

10. Top. Stagne Spodaj (Datoteka LI 2003, k.o. Velesovo, naselje Praprotna Polica)

11. Top. Stagne Zgoraj (Datoteka LI 2003, k.o. Velesovo, naselje Praprotna Polica).

12. Top. Stagne (Datoteka LI 2003, k.o. Trboje, naselje Trboje).

13. Top. Stagne (Datoteka LI 2003, k.o. Šenturska gora, Ravne).

14. Top. Stagne (Datoteka LI 2003, k.o. Štefanja gora, naselje Štefanja Gora).

15. Top. Stagne (Datoteka LI 2003, k.o. Cerklje, naselje Pšenična Polica).

16. Top. Stagne (Datoteka LI 2003, k.o. Moše, naselje Moše).

17. Top. Stagne (Datoteka LI 2003, k.o. Polje, naselje Polje pri Vodicah) ${ }^{13}$.

18. Top. Stegne (Datoteka LI 2003, k.o. Strahinj, naselje Kranj).

19. Top. Stegne (Datoteka LI 2003, k.o. Zalog, naselje Zalog pri Spodnje Gameljne).

20. Top. Stegne (Datoteka LI 2003, k.o. Šentvid nad Ljubljano).

21. Top. Stegne (Datoteka LI 2003, k.o. Dravlje, naselje Ljubljana).

22. Top. Stegnè, M mn. na Stegnàh 'zaselek naselja Dolenje/Domžale' (Na Stegnah izvira potok Erjávec; KLS 2, 82, Dolénje); prim. tudi Stegne 'zaselek pri Dolenjem' (AS 108/A2, Dob).

23. Top. Stègne, M mn. v Stègnah 'razloženo naselje na kraški vrtačasti planoti med grapo Rače in severim pobočjem Murovice' (KLS 2, 105, Stègne); prim. tudi Stegne 'naselje' (AS 108/B3, Dob).

24. Top. Stegne (Datoteka LI 2003, k.o. Kandrše, obč. Zagorje ob Savi, naselje Kandrše).

25. Top. Stegne (Datoteka LI 2003, k.o. Ponikva, naselje Ponikva pri Žalcu).

26. Top. Stegne (Datoteka LI 2003, k.o. Ravne, obč. Šoštanj, naselje Ravne).

27. Top. Stegne (Datoteka LI 2003, k.o. Roginska Gorca, naselje Spodnje Tinsko).

28. Top. Stegne 'zaselek' (AS 1985, 66/B2, Oplotnica).

29. Top. Stegnova (Datoteka LI 2003, k.o. Tinjska Gora, naselje Turiška vas na Pohorju).

${ }^{13}$ Iz Pleteršnikove rokopisne kartoteke ledinskih, kjer pa ubikacija ni mogoča, navedimo: mikrotoponime Stagne za različne geografske objekte (tj. za »pot, nj. zd. h.«) s pripisom, da se večkrat pojavljajo po Kranjskem. Mikrotoponime Stág(e)nca -e (»tr. gzd, st.«) v okolici Kamnika (občina Vodice) s Pleteršnikovim opozorilom na sam. stagne -gen 'der Viehtriebweg'. - Pleteršnik okrajšav ni razvezal, zato so podane v izvirni obliki. 
30. Verjetno je iz tega topoleksema treba izpeljati tudi top. Stegnerane, M mn. $v$ Stégneranah 'zaselek' (KLS 3, 181, Cúrnovec).

31. Ob top. Stáglance, M mn. v Stáglancah (KLS 3, 261-262, Kladje nad Blanco) se na tem področju v drugih virih pojavljata še obliki Stagonce 'zaselek' (AS 134/A3, Senovo), Staganca (Datoteka LI 2003, k.o. Kladje, naselje Rožno); zaradi á (prim. stag-) bi bila etimološka povezava s topoleksemom *stbgna vprašljiva celo v primeru, če bi za glasovni niz -glan- oz. -gon-/-gan- dokazali disimilativne spremembe ${ }^{14}$.

Različici stagne/stegne itd. sta po slovarjih enotno pomensko razložena (gl. zgoraj), medtem pa ledinska imena s tem topoleksemom oz. iz predložnih zvez s tem topoleksemom (gl. gradivo iz Jarca) za različne vrste geografskih objektov, npr. za »pot, travnik, njivo, gozd itd.« (gl. op. 14), dajejo slutiti podobno stanje, kot je v polj. (gl. v nadaljevanju), le da ni doseglo enake stopnje leksikalizacije.

\section{Vzhodnoslovanski makroareal:}

Vzhodnoslovansko besedno gradivo je razmeroma pičlo: Strus. leksem stъgna ž ed. v pomenih 'trg' in 'ulica' je bil v rabi do konca 14. stol (Vasmer 3, 763), v pisno-glasovni obliki stógna še pri M.V. Lomonosovu in drugih (Bezlaj 3, 314-315, M.S.), iz ruskih govorov pa sam. stógna ž ed., mn. stógny, v enakem pomenu (tj. 'ploščadь' in 'ulicy vъ gorodě') navaja V. Dalı (prim. na rasputija i stogny grada; velikij gradъ Petrovъ vъ edinu stognu uměstilsja; Dalı 4, 326, geslo stógna). Samoglasnik o govori o ppsl. glasovni obliki *stъgna < psl. * stbgna, prim. stcsl. stъgna, leksem pa se tudi pomensko povsem ujema s stcsl.

\section{Zahodnoslovanski makroareal}

Odrazi psl. leksema *stbgna so ohranjeni iz vseh zahodnoslovanskih jezikov, razen iz čeških in slovaških govorov. Najti jih je tudi v starejših lužsrb. slovarjih (prim. gluž. sćehno, arhaično tudi sćahno 'Hutung' (Pfuhl, Rězak); dluž. sćohna s ed. 'die Lehde, die Hutung; pustyrı, pastbišče, vygon, lugá' (Muka)), polab. stagnói ž mn. 'der Viehtrieb (ledinsko ime)' v zapisih auf dem Stagna, Staguer (Rost) (Zierhoffer 8).

\section{Poljsko gradivo}

Najobsežnejše gradivo se je ohranilo v polj., K Zierhofferju pa gre zasluga, da je problematika polj. besedja za pojem 'steza' predstavljena v študiji, kjer se izčrpno upoštevajo staropoljski, narečni in toponomastični viri, slovanski slovarji, predmetna literatura. Ustreznice polj. ścieżka in etimološko sorodnih izrazov (npr. *stbgna/*stbgno) so podane v slovanskem kontekstu, sledi prikaz leksemov stdza/

${ }^{14}$ F. Bezlaj v geslu Stegovnik 'pritok Tržiške Bistrice' zavrača povezavo z osnovo stegъ 'via', ki naj bi jo vsebovali sbh. Pristeg, Stegovac (Im.-Reg. II, 856 in 992), madž. Peresteg (Kniesza, AECO IV, 402), ker da v sln. osnova ni izpričana. (Bezlaj SVI 2, 219-220). Sicer pa so znana lastna imena (zemljepisna, hišna, priimki) z osnovo Steg-, npr. top. Stegujek 'zaselek' (KLS 2, 274, Nova Gora), Stegujek 'zaselek' (AS 130/B3, Sava); Stegóvci 'zaselek vasi Šmarje' KLS 1, 28, Šmárje, obč. Ajdovščina); Stegovec (Luka Pintar, LZ $1914,565)$ itd. 
$\hookrightarrow \quad$ śćdza, stegna/stegno, ściegna/ściegno ${ }^{15}$, stecka/steczka, ścieżka, steżka/chodnik v zgodovini poljskega jezika, narečjih, toponomastiki, njihov pomenski razpon v poljščini (Zierhoffer 6-73). Zgodovinsko in narečno besedje, ki je povzeto po literarnih, listinskih idr. virih, po narečjeslovnih opisih, besedilnih zbirkah, slovnicah, folkloristični, etnografski idr. literaturi, slovarjih (npr. S.B. Linde, J. Karłowicz - A. Kriński - W. Niedźwiedzki, S. Ramułt, J. Karłowicz, Z. Gloger), dopolnjujem z gradivom iz sedmih poljskih govorov (OLA 4b, 100-101): s'tegna (t. 241/Wierzchucino, vojv. Gdańsk), s'teígna / s'tegna (t. 242/Wielka Wieś, vojv. Gdańsk), s'tẹigna (t. 243/Brzeźno, woj. Gdańsk), s'tegna (t. 244/Mirachowo, vojv. Gdańsk), stegna (t. 245/Karsin, vojv. Bydgoszcz), stegna (t. 248/Drawsko, vojv. Poznań), stegna / śćegna (t. 266/Radziuszki, vojv. Białystok).

Poljski leksem stegna ž ed. s pomenom 'steza', prim. pomorjansko stegna -é ž ed. (npr. Stegnami réxli zônzeš, jak droge 'ścieżkami rychlej zajdziesz, jak droga', Ramułt 203; Stegné ...njebeło«, Karłowicz 5, 231) je danes značilen za SZ Poljsko (tj. Kašubsko, Bori Tucholski, Kociewie, Krajna), a sega v tri velikopoljska okrožja (tj. czarnkowsko, chodziesko, wagrówiecko); razen na Kašubskem se povsod pojavlja skupaj s sinonimi. Primerjava sodobne razširjenosti leksema stegna $\mathrm{z}$ zgodovinsko ali/in toponomastično določljivo dokazuje, da se nekdanji areal (tj. Mazowsze, Łęczyckie, Kujawi, južna in osrednja Velikopoljska, deloma verjetno chełminska in dobrzynska dežela) krči (Zierhoffer 24-25, 39, 46).

Poljski leksem stegno s ed. (Karłowicz 5, 231; SJP 6, 413) danes pomeni 'ścieżka, droga, którązwierzyna zwykła chodzić i której stale się trzyma' (węgrowsko okrožje) in 'szlak wydeptany w lesie przez zwierzęta' (augustowsko okrožje) ali/oz. 'ślad, trop, linja śladów; szlak wydeptany w lesie przez zwierzęta' (prim. tylko trop zwierzęcy $i$ stegna udeptane (S. Twardowski)) ${ }^{16}$; njegov zgodovinski areal se je ujemal z arealom sam. stegna ž ed. (Zierhoffer 24-25, 39, 46-47).

Poljski leksem ściegna ž ed. je danes značilen za malopoljske govore (Sieradzkie, Łęczyckie) ter za dve točki v južni in vzhodni Velikopoljski, nekoč pa je segal celo na njen osrednji in zahodni del.

Poljski leksem ściegno (pogosta raba v I mn. ściegna) je značilen za Malopoljsko (Sieradzkie, Łęczyckie), za dve točki v dobrzynski deželi in na Podlasiu; v nekaterih malopoljskih okrožjih njegovo nekdanjo prisotnost potrjuje toponimija. Zgodovinski areal se $\mathrm{v}$ precejšnji stopnji ujema $\mathrm{z}$ arealom različice ściegna (Zierhoffer 27, 42-43, 47-48). Pomenski razvoj pri leksemu ściegna pa je potekal od dveh stpolj. pomenov (tj. 'ścieżka'; 'wygon') do štirih sodobnih pomenov: (tj. 'droga' - prim. celo śćygna 'większa droga'-; 'droga, którą się pędzi bydło, wygon'; 'ścierń, pastwisko, nieużytki, ugory, łąka mokra, mokradło'; 'rów przez łąkę, gdzie woda ścieka'). Podobno je tudi pomenski razvoj pri sam. ściegno potekal od stpolj. pomena (tj. 'ślad, trop') do štirih današnjih (tj. 'ścieżka'; 'droga, którą się

${ }^{15} \mathrm{~V}$ različicah stegno, stegnisko (S.B. Linde) je drugotna nazalizacija vezana na glasovno obliko stegn- (ne pa ściegn-).

${ }^{16}$ Ta pomen najdemo v staropoljski ilustrirani enciklopediji (geslo stegno z različico ściegno) v pomenu 'ścieżka udeptana nie przez ludzi, tylko przez bydlęta, liczne ślady tropów zwierzęcych' (Gloger 277-278). 
pędzi bydło, wygon'; 'szlak, wydeptany przez zwierzę'; ' pastwisko, nieużytki, łąka, mokradło') (Zierhoffer 48).

Poljske različice iz. ide. *stigh- se razlikujejo: po mehkosti vzglasnega sklopa ść- oz. st- (prim. ściegn- oz. stegn-), po slovničnem spolu (tj. ženski spol oz. srednji spol), po slovničnem številu (tj. ednina oz. množina). Mehkostni razloček v vzglasnih soglasnikih je posledica dveh ppsl. izhodišč, tj. etimološkega *stbg-na/ *stbg-no in neetimološkega *stъg-na/*stъg-no < *stbg- (Rozwadowski 122), prim. stcsl. stъgna. Na prehod $b>\boldsymbol{b}^{17}$ je morda regresivno vplival trdi soglasniški sklop gn, čeprav bi neprednjejezični $g^{18}$ moral preprečiti preglas. - Pomembno je, da polj. govori (skupaj s sln.) poznajo razločevanje po slovničnem spolu, tj. obliki *stbgna ž ed. (tj. ściegna oz. stegna) in *stbgno s ed. (tj. stegno oz. ściegno). Za razliko od slovenskih samomnožinskih oblik (in le omembi edninske stagna ž sp.) se polj. različici obeh slovničnih spolov razmeroma prosto uporabljata $\mathrm{v}$ ednini ( $\mathrm{tj}$. ściegna oz. stegna, stegno oz. ściegno) in množini (tj. ściegny oz. stegny, stegna oz. ściegna). Povsod drugod (tj. hrv., stcsl., bolg., rus.) pa se pojavlja izključno leksem ženskega spola.

Poljske različice se razlikujejo tudi po pomenski strukturiranosti (tj. po številu, vrsti pomenov) kot rezultatom pomenskega razvoja. Najmanjši pomenski razpon izkazujeta stegno (1) in stegna (2), največjega pa ściegno in ściegna (4). Domnevno prvotni besed pomen 'szlak wydeptany przez zwierzęta'19 se pojavlja v edninskih oblikah stegno (kot edini pomen) in ściegno (kot tretji pomen), pomen 'gonje' se pojavlja v ściegna in ściegno, pomen 'steza' se pojavlja v stegna in ściegno, pomen 'cesta' (tudi 'velika cesta') samo v ściegna, drugi sekundarni pomeni pa v različlicah ściegna, stegna in ściegno ${ }^{20}$.

\section{Sklepi}

1. Najbogatejše gradivo o psl. *stbgna, *stbgno, ki omogoča vpogled v oblikovni in pomenski razvoj, je doslej objavljeno v polj. in sln. in je nepogrešljivo za študij jezikoslovne problematike teh besed. Skupno vsem slovanskim jezikom

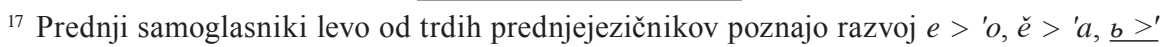
$\underline{\underline{b}}$.

${ }^{18} \mathrm{Za}$ dvoje odraze pred desnim sklopom podobne strukture, ki ga uvajata ustničnik ali/oz. mehkonebnik, prim. stpolj./nareč. śćkło, źdźbło $(<*$ śćbło $)<*$ stbklo, *stbblo oz. stpolj. skło, zdbło $(<$ stbło $)<*$ stъklo, *stъblo.

${ }^{19}$ Prastare steze so naredile (divje) gozdne živali (prim. sln. sled (npr. zajčji, lisičji), stopinja; polj. ślad, trop; (SSKJ 1244, gesli slệd in slệ)) sledijo poti, po katerih so gonili govedo, drobnico na pašo (sln. gonje, tiri, stagne; polj. wygon, češ. hony), nato so ulice in ceste, ki jih uporablja človek za druge dejavnosti. Podobno se uporablja polj. ścieżka z manjš. ścieżeczka v sintagmah: świnia ścieżka in ścieżka v pomenu 'ślad zająca dobrze oznaczony' (Karłowicz 5, 340-341).

${ }^{20} \mathrm{~V}$ polj. stegna/ścieżka so se pomeni 'pasture', 'bog, marsh', 'virgin soil' pojavili šele po asociativnem stiku iz pomena 'small road, path' < 'trace, track', 'run made by animals', 'track for running' (Konnova 326). 
$-\quad$ je, da so kot apelativi imeli izrazito narečni značaj in da se umikajo iz aktivnega besednjaka.

2. Različici *stbgna ž sp. in *stbgno s sp. nista prostorsko, pomensko in naglasno (sln.) strogo razmejeni.

3. Narava razmerja (tj. besedotvorna, oblikoslovna) med psl. različicama *stbgna ž sp. in *stbgno s. sp. s stališča notranje in zunanje rekonstrukcije še ni zadostno osvetljena. Različica *stbgna ž sp. bi lahko nastala tudi sekundarno s singularizacijo prvotno množinskih oblik s sp., obratna razvojna smer je malo verjetna. Tako razvojno možnost bi podpiral naglas v rus. stógna ž ed. (tudi bolg. stb̀gda ž ed.) in sln. stágna s mn. oz. stágne ž mn. < s mn. *stb̀gna a.p. b, ki ga od leksema ž ed. *stbgnä a.p. $b$ ne bi pričakovali.

4. Iz slovanskega gradiva lahko ugotovimo, da sta stcsl., hrv.-čak., rus. pomen 'ulica' v edninski obliki *stbgna (prv. najbrž *'pot do naselja in skozenj') in stcsl., rus. pomen 'trg' v množinski obliki *stbgny (prv. najbrž *'razširjeni del ulice') lahko pomensko prenesena na objekte v urbaniziranem okolju, podobno kot so polj. pomeni (prim. op. 21) preneseni na objekte v ruralnem okolju (npr. pašnik; loka; jarek, po katerem odteka voda; nedostopni kraji ipd.). Sicer pa pomenske motivacije za besedje tega pojmovnega polja najdemo v podpoglavjih $10.71 \mathrm{Road}, 10.72 \mathrm{Path}$, 10.73 Street (Buck 717-719, 719-720, 720-721) ${ }^{21}$, a pa med slovanskim gradivom pogrešamo tip *stbgna, ki ga med leksemi za 'die Landstraße' omenja O. Schrader (RL 494, geslo Straße) $)^{22}$.

\section{Viri in literatura}

Badjura - Rudolf Badjura, Ljudska geografija, Terensko izrazoslovje, Ljubljana 1953.

Bezlaj - France Bezlaj, Etimološki slovar slovenskega jezika 3, Ljubljana 19762005.

Buck - Carl Darling Buck, A Dictionary of Selected Synonyms in the Principal Indo-European Languages, Chicago - Illinois 1949.

Čop 1983 - Dušan Čop, Imenoslovje gornjesavskih dolin, Disertacija, Ljubljana 1983.

Dalı - V1. Dalı, Tolkovyj slovarb živago velikoruskago jazyka 1-4, Moskva 1980.

Datoteka LI 2003 - Digitalna datoteka ledinskih imen Agencije RS za kmetijske trge in razvoj podeželja, Hrani Etimološko-onomastična sekcija Inštituta za slovenski jezik Frana Ramovša ZRC SAZU. Na tem mestu se zahvaljujem za dostop do digitalne datoteke.

Gloger - Zygmunt Gloger, Encyklopedja staropolska ilustrowana 4, Warszawa 1903.

${ }^{21}$ Podani so psl. leksemi *pqtb, *cěsta, *dorga; *stbza, rus. tropa; stcsl. raspqtije, *ulica.

${ }^{22}$ Podani so še leksemi: *dorga, *cěsta, rus.-ukr. šljaxъ, rus. traktb, *ulica. 
Jarc - Tine Jarc, Ledinska imena pod Stolom, Begunjščico in Dobrčo, [v:] Starodavne poti pod Karavankami, Bled, Radovljica, Žirovnica 2004.

Jagić - Vatroslav Jagić, Studien über das altslovenisch-glagolitische Zographos-Evangelium, Archiv für slavische Philologie I. Berlin 1876, str. 1-55.

Karłowicz - Jan Karłowicz, Słownik gwar polskich 6, Kraków 1900-1911.

Konnova - Vera Konnova, Polish Dialect Atlases as a Source for the Study of Lexico-Semantic Change, The Slavonic and east European Rewiew, Vol. 56, Num. 3, July 1978, 321-328.

Miklošič - Franz Miklosich, Vergleichende Grammatik der slavischen Sprachen II., Manuelneudruck der Erstausgabe von 1875, Heidelberg 1926.

Miklošič LP - Franz Miklosich, Lexicon palaeoslovenico-graeco-latinum, Vindobonae 1862-1865.

Miklošič EW - Franz Miklosich, Etymologisches Wörterbuch der slavischen Sprachen, Wien 1886.

Mladenov - Stefan Mladenov, Etimologičeski i pravopisen rečnik na bъlgarskija knižoven ezik, Sofija 1941.

Moguš - Milan Moguš, Povijest hrvatskoga književnoga jezika, Zagreb 1993. - (Biblioteka posebna izdanja / Globus).

OLA 4b - Vera Smole, Angelina Pančevska, F $722 * s t / b / z a-* s t / b / g a$, Karta no. 38. [V:] Jenč, Helmut (ur.), Basara, Jan (ur.), Siatkowski, Janusz (ur.), Kenda-Jež, Karmen (ur.), Logar, Tine (ur.), Smole, Vera (ur.) [etc.]: Obščeslavjanskij lingvističeskij atlas, Serija fonetiko-grammatičeskaja, Vypusk 4b. Refleksy ${ }^{*}$, ${ }^{*}$ b. Vtoričnye glasnye, Beograd - Skopje 2003, Meždunarodnyj komitet slavistov [1988]-<2003>, 2003, zv. 4b, str. 100-101.

Pedersen 1905 - Holger Pedersen, Die nasalpräsentia und der slavische akzent, Zeitschrift für vergleichende Sprachforschung auf dem Gebiete der Indogermanischen Sprachen, Begründet von A. Kuhn. Herausgegeben von E. Kuhn und W. Schulze, Band 38, Neue Folge Band 108. Gutersloch 1905, 296-421.

Pleteršnik - Maks Pleteršnik, Slovensko-nemški slovar 2 [Uredila Metka Furlan], Ljubljana 2006.

Ramovš 1924 - Fran Ramovš, Historična gramatika slovenskega jezika II. Konzonantizem. Ljubljana 1924.

Ramovš 1997 - Fran Ramovš, Slovenski $o$ iz $ъ$ in $b$, posebe še dial. donəs za dbnbsb. Zbrano delo, Druga knjiga: Razprave in članki, SAZU, Dela 23/II, Ljubljana 1997.

Ramułt - Stefan Ramułt, Słownikjęzyka pomorskiego czyli kaszubskiego, W Krakowie, Wydawnictwo Akademii Umiejętności 1893.

RL - O. Schrader, Reallexikon der indogermanischen Altertumskunde II, Herausgegeben von A. Nehring, Berlin-Leipzig 1929.

Rozwadowski - Jan Rozwadowski, Historyczna fonetyka czyli głosownia, Kraków 1923.

SJP - Jan Karłowicz, Adam Kriński, Władysław Niedźwiedzki, Słownik języka polskiego VI, Wydanie fotooffsetowe, Warszawa 1952.

SJS - Slovník jazyka staroslověnského, Zv. 38 (slěps - stydostb), Československá Akademie Věd. Ústav pro jazyk český, Praha 1985. 
- Skok - Petar Skok, Etimologijski riječnik hrvatskoga ili srbskoga jezika 3. Zagreb 1973.

SPsł - Słownik prasłowiański I. Polska Akademia Nauk, Wrocław - Warszawa - Kraków - Gdańsk 1974.

Šimunović 1972 - Petar Šimunović, Toponimija otoka Brača, Supetar 1972.

Šimunović 2006 - Petar Šimunović, Rječnik bračkih čakavskih govora, Supetar, Brevijar 2006.

Tuma - Henrik Tuma, Imenoslovje Julijskih Alp, Ljubljana 1929.

Vaillant - André Vaillant, Grammaire comparée des langues slaves, Tome IV: La formation des noms, Paris 1974.

Vasmer - Maks Fasmer, Ėtimologičeskij slovar' russkogo jazyka 3. Moskva 1971.

Vondrák 1906 - Vaclav Vondrák, Vergleichende slavische Grammatik I, Göttingen 1906.

Zaliznjak - Andrej A. Zaliznjak, Ot praslavjanskoj akcentuacii k russkoj, Akademija Nauk SSSR, Moskva 1985.

Zierhofer - Karol Zierhofer, Ścieżka i jej synonimy w gwarach i historii języka polskiego na tle ogólnosłowiańskim, Polska Akademia Nauk, Monografie polskich cech gwarowych 3. Wrocław 1959.

\section{Reflexes of Proto Slavic *stogna in Slovenian Dialects \\ Summary}

This article provides a detailed analysis of the original Proto Slavic accentual and morphological features of the Proto Slavic lexeme *stogna that resulted in the formation of two phonological and morphological reflexes in Slovenian (i.e., stágn- and stəgn-). Franc Miklošič's Etymologisches Wörterbuch der Slavischen Sprachen (Etymological Dictionary of the Slavic Languages, 1886) properly identified the base of this lexeme and also explained its word formational structure (i.e., suffixation). The spatial distribution of the reflexes of this lexeme in Slovenian dialects and other Slavic languages is presented based on the data available.

Alenka Šivic-Dular

Filozofska fakulteta Univerze v Ljubljani, Aškerčeva c. 2, 1000 Ljubljana

asd@guest.arnes.si 


\title{
Narečno besedilo kot vir za imenoslovno raziskavo
}

\author{
Jožica Škofic (Ljubljana)
}

IZVLEČEK: V članku je prikazano, katere podatke različnih jezikovnih ravnin je mogoče pridobiti s $t$. $i$. (delno) anketno metodo ob enkratnem obisku pri narečnem govorcu z intervjujem, ki informanta ne omejuje v njegovem pripovedovanju, ampak mu omogoča, da ob odgovarjanju na deloma vnaprej pripravljena vprašanja sledi tudi svojim asociacijam in se sproščeno razgovori. Osrednji del razprave prinaša analizo okrog 100 tako zbranih (gorenjskih) mikrotoponimov, tu predstavljenih $v$ obliki slovarskih člankov.

ABSTRACT: This article demonstrates what kind of data from various linguistic levels can be acquired through a (partial) survey method during an individual visit with a dialect speaker by using an interview that does not limit the informant's narrative, but enables him to follow his associations and speak in a relaxed manner in addition to replying to questions partially constructed in advance. The main part of the discussion concentrates on an analysis of approximately 100 (Upper Carniolan) micro-toponyms collected in this manner, presented here in the form of dictionary entries.

\section{Uvod}

Narečjeslovje je veda, ki predmeta svojega raziskovalnega dela - narečij in krajevnih govorov, kot se (vsaj v osnovi) uresničujejo v govorjenih besedilih, ne more pridobiti brez tesne povezanosti terenskega in kabinetnega dela. Prvo v širšem smislu največkrat pomeni pogovor (in če je le mogoče tudi njegovo snemanje) z narečnimi govorci, drugo pa natančni zapis narečnega govora in njegovo analizo. Pogovor z narečnimi informanti lahko poteka v obliki ankete, ko raziskovalec skuša pridobiti čimbolj natančne odgovore na vprašanja iz vnaprej pripravljene vprašalnice od različnih govorcev, ali kot intervju, ko zbira podatke o raziskovanem govoru $\mathrm{z}$ zastavljanjem (vnaprej pripravljenih ali spontanih) vprašanj, namenjenih le enemu informantu. Raziskovalec lahko tudi snema ${ }^{1}$ (teže

1 Dejstvo, da snemanje naskrivaj ni primerno, so dialektologi in etnologi/slovstveni folkloristi že potrdili - raziskovalec si pač mora vzeti čas in poskrbeti za sproščeno vzdušje in zaupen odnos z informantom kljub mikrofonu ali kameri v bližini. 
pa sproti zapisuje) nenačrtovani/spontani govor narečnega govorca - tako gradivo je za ugotavljanje značilnosti narečnega govora gotovo najpristnejše, vendar pa je njegovo pridobivanje prezamudno, da bi ga pogosteje izrabljali.

V članku je prikazano, koliko podatkov in kakšne kakovosti je mogoče pridobiti s t. i. (delno) anketno metodo, ${ }^{2}$ in sicer ob enkratnem obisku pri narečnem govorcu z intervjujem, ki govorca - informanta ne omejuje v njegovem pripovedovanju, ampak mu omogoča, da ob odgovarjanju na deloma vnaprej pripravljena vprašanja sledi tudi svojim asociacijam in se sproščeno razgovori. Tak način dela raziskovalcu omogoča ne le zbiranje vnaprej pričakovane vrste podatkov (v tem primeru ledinskih imen), ampak tudi analizo drugih ravnin jezikovnega sistema, pri čemer je ob glasoslovju in oblikoslovju zanimiva zlasti povedna in besedilna skladnja.

\section{Potek govornega dogodka ${ }^{3}$}

$\mathrm{V}$ govornem dogodku (posnet je bil 1. aprila leta 2003 na domu informanta Valentina Šparovca (r. 1925) v Kamni Gorici na Gorenjskem), katerega delček je predstavljen $\mathrm{v}$ tem članku, so poleg avtorice in narečnega informanta sodelovati tudi člani osnovnošolskega narečjeslovnega krožka, ki so v tem šolskem letu zbirali hišna in ledinska imena v svojem šolskem okolišu. ${ }^{4} \mathrm{~V}$ pogovoru so sodelovali vsi prisotni (vsi so domačini iz bližnjih krajev in vsi so se vsaj na pogled poznali že pred tem srečanjem), informant je bil vnaprej (okvirno) obveščen o temi pogovora in vzroku zanj, zato je pogovor hitro in sproščeno stekel. Zaradi preobsežnosti besedila za primer navajamo le tri kratke odlomke iz govornega dogodka:

/.../ Dornọ́zuc je p'rounzap'roụ na dẹ́rsno stràin, če gre'mo po uórdi, a'ne, tọ̀: pa

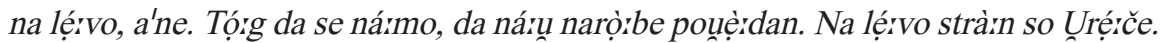
Urérče se začné:jo dóll por Dobràunskmo mórstu in se jẹ́rnajo u Čàninarju, kəkər mì

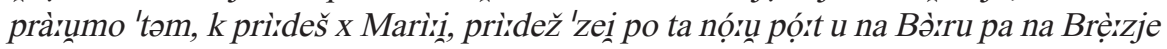

2 A. Šivic-Dular, 2002: 23 z anketno metodo označuje »zbiranje zemljepisnih imen na terenu in neposredno od krajevnih govorcev«.

3 Besedilo v ležečem tisku je fonetični zapis informantovega govora, v oklepajih in navadnem tisku pa je zapisan poknjiženi govor drugih sodelujočih (tj. raziskovalcev) v govornem dogodku ali komentarji o nejezikovnem sporazumevanju (npr. smeh) in različnih okoliščinah sporočanja, ki so vplivale na potek govornega dogodka. Izpuščeni deli govornega dogodka so nakazani s tremi pikami med poševnicama - navadno gre za nejasnost posnetka zaradi različnih šumov, izpuščeni pa so tudi nekateri deli besedila, kjer udeleženci govornega dogodka govorijo drug čez drugega ali pa se pripovedovanje preveč odmakne od rdeče niti pogovora. Za (slovensko dialektološko) fonetično transkripcijo je bil uporabljen vnašalni sistem in font ZRCola, ki ga je na ZRC SAZU razvil dr. Peter Weiss.

4 Sodelovali so učenci OŠ Staneta Žagarja v Lipnici Mojca Škofic, Erazem Dolžan in Katarina Šlibar. Del svojega raziskovalnega dela so ti učenci doslej že predstavili v publikaciji Hišna imena v KS Srednja Dobrava (izdalo Društvo prijateljev mladine Srednja Dobrava 1. 2004) in na javnih predstavitvah z naslovom Od imena do zgodbe ob dnevu muzejev maja 2004 v Kovaškem muzeju v Kropi in v OŠ Staneta Žagarja v Lipnici marca 2005. 
dó:l pa na Globọ́ko, 'no. 'Tom k je tìzzdga xrírba kó:nc in na tìst xrírp prìđdemo, je pa dolínna, na xrírbu je 'še Fortá:la. /.../

U Rokounírcax se pa zatọ̀ rérče, $k$ so járgro 'tom górr, Kàıpus plẹmenìti je járgo naštírmoụ, da so šlo járgat, sevẹ́rda i gospọ̀t rokouírce i'mu, $k$ so da'mu poršllo, x Kà:pso, pa rokouirc nír bọ́r. Pór so pa tìst ta zagná:n járgro šllo rokouírce is'kət, so ix 'tom górr čìst na ù̀rrx dobìl, $k$ jox je zgùrbu. 'No, in no'ben dorgàrč nír uéridu, $k$ pa u Rokouírcax, pa še dó:ns u'sa ve'jo za Rokouírce. /.../

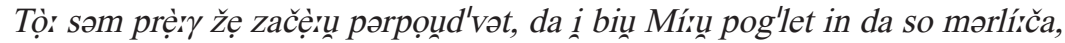
so recímo nosíll po Svetínnouno, 'tom, $k$ som povẹ́rdọu, mẹm pokopalíša, mẹm brìtofa, a'ne, u'se so tọ̀r nosírl, nír bvo 'nə亏̌ za vózzot, a'ne, če i, 'tom z dnár mọ̀rgu imẹ́rt, če s ..., pór so ga pa nérslo in so ga nérslo skọ Búrkoule, pór so ga pod Mọ́ršno dó:l nérslo, Raunírco, Raunírco, póri so ga pa nérslo pot, 'ko pa se i 'zẹi žẹ 'tom rérkvo, ana tá:ka mlakúrža i bva, na Piržounmo, na Pirža 'ke, 'tom górr, pa nazári górr pa na brìtof, a'ne. Vẹ́rš, kokọ́r i bo tọ̀ dérleč! In so na Svetínnoumo studérnc, Svetínoụ studérnc je biu z'lo lẹ̀:p, je i'mu tokọ̀le vérlok kapnírk, pa so ga póri tìrst Svetínnou fantìn otrórrgal p'reč, so mírsləl, kogár bọ̀', da ga unjo domà: za unkràisək imẹ́rl, pa nír 'ne d'ga pa 'ne gùinga. Ampak bìu pa 'je studérnc 'zẹi 'tom s skárle je dórl xórtu, da $i$ kapníxk ràstọu s tìzdga, a'ne. 'Tom so u'so pìrl, kẹ́rr je u Radọ̀lco šu na tàr načìn, so popirl. In 'tom so rérkəl, 'zẹi bomo pa 'tomle se máru oxlàrdlo, pa bomo nẹ́rkẹi popirl, vórde, a'ne, morbírt je še 'kəšno flárško kẹ́rr sàıoi i'mu, in k so morlírča dósl uzẹ̀ll, je an'mo podrééfnu, je pàrdu mor'ləč nàrnga in ga i mor'ləč u'bu. Zatọ̀r so rérkəl, da $i$ ta mórrtu ta žìugga úlbu. /.../

\section{Lastna imena v zapisanem gradivu}

Informant je v približno uro in četrt dolgem govornem dogodku nanizal skoraj 100 lastnih imen. Med njimi je največ zemljepisnih lastnih imen, saj so ga na to temo usmerjala vprašanja raziskovalcev, nekaj je tudi stvarnih in osebnih lastnih imen. V nadaljevanju so ta imena predstavljena v obliki slovarskih člankov, kjer poknjiženi iztočnici in puščici ( ) sledi v narečni transkripciji zapisano lastno ime v prvi in drugi slovarski obliki - ker gre večinoma za samostalnike in samostalniške besedne zveze, so te torej zapisane $\mathrm{v}$ imenovalniku in rodilniku ednine (pri množinskih samostalnikih samo v množini), zaradi specifičnosti rabe zemljepisnih lastnih imen je navedena še oblika mestnika. Sledi besedotvorna oznaka iztočnice - m, ž in s so oznake za spol samostalnika oz. samostalniškega jedra imena (kar velja tudi za predložne besedne zveze). Nesamostalniške iztočnice, tj. imena s stavčno strukturo, imajo navedeno samo prvo/edino osnovno obliko imena; da drugih oblik ni, nakazujeta dva vezaja (--). Temu sledi pomenska razlaga imena v ležečem tisku - ali gre za ime kraja (v govornem dogodku so bili imenovani nekateri bližnji gorenjski kraji, s katerimi je bila v 20. stoletju Kamna Gorica močno povezana) ${ }^{5}$ ali njegovega dela (gre za imena delov Kamne Gorice), ledinsko ime, ime prebivalca, stvarno lastno ime (stavbe, mostovi), hišno ime (v Kamni Gorici je danes nekaj čez sto hišnih številk, vendar imajo domača hišna imena samo hiše v starem delu, tj. okrog sedemdeset hiš, ne pa tudi tiste, ki so bile v 2. polovici 20.

${ }^{5}$ Izpuščena so imena bolj oddaljenih zemljepisnih realij, npr. Ljubljana, Afrika ipd. 
$4 \quad$ stoletja zgrajene na Polju in v Logu - tu so zapisana le tista hišna imena, ki so bila omenjena v obravnavanem govornem dogodku) ${ }^{6}$ ipd. Razlagi pomena večinoma sledi ponazarjalno gradivo, tj. iztržki iz zapisanega besedila, v katerih se ime pojavlja v različnih slovničnih oblikah. Znaku II sledi enciklopedični razdelek, $\mathrm{v}$ katerem so pojasnila o omembah imena $\mathrm{v}$ drugih (predvsem zgodovinskih in kartografskih) virih, saj je v analizo narečnega imenskega gradiva treba zajeti tudi arhivsko gradivo s čim starejšimi zapisi imen (npr. v katastrih - Franciscejski kataster 1826 in Reambulančni kataster za Kranjsko 1868, v matičnih knjigah, na vojaških zemljevidih, v urbarjih ...), kar omogoča tako primerjavo s sodobnim stanjem kot še natančnejšo analizo zbranega imenja. Z Znaku I sledi pojasnilo pomenske motivacije poimenovanja oz. etimološko pojasnilo občnega imena/ apelativa, iz katerega je nastalo lastno ime (vir pojasnila je naveden v oklepaju), prav tako je označeno, če je topoleksem zapisan tudi v Pleteršnikovem slovarju. Večina lastnih imen je nastala s polastnoimenjenjem/onimizacijo apelativov na različne načine, ki so predstavljeni v posameznih geslih. Nekatera gesla imajo na koncu še kazalko $(\rightarrow)$, ki usmerja k drugemu/sinonimnemu poimenovanju istega objekta.

\subsection{Slovarček lastnih imen, zajetih v tem govornem dogodku}

Boga vas • Bọ̀rga vàzs Bọ̀yge vasì:, u Bọ̀zk váis ž ime dela Kamne Gorice - ime je morda nastalo kot izpeljanka iz starega slovanskega/predsvetniškega osebnega imena s sestavino Bog- $^{8}$ in psl. *Vb̈sь 'vas' (SES: 807)

Bohinjec • Boxìnnc -a, pər Boxìnnc m hišno ime: je od Boxì̀nca kú:pu \| Wochinzou Polle (FK, 1826), ${ }^{9}$ Bohincovo Polje (RKK, 1868), ${ }^{10}$ Bohinjc (TTN5) iz osebnega lastnega imena, izpeljanke iz zemljepisnega lastnega imena Bohinj ${ }^{11}$ s pripono $-\partial c$

Brezje • Brẹ̀zje -zij, na Brẹ̀:zjax ž mn. naselbinsko ime: prì:deš na Brẹ̀:zje dó:1 || dacz Fresiach, 1350 9/6 (1 DA Lj.) (Kos I: 49) 『 pogost toponim, izpeljanka iz rastlinskega imena breza, psl. *berzā (ESSJ I: 43), s pripono -je (Plet.: brệzje) oz. s stanovniško pripono -jane

${ }^{6}$ O kamnogoriških hišnih imenih med drugim natančneje pišeta Marjan Kunej in Valentin Šparovec v knjigi Kamna Gorica na nakovalu časa, na straneh 165-178.

7 A. Šivic-Dular, 2002, 23 »pridobivanje zgodovinske dokumentacije vseh vrst imen« imenuje zgodovinska metoda, »določanje etimologije, izvora imena« pa etimološka metoda.

8 Za opozorila na staroslovanske osebnoimenske sestavine v zbranih toponimih se zahvaljujem imenoslovcu mag. S. Torkarju z ISJFR ZRC SAZU. V prid razlagi imena Boga vas iz antroponima govorijo tudi slovenski toponimi Boga vas v občini Ivančna Gorica, Boginja vas v občini Metlika, Bogneča vas v občini Mokronog-Trebelno, Bogo v občini Sežana, Bogojina v občini Moravske Toplice. Domačini pa izvor prilastkovega dela te besedne zveze razlagajo iz pridevnika ubog 'reven', psl. *uboğ̈ (SES: 795), ker je bila v tem delu vasi ubožnica in le nekaj manjših/revnejših hiš ter polje.

9 Vir: http://www.gov.si/arhiv/kataster/imgb/1/1136a08.jpg.

${ }^{10}$ Vir: http://www.gov.si/arhiv/kataster/imgb/1/1136c09.jpg.

${ }^{11}$ O imenu Bohinj piše Bezlaj 1956: 73-74. 
Brv Bàru Bərvì:, na Bər'və ž krajše ime Fuxove ${ }^{12}$ brvi čez Savo pod Radovljico: na Bòrru \ ime je nastalo s pomenskim prenosom iz apelativa brv, psl. *brb̈vb 'brv, most' (SES: 62) (Plet.: br̂v)

Bukovlje • Bú:kọule Búzkọula, un Bú:kọula s ledinsko ime: na/u/skọz Búkkọule \| $u$ Bukoule (FK, 1826) ${ }^{13}$, bukovlje (RKK, 1868), ${ }^{14}$ Bukovje (TTN5); Búkounje, Búkounle, gozd, gozd. i., l. ali gozd. ime (Čop 1983: 77) п izpeljanka iz rastlinskega imena bukev, slov. büky iz prazah. germ. bọk $\breve{\bar{u}}$ (SES: 64), s pripono -je (in z epentetičnim -l-) s pomenom ‘bukov gozd' (Plet.: búkovje)

Čajnar • Č̀̀inar -ja, u Č̀̀zinarjə/u Č̀̀inarju m ledinsko ime \| Zhainarjou Lefs (FK, 1826), ${ }^{15}$ Cajnar (RKK) ${ }^{16}{ }^{\check{C}}$ ajnar (TTN5) 『 verjetno gre za izpeljanko iz nekdanjega hišnega imena iz starega slovanskega imena s sestavino $\breve{C a j}^{17}$ in pripono $-n-a r$

Dobrava • Dobràzưa -e, na Dobràzu ž naselbinsko ime: za Dobràive mì: uəd'mo; potẹ́gne z Dobràive 'səm || Oberhard, 1351 28/8 (1 DAD), Hard, 1368 20/7 (1 DAD, Kom.), am Niderhard genant Nadabra, 1498 (urb. Radovljica) (vse Kos: 104), Dobrava (Jarc: 125) \ pogost toponim s prvotnim pomenom 'gaj, listnat gozd', izpeljan iz psl. korena *dobrъ 'hrast' s pripono -ava (ESSJ I: 106) (Plet.: dobrâva)

Dobravec • Dobràzúc -a m prebivalec Dobrave ali Dobravice: Dobràzúc so pa pó:i tìsst ta pòrrvi /.../ stanovà:lci ø izpeljanka iz krajevnega imena Dobrava s pripono -ec

Dobravica • Dobrà:úca -e, u Dobràrục ž naselbinsko ime: górr so Dobràzúce; pẹ́:le un Dobrà:unco \| Na Dobravi(TTN5) 【 izpeljanka iz psl. fitonima *dobrъ 'hrast' (ESSJ I: 106) s pripono -av-ica

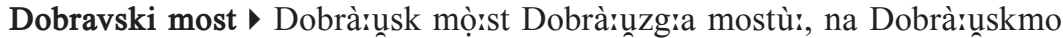
mórst/mó:stu m ime mostu čez Lipnico pod Zgornjo Dobravo: por Dobràruskmo mósstu $\square$ besedna zveza iz naselbinskega imena Dobrava s pripono -ski in apelativa most, psl. *möstъ (SES: 416)

Drnovec • Dərnọ́:ưc -a, na Dərnọ́:úcə m ime hriba: ob Dornọ́zúcu \| Dernoutz (FK, 1826), ${ }^{18}$ dernovc (RKK, 1868), ${ }^{19}$ Drnovec (TTN5) घ izpeljanka z besedotvorno podstavo drn, psl. *d"̈rnъ ‘ruša', prvotno ‘kar je odtrgano, izruvano’ (SES: 125), in pripono $-\mathrm{OV}$-ec

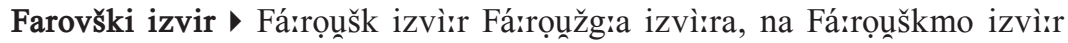
m ime studenca pri župnišču $\mathbf{~ b e s e d n a ~ z v e z a ~ i z ~ p r e v z e t e ~ b e s e d o t v o r n e ~ p o d s t a v e ~}$ farovŽ (prim. nem. Pfarrhaus ‘župnišče') s slov. pripono -ski/-ški ter sestavljenke izvir s psl. korenom *vîrъ/virb̈ in predpono iz-

Frtala Fərtá:la -e, na Fortá:l ž ime skale: na Fortá:lo \| Frrtála, g. i. (nem.

\footnotetext{
${ }^{12}$ Brv je poimenovana po svojem konstruktorju dr. Riku Fuxu.

${ }^{13}$ Vir: http://www.gov.si/arhiv/kataster/imgb/1/1136a04.jpg.

${ }^{14}$ Vir: http://www.gov.si/arhiv/kataster/imgb/1/1136c04.jpg.

${ }^{15}$ Vir: http://www.gov.si/arhiv/kataster/imgb/1/1239a01.jpg.

${ }^{16}$ Vir: http://www.gov.si/arhiv/kataster/imgb/1/1239c01.jpg.

${ }^{17}$ Bezlaj 1956: 109 razlaga (po Miklošiču) ime Čajna iz slovanskega antroponima Nečaj, izvedenega iz pridevniške oblike *(ne)čajъna.

${ }^{18}$ Vir: http://www.gov.si/arhiv/kataster/imgb/1/1270a01.jpg.

${ }^{19}$ Vir: http://www.gov.si/arhiv/kataster/imgb/1/1270c01.jpg.
} 
$\hookrightarrow \quad$ verteilen?) (Čop 1983: 59) 『 v kamnogoriškem krajevnem govoru poznajo tudi besedo fortá:uka igrača, ki se vrti', ${ }^{20}$ skala je nekoliko sploščene okrogle oblike in se podlage dotika z manjšim delom, kot je njen obseg, zato nekoliko spominja na vrtavko (Plet.: frtâvka)

Gabele • Gabẹ̀:le -ř, po Gabẹ̀l/po Gabẹ̀:u ž mn. ime poti iz Kamne Gorice proti Dobravici — Bezlaj meni, da je ime izposojeno iz srlat. in it. gabella 'davek' (ESSJ I: 134), Čop pa izvaja besedo iz globela ('poglobljena pot') preko švapanja ${ }^{21}$ (Plet.: globệla)

Galerije • Galerì̀je Galerì̀i, na Galerì̀jax ž mn. ledinsko ime \| Galerije (TTN5) - s pomensko izpeljavo (zaradi podobnosti) in spremembo slovničnega števila iz apelativa galerija prevzeto ime: galerîja $<$ nem. Galerie $<$ ital. galleria 'razstavni prostor' in 'predor, rov, balkon' (SES: 165) (Plet.: galerîja)

Globoko • Globọ́:k/Globọ́:ko Globọ́:g:a, un Globọ́:kəm posam. prid., s naselbinsko ime: g'reš na Globọ́:k; g'reš u Globọ́:ko \| Globoch 20/7 (1 DAD, Kom.), Glabock, Globach, 1498 (urb. Radovljica) (oboje Kos I: 144); Globoko, nar. Gobọk, top. (< globoks ,tief“) (Čop 1983: 89) \ pogost toponim, posamostaljena izpeljanka s psl. korenom * $g l o b ヶ$ 'profundus' in pridevniško pripono -ok (ESSJ I: 149) (Plet.: globòk)

Hotin • Xórton Xotírna, na Xotìn m ledinsko ime \| na hotin in mali hotin (FK, 1826) ${ }^{22}$, hotinj (RKK, 1868), ${ }^{23}$ Kutina (TTN5); Kutina, polja, napačno v zapisu za Hotinj, nar. na Xotín (Čop 1983: 2) 『 toponim verjetno izveden iz starega slovanskega osebnega imena/antroponima Chots ${ }^{24}$ in pripone -in

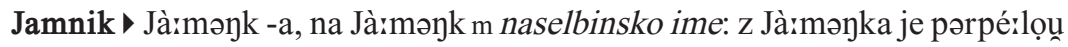
|| Naseciravn, 1291 (Urb. 4, 164), 1318 (Urb. 4, 210), Jamnyc, Jämnyk, 1476 (rač. knjige, Loka), Seytzirawn, 1500 (Urb. Loka 72), Seyczi Rauni oder am Jämnickh (Urb 1631) (vse Kos I: 221-122) 『 pogost toponim, izpeljanka iz besede jama, psl. *ja̋ma ‘kar je izkopano’ (SES: 234), s pripono -nik (Plet.: jâmnik)

Jazbečevina • Jazbačevírna -e, na Jazbačevín ž ledinsko ime: Jazbačevínno || izpeljanka iz živalskega imena jazbec, psl. *ě̆zvьcь (SES: 237), s pripono -ev-ina (Plet.: jazbəčevína)

Jelplast • Jẹ́:lplà:st Jẹ́lplà:sta m ime stavbe || Jelplast (TTN5) | v stavbi je bilo v letih 1972-1996 $6^{25}$ podjetje Jelplast, katerega ime je nastalo kot sklop okrajšav oronima Jelovica (jel-, psl. *edla, *edlъ ‘jelka' (ESSJ I: 226)) in apelativa plastika $(<$ nem. Plastik)

Jez • Jẹ̀rs Jẹ̀za, na Jẹ̀rs m ime jezu na Lipnici v Kamni Gorici med Logom in Malo gaso: prọt Jẹ̀zz I s pomenskim prenosom iz apelativa jez, psl. *e̊ż 'pregrada na reki, nasip' (SES: 241), nastali toponim (Plet.: jệz)

${ }^{20}$ Podatek je iz Slovarčka narečnih izrazov/lokalizmov v Kamni Gorici, objavljenega v Kunejevi knjigi Kamna Gorica na nakovalu časa, str. 213.

${ }^{21}$ O tem Škofic 1998: 50.

${ }^{22}$ Vir: http://www.gov.si/arhiv/kataster/imgb/1/1270a01.jpg.

${ }^{23}$ Vir: http://sigov3.sigov.si/cgi-bin/htqlcgi/arhiv/enos_isk_kat.htm.

${ }^{24}$ O tem tudi Bezlaj 1956: 213-214.

${ }^{25}$ Prej je bilo tu podjetje Okovje, od 1. 2007 je v stavbi podjetje Cometal. Za podatke se zahvaljujem g. Zdravku Bolčini iz Kamne Gorice. 
Jezus težki križ nese • Jẹ̀:zus térški kríiš né:se -- ledinsko ime 【 toponim s strukturo stavka, sestavljenega iz naslednjih besed: Jezus 'ime božjega sinu' (SES: 242), prid. iz psl. *tęžă oz. tę̂žskı (SES: 763), apelativ križ, verjetno nastal iz starofurlanske predloge *krộ(d)že iz vlat. crọcem, tož. iz klas. lat. crux 'križ' (SES: 325), in nesti, psl. *nestí (SES: 443)

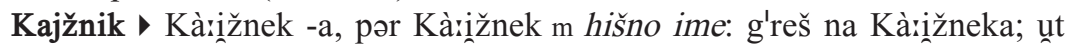
Kà:ižneka \| Kajžnek (TTN5) 『 izpeljanka iz apelativa kajža 'preprosta hiša, h kateri spada nekaj obdelovalne zemlje', prevzetega iz srvnem. *küse, kamor je bilo verjetno prevzeto iz psl. *xýša 'hiša' (SES 249), ${ }^{26}$ s pripono -n-ik (Plet.: kâjžnik)

Kamna Gorica Ká:mna Gorírca Ká:mne Gorírce, u Ká:mən Gorírc ž naselbinsko ime: obuọ̀zzənca skọs Ká:mno Goríco; je bụa u Ká:mnə Gorícc; maš do Ká:mne Goríce \|l Steinpüchel (1. radovljiški urbar iz 1. 1498), Steinbichel (Valvasor, Slava vojvodine Kranjske, 1689), ${ }^{27}$ Steinbüchel (FK, 1826), ${ }^{28}$ Kamna Gorica (RKK, 1868), ${ }^{29}$ Kamna Gorica (Jarc: 126), Kámna goríca, top. s pripono -ica/-ьca (Čop 1983: 113) 『 besedna zveza iz besede gora 'mons' z deminutivno pripono -ica (ESSJ I: 162) in prilastka iz psl. *kamy 'kamen' s pripono -en oz. -na (ESSJ II: 13)

Kamničan • Kàrmənčan -a m prebivalec Kamne Gorice \|| Kâmnčan(ə), -nke, preb. (etnik), elipsa - izpust samostalnika (Čop 1983: 122) in Kâmnčano, etn. (Čop 1983: 24) 匹 izpeljanka iz prvega/prilastkovega dela naselbinskega lastnega imena, s pripono -(j)an $\rightarrow$ Kamnogoričan

Kamnogoričan • Kamnogoríčan -a m prebivalec Kamne Gorice izpeljanka iz besedne zveze Kamna Gorica s pripono -(j)an $\rightarrow$ Kamničan

Kapus • Kà:ps/Kà:pus -a, pər Kà:ps m hišno ime: so pəršllə x Kà:psə

Kavčič • Kàrứčič -a, pər Kàrưčič m hišno ime: ${ }^{30}$ 'təm so Kà:ư⿱čičọu

Konjski britof • Kọ́:nsk brìstof Kọ́:nzg:a brìstofa, na Kọ́:nskmo brì̀tof m ledinsko ime || Kónsko brîtof, 1. i. (Čop 1983: 24) ■ besedna zveza iz pridevnika konjski z besedotvorno podstavo konj, psl. *kon"b, (SES: 302) in pripono -ski, ter samostalnika britof 'pokopališče', prevzetega iz srvnem. vrîthof 'negovan ograjen prostor pri cerkvi' (SES: 59) - še pred nekaj desetletji so namreč tu pokopavali poginule živali in ostanke klavnih živali

Kropa • Krọ́:pa -e, u Krọ́:p ž naselbinsko ime: s Krọ́:pe gó:r ste pəršlli \| Chropp (Žaga), die hamer Chrop, in der Krupp (Urb. Radovljica, 1498) (Kos I: 298), Kropp (FK, 1826), ${ }^{31}$ Kropa (RKK, 1868) ${ }^{32}$ toponim iz vodnega imena kropa, psl. *kropa 'močan kraški izvir' (ESSJ II: 99)

Kropar Krọ̀:par -ja m prebivalec Krope 『 izpeljanka iz krajevnega imena Kropa s pripono -ar

\footnotetext{
${ }^{26}$ Bezlaj v ESSJ (II: 10) razlaga prevzem slov. chyša v bavarsko nemško *küše, kjer je prišlo do diftongizacije, od koder je bilo sprejeto nazaj v slovenščino mdr. kot kajža.

${ }^{27}$ Podatki so iz Kunejeve knjige Kamna Gorica na nakovalu časa, str. 13.

${ }^{28}$ Vir: http://www.gov.si/arhiv/kataster/imgb/1/1270a01.jpg.

${ }^{29}$ Vir: http://www.gov.si/arhiv/kataster/imgb/1/1270c01.jpg.

${ }^{30}$ Hišno ime in priimek Kavčič je izpeljanka iz glagola tkati (ESSJ IV: 185).

${ }^{31}$ Vir: http://www.gov.si/arhiv/kataster/imgb/1/1128a03.jpg.

${ }^{32}$ Vir: http://www.gov.si/arhiv/kataster/imgb/1/1128c03.jpg.
} 
Lipnica L Lìrpənca -e, na Lì̀pənc ž naselbinsko ime (vas zahodno od Kamne Gorice): smo šlə na Lìspənco \| Leibnitz, in der Leibnitz, Leibnitzer alben (Urb. Radovljica, 1498) (Kos I: 323) 『 izpeljanka iz rastlinskega imena lipa 'Tilia', psl. lípa, s pripono -n-ica (SES: 358)

Lipnica L Lì:pənca -e, u Lì:pənc ž naselbinsko ime (vas vzhodno od Kamne Gorice) || Lippenza (FK, 1826), ${ }^{33}$ Lipnica (RKK, 1868) ${ }^{34}$

Lipnica • Lì̀sponca -e, u Lì:ponc ž ime potoka \| pach Lipnicz, 1481 (f. 36, 192), Leibnitz (Urb. Radovljica, 1498) (vse Kos I: 232), Leibnitz Bach (FK, 1826), ${ }^{35}$ Lipnica potok (RKK, 1868), ${ }^{36}$ Lipnica (Jarc: 125)

Lipniški most • Lì̀pənšk mọ̀rst Lì:pənžg:a mostùi, na Lì:pənškmo mórst m ime mostu čez Lipnico pri Zgornji Lipnici: na Lìrponšk mọ̀sst

Log • Vọ̀:x Vọ̀gga, u Vọ̀:x m ime dela Kamne Gorice lastno ime je nastalo s pomenskim prenosom iz topoleksema $\log$, psl. *lọg $g_{b}$ 'nižje ležeč teren, kotlina' (SES: 362) (Plet.: lọg)

Logar Vọ̀gar -ja m prebivalec Loga, dela Kamne Gorice ø izpeljanka iz mikrotoponima Log s pripono -ar

Mala gasa • Màrúa gàisa Mà:le gàıse, po Màıl gà:s ž ime dela Kamne Gorice - besedna zveza iz pridevnika mali, psl. *malı̈ (SES: 375), in samostalnika gasa, prevzetega iz srvnem. gazze 'steza' (SES: 168)

Mali kraj • Màzư k'rẹi Màılga kráija, po Màılmo krà:i m ime poti, ki z Male gase vodi $k$ farni cerkvi @ besedna zveza iz pridevnika mali, psl. *malı̈ (SES: 375), in samostalnika kraj, psl. *kräjb (SES: 317)

Mesar Mesá:r -ja, pər Mesáirjə m hišno ime: je bva ana mesnícca Mesá:rjova

Mili pogled • Míru pog'let Mírugga poglẹ́:da, na Mírumo poglẹ̀t m ledinsko ime - besedna zveza iz pridevnika mil, psl. *mîlı 'ljub, drag’ (SES: 401), in samostalnika pogled, sestavljenke z besedotvorno podstavo gled-, psl. *ględ-(SES: 174), in predpono po-

Mišače Məšáiče Məšà:č, na Məšá:čax žmn. naselbinskoime: tọ̀: i Konì:čarjọu z Məšà:č || Meyssach, 1368 20/7 (1 DAD, Kom.), Mischacz (Urb. Radovljica, 1498) (vse Kos 1975), Mischatsche (FK, 1826), ${ }^{37}$ Mišače (RKK, 1868), ${ }^{38}$ - Bezlaj 1961: 24 ugotavlja, da imeni Mišatovec in Mišetnica izvirata iz staroslovanskih antroponominov *Myšata, *Myšęta in z njim primerja tudi toponim Mišače (cit. po Kosu 1975); S. Torkar meni, da gre za nastanek toponima iz osebnoimenske oblike Mišak (s svojilno pripono -jb in stanovniško pripono -jane): Mišak-je (selo) $>$ Mišače (ed.) > Mišačane > Mišače (mn.)

Mlaka • Múákka, z Munáike, po Munáik ž ime dela Kamne Gorice, ulica, ki

${ }^{33}$ Vir: http://www.gov.si/arhiv/kataster/imgb/1/1034a03.jpg.

${ }^{34}$ Vir: http://www.gov.si/arhiv/kataster/imgb/1/1034c03.jpg.

${ }^{35}$ Vir: http://www.gov.si/arhiv/kataster/imgb/1/1270a01.jpg.

${ }^{36}$ Vir: http://www.gov.si/arhiv/kataster/imgb/1/1270c01.jpg.

${ }^{37}$ Vir: http://www.gov.si/arhiv/kataster/imgb/1/1239a01.jpg.

${ }^{38}$ Vir: http://www.gov.si/arhiv/kataster/imgb/1/1239c01.jpg. 
povezuje Malo in Veliko gaso $\mathbf{n}$ ime je nastalo s pomenskim prenosom iz apelativa mlaka, psl. *mölka ‘luža, kotanja z blatno tekočino’ (SES: 407) (Plet.: mláka)

Mošnja • Mọ́:šna -e, pod Mọ́:šno ž ledinsko ime \| Pewscheldorff, 1414 5/8 (1 DAD), am Bawtl, Bewtl (Urb. Radovljica, 1498) (Kos I: 382), Moschna, pod Moschna, u Moschne (FK, 1826) ${ }^{39}$, Mošna, pod Mošno (RKK, 1868), ${ }^{40}$ Mọ́šna, top., na Mọ́šən, Mošnja < mansion(em) k mansio, ōnis 'prenočišče, odpočitek' > * mošuńa ali mošińa, (Čop 1983: 52) 『 etimologija ni jasna (glej tudi geslo Mošnje)

Mošnje • Mọ̀:šne Mọ̀:šən, un Mọ̀:šnax ž mn. naselbinsko ime || ecclesiam in loco qui Mosnach dicidur, 1154 1/4 (Gr. 4, 323) (Kos I: 382), Mošnje (RKK, 1868), ${ }^{41}$ Mošnje (Jarc: 125) 』 predvidoma toponim z izhodiščem v latinskem mansione, kar je tvorjeno iz ptc. perf. mansum k manēre 'prebivati' (ESSJ II: 196-197); Bezlaj 1961: 36 predvideva več možnosti za nastanek imena, med drugim izvor v antroponimu Mošna ali apelativu *mošbńa ali v stanovniškem imenu *mošćen-jane (k *mostъ), ,težko pa bi bilo po tvorbi razložiti top. Mošnja“

Mršov Məršọ́:u Məršózva, pər Məršọ́:u m hišno ime: g're mẹm Məršọ́:ưa

Muhovc • Múixọuc -a, pər Múixọuç m hišno ime: je biư Mú:xọụcộu

Okrog bošta Okrọg bọ́:šta m ledinsko ime n predložno lastno ime, sestavljeno iz predloga okrog, psl. *krọgъ (SES: 327), in samostalniške izposojenke bošt, prim. nem. Forst 'gozd'

Penzijon • Penzjọ̀:n -a, u Penzjọ̀n m ime stavbe $\mathbf{n}$ iz apelativa penzion, prim. nem. Pension, izvedeno lasno ime; v nekdanji Tomanovi rezidenci je bil od leta 1929 Pension Jelovca, počitniški dom ljubljanskega magistrata, ${ }^{42}$ po 2 . svetovni vojni pa Zavod oz. Dom Matevža Langusa (za prizadete otroke) Pírcəlnə

Picelj • Pírcəl -na, pər Pírcəlnə m hišno ime: i biun Pícəlnọu; je bvə pər

Pikeljc • Pìrkəlc -a, pər Pìrkəlčounəx m hišno ime: so bli Pìrkəlčọu

Pižev most • Pìzžọ mọ̀rst Pì:žọuga mostù:, na Pì:žọunmo mó:st m ime mostu čez Savo pod Radovljico: čes Pìž̌ọ mọ̀sst \ besedna zveza iz hišnega imena pri Pižu in apelativa most

Pod lipo • / Pod lì:po Spod lí:pe ž ime dela Kamne Gorice 『 predložno lastno ime, sestavljeno iz predloga pod in fitonima lipa 'Tilia', psl. lípa (na osrednjem vaškem trgu, kjer je nekoč stala fužina, raste mogočna lipa)

Podnart > Pod'nərt Podná:rta, u Podnàirt/u Podnáirtə m naselbinsko ime: sta peláiva u Pod'nərt \ substantivizirana predložna zveza s podstavo nart 'del noge pod gležnjem, der Fußrücken, der Rist' (ESSJ II: 215) in predpono pod- - gre za poimenovanje zaradi značilne lege ob vznožju hriba/terase ob sotočju Save in Lipnice

Polica Polírca Polìrc, na Polírcax s mn. ledinsko ime: g'reš na Políca; na vòrrx Políce || Polica (TTN5) 『 Badjura 1953: 26-27 navaja topoleksem polica,

\footnotetext{
${ }^{39}$ Vir: http://www.gov.si/arhiv/kataster/imgb/1/1136a04.jpg.

${ }^{40}$ Vir: http://www.gov.si/arhiv/kataster/imgb/1/1239a01.jpg.

${ }^{41}$ Vir: http://www.gov.si/arhiv/kataster/imgb/1/1136c05.jpg.

${ }^{42}$ Podatek iz knjige Kamna Gorica na nakovalu časa, str. 92-94.
} 
$\hookrightarrow$ police kot izraz ljudske geografije, ki označuje večinoma podolgovate ploskve, terase v gorskem svetu, čemur ustreza tudi poimenovana realija (Plet.: políca)

Polje • Pọ̀ıle -a, na Pọ̀ıl s ime dela Kamne Gorice \|l dole(RKK, 1868) ${ }^{43}$ ime je nastalo s pomenskim prenosom iz apelativa polje, psl. *pöl'e (SES: 541) (Plet.: pộlje in polję)

Pri Mariji • / Pər Marì̀i, od Marì̀je ž ledinsko ime, ime križišča pešpoti: x Marìi @ predložno lastno ime, sestavljeno iz predloga pod in antroponima Marija - tu je sakralno znamenje z podobo Marije z Brezij

Radovljica • Radọ̀llca -e, un Radọ̀llc ž naselbinsko ime: un Radọ̀ılco i'tə || apud locum qui vulgo Radilidorf nominatur, 1050-ok. 1065 (Gr. 3. 169), Ratmarsdorf, 1169 24/3 (Gr. 4, 501), Radmansdorf, plebs, plebanus, cum prebenda civitatis, 1296 (MIÖG 30, 634; Studi e testi 96, 32) (vse Kos II: 499), Radoljca (RKK, $1868)^{44}$ izpeljanka iz staroslovanskega osebnega imena Radov $^{45}$ s pripono -ica in epentetičnim -1-

Ravnica • Raunírca -e, na Raunícc ž naselbinsko ime: so ga nérslə/u/ Raunírco \| Ravnica (TTN5) 【 toponim je izpeljanka iz pridevnika raven, psl. *órvbnъ iz *orvö 'ravnina, odprt svet' (SES: 604), s pripono -ica ${ }^{46}$ (Plet.: ravníca)

Ravnica • Rọ́:nca -e, na Rọ́:nc ž ledinsko ime \| na Rouenza (FK, 1826), ${ }^{47}$ ravnica (RKK, 1868), ${ }^{48}$ na Rọ́nc, 1. i. < Róunnca $<$ Ravnica $<$ adj. raven (stsl. *orvbnъ) (Čop 1983: 60) in na Rọ́nc in Rọunnc, 1. i., po monoftongiz. iz Rọ́unica < Ravnica (Čop 1983: 12)

Rokavice Rokouírce Rokouìyc, u Rokouírcax ž mn. ledinsko ime: za Rokouírce ime je nastalo s pomenskim prenosom iz apelativa rokavica, izpeljanke iz besede roka, psl. *rokä, (SES: 628) s pripono -av-ica (ime naj bi bilo motivirano z najdbo rokavice V. Kapusa v tem delu Vrčice) (Plet.: rokavíca)

Sava • Sáiva -e, za Sàrvo ž ime reke \| Saus, 799 (Gr. 1, 329), circa Savun fluvium, 820 ( Gr. 2, 61), fluvium Sawa, 838 (Gr. 2, 123) (vse Kos II: 532), Sau Flus (FK, 1826), ${ }^{49}$ Sava reka (RKK, 1868), ${ }^{50}$ Sava (TTN5) ${ }^{51}$

Skalar Skà:lar -ja, pər Skàılarjə m hišno ime: tọ̀ i pər Skàılarjə

Srček • Sàrrčək -čka, pər Sàrrčkə m hišno ime: je bọ pret Sə̀rrčkəm

Svetina • Súctí:na -a, pər Sưetí:n m hišno ime: Svetí:nọu fantì̀n

Svetinov studenec • Svetínọu studé:nc Svetínọugga studé:nca, pər Svetínọumo studé:nc m ime studenca — ime je tvorjeno iz hišnega imena, ki je

${ }^{43}$ Vir: http://www.gov.si/arhiv/kataster/imgb/1/1270c01.jpg.

${ }^{44}$ Vir: http://www.gov.si/arhiv/kataster/imgb/1/1136c04.jpg.

${ }^{45}$ O izvoru imena Radovljica so pisali Levec v Carnioli 1911 (letnik II, zvezek 3, Mali zapiski, 231) in Planinskem vestniku (II, 1896, 74-75), Skok 1924 (ČJKZ, Tri etimologije) in Šivic-Dular (1989). (Za podatke se zahvaljujem Silvu Torkarju.)

${ }^{46}$ Badjura 1953: 39 piše, da izraz ravnica na Gorenjskem pomeni »le svet, kjer je malo ravnega

${ }^{47}$ Vir: http://www.gov.si/arhiv/kataster/imgb/1/1270a01.jpg.

${ }^{48}$ Vir: http://www.gov.si/arhiv/kataster/imgb/1/1270c01.jpg.

${ }^{49}$ Vir: http://www.gov.si/arhiv/kataster/imgb/1/1136a04.jpg.

${ }^{50}$ Vir: http://www.gov.si/arhiv/kataster/imgb/1/1136c04.jpg.

${ }^{51}$ O imenu Sava piše Bezlaj 1961: 171-174. 
verjetno nastalo kot besedna zveza pridevniške izpeljanke iz predsvetniškega slovanskega rojstnega imena s sestavino Svet- in hidronima studenec, psl. *studenьcb̈ (SES: 708)

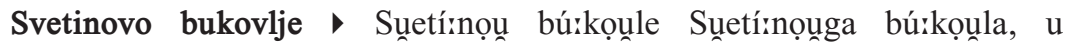
Suetí:nọumo bú:kọulo s ledinsko ime

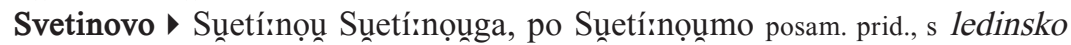
ime

Šola S Sọ̀yla Šọ̀:le, un Šọ̀:l ž ime stavbe ime je nastalo s pomenskim prenosom iz apelativa šola, prevzeto iz srvnem. schoule - v stavbi je bila namreč do 1. 1957 osnovna šola, danes so v njej otroški vrtec in stanovanja (Plet.: šộla)

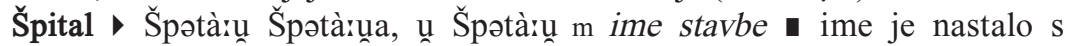
pomenskim prenosom iz apelativa špital, prevzetega iz nem. Spital 'bolnica' (SES: 738) (Plet.: špitâl) $\rightarrow$ Ubožnica

Štajerski most • Štá:jərsk mọ̀ist Štá:jərskəga mostùr, na Štárjərskmo mó:st m ledinsko ime: za Štárjərsk mọ̀rst I| Štájersk mộst, 1. i. (Čop 1983: 24) ם besedna zveza iz pridevnika štajerski in apelativa most

Štenge • Štẹ̀:nge -nk, po Štẹ̀ngax žmn. ime poti ime je nastalo s pomenskim prenosom iz apelativa štenge, prevzetega iz srvnem. stëge, stiege 'stopnice' (SES: 740) (Plet.: štę̂nge)

Tam, kjer je ta mrtvi ta živega ubil • 'Təm k je ta mórrtu ta žìunga ứbu -- ledinsko ime - toponim s strukturo stavka, sestavljenega iz naslednjih besed: kazalnega krajevnega zaimka tam, psl. *ta̋mo/*ta̋mı (SES: 749), oziralnega krajevnega zaimka kjer, *kъde že (SES: 273), posamostaljenih pridevnikov mrtvi, psl. *mbrtvb̆ (SES: 422), in živi, psl. *žîvъ (SES: 870), z določnim členom ta in glagola ubiti, psl. *ubïti (SES: 795); motivacija poimenovanja je pojasnjena $\mathrm{v}$ besedilu

Toman • Tọ̀:man -a, pər Tọ̀:man m hišno ime: Tọ̀:manọu Mí:xa

Trpin T Tərpì̀n -a, pər Tərpì:n m hišno ime: je té:kưa na Tərpì:na

Ubožnica • Ubọ̀:žənca -e, v Ubọ̀:žənc ž ime stavbe 』 ime je nastalo s pomenskim prenosom iz apelativa - izpeljanke $\mathrm{z}$ besedotvorno podstavo ubog-, psl. *ubogb̆ (SES: 795), in pripono -nica (Plet. ubôžnica) $\rightarrow$ Špital

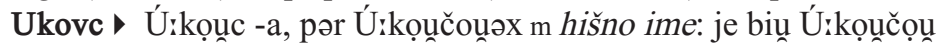

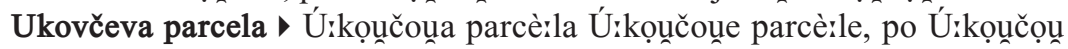

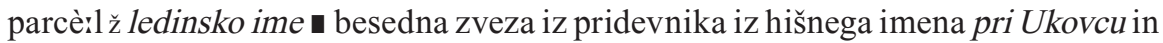
apelativa parcela, iz frc. preko nem. Parzelle 'majhen kos zemlje' (Plet.: parcēla)

Velika gasa V Vẹ̀ilka gàisa Vẹ̀llke gàise, po Vẹ̀rlk gàis ž ime dela Kamne Gorice besedna zveza iz pridevnika velik, psl. *velíkъ (SES: 812), in samostalnika gasa, prevzetega iz srvnem. gazze 'steza' (SES: 168)

Veliki kraj • Vẹ̀:lk k'rẹi Vẹ̀rlgıa krá:ja, po Vẹ̀:lkmu kràri m ime dela Kamne Gorice besedna zveza iz pridevnika velik, psl. *velíkъ (SES: 812), in samostalnika kraj, psl. *kräjb (SES: 317) (Plet.: kràj)

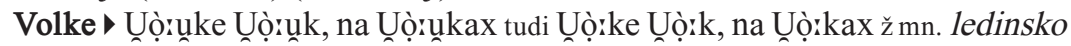
ime \| Ouzhize(FK, 1826), ${ }^{52}$ Zgornje Loke(TTN5), Konîčarjove wọ́ke, 1. i. Globoko 
$\hookrightarrow \quad$ (Čop 1983: 74) \ poknjiženje v Loke (topoleksem loka, psl. *lokä (SES: 363), iz Uọ:ke bi glede na lego (mokrotnega) travnika ob Savi sicer bilo mogoče, toda temu nasprotuje tonem in kamnogoriška različica Uọ̀zuke - tako ọ̣ kot ọ’ú pa je mogoče izvesti iz -ol- v besedi volk, psl. *Vb̂lkb (SES: 830), ki se je v nekaterih gorenjskih govorih asimiliral v dolgi ozki ọ:; zapis v Franciscejskem katastru sicer kaže na izvor toponima v apelativu ovca, psl. *ovьca̋ (SES: 483), vendar taka povezava zaradi glasoslovnih razvojnih zakonitosti ni mogoča

Vrčica • Uərčíica -e, u Uərčíćc ž ime doline in njenega potoka ll rečica (RKK, 1868), ${ }^{53}$ Vorčíca, v. i. (Čop 1983: 41), Vrčíca, v. i. < v + rěkica ${ }^{54}$ (Čop 1983: 13), Vrčíca in ročíca, u ročíc, v. i., l. i. (potok in dolina) < rěka-ica (Rečica, ne < vir) (Čop 1983: 118, 123) \ Bezlaj (1961: 316) predvideva izvor imena Vrčica iz *virčica $\mathrm{k}$ demin. virek, virček, virčec $\mathrm{z}$ reduciranim nenaglašenim prvim zlogom

Vreče UUrẹ́:če UUrẹ̀:č, na UUrẹ́:čax žmn. ime hriba med Frtalo in Zgornjo Dobravo \| Wrezhje(FK, 1826), ${ }^{55}$ Vreče (RKK, 1868), ${ }^{56}$ Vreče(TTN5) 【 etimologija ni znana, ljudska razlaga imena je v pomenskem prenosu iz apelativa vreča, psl. *vërt'a (SES: 834), ker je hrib poln vrtač, ki naj bi spominjale na vreče (Plet.: vrẹ́ča)

Zgornja Lipnica • Zgọ̀rna Lì̀pənca Zgọ̀rne Lì̀pənce, na Zgọ̀rən Lì:pənc ž naselbinsko ime: je z Zgọ̀irne Lì̀pənce \|l Ober Leibnitz(FK, 1826), ${ }^{57}$ Gorenja Lipnica (RKK, 1868), ${ }^{58}$ Zgornja Lipnica (TTN5), Zg. Lipnica (Jarc: 126) 【 besedna zveza iz pridevnika zgornji s psl. korenom *göre 'kvišku' (ESSJ I: 162) in samostalnika, izpeljanega iz rastlinskega imena lipa, psl. lípa (SES: 358), s pripono -n-ica

Zijavka • Zjà:ukka -e, na Zjàzuk ž ledinsko ime, ime skale \| Zjavka (TTN5), Zjâuka, g. i. (Čop 1983: 16) in Zjâuka, ime jame, s pripono -ka (Čop 1983: 117) 『 zijavka je manjša ali večja duplina v skalovju s skoraj ravnim dnom, ${ }^{59}$ topoleksem je izpeljanka iz glagola zijati 'biti na široko odprt', psl. *zijäti (SES: 854), s pripono -l-ka (Plet.: zijâvka) pred Žvàinam

Žvan • Žvà:n -a, pər Žvà:n m hišno ime: i bọ Žvà:novəx velíik; 'təmle dó:l

Žvanova planja • Žuàznoựa plá:na Žuàanoune plá:ne, na Žuàanọu pláin ž ledinsko ime $\square$ ime je tvorjeno iz hišnega imena in je nastalo kot besedna zveza iz pridevnika iz hišnega imena pri Žvanu in apelativa planja ${ }^{60}$ izpeljanke s psl. korenom *pôlnb 'raven' (SES: 521), neporaščen z drevjem' (Plet.: plánja)

${ }^{53}$ Vir: http://www.gov.si/arhiv/kataster/imgb/1/1270c03.jpg.

${ }^{54}$ Čopovo mnenje, da ime Vrčica izhaja iz predložne zveze $v+$ rěkica se zdi verjetna, saj je tako tvorjenje imen v gorenjščini pogosto (iz tega območja npr. še Podnart, Podvin, Podrsec idr.).

${ }^{55}$ Vir: http://www.gov.si/arhiv/kataster/imgb/1/1034a02.jpg.

${ }^{56}$ Vir: http://www.gov.si/arhiv/kataster/imgb/1/1034c02.jpg.

${ }^{57}$ Vir: http://www.gov.si/arhiv/kataster/imgb/1/1136a08.jpg.

${ }^{58}$ Vir: http://www.gov.si/arhiv/kataster/imgb/1/1136c04.jpg.

${ }^{59}$ R. Badjura 1953: 294-295 zijavke uvršča med t. i. slepe votline.

${ }^{60}$ R. Badjura 1953: 45 »plan svet«, tudi planjo, opredeljuje kot »prostranejša ali manjša odprta, preglednejša ravnina brez gosto stoječih dreves«. 


\section{Kratka jezikovna analiza na glasoslovni in oblikoslovni ravnini}

Jezikoslovna analiza zapisanega narečnega gradiva zahteva tako ugotavljanje njegovih sinhronih značilnosti, kot rekonstrukcijo razvoja raziskovanega govora/ narečja. $\mathrm{V}$ tem prispevku je (tudi zaradi pomanjkanja prostora) narečno gradivo analizirano le z metodo sinhronega opisnega jezikoslovja, medtem ko je pregled razvoja tega krajevnega govora (torej njegov diahroni vidik) izpuščen. Informant je v tem govornem dogodku predstavil gorenjsko narečje, kot se govori v Lipniški dolini, z nekaterimi interferencami iz knjižnega jezika, ki so tako posledica govornega položaja (prisotni otroci iz osnovne šole in slovenistka, snemanje $\mathrm{z}$ mikrofonom) kot značilnost informantovega idiolekta (informant npr. relativno pogosto javno nastopa na lokalnih prireditvah, piše pesmi).

Glavne glasoslovne značilnosti tu zapisane gorenjščine je mogoče strniti v naslednje ugotovitve:

- samoglasniški sistem je monoftongičen, naglasno mesto je svobodno, govor pozna dolge naglašene ter kratke naglašene in nenaglašene samoglasnike, pri čemer je na dolgih naglašenih samoglasnikih mogoč akut ali cirkumfleks (tonemska opozicija), kratki samoglasniki v zadnjem ali edinem zlogu pa so naglašeni jakostno (ir - velírk, se vìt; ẹr - bo uẹérdu, glẹ̀rdaš; ex - i rérkua; ar - dànn, gospodárr; or-unórde; or-mọ̀rst, 'nemogọ́rče; ur-drùxx, rúrdo; orr-otrór'Rgal; e- jes, razg'let; o- 'koi, kamno'lom, uəd'mo; ә-i'tə, 'təm, 'mon; u- 'tud; a - al 'pa (kratki naglašeni $u, i$ in a ter jat so večinoma oslabeli v kratki naglašeni polglasnik);

- za gorenjščino, tudi za kamnogoriški krajevni govor, je značilna velika redukcija (popolna in delna) nenaglašenih in kratkih naglašenih samoglasnikov, zlasti ob zvočnikih in v izglasju (so popraulá:l 'so popravljali', u kràri 'v kraju', velík 'veliko', d'ga 'tega', dorgàrč 'drugače', mọ̀rrš 'moraš', narjérna 'narejena', pornẹ́rsu 'prinesel', mamo 'imamo', unbọ̀ž̌onca itd.); ${ }^{61}$ sklop -ẹ:in se je lahko asimiliral v -ẹ́r (naprẹ́: 'naprej' - toda tudi naprẹ́ri ), kratki naglašeni a pred $i$ je prešel v ẹ ('zẹi 'zdaj'), pred u pa v o ( $p^{\prime} l o \underline{u}$ 'plav, moder');

- ni preglasa -o- > -e- za mehkimi soglasniki (Múxxọučọn, Úxkoụčoun, Prá:uxxarjọu);

- pogosta je oksitoneza (npr. a'no 'eno', a'dən 'eden', ubər'nu 'obrnil', gre'mo 'gremo', uِ ud'mo 'vemo', samì 'sami', torjẹ: 'trije', məd'va 'midva', se porounnà: 'se porovna', sva bva mok'ra 'sva bila mokra', novì lastník $-(\breve{c}) i-(\check{c}) e m /-(\check{c}) t-(\breve{c}) e m$ in $-(s) t i-(s) e m /-(s) t /-(s) e m)$ je v sedanjiku množine pogosto naglas na priponi (rẹčérmo, pornesérjo);

- kamnogoriški soglasniški sistem je enak knjižnemu, le distribucija tako zvočnikov kot nezvočnikov se v obeh zvrsteh nekoliko razlikuje zaradi naslednjih gorenjskih narečnih pojavov:

- tako pred sprednjimi kot pred zadnjimi samoglasniki je mogoč izgovor $V$ in ư, vendar je dvoustnični izgovor pogostejši (ve'jo/une'jo, úórda/vórda);

- švapanje, ${ }^{62}$ tj. prehod velarnega 1 pred zadnjimi samoglasniki v $v / u$ (npr.

${ }^{61} \mathrm{O}$ moderni voklani redukciji v gorenjščini je avtorica že pisala v članku Onemitev in oslabitev samoglasnikov v kroparskem govoru (glej Literaturo).

${ }^{62}$ Informant V. Šparovec ne švapa dosledno, njegov govor pa je zapisan »nepopravljen«. 
$4 \quad$ je xodìua, je bua, i rérkua, nírs unídua, sta šuna, i dáulua, nír mórguna, i rérkua, je mẹ́rua, sta pelárva, imẹ́rva, mọ̀gva, sva pograbíuna, zadérvana, je nardírua, cẹ́runo 'celo', Vọ̀garjo 'Logarji, prebivalci Loga', z'û - toda tudi z'lo, je té:kla in je térkua, pornéssla, plárčat, zaslú:žu, xlà:pco, u šọ̀:lo); v govornem dogodku je zelo redka asimilacija skupine -lo- > -vo-> -o-/u- (ux'ka 'lahko', $i$ bo ‘je bilo', ní: bo ‘ni bilo’ - toda tudi nír bvo); ${ }^{63}$

- gorenjščina pozna protetični V-/un- (úórtok, unọ̀gle, z uọ̣gglarskəm sanmír, pọ̀zu unúrre) in protetični g- (na gù:no ‘na ono');

- soglasnika $l$ ' in n' sta otrdela v $l$ in $n$ (za nírm, nìxoụ, nẹ́r 'nje', negọ́run, nérga, mená:l so, kó:na, zunonérne, knírga, Lublárno, pẹ́lle, unbnọullen, ubná:unla, pọ̀:le, naplá:ulena, so popraúlá:l, 'bəl, pokú:plen, podəržàứlenga, pərpẹ́:lejo);

- v skupini -vj- se na morfemski meji pojavlja vrinjeni/epentetski -1 (Bú:kọule < bukovje);

- narečno mehčanje mehkonebnikov (sekundarna palatalizacija velarov) $k$, $g, x$ pred sprednjimi samoglasniki v $\breve{c}, j, \breve{s}$ je večinoma leksikalizirano, v posnetem besedilu je le nekaj primerov narečnega mehčanja $k \mathrm{v} \check{c}$ (npr. tář̌gale 'takegale', sẹ́rčejo, 'sekajo/kosijo travo', čẹ́r - toda tudi kẹ́r 'kje');

- izglasni - $d$ je v nekaterih besedah prešel v - $x$ (prẹ̀: $x$ 'pred, prej');

- druge olajšave $\mathrm{v}$ izgovoru soglasniških skupin (različne asimilacije in

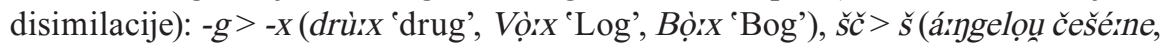
'angelovo čaščenje', pokopalíš̌e, rẹ́rušñno 'revščini', so spušáil), tj $>k>c ̌$ (pa tọ́:k če

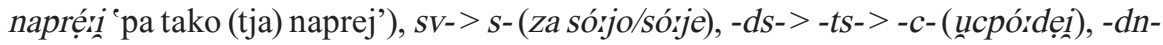
$>-n-\mathrm{v}$ besedah dopọ̀zune, upọ̣:une, zapòzuna, pomožni glagol biti v prihodnjiku se je obrusil v ŭ- (ǔš ‘boš’, ná:unjo ‘ne bojo'), v soglasniškem sklopu -kr-v besedi krat se $r$ večinoma reducira ( $\eta$ 'kət, 'kərká:t, 'kulkást, ta'kət, trìkat - toda tudi tak'rət), ${ }^{64} \mathrm{v}$ soglasniškem sklopu -kš- se -k- lahko reducira ('kəšno 'kakšno').

$\mathrm{V}$ posnetem besedilu izkazane gorenjske oblikoslovne posebnosti pa so na kratko naslednje:

- maskulinizacija srednjega spola v ednini (je drẹ́rụje zaràisu, unsàrk lẹ́st, tá:k vérlok torplẹ̀ne $i$ biun, an járic tìsst obrọ̀čen) in feminizacija v množini (tárke imẹ̀:na, tìste pẹ́rra);

- končnica -am v orodniku ednine samostalnikov moškega spola ( $z$ bráitam, s kó:nam, za fárroụžam - toda tudi pret Ṡ̀rrčkəm);

- mestnik in orodnik ednine pridevnikov in pridevniških zaimkov moškega spola ima večinoma končnico -mo (na ta drùrgmo, na Lìponškmo mórst, na Fárrọuš̌kmo izvìrr, po náršmo kórnc, u tá:kmo kràri, s tì̀stmo rẹ̀rməlnam);

Včasih se je informant popravil sam, npr. po Mlárk, po Múá:k smo ré:klo, nèr po Mlá:k, sicer pa se zdi, da je švapanje doslednejše ob čustvenem vznemirjenju in govorjenje na 1 pogostejše, ko (samo)nadzorovano pripoveduje. Tudi analogičnega menjavanja med $l$ in $v$ $\mathrm{v}$ tu zapisanem govoru ni.

${ }^{63}$ Primer asimilacije -ov-(lahko iz -ol-) > -o-navajamo naselbinsko ime Radọ:lca iz Radovljica in ledinsko ime Uọ̣ke.

${ }^{64} \mathrm{~V}$ besedilu je zapisana tudi oblik/besedna zveza unsàiko ḃ̀rt 'vsakič, vsakokrat'. 
monù̀te);

- samostalniki ženskega spola imajo dvojino enako množini (dụẹr

- osebni zaimki imajo v mestniku množine lahko iz dajalnika prevzeto obliko ( $p ə r$ 'unəm - toda tudi pər 'nəs);

- kazalni zaimek ta ima $\mathrm{v}$ zvezi s števnikom $d v a$, nanašajočim se na samostalnik moškega spola, žensko množinsko obliko (tẹ̀r dvạar sta šuna);

- glagoli na -iti -im (v knjižni slovenščini) imajo v tem govoru v množini in dvojini sedanjiško pripono -e-(nardérjo);

- zanimiva je oblika preteklega pogojnika: če bli /.../ šlø 'če bi bili šli' ${ }^{65}$

\section{Sklep}

Večina zbranih zemljepisnih lastnih imen v Kamni Gorici in njeni okolici je nastala s pomensko izpeljavo/konverzijo iz občnih zemljepisnih imen. Med njimi so izkazane različne pomenske skupine topoleksemov, npr. poimenovanja za oblike zemeljskega površja in druge značilnosti tal (zijavka, planja, polica, globoko, ravnica, $\log$ ) in poimenovanja za različne oblike voda (kropa). V to skupino gredo lahko tudi pomenske izpeljave iz poimenovanj za človekove dejavnosti v prostoru/ naravi (polje) in za človekove stvaritve (brv, most, jez, štenge) ali objekte, ki so človekovim stvaritvam podobne (galerije). Pogosta so tudi imena, ki so nastala $\mathrm{z}$ besedotvornim postopkom izpeljavo tako iz topoleksemov (npr. $d r n-O V-e c$ ) kot iz poimenovanj za rastlinstvo (brez-je, buk-ov-je, dobr-ava, dobr-av-ica), poimenovanj za živalstvo (jazbeč-ev-ina) in iz osebnih lastnih imen, tj. iz hišnih imen (npr. Žvanova planja), in staroslovanskih antroponimov (npr. Svetinovo bukovlje, Čajnar, Mišače, Hotin, Radovljica). Nekatera imena so nastala s t. i. slovnično izpeljavo, npr. s spremembo slovničnega števila in/ali spola ( lobel $>$ Gabele, volk $>$ Volke).

S stališča strukture imen so zbrana imena enobesedna (edninski in množinski samostalniki različnih spolov: Log, Brv, Frtala, Polje, Rokavice), samostalniške besedne zveze s pridevniškim prilastkom, ki označuje lastnost ali svojino kakega objekta (Boga vas, Mili pogled, Velika gasa, Žvanova planja), predložne besedne zveze, ki označujejo prostorsko dimenzijo poimenovanega objekta (Pod lipo, Okrog bošta), ali besedne zveze s strukturo stavka (Jezus težki križ nese, Tam, kjer je ta mrtvi ta živega ubil). Samostalniki kot samostojna imena ali jedra besednih zvez so večinoma izpeljanke z naslednjimi priponami: -ov-ec, -n-ica, -ava, -av-ica, -ev-ina, -je, -ov-je idr.

\section{Literatura in viri}

Badjura, Rudolf, 1953, Ljudska geografija. Terensko izrazoslovje, Ljubljana: Državna založba Slovenije.

Bezlaj, France, 1956, Slovenska vodna imena, I. del, A-L, Ljubljana: SAZU. Bezlaj, France, 1961, Slovenska vodna imena, II. del, M-Ž, Ljubljana: SAZU.

Bezlaj, France, 1977, Etimološki slovar slovenskega jezika, A-J, Ljubljana: SAZU.

${ }^{65}$ Tak pretekli pogojnik je značilen za sosednji kroparski govor. 
$\dashv$ Bezlaj, France, 1982, Etimološki slovar slovenskega jezika, K-O, Ljubljana: SAZU.

Bezlaj, France, 1995, Etimološki slovar slovenskega jezika, P-S, Ljubljana: SAZU, ISJ FR.

Bezlaj, France, 2005, Etimološki slovar slovenskega jezika, Š-Ž, Ljubljana: SAZU, ISJ FR.

Bezlaj, France, 2003, Zbrani jezikoslovni spisi I-II, Ljubljana: Založba ZRC, ZRC SAZU.

Čop, Dušan, 1983, Imenoslovje zgornjesavskih dolin. Disertacija. Ljubljana: Tipkopis.

Čop, Dušan, 1995, Jezikovne in imenske značilnosti okrog Krope in v dolini Lipnice. Kroparski zbornik. Ob 100-letnici Plamena, Kropa, Radovljica: Muzeji radovljiške občine, 190-197.

Čop, Dušan, 2002, Gorska, terenska (ledinska) in vodna imena v Sloveniji, Jezikoslovni zapiski 8/2, Ljubljana: ZRC SAZU, 93-108.

Franciscejski in RKK, L270 Kamna Gorica (AS 3000/L270), Arhiv Republike Slovenije.

Jarc, Tine, 1999, Srednjeveške poti in železarstvo na Visoki Gorenjski, Radovljica: Samozaložba.

Kos, Milko, 1975, Gradivo za historično topografijo Slovenije (Za Kranjsko do leta 1500), I (A-M), II (N-Ž), Ljubljana: Inštitut za občo in narodno zgodovino SAZU.

Kunej, Marjan, 1999, Kamna Gorica na nakovalu časa. Kranj: Gorenjski muzej.

Merkù, Pavle, 1991, Krajevno imenoslovje na Tržaškem, Zgodovinski časopis 45, št. 4, 565-580.

Merkù, Pavle, 1992, Prispevek k mikrotoponomastiki tržaške okolice, Slavistična revija 40, št. 1, Ljubljana, 32-41.

Pleteršnik, Maks, 1894-1895, Slovensko-nemški slovar, Ljubljana: Knezoškofijstvo.

Rokopisno gradivo iz leta 1941 - zbirke ledinskih imen iz okolice Krope in Kamne Gorice, arhiv Kovaškega muzeja v Kropi.

Snoj, Marko, 2003, Slovenski etimološki slovar, Ljubljana: Modrijan.

Šekli, Matej, 2006, Strukturni tipi ledinskih imen v kraju Livek in njegovi okolici, Jezikovna predanost, Zora 44, Maribor: Slavistično društvo, Ljubljana: SAZU, 477-491.

Šivic-Dular, Alenka, 2002, Zgodovina imenoslovja v Sloveniji, Jezikoslovni zapiski 8, Ljubljana: ISJ FR ZRC SAZU, 7-27.

Šivic-Dular, Alenka, 1988, Besedotvorne vrste slovenskih zemljepisnih imen na gradivu do leta 1500, Obdobja 10. Srednji vek v slovenskem jeziku, književnosti in kulturi, Ljubljana, 229-244.

Škofic, Jožica, 1996, Onemitev in oslabitev samoglasnikov v kroparskem govoru, Slavistična revija 44, št. 4, 471-479.

Škofic, Jožica, 1998, Mikrotoponimi v Kropi in bližnji okolici, Jezikoslovni zapiski 4, Ljubljana: ZRC SAZU, 47-71. 
Škofic, Jožica, 2001, Hišna imena v Kropi, Simpozij Slovenska lastnoimenskost, Pišece: Komisija Maks Pleteršnik, Novo mesto: Dolenjska založba, 21-40.

Škofic, Jožica, 2003, O zemljepisnih lastnih imenih Krope, Lipnice, Kamne Gorice in Dobrav, Vigenjc III. Zemeljska bogastva Lipniške doline, Kropa: Muzeji radovljiške občine, 109-121.

Škofic, Jožica, 2004, Zemljepisna lastna imena na Dobravah med dolinama Lipnice in Save, Besedoslovne lastnosti slovenskega jezika. Slovenska zemljepisna imena, Ljubljana: SDS, Pišece: Društvo Pleteršnikova domačija, 60-73.

TTN5, list D2643, 1981, (C) Geodetska uprava Republike Slovenije.

Http://www.gov.si/arhiv/kataster (Arhiv Republike Slovenije na svetovnem spletu.).

\section{Dialect Texts as a Resource for Onomastic Study}

Summary

This article demonstrates what kind of data at various linguistic levels can be acquired through a (partial) survey method during an individual visit with a dialect speaker by using an interview that does not limit the informant's narrative, but enables him to follow his associations and speak in a relaxed manner in addition to replying to questions partially constructed in advance. In addition to analyzing the local dialect of Kamna Gorica in Upper Carniola (in the Municipality of Radovljica) at the phonological and morphological levels, the main part of the discussion concentrates on an analysis of approximately 100 collected micro-toponyms and several other proper nouns and oeconyms presented here in the form of dictionary articles. The majority of geographical names collected in Kamna Gorica and the surrounding area were created through semantic derivation/conversion from common geographical names. These indicate various semantic groups of topolexemes such as names denoting the forms of the Earth's surface and other characteristics of the ground (i.e., zijavka 'cavern', planja 'plateau', polica 'ledge', globoko 'depth', ravnica 'plain', and log 'meadow'), and names denoting various water phenomena (i.e., kropa 'vauclusian spring'). This group also includes semantic derivations from terms denoting human activities outdoors (i.e., polje 'field') and human creations (i.e., brv 'footbridge', most 'bridge', jez 'weir', and štenge 'steps'), or structures resembling human creations (i.e., galerije 'galleries'). Names were frequently created with word-formative derivation from topolexemes (i.e., drn-ov-ec 'turf cutter') as well as names denoting plant life (i.e., brez-je 'birch forest', buk-ov-je 'beech forest', and dobr-ava, dobr-av-ica 'rolling lowland' < 'oak'), wildlife (i.e., jazbečev-ina 'badger sett'), and from personal names or oeconyms (i.e., Žvanova planja), and Old Slavic anthroponyms (i.e., Svetinovo bukovlje, Čajnar, Mišače, Hotin, and Radovljica). Some names were created through grammatical derivation such as alteration of grammatical number and/or gender (i.e., m.sg. globel 'dell' > f.pl. Gabele, and m.sg. volk 'wolf' > f.pl. Volke). In terms of structure, the collected names are single-word terms (singulare and plurale tantum of various genders: m.sg. Log, f.sg. Brv, Frtala, n.sg. Polje, and f.pl. Rokavice), nominal phrases with 
$-\quad$ an attributive adjective denoting a quality or possession of the object (i.e., Boga vas 'poor village', Mili pogled 'gentle view', and Velika gasa 'big alley'), prepositional phrases denoting the spatial dimension of the object named (i.e., Pod lipo 'under the linden' and Okrog bošta 'around the forest'), or phrases in the form of a sentence (i.e., Jezus težki križ nese 'Jesus bears the heavy cross'). Nouns as independent names or phrasal heads are mostly derivatives with the following suffixes: -ov-ec, -n-ica, -ava, -av-ica, -ev-ina, -je, -ov-je, and so on.

\section{Jožica Škofic}

Inštitut za slovenski jezik Frana Ramovša ZRC SAZU

Novi trg 2, 1000 Ljubljana 


\title{
Etymon, pojmenovací motiv a význam vlastních jmen
}

\author{
Rudolf Šrámek (Brno)
}

IZVLEČEK: V pričujočem članku je v kratkem opisu pojmov (= sistemskih kategorij) etimon, proprialni poimenovalni motiv in proprialna vsebina podan poskus, da bi zajeli najbolj bistveno, kar ustvarja razliko med apelativnim in proprialnim. Na koncu je opozorjeno na razvojne tendence, ki se v imenoslovju izraziteje uveljavljajo od polovice 20. stoletja naprej.

\section{The Etymon, Naming Motif, and Meaning of Proper Names} ABSTRACT: This article provides a short description of the terms (or system categories) of etymon, proper naming motif and proper content, and seeks to capture the most essential features that create the difference between the appellative and proper. It concludes by drawing attention to developmental tendencies whose application in onomastics has become more pronounced since the second half of the 20th century.

0. Pro slovanskou komparatistickou toponomastiku není obtížené v jednotlivých slovanských jazycích objevit množství místních jmen sídlištních i nesídlištních (= oikonym i anoikonym), ve kterých v různých způsobech ,pokračuje“ život praslovanských etymonů nebo kořenů. Tak např. k psl. bukъ ,(Rot)buche, fagus silvatica L." lze sestavit celé hnízdo jmen, reprezentujících nejrozmanitější názvotvorné ${ }^{1}$ struktury, srov. z oikonym např. čes. Buk, Buková, Bukovsko, sloven. Buková, Bukovec, pol. Buków, Buczyna, dolluž. Bukovina, horluž. Bukowc, starosrb. *Bukovina (>něm. Buckwitz), polab. *Bukovnica (>něm. Büknitz), slovin. Bukovnica, bulh. Búčeto, mak. Bukovo, Bukov Dol, chorv. a srb. Bukovac, rus. Bukovišče, ukr.

1 Termín názvotvorný je užitý jako propriální protiklad k termínu slovotvorný, jak to popsal Henryk Borek ve studii Potrzeby $i$ zadania nazwotwórstwa $w$ toponymii stowiańskiej. In: Z Polskich Studiów Slawistycznych. Językoznawstwo 6. Warszawa 1983, s. 51-62. - Podrobnou analýzu podává Aleksandra Cieślikowa, Profesor Henryk Borek i Jego nowe spojrzenie na nazwy własne. In: St. Gajda (red.), Region w świetle nazw własnych. Opole 2007, s. 37-47. - Viz také: Rudolf Šrámek, Úvod do obecné onomastiky. Brno 1999, s. 36. 
$\hookrightarrow \quad$ Bukovec, brus. Buk. ${ }^{2}$ Bohatým pramen jsou anoikonyma, jejichž struktury jsou ve srovnání s oikonymy rozvinuty bohatěji, protože jejich tvoření je zakotveno $\mathrm{v}$ místních regionálních dialektech, srov. např. pomístní jména (= Flurnamen) z češtiny: Bučanka, Buči/Boučí, Bučice, Bučicko, Bučina/Boučina, Bučinka, Bučník, Bukovský, Buk, Bukáň, Bukanov, Bukavky, Bukov, Buková, Bukovačky, Bukovnice, Bukovanka, Bukovanky, Bukovčice, Bukovec, Bukoveček, Bukoví, Bukovice, Bukovina, Bukovinka, Bukovinný, Bukovinský, Bukovinsko, Bukoviště, Bukovka, Bukovna, Bukovnice, Bukovnický, Bukovnik, Bukovno, Bukovsko, Bukový atd. ${ }^{3} \mathrm{Z}$ polských pomístních jmen jsou známy podoby jako Buczyzna, Bukowizna, Bukora aj. - Anoikonyma představují nesmírně cenný materiál, ${ }^{4}$ bohužel není zatím na slovanském teritoriu sebrán tak, aby mohl být systematicky zpracován a dokumentován v anoikonymické části budoucího Slovanského onomastického atlasu.

Už stručný výběr toponymického materiálu, který jsme výše na jménech s etymonem bukъ představili, odkrývá problémy, které ve slovanské onomastice souvisejí s interpretací etymonu, struktury, pojmenovacího motivu a významu vlastních jmen. Problémy lze shrnout do dvou skupin:

- Absence jednotného obecně teoretického konceptu onomastiky:

To se projevuje nejednotným definováním kategorie „vlastní jméno“, zaměňováním apelativní a propriální sféry jazyka (zejména nerozlišováním funkce apelativ a funkce proprií a slovotvorby a názvotvorby) a nedostatečným zřetelem ke kategorii „propriální význam“.

- Pojetí studia vlastních jmen jako „etymologie“.

To vyvolává ve slovanské onomastice značně nerovnoměrnou situaci - metodologie onomastické práce je stále závislá a na etymologickém př́stupu pozitivisticko-filologické školy, zatímco obecná onomastická teorie pracuje s výdobytky moderní lexikologie, sémantiky, sémiotiky a komunikačních teorií. Ještě v 1. polovině 20. stol. se onomastika jevila jako výkladová disciplina převážně etymologická a onomastická teorie stála pouze v začátcích, dnes se situace obrácená:

2 Viz Vladimír Šmilauer, Př́ručka slovanské toponomastiky. Handbuch der slawischen Toponomastik. Praha 1970, s. 44.

3 Pro české jazykové území jsou pomístní jména sebrána téměř v úplnosti: $\mathrm{z}$ historického území Čech kolem půl milionů, z Moravy a Slezska čtvrt milionů. Materiál je uložen v archívech Ústavu pro jazyk český AV ČR v Praze (pro Čechy) a v Brně (pro Moravu a Slezsku). Bylo zahájeno jejich lexikografické zpracování, pracuje se na digitalizaci. Viz: Libuše Olivová-Nezbedová, Jana Matúšová, Index lexikálnich jednotek pomistních jmen v Čechách. Praha 1991, a Retrográdní index slovniku pomístních jmen v Čechách, Praha 1991. - Libuše Olivová-Nezbedová, Miloslava Knappová, Jitka Malenínská, Jana Matúšová, Pomístni jména v Čechách. O čem vypovídají jména polí, luk, lesů, hor, vod a cest. Praha 1995. - Libuše Olivová-Nezbedová, Jitka Malenínská, Slovník pomístních jmen v Čechách. Úvodní svazek. Praha 2000. - Slovnik pomistních jmen v Čechách. Sv. I. Praha 2005, sv. II. Praha 2006.

4 Prokazuje to i práce našeho jubilanta Krajevno imenoslovje na slovenskem zahodu. Uredila Metka Furlan in Silvo Torkar. Ljubljana 2006. 
velmi intenzivně se propracovávají teoretické principy onomastiky a tím se nauka o vlastních jménech zařazuje do proudu moderní lingvistiky jako její relativně samostatná disciplina. ${ }^{5}$

V následující části bychom na zmíněnou nerovnoměrnost chtěli na vybraných jevech poukázat blíže.

\section{Etymon}

Je nesporné, že základem (kořenem i odvozovacím základem) výše uvedených toponym je etymon bukъ. Ten je, jak známo všeslovanský, s výjimkou jižní slovanštiny, která má bukev, bukva. ${ }^{6}$ Výklady jmen přešly od původně naivních (pseudovědeckých, nesystémových) a lidových (folklorních) interpretací do metodologie vědecké analýzy vlastně tehdy, až si začaly všímat dvou stránek vlastních jmen - jejich etymonů a jejich afixálních částí. Tento krok nastínil už Josef Dobrovský, ale typickým způsobem ho propracovala až škola France Miklošiče, ${ }^{7}$ podle jehož principů se materiál $\mathrm{v}$ onomastických dílech a slovnících řadil hnízdovým způsobem k etymonům. Klasickým prríkladem je první reprezentativní knižní dílo slovanské toponomastiky - slovník Moravská jména místní. Výklady filologické od Františka Černého a Pavla Váši (Brno 1907). Zároveň se ovšem předpokládalo, že východiskem toponyma je existující homonymní apelativum, a to i tam, kde takový lexém v apelativech doložený není. U Černého - Váši (s. 182) zní proto heslo s etymonem bukъ takto (zkráceno):

buk- (cizí, srov. stnor. bók = buk).

buk de Buk 1349

bukov Bukov 1242, Buccou $1258 \ldots$

buková z buk-ov-...

bukovina z buk-ov-ina; deminut. Bukovina ...

bukovany pův. Bukověné, Bukouaz 1131, Bukouany 1176 ...

bukovice pův. buk-ov-ica, de Bukouicz 1361 ...

pobuči pův. po-buč-bje, Pobus, Pobitz 1275....

Srov. Buk, Buky, Bučí, Bukov, Buková, Bučina, Bukovina, Bukovno, Bukovník, Bukovice, Bukovka, Bukovec, Bukovsko v Čechách.

Z organizace hesla je vidět, že metodologický postup výkladu propria má na počátku stanovení etymonu, po němž následuje výčet reálně existujících nebo jen

5 Podrobněji viz Rudolf Šrámek, Onomastická teorie ve slovanské onomastice. In: Słowiańska onomastyka. Encyklopedia. T. I. Warszawa - Kraków 2002. s. XXX-XLIII.

6 Viz Václav Machek, Etymologický slovnik jazyk českého, Praha 1968, s. 76

7 Viz Franz Miklosich, Die Bildung der slawischen Personennamen. In: Denkschrift der Akademie der Wissenschaften. Philos.-hist. Klasse, Bd. 10. Wien 1860, s. 215-330, a Die Bildung der Ortsnamen aus Personennamen im Slawischen. In: Denkschrift ... Bd. 14, Wien 1865, s. 1-74. Společné vydání: Franz Miklosich, Die Bildung der slavischen Personen- und Ortsnamen. Manuelneudruck. Heidelberg 1927. 
$\because$ potencionálně existujících apelativ, ke kterým se přiřazují „homonymni““ toponyma. Tak se základní předmět slovníkové práce, tj. vlastní jména místní, ocitá vlastně až na posledním místě. Proprium se tak stává pouhou exemplifikací „,apelativ“. Nepočítá se s vysvětlením faktu, že některá výchozí apelativa skutečně existují nebo ve starších vývojových fázích jazyka existovala (u hesla buk- jsou to v češtině jen čtyři: buk, buková, bukovice, bukovina. Ostatní lexémy jako apelativa známy nejsou: bukov, bukovany, pobučí. Mezi „apelativy“ a homonymními proprii se tedy nečiní žádné diference. Takto pojatý slovník vykládá pomocí vlastních jmen existenci doložených i nedoložených apelativ, jejichž spojujícím znakem je shodný etymon. Metodologicky tu na prvním místě stojí princip shodný s rekonstrukcí „původních“ apelativ v etymologických slovních a s historicko-filologickou přesností popisu vývoje jazyka, zejména jeho hláskoslovné a „slovotvorné“ stránky. Srov. např. u slova bukovina zdůraznění struktury buk-ov-ina nebo u pobuči rekonstrukci po-buč-bje.

Výklad propria na základě jeho etymonu (a jeho odvozenin) má však několik předností, bez kterých se ani současná lingvisticky orientovaná onomastika neobejde. Zdůrazňuji jen tři přednosti:

- Prostřednictvím etymonů je možné odkrýt vazbu proprií na lexikální zásobu konkrétního jazyka a na strukturu lexikálně sémantických významů. Vznikají tak klasifikace proprií podle toho, co jméno „znamená“ - vznikají tak tř́́dění proprií podle sémantických okruhů typu „př́roda“, „vodstvo“, „,vertikální členění povrchu“, „typ a kvalita půdy“, „způsob dobývání půdu a hospodaření na ní“, ,jídlo“, ,jevy duchovní kultury“, ,posesivita“ atd. Zapomíná se však, že se význam (obsah) etymonu nebo jeho odvozeniny v propriu neodráží v úplnosti a z funkčního hlediska se ani odrážet nemůže. O tom podrobněji v kap. 2.

- Protože vývojové procesy, které probíhají v apelativní a propriální sféře jazyka, nejsou zcela identické, mohou propria poskytovat jiný obraz o vývojových vrstvách a jiné zeměpisné distribuci lexikální zásoby jazyka; obvykle petrifikují starší vývojový stav. Tak např. má čeština pro „Dorf, villa“ ve své západní části apelativní pojmenování ves, vesnice, na východě jazykového území je však dědina. ${ }^{8}$ Avšak zeměpisná distribuce oikonym Dédina, Ves, Viska, Vsiště vykazuje jiné parametry $-\mathrm{v}$ areálu apelativního ves se na starém sídelním areálu objevují oikonyma Dědina, Dědinky, v areálu apelativa dědina jsou doložena oikonyma Ves, Viska, anoikonyma Vsisko, Vsiště, Podevsí apod. Zobecněně řečeno: toponymie (zejm. oikonyma a hydronyma) není vázána na teritoria jednotlivých slovanských jazyků a často vytváŕí celoslovanský areál (srov. např. hydronymum čes. Bystřice, pol. Bystrzyca, rus. Bystrica atd.), nebo dělí území se slovanskými jazyky jinak než „klasické“ lexikální diference (srov. např. areály toponyma s etymony ves $X$ dědina $X$ derevnja, lhota X pol. wola, bar-X bag- , bor- X sosn-, porub-X polom- aj.). Studium etymonů a toponymických lexémů vůbec je proto důležitým (a někdy

8 Viz Jan Balhar, Pavel Jančák (vedoucí autorského kolektivu), Český jazykovýatlas. Sv. 1. Praha 1992, s. 350, mapa č. 185. 
dokonce jediným) pramenem pro poznání nebo rekonstrukci starších vývojových fází slovní zásoby a vztahu k mimojazykovým skutečnostem. ${ }^{9}$

- Velmi komplikovaná je otázka stanovení etymonů v hydronymii, v níž, jak známo materiál vytvárí na evropském prostoru výrazné vrstvy chronologické, areálové i vývojové, na jejichž základě se může zrekonstruovat různé jazykově genetické zakotvení hydronyma (jeho etymonu). Míra práce s etymony je v hydronomastice největší: základy (kořeny) starých hydronym i většina způsobu jejich tvoření nenesou ještě znaky diferenci mezi pozdějšími jednotlivých jazyky, a proto mohou vykazovat i souvislosti indoevropské.

Onomastik-lingvista si musí být těchto předností vědom. Na rozdíl od etymologické onomastiky jeho práce však zde nekončí, ale vlastně teprve začíná, protože koncentrace na etymony sama o sobě zužuje nebo znemožňuje pohled na studium diferencí mezi apelativy a proprii a na typické vlastnosti propriálně pojmenovacího procesu a propriální sféry jazyka.

\section{Propriálně pojmenovací motiv}

Jako je pro apelativní slovní zásobu základním strukturujícím znakem kategorie lexikálně sémantického významu, je v propriální sféře jazyka, která je vybudovaná na jiné podstatě kategorie významu, tímto prvkem propriálně pojmenovací motiv. Centrální otázkou onomastické interpretace je proto - řečeno zjednodušeně - popis příčin, důvodů a okolností, za kterých bylo nějaké proprium vytvořeno. Centrem je proto studium propriálně pojmenovacího aktu. Pouze v momentu propriálně pojmenovacího aktu se aktivují všechny prvky a elementy, které proces vzniku propria vyžaduje a které při vzniku propria musejí být obligatorně přítomny. Vytvářejí typicky propriální celek, který nemá pendant v apelativní sfére jazyka. Jestliže tyto prvky a elementy (tento „,elek“) nejsou přítomny, nejedná se o propriální, ale o apelativní pojmenovací akt a výsledkem není proprium, ale apelativum. Prvky propriálně pojmenovacího aktu jsou:

- Onymický objekt

Je to ten objekt nebo jev, který ze společenských důvodů, ve společenské komunikaci musí být pojmenován jako jednotlivina, nap̌r. je postavena nová ulice a ta dostane jméno Buková. Systémy a tř́́dy onymických objektů jsou mimojazykovým, objektovým podkladem jednotlivých druhů vlastních jmen bionym, geonym a chrématonym. ${ }^{10}$ Bionymické, geonymické a chrématonymické objekty jsou ve společenské komunikaci fixovány vždy v odlišných souvislostech a vztazích: bionyma $\mathrm{v}$ společenskokulturních, geonyma $\mathrm{v}$ geografických a

9 Tento význam vlastních jmen je od poloviny 19. stol. obecně známý, ale jako metodologická zásada byl propracován až vlastně v 20. stol. Srov. např. France Bezlaj, Význam onomastiky pro studium praslovanského slovníku, Slavia, 27, 1958, s. 353-364.

${ }^{10}$ Jejich dalším dělením se zde nezabýváme. Např. bionyma se dělí dále na antroponyma a zoonyma atd. 
geografickokulturních a chrématonyma v ekonomických, politickokulturních a ideologických. - Společnost si uvědomuje, c o propriálně pojmenovává.

- Propriálně pojmenovací motiv

Ze všech sémantických znaků daného objektu je zvolen jeden, který se stane pojmenovacím motivem: uliční název Buková neznamená totéž, co kvalitativní adjektivum bukový, např. ve spojení bukový stůl. Pojmenovací motiv odráží potřebu nazvat ulici podle nějakého znaku, který zaručí, že proprium bude plnit individualizující, diferencující a lokalizující funkci bez ohledu na to, co je etymonem sémanticky vyjádřeno. A proto najde ulici se jménem Buková i cizinec, který názvu vůbec „,nerozumí“, tj. kterému není zřejmý etymologický (apelativní) význam výchozího adjektiva. Propriální motiv je sémanticky konstruován jinak než apelativní: v uličním názvu Buková to podle konkrétní situace může být poukaz na to, že „na konci ulice stojí mohutný buk“, „ulice je na kraji města a vede k bukovému lesu“, „,byla zde kdysi buková alej“, „,sousední ulice se jmenují Lipová, Dubová, Jedlová apod., takže s nimi vytváŕí Buková určité sémanticky specifické pole“ atd. Volba propriálního motivu musí zaručovat individualizaci a singulárnost propriálního objektu. Kategorie propriálního motivu je propirálně univerzální a není vázána na konkrétní jazyk, nýbrž na charakter norem společenské komunikace a života společnosti. Z toho vyplývá, že např. čes. Buková, pol. Bukowa, rus. Bučnaja atd. je propriálně identické s něm. Buchen (-straße, -dorf, -bach). ${ }^{11}$ - Společenost si tedy uvědomuje, p r o č a na základě j a k ý c h znaků daný objekt propriálně pojmenovává. Zatímco v apelativní slovotvorbě se tvoření jmen maximálně podřizuje morfematickým strukturám slovotvorných typů (např. v kategorii „,nomen agentis““ nelze uplatnit stejně slovotvorné prostředky jako v kategorii „nomen instrumenti“), v propriální sféře je volby pojmenovacích prostředků podřízena volbě propriálně pojmenovacího motivu.

- Vlastní jazykové zpracování

Je vázáno na podmínky konkrétního jazyka. Které jazykové prostředky jsou při tvorbě jmen využity (,,aktivovány“), to určuje onymická norma, která v době vzniku jména působí jako regulativ. Je třeba upozornit, že ne všechny slovotvorné prostředky se uplatní jako názvotvorné. Dủležité však je, že názvotvorný proces probíhá v intencích slovotvorby daného jazyka, a proto mohou propria působit jako ,gramaticky dobře utvořená““, ,jako bezchybná“ apod. Popis jazykové stránky proprií zahrnuje velmi širokou problematiku lexikálních základů (lexémů) a jejich vztahu k slovní zásobě fundujícího jazyka a problematiku formálních prostředků a „strukturních vzorců (modelů)“،. Společnost si uvědomuje, j a k ý m jazykem a j a k ý m způsobem (podle jakého názvotvorného modelu) proprium vytvoří.

${ }^{11}$ Explicitnost v pojmenování propriálních objektů -straße, -dorf, -bach a jejich implicitnost (nevyjádřenost) ve jménech slovanských nevyplývá z nějakých specifik propriálních systémů konkrétních jazyků, ale z geneticko-typologických vlastností daného jazyka: slovanské jazyky dávají přednost afixální derivaci, germánské kompozici. Tím se systemově adekvátně rovněž vysvětlí např̀. to, že při přejímání jmen z jednoho jazyka do druhého jsou propria vřazena do propriálního systému přejímajícího jazyka a tím mohou proměňovat svou strukturu, srov. např. čes. Petrovice $>$ něm. Petersdorf, něm. Richenberg $>$ čes. Liberec atd. Jde o problematiku integrace jmen. 
V procesu vlastního jazykového zpracování pojmenovacího motivu v proprium je rozhodující způsob, jakým se to děje. $Z$ toho hlediska je třeba od sebe odlišovat tři typy:

a) Přimý způsob pojmenování, kdy zvolený pojmenovací motiv je maximálně shodný s lexikálně sémantickým obsahem motivujícího znaku. Např. oikonymum Buk vzniklo jako odraz skutečnosti, že ves byla založena $u$ buku, kolem buku. Těmto jménům se obvykle terminologicky říká jména prímá.

b) Metaforický způsob pojmenování, kdy vztah mezi propriálně pojmenovacím motivem a obsahem motivujícího slova je zprostředkován metaforou. Např. čes. anoikonyma (= Flurnamen) typu Břicho, Chobot, Noha, Lopata, Plachta obsahují sice apelativa bricho „Bauch“, chobot „Rüssel“, noha „Fuß, Bein“, lopata „Schaufel“, plachta dialektově „Laken, Bettuch“, ale ze struktury jejich významů vydělují pouze jeden sém, který je schopen metaforicky pojmenovat propriálně relevantní vlastnost konkrétního pojmenovaného objektu: Břicho $=$ pole, které je uprostřed vypouklé, Chobot = pole, louka, velmi často rybník, který má tvar chobotu, Noha = pole, louka, rybník, který je úzký a dlouhý a na jednom konci poněkud rozšířený, Lopata = široké, rovné, pravidelně ohraničené pole, Plachta = široké, rovné, ale velmi rozlehlé pole (vlastně motivicky synonymní s Lopata). Hydronyma typu Hlavnice, Hlavatá jsou metaforickým pojmenováním horních toků malých říček a potoků nebo pramenných úseků ležících na kopci. Jde o velmi starobylý propriální motiv, srov. Kapitol v Rímě (lat. caput „hlava“), biblickou horu Golgota „lebka“12 (= lat. oronymum Calvaria „Schädelstätte“), tj. vlastně „hlava“ (< aramejsky gulgaltha „lebka“). Metaforická pojmenování jsou antropokulturním fenoménem.

c) Metonymicky zpi̊sob pojmenování se ve slovanské toponymii prosadil velmi markantně, jak to ukazují např. oikonyma patronymického původu: ukr. oikonymum Jaroslavyčy je motivováno pojmenováním „,příslušníků rodu muže, který se jmenoval Jaroslav". Srov. čes. Jaroslavice, pol. Jarosławice. Jméno rodu se metonymicky uplatnilo jako jméno místa, kde se tento rod usadil. Antroponymum se transformovalo na toponymum, což znamená, že se proměnily propriálně specifikující funkce.

Jak vidět, východiskem pojmenování (= nositelem propriální motivace) může být jak apelativum (nebo jeho etymon), tak proprium. Podle toho je třeba celou onymii dělit na deapelativa a depropria. Toto dělení má zásadní význam v tom, že mezi oběma skupinami existují rozdíly v typu propriální motivace. Jestliže je jméno města Bystřice odvozeno přenesením ( $\mathrm{tj}$. transonymizací) hydronyma Bystřice, protože město leží kolem břehů stejnojmenné řeky, pak je oikonymum původu propriálního (je deproprium), vzniklo metonymickým způsobem a etymon bystr- není pro motivaci oikonyma vůbec relevantní. To znamená, že je výklad oikonyma Bystřice jako ,substantivizace adj. bystrá, tj. voda“ nebo jako ,sufix -ica k bystr-“ metodologicky i teoreticky chybný, protože interpretuje proprium jako apelativum. Oikonymum Bystřice je přece motivováno polohou (lokací) na řece se jménem Bystřice a to podává informaci typu „kde“: ves leží „na Bystřici“. Jestliže

12 Viz v evangeliu Matoušově 17, 33. 
$4 \quad$ však analyzujeme jméno řeky, musíme na vztah propriálního motivu k etymonu bystr- přihlížet, nebot' ten odráží vlastnosti pojmenovaného objektu. Hydronymum Bystřice je tak informací o objektu s rychle, bystře tekoucí vodou a patři do motivického okruhu ,jakýc“ ${ }^{13}$ Podobně u antroponym: př́ijmení (= Familienname) Vrba sice etymologicky souvisí s vrba „Weide“, ale antroponymicky relevantní motiv spočívá na metaforickém pojmenování osoby s dlouhými vlasy nebo toho, kdo bydlí u vrby, popř. kdo vyráběl (pletl) z vrbového proutí koše.

\section{Včlenění hotového propria do jazykové a společenské komunikace}

Propriálně pojmenovací akt je dovršen včleněním hotového propria do jazykové a společenské komunikace. Tím se zahajuje fáze fungování jména. Toto přehodnocení se projevuje dvěma nejdůležitějšími okolnostmi:

- Apelativní typ významu etymonu nebo výchozího apelativa je eliminován a formuje se a stabilizuje nový typ významu, totiž význam propriální, který se vztahuje pouze na jeden pojmenovaný objekt: Bukovice propriálně znamená ,ves $8 \mathrm{~km}$ východně od bývalého okresního města Tišnov, severně od Brna, doložena poprvé r. 1259 Bvkowize, nemající kostel, vždy s českým obyvatelstvem ..." “. ${ }^{14}$ Jedině pod tímto významem, který je identický s lokalizující funkcí, plní ve společenské komunikaci oikonymum Bukovice svou roli jako propium. Protože význam „,buk“, který je skrytý v etymonu, je pro fungování irelevantní, nelze jej v oikonymu ,přeložit“: i v německých textech zůstává Bukovice, ovšem v něm. adaptaci Bukowitz. Znalost apelativní sémantiky etymonu nebo fundujícího apelativa není už vůbec nutná - u většiny propií tuto okolnost běžný uživatel jazyka nezná a přesto jich jako proprií užívá, např. Ljubljana, Maribor, Brioni, Protorož, Terst atd. Uvedená jména nepodávají žádnou ,,apelativní“ informaci, jsou jazykovou značkou svého objektu.

- Hotové proprium se počíná vyvíjet jako samostatná jednotka jazyka: začleňuje se do gramatických, syntaktických a pravopisných pravidel, nabývá dialektových podob, vznikají všelijaké varianty, vstupuje do mezijazykových vztahů. Od vývojových tendencí apelativ se však odlišuje určitou retardací, petrifikací starší vývojových forem (stadií) a uvolněnějším vztahem ke gramatickým normám.

\section{Význam vlastního jména}

Z toho, co bylo řečeno výše, vyplývá, že je zapotřebí diferencovat mezi třemi typy významu vlastních jmen:

${ }^{13}$ Paradigma typů motivických modelů je podáno ve studii: Rudolf Šrámek, Toponymické modely a toponymický systém. Slovo a slovesnost, 33, 1972, s. 304-318. Německý překlad: Zum Begriff ,,Modell" und „System“ in der tschechischen Toponymie. ONOMA, 27, 1972/1973, s. 55-75.

${ }^{14}$ Viz Ladislav Hosák, Rudolf Šrámek, Místni jména na Moravě a ve Slezsku. I. Praha 1970, s. 133, II. Praha 1980. 
- Etymologický význam se vztahuje na etymon jména nebo na jeho (existující nebo jen rekonstruované) výchozí apelativum a je branou k objasnění „obsahu“ (= Inhalt) propriálně pojmenovacího motivu. Počáteční vývojové fáze onomastiky byly zaměřeny právě na odkrytí toho typu významu, a proto není rozdílu mezi etymologickými slovníky apelativ a proprií.

- Propriální význam vzniká na základě individualizovaného (singulativního) vztahu $\mathrm{k}$ pojmenovanému objektu, je vázán pouze na tento objekt, nemá proto charakter pojmu a je nepřeložitelný, protože nereflektuje strukturu apelativního významu, nýbrž struktur propriálně relevantního motivu. Jedině tak mohou propria v jazykové a společenské komunikaci plnit roli „,proprií“. V komunikaci je nutno znát propriální, nikoli etymologický význam.

- Uzuální význam propria vyplývá z užití propria v konkrétních komunikačních situacích. Uzuální význam není odrazem propriálně pojmenovacího aktu, ale stylistických, emocionálních, modálních, konotativních a jiných vlastností textu. Vzniká nový obor onomastiky - propria v textu. ${ }^{15}$

\section{Závěr}

Onomastika jako speciální vědecká disciplína se od poloviny 20. století rozvíjí velmi intenzivně, a to zvláště třemi směry:

Budují se její obecně teoretické a metodologické základy, které jí umožňují chápat propria jako lingvistický (nikoli jen jako etymologický nebo filologický) fakt.

Pole jejího vědeckého zájmu se od „klasické“ orientace na původ a vývoj proprií rozšiřuje o problematiku fungování proprií $\mathrm{v}$ komunikaci, textech, promluvách atd.

Interdisciplinárnost onomastiky není již chápána ,jen“ jako tradiční spolupráce s vědami historickými, jak tomu bylo zejména v 19. století, ale zapojují se o zřetele sociologické, psychologické, ekonomické, právní aj. Dobrou ukázkou jsou témata, která se dotýkají vztahu proprií a systému společenských kulturních hodnot, jak jsou zpracovávána v onomastice skandinávské a polské.

Lze proto říci, že se mění paradigma onomastiky. Stává se z ní relativně samostatná subdisciplina lingvistiky, která zkoumá nejen vznik a původ proprií, ale také jejich systémové a komunikační vlastnosti. Propria neinterpretuje jako jednotliviny, nýbrž jako prvky komplikovaných vztahů, které v rámci jazyka vytvářejí propriální sféru jazyka (neboli druhou vrstvu jazyka).

\section{Literatura}

Jan Balhar, Pavel Jančák (vedoucí autorského kolektivu), Český jazykový atlas, Sv. 1. Praha 1992.

15 Viz např. Heinrich Kalverkämper, Textlinguistik der Eigennamen. Stuttgart 1987. 
4 France Bezlaj, Význam onomastiky pro studium praslovanského slovníku, Slavia, 27, 1958, s. 353-364.

Henryk Borek, Potrzeby i zadania nazwotwórstwa w toponimii słowiańskiej, Z Polskich Studiów Slawistycznych, Językoznawstwo 6, Warszawa 1983, s. 51-62.

Aleksandra Cieślikowa, Profesor Henryk Borek i Jego nowe spojrzenie na nazwy własne, St. Gajda (red.), Region w świetle nazw własnych, Opole 2007, s. $37-47$.

Ladislav Hosák, Rudolf Šrámek, Místní jména na Moravě a ve Slezsku. I. Praha 1970, II., Praha 1980.

Václav Machek, Etymologický slovnik jazyk českého, Praha 1968.

Heinrich Kalverkämper, Textlinguistik der Eigennamen, Stuttgart 1987.

Pavle Merkù, Krajevno imenoslovje na slovenskem zahodu, Uredila Metka Furlan in Silvo Torkar, Ljubljana 2006.

Franz Miklosich, Die Bildung der slawischen Personennamen, Denkschrift der Akademie der Wissenschaften, Philos.-hist. Classe, Bd. 10. Wien 1860, s. 215-330.

Franz Miklosich, Die Bildung der Ortsnamen aus Personennamen im Slawischen. In: Denkschrift der Akademie der Wissenschaften, Philos.-hist. Classe, Bd. 14, Wien 1865, s. 1-74.

Franz Miklosich, Die Bildung der slavischen Personen- und Ortsnamen, Manuelneudruck, Heidelberg 1927.

Libuše Olivová-Nezbedová, Miloslava Knappová, Jitka Malenínská, Jana Matúšová, Pomístní jména v Čechách, O čem vypovídaji jména polí, luk, lesů, hor, vod a cest, Praha 1995.

Libuše Olivová-Nezbedová, Jitka Malenínská, Slovník pomístních jmen v Čechách, Úvodní svazek, Praha 2000.

Libuše Olivová-Nezbedová, Jana Matúšová, Index lexikálních jednotek pomístních jmen v Čechách. Praha 1991, a Retrográdní index slovníku pomistních jmen $v$ Čechách, Praha 1991.

Slovník pomístních jmen v Čechách. Sv. I. Praha 2005, sv. II, Praha 2006.

Vladimír Šmilauer, Přriručka slovanské toponomastiky, Handbuch der slawischen Toponomastik, Praha 1970.

Rudolf Šrámek, Úvod do obecné onomastiky, Brno 1999.

Rudolf Šrámek, Onomastická teorie ve slovanské onomastice, Słowiańska onomastyka, Encyklopedia, T. I., Warszawa-Kraków 2002. s. XXX-XLIII.

Rudolf Šrámek, Toponymické modely a toponymický systém, Slovo a slovesnost, 33, 1972, s. 304-318. Německý překlad: Zum Begriff „Modell“ und „System“ in der tschechischen Toponymie, ONOMA, 27, 1972/1973. 


\section{Etimon, poimenovalni motiv in pomen lastnih imen}

Povzetek

V pričujočem člankuje v kratkem opisu pojmov (= sistemskih kategorij) etimon, proprialni poimenovalni motiv in proprialna vsebina podan poskus, da bi zajeli najbolj bistveno, kar ustvarja razliko med apelativnim in proprialnim. Etimon predstavlja povezanot $v$ tvorbo imen pritegnjenih občnih imen (iztočnice) in temeljnega besedja poimenovalnega jezika. Proprialni poimenovalni motiv je treba pojmovati kot premostitev $t$. $i$. proprialnih objektov (= proprialno $k$ poimenovanim objektom) in takega po njihovih lastnostih, ki odsevajo vsebino proprialnega poimenovalnega motiva. Kategorija proprialne vsebine ne more biti apelativne narave (in tudi ni), ker se lastno ime posameznega objekta lahko nanaša samo na posamezni objekt in ne more ustrezati na apelativni način pojmovno strukturiranemu vsebinskemu tipu. Na koncu je opozorjeno na razvojne tendence, ki se uveljavljajo v imenoslovju od polovice 20. stoletja naprej.

Rudolf Šrámek

M. Steyskalové 70, CZ 61600 Brno

Rudolf.s@seznam.cz 



\title{
*Bblva, *Bblvanz та ін. \\ (фрагмент праслов'янського антропонімного фонду)
}

\author{
Віктор П. Шульгач (Kijev)
}

IZVLEČEK: Članekje posvečen rekonstrukciji fragmenta praslovanskega antroponimičnega fonda (izpeljanke z osnovo *Bъlv-).

\section{*Bblva, *Bblvanz and the rest (A fragment of the Old-Slavonic anthroponymical fund)}

ABSTRACT: The article is devoted to the Old-Slavonic anthroponymical fund reconstruction (derivates with the *Bblv-root).

Основа *Bъlv- репрезентує тип кореневих структур, яким властиві: а) реалізація сполуки «голосний -ъ- + плавний -l-» як -ал-, -ол-, -ел-, -yл-, -іл$(-и л-)^{1 *}$; б) лабіалізація плавного (-л- >-в-); в) абсорбція плавного; г) явище солодкозвуччя, тобто перехід -л- >-л'- >-ц̌-; г) метатеза (-ль- >-вл-); д) розвиток секундарних голосних у позиції після плавного. Ці фонетичні явища мають регулярний характер, тобто цілком чи вибірково властиві не тільки для гнізда 3 коренем *Bъlv-, а й для однотипних структур на зразок * $B b l b-,{ }^{*} B b l x-,{ }^{*} B b l d-$, *Bblt-, "Bъls- тощо. Вони різняться між собою лише розширювачем кореня (детермінативом). Деякі з названих гнізд вже описані й прокоментовані

1 *Див. про це явище: Шахматов А.А. К истории звуков русского языка. О полногласии и некоторых других явлениях. СПб., 1903, С. 68-85, 126-137 та ін. Про різноманітну вокалічну реалізацію сонанта 1, рівну п'ятифонемному ряду, та ін. явища в структурах tlt > tъlt, практично не відображені й не прокоментовані в історичних граматиках слов'янських мов, див.: Казлова Р.М. Славянская гідранімія. Праславянскі фонд. Гомель, 2003, Т. III, С. 315-318. Ми цілком поділяємо їхні погляди.

Про вокалізм у групах типу tъlt (спеціально для східнослов'янського лінгвального континууму) див: Козлова Р.М. К проблеме вокализма в структурах tъrt, tъlt в восточнославянских языках // Историческое развитие языков и методы его изучения: Тезисы межвузовской конференции. Свердловск, 1988, Ч. 2, С. 162-163; ї̈ ж: Об учете звуковых изменений в основах типа tъrt-, tъlt- при этимологизации восточнославянской лексики // Проблеми української діалектології на сучасному етапі. XVI Республіканська діалектологічна нарада: Тези доповідей і повідомлень. Житомир, 1990, С. 149-150. Ці спостереження й узагальнення, на жаль, часто залишаються поза увагою наукових кіл або сприймаються ними неадекватно. 
$\hookrightarrow$ в науковій літературі, інші ще чекають своїх дослідників. 3 огляду на сказане й відбирався фактичний матеріал, на основі якого відновлюється праслов'янська лексико-словотвірна парадигма з коренем * $B b l v$-.

"Bъlva, *Bъlvъ, *'Въlvo: укр. Иванъ Болва, 1723 р. (Швидько 284), Балва, 1752 р. (Пивовар 61), сучасні укр. Болва (КПУ Дн. 8, 229), Бальва (КПУ Дн. 5, 434), Більва (Горпинич 76), а також Байва (КПУ Полт. 8, 564), Буйва (Ровенськ. обл.; Анк.) < "Бал(') ва, ${ }^{*} Б у л л^{(')} в а$, Бовла (ПСС 221), яке тлумачиться нами як метатезний варіант до *Болва, ст.-блр. Матей Буйва, 1567 р. (ЛМ I/3, 629), блр. Булва (Бірыла 67) з більш виразним лабіальним -y- під впливом сусідніх губних $Б$ - та -в-, ст.-рос. Балва, 1557-1561 pp. - ногайський гонець (ОПК 169), рос. Болов (Лет. ЖС № 14-26, 35) < Болв (друге повноголосся), хорв. Baljva, Bulva, Buva, Buvo (Leksik 22, 82, 86), пол. Balwa, Bulwa (SN I, 145, 562), чеськ. Bulva (ЧП).

До цього списку долучаються форми з абсорбованим -л- (-l-): укр. Бова (СП 49), Бовенко (ОКІУМ) - патронім на -енко, Бева (КПУ Харк. 2, 446), блр. Бава́ (Бірыла 30), ст.-рос. Бова Болвановъ сынъ Скрыпицынна, 1581 р. (Шумаков 319), Бовъ, 1664 р. (Тупиков 50), (похідне) Бовина гора, 1647 р. - топонім (Полякова 59), рос. Яга-Бова, Ога-Бова - прізвиська (СРНГ 3, 40), пол. Bow, Bowa (SN I, 454), чеськ. Воuva, Buva, Bůva (Beneš 105). Укр. Небова (Рівне 444) постало з первісного *Ne-bzlva. Пор. також слов'ян. Бово (Памяць 309), Був / Буф (Ратіе̨с́ 2, 171), які континують * Болво, *Булв.

Заголовкові праантропоніми мотивовані відповідними апелятивами, продовження яких подекуди фіксуються в слов'янських мовах. Пор., наприклад, укр. діал. бо́льфа 'пухир, пухлина' (СБук.Г 536) < *болва (субституція -б->- $\phi$-), рос. діал. булва бот. 'Heliantus tuberosus L.' (Анненков 48). Р.М. Козлова наводить ще пол. діал. batwa 'вал, водна хвиля' (Казлова 2000, 66). Семантика наведених апелятивів закономірно континує генетичне значення i.-€. " $b(h) e l-$ 'що-небудь опукле, заокруглене'.

Від базових * Bъlva, ${ }^{*} B b l v ъ,{ }^{*} B ъ l v o$ утворилися демінутиви:

*Въlvica: луж. Bólwica (Zběrka 41).

*Выуьсь: рос. Бовеи (КПУ Ув. Дон. 2, 67), хорв. Bovac (Leksik 65), слвн. Bovec (ZSSP 51), пол. Bowiec (SN I, 454).

"Въlvikъ: пол. Bowik, Bulwik (SN I, 454, 562).

На основі суфіксальної варіантності пов'язані такі деривати:

"Błlvaka, *'Bъlvakъ, *'Въlvakjь > "Въlvačь: ст.-укр. Иван Боловач, 1653 р. (ВУР 3, 421) - форма із секундарним -о-, із *Болвач, укр. Больвак (КС Дн. 3, 133), Бувак (КПУ м. Київ 1, 242), Бувака (КПУ Черк. 4, 55), блр. Балвака (Бірыла 38), Batwacz, 1770 р. (АВК XXXV, 177), ст.-рос. Бовачев (АФЗХ II, 268), рос. Болвакин (КП Алтай 2, 47), Бульваков (Ратіе̨с́ 2, 191), Болвачев (КПУ Од. 1, 358), хорв. Boljvak, Buvač (Leksik 59, 86), яке мотивувало топонім Buvači (Im.m. 107) - з регулярним для хорватської мови фонетичним розвитком 1 > $u$, пол. Bowak (SN I, 454). Ці й подібні до них факти постали в результаті пропріалізації відповідної апелятивної лексики, пор., наприклад, блр. балвака 'нерозумна людина' (ЭСБМ 1, 291).

*Bъlv'akъ: пол. Bujwiak (SN I, 554) < 'Bulwiak. 
"Błlvyka, "Bъlvykъ: ст.-poc. Бовылка, Бовыкинъ, XV ст. (НПК I, 180; III, 318), (похідні) Бовыково, Бовылина (2) - топоніми (НПК IV, 16; Копанев 206), пол. Воwycz (SN I, 455) < *Bowykjb - усі з абсорбцією -л- (-l-).

Найпродуктивніше реалізувалася словотвірна модель 3 приголосним -n- у суфіксі:

*Bъlvanъ: ст.-укр. Васко Бовъванъ, 1649 р. (Реєстр 448), Ивашка Болван, 1654 р. (ПК 143), укр. Левко Бовванъ, 1723 р. (Швидько 288), Болван (РІ ІФ 3, 287), Балван (Панцьо 95), Бойван (КПУ Дн. 7, 36), Буйван (КПУ Сум. 3, 99) форми з переходом -л- >-л'- >-й-, Бован (Панцьо 97) < Бовван / 'Болван, Буфан (с. Вузлове Радехівськ. р-ну Львівськ. обл.; Анк.) < Буван (- $\phi-<-в-),($ похідне) Боанова криниия - мікротопонім у Ровенській обл. (Пура I, 33) < Боан < "Бован (втрата інтервокального -в-), ст.-рос. Болван, XV ст. (Веселовский 44), Меньшой Балван, 1657 р. (Прозоровский 123), рос. Бовван (САЛ 351), Буванов (СКТ 98), Буфанов (Горпинич, Корнієнко 36) < "Буванов, (похідні) Баваново назва поселення в колишній Смоленській губ. (Vasmer RGN I, 224), Болвань (4), Болваново Нижнее, Болваново Вышнее - ойконіми в колишніх В'ятській, Саратовській, Смоленській, Тверській губ. (Vasmer RGN I, 450), Болваново (5), Болвановское, Болвань - топоніми в колишній Псковській губ. (Списки Псков. 511), ст.-блр. Буйван, XVI ст. (ОДВ VI, 117), блр. Балва́н, Бо́лван (Бірыла 38), (похідні) Балвановка - топонім у колишній Могильовській губ. (Vasmer RGN I, 250), Балванішкі - назва поселення в Гродненській обл. (Рап. Гродз. 30) < Балван-ішкі, болг. Балванов (Илчев 61), хорв. Balvan, Belvanović (Leksik 22, 38), серб. Балван (Грковић 156), Бован (СБР I, 588), слвн. Виvаn (ZSSP 68), пол. Batwan, Balwan, Bołwan, Bolwan, Bowan, Bulwan, Bujwan (SN I, 145, 153, 412, 415, 454, 554, 562), чеськ. Balvan, Bolvan, Bovan (ЧП), слвц. Balvan (TZ Trnava 60). Незвичний на перший погляд вокалізм окремих фактів може бути зумовлений також «міграційною» здатністю антропонімів.

Зі слов’янських мов запозичено лтськ. Bulvans, лит. Bulvanas, Bulvonas, на що свого часу вказував К. Буга (LPŽ I, 346).

Стосовно апелятивного підгрунтя пор., наприклад, укр. діал. болва́н 'дурень' (Жегуц, Піпаш 23), рос. діал. болва́н 'голова' (СГРС 1, 136), ‘бешкетник, неслухняне дитя', 'хамовита людина, невіглас' (НОС 1, 65), болован 'дурень, болван' (СРНГ 3, 76), блр. болван 'дурень' (ЭСБМ 1, 291), болг. балван 'вайлувата, невихована людина' (БТР 39), пол. діал. batwan 'дурень' (SJP 1, 91), слвц. bolvan 'лежебока, нероба' (SSJ 1, 117).

3 огляду на сказане може бути переглянута версія М.О. Баскакова, за якою рос. Болван виводилося $з$ тюрк. palwan < перс. pähläwan 'атлет, герой, воїн, борець' (Баскаков 34).

Додамо також, що рефлекси псл. 'Bъlvanъ, крім сфери антропонімії, фіксуються й в інших класах онімів, про що нам уже доводилося писати (Шульгач 1996, 92-94; Шульгач 1998, 29-33). Див. ще: (Казлова 2000, 6162).

*Bъlvanьсь: ст.-рос. (похідне) Болванщьы, 1556 р. - мікротопонім (АС 404), рос. (похідне) Болванцево - топонім у колишній Псковській губ. (Списки Псков. 511), хорв. Balvanac (Leksik 22) і под. Їх можна кваліфікувати як 
$\hookrightarrow$ демінутиви на *-ьсь або як семантичні деривати, пор., наприклад, рос. діал. болванец 'пуголовок' (Мордов. 1, 42).

*Bъlvinъ *'який стосується *Bъlvy': укр. Болвин (СП 51), Бойвин (КПУ Дн. 12/1, 139), Бавин (КПУ Луг. 9, 39), Бувин (КПУ Дон. 20, 337), (похідне) Бовинский - ойконім на Полтавщині (Vasmer RGN I, 418), ст.-рос. (похідне) Больвино, XVII ст. - назва пустища в колишній Московській губ. (ОПКМ 266), рос. Болвин (СП 51), Болвинов (КПУ Ник. 6, 245), Бильвин (Рamięć 2, 531), кореневий вокалізм якого міг оформитися під впливом наступного -и-, Бовин, Бовін (СП 49), Бувин (КП Керчь 1, 57), (похідні) Бовинская (3) - ойконіми в колишній Пермській губ. (Vasmer RGN I, 418). Антропонім *Болвин (> Боловин і под. - як форми $з$ другим повноголоссям) відобразився також у назвах поселень: Боловин Починок (колишня Тверська губ.), Боловино (колишні Костромська, Нижегородська, Тверська, Ярославська губ.), Баловино (колишня Псковська губ.), Балавино (колишня Ярославська губ.) (Vasmer RGN I, 246, 254, 453). Пор. ще Боловинский конец, Боловина лавица - назви внутрішньоміських об'єктів Пскова середини XV ст. (Прозоровский Древний Псков 181), а також блр. (похідне) Bilviny - назва поселення в колишній Гродненській губ. (Vasmer RGN I, 389), хорв. Beuvin, Buvinić (Leksik 44, 85), пол. Balwin, Bowin, Buwin (SN I, 145, 454, 589), чеськ. Balvín (ЧП). Сюди ж слов'ян. Бильвиново, Бильвиново или Осока - ойконіми на Сувалкщині (Вольтер 4) < *Бълвин-ов-о - відантропонімного походження.

Зі слов’янських мов запозичено основи литовських прізвищ Bovinas, Bovynas (LPŽ I, 295).

*'Bъlvonъ, ${ }^{*}$ Въlvonъ: болг. Балавонски (Илчев 60)-як формаз секундарним -a-, із *Балвонски, пол. Batwon (Rymut I, 17), Belwon, Belwoń, Betwon, Betwoń (SN I, 238, 239). Щодо мотивації зішлемося на чеськ. blvoň 'дурень, йолоп' (Kott I, 75).

*Bъlvunъ: ст.-укр. Иван Баивунєнко, 1649 р. (Реєстр 306) - патронім на -єнко, слов'ян. (похідне) Буйвуны - ойконім у колишній Віленській губ. (Vasmer RGN I, 659), відомий під 1564 р.: Гришко Якубовичъ з Буйвунъ (ЛМ $\mathrm{I} / 3,650)$.

Фактичний матеріал дозволяє реконструювати антропонімні деривати 3 іншими стрижневими консонантами суфіксальних морфем, переважна більшість яких виникла лексико-семантичним способом:

*Bъlvaјь: укр. Бавай (Богдан 9) < "Баввай / "Балвай, ст.-рос. (похідне) Боваев, XVII ст. - урбанонім у Нижньому Новгороді (РИБ ХІХ, 171) < "Болваев, рос. Боваев (Лет. ГС № 5, 31), пол. Bujwaj (SN I, 554) < *Bulwaj.

*Bъlvasъ, "Въlvasь: укр. Бальвас (СКТ 41), Бавласюк (Раmięć 2, 336) < *Балвасюк, (похідне) Бевасове - назва озера у Вінницькій обл. (ОКІУМ) < *Беввас-ове чи *Белвас-ове, ст.-рос. Болвасов, XVI ст. (Анпилогов 65), рос. (похідне) Болвасово - ойконім у колишній Московській губ. (Vasmer RGN I, 250), пол. Balwas, Batwas, Baławas, Batwaś, Bauwas (SN I, 145, 148, 153, 210), чеськ. Bulvas (ЧП).

*Въlvatъ: укр. Боват (КПУ Дн. 2, 530) < "Бовват / "Болват, Бельватенко (КПУ Сум. 5, 56), пол. Batwat (SN I, 153). 
"Bъvitъ: укр. Бовит (КПУ Дон. 17, 161), Бовіт (КПУ Дн. 3/1, 82) - форми зі стягненням -вв- > -в- чи абсорбцією плавного -л-.

*Въlvitјь: укр. Бойвич (Богдан 22), Буйвіч (КПУ Полт. 7, 363), Бович (CKT 71), блр. Belwicz, 1783 р. (АВК XXXV, 556), Буйвіч (Бірыла 65), (похідне) Буйвичи - ойконім у колишній Віленській губ. (Vasmer RGN I, 569), ст.-рос. (похідне) Болвичевская, XVII ст. - мікротопонім у колишній Московській губ. (ОПКМ 226), (похідне) Буловицы - назва поселення на Смоленщині (Vasmer RGN I, 579) < "Боловичи < "Болвичи, пол. Bewicz, Bowiczyk (SN I, 270, 454).

*Bъlvqtъ: пол. Batwut (SN I, 153) - деназалізована форма чи запозичення з східнослов'янських мов.

"Въlvaхъ/"Въlvašь < "Выvaхјь: укр. Болвах (КПУ Од. 1, 63), болг. Бълвашев (Илчев 96), пол. Botwach (SN I, 415). У діалектах російської мови зберігся мотивуючий апелятив, пор. болва́шка 'важка дерев’яна палиця' (НОC 1, 65).

*Błlvišь , "Въlvyšь: пол. Bolwisz, Bowysz (SN I, 412, 455).

*Bъlvišče: укр. Бовище (КПУ Київ. 1,418)-дериват на-ǐ̌čе з пейоративною семантикою.

Як свідчить зібраний з доступних джерел і проаналізований фактичний матеріал, похідні з основою * $B ъ l v$ - реалізувалися на слов'янських теренах 3 різною долею продуктивності, проте їх рефлекси засвідчено практично в усіх слов'янських антропоніміконах. Попередньо окреслені контури розмитого, але розлогого генетичного гнізда 3 коренем ${ }^{*} B b l v$-, куди належить і псл. *Bъlvanz, - один із вагомих аргументів на користь питомості й відповідного апелятива - псл. " bъlvanъ, з приводу генези якого немає одностайності.

\section{Скорочення}

АВК - Aкmы , изд. Виленскою Археографическою комиссиею. Вильна 1910, T. XXXV.

Анк. - Анкета для збору ономастичних матеріалів.

Анненков - Анненков Н., Простонародные названия русских растений, Москва 1858.

Анпилогов - Анпилогов Г.Н., Рязанская писцовая приправочная книга концฺа XVI века, Москва 1982.

AC - Архив П.М. Строева, I, In: Русская историческая библиотека, Петроград 1915. T. XXXII.

АФЗХ - Акты феодального землевладения и хозяйства, Подг. к печати А.А. Зимин. Москва 1956, Ч. II.

Баскаков - Баскаков Н.А. Русские фамилии тюркского происхождения. Москва 1979.

Бірыла - Бірыла М.В., Беларуская антрапанімія, 2: Прозвішчы, утвораныя ад апелятыўнай лексікі, Мінск 1969.

Богдан - Богдан Ф., Словник украӥнських прізвищ у Канаді, Вінніпег 1974. БТР - Български тълковен речник. Трето изд. София 1973. 
4 Веселовский - Веселовский С.Б., Ономастикон: Древнерусские имена, прозвищуа и фамилии, Москва 1974.

Вольтер - Вольтер Э.А., Список населенных мест Сувалкской губернии как материал для историко-этнографической географии края, Санкт-Петербург 1901.

ВУР - Воссоединение Украины с Россией: Документы и материаль. Москва 1953, T. 3.

Горпинич - Горпинич В.О., Прізвища степової Украӥни: Словник, Дніпропетровськ, 2000.

Горпинич, Корнієнко - Горпинич В.О., Корнієнко І.А., Прізвища Дніпровського Припоріжжя (словник). Дніпропетровськ, 2003.

Грковић - Грковић М., Речник личних имена код Срба, Београд 1977.

ЭСБМ - Этылмалагічны слоўнік беларускай мовы. Рэд. В.У. Мартынаў. Мінск 1978, Т. 1.

Жегуц, Піпаш - Жегуц І., Піпаш Ю., Словник гуцульського говору в Закарпатmi, Мюнхен 2001.

Илчев - Илчев $C$. Речник на личните и фамилни имена у българите, София 1969.

Казлова 2000 - Казлова Р.М., Беларуская і славянская гідранімія: Праславянскі фонд, Гомель 2000, Т. І.

Копанев - Копанев А.И., История землевладения Белозерского края XV-XVI в., Москва; Ленинград 1951.

КП Алтай - Книга памяти: Поименный список воинов Алтая, павиих в боях Великой Отечественной войны 1941-1945 г2.: В 2 т. Барнаул 1986-1988.

КП Керчь - Книга памяти города-героя Керчи и Керченского полуострова. Симферополь 1999, Т. 1.

КПУ Дн. - Книга пам’яті України: Дніпропетровська область, Дніпропетровськ 1994, Т. 2, 3/1; 1995, Т. 5, 7, 8; 1996, Т. 12/1.

КПУ Дон. - Книга памяти Украины: Донеикая область, Донецк 1998, Т. 17; 1999, Т. 20.

КПУ Київ. - Книга пам'яті Украӥни: Київська область, Київ 1995, Т. 1.

КПУ Луг. - Книга памяти Украины:: Луганская область, Луганск 1995, Т. 9.

КПУ м. Київ - Книга пам'яті України: Київ, Київ 1994, Т. 1.

КПУ Ник. - Книга памяти Украины: Николаевская область, Николаев 1999, T. 6.

КПУ Од. - Книга памяти Украинь:: Одесская область, Одесса 1994, Т. 1.

КПУ Полт. - Книга пам'яті Украӥни: Полтавська область, Полтава 1998, T. 7, 8 .

КПУ Сум. - Книга пам'яті України: Сумська область, Суми 1995, Т. 3, 5.

КПУ Ув. Дон. - Книга памяти Украины по увековечению участников боевых действий, умерших в послевоенные годы: Донецкая область, Донецк 2002, T. 2.

КПУ Харк. - Книга пам’яті України: Харківська область, Харків 1994, Т. 2. КПУ Черк. - Книга пам'яті України: Черкаська область, Київ 1996, Т. 4. 
КС Дн. - Книга скорботи Украӥни: Дніпропетровська область, Дніпропетровськ 2003, T. 3.

Лет. ГС - Летопись газетных статей, Москва 2005.

Лет. ЖС - Летопись журнальных статей, Москва 2005.

ЛМ - Литовская метрика, Отдел I, часть 3: Книга публичных дел. Перепись войска Литовского. In: Русская историческая библиотека, Петроград 1915, T. XXXIII.

Мордов. - Словарь русских говоров на территории Мордовской АССР: Учебное пособие по русской диалектологии. Отв. ред. Т.В. Михалева, Саранск, 1978. Вып. 1.

НПК - Новгородские писиовые книги, изд. Археографическою комиссиею, Санкт-Петербург 1859-1915. Т. 1-6 и указатель.

НОС - Новгородский областной словарь, Отв. ред. В.П. Строгова, Новгород 1992, Вып. 1.

ОДВ - Опись документов Виленского центрального архива древних актовых книг, Вильна 1906, Вып. VI.

ОКІУМ - Ономастична картотека Інституту украӥнськоӥ мови НАН Украӥни.

ОПК - Обзор посольских книг из фондов-коллекций, хранящихся в ЦБАДА (конец XV-начало XVIII в.), Сост. Н.М. Рогожин, Москва 1990.

ОПКМ - Обозрение писиовых книг Московской губернии с присовокуплением краткой истории древнего межевания, Сост. П. Иванов, Москва 1840.

Памяць - Памяць: Гісторыка-дакументальная хроніка Лоеўскага раёна, Гал. рэд. Г.П. Пашкоў, Мінск 2000.

Панцьо - Панцььо С.С., Антропонімія Лемківщини, Тернопіль 1995.

Пивовар - Пивовар А.В., Поселення Задніпрських місць до утворення Нової Сербії: в документах середини XVIII століття, Київ 2003.

ПК - Присяжні книги 1654 р.: Білочерківський та Ніжинський полки. Упоряд. М. Кравець, Київ 2003.

Полякова - Полякова Е.Н., К истокам пермских фамилий: Словарь, Пермь 1997.

Прозоровский - Прозоровский Д.И., Опись древних рукописей, хранящихся в музее имп. Русского археологического общества, Санкт-Петербург 1879.

Прозоровский Древний Псков - Прозоровский Д.И., Древний Псков по двум псковским летописям с дополнениями из других старых источников до конца XVIII в., In: Записки отделения русской и славянской археологии имп. Русского археологического общества, Санкт-Петербург 1879, Т. 4, C. $178-254$.

ПСС - Полягли в снігах Суомі (Серія: Книга пам’яті України про громадян, які загинули у воєнних конфліктах за рубежем. Т. 2), Київ 2004.

Пура - Пура Я.О., Походження назв територіальних мікрооб’єктів Рівненщиини, Рівне 1990, Т. І.

Рап. Гродз. - Рапановіч Я.Н., Слоўнік назваў населеных пунктаў Гродзенскай вобласиі, Мінск 1980. 
4 Реєстр - Реєстр Війська Запорозького 1649 року: Транслітерація тексту, Підготували до друку: О.В. Тодійчук (гол. упоряд.), В.В. Страшко, P.I. Ocташ та ін., Київ 1995.

РИБ - Русская историческая библиотека, Санкт-Петербург 1898, Т. XIX.

Рівне - Рівне: Щорічний телефонний довідник, Рівне 2006.

РІ ІФ - Реабілітовані історією: Івано-Франківська область, Івано-Франківськ 2002, T. 3.

САЛ - Список абонентов Ленинградской городской телефонной сети. 1965 , Ленинград 1965.

СБР - Српски биографски речник, Гл. уредници: М. Лесковац, А. Форишковић, Ч. Попов, Нови Сад 2004, Т. 1.

СБук.Г - Словник буковинських говірок. За заг. ред. Н.В. Гуйванюк, Чернівці 2005.

СГРС - Словарь говоров русского Севера. Под ред. А.К. Матвеева, Екатеринбург 2001. Т. 1.

СКТ - Справочник квартирных телефонов г. Киева, Сост. Д.М. Циолек, Киев 1976.

СП - Словник прізвищ: практичний словозмінно-орфографічний (на матеріалі Чернівеччини), Укладачі: Н.Д. Бабич, Н.С. Колесник, К.М. Лук’янюк (гол. ред.) та ін., Чернівці 2002.

Списки Псков. - Списки населенных мест Российской империи, изд. Центральным статистическим комитетом МВД, Санкт-Петербург 1885, Т. XXXIV, Псковская губерния.

СРНГ - Словарь русских народных говоров, Под ред. Ф.П. Филина, Ленинград 1968, Вып. 3.

Тупиков - Тупиков Н.М., Словарь древнерусских личных собственных имен, In: Записки Отделения русской и славянской археологии имп. Русского археологического общества, 1903, Т. 6, С. 86-914.

ЧП - Чоловічі прізвища громадян Чеської Республіки за даними Міністерства внутрішніх справ ЧР станом на 1.04. 2004, In: www.mver.cz.

Швидько - Швидько Г., Компут і ревізія Миргородського полку 1723 р., Дніпропетровськ 2004.

Шульгач 1996 - Шульгач В.П., Псл. "brlvanъ / 'Bzlvanъ (етимологічний аспект). In: Ономастика східних слов’ян, Тези доповідей наукового семінару, Київ 1996, C. 92-94.

Шульгач 1998 - Шульгач В.П., Праслов'янський гідронімний фонд (фрагмент реконструкиії), Київ 1998.

Шумаков - Шумаков С.А., Обзор Грамот Коллегии Экономии. Вып. 4. In: Чmeния в Обществе истории и древностей российских при имп. Московском университете, 1917, Кн. II. Отд. 1. С. 1-336.

Beneš - Beneš J., O českých př́jmeních, Praha 1962.

Im.m. - Imenik mesta, Pregled svih mesta i opština, narodnih odbora srezova i pošta u Jugoslaviji, Beograd 1956.

Kott-Česko-némecký slovník zvlášté grammaticko-fraseologický, Sest. Fr.Št. Kott, V Praze 1878, D. I. 
Leksik - Leksik prezimena Socijalističke Republike Hrvatske, Zagreb 1976.

LPŽ - Lietuviu pavardžiu žodynas, Vilnius 1985, T. I.

Pamięć - Pamięć. Память, Сост. Я. Пшимановский, Х. Прокопчук, Р. Мурани.

Пер. с пол. под ред. К. Козакевич, Варшава 1987, Ч. 1-2.

Rymut-Rymut K., Nazwiska polaków: Słownik historyczno-etymologiczny, Kraków 1999, T. I.

SJP - Słownik języka polskiego, Pod red. J. Karłowicza, A. Kryńskiego, W. Niedźwiedzkiego, Warszawa etc. 1904, T. I.

SN - Słowniknazwisk współcześnie w Polsce używanych, Wydał K. Rymut, Kraków 1992, T. I.

SSJ - Slovnik slovenského jazyka, Ved. red. Št. Peciar, Bratislava 1959. D. I.

TZ Trnava - Telefónny zoznam. 2004-2005, Trnava 2004.

Vasmer RGN - Russisches geographisches Namenbuch, Begr. von M. Vasmer, Wiesbaden 1962, Bd I.

Zběrka - Zběrka swójbnych mjen, Wot Radyserba, In: Časopis Maćicy Serbskeje, 1892, Lět. XLV., S. 41-47.

ZSSP - Začasni slovar slovenskih priimkov, Odg. red. F. Bezlaj, Ljubljana 1974.

*Bblva, *Bblvanz in dr. (fragment praslovanskega antroponimičnega fonda) Povzetek

$V$ članku je rekonstruiran fragment leksikalno-besedotvorne paradigme praslovanskih izpeljank z osnovo *Bъlv-. Na podlagi analize faktografskega gradiva prihaja avtor do sklepa, da so se izpeljanke z osnovo *Bъlv- realizirale v slovanskih jezikih z različno stopnjo produktivnosti, čeprav so njihovi odrazi izpričani praktično $v$ vseh slovanskih antroponimikonih. Posebno pozornost pri odbiri faktografskega gradiva je avtor posvečal formalnim modifikacijam, značilnim za korenske strukture tipa tъlt (realizacija ъl > al, ol, el, ul, il (yl); labializacija likvide; absorbcija likvide; premena $1>$ l' > j; metateza idr.).

Віктор Петрович Шульгач

Відділ ономастики Інституту української мови НАН України вул. Грушевського, 4, 01001 м. Київ, Україна v.shulgach@mail.ru 



\title{
Toponim Preserje in slovansko-romansko prepletanje pripon -jane in -anum
}

\author{
Silvo Torkar (Ljubljana)
}

IZVLEČEK: V prispevku je v prvem delu na podlagi primerjalnega slovanskega gradiva in literature podana etimologija toponima Preserje iz *Prě-syr-jane. V drugem delu je prikazana dilema glede jezikovne pripadnosti cele skupine toponimov v Furlaniji in na zahodnem slovenskem robu zaradi navideznega sovpada slovenske (prvotno stanovniške) pripone -jane in romanske pripone -ano/-ana $<$-anum ter predlagan slovenski izvor za nekatere od njih.

ABSTRACT: The article begins by presenting the etymology of the toponym Preserje from *Prě-syr-jane on the basis of comparative Slavic material and literature. The second part of the article presents the dilemma regarding the linguistic affiliation of the entire toponym group in Friuli and on the western Slovenian border due to illusory coincidence of the Slovenian suffix -jane (originally referring to inhabitants) and the Romance suffix -ano/-ana < -anum. In addition, a Slovenian origin is suggested for some of these toponyms.

\section{Preserje}

Na slovenskem etničnem ozemlju nosi kar osem krajev ime Preserje, od tega sedem v Republiki Sloveniji (RS), eden pa v Slovenski Benečiji: Presêrje pri Radomljah (o. Domžale), Presêrje pri Lukovici (o. Lukovica), Presêrje pri Zlatem polju (o. Lukovica), Préserje (o. Brezovica), Préserje (o. Nova Gorica), Préserje (o. Braslovče), Préserje pri Komnu (o. Komen) (SKI 1985, 221, http://www.stat.si), Preserjé (o. Srednje/Stregna v Benečiji) (SKII 1999, 61). Preserje je tudi poimenovanje dela naselja Hotavlje, sodeč po historičnih zapisih pa spadata sem tudi furlanski naselji Passariano pri Codroipu (UD) in Persereano v o. Pavia di Udine (Zuanella Dom). V RS je samo eno Preserje edninsko (v o. Brezovica), edninsko je tudi Preserjé v Benečiji. V mestniku se vsa Preserja vežejo s predlogom v, le v o. Nova Gorica živijo na Preserjah. Prebivalci so Preserjáni (4: 1 v o. Braslovče, 2 v o. Lukovica, 1 v Benečiji), Presérci (1 - v o. N. Gorica), Presérci ali Presêrci (1 - v o. Domžale), Préserci (1 - v o. Komen) in Préserci ali Presêrci (1 - v o. Brezovica). 


\begin{abstract}
Najstarejši historični zapisi imena Preserje so:
Prezeriach iz časa ok. 1200 za njive jugozahodno od Šempetra pri Gorici, 1507 Presseriach (Kos 1954, 107);
Preserje v o. N. Gorica: 1402 Pressriach, 1485 Pressirach (Kos 1954, 128, $145)$;
Preserje kot del Hotavelj: 1291 in villa Prezriach, 1500 Preseriach (Kos 1975, 479);

Preserje v o. Brezovica: 1420 Preszer, 1428 Presser (Kos 1975, 480);

Preserje pri Zlatem Polju: 1359 Presteriach (Kos 1975, 480);

Preserje pri Radomljah: 1333 Prezzeriach, 1344 Presaeriach (Kos 1975, 479);

Preserje pri Lukovici: 1341 cze Presteryach, 1449 Presseriech (Kos 1975, 480);

Preserje v o. Braslovče: 1419 zu Pressriach, 1424 in 1426 Presiriach, 1453 Presseriach (Blaznik HTŠK II, 139);

Passariano v Furlaniji: 1267 Persereano, 1300 Presereano (Frau 1978, 90);

Persereano v Furlaniji: 1031 Perseriano, 1166 Presaerian, Pressarian, 1176 Perseriano (Frau 1978, 91).
\end{abstract}

Luka Pintar je v svoji znameniti imenoslovni nadaljevanki O krajnih imenih (Pintar 1913, 547) o imenu Preserje bolj ugibal, ne da bi se prepričal o historičnih zapisih: »Preserja so menda, kakor Znojila, solncu odprti kraji. ... Rabi se tudi v množini »v Preserjah« (l in $r$ se včasi menjata, sŭr in sŭl). Preserje iz Presulje, tj. presoje.«

Fran Ramovš se v svojih delih tega imena sam od sebe ni dotaknil, pač pa ga je poklical na pomoč geograf Svetozar Ilešič, ko je pisal o naseljih na vzhodnem Gorenjskem (Ilešič 1933, 87). Ramovš je zaradi dveh zapisov Presteriach oz. Presteryach takrat izrazil mnenje, da izvira ime iz domačega leksema presrt v pomenu 'preval'. Izraza presrt sicer ne poznata ne Pleteršnikov slovar in ne Badjurova Ljudska geografija, tudi med zemljepisnimi imeni ga - vsaj v tej obliki - ne srečamo. Pleteršnik pozna le leksem srt 'nekaj ostrega'. Pač pa sta izraza prësrt s pomenom 'preval' in pridevnik prësrtan 'strm, navzdolen' znana v srbohrvaščini (Jurančič 1972, 857; RJA 1935, 716).

O imenu Preserje v Slovenski Benečiji je v 90. letih v časniku Dom razmišljal tudi beneškoslovenski duhovnik in imenoslovec Božo Zuanella (Zuanella Dom). Že on je upravičeno povezal Preserje v Benečiji s Passarianom pri Codroipu (UD) in Persereanom v o. Pavia di Udine, zavedal se je tudi stanovniške pripone -jane, ki jo je zaznal v obeh furlanskih toponimih, izvor imena pa je glede na oblikovanost terena iskal $\mathrm{v}$ geografskem apelativu s pomenom 'prehod med dvema dolinama', morda pod vplivom nekdanje Ramovševe razlage.

Ime Preserje je skušal razvozlati tudi etnolog Tone Cevc, ki je svoja dognanja strnil v krajevnem glasilu Vaščan (Cevc 1998). Z opazovanjem zemljepisne lege naselij z imenom Preserje in deloma s samovoljno interpretacijo dozdevno nemškega prevoda (Seydendorff ipd.) za Preserje pri Radomljah iz 14. in 15. stol. je ponudil razlago 'vas na zemljišču, ki se konča s prevalom'. Zgodovinar Božo Oto- 
repec je namreč avtorja Cevca posebej za ta članek oskrbel z dotlej neobjavljenimi historičnimi zapisi: 1342 Seydemdorf, 1354 Seydeinen doerf, 1360 Seydendorff, 1451 Seydendorffe, 1483 Seidendorff. Cevc je v Seyden, Seiden prepoznal nemško občno ime Seite, za kar je v Wahrigovem slovarju našel pomen 'das Herabhängende' - 'navzdol viseči svet'. Toda navedeni historični zapisi kažejo na drugačno genezo tega imena. O tem se najlaže prepričamo, če pogledamo najstarejše zapise za krajevni imeni Seitenstetten in Seiterndorf v Spodnji Avstriji ter za zaselek Žitečka vas v Zgornjem Dupleku in vas Žitence v o. Sveti Jurij v Slovenskih goricah. Seitenstetten ima številne historične zapise že od 1109 dalje: Sitansteten, 1250/60 Sidansteten, 1276 Seytenstetin itd., Seiterndorf pa od 1300 dalje: Seytendorf, 1309 Seiterndorf, 1530 Scheiderndorff itd. (Schuster 1994, 268-269). Žitečka vas ima zapise: 1286 Sitensdorf, Seitensdorf, 1406 Seittendorf, 1434 Seitendorf, 1454 Seykendorff, 1462 Seitzendorf, 1465 Zeyttendorf, ok. 1480 Seidenndorff, 1496 Seytendorff. Podobni zapisi so izpričani tudi za Žitence: 1319 Syteinsdorf, 1358 Sitesdorf, 1419 Sitterstorf, 1445 Seyttendorf. Vsa tri ponemčena imena tako kot tudi Žitečka vas in Žitence namreč skrivajo v sebi staroslovenske (slovanske) antroponime *Žitins, *Žitanz oz. *Žitı, ki predstavljajo hipokoristične oblike od zloženih imen *Žitigojb (Sitigoi), *Žitiljubs (Sitilieb), *Žitimyslb (Sitimuzil), *Žitivitb (Sitiuit), *Žitivlastb (Sitilaz), *Žitomirb (Sitmer), *Žitoradb (Situvradus) ipd., izpričanih na Koroškem in Štajerskem med letoma 888 in 1194 (Kronsteiner 1975, 90-91). Iz imen *Žitans oz. *Žitъ izvaja oba spodnjeavstrijska toponima tudi avstrijska slavistka Angela Bergermayer (2005, 299-300). Preserje pri Radomljah so potemtakem v srednjem veku poznale dve etimološko različni imeni: slovenske Preserje in delno ponemčeno Seydendorf ( $<*$ Žitinja vas).

Kot smo videli, se krajevno ime Preserje v Sloveniji pojavlja od Benečije do Savinjske doline, izven današnjega etničnega ozemlja pa tudi v Furlaniji. Ključ k razlagi imena pa se je skrival v historičnem zapisu Presiryani iz leta 1431 za izginulo vas v bližini Valone v Albaniji, ki ga je pritegnil bolgarski imenoslovec Jordan Zaimov iz objavljenega turškega vira (Zaimov 1967, 162). Ime je prepričljivo rekonstruiral kot *Prěsyrjane in ga izvajal iz predloga prě 'pred' in osnove syr-, ki jo je sicer zaslediti v ruski narečni besedi culps s pomenom 'vlaga' (Zaimov 1967, 169). Ruska ljudska geografija pozna v porečju Pečore in Srednjem Povolžju izraz cbıp s pomenom 'nizek kraj, poraščen s travo', 'vlažen kraj' (Murzajev 1984, 534). Ukrajinski jezikoslovec Viktor Šulgač rekonstruira praslovansko vodno ime *Syrbcb na podlagi večkrat izpričanega ukrajinskega vodnega imena Cupeu̧b, ruskega hidronima Colpeu, ruskega narečnega apelativa cblpéų 'mokra nižina' (Šulgač 1998, 287). Isto apelativno osnovo razodevajo krajevna imena Sirjana (v Grčiji) < *Syrjane, Sirjani (v JV Albaniji), Сирени (v Bolgariji) (Zaimov 1967, 169) in ра Обсирено, Обсирена, Obsirina (<*cup 'vlaga', 'vlažen kraj') (Zaimov 1967, 155). V Sloveniji zasledimo toponime iz iste osnove, kot so Nasirec (o. Hrpelje-Kozina), Sirči (o. Koper), Serjuče, 1826 Seriuze (o. Moravče), Sirendol (zaselek Knežaka, o. Ilirska Bistrica), Sirče (mikrotoponim v Podkorenu, o. Kranjska gora) in več podobnih parcelnih imen (TTN5).

Preserje je torej tisti kraj, tisto zadnje območje pred močvirjem, kjer so ljudje še lahko ustvarili naselbino. Preserje pri Radomljah, za katere je izpričano tudi 
$\hookrightarrow \quad$ ponemčeno ime iz staroslovenskega antroponima, bi lahko »prevedli« kot 'Žitinova vas pred barjem'. Naposled je prevladalo poimenovanje po legi pred barjem (*sirjem). Iz poimenovanja *pre(d)sirje, ki predstavlja pozabljeni zemljepisni apelativ, star ljudski zemljepisni termin, se je največkrat s pripono -jane izoblikovalo stanovniško, iz tega pa krajevno ime *Pre(d)sirjane. Najverjetneje je bil predlog pre v imenu že od začetka brez - $d$ ali pa je ta že zelo zgodaj izpadel, prim. 1377 Poglubin za *Podljubinj (danes Poljubinj) in Pomels za Podmelec na Tolminskem (Kos 1948, 56, 66), Prelesje (<*Predlesje, 4 kraji), Preloka (<*Predloka), Prelože (< *Predložane, 2 kraja), Prepolje (<*Predpolje), Prepuž (<*Predpolž), Prestranek (<*Predstranek). Nepojasnjeno ostaja vprašanje prehoda *-syr- >-ser-, ki se je izvršil presenetljivo dosledno na vseh enajstih lokacijah imena Preserj(jan)e, od Furlanije do Savinjske doline. Nekdanji -yr- je pod naglasom pričakovano prešel v -ir- (Nasirec, Sirči, Sirendol), nenaglašen pa je prehajal v -er-(Préserje, Serjúče), vendar se je enak prehod mestoma izvršil tudi pod naglasom (Presêrje v treh od osmih primerov).

\section{Slovenska imena na -jane ali romanska predialna imena na -ano/-ana $<$-anum ?}

*Preserjane so v svoji prvotni podobi, ko se pripona -jane še ni skrčila v -je, ohranjene danes samo še v poromanjenem delu Furlanije. Italijanski jezikoslovci Pellegrini (1958, 1983), Doria (1971), Frau (1978) in drugi so imena na -ano/-ana v Furlaniji in deloma tudi na slovenskem zahodu preveč posplošeno razglašali za predialna zemljepisna imena, ${ }^{1}$ ne da bi v zadostni meri upoštevali staroslovenska poromanjena ali tudi še v lastnem jezikovnem okolju živeča imena na -jane. Pellegrini je celo Volče pri Tolminu (1015 Valçana, it. še danes Volzana) izvajal iz romanskega imena Volcius, čeprav je očitno, da gre za stanovniško ime na -jane iz staroslovenskega rojstnega imena Volk (Pellegrini 1958, 113). Passariano in Perseriano je razlagal Frau zmotno kot predialni imeni iz *Perserius, tega pa iz Persius (Frau $1978,90,91)$. Frau se je seveda motil tudi, ko je izvajal Oseacco, italijansko varianto rezijanskega krajevnega imena Osojane, iz domnevnega romanskega imena Ocilius, čeprav italijanska oblika ohranja le brezpredložno mestniško obliko Osojah. Merkù je kot stanovniška imena na -jane že identificiral krajevna imena Iamiano, slov. Jamlje v o. Doberdob (<*Jamljane), Padriciano, slov. Padriče v o. Trst (<*Padričane), Trebiciano, slov. Trebče v o. Trst (<*Trebečane) (Merkù 2006, 92, 149, 197). Doria in za njim Frau $(1978,118)$ sta na silo razlagala Trebiciano kot predialno ime iz dozdevnih imen *Treviacus ali *Trebiacus, čeprav gre za zelo prozorno slovensko stanovniško ime iz hipokoristične oblike *Trebęta slovanskega osebnega imena *Trěbigojь (prim. tudi Trebče v o. Bistrica ob Sotli, Trebča vas v o. Žužemberk, Trpčane v o. Ilirska Bistrica, Trebenče v o. Cerkno, Trebeše v o. Koper itd.). Merkù

1 Predialno ime pomeni v romanskem jezikoslovju krajevno ime, ki je nastalo iz osebnega imena zemljiškega posestnika iz rimske dobe, z značilnima priponama -ana ali -anum, prim. lat. predium 'zemljišče, podeželsko posestvo, pristava'. 
je upravičeno zavrnil ali vsaj močno podvomil tudi o predialnem izvoru imen $\mathrm{Du}$ tovlje, Noax (slov. Novaki, pri samostanu Rožac), Sežana, Tipana (v Terski dolini), Turiacco (slov. Turjak v Bizjakiji), Visogliano (slov. Vižovlje v o. Devin Nabrežina), kot sta jih razložila Doria in Frau (Merkù 2006, 74, 141, 180, 196, 199, 205).

Že zgodovinar Simon Rutar je kot nekdaj slovenske vasi v Furlaniji - bolj ali manj po občutku in ne vselej utemeljeno - omenjal Sedegliano, Cleulan, pa tudi Risano, Lavariano, Bolzano, Manzano, Soleschiano, Boreana. Slednjo je - najbrž upravičeno - vzporejal z Borjano pri Kobaridu (Rutar 1883, 123, 125, 126), za katero je mogoče predpostavljati slovensko osnovo bor-in pripono -jane. Pri večini imen ni navajal ustreznih slovenskih oblik, ustavil se je le pri imenih Sedegliano, Cleulan (zdaj Clauiano) in Boreana. Prvo je docela upravičeno izvajal iz *Sedljane, drugo pa iz *Hlěvljane, kar se zdi glede na historične zapise (1031 Cleulanum, Clavianum, 1184 Cleulan, 1275 Claugano, 1278 in villa Clauliani) (Prampero 1882, 42) in slovaško vzporednico Chlievany Malé a Velké (Spal 1958, 85) dokaj verjetno. Frau je ime označil kot predialno, nastalo nemara iz imena *Clavilius (Frau 1978, 49).

Pellegrini je izvajanje toponima Sedegliano iz slov. *Sedljane (1226 Sedegliano, 1229 Sedelano, 1299 in villa Sedellani) (Prampero 1882, 177) zavrnil kot malo verjetno in toponim razglasil za predialno ime iz *Setilianum (Pellegrini 1983, 925), čeprav je mogoče najti med južnimi Slovani številne ojkonime Seljani, Seljana (Zaimov 1967, 169), prav tako tudi na Slovaškem Sel'any (iz *Sedl'any) (Spal 1958, 89). O tem, da se je na slovenskem zahodnem robu ohranila skupina -dl-, pričata tudi ojkonima Sedlò in Starsedlò (uradno: Staro selo), oba v o. Kobarid.

Pellegrini je tudi toponim Cervignano (912 de Cerveniana, 1041 castrum Cirvignanum cum sylva, 1062 in loco Cirvingane, 1277 in villa Cervignani) (Prampero 1882, 36-37) kljub mnenju avstrijskega jezikoslovca E. Kranzmayerja (1956, 71), da gre za etnik * Črvenjani, raje izvajal iz romanskega osebnega imena Cervinius. Le pri toponimu Tapogliano (1256 Tapoliano, 1257 Tapoglano, 1300 Tapoglan, Topoglano, 1372 Topoglano) (Prampero 1882, 194) je priznal težave pri predialni razlagi, saj da imeni *Tappulius oz. Tappulus nista izpričani, zato gre morda vendarle za slovenski etnik na -jane Topoljani iz fitonima topol (Pellegrini 1983, 926). Seveda so Topoljani zelo pogost slovanski ojkonim: v Sloveniji prim. Topole v o. Mengeš, Topole v o. Rogaška Slatina, Topolje v o. Železniki (http://www.stat. si), vse iz *Topoljane, na Moravskem Topolany (dvakrat), na Slovaškem Topol'any (Spal 1958, 70), več krajev z imeni Topojani, Topoliana, Topojan v Albaniji in Grčiji (Zaimov 1967, 175).

V primerjavi s Pellegrinijem, Dorio in Frauom so mlajši raziskovalci, zlasti Maurizio Puntin $(2003,2005)$ in Franco Finco (2003, 2005), uspešnejši pri ugotavljanju slovenskih jezikovnih prvin v poromanjenem delu Furlanije, saj se pri tem lahko opirajo tudi na novejše raziskave arheologov in zgodovinarjev. Puntin kot izvedenec za onomastiko tržiškega Teritorija oz. Bizjakije ${ }^{2}$ tako uvršča med toponime s slovansko pripono -jane kraje, kot so Begliano/Beljan - pri S. Canzianu d'Is./Škocjanu ob Soči, 1138 de Beliani, iz *Beljani; Cassegliano/Kaseljan - pri S. Pieru d'Is./Špetru

2 Il Territorio, danes Bisiacaria, je poimenovanje nekdanje beneške enklave na levem bregu Soče. 
ob Soči, 1295 Cassaulano, 1301 Casoliano, 1307 Kasglach, iz *Kasovljane, kar da je slovenska adaptacija romanskega imena; Staranzano/Štarancan - pri Monfalconu/Tržiču, 1375 Stranzano, 1422 villa Starançani, 1464 sub Stranzan, kar da izhaja iz *Straničane, nikakor pa ne iz latinskega imena Terentius, kot sta ime razlagala Pellegrini in Frau (Puntin 2003, 47-48, 126-127; Puntin 2005, 56-57).

Kot lahko vidimo pri zanesljivo dokazanih slovenskih imenih na -jane, so Italijani to pripono adaptirali večinoma s svojo pripono -ano: Jamlje $>$ Jamiano, Treb$\check{c} e>$ Trebiciano, Padriče $>$ Padriciano, Vipolže (v o. Brda) > Vipulzano, Lože (v o. Dolenje/Dolegna del Collio) > Lonzano (< Log; Frau 1978, 75 ga izvaja iz imena Leontius!), Renče (pri Novi Gorici) > Ranziano, Orehovlje (v o. Miren-Kostanjevica) $>$ Raccogliano. V nekaterih primerih pa so namesto pripone -ano uporabili pripono -ana: Volče (v o. Tolmin) > Volzana, Merče (v o. Sežana) > Merzana (1348 še Merçano, gl. Merkù 2006, 131). V Terski dolini zasledimo v o. Neme že pofurlanjeno vas Dolenjena, it. Cergneu di Sotto, torej dobesedno Dolenja Černjeja, 1200-1250 še Dolegnana (Prampero 1882, 53), in Orenjena, it. Nongruella, brez historičnih zapisov ( $<*$ Gorenjena). Nedaleč proč, v Nadiški dolini, v o. Podutana, pa najdemo vas Dolenjane, it. Dolegna, 1301 Dolegnano (Prampero 1882, 53).

Toda pri stanovniških imenih je mogoče zaslediti prehod pripone -jane v -jana tudi v čisto slovenskem jezikovnem okolju. Na ta pojav je prvi opozoril jezikoslovec L. Pintar že 1. 1908, ko je pisal o etimologiji imena Ljubljana (Pintar 1908, 312-313). Navedel je primere: Radomlje, stanovniško ime Radomljana, Škrjanče - Škrjančana, Moravče - Moravčana, Dob - Dobljana, Volčji Potok - Vowčana, Holmec - Hbmčana. Pozneje je ta posebnost v tvorbi stanovniških imen na vzhodnem Gorenjskem vzbudila tudi pozornost etimologa in onomasta F. Bezlaja, ki je podatke s terena prejel od dialektologa T. Logarja. Bezlaj je navedel primere iz Tuhinjske doline: Wažâna (Laze), Silâna (Sela), Bəčâna (Buč), Guličâna (Golice), Rakîtnčana (Rakitovec), Čêišsnčana (Češnjice), in iz okolice Litije Vačâna (Vače), Kandršâna (Kandrše), Lutjâna (Litija). Menil je, da »to nenavadno obrazilo ne more biti mlada inovacija« (Bezlaj 1969, 244; Bezlaj 2003, 366).

Za Miklošičem $(1859,183)$ in Pintarjem $(1908,312)$ ter Bajcem $(1950,44)$ je tudi Ramovš naposled $(1952-53,158)$ sprejel mnenje, da v imenu Ljubljana tiči stanovniška pripona -jane, ki je prešla $\mathrm{v}$-jana s prekozložno asimilacijo. S prehodom -jane > -jana pa se je v nekaterih primerih izvršila tudi singularizacija, na kar so, pravi Pintar, verjetno vplivali primeri kolektivnih samostalnikov ženskega spola, kot so gospoda, družina, živina, a tudi samostalnikov s pripono -ana, kakršno zasledimo v leksemu poljana < polje. Poleg sovpadanja z romansko pripono -ana, ki je nedvomno prisotna na zahodnem robu slovenskega etničnega ozemlja, imamo torej opraviti še s sovpadanjem dveh domačih pripon. Zato ni čudno, da je na prvi pogled težko presoditi, ali so imena Ljubljana, Sežana, Košana, Borjana, Biljana, Pečana res substratna, kot je domneval Bezlaj, ali so vendarle domače tvorjenke s pripono -jane ali pa nemara -ana.

Paralele, ki govorijo za razvoj -jana < -jane, najdemo tudi drugod po slovanskem svetu: Repljana (Репляна), vas v severozahodni Bolgariji (Vidinska oblast) (Zaimov 1967, 165), ukrajinski vasi Nižnja in Verhnja Ozerjana (Нижня, Верхня Озеряна) v Harkovski oblasti; srbska vas Trnjana (Трњана) v Pirotskem okrožju, 


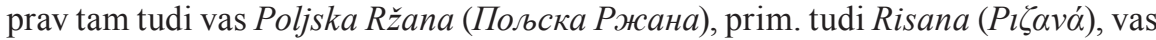
na Peloponezu, domnevno iz *Ržane (Zaimov 1967, 166). Večje število zemljepisnih imen na -ana s slovanskimi osnovami je vsekakor opaziti na ozemljih, kjer je delovala naslonitev na analogne romanske in grške vzorce, torej v Italiji, Grčiji, Romuniji in Albaniji.

Med imena na -jane v Furlaniji in na zahodnem slovenskem robu smemo po vsej verjetnosti uvrstiti tudi naslednja:

Bróčana (it. Brocchiana), del vasi Ronac v o. Podbonesec/Pulfero, izhaja iz *Brodčane. Na levem bregu Soče, južno od Škocjána ob Soči/S.Canzian d'Isonzo, je zaslediti več mikrotoponimov Brodec, Brodac, ki kažejo na prisotnost tega leksema v zahodnoslovenski toponimiji.

Gročána (it. Grozzana) v o. Dolina pri Trstu, s historičnimi zapisi iz 1.1298 Groczan (Bezlaj 1976, 180), 1316 Groçana (Merkù 2006, 84), 1498 Grottschane (Kos 1954, 253), kaže na *Gradčane (<*Gradec), čeprav v tem primeru celo Bezlaj $(1976,180)$ meni, da gre za predialno ime. Ojkonim Gračane (Грачане) najdemo tudi v Srbiji (pri Novem Pazarju), Gračani (Грачани) pa v Makedoniji in v Zagrebu kot del mesta (Imenik 1951, 223). Svetovno znani so Hradčany v Pragi.

Coseano pri S. Danielu, z zapisi 1200-1300 Coselano, 1275 in villa de Coseglano ipd. kaže prej na *Kozljane (z izpustom -l- kot v Jamljane > Iamiano) kot na predialno ime iz Caucilius ali Cocilius, za kar ga razglaša Frau $(1978,55)$. Ime lahko primerjamo s slovenskimi Kozjanami v o. Divača, morda tudi s Kozano v o. Brda, vsekakor pa z dvema ojkonimoma Kozlany na Moravskem (Hosák-Šrámek 1970, 436).

Malisana v o. Torviscosa, z zapisi 1161 de Malesan, 1262-1282 de Malisana, razlaga Pellegrini in za njim Frau iz priimka Malisa (Pellegrini 1958, 102; Frau 1978, 77). Veliko bolj prepričljivo ga lahko razložimo iz slovenskega antroponima Maleša ali Maleš s pripono -jane, torej *Malešane.

Raccolana v o. Kluže/Chiusaforte z zapisom 1271 de Racolana; Prampero (1882, 153) navaja tudi Raccogliano di Romans v okrožju Gradisca, s historičnim zapisom Racoliano iz 1. 1300. Frau $(1978,99)$ nastopa $z$ neverjetno trditvijo, da gre za predialno ime iz Herculius, nastalo z metatezo. Najboljši dokaz za transformacijo imena so historični zapisi za Orehovlje pri Mirnu: okr. 1780 Racoglia in Racogliano (Jožefinski 1997, 95), ${ }^{3} 1822$ Raccogliano (FK 1822); skoraj ni dvoma, da sta tudi Raccolana in Raccogliano di Romans nastala iz *Orehovljane.

Košána (Gornja, Dolnja) je ime dveh vasi v o. Pivka, ki nikakor ne kažeta romanskega izvora. Videti je, da gre za *Košane, vzporednica je ime Коšani (Кошани) za vas pri Kavadarcih v Makedoniji, Košani (Кошани) pa so tudi vas vzhodno od Kijeva v Ukrajini; skupna motivacija je verjetno koš, košara.

3 Iz besedila $\mathrm{k}$ Jožefinskemu vojaškemu zemljevidu lahko razberemo tako imenovalniško kot rodilniško obliko, pač glasovno substituirani v skladu z italijanskimi govornimi in pisnimi navadami: $\mathrm{v}$ naslovu $\mathrm{k}$ besedilu uporabi pisec nemškega originala obliko Racoglia (= Orehovlje), pri navajanju oddaljenosti drugega kraja od (nemško: von) Orehovelj pa uporabi stari množinski rodilnik Racogliano (= Orehovljan). 
Merkù je v tržaških arhivih za obdobje srednjega veka našel številne dragocene historične zapise ojkonimov na -jane z območja Krasa, ki odražajo arhaični rodilnik množine, npr. za Dutovlje, 1316-1317 Iurius de Duotolan 'Jurij iz Dutovljan' (Merkù 2006, 74). Isti ojkonimi se že takrat pojavljajo tudi v italijanizirani obliki na -ano, npr. 1390 de Dotoglano (prav tam). Poglejmo še nekaj primerov, vsi so iz okolice Sežane: Voglje, 1348 de Voglian, Vrhovlje, 1316 sl. de Vercoglan, Kreplje, 1316 de Crepeglan, Utovlje, 1368 de Outoglan, Godnje, 1316 de Godignan, Šepulje, 1316 de Xipuglian, Štorje, 1312 de Xetoriano, Kazlje, 1316 de Caslan/Casglan, Žirje, 1405 Crisman Sirian (iz Žirjan), Merče, 1348 de Merçano, Brje pri Koprivi, 1525 Gregorius de Brian (vsi primeri so iz Merkù 2006).

Mogoče je, da v isto kategorijo ojkonimov spada tudi Sežana, o čemer utegne pričati najstarejši historični zapis villa Cesan iz leta 1152 (Kos 1915, 167). ${ }^{4}$ Ime ima pri vseh naslednjih zapisih že pripono -ano oz. -ana: 1252 Cesano (Gradivo 2002, 191), 1293 sl. Ses(s)ana; 1298 de sesano; 1309 sl. Sexana, Xexana; 1344 Ces(s)ana; 1426 sexena (Merkù 2006, 180). O osnovi imena še ni mogoče reči nič zanesljivega, čeprav skoraj ni dvoma, da je slovanska.

V slovenski ojkonimiji poznamo v ljudskem jeziku primere singularizacije rodilniške množinske oblike krajevnega imena na -jane oz. -jene (o tej priponi prim. Bezlaj 2003, I, 197-206 in Trubačov 2004). To je vas V́rbljene (pri Igu), ki ima v lokalni rabi edninsko obliko V́rbljen. Historični zapisi od 1323 dalje so v skladu z nemškimi zapisovalnimi navadami v lokativu: 1323 Verblach, 1385 Werbliach, 1444 Warblach itd. Podobno se obnaša tudi krajevno ime Smŕjene (kraj leži v neposredni bližini Vrbljen) s historičnimi zapisi 1399 Smeriach, 1485 Smeryen, lokalna raba za krajevno ime pa je edninska: Smrjen. Ni izključeno, da v ta model spadajo tudi krajevna imena Strunján (prim. Strominiane v Grčiji, Strumiany na Poljskem, iz apelativa strúmen 'potok, struga') (Spal 1958, 54; Zaimov 1967, 172; M. Snoj pri Bezlaj 1995, 335), Tinján (iz apelativa tin oz. tinj 'pregradna stena, ograja iz desk') (Spal 1958, 90; Bezlaj 2005, 181) in še nekatera.

Videti pa je, da spadajo v kategorijo ojkonimov, nastalih s singularizacijo rodilniških množinskih oblik, tudi vsi međimurski ojkonimi na -ec in -an, poleg njih pa še nekateri tovrstni ojkonimi na slovenski strani meje s Hrvaško. Od skupno 129 međimurskih ojkonimov jih ima danes pripono -ec kar 54 (npr. Bogdanovec, Čakovec, Domašinec, Dragoslavec, Draškovec, Ivanovec, Križovec, Lopatinec, Pribislavec, Stanetinec itd.), 8 pa pripono -an (npr. Cirkovljan, Goričan, Mihovljan, Vrhovljan) (Frančić 2007, 151-152). Starejše kajkavske listine (iz 1. 1598) nam izpričujejo nekdanjo množinsko obliko teh ojkonimov, npr. z ternowecz, z maleh Mihalewecz, z Lopatinecz, enake množinske oblike pa se v ljudskem jeziku uporabljajo še danes, npr. Idem u Mihaljefce (Frančić 2007, 149). Če so v Pomurju in Prekmurju pri večini ojkonimov ostale običajne imenovalniške množinske oblike na -ci, -ovci, -inci, so pri kajkavcih Medimurja in vzdolž meje s Hrvaško ponekod tudi na slovenski strani ojkonimi prejeli obliko singulariziranih narečnih rodilnikov množine, kakršne poznajo prekmurska in pomurska narečja ter prekmurski po-

${ }^{4}$ Listina iz 1. 1085, ki jo nekateri radi navajajo, je ponaredek s konca 15. stol., kar je ugotovil že F. Kos v Gradivu za zgodovino Slovencev, 3. knjiga, Ljubljana 1911. 
krajinski knjižni jezik: (iz) Ivanovec, (iz) Stanetinec, (iz) Cirkovljan, (iz) Goričan, prim. ustreznike Ivanovci, Stanetinci, Cirkulane, Goričane. Na slovenski strani so primeri: Jereslavec (o. Brežice), lok. tudi Jereslavci, Mihalovec (o. Brežice), lok. tudi Mihalovce, Trnovec (o. Videm), lok. tudi Trnce, Župelevec (o. Brežice), lok. tudi Župelevce (SKI 1985, 116, 172, 303, 355).

\section{Viri in literatura}

Bajec 1950 - Bajec, A., Besedotvorje slovenskega jezika I, Ljubljana.

Bezlaj 1969 - Bezlaj, F., Naloge in poti slovenskega imenoslovja, Onomastica jugoslavica 1, Zagreb, 243-248, ponatis v: Bezlaj 2003, 366-371.

Bezlaj 1976 - Bezlaj, F., Etimološki slovar slovenskega jezika, Prva knjiga, A-J, Ljubljana.

Bezlaj 1995 - Bezlaj, F., Etimološki slovar slovenskega jezika, Tretja knjiga, P-S, Dopolnila in uredila M. Snoj in M. Furlan, Ljubljana.

Bezlaj 2003 - Bezlaj, F., Zbrani jezikoslovni spisi I, Uredila M. Furlan, Ljubljana.

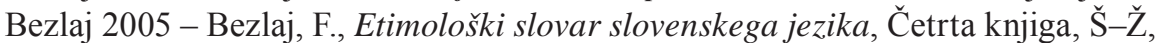
Avtorji gesel F. Bezlaj, M. Snoj in M. Furlan, Ljubljana.

Bergermayer 2005 - Bergermayer, A., Glossar der Etyma der eingedeutschten Namen slavischer Herkunft in Niederösterreich, Wien.

Blaznik HTŠK - Blaznik, P., Slovenska Štajerska in jugoslovanski del Koroške do leta 1500, I-III, Historična topografija Slovenije, Maribor 1986-1989.

Cevc 1998 - Cevc, T., Kaj vemo o izviru imena Preserje pri Homcu in prvih omembah vasi v zgodovinskih virih, Vaščan 6, št. 4, Homec, 21-25.

Doria 1971 - Doria, M., I nomi prediali in -anum nella provincia di Trieste, Studi di filologia romanza offerti a Silvio Pellegrini, Padova, 145-173.

Finco 2003 - Finco, F., Toponimi di origine slovena nella pianura friulana, Slovenia, un vicino da scoprire, Udine, 539-558.

Finco 2005 - Finco, F., Dall' appelativo slavo al toponimo romanzo: per un'analisi dei nomi di luogo di matrice slovena della pianura friulana, v: Quaderni Internazionali di RIOn 1, Denominando il mondo, Dal nome comune al nome proprio, Atti del simposio internazionale, Zara, 1-4 settembre 2004 / Naming the World, From common nouns to proper names, Proceedings from the international symposium, Zadar, September $1^{\text {th }}-4^{\text {th }}, 2004$, a cura di / Editors Dunja Brozović-Rončević - Enzo Caffarelli, Roma, 397-414.

FK 1822 - Arhiv Republike Slovenije, Franciscejski kataster za Primorsko, k.o. Orehovlje, http://sigov3.sigov.si/cgi-bin/htqlcgi/arhiv/enos isk kat.htm.

Frančić 2007 - Frančić, A., Uvid u hrvatsku toponimiju na sjeverozapadnoj međi, Jezikoslovni zapiski 13, št. 1-2 (Merkujev zbornik), Ljubljana, 147-157.

Frau 1978 - Frau, G., Dizionario toponomastico del Friuli - Venezia Giulia, Udine.

Gradivo 2002 - Gradivo za slovensko zgodovino v srednjem veku 6/1 (listine 1246-1255), uredil F. Baraga na podlagi gradiva B. Otorepca), Ljubljana. 
— Hosák-Šrámek 1970 - Hosák, L., Šrámek, R., Místní jména na Moravě a ve Slezsku I, A-L, Praha.

http://www.stat.si - rubrika Krajevna imena.

Ilešič 1933 - Ilešič, S., Kmetska naselja na vzhodnem Gorenjskem, Geografski vestnik 9, Ljubljana, 3-94.

Imenik 1951 - Imenik naseljenih mesta u FNRJ, Stanje 1 januara 1951 godine, Beograd.

Jožefinski 1997 - Slovenija na vojaškem zemljevidu 1763-1787, zv. 3, Ljubljana.

Jurančič 1972 - Jurančič, J., Srbskohrvatsko-slovenski slovar, 2. razširjena izdaja, Ljubljana.

Kos 1915 - Kos, F., Gradivo za zgodovino Slovencev v srednjem veku, Četrta knjiga (1101.-1200.), Ljubljana.

Kos 1948 - Kos, M., Urbarji Slovenskega Primorja I, Ljubljana.

Kos 1954 - Kos, M., Urbarji Slovenskega Primorja II, Ljubljana.

Kos 1975 - Kos, M., Gradivo za historično topografijo Slovenije (za Kranjsko do leta 1500), I-II, Ljubljana.

Kranzmayer 1956 - Kranzmayer E., Ortsnamenbuch von Kärnten I, Klagenfurt.

Merkù 2006 - Merkù, P., Krajevno imenoslovje na slovenskem zahodu, Uredila M. Furlan in S. Torkar, Ljubljana.

Miklošič 1859 - Miklosich, F., Ljubljana, Laibach, Vodnikov spomenik, Ljubljana, 182-184.

Murzajev 1984 - Мурзаев, Э.М., Словарь народных географических терминов, Москва.

Pellegrini 1958 - Pellegrini G. B., Osservazioni sulla toponomastica prediale Friulana, Studi Goriziani 23, Gorizia, 93-113.

Pellegrini 1983 - Pellegrini, G. B., Contatti linguistici slavo-germanico-romanzi, Gli Slavi occidentali meridionali nell' Alto Medioevo (15-21 aprile 1982), tomo II, Spoleto, 911-977.

Pintar 1908 - Pintar, L., Satura, Ljubljanski zvon 28, Ljubljana, 243-248, 310313.

Pintar 1913 - Pintar, L., O krajnih imenih, Ljubljanski zvon 33, Ljubljana.

Prampero 1882 (2001) - Prampero A., Saggio di un glossario geografico friulano dal VI al XIII secolo, Venezia (Tavagnacco).

Puntin 2003 - Puntin, M., Toponomastica storica del Territorio di Monfalcone e del comune moderno di Sagrado, Gradisca d'Isonzo.

Puntin 2005 - Puntin, M., Slovenci na tržiškem Teritoriju, Obdobje med 7. in 17. stoletjem, Slovenci v Laškem, Tržič, 15-60.

Ramovš 1952-53 - Ramovš, F., Iz slovenske toponomastike, Zgodovinski časopis 6-7, Ljubljana, 154-158, ponatis v: Zbrano delo, 2. knjiga, Ljubljana 1997, $737-741$.

RJA 1935 - Rječnik hrvatskoga ili srpskoga jezika, dio XI. Obradio T. Maretić. Zagreb.

Rutar 1883 - Rutar, S., Slovenske naselbine po Furlanskem, Ljubljanski zvon 3, 53-60, 122-128, 188-193. 
Schuster 1994 - Schuster, E., Die Etymologie der niederösterreichischen Ortsnamen, 3. Teil, Wien.

SKI 1985 - Jakopin, F., Korošec, T., Logar, T., Rigler, J., Savnik, R., Suhadolnik, S., Slovenska krajevna imena, Ljubljana.

SKII 1999 - Merkù, P., Slovenska krajevna imena v Italiji, Priročnik, Trst.

Spal 1958 - Spal, J., Místní jména obyvatelská, zakončená na -any, Sbornik Vyšši pedagogické školy v Plzní, Jazyk a literatura, I, Praha.

Šulgač 1998 - Шульгач, В.П., Праслов'янський гідронімний фонд (фрагмент реконструкиіï), Київ.

Torkar 2005 - Torkar, S., Zakaj bi lahko bilo Cerkno Cirkno, pa to ni, Siga'čan 33, Leto VI, december 2005, Cerkno, 24-26.

Trubačov 2004 - Трубачев, О., Из исследований по праславянскому словообразованию: генезис модели на -е̌ninъ, *-janinъ, v: Трубачев, О. Н., Труды по этимологии, Том 2, Москва, 327-340.

TTN5 - Temeljni topografski načrt 1:5.000, GURS.

Zaimov 1967 - Заимов, Й., Заселване на българските славяни на Балканския полуостров, Проучване на жителските имена в българската топонимия, София.

Zuanella Dom - Zuanella, B., Preserje, http://www.lintver.it.

\section{The Toponym Preserje and Slavic-Romance Mixing of the Suffixes -jane and -anum}

Summary

Despite efforts by the linguists Luka Pintar and Fran Ramovš, and the ethnologist Tone Cevc, the etymology of the toponym Preserje has not yet been satisfactorily determined, although nine settlements or their parts in Slovenian ethnic territory from the Savinja Valley to the Venetian Slovenia bear this name, and a further two (Passariano and Persereano) are used in the Romance part of Friuli. Using a historical record from 1431 for the defunct village of Presiryani in Albania, published by Jordan Zaimov in 1967 and accompanied by a convincing explanation of the name's development from *Prě-syr-jane ('before' + 'moist lowland' + -jane), it was also possible to provide a suitable explanation for Slovenian Preserje.

Especially in the toponyms from the area in contact with the Romance world, the Slovenian suffix -jane (originally referring to inhabitants), due to its development into -ana and singularization (this phenomenon was first described by Luka Pintar in 1908 based on the toponym Ljubljana), coincided with the Romance suffix -ana or was adapted into the suffix -ano. This caused the Italian linguists Giovanni Battista Pellegrini, Mario Doria, and Giovanni Frau to describe, in an overly generalized manner, almost all of the toponyms ending in -ano/-ana at the Slovenian-Romance linguistic border as predial names created with the Latin suffix-anum from former Romance personal names.

The victims of this generalization even included toponyms such as Volče (It. 
- Volzana), Trebče (It. Trebiciano), Lože (It. Lonzano) and Osojane (It. Oseacco). [I] Taking into account historical records, this article suggests a Slovenian origin $\mathrm{N}$ for the toponyms Sedegliano $(<*$ Sedljane), Cleulan $(<*$ Hlěvljane), Cervignano $-\quad(<*$ Červenjane), Tapogliano $(<*$ Topoljane), Coseano $(<*$ Kozljane), Malisana 줏 (<*Malešane), Raccolana (<* Orehovljane), Bróčana ( $<*$ Brodčane), Gročána $(<$ * *Gradčane), and Košana ( $<$ *Košane).

Silvo Torkar Inštitut za slovenski jezik Frana Ramovša ZRC SAZU Novi trg 2, 1000 Ljubljana silvot@zrc-sazu.si 


\title{
Iz prvotnih ledinskih imen tvorjena hišna imena v spodnji Zadrečki dolini
}

\author{
Peter Weiss (Ljubljana)
}

IZVLEČEK: V Zgornji Savinjski dolini so najstarejša hišna imena tista, ki so tvorjena iz prvotnih ledinskih imen. Prispevek predstavlja današnjo razširjenost tovrstnih hišnih imen v spodnji Zadrečki dolini (kjer se med Gornjim Gradom in Nazarjami govori zgornjesavinjsko narečje) z izpeljankami vred.

ABSTRACT: In the Upper Savinja Valley, the oldest oeconyms were formed from names that were originally microtoponyms. This article presents today's distribution of such oeconyms in the Lower Dreta Valley (where the Upper Savinja dialect is spoken between Gornji Grad and Nazarje), including their derivatives.

0 V Zgornji Savinjski dolini so med najstarejšimi hišnimi imeni tista, ki so tvorjena iz prvotnih ledinskih imen. Prvič so bila strnjeno zapisana leta $1426 \mathrm{v}$ urbarju benediktinskega samostana v Gornjem Gradu (Orožen 1876, 215-322). Raba tovrstnih imen na severozahodu Zgornje Savinjske doline, predvsem v okolici Solčave in tudi v okolici Luč, je bila obravnavana že večkrat (Štiftar 1873; Mišič 1938, predvsem 191-192; Mišič 1940; Vider 1982, 86-90), ${ }^{1}$ za spodnjo Zadrečko dolino, kjer se med Gornjim Gradom in Nazarjami govori zgornjesavinjsko narečje, pa podrobneje še ni bila opisana. Tule je obravnavano isto zemljepisno področje kot v poskusnem zvezku slovarja govorov Zadrečke doline med Gornjim Gradom in Nazarjami (Weiss 1998, 8-9, 6).

1 Razlikovanje hišnih imen, ki so nastala iz prvotnih ledinskih, od hišnih imen, ki so tvorjena iz priimka (»rodbinskega imena«), imena, vzdevka, poklica ipd., tipa Tinček/Tinčki in Kovač/Kovači je mogoče najti pri Francu Mišiču: »Prevladovanje hišnih imen, ki so nastala iz ledinskih, nad hišnimi imeni, ki so osebnega značaja, je razumljivo iz poseljenosti pokrajine; zaledje Luč je izrazito ozemlje

1 Podatke o oblikah hišnih ipd. imen za Solčavo in okolico mi je 18. februarja 1988 poslal gospod Valent Vider iz Solčave, za kar se mu tudi tu lepo zahvaljujem. Primerjava njegovega seznama s stanjem v spodnji Zadrečki dolini kaže, da nekateri tipi tvorbe pridevnikov iz hišnih imen oz. iz imena gospodarja tu niso znani (žibovčji, šúmečji, kleménčji). 
$\hookrightarrow \quad$ samotnih kmetij, kjer stik med ljudmi ni tako živ kakor v sklenjenih vaseh, zato je tu pri poimenovanju prihajala $v$ večji meri do izraza označitev lege ali položaja kmetskega dvorca ko karakteristika njegovega prebivalca.« (Mišič 1940, 49) In še: »Iz objavljenega gradiva vidimo, da so ledinska in njim odgovarjajoča hišna imena v okolici Luč zelo stara in da so se v večini primerov skozi stoletja ohranila prav do danes. Hišno ime, nastalo iz imena ledine, na kateri hiša stoji, je izraz povezanosti naselnika z ledino in zemljo, ki jo obdeluje, in je zato stalno in skoraj neizpremenljivo [..] Krije se hišno ime z rodbinskim tam, kjer je dom ostal nepretrgano v lasti prvotnega rodu. To, kar pa je tudi pri izpremembah v lastništvu ostalo in ostaja neizpremenjeno, je hišno ime.« (Mišič 1940, 49)

2.1 Zemljevidi (npr. Gornji Grad 075; Mozirje 076; AS 1996) in imeniki (npr. Blaznik 1986) za obravnavano področje namesto teh, prvotno ledinskih in danes (tudi) hišnih imen, ki so danes množinska, večinoma navajajo kot hišna imena shematične edninske oblike, kakršne najdemo marsikje na podeželju na siceršnjem slovenskem jezikovnem ozemlju, kar pa je za spodnjo Zadrečko dolino neustrezno, saj tu pomeni ime gospodarja v konkretni hiši. ${ }^{2}$

$2.2 \mathrm{Na}$ zemljevidih in $\mathrm{v}$ imenikih so na obravnavanem področju namesto dejanskih hišnih imen rabljena poknjižena edninska poimenovanja za gospodarja praviloma tudi tam, kjer je današnje hišno ime nastalo iz prvotnega ledinskega imena, ki se še vedno uporablja za posestvo in kot hišno ime. V tukajšnjem gradivu je ta, pisarniška raba dokumentirana z državno topografsko karto (Gornji Grad 075; Mozirje 076).

3.1 Večinsko rabljena hišna imena na obravnavanem področju spodnje Zadrečke doline so tipa Tínčki in Kováči in izkazujejo tákole besedno družino:

(a) hišno ime, ki je (samo)množinska oblika imena gospodarja (tako da so ta imena vedno moškega spola ${ }^{3}$ ); pri tovrstnih imenih so v rabi predlogi pri (na vprašanje $k j e$ ), $k / h$ (na vprašanje $k a m$ ) in od (na vprašanje od kod);

(b) ime gospodarja;

(c) ime gospodarice in/ali gospodinje;

(č) pridevnik iz hišnega imena na $-O V-a-o$ ipd.

3.1.1 Hišna imena, ki niso nastala iz ledinskih imen, so (samo)množinska (npr. "ma'rinšake -u m mn. Marínščaki Marínšeki|Bočna| [Gornji Grad 075, Marinšek]). Edninska oblika, ki je na velikem delu slovenskega ozemlja hkrati tudi hišno ime, ${ }^{4}$ se uporablja za gospodarja ("ma'rinšak -a m mn. Marínščak Marín-

2 Na kartah Gornji Grad 075 in Mozirje 076 državne topografske karte v merilu 1 : 25.000 so zapisana hišna imena, ki jih v taki obliki večinoma navaja tudi AS $1996 \mathrm{v}$ več izdajah v merilu $1: 50.000$, vendar pa jih je v atlasu manj; v njem npr. manjka ime vzpetine Juški vrh.

3 Prim. npr. pri Jerici, pri Marini, pri Pavli (Škofic 2001, 24, 26).

4 »hišno imé - osebno ime, s katerim se navadno v kmečkem okolju poimenuje hiša, domačija, ne glede na priimek, ime ali vzdevek trenutnega gospodarja (Keber 2002a, 143). Prim. še Keber 2002, 61, kjer je ob nejasnostih o edninskih oz. množinskih oblikah hišnih imen treba poudariti sklepno Kebrovo ugotovitev pri hišnih imenih: »Glede na po- 
šek), za gospodarico in/ali gospodinjo pa izpeljanka iz tega imena ("ma'rinšca -e ž Marínščica). Pridevnik iz imena gospodarja (v konkretnem primeru "ma'rinšakọ -ava -ə prid. Marínščakov Marínšekov) se nanaša tako na konkretnega gospodarja kot na hišo oz. družino, s tem da je natančno pomensko razlikovanje med enim in drugim včasih težavno, če je sploh potrebno. Če je že treba razlikovati, se uporabi konstrukcija od + rod. (v ednini za gospodarja in v množini za hišo oz. družino), kar je sploh navadno, če je priložnostna razlikovalna sestavina hišnega imena ali imena gospodarja pridevnik, največkrat Spodnji ali Zgornji pred ustreznim imenom ali pridevnik iz naselijskega imena, ki natančneje določa hišo ali gospodarja, ki sta imenovana enako v različnih vaseh: razlikovanje pri hišnem imenu na način kráški (< spodnjekraški< Spodnje Kraše) :: šmárčki Hrástniki (ali Hrástniki iz Kráš :: iz Šmártna ali $v$ Krášah :: $v$ Šmártnu) je redko, ker ga večinoma določa sobesedilo, pogostejše pa je pri gospodarju na način kráški :: šmárčki Hrástnik (ali vzporedno Hrástnik iz Kráš :: iz Šmártna ali $v$ Krášah :: v Šmártnu), ker so gospodarji pač mobilnejši. (K pridevniku iz hišnega imena v zvezah Kovačeva teta (Micka) ali Vrtački stric Franc prim. Weiss 2003, 210-211.)

3.1.2 Posebnost je narečna končnica -e (oz. -ə) pri tovrstnih hišnih imenih v mestniku množine, ko se odgovarja na vprašanje kje. Npr. pər "ma'rinšake pri Marínščakih je za hišno ime navadno in običajno, vendar pa izjemno v primerjavi z občnoimenskimi predložnimi zvezami pər 'bikex, pər 'mo:žax, pər 'kư⿱o:nex (prim. Weiss 1998, 33-34, predvsem opombe m1/7, m2/4 in m3/3). Končnica -e (nam. -ex) oz. -ə (nam. -ax), če se osnova končuje na za č š ž ̌̌ r j, je iz mestnika ednine (Ramovš 1952, 41, 49), tako kot v starinski stalni zvezi pə s'vẹ:tẹ nam. navadnega pə s'vie:tə 'po svetu' ali v prislovu na 'varrxę 'zgoraj'. Vendar pa je končnica -e (oz. -ə) pri hišnih imenih možna le, če samostalnik na levi nima pridevnika; če ga ima, je tudi pri hišnih imenih navadna končnica -ex oz. -ax, torej pər 'bỏ:čkęx "kə'vå:čax (pri Kovačih v Bočni - prim. točko 2.1.1), pər z'gỏ:rnẹx "pə'tọ:čnękex (priložnostno, v pomenu $v$ Zgornjem Potoku (v Rovtu pod Menino)) ali pər 'tətęx "'tinčke 'dẹ: pri teh Tinčkih (tj. pri družini, ki živi v hiši Tinčkovih) zdaj. Ta končnica se kdaj sliši tudi v mestniku (nat "kə'vårčə nad Kovači namesto sploh v siceršnjih, torej nehišnoimenskih besedah navadne končnice -əm, npr. nat "kə'vå:čəm, v Bočni pa ob tem tudi nat "kə'vå:čax), vendar pa gre tu za vpliv knjižnega jezika.

3.2 Na obravnavanem področju najstarejši govorci dobro razlikujejo bližnji rabi podobnih poimenovanj, in sicer ime gospodarja kake hiše in ime katerega koli drugega moškega v tej hiši, pa tudi ime gospodarice in/ali gospodinje in ime katere koli druge ženske v konkretni hiši.

Pri poimenovanjih moških po hišnem imenu je "ble'kå:č -a (in povsod tudi "blẹ-) m Blekáč|Spodnje Kraše| gospodar, "ble'kå:čọ -ga m oz. prid., ed. m. sp. Blekáčev pa splošno poimenovanje za katerega koli drugega moškega v tej hiši, s stališča mlajših z dodatkom st'rịc (kar lahko glede na okoliščine pomeni tudi gospodarja, konkretizira pa se lahko še z dodanim razlikovalnim rojstnim imenom na način "vər'tå:čke st'rịc "f'rənc Vrtački stric Franc ali "vər'tå:čke st'rịc "rud'l Vrtački stric

vedano je kljub dobri raziskanosti posameznih predelov za zdaj težko podati kakšne celovite izsledke o hišnih imenih na slovenskem etničnem ozemlju.« 
- Rudelj) ali "ble'kårčọ 'pó:p Blekačev fant ali "ble'kå:čọ "tỏ:na Blekačev Tona ipd. (Na ta način se glede na okoliščine s stališča starejših od njega ali s stališča njegovih vrstnikov lahko imenuje gospodar ali pa kateri koli od Blekačevih moških.)

Pri poimenovanjih žensk po hišnem imenu je npr. "bleka'çica -'čice (in povsod tudi blẹ-) ž Blekačíca (< Blekáć) gospodarica in/ali gospodinja, medtem ko je "ble'kå:čova -e ž, rod. mn./dv. -ęx poimenovanje za snaho ali za katero koli drugo žensko iz hiše Blekačevih, ki ni gospodarica in/ali gospodinja (kar pa z dodatkom 'tieita ali $\mathrm{z}$ dodanim rojstnim imenom ponazori odnos govorečega do $\mathrm{v}$ konkretnem primeru gospodarice in/ali gospodinje). Mlajši govorci imena gospodarjev in gospodaric in/ali gospodinj čedalje pogosteje zamenjujejo z drugim tipom (npr. "ble'kå:čọ (st'rịc ali "tỏsna) Blekačev stric ali Tona ali "ble'kå:čova ('tie:ta ali "brị'gịta, star. "bri'gịta) Blekačeva teta ali Brigita).

4 Praviloma je besedna družina hišnega imena iz prvotnega ledinskega imena na obravnavanem področju takale: ${ }^{5}$

(a) prvotno ledinsko ime (večjega ali manjšega zemljepisnega področja), ki se je preneslo na hišo, dom, in je s tem vzpostavilo hišno ime; ime tako identificira dvoje, pri čemer ni mogoče vedno natančno določiti, na kaj točno se nanaša: Bil sem na Vrtačah |Spodnje Kraše| pri stricu Francu se z veliko gotovostjo na hišo, Sankali smo se na Vrtačah pa na ledinsko (ali terensko) ime (ali mikrotoponim) oz. - širše - na posestvo v lasti Vrtačkih; predlog, ki je v rabi za tovrstno ime, je na (:: $z / S)$ ali $v(:: i z$ - ta $v$ narečju oblikovno sovpade s predlogom $z / s)$, ne pri itd., kot pri imenih tipa Kovači;

(b) ime gospodarja;

(c) ime gospodarice in/ali gospodinje;

(č) pridevnik iz hišnega imena na $-s k i-a-o,-s ̌ k i-a-o,-c ̌ k i-a-o{ }^{6}$

4.1 V skupini prvotnih ledinskih imen so vsa imena, ki izkazujejo katero od naštetih značilnosti ledinskih imen, saj je brez novih virov nemogoče ugotoviti, ali so ta imena kako značilnost izgubila ali pa je nikoli niso imela (npr. ob izkazanem ledinskem imenu v vlogi hišnega imena pridevniške oblike na -ski, ki jo je morda nadomestila oblika na -oV - prim. točko $\mathbf{5 . 3}$ - ali ob izkazani pridevniški obliki na -ski neobstoj ledinskega imena - prim. točko 5.2).

5 Vpliv preostalih, mlajših hišnih in večinskih imen tipa Kováči je pri nekaterih imenih in pri pridevnikih $\mathrm{k}$ njim povzročil posamezne posebne razvoje, te posebnosti pa je smiselno dokumentirati. Izjeme pri tem vzorcu ne prizadevajo imen gospodarja in gospodarice in/ali gospodinje in so treh vrst.

5 Natančnejši podatki za Solčavo in okolico izpričujejo še kak tip hišnih imen, in sicer samostalnik na -ovo, tvorjen iz imena gospodarja: Matkovo, na Matkovem < Matk, Kolarjevo, na Kolarjevem < Kolar, pa tudi Klemenče, na Klemenčem, prid. klemenč (h Klemenšek), Šúmeče, na Šumečem, prid. šumeč < Šumet in Žibovče, na Žibovčem, prid. žibovč < Žibovt. Te podatke mi je pisno posredoval gospod Valent Vider iz Solčave.

6 O pisanju tovrstnih pridevnikov z veliko začetnico (kot v primerih Janez Bleiweis pl. Trsteniški in Ivan Klodič vitez Sabladolski) glede na malo pri drugih podobnih (slovenski, ljubljanski ...) prim. Weiss 2004, 151. 
5.1 Na obravnavanem področju je večina hišnih imen sicer v množinski obliki, in to iz imena gospodarja (Skónčnjaki Skónčneki iz Skónčnjak Skónčnekv Bočni, Tínčki iz Tínček v Spodnjih Krašah).7 Ta vzorec je mogoče ugotavljati tudi v posameznih primerih, ko se poleg hišnega imena iz prvotnega ledinskega imena govori hišno ime, ki je množinska oblika imena gospodarja (Pódgorje in Pódrščaki Pódršeki, Góvek in Góveki, Pródi in Pródniki, Srnják in Srnjákerji). Pri hišnih imenihGóvek in Góveki ter Srnják in Srnjákerji je pridevnik na -ov ipd., pri drugih parnih pa na -ski ipd.

5.2 V nekaterih primerih, kjer v besedotvornem nizu k hišnemu imenu nastopa pridevniška oblika na -ski ipd., ne na -ovipd., je sámo hišno ime množinska oblika imena gospodarja (Skónčnjaki - Skónčki, Zijávčnjaki - Zijávčki, Jugôvniki - Jugôvski). Redko (pri mlajših govorcih čedalje pogosteje) se da slišati priložnostne oblike svojilnih pridevnikov na -ovipd. iz teh hišnih imen, torej Skónčnjakov, Zijávčnjakov, Jugôvnikov.

5.3 Pri hišnih imenih iz prvotnih ledinskih imen je pridevniška oblika na -ski ipd. sicer večinska (Bákovica - bákovski), vendar pa so pri nekaterih hišnih imenih iz prvotnih ledinskih imen v rabi samo pridevniki na -ov (Hósta - Hóstnikov, Láze - Láznikov, Slopí-Slopníkov; Sprebíja in Sprebítniki-Sprebítnikov in Sprebítkov, Srnják in Srnjákerji-Srnjákerjev, Góvek in Góveki-Góvekov).

5.4 Prvotno ledinski in tudi hišni imeni Péšanik in Góvek se oblikovno ujemata $\mathrm{z}$ imenom gospodarja, s tem da ima ime gospodarja podspol živosti, ki ga hišno (in ledinsko) ime seveda nima. Pridevnik iz ledinskega in hišnega imena Péšanik je na -ski, iz enako glasečega se imena gospodarja pa seveda na -ov, medtem ko je pridevnik iz obeh imen Góvek na -ov.

6.1 Predvsem mlajši narečni govorci so pri nekaterih besednih oblikah negotovi, saj imena gospodarjev in gospodaric in/ali gospodinj govorijo redko, jih pa od starejših lahko vendarle še pogosto slišijo. Za starejše se jim namreč ne spodobi uporabljati imen Kováč in Kovačíca in namesto njih govorijo na način Kóčnikov stríc, Kóčnikov stríc Frànc (na način Kóčnikov Frànc govorijo o konkretnem posamezniku vrstniki ali starejši od njega), Kováčeva têta, Kováčeva têta Mícka (kjer spet na način Kováčeva Mícka govorijo o konkretni posameznici vrstniki ali starejši od nje). Namesto hišnih imen iz prvotnih ledinskih imen je predvsem pri mlajših čedalje pogosteje slišati množinske oblike imena gospodarja (na način pri Vrtáčniki) ali v vlogi hišnih imen kar ime gospodarja (na način pri Vrtáčniku).

Hišna imena iz prvotnih ledinskih imen so torej le omejeno tvorna ( $\mathrm{Vi}$ clôvec $\rightarrow$ Viclôvnik), medtem ko hišna imena iz imena gospodarja so, v Spodnjih Krašah npr. Zvíri $\leftarrow$ Zvír ali Zvírnjaki $\leftarrow$ Zvírnjak, Drágoti iz rojstnega imena Drágo, Gréhčev Tóna $\leftarrow$ Gréhci in predvsem pri mlajših govorcih v zadnjem času

7 Janez Trdina je leta 1870 to vrsto imena, kot je bilo v rabi na Dolenjskem, imenoval družinsko ime. »Rabijo se tod [namreč v Bršljinu pri Novem mestu, kjer je Trdina živel leta 1870 - Trdina 1987, *12] vedno še družinske imena, na pr.[imer] grem k Malnarjevim, ne: k Malnarju, pri Kovačevih, Ljubčevih, Jelenčevih etc.« (Trdina 1987, 16). 
Vrtáčniki $\leftarrow$ Vrtáče. ${ }^{8}$ Od tod do pridevnika Vrtáčnikov iz hišnega imena Vrtáčnikov nam. Vrtáčki ni več daleč. ${ }^{9}$

6.2 Nekatera hišna imena obstajajo le še v spominu informatorjev, saj so hiše, na katere so se nanašala, izginile in so lahko z gozdom zaraščena tudi že cela posestva, npr. v Nadbočni, zaselku Bočne na severnem pobočju Menine. Tu k hišnima imenoma Petríja || "pẹt'rija -a ž $\rangle$ u "pẹt'rijo in Žvotíja Žvatíja || "žva'tija -a ž \langle\rangle u "žva'tijə ni mogoče več slišati drugih oblik (imen gospodarja in gospodarice in/ali gospodinje ter pridevnika $\mathrm{k}$ hišnemu imenu).

7.1 Hišna imena iz prvotnih ledinskih imen - tule jih je 43 (osnove soodnosnih imen s pridevnikoma Spodnji in Zgornji so štete po enkrat) - so iz 12 vasi (od $14 \mathrm{z}$ obravnavanega področja):

Bočna (9): Bákovica, Hósta, Hríber, Krvíja, Lipíca, Mataróžniki, Pogledíja, Skónčnjaki, Zakót (Petríja in Žvotíja - gl. točko 6.2)

Čreta pri Kokarjah (3): Javórje, Jugôvec, Závršniki

Dobletina (1): Gomírje

Kokarje (3): Góvek, Zijálka, Žífrje

Lačja vas (4): Péšanik, Séče, Šetínec, Viníše

Potok (3): Pródi, Srnják, Tráte

Pusto Polje (2): Kozólčnjaki, Plónova

Rovt pod Menino (13): Drága, Gnilôvec, Járše, Kŕnčnjaki, Láze, Léskelica, Pistôta, Pôtok, Slopí, Temník, Viclôvec, Vóloga, Vrtáčniki

Spodnje Kraše (1): Vrtáče

Šmartno ob Dreti (1): Sprebíja

Volog (2): Litóžič, Pódgorje

Zavodice (1): Júšje

7.2 Sestavine gesla v tu dodanem seznamu so: (1) hišno ime s podatkom o naselju, v katero spada hiša, na katero se nanaša ime, za \langle\rangle pa stoji mestniška oblika, ki odgovarja na vprašanje kje?, (2) ime gospodarja, (3) ime gospodarice in/ali gospodinje, (4) pridevnik. Povsod so dodani potrebni slovnični podatki (spol pri samostalnikih, samomnožinskost, kjer oblika ni samoedninska, pridevnik) in uveljavljeni stranski sklonski podatki (pri hišnih imenih za \langle\rangle še mestniška oblika). - V navadnih oklepajih so za označevalnikom in ali tudi navedene glasovne različice, v oglatih oklepajih pa je izpričana oblika imena na državni topografski karti iz leta 1998 (Gornji Grad 075, Mozirje 076). Ponekod je v okroglem oklepaju navede-

8 Malce nenavadno razlaga razvoj tovrstnih imen Janez Mrdavšič: »Pri domačih imenih, kjer je prišlo do nastanka novih domačijskih imen, so ta zapisana pod b« (Mrdavšič 2001, 22). V primeru »a) Knéz [..] b) Knéže, na Knéžem, Knéži« (Mrdavšič 2001, 48) je tako, v primeru »a) Gradišnik [..] b) Gradišse, na Gradíšu, gradišk'« (Mrdavšič 2001, 37) pa najbrž ne.

9 Podobno ugotavlja Mrdavšič 1988, 82: »Najevska lipa [..] pripada najevski domačiji, ne gospodarju, ki ni nujno, da se tudi piše Najevnik, je zato Najevska in ne Najevnikova, kakor jo zadnje čase imenujejo.« 
na še onaglašena oblika priimka, ki domnevno izvira iz imena gospodarja. Zapis priimka ni narečen, ker se v narečju priimki uresničujejo v polcitatni obliki.

7.2.1 Poknjižene oblike imajo včasih navedene različice, s tem da kdaj na prvem mestu stojijo bolj upravičene, vendar presenetljive (Plónovščak Plónovšek) včasih pa so nenavadne in nepričakovane tule edine oblike glede na priimke (Vinišnjak v primerjavi s priimkom in na zemljevidih zapisano obliko hišnega imena Venišnik - prim. Bajec 1950, 82-83). ${ }^{10}$ - K veliki začetnici pridevnika na -ski ipd. (Hudabivška Meta :: karniški Ožbej pri Prežihovem Vorancu) prim. Weiss 2004, 151.

Bákovica (Bočna) ||"båxkọca -e ž〈〉u "bå:kọcę

Bákovnik ||"bå:kọnęk -a (in -nị-) m živ. [Gornji Grad 075, Bakovnik]

Bákovnica ||"bårkọnca -e ž

Bákovski ||"'bå:kọs'ke -a -ə prid.

Dráge (Rovt pod Menino) || "d'rå:ge "d'rå:k ž mn. 〈〉u "d'rå:gex

Drážnik \|" d'rå:žnȩk -a (in -nị-) m živ.

Drážnica || "d'rå:žənca -e ž

Dráški \|| "d'råsške -a -ə prid.

Gnilôvec (Rovt pod Menino) || "gnę'łọ:c -a (in gnị-) m \langle\rangle u "gnę'łọ:cə (in gnị-) [Mozirje 076, Gnovec]

Gnilôvčan in Gnilôvčnjak Gnilôvčnek || "gnę'łọ:čan -a (in gnị-) in "gnę'łọ:čnek -a (in gnị-) $m$ živ.

Gnilôvčanka in Gnilôvčnica \|" "gnẹ'łọ̣čayka -e (in gnị-) in "gnẹ'łọ̣čənca -e (in gnị-) ž

Gnilôvčki || "gnę'łọ:čkę -a -ə prid.

Gomírje (Dobletina) \|" "ga'mèrrjə -a s \langle\rangle u "ga'mėirjə

Gomírščak Gomíršek || "gə’mė:ršak -a m živ.

Gomírščica || "ga'mèrršca -e ž

Gomírski || "gə'mè:rs'ke -ska -ə prid. 〈〉"gə่mė:rs'kẹ k'łårnc (klanec na cesti Nazarje-Gornji Grad v Dobletini)

Góvek (Kokarje) || "gó:vek -a (in -vẹ-) m 〈〉u "gó:vekə (in -vẹ-) [Mozirje 076: Govek] (tudi zgradba kmetijske zadruge)

in Góveki ||"'göıvẹkę -vekọ m mn. 〈〉pər "górvẹkę

Góvek ||"'gó:vek -a (in -vẹ-) m živ.

Góveščica ||"gó:vẹšca -e ž

Góvekov \|" gó:vekọ -va -ə (in -vẹ-) prid.

Hósta (Bočna) || "xọ:sta -s’te ž \langle\rangle u "xọ:s'tę

Hóstnik || 'xọ:s't’nęk -a (in -s’n-; in -nị-) m živ. [Gornji Grad 075, Hrastnik(?)]

Hóstnica \|" "xọrstñca -e (in -sən-) ž

Hóstnikov || 'xọ:s't'nękọ -ava -ə (in -s'n-; in -nị-) prid.

Hríber (Bočna) || "x'rịbər -bra m 〈〉 na "x'rịbrə

10 »Pomen je dan že v pridevnikih na -ski: splošna, ne osebna posest. Besede so v rabi zlasti na vzhodu, v centralnih narečjih se je po glasovnih zakonih -ščak reduciral v-šček, -šč zk in -šsk, tako da danes v njem občutimo obrazilo - $ə k$, zlasti pogosto v rodovinskih imenih: Zakrajšek, Savinšek, Jevšek itd.« (Bajec 1950, 82-83) 
Hríbrnjak Hríbrnek || "x'rịbərnek -a m živ. [Gornji Grad 075, Hribernik]

Hríbrnica || "x'rịbrənca -e ž

Hríbrski || "x'rịbərs'kę -ska -ə prid.

Járše (Rovt pod Menino) ||"jå:rša "jå:rš ž mn. 〈〉u "'jå:ršax

Járšnik ||"jå:ršnęk -a (in -nị-) m živ. [Gornji Grad 075, Jaršnik]

Járšnica ||"jå:ršənca ž

Járški ||"jå:rškę -a -ə prid.

Javórje (Čreta pri Kokarjah) || "ja'vó:rjə (tudi -a) -a s \langle\rangle na "ja'vó:rjə

Javórščak Javóršek \|" ja'vó:ršak -a m živ.

Javórščica \|" ja'vỏiršca -e ž

Javórski || "ja'vỏsrs'kę -ska -ə prid.

Jugôvec (Čreta pri Kokarjah) || "jə'gọ:c -a m \langle\rangle u "jə'gọ:cə

in Jugôvniki || "jə'gọ:ykẹ -ọ m mn. 〈〉 pər "jə'gọ:yke

Jugôvnik ||"ja'gọ:nęk -nka m živ. [Mozirje 076: Jegovnik]

Jugôvnica || "jə'gọ:nca -e ž

Jugôvski || "ja'gọ:s'kę -ska -ə prid.

in Jugôvnikov \|" jə'gọ:ykọ -va -ə prid.

Júšje (Zavodice) ||"jušjə (tudi -a) -a s \langle\rangle na "jušjə

in Júšniki ||"jušnękę (in -ni-) -ọ (in -nị-) m mn. 〈〉 pər"'jušnękę (in -ni-)

Júšnik ||"jušnȩk -a (in -nị-) m živ. [Mozirje 076, Jušnik]

Júšnica \|"jušənca -e ž

Júški ||"juškę -a -ə prid. [Mozirje 076, Juški vrh (517 m)]

Kozôlčnjaki Kozôlčneki (Pusto Polje) || "kə’zọ:čnẹkẹ -ọ (in -nẹ-) m mn. 〈〉 pər "kə'zọ:čnẹkę

Kozôlčnjak Kozôlčnek || "ka'zọ:čnek -a m živ.

Kozôlčnica ||"kə'zọ:čənca -e ž

Kozôlčki || "kə'zọ:čkę -a -ə prid.

Kŕnčnjaki Kŕnčneki (Rovt pod Menino) ||"ka:rənčnẹkę -nekọ (in -nẹ-) m mn. 〈〉pər "ka:rənčnẹke

Kŕnčnjak Kŕnčnek ||'ka:rənčnek -a (in -nẹ-) m [Mozirje 076, Krnčnik]

Kŕnčnica ||"ka:rənčənca -e ž

Kŕnčki ||"'ka:rənčkę -a -ə prid.

Krvíja (Bočna) || "kər'vija -a ž 〈〉 u "kər'vijə"

Krvénik || "kər'vẹ:nęk -'ve:yka (in -'vẹ:-) m živ. [Gornji Grad 075, Krvavnik]

Krvénica || "kər've:nca (in -'vẹ:-) -'vẹ:n'ce ž

Krvêjski || "kər'vẹ:s'kę -'vesska -ə (in -'vẹ:-) prid. [Gornji Grad 075, Krevejske peči]

Láze (Rovt pod Menino) \|" "łå:ze "łå:s ž mn. 〈〉 u "łå:zex

in Lázniki \|" ‘å:z’nękę (in -ni-) -ọ (in -nị-) m mn.

Láznik || 'łå:z’nęk -a (in -nị-) m živ. [Mozirje 076, Laznik]

Láznica \|"'łå:znoca -e ž

Láznikov ||"łå:z’nękọ -va -ə prid.

${ }^{11}$ V govorih spodnje Zadrečke doline ẹ pred j alternira z i, zato "kər'vẹıs'kę in "kər'vija (in tako še 'vẹ:ja in 'vija 'veja', 'rẹ:ja in 'rija 'reja', b'rẹ:ja in b'rija 'breja', u'dẹija in u'dija 'odeja' itd. (Weiss 2001, 329). 
Léskelica (Rovt pod Menino) || "lẹss'kẹlca -e ž \langle\rangle u "lẹss'kẹlcę

Léskovnik ||"lerskọnęk -a (in "lẹ:-; in -nị-) m živ.

Léskovnica ||"'lesskọnca -e (in "lẹi-) ž

Léskovški \||"lerskọškę -a -ə (in "'lẹ:-) prid.

Lipíca (Bočna) || "lę́pịca -'pice ž 〈〉 na "lę̣pịcę

Lipíčnik || "lę'pičnȩk -a (in -nị-) m živ.

Lipíčnica \|" "lę'pičənca -e ž

Lipíčki ||"lę pičke -a -ə prid.

Litóžičč ${ }^{2} \sim$ Litóšč (Volog) || "lẹt'tỏ:šč -a m \langle\rangle u "lệtỏ:ščə (tudi vodno ime)

Litóžnik || "lę'tó:žnȩk -a (in -nị-) m živ. [Gornji Grad 075, Letožnik]

Litóžnica \|" "lę'tó:žənca -e ž (tudi vodno ime)

Litóški || "lę'tȯ:ške -a -ə prid.

Mataróžniki (Bočna) || "mata'rọ:žnękę (in -ni-) -u (in -nị-) m mn. 〈〉 pər "mata'rọ:žnẹkẹ (in -ni-)

Mataróžnik || "mata'rọ:žnęk -a (in -nị-) m živ.

Mataróžnica || "mata'rọ:žənca -e ž

Mataróški || "mata'rọ:ške -a -ə prid.

Péšanik (Lačja vas) || "pẹišanęk -nka m \langle\rangle u "pẹišajkə

Péšanik || "pẹišanęk -nka m živ.

Péšanica ||"pẹ:šanca -e ž

Péšanski ||" "pẹıšans’kę -ska -ə prid.

Pistôta (Rovt pod Menino) \|| "pęs'tuorta -e ž $\langle>$ na "pęs'tuortę

Pistótnik || "pess'tó:t'nȩk -a (in -nị-) m živ. [Mozirje 076, Pestotnik]

Pistótnica || "pęs'tỏ:tnoca -e ž

Pistóčki || "pess'tócčkę -a -ə prid. [Mozirje 076: Pestoški vrh (614 m)]

Plónova (Pusto Polje) || "p'łọ:nọva -e ž 〈 u "p'łọ:nọvę

Plónovščak Plónovšek || "p'łọ:nọšak -a m živ. (priimek Plánovšek)

Plónovščica || "p'łọ:nọšca -e ž

Plónovski || "p'łọ:nọs'kę -ska -ə prid.

Pódgorje (Volog) ||"pó:dgərjə -a s \langle\rangle star. u "pó:dgərjə

in Pódrščaki Pódršeki || "pó:dəršakę -ọ/-u m mn. 〈〉 pər "pó:dəršakę

Pódrščak Pódršek || "pó:dəršak -a m živ. [Mozirje 076, Podgoršek]

Pódrščica ||"pó:dəršca -a ž

Pódrski \||"pó:dərs'kę -ska -ə prid.

Pogledíja (Bočna) || "pəglệ'dija -a ž \langle\rangle na "pəglệdijə

in Poglédniki \|| "pəg'lè:d'nękę -u (in -ni-) m mn. 〈〉 nov., redk. pər "pəg'lè:d'nękę

Poglédnik || "pəg'lè:d'nęk -a (in -nị-) m živ. [Gornji Grad 075, Poglednik]

Poglédnica || "pəg'lèidñca -e ž

Poglédski || "pəg'lèic'ke -cka -ə prid.

Pôtok (Rovt pod Menino) || "punortək "pə'tỏika (nov. "pə'tọ:ka) m〈〉u ("s'pó:d’nęmə, "z'gó:rnęmə) "pə'tỏ:kə (nov. "pə'tọ:kə)

${ }^{12} \mathrm{Za}$ ustno opozorilo na to obliko se zahvaljujem kolegu Silvu Torkarju.

${ }^{13}$ Pôtok je tudi ime naselja v občini Nazarje, ki ima v stranskih sklonih druge oblike: "puno:tək "pə'tọ:ka m 〈〉 u "pə'tọ:kə. 


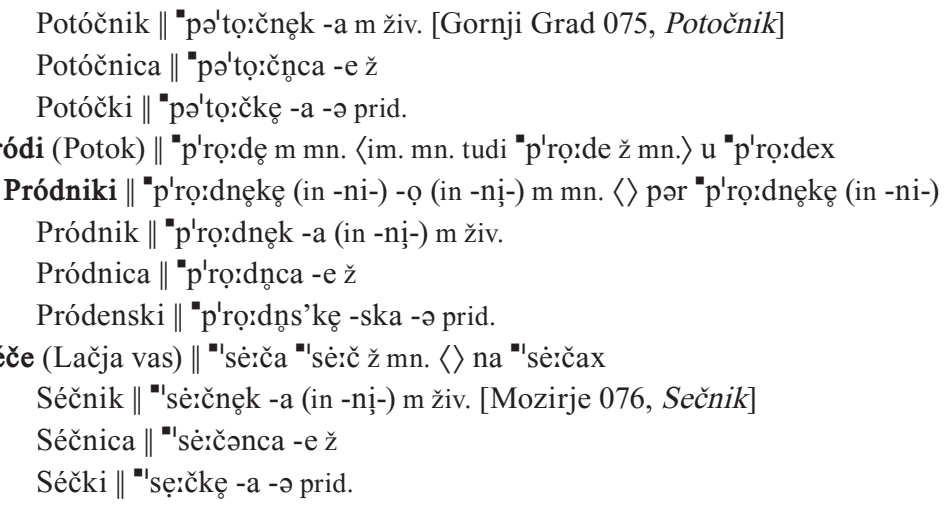

Skónčnjaki Skónčneki (Bočna) || "s'kọ:nčnẹkę -u m mn. 〈〉 pər "s'kọ:nčnẹkẹ

Skónčnjak Skónčnek || 's'kọ:nčnek -a (in -nẹ-) m živ. (priimek Skónčnik)

Skónčnica || "s'kọ:nčənca -e ž

Skónčki ||"s'kọ:nčkę -a -ə prid.

Slopí (Rovt pod Menino) || "słə'pi "słə'pi ž mn. 〈〉 na "słə'pe:x

Slopník || "słəp'nịk -a m živ. (priimek Slápnik)

Slopníca || "słəp'nịca -'nice ž

Slopníkov || "słəp'nịkọ -va -ə prid.

Sprebíja (Šmartno ob Dreti) \|" spra'bija -a ž $\rangle$ na "spra'bijə

in Sprebítniki || "spra'bit'nȩkę (in -ni-) -ọ (in -nị-) m mn. 〈〉 pər "spra'bit’nȩkę (in -ni-)

Sprebítnik || "spra'bit'nȩk -a (in -nị-) m živ. [Mozirje 076, Sprebitnik]

Sprebítnica || "spra'bịtnoca -e ž

Sprebítnikov || "spra'bit'nękọ -va -ə (in -nị-) prid.

tudi Sprebítkov || "spra'bit'ko -va -ə prid. ${ }^{14}$

Srnják (Potok) \|" "sər'n’åkk -a m \langle\rangle na "sər'n’åkə

in Srnjákerji || "sər'n’å:kẹjə -ọ m mn. 〈〉 pər "sər'n’åkẹrjə

Srnjáker || "sər'n’å:ker -kẹrja m živ.

Srnjákerica || "sər'n’å:kerca -kẹrce ž

Srnjákerjev || "sər'n’åkerjọ -va -ə prid.

Šetínec (Lačja vas) || "ša'tịnc -a m \langle\rangle u "ša'tịncə

Šetínščak $\sim$ Šetínšek ||"ša'tinšak -a m živ.

Šetínščica ||"ša'tinšca -e ž

Šetínski || "ša'tin'skę -ska -ə prid.

Temník (Rovt pod Menino) \|" "təm'nịk -a m 〈〉 u "təm'nịkə

Tomníščak $\sim$ Tomníšek \| "təm'nišak -a m živ. [Mozirje 076, Tomnišek] (priimek Tomínšek $)^{15}$

${ }^{14}$ Prim. Weiss 1990, 206: »za sprav'bit'kave [..] 'nivę«.

${ }^{15}$ O tem Janez Keber 1982, 231 v prispevku o izvoru priimkov na -šek: »[..] priimek Tominšek ni iz kr.[ajevnega] imena Tolmin, ampak iz mikrotoponima Temine, kar dokazuje zgodovinski material, a tudi današnja značilna razprostranjenost itd.« V opombi k temu pa: »Prim. por.[očno] knjigo Gornji grad: 1771 Georgius Thominshegk, 1774 Josephus teminscheg in isti 1775 in 1779 Temnischeck itd.« Sámo ledinsko ime je zapisano že v urbarju iz leta 1426: »Michel in temnikch« (Orožen 1876, 260). 
Tomníščica || "təm'nišca -e ž

Temníški || "təm'niškę -a -ə prid.

Tráte (Potok) || "t'rå:te "t'rå:t ž mn. 〈〉 na "t'rå:tex

Trátnik || "t'rå:tnęk -a (in -nị-) m živ. (priimek Trátnik)

Trátnica \|" t'rå:tñca -e ž

Trátenski || 't'rå:tnos'kę -a -ə prid.

Viclôvec (Rovt pod Menino) || "vẹc'lọ̣c -a m 〈〉 u ("s'pó:d'nęmə, "z'gỏ:rnęmə) "vęc'lọ:cə

Viclôvnik || "vęc'lọ:nęk -1ka m živ. [Gornji Grad 075, Vrclovnik]

Viclôvnica \|| "vẹc'lọ:nca -e ž

Viclôvški || "vęc'lọ:škę -a -ə prid.

Viníše (Lačja vas) || "vę'niša "vę'niš ž mn. 〈〉 na ("s'pỏ:d'nęx, "z'gó:rnęx) "vę'nišax

Viníšnjak Viníšnek \| "vẹ'nišnek -a m živ. [Mozirje 076, Venišnik] (priimek Veníšnik)

Viníšnica || "vę'nišənca -e ž

Viníški \|"vè'niške -a -ə prid.

Vóloga (Rovt pod Menino) \|" vəłaga -e ž $\rangle$ u"vəłage

Vóložnik ||"vəłažnęk -a (in -nị-) m živ. [Mozirje 076, Volažnik]

Vóložnica ||"vəłažənca -e ž (tudi vodno ime [Mozirje 076: Voložnica])

vóloški || 'vəłaškę -a -ə prid.

Vrtáče (Spodnje Kraše) || "vər'tå:ča "vər'tå:č ž mn. 〈〉 na "vər'tå:čax ${ }^{16}$

Vrtáčnik || "vər'tå:čnȩk -a (in -nị-) m živ. [Mozirje 076: Vrtačnik] (priimek Vrtáčnik)

Vrtáčnica || "vər'tå:čənca -e ž

Vrtáčki || "vər'tå:čkę -a -ə prid.

Vrtáčniki (Rovt pod Menino) || "vər'tå:čnękę (in -ni-) -ọ (in -nị-) m mn. 〈〉 pər "vər'tå:čnękę (in -ni-)

Vrtáčnik || "vər'tå:čnȩk -a (in -nị-) m živ.

Vrtáčnica || "vər'tå:čənca -e ž

Vrtáčki || "vər'tå:čkę -a -ə prid.

Zakót (Bočna) \|" "za'kọ:t -a m \langle\rangle u "za'kọstə

Zakótnik || "za'kọ:t'nȩk -a (in -nị-) m živ.

Zakótnica \|" za'kọ:tnoca -e ž

Zakóčki || "za'kọ:čkę -a -ə prid.

Závršniki (Čreta pri Kokarjah) ||"'zå:vəršnękę (in -ni-) -ọ (in -nị-) m mn. 〈〉 pər "zå:vəršnękę (in -ni-)

Závršnik ||"zåivəršnȩk -a (in -nị-) m živ. [Mozirje 076, Završnik]

Závršnica ||"zå:vəršənca -e ž

Závrški ||"'zå:vərške -a -ə prid. [Mozirje 076, Završki vrh (828 m)]

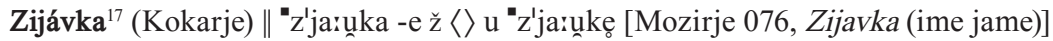

${ }^{16}$ Gole Vrtače je ime področja južno od Šmartna ob Dreti in Spodnjih Kraš (Mozirje 076).

${ }^{17}$ Badjura 1953, 295, 296, 297 ima - tako kot pred njim že Pleteršnik v slovensko-nemškem slovarju iz leta 1895 - zijavka, medtem ko ima Slovenski pravopis 2001/2003 zijávka (v geslu zijávec, slabšalno za 'radovedna opazovalka') in čisto drugo obliko v geslu Potóčka zijálka (zadnje bi se glede na to, da posebni izgovor ni zapisan, torej v knjižnem jeziku moralo izgovarjati z [1k]). 
in Zijávčnjaki Zijávčneki || "z'ja:ưčnẹkę -nekọ (in -nẹ-) m mn. 〈〉 pər "z'ja:ưčnẹkẹ Zijávčnjak Zijávčnek ||"z'ja:ǔčnek -a (in -nẹ-) m živ.

Zijávčnica || "z'ja:ưčənca -e ž

Zijávčki \||"z'ja:ưčkę -a -ə prid.

Žífrje (Kokarje) \|" "žifərjə -a s \langle\rangle u "žịfərjə [Mozirje 076, Žiferje (ledinsko ime)] Žífrnjak Žífrnek || '̌̌ịfərnek -a m živ. [Mozirje 076, Žifernik]

Žífrnica \| '̌̌i̧frənca -e ž

Žífrski ||"Žịfərs'kę -ska -ə prid.

\section{Navedenke}

AS 1996 = Atlas Slovenije, ur. Vili Kos, Ljubljana, Mladinska knjiga - Geodetski zavod Slovenije, ${ }^{3} 1996$.

Badjura 1953 = Rudolf Badjura, Ljudska geografija: terensko izrazoslovje, Ljubljana, DZS, 1953.

Bajec 1950 = Anton Bajec, Besedotvorje slovenskega jezika 1: Izpeljava samostalnikov, Ljubljana,SAZU, 1950 (Dela razreda za filološke in literarne vede 1).

Blaznik 1986 = Pavle Blaznik, Historična topografija slovenske Štajerske in jugoslovanskega dela Koroške do leta 1500 1-2: A-M, N-Ž, Maribor, Obzorja, 1986.

Gornji Grad 075 = Državna topografska karta Republike Slovenije 1 : 25.000: Gornji Grad (075), Ljubljana, Geodetska uprava Republike Slovenije, 1998.

Keber 1982 = Janez Keber, O izvoru priimkov na -šek, Onomastica Jugoslavica 9 (1982), str. 229-236.

Keber 2002 = Janez Keber, Rojstna imena, hišna imena, vzdevki, psevdonimi $\mathrm{v}$ Sloveniji, Jezikoslovni zapiski 8 (2002), št. 2, str. 47-69.

Keber 2002a = Janez Keber, Slovarček imenoslovnih in drugih jezikoslovnih izrazov, Jezikoslovni zapiski 8 (2002), št. 2, str. 141-148.

Mišič 1938 = Franc Mišič, O ledinskih in hišnih imenih okoli Solčave, Časopis za zgodovino in narodopisje 33 (1938), str. 191-201.

Mišič 1940 = Franc Mišič, Ledinska in hišna imena okoli Luč, Časopis za zgodovino in narodopisje 35 (1940), str. 40-49.

Mozirje 076 = Državna topografska karta Republike Slovenije 1 : 25.000: Mozirje (076), Ljubljana, Geodetska uprava Republike Slovenije, 1998.

Mrdavšič 1988 = Janez Mrdavšič, Krajevna in domača imena v Črni na Koroškem in njeni širši okolici, Ravne na Koroškem: Koroška osrednja knjižnica »Dr. Franc Sušnik« - Kulturna skupnost, 1988.

Mrdavšič 2001 = Janez Mrdavšič, Krajevna in domača imena v Mežiški dolini, Ravne na Koroškem: ČZP Voranc, 2001.

Orožen 1876 = Ignac Orožen, Das Benediktiner-Stift Oberburg, Marburg, 1876 (Das Bisthum und die Diözese Lavant I/1).

Ramovš 1952 = Fran Ramovš, Morfologija slovenskega jezika: skripta, prirejena po predavanjih prof. dr. Fr. Ramovša v l. 1947/68, 48/49, Ljubljana: DZS (za Univerzitetno študijsko komisijo), 1952. 
Škofic 2001 = Jožica Škofic, Hišna imena v Kropi, Simpozij Slovenska lastnoimenskost: zbornik s simpozija '99 v Pišecah, ur. Jože Toporišič, Pišece, Komisija Maks Pleteršnik - Novo mesto, Tiskarna Novo mesto, Dolenjska založba, str. 21-40.

Štiftar 1873 = France Štiftar, O vlastnih imenih kmetij i posestnikov v Solčavi, Vestnik Zore 1873, str. 168-170.

Trdina 1987 = Janez Trdina, Podobe prednikov: zapiski Janeza Trdine iz obdobja 1870-1879, ur. Snežana Štabi - Igor Kramberger, Ljubljana, Univerzitetna konferenca ZSMS, 1987 (Knjižna zbirka Krt 30-32).

Vider 1982 = Valent Vider, Zapiski o Solčavi in njeni okolici: prispevki kzgodovinskemu in etnografskemu gradivu, Solčava, Turistično društvo, 1982.

Weiss 1990 = Peter Weiss, Govori Zadrečke doline med Gornjim Gradom in Nazarjami: glasoslovje, oblikoslovje in skladnja - magistrsko delo, Ljubljana, 1990 (tipkopis).

Weiss 1998 = Peter Weiss, Slovar govorov Zadrečke doline med Gornjim Gradom in Nazarjami: poskusni zvezek (A-H), Ljubljana, Založba ZRC, 1998 (Slovarji).

Weiss 2001 = Peter Weiss, Folološki opis govora kraja Spodnje Kraše (SLA 314), Jezikoslovni zapiski 7 (2001), št. 1-2, str. 321-347.

Weiss 2003 = Peter Weiss, Načini ogovarjanja in govorjenja o odsotni osebi v govorih spodnje Zadrečke doline, v: Glasoslovje, besedoslovje in besedotvorje v delih Jakoba Riglerja, ur. Zinka Zorko - Mihaela Koletnik, Maribor: Slavistično društvo, 2003 (Zora 25), str. 199-215.

Weiss 2004 = Peter Weiss, Izhodišča za slovar imen v govorih spodnje Zadrečke doline, Besedoslovne lastnosti slovenskega jezika: slovenska zemljepisna imena, ur. Marko Jesenšek, Ljubljana, Slavistično društvo Slovenije - Pišece, Društvo Pleteršnikova domačija, 2004, str. 147-153.

\section{Oeconyms Formed from Choronyms in the Lower Dreta Valley} Summary

In the Upper Savinja Valley, the oldest oeconyms were formed from names that were originally microtoponyms; for example, Potok 'creek' and the prepositional phrase v Potoku. Adjectives added to these house names usually have the suffix -ski etc. (e.g., Potočki), whereas the suffix -ov etc. from the owner's name (e.g., Hosta, v Hosti-Hostnikov) is less frequently used. However, the latter is the only suffix used with most of the more recent house names (e.g., Tinčki, pri Tinčki - Tinčkov). With both types of oeconyms, the adjectival form in -ov etc. refers to the owner (e.g., Potočnik, Tinček - Potočnikov, Tinčkov). The type Skončnjaki, pri Skončnjaki - skončki is rare; the original microtoponym is no longer present (or has never been), but the adjective behaves as though it were (or had been). This article presents today's distribution of oeconyms formed from names that were originally choronyms in the lower Dreta Valley (where the Upper Savinja dialect is 
$\rightarrow \quad$ spoken between Gornji Grad and Nazarje), including derivatives and prepositional phrases. In addition, attention is called to their diminishing use.

Peter Weiss

Inštitut za slovenski jezik Frana Ramovša ZRC SAZU Novi trg 2, 1000 Ljubljana 


\section{Voščilo Varji Cvetko Orešnik}

Tretjega maja je dopolnila šestdeset let prof. dr. Varja Cvetko Orešnik, ki jo strokovna javnost pozna po njenih indoevropeističnih, pretežno indoiranističnih in slavističnih objavah, študenti in sodelavci Filozofske fakultete kot profesorico za primerjalno indoevropsko jezikoslovje, širša znanstvena in kulturna javnost pa kot dolgoletno predstojnico Inštituta za slovenski jezik Frana Ramovša ZRC SAZU.

Njena znanstvena pot se je začela na ljubljanski Filozofski fakulteti, kjer je leta 1972 diplomirala iz primerjalnega indoevropskega jezikoslovja in iz slovenskega jezika s književnostjo. Istega leta je postala stažistka na Oddelku za primerjalno jezikoslovje in orientalistiko. Po enoletnem izpopolnjevanju na Dunaju je bila leta 1974 izvoljena v asistentko za smer indoiranski jeziki. Disertacijo z naslovom Baltoslovansko-indoiranski jezikovni odnosi v luči raziskav indoevropske arealne lingvistike je leta 1979 zagovarjala pred komisijo, ki ji je predsedoval njen učitelj Bojan Čop. Naslednjega leta je bila izvoljena v docentko za primerjalno jezikoslovje, leta 1986 za izredno profesorico za vzhodne indoevropske jezike in leta 1992 za redno profesorico za primerjalno jezikoslovje. Je članica dveh uglednih mednarodnih jezikoslovnih društev, Wiener Sprachgesellschaft in Indogermanische Gesellschaft.

Področje njenega raziskovalnega in pedagoškega dela je bilo sprva usmerjeno predvsem v staro indijščino v indoevropeistični luči ${ }^{2}$ in v problematiko izoglos ter stikov med iranskimi jeziki in praslovanščino, ${ }^{3}$ kasneje se vse bolj pomika na področje slovanskih jezikov in še posebej slovenščine, ${ }^{4}$ seveda v diahroni, primerjalni

1 Predelano in prenovljeno besedilo njene disertacije je pod naslovom K metodologiji preučevanja baltoslovansko-indoiranskih jezikovnih odnosov kot monografija izšlo leta 1998 pri založbi ZRC.

2 S tega področja je treba omeniti predvsem njeno razpravo Zur Problematik der altindischen Kausativa mit langem Vokalismus (Linguistica XVIII /1978/, 57-98.

3 Poleg disertacije in $\mathrm{v}$ prvi opombi navedene monografije prim. zlasti njeno razpravo Zu neueren iranisch-baltoslawischen Isoglossen-Vorschlägen (Linguistica XXIII /1983/, 175-256).

4 Najodmevnejše so njene razprave Zum Rhotazismus im Südslawischen (Klagenfurter Beiträge zur Sprachwissenschaft XIII /1988/, 433-446), H kritikam Ramovševe interpretacije Brižinskih spomenikov: ot zlodeine oblazti : od flauui bofige (Slavistična revija XL /1992/, 269-289) in Kritische Sicht der Literatur über die (südslawische) Entsprechung der Gruppe tl/dl unter spezieller Berücksichtigung des rumänischen mocirlă (Linguistica XXXIII /1993/, 35-48). 

$\mathrm{v}$ luči teorije naravnosti. ${ }^{5}$

Družbeno in politično dogajanje v začetku devetdesetih let prejšnjega stoletja je poleg večine ugodnih prineslo tudi nekaj slabše premišljenih sprememb, med katere vsekakor lahko uvrstimo razvoj znanstvene politike, ki je vrednotenje znanstvenih rezultatov - vsaj v humanistiki - še bolj oddaljil od kompetentnih strokovnjakov in ga predal v presojo uradnikom z visokimi državnimi nazivi. Posledica te politike je (in je danes vedno bolj) zlivanje vseh znanosti v eno $\mathrm{z}$ najpomembnejšim vprašanjem, kako pridobiti denar od pristojnega ministrstva. To pomeni boj za obstanek vsake znanstvene panoge posebej ne glede na nacionalno pomembnost, saj državni uradniki pač niso in še ne morejo dojeti, da Slovenci brez sodobnega slovarja knjižnega jezika, brez uporabnega pravopisa, brez etimološkega in zgodovinskega slovarja, brez dialektoloških atlasov in brez najrazličnejših terminoloških slovarjev ne bi bili kulturni narod, medtem ko bi brez mnogih drugih, v uradniških očeh pogosto priviligiranih znanstvenih dejavnosti, naša kultura ne utrpela dosti škode. Za obrambo slovenske institucionalne slovaropisne dejavnosti pred oblastmi, torej pred onimi, ki bi jo morali v prvi vrsti ščititi in hraniti, je poleg ustreznih znanstvenih referenc in primernega značaja potreben tudi kritični, analitično-sintetični in kombinatorični razum. Ker Varja Cvetko Orešnik ima vse naštete kvalitete, je v tem poslanstvu zagledala svoj osebni izziv in tako je februarja 1992 postala predstojnica Inštituta za slovenski jezik ZRC SAZU, ki ga uspešno vodi že šestnajsto leto. Vodenje inštituta s tako pomembnimi in raznovrstnimi nalogami (ne smemo pozabiti, da je bila Akademija znanosti in umetnosti na Slovenskem ustanovljena predvsem zaradi nalog, ki jih še danes izvaja Inštitut za slovenski jezik) je kompleksna dejavnost, ki zahteva primerna ukrepanja navzgor, navzdol, vstran in verjetno še kam drugam. Varja Cvetko Orešnik to poslanstvo opravlja predano, požrtvovalno, z glavo in srcem, kar se da človeško. Vedno rada prisluhne posamezniku in mu, če je le v njeni moči, pomaga rešiti težavo. Morda nismo vedno vsi soglašali z vsakim predstojničinim korakom (kar je odraz zdravega odnosa do oblasti), smo se pa menda vsi strinjali z njeno osnovno usmeritvijo, ki jo lahko strnjeno označimo kot nenehno prizadevanje za ohranitev in razvoj slovenistične slovaropisne dejavnosti. $\mathrm{V}$ zadnjih petnajstih letih je na Inštitutu nastalo ali bilo dokončano več temeljnih in za slovenstvo ključnih slovarskih del, naj omenim samo Slovenski pravopis, Slovar slovenskega knjižnega jezika v enem zvezku (oboje tudi v elektronski izdaji), Etimološki slovar slovenskega jezika, Slovar stare knjižne prekmurščine in večje število terminoloških slovarjev, ${ }^{6}$ katerih skupna naklada se meri v več deset tisoč

5 Prim. njeni razpravi The o-grade of the Indo-European ablaut in the light of naturalness (Linguistica XLI /2001/, 159-162) in The aorist and the perfect of the Old Indian causatives in the light of natural morphosyntax (Linguistica XLVI /2006/, 117-120).

${ }^{6} \mathrm{Z}$ omembo samo teh del v glavnem besedilu ne delam krivice samo mnogim specialnim znanstvenim monografijam in množici raznovrstnih jezikoslovnih člankov v periodičnem ali priložnostnem tisku, ki so izpod peres članov Inštituta izšli v zadnjem poldrugem desetletju, temveč tudi in predvsem nastajajočim delom, kot so Slovar sinonimov slovenskega jezika, Frazeološki slovar slovenskega jezika, Slovar novejšega besedja, Slovar jezika slovenskih protestantskih piscev 16. stoletja, dialektološki atlasi, če se ponov- 


\section{Navodila avtorjem}

Jezikoslovni zapiski so periodično glasilo Inštituta za slovenski jezik Frana Ramovša ZRC SAZU in slovenska znanstvena jezikoslovna revija, ki izhaja dvakrat na leto. Uredništvo sprejema prispevke praviloma do konca marca za prvi in do konca julija za drugi zvezek $v$ tekočem letu, glasilo pa izide predvidoma $v$ juliju in novembru. Razen delavcev Inštituta so k sodelovanju vabljeni tudi drugi domači in tuji raziskovalci slovenskega in drugih slovanskih jezikov. Uredništvo za pisanje posebej vzpodbuja mlade raziskovalce in raziskovalke.

Predviden okvirni obseg člankov je ena avtorska pola, tj. 16 strani s po $30 \mathrm{vr}-$ sticami, za razprave po dogovoru $\mathrm{z}$ uredništvom tudi več. Poročila naj bi obsegala do pet, recenzije, predstavitve ali kritike jezikoslovnih del do 10 strani. Tekste, ki morajo biti izvirni in še ne objavljeni, je treba oddati uredništvu na disketi 3,5 in vnesene v oknih v programu Word ter v pisavi Times New Roman (velikost 10). Vse posebne in naglašene znake, ki se jih ne da vnesti prek tipkovnice, je treba vzeti iz Wordovih Simbolov, Wordovih naborov Brane 1, 12, 3, 4 ali navesti zanje posebne kode. Pri tabelah, grafih ipd. je treba upoštevati format Jezikoslovnih zapiskov. Pri pisanju naj avtorji ne uporabljajo slogov. Oblikovanje prispevka naj prepustijo Založbi ZRC, označene so lahko pisave krepko, ležeče, podčrtano. Disketi naj bo priložen iztis na formatu A $4 \mathrm{v}$ dveh izvodih. Razprave in clanki morajo imeti na začetku slovenski izvleček. Temu bo sledil angleški prevod izvlečka. Na koncu bo angleški povzetek (avtorji naj slovenski izvleček in povzetek odtisnejo posebej za prevajalko). Povzetek naj ima največ 15 vrstic. Prispevki v razdelku GRADIVO, OCENE, POROČILA imajo na začetku slovenski in angleški izvleček. Pri člankih in razpravah mora biti pred povzetkom seznam virov in literature ali navedenk, ki se nanašajo na obravnavano tematiko. Pri tem naj se avtorji ravnajo po zadnjem letniku Jezikoslovnih zapiskov. Pri navajanju virov in literature je zaželeno, da se ime, ki je zapostavljeno priimku $\mathrm{z}$ vejico, (po možnosti) navede neokrajšano.

Vse prispevke preberejo clani uredniškega odbora, ki clanke in razprave praviloma tudi recenzirajo. Pri recenziranju sodelujejo tudi zunanji recenzenti. Priporočila in popravki članov uredniškega odbora oziroma recenzentov so posredovani avtorjem, da jih upoštevajo in jih pred oddajo $\mathrm{v}$ tisk vnesejo na disketo.

Uredniški odbor Jezikoslovnih zapiskov si pri pripravljanju revije želi čim širšega sodelovanja. Zato poziva sodelavce in bralce revije ter vse zainteresirane, da pošiljajo svoje predloge in mnenja $\mathbf{v}$ zvezi $\mathbf{z}$ obliko in vsebino revije ter delom uredniškega odbora. Objavljeni bodo v razdelku ODMEVI.

\section{Naslov uredniškega odbora Jezikoslovnih zapiskov:}

Inštitut za slovenski jezik Frana Ramovša ZRC SAZU

Novi trg 2, 1000 Ljubljana, Slovenija

Telefon: 014706 160, e-pošta: ISJ@zrc-sazu.si

Glavni urednik: telefon: 014706 177; e-pošta: keber@zrc-sazu.si 


\section{MERKUJEV ZBORNIK}

Kozma Ahačič

Rosanna Benacchio

Hubert Bergmann

Urszula Bijak

Inge Bily

Дмитро Бучко

Aleksandra Cieślikowa

Varja Cvetko Orešnik

Barbara Czopek-Kopciuch

Dušan Čop

Александр Д. Дуличенко

Goran Filipi

Anđela Frančić

Metka Furlan

Helena Grochoła-Szczepanek

Елка Јачева-Улчар

Tjaša Jakop

Helena Jazbec

Janez Keber

Vlado Klemše

Фёдар Д. Клімчук

Marija Kozar-Mukič

Andreja Legan Ravnikar

Валянціна П. Лемцюгова
Maria Malec

Witold Mańczak

Jožica Narat

France Novak

Janez Orešnik

Urška Petek

Heinz Dieter Pohl

Maurizio Puntin

Ludwig Selimski

Mitja Skubic

Vera Smole

Marko Snoj

Liliana Spinozzi Monai

Љубица Станковска

Krystyna Szcześniak

Agata Šega

Matej Šekli

Alenka Šivic-Dular

Jožica Škofic

Rudolf Šrámek

Віктор П. Шульгач

Silvo Torkar

Peter Weiss

$14 €$

ISSN 0354-0448

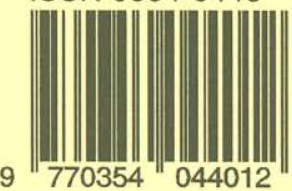


prodanih izvodih in kilometrih polic s knjigami, ki jih pišoči Slovenci uporabljamo vsak dan. Izdelava vseh teh del je tako očitna uspešnost, da je ne more spregledati nihče. Omalovažuje jo lahko samo po meri drugih narejeni sistem vrednotenja in posledično financiranja znanstvene dejavnosti na Slovenskem. ${ }^{7}$

Okrogla obletnica je čas strnjenega pogleda na preteklost in razumno vedrega pogleda v prihodnost. Je torej čas za zgornje vrstice in čas, da v imenu vseh sodelavcev (kar kot spolno nevtralno vključuje tudi sodelavke) Inštituta za slovenski jezik Frana Ramovša ZRC SAZU in Oddelka za primerjalno in splošno jezikoslovje ljubljanske Filozofske fakultete voščim Varji vse najboljše ob njenem prazniku z željo, da bi svoje delo, ki ga ima rada, opravljala še dolgo vrsto let.

Marko Snoj

no omejim samo na nekatera. Pod črto je treba omeniti tudi predstojničinega odprtega duha, ki članom Inštituta dopušča sodelovanje z zunanjim svetom, kar na eni strani omogoča kakovostnejše ustvarjanje, na drugi pa boljši pretok znanstvenih spoznanj do bralcev.

$7 \mathrm{~V}$ tem odstavku opisani pogled na dogajanje in stanje je osebni pogled podpisanega. 